\title{
Strafbare overheden : een rechtsvergelijkende studie naar strafrechtelijke aansprakelijkheid van overheden voor milieuverstoring
}

Citation for published version (APA):

Roef, D. (2001). Strafbare overheden : een rechtsvergelijkende studie naar strafrechtelijke aansprakelijkheid van overheden voor milieuverstoring. [Doctoral Thesis, Maastricht University]. Intersentia. https://doi.org/10.26481/dis.20010627dr

Document status and date:

Published: 01/01/2001

DOI:

10.26481/dis.20010627dr

Document Version:

Publisher's PDF, also known as Version of record

Please check the document version of this publication:

- A submitted manuscript is the version of the article upon submission and before peer-review. There can be important differences between the submitted version and the official published version of record.

People interested in the research are advised to contact the author for the final version of the publication, or visit the DOI to the publisher's website.

- The final author version and the galley proof are versions of the publication after peer review.

- The final published version features the final layout of the paper including the volume, issue and page numbers.

Link to publication

\footnotetext{
General rights rights.

- You may freely distribute the URL identifying the publication in the public portal. please follow below link for the End User Agreement:

www.umlib.nl/taverne-license

Take down policy

If you believe that this document breaches copyright please contact us at:

repository@maastrichtuniversity.nl

providing details and we will investigate your claim.
}

Copyright and moral rights for the publications made accessible in the public portal are retained by the authors and/or other copyright owners and it is a condition of accessing publications that users recognise and abide by the legal requirements associated with these

- Users may download and print one copy of any publication from the public portal for the purpose of private study or research.

- You may not further distribute the material or use it for any profit-making activity or commercial gain

If the publication is distributed under the terms of Article $25 \mathrm{fa}$ of the Dutch Copyright Act, indicated by the "Taverne" license above, 
Strafbare Overheden

Een rechtsvergelijkende studie naar de strafrechtelijke aansprakelijkheid van overheden voor milieuverstoring 
Dit boek werd als proefschrift verdedigd op 27 juni 2001 aan de Universiteit Maastricht.

Promotores:

Prof.dr. M.G. Faure

Prof.mr. Th.A. de Roos (Universiteit Leiden)

Beoordelingscommissie:

Prof.mr. E. Prakken (voorzitter)

Prof.mr. G.E. van Maanen

Prof.mr. A. de Nauw (Vrije Universiteit Brussel) 


\section{Strafbare Overheden}

Een rechtsvergelijke studie naar de strafrechtelijke aansprakelijkheid van overheden voor milieuverstoring 


\section{David Roef}

Strafbare Overheden. Een rechtsvergelijkende studie naar de strafrechtelijke aansprakelijkheid van overheden voor milieuverstoring

\section{ISBN 90-5095-183-X}

$\mathrm{D} / 2001 / 7849 / 25$

\section{NUGI 693}

Ontwerp: Bureau JA Vormgevers, Tilburg

(C) 2001 Intersentia Uitgevers Antwerpen - Groningen

Behoudens uitzondering door de wet gesteld, mag zonder schriftelijke toestemming van de rechthebbende(n) op het auteursrecht c.q. de uitgever van deze uitgave, door de rechthebbende(n) gemachtigd namens hem (hen) op te treden, niets uit deze uitgave worden verveelvoudigd en/of openbaar gemaakt door middel van druk, fotokopie, microfilm of anderszins, hetgeen ook van toepassing is op de gehele of gedeeltelijke bewerking. De uitgever is met uitsluiting van ieder ander onherroepelijk door de auteur gemachtigd de door derden verschuldigde vergoedingen van kopiëren, als bedoeld in artikel 17 lid 2 der Auteurswet 1912 en in het KB van 20-6-'74 (Stb. 351) ex artikel 16b der Auteurswet 1912, te doen innen door (en overeenkomstig de reglementen van) de Stichting Reprorecht te Amsterdam.

Niets uit deze uitgave mag worden verveelvoudigd en/of openbaar gemaakt door middel van druk, fotokopie, microfilm of op welke andere wijze ook, zonder voorafgaande schriftelijke toestemming van de auteur.

No part of this book may be reproduced in any form, by print, photo copy, microfilm or any other means, without written permission from the author. 


$\mid$

\section{Voorwoord}

Het schrijven van een proefschrift is een vruchtbare zoektocht naar het ideale evenwicht tussen solistisch bezig zijn en een beroep (durven) doen op de medewerking van anderen. Geen enkele dissertatie is het uitsluitende product van de schrijver. Niemand is een eiland, zelfs wanneer men zich door omstandigheden in die positie gedwongen voelt. $\mathrm{Er}$ is een aantal mensen die ik daarom graag zou willen danken voor de hulp en steun die ik van hen kreeg bij de totstandkoming van dit boek

Allereerst zijn dat mijn promotores, Prof.mr. M. Faure en Prof.mr. Th.A. de Roos. Zij waren degenen die mij tot het schrijven van Strafbare overheden hebben geïnspireerd, waarbij zij mij steeds de vrijheid lieten om in het onderzoek mijn eigen weg te gaan. Zonder hun enthousiaste en stimulerende begeleiding zou dit boek niet zijn tot stand gekomen. Ik hoop dan ook dat de waardevolle lessen die ik van hen heb geleerd in dit proefschrift terug te vinden zijn. Ik ben ook dank verschuldigd aan het faculteitsbestuur omdat zij mij de kans heeft gegeven in alle rust dit proefschrift af te ronden.

Vervolgens wil ik de leden van de beoordelingscommissie bedanken: Prof.mr. E. Prakken (voorzitter), Prof.mr. G.M. van Maanen en Prof.mr. A. de Nauw (Vrije Universiteit Brussel). Ik ben hen zeer erkentelijk voor het kritisch becommentariëren van mijn tekst.

Daarnaast wil ik het Max-Planck-Institut für ausländisches und internationales Strafrecht bedanken voor mijn aangenaam verblijf in Freiburg im Breisgau, waar ik het overgrote deel van mijn rechtsvergelijkend onderzoek heb kunnen verrichten. Ik ben vooral Prof. G. Heine dankbaar voor zijn bereidheid mij in te wijden in de finesses van het Duitse milieustrafrecht. Ook ben ik in de gelegenheid geweest enkele maanden stage te lopen bij het openbaar ministerie te Maastricht. Ik ben de arrondissementsrechtbank Maastricht en in het bijzonder (voormalig) milieuofficier Maarten Vos zeer erkentelijk voor het mogen toetsen van mijn theoretische bevindingen aan de praktijk van het milieustrafrecht.

Dan zijn er nog de collega's bij de capaciteitsgroep Strafrecht en Criminologie, het instituut METRO en de onderzoeksschool Ius Commune. Zij geven mij het gevoel op de juridische faculteit 'thuis' te zijn en zijn steeds bereid geweest mijn klaag- en vreugdezangen bij het schrijven van dit boek te aanhoren. De aangename sfeer binnen METRO en de 
capaciteitsgroep liet mij toe dit boek succcesvol af te ronden. Marina Jodogne, werkzaam als secretaresse bij METRO, verdient bovendien lof voor de zorg die zij heeft besteed aan het camera ready maken van het manuscript. Enkele collega's verdienen hier aparte vermelding. Dat is in de eerste plaats Marleen Hertoghs. Marleen, zonder jouw belangstelling voor mijn onderzoek zou dit proefschrift nooit zijn geworden tot wat het nu is. We hebben ontelbare uren gediscussieerd en jouw ideeën hebben mij enorm gestimuleerd. Ook Harmen van der Wilt en Peter Bal wil ik hier danken voor de trouwe ondersteuning tijdens 'de laatste loodjes'.

Rest mij alleen nog mijn familie en mijn Antwerpse en Brusselse vrienden te bedanken voor de belangstelling die zij hebben getoond tijdens het schrijven van dit boek.

Het manuscript is op 1 januari 2001 afgesloten. Met eventuele ontwikkelingen daarna kon slechts incidenteel rekening worden gehouden.

David Roef 


\section{Inhoudsopgave}

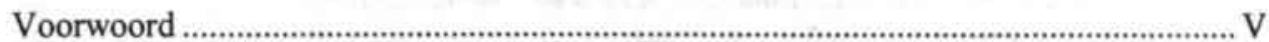

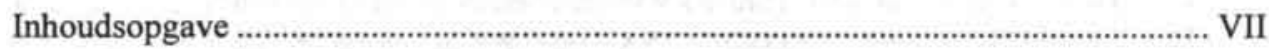

Afkortingen ……................................................................................................... XIX

\section{Hoofdstuk I}

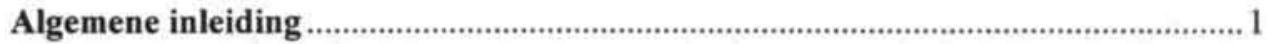

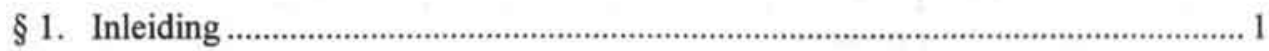

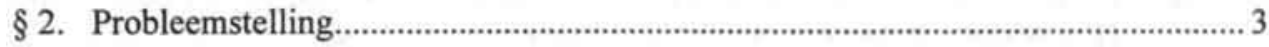

§3. Enkele belangrijke onderzoeksvragen geîllustreerd aan de hand van de Nijmeegse vuile grond affaire ....................................................................... 5

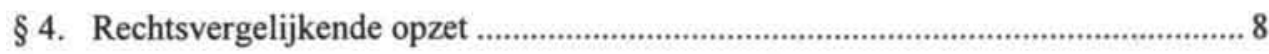

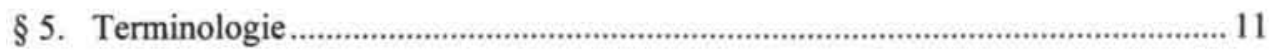

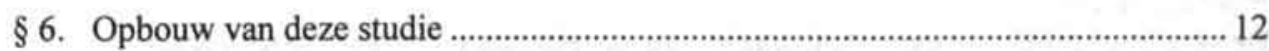

\section{Hoofdstuk II}

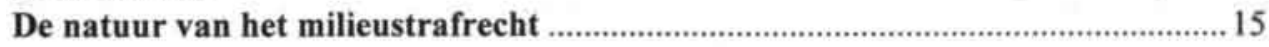

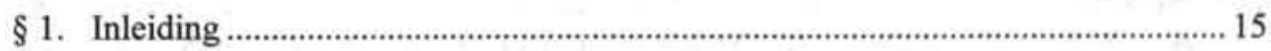

§ 2. Het rechtskarakter van het milieustrafrecht........................................................ 17

A. HET KLASSIEKE STRAFRECHT IN HET LICHT VAN HET RELATIONELE

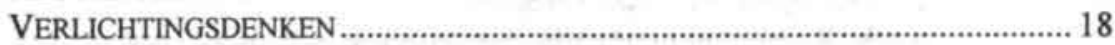

B. HET INSTRUMENTALISTISCHE KARAKTER VAN HET MILIEUSTRAFRECHT.........21

C. MILIEUSTRAFRECHT IN HET LICHT VAN DE RISICOMAATSCHAPPIJ ....................24 
1. De risicomaatschappij

2. Milieuverstoring en de risicomaatschappij

§3. Indicaties en consequenties van het rechtskarakter van het milieustrafrecht ........ 33

A. ANIMOSITEIT, ANONIMITEIT EN DE VERSNIPPERING VAN HET JURIDISCHE ..... 33

B. DE ADMINISTRATIEVE AFHANKELIJKHEID VAN HET MILIEUSTRAFRECHT........ 35

1. Het naar voren halen van de strafbaarheid. ........................................... 35

2. Verschillende vormen van administratieve afhankelijkheid ..................... 38

a. Strafbaarstelling van administratieve ongehoorzaamheid ..................... 38

b. Strafbaarstelling van het niet-naleven van vergunningsvoorschriften.. 39

c. Verwaltungsaktsakzessorietät versus Verwaltungsrechtsakzessorietät

d. Bescherming van de ecologische rechtsgoederen: concrete gevaarzettingsdelicten

3. De verbestuurlijkte inhoud van de wederrechtelijkheid.

4. De uitholling van het schuldvereiste in het milieustrafrecht.

C. HET RECHTSSTATELIJK TEKORT VAN DE ZORGPLICHTBEPALINGEN.

D. DE BESTUURSAFHANKELIJKHEID VAN HET OPENBAAR MINISTERIE . 51

E. DE VERSTARRING VAN DE ECOLOGISCHE WERKELIJKHEID 54

F. MILIEUBESCHERMING: BESCHERMING VAN DE NATUUR OF BESCHERMING VAN FEN BFHEFRSIDEOLOGIE?

§4. Consequenties en complicaties voor de strafbaarheid van overheden.

A. EEN INSTRUMENTALISTISCH MILIEUSTRAFRECHT RICHT ZICH EENZIJDIG TOT BURGERS

B. INSTRUMENTALISME, STRAFVERVOLGING VAN OVERHEDEN EN HET OM ......69

C. HET IN ELKAAR OVERVLOEIEN VAN DEMOCRATISCHE EN RECHTSSTATELUKE LEGITIMATIE

D. STRAFBAAR OVERHEIDSHANDELEN EN MILIEUSTRAFRECHTELUKE WEDERRECHTELUKHEID

$\S 5$. Conclusies

\section{Hoofdstuk III}

De strafrechtelijke aansprakelijkheid van overheden in rechtsvergelijkend perspectief.

$\S 1$. Inleiding

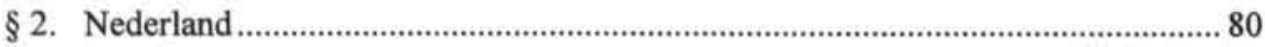

A. STRAFVERVOLGING VAN OVERHEDEN IN HET LICHT VAN ARTIKEL 51 SR ......81

B. STRAFVERVOLGING VAN OVERHEDEN IN DE RECHTSPRAAK ........................... 85

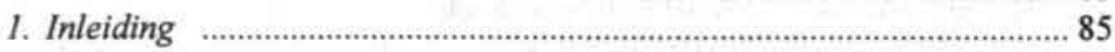

2. De rechtspraak tot aan Pikmeer II.......................................................86 86

a. Welke publiekrechtelijke rechtspersonen genieten een strafrechtelijke immuniteit? 


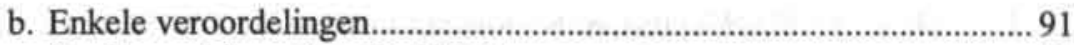

c. Strafvervolging via artikel $12 \mathrm{~Sv}$..........................................................94

d. Problemen met het taakcriterium.........................................................95

e. De irrelevantie van legaliteit .............................................................98

f. De strafvervolging van de staat: het Volkel-arrest .............................. 102

g. Strafvervolging van de leidinggevende ambtenaar: het Eerste

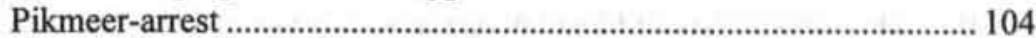

h. De reactie van het kabinet op Pikmeer I........................................... 107

i. Van Pikmeer I naar Pikmeer II........................................................ 112

3. Het Tweede Pikmeer-arrest: de Hoge Raad gaat om ............................. 114

a. De overheid staat niet boven de wet................................................... 114

b. De immuniteitscriteria zijn onbevredigend .......................................... 115

c. Nieuwe ontwikkelingen nopen tot herziening .................................... 117

d. De aanscherping van de strafrechtelijke immuniteit ........................... 118

e. Het stelsel van rechtvaardigingsgronden............................................. 119

f. Strafoplegging, strafmaat en normbevestiging .................................... 120

g. De opportuniteit van de strafvervolging ............................................ 122

h. Politieke en bestuurlijke controle sluiten strafrechte-

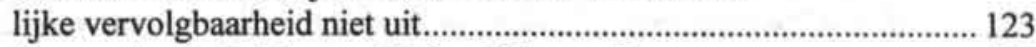

i. De reactie van kabinet en OM op Pikmeer II .................................... 123

4. Post-Pikmeer jurisprudentie ............................................................ 125

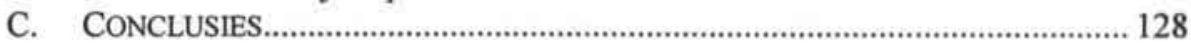

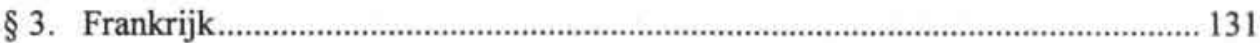

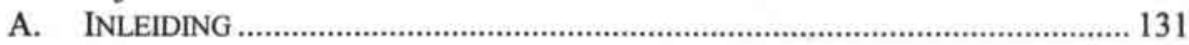

B. WETTELIJKE NIET-STRAFBAARHEID VAN OVERHEDEN ................................ 132

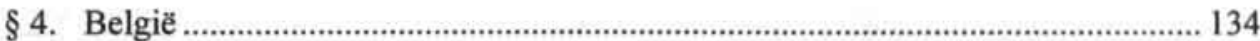

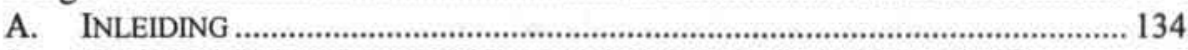

B. DE RECHTSPERSOON IN HET BELGISCHE STRAFRECHT VÓÓR DE WET VAN 4 MEI 1999

C. DE WET VAN 4 MEI 1999 TOT INVOERING VAN DE STRAFRECHTE-

LIJKE VERANTWOORDELIJKHEID VAN DE RECHTSPERSOON IN BELGIE:

EEN STAP VOORUIT?

1. Wanneer is een rechtspersoon strafrechtelijk aansprakelijk? ................ 141

a. Het materieel element........................................................................ 141

b. Het moreel element ..................................................................... 143

2. De strafbaarheid van de natuurlijke persoon en het cumulatie-

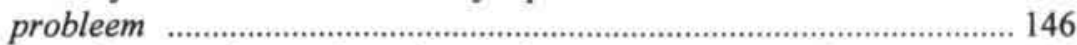

3. Cumulatieregeling in de rechtspraak ................................................ 150

D. DE STRAFRECHTELIJKE TOEREKENING VAN DOOR OVERHEDEN

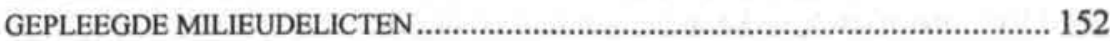

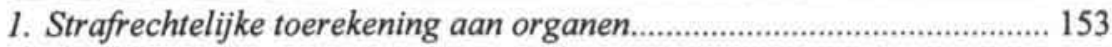

2. Cumulatieve strafrechtelijke toerekening aan leidinggevenden en ondergeschikten.

E. WAAROM ZIJN OVERHEDEN NIET STRAFRECHTELIJK VERANTWOORDELIJK? 
F. DE CIVIELRECHTELIJKE AANSPRAKELIJKHEID VAN GEMEENTE EN PROVINCIE: EEN BEDENKELIJK ALTERNATIEF.............................................. 159

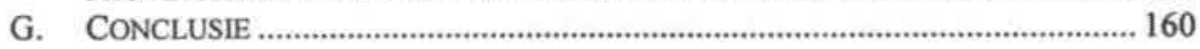

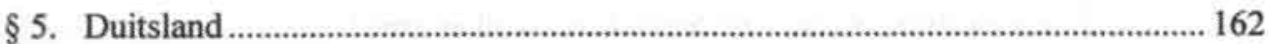

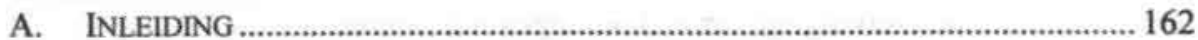

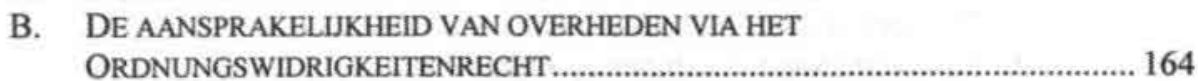

1. Algemeen ............................................................................................... 164

2. Materiële voorwaarden van de oplegging van de Verbandsgeldbuße.... 167

3. Procedurele voorwaarden van de oplegging van de

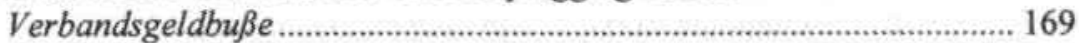

4. Zijn overheden op grond van $\S 30$ OWiG sanctioneerbaar? ................... 171

C. DE STRAFRECHTELIJKE AANSPRAKELIJKHEID VAN AMBTENAREN: DE 'ORGAN- UND VERTRETERHAFTUNG'. ...................................................... 175

1. Algemeen ................................................................................................ 175

2. Het belang van $\S 14$ StGB voor de strafrechtelijke aansprakelijkheid van ambtenaren .................................................................................. 179

3. De 'Amtsträgerstrafbarkeit' in de rechtspraak: de belangrijkste knelpunten................................................................................................ 181

a. Strafrechtelijke aansprakelijkheid van burgemeesters........................ 181

b. Strafrechtelijke aansprakelijkheid van gemeenteraadsleden .............. 186

c. Strafrechtelijke aansprakelijkheid van niet-organen (Beauftragten) .. 191

d. Milieudelicten gepleegd door nalaten: het probleem van de vereiste zorgplicht ........................................................................... 193

(1) Algemeen

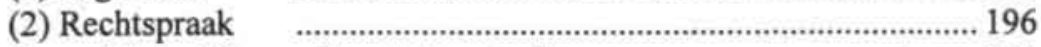

e. De problematiek van de noodtoestand ............................................. 202

(1) Financiële problemen als rechtvaardigingsgrond ........................203

(2) Conflict tussen bestuursrechtelijke en strafrechtelijke plichten ....206

4. Het standpunt van het Bundesgerichtshof........................................... 211

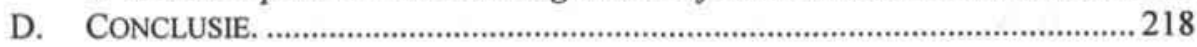

§ 6. Rechtsvergelijkende conclusies......................................................................222

\section{Hoofdstuk 4}

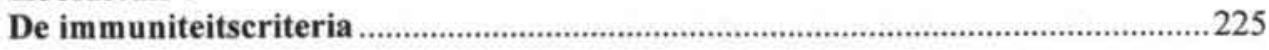

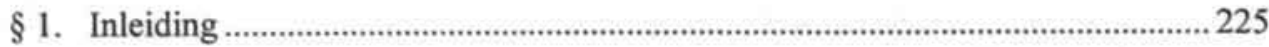

$\S 2$. Het buitenwettelijke karakter van de vervolgingsuitsluitingsgrond .....................225

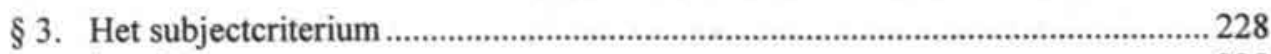

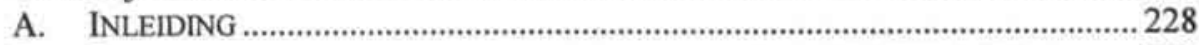

B. PUBLIEKRECHTELIJKE RECHTSPERSONEN EN OPENBARE LICHAMEN .............229 


\section{Privaatrechtelijke, publiekrechtelijke en 'strafrechtelijke'}

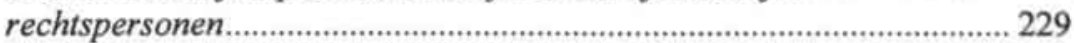

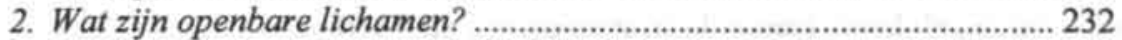

3. De bijzondere positie van de staat .......................................................... 236

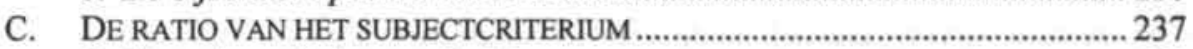

1. Verordenende bevoegdheid................................................................ 237

2. Gemeenschapsverband en publiekrechtelijke controlemechanismen ..... 238

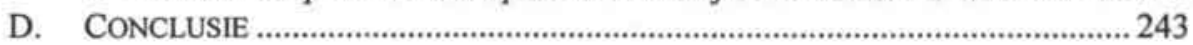

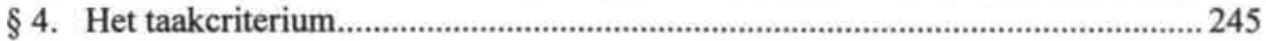

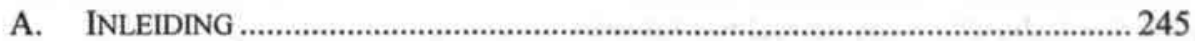

B. DE OVERHEIDSHOEDANIGHEID IN HET PERSPECTIEF VAN DE

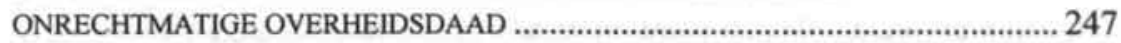

1. De overheidshoedanigheid in relatie tot de bevoegdheid van de

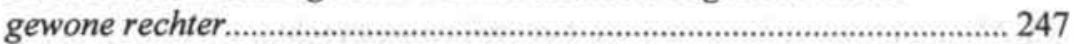

2. De overheidshoedanigheid in relatie tot de onrechtmatigheid ................253

3. De toetsing van zuiver overheidshandelen en de beleidsvrijheid ........... 255

C. EEN ZUIVERDER UITGANGSPUNT: DE OVERHEID TREEDT ALTIJD OP

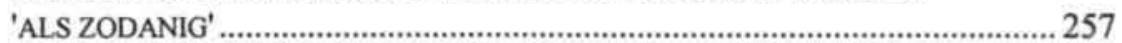

D. DE WANKELE BASIS VAN HET TAAKCRITERIUM IN PIKMEER II .......................2265

1. Het exclusiviteitselement: een schijnoplossing? ..................................... 266

2. Wat valt onder het taakcriterium? ………………............................ 268

3. De (achterhaalde) ratio van het taakcriterium .....................................272

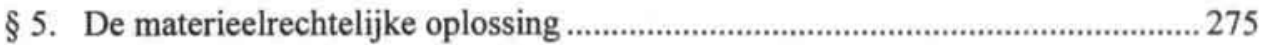

\section{Hoofdstuk V}

Argumenten voor en tegen een strafrechtelijke immuniteit van overheden

$\S 1$. Inleiding

§2. Machtenscheiding

A. ALGEMENE BEZWAREN TEGEN HET ARGUMENT VAN DE MACHTENSCHEIDING

B. DE MACHTENSCHEIDING ALS EEN ARGUMENT VOOR

STRAFRECHTELIJKE CONTROLE: DE BELGISCHE KIJK OP

RECHTERLIJKE TOETSING

1. Absolute machtenscheiding, Montesquieu en het Franse

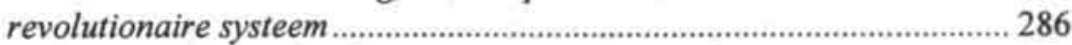

2. Absolute machtenscheiding en immuniteit van ambtenaren ................... 290

3. Artikel 159 BGW als reactie tegen de Besluitenregering van Willem I.. 293

§3. Doorkruising van politieke en bestuurlijke controle

$\S 4$. Vertrouwensverlies 
$\S 5$. Continuliteit van de openbare dienst en bestraffing van de gemeenschap

$\S 6$. De ongelijkheid tussen de staat en decentrale overheden 300

$\S 7$. De staat vervolgt zichzelf en de eenheid van de regering 302

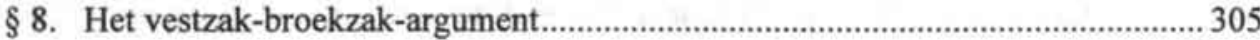

§ 9. Individuele strafrechtelijke aanpak volstaat niet ................................................... 307

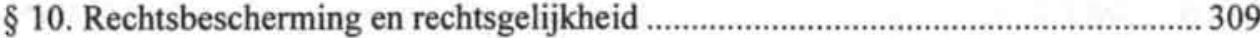

$\S 11$. Strafvervolging als correctief op de administratieve afhankelijkheid .................. 309

§ 12. Machtskritische herijking van het (milieu)strafrecht............................................. 310

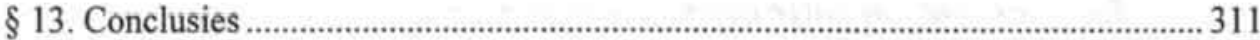

\section{Hoofdstuk VI}

Het daderschap van overheden voor milieuverstoring ….............................. 315

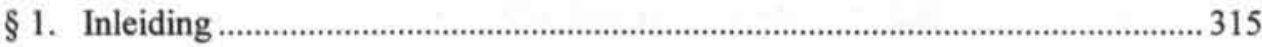

$\S 2$. De precaire verhouding tussen de strafbaarheid van de rechtspersoon en het schuldbeginsel

A. GEEN STRAF ZONDER SCHULD (OOK IN EEN RISICOMAATSCHAPPI) ...............316

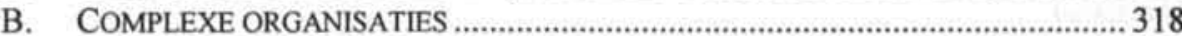

C. STRAFRECHTELIJKE AANSPRAKELIJKHEID VAN OF BINNEN DE COMPLEXE ORGANISATIE?

D. INVLOED VAN EN AANDACHT VOOR DE INSTRUMENTELE RATIO'S VAN HET MILIEUSTRAFRECHT

§ 3. Daderschapscriteria in het licht van de schuld .....................................................326

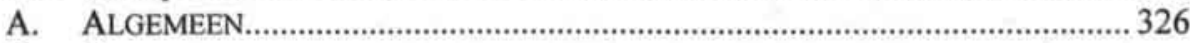

B. GEDRAGINGEN VAN ORGANEN ALS GRONDSLAG VOOR

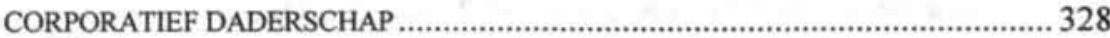

C. DE IJZERDRAADCRITERIA: EEN GELIJKSCHAKELING VAN DE RECHTSPERSOON-FUNCTIONARIS MET DE NATUURLIJKE PERSOON-FUNCTIONARIS

D. EEN CIVIELRECHTELIJKE BENADERING:

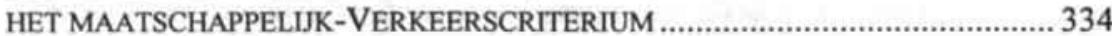

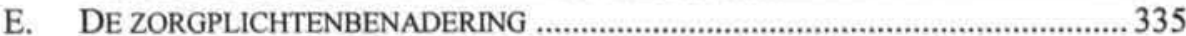

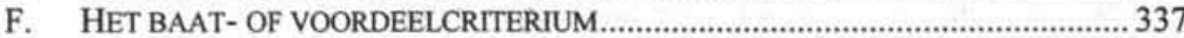

G. DE BEDRUFSVOERING VAN DE RECHTSPERSOON ALS CRITERIUM …................338

H. NIET DE BEDRIJFSVOERING, MAAR DE BEDRIJFSVOERINGSSCHULD ALS CRITERIUM 
$\S 4$. Het schuldvereiste in het milieustrafrecht

A. SCHULDELEMENT EN SCHULDVORMEN BI MILIEUDELICTEN ...........................344

B. HET ONDERSCHEID TUSSEN FUNCTIONELE EN NIET-FUNCTIONELE DELICTEN

§ 5. Daderschap bij abstracte gevaarzettingsdelicten

A. ABSTRACTE GEVAARZETTINGSDELICTEN: FUNCTIONELE DELICTEN ZONDER SUBJECTIEVE BESTANDDELEN

B. DADERSCHAP BU ABSTRACTE GEVAARZETTINGSOVERTREDINGEN ................351

C. DADERSCHAP BIJ ABSTRACTE GEVAARZETTINGSMISDRIJVEN .......................355

1. De illegale geluidswal van de gemeente Druten...................................356

2. De grafheuvel en de Rijksuniversiteit Groningen ..................................358

3. Daderschapsproblemen tengevolge van interne organisatiestructuur ... 361

§ 6. Daderschap bij concrete gevaarzettingsdelicten.

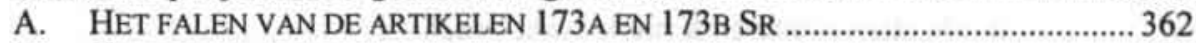

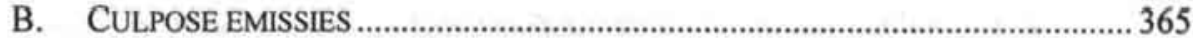

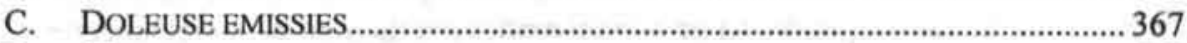

D. WETENSCHAP OF ERNSTIG VERMOEDEN VAN HET TE DUCHTEN GEVAAR ......369

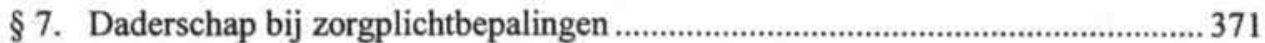

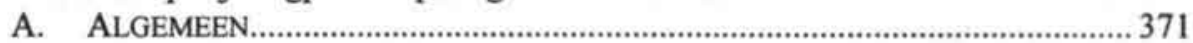

B. DE SUBJECTIEVE BESTANDDELEN IN ARTIKEL 13 WBB (EN VOLKEL).............373

C. ARTIKEL 13 WBB ALS MISDRIJF EN ALS OVERTREDING.................................374

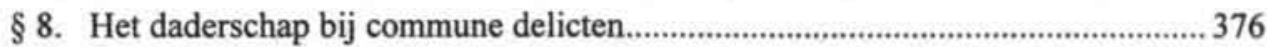

A. DE DERESPONSABILISERENDE WERKING VAN COMMUNE DELICTEN ................376

B. HET DADERSCHAP BIJ DOOD OF ZWAAR LICHAMELIJK LETSEL DOOR

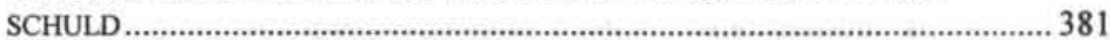

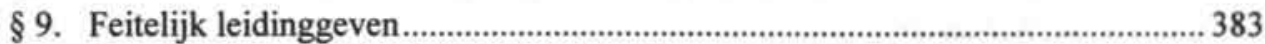

A. DE AMBIGUE VERHOUDING TUSSEN FEITELIJK LEIDINGGEVEN

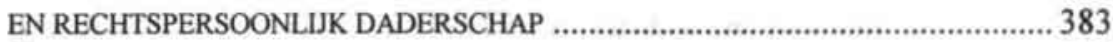

B. DE VOORWAARDEN VAN FEITELIJK LEIDINGGEVEN .....................................384

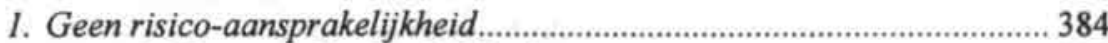

2. Het schuldvereiste bij feitelijk leidinggeven .......................................... 386

a. Feitelijk leidinggeven aan de 'bedrijfsvoering' ....................................386

b. De verwijtbare betrokkenheid bij de verboden gedraging: culpa of opzet?

3. Beschikken en aanvaarden in hoofde van de feitelijk leidinggever .........389

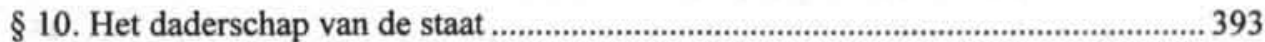

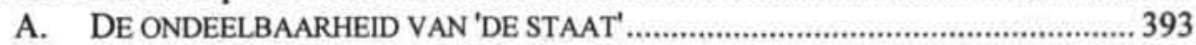

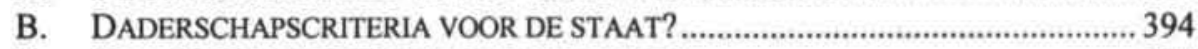

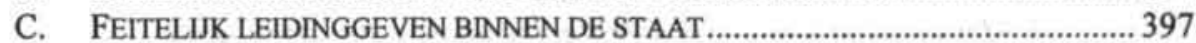

D. AFSCHEID VAN DE RECHTSPERSOONLIJKHEID VAN DE STAAT IN

HET STRAFRECHT? 


\section{Hoofdstuk VII}

Wederrechtelijke vergunningverlening

$\S 1$. Inleiding

§2. De toetsingsbevoegdheid van de strafrechter 406

A. NEDERLAND.

1. Inleiding

2. De toetsingsbevoegdheid van de strafrechter: doel en beginselen 407

3. De invloed van de formele rechtskracht op de strafrechtelijke toetsing. 410

a. De civiele rechter en formele rechtskracht.

b. De strafrechter en formele rechtskracht.

4. De invloed van de administratiefrechtelijke uitspraak op de toetsing .... 422

a. De uitspraak van de administratieve rechter en de civiele rechter...... 422

b. De uitspraak van de administratieve rechter en de strafrechter

5. Samenvatting

B. DUITSLAND

1. Inleiding

2. Een principieel toetsingsverbod: strafrechtelijke rechtmatigheid is bestuursrechtelijke rechtsgeldigheid.

3. Uitzonderingen op het principiële toetsingsverbod.

a. Met terugwerkende kracht ingetrokken beschikkingen

b. Door rechtsmisbruik aangetaste vergunningen.

c. Strafrechtelijke toetsing en $\S 330 \mathrm{~d} \mathrm{Nr} .5 \mathrm{StGB}$

d. Strafrechtelijke toetsing bij lichamelijk letsel

4. Argumenten voor en tegen een strafrechtelijk toetsingsverbod ............... 438

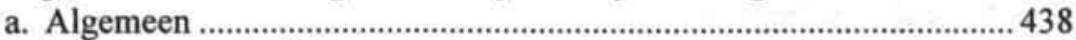

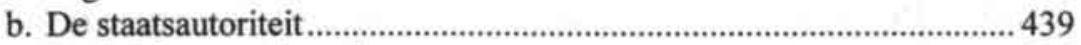

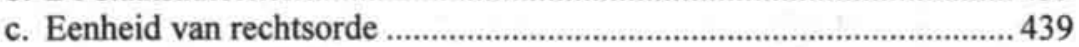

(1) Verwijst eenheid van rechtsorde naar een materiële rechtmatigheid of slechts naar een formele rechtmatigheid?

(2) De mythe van een eenduidig wederrechtelijkheidsbegrip .

d. Het vertrouwensbeginsel

e. De rechtszekerheid voor de burger.

f. De Funktionsfähigkeit van het bestuur

g. Machtenscheiding.

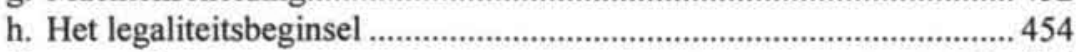

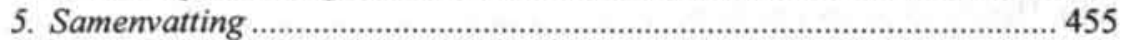

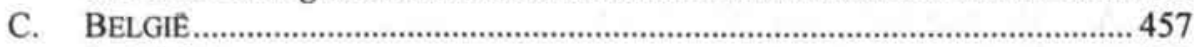

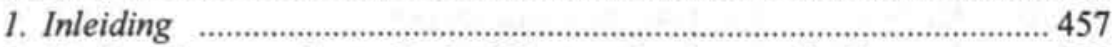

2. Het karakter van de strafrechtelijke toetsingsbevoegdheid ..................... 458

a. Artikel $159 \mathrm{BGW}$ is van openbare orde en dwingend .......................... 458

b. Artikel 159 BWG betreft ook toetsing van vergunningen.................... 459 
c. Onderscheid met het annulatieberoep bij de Raad van State

3. De invloed van de niet-gevolgde administratieve rechtsgang

4. De invloed van een administratiefrechtelijke uitspraak.

5. De schorsing van de strafvervolging hangende de administratieve rechtsgang.

6. Samenvatting

$\S 3$. De inhoud van de milieustrafrechtelijke wederrechtelijkheid

A. INLEIDING

B. AAN WELKE RECHTSNORMEN KAN DE VERGUNNING(SVOORWAARDE) WORDEN GETOETST?

1. De inhoud van de strafrechtelijke toetsing in Nederland.

a. Wettelijke toetsingsgronden

b. Grondwettelijke, internationale en Europeesrechtelijke bepalingen .. 474

c. De algemene beginselen van behoorlijk bestuur

d. Milieubeleidsregels en richtlijnen

2. De inhoud van de strafrechtelijke toetsing in België

a. Interne en externe wettigheid

b. Toetsing van de beleidsvrijheid aan redelijkheid en behoorlijkheid .. 482

3. Samenvatting

C. DE INHOUD VAN DE MILIEUSTRAFRECHTELIJKE WEDERRECHTELIJKHEID ......484

1. Van Verwaltungsaktsakzessorietät naar Verwaltungsrechtsakzessorietät

2. Eerste alternatief: koppeling aan de materiële rechtmatigheid of ook aan de formele rechtmatigheid?

3. Tweede alternatief: koppeling aan zowel materiële als formele voorschriften die het leefmilieu beschermen.

4. Derde alternatief: een autonoom strafrechtelijk wederrechtelijkheidsbegrip

D. CONCLUSIES.

§4. De strafrechtelijke aansprakelijkheid voor wederrechtelijke vergunningverlening

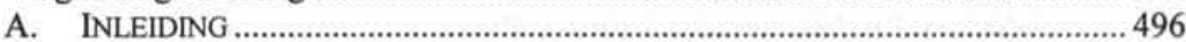

B. DUITSLAND

1. Inleiding

2. Amtsträgerstrafbarkeit volgens de heersende leer................................500 500

a. Verlening van nietige vergunningen ..............................................500

b. Verlening van onrechtmatige (rechtsgeldige) vergunningen...............501

c. Verlening van door rechtsmisbruik aangetaste vergunningen .............504

3. Enkele illustraties uit de rechtspraak .................................................... 506

a. Principieel toetsingsverbod ................................................................506

b. Gevolgen voor de Amtsträgerstrafbarkeit bij gemene milieudelicten

c. Gevolgen voor de Amtsträgerstrafbarkeit bij kwaliteitsmilieudelicten 
4. De Amtsträgerstrafbarkeit volgens de Verwaltungsrechtsakzessorische visie

a. Verlening van nietige vergunningen ...............................................5 515

b. Verlening van onrechtmatige (maar rechtsgeldige) vergunningen ..... 517

5. Amtsträgerstrafbarkeit volgens het Bundesgerichtshof..

a. Strafrechtelijke aansprakelijkheid voor (advies tot) verlening van een illegale afvalvergunning

b. Strafrechtelijke aansprakelijkheid op grond van Mittäterschaft..........521

c. Strafrechtelijke aansprakelijkheid op grond van mittelbare Täterschaft.

6. Samenvatting

C. NEDERLAND

1. Inleiding

2. De invloed van de formele rechtskracht

3. De invloed van de administratiefrechtelijke toetsing.

4. De dogmatische kwalificatie van de wederrechtelijke vergunningverlening.

a. De toepasselijkheid van de deelnemingsvormen op de (kwaliteits)milieudelicten

b. Strafbare vergunningverlening op grond van medeplegen en medeplichtigheid.

c. Strafbare vergunningverlening op grond van doen plegen en uitlokking

D. BELGIE

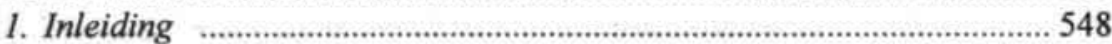

2. De strafrechtelijke toetsing van de vergunningverlening ...................... 550

3. De dogmatische kwalificatie van de wederrechtelijke vergunningverlening

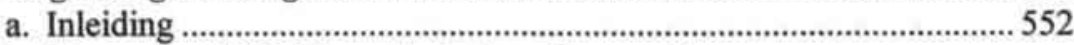

b. De toepasselijkheid van de deelnemingsregeling op (kwaliteits)milieudelicten

c. Strafbare vergunningverlening op grond van mededaderschap en medeplichtigheid

E. NAAR EEN STRAFBAARSTELLING VAN

WEDERRECHTELIJKE VERGUNNINGVERLENING?

\section{Hoofdstuk VIII}

Eindconclusies en aanbevelingen

§1. Inleiding

§ 2. Primaat van rechtsstatelijk realisme: overheden zijn onderworpen aan de regels van het strafrecht. 
§ 3. De strafrechtelijke positie van openbare lichamen: afscheid van de partie̋le immuniteit

$\S 4$. De strafrechtelijke positie van de staat: doorbreking van de absolute immuniteit en de civielrechtelijke rechtspersoonlijkheid

$\S 5$. De opportuniteit van de strafvervolging van overheden

§6. Geen vervolgingsuitsluitingsgronden maar rechtvaardigingsgronden als oplossing

$\S 7$. Het daderschap van overheden en het feitelijk leidinggeven

§ 8. Strafrechtelijke vraagstukken bij wederrechtelijke vergunningverlening

§9. Slotopmerking

Samenvatting

Summary

Literatuur

Jurisprudentieregister

Curriculum Vitae 



\section{Afkortingen}
AA
Ars Aequi
$\mathrm{AB}$
Administratiefrechtelijke beslissingen
ABRvSt
Abs.
Afdeling Bestuursrechtspraak Raad van State
AG
Absatz
amvb
APR
Advocaat-Generaal
algemene maatregel van bestuur
APV
Arr. Cass.
Art.
Awb
BS
Algemene Praktische Rechtsverzameling
Algemene Politieverordening/Algemene Plaatselijke Verordening
Arresten van het Hof van Cassatie
Artikel
(Nederlandse) Algemene wet bestuursrecht
Belgisch Staatsblad
Cass.
(Belgisch) Hof van Cassatie
corr
correctionele rechtbank
DD
e.a.
Delikt en Delinkwent
en andere
EG
Europese Gemeenschap
EHRM
e.v.
Europees Hof voor de Rechten van de Mens
en verder
EVRM
Europees Verdrag tot bescherming van de Rechten van de Mens en de fundamentele vrijheden (Verdrag van Rome, 1950)
GA
Goltdammer's Archiv für Strafrecht
HR
Hoge Raad
IVBPR
jo.
Internationaal Verdrag inzake Burgerrechten en Politieke
Rechten
juncto
JB
Jurisprudentie Bestuursrecht
Journal des Tribunaux
JTT
Jur. Liège
$\mathrm{JZ}$
Journal des Tribunaux de Travail
Jurisprudence de Liège
Juristenzeitung
JZ-GD
Juristenzeitung Gesetzgebungsdienst 
KB

kRITv

MDR

MenR

m.nt.

NJ

NJB

NJW

nr.

NStZ

NTB

O.M.

o.m.

Parl. St.

Pas.

PbEG

Pol.rb.

$\mathrm{Rb}$.

$\mathrm{RC}$

RCJB

RDP

Rev.Soc.

RIDP

m.

R\&R

RvS

RW

$\mathrm{Sr}$

Stb.

StGB

Sv

Sw

t.

TBP

TCR

TGR

TK

TMA

TMR

TPR

Trb.

TRD\&I

UPR
Koninklijk Besluit

Kritischer Verein

Monatsschrift für deutsches Recht

(Nederlands) Tijdschrift voor Milieu en Recht

met noot

Nederlandse Jurisprudentie

Nederlands Juristenblad

Neue Juristische Wochenschrift

nummer

Neue Zeitschrift für Strafrecht

Nederlands Tijdschrift voor Bestuursrecht

Openbaar Ministerie

onder meer

Parlementaire Stukken (België)

Pasicrisie (België)

Publicatieblad der Europese Gemeenschappen

Politierechtbank

Rechtbank

Rechter-Commissaris

Revue Critique de Jurisprudence Beige

Revue de Droit Pénal et de Criminologie

Revue des Sociétés

Revue Internationale de Droit Pénal

randnummer

Nederlands tijdschrift voor Rechtsfilosofie en Rechtstheorie

(Nederlandse) Raad van State

Rechtskundig Weekblad

(Nederlandse) Wetboek van Strafrecht

(Nederlands) Staatsblad

Strafgesetzbuch

(Nederlandse) Wetboek van Strafvordering

(Belgische) Strafwetboek

tegen

Tijdschrift voor Bestuurswetenschappen en Publiekrecht

Tanker Cleaning Rotterdam

Tijdschrift voor Gentse Rechtspraak

Tweede Kamer

Tijdschrift voor Milieuaansprakelijkheid

(Vlaams) Tijdschrift voor Milieurecht

Tijdschrift voor Privaatrecht

Tractatenblad

Tijdschrift voor Rechtsdocumentatie en Informatie

Umwelt- und Planungsrecht 
VLAREM I

VLAREM II

VROM

Wbb

WED

Wet RO

Wistra

Wm

Wms

WuV

Wvo

ZfU

ZRP

ZStW
Besluit van de Vlaamse Regering van 6 februari 1991 houdende vaststelling van het Vlaams Reglement betreffende de milieuvergunning

Besluit van de Vlaamse Regering van 1 juni 1995 houdende algemene en sectorale bepalingen inzake milieuhygiëne Ministerie van Volkshuisvesting, Ruimtelijke Ordening en Milieubeheer

(Nederlandse) Wet Bodembescherming

(Nederlandse) Wet op de Economische Delicten

(Nederlandse) Wet op de Rechterlijke Organisatie

Zeitschrift für Wirtschaft, Steuer und Strafrecht

(Nederlandse) Wet milieubeheer

(Nederlandse) Wet milieugevaarlijke stoffen

Wirtschaft und Verwaltung

(Nederlandse) Wet verontreiniging oppervlaktewateren

Zeitschrift für Umweltrecht

Zeitschrift für Rechtspolitik

Zeitschrift für die gesamte Strafrechtswissenschaft 



\title{
Algemene inleiding
}

\begin{abstract}
De jurist komt zo zeer onder de indruk van het handelen van de overheid in het algemeen belang, dat hij zich dit handelen nauwelijks als onrechtmatig kan denken. ${ }^{l}$
\end{abstract}

\section{§ 1. Inleiding}

Het Nederlandse milieustrafrecht staat volop ter discussie. Mede naar aanleiding van enkele spectaculaire milieustrafzaken, zoals de TCR-zaak, richt het rechtsgeleerd onderzoek zich voornamelijk op de effectiviteit van de strafbaarstellingen in het milieustrafrecht. Zo wordt in de doctrine steeds meer kritiek geuit op de nadelen van de administratieve afhankelijkheid in het milieustrafrecht. ${ }^{2}$ Daarnaast wordt ook de werking van de in 1989 ingevoerde artikelen $173 \mathrm{a}$ en $173 \mathrm{~b} \mathrm{\textrm {Sr } ^ { 3 }}$ en de rechtsstatelijke gepastheid van de strafrechtelijke handhaving van zorgplichtbepalingen ${ }^{4}$ in vraag gesteld. Er kan worden gewezen op het proefschrift van Koopmans, De strafbaarstelling van milieuverontreiniging ${ }^{5}$ en het recent gepubliceerde onderzoek van Faure en Visser, De strafrechtelijke bescherming van het

1. Schoordijk, H.C.F., Bestuursrecht en privaatrecht, Deventer, 1984, 6. Tevens aangehaald in Foqué, R., De ruimte van het recht, Amhem, Gouda Quint, 1992, 36.

2. Zie o.m. Faure, M.G., 'De gevolgen van de "administratieve afhankelijkheid" van het milieustrafrecht: een inventarisatie van knelpunten", in Faure, M.G., Oudijk, J.C. en Schaffmeister, D. (red.), Zorgen van heden. Opstellen over het milieustrafrecht in theorie en praktijk, Arnhem, Gouda Quint, 1991, 91-150. Zie over deze administratieve afhankelijkheid of het bestuursaccessoire karakter van het milieustrafrecht nader hoofdstuk II.

3. Zie o.m. De Jonge, L., 'Praktische problemen bij de strafrechtelijke handhaving", in Biezeveld, G.A., e.a. (red.), Strafrechtelijke aanpak van grensoverschrijdende milieucriminaliteit, Capita Selecta, Zwolle, W.E.J. Tjeenk Willink, 1996, 243-247; Faure, M., 'Het Nederlandse milieustrafrecht: dringend aan herziening toe!', Rechtsgeleerd Magazijn Themis, 1997, 3-12.

4. Zie o.m. Visser, M., 'Uitholling van het schuldbeginsel bij zorgplichtbepalingen door schending van het lex certa-beginsel', in Borgers, M.J., Koopmans, I.M. en Kristen, F.G.H. (red.), Verwijtbare uitholling van schuld?, Ars Aequi Libri, Nijmegen, 1998, 65-80.

5. Koopmans, I., De strafbaarstelling van milieuverontreiniging, Arnhem, Gouda Quint, 1996. 
leefmilieu in België, Duitsland en Nederland. ${ }^{6}$ In beide studies worden vanuit rechtsvergelijkend perspectief de verschillende modellen van strafbaarstelling kritisch onderzocht en worden enkele concrete aanbevelingen ter verbetering van het Nederlandse milieustrafrecht geformuleerd.

Doorgaans wordt het milieustrafrecht onderzocht vanuit de vrij vanzelfsprekende vraagstelling hoe de wetgever en de verschillende voor de bescherming van het leefmilieu verantwoordelijke instanties kunnen bijdragen tot een efficiëntere bestrijding van milieuverstoring. De laatste jaren wordt de discussie rond de instrumentele en de rechtsstatelijke waarde van het milieustrafrecht echter op de spits gedreven door de ontnuchterende vaststelling dat niet alleen bedrijven en burgers, maar ook overheden en bestuursfunctionarissen zich schuldig maken aan strafbare milieuverstoring. Er kan worden vastgesteld dat overheden in toenemende mate worden geverbaliseerd en voor de strafrechter verantwoording moeten afleggen voor door hen gepleegde milieudelicten.

Het is overduidelijk dat betekenis en nut van het milieustrafrecht sterk op de proef worden gesteld wanneer overheden van burgers gehoorzaamheid aan milieuvoorschriften verlangen terwijl deze zelf vaak schaamteloos de milieuregelgeving overtreden. Dit doet de cruciale vraag rijzen of niet alleen particulieren, maar ook overheden onder de werking van het milieustrafrecht vallen. Een essentieel kenmerk van een rechtsstaat is immers dat de overheid aan wet en recht is gebonden. Dit impliceert onder meer dat elk overheidshandelen in beginsel aan rechterlijke controle is onderworpen. Het is de heerschappij van het recht die de overheid aanspraak geeft op gehoorzaamheid van de burger aan de op democratische wijze tot stand gekomen rechtsregels. ${ }^{7}$ Maar is de overheid ook gebonden aan de regels van het (milieu)strafrecht en zijn milieuverstorende overheidsgedragingen ook aan (milieu)strafrechtelijke controle onderworpen?

Dit lijkt een zuiver retorische vraag. Waarom zou een overheid die aan bestuursrechtelijke en privaatrechtelijke regels is onderworpen boven de strafwet mogen staan? Toch dienen volgens de Hoge Raad overheden van de werking van het strafrecht te worden uitgesloten, althans in bepaalde gevallen. Zo heeft de Hoge Raad in 1994 in een zaak waarin voor het eerst de Staat der Nederlanden was gedagvaard, wegens bodemvervuiling op de vliegbasis Volkel, geoordeeld dat de staat voor zijn handelingen niet strafrechtelijk verantwoordelijk is en daarom niet kan worden vervolgd. ${ }^{8}$ De staat geniet een absolute strafrechtelijke immuniteit. In eerdere rechtspraak heeft de Hoge Raad reeds geoordeeld dat ook openbare lichamen, zoals gemeenten, een strafrechtelijke immuniteit genieten, zij het onder de voorwaarde dat het gepleegde delict moet zijn begaan bij de behartiging van een wettelijke

6. Faure, M. en Visser, M., De strafrechtelijke bescherming van het leefmilieu in België, Duitsland en Nederland. Modellen van strafbaarstelling en hun bewijsrechtelijke implicaties, AntwerpenGroningen, Intersentia, 1999.

7. Vgl. Witteveen, W.J., 'Staat de overheid boven de wet', in Elzinga, D.J. (red.), Strafbaarheid van overheden, Publikaties van de staatsrechtkring, Zwolle, W.E.J. Tjeenk Willink, 1998, 1.

8. HR 25 januari 1994, NJ 1994, 598 met noot Corstens. De rechtspraak van de Hoge Raad komt vanzelfsprekend later nog uitgebreid aan bod: zie hoofdstuk III. 
bestuurstaak. ${ }^{9}$ Openbare lichamen genieten dus een partiële strafrechtelijke immuniteit. In het Eerste Pikmeer-arrest van 23 april 1996 werd de strafrechtelijke overheidsimmuniteit bovendien uitgebreid tot ambtenaren en arbeidscontracten die aan het strafbare overheidshandelen feitelijk leidinggeven. ${ }^{10}$ Recentelijk is met het Tweede Pikmeer-arrest van 6 januari 1998 een belangrijke koerswijziging ontstaan in de strafvervolging van overheden." doctrine op zijn eerdere jurisprudentie, de strafrechtelijke immuniteit herzien: openbare lichamen genieten slechts nog strafrechtelijke immuniteit wanneer het strafbare feit is begaan bij de uitvoering van een wettelijke bestuurstaak mits deze rechtens alleen door bestuursfunctionarissen kan worden uitgevoerd. Met deze uitspraak werd de immuniteit van openbare lichamen beperkt tot zogenaamde exclusieve bestuurstaken, en is derhalve een belangrijke opening gecreëerd in de mogelijkheid om overheden strafrechtelijk te vervolgen voor door hen gepleegde milieudelicten. Gevallen die vroeger op een nietontvankelijkheidsoordeel stuitten, zoals het illegaal storten van afval, zijn nu wel vervolgbaar. Niettemin blijft een aantal zaken onopgehelderd. Zo rijst bijvoorbeeld de vraag waarom openbare lichamen (alleen) bij zuivere bestuurstaken nog steeds een strafrechtelijke immuniteit genieten en waarom de staat in geen enkel geval kan worden vervolgd. Deze uitspraken van de Hoge Raad over de strafvervolging van overheden vormen de concrete aanleiding van deze studie.

\section{§ 2. Probleemstelling}

De probleemstelling van dit onderzoek luidt aldus:

Kunnen overheden voor milieuverstoring strafrechtelijk aansprakelijk worden gesteld, en moet een strafrechtelijke aansprakelijkheid alsnog mogelijk zijn wanneer deze in bepaalde gevallen wordt uitgesloten?

Hoewel het vraagstuk van de strafrechtelijke aansprakelijkheid van overheden vanzelfsprekend niet slechts betekenis heeft voor milieudelicten, is deze probleemstelling juist voor het milieustrafrecht van groot belang. Niet voor niets zijn de meeste strafzaken waar het overheidsoptreden in geding is vrijwel steeds milieustrafzaken. Twee situaties dienen daarbij van elkaar te worden onderscheiden.

De eerste is die waarin het milieudelict zelf rechtstreeks door een overheid wordt begaan, zoals het wederrechtelijk uitbaten van een stortplaats door een gemeente. Het betreft dan een klassiek geval van corporatieve milieucriminaliteit met dit belangrijke verschil dat de milieuverstoring niet plaatsvindt binnen een commerciële onderneming, maar binnen een publiekrechtelijke organisatie. Deze situatie heeft tot nu toe in de Nederlandse rechtspraak

9. Zie o.m. HR 23 oktober 1990, NJ, 1991, 496 met noot Schalken (Voorburgse reigersnesten); HR 9 juni 1992, NJ 1992, 794 (Streekgewest Oostelijk Zuid-Limburg).

10. HR 23 april 1996, $N J 1996,513$ met noot 't Hart (Pikmeer I)

11. HR 6 januari 1998, $N J$ 1998, 367 (Pikmeer II) 
en doctrine de meeste aandacht gekregen en zal daarom in deze studie het meest aan bod komen.

Belangrijk is echter ook een tweede scenario waar overheden niet rechtstreeks een milieudelict plegen, maar op onrechtstreekse wijze door onzorgvuldige vergunningverlening of gebrekkige controle bijdragen tot milieuverstoring, die door derden wordt veroorzaakt. Het belang van een mogelijke strafrechtelijke aansprakelijkheid van overheden in dergelijke gevallen houdt ten zeerste verband met de wijze waarop het huidige milieustrafrecht is geconcipieerd. Het milieustrafrecht wordt gekenmerkt door een 'administratieve afhankelijkheid', een sterke verwevenheid tussen strafrecht en bestuursrecht. De voorwaarden van strafbaarheid worden in belangrijke mate door het bestuursrecht beïnvloed. Milieuoverheden spelen hierbij een cruciale rol. Zij bepalen ingevolge de administratieve afhankelijkheid de toelaatbare graad van verontreiniging door het vaststellen van emissienormen in vergunningen en ontheffingen. $\mathrm{Zij}$ zijn eveneens verantwoordelijk voor het toezicht op de naleving van de milieuregelgeving. De uitoefening door deze administratieve instanties van de aan hen toegekende bevoegdheden op het vlak van vergunningverlening en handhaving heeft dan ook een aanzienlijke invloed op de kwaliteit van het leefmilieu. Zowel gebrekkige vergunningverlening als falende controle op milieuverstorende activiteiten bemoeilijken de strafvervolging van de daders en kunnen daarom leiden tot een verdergaande aantasting van het leefmilieu. De vraag rijst dan in hoeverre milieuoverheden en de daarin werkzame functionarissen strafrechtelijk aansprakelijk kunnen worden gesteld indien door hun falen milieudelicten worden gepleegd of in stand worden gehouden. In tegenstelling tot bijvoorbeeld Duitsland krijgt deze problematiek in het Nederlandse milieurecht nauwelijks aandacht. In dit boek wordt daarom ook stilgestaan bij deze meer indirecte vormen van door overheden veroorzaakte milieuverstoring. De aandacht gaat in deze studie voornamelijk uit naar het probleem van de wederrechtelijke vergunningverlening, omdat de 'macht' van de vergunning in het milieustrafrecht, in het bijzonder de strafuitsluitende werking van de vergunning, duidelijk de kern raakt van de administratieve afhankelijkheid. Teneinde de omvang van dit boek binnen redelijke proporties te houden, komt de strafrechtelijke aansprakelijkheid voor gebrekkige controle niet aan bod. Ik heb er bovendien voor gekozen de problematiek van falend toezicht in een afzonderlijke publicatie over 'De gevolgen van gedogen in het milieustrafrecht' te behandelen.

De relevantie van de probleemstelling moge duidelijk zijn: juist in een rechtsgebied als het milieurecht, waar overheden zelf via de verschillende verantwoordelijke bewindslieden vorm en inhoud geven aan regelgeving enerzijds en de handhaving ervan anderzijds, is de vraag gerechtvaardigd of deze overheden strafrechtelijk ter verantwoording kunnen worden geroepen wanneer zij zelf de milieuwetgeving met de voeten treden.

Het is nuttig om in dit inleidend hoofdstuk de probleemstelling aan de hand van een concrete casus nader te illustreren en uit te werken. Zo wordt ook duidelijk tot welke verschillende onderzoeksvragen de probleemstelling aanleiding geeft. 


\section{§ 3. Enkele belangrijke onderzoeksvragen geillustreerd aan de hand van de Nijmeegse vuile grond affaire}

Een burger meldt begin '95 bij de Regionale Criminele Inlichtingendienst (R-CID) in Nijmegen dat de Centrale Vervoersdienst (CVD) van Nijmegen het bij slagerijen en horeca-gelegenheden opgehaalde vet in het riool loost. Het gaat hoofdzakelijk om frituurvet en slaolie. Hoewel de politie in eerste instantie de anonieme tip niet wil geloven, gaan een paar agenten in burger toch op onderzoek uit en volgen zij twee wagens van de CVD. Zij stellen vast hoe twee reinigingsagenten in de Bredestraat een putdeksel oplichten en het opgehaalde vet in de riolering laten lopen. ${ }^{12}$ Naar aanleiding van deze observatie wordt een grootscheeps politie-onderzoek gestart. Na enkele weken wordt duidelijk dat de Nijmeegse Stadsreiniging reeds sinds 1981 met deze illegale methode werkt en dat de vetlozingen slechts de top van de ijsberg zijn. ${ }^{13}$

Tijdens het onderzoek wordt een aannemer betrapt op het illegaal storten van afval op de militaire vliegbasis Delen. Snel blijkt dat hij goede contacten heeft met een milieuambtenaar bij de afdeling Grondzaken, die in strijd met de wet verklaringen van 'goede grond' afgeeft mits daarvoor de juiste prijs wordt betaald. De ambtenaar wordt verhoord en onthult dat zijn gedrag niet zo uitzonderlijk is binnen de gemeente Nijmegen. Er zou met illegale vergunningen ernstig vervuilde grond worden verplaatst en stelselmatig niet worden gesaneerd. Het OM besluit om de gehele gemeente Nijmegen door te lichten en ontdekt dat niet alleen de afdeling Grondzaken, maar ook de afdeling Milieu, die trouwens geen eigen adviesbevoegdheid heeft en slechts deel uitmaakt van de afdeling Volkshuisvesting, en de afdeling Weg- en Waterbouw bij de illegale activiteiten betrokken zijn. Vanaf de periode ' 90 -'91 blijkt door de gemeente op een dertiental lokaties vervuilde grond te zijn gestort. Deze lokaties zijn voor het publiek toegankelijk en op sommige plaatsen is de grond zelfs dermate vervuild dat kan worden aangetoond dat gevaar voor de menselijke gezondheid bestaat. De opdracht van de provincie om de vervuilde grond met schone grond af te dekken wordt door de gemeente niet uitgevoerd. De situatie wordt alleen maar erger: de reeds vervuilde grond wordt met andere lagen vervuilde grond bedekt. Ook de verschillende waarschuwingen van de afdeling Milieu van de gemeente worden door de andere afdelingen niet au serieux genomen. Wanneer in de gemeente een stadvernieuwingsproject moet worden gerealiseerd, graaft men uiteindelijk de vervuilde grond weg en stort men deze vervolgens op een illegale stortplaats.

Tijdens het strafrechtelijk onderzoek van deze illegale grondtransporten en gronddeponeringen, krijgt het $\mathrm{OM}$ te maken met een aantal juridische problemen. Zo blijkt een aantal delicten reeds te zijn verjaard, daar het gaat om overtredingen waarop een verjaringstermijn van twee jaar staat. Het $\mathrm{OM}$ wil vanwege bewijsproblemen deze delicten niet als misdrijven ten laste leggen. Er wordt ook overwogen om op basis van valsheid in

12. X, 'Nijmegen steekt hand in eigen boezem, maar niet te diep', Handhaving, 1996, nr.1, 12.

13. Zie over deze casus tevens Jansen, M.V.C., Overtredende overheden. Een analyse-model voor overheidscriminaliteit, Landbouwuniversiteit Wageningen, 1998, registratienummer: 72-01-16393-100. 
geschrifte te vervolgen, maar ook dit zou volgens het OM moeilijk kunnen worden bewezen. ${ }^{14}$ Het belangrijkste obstakel is echter het Eerste Pikmeer-arrest waarin de Hoge Raad niet alleen de strafrechtelijke immuniteit van openbare lichamen bevestigde maar deze ook nog uitbreidde tot de feitelijke leidinggevers. Dit zorgt er uiteindelijk voor dat het $\mathrm{OM}$ de zaak seponeert. Het $\mathrm{OM}$ overweegt nog wel om enkele individuele ambtenaren te vervolgen, maar acht dit niet rechtvaardig omdat het hier duidelijk gaat om het falen van een hele overheidscultuur. Milieugroeperingen trachten om het sepot van de officier aan te vechten door de beklagprocedure neergelegd in artikel $12 \mathrm{~Sv}$ in te stellen, maar daar de beroepstermijn van twee maanden is verstreken, komt dit protest te laat.

Er wordt uiteindelijk dus geen rechter in deze vuile grond-zaak betrokken. Pas op het moment dat het strafrechtelijk onderzoek ophoudt legt de provincie aan de gemeente een saneringsplicht op. De politieke controle binnen de gemeente laat ook te wensen over. De Nijmeegse gemeenteraad wordt gevraagd een oordeel te vellen over de affaire. Dat blijkt zowel de meerderheid van de raad als B\&W niet nodig te vinden. Een dertiental raadsleden zijn het hiermee niet eens en spannen op basis van de gemeentewet een kort geding aan om alsnog inzage te krijgen in de dossiers teneinde een diepgaand politiek debat uit te lokken. De rechter acht de gemeentewet hiervoor niet geschikt en wijst het verzoek af. Van democratische controle komt weinig terecht. Uiteindelijk slaagt de krant de Gelderlander er wel in om op grond van đe wet openibaarheid van bestuur de stuḱḱken in te zien. Mied̉e naar aanleiding van de media-aandacht heeft er ondertussen wel een aantal veranderingen plaatsgevonden binnen de gemeente. De afdeling Milieu is vernieuwd en uitgebreid. Nog maar vijftig procent van het aantal mensen dat oorspronkelijk op deze dienst werkzaam was, werkt nog op deze afdeling. De afdeling Grondzaken is gereorganiseerd en er is een gemeentelijke rekenkamer ingesteld die op de compensatieregeling voor aannemers moet toezien en de administratie moet controleren. ${ }^{15}$

De Nijmeegse vuile grond-affaire illustreert treffend het belang en de complexiteit van een mogelijke strafrechtelijke aansprakelijkheid van overheden voor milieuverstoring en ook de verschillende onderzoeksvragen die in dat verband moeten worden beantwoord.

In de eerste plaats is er de vraag wanneer overheden naar huidige recht strafrechtelijk kunnen worden vervolgd. Dat het OM in deze zaak tot seponering is overgegaan, houdt rechtstreeks verband met de door de Hoge Raad gecreëerde immuniteit voor overheden. In de periode van het strafrechtelijk onderzoek was een gemeente immers niet vervolgbaar indien het delict is begaan bij de uitvoering van een wettelijke overheidstaak, ook al kan deze in de praktijk door particulieren worden uitgevoerd. In dit geval betekende dit dat het OM weinig kans van slagen had om de gemeente Nijmegen of één van haar leidinggevende ambtenaren voor de illegale grondtransporten en -storten met succes voor de strafrechter te brengen. Hoewel inmiddels met Pikmeer II de immuniteitscriteria door de Hoge Raad zijn bijgesteld, is de kwestie welke overheidsgedragingen vervolgbaar zijn nog niet volledig uitgekristalliseerd. Bij zuivere bestuurstaken blijft de immuniteit immers bestaan. Dit doet 
niet alleen de vraag rijzen wanneer een overheidsgedraging moet worden aangemerkt als uitgevoerd binnen het kader van een zuivere bestuurstaak, maar vooral of enig onderscheid in type overheidsgedraging een strafrechtelijke immuniteit kan rechtvaardigen. Het illegaal verplaatsen en storten van vervuilde grond zou nu wellicht kunnen worden vervolgd, daar dergelijke handelingen volgens Pikmeer II niet uitsluitend door bestuursfunctionarissen, maar ook door derden, zoals aannemers, kunnen worden uitgevoerd. Maar hoe zit het bijvoorbeeld met de verlening van illegale vergunningen, die in casu het grondtransport hebben mogelijk gemaakt? Vergunningverlening is immers een strikte overheidstaak en valt daarom onder de strafrechtelijke immuniteit. Kortom, een eerste belangrijke onderzoeksvraag die in deze studie wordt behandeld is onder welke voorwaarden overheden strafrechtelijk kunnen worden vervolgd voor door hen gepleegde milieudelicten. Meer bepaald moet worden onderzocht of strafvervolging in alle gevallen mogelijk moet worden of dat er daarentegen situaties denkbaar zijn waarin dit moet worden uitgesloten.

Dit brengt ons tot een tweede meer principiële onderzoeksvraag, namelijk waarom overheden een strafrechtelijke immuniteit zouden moeten genieten: wat zijn de argumenten tegen een strafrechtelijke controle van overheden? Daarmee hangt samen de vraag of het gerechtvaardigd is dat de staat een ruimere immuniteit geniet dan andere overheden. Ter verdediging van een strafrechtelijke immuniteit zou kunnen worden betoogd dat een strafrechtelijke controle op overheidshandelen onwenselijk is omdat de machtenscheiding zich hiertegen verzet, of omdat bijvoorbeeld de bestuurlijke beleidsvrijheid en de interne democratische controle worden doorkruist. Ook zou kunnen worden verdedigd dat alternatieve verantwoordingsmechanismen, zoals bestuurlijk toezicht door hogere overheden, reeds voldoende in staat zijn het verboden overheidsoptreden te controleren en te sanctioneren. De Nijmeegse affaire illustreert echter dat de overheid hier zijn beleidsvrijheid schromelijk heeft misbruikt en dat politieke of bestuurlijke alternatieven niet steeds blijken te werken zodat wellicht toch plaats is voor een strafrechtelijke aanpak van overheidscriminaliteit.

In de derde plaats geeft deze affaire goed weer dat binnen overheidskader gepleegde milieucriminaliteit doorgaans de verantwoordelijkheid van individuele personen overstijgt. In beginsel is een vervolging van individuele ambtenaren natuurlijk best mogelijk, temeer wanneer sprake is van ambtsdelicten. Maar zelfs indien er op dat vlak geen onoverkomelijke bewijsproblemen zouden bestaan, rijst toch de vraag of een dergelijke individualisering van hoofdzakelijk collectieve en organisatorische strafbare gedragingen een efficiënte en rechtvaardige strafrechtelijke aanpak van overheidscriminaliteit uitmaakt. Een cruciale onderzoeksvraag is op welke manier zowel instrumenteel gezien als vanuit rechtsbeschermend oogpunt zo goed mogelijk de strafrechtelijke aansprakelijkheid van overheden en hun ambtenaren kan worden geëffectueerd. Dit betekent onder meer dat moet worden bekeken in welke gevallen een vervolging van de overheid, van de verantwoordelijke ambtenaren of van beiden in de rede ligt. Wat moet worden vermeden is dat diegenen waarbij de verantwoordelijkheid het zwaarste doorweegt (de organisatie of bepaalde individuen) strafrechtelijk vrijuit gaan of dat op ondoordachte wijze met een strafrechtelijke controle op overheidsgedragingen wordt omgegaan. 
In de vierde plaats doet de vaststelling dat de verantwoordelijkheid voor het strafbaar gedrag veeleer moet worden geplaatst bij de organisatie als geheel en niet slechts bij enkele individuele personen belangrijke materiële aansprakelijkheidsvragen rijzen, meer bepaald de vraag wanneer de overheid in kwestie als dader van een milieudelict moet worden beschouwd. Eens wordt aanvaard dat strafvervolging van een overheid mogelijk moet zijn, moet over de grond van de zaak worden geoordeeld en dient het daderschap in hoofde van de overheid te worden vastgesteld. Nu sinds Pikmeer II strafvervolging van overheden makkelijker is geworden, is deze vraag aan belang toegenomen en zal de strafrechter moeten beoordelen wanneer de verdachte overheid geacht wordt een strafbaar feit te hebben gepleegd. Een belangrijke onderzoeksvraag is daarom welke daderschapscriteria kunnen worden toegepast om overheden strafrechtelijk aansprakelijk te stellen voor door hen gepleegde milieudelicten. Deze vraag krijgt een bijzondere dimensie wanneer we vaststellen, zoals ook uit de Nijmeegse casus blijkt, dat 'de mate van schuld' niet alleen in de tijd maar ook over verschillende afdelingen en sub-afdelingen is verspreid. Daarnaast is er het probleem dat voor een zelfde milieuverstorende gedraging doorgaans verschillende delicten voor een concrete tenlastelegging in aanmerking kunnen komen, waaronder zelfs commune delicten als valsheid in geschrifte. Dit betekent dat per type (milieu)delict moet worden bekeken wanneer een overheid als dader kan worden aangemerkt.

In dit boek wordt op deze vragen een antwoord gegeven. Dit gebeurt in de eerste plaats vanuit een beschrijving en analyse van het huidige positieve recht. Op basis daarvan wordt getracht, zo nodig, aanbevelingen te geven voor verbetering. Natuurlijk kan de probleemstelling ook op een andere manier worden uitgewerkt. Zo zou men kunnen overwegen om de aandacht niet alleen op het strafrecht te richten, maar ook op een analyse en voorstellen tot verbetering van bestuursrechtelijke of civielrechtelijke alternatieven. Of men zou naast milieucriminaliteit ook andere vormen van overheidscriminaliteit bij het onderzoek kunnen betrekken. De in deze studie gemaakte keuzes over te behandelen onderzoeksvragen zijn echter voornamelijk bepaald en afgebakend door enerzijds een zuiver milieustrafrechtelijke benadering en anderzijds een strafrechtsdogmatische invalshoek waarbij vraagstukken als strafvervolging, strafrechtelijke toetsing van overheidshandelen, wederrechtelijkheid, schuld en daderschap centraal staan.

\section{§4. Rechtsvergelijkende opzet}

De vraag of overheden en hun ambtenaren strafrechtelijk aansprakelijk kunnen worden gesteld voor milieuverstoring wordt in dit boek grotendeels vanuit de rechtsvergelijking bekeken. Het zal niemand verbazen dat door overheden gepleegde milieucriminaliteit niet een typisch Nederlands probleem is.

Een belangrijk deel van de behandelde vragen komt uitvoerig in de Nederlandse rechtspraak en doctrine aan bod. Andere onderwerpen komen evenwel niet expliciet in de Nederlandse literatuur aan de orde, terwijl dit wel het geval is in een aantal andere rechtsstelsels. Bovendien is het aardig om vast te stellen dat vragen waaraan in alle bestudeerde rechtsstelsels aandacht wordt besteed, kunnen leiden tot soms gelijke, maar vaak ook tot verschillende oplossingen. Daarom lijkt de rechtsvergelijking bij uitstek een 
aangewezen weg om inzicht te krijgen in de probleemstelling. Daarbij zal voornamelijk worden gekeken naar de situatie in Duitsland en België. Ook Frankrijk komt terloops aan bod. Er zijn verschillende redenen waarom voor deze landen is gekozen.

In het Duitse milieustrafrecht wordt in toenemende mate aandacht besteed aan de rol van overheden bij de totstandkoming van milieudelicten. Met name sinds de invoering vanaf 1 juli 1980 van milieustrafbepalingen in het Strafgesetzbuch, die in beginsel ook toepasbaar zijn op door overheden veroorzaakte milieuverstoring, wordt in de Duitse doctrine uitvoerig besproken op welke wijze door overheden gepleegde milieucriminaliteit strafrechtelijk moet worden aangepakt. De problematiek krijgt daar zelfs zoveel aandacht dat dit onder de term 'Amtsträgerstrafbarkeit' een zelfstandig strafrechtelijk leerstuk is geworden. ${ }^{16}$ Wat de Duitse situatie zo interessant maakt, is dat in tegenstelling tot Nederland het Duitse strafrecht niet de strafrechtelijke aansprakelijkheid van de rechtspersoon kent zodat overheden niet als (publiekrechtelijke) rechtspersonen kunnen worden vervolgd. Dit betekent dat wanneer een overheid, bijvoorbeeld een gemeente, een milieudelict begaat, de strafvervolging zich concentreert op de individuele functionarissen (ambtsdragers of ambtenaren) binnen de overheidsorganisatie. $\mathrm{Er}$ is dan ook een aantal belangrijke strafzaken waarin bijvoorbeeld burgemeesters voor milieudelicten zijn veroordeeld. Opvallend is ook dat in de Duitse literatuur met name de strafrechtelijke aansprakelijkheid voor wederrechtelijke vergunningverlening veel aandacht krijgt, terwijl de in de praktijk meer voorkomende gevallen van rechtstreekse milieuverstoring nauwelijks worden besproken. Zoals later nog aan bod komt, laat dit zich grotendeels verklaren door het gegeven dat de Duitse strafrechter vrijwel niet in staat is vergunningen op hun rechtmatigheid te toetsen zodat ook wederrechtelijk verleende vergunningen in staat zijn door particulieren veroorzaakte milieuverstoringen te rechtvaardigen. Het is dan begrijpelijk dat Duitse penalisten de aandacht zo sterk op de strafbaarheid van vergunningverlenende instanties richten en dat enkele auteurs zelfs pleiten voor een afzonderlijke strafbaarstelling van wederrechtelijke vergunningverlening. ${ }^{17}$ In het hoofdstuk over wederrechtelijke vergunningverlening (hoofdstuk VII) komt deze kwestie dan ook voornamelijk vanuit het Duitse perspectief aan bod.

16. Zie o.m. Keller, R., 'Zur strafrechtlichen Verantwortlichkeit des Amtsträgers für fehlerhafte Genehmigungen im Umweltrecht', in Festschrift für Kurt Rebmann zum 65. Geburtstag, München, 1989, 241-257; Meinberg, V., 'Amtstrăgerstrafbarkeit bei Umweltbehörden', NJW, 1986, 2220-2228; Rudolphi, H.J., 'Strafrechtliche Verantwortlichkeit der Bediensteten von Betrieben für Gewăsserverunreinigungen und Begrenzung durch den Einleitungsbescheid, in Festschrift für Karl Lackner zum 70. Geburtstag am 18. Februar 1987, Berlin, 1987, 863-887; Rogall, K., Die Strafbarkeit von Amtsträgerverantwortlichkeit im Umweltbereich, Berlijn, 1991; Dahs, H., 'Zur straflechtigen Haftung des Gewasserschutzbeauftragten nach $\S 324 \mathrm{StGB}$ ', NStZ, 1986, 97-103; Geisler, C., 'Strafbarkeit von Amtsträgern im Umweltrecht', NJW, 1982, 11-15; Horn. E., 'Strafbares Fehlverhalten von Genehmihungs- und Aufsichtbehörden?', NJW, 1981, 111; Immel, B., Strafrechtliche Verantwortlichkeit von Amtsträgern im Umweltstrafrecht, Frankfurt, 1987; Knopp, L., 'Zur Strafbarkeit von Amtsträgern in Umweltverwaltungsbehörden unter besonderer Berücksichtigung der BGH-Rechtsprechung', DoV, 1994, 676-684.

17. Zo bijvoorbeeld Immel, B., 'Die Notwendigkeit eines Sondertatbestandes im Umweltstrafrecht Umweltreue', ZRP, 1989, 105-110. 
Ook België is voor een rechtsvergelijkende behandeling van de probleemstelling van groot belang. Het Belgische rechtsstelsel neemt een opmerkelijke positie in omdat recent, namelijk op 4 mei 1999, de strafrechtelijke verantwoordelijkheid van de rechtspersoon in het Belgische Strafwetboek is ingevoerd. Daarbij valt op dat de Belgische wetgever niet alleen de staat, maar ook decentrale overheden volledig van de werking van het strafrecht heeft uitgesloten. Dit is een radicale breuk met het verleden omdat vóór de invoering van de strafbaarheid van de rechtspersoon niets zich verzette tegen de vervolging en bestraffing van individuele bestuursfunctionarissen voor milieudelicten, die door de overheden waartoe zij behoren, werden gepleegd. Het Belgische recht is ook nog om een andere reden van belang. Daar waar de Duitse strafrechter nauwelijks vergunningen aan wet en recht kan toetsen, is in de Belgische Grondwet een strafrechtelijke toetsingsplicht van overheidsbeschikkingen verankerd. Deze rechterlijke toetsingsbevoegdheid wordt in Belgie gezien als een logische toepassing van de leer van de machtenscheiding. Een bespreking van het Belgische systeem is dus bijzonder interessant in het licht van het klassieke argument dat een strafrechtelijke controle van overheidshandelen vanwege de machtenscheiding moet worden uitgesloten.

Ook de Franse situatie komt, zij het zeer bondig, aan bod. In 1994 heeft de Franse wetgever de strafrechtelijke aansprakelijkheid van de rechtspersoon in de nieuwe Code pénal ingevoerd, maar daarbij is wel, zij het na een ware parlementaire strijd, voor de staat een absolute en voor lagere overheden een partiële immuniteit gecreëerd.

Over de gevolgde methode van rechtsvergelijking, moet nog het volgende worden opgemerkt. De verschillende rechtsstelsels worden niet steeds systematisch naast elkaar besproken. Bij sommige thema's wordt een horizontale rechtsvergelijking gebruikt. Dit is bijvoorbeeld het geval in hoofdstuk III waar per land wordt bekeken in welke mate overheden en hun functionarissen voor door hen gepleegde milieudelicten kunnen worden vervolgd. Bij andere onderwerpen zoals de argumenten voor en tegen een strafrechtelijke aansprakelijkheid van overheden, en de strafrechtelijke vraagstukken bij wederrechtelijke vergunningverlening is gekozen voor een aanpak waarbij de verschillende relevante vragen op een meer geïntegreerde en probleemgeoriënteerde wijze worden geanalyseerd. Daarnaast is gestreefd naar een rechtsvergelijking die zich niet beperkt tot een eenvoudig literatuuronderzoek. Het verschil tussen 'law in books' en 'law in action' indachtig lijkt het me van belang weer te geven hoe in de bestudeerde rechtsstelsels niet alleen in theorie maar ook in de praktijk met de probleemstelling wordt omgegaan. Aldus komt ook de bestudeerde literatuur beter tot zijn recht. Het is immers meestal naar aanleiding van de in de rechtspraktijk gesignaleerde problemen dat de doctrine zich over een antal belangwekkende vraagstukken uitspreekt. Een kennisname van de relevante rechtspraak in de bestudeerde landen is daarom noodzakelijk voor een goed begrip van de soms zeer verschillende standpunten in de literatuur. Dit geldt in het bijzonder voor de Duitse situatie waar de 'Amtsträgerstrafbarkeit' voorwerp uitmaakt van een vurige strafrechtsdogmatische meningenstrijd. Het nadeel van zo'n rechtspraakanalyse is wellicht dat de rechtsvergelijking op sommige punten als zeer detaillistisch kan worden ervaren, maar het voordeel is evenwel dat op die manier het heersende recht van de bestudeerde rechtsstelsels zowel kritisch als genuanceerd aan bod kan komen. 


\section{§5. Terminologie}

In rechtsgeleerd onderzoek is de kwestie van terminologie niet onbelangrijk. Juridische taal en begrippen maken immers ordening en inzicht mogelijk. In deze studie staat de strafrechtelijke vervolging en aansprakelijkheid van overheid en overheden centraal. Hoewel deze woorden in de omgangstaal nauwelijks vragen doen rijzen, kunnen zij in de rechtstaal problemen opleveren. Overheid en overheden zijn immers containerbegrippen waarvan de precieze betekenis in het recht voornamelijk afhangt van het rechtsgebied en de context waarin ze worden gebruikt. Een jurist die zich 'de overheid' probeert voor te stellen, stuit op een terminologische overvloed. Hij of zij kan dan denken aan begrippen als: de staat, het bestuur, het Rijk, bestuursorganen, zelfstandige bestuursorganen, openbare lichamen, publiekrechtelijke rechtspersonen en dergelijke meer. Het is dus van belang aan te geven wat in deze studie met overheden wordt bedoeld.

De termen overheid en overheden hebben in het strafrecht, net zomin trouwens als de woorden burger of onderneming, geen eigen zelfstandige betekenis. Dit geldt met name voor de strafrechtelijke aansprakelijkheid. Artikel $51 \mathrm{Sr}$ bepaalt immers dat strafbare feiten kunnen worden begaan door natuurlijke personen en rechtspersonen. Onder rechtspersonen dienen te worden verstaan privaatrechtelijke en publiekrechtelijke rechtspersonen. Een publiekrechtelijke rechtspersoon is een rechtspersoon waarvan de organisatorische inrichting door publiekrechtelijke regels wordt beheerst. De publiekrechtelijke rechtspersoon is dus een species van het genus rechtspersoon. Er bestaan verschillende publiekrechtelijke rechtspersonen. De belangrijksten zijn de in artikel 2:1, eerste lid, BW genoemden: de staat, de provincies, de gemeenten, de waterschappen, en ook alle lichamen waaraan op grond van de Grondwet verordenende bevoegdheid is verleend. Daarnaast worden in bijzondere wetten verschillende publiekrechtelijke rechtspersonen aangeduid. Wanneer in deze studie wordt gesproken over de strafrechtelijke vervolging en aansprakelijkheid van overheden, gaat het dus in de eerste plaats over publiekrechtelijke rechtspersonen. Niettemin verkies ik het begrip overheid boven het strafrechtelijk gezien meer nauwkeurige publiekrechtelijke rechtspersoon, niet alleen omdat dit laatste begrip veel te omslachtig is, maar ook omdat er overheidsinstellingen zijn die geen eigen rechtspersoonlijkheid kennen, zoals de meeste zelfstandige bestuursorganen. Niettemin rijst ook bij overheidsorganisaties zonder eigen rechtspersoonlijkheid mogelijk de vraag naar een strafrechtelijke aansprakelijkheid. ${ }^{18}$ Daarnaast bestaan er ook privaatrechtelijke rechtspersonen met publiekrechtelijke taken, zoals bedrijfsverenigingen, die ook als overheidsinstellingen kunnen worden waargenomen. Bovendien geeft de term overheid, ondanks zijn vaagheid, meer de kern van de probleemstelling weer, namelijk of overheidshandelen strafrechtelijk moet kunnen worden gecontroleerd.

Een zelfde opmerking past bij de term overheidscriminaliteit. Daaronder dient in deze studie te worden verstaan delicten die worden gepleegd door overheidsorganisaties als 
zodanig, of deze nu rechtspersoonlijkheid genieten of niet, of door leden of groepen van die organisatie binnen het kader van de door deze organisatie verrichte werkzaamheden of functies.

In dit boek wordt ook gebruik gemaakt van het woord milieuverstoring. Ik verkies in navolging van Bocken milieuverstoring omdat milieuverontreiniging of milieuvervuiling beperkter is en aantasting van ecologische rechtsgoederen anders dan door verontreiniging door emissie uitsluit. ${ }^{19}$ Zo kan het illegaal verwijderen van beschermde vogelnesten nog worden gezien als een verstoring maar niet als een verontreiniging van het leefmilieu.

Ook bij daderschap van overheden past een terminologische opmerking. Dader is gebruikt als een synoniem van pleger, dat wil zeggen diegene die alle objectieve en subjectieve bestanddelen in een delictsomschrijving vervult. De wettelijke omschrijving van daderschap is natuurlijk ruimer. Artikel $47 \mathrm{Sr}$ ziet immers als daders mede zij die een delict doen plegen, medeplegen en uitlokken. ${ }^{20}$

$\mathrm{Nu}$ dit boek een in belangrijke mate rechtsvergelijkende opzet heeft, kunnen er natuurlijk ook terminologische verschillen optreden tussen de verschillende bestudeerde landen. $\mathrm{Zo}$ wordt bijvoorbeeld in het Belgische strafrecht veeleer gesproken van het moreel element (l'élément moral) van een strafbaar feit, dan van het subjectief element en wordt schuld in de zin van culpa in België als fout of onachtzaamheid en in Duitsland als Fahrlässigkeit aangeduid. Ook zijn er opmerkelijke verschillen tussen de bestudeerde rechtsstelsels op het vlak van de daderschaps- en deelnemingsregeling. Zo is het Duitse Mittäterschaft op bepaalde punten zeer verschillend van de Nederlandse deelnemingsvorm medeplegen. Omwille van de helderheid wordt er naar gestreefd om ook bij de bespreking van de andere landen zoveel mogelijk gebruik te maken van (vertaling in) Nederlandse strafrechtsbegrippen, maar het spreekt voor zich dat dit niet steeds kan worden volgehouden. Waar nodig wordt daarom aangegeven welke betekenis een bepaald begrip in het Nederlandse, Belgische, Duitse of Franse recht heeft.

\section{§6. Opbouw van deze studie}

Dit boek is als volgt opgebouwd. Na dit inleidende hoofdstuk wordt eerst op een meer rechtstheoretisch niveau aandacht besteed aan enkele belangrijke grondslagen en kenmerken van het huidige milieustrafrecht. Een kennismaking met het specifieke rechtskarakter van het milieustrafrecht is onontbeerlijk voor een inzicht in de strafrechtelijke positie van overheden in het milieustrafrecht. Een strafrechtelijke aansprakelijkheid van overheden en hun functionarissen voor milieuverstoring zal immers steeds een milieustrafrechtelijke aansprakelijkheid zijn (II). Vervolgens wordt via een rechtsvergelijkende analyse weergegeven hoe in de verschillende rechtstelsels de lege lata met door

19. Zie Bocken, H., Het aansprakelijkheidsrecht als sanctie tegen de verstoring van het leefmilieu, Brussel, Bruylant, 1979, 3-4, alsook Faure, M. en Visser, M., o.c., 1999, 1.

20. Zie hierover o.m. Woensel, A.M., In de daderstand verheven, Arnhem, Gouda Quint, 1993, 5 en 7-44. 
overheden gepleegde milieucriminaliteit strafrechtelijk wordt omgegaan (III). Daarna volgt een kritische bespreking van de door de Hoge Raad ontwikkelde criteria op basis waarvan moet worden bepaald in welke gevallen decentrale overheden een strafrechtelijke immuniteit genieten (IV). In hoofdstuk V staan de belangrijkste argumenten voor en tegen een strafrechtelijke aansprakelijkheid van overheden centraal, waarbij wordt gedifferentieerd al naargelang het gaat om de staat of decentrale overheden. Een belangrijk deel van deze studie bestaat uit een beschrijving van het daderschap van overheden voor milieuverstoring. Daarin wordt niet alleen bekeken hoe het daderschap van overheden per type milieudelict zo goed mogelijk zou kunnen worden geformuleerd, maar komt ook de problematiek van het feitelijk leidinggeven en het daderschap van de staat aan bod (VI). Vervolgens worden op rechtsvergelijkende wijze enkele belangrijke vraagstukken besproken die verband houden met de strafrechtelijke consequenties van wederrechtelijke vergunningverlening. Naast de vraag in welke mate de strafrechter vergunningen kan toetsen en de kwestie in hoeverre onrechtmatige vergunningen milieuverstorende gedragingen kunnen rechtvaardigen, wordt ook aandacht besteed aan de mogelijke strafbaarheid van de vergunningverlenende instanties (VII). Het boek wordt afgesloten met enkele eindconclusies en aanbevelingen in hoofdstuk VIII. 



\title{
Hoofdstuk II
}

\section{De natuur van het milieustrafrecht}

\begin{abstract}
'Door de industrie veroorzaakte problemen van vandaag, gebaseerd op technologische innovaties van gisteren en investeringen van eergisteren, kunnen in het beste geval morgen met tegenmaatregelen bestreden worden die eventueel overmorgen effect zullen hebben. ${ }^{21}$
\end{abstract}

\section{§1. Inleiding}

In voorliggend hoofdstuk wordt een zoektocht ondernomen naar het rechtskarakter van het milieustrafrecht. Er wordt aandacht besteed aan een aantal belangrijke kenmerken en knelpunten van het huidige milieustrafrecht. Dit is voor een onderzoek naar een strafrechtelijke aansprakelijkheid van overheden voor milieuverstoring om verschillende redenen van belang.

Een eerste reden houdt verband met het simpele gegeven dat, eens is aanvaard dat niet alleen particulieren maar ook overheden moeten kunnen worden vervolgd voor milieudelicten, de strafrechtelijke ansprakelijkheid moet plaatsvinden via het bestaande milieustrafrecht. Afgezien van een mogelijk gebruik van bepaalde commune delicten, zoals valsheid in geschrifte (artikel $225 \mathrm{Sr}$ ), moet primair gebruik worden gemaakt van de bestaande milieustrafbepalingen ${ }^{22}$ Een strafrechtelijke aansprakelijkheid van overheden voor milieuverstoring is steeds ook een milieustrafrechtelijke aansprakelijkheid. Een voorbeeld kan dit verduidelijken. Indien een gemeente op illegale wijze bouw- of sloopafval stort, rijst de vraag op welke wijze de gemeente hiervoor strafrechtelijk aansprakelijk kan worden gesteld. Dit betekent dat onder meer moet worden bekeken wanneer de gemeente als dader van het gepleegde milieudelict kan worden aangemerkt.

21. Jänicke aangehaald in Piret, J.-M., 'Filosofische beschouwingen bij de grondslagen van het milieurecht', in Gutwirth, S. en van Maanen, G., De natuur van het milieurecht. Verkenningen naar de grondslagen van het milieurecht, Ars Aequi Libri, Nijmegen, 1995, 28.

22. Zie over het gebruik van commune delicten in milieustrafzaken hoofdstuk VI. Zie tevens Faure, M. en Visser, M., o.c., 1999, 365-396. 
Deze daderschapsvraag is alleen te beantwoorden indien rekening wordt gehouden met de specifieke eisen en kenmerken van het milieustrafrecht omdat de formulering en het bewijs van het daderschap grotendeels worden bepaald door het type milieudelict dat wordt ten laste gelegd. ${ }^{23} \mathrm{Zo}$ wordt duidelijk dat men de strafrechtelijke aansprakelijkheid van overheden voor milieuverstoring onmogelijk los kan koppelen van het bijzonder rechtsgebied, het milieustrafrecht, waarbinnen deze aansprakelijkheid gestalte moet krijgen. Alvorens tot enige conclusies te komen over de mate waarin overheden via het milieustrafrecht aansprakelijk kunnen worden gesteld, is het daarom wenselijk eerst de uitgangspunten en grondslagen van dit milieustrafrecht nader te bekijken. Een bezinning op het huidige milieustrafrecht is des te meer gerechtvaardigd nu dit deelgebied van het bijzonder strafrecht zich traditioneel tot burgers en bedrijven (particulieren) richt en niet in de eerste plaats (ook) tot overheden en hun functionarissen wat mede een weigerachtige houding ten aanzien van een vervolgbaarheid en strafbaarheid in de hand kan werken. Overheden passen als reguleerders en handhavers van het milieurecht immers niet in het milieustrafrechtelijke 'boefbeeld'. ${ }^{24}$

Een tweede reden hangt samen met de wijze van strafbaar stellen. Het overgrote deel van het milieustrafrecht bestaat uit strafbepalingen die als sluitstuk in de bijzondere milieuwetten zijn opgenomen. De hoofdmoot van de overtredingen van deze strafbepalingen vallen onder het toepassingsgebied van de Wet economische delicten (WED). ${ }^{25}$ Daarnaast kennen enkele bijzondere milieuwetten eigen strafbepalingen. Tenslotte bevat het Wetboek van Strafrecht enkele algemene bepalingen ter bescherming van de gezondheid van de mens, waarvan artikel 173a Sr en 173b Sr de belangrijkste zijn. Wat al deze strafbepalingen gemeen hebben, is dat zij niet rechtstreeks de ecologische rechtsgoederen beschermen, maar het handelen zonder of in strijd met een door het bestuur gegeven vergunning strafbaar stellen. Men kan dan ook spreken van een 'administratieve afhankelijkheid' van het milieustrafrecht. ${ }^{26}$ Ingevolge deze administratieve afhankelijkheid bepalen de voor de bescherming van het leefmilieu verantwoordelijke overheden de voorwaarden voor strafbaarheid aangezien zij de toelaatbare graad van milieuverstoring vastleggen door het voorschrijven van emissienormen in vergunningen. Dit brengt met zich mee dat de administratieve overheid de milieuverstoring mee kan veroorzaken of helpen in stand houden indien zij zeer soepele vergunningsvoorwaarden zou voorschrijven. In een dergelijk geval rijst de vraag in hoeverre de overheid en de daarin werkzame functionarissen aansprakelijk kunnen worden gesteld voor de door de onzorgvuldige vergunningverlening veroorzaakte milieuschade. De aansprakelijkheid van de milieu-

23. Het daderschap van overheden bij milieudelicten wordt behandeld in hoofdstuk VI, waar per type milieudelict wordt bekeken onder welke voorwaarden een rechtspersoon als dader kan worden aangemerkt.

24. Zie hierover de oratie van Van den Heuvel, G.A.A.J., Collusie tussen Overheid en Bedrijf. Een vergeten hoofdstuk uit de organisatiecriminologie, Universiteit Maastricht, 1998.

25. Zie hierover Hendriks, L.E.M. en Wöretshofer, J., Milieustrafrecht, Zwolle, W.E.J. Tjeenk Willink, 1995, 21-36.

26. Zie hierover o.m. Faure, M.G., 'De gevolgen van de "administratieve afhankelijkheid" van het milieustrafrecht: een inventarisatie van knelpunten', in Faure, M.G., Oudijk, J.H.C. en Schaffmeister, D. (red), o.c., 1991, 91-150; Koopmans, I.M., o.c., 1996, 7-24. 
administratie kan dan als een mogelijk correctief van de administratieve afhankelijkheid worden gezien dat er toe strekt prikkels te geven tot een meer zorgvuldige vergunningverlening. ${ }^{27}$ In dit licht kan een kritische bespreking van het administratieve karakter van het milieustrafrecht moeilijk achterwege blijven.

Een derde reden is dat een kritische analyse van de grondslagen van het milieustrafrecht ons stimuleert antwoorden te geven op de meer fundamentele vraag of het milieustrafrecht als zodanig niet aan een grondige herziening toe is. Het basisprobleem is immers dat de strafrechtelijke aansprakelijkheid van overheden, vooral bij foutieve vergunningverlening, hoofdzakelijk wordt verdedigd als tegengewicht voor de huidige structuur van de strafbaarstellingen, die zeer eng met de schending van administratieve plichten zijn verbonden. Men zou echter ook kunnen overwegen of er geen andere wijze van strafbaarstelling mogelijk is teneinde de nadelen van de administratieve afhankelijkheid op te vangen in plaats van onmiddellijk naar een strafrechtelijke aansprakelijkheid van overheden te grijpen als correctief voor deze bestuursafhankelijkheid. In dat verband kan ook nog worden opgemerkt dat het probleem vooral rijst wanneer men aanneemt dat de vergunning een absoluut strafuitsluitende werking heeft voor milieuverstoring, zoals onder meer in Duitsland het geval is, omdat het de strafrechter niet toegelaten is onrechtmatige vergunningen opzij te zetten. Daarom is het ook begrijpelijk dat vooral in Duitsland zoveel aandacht is besteed aan de Amtsträgerstrafbarkeit. ${ }^{28}$ Men dient voor ogen te houden dat een ondoordacht uitwijken naar overheidsaansprakelijkheid als hét sluitstuk van het milieustrafrecht, zonder dit deelgebied van het strafrecht zelf kritisch te belichten, wel eens veeleer blijk zou kunnen geven van machteloosheid dan van machtscontrole.

Dit in hoofdzaak theoretisch getinte hoofdstuk is als volgt opgebouwd. Eerst wordt vanuit een meer algemeen rechtstheoretisch perspectief aandacht besteed aan het rechtskarakter van het huidige milieustrafrecht $(\S 2)$. Vervolgens wordt een schets gegeven van enkele indicaties en gevolgen van dat rechtskarakter. In het bijzonder komen de wijze van strafbaar stellen en enkele nadelen van de administratieve afhankelijkheid aan bod (§3). Daarna wordt besproken wat daarvan de mogelijke gevolgen en complicaties zijn voor de vervolgbaarheid en strafbaarheid van overheden $(\S 4)$. Ik eindig met enkele conclusies die tevens de basis leggen voor de volgende meer positiefrechtelijke hoofdstukken (§5).

\section{§ 2. Het rechtskarakter van het milieustrafrecht}

Voor een goed begrip van functie en betekenis van een bijzonder deelgebied van het strafrecht als het milieustrafrecht is het aardig om eerst enkele algemene uitgangspunten en beginselen van het klassieke strafrecht in herinnering te brengen. Ik grijp daarbij grotendeels terug op de relationele rechtsvisie zoals deze is geherwaardeerd en uitgewerkt

27. Faure, M.G., Oudijk, J.C. en Koopmans, I.M., 'Strafrechtelijke aansprakelijkheid van ambtenaren in het milieurecht -een rechtseconomische analyse', TMR, 1993, 12-23.

28. Zie hierover de in opdracht van het Duitse 'Umweltbundesamt' uitgevoerde studie van Rogall, K., Die Strafbarkeit von Amsträgern im Umweltbereich, Berlijn, Erich Schmidt Verlag, 1991, 246-271 en de daarin opgenomen literatuur. 
door Foqué, 't Hart en Gutwirth (A). Vervolgens kan in dat licht aandacht worden besteed aan het eigen karakter van het milieustrafrecht (B en C).

\section{A. HET KLASSIEKE STRAFRECHT IN HET LICHT VAN HET RELATIONELE VERLICHTINGSDENKEN}

Het klassieke strafrecht kan worden gezien als een reactie op het onderdrukkende en arbitraire karakter van het strafrecht van het Ancien Régime waarbij recht niet meer was dan een geheel van bevelen van een autarke soeverein. Vanuit zowel een rechtstheoretische als een historische invalshoek kan het klassieke strafrecht ideaaltypisch worden beschouwd als een poging om de anti-despotische Verlichtingsidealen juridisch te verwezenlijken. Die hervormingsidealen, zoals we die herkennen bij Beccaria (contractleer) en Montesquieu (trias politica), omvatten enerzijds de verwezenlijking van een gemeenschappelijk maatschappelijk vormgevingsproject waarbij zelfontwikkeling, mondig burgerschap en de daartoe noodzakelijke vrijheid van het individu centraal staan. Anderzijds zijn zij gericht op een bescherming van samenleving en burger tegen een onzeker en ongelimiteerd overheidsingrijpen. ${ }^{29}$ Het strafrecht wordt gekenmerkt door een instrumentele (ordenende, sturende) en een rechtsbeschermende (machtskritische) functie. Deze twee aspecten vormen geen tegengestelden daar zij beiden de verwezenlijking en het garanderen van individuele vrijheid gemeenschappelijk hebben. Voorop staat de doelstelling de burger te beschermen zowel tegen maatschappelijke chaos en onveiligheid als tegen gouvernementele excessen en willekeur. ${ }^{30}$ Met andere woorden, het recht wordt vanuit het perspectief van de Verlichtingsdenkers beschouwd als een relationele of bemiddelende structuur die tot doel heeft de verhoudingen tussen verschillende machten (zowel van burgers als van overheden) te moduleren teneinde op die manier menselijke vrijheid en maatschappelijke ordening op evenwichtige wijze te waarborgen.

Van belang hierbij is dat dit relationele rechtsbegrip als uitgangspunt neemt dat het strafrecht niet kan worden opgevat als een geheel van bevelsconstructies, die geworteld zijn in een ondeelbare soevereiniteit van de overheid, maar als een normering en kanalisering van maatschappelijke verhoudingen. ${ }^{31}$ De precaire relatie tussen overheid en burger is in de eerste plaats een rechtsbetrekking en niet uitsluitend een machtsverhouding. Recht kan

29. Foqué, R.M.G.E., 'Legitimiteit van het huidige strafrechtssysteem', in de Doelder, H., Foqué, R.M.G.E. en Gerding, R.A.F. (red.), Taak en functioneren van het $O M$, Arnhem, Gouda Quint, 1994, 14-15; Foqué, R. en 't Hart, A.C., Instrumentaliteit en Rechtsbescherming, Arnhem, Gouda Quint, 1990.

30. 'Die Selbstbeschreibung des klassischen Strafrechts sieht zur Zeit der Aufklarung das Strafrecht vorrangig als Mittel der bürgerlichen Freiheitssicherung gegen feudale Justizwillekur'; Albrecht, P.A., 'Das Strafrecht im Zugriff populistischer Politik', in Von Unmogglichen Zustand des Strafrechts, Frankfurt a. M., 1995, 430. Nu is die tweezijdigheid geen eigenaardigheid van het strafrecht; elk recht heeft instrumentele en beschermende facetten. Wel kan worden vastgesteld dat in het strafrecht steeds - vaak meer dan in de overige rechtstakken - het zoeken naar een ideaal evenwicht tussen het instrumentele en machtskritische aspect heeft vooropgestaan.

31. Foqué, R.G.E.M., 'Legitimiteit van het huidige strafrechtssysteem', in de Doelder, H., Foqué, R.M.G.E. en Gerding, R.A.F. (red.), o.c., 1994, 16; Gutwirth, S., Waarheidsaanspraken in recht en wetenschap, Antwerpen-Apeldoorn, MAKLU, 1993. 
daarom niet worden herleid tot een etatistisch of imperativistisch éénrichtingsverkeer waarbij het strafrecht dan beperkt zou zijn tot louter te sanctioneren eenzijdig opgelegde verboden en geboden van wetgevende of uitvoerende macht. In de woorden van Hassemer:

\begin{abstract}
'Sie (de staat, DR) rechtfertigt sich nämlich aus ihrer Aufgabe, die Teilnehmer am Sozialvertrag im Rechtszustand miteinander existieren zu lassen [...] Nicht der Bürger also wird vom Staat her funktionalisiert, sondern der Staat vom Bürger her [...] Der Staat is eine von den Rechten des Bürgers abgeleitete Institution, und man muß seine Macht von den Bürgerrechten her begründen und begrenzen. Der Sozialvertrag verträgt keine unabgeleitete Macht und keinen Usurpator. Deshalb ist die Macht des Staates gerade im Strafrecht, wo sie sich besonders deutlich zeigt, prinzipiell zu binden und von den Rechten des Individuums her zu konzipieren: ihnen hinanzustellen. ${ }^{32}$
\end{abstract}

Het rechtskarakter van het strafrecht ligt met andere woorden niet alleen in de bijna vanzelfsprekende maatschappelijke controle en repressie met het oog op criminaliteitsbestrijding, maar tevens in de beperking van de repressieve bevoegdheden van de overheid:

\title{
'Die Strafrechtsphilosophie der Freiheit ist voller Mißtrauen gegen Machtsausübung, gleichgültig, ob die Macht beim Straftäter oder beim strafenden Staat liegt [...] Dieser Gedanke läßt ein hart profiliertes Strafrecht entstehen: strenge strafende Reaktion auf die Überwältigung der Freiheit eines anderen, strenge juristischen Kontrolle dieser Reaktion selbst. ${ }^{33}$
}

De machtsaanspraken van de overheid die zich in het strafrecht vertalen in zijn rationele doelgerichte ordenings- en controlefuncties zijn eigenlijk van nature gegeven. Volgens Peters ligt daarom de specifiek juridische waarde van het strafrecht veeleer in het normeren van die maatschappelijke controle en de daarmee samenhangende overheidsmacht. Ik citeer een centrale passage van zijn befaamde inaugurele rede:

'het zijn juist deze, niet uit rationele doelgerichtheid verklaarbare, en orthogonaal op de ordeningsfunctie van het strafrecht staande, residuale beperkingen van de bevoegdheden van de staat, die de eigenlijke juridische dimensie van het strafrecht constitueren. Deze beperkingen vormen bij uitstek de juridische waarden in het strafrecht. Het specifieke van het strafrecht - net als van het overige recht - ligt niet in zijn ordeningsfunctie [maar] in secundaire controle: in het normeren van de

33. Naucke, W., 'Schwerpunktverlagerungen im Strafrecht', KritV, 1993, 137. 
maatschappelijke controle zoals die min of meer spontaan groeit of wordt gesteld door de staat en andere machthebbers. ${ }^{34}$

Deze rechtsbeschermende of machtskritische functie van het strafrecht vindt zijn neerslag in de bekende strafrechtelijke beginselen: het legaliteitsbeginsel, inhoudend dat geen feit strafbaar is en dus niet kan worden vervolgd, dan krachtens een voorafgaande, duidelijke en nauwkeurig gespecificeerde wettelijke strafbepaling (lex certa, Bestimmtheitsgebot); het beginsel van schadelijkheid van het gedrag, vooropstellend dat een straf slechts kan worden opgelegd wanneer er sprake is van een daadwerkelijke krenking van of concrete schadetoebrenging aan individualiseerbare rechtsgoederen (vrijheid, eigendom); het schuldbeginsel, inhoudend dat de strafwet alleen van toepassing is op degene die verwijtbaar de wet overtreedt; het proportionaliteitsbeginsel dat voorschrijft dat de sanctie evenredig is an de schade die voortvloeit uit het gepleegde feit; en het seculaire vergeldingsbeginsel, inhoudend dat de straf niet gemotiveerd wordt door het te verwachten maatschappelijk effect, maar overeenstemt met de objectieve ernst van de wetsovertreding waarbij de vergelding beantwoordt aan de menselijke verantwoordelijkheid die immers de kern uitmaakt van de klassieke individuele strafrechtelijke aansprakelijkheid. ${ }^{35}$ Met dit vergeldingsbeginsel hangt ook samen het uitgangspunt dat het strafrecht alleen retrospectief en daadgeoriënteerd mag zijn. Dat wil zeggen, dat het strafrecht uitsluitend mag reageren op een in het verleden gepleegde daad en niet op een mogelijke toekomstige gebeurtenis of

34. Peters, A.A.G., 'Het rechtskarakter van het strafrecht', in Peters, A.A.G., Recht als kritische discussie, Arnhem, Gouda Quint, 1993, 19. Volgens Peters ligt de ordeningsfunctie (de instrumentaliteit) in tegenstelling tot de machtskritische functie van het strafrecht (de rechtsbescherming) in de niet-juridische profane sfeer. Hij verbindt daaraan de conclusie dat het instrumentele moreel neutraal zou zijn. De morele dimensie van het strafrecht staat haaks op de doelgerichte ordeningsfunctie. Het is de vraag of dit wel zo zwart-wit kan worden voorgesteld. Ook zuivere rationele doelmatigheidscriteria die de instrumentele bouwstenen vormen van een strafrechtelijk beleid zijn normatief en allerminst waardenneutraal. Zo kan het veronachtzamen van doelmatigheidsdoelstellingen een deugdelijke wetgeving, een zorgvuldige handhaving en een behoorlijk bestuur frustreren en in die zin ook de rechtsbescherming op de helling zetten. Wanneer de instrumentaliteit of de maatschappelijke ordeningsfunctie buiten het rechtskarakter van het strafrecht wordt geplaatst - wordt geprofaniseerd -, ontstaat het risico dat deze instrumentaliteit verwordt tot een ongebreidelde machtsuitoefening, die niet in staat is de menselijke integriteit te waarborgen. Anderzijds zijn ook prodecurele waarborgen en machtskritische beginselen slechts maatschappelijk nuttig wanneer zij getuigen van een zodanige 'efficiency' dat zij inderdaad een daadwerkelijke controle op overheidshandelen mogelijk maken. Ook rechtsbescherming moet instrumenteel inzetbaar en geordend zijn, wil deze dimensie niet stranden in een loutere utopie. Zie hierover 't Hart, A.C., Openbaar ministerie en rechtshandhaving, Deventer, Gouda Quint, 1994, 204-208. Anders dan Peters, ben ik van mening dat het instrumentele streven naar orde niet 'profaan' maar net zo 'sacraal' is als het streven naar rechtsbescherming zolang die ordeningsfunctie maar wordt ingegeven door het verwezenlijken en instandhouden van een rechtsorde en niet slechts tot doel heeft de implementatie van een orde die eenzijdig zonder rechtsstatelijke kwaliteitseisen door de overheid wordt gewenst. Zie over een meer normatieve en kritisch filosofische benadering van instrumentalisme ook Rozemond, K. 'Preadvies "Pleidooi voor een kritisch instrumentalisme"', $R \& R, 1996,169-191$; Rozemond, K., Strafvorderlijke rechtsvinding, Deventer, Gouda Quint, 1998, 346-353; De Roos, Th. A., 'Recht, orde en het nut van het algemeen', $R \& R, 1997,28-33$.

35. Peters, A.A.G., o.c., 1993, 15 . 
criminele instelling van de dader. ${ }^{36}$ Er moet worden benadrukt dat deze rechtsbeginselen zelf een uitdrukking vormen van een relationele zienswijze op het strafrecht. Dat wil zeggen dat aan deze beginselen zowel rechtsbeschermende of machtsnormerende als instrumentele of doelrationele ratio's ten grondslag liggen en dat zij daarom slechts volledig kunnen worden begrepen indien ze relationeel worden opgevat. Zo wordt met het uit het legaliteitsbeginsel voortvloeiende lex certa-vereiste niet alleen beoogd de burger duidelijk te maken welk gedrag al dan niet strafbaar is, maar wordt hiermee ook aan de overheid duidelijk afgebakende instrumentele doelstellingen gegeven voor een efficiënt gebruik van strafrechtelijke bevoegdheden. Het schuldbeginsel heeft niet alleen betrekking op de machtskritische eis dat alleen 'schuldigen' mogen worden gestraft, maar verwijst ook naar de instrumentele eis dat een strafrechtelijke aansprakelijkheid slechts 'werkt' indien deze voortvloeit uit een feitelijk bestaande morele of maatschappelijke verantwoordelijkheid: geen strafrechtelijke aansprakelijkheid zonder morele of maatschappelijke verantwoorelijkheid. Of simpeler gezegd: geen risico-aansprakelijkheid. Het relationele karakter van de strafrechtelijke beginselen behoedt ons in die zin voor de vooronderstelling dat instrumentele doelstellingen a priori makkelijker bereikt zouden kunnen worden door een depreciatie van rechtsbeschermende waarborgen; dat, met andere woorden, minder rechtsbescherming automatisch leidt tot meer 'efficiency'. Vanuit het relationele perspectief, het uitgangspunt dat instrumentaliteit en rechtsbescherming niet elkaars tegengestelden zijn, is het veeleer zo dat een strafrechtelijk beleid dat expliciet kiest voor een uitholling van rechtsbeschermende beginselen, op den duur ook zijn eigen instrumentele doelstellingen zal ondergraven. Wil men de instrumentele functie effectueren, dan dient ook steeds de machtskritische functie in voldoende mate gewaarborgd te worden. Omgekeerd kan een té formalistische kijk op bepaalde rechtsbeginselen leiden tot een uitholling van de instrumentele werking die men van het strafrecht mag verwachten. Een in mijn ogen typisch voorbeeld hiervan is in het Belgische strafrecht zeer duidelijk terug te vinden. Decennialang heeft men uit 'respect' voor het schuldbeginsel geweigerd de rechtspersoon als strafrechtelijk rechtssubject te erkennen: rechtspersonen waren immers niet schuldbekwaam. Het uiteindelijke eindresultaat was wel dat het schuldbeginsel in hoofde van natuurlijke personen werkzaam binnen rechtspersonen danig werd uitgehold en dat een dergelijke strafrechtelijke aansprakelijkheid van natuurlijke personen voor feiten gepleegd door rechtspersonen evenmin instrumenteel gezien werkte. ${ }^{37}$

\section{B. HET INSTRUMENTALISTISCHE KARAKTER VAN HET MILIEUSTRAFRECHT.}

De oriëntatie op bovengenoemde rechtsbeginselen, die relatief zelfstandig zijn ten aanzien van het conflictoplossende gebruik van het strafrecht, is de laatste decennia duidelijk op de achtergrond geraakt. Het instrumentele doel van de straf, sturing van de maatschappelijke orde en bestrijding van criminaliteit, is steeds meer op de voorgrond komen te staan. Deze

36. Kelk, C., De menselijke verantwoordelijkheid in het strafrecht, Arnhem, Gouda Quint, 1994, 24; Hassemer, W., l.c., 381.

37. Zie hierover hoofdstuk III waar meer uitgebreid op de strafrechtelijke aansprakelijkheid van de rechtspersoon in Belgiê wordt stilgestaan. 
positie waarin het strafrecht is komen te verkeren, is onlosmakelijk verbonden met de visie in een verzorgingsstaat over democratie, recht en maatschappelijk bestuur:

\begin{abstract}
'Als "democratie" wordt dan vooral beschouwd het formele democratiebegrip van de bestuursvorm van de parlementaire meerderheid: het primaat van de politiek. Eigen aan de democratie zou zijn, dat de overheid - regering en gekozen volksvertegenwoordiging - de maatschappij representeert en op haar beurt de maatschappij beheerst: zij vormt als het ware het instrument waarmee de maatschappij zichzelf bestuurt. ${ }^{38}$
\end{abstract}

Het project van de verzorgingsstaat is een project van streven naar zekerheid; een garanderen van een gemeenschappelijke basis van welzijn en welvaart voor alle individuele burgers. De verzorgingsstaat is daarom een 'verzekeringsmaatschappij', een société assurancielle $^{39}$, waarin individuele risico's zoveel mogelijk zijn gecollectiveerd. Dat heeft er toe geleid dat het recht is gaan ingrijpen meer op grond van een solidariteitsidee en het waarborgen van vooruitgang en welvaart dan op grond van de wilsautonomie of de individuele verantwoordelijkheid die in de negentiende eeuw nog zo centraal stonden. Die verzekerende functie van de staat is slechts mogelijk door een ver doorgevoerde planning van het maatschappelijke leven teneinde zo het staatsingrijpen uit te breiden tot bijna alle terreinen van de samenleving hetgeen resulteert in een zich steeds verder uitbreidend netwerk aan regelgeving en handhaving waarbij het strafrecht vrijwel automatisch als sluitstuk wordt ingezet.

Aan de gedachte van maakbaarheid is ook de strafrechtsbedeling niet kunnen ontsnappen. Het strafrecht wordt dan vanuit een instrumentalistisch streven ingeschakeld ten dienste van de overheid om de maatschappij te (her)structureren. Schuyt heeft in een vijftal punten het instrumentalistische gebruik van het recht als volgt samengevat. ${ }^{40}$ In de eerste plaats wordt het recht van zijn eigen waarden ontbloot en neutraal ingezet ten opzichte van het gestelde overheidsdoel. Daaruit volgt het tweede kenmerk: het recht is als instrument ondergeschikt aan de door de politiek ingevulde waarden. Ten derde verwordt het recht hierdoor tot een sturingsmiddel vanuit een machtscentrum. Instrumentalisme gaat dus hand in hand met machtscentralisme. Daamaast moet het recht 'consequentiegericht' zijn, hetgeen betekent dat het vrijwel uitsluitend wordt beoordeeld op zijn extra-juridische effecten die maatschappelijk-politiek verwezenlijkt worden: doelmatigheid en rechtmatigheid geraken hierdoor meer en meer in elkaar vervlochten. Tenslotte kan als vijfde kenmerk worden aangeduid dat de politieke doelstellingen van het recht worden vastgesteld en gerechtvaardigd door de inzet van sociaal- en naturwetenschappelijke disciplines en deskundigheid. Het is de taak van de wetenschappen om zowel de maatschappelijke probleemgebieden in kaart te brengen als ook om aan te geven wat de technisch haalbare

38. 't Hart, A.C., Recht als schild van Perseus, Amhem, Gouda Quint, 1991, 102-103.

39. Zie hierover Ewald. F., L' Etat providence, Paris, Grasset, 1986.

40. Schuyt, C.J.M., 'Sturing in het recht', in Bovens, M.A.P. e.a. (red.), Het schip van staat. Beschouwingen over recht, staat en sturing, Zwolle, W.E.J. Tjeenk Willink, 1985, 113-124. Deze vijf kenmerken van het instrumentalisme zijn ook besproken in 't Hart, A.C., o.c., 1994, 184-185. 
oplossingen zijn waarvoor het recht moet worden ingeschakeld. Met andere woorden, de wetenschappelijke waarheidsaanspraken vormen de grondslag voor de politieke machtsaanspraken. In de woorden van Gutwirth, die uitvoerig aan dit belangwekkende vraagstuk aandacht besteedt:

\begin{abstract}
'Als hoedster van de waarheid over de wereld, net als God eertijds, verovert de wetenschappelijke gemeenschap het recht m.b.t. de wereld. Dit betekent dat het niet-recht, het objectieve geweld dat het pactum sapientum t.o.v. de wereld huldigt, de inhoud wordt van het recht dat de menselijke gemeenschap in globo t.a.v. deze wereld onderhoudt (...) De werkelijke beheersingsmogelijkheden die wetenschap en techniek t.a.v. de wereld in het leven roepen, gekoppeld aan de onmiddellijke legitimatie hiervan in het recht, verlenen aan die instellingen een enorme maatschappelijke machtspositie.(...) Dat de wetenschap de ontologie beheerst heeft verregaande gevolgen in het juridische veld. De macht die zij uitoefent op de wereld vormt immers de epistemologische grondslag van het recht, precies omdat die wetenschap geacht wordt de waarheid over de wereld te spreken. ${ }^{41}$
\end{abstract}

Meteen wordt zo duidelijk dat we ver verwijderd zijn van de klassieke strafrechtelijke uitgangspunten. In de instrumentalistische visie wordt het strafrecht niet langer opgevat als een relationele grondstructuur maar 'als instrument van het menswetenschappelijk management van de samenleving'. Of nog, als 'de dienstbaarheid aan de verwetenschappelijkte aanspraken van de verzorgingsstaat. ${ }^{.42}$ Met name in het ordeningsrecht wordt het strafrecht vaak eenzijdig als een maatschappelijk sturingsmedium beschouwd ter behartiging van sociale, economische en ecologische programma's. ${ }^{43}$

Naar de beheersing van de leefmilieuproblematiek vertaald, betekent dit dat in de kwetsbaarheid van de natuur en de schadelijkheid van het menselijke gedrag blijkbaar de noodzaak tot een sterke staat ligt besloten. De (schijnbare) weerloosheid van Moeder Natuur lijkt de kracht van Vader Staat te rechtvaardigen. Echter, de in de rechtsbescherming gelegen doeleinden van een daadwerkelijke verwezenlijking van vrijheid en sociale, economische en culturele emancipatie, voorwaarden voor een volwassen en kritisch burgerschap (wat op zich weer een noodzaak is voor een gezonde en waardenpluralistische democratie), zijn vaak evenzoveel hinderpalen in de wens van een sterke staat tot beheersbaarheid. Het machtskritische gezichtspunt, dat door de macht van het recht voortdurend het recht van de macht wil relativeren, kan hierdoor, omwille van de vervolmaking van het uitgestippelde overheidsbeleid, worden geminimaliseerd. Het is immers de kwetsbaarheid van de natuur die op het spel staat; de zwakke plekken van de macht van de staat passen niet meteen in het milieubeschermingsproject. Er is dus een zekere tegenstrijdigheid mogelijk tussen het maatschappelijk maakbaarheidsideaal van een

41. Gutwirth, S., o.c., 1993, 374-375.

42. Gutwirth, S., o.c., 1993, 335.

43. Vgl. Peters, A.A.G., o.c., 1993, 16. 
sterke staat enerzijds en de verwezenlijking van een vrije samenleving anderzijds. Deze tegenspraak vertaalt zich ook in het milieustrafrechtsbegrip. Het milieu(straf)recht krijgt primair en expliciet een ordenende taak toebedeeld teneinde de sturingsbehoefte van de overheid te reguleren en te legitimeren. Ook op ecologisch vlak wordt het strafrecht ingezet als ordeningsinstrument ter ondersteuning en verwezenlijking van het door de overheid beoogde leefmilieubeschermingsproject.

Bemerk evenwel dat de (dominante) anwezigheid van het instrumentele in het (milieu)strafrecht niet het kernprobleem is; het instrumentele is immers een aan het strafrecht eigen aspect. Problematisch is wel de bijna vanzelfsprekende ideologisering van die instrumentele dimensie: het instrumentalisme. Uitgangspunt dreigt te zijn dat het strafrecht niet meer is dan één van de instrumenten om te komen tot een zo effectief en efficiënt mogelijke implementatie van het door de overheid gewenste milieubeleid. Dit betekent dat de verbetering en instandhouding van het leefmilieu de enkele doelstellingen zijn die zo doelmatig en doeltreffend mogelijk moeten worden bereikt. Centraal staat de geschiktheid dat doel, dat buiten het geneutraliseerde strafrecht wordt geplaatst, te verwezenlijken. Dat leidt uiteindelijk tot een ondergeschiktheid van het strafrecht en zijn rechtsbeginselen aan de door de overheid gekozen milieuwaarden. ${ }^{44}$ Vanuit dat instrumentalistisch perspectief wordt de hoogste prioriteit toegekend aan de bestrijding van milieuverstoring en zijn de rechtsbeschermende waarden in termen van procedurele voorzieningen en machtskritische beginselen onnodige obstakels in de strijd tegen milieuverstoring. ${ }^{45} \mathrm{Nu}$ is een 'schoner' leefmilieu een zeer nobel streven. Het gevaar bestaat echter dat in een sterk instrumentalistisch gekleurd milieustrafrecht machtskritiek van het instrumentele wordt losgekoppeld. Zij wordt weliswaar niet tenietgedaan, maar door die loskoppeling wordt ze wel een buiten het milieurecht gelegen doelstelling, die tegen de doelstelling van milieucriminaliteitsbestrijding en ecologische bescherming dient te worden afgewogen en, zoals 't Hart opmerkt, wanneer de 'hoogste prioriteit wordt toegekend aan 'criminaliteitsbestrijding', kan bij de afweging uiteindelijk vrijwel alles daaraan ondergeschikt worden gemaakt. ${ }^{46}$

\section{MILIEUSTRAFRECHT IN HET LICHT VAN DE RISICOMAATSCHAPPIJ}

Het instrumentalistische karakter van het milieustrafrecht kan worden gerelateerd aan én verduidelijkt met wat recente sociologische studies als die van Beck, Ewald, Douglas, Giddens en Wildavsky aanduiden als de risicomaatschappij. ${ }^{47}$ De opkomst van de risicomaatschappij geeft aan het verzorgingsstaatsinstrumentalisme een bijzondere

44. Roef, D., 'Strafrecht versus leefmilieu: van geschiktheid naar ondergeschiktheid?', $T M R, 1995$, 466-476.

45. Heine, G., 'Umweltstrafrecht im Rechtsstaat', ZUR, 1995, 70-71.

46. 't Hart, A.C., o.c., 1994, 188-189.

47. Beck, U., Risikogesellschaft; Auf dem Weg in eine andere Moderne, Frankfurt am Main, Suhrkamp Verlag, 1986; F. Ewald, 'Die Versicherungsgesellschaft', in Beck, U., Politik in der Risikogesellschaft, Frankfurt am Mainz, Suhrkamp Verlag, 1991, 288-302; Giddens, A., The consequences of Modernity, Cambridge, 1990; Douglas, M. en Wildavsky, A., Risk and Culture. An Essay on the selection of Technical and Environmental Dangers, London, 1982. 
dimensie, met name op het vlak van verantwoordelijkheids- en sturingsvraagstukken. We grijpen hier hoofdzakelijk terug op het werk van Ulrich Beck omdat voornamelijk in de recente Duitse milieustrafrechtelijke literatuur gretig gebruik wordt gemaakt van de Beckiaanse visie. $^{48}$

\section{De risicomaatschappij}

Belangrijk uitgangspunt in de typering van onze samenleving als een 'risicomaatschappij' is de vaststelling dat het maakbaarheidsproject van de verzekeringsmaatschappij (de verzorgingsstaat) zijn grenzen heeft bereikt. ${ }^{49}$ De oorzaken hiervan lijken niet zozeer te liggen in externe obstakels of in ontoereikende inspanningen om het maakbaarheidsproject te verwezenlijken, als wel in de logica van het systeem zelf. De erosie van de verzorgingsstaat kan voor een belangrijk deel worden toegeschreven aan de wetenschappelijketechnologische doelrationaliteit waarop de verzekeringsmaatschappij ter vermeerdering van de welvaart en ter verbetering van de maatschappelijke sturing voortdurend beroep doet. ${ }^{50}$ $\mathrm{Er}$ is scepsis ontstaan over het uitgangspunt dat maatschappelijke vooruitgang, stabiliteit, veiligheid en zekerheid automatisch voortvloeien uit steeds verdergaande wetenschappelijke, industriële en technologische ontwikkelingen. De samenleving wordt steeds meer geconfronteerd en is zich ook steeds beter bewust geworden van de negatieve neveneffecten van het industrialiserings- en moderniseringsproces en de rol die collectieve actoren daarbij vervullen. Hiermee verandert de maatschappij zelf van gedaante:

'Die siegreiche Industriegesellschaft (und in ihrer Folge der siegreiche Sozialstaat) hat nachdrücklich ein historisch neues Thema auf die gesellschaftliche Tagesordnung gesetzt: das der Folgen, der Risiken. ${ }^{\text {s1 }}$

Beck introduceert het concept van de Risikogesellschaft als een transformatie van de Versicherungsgesellschaft. ${ }^{52}$ De verzorgingsstaat heeft een lappendeken van instellingen en

48. Zie o.m. Heine, G., Die strafrechtliche Verantwortlichkeit von Unternehmen. Von individuellen Fehlverhalten zu kollektiven Fehlentwickelungen, insbesondere bei Großrisiken, Baden-Baden, Nomos Verlagsgesellschaft, 1996.

49. Zie over de problematische positie waarin de verzorgingsstaat verkeert o.m. 't Hart, A.C., o.c., 1991, 105-109 en de daarin vermelde literatuur.

50. Breuer, S., 'Das Ende der Sicherheit. Ulrich Becks "Gegengifte"', in Beck, U., o.c., 1991, 266.

51. Schmid, Th., 'Die Chancen der Risikogesellschaft', in Beck, U., o.c., 1991, 218.

52. Beck werkt met een driestadiamodel van sociale verandering; de vóórmoderniteit, de eenvoudige (of einfache) moderniteit en de 'reflexieve' moderniteit. Hij keert zich radicaal tegen het etiket postmoderniteit omdat dit uiteindelijk nietszeggend is en geen vruchtbare basis biedt voor zowel nieuwe (sociologische) theorievorming als voor maatschappelijke vernieuwing. Het stadium van de 'einfache' moderniteit valt bij Beck grotendeels samen met de industriële maatschappij. De 'reflexieve' moderniteit valt samen met de post-industriële of risicomaatschappij. Kenmerkend voor de reflexieve moderniteit is dat mensen zich niet langer blindelings door het moderniseringsproces laten leiden en sturen, maar zich van de schadelijke neveneffecten bewust zijn gaan worden en zo het moderningsproces in vraag durven stellen. Simpel gezegd, stilaan wordt het inzicht gemeengoed dat vooruitgang iets anders moet zijn dan een utopisch voortgaan op dezelfde weg. Beck legt dus de nadruk op de negatieve kanten van de moderniteit teneinde deze expliciet te maken, maar zonder de moderniteit als dusdanig af te schrijven en in het 
een netwerk van regelgeving gecreëerd ten einde een verdeling van welvaart en groei mogelijk te maken. Volgens Beck is echter één van de kenmerken van de moderne samenleving dat de maakbaarheid zijn limiet heeft bereikt en dat de verzorgingsstaat tekort schiet waar het gaat om de aanpak of opvang van de onbedoelde schadelijke gevolgen en risico's die de industriële maatschappij, de moderniteit zelf met zich meebrengt. In de verzekeringsmaatschappij heerst nog een maatschappelijke consensus over de wenselijkheid van toenemende vooruitgang en het 'op de koop toe nemen' van daaruit voortvloeiende risico's en gevaren. De schoorsteen moet als het ware blijven roken. ${ }^{53}$ In de risicomaatschappij is dit niet langer het geval.

Kenmerkend voor de risicomaatschappij is dat niet alleen de risico's, maar ook de houding daaromtrent zijn veranderd. Dit is hoofdzakelijk veroorzaakt door een drietal met elkaar samenhangende ontwikkelingen. In de eerste plaats is er de feitelijke toename van collectieve gevaren - denk maar aan kernenergie, milieuverstoring, gentechnologie, bioindustrie en informaticatechnologie - die verband houden met de activiteiten van complexe organisaties. ${ }^{54}$ In de tweede plaats kan worden waargenomen dat, nu oude risico's (zoals ondervoeding en epidemieën) tot op zekere hoogte door de sturings- en verzekeringsmechanismen van de verzorgingsstaat zijn gerepareerd, de maatschappelijke en politieke aandacht verschoven is naar nieuwe risico's, zoals het gevaar van bepaalde technologische ontwikkelingen. Deze nieuwe risico's zijn niet, zoals de oude risico's, het voorwerp van welvaartsverhoging, technologische sturing en beheersing maar zijn daarvan nu net de uitkomst. ${ }^{55}$ In de derde plaats heeft de toegenomen emancipatie en mondigheid van de

pessimisme te vervallen van postmoderne sociale wetenschappers als Foucault. Hij wil geen breuk met de moderniteit, maar een radicalisering daarvan door reflexiviteit, namelijk via een door brede lagen van de bevolking gedragen kritische reflectie op de rol van wetenschap en technologie, die aan de basis liggen van de éffets pervers van de risicomaatschappij en niet door een (al te makkelijke) negatie van hun maatschappelijke waarde en belangrijkheid. Hij pleit voor een democratisering van de technisch-economische ontwikkeling, democratisering als instrument om de wetenschappelijke-technologische ontwikkeling in zijn greep te krijgen. Deze democratisering kan volgens Beck niet langer uitsluitend plaats vinden via de geïnstitutionaliseerde politiek. Een dergelijke politiek gaat nog te veel uit van de verzorgingsstaatsgedachte dat dergelijke ontwikkelingen vanuit een enkel machtscentrum zouden te sturen zijn. Kenmerkend voor onze maatschappij is dat er geen enkelvoudig machtscentrum meer is: de politiek is centrumloos geworden en ontgrenzd. Wat daarvoor in de plaats moet komen is wat hij sub-politiek of secundaire politiek noemt. Belangrijke condities daarvoor zijn sterke en onafhankelijke rechtscolleges en media. Cruciaal is tevens het stimuleren van zelfcontrole en zelfkritiek van alle belangrijke professionele groeperingen, die aan de basis liggen van het moderniseringsproces. Het recht moet in dat licht niet zozeer een sturingsinstrument zijn in handen van een centrale overheid, maar moet de nodige ruimte creëren om die zelfkritiek mogelijk te maken. Zie tevens Van Steenbergen, B, De toekomst vanuit het onderbouwperspectief (2): de postverspillingsmaatschappij', in van Hoof, J. en Van Ruysseveldt, J. (red.), Sociologie en de moderne samenleving, Amsterdam, Boom, 1996, 485-489.

53. Hajer, M. en Schwarz, M., 'Contouren van de risicomaatschappij', in Beck, U., De wereld als risicomaatschappij, Amsterdam, De Balie, 1997, 10.

54. Zie over het begrip 'complexe organisaties' nader hoofdstuk VI.

55. Blanke, Th., 'Zur Aktualităt des Risikobegriffs. Öber die Konstruktion der Welt und die Wissenschaft von ihr', in Beck, U., o.c., 1991, 275-287. 
burger (een rechtstreeks gevolg van de verzorgingsstaat) ertoe geleid dat diens bewustwording van deze risico's groter is geworden.

Dit alles heeft tot gevolg dat de overheid en het recht als beheersingsinstrument steeds meer op de proef worden gesteld om potentiële gevaren zo veel en zo snel mogelijk in te dijken. In de Versicherungsgesellschaft staat nog de vraag centraal in welke mate de modernisering en industrialisering van onze samenleving in staat zijn de maatschappelijk geproduceerde rijkdommen (consumptiegoederen, inkomens, loopbaanperspectieven, etc...) rechtvaardig en legitiem te verdelen: het gaat om 'the distribution of goods'. In de Risikogesellschaft komt een ander maatschappelijk vraagstuk op de voorgrond - zonder dat trouwens de doelstellingen van de verzorgingsstaat verdwijnen - namelijk in hoeverre de risico's die door het industrialiserings- en moderniseringsproces zelf zijn veroorzaakt, kunnen worden verhinderd of gecompenseerd: het gaat dan meer om 'the distribution of bads'. Is vanuit het perspectief van de verzorgingsstaat de modernisering en technologisering nog onderdeel van conflictoplossing en sturing, in de risicomaatschappij worden zij hoe langer hoe meer gezien als onderdeel van maatschappelijke onzekerheid en onveiligheid. De recente 'Belgische' dioxinecrisis is daarvan een pregnant voorbeeld. Zij illustreert duidelijk dat de modernisering en technologisering zelf de bron van te beheersen risico's zijn geworden. In algemene zin kan worden gesteld:
'Sind Reichtum, Risiken und Ängste groß, ist auch das Sicherheits- bedürfnis groß. Entsprechend hoch ist dann der Anspruch an die Politik, diese Sicherheit zu gewährleisten. Sicherheit zu garantieren aber heißt, Schutz zu gewähren - Schutz nicht nur vor den äußeren Feinden, sondern Schutz auch vor den Risiken der Modernisierung im Inneren. ${ }^{56}$

In dat licht is het niet onbelangrijk op te merken dat wat lange tijd, vanuit een klassiek verzorgingsstaatsdenken, als een onaantastbaar uitgangspunt van milieubeleid en (dus) milieurecht werd gezien, namelijk 'sustainability', 'duurzaamheid', of 'duurzame ontwikkeling', meer en meer ter discussie staat. Typisch voorbeeld is het in 1994 verschenen rapport Duurzame risico's: een blijvend Gegeven van de Wetenschappelijke Raad voor het Regeringsbeleid (WRR), dat zich vrij radicaal verzet tegen de idee van 'duurzame ontwikkeling' als onvoorwaardelijk gebod van het milieubeleid. De WR introduceert als tegenhanger van duurzaamheid het begrip risico in navolging van Ulrich Beck's Risikogesellschaft. $^{57}$

Wat zowel de objectieve toename als het fundamenteel andere karakter van moderne risico's betreft, past nog een enkele kanttekening. Er zou kunnen worden betoogd dat de diagnose van de moderne samenleving als een risicomaatschappij getuigt van ongefundeerd

56. Lafontaine, O., 'Leben in der Risikogesellschaft', in Beck, U., o.c., 1991, 211.

57. Wetenschappelijke Raad voor het Regeringsbeleid, Duurzame risico's: een blijvend Gegeven, Den Haag, Sdu, 1994. Zie voor een korte beschrijving van dit rapport in het licht van de risicomaatschappij: Van Steenbergen, B., 'De toekomst vanuit het onderbouwperspectief (2): de postverspillingsmaatschappij', in Van Hoof, J. en Van Ruysseveldt, J. (red.), o.c., 1996, 484-494. 
vooruitgangspessimisme en een welhaast apocalyptisch ongenuanceerd doemdenken. Beck gaat daar zelf enigszins cynisch op in:

\begin{abstract}
'Zijn risico's niet minstens zo even oud als de industriële maatschappij of misschien zelfs zo oud als de mensheid zelf? Staat het hele leven niet in het teken van het risico van de dood? Zijn en waren dus niet alle maatschappijen in alle tijden "risicomaatschappijen"? [...] Zijn de onvermijdelijke "restrisico's" niet domweg de keerzijde van de kansen op welvaart, relatief grote sociale zekerheid en algemeen comfort - die de ontwikkelde industriële maatschappij de meerderheid van haar leden op historisch ongeëvenaarde wijze biedt? Is het dramatiseren van dergelijke risico's dus uiteindelijk niet gewoon een typisch mediaspektakel dat voorbijgaat aan de inzichten van de experts? $?^{58}$
\end{abstract}

Het antwoord op deze vragen is volgens Beck negatief. Het grote verschil tussen industriële risico's (bijvoorbeeld milieurampen en gezondheidsbedreigende activiteiten in de bioindustrie) en pre-industriële risico's (bijvoorbeeld armoede, honger en epidemieën) ligt immers in hun ontstaansgeschiedenis. De moderne risico's onderscheiden zich in Beckiaanse zin van andere gevaren doordat zij op beslissingen berusten, op overwegingen en praktijken die technisch-economische voordelen en mogelijkheden voor ogen hebben en gevaren als keerzijde van de vooruitgang op de koop toe nemen. Indien deze risico's zich vervolgens als schadeposten verwezenlijken kan men deze risico's daarom niet eenvoudigweg maatschappelijk 'verhullen' door hen te bestempelen als 'toevallige incidenten'. Dat zijn ze, enkele uitzonderingen daargelaten, meestal niet. Zo is het te simpel om bijvoorbeeld de dioxinecrisis (maar ook andere bio-industriële crises, zoals de crises rond de gekke koeien en de varkenspest) qua ontstaansgeschiedenis eenzijdig te reduceren tot de verantwoordelijkheid van een of twee bedrijven en het falen van de inspectiediensten, of door dit voor te stellen als een 'toevallig' incident dat nu eenmaal hoort bij onze geïndustrialiseerde 'voedselketen'. Een dergelijke eenzijdige benadering frustreert op voorhand al de vraag of deze 'keten' zelf nog wel helemaal deugt. ${ }^{59}$

De moderne risico's zijn daarenboven niet eenzijdig terug te voeren op externe oorzaken. Evenmin zijn ze toe te schrijven aan beslissingen genomen door aanwijsbare individuen. ${ }^{60}$ Het gaat veelal om langdurige processen en in tijd verspreide beslissingen die zijn genomen door hele organisaties en maatschappelijke groeperingen:

58. Beck, U., o.c., 1997, 55; Beck, U., o.c., 1986, 28-31.

59. Vgl. Lafontaine, O., 'Leben in der Risikogesellschaft', in Beck, U., o.c., 1991, 210.

60. In de woorden van Heine: 'Ein Großer Teil der Schädigungsprozesse (wohl die bedrohlichtsen, vergegenwärtigt man sich das aus-dem-Ruder-Laufen industrieller Prozesse, etwa im Bereich der chemischen Industrie) läßt sich nicht auf eine einzige fehlerhafte Entscheidung zurückführen, sondern ist das Ergebnis von Risiken, die sich "in der Zeit" entwickeln'. Heine, G., l.c., 1995, 66; 'Diese (risico's, DR) sind nur zu begreifen als Produkte einer industriellen Entwicklung, die systematisch und prozeßhaft gesteigert wird'. Heine, G., o.c, 1995, 61 . 
'Pre-industriële gevaren, hoe groot en verschrikkelijk ze ook geweest mogen zijn, waren "rampspoeden" die van "buitenaf" over de mensheid heen kwamen en aan een "ander" - de goden, demonen, natuur - konden worden toegeschreven [...] Met het ontstaan van industriële risico's komt ook onvermijdelijk het probleem op van maatschappelijke aansprakelijkheid en verantwoordelijkheid, zelfs op terreinen waar de geldende regels van wetenschap en recht aansprakelijkheid slechts bij uitzondering toestaan. ${ }^{61}$

Buruma vat het als volgt treffend samen:

'We zijn gaan beseffen dat ongelukken en gevaren inherent zijn verbonden aan maatschappelijke processen: steeds opnieuw worden beslissingen genomen op grond van (subjectieve of statistische) inschattingen van de waarschijnlijkheid dat er ongewenste gevolgen zullen optreden. Catastrofes (een kernreactor die een melt down krijgt) zijn dikwijls het gevolg van aldus geaccepteerde risico's. Maar waar een catastrofe vroeger als een Act of God werd beschouwd, zoeken wij nu naar schuldigen die wij aansprakelijk kunnen stellen voor de gevolgen. Vooral als de gevolgen 'onverzekerbaar groot' zijn, denken we ook aan een strafrechtelijke reactie. ${ }^{162}$

Kortom, het recht wordt steeds meer geconfronteerd met uiterst complexe sturings- en verantwoordelijkheidsvraagstukken, vooral wanneer er onverwacht iets mis mocht gaan. Burgers ervaren de moderne risico's als onzichtbare en onvoorspelbare gevaren waarop de overheid met behulp van het recht dient te anticiperen en te reageren. De verantwoordelijkheid van overheden als risico-managers wordt op de spits gedreven:

'Der einzelne reagiert auf sie (de risico's, DR) entsprechend hilflos. Zur objektiven Gefahr von gewaltigen Ausmaßen tritt deshalb ein Gefühl des Ausgeliefertseins, tritt eine Angst, die ihrerseits neue gesellschaftliche Probleme schafft. Und die Situation wird dadurch kompliziert, daß Ängste sich verselbständigen, also auch dort auftreten können, wo objektiv die Gefährdung nicht zugenommen ist. ${ }^{63}$

\section{Milieuverstoring en de risicomaatschappij}

Dat moderne risico's inderdaad fundamenteel verschillen van pre-industriële gevaren, kan duidelijk worden geillustreerd aan de hand van een korte typering van de gevaren van

61. Beck, U., o.c., 1997, 56.

62. Buruma, Y., 'Het schuldig subject', in Borgers, M.J., Koopmans, I.M. en Kristen, F.G.H. (red.), o.c., $1998,4$.

63. Seelman, K., 'Risikostrafrecht. Die "Risikogesellschaft" und ihre "symbolische Gesetzgebung im Umwelt-und Betăubungsmittelstrafrecht"', KritV, 1992, 453. 
milieuverstoring. Het is immers niet toevallig dat Beck zich hoofdzakelijk concentreert op de ecologische crisis en dat zijn eerste en belangrijkste publicaties zijn geschreven mede naar aanleiding van de ramp in Tsjernobyl.

In de eerste plaats is milieuverstoring in de meeste gevallen niet concreet vaststelbaar en met de menselijke zintuigen waarneembaar. ${ }^{64}$ Pre-industriële gevaren zoals hongersnood en armoede waren nog rechtstreeks voor de slachtoffers daarvan te ervaren en kwamen overeen met de dagelijkse werkelijkheid. Kennis en ervaring vielen in de beleving van de burger op pijnlijke, maar daarom ook op voelbare en dus concrete wijze samen. Bij milieuverstoring daarentegen zijn de schadelijke gevolgen vaak pas na vele jaren traceerbaar en dan nog slechts via wetenschappelijke deskundigheid en bewijsbaarheid. Hiermee is een scheiding ontstaan tussen kennis en ervaring. ${ }^{65}$ Problematisch is evenwel dat deze wetenschappelijke expertise meer dan in de hoogtijdagen van de verzorgingsstaat publiekelijk wordt gewantrouwd, dat deskundigen vaak tegenstrijdige opvattingen verdedigen en gegrepen zijn in een veelal ondoorzichtige belangen- en meningenstrijd. Dit resulteert in een groeiende maatschappelijke onzekerheid over de waarde van de waarheidsaanspraken van de wetenschap. ${ }^{66} \mathrm{Nu}$ wetenschappelijke waarheidsaanspraken in onze samenleving een voorname legitimatie vormen voor de machtsaanspraken van de sturende overheid, spreekt het voor zich dat in een risicomaatschappij de ordeningspretenties van deze overheid zelf sterk ter discussie komen te staan. Dit heeft in concreto bijvoorbeeld tot gevolg dat het milieurechtelijk wetenschapsafhankelijk sturingssysteem bij uitstek, namelijk het vergunningenstelsel en de handhaving daarvan, meer en meer kritisch wordt benaderd. ${ }^{67}$ We zien dan ook vanaf de midden jaren tachtig een duidelijke breuk binnen het milieurecht in de wijze waarop de overheid met voor het leefmilieu gevaarlijke of risicovolle activiteiten dient om te gaan. Staat in de klassieke verzorgingsstaatgedachte nog de gedachte centraal dat de panacee van overheidssturing in het milieurecht moet worden gevonden in een tot in detail uitgewerkt vergunningensysteem, dan zien we recentelijk een sterke tendens tot deregulering en een toenemend gebruik van zelfregulering. ${ }^{68}$ De deregulering heeft ook juridische consequenties omdat de aandacht meer

64. Heine, G., l.c., 1995, 65 .

65. Beck, U., o.c., 1997, 23-25.

66. Zie hierover Gutwirth, S., 'Mens, natuur en recht. Grondslagentheoretische bedenkingen bij de verhoudingen tussen rechtssubjcten en rechtsobjecten', in Gutwirth, S. (red.), Milieu rechtgezet? Een bezinning over de grondslagen en toepassing van het milieurecht, Gent, Mys \& Breesch, $1994,3-11$ en 20.

67. Zie bijvoorbeeld het rapport van de Rekenkamer over vergunningen TK 1995/1996, 24 656, nrs. 1-2, maar ook in een ruimere context de evaluatie van het vergunningenstelsel en de handhaving daarvan door de Commissie bestuursrechtelijke en privaatrechtelijke handhaving, Handhaven op niveau, Deventer, W.E.J. Tjeenk Willink, 1998. Die wetenschaps- en sturingsonzekerheid wordt op zijn beurt gevoed door de twijfel aangaande het succes van technologische-industriële vooruitgang.

68. Dit kadert onder meer in het door de Nederlandse overheid afgekondigde project Marktwerking, Deregulering en Wetgevingskwaliteit: TK, 1995-1996, 24 400, nr. 2, 16. Het doel van de MDWoperatie is 'te komen tot vermindering en vereenvoudiging van regelgeving en vesterking van de uitvoerbaarheid en handhaafbaarheid. Dit met het oog op vermindering van de lasten van burgers en bedrijfsleven en versterking van de economische dynamiek'. TK 1995-96, 25 000, nr. 2, 50. Zie tevens Faure, M. en Visser, M., o.c., 1999, 48 e.v. 
uitgaat naar 'vergunningen in hoofdlijnen', vage normen en beginselen die in algemene maatregelen van bestuur zouden moeten worden vastgelegd, eerder dan in gedetailleerde vergunningsvoorschriften. ${ }^{69}$ Daarnaast gaat de aandacht in toenemende mate uit naar de bedrijfsinterne milieuzorg. In zo'n ontwikkeling zien we een illustratie van de wijze waarop verantwoordelijkheids- en sturingsvraagstukken in een risicomaatschappij naar voren komen:

\begin{abstract}
'Risicomaatschappijen zijn dan ook tegelijk verzekerings-, ja zelfs veiligheidsmaatschappijen, die uitgebreide controlesystemen vergen om risico's vroegtijdig op het spoor te komen en om ze te bezweren. Maar de risicomaatschappij vergt ook een grote mate aan disciplinering en Selbstzwang vanwege de burger, omdat kleine zogeheten 'menselijke fouten' gigantische schade kunnen aanrichten. $\mathrm{Zij}$ vergt van de burger een hoge graad aan rationaliteit, opdat de hoogtechnologische systemen geolied zouden kunnen functioneren. Van mensen wordt verwacht dat zij zich aan de vereisten van de technologie aanpassen, zich onderwerpen aan hun standaarden. ${ }^{70}$
\end{abstract}

Dergelijke ontwikkelingen hebben ook strafrechtelijke consequenties in de zin dat de strafrechtelijke aansprakelijkheid voor milieuverstoring meer en meer wordt geformuleerd en toegepast via bijvoorbeeld strafbaar gestelde zorgplichten, die de aandacht verschuiven van door de overheid voorgeschreven precisievoorschriften naar meestal vage maatschappelijk vereiste zorgplichtnormen in hoofde van de burger, teneinde zo belangrijke lacunes op aansprakelijkheidsvlak te kunnen dichten. ${ }^{71}$

In de tweede plaats zijn bij milieuverstoring de mogelijke slachtoffers niet individualiseerbaar - Smog ist demokratisch ${ }^{72}$ - of zelfs niet identificeerbaar; zij zijn even collectief en anoniem als de gevaren die hen bedreigen. Milieurisico's overstijgen als het ware de grenzen van tijd en ruimte: zij bedreigen niet alleen de huidige generatie maar ook het nageslacht. Trouwens, het eerste 'slachtoffer' betreft nog steeds het leefmilieu zelf, waaraan zowel verontreinigers als slachtoffers hun bestaan te danken hebben; het leefmilieu als 'slachtoffer' is weliswaar al te bekend maar helaas ook al te onmondig en dus evenmin eenvoudig in kaart te brengen. ${ }^{73}$

69. Zie hierover o.m. Faure, M. en Visser, M., o.c., 1999, 48; Van Gestel, R.A.J., 'Milieuzorg op maat', in Bedrijfsinterne milieuzorg en vergunningverlening. 'Is het gras groener bij de buren?', Zwolle, W.E.J. Tjeenk Willink, 1998, 26-68.

70. Raes, K., 'Een samenleving van onverantwoordelijken. Grenzen aan deresponsabilisering', in WODC, Schuld, Justitiële Verkenningen, nr. 5, 1999, 25.

71. Faure, M. en Visser, M., o.c., 1999, 325-326.

72. Beck, U., o.c., 1986, 48 .

73. Zie over deze problematiek o.m. Gutwirth, S., o.c., 1993, 362-473; Roef, D., 'M. Serres. Het contract met de natuur', in Gutwirth, S. en van Maanen, G. (red), o.c., Ars Aequi Libri, Nijgemen, 1995, 557-563. 
In de derde plaats zijn de mogelijke schadeposten van milieuverstoring vrijwel onomkeerbaar. De gevolgen van bijvoorbeeld chemische en radioactieve stoffen voor mens en leefmilieu zijn soms niet te overzien of zelfs onbekend.

Ten slotte zijn de oorzaken van milieuverstoring vaak evenzeer collectief als de gevolgen daarvan. De causaliteit van vervuiling is uiterst gecompliceerd en in de regel niet toe te schrijven aan één of zelfs meerdere individuele gedragingen hetgeen impliceert dat klassieke aansprakelijkheidsconcepten en dogmatische begrippen niet steeds in staat zijn om verantwoordelijkheid en schade op elkaar af te stemmen. Ook op strafrechtelijk vlak roept dit problemen op. Buruma illustreert dit als volgt:

'In de risicomaatschappij begrijpen we dat bepaalde beslissingen een onstuitbaar proces in gang zetten; als het (misschien ex tunc verantwoorde) risico dan wordt geactualiseerd tot een schade, zijn we echter steeds geneigd de risiconemer als een autonoom handelend individu daarop "af te rekenen". Daarmee doemt het gevaar van willekeur op. In een lange besluitvormingsketen kunnen velen het niet-gewilde gevolg afwenden. Is het zinnig een verantwoordelijke operator van een controlemonitor in Tsjernobyl strafrechtelijk aansprakelijk te stellen, of de directeur van de reactor, of de commissaris die besloot niet te investeren in nieuwe apparatuur? ${ }^{74}$

Het is duidelijk dat individualistische concepten geënt op een negentiende eeuwse atomistische visie op menselijk gedrag niet langer kunnen volstaan om naar behoren een strafrechtelijke verantwoordelijkheid te constitueren, die meer wil zijn dan een loutere symbolische reactie uit onmacht. In hoofdstuk VI, waar we uitgebreid stilstaan bij het daderschap bij milieudelicten, zal aan deze problematiek daarom uitvoerig aandacht worden besteed.

Samengevat: de samenleving verschuift naar een risicomaatschappij waarbij de sociale conflicten in onze samenleving steeds minder over de verdeling van welvaart gaan maar in toenemende mate over de verdeling van risico's, over verantwoordelijkheidsvragen bij de gevolgen van ongevallen en catastrofes en over de vraag wie mag beslissen wie welke risico's mag lopen. ${ }^{75}$ De typering 'risicomaatschappij' legt in die zin de schaduwkant bloot van het vooruitgangsstreven van de industriële maatschappij enerzijds en de maakbaarheidsfixaties van de verzorgingsstaat anderzijds. Het verzorgingsstaatsideaal van positieve solidariteit van een maakbare samenleving dreigt daarbij te worden ingeruild voor een meer negatieve solidariteit van beheersbaarheid van gevaren en risicotaxatie, die wordt gevoed door een 'ecologie van angst, onveiligheid en onzekerheid'. ${ }^{76}$

74. Buruma, Y., 'Het schuldig subject', in Borgers, M.J., Koopmans, I.M. en Kristen, F.G.H., o.c., 1998, 4.

75. Hajer, M. en Schwarz, M., 'Contouren van de risicomaatschappij', in Beck, U., o.c., 1997, 10.

76. Van Swaaningen, R., 'Justitie als verzekeringsmaatschappij. "Actuarial justice" in Nederland', in De risicomaatschappij. Justitiële verkenningen, WODC, Arnhem, Gouda Quint, 1996, 82. 
Als illustratie van de tot nu toe hoofdzakelijk theoretische beschrijving van het milieustrafrecht dienen nu enkele indicaties en consequenties van het instrumentalisme nader te worden bekeken. Vooropgesteld moet worden dat deze indicaties niet los van elkaar kunnen worden begrepen; zij staan voortdurend met elkaar in verband.

\section{§3. Indicaties en consequenties van het rechtskarakter van het milieustrafrecht}

\section{A. ANIMOSITEIT, ANONIMITEIT EN DE VERSNIPPERING VAN HET JURIDISCHE}

Een eerste consequentie van het zojuist geschetste instrumentalisme in het milieustrafrecht vloeit voort uit het feit dat de twee dimensies van het strafrecht, instrumentaliteit en rechtsbescherming, lijnrecht tegenover elkaar dreigen te worden gesteld. Deze extreme polarisering van de doelstellingen van het strafrecht creëert een vijandbeeld van verdachten en daders. De milieuproblematiek dreigt aldus te worden voorgesteld als een onvermijdelijke kloof tussen de belangen van de maatschappij bij veiligheid en ecologische leefbaarheid en de belangen van de daders, alsof dat steeds volkomen gescheiden categorieën belangen zouden zijn. ${ }^{77}$ Die belangen worden vervolgens - vaak als statistische gemiddelden - tegenover elkaar geplaatst. Niet langer de persoon van de dader en nog minder de persoon van het slachtoffer staan hierbij centraal, maar anonieme personificaties van hun door de overheid ingelezen belangen en verwachtingspatronen; de animositeit leidt tot anonimiteit. Een uitsluitend conflictoplossend en op 'crime control' gericht strafrecht noopt daartoe. Om (onder meer) via het strafrecht een doeltreffende planning van de economische en ecologische terreinen te kunnen waarborgen, is strafrechtelijk beleid en stroomlijning van het instrumentarium nu eenmaal noodzakelijk. ${ }^{78}$ Een dergelijk beleid is verplicht te werken met 'gemiddelden' en 'belangen'. Meteen moet worden opgemerkt dat deze omstandigheid door het maatschappelijke terrein, waarin het milieustrafrecht een ordenende functie krijgt toebedeeld, zelf in de hand wordt gewerkt. Zoals is opgemerkt, treden bij milieuverstoring de schadelijke gevolgen vaak zo verspreid op, dat niet kan worden gesproken van 'het slachtoffer'. Ook kunnen de schadelijke effecten zich pas lange tijd na de verontreiniging manifesteren. Dat heeft een zelfde identificatieprobleem van mogelijke daders tot gevolg.

De maatschappelijk-politieke sturingsproblemen van de risicomaatschappij enerzijds en de economisch-ecologische alsook naturwetenschappelijke complexiteit inherent aan milieuverstoring anderzijds impliceren dus een noodzaak tot een beleidsmatige milieustrafrechtshantering; daders worden tot abstracte categorieën vereenvoudigd, die voor het milieustrafrecht de stereotype doelgroepen (de vergunningplichtigen) zijn waartegen moet worden opgetreden in naam van een even abstract waargenomen groep van

77. Vgl. 't Hart, A.C., o.c., 1994, 191.

78. Heine, G., 'Verwaltungsakzessorietät des Umweltstrafrechts. Rechtsvergleichende Funktionsanalysen - unbestimmte Rechtsbegriffe - Reichweite von Genehmigungen', in Schulz, R. (Hrgb), Ökologie und Recht, Köln, Carl Heymanns Verlag KG, 1991, 56-58. 
slachtoffers, die op hun beurt de vertolking uitmaken van een zekere 'maatschappelijke, economische en ecologische onvrede', die door de overheid als 'Deus ex machina' moet worden verholpen. Een belangrijke consequentie van deze instrumentalistische grondtoon in ons milieurecht is een visie over regulering waarbij de overheid wordt versimplifieerd tot de neutrale behartiger van het algemeen belang; een overheid die steeds milieuregulering ten gunste van de ecologische leefbaarheid zou uitvaardigen. De realiteit is niet steeds even idealistisch. Juist door de ondoorzichtigheid, de stereotypering en vervolgens het polariseren van de belangen van 'daders' en 'slachtoffers' ontstaat op overheidsniveau soms een ongrijpbaar vacuüm dat niet zozeer door het algemeen belang als wel door belangengroepen nader wordt ingevuld. Zowel regelgeving als handhaving worden dan eerder door economische en (wellicht in iets mindere mate) ecologische lobbies en capturers bepaald dan door meer transparante democratische en rechtsstatelijke procedures. ${ }^{79}$ Overheidsregulering wordt dan niet slechts gebruikt ter realisatie van het instrumenteel te bereiken doel, zijnde een beter leefmilieu, maar wordt soms gebruikt om een welvaartsoverdracht in het voordeel van een bepaalde belangengroep te verwezenlijken. ${ }^{80}$ Als slechts één voorbeeld van deze belangengroepenregulering kan worden verwezen naar de Belgische dierenbeschermingswet van 14 augustus $1986{ }^{81}$ Deze wet blijkt in eerste instantie te zijn geïnspireerd door het veilig stellen van de economische belangen van de reeds gevestigde dierenhandel, onder meer door een verbod van het verhandelen van gezelschapsdieren en sierdieren op markten. Door deze wet is een bestaande bedrijfssector via lobbying erin geslaagd te profiteren van de door de overheid gerealiseerde regulering door tegelijk beperkingen van de markttoegang voor nieuwkomers mogelijk te maken ${ }^{82}$ Dierenbescherming komt pas op de tweede plaats. De ontnuchterende vaststelling dat milieuwetgeving, die tevens strafrechtelijk wordt gehandhaafd, in sterke mate dreigt te worden bepaald door belangengroepenregulering stelt niet alleen de democratische legitimatie van het huidige milieu(straf)recht ter discussie maar nuanceert meteen ook het beheersingsideaal dat achter het instrumentalisme schuil gaat.

79. Met de term lobbying doel ik hier vooral op de invloed van sterke belangengroepen op het niveau van de totstandkoming van de milieuregelgeving. De invloed van deze belangengroepen laat zich echter ook op het niveau van de vergunningverlening en de handhaving sterk voelen. Er kan dan eerder worden gesproken van 'capturing' (verovering) van vergunningverlener en/of handhaver door de bedrijfswereld die zij controleren. Zie over lobbying en capturing in het milieurecht: Faure, M.G., Oudijk, J.C. en Koopmans, I.M., l.c., 1993, 18-20.

80. Zo ook Heine, G., l.c., 1991, 59: 'Insbesondere im Umweltrecht macht sich international ein (bedenklicher) Trend breit, die Entscheidungsmacht vom Parlement auf die Administration bzw. auf außerstaatlichen Gremien (Sachverständige) zu verlagern. Mit dieser Entwicklung geht Hand in Hand, daß tendenziell and die Stelle einseitiger Anordnung durch den Staat ein Verhandlungsproze $B$ (bargaining) tritt. Diese Ausprägungen durch des verwaltungsrechtlichen Kooperationsprinzips können zur Folge haben, daß sich der förmliche Genehmigungsbescheid, lăngst schon im Vorfeld mit mächtigen (industriellen) Interessengruppen ausgehandelt, in eine Art "Beurkundungsakt" verwandelt.'

81. B.S. 3 december 1986.

82. Faure, M.G., 'Bedenkingen over de rol van het strafrecht bij de bestrijding van milieuverontreiniging', in Om deze Redenen, Liber Amicorum van Armand Vandeplas, Gent, Mys \& Breesch, 1994, 251-255. 
Aan belangengroepenbehartiging en bestuurlijke behoeftenbevrediging kan ook het strafrecht niet ontsnappen wat in de eerste plaats heeft geresulteerd in een versnippering op legislatief vlak. Gaandeweg werd het gehele maatschappelijk leven overdekt met een onoverzichtelijk netwerk van raamwetgeving, koninklijke besluiten, administratieve regelgeving en uitvoeringsmaatregelen. De sterke groei van de publiekrechtelijke regelgeving die betrekking heeft op het leefmilieu ging pari passu gepaard met een even sterke toename aan strafbaarstellingen waarvan de redactie niet wordt opgesteld 'door criminalisten maar door ambtenaren door wie aan de administratieve regels in fine en als een automatisme als het ware nog snel enkele strafbepalingen worden toegevoegd. ${ }^{83} \mathrm{Het}$ zijn deze verspreide strafbepalingen in de bijzondere milieuwetten, de artikelen 173a en $173 \mathrm{~b} \mathrm{Sr}$ en de zorgplichtbepalingen uitgezonderd, die het huidige materiële milieustrafrecht uitmaken ${ }^{84}$ Een dergelijke gang van zaken zet niet alleen de strafrechtelijke rechtsbeginselen zwaar onder druk maar heeft ook een zware overbelasting van het strafrechtsbedrijf tot gevolg. Dan rijst de vraag of de oorspronkelijke idealen van doeltreffendheid en doelmatigheid wel degelijk kunnen worden geëffectueerd: 'De winst van een slagvaardiger wetgeving blijkt dan een korte termijnwinst te zijn ${ }^{185}$ zodat wellicht zelfs aan het te bereiken overheidsdoel - een beter leefmilieu - niet altijd evenveel recht kan worden gedaan.

\section{B. DE ADMINISTRATIEVE AFHANKELIJKHEID VAN HET MILIEUSTRAFRECHT.}

\section{Het naar voren halen van de strafbaarheid.}

De nood tot sturing van risicovol gedrag leidt in het milieustrafrecht in de eerste plaats tot een naar voren halen van de criminalisering (Vorfeldkriminalisierung). Dit uit zich onder meer in een andere invulling van de rechtsgoedbeschermende functie van het strafrecht. Staat in het klassieke strafrecht de bescherming van welomlijnde individualiseerbare rechtsgoederen centraal, zoals fysieke integriteit, eigendom en leven, in een 'risico'strafrecht ${ }^{86}$ als het milieustrafrecht gaat het om de bescherming van meer collectieve rechtsgoederen, zoals het leefmilieu, volksgezondheid, maar ook concurrentieverhoudingen. ${ }^{87}$ Eigenlijk gaat het veeleer om de bescherming van bepaalde socio-economische belangen en processen, dan om concrete, tastbare rechtsgoederen. ${ }^{88}$ Hassemer merkt hierover het volgende op:

83. Morrens, P., 'Enkele actuele knelpunten in het leefmilieustrafrecht', $R W, 1987-1988,1281$.

84. Schaffmeister, D., 'De strafrechtelijke bescherming van ecologische rechtsgoederen', in Faure, M., Oudijk, J. en Schaffmeister, D., o.c., 1991, 157 e.v..

85. De Roos, Th., Strafbaarstelling van economische delicten, Amhem, Gouda Quint, 1987, 77.

86. Met de term risicostrafrecht, doel ik niet op risicoaansprakelijkheid, maar op een strafrecht, dat, zoals het milieustrafrecht, zich hoofdzakelijk richt tot het strafbaarstellen van risicovolle gedragingen en activiteiten in onze samenleving. De manier waarop dit gebeurt hoeft niet automatisch te leiden tot het instellen van een strafrechtelijke risicoaansprakelijkheid, hoewel dit gevaar, zoals later zal blijken, wel aanwezig is.

87. Rengier, R., 'Zur Bestimmung und Bedeutung der Rechtsgüter im Umweltstrafrecht', NJW, 1991, 2506.

88. Tiedemann, K. en Kindhäuser, U., 'Umweltstrafrecht - Bewährung oder Reform?', NStZ, 1988, 339-340: 'Das Umweltstrafrecht stellt den strafrechtlichen Rechtsgüterschutz in mehrfacher Hinsicht vor neue Probleme. Zunächst kőnnen die Güter hier nicht als vorgegebene Größen 
'Der Rechtsgüterschutz wird im modernen Strafrecht zum Institutionenschutz. Dem entspricht es, daß die Rechtsgüter, um deren Schutz es jeweils gehen soll, nicht Individual-, sondern Universalrechtsgüter sind [...] Die Rechtsgüter, welche das moderne Strafrecht zur Legitimation von Strafdrohungen benennen kann, diskriminieren nicht mehr: es gibt kaum eine menschliche Verhaltensweise, welche man heute mit Berufung auf das Prinzip des Rechtsgüterschutz entkriminalisieren müßte. ${ }^{89}$

Rechtsgoedbescherming wordt vanuit een dergelijk perspectief niet meer gezien als een negatief strafbaarstellingcriterium, maar als een positief strafbaarstellingscriterium ${ }^{90}$ :

'Das Prinzip des Rechtsgüterschutz wandelt sich von einem bedingten Bestrafungsverbot, in ein Bestrafungsgebot. ${ }^{.91}$

Daarmee dreigt het gevaar dat bijna iedere crimineel-politieke grond voor een terughoudend gebruik van het strafrecht wegvalt. ${ }^{92}$

Terwijl in het klassieke strafrecht hoofdzakelijk retrospectief, dat wil zeggen op grond van een gepleegde daad, wordt opgetreden, staan preventief en toekomstgericht optreden in het milieustrafrecht (uit noodzaak) duidelijk op de voorgrond. Het milieustrafrecht maakt daarom bij voorkeur gebruik van abstracte gevaarzettingsdelicten en (de laatste jaren) van zorgplichtbepalingen omdat zo risicovolle activiteiten als dusdanig strafrechtelijk kunnen worden aangepakt zonder dat er daadwerkelijk sprake moet zijn van schade of krenking. ${ }^{93}$ Een oriëntatie op risicobeheersing veronderstelt per definitie een toekomstgericht gebruik van het strafrecht:

verstanden werden. Wăhrend Leib, Leben oder Eigentum unter Bezugnahme auf natürliche oder normative Kriterien hinreichend präzise definiert und mit Blick auf diese Bestimmung zweckrational geschützt werden können, sind die Güter des Umweltschutzes bereits lädiert: Der status quo ist - in der Regel - nicht der gewünschte wertvolle Ist-Zustand; vielmehr befinden sich Wasser, Luft und Boden in einem Verbesserungsbedürftigen Stadium. Deshalb ist ein SollZustand festzulegen, und dabei kann sich das Strafrecht durchaus autonom für eine möglichst optimale okologischen Restitution des Naturhaushaltes (auch um seiner selbst willen) entscheiden.'

89. Hassemer, W., l.c., 1992, 381.

90. Zie hierover Hohman, O., Das Rechtsgut der Umweltdelikte. Grenzen des strafrechtlichen Umweltschutzes, Frankfurt am Main, Peter Lang Verlag, 1991, 179-234.

91. Hassemer, W., l.c., 1992, 380.

92. Aldus Seelman, K., l.c., 1992, 453-454.

93. Zie voor een, in het licht van de rechtsstatelijke beginselen, grondige analyse van abstracte gevaarzettingsdelicten en zorgplichtbepalingen in het milieustrafrecht Faure, M. en Visser, M., 'How to punish Environmental Pollution? Some Reflexions on Various Models of Criminalisation of Environmental Harm', European Journal of Crime, Criminal Law and Criminal Justice, 1995, 316-368; Faure, M. en Visser, M., 'Het tekort van het Nederlandse milieustrafrecht', in Van Kraaij, M. en Van Veen, A. (red.), Onderneming en strafrecht, Nijmegen, Ars Aequi Libri, 1997, 123-144; Faure, M. en Visser, M., o.c.,1999, 53-226 en 321-364. 
'Die Risikogesellschaft hat offenbar dort, wo sie die Gefahren nicht leugnen kann, ein Bedürfnis nach Minimierung von Unsicherheit. Dieses Bedürfnis wirkt sich einmal aus in der Neigung, das Entstehen bestimmter nicht konsentierter Gefahren schon in einem sehr frühen Stadium der Entwicklung mit Hilfe des Strafrechts zu stoppen. Man will es gar nicht zu einer konkreten Gefahr kommen lassen, sondern bereits Handlungsweisen, die gefahrbegründer sein könnten, weit im Vorfeld abfangen. ${ }^{94}$

Wanneer echter schade uit het blikveld verdwijnt, verdwijnt hiermee ook de klassieke aansprakelijkheidsbegrenzer van de causaliteit op de achtergrond. De voor het milieustrafrecht typische gevaarzettingsdelicten zijn immers bedoeld om het causaliteitsvraagstuk vrijwel overbodig te maken. ${ }^{95}$

Strafrechtelijke risicobeheersing via het naar voren halen van de strafbaarheid leidt tenslotte tot een verbestuurlijking van het strafrecht, tot 'métamorphoses administratives du droit pénal $^{196}$, in de zin dat om redenen van doelmatigheid het strafrecht bestuursaccessoir of administratief afhankelijk wordt gemaakt. Hoewel de bescherming van ecologische rechtsgoederen als rechtvaardiging voor strafbaarstelling wordt aangevoerd, worden zij doorgaans niet rechtstreeks beschermd, maar indirect via opgelegde administratieve plichten. Deze administratieve plichten worden op grond van een vergunningensysteem door overheden vastgelegd. Dat komt goed tot uiting in het huidige milieustrafrecht waar iemand normaal gesproken zich pas schuldig maakt aan milieuverstoring indien deze niet over een vergunning beschikt of zich niet aan de vergunningsvoorwaarden houdt. ${ }^{97}$ Deze administratieve afhankelijkheid heeft onder meer tot gevolg dat

'die Strafrechtsnormen werden [...] zu einem Instrument der Administration partikulärer Situationen und außergewöhnlicher Risiken, m.a.W. zu einem Instrument der kontingenten und punktuellen Reaktion auf konkrete "Gefährdungen". .98

Laten we nu wat dieper op deze beruchte administratieve afhankelijkheid ingaan.

94. Seelman, K., l.c., 1992, 453.

95. Hassemer, W., l.c., 1992, 381; Stratenwerth, G., 'Zukunfstsicherung mit den Mitteln des Strafrechts', ZStW, 1993, 681-682.

96. Aldus De Nauw, A., Les métamorphoses administratives du droit pénal de l'entreprise, Gent, Mys \& Breesch, 1994.

97. Zie over de voor- en nadelen van de administratieve afhankelijkheid, Faure M.G., 'De gevolgen van de "administratieve afhankelijkheid" van het milieustrafrecht: een inventarisatie van knelpunten', in Faure, M.G., Oudijk, J.C. en Schaffmeister, D., o.c, 1991, 91-150.

98. Barrata, A., 'Jenseits der Strafe - Rechtsgüterschutz in der Risikogesellschaft. Zur Neubewertung der Funktionen des Strafrechts', in Festschrift Kaufmann, 1993, 401. 
De belangrijkste illustratie van het instrumentalistische karakter van het milieustrafrecht blijkt uit de administratieve afhankelijkheid op het niveau van de strafbaarstellingen. In het milieustrafrecht worden de ecologische rechtsgoederen zoals zuiver oppervlaktewater, schone bodem en schone lucht niet rechtstreeks maar via opgelegde administratieve plichten beschermd. Deze administratieve plichten worden door de onderscheiden milieuoverheden meestal in vergunningen vastgelegd. Een dergelijk stelsel, waarbij kan worden gesproken van een zekere 'Selbstentmachtigung' of 'afdanking' van de strafwetgever, vindt zijn voornaamste rechtvaardiging in het streven naar een doelmatig en doeltreffend milieubeleid. ${ }^{99}$ Het blijkt immers efficiënter dat het bestuur ex ante de afweging maakt van wat strafbaar is, door het opleggen van vergunningsvoorwaarden, dan dat de strafrechter dit ex post zou doen. Het bestuur beschikt ook over meer expertise. ${ }^{100}$ Bovendien zou de administratieve afhankelijkheid beter dan het strafbaar stellen van verontreiniging op zich in staat zijn het lex certa-beginsel te respecteren:

\begin{abstract}
'Des incriminations générales en matière d'atteinte à l'environnement constituent des normes floues qui procurent aux diverses autorités intervenant dans le système de l'administration de la justice pénale un pouvoir pratiquement sans frein. Le principe de la légalité des infractions par lequel le droit pénal classique assure la défense de l'individu dans sa confrontation au pouvoir de punir de l'Etat est difficilement conciliable avec des incriminations de type ouvert de ce genre'. ${ }^{101}$
\end{abstract}

De administratieve afhankelijkheid kan in het milieustrafrecht verschillende vormen aannemen en het is van belang deze goed van elkaar te onderscheiden wanneer men het rechtskarakter van het milieustrafrecht wil evalueren. Men kan grosso modo een onderscheid maken tussen absolute en relatieve vormen van administratieve afhankelijkheid. ${ }^{102}$ Deze moeten afzonderlijk worden beoordeeld wil men tot zinnige uitspraken komen over de betekenis en de waarde van de administratieve afhankelijkheid in het milieustrafrecht als geheel. ${ }^{103}$

\title{
a. Strafbaarstelling van administratieve ongehoorzaamheid
}

In de meest absolute vorm van administratieve afhankelijkheid dient het strafrecht uitsluitend tot handhaving van administratieve plichten en het instandhouden van de bestuurlijke ordening. Het strafrecht is in die zin volledig ondergeschikt gemaakt aan de beslissingen en de desiderata van het bestuur, de administratieve overheden. Deze absolute administratieve afhankelijkheid kent op haar beurt weer verschillende toepassingen. De meest uitgesproken

99. Tiedemann, K., 'Umweltstrafrecht', in Kimminich, O., von Lersner, H. en Storm, P. (Hrsg.), Handworterbuch des Umweltrechts, Berlijn, De Gruyter, 1986, 853-854.

100. Faure, M., l.c., 1990, 67-80.

101. De Nauw, A., o.c., 1994, 84-85.

102. Koopmans, I.M., o.c., 1996, 17-24.

103. Tiedemann, K. en Kindhäuser, U., l.c., 1988, 342. 
variant is die waarin het strafrecht dient voor de handhaving van door het bestuur opgelegde controle- en meldingsplichten, zoals bepalingen die aan de justitiabele een schriftelijke rapportage opleggen. In het licht van de beoogde sturing heeft de overheid immers voor de uitoefening van haar wettelijke taak tot milieubescherming behoefte aan een groot aantal gegevens. Op basis van deze gegevens wordt een justitiabele verplicht om onder strafbedreiging gegevens te verstrekken aan de overheid. ${ }^{104}$ Een typisch voorbeeld is artikel 8.41, eerste lid van de Wet milieubeheer (Wm):

'Bij algemene maatregel van bestuur krachtens artikel 8.40 wordt de verplichting opgelegd tot het melden van het oprichten of veranderen van een inrichting waarop de maatregel betrekking heeft, dan wel van het veranderen van de werking daarvan.'

Van een absolute administratieve afhankelijkheid getuigen ook de strafbaar gestelde bepalingen die tot doel hebben het toezicht van de overheid mogelijk te maken. ${ }^{105}$ Een voorbeeld is artikel $18.6 \mathrm{Wm}$ :

'Ieder is verplicht aan de krachtens artikel 18.4 aangewezen ambtenaren desgevraagd alle medewerking te verlenen en alle inlichtingen te verstrekken, die zij redelijkerwijs bij de uitvoering van de hun op grond van deze wet opgedragen taak behoeven.'

Het hoeft nauwelijks betoog dat in deze absolute vormen van administratieve afhankelijkheid de instrumentalistische inzet van het strafrecht het sterkst tot uiting komt. Deze administratieve afhankelijkheid is uitsluitend gericht op de bestraffing van 'administratieve ongehoorzaamheid'. ${ }^{106}$ Het strafrecht staat zelfs niet ten dienste van het leefmilieu, maar van bestuurlijke beslissingen. ${ }^{107}$

\section{b. Strafbaarstelling van het niet-naleven van vergunningsvoorschriften}

Een iets minder absolute vorm van administratieve afhankelijkheid heeft betrekking op bepalingen die het milieuverstorend handelen in strijd met of zonder een vergunning strafbaar stellen. Het gaat dan om de zogenaamde abstracte gevaarzettingsdelicten. ${ }^{108}$ In deze bepalingen staat ook slechts de strafrechtelijke handhaving van administratieve voorschriften centraal, maar tot op zekere hoogte wordt wel rekening gehouden met de bescherming van de ecologische rechtsgoederen. Dit betekent dat men deze vorm van administratieve afhankelijkheid niet zomaar kan afschilderen als gericht op de loutere bescherming van administratieve belangen. ${ }^{109}$ Relevant is veeleer de vraag wat de inhoud

104. Zie hierover Faure, M. en Visser, M., o.c., 1999, 71.

105. Faure, M. en Visser, M., o.c., 1999, 73.

106. Heine, G., l.c., 1991, 59.

107. Waling, C., Het materiële milieustrafrecht, Arnhem, Gouda Quint, 1990, 16; Faure, M. en Visser, M., o.c., 1999, 65.

108. Zie hierover Faure, M. en Visser, M., o.c., 1999, 53 e.v.

109. Faure, M. en Visser, M., o.c., 1999, 65. 
en het doel is van deze beslissingen. In die mate dat deze (mede) dienen tot de bescherming van het leefmilieu, dient de strafrechtelijke handhaving van deze beslissingen ook het leefmilieu, zij het indirect. Het zijn bepalingen die meestal in eerste instantie een algemeen verbod om het milieu te verstoren inhouden - dat is de ecologische component van de bepaling - waarop vervolgens uitzonderingen mogelijk zijn door het hebben van een vergunning of ontheffing - dat is de administratieve component van de bepaling. Dergelijke vergunningen of ontheffingen zijn het resultaat van een belangenafweging waarbij het bestuur expliciet moet rekening houden met het belang van het leefmilieu en de doelstellingen van de bijzondere milieuwetten. De uiteindelijke door het bestuur bepaalde materiële norm dient dus onrechtstreeks de bescherming van de ecologische rechtsgoederen. Klassiek voorbeeld is artikel 1, eerste lid, Wvo:

'Het is verboden zonder vergunning met behulp van een werk afvalstoffen, verontreinigende of schadelijke stoffen, in welke vorm ook, te brengen in oppervlaktewateren.'

Men kan daarom niet volhouden dat de strafrechtelijke handhaving van bijvoorbeeld Wvovergunningsvoorschriften alleen maar dient om de bestuurlijke belangen te beschermen. Voor zover deze voorschriften het leefmilieu dienen, is het strafrecht ook gericht op de bescherming van de ecologische rechtsgoederen.

Wel moet worden opgemerkt dat ook deze vorm van administratieve afhankelijkheid niettemin als absoluut moet worden getypeerd. Immers, het strafrecht wordt nog steeds ingezet als handhavingsinstrument van bestuurlijke beslissingen en niet voor de rechtstreekse bescherming van ecologische rechtsgoederen. Door het (uitsluitend) via vergunningen strafbaar stellen van bepaald verontreinigend gedrag worden doel en middelen omgeruild:

'De doelstelling van de milieuwetgeving, namelijk de bescherming van het milieu, raakt op de achtergrond; de bestuurlijke middelen staan voorop en worden zelfs strafrechtelijk beschermd in de veronderstelling dat daardoor uiteindelijk het door de milieu-autoriteiten beheerde milieu veilig zal zijn.' ${ }^{110}$

Een dergelijke veronderstelling mag best naïef worden genoemd; ervan uitgaan dat milieuoverheden per definitie neutrale, zuiver efficiënte operationaliseerbare instrumenten zouden zijn, die hun eigen belangen geheel ondergeschikt zouden maken aan de bescherming van het leefmilieu is helaas een hersenschim. Bovendien wordt van hen een dergelijke eenzijdige milieubescherming binnen het systeem van de administratieve afhankelijkheid ook niet verlangd: hun taak is eigenlijk veel complexer. Zij dienen niet alleen het leefmilieu te behartigen, maar dienen bij de vergunningverlening een

110. Schaffmeister, D., 'De strafrechtelijke bescherming van ecologische rechtsgoederen', in Faure, M.G., Oudijk, J.C. en Schaffmeister, D. (red.), o.c., 1991, 169. 
belangenafweging te maken tussen ecologische en andere doorgaans sociale en economische belangen.

Het voornaamste verschil met de strafbaarstelling van de 'administratieve ongehoorzaamheid' is dat in deze administratieve voorschriften in ieder geval normen staan die betrekking hebben op de bescherming van het leefmilieu. Met andere woorden, het rechtsgoed is hier niet slechts de bestuurlijke beslissing, maar het via deze bestuurlijke beslissing beschermde ecologische rechtsgoed. Dit betekent evenwel dat de macht om te bepalen wat al dan niet strafbaar is, in sterke mate wordt bepaald door het bestuur. In die zin kan men nog steeds spreken van een absolute vorm van administratieve afhankelijkheid omdat de mate van strafrechtelijke bescherming van het rechtsgoed door het bestuur wordt gedefinieerd en niet door het strafrecht. ${ }^{111}$ Er kan dan ook reeds sprake zijn van een strafbaar feit zonder dat een ecologische rechtsgoed is geschonden louter en alleen omdat vergunningsvoorschriften zijn overtreden. Omgekeerd is er geen strafbaar feit wanneer vergunningconform is gehandeld ook al is het ecologische rechtsgoed feitelijk wel geschonden. Daar het bestuur via vergunningen of ontheffingen de strafbaarheid van verboden gedragingen bepaalt, hangt het succes van dergelijke strafbepalingen hoofdzakelijk af van de integriteit en de normconformiteit van het bestuurlijk handelen.

Dit doet vanuit strafrechtelijk perspectief allerlei vragen rijzen, zoals de kwestie in welke mate de strafrechter gebonden dient te zijn aan vergunningen: in hoeverre dient de strafrechter zich te confirmeren aan de beslissingen van het bestuur, met name in die gevallen waar deze beslissingen aan de ecologische rechtsgoederen schade berokkenen en evident in strijd zijn met de milieurechtelijke regels? $\mathrm{Zo}$ is het denkbaar dat vergunningen in strijd met in AMVB's neergelegde emissienormen verleend worden. Kan de justitiabele zich voor de strafrechter op zo'n vergunning beroepen ter rechtvaardiging van zijn milieuverstorend gedrag of is het daarentegen de plicht van de strafrechter zo'n onrechtmatige vergunning onverbindend te verklaren? ${ }^{112}$ Aan de kant van de overheid rijst vervolgens de vraag in welke mate deze voor de verlening van een onrechtmatige vergunning strafrechtelijk verantwoordelijk kan worden gesteld.

\section{c. Verwaltungsaktsakzessorietät versus Verwaltungsrechtsakzessorietät}

Het antwoord op bovenstaande vragen wordt voor een groot deel bepaald door de wijze waarop men inhoudelijk de administratieve afhankelijkheid van het milieustrafrecht benadert en de wijze waarop men de relatie tussen bestuur en strafrechter definieert. Verdedigt men een absolute administratieve afhankelijkheid waarbij het strafrecht alleen maar ten dienste staat van de handhaving van de vergunning(svoorschriften), dan is er geen of nauwelijks ruimte voor de strafrechter om onrechtmatige vergunningen naast zich neer te leggen. Een dergelijke benadering van de administratieve afhankelijkheid wordt in het

111. Koopmans, I.M., o.c., 1996, 19.

112. Heine, G., 'Zur Rolle des strafrechtlichen Umweltschutzes', ZStW, 1989, 731. 
Duits ook wel Verwaltungsaktsakzessorietät genoemd. ${ }^{113}$ Het gaat dan om een loutere beschikkings- of vergunningafhankelijkheid. In zo'n benadering is het instrumentalistische karakter van het milieustrafrecht zeer uitgesproken, omdat strafrechtelijk het ecologische rechtsgoed onbeschermd blijft in gevallen waar het bestuur faalt in zijn verantwoordelijkheden als risicomanager van milieuverstorende activiteiten. Wat het strafrecht doet is hoofdzakelijk bestuurlijke belangen beschermen ook al is het resultaat daarvan onrechtmatig en heeft dit dus een mogelijke milieuverstoring tot gevolg.

Als correctief op een Verwaltungsaktsakzessorische invulling van het milieustrafrecht kan een meer Verwaltungsrechtsakzessorische opvatting worden verdedigd. Dit betekent dat het strafrecht en dus ook de strafrechter niet zozeer afhankelijk dienen te zijn van bestuurlijke beslissingen, zoals vergunningen, maar van het bestuursrecht, meer bepaald van het materiële milieurecht. ${ }^{114}$ Uitgangspunt is dat strafrecht en strafrechter in de eerste plaats tot taak moeten hebben het objectieve milieurecht te handhaven en niet slechts (foutieve) administratieve beslissingen. Deze beslissingen verdienen slechts strafrechtelijke handhaving en bescherming voor zover zij de vertolking en de toepassing zijn van het milieurecht waaraan niet alleen de burger maar ook het bestuur zich bij zijn belangenafweging moet houden. ${ }^{115}$ Dat de keuze voor Verwaltungsaktsakzessorietät of Verwaltungsrechtsakzessorietät veel verschil uitmaakt in de toepassing van het milieustrafrecht, in het bijzonder wanneer sprake is van wederrechtelijke vergunningverlening, zal op verschillende momenten in deze studie blijken. $\mathrm{Nu}$ is het vooral van belang te weten dat de mate van administratieve afhankelijkheid niet alleen te maken heeft met de wijze van strafbaar stellen, maar ook met de manier waarop men in de praktijk vanuit een grondslagenperspectief met deze strafbaarstellingen wenst om te gaan. Het bovenstaande maakt ook duidelijk hoe nauw de band is tussen de administratieve afhankelijkheid van het milieustrafrecht enerzijds en het vraagstuk van de strafrechtelijke aansprakelijkheid van overheden anderzijds.

113. Zie o.m. Heine, G., L.c., 1991, 59; Heine. G., 'Milieustrafrecht in West-Europa. Rechtspolitieke trends, voorwaarden voor strafbaarheid en praktische problemen bij de vervolging', in Faure, M.G., Oudijk, J.C. en Schaffmeister, D. (red.), o.c., 1991, 466-467; Breuer, R., 'Verwaltungsrechtlicher und strafrechtlicher Umweltschutz - Vom Ersten zum Zweiten Umweltkriminalitătsgesetz', JZ, 1994, 1083-1085.

114. Heine, G., l.c., 1991, 61; Schall, H., 'Umweltschutz durch Strafrecht: Anspruch und Wirklichkeit', NJW, 1990, 1265; Rogall, K., 'Gegenwartsprobleme des Umweltstrafrechts', in Festschrift der Rechtswissenschaftlichen Fakultät zur 600-Jahr-Feier der Universität zu Köln, Köln, Carl Heymanns Verlag KG, 1988, 522: 'Die Verwaltungsrechtsakzessorietăt bringt das Strafrecht in Abhängigkeit von umweltverwaltungsrechtlichen Rechtsvorschriften. Die Strafbarkeit hăngt dann davon ab, daß der Täter z.B. "entgegen einer Rechtsvorschrift" gehandelt hat. Die Verwaltungsaktsakzessorietăt besteht darin, daß das Strafgesetz auf einen Verwaltungsakt hinweist. Für die Strafbarkeit ist dann etwa erforderlich, daß der Tăter "ohne Genehmigung" oder "entgegen einer Anordnung, Untersagung oder Auflage", gehandelt hat.'

115. Geulen, R., 'Grundlegende Neuregelung des Umweltstrafrechts', ZRP, 1988, 325. 


\section{d. Bescherming van de ecologische rechtsgoederen: concrete gevaarzettingsdelicten}

De meest relatieve vorm van administratieve afhankelijkheid betreft strafbaarstellingen die min of meer los van het bestuur de ecologische rechtsgoederen beschermen. Een mooi voorbeeld is de Duitse milieustrafbepaling $\S 324$ StGB:

'Abs. I Wer unbefugt ein Gewässer verunreinigt oder sonst dessen Eigenschaften nachteilig verändert, wird mit Freiheitsstrafe bis zu fünf Jahren oder mit Geldstrafe bestraft.

Abs. 2 Der Versuch ist strafbar.

Abs. 3 Handelt der Tăter fahrlässig, so ist die Strafe Freiheitsstrafe bis zu drei Jahren oder Geldstrafe.'

Een dergelijke strafbepaling heeft tot doel om bepaalde ecologische rechtsgoederen zoals water, bodem en lucht rechtstreeks te beschermen. ${ }^{116}$ Kenmerkend voor dergelijke strafbaarstellingen is dat wordt vereist dat er sprake is van een concreet gevaar voor het beschermde ecologische rechtsgoed. Men spreekt dan ook van concrete gevaarzettingsdelicten. In tegenstelling tot de absoluut bestuursafhankelijke strafbaarstellingen, de abstracte gevaarzettingsdelicten, is een emissie vereist die een concreet gevaar oplevert voor het leefmilieu, zodat de loutere overtreding van administratieve voorschriften zonder dat sprake is van een concrete gevaarzetting niet volstaat voor de strafbaarheid. ${ }^{117} \mathrm{Zo}$ is het in $\S 324 \mathrm{StGB}$ beschermde rechtsgoed het water in zijn functie voor mens en milieu en niet de bestuurlijke belangen. ${ }^{118}$

Dit betekent niet dat de band met het administratieve recht volledig wordt losgelaten. Immers, zolang de administratieve voorschriften worden nageleefd, is er normaliter geen strafbare gedraging, omdat de gedraging niet als wederrechtelijk kan worden aangemerkt. Bemerk evenwel dat ook binnen relatief administratief afhankelijke strafbepalingen nog steeds een Verwaltungsaktsakzessorische visie op het milieustrafrecht parten kan spelen. Ook bij deze strafbepalingen blijven bestuurlijke beslissingen een cruciale rol spelen doordat zij als rechtvaardigingsgrond kunnen worden aangemerkt. Opnieuw rijst dan de vraag in welke mate vergunningen een strafuitsluitende werking kunnen hebben en of de strafrechter de ruimte heeft daarover zelfstandig een oordeel te vellen. Verdedigt men ook bij deze strafbepalingen een vergunningafhankelijke visie op het milieustrafrecht, dan impliceert dit in beginsel dat iedere bevrijdende vergunning een strafuitsluitende werking kan hebben, of deze nu rechtmatig is of niet. Verdedigt men daarentegen een Verwaltungsrechtsakzessorische visie, dan kan men de instrumentalistische binding van het strafrecht aan het bestuur enigszins doorbreken door te eisen dat slechts die vergunningen strafuitsluitend mogen werken die rechtmatig zijn verleend. Dat dit niet steeds voor de hand ligt, kan nu worden geîllustreerd door iets dieper in te gaan op de inhoud van de wederrechtelijkheid in het milieustrafrecht.

116. Heine, G., l.c., 1989, 731.

117. Vgl. Faure, M. en Visser, M., o.c., 1999, 227 e.v.

118. Heine, G., L.c., 1991, 60; Koopmans, I.M., o.c., 1996, 91. 
Een strafrechtsdogmatisch gevolg van de administratieve afhankelijkheid is onder meer dat de wederrechtelijkheid aan betekenis inboet. Voornamelijk bij de abstracte gevaarzettingsdelicten valt materiële wederrechtelijkheid automatisch samen met een louter formele illegaliteit die dan hoofdzakelijk bestaat in een handelen zonder of in strijd met een vergunningsvoorschrift. De wederrechtelijkheid is van een materieel strafrechtelijke notie veranderd in de overtreding van bestuurlijke plichten. Zolang deze plichten rechtmatig zijn en in voldoende mate de bescherming van het leefmilieu behartigen, hoeft dit geen fundamentele bezwaren op te leveren. Het heeft ook duidelijke voordelen in de zin dat recht wordt gedaan aan de kenbaarheid van de strafbaar gestelde norm. De strafbaarheid van de milieuverstoring is voor burger, openbaar ministerie en strafrechter immers vrij eenvoudig vast te stellen. Dat het klassieke verbod wederrechtelijk te handelen in het milieustrafrecht grotendeels is vervangen door het gebod bestuursconform te handelen, is dan nog min of meer aanvaardbaar.

Dit wordt volgens mij anders indien het gaat om milieustrafbepalingen die tot doel hebben de ecologische rechtsgoederen meer rechtstreeks te beschermen, zoals bij concrete gevaarzettingsdelicten. Dan zou een meer van het bestuur onafhankelijk milieustrafrecht voorop moeten staan en zou de wederrechtelijkheid een inhoud moeten krijgen die niet eenzijdig en uitsluitend door het bestuur wordt ingevuld. Laten we het belang hiervan illustreren aan de hand van de bekendste Nederlandse milieustrafbepalingen, namelijk de artikelen 173a en 173b Sr. Artikel 173a Sr luidt als volgt:

'Hij die opzettelijk en wederrechtelijk een stof op of in de bodem, in de lucht of in het oppervlaktewater brengt, wordt gestraft:

1. met een gevangenisstraf van ten hoogste twaalf jaren of een geldboete van de vijfde categorie, indien de schuldige weet of ernstige reden heeft om te vermoeden, dat daarvan gevaar te duchten is;

2. met gevangenisstraf van ten hoogste vijftien jaren of een geldboete van de vijfde categorie, indien de schuldige weet of ernstige reden heeft om te vermoeden dat daarvan levensgevaar te duchten is en het feit iemands dood tot gevolg heeft.'

Artikel $173 \mathrm{~b} \mathrm{Sr}$ is de culpose variant. Het gaat hier om concrete gevaarzettingsdelicten. Er moet sprake zijn van een emissie die een concreet gevaar vormt voor het beschermde rechtsgoed. ${ }^{119}$ Voor dergelijke delicten is voor de strafbaarheid in beginsel geen schending van een administratief voorschrift vereist, bijvoorbeeld de overtreding van een vergunningsvoorwaarde, maar de naleving van deze administratieve voorschriften sluit over het algemeen de strafbaarheid wel uit. ${ }^{120}$

119. Waling, C., o.c., 1990, 23; Hendriks, L.E.M. en Wöretshofer, J., o.c., 1995, 38. Faure, M. en Visser, M., o.c., 1999, 227-228.

120. Faure, M. en Visser, M., o.c., 1999, 228. 
De vraag rijst nu wanneer administratieve voorschriften in staat zijn om de strafbaarheid uit te sluiten. Doorslaggevend is dus de inhoud en de betekenis van het bestanddeel wederrechtelijk. Men zou verwachten, klassiek strafrechtelijk geredeneerd, dat wederrechtelijk betekent in strijd met het objectieve recht, of op zijn minst in strijd met het milieurecht, de normen die in de milieuwetgeving zijn neergelegd en waaraan ook het bestuur bij de bepaling van de vergunningsvoorschriften zich moet houden. Verouderde of in strijd met de wet afgegeven vergunningen zouden dan niet rechtvaardigend kunnen werken. Niettemin lijkt dit toch het geval te zijn. Het bestanddeel 'wederrechtelijk' wordt immers absoluut administratief afhankelijk uitgelegd als handelen zonder of in strijd met een vergunning. Zolang men beschikt over een vergunning of geen administratieve voorschriften zijn overtreden, is er dus geen wederrechtelijke emissie. Dat blijkt duidelijk uit de parlementaire voorbereiding:

\begin{abstract}
'Handelt iemand in overeenstemming met zo een vergunning, dan is dit niet wederrechtelijk, [...] Het is billijk dat degeen die handelt in overeenstemming met de voorschriften die de milieu-autoriteiten in zijn concreet geval hebben gegeven, zich niet daarnaast zorgen hoeft te maken dat hij mogelijk in aanraking zal komen met de strafrechter. De overheid tone tegenover de burger één gelaat. Het kan niet zo zijn dat wat de milieuautoriteiten toestaan langs strafrechtelijke weg wordt verboden. ${ }^{121}$
\end{abstract}

De macht van de administratieve overheden in termen van invulling van de strafbaarheid is bij de artikelen 173a en 173b $\mathrm{Sr}$ dus vrijwel even groot als bij de abstracte gevaarzettingsdelicten. Een dergelijke Verwaltungsaktsakzessorische invulling van de wederrechtelijkheid schept allerlei problemen. Zo zijn emissies die een gevaar kunnen vormen voor de gezondheid blijkbaar niet langer strafbaar wanneer ze vergunningconform plaatsvinden.

Ook rijst de vraag in welke mate onrechtmatige vergunningen de strafbaarheid kunnen uitsluiten en of de strafrechter in staat is dergelijke vergunningen onverbindend te verklaren zodat de vergunninghouder zich niet langer op deze vergunningen kan beroepen. De strafrechter zal echter de Verwaltungsaktsakzessorische invulling van de artikelen 173a en $173 \mathrm{~b}$ Sr alleen kunnen doorbreken indien wordt aanvaard dat hij deze vergunningen op hun wet- en rechtmatigheid mag toetsen. Benadert men echter de taak van de strafrechter op een Verwaltungsaktsakzessorische wijze, dan is hij gebonden aan administratieve beschikkingen en is hij derhalve niet in staat een door een onrechtmatige vergunning gedekte emissie als een strafbaar feit aan te merken. Zoals reeds in de inleiding tot deze studie werd uiteengezet, worden dergelijke nadelen in de Duitse literatuur aangegrepen als argumenten voor een strafrechtelijke aansprakelijkheid van vergunningverlenende instanties wanneer zij door onzorgvuldige vergunningverlening meewerken aan milieuverstoring.

Kortom, het instrumentalistische karakter van het milieustrafrecht blijkt niet slechts uit de wijze van strafbaar stellen, zoals we bij de abstracte gevaarzettingsdelicten kunnen

121. MvT, TK $1984-85,19020$, nr. 103, 13. 
waarnemen. Ook bij strafbepalingen waar men een meer autonome en machtskritische van het bestuur onafhankelijke inzet van het strafrecht zou verwachten, is soms sprake van een doorgedreven instrumentalisme. Dit is wellicht dé pijnlijke paradox van het milieustrafrechtelijk instrumentalisme. Enerzijds wordt de bescherming van collectieve rechtsgoederen als water, bodem en lucht aangevoerd als legitimatie voor de inzet van het strafrecht. Daarin ligt de rechtvaardiging van de strafbaarstelling van risicovol gedrag. Anderzijds moet worden vastgesteld dat de uiteindelijke doelstelling in de praktijk veelal niet is gesitueerd op het vlak van die rechtsgoederen, maar hoofdzakelijk is gelegen op het gebied van hoofdzakelijk administratieve belangen, die slechts indirect de ecologische rechtsgoederen vermogen te beschermen.

Terloops zij opgemerkt dat de artikelen 173a en 173b Sr ook nog om andere redenen sterk worden bekritiseerd. Reeds bij het lezen van deze bepalingen wordt duidelijk hoe ingewikkeld de delictsbestanddelen zijn geformuleerd. Het hoeft daarom niet te verbazen dat in de literatuur kritiek is geuit op de redactie van deze strafbepalingen. ${ }^{122}$ In hoofdstuk VI wordt op die kritiek dieper ingegaan.

\section{De uitholling van het schuldvereiste in het milieustrafrecht.}

Het instrumentalistische karakter van het milieustrafrecht kan tenslotte worden geîllustreerd aan de hand van het klassieke schuldbeginsel. Net zoals ieder ander delict, veronderstelt een milieudelict de aanwezigheid van een schuldelement, zonder dewelke geen sprake kan zijn van een strafbaar feit. ${ }^{123}$ Een objectieve strafrechtelijke aansprakelijkheid moet dus in beginsel ook in het milieustrafrecht worden uitgesloten. ${ }^{124}$ De aanwezigheid van schuld (in de zin van verwijtbaarheid) moet blijken uit een of andere schuldvorm, namelijk opzet of culpa. Nu kan het subjectief element op verschillende manieren in de delictsomschrijving zijn verwerkt. Zo kan de wetgever ervoor kiezen het subjectief delictsbestanddeel nader te omschrijven. ${ }^{125}$ Het is echter kenmerkend voor het milieustrafrecht dat in de delictsomschrijving meestal geen subjectief bestanddeel is gepreciseerd. Zoals reeds werd opgemerkt, heersen in het milieustrafrecht vaak sterke instrumentalistische tendensen, die een minimalisering van het klassieke schuldbeginsel (en andere beginselen) tot gevolg kunnen hebben. In het milieustrafrecht kennen de meeste strafbepalingen in hun delictsomschrijving daarom geen bijzondere schuldvorm. Uitzonderingen op deze regel zijn de commune milieustrafbepalingen, de artikelen 173a en 173b Sr.

Het is wel van belang voor ogen te houden dat de meeste milieudelictsomschrijvingen onder het regime van de WED zijn gebracht. Hierdoor vindt de strafrechtelijke handhaving

122. Zie o.m. Waling, C., o.c., 1990, 25-57; Buiting, Th.J.B. en Huygen, A.E.H., 'Milieustrafrecht: een ondoordachte chaos', in Van Buuren, P.J.J, Betlem, G. en Ylstra, T. (red.), o.c., 1990, 72-95; Koopmans, I.M., 'Zeven jaar milieustrafrecht in Nederland: een evaluatie', $D D, 1996,352-356$; Faure, M. en Visser, M., o.c., 1999, 227-280 i.h.b. 268-273.

123. Remmelink, J., Mr. Hazewinkel-Suringa's Inleiding tot de studie van het Nederlandse strafrecht, Arnhem, Gouda Quint, 1995, 375.

124. Faure, M., o.c., 1992, 21-23.

125. Remmelink, J., o.c., 1995, 193-241. 
van deze bepalingen plaats op basis van artikel 1a WED waarin bijna alle milieudelicten zijn ondergebracht. In artikel la WED zijn de milieudelicten opgedeeld in een drietal categorieën met verschillende strafmaxima. ${ }^{126}$ De eerste categorie bestaat uit de ernstige milieudelicten. De tweede en derde categorie betreffen meestal delicten die het niet nakomen van administratieve plichten strafbaar stellen. Volgens artikel 2 lid 1 WED zijn de milieudelicten van de eerste en tweede categorie misdrijven voor zover ze opzettelijk zijn begaan. Indien dit niet het geval is, zijn ze overtredingen. De delicten van de derde categorie zijn uitsluitend overtredingen (artikel 2 lid 4 WED). De koppeling van milieudelicten aan de WED heeft niet slechts gevolgen voor de kwalificatie van het delict (misdrijf of overtreding), maar ook voor de toepasselijke strafmaat. ${ }^{127}$

Doorslaggevend voor de vaststelling van het schuldvereiste bij de meeste Nederlandse milieustrafbepalingen is dus de tenlastelegging: kiest het $\mathrm{OM}$ voor een opzettelijke variant of niet. Het OM zal bijgevolg steeds de ten laste gelegde schuldvorm moeten bewijzen. Belangrijk is evenwel dat bij de milieuovertredingen uit de WED een onderscheid moet worden gemaakt tussen enerzijds schuld als voorwaarde voor materiële strafbaarheid (het schuldelement) en anderzijds het bewijs daarvan. Wordt een milieuovertreding ten laste gelegd, dan is het schuldelement eenvoudig te bewijzen door de vaststelling dat aan het materiële bestanddeel is voldaan, hetgeen meestal is beperkt tot handelen zonder of in strijd met een vergunning. Schuld hoeft dus niet te worden ten laste gelegd of te worden bewezen. Met het bewijs van het materiële feit wordt schuld verondersteld, mits maar de mogelijkheid van verweer openstaat. ${ }^{128}$ Het verweer zal veelal een beroep op een schulduitsluitingsgrond zijn. Het is dan aan de verdachte om gemotiveerd feiten en omstandigheden aan te voeren waaruit aannemelijk wordt dat de schuld ontbreekt. Hoewel het dus niet gaat om een onweerlegbaar wettelijk schuldvermoeden, hetgeen in strijd zou zijn met de praesumptio innocentiae, maar om een weerlegbaar feitelijk vermoeden, dat met een zekere graad van geloofwaardigheid kan worden betwist, ${ }^{129}$ is wel duidelijk dat om

126. Hendriks, L.E.M. en Wöretshofer, o.c., 1995, 23-25.

127. Op grond van artikel 6 WED worden de milieudelicten van de eerste categorie, voorzover het om misdrijven gaat, bedreigd met een gevangenisstraf van ten hoogste zes jaren of een geldboete van de vijfde categorie (artikel 6 lid sub 1 WED). Gaat het om overtredingen dan is de strafbedreiging hechtenis van ten hoogste een jaar of geldboete van de vierde categorie (artikel 6 lid 1 sub 3 WED). De delicten van de tweede categorie kennen een lichtere strafbedreiging. Worden ze opzettelijk begaan en zijn het dus misdrijven dan is de maximum gevangenisstraf twee jaren of een geldboete van de vierde categorie (artikel 6 lid 1 sub 2 WED). De overtredingen worden bedreigd met een hechtenis van ten hoogste zes maanden en een geldboete van de vierde categorie (artikel 6 lid 1 sub 4 WED). Eenzelfde strafbedreiding geldt voor de overtredingen van de derde categorie (artikel 6 lid 1 sub 4 WED).

128. Keijzer, N., 'Enkele opmerkingen over de praesumptio innocentiae in strafzaken', in Enschedé Ch.J., e.a. (red.), Naar eer en geweten, Amhem, Gouda Quint, 1987, 252-253.

129. Dit vloeit voort uit het Water en Melk-arrest waarin door de Hoge Raad de schulduitsluitingsgrond afwezigheid van alle schuld is erkend. HR 14 februari 1916, NJ 1916, 618. Remmelink, J., o.c., 1995, 376; Van Bemmelen, J.M. en Van Veen, Th.W., Ons strafrecht I. Het materiële strafrecht, Algemeen deel, bewerkt door De Jong, D.H. en Knigge, G., Arnhem, Gouda Quint, 1998, 37-39. Ook het EHRM acht het gebruik van delictsomschrijvingen waarin schuld door de materiele wetsinbreuk wordt verondersteld slechts toelaatbaar onder de voorwaarde dat dit vermoeden voor de verdachte weerlegbaar moet kunnen zijn. EHRM 7 oktober 1988, NJ, 1991, 
redenen van doelmatigheid en bewijslastvermindering in het milieustrafrecht doorgaans niet al te hoge eisen worden gesteld aan schuld.

Dit betekent dat de strafrechtelijke aansprakelijkheid is gegeven zodra er in hoofde van de dader geen strafuitsluitingsgronden zijn. In de praktijk is het milieudelict immers geacht te zijn begaan wanneer het voorschrift is overtreden. Er kan hier worden verwezen naar het Furazolidon-arrest waar het daderschap van de rechtspersoon reeds werd bewezen verklaard door het enkele feit dat de lozing van een stof binnen de normale bedrijfsvoering heeft plaatsgevonden. ${ }^{130}$

$\mathrm{Nu}$ valt het met het schuldvereiste in het Nederlandse milieustrafrecht nog in die zin mee dat in ieder geval via de WED een nadere kwalificatie en differentiatie op het vlak van het schuldelement en (derhalve ook) de strafmaat mogelijk is gemaakt. In andere landen daarentegen wordt door de wetgever nauwelijks of helemaal niet nagedacht over het schuldvereiste. Typisch voorbeeld hiervan vormt het Belgische milieustrafrecht. Het Belgische milieustrafrecht bestaat voor een groot deel nog uit strafbepalingen die als sluitstuk aan de verschillende bijzondere milieuwetten (en -decreten) zijn toegevoegd. Hoewel het laatste decennium vooral in Vlaanderen het materieel milieurecht grondig is geïntegreerd, is helaas nauwelijks gestreefd naar een integratie van de strafbepalingen. ${ }^{131}$ Kenmerkend voor vrijwel alle milieustrafbepalingen in België - of het nu gaat om abstracte gevaarzettingsdelicten, concrete gevaarzettingsdelicten of zorgplichtbepalingen - is dat de delictsomschrijvingen geen bijzondere subjectieve bestanddelen kennen. ${ }^{132}$ Volgens de algemene beginselen van het Belgische strafrecht betekent dit noodzakelijkerwijs dat dogmatisch gezien bijna alle milieudelicten met overtredingen worden gelijkgeschakeld. ${ }^{133}$ Op het vlak van schuld worden voor overtredingen uit bijzondere wetten echter geen strenge eisen gesteld. De schuld wordt als een feitelijk vermoeden uit het begaan van de materiële wetsinbreuk afgeleid. Tenzij ter zake door de verdachte een geloofwaardig verweer wordt gevoerd, door het aanvoeren van schulduitsluitingsgronden, wordt (schuld aan) het strafbare feit vrijwel automatisch bewezen verklaard. ${ }^{134}$ Dat is een kwalijke zaak omdat deze delicten soms met zware straffen worden bedreigd. Zo wordt in artikel 50 van het Vlaamse Bodemsaneringsdecreet $(1995)^{135}$ nog steeds het niet nakomen van bepaalde administratieve verplichtingen, zoals het verhinderen van toezicht, bedreigd met een

351 (Salabiaku); EHRM 25 september 1992, NJ 1995, 593 (Pham Hoang); Van Bemmelen, J.M. en Van Veen, Th.W., o.c., 1995, 40-41.

130. HR 23 februari 1993, $N J$ 1993, met noot 't Hart, A.C.

131. Zie o.m. Deketelaere, K. (red.), Milieurechtstandpunten, nr. 10. Milieurecht in België. Status Questionis Anno 1997, Brugge, die Keure, 1997.

132. Zie Roef, D., 'De strafrechtelijke aansprakelijkheid van de rechtspersoon in het milieustrafrecht' in Belgische vereniging van bedrijfsjuristen, vereniging van praktijkjuristen in sociaal recht en vereniging voor arbeidsrecht, Vennootschappen weldra strafbaar. Wat is de neerslag op het bestaan van de ondernemingen?, Brussel, Bruylant, 1999, 105-118.

133. Dupont, L. en Verstraeten, R., Handboek Belgisch strafrecht, Leuven, Acco, 1990, 263.

134. Traest, Ph., Het bewijs in strafzaken, Gent, Mys \& Breesch, 1992, 206-207.

135. Artikel 50 van het Bodemsaneringsdecreet zoals gewijzigd door het decreet van 26 mei 1998 (B.S., 25 juli 1998). Zie hierover Ryckbost, D., 'Bijsturing van het Decreet betreffende de Bodemsanering', TMR, 1998, 334-352. 
gevangenisstraf van 1 maand tot 5 jaar en/of een geldboete van 100 tot $10.000 .000 \mathrm{BEF}^{136}$ Dat is op zich al een forse sanctie, maar ingevolge de opdeciemen dient de geldboete nog met 200 te worden vermenigvuldigd, ${ }^{137}$ zodat deze minimaal 20.000 BEF en maximaal 2.000.000.000 BEF bedraagt. Er is niet gedifferentieerd al naargelang het delict ecologische rechtsgoederen bedreigt, dan wel alleen administratieve belangen schendt. Evenmin is een onderscheid gemaakt al naargelang het delict opzettelijk of culpoos is begaan. ${ }^{138}$ Deze ondoordachte strafwetgeving heeft dus tot gevolg dat het (theoretisch) mogelijk is iemand te veroordelen tot de maximum gevangenisstraf en/of geldboete zonder dat het $\mathrm{OM}$ enige vorm van schuld hoeft te bewijzen, want dogmatisch gezien is iedere inbreuk niet meer dan een overtreding. Het moge duidelijk zijn dat in vergelijking met België het Nederlandse milieustrafrecht meer recht doet aan het schuldbeginsel door via de WED de zwaarste straffen slechts mogelijk te maken indien het milieudelict opzettelijk is begaan.

Dat schuld ook nog op een andere wijze in het milieustrafrecht aan betekenis inboet, kan worden geillustreerd aan de hand van een andere categorie van milieustrafbepalingen: de reeds aangehaalde zorgplichtbepalingen. Bij deze bepalingen is de administratieve afhankelijkheid volledig losgelaten, maar daarmee ook een aantal essentiële klassieke rechtsstatelijke waarborgen.

\section{HET RECHTSSTATELIJK TEKORT VAN DE ZORGPLICHTBEPALINGEN}

Het gebruik van (strafbaar gestelde) zorgplichtbepalingen is in Nederland zeer populair. ${ }^{139}$ Een bekend voorbeeld van een zorgplichtbepaling is artikel 13 Wet Bodembescherming:

'Ieder die op of in de bodem handelingen verricht als bedoeld in de artikelen 6 tot en met 11 en die weet of redelijkerwijs had kunnen

136. In het oorspronkelijke artikel was het strafmaximum zelfs $100.000 .000 \mathrm{BEF}$. Vermenigvuldigd met 200 opdeciemen was dat dus 20.000 .000 .000 BEF.

137. Sedert de wet van 24 december 1994 (B.S., 31 december 1993) moeten de geldboeten voor feiten gepleegd vanaf 1 januari 1995 met een factor van 200 worden vermenigvuldigd.

138. Faure, M., 'De handhaving van het bodemsaneringsdecreet via toezicht, dwangmaatregelen en strafsancties', in Deketelaere, K. (red.), Milieurechtstandpunten, nr.7. Het decreet betreffende de bodemsanering, Brugge, die Keure, 1995, 215-254.

139. Hendriks, L.E.M. en Wöretshofer, J., o.c., 1995, 85-87; Visser, M., 'Strafrechtelijke zorgplichtbepalingen over de grens? De strafrechtelijke afdwingbaarheid van milieuzorgplichtbepalingen in België en Nederland', in Faure, M. en Deketelaere, K. (red.), Ius commune en milieurecht, Antwerpen, Intersentia, 1997, 203-242. Zorgplichtbepalingen kunnen worden omschreven als: 'een vrij algemeen geformuleerde, tot de burger gerichte (zorg)verplichting die een bepaalde verantwoordelijkheid van de burger markeert en waarvan het de bedoeling is deze juridisch te handhaven. Een zorgplicht bevat een algemene verplichting tot het in acht nemen van een bepaalde graad van zorgvuldigheid met het oog op het door de desbetreffende wet te beschermen belang, en kan zowel betrekking hebben op een handelen als een nalaten van het normadressaat. De wetstechnische vormgeving van een zorgplichtbepaling kan verschillen; het kan gaan om een gebod (een positief geformuleerde verplichting), of om een verbod. De handhaving van de norm kan langs bestuurlijke, strafrechtelijke of privaatrechtelijke weg geschieden, of zelfs via een combinatie van deze methoden'. Commissie Toetsing van Wetgevingsprojecten, Advies van de Commissie voor de Toetsing van Wetgevingsprojecten inzake zorgplichtbepalingen, CTW 90/6, 20 augustus 1990, 3. Zie tevens Faure, M. en Visser, M., L.c., 1997, 132-133. 
vermoeden dat door die handelingen de bodem kan worden verontreinigd of aangetast, is verplicht alle maatregelen te nemen die redelijkerwijs van hem kunnen worden gevergd, teneinde die verontreiniging of aantasting te voorkomen, dan wel indien die verontreiniging of aantasting zich voordoet, de bodem te saneren of de aantasting en de directe gevolgen daarvan te beperken en zoveel mogelijk ongedaan te maken. Indien de verontreiniging of aantasting het gevolg is van een ongewoon voorval, worden de maatregelen onverwijld genomen. ${ }^{140}$

Ook in andere bijzondere milieuwetten komen geregeld zorgplichtbepalingen voor. ${ }^{141}$ Daarnaast worden zelfs in vergunningen zorgplichtbepalingen neergelegd. ${ }^{142}$

Bekijken we deze bepalingen in de sleutel van de schuld, dan stellen we vast dat zij in de delictsomschrijving eigen subjectieve bestanddelen kennen. Daarnaast zijn ze ook onder de WED ondergebracht, zodat opzet moet worden bewezen wanneer het OM de schending van een zorgplichtbepaling als een misdrijf wil vervolgen. Op het vlak van de subjectieve bestanddelen is er nauwelijks een probleem. Het schuldbeginsel is veeleer aangetast doordat deze bepalingen op gespannen voet staan met het lex certa-vereiste. Het is duidelijk dat de delictsomschrijving van deze categorie van milieudelicten zeer vaag is omschreven. Vanuit de bekende klassieke strafrechtelijke beginselen, zoals het legaliteitsbeginsel en het lex certa-vereiste, wordt daarom in de literatuur zware kritiek geleverd op de strafbaarstelling van deze vage normen. ${ }^{143} \mathrm{Er}$ zijn door de bijzondere wetgever weinig beperkingen gesteld aan de strafrechtelijke aansprakelijkheid. Niettemin zijn deze bepalingen volgens de rechtspraak niet in strijd met het legaliteitsbeginsel. ${ }^{144}$ Dit is instrumentalisme zonder grenzen. Omwille van de bescherming van het leefmilieu mogen blijkbaar de klassieke rechtswaarborgen worden opgeofferd.

Bemerk bovendien dat zorgplichtbepalingen tot eenieder zijn gericht en niet slechts tot de klassieke vanuit de bescherming van het leefmilieu beoogde doelgroepen zoals bedrijven. Bovendien is de norm zo vaag dat niet slechts gedragingen van voor het leefmilieu risicovolle functionarissen (zoals bedrijven) daaronder kunnen vallen, maar iedere gedraging die kan worden beschouwd als potentieel gevaarlijk voor het leefmilieu. ${ }^{145}$

140. Zie hierover uitvoerig Visser, M., 'Uitholling van het schuldbeginsel', in Borgers, M.J., Koopmans, I.M. en Kristen, F.G.H. (red.), o.c., 1998, 68-69.

141. Zo bijvoorbeeld artikel 13 , vierde lid (voorheen derde lid) Bestrijdingsmiddelenwet, artikel 2 Wet Milieugevaarlijke Stoffen en artikel 10.3 van de Wet Milieubeheer, hoofdstuk Afvalstoffen. Zie hierover Faure, M. en Visser, M., o.c., 1999, 327-328.

142. Zie voor voorbeelden Visser, M., l.c., 1997, 209-210.

143. Zie voor een kritische evaluatie van zorgplichtbepalingen vanuit het oogpunt van de klassieke strafrechtsbeginselen Visser, M., l.c., 1997, 216-236; Faure, M. en Visser, M., o.c., 1999, 339 357.

144. Zie o.m. Rb. Amsterdam 5 januari 1993, TMA, 1993, 77-83, met noot Faure, M.

145. Vgl. Faure, M. en Visser, M., o.c., 1999, 342. 
Niettemin menen sommige auteurs dat zorgplichtbepalingen de machtskritische toets van het lex certa-beginsel kunnen doorstaan. Zo stellen Hendriks en Wöretshofer:

\begin{abstract}
'De vraag dringt zich op of dergelijke zorgplichtbepalingen op gespannen voet staan met het strafrechtelijke lex certa-beginsel. Als de zorgplicht bestaat uit het nemen van maatregelen door de betrokkene (art. $13 \mathrm{Wbb}$, art. $2 \mathrm{Wms}$ ), geldt het volgende. In praktisch alle gevallen kan objectief wel worden aangegeven welke maatregelen hadden moeten worden genomen. Als dit in een specifiek geval niet zo blijkt te zijn, dan is toepassing van een zorgplichtbepaling ook niet op zijn plaats. Het gaat er echter om dat de maatregelen ook redelijkerwijs van de betrokkene kunnen worden gevergd. Door het betrekken van de persoonlijke beoordeling bij de vraag of iemand de zorgplicht heeft overtreden, is tegen de vaagheid in de algemene norm een zekere mate van bescherming ingebouwd. ${ }^{146}$
\end{abstract}

Ik ben het daar niet mee eens. Wat hier met elkaar wordt verward is (1) de wijze waarop in een concreet geval moet of kan worden vastgesteld dat een zorgplicht is overtreden (een vraag van bewijs van daderschap) en (2) de in het lex certa-beginsel neergelegde eis dat de strafbaar gestelde norm voor de justitiabele op voorhand duidelijk moet zijn. Ex post is het altijd eenvoudig vast te stellen welke normen zijn geschonden en hoe de dader zich had moeten gedragen. Dat kan zelfs vrij detaillistisch in een tenlastelegging worden omschreven. Maar daar gaat het bij het lex certa-beginsel niet om. Zoals Faure en Visser terecht opmerken:

'het lex certa-vereiste dat zich richt op het precieze van de delictsomschrijving voordat het gedrag wordt gesteld, mag natuurlijk niet worden verward met de eis dat na het delict een feit in voldoende precieze bewoordingen dient te worden ten laste gelegd. ${ }^{147}$

\title{
D. DE BESTUURSAFHANKELIJKHEID VAN HET OPENBAAR MINISTERIE
}

Naast de administratieve afhankelijkheid op het niveau van de strafbaarstellingen vormt de bestuursafhankelijkheid van het openbaar ministerie op het niveau van de handhaving een belangrijke instrumentalistische indicatie. In het milieustrafrecht - net als in de andere takken van het ordeningsstrafrecht - is het OM niet meer de enkele 'handhaver' van het recht. Een dominante preventieve en repressieve rol is weggelegd voor bestuursorganen en administratieve toezichthouders. De vaststelling van milieudelicten is voor een aanzienlijk deel opgedragen aan daartoe in het bijzonder aangestelde ambtenaren. Naast de OvJ's vormen de buitengewone opsporingsambtenaren een belangrijke spil bij de opsporing van milieudelicten. Tot de categorie van buitengewone opsporingsambtenaren behoren de verschillende ambtenaren van het rijk, de provincies, de waterschappen en de gemeenten

146. Hendriks, L.E.M. en Wöretshofer, J., o.c., 1995, 86.

147. Faure, M. en Visser, M., o.c., 1999, 346. 
alsook ambtenaren van de Inspectie Milieuhygiëne (IHM), de Algemene Inspectiedienst (AID) en Rijkswaterstaat. Deze ambtenaren zijn vaak tevens belast met het bestuursrechtelijke toezicht. ${ }^{148}$

Doordat de handhavingstaak is verdeeld over verschillende handhavingspartners, maar ook omdat de strafzaken op het terrein van de moderne milieucriminaliteit nu eenmaal zwaarder, technischer en ingewikkelder zijn dan de klassieke delicten waarmee het OM zowel qua organisatie als functioneren decennia lang is vertrouwd geweest, is er behoefte aan een gestroomlijnde milieurechtshandhaving, een doelmatige prioriteitenstelling en een planmatige strafrechtshantering. Dit betekent dat vanuit een resultaatgericht denken de milieustrafrechtelijke handhaving geen doeleinden en waarden kan dienen die, al is het slechts schijnbaar, met elkaar in conflict treden. Om snel en doelmatig te reageren op inbreuken op milieuwetgeving dienen centraal prioriteiten te worden gesteld. Een effectieve en efficiënte strafrechtelijke handhaving kan dan niet zonder een beleidsgerichte samenwerking. Dit heeft geleid tot een strategische heroriëntatie van het 'klassieke' OM in de strijd tegen milieucriminaliteit. Ook het $\mathrm{OM}$ moet zich meer als beleidsorgaan profileren, als instrument en onderdeel van een meer omvattend milieubeleid dat in eerste instantie wordt gestuurd door de milieuoverheden en wordt ingevuld in termen van het na te streven milieurendement. Een dergelijke evolutie hangt vanzelfsprekend samen met het instrumentalistische rechtsdenken en de maakbaarheidsdrang van een verzorgingsstaat waaraan ook de milieustrafrechtshantering niet kan ontsnappen.

$\mathrm{Nu}$ moet worden aangetekend dat bij de huidige stand van zaken een beleidsmatige oriëntatie van het OM noodzakelijk is en derhalve niet bij voorbaat negatief moet worden benaderd. Strafrechtelijke handhaving van (milieu)wetgeving kan niet efficiënt zijn zonder een gecoördineerd beleid en een gestructureerde samenwerking met de andere bij de handhaving betrokken instanties. De handhaving van het milieurecht is niet gediend met klaagzangen over een $\mathrm{OM}$ dat door haar beleidsmatige aanpak haar klassieke justitiële taak zou verliezen. De pragmatische noodzaak tot beleidsvoering binnen het $\mathrm{OM}$ en beleidsafstemming tussen OM en de onderscheiden milieuoverheden mag ons echter - juist wanneer we dit alles vanuit een meer kritisch grondslagenperspectief aanschouwen - niet de ogen doen sluiten voor een aantal met elkaar samenhangende problemen.

Zo is er het risico dat het $\mathrm{OM}$ en het strafrechtelijke beleid gevangen raakt in het bestuurlijke voorveld van de lokale milieuoverheden en -ambtenaren. Die bestuursafhankelijkheid uit zich onder meer in het feit dat het OM is aangewezen op de zaken die worden vrijgegeven door het bestuur.

'Weliswaar verplicht artikel $160 \mathrm{~Sv}$ het bestuur tot aangifte van strafbare feiten, maar in de praktijk blijken de bestuurlijke overheden daarin een eigen beleid te voeren. Veelal wordt aan een bestuurlijke optreden de

148. Hendriks, L.E.M. en Wöretshofer, J., o.c., 1995, 180-183. 
voorkeur gegeven en wordt maar mondjesmaat op een strafrechtelijke reactie aangestuurd door aangifte. ${ }^{149}$

De actie- en vervolgingsradius van het OM wordt in zekere mate afhankelijk van de (vaak afwachtende) houding bij de milieuinstanties, die meer zijn vertrouwd met de technicité van milieucriminaliteit. Deze 'gespecialiseerde' overheden zijn zowel verantwoordelijk voor bestuurlijk toezicht als voor opsporing van milieudelicten. Bovendien zijn de milieuambtenaren ook betrokken bij de vergunningverlening en het daarmee samenhangende beleid. Bij de vaststelling van een (mogelijk) crimineel feit geven zij de voorkeur aan onderhandelen met de overtreders en gaan zij niet meteen over tot (dreiging met) sanctionering. Milieuambtenaren zijn weinig op de hoogte van het strafrecht, denken in de eerste plaats niet juridisch maar politiek en bedrijfsmatig en beschikken vaak niet over de noodzakelijke kennis van opsporingstechnieken. Dit maakt dat de zaken die een officier van justitie (OvJ) uiteindelijk wel krijgt toebedeeld veelal worden gekenmerkt door bewijstechnische zwakheden. In zijn algemeenheid leidt de oriëntatie op samenwerking met ondernemingen ertoe dat de ambtenaren een strafrechtelijke reactie als een storende factor beschouwen in het breekbare onderhandelingsproces met de bedrijfswereld. Met betrekking tot dat onderhandelingsproces moet men wel bedenken dat het gevaar voor 'capturing' aanwezig kan zijn en dat de bestuurlijke positie en politieke invloed van de bedrijfswereld beklemmend kunnen worden in de zin dat

'de toezichthoudende beambten van gemeente en provincie juist zijn aangesteld door degenen, die de invloed van deze economische macht politiek of sociaal het meeste ondervinden. ${ }^{150}$

Het gevaar dat deze overheden de geconstateerde feiten niet of onzorgvuldig doorgeven aan het $\mathrm{OM}$, het geldende recht onnauwkeurig toepassen of onrechtmatige milieuverontreinigingen voor (on)bepaalde tijd gedogen, wordt hierdoor reëel. Vanuit een grondslagenperspectief bekeken, kan deze bestuursafhankelijkheid ertoe leiden dat het machtskritische element in het strafrecht wordt bevroren. Dat in ons milieurecht de inschakeling van het strafrecht primair is bedoeld om de administratieve plichten van de burger te benadrukken, en niet (tegelijk) is gericht op het aansporen van het bestuur tot een meer zorgvuldige nakoming van zijn plichten ten behoeve van de bescherming van de ecologische rechtsgoederen, werkt daarenboven het verlies aan machtskritiek mogelijk in de hand.

Dit mogelijke verlies aan een zekere onafhankelijkheid en machtskritiek uit zich niet alleen organisatorisch in de verhouding tussen $\mathrm{OM}$ en bestuur maar ook functioneel in de daarmee samenhangende verzwakking van de magistratelijkheid en zelfstandigheid van het $\mathrm{OM}$. Prangend is de vraag hoe het $\mathrm{OM}$, vanuit die magistratelijke verarming, haar taak van

149. Brussaard, W., Drupsteen, Th.G., Gilhuis, P.C., Koeman , N.S.J. (red.), Milieurecht, Zwolle, W.E.J. Tjeenk Willink, 1993, 488. Zie tevens van Duyne, P.C., 'Knelpunten in de Nederlandse strafrechtelijke milieurechtshandhaving', in Faure, M., Oudijk, J.C. en Schaffmeister, D. (red.), o.c., 1991, 337-369.

150. Van Duyne, P.C., 'Knelpunten in de Nederlandse strafrechtelijke milieurechtshandhaving', in Faure, M., Oudijk, J.C. en Schaffmeister, D. (red.), o.c., 1991, 345. 
handhaving van de rechtsorde, neergelegd in art. 124 Wet op de Rechterlijke Organisatie (RO), daadwerkelijk op het gebied van het milieurecht kan garanderen. In een hoofdzakelijk bestuursondersteundend milieustrafrecht kan dit leiden tot het op eenzijdige wijze afdwingen van een bepaalde hiërarchie van normen en waarden, die hoofdzakelijk door het bestuur zijn vastgelegd. Milieurechtshandhaving door het $\mathrm{OM}$ is dan op voorhand al beperkt door het nastreven en ondersteunen van een bepaalde sociaal-ecologische ordening waarin die hiërarchie heersend is. ${ }^{151}$ In de praktijk betekent dit dat milieurechtshandhaving dreigt te worden gereduceerd tot een kritiekloos dienen van bestuurlijk beleid. De via het strafrecht te handhaven rechtsorde valt dan samen met die orde die als doelstelling door de milieuoverheden - weliswaar na overleg en door middel van samenwerking met het $\mathrm{OM}$ - wordt nagestreefd. De door het bestuur nagestreefde (leefmilieu)orde hoeft echter niet automatisch gelijk te zijn aan een rechtsorde. Om van een rechtsorde te kunnen spreken moet niet slechts aan de democratische legitimatie, die op zich reeds, zoals opgemerkt, in het milieurecht door belangengroepen zwaar onder druk staat, zijn voldaan; primair moet ook sprake zijn van een rechtsstatelijke legitimatie en een eerbiediging van de klassieke strafrechtelijke beginselen. Dat betekent dat de democratische totstandkoming van een bepaalde orde en het daarop via overleg gebaseerde beleid zodanig open moet blijven dat de machtskritische werking van het strafrecht voldoende verzekerd blijft ten opzichte van het te bereiken doel. ${ }^{152}$ Is dat niet mogelijk dan houdt het milieustrafrecht uiteindelijk niet meer in dan de bekrachtiging van politieke (on)wil. Dit denatureert niet alleen het strafrecht maar uiteindelijk ook het leefmilieu.

\section{E. DE VERSTARRING VAN DE ECOLOGISCHE WERKELIJKHEID}

Aansluitend bij de voorgaande thematiek kan nu een andere fundamentele, zij het minder opvallende schaduwzijde van het milieustrafrecht, zoals het momenteel is onderbouwd, worden aangeduid. De aangehaalde consequenties en indicaties van een instrumentalistisch milieurechtsdenken illustreren volgens mij op een meer abstract niveau een bijzonder gevaar van het huidige milieustrafrecht. Dat gevaar zou voorlopig kunnen worden aangeduid als 'de verstarring van de ecologische levende werkelijkheid'. ${ }^{153}$

Vanuit een relationele rechtsvisie heeft het (straf)recht per definitie een ordenende structuur, die, eens geconfronteerd met de complexiteit van het menselijk handelen, tracht een communicatief, processueel en bemiddelend kader te verlenen om dat handelen maatschappelijk verstaanbaar te maken. ${ }^{154} \mathrm{Om}$ die bemiddelende functie zo open mogelijk te houden, dient het (straf)recht zoveel mogelijk te streven naar de idealen van alteriteit en meerduidigheid. Die idealen moeten garanderen dat niet reeds op voorhand bepaalde interpretaties, verklaringen, uitgangspunten over feitelijke gebeurtenissen uit het juridische discours worden verbannen. Die idealen worden op de helling gezet in een benadering van

151. Vgl., 't Hart, A.C., o.c., 1994, 141-163.

152. 't Hart, A.C., o.c., 1994, 306-311.

153. Vgl. 't Hart, A.C., o.c., 1991, 33.

154. Vgl. in meer algemene zin Foqué, R.E.M en 't Hart, A.C., o.c., 1990, 39-64; Gutwirth, S., o.c., $1993,428-441$. 
strafrecht waarbij deze laatste ten opzichte van het instrumenteel te bereiken doel - in het milieustrafrecht de verhoging van de ecologische leefbaarheid - neutraal wordt ingezet. Voor zover er door het milieustrafrecht waarden en idealen worden gediend, liggen die hoofdzakelijk in het ideaal van een ecologische leefbaarheid en de daarbij behorende belangenafwegingen, dus in het contra-juridische en politieke. De legitimatie van de inschakeling van het strafrecht ligt in die waarden ten dienste van een doorgaans gepolariseerd maakbaarheidsideaal. Die te verdedigen leefmilieuwaarden zijn op hun beurt politiek gelegitimeerd doordat zij eerst vanuit een zogenaamde technische en neutrale deskundigheid door wetenschappelijke disciplines als zodanig 'objectief' zijn vastgesteld en vervolgens door de overheid in beleidslijnen worden vastgelegd. In die zin kan worden gesproken van een mogelijke dubbele verstarring van de voor het (straf)recht noodzakelijke meerduidigheid. De wetenschappelijke disciplines van economie en ecologie zijn de enkele smeden van de milieureguleringsketen geworden. $\mathrm{Zij}$ worden ingehuurd om vast te stellen hoe de natuur en haar relatie met de socio-economische context nu werkelijk in elkaar zitten, zodat de ingewikkelde milieuproblematiek eenduidig te doorzien valt. Die eenduidigheid is noodzakelijk om aan te kunnen geven wat de meest haalbare en politiek werkbare middelen zijn om conform het vooropgezette maakbaarheidsideaal de meest doelmatige juridische oplossingen te realiseren. Dit is het zogenaamde tweetrapsinstrumentalisme:

'de sociale wetenschappen [maar ook de natururwetenschappen, DR] als instrument om de maatschappelijk werkelijkheid zuiver weer te geven en de technisch mogelijke ingrepen aan te geven, waarna politieke beslissingen worden geobjectiveerd in het beleid en het recht weer wordt gehanteerd om het beleid te implementeren. Vervolgens moet het recht, op grond van weer sociaalwetenschappelijk vast te stellen effecten vooral doelmatigheid en doeltreffendheid - telkens worden bijgesteld om de mogelijkheden tot sturing van de maatschappelijke werkelijkheid te optimaliseren'. ${ }^{155}$

In milieurechtelijke context betekent dit dat de kwestie van hoe het leefmilieu zo optimaal mogelijk moet worden bescherma en beheerd voortaan door 'waardenvrije' milieudeskundigen wordt bepaald:

'Zowel voor het milieu als voor de natuur, de technische als de ecologische infrastructuur, worden beheerders aangewezen: wij kunnen en mogen er de verantwoordelijkheid niet meer zelf voor dragen (...) Niet wat zich cultuur-historisch door het omgaan van generaties Nederlanders ermee als natuur ontwikkeld heeft, maar wat de ecoloog op grond van zijn modellen als natuursysteem definieert, bepaalt wat er ontwikkeld dient te worden. ${ }^{156}$

155. 't Hart, A.C, o.c., 1994, 185.

156. Achterhuis, H., Natuur tussen mythe en techniek, Baarn, Ambo, 1995, 122. 
Alleen de ogen van de eco- en technocraten, de leden van het wetenschappelijk en technologisch priesterschap kunnen de dreigende vernietiging van het leefmilieu in kaart brengen en verhinderen.

In paragraaf 2 is vastgesteld dat het instrumentalisme voor een belangrijk deel wordt bepaald door de complexiteit van het werkingsterrein, de bescherming van het leefmilieu, waarop het strafrecht wordt losgelaten. Een zelfde vaststelling gaat enigszins op voor de wetenschapsafhankelijkheid in het milieu(straf)recht. Verontreiniging en de gevolgen daarvan voor het milieu op lange en middellange termijn laten zich niet eenvoudig registreren. Daarvoor is de inschakeling van wetenschappelijke laboratoria en de meetapparatuur van eco-deskundigen onontbeerlijk. Wel moet worden beseft welke gevolgen deze afhankelijkheid met zich kan meebrengen. Een ongebonden wetenschappelijke en technologische verdediging van het leefmilieu kan leiden tot de teloorgang van de eigen directe menselijke ervaring en realiteit van de vrije natuur. In de oorlog tegen milieuverstoring krijgt de perceptie van deskundigen een vrijwel absolute volmacht toebedeeld: 'In de strijd om een duurzaam milieu krijgen hun aanwijzingen de kracht van wetten. ${ }^{157}$ Het milieurecht dreigt zo haar legitimatie van het sturende en het straffende te verbergen achter de door de wetenschap vooropgestelde objectiviteit zodat het lijkt alsof niet de overheid, zelfs niet de wetenschap maar de natuur zelf ons opdraagt hoe we moeten leven en overleven.

De teloorgang van het ideaal van meerduidigheid en de verstarring van de te beschermen ecologische werkelijkheid tot één enkele perceptie van die werkelijkheid wordt in de praktijk sterk in de hand gewerkt door de administratieve afhankelijkheid en het verdwijnen van kenbaarheid en eenvoud in het milieustrafrecht. De administratief afhankelijke wijze van strafbaar stellen zorgt ervoor dat de meerduidigheid van het leefmilieu en meer bepaald het voor dat milieu schadelijk menselijk gedrag via de juridische begrippelijkheid tot een beheersbare eenduidigheid wordt gebracht. Die eenduidigheid treedt op door een selectieen deformatieproces van de milieu-verontreinigende handelingen waardoor een nieuw juridisch relevant, wetenschappelijk geobjectiveerd en bestuurlijk hanteerbaarder beeld van milieuverontreiniging kan worden geconstrueerd. Bij dit selectieproces is een fundamenteel uitgangspunt

'de neiging om, zowel op wetgevend niveau als bij rechterlijke beslissingen, reeds bij het stellen van het probleem en dientengevolge bij gekozen oplossingen nogal wat afhankelijk te doen zijn van (ten onrechte?) als gegeven aanvaarde expertise'. ${ }^{158}$

Iemand als Beck komt dan ook tot de conclusie dat vooral een absolute administratieve afhankelijkheid niet fundamenteel kan bijdragen tot een werkelijke oplossing van het

157. Achterhuis, H., o.c., 1995, 84 .

158. Nijboer, H., 'Milieuzorg en strafwet; Opmerkingen over de strafbaarstelling van verontreiniging van lucht, bodem en water in het licht van de systematiek van de strafrechtelijke codificatie', in Faure, M.G., Oudijk, J.C. en Schaffmeister, D. (red.), o.c., 1991, 57. 
milieuprobleem. Integendeel, het gevaar dreigt dat zo een stille voortschrijdende vervuiling wordt verhuld en genormaliseerd. Volgens hem werkt een blind varen op de macht van vergunningen waarbij alles draait om de naleving van nauwelijks in vraag te stellen technische grenswaarden het milieuprobleem op lange termijn alleen maar in de hand:

'Grenzwerte für "zulässige" Schadstoff- und Giftspuren in Luft, Wasser und Nahrung haben im Zusammenhang mit der Risikoverteilung eine vergleichbare Bedeutung wie das Leistungsprinzip für die ungleiche Reichtumsverteilung: Sie lassen den Giftaussto $\beta$ zugleich zu und legitimieren ihn in eben dem eingeschränkten Umfang. Wer die Verschmutzung begrenzt, hat der Verschmutzung auch zugestimmt. Das, was jetzt noch möglich ist, ist per sozialer Definition "unschädlich" - wie schädlich es auch immer sein mag [...] Es geht also bei dieser "Verordnung" nicht um eine Verhinderung der Vergiftung, sondern um das zulässige $\mathrm{Ma} B$ der Vergiftung. Daß Vergiftung zulässig ist, ist auf der Grundlage dieser Verordnung keine Frage mehr [...] Grenzwerte ermöglichen eine Dauerration kollektiver Normalvergiftung [...] Wenn man überhaupt Vergiftung zuläßt, braucht man eine Grenzwert-Verordnung. Dann wird aber das, was nicht in ihr steht, noch wichtiger als das, was in ihr steht. Denn was nicht in ihr steht, von ihr nicht erfaßt wird, gilt nicht als Gift und kann frei und ungehemmt in Umlauf gesetzt werden. Das Schweigen der Grenzwert-Verordnung, ihre "weißen Flecken", sind ihre gefährlichsten Aussagen. Worüber sie nicht spricht, bedroht uns am meisten.' 159

De meeste wettelijke bepalingen met betrekking tot het behoud van het leefmilieu, die vervolgens in vergunningen worden geconcretiseerd, zijn inderdaad gerelateerd aan technische normen. Het zijn deze normen die strafrechtelijk worden gehandhaafd. Deze technisch-wetenschappelijke afhankelijkheid van het milieustrafrecht is trouwens ook aanwezig in die strafbepalingen waar geen sprake is van expliciet technische normering, zoals in de artikelen 173a en 173b Sr. Het in die artikelen vervatte strafrechtelijke begrip 'gevaar te duchten' steunt in de praktijk uitsluitend op bio-chemische normeringen. ${ }^{160} \mathrm{En}$ zoals reeds is besproken moet ook het bestanddeel 'wederrechtelijk' vergunningafhankelijk, derhalve wetenschapsafhankelijk worden ingevuld.

Net zoals voor Pythagoras, ${ }^{161}$ Kepler en Galilei ${ }^{162}$ wiskunde en meetkunde de enige talen waren waarin het verhaal van de natuur door de Goddelijke Demiurg wordt geschreven en begrensd, vormen voor de overheid en het recht de bio-chemische formules de enige

159. Beck, U., o.c., 1986, 86-87. Zie tevens Roef, D., 'Zoektocht naar een meer-zinnige betekenis van het strafrecht voor het leefmilieu', in Gutwirth, S. en van Maanen, G. (red.), o.c., 1995, 496.

160. Nijboer, J.F., 'Milieuzorg en strafwet; Opmerkingen over de strafbaarstelling van verontreiniging van lucht, bodem en water in het licht van de systematiek van de strafrechtelijke codificatie', in Faure, M.G., Oudijk, J.C. en Schaffmeister, D. (red.), o.c., $1991,57$.

161. Zie hierover Guthrie, W., The Pythagorean Sourcebook and Library, Michigan, Phanes Press, 1987.

162. Achterhuis, H., o.c., 1995,91 . 
meetbare en dus beheersbare grootheden, de enige taal door middel waarvan eco-kundigen de natuur kunnen begrijpen en herschrijven tot een te beheersen leefmilieu. Wat dus vooral in een Verwaltungsaktsakzessorisch milieustrafrecht relevant is, is niet zozeer de feitelijke vrije natuur - voor zover die nog bestaat - en de feitelijke ecologische schade - die maar al te zeer bestaat - maar het optreden zonder vergunning of de schending van emissienormen. Wat op het spel staat is veeleer een welbepaalde perceptie en interpretatie van de natuur en de daarin opgetreden verontreiniging. Met de sanctionering van inbreuken op emissienormen, die wetenschappelijk-empirisch zijn vastgelegd en daardoor vrijwel onbetwistbaar worden, wordt tegelijk het in vraag stellen van wetenschappelijke waarheidsaanspraken afgestraft. De juridische waarderingen en de normatieve kracht van het strafrecht vallen samen met wetenschappelijke waarderingen en technologische beoordelings- en waardensystemen. Hierdoor kan een kritische distantie - in het strafproces belichaamd in het contradictoire - tussen de juridische en de wetenschappelijk vormen van maatschappelijke normering op de achtergrond komen te staan.

Niet de zwarte toga's beoordelen dan nog het menselijk gedrag "naar hun beeld en gelijkenis" maar zij hebben plaats gemaakt voor "deskundigen" op ecologisch terrein, al dan niet in laboratoriumtenue gestoken. ${ }^{163}$

Daarbij wordt de schending van vergunningsvoorschriften, ingevuld door het bestuur en geverifieerd door de technische deskundigheid, benaderd alsof het een schending van het beschermde rechtsgoed zelf zou betreffen. De juridische afbeelding overheerst hier wat werkelijk gaande is en de wetenschappelijk relevante afbeelding overheerst op zijn beurt weer de juridische interpretatie van de feiten.

$\mathrm{Nu}$ is deze vaststelling geen eigenaardigheid van het milieurecht. Als interpretatiecode makt het recht vaak gebruik van mede door de wetenschap aangevoerde afbeeldingsconstructies. Bovendien moet het gebruik van dergelijke afbeeldingsconstructies niet louter negatief worden benaderd; zij vormen noodzakelijke ankerpunten voor het juridische beslissingsproces omdat zij de ondoorzichtigheid van menselijk en intermenselijk gedrag door middel van conceptualisering en abstrahering enigszins begrijpelijk en werkbaar maken. Maar zogenaamde wetenschappelijke analyses van feiten, zoals vervuiling, leiden niet automatisch tot een meer objectieve en dus betere informatieverwerking van die feiten. Ook die informatie gaat vaak uit van bepaalde niet-wetenschappelijke vooronderstellingen, onzekerheden en ondoorzichtige (vaak politieke en financiële) belangen. ${ }^{164}$

Informatie en verzameling van gegevens is bovendien een lege doos zonder interpretatie; elke vorm van informatie, ondanks de schijnbaar hoge graad van objectiviteit, is steeds vatbaar voor interpretatie en autonome betekenisverlening. Juist waar het gaat om

163. Nijboer, J.F., 'Milieuzorg en strafwet; opmerkingen over de strafbaarstelling van verontreiniging van lucht, bodem en water in het licht van de systematiek van de strafrechtelijke codficatie', in Faure, M., Oudijk, J.C. en Schaffmeister, D. (red.), o.c., 1991, 56.

164. Zie hierover de fraaie studie van Stevenson, L. en Byerly, H., The many faces of Science. An introduction to Scientists, Values and Society, Oxford, Westview Press, 1995, 79-105 en 133 154. 
betekenisverlening, wat meteen waardering en normering impliceert, is het utopisch te veronderstellen dat de wetenschap steeds vaststaande antwoorden kan geven. Zoals wetenschapsfilosoof Wilber krachtig en terecht verwoordt:

'There is no scientific meaning of the word "meaning"; there is no empirical test for value. Science cannot pronounce on the meaning or purpose of any phenomenon it encounters. That is not its job, that is not what it is engineered to do, and we certainly should not hold that against science, as many romantics do. ${ }^{165}$

Zo is de wetenschappelijke 'afbeelding' van water als $\mathrm{H}_{2} \mathrm{O}$ - wat op zich reeds een conceptmatige reductie van het ruime begrip 'water' inhoudt - niet meer dan een beschrijving van een chemische samenstelling. De betekenis die dat water in een bepaalde rivier voor een bepaalde omgeving zou kunnen hebben - zoals water als drinkwater of als de natuurlijke biotoop voor zoetwatervissen of water als schaarse industriële grondstof - is niet af te leiden uit deze formule. Omgekeerd is de technische beschrijving van bijvoorbeeld vervuiling door titaandyoxide, uitgedrukt in parameters, niet meer dan wat het is; een louter technische omschrijving van vervuiling en dan slechts het materiële aspect daarvan. Het geeft enkel een perceptie weer van (mogelijke) schade in de technische zin van belangrijkheid van die schade. Uit dergelijke kwantitatieve metingen zijn niet meteen betekenis- of waardenoordelen af te leiden.

Wat wetenschappelijke bewijsvoering betreft - ook hier weer van groot belang in het strafproces - kan worden opgemerkt dat zij soms niet meer kan opleveren dan waarschijnlijkheden binnen het eigen interpretatiekader van technologische en chemisch onderzoek. Als vervuiling en het plegen van milieucriminaliteit uitsluitend worden beschouwd als een kwestie van empirische feitelijkheden, kan dergelijke redenering zeer vreemd overkomen:

'But since pollution involves questions not only of concentrations but also of consequences, even 'hard' evidence is inevitable open to interpretation - hence the frequent spectacle of contradicting experts. ${ }^{166}$

Dit alles wil niet zeggen dat in het juridische discours, zowel op legislatief niveau als op het niveau van de rechtscolleges, niet langer aan betekenisverlening zou kunnen worden gedaan omdat dé betekenis van een feit nu eenmaal niet onder een microscoop kan worden vastgepind. Het betekent alleen dat vanuit het wetenschappelijk bastion een weliswaar nuttige maar tegelijk slechts relatief argumentatieve betekenis kan en mag worden verwacht. Ook vanuit puur instrumenteel en normatief perspectief is dit belangrijk. Daar technisch-wetenschappelijke toelaatbaarheid van vervuilend gedrag niets hoeft te zeggen

165. Wilber, K., Up from Eden. A transpersonal view of human evolution, Boston, Shambhala, 1986, 2.

166. Evernden, E., The Social Creation of Nature, Baltimore and London, The John Hopkins University Press, 1992, 4. 
over de maatschappelijke, juridische of zelfs de morele toelaatbaarheid van menselijk handelen, speelt hier een legitimerings- en handhavingsprobleem. Technische normen zijn nog geen rechtsnormen, worden ook niet meteen als dusdanig ervaren en dragen in zich, zolang zij blijven ingebed in een op verspilling en verontreiniging georiënteerde groeisamenleving, geen rechtsvormende werking. Van een strafrechtshantering die hoofdzakelijk is gericht op een bestuursafhankelijke handhaving van technische waarderingen, die niet tegelijk aansluiten bij andere sociale, culturele en morele waarderingen en die dus niet zijn verankerd in een maatschappelijk draagvlak, kan volgens mij weinig worden verwacht.

Enige nuancering is wel op zijn plaats. Niets dat ten nadele van de wetenschapsafhankelijkheid in het milieu(straf)recht is gezegd, moet worden opgevat als een geringschatting van wetenschap of rationalisme. De wetenschappelijke methode van hardnekkig vasthouden aan empirie en nauwgezet onderzoek stelt ons in staat ons van het arbitraire en dogmatische te bevrijden. Voor een democratische en pluralistische maatschappij is dit van onschatbare waarde. Wel mag, juist in een waardenpluralistische samenleving, het wetenschappelijke denken niet worden verheven tot een staatsfilosofie of een nieuwe beheersideologie, het sciëntisme, dat de sine qua non zou zijn van hoe de mens zich in relatie tot de natuur moet gedragen.

Daarom moet, hoe nuttig de wetenschapsafhankelijkheid ook mag zijn, steeds rekening worden gehouden met de daaruit voortvloeiende consequenties; niet alleen wat het mogelijk verlies aan machtskritiek en meerduidigheid betreft maar ook wat de bescherming van het leefmilieu zelf aangaat. Zo lijkt het me niet steeds gerechtvaardigd dat slechts een loutere schending van administratieve voorschriften, waarbij geen sprake hoeft te zijn van een feitelijke milieuschade, een strafrechtelijke reactie kan initiëren. Omgekeerd is het helemaal onwenselijk indien elke handeling die getrouw de vergunningsvoorschriften naleeft, zonder mogelijkheid van een ander verhaal, de wederrechtelijkheid van die handeling zou wegnemen. Dan is er geen sprake meer van een juridische werkelijkheid naast of zelfs boven de feitelijkheid. De juridisch geïnterpreteerde werkelijkheid gaat zichzelf dan, zoals Beck opmerkt, de werkelijkheid wanen. Dit toont het specifieke gevaar aan van een dergelijk juridisch stelsel, namelijk het verstenen van de werkelijkheid tot een dominante betekeniscode. Door de instrumentalistische behoefte aan eenduidigheid en de sciëntistische invulling daarvan is er in het milieustrafrecht bij uitstek sprake van zo'n interpretatiecode die het risico loopt de werkelijkheid eenzijdig te gaan innemen. De daadwerkelijke verontreiniging van een rivier, de feitelijke teloorgang van een vogelsoort, het werkelijk uitsterven van een insektensoort zijn niet of nauwelijks nog herkenbaar; zij hebben op den duur geen plaats meer in de 'ecologische werkelijkheid'. Hiermee komt de uitholling van de bemiddelende functie van het strafrecht in relatie tot de leefmilieuproblematiek sterk naar voren. Het bestuursondersteunende milieustrafrecht wordt dan een kader dat als vanzelfsprekend het denken en handelen van de rechtssubjecten bepaalt. Het kader is zelf nauwelijks nog in vraag te stellen. Ook zullen inspanningen van rechtssubjecten op het vlak van het leefmilieu niet verder gaan dan de grenzen van dat kader toelaten; immers, welk beschermenswaardig leefmilieu bestaat er nog buiten het 
gezichtsveld van overheid, wetenschap en milieuinstanties? Ook Raes ziet hier een zwaar onderschat probleem:

'De relatie tussen micro-ethiek en macro-ethiek is hier zoek (...): men neemt de milieuvervuiling bijzonder ernstig en wijst de vervuilers met de vinger, maar men is maar in zeer beperkte mate bereid de eigen levenswijze in termen van grotere milieuvriendelijkheid te wijzigen. ${ }^{167}$

Anderzijds is het dan volstrekt begrijpelijk dat rechtssubjecten, wanneer zij het leefmilieu feitelijk schade toebrengen, zich ten allen tijde willen en zullen beroepen op de rechtvaardigende werking van, terecht of onterecht, afgegeven vergunningen. De vergunningen vergemakkelijken immers het rechtvaardigingsproces juist omdat zij de aandacht van de werkelijke ecologische schade naar de administratieve belangenafweging verplaatsen; de geschade feitelijkheid wordt omgeruild voor een (althans) juridisch ongeschonden realiteit. Uiteindelijk betaalt ook hier weer het leefmilieu de kostprijs en wordt die prijs in het strafrecht niet steeds (volledig) verdisconteerd.

\section{F. MILIEUBESCHERMING: BESCHERMING VAN DE NATUUR OF BESCHERMING VAN EEN BEHEERSIDEOLOGIE?}

De in het milieustrafrecht gesignaleerde omzetting van de meerduidigheid van de ecologische werkelijkheid in sciëntistische en juridische eenduidigheid is niet een vanzelfsprekend gegeven. Het is op zijn beurt een weergave van een bepaald cultureel grondpatroon betreffende de relatie tussen mens en natuur, die een schijn van 'natuurlijkheid' heeft gekregen. Zo dreigt de natuur in al haar complexiteit en onbepaaldheid te worden gedenatureerd en loopt de juridische vertaling van de natuur in 'het te beschermen leefmilieu' het gevaar te worden verabsoluteerd:

'Misschien leven we straks inderdaad in een duurzaam milieu maar hebben we de natuur verloren'. ${ }^{168}$

Achter de verabsoluteerde betekeniscode van het huidige milieurecht schuilt een bepaalde historisch gegroeide ideologie: 'where there is dirt, there is system'. ${ }^{169}$ Dat betekent dat 'de natuur' ook steeds een culturele notie en een sociale constructie is:

'It is not just the environment that is at risk, but the very idea of environment, the social ideal of proper order. ${ }^{170}$

167. Raes, K., 'Een samenleving van onverantwoordelijken. Grenzen aan deresponsabilisering', in WODC, o.c., 1999, 33.

168. Achterhuis, H., o.c., 1995, 90.

169. Douglas, G., Purity and danger, London, Routledge \& Kegan Paul, 1966, 35.

170. Evernden, E., o.c., 1992, 6. 
Net zomin als cultuur kan worden gescheiden van het natuurlijke, kan de natuur niet van de werkingssfeer van het culturele en het historische worden buitengesloten. Gebeurt dit wel, dan is het risico groot dat de culturele en ideologische conceptualisering van 'de natuur' niet meer herkenbaar en dus niet langer ter discussie staat. Als het natuurlijke wordt losgekoppeld van het culturele krijgt het natuurlijke een extra-maatschappelijke status, een bijna bovennatuurlijke normatieve dimensie, die handig en vrijwel willekeurig door allerlei politieke, economische en ecologische groepen kan worden uitgebuit.

Deze vaststelling is vanuit een milieustrafrechtelijk grondslagenonderzoek zeer belangrijk en noopt tot enige nuchterheid; als het strafrecht ten behoeve van de bescherming van de natuur wordt ingezet - en daarin zijn legitimatie vindt -, moet worden benadrukt dat dit ook de bescherming inhoudt van bepaalde ideologische opvattingen over de natuur. Milieustrafrecht bekrachtigt in die zin steeds maatschappelijke metaforen, analogieën, beelden en modellen aangaande de natuur. De term leefmilieu is op zichzelf al een ideologische vertaling van het natuurbegrip. Daar is op zich weinig mis mee: deze metaforen en modellen zijn immers verankerd in onze taal en in onze denkpatronen. ${ }^{171}$ Het recht kan daar binnen zijn concepten niet aan ontsnappen. Wat wel moet worden vermeden, is dat het recht zich automatisch gaat vereenzelvigen met één bepaald ideologisch totaalbeeld, één machtsstructuur waarvoor het strafrecht dan wordt ingeschakeld. Anders doet het strafrecht niet meer dan die machtsstructuur door sanctionering handhaven. Ook het milieustrafrecht moet daarom idealiter steeds zo veel mogelijk een open debatstructuur behouden en een bemiddelend kader kunnen aanleveren om één absolute macht onmogelijk te maken. Dat is in een instrumentalistische benadering van de ecologische crisis bijna onmogelijk.

Wanneer we dit plaatsen binnen de context van het huidige milieu(straf)recht, dan moet worden toegegeven dat die open en bemiddelende structurur voor een belangrijk deel is dichtgeslibd. Klassieke machtskritische beoordelingsmomenten zoals de wederrechtelijkheidsvraag en de schuldvraag zijn veelal herleid tot vanzelfsprekende veronderstellingen. Ons milieustrafrecht, doordrongen van instrumentalisme en sciëntisme, is vaak niet meer dan een articulatie van één bepaalde ideologie. Die ideologie kan worden getypeerd als de schaarste-ideologie waarbij de wetenschappelijke, materialistische metafoor van de natuur als een levenloze machine de officiële en enige toelaatbare metafoor is geworden. ${ }^{172}$ Veel wetenschappers en politici gaan ervan uit dat deze benadering van de natuur ook de enig objectieve is. Andere meer organische benaderingen worden vaak afgeschilderd als onwetenschappelijke folklore, nostalgie of als antropocentrisch. Dergelijke vaak emotioneel geladen reacties illustreren treffend de gevolgen van ideologische verstarring. Bovendien valt op die reacties (ook wetenschappelijk!) nog wat af te dingen. Zo is de ideologische voorstelling van de natuur als een levende 'Moeder Aarde', een organische metafoor die onder andere in de middeleeuwen centraal stond, heel wat minder antropocentrisch dan het beeld van de natuur als een door de mens te besturen machine.

171. Sheldrake, R., De wedergeboorte van de natuur, Utrecht, Kosmos, 1995, 20.

172. Zie over het begrip schaarste en schaarste-ideologie: Achterhuis, H., Het rijk van de schaarste. Van Thomas Hobbes tot Michel Foucault, Baarn, Ambo, 1988. 
Zowel de organische als de mechanische benadering zijn metaforen en zijn om die reden alleen al gelijkwaardig. Maar terwijl de organische metafoor van Moeder Aarde is gebaseerd op in de natuur aanwezige levensprocessen, die onafhankelijk van de mens werkzaam zijn, is de mechanische metafoor enkel geworteld in door mensen (!) vervaardigde machines. ${ }^{173}$ Het kenmerkende van deze ideologie is bovenal dat de daaruit voortvloeiende 'onderwerping en beheersing van de natuur hierin als enige rationele antropologische houding worden gezien en dat van daaruit de natuurvernietiging min of meer systematisch en permanent plaatsvindt.'174

Vanuit een strafrechtelijk grondslagenperspectief is het belangrijk te onderstrepen dat het hier gaat om een verhuld wereldbeeld. Het is verhuld omdat mensen noch het milieurecht, noch de achterliggende ideologie, herkennen als slechts één ordenende structuur van bemiddeling. Een dergelijk versteend dominant werkelijkheidsbeeld censureert mogelijk andere alternatieve werkelijkheidsconstructies omtrent de relatie tussen mens en natuur.

\section{§4. Consequenties en complicaties voor de strafbaarheid van overheden.}

$\mathrm{Nu}$ het rechtskarakter van het milieustrafrecht in grote lijnen is geschetst en geillustreerd, kan worden bekeken in welke mate dit karakter de mogelijkheid om overheden (en hun functionarissen) strafrechtelijk te vervolgen voor door hen veroorzaakte milieuverstoring beïnvloedt. De stelling is dat mede door het sterk instrumentalistische karakter van het huidige milieustrafrecht een vervolging en bestraffing van overheden (in het bijzonder van de staat) zowel theoretisch als praktisch niet meteen voor de hand ligt.

\section{A. EEN INSTRUMENTALISTISCH MILIEUSTRAFRECHT RICHT ZICH EENZIJDIG TOT BURGERS}

Een eerste consequentie en complicatie in relatie tot de vraag of ook overheden onder de werking van het (milieu)strafrecht moeten vallen, heeft te maken met het gegeven dat het huidige milieustrafrecht via de administratieve afhankelijkheid zodanig is geconcipieerd dat het zich primair tot burgers en niet ook tot overheden richt. Daarin ligt voor een belangrijk deel de instrumentele legitimatie van het milieustrafrecht: doel is de strafrechtelijke handhaving van door overheden opgestelde en tot burgers gerichte normen. Het milieustrafrechtsbegrip is niet zozeer relationeel, gaat niet zozeer uit van een rechtsbetrekking tussen overheid en burger, maar van een machtsverhouding waarbij de strafbepalingen kunnen worden getypeerd als bevelsconstructies van de overheid die aan burgers worden opgelegd.

Overheden zijn binnen een overheidsondersteunend milieustrafrecht niet de eerste groep van normadressaten waaraan men denkt indien men een milieustrafbepaling leest. Zij zijn niet diegenen die bij uitstek als voor het leefmilieu gevaarlijke risicogroepen worden aangemerkt. Dat zijn voornamelijk particuliere bedrijven die worden onderworpen aan strafbaar

173. Sheldrake, R., o.c., 1995, 20.

174. Achterhuis, H., o.c., 1988, 234. 
gestelde vergunningenplichten en andere milieuvoorschriften. De overheden staan als het ware bij voorbaat al aan de andere kant: overheden worden niet waargenomen als mogelijke gevaarzetters, maar hebben nu net de taak van 'risicomanagers' toebedeeld gekregen. Binnen het leefmilieubeschermingsproject is het hun taak om de voor het leefmilieu gevaarlijke activiteiten te beheersen en te sturen. Door de administratieve afhankelijkheid van het milieustrafrecht is aan overheden een grote verantwoordelijkheid toebedeeld zowel op het vlak van de bepaling van de voorwaarden voor strafbaarheid als op het vlak van de controle op de naleving daarvan.

Wanneer een burger (of een onderneming) de milieuwetgeving overtreedt, bijvoorbeeld door het schenden van een vergunningsvoorwaarde, dan wordt de vraag of een strafrechtelijke reactie mogelijk moet zijn probleemloos positief beantwoordt. Wanneer nu overheden zelf milieudelicten plegen, krijgt deze vraag bijna als vanzelf een andere meer gevoelige lading. Met name in die gevallen waarin de milieuverstoring voortvloeit uit een onzorgvuldige risicobeheersing vanwege de administratieve overheid omdat ofwel een wederrechtelijke vergunning is afgegeven of omdat de handhaving ontoereikend is. De vraag naar een strafrechtelijke aansprakelijkheid van overheden raakt dan immers de kern van één van de centrale problemen in een Risikogesellschaft: namelijk dat moderne risico's niet slechts het voorwerp zijn van de beheersing van mogelijk schadelijk gedrag, maar daarvan ook de uitkomst kunnen zijn. Vergunningen en de controle op de naleving van de daarin vastgelegde administratieve plichten zijn bedoeld om zo goed mogelijk, als het ware direct bij de bron (of kort op de bal), de risicovolle activiteiten van bedrijven te beheersen. Maar deze risicobeheersing wordt zelf een mogelijke bron van risico's wanneer de verantwoordelijke overheden rechtstreeks bijdragen tot de ontoelaatbare verontreiniging door een wederrechtelijke vergunningverlening of een gebrekkige handhaving. Vanuit een zuiver instrumentalistisch perspectief is echter voor een strafrechtelijke reactie op dergelijk overheidshandelen nauwelijks ruimte. Voorwerp van strafbaarstelling en strafvervolging zijn immers de externe door particulieren veroorzaakte risicovolle activiteiten die de kwetsbaarheid van het leefmilieu bedreigen en niet (ook) de risico's inherent aan het optreden van de overheden zelf; dat milieuoverheden zelf wel eens rechtstreeks of onrechtstreeks een bedreiging voor het leefmilieu zouden kunnen vormen, past niet meteen in de 'Wij-Zij' tegenstelling die zo kenmerkend is voor risicobeheersing: de zwakke plekken - de risico's - van de macht van overheden passen niet van nature in het milieubeheersingsproject. De achterliggende veronderstelling ligt voor de hand: overheden bestrijden, maar veroorzaken geen risico's. Het idee dat ook het overheidsoptreden gevaarzettend zou kunnen zijn, en daarom milieustrafrechtelijk relevant, is vrijwel ondenkbaar wil de leefmilieubeheersing omwille van het wegnemen van onzekerheid(sgevoel) en onveiligheid(sgevoel) maatschappelijk acceptabel blijven en kans van slagen hebben. Dit verklaart wellicht mede het feit dat de Hoge Raad voor de centrale overheid (de staat) in zijn geheel nog steeds strafvervolging uitsluit - strafvervolging zou immers het machtscentralisme in vraag kunnen stellen - en voor decentrale overheden vervolging slechts toelaat wanneer het feit is gepleegd in het kader van een activiteit die ook door particulieren kan worden verricht. Dan treedt de overheid immers niet op als overheid maar treedt zij op als gelijk aan burgers, die het voorwerp van de milieu(straf)rechtelijke sturing zijn. Daarnaast hoeft het nauwelijks te verbazen dat binnen zo'n eenzijdige perceptie van de rol van de overheid 
in het milieurecht, het mogelijke verlies van vertrouwen van de burger in die overheid wordt aangegrepen als een belangrijk argument tegen een strafvervolging van overheden. De idee dat overheden ook 'als overheden' weleens de milieuwetgeving zouden kunnen overtreden, of dat zij zelfs milieucriminaliteit gepleegd door bedrijven zouden kunnen bevorderen, past niet automatisch binnen een instrumentalistische perceptie van het recht. Voor gemeenten, provincies, maar ook voor de centrale overheid (de staat) is de taak van regulering en normhandhaving weggelegd, niet de mogelijkheid van normovertreding.

Wellicht dat bovenstaande analyse als enigszins overtrokken wordt waargenomen, maar zij wordt (helaas) wel bevestigd door de visie van de wetgever op de vraag wie als normadressaat moet gelden in het milieustrafrecht. Dit kan worden geíllustreerd aan de hand van de zorgplichtbepalingen. Zoals besproken, vormen zorgplichtbepalingen een belangrijke categorie van milieustrafbepalingen. Nu zou men bij deze bepalingen verwachten dat ook de overheid als normadressaat moet worden beschouwd, daar deze zorgplichten zo vaag zijn omschreven dat zij zich tot 'eenieder' richten. Niettemin stelt de Commissie Toetsing van wetgevingsprojecten, die over de wenselijkheid van zorgplichtbepalingen aan de Ministerraad advies moest geven, dat onder een zorgplicht moet worden verstaan

'een vrij algemeen geformuleerde, tot de burger gerichte (zorg)verplichting die een bepaalde verantwoordelijkheid van de burger markeert en waarvan het de bedoeling is deze juridisch te handhaven. Een zorgplicht bevat een algemene verplichting tot het in acht nemen van een bepaalde graad van zorgvuldigheid met het oog op het door de desbetreffende wet te beschermen belang, en kan zowel betrekking hebben op een handeling als een nalaten van de normadressaat. De wetstechnische vormgeving van een zorgplichtbepaling kan verschillen; het kan gaan om een gebod (een positief geformuleerde verplichting), of om een verbod. De handhaving van de norm kan langs bestuurlijke, strafrechtelijke of privaatrechtelijke weg geschieden, of zelfs via een combinatie van deze methoden (Cursief, DR). ${ }^{175}$

In haar jaarverslag geeft de Commissie een verkorte definitie met een zelfde strekking: een zorgplichtbepaling is

'een vrij algemeen geformuleerde, tot de burger gerichte (zorg)verplichting die een bepaalde verantwoordelijkheid markeert en waarvan het de bedoeling is deze juridisch (bestuurlijk, privaatrechtelijk of strafrechtelijk) te handhaven. (Cursief, DR) ${ }^{176}$

Er is weinig kritiek geweest op de hier gehanteerde definities van een zorgplicht, op één punt na; namelijk de vraag wie normadressaat is van de zorgplichtbepaling. Volgens de

175. Commissie Toetsing van Wetgevingsprojecten, o.c., 1990, 3.

176. Jaarverslag van de Commissie voor de toetsing van wetgevingsprojecten over het jaar 19891990, o.c., 33. 
Commissie is dit slechts de burger. De overheid is blijkbaar geen normadressaat, maar alleen de handhaver van deze bepalingen. Lambers merkt naar aanleiding van deze definitie terecht op waarom een zorgplicht alleen ten aanzien van burgers zou gelden en niet ook ten aanzien van overheden. ${ }^{177}$ Dat ook overheden zorgplichtbepalingen kunnen overtreden, is inmiddels wel duidelijk geworden. In 1994 moest de Hoge Raad zich uitspreken over de vraag of de staat strafrechtelijk aansprakelijk kan worden gesteld voor de overtreding van artikel 14 (nu artikel 13) Wbb. Zoals bekend, werd het OM niet ontvankelijk verklaard.

Enkele schrijvers vinden het vanzelfsprekend dat de milieustrafwet zich niet tot overheden richt. Strafbare overheden zijn een contradictio in terminus. Dat geldt dan in het bijzonder voor de staat. Zo stelt Boersema:

'En tenslotte dan de strafrechtelijke aansprakelijkheid van de staat. In zijn algemeenheid is die onzinnig, want in strijd met de soevereiniteit van de staat. Dat is geen petitio principii, maar hangt samen met de raison d'être van de staat. Daarom rijst ook de vraag waaraan het overheidsoptreden dan wel getoetst zou worden. Het is veelzeggend dat die vraag in de discussie nergens wordt gesteld. Wellicht omdat het antwoord 'aan de wet' zo voor de hand liggend wordt gevonden. Dat is echter valse schijn. Wetgeving is immers de vorm waarin de staat de samenleving regelt, niets meer. Als bijvoorbeeld in een wet staat: "Gij zult geen vervuild slib in het Pikmeer storten" kan slechts zijn bedoeld: "Gij burgers moogt dat niet." Ook al staat dat er niet met zoveel woorden, het is een noodzakelijke implicatie van elke wet. $\mathrm{Er}$ is in die zin dus ook helemaal geen toepasselijke wetgeving waaraan dergelijk overheidsoptreden kan worden getoetst. De wet is per se niet het instrument waarmee de staat zichzelf kan binden of faciliteren. Ook de strafwet niet. Niemand mag bijvoorbeeld een ander doden. Maar de staat (onder omstandigheden) blijkbaar wel! !178

De visie die achter Boersema's stellingname schuil gaat, neemt een wel zeer achterhaald etatistisch soevereiniteitsbegrip als rechtvaardiging voor de staatsimmuniteit. Centraal staat een visie op het recht dat niet meer is dan een bevelsconstructie, een product van de staat dat uitsluitend bedoeld is voor de sanctionering van burgers. Vat men het recht zo op, dan is er in beginsel inderdaad weinig op te merken tegen de staatsimmuniteit, want recht en staat vallen vrijwel samen. Het heeft er alle schijn van dat dit ook de redenering is die in het Volkel-arrest besloten ligt, hoewel vanwege de bondigheid van de motivering enige voorzichtigheid gepast is met de interpretatie van deze uitspraak. De Hoge Raad oordeelt:

'Als uitgangspunt heeft te gelden dat de handelingen van de Staat geacht moeten worden te strekken tot de behartiging van het algemeen belang.

177. Zie hierover ook Visser, M., l.c., 1996, 206.

178. Boersema, D.A.A., 'Strafbare overheid: een contradictio in terminus?', in Elzinga, D.J. e.a. (red), o.c.,1998, 33-34. 
Daartoe kan de Staat door wet- en regelgeving, bestuur, feitelijke gedragingen of anderszins zich alle aangelegenheden aantrekken. (cursief, DR)',179

In deze twee zinnen wordt veel gezegd. De fictie van het algemeen belang wordt hier als rechtvaardiging van de immuniteit gezien en de middelen waarover de staat beschikt om zich dat algemene belang aan te trekken zijn blijkbaar onbeperkt. Witteveen merkt op dat de Hoge Raad hier een volledig achterhaalde absolute staatssoevereiniteit verdedigt. ${ }^{180} \mathrm{De}$ redenering die op het machtswoord volgt is dan ook enigszins voorspelbaar:

\begin{abstract}
'Voor de handelingen van de Staat zijn ministers en staatssecretarissen in het algemeen verantwoording schuldig aan de Staten-Generaal. Daarnaast kunnen zij ter zake van ambtsmisdrijven strafrechtelijk worden vervolgd en berecht op de voet van de artikelen 438 en volgende Sv. Met dit stelsel strookt niet dat de Staat zelf voor zijn handelingen strafrechtelijk aansprakelijk kan worden gesteld. ${ }^{181}$
\end{abstract}

Hiervoor is reeds uiteengezet dat het strafrecht vanuit het relationeel verlichtingsdenken moet worden gezien als een verzet tegen recht opgevat als een geheel van overheidsbevelen, of deze nu door een autarke vorst of door volkssoevereiniteit zijn gelegitimeerd. Foqué merkt in verband met de steeds toenemende overheidsmacht ter bestrijding van de georganiseerde misdaad op:

'De macht van het recht kan nooit losgekoppeld worden van het recht van de macht (...) Duidelijk dient daarbij te zijn dat het noodzakelijke machtsvormende vermogen van de staat niet meteen dient te impliceren dat de staatsmacht dus als de natuurlijke representant van vaststaande en homogene normen en waarden moet worden opgevat. Maar evenmin van normen en waarden die slechts naar het eigen inzicht en naar eigen maatstaven van de overheid worden vastgesteld. Veeleer dient het machtsvormende vermogen van de staat te worden gezien als het complement én als de garantie van het vermogen tot samen handelen van zijn burgers. Om dat te kunnen bewerkstelligen zal de macht zich gekanaliseerd moeten weten door het recht en zal het optreden van de overheid rechtszekerheid moeten kunnen tot stand brengen bij de burgers. Dat laatste betekent dat het overheidsoptreden geloofwaardig en betrouwbaar moet zijn ten aanzien van de legitieme verwachtingen die overheid en burgers ten opzichte van elkaar koesteren en in het leven roepen. Daarin past niet een conceptie van overheidsbeleid, waarin, op de

179. HR 25 januari 1994, $N J$ 1994, 598, r.o. 6.1. Zie voor een inhoudelijk bespreking van dit belangrijke arrest hoofdstuk II.

180. Witteveen, W.J., 'Staatssoevereiniteit: machtswoord en toverspreuk', in Elzinga, D.J. e.a. (red), o.c., $1998,40$.

181. HR 25 januari 1994, $N J 1994,598$. 
haast fantasmatische golven van de totale oorlog tegen de georganiseerde misdaad, doelmatigheid en doeltreffendheid zò zouden worden verabsoluteerd dat een decisionistische overheidsmacht uiteindelijk het recht naar eigen hand zou kunnen zetten en restloos zou kunnen ommunten tot juridisch instrumentalisme. De dialectiek van de macht van het recht en het recht van de macht zou dan onmogelijk worden gemaakt en daarmee zou de bijl worden gelegd aan de wortels van onze rechtsstaat $^{182}$

Deze wijze inzichten hebben ook binnen het milieustrafrecht hun waarde. Het is duidelijk dat de principiële kwestie of het (milieu)strafrecht zich niet alleen tot burgers richt, maar ook tot overheden, in de eerste plaats wordt bepaald door de rechtstheoretische en crimineel-politieke visie op de waarde van het strafrecht. Uitsluitend binnen een meer machtskritische of relationele visie op het recht is er voldoende ruimte tussen het strafrecht en de overheidsmacht om het voor de eerste mogelijk te maken de laatste te normeren. ${ }^{183}$ Binnen een louter instrumentalistische benadering daarentegen bestaat die ruimte niet of nauwelijks, in het bijzonder niet wanneer exclusieve overheidstaken aan een strafbaar feit ten grondslag liggen of wanneer de centrale overheid (de staat) in het geding is. Puur instrumentalistisch gezien is strafrecht immers niet meer dan een waardenneutraal instrument in handen van de staat en niet ook een controle-instrument op het optreden van de staat. Zoals ik elders heb beschreven: binnen een instrumentalistisch (milieu)strafrecht kan de staat inderdaad niet in zijn eigen staart bijten. ${ }^{184}$

Ook Witteveen bekritiseert hevig, mede vanuit het relationele rechtsdenken, de opvatting dat concepten als staatssoevereiniteit, zoals door Boersema opgevat, zich zouden verzetten tegen de werking van het strafrecht op overheden (inclusief de staat). Hij ziet juist als hoofdkenmerk van de rechtsstaat de zelfbinding van de overheid:

'Een overheid die zonder voortdurend feitelijk geweld te gebruiken en zonder op tirannieke wijze vrees te zaaien, dus als democratische overheid, een gezagsaanspraak wil vestigen, kan dit alleen bereiken door zichzelf aan wetten en rechtsbeginselen te binden. Vertaald naar de context van het milieustrafrecht: een overheid die wil bereiken dat bedrijven en burgers zich aan milieunormen houden, moet zelf ook in al haar verschijningsvormen die milieunormen respecteren. Gebeurt dit niet, en worden deze normovertredingen door de leer van de staatssoevereiniteit met de tovermantel der liefde bedekt, dan vervalt een belangrijke aansporing aan bedrijven en burgers om zich ook aan de wet te houden. ${ }^{185}$

182. Foqué, R.M.G.E, 'De legitimiteit van het strafrechtssysteem', in De Doelder, H., Foqué, R.M.G.E. en Gerding, R.A.F. (red.), o.c., 1994, 19-20.

183. Vgl. Foqué, R., De Ruimte van het recht, Amhem, Gouda Quint, 1992.

184. Roef, D., 'Kan de Staat in zijn eigen staart bijten?', DD, 1995, 332-348.

185. Witteveen, W.J., 'Staat de overheid boven de wet?', in Elzinga, D.J. (red.), o.c., 1998, 44. 
Dat een tekort aan machtskritiek in het huidige milieustrafrecht niet slechts een principieel belang heeft, maar ook in de vervolgingspraktijk parten kan spelen blijkt wel uit de vervolgingspraktijk. De lakmoestest voor de zelfstandige, a-politieke en machtskritische waarden van het strafrecht enerzijds en de functionele onafhankelijkheid van het $\mathrm{OM}$ ten overstaan van het bestuur anderzijds, zijn immers die situaties waarin overheden zelf de milieuwetten overtreden. Nu komt juist op dit niveau de achilleshiel van een instrumentalistisch milieustrafrecht sterk naar voren. Milieuofficieren willen in beginsel overheden niet anders behandelen dan particuliere verdachten. Maar hun bestuursafhankelijke positie plaatst hen soms in een lastig parket. Door een strafrechtelijk optreden kan de samenwerking met de lokale milieuoverheden - tevens handhavingspartners - onder druk komen te staan. Dat leidt ertoe dat dergelijke milieuzaken, ondanks de voorbeeldfunctie van overheden en de niet geringe verantwoordelijkheid die deze overheden hebben op het vlak van milieuregulering en handhaving, niet zelden op een andere wijze worden afgedaan dan milieuzaken tegen particulieren. Uit onderzoek blijkt dat in de periode 1990-1992 van de 56 milieuzaken tegen overheden in 26 gevallen de zaak is geseponeerd, in 27 zaken een transactie werd aangeboden, terwijl slechts in 3 zaken tegen de verdachte overheid een dagvaarding is uitgegaan. ${ }^{186}$ De conclusie is, als we vergelijken met milieuzaken in het algemeen,

'dat zaken tegen overheden in verhouding vaker geseponeerd, minder vaak getransigeerd en naar alle waarschijnlijkheid minder vaak zijn gedagvaard. In algemene termen gesproken, blijken overheden milder te zijn gesanctioneerd dan particuliere verdachten. ${ }^{187}$

Dergelijke cijfers wijzen op praktische moeilijkheden van vervolging die voortvloeien uit het bestuursondersteunend karakter van het milieustrafrecht. Bekeken in het licht van een instrumentalistisch rechtsdenken is de vervolgingsproblematiek bij overtredende overheden volkomen begrijpelijk. Een milieustrafrechtshantering, die hoofdzakelijk is gericht op een implementatie van bestuurlijke voorschriften en waarbij OvJ's niet meer zijn dan gens $d u$ roi, of op zijn best gens du loi, is a priori al gehinderd bij de strafrechtelijke aanpak van overheden. Een strafrechtelijke reactie is in die gevallen niet langer een waardenvrij instrument in handen van de overheid, maar betekent fundamenteel een punt van kritiek op de bestuurlijke macht en stelt zo de door de overheid gewenste orde in vraag. Wanneer echter strafrechtelijke milieurechtshandhaving hoofdzakelijk wordt voorgesteld als een éénrichtingsverkeer waarbij de overheid van de samenleving respect voor het recht en het leefmilieu eist zonder tegelijk rechtsstatelijk zelfrespect te tonen dan 'plaatst die overheid

186. Kleiman, W.M., Van den Berg, E.A.I.M. en Van der Linden, E.J.A. (red.), Overtredende overheden. Vervolgingsbeleid inzake milieudelicten, WODC, 1995.

187. Idem, 3 . 
zichzelf in de ongebonden positie van de macht die van buitenaf naar eigen maatstaven beschikt over het recht. ${ }^{\prime 88}$

\title{
C. HET IN ELKAAR OVERVLOEIEN VAN DEMOCRATISCHE EN RECHTSSTATELIJKE LEGITIMATIE
}

De instrumentalistische positie waarin het strafrecht als geheel en het milieustrafrecht in het bijzonder is komen te verkeren, is onlosmakelijk verbonden met de visie in een verzorgingsstaat over democratie, recht en maatschappelijk bestuur:

\begin{abstract}
'Als democratie wordt vooral beschouwd de bestuursvorm waarin uiteindelijk een gekozen parlementaire meerderheid het voor het zeggen heeft. Dat is een formele opvatting van democratie. Kenmerkend voor de democratie zou zijn dat de overheid, in het bijzonder de regering en gekozen volksvertegenwoordiging, de maatschappij representeert en op haar beurt de maatschappij beheerst: de staat is het instrument waarmee de maatschappij zichzelf bestuurt. ${ }^{189}$
\end{abstract}

Of zoals de Hoge Raad in Volkel stelt: de staat is de behartiger van het algemeen belang en kan zich dit algemene belang via alle middelen aantrekken. Een mogelijk gevolg van zo'n democratiebegrip is dat het zijn schaduw vooruitwerpt op de inhoud van de rechtsorde en hoe deze kan worden gehandhaafd. Meer bepaald bestaat het risico dat rechtsstatelijke legitimatie van overheidshandelen wordt gelijkgeschakeld met democratische legitimatie van het overheidshandelen. Dat dit niet het geval is, daarvan getuige de bijna dagelijks door de bestuursrechter vernietigde maar niettemin democratisch gelegitimeerde bestuurlijke besluiten. Het is echter opvallend dat juist in de (vooral politieke!) discussie over de strafrechtelijke aansprakelijkheid van overheden de democratische legitimatie van het overheidshandelen wordt geproclameerd als een wezenlijk argument tegen strafvervolging van overheden. Een eerste voorbeeld kan worden gevonden in de MvT op de Belgische Wet tot invoering van de strafrechtelijke verantwoordelijkheid van de rechtspersoon van 4 mei 1999. In deze wet worden overheden van de werking van het strafrecht uitgesloten zonder dat daarbij wordt onderscheiden tussen decentrale overheden en de centrale overheid en ongeacht de hoedanigheid waarin ze maatschappelijk functioneren (als overheid of als particulier). Het enige argument dat door de minister van justitie wordt gegeven is dat deze overheden bestaan uit democratisch gekozen organen. Met andere woorden, de democratische legitimatie en controle van overheidsmacht sluit de strafrechtelijke controle op die macht uit. Een tweede voorbeeld kan worden gevonden in de Nederlandse Kabinetsnota Strafrechtelijke aansprakelijkheid van overheidsorganen. Het kabinet neemt als uitgangspunt dat moet worden uitgegaan van een strafrechtelijke immuniteit van overheden en/of diegenen die bij deze overheden in dienst zijn binnen het kader van de uitoefening van een bestuurstaak. Het primaat ligt bij de politiek en het

188. Foqué, R.M.G.E., 'Legitimiteit van het huidige strafrechtssysteem', in De Doelder, H., Foqué, R.M.G.E. en Gerding, R.A.F. (red.), o.c.,1994, 23.

189. 't Hart, A.C., o.c., 1991, 102-103. 
bestuursrecht. Het strafrecht heeft kennelijk ter zake geen rol te vervullen. Toch is de visie van het kabinet niet zo duidelijk en rechtlijnig als op het eerste gezicht lijkt. Het kabinet ziet immers in bepaalde gevallen toch nog ruimte voor strafvervolging, namelijk

\begin{abstract}
'indien het handelen van het overheidsorgaan redelijkerwijs niet meer kan worden gerekend tot de uitvoering van de overheidstaak [en] de aantasting van het door de strafbepaling beschermde belang redelijkerwijs niet geacht kan worden te strekken tot behartiging van de andere aan de overheid toevertrouwde belangen.' 190
\end{abstract}

Cruciale vraag is natuurlijk wanneer er redelijkerwijs niet langer sprake is van een uitvoering van een overheidstaak. Naar het oordeel van het kabinet is daarbij determinant in hoeverre het betrokken handelen verwijderd is van de oorspronkelijke overheidstaak en vooral in welke mate het overheidshandelen de goedkeuring heeft van een vertegenwoordigend lichaam (bijvoorbeeld de gemeenteraad) en aldus democratisch gelegitimeerd is. Is dit laatste het geval dan kan het betrokken handelen nog worden beschouwd als behorende tot de uitvoering van een overheidstaak. ${ }^{191}$

Het kabinet laat dus een zekere terughoudende (redelijkheids)toetsing door de strafrechter toe. Een vergelijking wordt gemaakt met de toetsingsmogelijkheden waarover de bestuursrechter en de civiele rechter beschikken. Dat de bij overheden aanwezige beoordelings- of beleidsvrijheid de rechter tot terughoudendheid verplicht zal niemand betwisten: een rechter mag niet op de stoel van het bestuur zitten. ${ }^{192}$ Interessant is vooral de overweging van het kabinet dat de democratische legitimatie van het overheidshandelen reeds kan volstaan om strafvervolging uit te sluiten omdat het handelen dan 'redelijkerwijs' kan worden gezien als ter uitvoering van een overheidstaak. Dit is een vreemde en betwistbare redenering. Dit zou immers betekenen dat bijvoorbeeld een gemeente zich met succes op de immuniteit zou kunnen beroepen telkens wanneer de gemeenteraad voor het betreffende handelen bestuurlijke en politieke verantwoordelijkheid aanvaardt, hetgeen bijvoorbeeld in de tweede Voorburgse Reigersnestenzaak het geval was. ${ }^{193}$ In deze zaak werd het zonder vergunning (van de Minister van LNV) verwijderen van door de Vogelwet beschermde blauwe reigersnesten door $\mathrm{B} \& \mathrm{~W}$ aan de raad voorgelegd. De instemming van de gemeenteraad kan moeilijk worden gezien als een voorbeeld van een zorgvuldige besluitvorming, tenzij men rechtmatigheid gelijkschakelt met politieke consensus. Dit kan niet 'redelijkerwijs' worden aangemerkt als ter uitvoering van een overheidstaak; het bewust ontkennen van de hiërarchie van rechtsnormen en het negeren van de (trouwens evenzeer

190. TK 1996-1997, 25492 , nr. $2,7$.

191. TK, 1996-1997, 25000 , VI, nr. 31.

192. Deze kabinetsnota wordt later meer diepgaand besproken, maar terloops weze opgemerkt dat het kabinet in deze nota volledig uit het oog verliest, dat de toenmalige jurisprudentie van de Hoge Raad zelfs een terughoudende toetsing uitsloot, zodat de vergelijking met de bestuursrechter en de civiele rechter niet opgaat. Zie hierover hoofdstuk III.

193. HR 23 oktober 1990, NJ 1990, 496 met noot Schalken. 
democratisch gelegitimeerde) milieuwetgeving zou zelfs veeleer als een strafverzwarende omstandigheid moeten worden aangemerkt. ${ }^{194}$

Uiteindelijk wil dit zeggen dat een wetsovertredende overheid zelf strafrechtelijke controle en aansprakelijkheid kan verhinderen door een louter politieke goedkeuring van het gepleegde feit. Zelfs indien men verdedigt dat er een groot verschil bestaat, ook in strafwaardigheid, tussen situaties waarin het strafbare overheidshandelen door het vertegenwoordigend orgaan van de overheid is goedgekeurd of in ieder geval het resultaat is van een democratische besluitvorming en situaties waarin dit niet zo is, ${ }^{195}$ lijkt het mij principieel onverdedigbaar dat de enkele democratische legitimatie van een bepaald overheidshandelen de onvervolgbaarheid met zich mee kan brengen. Het feit dat een bepaalde handeling democratisch gelegitimeerd is, betekent nog niet dat de beslissing daartoe rechtmatig is tot stand gekomen. Het komt geregeld voor dat de administratieve rechter besluiten vernietigt die in eerste instantie de goedkeuring hebben gekregen van het vertegenwoordigend lichaam. Betekent dit dan dat vervolging wel mogelijk is wanneer een door het vertegenwoordigend lichaam goedgekeurde beslissing later door de bestuursrechter wordt vernietigd? ${ }^{196}$ Kortom, het kan moeilijk worden verdedigd dat de overtreding door een overheid van in de wet neergelegde strafrechtelijke normen niet langer strafwaardig is door de goedkeuring van het vertegenwoordigend lichaam van die overheid.

Achter deze redenering gaat opnieuw een instrumentalistische visie op recht en rechtsorde schuil waarin democratische legitimatie en rechtsstatelijke legitimatie stilaan synoniemen zijn geworden of in elkaar overvloeien. In een instrumentalistische benadering is de rechtsorde alleen die maatschappelijke orde die als doelstelling door de overheid wordt nagestreefd en ten dienste waarvan het (straf)recht als neutraal instrument wordt ingeschakeld. ${ }^{197}$ Illegale besluiten en door overheden gepleegde strafbare feiten zouden dan de status van legaliteit en onvervolgbaarheid moeten kunnen krijgen alleen maar omdat zij door de democratische organen zelf zijn aanvaard. Is de uitoefening van bepaalde bevoegdheden en overheidstaken het gevolg van op democratische wijze geldig tot stand gekomen besluiten dan is daarmee eigenlijk iedere legitimatie gegeven. Binnen zo'n argumentatie is nauwelijks plaats voor strafvervolging van overheden omdat het strafrecht zelf moeilijk nog kritisch kan staan tegenover het overheidsoptreden. Recht is dan niet meer dan het resultaat van politieke meerderheidsbeslissingen hetgeen dan vanzelfsprekend nauwelijks ruimte laat voor een rechterlijke controle die verder gaat dan de politieke machthebber zelf toelaat.

194. Vgl. Fransen, A.M., 'Crimineel overheidsgedrag in de doofpot. Een ongeschreven titel van het Wetboek van Strafrecht', NJB, 1997, 13.

195. Dat laatste is trouwens vaak het geval. Meestal gaat het om uitvoeringshandelingen, zoals illegale slibstort, en komen de vertegenwoordigende organen er pas maanden of jaren later achter.

196. Zie ook Peters, J.A.F., 'Wordt vervolgd? Over de criteria gebruikt bij het beleid inzake vervolging van overheden', NTB, 1997, 386 .

197. 't Hart, A.C., o.c., 1994, 186-187. 
Bovendien kan in algemene zin worden opgemerkt dat in onze risicomaatschappij deze democratische legitimatie zelf sterk onder druk staat. Dit geldt met name binnen zulke ingewikkelde domeinen als milieubeleid en milieurecht. Door de toenemende complexiteit van onze maatschappij ontsnappen heel wat ontwikkelingen aan de greep van de democratisch gelegitimeerde politiek. Veel technologische evoluties voltrekken zich aan het zicht van de geïnstitutionaliseerde politiek. Ulrich Beck heeft dit proces geanalyseerd onder de benaming 'sub-politiek' en heeft dit op overtuigende wijze geillustreerd. ${ }^{198} \mathrm{De}$ democratisch gelegitimeerde politiek beschikt traditioneel over drie sturingsinstrumenten: recht (juridische regelgeving), geld (overheidsinvesteringen, belastingen) en informatie. ${ }^{199}$ Deze machtsinstrumenten kunnen slechts via trage en moeizame wegen worden geïmplementeerd en kunnen bijgevolg slechts met vertraging effect hebben. De cruciale beslissingen over industriële productieprocessen, onderzoek en ontwikkeling van allerlei voor mens en leefmilieu mogelijk bedreigende technologische innovaties daarentegen worden rechtstreeks op bedrijfsniveau genomen waarop de democratisch gelegitimeerde politiek altijd slechts achteraf kan reageren. Piret verwoordt het aldus:

\begin{abstract}
'De politiek houdt zich op die manier steeds meer bezig met gevolgen van beslissingen en keuzes die "niemand" genomen heeft of waar althans geen publieke debatten aan vooraf gegaan zijn die op grond van democratische besluitvorming tot maatschappelijke keuzes geleid hebben. En toch is de gemeenschap in laatste instantie verantwoordelijk voor de negatieve nevengevolgen en moet zij niet zelden opdraaien voor de kosten van al die beslissingen die ze niet genomen heeft. (...) De versplintering van de politiek in gedecentraliseerde en gelokaliseerde 'subpolitieken' mag de ogen echter niet doen sluiten voor de kwaliteit van die decentralisering. Demokratie-theoretisch impliceert dit dat er gezocht dient te worden naar een antwoord op de vraag hoe in deze context "volkssoevereiniteit" weer operationeel gemaakt kan worden. ${ }^{200}$
\end{abstract}

\title{
D. STRAFBAAR OVERHEIDSHANDELEN EN MILIEUSTRAFRECHTELIJKE WEDERRECHTELIJKHEID
}

De vraag naar een strafrechtelijke aansprakelijkheid van overheden rijst niet alleen in de klassieke gevallen waarin overheden zelf rechtstreeks milieudelicten plegen. Het is ook mogelijk dat overheden bijdragen tot milieuverstoring via onzorgvuldige vergunningverlening of ontoereikend toezicht. Een strafrechtelijke aansprakelijkstelling voor bijvoorbeeld wederrechtelijke vergunningverlening is echter binnen een instrumentalistisch getint milieustrafrecht moeilijk denkbaar. Vanwege de sterke administratieve afhankelijkheid is het milieustrafrecht immers zodanig geconcipieerd dat het zich vrijwel uitsluitend richt tot vergunningplichtigen en -houders en niet tot de vergunningverlenende of toezichthoudende

198. Beck, U., o.c., 1986.

199. Zie hierover Piret, J.-M., 'Filosofische beschouwingen bij de grondslagen van het milieurecht, in Gutwirth, S. en Van Maanen, G. (red.), o.c., 1995, 27 e.v.

200. Idem, 29. 
instanties. Centraal uitgangspunt van het milieustrafrecht is de strafbaarstelling van het handelen zonder of in strijd met een vergunning en niet een strafbaarstelling van verontreiniging die bijvoorbeeld terug te voeren is tot de vergunningverlening zelf. Nu geen afzonderlijke strafbepalingen bestaan die het mogelijk maken overheden en/of ambtenaren voor wederrechtelijke vergunningverlening te vervolgen, moeten noodzakelijkerwijs de bestaande milieustrafbepalingen worden toegepast. Niet alleen voor rechtstreeks door overheden veroorzaakte milieuverstoring, maar ook in gevallen van verstoring waaraan een foute vergunningverlening ten grondslag ligt, zal de aansprakelijkstelling dus grotendeels moeten gebeuren via een milieustrafrecht dat meestal (absoluut) administratief afhankelijk is.

Dit werpt allerlei vragen op. Allereerst rijst de vraag of de gebrekkige vergunningverlening wel onder een milieudelictsomschrijving kan worden geplaatst. Met andere woorden, kan een wederrechtelijke vergunningverlening wel worden gekwalificeerd als een strafbaar feit. Indien de delictsomschrijving, zoals in een administratief afhankelijk systeem meestal het geval is, zich alleen richt tot een vergunninghouder of tot bedrijfsmatig handelen, dan is daderschap van de vergunningverlener vrijwel uitgesloten omdat deze immers niet beantwoordt aan de vereiste daderschapskwaliteit: dader is slechts de vergunningplichtige of het bedrijf in kwestie. Dit betekent dat de verdachte overheid of ambtenaar mogelijk alleen via een deelnemingsfiguur zou kunnen worden vervolgd. Strafrechtsdogmatisch komt deelneming echter alleen in aanmerking wanneer het milieuvervuilende optreden van de dader (de vergunninghouder) een strafbaar grondfeit uitmaakt en dat hangt weer af van de strafuitsluitende werking van de vergunning. Wie dus de vraag stelt naar een strafrechtelijke aansprakelijkheid voor wederrechtelijke vergunningverlening komt dus vlug in een dogmatisch labyrint terecht. Uiteindelijk rijst onvermijdelijk de vraag in hoeverre onrechtmatige vergunningen milieuverontreiniging kunnen rechtvaardigen en daarmee houdt verband of het de strafrechter wel toegelaten is vergunningen op hun rechtmatigheid te toetsen. Zoals gezien, is strafrechtelijke toetsing van vergunningen alleen maar mogelijk in een Verwaltungsrechtsakzessorische benadering van het milieustrafrecht waarin de machtskritische eis centraal staat dat ook de vergunningverlenende instanties zich moeten houden aan het objectieve milieurecht en het de strafrechter derhalve is toegestaan overheidshandelen af te keuren dat hiermee in strijd is. Binnen een Verwaltungsaktsakzessorische opvatting is toetsing onmogelijk of zeer beperkt hetgeen betekent dat dergelijke vormen van milieuverontreiniging onbestraft zullen blijven. Al deze praktische obstakels om tot een strafrechtelijke aansprakelijkheid te komen van vergunninghouder en/of vergunningverlener in gevallen waar de vergunningverlening in strijd met het recht geschiedt, spruiten dus rechtstreeks voort uit een absolute bestuursafhankelijke inkleuring van het milieustrafrecht.

Kortom, indien men een strafrechtelijke aansprakelijkheid voor wederrechtelijke vergunningverlening of onzorgvuldige handhaving voorstaat, dan is dit slechts mogelijk binnen een milieustrafrecht dat zowel op het niveau van de strafbaarstellingen als op het niveau van strafrechtstoepassing voldoende machtskritische ruimte of vermogen heef, dat wil zeggen, zodanig is geformuleerd dat het onrechtmatige overheidsoptreden ook onder de werking van de milieustrafwet kan vallen. 


\section{$\S 5$. Conclusies}

In dit hoofdstuk wordt een schets gegeven van het rechtskarakter van het milieustrafrecht en wordt beschreven hoe dit rechtstreeks en onrechtstreeks zijn schaduw vooruitwerpt op de vervolgbaarheid en de strafbaarheid van overheden.

We stellen vast dat het huidige milieustrafrecht instrumentalistisch is georiënteerd. Aan de daaruit voortvloeiende problemen kan niet eenvoudig met praktische (nood)oplossingen worden voorbijgegaan zonder niet tegelijk een grondslagendebat aan te durven. Een pleidooi tot herbezinning in het milieustrafrecht van de twee klassieke pijlers van het strafrecht, instrumentaliteit en rechtsbescherming, is zeker op zijn plaats. Een waardevol uitgangspunt blijft dat het strafrecht niet zomaar te reduceren valt tot een instrument waarmee als met een hamer moet worden omgegaan. ${ }^{201}$ Dit is niet iets dat slechts geldingskracht heeft in het klassieke strafrecht. Het is waar dat in de bijzondere deelgebieden van het strafrecht, zoals economisch strafrecht en het milieustrafrecht, meer en andere instrumentalistische ratio's gelden dan binnen het meer klassieke commune strafrecht. Er zou daarom kunnen worden betoogd dat dit instrumentalistische karakter van het milieustrafrecht is gerechtvaardigd vanwege de importantie van het te bereiken doel; een succesvolle bestrijding van milieuverstoring ten behoeve van een schoner leefmilieu. De betekenis van het strafrecht voor het leefmilieu dient dan hoofdzakelijk te worden beoordeeld naar zijn extra-juridische merites. De achterstelling van het machtskritische element vormt daarbij een noodzakelijk prijs die voor een beter leefmilieu moet worden betaald. Naar mijn mening getuigt een dergelijke redenering van een nauwelijks te rechtvaardigen vereenvoudiging van zowel de specifieke waarde van het strafrecht alsook van de uiterst complexe maatschappelijke problemen zoals deze zich in onze risicomaatschappij voordoen en waarvan milieuverstoring een uitgesproken voorbeeld is.

Een meer genuanceerde en duurzame beoordeling van de conflictoplossende en sturende werking van het strafrecht in relatie tot de milieuproblematiek kan niet louter op instrumentele noties en verwachtingen worden gebaseerd. Gebeurt dat wel dan wordt het instrumentele verheven tot een risicobeheersingsideologie die slechts nog ter discussie kan staan in termen van justitieel rendement. Dit heeft onvermijdelijk een depreciatie van het machtskritische element in het strafrecht tot gevolg. Mijns inziens bedreigt een dergelijke depreciatie niet alleen de klassieke grondslagen van het strafrecht maar staat dit uiteindelijk ook een degelijke bescherming van het leefmilieu in de weg. De redenering dat minder rechtsbescherming en machtskritiek automatisch zullen leiden tot meer 'efficiency' op het vlak van de bescherming van het leefmilieu lijkt al te eenvoudig. Op den duur ondergraaft een louter instrumentalistisch milieustrafrecht (ook) de eigen extra-juridische legitimatie, die is gelegen in (de door de overheid geviseerde) behartiging van het leefmilieu.

201. Glastra van Loon, J.F., 'De hoeksteen van de rechtsstaat', in Glastra van Loon, J.F. en Kelk, C., o.c., 21 . 
Tevens is vastgesteld hoe binnen een instrumentalistisch milieustrafrecht nauwelijks ruimte is voor een strafrechtelijke aansprakelijkheid van overheden: dominant is een visie waarbij het niet mogelijk of wenselijk wordt geacht dat ook overheden onder de werking van het milieustrafrecht vallen, in ieder geval niet in die situaties waarin zij exclusief als 'overheden' optreden. Dit kan moeilijk anders zolang men blijft uitgaan van een uitsluitend overheidsondersteunend milieustrafrecht, dat niet tegelijk overheidsnormerend of controlerend wil of kan zijn. Vanuit een grondslagenperspectief dienen daarom vooreerst de fundamenten van ons milieustrafrecht anders te worden benaderd. Wil men vernieuwing in de praktijk dan dient deze zijn complement te vinden in een theoretische conceptualisering van die praktijk. De gesignaleerde problemen, zoals de nadelen van de administratieve afhankelijkheid, zijn diep geworteld in de grondstructuur van ons milieustrafrecht. Mogelijke oplossingen dienen dan ook eerst in een herordening van die grondstructuur te worden gevonden. Een begin van herordening van de uitgangspunten van het milieustrafrecht kan mogelijk worden gevonden in een herformulering van de verhouding tussen instrumentaliteit en rechtsbescherming in het milieustrafrecht.

Inspiratie kan onder meer worden gevonden in wat Foqué, ' $\mathrm{t}$ Hart en anderen aanduiden als het relationeel rechtsdenken van de Verlichting. ${ }^{202}$ De centrale functie van het strafrecht is niet enkel instrumenteel, noch is haar rechtskarakter uitsluitend beschermend. In het relationele rechtsdenken geldt de wederzijdse afhankelijkheid van beide functies als uitgangspunt: zij houden elkaar wederkerig in de ban. Het strafrecht heeft primair als functie

'de articulatie te bewerkstelligen van een rechtsbeschermende functie, die een rem is op de ontsporingen van een centraliserende despotische macht, en een instrumentele functie, gericht op de schepping van de mogelijkheden voor een samenleving waarin vrijheid verwezenlijkt kan worden. ${ }^{203}$

Het strafrecht heeft in de eerste plaats een bemiddelende taak en moet steeds de in een samenleving aanwezige machtsstructuren en wereldbeelden kunnen herbepalen zodat de dominantie van één machtsstructuur kan worden verhinderd. De grondstructuur van het recht vereenzelvigt zich als dusdanig niet met bepaalde machtsstructuren, maar valideert zichzelf gedurende de bemiddelende activiteit tussen die machtsstructuren.

Het rechtsbeschermende en machtskritische krijgt zo een ruimere betekenis. Een rechtsorde die niet wil samenvallen met een machtsorde, van welke aard ook, moet zich kunnen beschermen tegen elke vorm van bedreiging. Een mogelijke bedreiging kan inderdaad uitgaan van criminaliteit. Een andere vorm is echter de bedreiging die van de overheid zelf uitgaat, vooral wanneer zij zelf strafbare feiten pleegt. Bovendien houdt in die gezichtshoek machtskritiek meer in dan kritiek binnen één bepaalde machtsstructuur of heersende werkelijkheidsinterpretatie. Willen we niet slechts het leefmilieu, maar ook de rechtsorde

203. Gutwirth, S, l.c., 1994, 23. 
vrijwaren van verval dan moet het machtskritische de mogelijkheid hebben de bestaande machtsverhoudingen en waarheidsuitspraken te overstijgen. Dit laatste is machtskritiek als bescherming van het ongehoorde verhaal, van de niet officiële visies op de complexe feitelijkheid. $^{204}$

Naar het milieustrafrecht vertaald, betekent dit dat de bescherming van het leefmilieu niet langer als een uitsluitend extern te bereiken overheidsdoelstelling onder de instrumentele noemer moet worden geplaatst. Door milieubescherming buiten de bemiddelende functie van het strafrecht te situeren, valt het onvermijdelijk ten prooi aan dominante waarheidsaanspraken van onder andere bestuur en wetenschap. Milieustrafrecht moet verder kunnen gaan dan de loutere implementatie van de door de overheid geviseerde bescherming van het leefmilieu, die dan nog meestal is beperkt door een absolute administratieve afhankelijkheid. De juridische bescherming van het leefmilieu moet daarom niet langer worden gezien als het monopolie van de overheid of enige andere machthebber. Zolang milieurecht inderdaad is gerelateerd aan één bepaalde machtsconcentratie kan rechtsbescherming en machtskritiek, die de controle uitmaakt op de machtsuitoefening, nooit de grenzen van die macht overstijgen. Uiteindelijk kan ook de bescherming van het leefmilieu nooit verder gaan dan door deze machtsstructuur wordt toegelaten. Het relationele rechtsdenken moet dus ook de verhoudingen tussen burger, overheid en natuur als deelnemers aan onze leefomgeving - noodzakelijke grondvoorwaarde van onze rechtsorde - behelzen ${ }^{205} \mathrm{De}$ tot nu toe exclusieve doelstellingen van het milieustrafrecht moeten in die zin inclusief worden en betrokken blijven in de dialectische openheid van het juridisch discours. Binnen zo'n relationele herijking van het milieustrafrecht is wel degelijk plaats voor een strafrechtelijke aansprakelijkheid van overheden, een aansprakelijkheid die ook ten aanzien van die overheden meer moet zijn dan een louter instrumentalistische doelstelling.

204. 't Hart, A.C., o.c., 1991, 46-56.

205. Gutwirth, S., l.c., 1991. 

Hoofdstuk III

\title{
De strafrechtelijke aansprakelijkheid van overheden in rechtsvergelijkend perspectief
}

\author{
In de mij ter beschikking staande buitenlandse \\ litteratuur heb ik niet veel gevonden dat van belang \\ is, mede omdat Duitsland en België de strafbaarheid \\ van de rechtspersoon helemaal niet kennen ${ }^{206}$
}

\section{§1. Inleiding}

Zoals aangekondigd, wordt de vraag op welke wijze overheden strafrechtelijk aansprakelijk kunnen worden gesteld in de eerste plaats vanuit de rechtsvergelijking bekeken. Wat voor dit onderwerp de rechtsvergelijking zo interessant maakt, is dat van de onderzochte landen Nederland, Frankrijk en (recentelijk ook) België de strafrechtelijke aansprakelijkheid van de rechtspersoon aanvaarden, terwijl Duitsland tot op heden deze aansprakelijkheid niet kent.

Dit onderscheid is wezenlijk omdat de strafbaarheid van de rechtspersoon noodzakelijk is om tot een strafbaarheid van de overheid te komen. Overheden vormen als publiekrechtelijke rechtspersonen immers een species van de rechtspersoon. In landen waar de strafrechtelijke aansprakelijkheid van de rechtspersoon niet wordt aanvaard, kunnen overheden dan ook niet strafrechtelijk aansprakelijk worden gesteld. Daaruit mag echter niet worden afgeleid dat de milieuverstoring, die door overheden wordt veroorzaakt, onbestraft blijft. Het betekent wel dat deze landen verplicht zijn te zoeken naar alternatieven om de door overheden gepleegde milieucriminaliteit strafrechtelijk aan te pakken. $\mathrm{Zij}$ richten dan met name de aandacht op de vervolging van individuele functionarissen, die binnen de overheid een belangrijke rol spelen. Langs de andere kant mag uit het bestaan van de strafrechtelijke aansprakelijkheid van de rechtspersoon niet zomaar worden geconcludeerd dat overheden probleemloos vervolgd kunnen worden. Zowel Nederland, Frankrijk als België kennen de strafbaarheid van de rechtspersoon, maar voor overheden worden in bepaalde gevallen op die strafbaarheid uitzonderingen gemaakt, 
hetgeen betekent dat ook in die landen de vervolging van individuele functionarissen vaak het enige strafrechtelijke alternatief is.

Nederland heeft reeds in 1976 de strafrechtelijke aansprakelijkheid van de rechtspersoon in het Wetboek van Strafrecht ingevoerd. De vervolgbaarheid en strafbaarheid van overheden zijn evenwel tot op heden niet wettelijk geregeld. De criteria aan de hand waarvan moet worden bepaald in welke gevallen overheden vervolgd kunnen worden, zijn de resultante van een lange, ingewikkelde en omstreden jurisprudentiële ontwikkeling $(\S 2)$.

De Franse wetgever heeft in 1994 de strafrechtelijke aansprakelijkheid van de rechtspersoon in het strafwetboek ingevoerd en heeft daarbij wel expliciet rekening gehouden met de vraag of overheden onder de werking van het strafrecht dienen te vallen. In Frankrijk is derhalve wettelijk geregeld in welke gevallen overheden strafrechtelijk aansprakelijk kunnen worden gesteld $(\S 3)$.

België is bijzonder interessant omdat pas in 1999 de strafrechtelijke aansprakelijkheid van de rechtspersoon is ingevoerd. Daarbij valt op dat de wetgever overheden in alle gevallen van de werking van het strafrecht heeft uitgesloten. Dit is zeer opmerkelijk omdat vóór de invoering van de strafrechtelijke aansprakelijkheid van de rechtspersoon, door overheden gepleegde milieudelicten aan de verantwoordelijke functionarissen (bijvoorbeeld de burgemeester) strafrechtelijk werden toegerekend. De vraag rijst nu wat de consequenties zijn van de door de wetgever gecreëerde niet-strafbaarheid van overheden $(\S 4)$.

Duitsland bevindt zich in een merkwaardige positie. Hoewel het Duitse recht formeel niet de strafrechtelijke aansprakelijkheid van de rechtspersoon kent, bestaat materieel wel de mogelijkheid om via het zogenaamde Ordnungswidrigkeitenrecht aan rechtspersonen, inclusief overheden, geldboetes op te leggen die duidelijk een strafrechtelijk karakter hebben. Daarnaast bestaat in Duitsland, net als in België, de mogelijkheid het door de overheid gepleegde feit aan de natuurlijke persoon toe te rekenen (§5).

\section{§ 2. Nederland}

De strafvervolging van overheden is naar Nederlands recht niet bij wet geregeld. De criteria aan de hand waarvan moet worden bepaald welke overheden in welke gevallen kunnen worden vervolgd, is een kwestie die aan de rechtspraak is overgelaten. In deze paragraaf wordt aan deze rechtspraak aandacht besteed.

De opbouw is als volgt. Eerst wordt de problematiek van strafvervolging van overheden gesitueerd binnen het kader van artikel $51 \mathrm{Sr}$ waarmee in 1976 de strafrechtelijke aansprakelijkheid van de rechtspersoon in het Nederlandse Wetboek van Strafrecht is ingevoerd (A). Vervolgens wordt een kritisch overzicht gegeven van de jurisprudentiële ontwikkeling waarbij ook het standpunt van het openbaar ministerie en het kabinet ten aanzien van strafvervolging van overheden wordt bekeken (B). 
In Nederland is de strafrechtelijke aansprakelijkheid van rechtspersonen reeds geruime tijd een feit. Voor het economische strafrecht bestond als sinds 1950 een strafrechtelijke aansprakelijkheid van de rechtspersoon neergelegd in oud artikel 15 Wet Economische Delicten (WED). ${ }^{207}$ Sinds 1976 kent Nederland een algemene strafrechtelijke aansprakelijkheid van de rechtspersoon neergelegd in artikel 51 van het Wetboek van Strafrecht (Sr).

Reeds bij de toepassing van de WED heeft het vraagstuk van de strafrechtelijke aansprakelijkheid van overheden geleid tot hevige discussies en dit naar aanleiding van de veroordeling van enkele gemeenten wegens overtreding van artikel 17 Wederopbouwwet. ${ }^{208} \mathrm{Zo}$ is op 4 september 1951 de Gemeente Apeldoorn door de Economische kamer van de rechtbank te Zutphen wegens verboden bouwen veroordeeld tot een geldboete van 25.000 gulden. In hoger beroep werd de boete verlaagd tot 5000 gulden. ${ }^{209}$ Naar aanleiding van deze veroordelingen werd door Mulder betoogd dat een publiekrechtelijke rechtspersoon slechts vervolgd zou mogen worden voor zover deze aan het marktverkeer deelneemt en concurrenten benadeelt. ${ }^{210}$ Daarnaast stelde hij voor in wetten die de vervolging van publiekrechtelijke rechtspersonen toelaten de volgende bepaling op te nemen:

'Indien het feit wordt begaan door of vanwege een publiekrechtelijk lichaam, wordt geen strafvervolging ingesteld, tenzij met de uitvoering van de wet belaste minister verklaart dat het lichaam door het begaan van het feit de concurrentieverhoudingen op de markt heeft verstoord. ${ }^{211}$

207. Art. 15 WED, lid 1 en 2 luidde:

1. Indien een economisch delict wordt begaan door of vanwege een rechtspersoon, een vennootschap, enige andere vereniging van personen of een doelvermogen, wordt de strafvervolging ingesteld en worden de straffen en maatregelen uitgesproken:

hetzij tegen die rechtspersoon, die vennootschap, die vereniging of dat doelvermogen, hetzij tegen hen, die tot het feit opdracht hebben gegeven of die feitelijk leiding hebben gehad bij het verboden handelen of nalaten, hetzij tegen beiden.

2. Een economisch delict wordt onder meer begaan door of vanwege een rechtspersoon, een vennootschap, een vereniging van personen of een doelvermogen, indien het begaan wordt door personen, die hetzij uit hoofde van een dienstbetrekking hetzij uit anderen hoofde handelen in de sfeer van de rechtspersoon, de vennootschap, de vereniging of het doelvermogen, ongeacht of deze personen ieder afzonderlijk het economisch delict hebben begaan dan wel bij hen gezamenlijk de elementen van het delict aanwezig zijn.

208. Mulder, A., Schets van het economisch strafrecht, Zwolle, W.E.J. Tjeenk Willink, 1983, 93.

209. Torringa, R.A., Strafbaarheid van rechtspersonen, Arnhem, Gouda Quint, 1984, 154.

210. Torringa, R.A., o.c., $1984,154$.

211. Mulder, A., 'De gemeenten en de verbodsbepaling van art. 17 Wederopbouwwet', De Nederlandse gemeente, 1963, 517. 
Het vraagstuk kwam vervolgens in 1966 aan de orde in het preadvies Kist voor de Nederlandse Juristenvereniging. ${ }^{212} \mathrm{Hij}$ stelde voor een onderscheid te maken tussen de publiekrechtelijke lichamen zelf en bedrijven en ondernemingen van deze lichamen, zoals een gemeentelijk vervoerbedrijf, dat op gelijke voet als particulieren aan het maatschappelijk verkeer deelneemt. Een strafrechtelijke reactie zou volgens hem niet zijn aangewezen, hoewel er geen onoverkomelijk bezwaar tegen bestaat nu een gemeente ook civielrechtelijk aansprakelijk kan worden gesteld. Alternatieve middelen, zoals het administratieve recht, zouden een strafrechtelijke tussenkomst meestal overbodig maken. ${ }^{213}$

Voor de huidige situatie is artikel $51 \mathrm{Sr}$ van belang:

'1. Strafbare feiten kunnen worden begaan door natuurlijke personen en rechtspersonen.

2. Indien een strafbaar feit wordt begaan door een rechtspersoon, kan de strafvervolging worden ingesteld en kunnen de in de wet voorziene straffen en maatregelen indien zij daarvoor in aanmerking komen, worden uitgesproken:

1. tegen die rechtspersoon, dan wel

2. tegen hen die tot het feit opdracht hebben gegeven, alsmede tegen hen die feitelijk leiding hebben gegeven aan de verboden gedraging, dan wel

3. tegen de onder 1 en 2 genoemde te zamen.

3 . Voor de toepassing van de vorige leden worden met de rechtspersoon gelijkgesteld: de vennootschap zonder rechtspersoonlijkheid, de maatschap, de rederij en het doelvermogen.'

De wet is helder: artikel $51 \mathrm{Sr}$ maakt geen onderscheid tussen privaatrechtelijke en publiekrechtelijke rechtspersonen. De bedoelingen van de wetgever zijn minder duidelijk. $^{214}$ Hoewel de wijziging van artikel $51 \mathrm{Sr}$ kan gelden als een belangrijke gebeurtenis in de geschiedenis van het Nederlandse strafrecht werd dit door haar ontwerpers niet behandeld als een revolutionaire vernieuwing. Het leek de toenmalige minister van Justitie 'niet vereist aan de strafbaarstelling van de rechtspersoon thans een diepgravende rechtstheoretische beschouwing te wijden. ${ }^{215}$

212. Kist, F.C., 'Dient het Wetboek van Strafrecht bepalingen te bevatten betreffende het daderschap en de strafrechtelijke aansprakelijkheid van andere dan natuurlijke personen?', preadvies, Handelingen NJV, Zwolle, W.E.J. Tjeenk Willink, 1966, deel I, 38 en 66.

213. Zie ook Torringa, R.A., o.c., 1984, 155.

214. Het is wellicht niet overbodig erop te wijzen dat de bedoelingen van de wetgever niet altijd even eenvoudig te kennen zijn. Bovendien is het nog steeds zo dat door het parlement niet een toelichting maar een wetsvoorstel wordt aanvaard. Trouwens, 'al zouden we kunnen vaststellen dat inderdaad alle leden van beide colleges en de Minister en ten slotte de Kroon alle met een bepaalde wetsregel hetzelfde hadden beoogd, dan nog zou ons dat niet binden. Door de wet, niet anders, kan de wetgever ons iets bevelen...', aldus Scholten, P., Handleiding tot de beoefening van het Nederlands burgerlijk recht, algemeen deel, Zwolle, W.E.J. Tjeenk Willink, 1974, 41.

215. MvT, Tweede Kamer, zitting 1975-1976, 13 655, nrs. 1-3, 8. Verder geciteerd als de MvT. 
Het theoretisch tekort blijkt ook uit paragraaf 10 van de Memorie van Toelichting (MvT) waarin de strafbaarheid van publiekrechtelijke rechtspersonen wordt behandeld. ${ }^{216}$

In de eerste plaats wordt vooropgesteld dat vervolging van publiekrechtelijke lichamen voor door hen gepleegde strafbare feiten in het algemeen weinig opportuun is; 'veelal zal langs administratieve weg afdoende correctie mogelijk zijn. ${ }^{217}$ Anderzijds ziet de wetgever in dat de algehele onmogelijkheid een dergelijk lichaam te vervolgen en te bestraffen ook niet wenselijk is. ${ }^{218} \mathrm{Er}$ zijn immers situaties denkbaar waarin het 'als onrechtvaardig, met name in strijd met het gelijkheidsbeginsel, wordt ervaren, indien strafbare activiteiten van (ondernemingen van) publiekrechtelijke lichamen of instellingen onvervolgd zouden moeten blijven. ${ }^{219}$ Daarbij aansluitend stelt de Memorie van Antwoord dat het onbillijk zou zijn 'als strafbare handelingen van publiekrechtelijke lichamen, die ondernemingsactiviteiten verrichten, niet gestraft kunnen worden'. ${ }^{220}$ Kortom, 'bij een figuur die in zo uiteenlopende verschijningsvormen en functies aan het maatschappelijk verkeer deelneemt als de publiekrechtelijke rechtspersoon is de vraag of strafbaarheid in beginsel dient te worden uitgesloten of aanvaard niet in het algemeen te beantwoorden. ${ }^{.221} \mathrm{Er}$ is dus een differentiatie nodig. Volgens de wetgever kan een onderscheid worden gemaakt 'naar gelang het strafbare feit is gepleegd bij de uitvoering van een algemene of specifieke bestuurstaak waarmee de publiekrechtelijke rechtspersoon is belast, dan wel is gepleegd binnen het kader van een ondernemingsactiviteit die ook door particulieren wordt of kan worden verricht. ${ }^{222}$ Slechts in het laatste geval is het mogelijk strafrechtelijk te vervolgen. In het eerste geval is dit uitgesloten.

Uit de MvT kunnen wat de strafrechtelijke aansprakelijkheid van publiekrechtelijke rechtspersonen betreft drie belangrijke conclusies worden afgeleid. ${ }^{223}$

Allereerst is niet duidelijk wat de wetgever precies voor ogen hield. Duidelijk is slechts dat de wetgever in bepaalde gevallen de strafrechtelijke aansprakelijkheid van publiekrechtelijke rechtspersonen wilde uitsluiten. De vraag is echter op welk niveau - processueel of materieel - deze uitzondering op de in artikel $51 \mathrm{Sr}$ neergelegde aansprakelijkheid van de rechtspersoon wenselijk werd geacht. Zoals uit de aanhalingen blijkt, heeft de MvT het afwisselend, zonder hierbij enig helder onderscheid te maken, over de (opportuniteit van de) vervolgbaarheid en de strafbaarheid. Het is niet helemaal duidelijk of de wetgever met betrekking tot publiekrechtelijke rechtspersonen, die een bestuurstaak uitvoeren, voorstander was van een vervolgingsuitsluitingsgrond of een strafuitsluitingsgrond. Een dergelijke terminologische verwarring en dogmatische onnauwkeurigheid maakt het

216. De MvT, 20-21.

217. De MvT, 20.

218 De MvT, 21.

219. De MvT, 21.

220. MvA, Tweede Kamer, zitting 1975-1976, 13655, nr, 4, 2.

221. De MvT, 21.

222. De MvT, 21.

223. Zie Roef, D., l.c., 1995, 334-336. 
moeilijk de werkelijke bedoeling van de wetgever te achterhalen. ${ }^{224} \mathrm{Nu}$ kunnen de desbetreffende passages in de MvT best als een pleidooi voor een vervolgingsuitsluitingsgrond voor overheden worden uitgelegd. De MvT laat echter ook andere, even valabele interpretaties toe. De keuze voor een vervolgingsuitsluitingsgrond is daarom wellicht veeleer een kwestie van onheldere redactie dan van een goed doordachte criminele politiek. In ieder geval, welke uitsluitingsgrond de wetgever ook voorstond, wettelijk heeft er nooit een strafrechtelijke immuniteit bestaan. Dat de wetgever in de MvT met zoveel woorden een vervolgingsuitsluitingsgrond zou te berde brengen, verandert niets aan deze vaststelling; de wet en niet de wetgever is bindend. Als de wetgever het onderscheid tussen privaatrechtelijke en publiekrechtelijke rechtspersonen in dergelijke mate principieel achtte dat hij het noodzakelijk vond, althans in bepaalde gevallen, een garantie voor strafrechtelijke immuniteit te moeten afgeven, dan had hij dat duidelijk in een wettelijke immuniteit tot uitdrukking moeten brengen in plaats van deze belangwekkende kwestie aan de rechtspraak over te laten.

Een tweede vaststelling is de verwarring over wat kan worden gezien als een 'publiekrechtelijke rechtspersoon'. Opmerkelijk is dat de indeling die in de MvT wordt gevolgd niet volledig overeenstemt met het uitgangspunt van artikel $51 \mathrm{Sr}$ zelf. Om te weten wat in artikel $51 \mathrm{Sr}$ onder rechtspersoon moet worden verstaan, dient primair te worden gekeken naar het civiele recht en dan in het bijzonder naar het op 26 juli 1976 in werking getreden Tweede Boek van het Burgerlijk Wetboek (BW). ${ }^{225}$ Artikel $51 \mathrm{Sr}$ sluit aan bij de rechtspersoonlijkheid zoals die in artikel 2:1 BW is geformuleerd. Artikel 2:1, eerste lid, BW spreekt over de staat, gemeenten, provincies, waterschappen en alle openbare lichamen waaraan krachtens de Grondwet verordenende bevoegdheid is verleend. Daarnaast zijn volgens artikel 2:1, tweede lid, BW ook andere lichamen, waaraan een deel van de overheidstaak is opgedragen, publiekrechtelijke rechtspersonen. De MvT blijft daarentegen vrij vaag in de omschrijving van de publiekrechtelijke rechtspersoon door achtereenvolgens te spreken over 'algemene of specifieke bestuurstaak waarmee het publiekrechtelijk lichaam is belast', 'het publiekrechtelijk lichaam als bestuurder', 'instellingen en organen die daartoe

224. Nieboer maakt over het verwarrende gebruik van de wetgever van vervolgbaarheid en strafbaarheid teneinde op een bepaald niveau de strafrechtelijke aansprakelijkheid uit te sluiten de volgende interessante opmerkingen: 'opvallend is dat de wetgever in het materiēle strafrecht zo vaak opereert met de term "vervolgbaarheid". Het gaat dan niettemin over onderwerpen die rechtstreeks betrekking hebben op de aansprakelijkheid. Onder het hoofd "vervolgbaarheid" worden allerlei onderwerpen behandeld zonder veel onderlinge samenhang. Ik beschouw dit uitwijken naar het processuele begrip "vervolgbaarheid" als een noodsprong. De oorzaak hiervan zoek ik in het kortschieten van 's wetgevers begrippenapparaat. Men zegt dan wel: "De delictsomschrijvingen doen de vervolgbaarheid ontstaan en daarom moet haar verval enz. ook in het materiële recht een plaats krijgen"- akkoord, maar de uitdrukking "ontstaan van vervolgbaarheid' zelf betekent al de introductie van een processueel begrip...'. Iets verder stelt de auteur: 'Het invoeren van de vervolgbaarheid als processueel begrip in het materiele stelsel is extra disfunctioneel omdat het materiële meestal over het processuele heen springt.' Nieboer, W., Schets materieel strafrecht, Arnhem, Gouda Quint, 1991, 236-237 en 282.

225. Zie o.m. Remmelink, J., o.c., 1995, 145; Strijards, G.A.M., Aansprakelijkheidsgronden, Zwolle, W.E.J. Tjeenk Willink, 1988, 66 e.v. 
in het staats- en administratieve recht in het bijzonder zijn aangewezen'. ${ }^{226}$ Gelet op deze terminologische overvloed hoeft het geen verbazing te wekken dat de Hoge Raad later zelf immuniteitscriteria is gaan ontwikkelen.

Een laatste belangrijke vaststelling is dat de vraag of de staat voor door haar gepleegde strafbare feiten kan worden vervolgd niet in de MvT afzonderlijk is behandeld. De staat wordt slechts aangehaald als één van de vele bestaande publiekrechtelijke rechtspersonen. ${ }^{227}$ Aan de hand van de wetsgeschiedenis kan alleen worden afgeleid dat wat vervolgbaarheid en strafbaarheid betreft er geen reden is de staat van de andere publiekrechtelijke rechtspersonen te onderscheiden. Noch in de wet, noch in de parlementaire stukken wordt gepleit voor een aparte, van andere overheden onderscheiden, strafrechtelijk positie voor de staat.

\section{B. STRAFVERVOLGING VAN OVERHEDEN IN DE RECHTSPRAAK}

\section{Inleiding}

De strafvervolging van overheden heeft in de rechtspraak een bewogen en complexe voorgeschiedenis gekend. De meest ophefmakende arresten in dit verband zijn ongetwijfeld de zogenaamde Pikmeer-arresten. Met het Eerste Pikmeer-arrest (1996) werd de immuniteit voor decentrale overheden, die bij de uitvoering van een wettelijke overheidstaak een strafbaar feit plegen immers uitgebreid tot hun leidinggevende ambtenaren hetgeen zowel in de pers, de doctrine als bij het openbaar ministerie tot hevige kritische reacties leidde. Mede naar aanleiding van deze kritiek bepaalde de Hoge Raad in het Tweede Pikmeer-arrest (1998) dat overheden meer dan tot dan toe mogelijk was vervolgd moeten kunnen worden: alleen wanneer de overheidstaak rechtens uitsluitend door bestuursfunctionarissen kan worden uitgevoerd, is beroep op de immuniteit mogelijk. Pikmeer II vormt in die zin het voorlopige keerpunt in de jurisprudentiële ontwikkeling.

In deze paragraaf staat een beschrijving van deze jurisprudentiële ontwikkeling centraal. Alvorens de ommegang van de Hoge Raad in het Tweede Pikmeer-arrest te bespreken, wordt eerst aandacht besteed aan de daaraan voorafgaande jurisprudentie zodat de huidige stand van zaken beter kan worden begrepen. De strafrechtelijke positie van de staat komt afzonderlijk aan bod, nu deze een van decentrale overheden onderscheiden onbeperkte immuniteit geniet.

226. Zie tevens Brants, C.H. en de Lange, R., Strafvervolging van overheden, Arnhem, Gouda Quint, 1996, 7.

227. De MvT, 20. 


\section{De rechtspraak tot aan Pikmeer II.}

a. Welke publiekrechtelijke rechtspersonen genieten een strafrechtelijke immuniteit?

\section{HR 27 oktober 1981, NJ 1982, 474 met noot GEM (Tilburgse Verkeersdrempels)}

In 1981 werd de vraag naar de strafrechtelijke aansprakelijkheid van publiekrechtelijke rechtspersonen voor het eerst aan de Hoge Raad voorgelegd. De Kantonrechter te Tilburg had de gemeente Tilburg in 1980 veroordeeld tot een geldboete van één gulden wegens het zonder verlof van het bevoegde gezag plaatsen van verkeersdrempels. De Hoge Raad vernietigde het vonnis daar de aan de gemeenten verweten gedragingen, te weten de zorg voor de veiligheid der wegen, een overheidstaak uitmaken:

'Daarvoor kan een gemeente niet strafrechtelijk verantwoordelijk worden gesteld. Derhalve heeft de kantonrechter het recht geschonden door de OvJ te ontvangen in zijn strafvervolging.'

De Hoge Raad volgt hierin A-G Biegman-Hartogh die, onder verwijzing naar het preadvies van Kist en de wetsgeschiedenis van artikel $51 \mathrm{Sr}$, oordeelt dat er sprake zou zijn van een 'volstrekt verkeerde toepassing van het strafrecht' wanneer een gemeente vervolgd zou kunnen worden wegens het behartigen van een belang dat haar op grond van (oud) artikel $209 \mathrm{~h}$ Gemeentewet specifiek zou zijn opgedragen. Naar het oordeel van de A-G hebben noch de strafrechter, noch de civiele rechter de taak doelmatigheidskwesties te beoordelen. Toch kan de vraag worden gesteld of het daar wel werkelijk om ging. De aanleg van een verkeersdrempel is nog steeds een feitelijke handeling waartegen bij de civiele rechter wel degelijk rechtsbescherming openstaat. De A-G maakt niet duidelijk waarom dan wel de strafrechtelijke aansprakelijkheid zou zijn uitgesloten wanneer deze feitelijke handeling een strafbaar feit constitueert. Daarnaast gaat het niet om een doelmatigheidscontrole maar om een rechtmatigheidscontrole.

Met dit arrest heeft de Hoge Raad voor het eerst een buitenwettelijke vervolgingsuitsluitingsgrond gecreëerd voor publiekrechtelijke rechtspersonen die handelen ter uitvoering van een overheidstaak. De Hoge Raad geeft echter geen criterium om te bepalen wat nu precies onder een overheidstaak moet worden verstaan. Evenmin wordt enige motivering gegeven waarom de strafrechter dergelijk overheidshandelen niet zou mogen beoordelen. Torringa neemt aan dat de Hoge Raad dezelfde rechtsgrond op het oog had als de MvT bij artikel $51 \mathrm{Sr}$ : doordat de verantwoording zal "behoren te geschieden aan de instellingen en organen, die daartoe in het staats-en administratief recht in het bijzonder zijn aangewezen' dient de strafrechtelijke weg te worden uitgesloten. ${ }^{228}$

De gebrekkige motivering van de Hoge Raad is trouwens zelf enigszins tegenstrijdig. De Raad stelt voorop dat een gemeente niet strafrechtelijk verantwoordelijk kan worden

228. Torringa, R.A., o.c., 1984, 157. 
gesteld wanneer de aan de gemeente verweten gedraging een overheidstaak betreft. Vervolgens wordt het openbaar ministerie niet-ontvankelijk verklaard in zijn vervolging. Dit doet de vraag rijzen wat nu precies wordt uitgesloten: de strafrechtelijke verantwoordelijkheid van overheden of de strafrechtelijke vervolging van overheden? Anders gezegd, wordt het $\mathrm{OM}$ niet-ontvankelijk verklaard omdat overheden nu eenmaal niet strafrechtelijke verantwoordelijk zijn wanneer zij delicten plegen bij de uitvoering van een overheidstaak, of is het veeleer zo dat overheden niet strafrechtelijk verantwoordelijk kunnen worden gesteld omdat zij voor de door hen begane delicten niet mogen worden vervolgd?

Zoals bekend, sluit normaal gezien de niet-onvankelijkheid van het OM niet de strafrechtelijke verantwoordelijkheid uit maar de strafrechtelijke vervolgbaarheid. Het is belangrijk in herinnering te brengen dat strafrechtsdogmatisch gezien een niet-ontvankelijkheidsoordeel - een negatief oordeel over de vervolgbaarheid - weinig te maken heeft met de strafrechtelijke verantwoordelijkheid van de vervolgde. De vervolgbaarheid is weliswaar een processuele voorwaarde om een strafrechtelijke verantwoordelijkheid te kunnen vaststellen, maar het is geen onderdeel van deze verantwoordelijkheid. Vervolgbaarheid en verantwoordelijkheid zijn duidelijk van elkaar te onderscheiden strafrechtelijke dimensies. Anders gezegd, de (on)mogelijkheid te vervolgen raakt niet aan het al dan niet aanwezig zijn van enige vorm van strafrechtelijke verantwoordelijkheid. Omgekeerd tast het al dan niet strafrechtelijk verantwoordelijk zijn van een verdachte als dusdanig niet de vervolgbaarheid aan. ' $Z 0$ ligt in de niet-ontvankelijkheid van het $\mathrm{OM}$, uitgesproken omdat de verdachte reeds voor hetzelfde feit is veroordeeld ( $a r t .68 \mathrm{Sr}$ ) bepaald niet besloten dat hij geen strafbaar feit heeft begaan. De eerdere veroordeling wijst in de richting van het tegendeel. Evenzo kan na de verjaring van het feit (art. $70 \mathrm{Sr}$ ) of na het overlijden van de verdachte (art. $69 \mathrm{Sr}$ ) niet gezegd worden dat achteraf bezien geen strafbaar feit is gepleegd. Over dat - mogelijk - gepleegd feit mag de rechter alleen niet meer oordelen. ${ }^{229}$ Een zelfde ratio is ook te vinden in de in de Grondwet neergelegde immuniteiten. De personen die deze immuniteiten genieten, zoals de Koning, kunnen wel degelijk strafbare feiten plegen en zijn in die zin in beginsel strafrechtelijk verantwoordelijk. De bestaansredenen van de niet-ontvankelijkheid van het OM liggen niet zozeer in de afwezigheid van de strafrechtelijke verantwoordelijkheid, maar vinden daarbuiten hun motivering. Het is nu juist deze motivering die in het Tilburgse Verkeersdrempels-arrest volledig ontbreekt. De onvervolgbaarheid (niet-ontvankelijkheid van het OM) wordt door de Hoge Raad afgeleid uit het feit dat de gemeente in casu niet strafrechtelijk verantwoordelijk kan worden gesteld. In die zin is de uitspraak van de Hoge Raad enigszins onvolledig door de onvervolgbaarheid van de gemeente uitsluitend te koppelen aan of te motiveren met het ontbreken van enige strafrechtelijke verantwoordelijkheid. Daarmee is immers nog geen duidelijke en afdoende motivering gegeven van het niet-ontvankelijkheidsoordeel.

Strijards heeft in gelijkaardige zin kritiek op dit arrest, hoewel hij een ander uitgangspunt neemt. Hij hekelt het niet-ontvankelijkheidsoordeel om de eenvoudige reden dat in zijn visie een publiekrechtelijke rechtspersoon per definitie bij de uitvoering van een overheids-

229. Knigge, G., 'Het subsociale en de structuur van het strafbare feit', in Naar eer en geweten. Liber Amicorum Remmelink, J., Amhem, Gouda Quint, 1987, 292. 
taak nimmer een strafrechtelijke gedraging kan verrichten. Volgens Strijards dient eerder sprake te zijn van een materiële daderschapsuitsluiting. Hij bepleit voor overheden een volledige uitsluiting van de strafrechtelijke aansprakelijkheid. Zoals later zal blijken, is dit ook min of meer de Belgische kijk op de problematiek. Een vervolgingsuitslui-tingsgrond teneinde de strafrechtelijke aansprakelijkheid van de publiekrechtelijke rechts-persoon onmogelijk te maken is volgens Strijards onlogisch:

'Ik zou zo denken dat als vaststaat dat een publiekrechtelijke rechtspersoon is opgetreden ter uitvoering van zijn specifieke overheidstaak, zulks eo ipso moet betekenen dat hij, dus doende, geen strafrechtelijke zorgplichtschending heeft begaan. Hier is geen gedraging in strafrechtelijke zin. Hier is een vrijspraak geïndiceerd. ${ }^{1230}$

\section{HR 10 november 1987, NJ 1988, 303 met noot ThWvV (RU Groningen)}

In $1987 \mathrm{kwam}$ de problematiek opnieuw aan de orde. Nu werd niet een overheid, maar een andere publiekrechtelijke rechtspersoon, namelijk een Rijksuniversiteit, vervolgd. Een archeoloog verbonden als wetenschappelijk medewerker aan het Biologisch Archeologisch Instituut van de Rijksuniversiteit te Groningen (RUG) had zonder vergunning graafwerkzaamheden verricht in een als monument beschermde grafheuvel. Zowel de archeoloog als zijn werkgever, de Rijksuniversiteit, werden vervolgd. Voor het Gerechtshof te Leeuwarden werd het verweer gevoerd dat, nu de Rijksuniversiteit als publiekrechtelijke rechtspersoon een overheidstaak, namelijk onderwijs en onderzoek, had uitgevoerd het openbaar ministerie niet ontvankelijk was in zijn vervolging. Het Hof verwierp deze argumentatie op basis van een gelijkstelling tussen openbare en bijzondere instellingen van hoger onderwijs. De immuniteit gaat niet op voor Rijksuniversiteiten, ook niet wanneer het delict wordt gepleegd bij de uitvoering van een overheidstaak. ${ }^{231}$ De Hoge Raad hield de uitspraak van het Hof in stand maar met een totaal andere overweging:

'Het Hof heeft het verweer terecht verworpen, reeds omdat de RUG geen openbaar lichaam is in de zin van hoofdstuk 7 van de Grondwet.'

Met dit arrest introduceert de Hoge Raad een tweede criterium voor strafrechtelijke immuniteit van publiekrechtelijke rechtspersonen. De niet-vervolgbaarheid van publiekrechtelijke rechtspersonen wordt beperkt tot de in hoofdstuk 7 van de Grondwet (Gw) opgenomen openbare lichamen. Andere publiekrechtelijke rechtspersonen kunnen zich niet op de immuniteit beroepen. Er is dus nu duidelijkheid in de kwestie welke publiekrechtelijke rechtspersonen strafrechtelijke immuniteit kunnen genieten. De Raad motiveert echter niet waarom hoofdstuk $7 \mathrm{Gw}$ een geschikt criterium zou zijn voor de beperking van de strafrechtelijke immuniteit. Dit is spijtig des te meer nu voor dit subjectcriterium geen aanknopingspunt is te vinden in de MvT bij artikel $51 \mathrm{Sr}$. In het volgende arrest wordt duidelijk dat het taakcriterium en het subjectriterium cumulatief moeten worden toegepast.

230. Strijards, G.A.M., o.c., 1988, 63.

231. Hof Leeuwarden, 25 september 1984, NJ 1985, 203. 
HR 23 oktober 1990, NJ 1991, 496 met noot Schalken; Gemeentestem 1991, 329 met noot Hennekens; MenR, 1991, nr. 54 (Voorburgse reigersnesten)

De gemeente Voorburg handelde in strijd met artikel 8 Vogelwet dat het verstoren van beschermde vogels verbiedt tenzij daarvoor een vergunning is verleend. De gemeente had namelijk in het park 'Vreugde en Rust' nesten van blauwe reigers verstoord omdat die schade aan bomen zouden toebrengen. Voor de rechtbank 's Gravenhage beriep de gemeente zich op haar bestuurlijke taak zorg te dragen voor de instandhouding van plantsoenen zoals omschreven in de Gemeentewet. De rechtbank honoreerde het verweer van de gemeente die zich op de strafrechtelijke immuniteit beriep:

'nu de ten laste gelegde gedragingen - die zich in het openbare park "Vreugde en Rust" hebben afgespeeld met het oog op het behoud van de aldaar door reigersnesten bedreigde bomen - zijn verricht ter behartiging van de haar in art. 209 aanhef en onder h Gem. W. opgedragen "zorg voor plantsoenen/andere plaatsen tot gemeenen dienst voor allen bestemd"'. Genoemde bepaling behelst een specifieke bestuurstaak van B en W en de gemeente heeft aannemelijk gemaakt dat zij ter behartiging van die bestuurstaak is opgetreden ${ }^{1232}$

Op het door de OvJ ingestelde cassatieberoep beslist de Hoge Raad als volgt:

\begin{abstract}
'5.2. Aldus overwegende heeft de rechtbank geen blijk gegeven van een verkeerde rechtsopvatting. Het middel, in zijn derde onderdeel, miskent dat de gemeente een openbaar lichaam is in de zin van hoofdstuk 7 van de Grondwet, aan hetwelk bij artikel 209 aanhef en onder h Gem. w. "de zorg (...) voor de instandhouding (..) der (..) plantsoenen (..) tot gemeenen dienst van alle bestemd" in het bijzonder is opgedragen.'
\end{abstract}

Beide immuniteitscriteria - openbaar lichaam in de zin van hoofdstuk $7 \mathrm{Gw}$ en specifieke wettelijke bestuurstaak - zijn dus cumulatief. Slechts een publiekrechtelijke rechtspersoon die behoort tot de categorie openbare lichamen zoals aangeduid in hoofdstuk $7 \mathrm{Gw}$ die een strafbaar feit hebben gepleegd bij de behartiging van de overheidstaak kunnen beroep doen op de immuniteit. Omgekeerd betekent dit dat publiekrechtelijke rechtspersonen die niet tegelijk een openbaar lichaam zijn steeds vervolgbaar blijven ook al is het delict gepleegd bij de uitvoering van een overheidstaak. ${ }^{233}$

Kortom, voor immuniteit moet steeds aan twee vereisten worden voldaan. Het eerste is de hoedanigheid van openbaar lichaam in de zin van hoofdstuk 7 van de Gw. Is aan deze eis voldaan dan moet alsnog voldaan zijn aan het taakcriterium, namelijk dat het openbaar

232. Rechtbank 's Gravenhage, 8 mei 1990, MenR, 1990, 78.

233. Wortel, J., 'Verdachte overheden', NJB, 1988, 1515; anders Van Veen in zijn noot bij HR 10 november 1987, $N J 1988,303$. 
lichaam de litigieuze gedraging heeft verricht ter behartiging van een wettelijke bestuurstaak.

Van belang is ook dat de Hoge Raad het taakcriterium heeft aangescherpt. Het moet immers gaan om een wettelijke bestuurstaak, terwijl in het Tilburgse Verkeersdrempelsarrest het meer vage begrip overheidstaak werd gehanteerd. Dit betekent dat pas aan het taakcriterium is voldaan wanneer er een wettelijke grondslag kan worden gevonden waaruit die specifieke overheidstaak blijkt. Nu is de gemeente Voorburg onmiskenbaar een openbaar lichaam in de zin van hoofdstuk $7 \mathrm{Gw}$. De vraag of de verwijdering van de vogelnesten kadert binnen een aan de gemeente opgedragen wettelijke bestuurstaak is een andere kwestie. De Hoge Raad beantwoordt deze vraag positief door - net als in het Tilburgse Verkeersdrempels-arrest - te verwijzen naar (oud) artikel 209 Gemeentewet. Dit artikel zou dan de wettelijke grondslag leveren voor een aantal gemeentelijke overheidstaken (zoals de zorg van de publieke wegen en de plantsoenen). De Hoge Raad miskent evenwel op die manier de ware betekenis van artikel 209 Gemeentewet. Dit artikel bepaalt niet wat een gemeentetaak is en wat niet. Zoals Hennekens terecht opmerkt:

'Deze bepaling is niet meer en ook niet minder dan een intern competentievoorschrift; zij geeft aan welk orgaan (...) bevoegd en verplicht is binnen de gemeentelijke organisatiestructuur te zorgen voor de instandhouding, bruikbaarheid, vrijheid en veiligheid van de openbare wegen. Dit artikel bepaalt niet, dat het onderhouden van openbare wegen een gemeentelijke taak zou zijn noch kent het aan $\mathrm{b}$ en $\mathrm{w}$ de bevoegdheid toe burgers plichten op te leggen (...) deze interpretatie miskent dat hier (slechts) wordt bepaald dat het om dagelijks bestuur van de gemeente gaat waartoe het college van $b$ en $w$ is aangewezen en dat het niet betreft een aan de gemeente toekomende zorg. ${ }^{.234}$

(Oud) artikel $209 \mathrm{~h}$ Gemeentewet is dus een bepaling die uitsluitend de onderlinge verhouding tussen de bevoegdheden van B\&W en de raad regelde en geen bevoegdheidsgrondslag. ${ }^{235}$

Kan nog worden opgemerkt dat met betrekking tot de vereiste vergunning tot het verwijderen van de reigersnesten vooraf een bestuursrechtelijke procedure werd gevoerd die heeft geleid tot een uitspraak van de Afdeling rechtspraak van de Raad van State waarbij het beroep van de gemeente Voorburg tegen de weigering van de vergunning werd verworpen. ${ }^{236}$ De gemeente was dus duidelijk op de hoogte van de vergunningplicht.

234. Noot van Hennekens, H. onder het arrest inzake de Voorburgse reigersnesten (HR 23 oktober 1990), Gemeentestem, 1990, 329.

235. Zie ook Brants, C.H. en De Lange, R., o.c., 1996, 10.

236. ARRS, 2 december 1991, $A B$ 1992, 475 met noot Sewandono, I. 


\section{b. Enkele veroordelingen}

Niet altijd resulteert een vervolging in een niet-ontvankelijkheidsoordeel. $\mathrm{Er}$ is ook een aantal arresten waar openbare lichamen met succes worden vervolgd én veroordeeld omdat niet aan de immuniteitscriteria is voldaan.

HR 19 maart 1991, NJ 1992, 122 met noot Corstens (Gemeente Stein - Omgevallen Hijskraan)

De gemeente Stein werd door het Gerechtshof 's-Hertogenbosch veroordeeld wegens schending van een voorschrift gesteld krachtens artikel 26 Arbo-wet. De gemeente had als werkgever toegestaan dat een hijskraan een last boven de $5.000 \mathrm{~kg}$ verplaatste waardoor de hijskraan is omgevallen. Zowel de kraanmachinist als de havenopzichter onder wiens toezicht hij werkte waren gemeenteambtenaren. De verdachte gemeente voerde als verweer dat de kraanmachinist niet onder haar gezag werkte maar 'ter beschikking was gesteld' aan een particuliere onderneming, Driessen BV. Het Hof oordeelt dat de kraanmachinist weliswaar ten behoeve van Driessen werkte, maar nog wel steeds onder het gezag stond van de gemeente. De Hoge Raad overweegt:

\section{'5.2. Het in de hiervoor onder 5.1. weergegeven overwegingen besloten liggende oordeel van het hof dat het bij de verdachte in dienst zijnde kraanmachinist Smeets niet aan Driessen BV ter beschikking was gesteld voor het verrichten van arbeid, in de zin van art. 1 eerst lid Arbo-wet, geeft geen blijk van een onjuiste opvatting omtrent het bepaalde in voormelde wetsbepaling en is niet onbegrijpelijk, gelet op de inhoud van de door het hof gebezigde bewijsmiddelen.'}

In deze zaak staat de gemeente als werkgever terecht. Volgens annotator Corstens is in casu dan ook geen sprake van een vervulling van een aan de gemeente wettelijk opgedragen overheidstaak zodat beroep op de strafrechtelijke immuniteit is uitgesloten.

\section{HR 8 juli 1992, NJ 1993, 12 (Urker Visafslag)}

De gemeente Urk werd in hoger beroep door het Hof Arnhem veroordeeld wegens overtreding van voorschriften gesteld krachtens artikel 3a derde lid Visserijwet, meermalen gepleegd. De Hoge Raad houdt deze uitspraak in stand nu de exploitatie van een visafslag niet kan worden gezien als een specifieke overheidstaak van de gemeente. Deze zaak illustreert dat met overheidscriminaliteit vaak veel geld is gemoeid. Het totale door de gemeente te betalen geldbedrag (boete èn het wederrechtelijk verkregen voordeel) bedraagt meer dan 300.000 gulden. Zo wordt duidelijk dat de vervolging van overheden meer kan behelzen dan het eenvoudigweg opleggen van boetes. Ook maatregelen, zoals de ontneming van het wederrechtelijk verkregen voordeel, kunnen door de strafrechter worden 
uitgesproken. ${ }^{237} \mathrm{Nu}$ is deze zaak relatief eenvoudig omdat de exploitatie van een visafslag een ondernemingsactivịteit uitmaakt. Moeilijker wordt het wanneer we te maken krijgen met situaties waar overheden de uitvoering van overheidstaken aan anderen uitbesteden. En wat als de uitvoering van deze taak niet zozeer aan een particulier maar aan een andere overheid wordt uitbesteed? Deze kwestie kwam in het volgende arrest aan de orde.

\section{HR 9 juni 1992, NJ 1992, 749; MenR 1993, nr. 37 (Streekgewest Oostelijk Zuid-Limburg)}

Het streekgewest Oostelijk Zuid-Limburg werd ten laste gelegd dat zij 'een houtopstand heeft geveld, althans heeft doen vellen, anders dan bij wijze van dunning, als bedoeld in artikel 1 Boswet, zonder dat van het voornemen tot voormeld vellen een voorafgaande tijdige kennisgeving, als bedoeld in artikel 2 Boswet was gedaan.' Dit is een overtreding van een bij of krachtens artikel 2, lid 3 Boswet gesteld voorschrift en strafbaar gesteld in artikel 1 sub 4 j 6 Wet op de economische delicten. De bomen werden gekapt ten behoeve van de vliegveiligheid van AWACS-vliegtuigen. Daartoe had het streekgewest een privaatrechtelijke overeenkomst met het Ministerie van Defensie gesloten. Als verweer werden de bekende immuniteitscriteria aangevoerd:

\section{'dat het streekgewest Oostelijk Zuid-Limburg een publiekrechtelijke rechtspersoon is en tevens een openbaar lichaam als bedoeld in hoofdstuk $7 \mathrm{Grw}$. De onderhavige werkzaamheden waren een uitvoering van de haar krachtens de wet opgedragen overheidstaak, te weten beheer van een tot "natuurgebied" aangewezen stukje bos, in eigendom toebehorende aan de Staat. Het streekgewest is derhalve bij de uitvoering van haar taak gebleven op een terrein dat haar op grond van de wet is toevertrouwd.'}

De politierechter verwierp het verweer zonder nader in te gaan op deze criteria, door te stellen dat in casu sprake was van een privaatrechtelijke overeenkomst tussen het streekgewest en de Staat der Nederlanden hetgeen zou impliceren dat de gedragingen in kwestie niet vallen onder een specifieke bestuurstaak van het streekgewest. De Hoge Raad bevestigt deze uitspraak:

'5.2. Blijkens diens overwegingen heeft de economische politierechter kennelijk geoordeeld dat de ten laste gelegde gedraging niet is verricht ter behartiging van een bij of krachtens de wet aan de verdachte in het bijzonder opgedragen overheidstaak.

5.3. Dat oordeel is niet onbegrijpelijk gelet op de in voormelde overwegingen besloten liggende vaststelling dat de desbetreffende gedraging is verricht ter uitvoering van een door de verdachte met de Staat (ministerie van Defensie) gesloten privaatrechtelijke overeenkomst. Evengenoemd oordeel geeft voorts geen blijk van een onjuiste rechtsopvatting en kan,

237. Zie hierover Faure, M. en De Roos, Th.A., De berekening van het wederrechtelijk verkregen voordeel uit milieudelicten, Den Haag, Sdu, 1998. 
verweven als het is met waarderingen van feitelijke aard, in cassatie niet verder worden getoetst.'

De Hoge Raad beantwoordt niet de vraag of het streekgewest behoort tot een openbaar lichaam in de zin van hoofdstuk $7 \mathrm{Gw}$. Hiermee wordt nogmaals het cumulatieve karakter van de immuniteitscriteria duidẻlijk. Indien aan één van de twee criteria niet is voldaan zijn er geen redenen aanwezig om een strafrechtelijke immuniteit aan te nemen. Nu het hier volgens de Raad niet gaat om een wettelijke overheidstaak behoeft de kwestie of de publiekrechtelijke rechtspersoon een openbaar lichaam is geen nader onderzoek.

Dit arrest doet de vraag rijzen in welke mate het op privaatrechtelijke wijze uitvoeren van overheidstaken de strafrechtelijke aansprakelijkheid beïnvloedt. In casu werd een overheidstaak van de staat - het kappen van een houtopstand ter beveiliging van een militaire aanvliegroute - op basis van een privaatrechtelijke overeenkomst door het streekgewest uitgevoerd. Heeft de Hoge Raad met dit arrest nu besloten dat privaatrechtelijk handelen van een openbaar lichaam een beroep op de immuniteit uitsluit omdat in een dergelijk geval geen sprake kan zijn van een overheidstaak? We raken hiermee de lastige materie van de privatisering van overheidstaken en de uitbesteding van overheidstaken (aan overheden of particulieren) in het bijzonder.

Voor een goed begrip van de draagwijdte van dit arrest is het nodig de volgorde van beide overwegingen (5.2. en 5.3.) in acht te nemen. ${ }^{238}$ Doorslaggevend voor het ontbreken van een immuniteit is dat de ten laste gelegde gedraging niet kan worden gezien als een 'aan de verdachte in het bijzonder opgedragen overheidstaak.' De politierechter kon tot dit oordeel komen door de 'vaststelling dat de desbetreffende gedraging is verricht ter uitvoering van een door de verdachte met de Staat (Ministerie van Defensie) gesloten overeenkomst.' Hiermee is helemaal niet gezegd dat het privaatrechtelijke karakter van het overheidshandelen de immuniteit uitsluit. De Hoge Raad heeft in dit arrest slechts beslist dat de uitvoerder, het streekgewest, strafrechtelijk aansprakelijk kan worden gesteld omdat de betreffende (defensie)taak hem niet in het bijzonder bij wet was opgedragen: de grondslag van het ten laste gelegde handelen is niet de wet maar de overeenkomst, en slechts een bij de wet opgedragen overheidstaak maakt een beroep op de immuniteit mogelijk. Met andere woorden, niet zozeer de privaatrechtelijke vorm van de overeenkomst, evenmin het feit dat het streekgewest hier een activiteit verricht die ook door particulieren zou kunnen worden verricht - de staat had immers de overeenkomst ook met een particuliere onderneming kunnen afsluiten -, maar het feit dat de betreffende taak niet bij of krachtens een wet in het bijzonder aan dit openbaar lichaam was opgedragen bracht de Hoge Raad tot zijn beslissing. $^{239}$

Dit arrest illustreert goed de mogelijke complicaties die kunnen optreden in gevallen waar overheidstaken door andere openbare lichamen worden uitgevoerd. Stel dat een provincie

238. Van der Jagt, J.A.E., Decentraal bestuur vervolgbaar? Een onderzoek naar de strafrechtelijke en bestuursrechtelijke aspecten van het Pikmeer II-arrest, Deventer, Gouda Quint, 2000, 36-37.

239. Brants, C.H. en De Lange, R., o.c., 1996, 40-41. 
besluit de uitvoering van een haar wettelijk opgedragen taak via een privaatrechtelijke overeenkomst uit te besteden aan een ander openbaar lichaam (bijvoorbeeld een gemeente), dan kan deze laatste zich niet beroepen op de immuniteit daar deze taak niet bij wet aan de gemeente is opgedragen. Voert de provincie daarentegen de taak zelf uit dan kan niet worden vervolgd. Met de privaatrechtelijke overdracht van de uitvoering van een overheidstaak wordt dus niet de immuniteit overgedragen. Dit leidt tot ongerijmde uitkomsten.

\section{c. Strafvervolging via artikel $12 \mathrm{~Sv}$}

Overheidsoptreden dient steeds geloofwaardig en betrouwbaar te blijven ten aanzien van de gerechtvaardigde en legitieme verwachtingen van de burger. Het is dan ook begrijpelijk dat burgers moeilijk kunnen aanvaarden dat de overheid haar eigen regels onbestraft kan overtreden. De volgende uitspraken zijn in die zin van belang omdat via de beklagprocedure van artikel $12 \mathrm{~Sv}$ om de vervolging van een gemeente wordt gevraagd. ${ }^{240}$

\section{Hof Leeuwarden 6 juni 1995, MenR 1996/1, nr. 4 (Gemeente Sneek)}

De klager wenst strafvervolging van de gemeente Sneek omdat deze zonder kapvergunning drie platanen en de overige houtopstand van ongeveer 50 bomen die aan de gemeente toebehoorden en in de nabijheid van de woning van de klager stonden had gerooid. De verdachte voerde als verweer dat de gemeente Sneek in het algemeen geen kapvergunningen voor zichzelf aanvraagt en dat met betrekking tot die grond reeds een bouwvergunning was afgegeven hetgeen tevens een kapvergunning impliceert. Het Hof Leeuwarden oordeelt:

'4. (...) dat er sprake is van een redelijk vermoeden dat beklaagde art. 4.5.2 eerste lid van de Algemene Plaatselijke Verordening van de gemeente Sneek, meermalen heeft overtreden.

5. Waar voorts gemeenten een voorbeeldfunctie hebben ten aanzien van het naleven van wettelijke voorschriften waaronder hun eigen verordeningen, vergt het openbaar geding dat vervolging wordt bevolen van de gemeente Sneek ter zake van overtreding van het kapverbod, meermalen gepleegd.

6. Deze vervolging kan mede dienen tot herstel van aangerichte schade door een al dan niet geheel voorwaardelijke straf te vorderen met als bijzondere voorwaarde dat de gemeente Sneek binnen een bepaalde tijd tot herplant overgaat, dan wel dat zij, zo op dezelfde plaats herplant onmogelijk is, in de nabijheid een adequate compensatie realiseert'

Deze motivering bij het bevel tot vervolgen illustreert opnieuw dat een strafrechtelijke reactie meer inhoudt dan een simpele boeteoplegging. In bepaalde gevallen kan het herstel van de veroorzaakte schade een ideale strafrechtelijke reactie zijn, al dan niet in combinatie 
met de oplegging van een boete. Opvallend is ook dat uitdrukkelijk naar de voorbeeldfunctie van de overheid wordt verwezen.

\section{Hof Arnhem 19 december 1997, MenR, 1998, 50 met noot Hendriks (Gemeente Nijmegen)}

Zoals in hoofdstuk I is beschreven, werd ook in de Nijmeegse Vuile Grond-affaire door een aantal natuur- en milieuorganisaties een beklagprocedure op grond van artikel $12 \mathrm{~Sv}$ ingesteld. De gemeente zou zonder vergunning een inrichting hebben opgericht en in werking hebben gehad terzake van het opslaan, gebruiken en in de bodem brengen van vervuilde grond op verschillende locaties binnen haar gemeente, hetgeen een overtreding is van artikel 8.1. Wet milieubeheer, strafbaar gesteld in artikel 1a sub1 j6 WED. De officier van justitie had de gemeente medegedeeld dat zij niet verder vervolgd wordt op grond van zijn niet-ontvankelijkheid. Tegen deze beslissing richt de beklagprocedure zich. Het Hof wijst het beklag af met de volgende overweging:

'Ingevolge het bepaalde in art. $12 \mathrm{~Sv}$ kan beklag worden gedaan over onder meer het niet voortzetten van de vervolging van een strafbaar feit. Deze bepaling heeft echter geen betrekking op zaken, die reeds geëindigd zijn en waarin het recht tot strafvordering niet meer bestaat of niet meer kan worden uitgeoefend. In het bijzonder is daarvan sprake wanneer de zaak door een kennisgeving van niet verdere vervolging is geëindigd. Dan kan de buiten vervolging gestelde niet opnieuw in rechte worden betrokken, tenzij nieuwe bezwaren bekend zijn geworden. Van nieuwe bezwaren is in deze niet gebleken.'

Het Hof komt niet toe aan de beantwoording van de vraag of de officier van justitie al dan niet niet-ontvankelijk moet worden verklaard omdat de gemeente binnen het kader van een haar wettelijk opgedragen bestuurstaak heeft gehandeld. ${ }^{241}$

\section{d. Problemen met het taakcriterium}

De door de Hoge Raad ontwikkelde criteria zijn niet steeds even duidelijk. Dat feitenrechters in de praktijk vooral met het taakcriterium veel moeite hebben, blijkt uit de volgende twee uitspraken.

Hof Arnhem 22 mei 1989, MenR, 1989, nr. 81, met noot Addink en P.J.P. Tak (Afval gemeente Druten)

In deze zaak werd de gemeente Druten veroordeeld tot een geldboete van 5000 gulden wegens het oprichten van een geluidswal zonder vergunning, zijnde een overtreding van artikel 33 Afvalstoffenwet. Het verweer van de gemeente dat het hier zou gaan om een overheidstaak, namelijk de zorg voor het weren van geluidshinder, wordt door het Hof onder verwijzing naar het Tilburgse Verkeersdrempels-arrest uitdrukkelijk verworpen:

241. Van der Jagt, J.A.E., o.c., 2000, 49. 
'omdat aan de gemeente niet wordt verweten dat zij een geluidswal heeft opgericht, doch dat zij zulks heeft gedaan met gebruikmaking van zodanige materialen dat zij daarvoor een vergunning krachtens de Afvalstoffenwet diende te bezitten, terwijl zij die niet bezat.'

Het Hof voegt daar nog aan toe:

'dat het onrechtvaardig zou zijn om strafrechtelijke aansprakelijkheid van de gemeente uit te sluiten, nu het i.c. gaat om feiten, die gepleegd zijn binnen een ondernemersactiviteit die ook door particulieren kan worden verricht'.

Het Hof gaat hier duidelijk verder dan tot dan toe door de Hoge Raad werd toegestaan. Het gaat immers niet om de vraag of de betreffende gedraging ook door particulieren kan worden verricht. Het gaat er om of de gedraging is uitgevoerd in het kader van een wettelijk opgedragen overheidstaak. Dat in casu de activititeit ook wel door een particuliere onderneming zou kunnen worden uitgevoerd is van geen belang. Bovendien gaat het hier niet om een ondernemersactiviteit, maar om twee wettelijke overheidstaken, te weten de zorg voor het weren van geluidshinder en de zorg voor een doelmatige afvalverwijdering. ${ }^{242}$ De gemeente Druten is in casu wel degelijk opgetreden als overheid ter behartiging van een - vanuit het perspectief van de Hoge Raad rechtspraak - wettelijk opgedragen bestuurstaak. Strafvervolging is dan uitgesloten. Dat dit volgens het Hof 'onrechtvaardig zou zijn' doet niet ter zake. Annotator Addink merkt daarom terecht op dat hier geen ondernemings-activiteit maar een conflict tussen twee overheidstaken centraal staat: enerzijds de zorg voor het weren van geluidshinder en anderzijds de zorg voor afvalverwijdering. ${ }^{243}$ Beide overheidstaken kunnen trouwens door particulieren worden verricht. De tweede annotator, P.J.P. Tak, wijst er op dat deze zaak duidelijk maakt hoe moeilijk het is om in de praktijk een onderscheid te kunnen maken tussen pure overheidstaken en activiteiten die ook door particulieren kunnen worden verricht. Volgens hem is het onderscheid 'onwerkbaar' nu er niet veel overheidstaken zijn die niet ook als ondernemingsactiviteit kunnen worden verricht. ${ }^{244}$

\section{Rb. 's Gravenhage 15 december 1995, MenR, 1996, nr. 22k (Voorburgse reigersnesten II)}

In deze zaak werd de gemeente Voorburg opnieuw vervolgd voor een overtreding van de Vogelwet omdat zonder vergunning tijdens het broedseizoen reigernesten werden verstoord. Ditmaal bij de herinrichting van park 't Loo. ${ }^{245}$ Namens de gemeente wordt aangevoerd dat deze herinrichting tot stand is gekomen na een zorgvuldige bestuurlijke en politieke belangenafweging, en dat de werkzaamheden zijn uitgevoerd in het kader van de

242. Van der Jagt, J.A.E., o.c., 2000, 33.

243. Noot van Addink, G.H. bij dit arrest, MenR, 1989, 480.

244. Noot van Tak, P.J.P. bij dit arrest, MenR, 1989, 480.

245. Van der Jagt, J.A.E., o.c., 2000, 43-44. 
publieke taak van de gemeente, zodat de OvJ niet-ontvankelijk dient te worden verklaard. De rechtbank is met de gemeente van oordeel dat er op de gemeente inderdaad een bestuurstaak rust voor wat betreft de zorg voor het park. Maar dit laat onverlet dat de gemeente strafbaar is voor het uitvoeren van werkzaamheden ter verwezenlijking van het besluit (om het park te herinrichten, DR) tijdens het broedseizoen.

\begin{abstract}
'Gebleken is dat de gemeente op grond van intern organisatorische en financiële overwegingen de tijdstippen heeft bepaald waarop de werkzaamheden zijn uitgevoerd; daaraan heeft geen enkele bij of krachtens aan de gemeente opgelegde bestuurstak ten grondslag gelegen. De gedragingen strekken dan ook niet tot behartiging van het algemeen belang. De OvJ is ontvankelijk in zijn strafvervolging.'
\end{abstract}

Deze overwegingen van de rechtbank stroken niet met de door de Hoge Raad uitgewerkte criteria. Immers, welke motivatie ook aan de herinrichting van het park ten grondslag mag hebben gelegen, het feit blijft dat deze activiteit op basis van eerdere jurisprudentie moet worden gezien als een gedraging verricht ter behartiging van een aan de gemeente bij of krachtens de wet opgedragen overheidstaak (vergelijk de eerste Voorburgse zaak). Aan de beoordeling van de door de gemeente gemaakte afweging zou men normaal gezien helemaal niet mogen toekomen. ${ }^{246}$ De uitspraak maakt wel op schrijnende wijze duidelijk dat de gemeente in zijn zogenaamde zorgvuldige bestuurlijke en politieke afweging absoluut geen rekening heeft gehouden met de vraag of de herinrichting van het park wel rechtmatig is zonder eerst een vergunning aan te vragen. Daarnaast rijst de vraag of de gemeente ook aan de proportionaliteit van de herinrichting de nodige aandacht heeft gegeven. Zo kan men zich afvragen of dit niet buiten het broedseizoen kon gebeuren. In

246. Zie ook Rb Rotterdam 4 december 1992, MenR, 1993, 38 (Kerstboomverbranding). In deze zaak wordt de gemeente Bernisse vervolgd wegens het in strijd met artikel 33 Afvalstoffenwet en artikel 14 bodembescherming zonder vergunning georganiseerd verbranden van kerstbomen. De gemeente voert aan dat de kerstboomverbrandingen plaatsvinden binnen de uitoefening van specifieke taken, te weten het voorkomen van brand en de handhaving van de openbare orde als bedoeld in de artikelen 168, 209 onder $\mathrm{h}$ en u en 219 gemeentewet en artikel 1 lid 4 Brandweerwet. De kerstboomverbranding is namelijk door de gemeente georganiseerd om illegale 'vreugedevuren' te voorkomen. De economische politierechter geeft de gemeente gelijk en overweegt: ' $\mathrm{Nu}$ aannemelijk is geworden dat het organiseren van kerstboomverbrandingen door de gemeente Bernisse, zijnde een openbaar lichaam in de zin van hoofdstuk 7 van de Grondwet, is geschied in het kader van de specifieke taken die het gemeentebestuur heeft ter voorkoming van brand en ter voorkoming van verstoringen van de openbare orde, het college van burgemeesters en wethouders van Bernisse de gemeenteraad heeft geïnformeerd over het op dit punt te voeren beleid, adequate maatregelen zijn getroffen in het belang van de veiligheid en ter voorkoming van bodemverontreiniging en de gemeente zich er vooraf van heeft vergewist dat tegen het verbranden van kerstbomen geen bezwaren bestonden bij het provinciebestuur, kan de gemeente zich [...] in de gegeven omstandigheden met recht beroepen op haar strafrechtelijke immuniteit $[\ldots]$ Een eventuele toetsing dient te geschieden in het bestuursrechtelijk kader' Omtrent het betoog van de OvJ dat de gemeente over andere (legale) mogelijkheden beschikte om het brandgevaar te voorkomen, overweegt de politierechter dat de bij de keuze van de genomen maatregel 'gemaakte afweging is voorbehouden aan het gemeentebestuur bij de uitvoering van zijn taken op het gebied van de openbare orde.' Zie over deze zaak Van der Jagt, J.A.E., o.c., 2000, 41-43. 
ieder geval, doordat er geen vergunning is aangevraagd, heeft de bevoegde instantie (de Minister van VROM) nooit de mogelijkheid gehad deze afweging wel te maken. ${ }^{247}$

\section{e. De irrelevantie van legaliteit}

Wat zowel in het gemeente Druten-arrest alsook in de Voorburgse reigerszaak centraal staat is niet zozeer het karakter van het overheidshandelen maar veeleer hoe met het conflict tussen meerdere overheidstaken strafrechtelijk moet worden omgegaan. Addink herhaalt in zijn annotatie op het gemeente Druten-arrest de klassieke redenering wanneer hij stelt dat het een oneigenlijke toepassing van het strafrecht zou zijn 'wanneer een gemeente zou worden vervolgd voor het behartigen van een belang dat zij in het kader van de Wet geluidhinder dient te behartigen. ${ }^{248}$ Dit klinkt overtuigend. De vraag is echter of de beoordeling van een dergelijk conflict niet typisch thuishoort op het niveau van de rechtvaardigingsgronden. Bovendien is niet zozeer de vraag aan de orde of de overheid de ene taak boven de andere of het ene belang boven het andere mag doen prevaleren. Dat is immers de kern van bestuurlijk handelen. De vraag is veeleer of een overheid deze afweging op een onrechtmatige wijze kan maken. De wezenlijke vraag is dus niet of een gemeente, zoals Druten, het vermijden van geluidshinder mag plaatsen boven het belang van afvalverwerking, maar of deze keuze mag geschieden in strijd met het recht door een geluidswal te bouwen zonder de vereiste vergunning. En deze vraag is geen doelmatigheidsvraag, maar een rechtmatigheidsvraag. Kortom, de cruciale vraag in bijna alle tot nu toe besproken zaken is of het wel te rechtvaardigen is dat op onrechtmatige wijze aan een bepaalde overheidstaak de voorkeur wordt gegeven als door de wetgever een rechtmatige weg is gecreëerd om deze keuze te maken? Dit komt expliciet ter sprake in de volgende arresten.

\section{HR 23 april 1996, NJ 1996, 512 (Waterschap West-Friesland)}

HR 23 april 1996, NJB, 14 juni 1996, nr. 61 (Provincie Noord-Holland)

Beide arresten kunnen tezamen worden behandeld nu het gaat om gelijkaardige casus. Zowel het waterschap als de provincie worden vervolgd wegens rietbranden zonder vergunning dan wel in strijd met vergunningsvoorwaarden, zijnde een overtreding van artikel 10.3 lid 2 Wet Milieubeheer, en subsidiair, in strijd met de APV van respectievelijk de gemeente Alkmaar en de gemeente Obdam. In beide gevallen is door de rechtbank te Alkmaar het OM niet-ontvankelijk verklaard met de bekende motivering dat het hier gaat om openbare lichamen in de zin van hoofdstuk $7 \mathrm{Gw}$ en de ten laste gelegde gedragingen zijn verricht in het kader van de uitoefening van een wettelijke overheidstaak.

In beide zaken wordt in cassatie niet alleen aangevoerd dat het hier niet om een overheidstaak gaat, maar vooral dat de rechtbank over het hoofd heeft gezien dat er voor de provincie en het waterschap twee legale opties openstonden. Ofwel hadden zij een vergunning of ontheffing kunnen vragen voor het rietbranden, ofwel hadden zij het rietafval

248. Noot Addink, G.H. bij Hof Arnhem 22 mei 1989, MenR, 1989, 479. 
in overeenstemming met de wettelijke regeling kunnen verwijderen. ${ }^{249}$ De redenering van het $\mathrm{OM}$ is duidelijk: niet alleen de kwestie of de verdachten de betreffende gedraging hebben verricht in het kader van een overheidstaak is hier van belang, maar ook de omstandigheid dat dit gebeurde op een illegale wijze. Nu zij hebben verzuimd de rechtmatige weg te bewandelen, zou de OvJ wel degelijk ontvankelijk moeten worden verklaard: 'Immers juist een publiekrechtelijke rechtspersoon dient zich in die situatie te onthouden van het plegen van strafbare feiten!'

De Hoge Raad wijst dit argument zonder motivering van de hand:

'De in de toelichting op het middel aangevoerde omstandigheid dat de verdachte heeft "nagelaten te opteren voor een uitvoering waarbij het plegen van strafbare feiten achterwege had kunnen blijven" doet aan het evenoverwogene (dat de rechtbank terecht de OvJ niet-ontvankelijk verklaarde, DR) niet af'

In zijn conclusie voor dit arrest wijst A-G Fokkens erop dat het cassatiemiddel betekent dat de strafrechter zou moeten onderzoeken of er voor de verdachte overheid inderdaad legale opties openstonden en dat zou tot gevolg hebben dat voor de strafrechter verantwoording moet worden afgelegd, terwijl de immuniteit er nu net in bestaat dat de

'lagere overheden (...) zich voor hun bestuurlijk handelen (...) voor de daartoe in het staats-en bestuursrecht aangewezen organen dienen te verantwoorden (...). Wat het middel als voorwaarde stelt, impliceert dat de strafrechter zou moeten onderzoeken en vervolgens beoordelen of het openbaar lichaam in casu geen gebruik had kunnen en behoren te maken van legale opties. Dat komt neer op het afleggen van verantwoording aan de strafrechter, hetwelk de wetgever juist heeft willen vermijden.'

De A-G merkt ook op dat het argument dat hier sprake zou zijn van een onaanvaardbare rechtsongelijkheid niet opgaat. Er wordt

'uit het oog verloren dat ten aanzien van de bedoelde "lagere" overheden op zich voldoende mogelijkheden tot correctie en preventie in het staatsen bestuursrecht besloten liggen, terwijl ten aanzien van andere organisaties dan deze overheden buiten de strafrechtelijke handhaving in een aantal gevallen onvoldoende mogelijkheden tot handhaving aanwezig zijn. Anders gezegd: ten aanzien van overheden ontbreekt in zoverre de noodzaak van strafrechtelijke handhaving.'

Hij voegt daar nog aan toe dat zelfs in die gevallen waar dit bestuurlijke toezicht niet werkt en de strafrechtelijke handhaving bij overtreding van die regels door particulieren op gespannen voet komt te staan met het gelijkheidsbeginsel niet hoeft te betekenen dat 'in

249. Van der Jagt, J.A.E., o.c., 2000, 44-45. 
dergelijke gevallen ook de betreffende overheid wordt vervolgd.' Met andere woorden, of niet-strafrechtelijke alternatieven nu effect hebben of niet, er is geen reden om wetsovertredende overheden strafrechtelijk aan te pakken. Wat er dan wel moet gebeuren wordt niet aangegeven. ${ }^{250}$

De motivering van deze arresten dient dus gevonden te worden in het klassieke argument dat het strafrecht niet in de beleidsruimte van het bestuurlijke handelen mag treden: dat is een taak die is voorbehouden aan de staats- en bestuursrechtelijke controle. Of dit argument wel volledig sluitend is, laat ik voorlopig even in het midden. Wel kan hier de vraag worden gesteld of in deze zaken wel sprake is van enige beleidsruimte (waaraan dan de strafrechter niet zou mogen raken). De zaken worden hier voorgesteld - ook in de cassatieschriftuur - alsof het waterschap en de provincie een volledig vrije keuze zouden hebben gehad tussen illegale en legale opties voor het rietbranden en dat het niet aan de strafrechter is om deze keuze te beoordelen. Maar is hier eigenlijk wel een keuze in hoofde van de verdachte overheden. Zij zijn, evenals particulieren, wettelijk verplicht het rietbranden op een legale wijze te verrichten. De wetgever heeft hen niet de bevoegdheid gegeven en dus evenmin beleidsruimte om zelfstandig te bepalen of zij een vergunning nodig hebben of niet, of dat ze zich al dan niet aan de wettelijk voorgeschreven normen moeten houden. Anders gezegd, de vergunningplichtige - of het nu gaat om een particulier of een overheid - is verplicht de weg te bewandelen die door de wetgever is bepaald. In die zin is er in beide zaken nauwelijks sprake van een legale optie of mogelijkheid, maar van een legale plicht. Een strafrechter die de schending van deze plicht vaststelt, betreedt niet de beleidsruimte van de wetsovertredende overheid. De enige overheden die in dat verband al beleidsruimte zouden kunnen en mogen hebben, zijn steeds de vergunningverlenende overheden en niet de vergunningplichtige overheden. De wetgever geeft aan de vergunningverlener beleidsruimte en niet aan de vergunningplichtige of vergunninghouder. Een andere redenering zou betekenen dat de vergunningplichtige zelf kan bepalen of hij al dan niet een vergunning nodig heeft. Of iemand een vergunning nodig heeft, is echter een vraag die in eerste instantie door de wetgever en in tweede instantie door de daartoe bevoegde vergunningverlenende instantie wordt beantwoord. Ook in die gevallen waar de verdachte overheid zowel vergunningplichtige als vergunningverlener is, komt het op hetzelfde neer: de overheid als vergunningplichtige dient dan aan zichzelf een vergunning aan te vragen en eens geleverd zich daaraan te houden. Zowel het aanvragen als het volgen van de vergunning is een wettelijke verplichting waar overheden zich aan moeten houden. Een ander vraagstuk is wat de strafrechtelijke consequenties (dienen te) zijn indien de vergunningverlenende overheid geen vergunning heeft gegeven of op onrechtmatige wijze er een heeft verleend. Pas dan komt de beleidsruimte om de hoek kijken, maar dan staat niet het zonder of in strijd met de vergunning handelen ter discussie maar de onrechtmatige vergunningverlening zelf en daar ging het in deze zaken niet om.

Met deze arresten heeft de Hoge Raad zeer duidelijk aan openbare lichamen een vrijbrief tot het plegen van strafbare feiten gegeven. Overheden hoeven zich bij de uitoefening van

250. Zie voor een kritisch commentaar ook Brants, C.H., 'The king can do no wrong: naschrift', $D D$, 1996, 655-657. 
hun bestuurstaak niet langer aan de strafwet te houden. Dit betekent dat het strafrecht machteloos staat tegenover overheden die voor hun bestuurlijk handelen geen vergunningen meer aanvragen of de vergunningsvoorwaarden schaamteloos overtreden als hun dat politiek, financieel of om wat voor reden ook niet uitkomt. Ook het volgende arrest is hiervan een goede illustratie.

\section{Hof Leeuwarden 4 november 1997, MenR 1988, nr. 18 met noot. De Lange (De Gouden Bodem)}

De provincie Friesland werd vervolgd voor het zonder vergunning of in ieder geval in strijd daarmee overbrengen van vervuild slib van het depot 'De Gouden Bodem' naar het depot 'Meersloot'. Van belang is hier dat de noodzakelijke vergunning werd verleend door de GS van de provincie. De provincie is zowel vergunninghouder van een slibdepot als vergunningverlener en is bovendien verantwoordelijk voor het toezicht hoewel moet worden benadrukt dat de provincie deze rollen in de ambtelijke organisatie op van elkaar onderscheiden plaatsen heeft ondergebracht. Het Hof Leeuwarden laat in het midden in welke mate de overbrenging van het slib nog kan worden aangemerkt als een overheidstaak en komt via een uiterst beknopte redenering tot een niet-ontvankelijkheid van het OM:
'nu de Wet Milieubeheer de provincie (...) uitdrukkelijk aanwijst als bevoegd gezag en dus zowel de verlening van vergunningen als de hand- having van de naleving van de aan de vergunning verbonden voorwaar- den een taak is die door de wet aan de provincie is opgedragen, dient te worden geconcludeerd, dat in het onderhavige geval de provincie Fryslân heeft gehandeld ter behartiging van een haar opgedragen overheidstaak en zich kan beroepen op strafrechtelijke immuniteit.'

Met deze uitspraak heeft het Hof wel uit het oog verloren dat niet de vergunningverlening cq het toezicht ter discussie stond, maar de vraag of het zonder of in strijd met de vergunning overbrengen van verontreinigd slib van het ene naar het andere depot moet worden aangemerkt als een overheidstaak. ${ }^{251}$ Het uitbaggeren van de provinciale wateren kan nog worden gezien als een overheidstaak, maar de overdracht van het slib staat daar los van. Ook de opslag van het slib is geen specifieke bij wet opgedragen overheidstaak. Het Hof ontwijkt daarom de inhoudelijke discussie over het taakcriterium en komt met een veel simpelere oplossing: de provincie is hier het bevoegde gezag en belast met vergunningverlening en toezicht, zijnde overheidstaken, en kan derhalve niet worden vervolgd.

Opnieuw is duidelijk hoe moeilijk het is een haarfijn onderscheid te maken tussen overheids- en andere taken en wat de verstrekkende gevolgen zijn van de strafrechtelijke immuniteit. Een openbaar lichaam kan moeiteloos de aan haar door de wetgever toegekende taken in strijd met de strafwet uitoefenen. De consequentie is ook dat een openbaar lichaam straffeloos in strijd met de wet vergunningen kan afgeven of op onrechtmatige wijze kan (nalaten te) handhaven. Zowel vergunningverlening als handhaving zijn

251. Van der Jagt, J.A.E., o.c., 2000, 40. 
immers specifieke overheidstaken, hetgeen impliceert dat een strafbaar feit gepleegd in het kader van deze vergunningverlening $\mathrm{cq}$ handhaving onvervolgbaar blijft. Wat 'De Gouden Bodem'-affaire natuurlijk zo bijzonder maakt is dat de provincie zowel vergunningverlener als vergunningplichtige is. Maar ook in situaties waarin de vergunningverlenende overheid in strijd met wet en recht een vergunning afgeeft aan een particulier of aan een andere overheid en zo als medepleger of als medeplichtige rechtstreeks betrokken is bij een milieudelict geldt dezelfde regel: de betreffende overheid kan niet worden vervolgd nu het feit is gepleegd bij de uitvoering van een overheidstaak. Dat, nogmaals, deze uitvoering op een legale wijze kon en zelfs moest worden volbracht is irrelevant. Van belang zijn enkel de twee immuniteitscriteria.

Inmiddels heeft de Hoge Raad op 30 juni 1998 de uitspraak van het Hof Leeuwarden vernietigd met toepassing van de rechtsregel zoals die in het Tweede Pikmeer-arrest is neergelegd. Bij de bespreking van Pikmeer II komt dan ook opnieuw 'De Gouden Bodem'affaire aan bod.

\section{f. De strafvervolging van de staat: het Volkel-arrest}

Naast de decentrale of lagere overheden is ook de centrale overheid in de vorm van de Staat der Nederlanden een publiekrechtelijke rechtspersoon. Tot de staat behoort een groot aantal entiteiten, waaronder de verschillende departementen. Deze entiteiten hebben zelf geen rechtspersoonlijkheid, hetgeen betekent dat zij slechts via de rechtspersoon 'de staat' strafrechtelijk kunnen worden aangesproken. Van belang is ook dat de staat als zodanig niet is opgesomd als een openbaar lichaam in de zin van hoofdstuk $7 \mathrm{Gw} .{ }^{252}$ Hoofdstuk $7 \mathrm{Gw}$ beoogt immers een regeling van de decentrale openbare lichamen. Wel wordt in een aantal wetten de staat of het Rijk als openbaar lichaam aangeduid. ${ }^{253}$ De Hoge Raad kreeg in 1994 de kans zich over de strafrechtelijke positie van de staat uit te spreken.

\section{HR 25 januari 1994, NJ 1994, 598 met noot Corstens (Viegbasis Volkel) ${ }^{254}$}

In februari 1992 stroomde op de vliegbasis Volkel tijdens overpompwerkzaamheden een aanzienlijke hoeveelheid kerosine uit een brandstofopslagtank. Het was niet de eerste keer dat op dit terrein van het Ministerie van Defensie een dergelijk milieuvervuilend incident plaatsvond. Reeds tweemaal werd voor gelijksoortige feiten aan de staat een transactie aangeboden. Beide transacties werden trouwens keurig door de staat betaald. Mede gelet op de recidive ontkwam de staat echter niet voor de derde keer aan een strafvervolging. 'De Staat der Nederlanden' werd nu gedagvaard voor de economische strafkamer van de rechtbank in Den Bosch vanwege overtreding van artikel 14 van de Wet Bodem-

252. Zie noot Hennekens, H. onder HR 23 oktober 1990, De Gemeentestem, 1991, 329-331, met name 330.

253. Art. 15 eerste lid onder c. Wet op belastingen van rechtsverkeer; art. 11 derde lid Vreemdelingenwet; art. 14a, eerste lid Wet tot behoud van cultuur bezit. Zie voor een opsomming ook Brants, C.H. en De Lange, R., o.c., 1996, 28-29.

254. Voor een kritische analyse van dit arrest zie noot de Hullu, J. onder HR 25 januari 1994, AAe 1995, 50-56; Roef, D., l.c., 1995, 332-348. 
bescherming. In deze bepaling wordt aan de gebruiker van de grond een zorgplicht opgelegd om te voorkomen dat vervuiling van de bodem optreedt. Deze zorgplichtbepaling richt zich, naar de letter van de wet, tot eenieder die handelingen op of aan de bodem verricht, dus ook tot overheden inclusief de staat. ${ }^{255}$

Centraal stond de vraag of de staat voor zijn handelingen strafrechtelijk aansprakelijk kon worden gesteld. De rechtbank Den Bosch verklaarde het Openbaar Ministerie ontvankelijk in de vervolging:

'Het hoeft geen betoog dat in een strafzaak als de onderhavige, elke straf
of maatregel enkel een symbolische werking kan hebben. Via de openbare
behandeling en uitspraak is een strafrechtelijke vervolging slechts een van
de signalen naar de vertegenwoordigende lichamen om inzake milieu-
incidenten wel of geen actie te nemen richting de politiek verantwoor-
delijke bewindsman of -vrouw. Recht doen is kiezen in het openbaar, gaat
minder ver dan politiek controle maar kan daaraan, in een democratisch
bestel, in belangrijke mate bijdragen. De ingewikkeldheid van de milieu-
regelgeving en het gegeven dat het bij zaken het milieu betreffende om
een samenlevingsgevoelige materie gaat, brengen mee, dat op de in alle
objectiviteit oordelende rechter de plicht rust meer dan in andere zaken
uitleg te geven. Die uitleg brengt met zich mee, dat naar het oordeel van
de rechtbank de Staat in deze milieuzaak geen andere positie inneemt dan
elke andere verdachte in een vergelijkbare zaak. De rechtbank laat in dit
verband zwaar wegen de wijze waarop de Staat zelf via de verschillende
verantwoordelijke bewindslieden vorm en inhoud geven geeft aan de
handhaving van het milieurecht.256

Uiteindelijk werd een schuldigverklaring zonder strafoplegging uitgesproken.Tegen deze uitspraak werd door de staat een cassatieberoep ingesteld. De Hoge Raad acht het beroep gegrond en vernietigt op 25 januari 1994 de bestreden uitspraak. De Hoge Raad is met een bijzonder korte overweging voor de staat opmerkelijk coulant:
'6.1. Als uitgangspunt heeft te gelden dat de handelingen van de Staat geacht moeten worden te strekken tot de behartiging van het algemeen belang. Daartoe kan de Staat door wet- en regelgeving, bestuur, feitelijke gedragingen of anderszins zich alle aangelegenheden aantrekken.
6.2. Voor de handelingen van de Staat zijn ministers en staatssecretarissen in het algemeen verantwoording schuldig aan de Staten-Generaal. Daarnaast kunnen zij ter zake van ambtsmisdrijven strafrechtelijk worden vervolgd en berecht op de voet van artikelen 483 en volgende Sv.

255. Bemerk dat volgens de Commissie Toetsing van wetgevingsprojecten, die over de wenselijkheid van zorgplichtbepalingen aan de Ministerraad advies moest geven, zorgplichtbepalingen uitsluitend tot de burger zijn gericht. Zie hierover hoofdstuk II.

256. Rb Den Bosch 1 februari 1993, NJ 1993, 257; MenR, 1993, 370 met noot Hendriks, L.E.M. 


\subsection{Met dit stelsel strookt niet dat de Staat zelf voor zijn handelingen strafrechtelijk aansprakelijk kan worden gesteld. \\ 6.4. Het vorenoverwogene brengt mee dat de Rechtbank de Officier van Justitie niet-ontvankelijk had behoren te verklaren in zijn vervolging. \\ 6.5. Het middel is derhalve gegrond.'}

De staat kan voor zijn handelingen ter zake van een strafbaar feit niet vervolgd worden. De staat kan zichzelf niet in de staart bijten. ${ }^{257}$ De staat staat letterlijk 'boven de wet'. ${ }^{258}$

Met het Volkel-arrest heeft de Hoge Raad voor wat de staat betreft uitdrukkelijk afstand genomen van de in de eerdere rechtspraak ontwikkelde immuniteitscriteria. Hiermee wordt niet alleen de afstand tot de wet (artikel $51 \mathrm{Sr}$ ) groter, maar krijgt de staat in vergelijking met de andere overheden een bevoorrechte positie. Door de summiere overwegingen van de Hoge Raad is de ratio van de algemene strafrechtelijke immuniteit moeilijk te achterhalen. Het feit dat de staat optreedt ter behartiging van het algemeen belang kan nauwelijks de discrepantie tussen decentrale overheden en de centrale overheid verklaren: ook decentrale overheden treden op in naam van het algemeen belang, zelfs wanneer het niet om overheidstaken gaat. Bovendien kan de vraag worden gesteld of de Hoge Raad hier strafvervolging van de staat of strafrechtelijke verantwoordelijkheid van de staat heeft willen uitsluiten.

\section{g. Strafvervolging van de leidinggevende ambtenaar: het Eerste Pikmeer-arrest ${ }^{259}$}

Mede naar aanleiding van het Volkel-arrest rees de vraag of ook natuurlijke personen die optreden in het kader van de niet-vervolgbare (de)centrale overheid beroep kunnen doen op de immuniteit. Immers, nu decentrale overheden een partiële en de staat een absolute immuniteit genieten, is de vervolging van natuurlijke personen binnen die overheden het enige strafrechtelijke alternatief. Artikel 51, tweede lid, Sr bepaalt dat indien een strafbaar feit wordt begaan door een rechtspersoon, de strafvervolging kan worden ingesteld en de in de wet voorziene straffen en maatregelen kunnen worden uitgesproken ofwel tegen die rechtspersoon, ofwel tegen hen die tot het feit opdracht hebben gegeven, alsmede tegen hen die feitelijk leiding hebben gegeven aan de verboden gedraging, of nog tenslotte tegen de rechtspersoon en de opdrachtgever of feitelijk leidinggever tezamen. Daarnaast sluit de vervolging van een rechtspersoon de vervolging van andere natuurlijke personen, die geen opdrachtgever of feitelijk leidinggever zijn, niet uit. ${ }^{260}$

257. Roef, D., l.c., 1995, 332.

258. De Lange, A., 'De dictatuur van de magistratuur', NJB, 1995, 445.

259. Roef, D., 'De strafbaarheid van overheden en leidinggevende ambtenaren; enkele beschouwingen naar aanleiding van het Pikmeer-arrest', $J B, 1996,1110-1118$.

260. Torringa, R.A., o.c., 1984, 109-128; Torringa, R.A., De rechtspersoon als dader; strafbaar leidinggeven aan rechtspersonen, Arnhem, Gouda Quint, 1988, 41. 
Een deel van de literatuur gaat er van uit dat de opdracht- of leidinggever niet onder dezelfde immuniteit kan vallen als de publiekrechtelijke rechtspersoon. ${ }^{261}$ Sommige schrijvers zien dit zelfs als het voordeel van de vervolgingsuitsluitingsgrond die de Hoge Raad hanteert. ${ }^{262}$ Zuiver strafrechtsdogmatisch gezien lijkt op het eerste gezicht inderdaad niets zich te verzetten tegen de vervolgbaarheid en strafbaarheid van de opdracht- of leidinggever. Dit komt doordat de opdracht- of leidinggevers worden gestraft op grond van het daderschap van de rechtspersoon. Daarom is vervolging en bestraffing van deze personen enkel mogelijk, wanneer de rechtspersoon dader is. Bij de vervolging en bestraffing is het echter van geen belang of de verdachte rechtspersoon ook vervolgd kan worden. $\mathrm{Nu}$ de Hoge Raad blijkbaar niet het daderschap maar de vervolging in hoofde van overheden uitsluit, is er dogmatisch geen bezwaar (alsnog) de opdracht- of leidinggever te vervolgen voor de feiten gepleegd door de publiekrechtelijke rechtspersoon.

Andere schrijvers menen daarentegen dat het niet consequent is om enerzijds overheden een immuniteit toe te kennen en anderzijds opdracht- of leidinggevers daarvan uit te sluiten. Vanuit de ratio van de strafrechtelijke immuniteit geredeneerd lijkt dit een terechte stellingname. Die ratio is dat 'strafrechtelijk toezicht niet in de plaats mag treden van politiek toezicht, zelfs niet indien onze vertegenwoordigers er voor kiezen onrechtmatig overheidsoptreden te accepteren. ${ }^{263}$ Die argumentatie geldt dan evenzeer voor natuurlijke personen die optreden in het kader van de overheid. In de MvT bij artikel $51 \mathrm{Sr}$ lijkt de wetgever hetzelfde standpunt in te nemen. ${ }^{264}$

\section{HR 23 april 1996, NJ 1996, 513 met noot't Hart (Pikmeer I)}

De Hoge Raad heeft zich in het Eerste Pikmeer-arrest over deze netelige kwestie uitgesproken. Aan de gemeente Boarnsterhim werd ten laste gelegd het tezamen en in vereniging met een naamloze vennootschap (Grontmij N.V.) storten van verontreinigde baggerspecie in het Pikmeer. Voor deze strafbare feiten werd niet de gemeente, maar het hoofd van de afdeling nieuwe werken van de gemeente, die de opdracht daartoe dan wel feitelijk leiding daaraan zou hebben gegeven, vervolgd. Rechtbank en Hof kwamen tot een bewezenverklaring. ${ }^{265}$ Interessant zijn de overwegingen van het Hof ten aanzien van de ontvankelijkheid van het OM:

261. Noot Mulder, G.E.M. onder het Verkeersdrempel-arrest HR 27 oktober 1981, NJ 1982, 474; Torringa, R.A., o.c., 1984, 121.

262. Van Strien, A.L.J., 'De strafrechter en de bestuurlijke mantel der liefde, Over de vervolgbaarheid van publiekrechtelijke rechtspersonen', $D D, 1987,590$.

263. Wortel, J., l.c., 1988, 1517.

264. Zie MvT, 21: De immuniteit van (bepaalde) publiekrechtelijke rechtspersonen 'sluit (...) niet uit, dat een bepaalde bestuurder bij wie alle bestanddelen van een bepaald strafbaar feit aanwezig zijn uit eigen hoofde, dus wegens een door hem gepleegd delict, voor de strafrechter ter verantwoording kan worden geroepen.' Daaruit volgt dat de opdracht- of leidinggever in kwestie alleen kunnen worden vervolgd indien zij zelf de bestanddelen van het delict hebben verwezenlijkt.

265. Brants, C.H., l.c., 1996, 657 . 
'Indien de gemeente Boarnsterhim strafrechtelijk niet kan worden vervolgd, neemt dit niet weg dat zij strafbare feiten kan plegen en dat degene die feitelijk leiding heeft gegeven aan de verboden gedraging daarvoor kan worden vervolgd.'

Het Hof volgt de zuivere strafrechtsdogmatische redenering zoals die wordt verdedigd door een belangrijk deel van de literatuur. De verdachte gaat in cassatie met als verweer dat indien de gemeente niet kan vervolgd worden, eveneens de feitelijk leidinggever die immuniteit geniet. De Hoge Raad beshuit tot vernietiging van het bestreden arrest:

'De vervolgbaarheid van (rechtspersoon) en (feitelijk leidinggever) zijn zo nauw met elkaar verbonden dat de omstandigheid dat de rechtspersoon zelf niet vervolgd kan worden omdat deze een openbaar lichaam in de zin van Hoofdstuk 7 van de Grondwet is en optreedt ter vervulling van een in de wet opgedragen bestuurstaak, meebrengt dat een strafvervolging evenmin kan worden ingesteld tegen ambtenaren en arbeidscontractanten in dienst van het openbaar lichaam indien dezen in die hoedanigheid ter uitvoering van die bestuurstaak opdracht hebben gegeven tot of feitelijk leiding hebben gegeven aan de verboden gedraging $(. . .)^{\prime}$

De Hoge Raad hakt de knoop door in het voordeel van een gelijkschakeling van rechtspersoon en feitelijk leidinggever. Vanuit dogmatisch oogpunt is er een en ander op de motivering aan te merken. Immers, de verwevenheid van rechtspersoon en natuurlijke persoon speelt niet op het niveau van de vervolgbaarheid, maar van de strafbaarheid. ${ }^{266}$ In het licht van het argument dat de strafrechter geen bestuurstaken mag beoordelen wordt de uitspraak begrijpelijk. Dit is ook de redenering van A-G Van Dorst in zijn conclusie voor het arrest. De A-G gaat zelfs verder: de immuniteit

'geldt dunkt mij zelfs - en in zoverre ga ik verder dan de MvT - indien de opdrachtgever of feitelijke leidinggever alle bestanddelen uit eigen hoofde, dus wegens een door hem gepleegd delict, vervolgd zou kunnen worden.'

Het pijnlijke van dit arrest ligt tevens in het feit dat een medepleger is betrokken, Grontmij N.V., en ten aanzien van (de leidinggever van) deze privaatrechtelijke rechtspersoon is het strafrecht wel toegepast. ${ }^{267}$ Dit betekent dat wanneer een gemeente in de uitoefening van zijn overheidstaak de wet overtreedt en daartoe de hulp zoekt van een onderneming, de gemeente en haar leidinggevende ambtenaren strafrechtelijk vrijuit gaan terwijl het bedrijf

266. Brants, C.H., L.c., 1996, 658.

267. Hof Leeuwarden, 31 januari 1995, ongepubliceerd: zie Brants, C.H., L.c., 1996, 658. Deze zaak is nooit tot bij de Hoge Raad geraakt, nu in casu het feitelijk leidinggeven niet kon worden bewezen. Kennelijk is wel de vervolgbaarheid van de feitelijk leidinggever aangenomen. 
en zijn werknemers risico lopen een zware straf te krijgen opgelegd. Het hoeft dan niet te verbazen dat op dit arrest ook in de media de nodige kritiek werd geuit. ${ }^{268}$

De vraag rijst hoe het nu staat met de strafrechtelijke aansprakelijkheid van ambtenaren die geen opdracht- of leidinggever zijn. De Hoge Raad heeft zich hierover immers niet uitgesproken. Aangenomen wordt - in tegenstelling tot de visie van A-G van Dorst - dat de immuniteit niet geldt voor ambtenaren die bij de uitoefening van een overheidstaak zelfstandig uit eigen hoofde een strafbaar feit plegen. De immuniteit geldt enkel voor ambtenaren die opdracht geven tot of leiding geven aan het feit gepleegd door de overheid. $^{269}$ Deze situatie is zeer ongelukkig. Allereerst wordt voor overheden de strafrechtelijke dogmatiek gewoonweg omzeild door de vervolgbaarheid van de leidinggever niet alleen van het daderschap maar ook van de vervolgbaarheid van de rechtspersoon te laten afhangen. Bovendien rijst de vraag waarom die immuniteit niet eveneens kan gelden voor de ambtenaar die uit eigen daderschap kan worden veroordeeld. ${ }^{270}$ De band tussen overheid en uitvoerend ambtenaar is in de praktijk toch vaak even groot als de verbondenheid tussen overheid en leidinggever.

\section{h. De reactie van het kabinet op Pikmeer I}

Pikmeer I leidde niet alleen tot commotie bij het openbaar ministerie ${ }^{271}$ maar ook tot parlementaire vragen aan de toenmalige minister van Justitie Sorgdrager. ${ }^{272}$ Naar aanleiding daarvan heeft het kabinet een standpunt geformuleerd in de nota 'Strafrechtelijke aansprakelijkheid van overheidsorganen'. Het kabinet neemt als uitgangspunt dat moet worden uitgegaan van een strafrechtelijke immuniteit van overheden en/of diegenen die bij deze overheden in dienst zijn binnen het kader van de uitoefening van een bestuurstaak. ${ }^{273}$ $\mathrm{Bij}$ de controle op overheidshandelen behoren de politieke en bestuurlijke controlemechanismen voorop te staan. Indien deze gebrekkig functioneren en niet voldoende in staat zijn het overheidshandelen te corrigeren dan moet eerder aandacht worden besteed aan

268. O.a. 'Straffeloze overheid', NRC Handelsblad, 15 augustus 1996; 'Pikmeer-arrest geldt voor alle overheidsdiensten', Volkskrant, 14 augustus 1996; Van Nispen tot Sevenaer, W., 'De Staat staat boven de wet, maar zijn dienaren niet', NRC Handelsblad, 29 augustus 1996; Van Elst, R., 'Straffeloosheid van ambtenaar en overheid schaadt rechtsgevoel', NRC Handelsblad, 9 september 1996; Rehwinkel, P. en Swildens-Rozendaal, W., 'Wetsovertreding overheid inhoudelijk beoordelen', NRC Handelsblad 28 september 1996; Roef, D., 'Overtredingen overheid mogen niet onbestraft blijven', Volkskrant, 25 september 1996.

269. Dit was ook het standpunt van minister van Justitie Sorgdrager: zie Tweede Kamer, Handelingen, 1995-96, 2851.

270. In die zin is het standpunt van A-G Van Dorst begrijpelijk.

271. Zie bijvoorbeeld Fransen, A.M., l.c., NJB, 1997, 10. Naar aanleiding van kamervragen is in december 1996 door het College van Procureurs-Generaal een advies inzake 'strafvervolging overheden' aan de minister van Justitie werd uitgebracht waarin in sterke bewoordingen werd gepleit voor een koerswijziging van de Hoge Raad. Mocht de Hoge Raad in de toekomst niet omgaan, dan ligt volgens de P-G's een wetswijziging voor de hand waarmee de strafrechtelijke immuniteit wordt vervangen door een mogelijk beroep op een rechtvaardigingsgrond. Zie TK, 1996-1997, 25000 , VI, nr. 31.

272. TK, Handelingen, 1995-1996, 2851-2852 en TK, Handelingen, 1995-96, 3169-3170.

273. TK 1996-1997, 25294 , nr. 2, 1. 
een versterking van die mechanismen dan aan een uitbreiding van de strafrechtelijke vervolgbaarheid. De achterliggende reden voor de strafrechtelijke immuniteit van overheden ziet het kabinet in het feit dat overheden beschikken over een bepaalde beleidsof beoordelingsvrijheid bij de uitvoering van de hun wettelijk toegewezen overheidstaken. De overheid heeft deze vrijheid nodig om alle betrokken belangen af te wegen en het is onwenselijk dat de strafrechter aan die bestuurlijke vrijheid raakt:

'De aan overheidsorganen toekomende beleids- of beoordelingsvrijheid betekent, mede gelet op het aan het Nederlandse staatsrecht ten grondslag liggende beginsel van scheiding en spreiding van macht en bevoegdheid, dat de rechter bij de beoordeling van de wijze waarop een overheidsorgaan van die vrijheid gebruik heeft gemaakt, enige terughoudendheid betracht. Dit geldt zowel voor de strafrechter als voor de bestuursrechter en de civiele rechter. Achtergrond van deze rechterlijke terughoudendheid is dat de beoordeling van de implicaties die het algemeen belang heeft voor de besluitvorming en het feitelijk handelen van overheid primair toekomt aan de organen die uiteindelijk politieke verantwoording dienen af te leggen en aldus hun besluitvorming democratisch gelegitimeerd zien. $^{.274}$

Het primaat ligt bij de politiek en het bestuursrecht. Het strafrecht heeft kennelijk terzake geen rol te vervullen. Toch is de visie van het kabinet niet zo duidelijk en rechtlijnig als op het eerste gezicht lijkt. Het kabinet ziet immers in bepaalde gevallen toch nog ruimte voor strafvervolging, namelijk

'indien het handelen van het overheidsorgaan redelijkerwijs niet meer kan worden gerekend tot de uitvoering van de overheidstaak [en] de aantasting van het door de strafbepaling beschermde belang redelijkerwijs niet geacht kan worden te strekken tot behartiging van de andere aan de overheid toevertrouwde belangen. ${ }^{.275}$

Deze 'ontsnappingsclausule' lijkt verdacht veel op de willekeurformule die lange tijd door de civiele rechter werd gehanteerd ten einde beleidsvrij overheidshandelen te kunnen toetsen. ${ }^{276}$ Het is opmerkelijk dat wat de civielrechtelijke overheidsaansprakelijkheid aangaat reeds in 1987 met het Ikon/Amsterdam-arrest dergelijke restrictieve of indirecte toetsing via het willekeurverbod is verlaten en sindsdien alle overheidshandelen aan geschreven en ongeschreven recht (a.b.b.b.'s) rechtstreeks kan worden getoetst. ${ }^{277}$

274. TK 1996-1997, 25294, nr. $2,3$.

275. TK 1996-1997, 25492 , nr. $2,7$.

276. Zie onder meer het Doetinchemse Woonruimtevordering-arrest ( 25 februari 1949, NJ 1949, 558 met noot Veens). Zie hoofdstuk IV.

277. HR 27 maart 1987, NJ 1987, 727 met noot Scheltema. 
Cruciale vraag is natuurlijk wanneer er redelijkerwijs niet langer sprake is van een uitvoering van een overheidstaak. Naar het oordeel van het kabinet is daarbij determinant in hoeverre het betrokken handelen verwijderd is van de oorspronkelijke overheidstaak en vooral in welke mate het overheidshandelen de goedkeuring heeft van een vertegenwoordigend lichaam (bijvoorbeeld de gemeenteraad) en aldus democratisch gelegitimeerd is. Is dit laatste het geval dan kan het betrokken handelen nog worden beschouwd als behorende tot de uitvoering van een overheidstaak. ${ }^{278}$ Ook de door het College van Procureursgeneraal opgestelde 'Richtlijn opsporings- en vervolgingsbeleid overheden', die kort na de kabinetsnota is verschenen, gaat hiervan uit wanneer wordt gesteld dat er nog sprake is van handeling ter uitvoering van een overheidstaak wanneer daaraan een strafrechtelijk te respecteren bestuurlijke belangenafweging ten grondslag ligt. Een positieve indicatie daarvoor is

\begin{abstract}
'een zorgvuldige bestuurlijke procedure, waarmee het besluit dat aan het overheidshandelen ten grondslag ligt, tot stand is gekomen en met name ook of het overheidshandelen de uitdrukkelijke goedkeuring had van een vertegenwoordigend lichaam en aldus democratisch gelegitimeerd was (cursief, DR). ${ }^{279}$
\end{abstract}

Het standpunt van het kabinet kan op verschillende punten worden bekritiseerd. ${ }^{280}$ In de eerste plaats meent het kabinet dat haar visie volledig strookt met de rechtspraak van de Hoge Raad. Daarom ziet het kabinet alsnog geen reden om tot wetswijziging over te gaan. ${ }^{281} \mathrm{Ik}$ meen dat het kabinet de rechtspraak verkeerd heeft begrepen. Er zijn zelfs grote verschillen tussen de visie van het kabinet en de jurisprudentie van de Hoge Raad. Het kabinet laat immers in tegenstelling tot de Hoge Raad een zekere terughoudende (redelijkheids)toetsing door de strafrechter toe. Het kabinet maakt zelfs een vergelijking met de toetsingsmogelijkheden waarover de bestuursrechter en de civiele rechter beschikken. Dat de bij overheden aanwezige beoordelings- of beleidsvrijheid de rechter tot terughoudendheid verplicht, zal niemand betwisten: een rechter mag niet op de stoel van het bestuur zitten. Wat het kabinet echter uit het oog verliest, is dat de Hoge Raad nu juist zelfs een terughoudende toetsing, waarover de civiele rechter en de bestuursrechter wel beschikken, heeft uitgesloten: de strafrechter kan blijkbaar niet wat zijn bestuursrechtelijke en civielrechtelijke collega's wel kunnen.

Daarnaast bepleit het kabinet een materiële invulling van wat moet worden gezien als de uitvoering van een overheidstaak waarbij het kabinet trouwens oordeelt dat deze invulling moet gebeuren bij de ontvankelijkheidsvraag en niet bij de wederrechtelijkheidsvraag. Indien het overheidshandelen niet meer kan worden beschouwd als een uitvoering van een overheidstaak zou strafvervolging mogelijk moeten zijn. Ook op dat punt miskent het

278. TK 1996-1997, 25000 , VI, nr. 31.

279. Richtlijn opsporing- en vervolgingsbeleid overheden, Stcrt., 1997, 135, uitgangspunten vervolgingsbeleid nr.3.

280. Deze kritiek geldt evenzeer voor de door het OM opgestelde richtlijn.

281. TK 1996-1997, 25 294, nr. 2, 10-12. 
kabinet de bestaande rechtspraak. Volgens de Hoge Raad is er immers geen ruimte voor een materiële benadering van het vraagstuk: vanaf het moment dat de betreffende gedraging is verricht ter uitvoering van een wettelijke overheidstaak is vervolging uitgesloten. In de Rietbrand-arresten wordt duidelijk gesteld dat de in hoofde van de overheid aanwezige keuze om op legale of illegale wijze overheidstaken uit te voeren aan de immuniteit geen afbreuk doet. Alleen het taak- en subjectcriterium zijn van belang.

Interessant is ook de overweging van het kabinet - en het standpunt van het OM sluit daarbij aan - dat de democratische legitimatie van het overheidshandelen reeds kan volstaan om strafvervolging uit te sluiten omdat het handelen dan 'redelijkerwijs' kan worden gezien als ter uitvoering van een overheidstaak. Dit is een vreemde en zelfs enigszins gevaarlijke redenering. Het zou immers betekenen dat bijvoorbeeld een gemeente zich met succes op de immuniteit zou kunnen beroepen telkens wanneer de gemeenteraad voor het betreffende handelen bestuurlijke en politieke verantwoordelijkheid aanvaardt, hetgeen bijvoorbeeld in de tweede Voorburgse Reigersnestenzaak het geval was. Uiteindelijk wil dit zeggen dat een wetsovertredende overheid zelf strafrechtelijke controle en aansprakelijkheid kan verhinderen door een in wezen politieke goedkeuring van het gepleegde feit. Nu kan moeilijk worden ontkend dat er een groot verschil bestaat, ook in strafwaardigheid, tussen situaties waarin het strafbare overheidshandelen door het vertegenwoordigend orgaan van de overheid is goedgekeurd of in ieder geval het resultaat is van een democratische besluitvorming, en situaties waarin dit niet zo is. Dat laatste is trouwens vaak het geval. Meestal gaat het om uitvoeringshandelingen, zoals illegale slibstort, en komen de vertegenwoordigende organen er pas maanden of jaren later achter. Niettemin lijkt het mij onverdedigbaar dat de enkele democratische legitimatie van een bepaald overheidshandelen de onvervolgbaarheid met zich mee kan brengen. Het feit dat een bepaalde handeling democratisch gelegitimeerd is, betekent nog niet dat de beslissing daartoe bestuursrechtelijk gezien op zorgvuldige wijze is tot stand gekomen. Het komt geregeld voor dat de administratieve rechter besluiten vernietigt die in eerste instantie de goedkeuring hebben gekregen van het vertegenwoordigend lichaam. Betekent dit dan dat vervolging wel mogelijk is wanneer een door het vertegenwoordigend lichaam goedgekeurde beslissing later door de bestuursrechter wordt vernietigd? ${ }^{282}$ Kortom, het kan moeilijk worden verdedigd dat de overtreding door een overheid van in de wet neergelegde strafrechtelijke normen niet langer strafwaardig is door de loutere goedkeuring van het vertegenwoordigend lichaam van die overheid.

Zoals in hoofdstuk II is uiteengezet, gaat achter deze redenering een visie schuil waarin democratische legitimatie en rechtsstatelijke legitimatie stilaan synoniemen zijn geworden of met elkaar worden vereenzelvigd. Door overheden gepleegde strafbare feiten zouden onvervolgbaar zijn alleen maar omdat zij door deze overheden zelf zijn aanvaard. Een dergelijke opvatting illustreert duidelijk wat eerder als een instrumentalistische visie op de rechtsorde werd genoemd. Deze visie werd ook beschreven als één van de voornaamste obstakels bij de strafvervolging van overheden. Zoals reeds werd bepleit, is een noodzake-

282. Zie ook Peters, J.A.F., 'Wordt vervolgd? Over de criteria gebruikt bij het beleid inzake vervolging van overheden', NTB, 1997, 386. 
lijk uitgangspunt voor een machtskritisch verantwoorde vervolgbaarheid van overheden een relationele kijk op het recht en de rechtsorde. ${ }^{283}$ In een instrumentalistische benadering is de rechtsorde alleen die maatschappelijke orde die als doelstelling door de overheid wordt nagestreefd en ten dienste waarvan het (straf)recht als neutraal instrument wordt ingeschakeld. ${ }^{284}$ Is de uitoefening van bepaalde bevoegdheden en overheidstaken het gevolg van op democratische wijze geldig tot stand gekomen besluiten dan is daarmee eigenlijk alle legitimatie gegeven. Binnen zo'n argumentatie is nauwelijks plaats voor strafvervolging van overheden omdat het strafrecht zelf moeilijk nog kritisch kan staan tegenover het overheidsoptreden. Recht is dan niet meer dan het resultaat van een politieke consensus of meerderheid hetgeen dan vanzelfsprekend nauwelijks ruimte laat voor een rechterlijke controle die verder gaat dan de politieke machthebber zelf toelaat.

Tenslotte spreekt het kabinet zich ook nog uit over de absolute staatsimmuniteit. Volgens het kabinet dient de uitzonderingspositie van de staat behouden te blijven. Een vervolging van de staat zou immers neerkomen op een vervolging door één van haar eigen organen, het openbaar ministerie: de staat zou zichzelf vervolgen. Een ander argument tegen de vervolgbaarheid van de staat - ook in die gevallen waar decentrale overheden wel kunnen worden vervolgd - betreft hoofdzakelijk een politiek argument:

'een groter bezwaar is dat vervolging dóór de Staat ván de Staat het risico meebrengt dat de eenheid van de regering en het regeringsbeleid in gevaar wordt gebracht. In feite komt een dergelijke vervolging er immers op neer dat het ene lid van het kabinet - de minister van justitie, die in ons strafrechtelijk systeem verantwoordelijk is voor het vervolgende orgaan een ander lid van het kabinet, onder wiens verantwoordelijkheid het betrokken handelen heeft plaatsgevonden, aanklaagt wegens overtreding van de strafwet. Niet alleen leidt dit tot een innerlijke tegenstrijdigheid in het optreden van de regering en het regeringsbeleid, maar ook wordt daarmee de ene minister als het ware onder toezicht van de andere (i.c. de minister van Justitie) geplaatst en aan deze ondergeschikt gemaakt. ${ }^{285}$

Niet alleen wordt in zo'n voorstelling van zaken verschillende verantwoordelijkheden op een hoop gegooid - ministeriële en politieke verantwoordelijkheid, persoonlijke strafrechtelijke verantwoordelijkheid van ministers, strafrechtelijke verantwoordelijkheid van de staat -, ook wordt de staat eenzijdig vereenzelvigd met de regering. Dat lijkt me wel zeer etatistisch. Opnieuw ontbreekt elke kritische distantie tussen recht en (politieke) orde hetgeen in concreto betekent dat het OM blijkbaar niet meer het recht in de rechtsorde kan vertegenwoordigen, maar uitsluitend nog de staat. Wat de onvervolgbaarheid van de staat betreft past de visie van het kabinet dus wel duidelijk binnen de rechtspraak van de Hoge Raad. 
Uiteindelijk bleek de kabinetsnota voor de Tweede Kamer niet op alle vlakken even overtuigend. ${ }^{286} \mathrm{Er}$ werden twee moties ingediend waarin werd vooropgesteld dat ook overheden in beginsel strafrechtelijk vervolgbaar moeten zijn en de regering werd verzocht een wetsvoorstel voor te bereiden. De motie Rehwinkel ${ }^{287}$ met betrekking tot de decentrale overheden en de motie Koekoek ${ }^{288}$ met betrekking tot de staat. De motie Rehwinkel werd met bijna algemene stemmen door de Tweede Kamer aangenomen en de motie Koekoek verworpen.

\section{i. Van Pikmeer I naar Pikmeer II}

De Pikmeer-zaak wordt door de Hoge Raad teruggewezen naar de Economische Kamer van het hof omdat dit slechts 'veronderstellenderwijs had aangenomen' dat de gemeente handelde ter uitvoering van haar bestuurstaak. ${ }^{289}$ Het hof moest onderzoeken of dit in feite wel het geval was. Tegelijk wijst de Hoge Raad erop - anders dan de Advocaat Generaal in zijn conclusie voor het arrest - dat de tot de leidinggever uitgebreide immuniteit niet belet dat de verdachte mogelijkerwijs 'uit hoofde van eigen daderschap' (hetgeen subsidiair was ten laste gelegd) kan worden veroordeeld. ${ }^{290}$

Na terugwijzing oordeelde het hof Leeuwarden dat het afvoeren van het bij de baggerwerkzaamheden vrijgekomen slib zozeer als een gevolg van die baggerwerkzaamheden moet worden beschouwd dat het in zijn algemeenheid mogelijk is dat met het uitbaggeren van een gemeentewater en het afvoeren van het daarbij vrijgekomen slib is gehandeld ter behartiging van een aan de gemeente opgedragen bestuurstaak. Daarbij werd verwezen naar de ingevolge (oud) artikel 209, aanhef en onder h, gemeentewet aan de burgemeesters en wethouders opgedragen taak te zorgen voor de instandhouding en bruikbaarheid van de publieke wateren en vaarten. Vervolgens bekeek het hof of in casu wel sprake was van een behartiging van een bestuurstaak. Het hof kwam tot de conclusie dat dit niet het geval was omdat uit de stukken bleek dat van het uitbaggeren van de Groundaem alsook de baggerwerkzaamheden in het Pikmeer door de gemeente bewust werd afgezien, juist vanwege het feit dat het slib sterk was vervuild en voor de afvoer daarvan geen financieel verantwoorde oplossing kon worden gevonden. De niet-ontvankelijkheid van het openbaar ministerie wegens de immuniteit van de gemeente wordt verworpen met de volgende overweging:

'Indien zou worden bewezen dat onder die omstandigheden de verdachte, en via hem de gemeente, ondanks het ontbreken van een besluit daartoe, opdracht heeft gegeven in de Groundaem te baggeren en het daarbij vrijgekomen slib te storten in het Pikmeer, moet worden geoordeeld dat die werkzaamheden niet zijn verricht ter behartiging van de aan de

287. TK 1996-1997, 25294, nr. 3.

288. TK 1996-1997, 25249 , nr. 7.

289. HR 23 april 1996, $N J 1996,513$, rechtsoverweging 6.2.

290. HR 23 april 1996, $N J 1996,513$, rechtsoverweging 7.2. 
gemeente opgedragen taak, zodat de gemeente niet het beroep op strafrechtelijke immuniteit zou toekomen dat haar wel zou zijn toegekomen als tot de tenlastegelegde handelingen zou zijn besloten of als de gemeente achteraf voor deze handelingen bestuurlijke verantwoordelijkheid zou hebben aanvaard. Het Hof is derhalve van oordeel dat de gemeente strafrechtelijk kan worden vervolgd en dat het openbaar ministerie ontvankelijk is in de vervolging van de verdachte. ${ }^{1291}$

Het interessante van deze overweging is dat het hof de immuniteit van de gemeente koppelt aan een aanvaardingscriterium dat sterk gelijkt op de daderschapscriteria die zijn geformuleerd in de IJzerdraad- en Slavenburgrechtspraak. ${ }^{292}$ Merkwaardig is echter dat het aanvaardingsciterium in casu niet wordt gebruikt voor de invulling van de strafrechtelijke aansprakelijkheid van de rechtspersoon (de gemeente), maar voor diens immuniteit! Volgens het hof kan slechts een beroep worden gedaan op de immuniteit indien de gemeente tot de strafbare gedraging zou hebben besloten of deze achteraf voor haar rekening zou hebben genomen. Dit is een vreemde constructie omdat op deze wijze een gemeente zich met succes op de immuniteit zou kunnen beroepen telkens wanneer deze daarvoor bestuurlijke verantwoordelijkheid aanvaardt. Dit is een redenering die ook in de hierboven besproken kabinetsnota is terug te vinden. Dit zou impliceren dat de wetsovertredende overheid zelf een strafvervolging kan verhinderen door een in wezen politieke aanvaarding van het gepleegde feit. Daardoor zou in de Pikmeercasus ook de verdachte ambtenaar vrijuit zijn gegaan. Nu echter van een dergelijke aanvaarding geen sprake was, bleef de gemeente Boarnsterhim en dus ook de ambtenaar vervolgbaar. Het hof komt uiteindelijk op basis van de stukken - waaronder een beschikking van de Gedeputeerde Staten dat voor de verplaatsing van het slib geen vergunning wordt verleend - tot de bewezenverklaring. De ambtenaar wordt veroordeeld tot een onvoorwaardelijke geldboete van 1500 gulden, subsidiair 15 dagen hechtenis. ${ }^{293}$ Als nadere bewijsoverweging wordt aangevoerd dat de verboden gedraging van de ambtenaar aan de gemeente moet worden toegerekend, omdat deze gedragingen in het maatschappelijk verkeer hebben te gelden als gedragingen van de gemeente. Voorts heeft het hof overwogen dat er wel degelijk sprake was van feitelijk leidinggeven aan deze gemeentelijke gedraging nu de verdachte op de hoogte was van het feit dat in strijd met die vergunning vervuild slib in het Pikmeer werd gestort en hij, hoewel bevoegd en gehouden het storten in het Pikmeer te voorkomen, heeft bevorderd dat die verboden gedraging doorgang heeft gevonden.

291. Hof Leeuwarden 12 november 1996, MenR, 1997, nr. 1 met noot De Lange, A. Zie ook De Roos, Th.A., 'Het Pikmeerarrest en zijn gevolgen', AAe, 1997, 226-233.

292. Zie tevens De Roos, Th.A., l.c., 1997, 228.

293. De eerste rechter legde slechts een voorwaardelijke boete op. 


\section{Het Tweede Pikmeer-arrest: de Hoge Raad gaat $\mathrm{om}^{294}$}

HR 6 januari 1998, NJ 1998, 367 met noot 't Hart; MenR, 1998, nr. 19.; JB, 1998, nr. 4. (Pikmeer II)

De Hoge Raad heeft het vervolg van de Pikmeer-zaak aangegrepen om zijn eerdere jurisprudentie bij te stellen. De Raad behandelt de vervolgbaarheid van lagere overheden in een afzonderlijke, maar liefst 10 pagina's tellende beschouwing, voorafgaand aan de eigenlijke beoordeling van het tweede middel. De uitvoerige motiveringen in dit arrest staan daarmee in schril contrast met de totale afwezigheid van motivering in de eerdere jurisprudentie. Dit toont reeds aan dat de Hoge Raad niet ongevoelig is gebleken voor de hevige kritiek op Pikmeer I. Hier volgen de belangrijkste uitgangspunten van het arrest.

\section{a. De overheid staat niet boven de wet}

\section{De Hoge Raad neemt als vertrekpunt}

'dat de overheid, zowel de Staat als decentrale overheden, zoals provincies, gemeenten en waterschappen, zich als ieder burger dient te houden aan de wet (r.o. 5.1.)'

Dit lijkt vanzelfsprekend. Toch is het de eerste keer dat de Hoge Raad dit beginsel wat de vervolgbaarheid van overheden betreft uitdrukkelijk vooropstelt. Daarmee rijst immers de tot dan toe ontweken vraag of het principe dat overheden zich aan de wet dienen te houden ook impliceert dat op wetsovertredingen van de overheid een strafrechtelijke reactie kan volgen. Dat is al minder vanzelfsprekend. Ook het kabinet onderschrijft immers dat overheden zich bij de uitoefening van hun bestuurstaken aan de wet dienen te houden maar verbindt daaraan niet automatisch de conclusie dat de reactie op wetsovertredingen ook een strafrechtelijke kan zijn. Er zijn immers nog andere verantwoordingsfora. De vraag dient zich nu aan of deze fora inderdaad een strafrechtelijke aansprakelijkheid van overheden in de weg staan. Het kabinet is van oordeel dat het bijzondere karakter van het overheidshandelen, en meer bepaald de aan de overheidsorganen toekomende beleids- of beoordelingsvrijheid, een van burgers verschillende behandeling rechtvaardigen. ${ }^{295}$ Het bestaan van niet-strafrechtelijke controlemechanismen, zoals bestuurlijke en politieke controle, wijst daar reeds op. Indien er sprake is van strafbare feiten, dan is - aldus het kabinet - een terughoudende toepassing van deze instrumenten niet aan de orde. Toch is, zoals reeds

294. Zie Brants, C.H., 'Strafvervolging van de overheid: het Pikmeer II-arrest, Militair Rechtelijk Tijdschrift, 1998a, 309-319; Brants, C.H., 'Wordt vervolgd...Het Pikmeer II-arrest (HR 6 januari 1998)', DD, 1998, 318-343; Peters, J.A.F., 'Wordt vervolgd: aantekeningen bij het Pikmeer IIarrest, NTB, 1998, 31-35; Viering, M.L.W.M. en Widdershoven, R.J.G.M., 'De strafrechtelijke positie van de overheid na Pikmeer II, in Elzinga, D.J. en De Jong, H.M. (red.), o.c., 1998, $67-$ 85; Hendriks, L.E.M. en De Lange, A., 'Strafvervolging van overheden na het Tweede Pikmeerarrest', MenR, 1998, 41-47; Roef, D., 'De ommekeer in Pikmeer. Over de vervolgbaarheid van overheden na Pikmeer II, JB, 1998, 215-226.

295. TK 1996-1997, 25294 , nr. 2, 2-3. 
werd besproken, de visie van het kabinet niet geheel in overeenstemming met die van de Hoge Raad. Volgens het kabinet zou immers in gevallen waar de uitvoering van de overheidstaak een strafbaar feit uitmaakt geen plaats meer zijn voor een immuniteit, omdat dan geen sprake meer is van een gedraging ter behartiging van een overheidstaak. A-G Fokkens wijst er in zijn conclusie nog eens op dat deze redenering niet wordt gedeeld door de Hoge Raad. ${ }^{296}$ Voor een strafrechtelijke reactie is daarom slechts ruimte indien het gaat om strafbare feiten die niet in de uitoefening van specifieke overheidstaken zijn begaan. Dat deze taken op onzorgvuldige of onrechtmatige wijze zijn uitgevoerd speelt daarbij geen rol. De Hoge Raad vindt deze ruimte voor strafvervolging nu blijkbaar zelf te eng.

\section{b. De immuniteitscriteria zijn onbevredigend}

Voor het eerst geeft de Hoge Raad een expliciete motivering van zijn eerdere jurisprudentie. Tot nu toe ontbrak deze steeds en moest worden gezocht naar motiveringen in de conclusies van de Advocaat-Generaal. In Pikmeer II verwijst de Raad uitdrukkelijk naar de MvT bij artikel $51 \mathrm{Sr}$ als basis voor de strafrechtelijke immuniteit (r.o. 5.2.) en wordt uitgelegd wat daarvan de bestaansreden is:
'5.3. (...) Uit de rechtspraak blijkt reeds dat niet iedere gedraging van een lagere overheid aan strafrechtelijke controle is onttrokken (...) De Hoge Raad heeft echter de strafrechtelijke immuniteit van openbare lichamen in de zin van hoofdstuk $7 \mathrm{Gw}$ erkend, indien deze een gedraging verrichten ter behartiging van een bij de wet aan dergelijke openbare lichamen opgedragen specifieke bestuurstaak (...) Aan het arrest van de Hoge Raad van 23 april 1996 (Pikmeer I, DR) ligt deze regel mede ten grondslag. Nadere eisen zijn aan het toekennen van die immuniteit niet gesteld.
5.4. De toepassing van laatstvermelde regel strookt met de bedoeling van de wetgever, zoals deze (...) uit de wetsgeschiedenis volgt, deze regel brengt tot uitdrukking dat bij de uitvoering door een decentrale overheid van een specifiek aan haar opgedragen bestuurstaak de rechtvaardiging van haar gedraging reeds tevoren is gegeven, zodat zij niet behoort te worden vervolgd.'

Volgens de Hoge Raad was het dus de bedoeling van de wetgever decentrale overheden bij de uitvoering van een specifieke bestuurstaak van strafvervolging uit te sluiten omdat in dat geval de rechtvaardiging van de betreffende gedraging reeds tevoren in de wet is neergelegd. De Raad stelt daarmee duidelijk vast dat de kern van het probleem zit in het al dan niet wettelijk gerechtvaardigd zijn van een overheidsgedraging. Nu de wetgever deze kwestie heeft geregeld door bij wet de behartiging van specifieke bestuurstaken aan bepaalde overheden op te dragen, is het niet aan de strafrechter gedragingen die ter uitvoering van deze bestuurstaken zijn verricht, te beoordelen. De vraag rijst of dit wel zo overtuigend is. Er werd reeds vastgesteld dat niet zozeer problematisch is of overheden de aan hun opgedragen overheidstaken mogen behartigen en daartoe allerlei handelingen

296. Zie ook Brants, C.H., L.c., 1998, 332. 
mogen stellen. Evenmin problematisch is het feit dat overheden bij de behartiging van verschillende bestuurstaken de ene taak boven de andere doen prevaleren. De crux van het vraagstuk is of de keuze om een bepaalde bestuurstaak uit te voeren en of de behartiging van deze taak kan geschieden op een wijze die in strijd is met het recht. De behartiging van een overheidstaak mag dan reeds bij wet zijn geregeld en dus gerechtvaardigd zijn, maar dat betekent nog niet dat de wijze waarop de taak door de betreffende overheid wordt uitgevoerd in overeenstemming is met wet en recht. Er kan worden gedacht aan situaties waar de wet voor bepaalde overheidsgedragingen - ook ter behartiging van bestuurstaken! een vergunningplicht voorschrijft. Het is moeilijk vol te houden dat de uitvoering van een bestuurstaak nog wettelijk gerechtvaardigd is wanneer die uitvoering plaatsvindt in strijd met de wet. En wat te doen met de talrijke situaties waar de wetgever de manier waarop bestuurstaken behartigd moeten worden, heeft open gelaten? De Hoge Raad wijst zelf op deze moeilijkheden:

'Toepassing van deze regel (die van de immuniteit, DR) roept evenwel vragen op, omdat veelal niet scherp is omlijnd in welke gevallen aan de hier besproken vereiste is voldaan; het is immers doorgaans niet anders dan dat in de wet een bestuurstaak in min of meer algemene termen wordt omschreven. In een concreet geval zal de rechter derhalve moeten beoordelen of een verweten gedraging in redelijkheid heeft te gelden als uitvoering van een bij de wet opgedragen bestuurstaak. Daar komt bij dat toepassing van de tot vervolgingsuitsluiting leidende regel niet in alle gevallen tot een aanvaardbare oplossing leidt, met name niet in die gevallen waarin een decentrale overheid bij de uitvoering van een bestuurstaak in ernstige mate een met straf bedreigde norm overtreedt. De rechter komt immers niet toe aan een concrete beoordeling van de vraag of en in hoeverre de uitvoering van de overheidstaak in het geval in kwestie nog gerechtvaardigd is in het licht van een afweging van de betrokken belangen en met inachtneming van beginselen van proportionaliteit en subsidiariteit.

De Hoge Raad heeft daarom de vraag onder ogen gezien of de onder 5.4. bedoelde regel, gelet op de rechtsontwikkeling, thans precisering behoeft.'

Kortom, de immuniteit leidt vaak tot ongerijmde uitkomsten omdat zelfs in gevallen waar de overheid flagrant de wet overtreedt en dus een delict pleegt de strafrechter daarover geen oordeel kan vellen. Dergelijk oordeel behoort strafrechtsdogmatisch tot het domein van de rechtvaardigingsgronden maar door de vervolgingsuitsluitingsgrond komt de rechter daar niet aan toe. Deze kritiek werd al geruime tijd door de doctrine geuit. ${ }^{297}$ Dat de Hoge Raad met deze kritiek instemt, is dan ook toe te juichen. Het is niet alleen de doctrine die de Hoge Raad zijn standpunt heeft doen wijzigen. Ook andere factoren hebben een belangrijke rol gespeeld.

297. Zie o.m. De Lange, A., l.c., 1995, 441-447; Roef, D., l.c., 1995, 332-348; Brants, C.H. en De Lange, R., o.c., 1996, 103-108. 


\section{c. Nieuwe ontwikkelingen nopen tot herziening}

Het bijzondere karakter van het arrest blijkt ook uit het feit dat de Hoge Raad in zijn oordeel een aantal maatschappelijke, politieke en wetenschappelijke ontwikkelingen uitdrukkelijk mee heeft laten wegen.

Ten eerste stelt de Hoge Raad vast dat een aantal belangrijke nieuwe wetten minder specifiek dan voorheen de aan de decentrale overheid opgedragen taken omschrijven zodat het taakcriterium uiterst vaag is geworden:

\section{'(...) Zo kent de huidige Gemeentewet niet een opsomming van taken als} voorkwam in art. 209 gemeentewet. Ook art. 2 van de Waterschapswet bevat een meer globale taakomschrijving dan de Waterstaatswet 1900 of de bevoegdhedenwet waterschappen inhield.'(r.o. 5.5.)

Daarnaast worden vele overheidstaken ook door privaatrechtelijke rechtspersonen verricht (zoals bodemsanering) en is er veelal sprake van andere vormen van publiek-private samenwerking (zoals ook in de Pikmeercasus het geval was):

'In de bestuurlijke praktijk hebben zich ten aanzien van de in Hoofdstuk 7 $\mathrm{Gw}$ bedoelde openbare lichamen vormen van taakuitoefening ontwikkeld die meebrachten dat taken waarvoor de zorg aan een publiekrechtelijke rechtspersoon is opgedragen, niet door deze zelf worden verricht maar door privaatrechtelijke rechtspersonen, waarin de overheid in meer of mindere mate zeggenschap heeft, of door middel van andere vormen van privatisering of publieke-private samenwerking. Hierbij kan bijvoorbeeld worden gedacht aan het ophalen van afvalstoffen, de monumentenzorg of aan het onderhoud aan wegen en waterwegen.'

De Hoge Raad laat eveneens sterk meewegen dat de immuniteit in de samenleving hevig wordt bekritiseerd:

'De gewijzigde opvatting met betrekking tot de strafbaarheid van lagere overheden, in die zin dat er meer ruimte aanwezig moet zijn dan tot dusverre in de jurisprudentie wordt aangenomen, om tot strafvervolging te kunnen overgaan, wordt blijkens verscheidene publikaties in brede maatschappelijke kringen gedragen en blijkt uit de doctrine.'

Opmerkelijk is ook dat de Hoge Raad expliciet rekening houdt met het feit dat de Tweede Kamer - in tegenstelling tot het kabinet - een gematigd voorstander lijkt te zijn van een verruiming van de strafrechtelijke vervolging van overheden. De Hoge Raad verwijst met name naar de motie Rehwinkel:

'(...) In deze motie wordt vooropgesteld dat ook overheden in beginsel strafrechtelijk vervolgbaar dienen te zijn en dat de huidige jurisprudentie 
ertoe leidt dat feitelijk de mogelijkheden tot strafrechtelijke handhaving jegens overheden zeer beperkt zijn.

5.6.In de motie Rehwinkel c.s. wordt de regering verzocht om voorbereidingen tot wetswijziging in gang te zetten, waardoor de mogelijkheden tot strafrechtelijke vervolging van overheden worden verruimd. Deze bewoordingen alsmede de interpretatie die de Minister van Justitie daaraan heeft gegeven - te weten als een uitnodiging om de gedachtevorming over nadere regelgeving te stimuleren (...) wijzen er op dat er thans niet zodanig omlijnde voorbereidingen tot wetgeving worden getroffen dat deze de Hoge Raad tot terughoudendheid zouden moeten nopen in het ontwikkelen van nieuwe jurisprudentie op het hier aan de orde zijnde onderwerp.'

Vooral deze verwijzing naar enerzijds de gewijzigde opvatting over de vervolgbaarheid van overheden in de Tweede Kamer en anderzijds het 'stilzitten' van het kabinet is opmerkelijk. Al deze ontwikkelingen brengen de Hoge Raad ertoe te concluderen:

'dat er thans sprake is van een zodanige algemene opvatting dat lagere overheden in ruimere mate vervolgd moeten kunnen worden, dat de Hoge Raad aanleiding vindt de in 5.3. bedoelde regel [ i.e., de tot dusver in de jurisprudentie ontwikkelde immuniteitscriteria, DR], die in een aantal gevallen tot uitkomsten leidt die maatschappelijk als ongewenst worden ervaren, te heroverwegen. Daarbij verdient aantekening dat de tekst van art. $51 \mathrm{Sr}$ noch de wetsgeschiedenis welke daaraan ten grondslag ligt, daaraan in de weg staat, teminder waar de wetsgeschiedenis uitdrukkelijk vermeldt dat het hier gaat om een weerbarstige materie die moeilijk in wetsbepalingen is te vatten en dus aan de rechter wordt overgelaten (...) '

d. De aanscherping van de strafrechtelijke immuniteit

De principiële vernieuwing van Pikmeer II is natuurlijk de herziening van de immuniteitscriteria:

'5.7. Een meer bevredigende, aan de hiervoor genoemde ontwikkelingen aangepaste uitkomst kan als volgt worden bereikt. Enerzijds dient de immuniteit van een openbaar lichaam als bedoeld in hoofdstuk $7 \mathrm{Gw}$ slechts dan te worden aangenomen als de desbetreffende gedragingen naar hun aard en gelet op het wettelijk systeem rechtens niet anders dan door bestuursfunctionarissen kunnen worden verricht in het kader van de uitvoering van de aan het openbaar lichaam opgedragen bestuurstaak, zodat uitgesloten is dat derden in zoverre op gelijke voet als het openbaar lichaam aan het maatschappelijk verkeer kunnen deelnemen. In andere gevallen is er wegens de hier te betrachten gelijkheid geen aanleiding immuniteit aan het openbaar lichaam te verlenen en geldt deze evenmin voor de in art. 51 tweede lid onder $2, \mathrm{Sr}$ bedoelde personen' 
De door de Hoge Raad uitgewerkte oplossing kan eigenlijk worden gezien als een twee sporen-systeem. Enerzijds blijft de strafrechtelijke immuniteit bestaan voor handelingen die in het kader van een aan het openbaar lichaam wettelijk opgedragen bestuurstaak rechtens niet anders dan door bestuursfunctionarissen kunnen worden verricht. Er is dus een aanscherping van het takcriterium. Anderzijds geldt voor alle andere gevallen het strafrechtelijke stelsel van rechtvaardigingsgronden.

Dit nieuwe standpunt heeft duidelijk een sterke beperking van de immuniteit tot gevolg. Zaken die tot nu toe steeds niet-ontvankelijk zijn verklaard, zijn met dit nieuwe criterium in de toekomst wel vervolgbaar. Het plaatsen van een geluidswal, ${ }^{298}$ het verwijderen van vogelnesten, ${ }^{299}$ het vellen van een houtopstand, ${ }^{300}$ het rooien van bomen, ${ }^{301}$ het storten van slib $^{302}$ en het verbranden van riet ${ }^{303}$ zijn immers overheidstaken die ook door anderen dan bestuursfunctionarissen kunnen worden verricht. Met de beperking van de immuniteit tot gedragingen die uitsluitend door bestuursfunctionarissen kunnen worden uitgevoerd, heeft de Raad duidelijk willen afrekenen met het ongelijkheidsargument. Het kan immers niet zo zijn dat op het vlak van overheidstaken die zowel door particulieren als door overheden en hun functionarissen kunnen worden verricht, zoals afvalverwerking en bodemsanering, alleen de overheden beroep kunnen doen op de immuniteit. ${ }^{304}$ Ook de door de Raad zelf gesignaleerde ontwikkeling van privatisering en publiek-private samenwerkingsverbanden wijst reeds op de onbillijkheid van deze rechtsongelijkheid.

\section{e. Het stelsel van rechtvaardigingsgronden}

In de gevallen dat geen sprake is van een overheidstaak die rechtens alleen door bestuursfunctionarissen kan worden uitgevoerd, ziet de Hoge Raad ruimte voor de toepassing van rechtvaardigingsgronden. De Hoge Raad overweegt:

'5.8. Indien tegen een openbaar lichaam dan wel tegen de opdrachtgevers of leidinggevers een vervolging wordt ingesteld, kan de rechter met hantering van het stelsel van rechtvaardigingsgronden beslissen dat de verweten en ter behartiging van een specifieke bestuurstaak verrichte gedraging, hoewel strijdig met wettelijke voorschriften, in de omstandigheden van het geval gerechtvaardigd is en daarom tot straffeloosheid moet leiden.'

298. Hof Arnhem 22 mei 1989, MenR, 1989, nr. 81.

299. HR 23 oktober $1990, N J 1991,496$.

300. HR 9 juni 1992, NJ 1992, 794.

301. Hof Leeuwarden 6 juni 1995, MenR, 1996, nr. 4.

302. HR 23 april 1996, NJ 1996, 513 (Pikmeer I).

303. HR 23 april 1996, $N J 1996,512$.

304. Hendriks, L.E.M. en De Lange, A., l.c., 1998, 45. 
$\mathrm{Er}$ is duidelijk gekozen voor een meer materiële benadering van de problematiek. Dit is mijns inziens vanuit strafrechtelijk oogpunt ook de meest aangewezen weg. ${ }^{305}$ Zoals ook uit de vroegere rechtspraak blijkt, ligt aan de meeste door overheden gepleegde strafbare feiten een conflict van belangen of wettelijke voorschriften ten grondslag. Om te kunnen beoordelen of het gepleegde feit moet worden aangemerkt als een strafbaar feit is het noodzakelijk dat de strafrechter de bestuurlijke belangenafweging aan het recht toetst. De Hoge Raad weerlegt hiermee het argument dat de strafrechter bestuurlijk handelen niet zou mogen beoordelen. Natuurlijk zal dergelijke toetsing beperkt zijn tot een rechtmatigheidstoets wanneer in hoofde van het bestuur sprake is van een beoordelings- of beleidsvrijheid. De strafrechter zal dan evenals de administratieve en burgerlijke rechter slechts de rechtmatigheid kunnen toetsen. In de praktijk betekent dit dat de overheid in kwestie beroep zal kunnen doen op de rechtvaardigingsgrond 'wettelijk voorschrift' (art. $42 \mathrm{Sr}$ ) en de rechtvaardigingsgrond 'overmacht in de zin van noodtoestand' (art. $40 \mathrm{Sr}$ ) ${ }^{306} \mathrm{Te}$ denken valt aan acute noodsituaties die ter behartiging van een gerechtvaardigd doel (zoals volksgezondheid) wetsovertreding noodzakelijk maken. Er moet dan wel duidelijk sprake zijn van een hoger rechtsbelang dan het rechtsbelang dat door het strafbaar feit is geschonden. Dat zal niet vaak het geval zijn. Eigen financiële of economische belangen van het openbaar lichaam mogen geen rol spelen. Er mag immers niet worden vergeten dat het belangenconflict tussen milieubescherming en sociaal-econmische belangen in eerste instantie reeds door de wetgever en in tweede instantie door de vergunningverlenende instanties is beslecht. ${ }^{307}$ Dat betekent onder meer dat noodtoestand ook bij overheden alleen mag worden aangenomen indien de naleving van de (milieu)wetgeving in een concreet geval tot exceptionele niet door de wetgever voorziene consequenties zou leiden. Ik kom later meer uitgebreid terug op deze rechtvaardigingsgronden.

\section{f. Strafoplegging, strafmaat en normbevestiging}

De Hoge Raad neemt ook stelling in de kwestie van de strafoplegging. Zelfs indien de overheid in casu geen beroep zou kunnen doen op een rechtvaardigingsgrond betekent dat nog niet dat er daadwerkelijk een strafsanctie moet volgen. De Hoge Raad overweegt:

\section{'5.9.In geval de in aanmerking komende belangen de rechter geen reden} hebben gegeven tot het aannemen van straffeloosheid op grond van de aanwezigheid van een rechtvaardigingsgrond, is het niet uitgesloten dat de strafrechter, diezelfde belangen opnieuw afwegende, tot een andere bestraffing komt dan in het geval waarin een privaatrechtelijke rechtspersoon een vergelijkbare gedraging zou hebben verricht.'

De Raad schept in die zin een niet onbelangrijke opening om de aan het strafbare feit ten grondslag liggende bestuurlijke belangenafweging te laten meetellen in de uiteindelijke

305. Roef, D., l.c., 1995, 348; De Lange, A., l.c., 1995, 446 e.v.; Brants, C.H. en De Lange, R., o.c., $1996,32-40$.

306. Zie tevens Hendriks, L.E.M. en De Lange, A., l.c., 1998, 44-46.

307. Zie hierover Faure, M., 'Strafuitsluitingsgronden in het milieustrafrecht', $T M R, 1998,197-198$. 
strafmaat. Dat lijkt mij een goede zaak. Een belangrijk argument tegen de strafbaarheid van overheden was steeds dat het geen zin zou hebben overheden geldboeten op te leggen nu de gemeenschap daar uiteindelijk voor moet opdraaien ${ }^{308}$ Dergelijke argumentatie gaat echter uit van een puur instrumentalistische en punitief georiënteerde visie op de inzetbaarheid van het strafrecht: de strafrechtelijke aansprakelijkheid van overheden zou zich uitsluitend (moeten) beperken tot geldboetes. Een dergelijk eenzijdig gebruik van het strafrechtelijke sanctiearsenaal op overtredende overheden zou inderdaad aanleiding kunnen geven tot ongewenste neveneffecten. Er mag niet worden vergeten dat het sanctiearsenaal van de strafrechter zich niet beperkt tot boetes. Er kan ook worden gekozen voor de toepassing van maatregelen zoals het herstel van de opgetreden schade of de ontneming van het wederrechtelijk verkregen voordeel. ${ }^{309}$ Bovendien draait een strafrechtelijke veroordeling juist bij overheden niet alleen om sanctionering maar steeds ook om machtsnormering die van de symbolische en afkeurende uitstraling van een veroordeling uitgaat. ${ }^{310}$ Zoals in hoofdstuk II werd verdedigd is het vooral deze machtsnormerende of machtskritische functie van het strafrecht die ten opzichte van overheden centraal moet staan en niet alleen maar de punitieve kant van het strafrecht. In de praktijk blijkt het daar ook om te gaan: in de enkele gevallen waar overheden veroordeeld zijn geworden kiezen strafrechters nauwelijks voor het opleggen van hoge boetes. De 'veroordeling' van het illegale handelen als zodanig staat voorop. We kunnen in dat verband ook verwijzen naar de Volkel-casus waar het door de Hoge Raad vernietigde vonnis van de rechtbank 's-Hertogenbosch duidelijk zowel de symbolische en normbevestigende werking van het strafrecht beklemtoont alsook de voorbeeldfunctie van de centrale overheid: van een strafoplegging was geen sprake. Ook uit de beslissing van het hof Leeuwarden in de artikel $12 \mathrm{~Sv}$ procedure spreekt een sterke voorkeur voor machtskritische controle en een adequate compensatie voor het gepleegde feit.

De opmerking van de Hoge Raad dat niet iedere veroordeling van de overheid moet leiden tot een (gelijke) strafoplegging als bij privaatrechtelijke rechtspersonen houdt rekening met zowel de bijzondere aard van overheden als met de bijzondere functies die het strafrecht naar verdachte overheden kan hebben. De normbevestigende werking van het strafrecht mag in dit verband niet onderschat worden.

Tenslotte kan worden opgemerkt dat de door de Hoge Raad omschreven mogelijkheid tot andere bestraffing van overheden in mijn ogen niet steeds tot een lage(re) straf hoeft te leiden. Het is denkbaar én verdedigbaar dat in uitzonderlijke gevallen waar sprake is van evident onrecht en doelbewuste overtreding van de wet overheden juist vanwege hun voorbeeldfunctie en hun machtspositie een in vergelijking met privaatrechtelijke rechtspersonen zwaardere straf krijgen opgelegd.

308. Strijards, G.A.M., o.c., 1988, 66; Van Strien, A.L.J., l.c., 1987, 593.

309. Hendriks, L.E.M. en De Lange, A., L.c., 1998, 42; Roef, D., l.c., 1996, 1117.

310. Brants, C.H. en De Lange, R., o.c., 1996, 90. 
Dat de strafrechter in de door de Hoge Raad aangeduide gevallen bestuurlijk handelen mag beoordelen, betekent nog niet dat iedere wetsovertreding van de overheid dwingt tot een strafrechtelijke reactie. Er moet met de strafrechtelijke vervolging van overheden uiterst zorgvuldig worden omgegaan. Een ondoordacht gebruik van het strafrecht zou bestuurlijke apathie tot gevolg kunnen hebben. Ook wat wetsovertredende overheden betreft, dient het strafrecht ultimum remedium te blijven en slechts te worden toegepast wanneer andere verantwoordingsfora niet werken of hebben gefaald. Het is aan het $\mathrm{OM}$ om in goed maar kritisch (!) overleg met de andere handhavingspartners een consistent en verantwoord vervolgingsbeleid te voeren. De Hoge Raad geeft in dit verband dan ook aan dat de vervolging van overheden in de eerste plaats een opportuniteitsvraag is:

\section{'5.10. (...) het openbaar ministerie [heeft] op de voet van art. 167 en 242} Sv de bevoegdheid strafvervolging achterwege te laten of af te zien van verdere strafvervolging in geval een en ander strijdig zou zijn met het algemeen belang, waarbij ten aanzien van het vervolgingsbeleid ingevolge art. $5 \mathrm{RO}$ aanwijzingen kunnen worden gegeven door de Minister van Justitie. Een reden van algemeen belang kan bijvoorbeeld zijn gelegen in de omstandigheid dat ingrijpen van de strafrechter ontijdig is of de goede gang van een bestuurlijk proces verstoort.'

Dit lijkt inderdaad een verstandig uitgangspunt. Andere factoren die een rol zouden kunnen spelen in de beslissing om al dan niet strafrechtelijk te vervolgen, zijn de ernst van het gepleegde feit, de door het delict veroorzaakte schade, recidive, de houding van de overheid ten aanzien van de wetsovertreding, of door de overheid in kwestie reeds de nodige maatregelen zijn genomen om de schade te herstellen alsook het feit of er regelingen zijn getroffen ter voorkoming van herhaling. Nog een opmerking over de aanwijzingsbevoegdheid van de minister van Justitie. Het is ongetwijfeld zo dat ook binnen het kader van een vervolgingsbeleid aangaande verdachte overheden de minister gebruik moet kunnen maken van deze bevoegdheid. Maar juist in deze ook (partij)politiek gevoelige materie is een uiterst kritische distantie tussen $\mathrm{OM}$ en minister geen overdreven luxe. Hoe omstreden de staatsrechtelijke positie van het OM ook mag zijn, in dossiers waarin het overheidshandelen strafrechtelijk ter discussie staat, is de rechtsgemeenschap enkel gediend met een $\mathrm{OM}$ dat voldoende machtskritische onafhankelijkheid bezit om overheden die de regels overtreden te kunnen vervolgen. ${ }^{311}$ In dat verband is het interessant een voormalig minister van Justitie aan het woord te laten:

'Ik meen dat er slechts één gebied is waarop de minister van Justitie grote terughoudendheid moet betrachten in de uitoefening van zijn beïnvloedingsmogelijkheden. Hier kan het feit dat het openbaar ministerie deel uitmaakt van de rechterlijke macht van bijzondere betekenis zijn. Ik doel op de gevallen waarin de overheid of een andere overheidsfunctionaris,

311. Zie hoofdstuk II. 
dan wel een natuurlijke persoon of rechtspersoon die een gewichtige maatschappelijke functie vervult, als verdachte in een strafproces betrokken wordt... ${ }^{312}$

\section{h. Politieke en bestuurlijke controle sluiten strafrechtelijke vervolgbaarheid niet uit}

Cruciaal vraagstuk blijft nog steeds hoe de strafrechtelijke vervolgbaarheid van overheden zich nu verhoudt tot het systeem van politieke en bestuurlijke controle. De Hoge Raad wijst er nu uitdrukkelijk op dat het vervolgen van decentrale overheden niet strijdig is met bestuurlijke en politieke controle:

'5.10. Bij het vorenstaande moet nog het volgende worden aangetekend. Het vervolgen van decentrale overheden is op zichzelf niet strijdig met het stelsel van politieke verantwoordelijkheid van ambtsdragers binnen die lichamen, voorzover daarin wettelijk is voorzien, noch met het stelsel van op die lichamen uitgeoefend bestuurlijk toezicht. Beide stelsels nemen een eigen plaats in.'

Hiermee is een hoofdargument tegen een strafrechtelijke aansprakelijkheid van overheden van de baan. ${ }^{313} \mathrm{Er}$ zijn inderdaad geen doorslaggevende theoretische bezwaren tegen het naast elkaar bestaan van strafrechtelijke aansprakelijkheid en bestuurlijke/politieke controle. Immers, deze instrumenten hebben nooit een strafrechtelijke aansprakelijkheid van individuele ambtsdragers belet. Waarom zou dat dan ineens wel het geval zijn voor de overheden waarbinnen die ambtsdragers in het kader van een bestuurstaak werkzaam zijn? Politiek/bestuurlijk toezicht staat trouwens evenmin een civielrechtelijke aansprakelijkheid of bestuursrechtelijke controle van overheden in de weg. Niet valt in te zien waarom de strafrechter niet en zijn civielrechtelijke en bestuursrechtelijke collega's wel een oordeel zouden kunnen vellen over onrechtmatig overheidshandelen.

\section{i. De reactie van kabinet en OM op Pikmeer II}

Na het arrest verschijnt een notitie van het kabinet over de problematiek van de strafrechtelijke aansprakelijkheid van overheidsorganen. ${ }^{314}$ Het kabinet ondersteunt volledig de nieuwe leer van de Hoge Raad. De notitie beklemtoont dat Pikmeer II duidelijk maakt dat openbare lichamen in beginsel strafrechtelijk kunnen worden vervolgd en dat immuniteit zeer beperkt moet zijn. Volgens het kabinet is Pikmeer II een bevestiging van de in de eerdere kabinetsnota neergelegde uitgangspunten. De Hoge Raad is blijkbaar overtuigd

312. Korthals Altes, F., 'De verhouding tussen minister van Justitie en het openbaar ministerie', Trema, 1988, 372.

313. Zie voor een bespreking van de voornaamste argumenten tegen een strafrechtelijke aansprakelijkheid van overheden hoofdstuk V.

314. TK 1997-1998, 25 294, nr. 9. Naar aanleiding van het Tweede Pikmeer-arrest zijn ook Kamervragen gesteld aan de minister van Justitie; zie TK 1997-1998, Aanhangsel van de Handelingen, 1695-1696. Zie hierover ook Van der Jagt, J.A.E., o.c., 2000, 113-117. 
geraakt van de noodzaak om de mogelijkheden van vervolging van overheden te verruimen. Een belangrijk verschil tussen de (oude) nota en de nieuwe jurisprudentie betreft echter het niveau waarop een inhoudelijke beoordeling van het overheidshandelen dient plaats te vinden. Zoals gezien, werd in de nota het standpunt verdedigd dat het vóór Pikmeer II gehanteerde immuniteitscriterium mogelijkheden biedt voor een inhoudelijke beoordeling van strafbaar gedrag. In Pikmeer II is nu echter uitgemaakt dat de beoordeling bij de rechtvaardigingsgronden moet plaatsvinden. Het kabinet komt tot de conclusie dat beide standpunten echter zijn gegrondvest op een zelfde basisfilosofie, namelijk dat niets zich verzet tegen een inhoudelijke beoordeling van het overheidshandelen.

De notitie onderstreept ook dat de uitspraak zal leiden tot 'een vruchtbare rechtsontwikkeling langs de lijnen die alle deelnemers aan het nota-overleg voor ogen stonden'. In dat licht bespreekt het kabinet de wenselijkheid van wetswijziging. Het kabinet is van mening dat het voorstel van het College van Procureurs-Generaal, neergelegd in het Advies inzake 'strafvervolging van overheden', om artikel $51 \mathrm{Sr}$ met een vierde lid uit te breiden door de staat en andere overheden expliciet onder het begrip rechtspersoon te plaatsen, niet nodig is gelet op het feit dat zij reeds onder het rechtspersoonlijkheidsbegrip van artikel 51 $\mathrm{Sr}$ vallen. Ook de vraag of het wenselijk is om de (aangescherpte) immuniteit te codificeren wordt negatief beantwoord. De strafrechtelijke immuniteit is nu immers zo uitzonderlijk geworden, dat codificatie niets toevoegt. Bovendien kan een invulling van deze uitzondering op strafvervolging beter aan de rechtspraak worden overgelaten. Tot slot wordt op de noodzaak tot invoering van een specifieke rechtvaardigingsgrond voor overheidshandelen ingegaan. Zo'n wetswijziging heeft wellicht het voordeel van duidelijkheid, maar is in het licht van Pikmeer II niet nodig, daar volgens de Hoge Raad de bestaande rechtvaardigingsgronden (artikelen 40 en $42 \mathrm{Sr}$ ) volstaan. Het kabinet beantwoordt derhalve de vraag naar de wenselijkheid van wetswijzigingen in negatieve zin. Niet zonder belang is ook dat het kabinet zich niet uitspreekt over de noodzaak tot verbetering van de bestuurlijke controlemechanismen, hetgeen in de vorige nota toch zo centraal stond. Dit is vreemd. De wenselijkheid tot verbetering van andere controlemechanismen valt immers niet automatisch weg met de verruiming van de mogelijkheid tot strafvervolging. In welke mate het kabinet nog een verbetering van andere controleinstrumenten nodig acht, is dus niet duidelijk.

Ook het OM heeft uiterst positief op Pikmeer II gereageerd. Na deze uitspraak heeft het College van Procureurs-Generaal dan ook een nieuwe aanwijzing voor de opsporing en vervolging van overheden opgesteld. ${ }^{315}$ Het centrale uitgangspunt blijft dat, voor zover de (aangescherpte) immuniteit vervolging niet verhindert, openbare lichamen in beginsel op dezelfde manier als privaatrechtelijke rechtspersonen voor gelijkaardige overtredingen moeten worden strafrechtelijk aansprakelijk gesteld. Aan dit uitgangspunt ligt zowel het gelijkheidsbeginsel als de voorbeeldfunctie van overheden ten grondslag. Voorts worden enkele richtlijnen voorgesteld. De beslissing om al dan niet te vervolgen moet worden beoordeeld aan de hand van het beslissingsmodel van de artikelen 348 en 350 Sv. Op het

315. College van Procureurs-Generaal, Aanwijzing voor de opsporing en vervolging van overheden, Staatscourant, 1998, nr. 82, 18. Zie hierover ook Van der Jagt, J.A.E., o.c., 2000, 117-123. 
vlak van de ontvankelijkheid moet de OvJ eerst nagaan of ambtenaren niet uit eigen hoofde voor een door hen gepleegd feit moeten worden vervolgd. Pas als dat duidelijk niet het geval is, wordt de strafrechtelijke blik op het openbaar lichaam zelf gericht en moet worden bekeken of de nieuwe immuniteit voorligt. Is aan het immuniteitscriterium voldaan, dan volgt een technisch sepot wegens de niet-ontvankelijkheid van de OvJ. Ligt een positief antwoord op de ontvankelijkheidsvraag in de rede, dan dient op het niveau van de bewijsvraag te worden vastgesteld of er voor de verdachte overheid voldoende bewijs is voor daderschap en schuld. De belangrijkste vraag is echter of het feit strafbaar is. In dat verband moet de OvJ nagaan of de overheid zich mogelijk met succes zal kunnen beroepen op een rechtvaardigingsgrond als gevolg van een wettelijk voorschrift (artikel $42 \mathrm{Sr}$ ) of een conflict van belangen, die een noodtoestand opleveren (artikel $40 \mathrm{Sr}$ ). Als een rechtvaardigingsgrond voorligt, dient het $\mathrm{OM}$ te seponeren. Als er geen rechtvaardigingsgrond aanwezig is, moet tenslotte worden getoetst of een vervolging alsnog inopportuun is. Een strafvervolging wordt opportuun geacht indien sprake is van evident onrecht, indien een opzettelijke overtreding van zogenaamde kernvoorschriften met als gevolg een daadwerkelijke of dreigende ernstige aantasting van het te beschermen rechtsbelang voorligt en of er sprake is van recidive. Interessant zijn vooral de door het College aangegeven contraindicaties voor vervolging (artikel $167 \mathrm{~Sv}$ ). Zo moet worden afgezien van vervolging indien een effectieve politieke, bestuurlijke of bestuursrechtelijke reactie voorligt of wanneer een handelen, ondanks het ontbreken van een rechtvaardigingsgrond, toch kan worden gezien als een te respecteren bestuurlijke belangenafweging. Volgens de vorige, naar aanleiding van Pikmeer I verschenen richtlijn zou hiervan sprake zijn indien het besluit dat aan het overheidshandelen ten grondslag ligt met 'een zorgvuldige bestuurlijke procedure' is tot stand gekomen of als het 'overheidshandelen de uitdrukkelijke goedkeuring van een vertegenwoordigend lichaam' heeft. Deze laatste aanwijzing is in de nieuwe richtlijn weggelaten. Dit lijkt mij terecht. De vraag of er goedkeuring is van een vertegenwoordigend lichaam zegt nog niets over de inhoudelijke beoordeling van de zaak. $\mathrm{Nu}$ een dergelijke beoordeling strafrechtelijk mogelijk is geworden, heeft dit criterium weinig waarde. Bovendien kan worden herhaald dat een democratische goedkeuring nog niets hoeft te zeggen over de rechtmatigheid van de overheidsgedraging.

Bemerk dat mede naar aanleiding van Pikmeer II het kabinet aan de Raad van State advies heeft gevraagd aangaande de noodzaak de strafrechtelijke immuniteit voor overheden op te heffen, en dan in het bijzonder die van de centrale overheid. Het advies van de Raad van State d.d. 28 april $1999^{316}$ wordt evenwel in hoofdstuk V nader besproken daar het advies en de reactie hierop van de minister van Justitie - vooral stilstaat bij de argumenten tegen een strafrechtelijke aansprakelijkheid van de staat.

\section{Post-Pikmeer jurisprudentie}

Nog een woord over de feitelijke afloop van de Pikmeer-zaak. Zoals gezegd, komt de Hoge Raad tot een herziening van zijn eerdere rechtspraak in een paragraaf voorafgaand aan de eigenlijke beoordeling van de cassatiemiddelen. Omdat toepassing van de nieuwe

316. TK 1999-2000, 25294, A. 
rechtsregel in casu in strijd zou zijn met de eisen van een behoorlijke procesorde en de rechtszekerheid wordt de Pikmeer-zaak opgelost aan de hand van de oude jurisprudentie. Dit betekent dat het arrest van het hof Leeuwarden wordt vernietigd omdat het hof heeft vastgesteld dat de stort van het vervuilde slib niet kan worden geïsoleerd van de baggerwerkzaamheden en dus zowel die werkzaamheden als het afvoeren van het slib in het algemeen gesproken onder de uitvoering van een aan de gemeente opgedragen overheidstaak vallen. De Hoge Raad overweegt dan ook:

\begin{abstract}
'6.3. Op grond van deze vaststellingen had het Hof, gelet op art. 209, aanhef en onder $\mathrm{h}$, gemeentewet (oud), reeds aanstonds tot geen ander oordeel kunnen komen dan dat de in het primair telastegelegde vervatte gedraging van de gemeente een haar als zodanig bij de wet opgedragen overheidstaak betreft. Uit het voorafgaande volgt (...), dat het Openbaar Ministerie in de onderhavige zaak niet-ontvankelijk is in zijn vervolging van de verdachte ter zake van het primair telastegelegde.'
\end{abstract}

Met toepassing van Pikmeer II zou de verdachte vervolgbaar zijn geweest nu het hier duidelijk een overheidstaak betreft die ook door anderen dan bestuursfunctionarissen kon worden verricht.

Het Pikmeerdossier is daarmee nog niet afgesloten. De verdachte is naast feitelijk leiding geven ook eigen daderschap ten laste gelegd. Eigen daderschap is echter alleen aan de orde wanneer de verdachte niet heeft gehandeld in het kader van de uitvoering van de aan de overheid opgedragen wettelijke bestuurstaak en deze handeling niet door de overheid als het ware is 'gedekt'. De Hoge Raad heeft de zaak verwezen naar het hof Arnhem om te bezien of de ambtenaar in kwestie nu inderdaad uit eigen daderschap moet worden veroordeeld. ${ }^{317}$ Door de verdachte wordt voor het hof Arnhem aangevoerd dat een ambtenaar in de immuniteit van de overheid deelt als hij in diensttijd iets onwettigs doet. Het hof laat dit argument echter buiten beschouwing en oordeelt alleen of de ambtenaar als persoon een strafbaar feit heeft begaan, met andere woorden als dader kan worden aangemerkt. Het hof stelt vast dat er onvoldoende bewijs is dat de verdachte tezamen met anderen (de feitelijke uitvoerders van de lozing) het verontreinigde slib in het Pikmeer heeft gestort. De verdacht heeft weliswaar feitelijke zeggenschap over een baggerdepot in het Pikmeer gehad, maar niet is bewezen dat hij zelf opdracht heeft gegeven om als extra werk tevens de vaart uit te baggeren waar het vervuilde slib vandaan komt en dat slib vervolgens in het Pikmeer te storten. Er volgt dan ook vrijspraak. ${ }^{318}$

Inmiddels heeft op 30 juni 1998 de Hoge Raad voor het eerst de kans gekregen de in Pikmeer II neergelegde rechtsregel toe te passen. Het betreft de reeds besproken 'De Gouden Bodem'-affaire waarbij de provincie Friesland werd vervolgd voor het zonder vergunning of in ieder geval in strijd daarmee accepteren of opslaan van vervuild slib in het

317. Vgl. De Roos, Th.A., l.c., 1998, 226-233.

318. Hof Amhem, 4 mei 1998, nr. 21-000201-98, niet gepubliceerd. Zie voor een korte samenvatting Staatscourant 1998, nr. 119, 4. Zie tevens Van der Jagt, J.E.A., o.c., 2000, 101-102. 
depot 'Meersloot' dat van het depot 'De Gouden Bodem' is overgebracht. Van belang is hier dat de noodzakelijke vergunning werd verleend door de GS van de provincie. De provincie is zowel vergunninghouder van een slibdepot als vergunningverlener en is bovendien verantwoordelijk voor het toezicht. Het hof Leeuwarden laat in het midden in welke mate de overbrenging/acceptatie van het slib nog kan worden aangemerkt als een overheidstaak en komt via een onverwachte redenering tot een niet-ontvankelijkheid van het OM:

'nu de Wet Milieubeheer de provincie (...) uitdrukkelijk aanwijst als bevoegd gezag en dus zowel de verlening van vergunningen als de handhaving van de naleving van de aan de vergunning verbonden voorwaarden een taak is die door de wet aan de provincie is opgedragen, dient te worden geconcludeerd, dat in het onderhavige geval de provincie Fryslân heeft gehandeld ter behartiging van een haar opgedragen overheidstaak en zich kan beroepen op strafrechtelijke immuniteit. ${ }^{.319}$

Zoals reeds werd opgemerkt, heeft het hof hier uit het oog verloren dat niet de vergunningverlening cq het toezicht ter discussie stond, maar de vraag of het zonder of in strijd met de vergunning overbrengen en/of accepteren van verontreinigd slib moet worden aangemerkt als een overheidstaak. Het oordeel van het hof komt er eigenlijk op neer dat de provincie strafrechtelijk niet kan worden vervolgd omdat zij handelde in strijd met een vergunning die zij zichzelf had verleend. Dat is niet alleen onbegrijpelijk maar ook ongerijmd omdat dit zou impliceren dat een overheid straffeloos kan blijven door het aan zichzelf verlenen van vergunningen die ze nochtans wel overtreedt. Door de Procureur-Generaal wordt dan ook als cassatiemiddel aangevoerd dat het niet-ontvankelijkheidsoordeel niet voldoende is gemotiveerd nu het hof heeft nagelaten te onderzoeken of het accepteren van baggerslib naar zijn aard en gelet op het wettelijk systeem rechtens uitsluitend door functionarissen van de provincie, in het kader van de uitvoering van een haar opgedragen bestuurstaak kan plaatsvinden. Het gaat dus helemaal niet om de vraag of de provincie de taak had vergunningen te verlenen en toezicht te houden op de naleving van de vergunningsvoorwaarden. De Hoge Raad honoreert het cassatiemiddel en oordeelt met verwijzing naar Pikmeer II:

'5.3. Strafrechtelijke immuniteit van een openbaar lichaam als bedoeld in hoofdstuk 7 Grondwet dient slechts te worden aangenomen als de desbetreffende gedragingen naar haar aard en gelet op het wettelijk systeem rechtens niet anders dan door bestuursfunctionarissen kunnen worden verricht in het kader van de uitvoering van de aan het openbaar lichaam opgedragen bestuurstaak, zodat uitgesloten is dat derden in zoverre op gelijke voet als het openbaar lichaam aan het maatschappelijk verkeer deelnemen. In andere gevallen is er wegens de hier te betrachten gelijkheid geen aanleiding immuniteit aan het openbaar lichaam te verlenen (Vergelijk HR 6 januari 1998, NJ 1998, 367).

319. Hof Leeuwarden, 4 november 1997 , MenR, 1998, nr. 18 met noot De Lange, A. 
[...] 5.4.2. Voor de beantwoording van de vraag of de verdachte immuniteit - als bedoeld in 5.3 - geniet is slechts van belang of de tenlastegelegde gedraging voldoet aan de in HR 6 januari 1998, NJ 1998, 367 neergelegde eisen.

5.4.3. Daarbij doet niet terzake of de verdachte als vergunninghouder daarnaast eveneens belast is geweest met de verlening van de vergunning en het houden van toezicht op de naleving daarvan. ${ }^{1320}$

De Hoge Raad vernietigt de bestreden uitspraak en verwijst de zaak naar het Gerechtshof te Arnhem teneinde te beoordelen of in casu inderdaad sprake is van een exclusieve overheidstaak. Mijns inziens lijkt daarvan geen sprake. Aan de hand van de rechtspraak vóór Pikmeer II - de uitspraak van het Hof Leeuwarden dateert nog van die tijd - was de vraag of de acceptatie van het slib een overheidstaak is nog moeilijk te beantwoorden omdat, zoals gezien, daarbij moet worden bekeken in welke mate die activiteit is verbonden met het uitbaggeren hetgeen duidelijk wel een aan de provincie toegewezen overheidstaak is. Met de in Pikmeer II neergelegde aanscherping, namelijk dat het moet gaan om een overheidstaak, die niet anders dan door functionarissen kan worden verricht, is deze vraag makkelijker te beantwoorden. Zelfs indien de acceptatie of de overbrenging van het slib een specifieke wettelijke overheidstaak zou zijn, dan gaat de immuniteit niet op nu deze activiteit evenals het baggeren zelf ook door particulieren kan worden uitgevoerd.

\section{CONClusies}

Aan de hand van bovenstaande rechtspraakanalyse kan de huidige stand van zaken tamelijk eenvoudig in de volgende drie stelregels worden samengevat:

1. De publiekrechtelijke rechtspersoon 'de staat' is strafrechtelijk niet aansprakelijk voor haar gedragingen en derhalve niet vervolgbaar;

2. Andere publiekrechtelijk rechtspersonen zijn strafrechtelijk niet vervolgbaar indien zij behoren tot de categorie openbare lichamen in de zin van hoofdstuk 7 Gw en het strafbare feit is begaan bij de uitvoering van een wettelijke bestuurstaak die rechtens alleen door bestuursfunctionarissen kan worden verricht;

3. Ambtenaren of arbeidscontractanten zijn strafrechtelijk onvervolgbaar wanneer zij leiding hebben gegeven aan een strafbaar feit dat is gepleegd door openbare lichamen bij de uitvoering van een wettelijke bestuurstaak die rechtens alleen door bestuursfunctionarissen kan worden verricht.

Het is duidelijk dat met Pikmeer II een belangrijke opening is gecreëerd in de strafvervolging van overheden. De strafrechtelijke immuniteit is in ieder geval wat openbare lichamen betreft, beperkt tot strafbare feiten die zijn gepleegd bij de uitvoering van een specifieke wettelijke bestuurstaak die uitsluitend door bestuursfunctionarissen kan worden

320. HR 30 juni 1998, NJ 1998, 819 (Gouden Bodem). 
verricht. In andere gevallen staat voor deze lichamen een beroep op het stelsel van rechtvaardigingsgronden open. Met dit arrest heeft de Hoge Raad tevens uitdrukkelijk afstand genomen van het oorspronkelijke standpunt dat politieke en bestuursrechtelijke controlemechanismen een strafrechtelijke aansprakelijkheid in de weg zouden staan.

Niettegenstaande het aantal gevallen waarbij decentrale overheden een strafrechtelijke immuniteit genieten nu in de praktijk sterk is beperkt, is dit geen zuivere oplossing van de problematiek. Er blijven nog talrijke vragen onbeantwoord.

In de eerste plaats rijst de vraag hoe het nu zit met de vervolgbaarheid van de staat. Daar spreekt de Hoge Raad zich niet over uit. Er wordt alleen vermeld dat de staat zich net als andere overheden aan de wet dient te houden. In het Volkel-arrest wordt de absolute immuniteit van de staat nog gemotiveerd door de onverzoenbaarheid van strafrechtelijke controle met parlementaire controle en ministeriële verantwoordelijkheid. Nu de Hoge Raad in Pikmeer II stelt dat politieke en bestuursrechtelijke controle zich niet verzetten tegen een strafrechtelijke aansprakelijkheid van overheden, behoeft de bijzondere positie van de staat een nadere motivering.

In de tweede plaats is de aanscherping van het taakcriterium niet zonder problemen. ${ }^{321} \mathrm{De}$ vraag wanneer taken uitsluitend door overheden kunnen worden verricht, kan niet eenduidig worden beantwoord. ${ }^{322}$ In de pers werd als voorbeeld de uitgifte van paspoorten genoemd. Het is niet uit te sluiten dat dit ooit door privaatrechtelijke rechtspersonen zal gebeuren. In het recente verleden werd trouwens al door de staat de fabricage van een nieuw paspoort aan een onderneming (KEP) uitbesteed. ${ }^{323}$ Daarmee rijst de meer principiële vraag of het nieuwe taakcriterium niet een meer fundamentele en materiële oplossing ontwijkt. Een belangrijk bezwaar tegen de immuniteitscriteria (openbaar lichaam en wettelijke overheidstaak) die reeds golden vóór Pikmeer II was steeds dat deze uitsluitend een formeel karakter hadden. De Hoge Raad wilde een duidelijk onderscheid maken tussen handelen van de overheid 'als zodanig' en handelen van de overheid 'op gelijke voet met een particulier'. De zoektocht naar het verschil tussen acta iure imperii en acta iure gestionis, die op het vlak van de civielrechtelijke aansprakelijkheid al lang werd opgegeven, kreeg een centrale betekenis in de afbakening van de strafvervolging van overheden. De achterliggende idee was dat met deze formele criteria iedere materiële en inhoudelijke toetsing van het overheidshandelen kon worden vermeden door de zaak te doen stranden bij de ontvankelijkheidsvraag. Uitgangspunt was immers dat de controle op bestuurstaken moest plaatsvinden via het bestuurlijk toezicht en niet (ook) via de strafrechtelijke handhaving. Nu de Hoge Raad van dit standpunt terecht afstand heeft genomen, rijst de vraag wat de meerwaarde is van zowel het subjectcriterium als het aangescherpte taakcriterium. Het getuigt niet van originaliteit om de (ook door de Hoge Raad zelf erkende) kritiek op het formele karakter van niet-ontvankelijkheidscriteria op te lossen door de toevoeging van een nieuw formeel criterium, dat de problematiek alleen

321. Vgl. Peters, J.A.F., l.c., 1998, 33.

322. Zie tevens Hendriks, L.E.M. en De Lange, A., l.c., 1998, 44.

323. Zie Brants, C.H. en De Lange R., o.c., 1996, 40-41. 
maar verschuift. Alle argumenten die de Hoge Raad aanhaalt om tot een bijstelling te komen van zijn eerdere jurisprudentie rechtvaardigen evenzeer vervolgbaarheid van overheden voor handelingen die alleen door hun functionarissen kunnen worden verricht.

In de derde plaats doet de verwijzing naar het stelsel van rechtvaardigingsgronden de vraag rijzen of alleen decentrale overheden zich daarop kunnen beroepen of dat ook andere publiekrechtelijke rechtspersonen of wellicht zelfs privaatrechtelijke rechtspersonen die overheidstaken uitvoeren daar beroep op kunnen doen. Een zelfde vraag rijst met betrekking tot de opportuniteit van de strafvervolging en de strafmaat. Waarom zou een decentrale overheid bij de uitvoering van een niet-exclusieve overheidstaak zich eerder met succes op een rechtvaardigingsgrond kunnen beroepen of een lagere straf krijgen opgelegd dan een privaatrechtelijke rechtspersoon die zich in een gelijkaardige positie bevindt? Geldt ook dan niet het gelijkheidsbeginsel?

Meer algemeen kan worden opgemerkt dat met het huidige tweesporensysteem vervolgingsuitsluitingsgronden naast rechtvaardigingsgronden - de oorspronkelijke ratio van strafrechtelijke onvervolgbaarheid van overheden op de helling is komen te staan. De vóór Pikmeer II bestaande immuniteiten werden hoofdzakelijk gemotiveerd door de vooronderstelling dat strafbare feiten eigenlijk reeds op voorhand zijn gerechtvaardigd wanneer ze zijn gepleegd in het kader van een wettelijke overheidstaak. Het is echter duidelijk dat noch het algemeen belang, noch de kwalificatie overheidstaak als dusdanig het plegen van strafbare feiten kunnen rechtvaardigen. ${ }^{324}$ Dat wordt nu door de Hoge Raad ook met zoveel woorden toegegeven. Of een strafbaar feit, gepleegd in het kader van een overheidstaak, in concreto gerechtvaardigd is, moet blijken uit de door de overheid gemaakte belangenafweging die door de strafrechter op wet- en rechtmatigheid moet worden getoetst. Deze materiële beoordeling van de strafrechtelijke rechtmatigheid van overheidsgedragingen gebeurt strafprocessueel aan de hand van de rechtvaardigingsgronden. Het is dan vreemd dat een strafrechtelijke controle uitgesloten blijft wanneer het gaat om exclusieve overheidstaken, dat wil zeggen, taken die alleen door bestuursfunctionarissen kunnen worden uitgevoerd. Blijkbaar gaat de Hoge Raad er nog steeds van uit dat bij dit soort overheidstaken - in tegenstelling tot andere overheidstaken - de rechtvaardiging tot het plegen van strafbare feiten wel reeds op voorhand bestaat en zij dus daarom niet strafrechtelijk mogen worden gecontroleerd. De vraag rijst waarin die zogenaamde rechtvaardiging dan wel bestaat en waarop die is gebaseerd. Er kan in dat verband worden verwezen naar de problematiek van wederrechtelijke vergunningverlening die in hoofdstuk VII centraal staat. Overheden kunnen via wederrechtelijke vergunningverlening rechtstreeks bijdragen tot milieuverontreiniging. Vergunningverlening is net als handhaving een publiekrechtelijke bevoegdheid en dus op grond van Pikmeer II in beginsel een exclusieve overheidstaak hetgeen betekent dat overheden niet vervolgd kunnen worden voor het afgeven van illegale vergunningen. Niettemin kan moeilijk worden volgehouden dat het in strijd met wet en recht verlenen van vergunningen reeds op voorhand gerechtvaardigd zou zijn omdat het om een exclusieve overheidstaak gaat en dus om die reden iedere strafrechtelijke controle zou zijn uitgesloten. Of een vergunningverlening

324. Zie noot 't Hart, A.C. onder het eerste Pikmeer-arrest, $N J$ 1996, 513. 
inderdaad wederrechtelijk is en derhalve aan een strafbaar feit ten grondslag ligt moet steeds in concreto worden beoordeeld. En waar hoort dergelijk beoordeling anders thuis dan bij de beantwoording van de vraag of in casu sprake is van een rechtvaardigingsgrond? De immuniteitscriteria behoeven dus duidelijk een nadere verklaring, te meer nu men zich nauwelijks van de indruk kan ontdoen dat de ommegang van de Hoge Raad hoofdzakelijk lijkt te zijn ingegeven door pragmatisme en maatschappelijke druk.

\section{§3. Frankrijk}

\section{A. INLEIDING}

Met de invoering van de nieuwe Code pénal kent het Franse strafrecht sinds 1 maart 1994 de strafrechtelijke aansprakelijkheid van de rechtspersoon. Het gaat om artikel 121-2 CP:

'Les personnes morales, á l'exclusion de l'État, sont responsables pénalement, selon les distinctions des articles 121-4 à 121-7 et dans les cas prévus par la loi ou le règlement, des infractions commises, pour leur compte, par leurs organes ou représentants.

Toutefois, les collectivités territoriales et leurs groupements ne sont responsables pénalement que des infractions commisses dans l'excercice d'activités susceptibles de faire l'objet de conventions de délégation de service public. La responsabilité pénale des personnes morales n'exclut pas celle des personnes physiques auteurs ou complices des mêmes faits.'

Allereerst kan worden opgemerkt dat overeenkomstig artikel 121-2 lid 1 CP iedere rechtspersoon, dus ook de publiekrechtelijke rechtspersoon, slechts strafrechtelijk aansprakelijk kan worden gesteld 'dans les cas prévus par la loi ou le règlement'. Dat betekent dat steeds in voorkomend geval moet worden bekeken of de rechtspersoon wel voor een bepaald misdrijf vervolgd kan worden. Er is in tegenstelling tot Nederland gekozen voor het specialiteitsbeginsel, dat wil zeggen dat rechtspersonen slechts voor bepaalde delicten aansprakelijk kunnen worden gesteld. ${ }^{325}$

Om te kunnen bepalen voor welke delicten een strafrechtelijke aansprakelijkheid in de rede ligt, dient te worden gekeken naar het bijzondere deel van de Code pénal waar de misdaden, wanbedrijven (boeken II-IV) en overtredingen (boek VI) staan opgesomd. Daarnaast is een aantal bijzondere strafwetten van belang. Daaronder vallen ook talrijke milieuwetten, met name in de sfeer van luchtvervuiling, waterverontreiniging, zuiveringsinstallaties en afvalverwerking. ${ }^{326}$ Dergelijk enumeratiesysteem stuit in de literatuur op

325. Bouloc, B., 'Le domaine de la responsabilité pénale des personnes morales', Rev. Soc., 1993, 291: Mouloungui, C., 'La nature de la responsabilité pénale des personnes morales en France', RDP, 1995, 143; Geeroms, S., 'La responsabilité pénale de la personne morale: une étude comparative', R.I.D.C., 1996, 565-566.

326. Zie voor een gedetailleerde opsomming Deruyck, F., De rechtspersoon in het strafrecht., Gent, Mys \& Breesch, 1996, 230. 
gegronde kritiek. In de eerste plaats is het gevaar groot dat de selectie van strafbepalingen die ook door rechtspersonen kunnen worden overtreden niet op basis van inhoudelijke criteria maar arbitrair - vaak onder druk van lobbying - tot stand wordt gebracht. ${ }^{327}$ Daarnaast getuigt dergelijk stelsel nog steeds van een visie dat de verantwoordelijkheid van de rechtspersoon een (kwalijke) uitzondering vormt op het klassieke gedachtegoed dat het strafrecht primair is bedoeld voor natuurlijke personen. ${ }^{328}$

\title{
B. WETTELIJKE NIET-STRAFBAARHEID VAN OVERHEDEN
}

Wat de strafbaarheid van de publiekrechtelijke rechtspersoon aangaat, moet een onderscheid worden gemaakt naar gelang de aard van de publiekrechtelijke rechtspersoon. ${ }^{329}$ Voor de staat is expliciet in artikel 121-2 CP een volledige strafrechtelijke immuniteit neergelegd: 'Les personnes morales, à l'exclusion de l'État, sont responsables pénalement' (cursief, DR). Wat de lagere overheden, de zogenaamde 'collectivités territoriales' (zoals gemeenten en departementen) betreft, wordt slechts een gedeeltelijke immuniteit aanvaardt. Het tweede lid van artikel 121-2 CP bepaalt dat de strafrechtelijke aansprakelijkheid slechts mogelijk is voor 'les infractions commises dans l'exercice d'activités susceptibles de faire l'objet de conventions de délégations de service public.' Hetzelfde geldt voor de samenwerkingsverbanden, zoals de intergemeentelijke bestuursorganen ('syndicats de commune'). Met andere woorden, de strafrechtelijke aansprakelijkheid voor lagere overheden is uitgesloten wanneer het delict wordt gepleegd bij de behartiging van overheidstaken waarvan de uitvoering niet ook aan particulieren kan worden uitbesteed.

\begin{abstract}
'Ainsi, lorsqu'une commune exploite en régie un service de transport en commun, de cantine scolaire, de ramassage d'ordures ménagères ou de distribution d'eau, sa responsabilité pénale pourra être engagée pour les infractions commises dans l'exercice de cette activité, exactement comme pourrait l'être la responsabilité de la société concessionaire si ce mode de gestion avait été choisi. La disposition introduite par le Parlement permet donc d'éviter territoriale dans l'exercice de cette activité relevant de ses prérogatives de puissance publique: maintien de l'ordre public, tenue des registres de l'État civil... ne peuvent engager sa responsabilité pénale. ${ }^{.330}$
\end{abstract}

Andere publiekrechtelijke rechtspersonen, zoals de openbare instellingen ('etablissements publiques') kunnen daarentegen wel worden gestraft en dit ongeacht de aard van de activiteit die zij verrichten.

327. Coeuret, A., 'La nouvelle donne en matière de responsabilité', Droit social, 1994, 632.

328. Deruyck, F., o.c., 1996, 232.

329. Desportes, F. en Le Gunehec, F., 'Présentation des dispositions du nouveau Code pénal', JCP, 1992, I, 3615.

330. Desportes, F., 'Le nouveau régime de la responsabilité pénale des personnes morales', Sem. Jur., $1993,71$. 
Het is interessant te vermelden dat in het oorspronkelijke wetsontwerp van artikel 121-2 CP niet alleen de staat maar ook lagere overheden en 'groupements de collectivités publiques' volledig van de strafrechtelijke aansprakelijkheid van de rechtspersoon waren uitgesloten. De parlementaire bespreking over het ontbreken van enige strafrechtelijke aansprakelijkheid in hoofde van alle publiekrechtelijke rechtspersonen leidde uiteindelijk tot een ware politieke strijd tussen Kamer en Senaat. Terwijl de Senaat eerst niet wou raken aan een gehele immuniteit voor publiekrechtelijke rechtspersonen, ${ }^{331}$ werd door de Kamer aangevoerd dat met name overheidsinstellingen en de territoriale gemeenschappen zich aan een strafrechtelijke aansprakelijkheid moesten onderwerpen ${ }^{332}$ Een immuniteit zou leiden tot een ongerechtvaardigde ongelijkheid tussen privaatrechtelijke en publiekrechtelijke rechtspersonen. ${ }^{333}$ De Senaat bleef niettemin bij haar rigide standpunt. De Kamer formuleerde uiteindelijk een ook voor de Senaat aanvaardbaar compromis dat resulteerde in de huidige redactie van artikel 121-2 CP.

Ook op sanctioneel niveau werd voor de publiekrechtelijke rechtspersonen een aparte regeling gevonden. In artikel 131-39 CP werd een laatste lid opgenomen dat de straffen van ontbinding en onderbewindstelling niet van toepassing verklaart op publiekrechtelijke rechtspersonen. Een andere visie zou inderdaad een te grote inbreuk maken op de noodzakelijke continuïteit van de openbare diensten. ${ }^{334}$

Nu naar Frans recht overheden in talrijke gevallen zich zullen kunnen beroepen op de strafrechtelijke immuniteit, rijst de vraag of ook natuurlijke personen die deel uitmaken van de overheid onvervolgbaar zijn. Naar de letter van de wet lijkt de algemene immuniteit uitsluitend betrekking te hebben op de staat en de gedeeltelijke immuniteit enkel te gelden voor de 'collectivités territoriales' en hun 'groupements'. Daarnaast bepaalt het derde lid van 121-2 CP uitdrukkelijk dat 'la responsabilité pénale des personnes morales n'exclut pas celle des personnes physiques auteurs ou complices des mêmes faits.' Frankrijk heeft gekozen voor het principe dat de strafrechtelijke aansprakelijkheid van de rechtspersoon niet mag worden beschouwd als een substituut voor de eigen strafrechtelijke aansprakelijkheid van de natuurlijke persoon. Natuurlijke personen, via dewelke door de rechtspersoon het delict is gepleegd, blijven dus in eigen hoofde aansprakelijk. Het is aan het openbaar ministerie om te beslissen of de (publiekrechtelijke) rechtspersoon, ofwel de natuurlijke persoon (ambtenaar), ofwel beiden worden vervolgd. Nu de strafrechtelijke aansprakelijkheid van de natuurlijke persoon niet een verlengstuk is van de vervolgbaarheid of strafbaarheid van de rechtspersoon, maar een eigen aansprakelijkheid betreft - zoals die ook reeds bestond voor de invoering van artikel 121-2 CP - lijkt de conclusie gerechtvaardigd dat de immuniteit voor overheden niet opgaat voor de daarin werkzame functionarissen (bijvoorbeeld burgemeesters).

331. Zie het oorspronkelijke wetsontwerp zoals aangenomen door de Senaat en overgemaakt aan de Kamer, Franse Parl. St., Ass. Nat., 2ième S.O. 1988-89, nr. 693, 8.

332. Eerste verslag van de Kamercommisie 'des Lois constitutionnelles, de la législation et de l'administration générale de la République', Franse Parl. St., Ass. Nat., lière S.O. 1989-90, nr. $896,120-121$.

333. Deruyck, F., o.c., 1996, 178.

334. Deruyck, F., o.c., 1996, 178. 


\section{§4. België}

\section{A. INLEIDING}

De strafrechtelijke positie van overheden staat momenteel in België sterk ter discussie. Op 4 mei 1999 is immers de strafrechtelijke verantwoordelijkheid van de rechtspersoon in het Belgische Strafwetboek (BSw) ingevoerd en daarbij is door de wetgever bepaald dat overheden van de werking van het strafrecht moeten worden uitgesloten. ${ }^{335}$ Het nieuwe artikel 5, lid $4 \mathrm{BSw}$ stelt dat de federale staat, de gewesten, de gemeenschappen, de provincies, de Brusselse agglomeratie, de gemeenten, de binnengemeentelijke territoriale organen, de Franse gemeenschapscommissie, de Vlaamse gemeenschapscommissie en de gemeenschappelijke gemeenschapscommissie en de OCMW's niet strafrechtelijk verantwoordelijk zijn.

Dit is een belangrijke breuk met het verleden. Vóór de invoering van de strafrechtelijke verantwoordelijkheid van de rechtspersoon werden door overheden gepleegde milieudelicten aan natuurlijke personen toegerekend. Wegens het ontbreken van de strafrechtelijke verantwoordelijkheid van de rechtspersoon konden overheden, net zomin als ondernemingen, immers niet strafrechtelijk worden aangepakt. De strafrechter was dus genoodzaakt door overheden gepleegde strafbare feiten aan een natuurlijke persoon toe te rekenen. Het is belangrijk erop te wijzen dat tegen deze toerekening noch door de rechtspraak, noch door de rechtsleer fundamentele bezwaren werden geuit in de zin dat het

335. B.S. 22 juni 1999, 23411. Deze wet is in werking getreden op 2 juli 1999. Het aantal voorstanders voor de invoering van de strafrechtelijke aansprakelijkheid van de rechtspersoon in het Belgisch strafrecht was de laatste jaren in de literatuur sterk toegenomen: zie o.a. Constant, J., 'La protection pénale de l'environnement en droit belge', in Rapports Belges aux Xe Congrès International de Droit Comparé, Brussel, Bruylant, 1978, 565-602; Delatte, P., 'La question de la responsabilité pénale des personnes morales en droit belge', $R D P, 1980,191$ e.v.; De Swaef, M., 'Over de strafrechtelijke verantwoordelijkheid van rechtspersonen' (noot onder Antwerpen, 22 september 1984), $R W, 1985-86,1851-1852$; Deruyck, F., 'Over de problematiek van de rechtspersoon (en ermee gelijkgestelde groeperingen) in het strafrecht naar Belgisch en Duits recht: de administratieve weg?', $R W, 1990-91,1251-1267$; Deruyck, F., 'Societas delinquere potest... en wat dan nog? Over het ontbreken van strafrechtelijke verantwoordelijkheid van rechtspersonen naar Belgisch recht', Panopticon, 1991, 249-259; De Nauw, A., Les métamorphoses administratives du droit pénal de l'entreprise, Gent, Mys \& Breesch, 1994, 18 21; Faure, M. en Roef, D., 'Naar een wettelijke formulering van de strafrechtelijke aansprakelijkheid van de rechtspersoon', $R W, 1995-1996,417-432$; Deruyck, F., o.c., 1996. Ook op legislatief niveau was er de laatste jaren op dit vlak veel beweging. Zo werd reeds op het niveau van het Vlaamse Gewest in het voorontwerp decreet milieubeleid voorgesteld de strafrechtelijke aansprakelijkheid voor rechts-personen in te voeren. Zie Interuniversitaire Commissie tot Herziening van het Milieurecht, Voorontwerp Decreet Milieubeleid, Brugge, Die Keure, 1995, 799-805. Zie tevens Faure, M., 'Strafsancties', in Bocken, H. en Verbeek, P. (red.), Voorontwerp van Kaderdecreet Milieuhygiëne vol. 1, Interuniversitaire Commissie tot Herziening van het Milieurecht, Seminarie voor Milieurecht, Universiteit Gent, 1991, 199-261. Op basis van het regeerakkoord van de regering Dehaene II heeft de Belgische Ministerraad op 25 juli 1997 een wetsontwerp tot invoering van de strafrechtelijke aansprakelijkheid van de rechtspersoon goedgekeurd. De Wet van 4 mei 1999 is daarvan het eindresultaat. 
de strafrechter niet zou zijn toegestaan een oordeel te vellen over het overheidshandelen. Er werd dan ook verwacht dat met de invoering van de strafbaarheid van de rechtspersoon in België ook overheden zouden kunnen worden vervolgd, daar tot dan toe geen bezwaren bestonden om functionarissen voor door overheden gepleegde delicten te vervolgen, hoewel dit vaak een strafrechtelijke controle op het overheidshandelen als geheel impliceerde. In de literatuur werd dus niet zozeer het bestaan van strafrechtelijke controle op overheidshandelen gehekeld, maar het probleem dat, zoals bij ondernemingen, het door de overheidsorganisatie gepleegde delict aan een natuurlijke persoon moest worden toegerekend. Die problematiek blijft dus bestaan.

$\mathrm{Nu}$ is de invoering van de strafrechtelijke verantwoordelijkheid van de rechtspersoon in België op zichzelf wel een positief feit. De bestrijding van ondernemingscriminaliteit wordt hierdoor sterk vereenvoudigd omdat thans de bedrijven zelf kunnen worden veroordeeld en de strafrechter niet langer het strafbare feit moet toerekenen aan een natuurlijke persoon binnen de organisatie van de rechtspersoon. Wat de bestrijding van overheidscriminaliteit betreft rijzen nu echter een aantal wezenlijke vragen omdat overheden van de werking van het strafrecht zijn uitgesloten. Blijft alles nu bij het oude en zal nog steeds het door een overheid gepleegde feit aan een natuurlijke persoon moeten worden toegerekend of zullen ook zij zich op niet-strafbaarheid kunnen beroepen? Deze en ook andere vragen staan in deze paragraaf centraal.

Deze paragraaf is als volgt opgebouwd. Allereerst wordt voor een goed begrip van de huidige Belgische regeling aandacht besteed aan de positie van de rechtspersoon vóór de Wet van 4 mei 1999 (B). Vervolgens komen enkele strafrechtsdogmatische uitgangspunten van de Wet van 4 mei 1999 aan bod (C). Daarna wordt aan de hand van een rechtspraakanalyse besproken op welke wijze door overheden gepleegde milieudelicten aan natuurlijke personen tot nu toe werden toegerekend (D). Vervolgens wordt bij de ratio van de nietstrafbaarheid van de overheid stilgestaan (E) als ook bij de op 4 mei ingevoerde regeling van de civielrechtelijke aansprakelijkheid van gemeenten en provincies voor strafbare feiten door hun functionarissen begaan (F). Ik eindig met enkele slotbedenkingen (G).

\section{B. DE RECHTSPERSOON IN HET BELGISCHE STRAFRECHT VÓÓR DE WET VAN 4 MEI 1999}

Tot en met het begin van de twintigste eeuw gold in België het principe Societas non delinquere potest. In navolging van de individualistische geest die aan de Code pénal van 1810 en het Strafwetboek van 1867 ten grondslag lag, oordeelde het Hof van Cassatie meermaals dat een rechtspersoon geen strafbare feiten kon begaan. Een rechtspersoon was immers niet meer dan een abstract en fictief wezen. ${ }^{336}$ Vanaf de jaren dertig wordt meer en meer afstand genomen van het fictieve karakter van de rechtspersoon. Zo oordeelde het Hof van Cassatie in 1934 dat

336. Cass., 13 februari 1905, Pas., 1905, I, 127; in dit arrest werd de rechtspersoon omschreven als een 'un être fictif, dépourvu de volonté intelligente et libre.' Cass., 30 maart 1911, Pas., 1991, I, 193; Cass., 19 juni 1933, Pas., 1933, I, 270. 
'de verplichting om de wetten en reglementen na te leven evenzeer op een fictief wezen als op fysieke personen rustte'. ${ }^{337}$

Desondanks werd de rechtspersoon strafrechtelijk nog steeds als een fictie beschouwd wat werd bevestigd in de expliciete ontkenning van het daderschap van de rechtspersoon daar

\begin{abstract}
'een vennootschap zonder twijfel geen misdrijf kan begaan maar dat in dat geval het de fysieke personen zijn door wie zij gehandeld heeft, die in werkelijkheid de daders van de inbreuk zijn..."338
\end{abstract}

Voor een daadwerkelijke aanvaarding van het daderschap van de rechtspersoon moet worden gewacht tot na de Tweede Wereldoorlog.

Het Hof van Cassatie oordeelde in respectievelijk 1946 en 1948 dat rechtspersonen strafbare feiten kunnen begaan. ${ }^{339}$ Zo werd het oorspronkelijke adagium geherformuleerd in Societas delinquere potest, sed puniri non potest. Dit is tot en met de wet van 4 mei 1999 constante rechtspraak gebleven. Deze rechtspraak laat zich tamelijk eenvoudig samenvatten in de volgende drie stelregels: de rechtspersoon kan weliswaar een delict plegen, maar kan daarvoor niet worden gestraft, zodat het de natuurlijke persoon is die moet worden vervolgd. $^{340}$

De voornaamste reden voor uitsluiting van de strafrechtelijke aansprakelijkheid van de rechtspersoon situeerde zich op het niveau van de verwijtbaarheid of morele toerekenbaarheid. Daar ligt ook de legitimatie van de straf. Er dient, zo was de klassieke redenering, steeds een of andere vorm van verwijtbaarheid te worden toegerekend om tot strafbaarheid

337. Cass., 26 februari 1934, Pas., 1934, I, 180.

338. Cass., 26 februari 1934, Pas., 1934, I, 180.

339. Cass. 8 april 1946, A.C., 1946, 137; Cass., 16 december 1948, J.T., 1949, 150.

340. Deruyck, F., l.c., 1991, 253. De herformulering van het oude adagium betekende evenwel niet dat de rechtspersoon 'van nature' tot het begaan van strafbare feiten in staat werd geacht. Het daderschap van de rechtspersoon moest steeds worden gedacht als een constructie van feitelijke en morele toerekening van handelingen van fysieke personen aan rechtspersonen. 'Une personne morale peut donc commettre, par son organe, aussi bien un fait qualifié infraction qu'un autre acte illicite.' (cursief, DR), aldus Hayiot de Termicourt, R., Concl. bij Cass., 16 december 1948, $J . T ., 1949,150$. Het arrest van 1948 stelt eveneens dat 'de daad verricht in het kader van haar werkzaamheden door een orgaan van een rechtspersoon een daad is van de rechtspersoon zelf...'. Er wordt dus geen afbreuk gedaan aan de fictieleer. De werkelijke dader is steeds een natuurlijke persoon. In de latere cassatierechtspraak wordt deze visie behouden zij het verder uitgebouwd in de zin dat de categorie van fysieke personen via dewelke het daderschap van de rechtspersoon wordt geconstrueerd en aan dewelke dit daderschap vervolgens wordt toegerekend niet langer beperkt is tot organen maar wordt uitgebreid tot feitelijke bedrijfsvoerders, ondergeschikten, aangestelden en zelfs derden: zie o.a.: Cass., 17 september 1962, Pas., 1963, I, 61; Cass., 19 september 1972, A.C., 1973, 69; Cass., 1 oktober 1973, A.C., 1974, 105; Cass., 7 oktober 1974, A.C., 1975, 169; Cass., 15 april 1975, A.C., 1975, 890; Cass., 12 december 1978, A.C., 1978-79, 423; Cass., 10 april 1979, A.C., 1978-79, 953; Cass., 12 juni 1979, A.C., 1978-79, 1216; Cass., 25 april 1989, A.C., 1988-89, 990; Cass., 10 oktober 1989, T.B.H., 1990, 393. 
te kunnen besluiten. Daar deze verwijtbaarheid in hoofde van de rechtspersoon als onbestaande werd geacht, was men verplicht deze verwijtbaarheid bij fysieke personen vast te stellen. Het zijn deze laatsten die dan ook (moesten) worden gestraft. In het principe dat het wel de rechtspersoon is die het delict heeft gepleegd, maar dat het de natuurlijke persoon is die daarvoor dient te worden bestraft is de strafrechtelijke logica ver zoek. ${ }^{341}$

Het principe van de niet-strafbaarheid van de rechtspersoon werd echter op verschillende manieren uitgehold. Zo werd de onmogelijkheid om rechtstreeks aan rechtspersonen sancties op te leggen omzeild via de burgerrechtelijke aansprakelijkheid van de rechtspersoon voor de geldboeten en andere vermogensstraffen, die de natuurlijke persoon krijgt opgelegd. ${ }^{342}$ Daarnaast was het onmiskenbaar zo dat talrijke straffen, hoewel zij de iure aan een natuurlijke persoon worden opgelegd, de facto bij hun tenuitvoerlegging rechtstreeks de rechtspersoon zelf raken. ${ }^{343}$ Daarbij kan worden gedacht aan de sluiting van de inrichting, aanplakking of bekendmaking van de rechterlijke uitspraak en de verbeurdverklaring van de illegaal verworven winsten ${ }^{344}$. Daarenboven werden sancties toegepast die juridisch niet met de kwaliteit van straffen zijn bekleed, maar die desalniettemin een gelijke strekking hebben en rechtstreeks de corporatie kunnen treffen. Dat is het geval met de administratieve sancties. Het kan niet worden ontkend dat de onmogelijkheid rechtspersonen via het strafrecht aan te pakken mede ertoe heeft geleid dat de wetgever zijn toevlucht is gaan zoeken in het stelsel van administratieve sancties:

'On constate (...) que lorsque le système pénale bute sur l'irresponsabillité pénale des personnes morales, le législateur n'a pas remis ce principe fondamentalement en question mais fait appel à des sanctions dites administratives pour pouvoir les appliquer aux personnes morales. En réalité c'est la seule procédure qui est administrative, la sanction étant une peine. ${ }^{345}$

De keuze om rechtspersonen via administratieve sancties aan te pakken was niet zozeer door decriminalisering of depenalisering ingegeven maar door dejustitialisering en effectievere bestraffing. ${ }^{346}$ De niet-strafbaarheid van corporaties lag zo mede aan de basis van de

341. Deruyck, F., o.c., 1996, 43; François, L., 'Remarques sur quelques questions de droit pénal social, particulièrement sur l'imputabilité', $R D P, 1968-69,489-518$.

342. Faure, M., De strafrechtelijke toerekening van milieudelicten, Antwerpen, MAKLU, 1992, 8592; Deruyck, F., o.c., 1996, 45-48.

343. Screvens, S., 'Les sanctions applicables aux personnes morales dans les Etats des Communautés européennes', $R D P, 1980$, 166-168.

344. De verbeurdverklaring van de illegaal verworven winsten is sinds de wet van 17 juli 1990 tot wijziging van de artikelen 42,43 en 505 van het Strafwetboek en tot invoeging van een artikel 43 bis in hetzelfde wetboek een straf van het commune strafrecht geworden. Zie tevens Deruyck, F., o.c., 1996, 54-56.

345. De Nauw, A., o.c., 1994, 21.

346. Hartmann, A.R. en Van Russen Groen, P.M., 'Van strafrecht naar bestuursstrafrecht: de derde criminaliseringsgolf?', in De Doelder, H. en Rogier, L.J.J. (red.), Opstellen over bestuursstrafrecht, Arnhem, Gouda Quint, 1994, 61-78. 
depreciatie van het strafrecht en de punitivisering van het bestuursrecht. ${ }^{347}$ De meeste sancties die via het administratief recht aan rechtspersonen konden werden opgelegd, zoals de bedrijfssluiting, kunnen echter niet langer worden afgedaan als louter reparatoir; het gaat vrijwel steeds om klassieke leedtoevoegende en retributieve straffen. ${ }^{348}$ Blijkbaar was de loutere etikettering van de sanctie als 'administratief' voldoende om alle bezwaren tegen de bestraffing van de rechtspersoon, inclusief het schuldbeginsel, op te heffen.

Niet alleen vanuit dogmatisch en rechtstheoretisch perspectief maar ook vanuit praktisch oogpunt stuitte deze rechtspraak op ernstige bezwaren. De formulering van het adagium mocht dan gewijzigd zijn; de oplossing die de rechtspraak in concreto moest geven aan het vraagstuk van het ontbreken van de strafrechtelijke verantwoordelijkheid van rechtspersonen bleef onveranderd:

'ook nu moet worden nagegaan, via welke natuurlijke persoon de rechtspersoon gehandeld heeft. Alleen werd vroeger gesteld, dat op deze natuurlijke persoon zélf de strafrechtelijk gesanctioneerde verplichting rustte, zodat hij als werkelijke dader van het misdrijf moet beschouwd worden, terwijl nu wordt voorgehouden, dat het de rechtspersoon is, die de verplichting moet naleven en dus de dader van het misdrijf is, maar dat moet worden uitgemaakt op welke natuurlijke persoon dit daderschap vanuit het oogpunt van de bestraffing moet worden afgewenteld..$^{349}$

Het bleek dan vaak onmogelijk vast te stellen aan welke fysieke personen (organen, aangestelden, werknemers en zelfs derden) binnen de rechtspersoon het misdrijf kan worden toegerekend. ${ }^{350}$ Vooral bij complexe ondernemingen was een gedegen selectie van natuurlijke personen een moeilijke opgave. ${ }^{351}$ Geconfronteerd met een relatief groot aantal potentiële verdachten was het ook voor het openbaar ministerie (OM) lastig de opportuniteit van een vervolging naar behoren in te schatten. In milieuzaken stelt men dan ook vast dat 'een groot aantal verdachten terecht moet staan en dat de rechter dan maar moet uitmaken namens wie de rechtspersoon in het concrete geval was opgetreden'. ${ }^{352}$ Het probleem is dat de verantwoordelijkheid ofwel van de een naar de ander wordt doorgeschoven of te collectief is om bij een of zelfs meerdere personen te kunnen worden vastgesteld. $^{353}$

347. De Nauw, A., o.c., 1994, 19-21; Roef, D., 'Strafrecht versus leefmilieu: van geschiktheid naar ondergeschiktheid?', TMR, 1995, 471.

348. Legros, R., 'A propos du projet de loi sur les amendes administratives', JTT, 1971, 99.

349. Deruyck, F., l.c., 1991, 254; Colaes, J., l.c., 1984, 155.

350. De Swaef, M., L.c., 1985-86, 1851.

351. Deruyck, F., o.c., 1996, 41.

352. Faure, M., o.c., 1992, 116.

353. In dit verband kan worden verwezen naar het befaamde Petrochim-arrest waar een vrijspraak werd gebaseerd op de omstandigheid dat de ten laste gelegde feiten onmogelijk kunnen worden gedacht als 'het individueel en persoonlijk toedoen of de nalatigheid van de organen of de aangestelden van het bedrijf...', Antwerpen, 24 april 1992, TMR, 1992, 18, met noot Deruyck, F. 
Deze problemen verstoorden in de eerste plaats de finaliteit van de strafwetgeving en zetten de hanteerbaarheid van het (milieu)strafrecht op de helling. In de tweede plaats had deze problematiek een mogelijke uitholling van de rechtsbeschermende en machtsnormerende dimensie van het strafrecht tot gevolg. Volgens De Nauw leidt de toerekening van door rechtspersonen gepleegde feiten aan natuurlijke personen vanuit rechtsbeschermingsperspectief dan ook tot 'certaines injustices de procédures actuellement menées contre des personnes physiques..... ${ }^{354}$

Kenmerkend voor de rechterlijke toerekening is immers dat uit het oog wordt verloren dat gedragingen in de sfeer van de rechtspersoon veelal het individualisme overstijgen. Zo zijn in werkelijkheid vele fouten veeleer te wijten aan een gebrekkige takkverdeling in de organisatie zelf. Dit is veelal een collectieve nalatigheid veeleer dan een duidelijk aanwijsbare fout, die aan een of andere natuurlijke persoon kan worden toegeschreven. ${ }^{355}$ Dergelijke situaties hadden dan ook vaak vrijspraak tot gevolg omdat een individuele verdeling van de evident collectieve gedraging niet mogelijk was; soms leidde dit ook tot een geforceerde vaststelling van het feitelijk en moreel oorzakelijk verband tussen natuurlijke persoon en delict. ${ }^{356} \mathrm{Bij}$ grote bedrijven kon men vaststellen dat, tegen de achtergrond van het schuldbeginsel, zo de onwenselijke situatie ontstond dat leden van de raad van bestuur, die in de praktijk weinig te maken hadden met de feitelijke gang van zaken binnen hun bedrijf, strafrechtelijk aansprakelijk werden gehouden voor het gepleegde delict. ${ }^{357}$ Ook ondergeschikten kregen soms een aansprakelijkheid in hun schoenen geschoven waarvan de wenselijkheid zeer twijfelachtig is. ${ }^{358}$

Samengevat: kenmerkend voor het Belgische systeem, dat bestond vóór de invoering van de strafrechtelijke verantwoordelijkheid van de rechtspersoon, was dat de machtsnormerende draagkracht van het individuele schuldbeginsel en het daarmee samenhangende beginsel van de persoonlijkheid van de straf werden uitgehold. Deze vaststelling is interessant want de dogmatische integriteit van deze beginselen werd juist aangevoerd als argument tegen de strafrechtelijke aansprakelijkheid van de rechtspersoon. Deze situatie, waarbij corporatief handelen nog steeds als een fictie werd beschouwd, verplichtte de

354. De Nauw, A., o.c., 1994, 19.

355. Zie o.a. Colaes, J., 'De strafrechtelijke aansprakelijkheid van mandatarissen van rechtspersonen', in Dekeersmaeker, J. en Van Steenberge, J. (red.), o.c.,1984, 156; Vervloet, J.R., 'Strafrechtelijke aspecten van het sociaal strafrecht', in Liber Amicorum F. Dumon, Antwerpen, 1983, 550 en Roquet, F., 'Sanctions pénales et personnes morales', $R D P$, 1975-76, 689-706.

356. De Nauw, A., o.c., 1994, 19.

357. Zo werd door het Hof van Beroep te Antwerpen de strafrechtelijke aansprakelijkheid van een bedrijfshoofd van een dochteronderneming mede gebaseerd op de vaststelling dat uit het dossier nergens bleek dat hij de moederonderneming nopens de in zijn onderneming bestaande illegale toestand inlichtte (Antwerpen, 1 juni 1990 inzake OM t. De Schepper, Christiaensen, Beeckman, VECOM en ETERNIT, ongepubliceerd). Omgekeerd kunnen dergelijke inlichtingen voor bedrijfsvoerders disculperend werken, waarbij het gevaar ontstaat dat de eerlijkheid 'tussen moeder en dochter' een handig alibi is om te ontsnappen aan de aansprakelijkheid (zoals o.a. in het BRC-arrest Antwerpen, 10 april 1990, ongepubliceerd). Zie tevens Faure, M., o.c., 1992, 32 60.

358. Faure, M., o.c., 1992, 59-60. 
rechter de verwezenlijking van het morele element aan één of meerdere fysieke personen toe te rekenen terwijl de verwezenlijking van het materiële element bij iemand anders werd gevonden. Er ontstond een

'scission entre l'acte d'autrui, le geste de l'employé constituant matériellement l'infraction et la faute, intentionelle ou non, qui fonde moralement la responsabilité du "décideur"'. 359

Opmerkelijk is wel dat juist vanwege het ontbreken van een persoonlijke aansprakelijkheid van de rechtspersoon het vanuit de klassieke gedachte sterk verdedigde individueel handelingsbegrip en de persoonlijke verwijtbaarheid noodgedwongen in de praktijk werden gedepersonaliseerd doordat deze verschoven van de ene persoon naar de andere; er was dan eigenlijk sprake van een verwijtbaarheid voor daden van een ander. ${ }^{360}$ Het is echter naïef te veronderstellen dat het individueel schuldbeginsel en het beginsel van de persoonlijkheid van de straf onaangetast zouden kunnen blijven door in de context van ondernemingscriminaliteit krampachtig te zoeken naar individuen. Deze beginselen verliezen hierdoor eerder hun individueel, multi-interpretabel en machtskritisch karakter. ${ }^{361} \mathrm{Er}$ werd dan ook in de literatuur gepleit voor een recuperatie van deze beginselen. Daartoe moest wel de rechtspersoon als een zelfstandig strafrechtelijke rechtssubject worden erkend. Op 4 mei 1999 was de kogel eindelijk door de kerk: de strafrechtelijke verantwoordelijkheid van de rechtspersoon werd in het Belgische strafrecht ingevoerd.

\section{DE WET VAN 4 MEI 1999 TOT INVOERING VAN DE STRAFRECHTELIJKE VERANTWOORDELIJKHEID VAN DE RECHTSPERSOON IN BELGIË: EEN STAP VOORUIT?}

Wat zijn nu de belangrijkste uitgangspunten van de strafrechtelijke verantwoordelijkheid van de rechtspersoon naar huidig Belgisch recht? ${ }^{362} \mathrm{Ik}$ beperk mij tot twee wezenlijke vraagstukken. Allereerst natuurlijk de vraag wanneer een rechtspersoon strafrechtelijk aansprakelijk kan worden gesteld (1). Vervolgens bespreek ik de specifieke regeling van samenloop tussen de aansprakelijkheid van de rechtspersoon en die van de natuurlijke

359. Delmas-Marty, M., Le flou du droit. Du code pénal aux droits de l'homme, Paris, Presses Universitaires de France, 1986, 49.

360. Delmas-Marty, M., o.c., 1986, 54-56.

361. Zie over de machtskritische waarde van beginselen in het strafrecht Peters, A.A.G., o.c., 1994, $15-34$.

362. Zie voor een uitvoerige en kritische bespreking van de Wet tot invoering van de strafrechtelijke verantwoordelijkheid van de rechtspersoon o.m. Gollier, M. en Lagasse, M., 'La responsabilité pénale des personnes morales: une extension du filet pénal modalisée', J.T., 1999, 653-660; Traest, Ph., 'De Wet van 4 mei 1999 tot invoering van de strafrechtelijke verantwoordelijkheid van rechtspersonen', TRV, 1999, 451-489; Van Bavel, H., 'De Wet van 4 mei 1999 tot invoering van de strafrechtelijke verantwoordelijkheid van rechtspersonen', $A J T, 1999-2000,209-226$; De Nauw, A. en Deruyck, F., 'De strafrechtelijke verantwoordelijkheid van rechtspersonen', $R W$, 2000, 897-914. Zie ook Verstraeten, R, Handboek strafvordering, 3e dr., Antwerpen, Maklu, 1999, 79-80; Van den Wijngaert, Ch., Strafrecht en strafprocesrecht in hoofdlijnen, Antwerpen, Maklu, 1999, 103-114. 
persoon (2), waarna ook de eerste rechtspraak, die de wet van 4 mei 1999 toepast, in het kort aan bod komt (3).

\section{Wanneer is een rechtspersoon strafrechtelijk aansprakelijk?}

Voor het daderschap van de rechtspersoon dienen steeds twee vragen te worden beantwoord. Allereerst, welke gedragingen kunnen aan de rechtspersoon materieel worden toegerekend? Er moet dan worden beantwoordt welke categorie van gedragingen feitelijk aan de rechtspersoon kan worden toegerekend. Men kan zich voorstellen dat niet elke gedraging verricht in het kader van de organisatie ook meteen behoort tot de handelingssfeer van de rechtspersoon. De tweede vraag is wanneer deze gedragingen aan de rechtspersoon moreel moeten worden toegerekend? Dit heeft te maken met de vaststelling van verwijtbaarheid in hoofde van de rechtspersoon: slechts die gedragingen die ook te plaatsen zijn binnen de verantwoordelijkheidssfeer van de rechtspersoon kunnen ook moreel aan de rechtspersoon worden toegerekend. Het antwoord op deze vraag bepaalt tevens de grens tussen de aansprakelijkheid van de rechtspersoon en die van de natuurlijke persoon, die optreedt binnen het kader van de corporatie. Er kan immers sprake zijn van een delict gepleegd in de handelingssfeer van de rechtspersoon, maar dat betekent nog niet dat de rechtspersoon daarom verwijtbaar heeft gehandeld. Ook de Memorie van Toelichting (MvT) op de Wet van 4 mei 1999 benadrukt dat voor een strafrechtelijke aansprakelijkheid van rechtspersonen steeds sprake moet zijn van een materiële én morele toerekening:

'Het moet evenwel duidelijk zijn dat een strafrechtelijke veroordeling van een rechtspersoon voor een misdrijf altijd gegrond moet zijn op het gelijktijdig aanwezig zijn van het materieel en het intentioneel element van het misdrijf. $^{363}$

\section{a. Het materieel element}

Hoe wordt nu het daderschap van de rechtspersoon nader omschreven? Het opnieuw ingevoerde artikel 5, eerste lid BSw stelt:

'Een rechtspersoon is strafrechtelijk verantwoordelijk voor misdrijven die hetzij een intrinsiek verband hebben met de verwezenlijking van zijn doel

363. Parl.St., Senaat, 1998-1999, 1-1217/1, 2. Terloops zij opgemerkt dat de term 'intentioneel element' volgens het Hof van Cassatie refereert aan de schuldvorm van opzet (zie Cass., 31 januari 1989, Arr.Cass., 1988-89, 648). Deze term kan dus alleen gebruikt worden bij opzettelijke delicten. De MvT haalt hier duidelijk een aantal dogmatische begrippen door elkaar. Ook elders munt de MvT niet uit van strafrechtsdogmatische helderheid: zo wordt nalatigheid (onachtzaamheid) ten onrechte omschreven als een intentioneel element: onachtzaamheid is, net als opzet, een schuldvorm, maar nooit een intentioneel element. Zie o.m. Parl. St., Senaat, 1998$1999,1-1217 / 1,6$. 
of de waarneming van zijn belangen, of die, naar blijkt uit de concrete omstandigheden, voor zijn rekening zijn gepleegd..$^{364}$

Voor de beantwoording van de materiële toerekeningsvraag is duidelijk een aantal criteria in de wet neergelegd. ${ }^{365}$ Uitgangspunt is dat de rechtspersoon alle delicten kan plegen, op voorwaarde dat deze werden gepleegd binnen de voorwaarden neergelegd in artikel 5, eerste lid BSw. Volgens de MvT werd voor deze precieze formulering gekozen om te vermijden dat alle feiten die naar aanleiding van de uitoefening van de activiteiten van de rechtspersoon zijn gepleegd, ook automatisch aan de corporatie strafrechtelijk worden toegerekend. ${ }^{366}$ Deze keuze is inderdaad toe te juichen. Positief is ook dat de materiële toerekening zich niet beperkt tot feiten gepleegd ter verwezenlijking van het doel of ter behartiging van het belang van de rechtspersoon, maar dat ook delicten gepleegd voor rekening van de rechtspersoon aan de corporatie kunnen worden toegerekend. Zo wordt vermeden dat rechtspersonen slechts strafrechtelijk aansprakelijk zouden kunnen worden gesteld voor gedragingen verricht binnen het kader van de (officiële) statutaire doelstellingen en belangen ${ }^{367}$ Zou immers alleen maar naar statuten of andere officiële stukken worden gekeken, dan zou het voor malafide rechtspersonen wel heel makkelijk zijn zich aan de strafwet te onttrekken. ${ }^{368}$ Het gedrag liggend buiten de officiële maatschappelijke doelstelling van de rechtspersoon zou dan nooit kunnen worden aangemerkt als een strafbare gedraging van de rechtspersoon, ook al zou dat gedrag overeenstemmen met de feitelijke bedrijfspolitiek en doelstellingen van de rechtspersoon.

364. Het volledige artikel 5 BSw luidt als volgt:

'Een rechtspersoon is strafrechtelijk verantwoordelijk voor misdrijven die hetzij een intrinsiek verband hebben met de verwezenlijking van zijn doel of waarneming van zijn belangen, of die, naar blijkt uit de concrete omstandigheden, voor zijn rekening zijn gepleegd.

Wanneer de rechtspersoon verantwoordelijk gesteld wordt uitsluitend wegens het optreden van een geïdentificeerde natuurlijke persoon, kan enkel degene die de zwaarste fout heeft begaan worden veroordeeld. Indien de geidentificeerde natuurlijke persoon de fout wetens en willens heeft gepleegd kan hij samen met de verantwoordelijke rechtspersoon worden veroordeeld.

Met rechtspersonen worden gelijkgesteld:

1. tijdelijke verenigingen en verenigingen bij wijze van deelneming;

2. vennootschappen bedoeld in artikel 2 , derde lid van de gecoördineerde wetten op de handelsvennootschappen, alsook handelsvennootschappen in oprichting;

3. burgerlijke vennootschappen die niet de vorm van een handelsvennootschap hebben aangenomen.

Voor de toepassing van dit artikel kunnen niet als strafrechtelijk verantwoordelijke rechtspersoon worden beschouwd: de federale staat, de gewesten, de gemeenschappen, de provincies, de Brusselse agglomeratie, de gemeenten, de binnengemeentelijke territoriale organen, de Franse Gemeenschapscommissie, de Vlaamse Gemeenschapscommissie, de Gemeenschappelijke Gemeenschapscommissie en de openbare centra voor maatschappelijk welzijn.'

365. Zie hierover De Nauw, A. en Deruyck, F., l.c., 2000, 902-903.

366. Parl.St., Senaat, 1998-1999, 1-1217/1, 4.

367. Vellinga-Schootstra, F., Vellinga, W.H. en Van Strien, A.L.J., 'Het daderschap van de rechtspersoon', in Van der Neut, J.L. (red.), Daderschap en deelneming, Gouda Quint, Arnhem, 1993, 44-45.

368. Faure, M. en Roef, D., l.c., 1995, 420. 
Artikel 5, eerste lid BSw beoogt dat slechts die verboden gedragingen op conto van de rechtspersoon kunnen worden gezet die zijn verricht in het kader van de feitelijke doeldienstigheid van de corporatie. Elk andere gedraging moet terecht worden beschouwd als een factum alienum omdat het ligt buiten de handelingssfeer van de rechtspersoon, derhalve dient het ook buiten de risicosfeer van de rechtspersoon te blijven. ${ }^{369}$

\section{b. Het moreel element}

Wat niet in de wet is neergelegd, zijn criteria ter invulling van het moreel element in hoofde van de rechtspersoon. De vraag op welke wijze de corporatieve gedragingen aan de rechtspersoon moreel moeten worden toegerekend, is een feitenkwestie die aan de strafrechter wordt overgelaten. De MvT stelt wel voorop dat een objectieve aansprakelijkheid moet worden vermeden:

'Het algemeen principe van het strafrecht volgens hetwelk een intentioneel element een constitutief bestanddeel van ieder misdaad en ieder wanbedrijf is [is] eveneens van toepassing op de rechtspersoon. ${ }^{370}$

Dat de wet niets zegt over de wijze waarop de gepleegde feiten aan de corporatie moreel moeten worden toegerekend, houdt sterk verband met het theoretisch uitgangspunt van de wetgever. ${ }^{371}$ Hier is dus geen sprake van nalatigheid maar van een welbewuste keuze. De wetgever stelt voorop dat voor een strafrechtelijke aansprakelijkheid van de rechtspersoon afstand moet worden genomen van het klassieke fictiemodel waarbij de rechtspersoon slechts wordt beschouwd als niet meer dan een verzameling van natuurlijke personen. Er moet worden uitgegaan van de rechtspersoon

'als maatschappelijke realiteit die een eigen strafrechtelijke fout kan begaan en hier dan ook op strafrechtelijk vlak voor aansprakelijk moet kunnen worden gesteld... Dit is dan ook de reden waarom de strafrechtelijke aansprakelijkheid van de rechtspersoon in dit voorstel niet als een afgeleide aansprakelijkheid wordt beschouwd, die enkel tot vervolging en veroordeling aanleiding zou kunnen geven, wanneer het bewijs geleverd wordt van het plegen van een misdrijf door een geündividualiseerde natuurlijke persoon binnen de rechtspersoon, wiens gedrag toegerekend wordt aan de rechtspersoon. ${ }^{372}$

369. Faure, M. en Roef, D., l.c., 1995, 420. Zo moet het onder de toonbank verkopen van heroüne door de verkoper in een door een rechtspersoon uitgebaat warenhuis in beginsel worden beschouwd als een handelen buiten de rechtspersoon. Deze verkoop van heroĭne zal echter ophouden een factum alienum te zijn wanneer uit de concrete omstandigheden blijkt dat deze verkoop plaatsvindt voor rekening van de rechtspersoon en derhalve deel uitmaakt van de feitelijke bedrijfspolitiek. Voorbeeld ontleend aan Torringa, R.A., o.c., 1984, 94.

370. Parl.St., Senaat, 1998-1999, 1-1217/1, 5.

371. De Nauw, A. en Deruyck, F., l.c., 1999, 904.

372. Parl.St., Senaat, 1998-1999, 1-1217/1, 2. 
Dit is een verstandig uitgangspunt. Indien men de rechtspersoon op strafrechtelijk vlak slechts zou zien als een geheel van natuurlijke personen, makt men de denkfout dat rechtspersonen alleen verwijtbaar kunnen handelen (of nalaten) wanneer in hoofde van natuurlijke personen opzet of culpa aanwezig is. Dat zou betekenen dat men corporatieve verantwoordelijkheid eenzijdig herleidt tot menselijke verantwoordelijkheid, hetgeen tot: gevolg zou hebben dat men nog steeds, net zoals voorheen, het moreel element moet bewijzen in hoofde van natuurlijke personen. Het enige verschil is dan dat ten behoeve van de bestraffing van de corporatie deze schuld (fictief) aan de rechtspersoon zelf wordt toegerekend. Loth noemt dergelijke toerekeningsconstructies terecht een uiting van theoretisch reductionisme en maatschappelijk anachronisme omdat zo collectieve gedragingen in een individualistisch keurslijf worden geperst. ${ }^{373}$ Zoals in hoofdstuk VI op meer diepgaande wijze zal worden uiteengezet: indien men de rechtspersoon als strafrechtelijke dader werkelijk ernstig wil nemen, is men verplicht ook strafrechtsdogmatisch de conclusie te trekken dat een rechtspersoon niet alleen iets meer, maar ook iets anders is dan een verzameling van natuurlijke personen. ${ }^{374} \mathrm{Ik}$ acht het dan ook positief dat de wetgever niet heeft getracht het daderschap van de rechtspersoon te doen passen binnen het klassieke psychologisch gekleurde schuldbegrip. Bij kleine ondernemingen gaat een gelijkschakeling van de rechtspersoon met de daarin optredende (leidinggevende) individuen nog min of meer op, maar bij complexe organisaties moet men het eigen karakter van de rechtspersoon durven erkennen. ${ }^{375}$ Het heeft dan ook weinig zin het moreel element in hoofde van de rechtspersoon in de wet neer te leggen door bijvoorbeeld te eisen dat bepaalde leidinggevende personen binnen de rechtspersoon de corporatieve gedraging hebben bevolen, geleid of toegelaten. Dat zou de mogelijkheden van corporatieve verwijtbaarheid onnodig beperken.

Bij gebrek aan een wettelijk omschreven schuldelement in hoofde van de rechtspersoon, rijst dan wel de vraag hoe in de praktijk de strafrechter de corporatieve verwijtbaarheid inhoud kan geven. De MvT zegt hierover het volgende:

'Het spreekt echter vanzelf dat dit schuldelement beoordeeld zal moeten worden rekening houdend met de kenmerken die eigen zijn aan een rechtspersoon. Aangetoond zal moeten worden hetzij dat het misdrijf voortkomt uit een opzettelijke beslissing genomen binnen de rechtspersoon, hetzij dat er een nalatigheid is op het niveau van de rechtspersoon die in causaal verband staat met het misdrijf. Men beoogt bijvoorbeeld de hypothese waar een gebrekkige interne organisatie van de rechtspersoon, onvoldoende veiligheidsmaatregelen of onredelijke

373. Loth, M.A., Handeling en aansprakelijkheid in het recht, Amhem, Gouda Quint, 1988, 238.

374. Zie tevens Van Strien, A.L.J., De rechtspersoon in het strafproces. Een onderzoek naar de procesrechtelijke aspecten van de strafbaarheid van de rechtspersoon, Den Haag, Sdu, 1996, 7678.

375. Van Strien, A.L.J, o.c., 1996, 77; Roef, D. en De Roos, Th., 'De strafrechtelijke ansprakelijkheid van de rechtspersoon en zijn bestuurders: rechtstheoretische beschouwingen bij enkele praktische knelpunten', in Faure, M. en Schwarz, K. (red.), o.c., 1998, 91. 
budgettaire beperkingen de voorwaarden gecreëerd hebben die het misdrijf mogelijk hebben gemaakt. ${ }^{376}$

Vooral de laatste zin sluit goed aan bij de visie dat de verwijtbaarheid in hoofde van rechtspersonen niet via de omweg van schuld van een of meer (geïdentificeerde) natuurlijke personen hoeft te worden vastgesteld, en dat rechtspersonen als het ware een eigen, zij het niet-menselijk, verantwoordelijkheidsbesef hebben. Niet zozeer omdat leidinggevende leden daarover beschikken, maar meer omdat de interne organisatiestructuur, expliciete en impliciete beleidsdoelstellingen, te volgen afspraken, communicatiekanalen, controle- en besluitvormingsprocedures in corporatief verband de noodzakelijke voorwaarden voor verantwoordelijk handelen uitmaken ${ }^{377}$ Deze voorwaarden maken het verantwoordelijkheidsbesef van de rechtspersoon uit en overstijgen het moreel bewustzijn van de natuurlijke personen die van de organisatie deel uitmaken. Meer zelfs, deze voorwaarden sturen en voeden het gedrag en de psychische gesteldheid van het in de organisatie werkzame individu.

Op dit punt lijkt er trouwens in de MvT sprake te zijn van een contradictie. Hoewel het ontbreken van een wettelijk omschreven schuldelement terecht wordt gerechtvaardigd vanwege de ratio dat rechtspersonen een eigen van natuurlijke personen onderscheiden schuld hebben, wordt beklemtoond dat, om tot een vaststelling van deze schuld te kunnen komen, de strafrechter toch het moreel element in hoofde van natuurlijke personen zal moeten vaststellen:

'Om de totstandkoming en de veruiterlijking van het schuldelement bij de rechtspersoon te beoordelen, zal de rechter moeten peilen naar de houding van de organen binnen de rechtspersoon, met inbegrip van de feitelijke organen, die niet noodzakelijk als natuurlijke personen kunnen worden geïndividualiseerd. Het is niet de bedoeling de strafrechtelijke aansprakelijkheid van de rechtspersoon te beperken tot misdrijven gepleegd door haar wettelijke of statutaire organen. De strafrechtelijke aansprakelijkheid van de rechtspersoon kan ook het gevolg zijn van materiële feiten gepleegd door sommige van haar aangestelden of lasthebbers. $\mathrm{Zij}$ moeten dan minstens kennis hebben gehad van het voornemen om het misdrijf te plegen en daarmee hebben ingestemd dan wel zelf hebben aangedrongen op het plegen van het misdrijf. In geval van onopzettelijke misdrijven zal aangetoond moeten worden dat zij kennis hebben gehad van het risico voor het plegen van het misdrijf en nalatig geweest zijn met het nemen van maatregelen om het misdrijf te voorkomen. Indien de wet een algemeen of bijzonder opzet als constitutief bestanddeel vereist, zal bewezen moeten worden dat dit ook aanwezig was in hoofde van de leidinggevende instanties. ${ }^{378}$

377. Zie French, P.A., Collective and corporate responsibility, New York, 1984, 39 e.v.

378. Parl.St., Senaat, 1998-1999, 1-1217/1, 5-6. 
In deze passage wordt duidelijk gesteld dat het moreel element moet worden vastgesteld in hoofde van bepaalde natuurlijke personen, namelijk diegenen die gelet op de organisatiestructuur een leidinggevende positie bekleden. In de praktijk verschilt dit nauwelijks van het in de MvT zelf (!) bekritiseerde fictiemodel. Dit lijkt mij een te grote inperking van de mogelijkheid de rechtspersoon strafrechtelijk aansprakelijk te stellen. In het bijzonder de stringente eis dat leidinggevenden kennis moeten hebben gehad van het delict en daarmee moeten hebben ingestemd, en dat bij opzetdelicten het opzet in hoofde van deze leidinggevenden moet worden bewezen, lijkt onwenselijk. Wanneer een rechtspersoon bijvoorbeeld voor een milieudelict wordt vervolgd, betekent dit dan dat de rechter in concreto moet vaststellen dat iemand met leidinggevende positie binnen de organisatie van (het risico tot het plegen van) dat delict kennis had en daarmee heeft ingestemd? Hiermee is dus niets opgelost omdat onder diezelfde voorwaarden - reeds vóór de invoering van de strafrechtelijke aansprakelijkheid van de rechtspersoon - het door de corporatie gepleegde feit aan de natuurlijke persoon werd toegerekend hetgeen leidde tot bijna onoverkomelijke bewijsproblemen. Ook het advies van de Raad van State op het oorspronkelijke wetsontwerp wijst op deze tegenstrijdigheid tussen het theoretische uitgangspunt van rechtspersoonlijke schuld en de door de MvT aangewezen weg om tot de vaststelling van die schuld te komen. ${ }^{379}$

\section{De strafbaarheid van de natuurlijke persoon en het cumulatieprobleem}

Veelal worden normschendingen binnen de organisatie van een rechtspersoon voorgesteld als een uitvloeisel van de ingesteldheid en de intenties van de mensen die in of rond de organisatie werkzaam zijn. Maar uit de organisatiecriminologie kunnen we leren dat het vaak andersom is: de in de corporatie werkende individuen maken zich veelal schuldig aan bepaalde criminele feiten juist omdat binnen de organisatie alle daarvoor noodzakelijk criminogene voorwaarden aanwezig zijn. ${ }^{380}$ Strafrechtelijk gezien moet men daarom voor ogen houden dat waar natuurlijke personen in corporatief verband strafbare feiten plegen, schuld in hun hoofde aanwezig kan zijn omdat het reilen en zeilen van de organisatie als geheel of op onderdelen daarvan niet deugt. ${ }^{381}$ In die zin determineert de corporatieve schuld evenzeer de individuele schuld als vice versa. Het is zelfs denkbaar dat natuurlijke personen binnen een rechtspersoon wetens en willens (dus opzettelijk) een strafbaar feit plegen doordat de organisatie van de corporatie zelf faalt, bijvoorbeeld door een gebrekkige interne controle of dubbelzinnige instructies. In beginsel moet een strafrechtelijke aanspra-

379. Parl.St., Senaat, 1998-1999, 1-1217/6, 95.

380. Zie o.m. Sutherland, E.H., White Collar Crime, the uncut Version, New Haven, Yale University Press, 1983; Stone, C.D., 'The Place of Enterprise Liability in the Control of Corporate Conduct', Yale Law Journal, 1980, 1-77; Van de Heuvel, G.A.A.J., Onderhandelen of Straffen. Over organisatie-criminaliteit en overheidscontrole, Arnhem, Gouda Quint, 1993.

381. Zo komt het vooral bij complexe organisaties regelmatig voor dat de beleidsdoelstellingen binnen de verschillende afdelingen van de organisatie met elkaar in strijd zijn hetgeen normschendend gedrag door individuen in de hand kan werken. Zie hierover Bovens, M.A.P., Verantwoordelijkheid en organisatie: beschouwingen over aansprakelijkheid, institutioneel burgerschap en ambtelijke ongehoorzaamheid, Zwolle, W.E.J. Tjeenk Willink, 1990, 76. 
kelijkheid van de natuurlijke persoon naast die van de rechtspersoon mogelijk blijven, omdat ieder van hen heeft gefaald binnen zijn eigen verantwoordelijkheidssfeer. Een cumulatieve strafrechtelijke aansprakelijkheid van rechtspersoon en natuurlijke persoon kan daarom niet bij voorbaat als onwenselijk worden voorgesteld. Evenmin moet dergelijke cumulatie worden uitgelegd als een dubbele bestraffing van hetzelfde feit, net zomin als dat het geval is bij twee natuurlijke personen die tezamen een misdrijf plegen. Dat is slechts het geval indien men er ten onrechte van uitgaat dat de rechtspersoon volledig identiek is met bepaalde natuurlijke personen binnen de organisatie en beiden een zelfde verantwoordelijkheid dragen. Daarvan is slechts sprake bij kleine ondernemingen waar de distantie tussen de leidinggevende en de organisatie zelf zeer klein is; bij complexe organisaties is dat niet het geval. Ook bij het cumulatieprobleem moet dus opnieuw rekening worden gehouden met de eigen aard van rechtspersonen. Eens men aanvaardt dat in een organisatie corporatieve gedragingen kunnen bestaan naast individuele gedragingen en dat zij elkaar wederzijds beönvloeden, moet het uitgangspunt zijn dat corporatieve aansprakelijkheid de individuele aansprakelijkheid niet kan uitsluiten, aangezien corporatief en individueel handelen elkaar ook niet uitsluiten. ${ }^{382}$ In dit licht is de samenloop van de strafrechtelijke aansprakelijkheid van rechtspersonen en die van natuurlijke personen niet goed geregeld. ${ }^{383}$ Artikel 5 lid 2 BSw stelt immers:

'Wanneer de rechtspersoon verantwoordelijk gesteld wordt uitsluitend wegens het optreden van een geïdentificeerde natuurlijke persoon, kan enkel degene die de zwaarste fout heeft begaan worden veroordeeld. Indien de geïdentificeerde natuurlijke persoon de fout wetens en willens heeft gepleegd kan hij samen met de verantwoordelijke rechtspersoon worden veroordeeld.'

In de eerste plaats is deze bepaling moeilijk te rijmen met het uitgangspunt dat rechtspersoonlijke schuld onafhankelijk moet kunnen worden bekeken van die van de natuurlijke persoon. Het vereiste dat wanneer de rechtspersoon verantwoordelijk wordt gesteld uitsluitend wegens het optreden van een geïdentificeerde natuurlijke persoon, alleen diegene kan worden veroordeeld die de zwaarste fout heeft begaan, gaat er vanuit dat steeds ofwel bij de rechtspersoon, ofwel bij de natuurlijke persoon de meeste 'schuld' aanwezig moet zijn. Wanneer zowel de rechtspersoon als de natuurlijke persoon vervolgd worden, ontstaat dus de markante situatie dat één van beide moet worden vrijgesproken, niet omdat het ten laste gelegde feit in zijn hoofde niet kan worden bewezen verklaard, en evenmin omdat hem geen strafrechtelijk verwijt kan worden gedaan, maar omdat bij de ander de verwijtbaarheid groter zou zijn. Dat de rechtspersoon en de natuurlijke persoon ieder afzonderlijk een weliswaar andere, maar even zware schuld kunnen hebben, zodat een veroordeling van beiden gerechtvaardigd is, wordt blijkbaar a priori uitgesloten. Hier wordt gedaan alsof schuld van de rechtspersoon en die van de natuurlijk persoon in alle gevallen tegen elkaar kunnen worden afgewogen. Maar in de praktijk zijn het vaak verschillende

382. Loth, M.A., o.c., 1988, 257; Faure, M. en Roef, D., l.c., 1995, 423-424.

383. Zie hierover De Nauw, A. en Deruyck, F., L.c., 2000, 905-907; Traest, Ph., l.c., 1999, 488; Van den Wijngaert, Ch., o.c., 1999, 112 en Van Bavel, H., L.c., 1999, 214. 
grootheden, die moeilijk met elkaar kunnen worden vergeleken. Fout verwijst strafrechtsdogmatisch naar onachtzaamheid, een gebrek aan voorzichtigheid en voorzorg. ${ }^{384}$ Wat de strafrechter thans geval per geval moet aantonen is wie van de verdachten het meest een zorgvuldigheidsnorm heeft geschonden. Daarbij moet door de rechter bij de schuldvaststelling worden uitgegaan van de 'criterium-figuur', de normaal zorgvuldige en omzichtige persoon geplaatst in dezelfde omstandigheden als waarin het delict is gepleegd (de 'bonus ac diligens pater familias'). ${ }^{385}$ In een concreet geval moet de strafrechter echter niet alleen bekijken wie van beiden, de rechtspersoon of de natuurlijke persoon, een op hen rustende speciale zorgplicht (Garantenstellung) heeft geschonden, maar bij wie die schending het zwaarste doorweegt. Dat is een lastige opgave omdat deze zorgplicht vaak niet nader in de wet is omschreven hetgeen tot gevolg kan hebben dat de grenzen van de delictsomschrijving worden opgerekt en het aantal verwijtbare gedragingen waarvoor men kan worden veroordeeld wordt verruimd. ${ }^{386}$ Bovendien is het nog maar de vraag of de vergelijking van schuld in hoofde van de rechtspersoon met schuld in hoofde van de natuurlijke persoon aan de hand van een abstracte criteriumfiguur wel zo verstandig is. Het is best denkbaar dat voor beide immers andere zorgvuldigheidsnormen van toepassing zijn. Stel dat een ondergeschikte binnen een onderneming in strijd met expliciete bedrijfsinstructies op een zodanige wijze met gevaarlijk stoffen omgaat dat hierdoor een milieudelict wordt gepleegd. Wie heeft nu de zwaarste fout? Het antwoord op deze vraag hangt niet alleen af van de concrete feitenconstellatie, maar tevens van de zorgvuldigheidsnorm die de strafrechter zal hanteren. Zo kan men verdedigen dat op het bedrijf, ondanks het bestaan van uitdrukkelijke instructies, nog steeds een zorgplicht rust een behoorlijke controle op de gedragingen van zijn werknemers uit te voeren. Aan de andere kant kan worden betoogd dat er op de 'redelijke en voorzichtige' werknemer een zorgplicht bestaat zich aan de instructies te houden. Indien dit om één of andere reden onmogelijk mocht zijn, heeft de werknemer nog steeds de zorgplicht de leiding hiervan op de hoogte te brengen. Voor de organisatie als geheel en de natuurlijke persoon afzonderlijk kunnen dus andere zorgvuldigheidsnormen gelden: zij hebben immers een eigen verantwoordelijkheidssfeer. De vaststelling van de zwaarste fout wordt zo een ingewikkelde zoektocht naar de zwaarste zorgplicht. Deze bepaling getuigt dus niet van een realistische kijk op organisatiecriminaliteit.

Hoe moet de strafrechter trouwens vaststellen bij wie de zwaarste fout ligt? Welk strafrechtsdogmatisch referentiepunt moet worden ingenomen? Hier wreekt zich het theoretisch tekort van de wet. Het antwoord op deze vragen zal sterk worden bepaald door de visie van het openbaar ministerie en de strafrechter op organisatiecriminaliteit en rechtspersoonlijk daderschap. Legt men nadruk op het eigen en zelfstandige karakter van corporatief

384. Dupont, L. en Verstraeten, R., Handboek Belgisch strafrecht, Leuven/Amersfoort, Acco, 1990, 248-249 en 257 e.v.

385. Deze schuldvorm van de onachtzaamheid (of culpa) wordt in de rechtspraak gelijkgeschakeld met het aquiliaanse foutbegrip (de nalatigheid van art. $1382 \mathrm{BW}$ ). De schuld wordt dus grotendeels normatief bepaald. Zie o.m. Cass., 19 februari 1988, Arr.Cass., 1987-1988, 795; RW, 19881989, 159.

386. Kristen, F.G.H., Borgers, M.J. en Koopmans, L.M., 'Schuld in het strafrecht', in Borgers, M.J., Koopmans, I.M. en Kristen, F.G.H. (red), o.c., 1998, 25-26. 
handelen en ziet men de rechtspersoon niet slechts als een verzameling van natuurlijke personen, dan zal de zwaarste fout makkelijker bij de organisatie als geheel kunnen worden gelegd. In zo'n collectivistische benadering zal men immers vlugger het organisatorische falen zien als de voedingsbodem of de oorzaak van de door de natuurlijke persoon gepleegde fout. Hanteert men daarentegen de meer klassieke individualistische visie, waar delicten gepleegd in ondernemingsverband worden herleid tot een of meerdere 'menselijke' gedragingen, dan ligt het voor de hand de zwaarste fout bij de natuurlijke persoon te leggen, omdat bij deze laatste, en niet bij de organisatie zelf, de voornaamste oorzaak ligt van het gepleegde feit.

Helemaal problematisch is de bepaling dat cumulatie van de strafrechtelijke aansprakelijkheid van de rechtspersoon met die van de natuurlijke persoon alleen mogelijk is wanneer deze laatste het delict wetens en willens heeft begaan. Zowel in Nederland ${ }^{387}$ als in Frankrijk $^{388}$ heeft men bewust de mogelijkheid van cumulatieve aansprakelijkheid open gelaten, omdat anders het risico ontstaat dat de natururlijke persoon zich verschuilt achter de rechtspersoon. Met de term 'wetens en willens' wordt algemeen opzet (dolus generalis) bedoeld. ${ }^{389}$ De MvT formuleert het zo:

'Het gehanteerde principe houdt in dat cumulatie van aansprakelijkheden...uitgesloten is, tenzij aangetoond kan worden dat het misdrijf ook aan de natuurlijke persoon zelf kan worden toegerekend, die manifest opzettelijk gehandeld heeft. ${ }^{390}$

Cumulatie is dus alleen mogelijk bij opzettelijke delicten en niet bij culpose delicten ${ }^{391}$ :

'de uitsluiting van cumulatie [betreft] enkel delicten gepleegd met nalatigheid als intentioneel element. Het uitgangspunt is derhalve de wettelijke kwalificatie van het misdrijf. ${ }^{392}$

Ik zie niet in waarom voor cumulatie enig onderscheid tussen opzettelijke delicten en culpose delicten moet worden gemaakt. Juist in het Belgische milieustrafrecht lijkt me de cumulatieuitsluiting zeer nadelig omdat dit deelgebied van het Belgische strafrecht nauwelijks opzettelijke delicten kent. $^{393}$

387. Zie o.m. Torringa, R.A., o.c.,1988, 41 .

388. Artikel 121-2, derde lid van de Franse Code pénal luidt: 'La responsabilité pénale des personnes morales n'exclut pas celles des personnes physiques auteurs ou complices des mêmes faits.' Zie over de ontstaansgeschiedenis van deze bepaling Deruyck, F., o.c., 1996, 217-219.

389. Dupont, L. en Verstraeten, R., o.c., 1990, 248 en 249-250.

390. Parl.St., Senaat, 1998-1999, 1-1217/1, 6.

391. Aldus ook Deruyck, F., 'Naar een strafrechtelijke aansprakelijkheid van de rechtspersoon in België?', in Faure, M. en Schwarz, K. (red.), o.c., 1998, 41.

392. Parl.St., Senaat, 1998-1999, 1-1217/1, 6.

393. Zie hoofdstuk VI. 


\section{Cumulatieregeling in de rechtspraak}

Dat de cumulatieregeling een aantal vragen oproept, blijkt reeds uit de eerste rechtspraak met betrekking tot de toepassing van de wet van 4 mei 1999. De kern van het probleem is immers de wijze waarop het cumulatiecriterium 'willens en wetens' moet worden ingevuld. De wetgever benadrukte dat de uitsluiting van de cumulatie gebaseerd is op de wettelijke definitie van het delict. Het moreel element in abstracto moet als onderscheidingscriterium worden gebruikt. ${ }^{394}$ Sommige rechtsleer pleit evenwel voor een toepassing in concreto, zodat ook alle onachtzaamheidsdelicten onder de cumulregeling vallen voor zover het gebrek aan voorzichtigheid in concreto kan worden gekwalificeerd als een opzettelijke fout. ${ }^{395}$ Sommige rechtspraak lijkt deze laatste interpretatie genegen te zijn. ${ }^{396}$ Een mooie illustratie van de onduidelijkheid aangaande de toepassing van de cumulatieregeling is een zaak betreffende een inbreuk op een lozingsvergunning. Door de beklaagde, gedelegeerd bestuurder van een textielverwerkingsbedrijf, werd aangevoerd dat hij zou moeten worden vrijgesproken omdat het milieudelict hem 'niet toerekenbaar' is. Tot staving van dit standpunt verwijst hij naar artikel 5 al. 2 BSw waar immers wordt gesteld dat de natuurlijke persoon (alleen) kan worden veroordeeld indien bij deze de zwaarste fout aanwezig is of (desgevallend samen met de rechtspersoon) wanneer hij wetens en willens heeft gehandeld. De beklaagde voert aan dat deze bepaling van onmiddellijke toepassing is als mildere strafwet en derhalve ook op feiten, die aan de telastelegging ten grondslag liggen en dateren van voor de inwerkingtreding van de wet van 4 mei 1999, toepassing vindt. Het Hof van Beroep te Gent oordeelt echter:

'Met het Openbaar Ministerie oordeelt het Hof dat dit standpunt enkel kan worden bijgetreden wanneer de telastelegging betrekking heeft op een misdrijf waarvoor de wet, c.q. het decreet, geen algemeen of bijzonder opzet vereist. Ter zake evenwel brengt het art. 5 van het Strafwetboek niet mee dat de beklaagde niet zou kunnen worden veroordeeld voor zover de telastelegging bewezen zou zijn. $\mathrm{Nu}$ de betrokken bepalingen van het Milieuvergunningsdecreet geen aanduiding nopens het moreel element bevatten, is immers weliswaar voldoende doch vereist dat de beklaagde met algemeen opzet heeft gehandeld, dit is willens en wetens; dit bewust en vrijwillig handelen is te onderscheiden van loutere onachtzaamheid of nalatigheid'. ${ }^{397}$

Een eerste probleem dat in deze uitspraak duidelijk naar voren komt is de interpretatie van het schuldvereiste bij stilzwijgen van de bijzondere (milieu)wetgever. Het is immers zo dat

394. Parl. St. Senaat 1998-1999, nr. 1217/1, 6.

395. Zie Traest, P., 'De strafrechtelijke verantwoordelijkheid van rechtspersonen', IBR - Periodieke berichten, 2-2000. Zie hierover ook Waeterinck, P., 'De cumulatie van de strafrechtelijke verantwoordelijkheid van de rechtspersoon met die van de natuurlijke persoon. Art. 5, tweede lid Sw., een staaltje van onbehoorlijke regelgeving, $R W, 2001,1217-1229$.

396. Zie o.m. Gent 22 maart 2000, niet gepubliceerd, besproken in Arnou, L., 'Schuldig en toch vrijgesproken worden', De Juristenkrant, nr. 14, 2000, 3.

397. Hof Gent, 7 januari 2000, TMR, 2000, 165. 
wanneer de wetgever stilzwijgt bij een inbreuk op de bijzondere wetgeving onachtzaamheid of nalatigheid als subjectief element volstaat. ${ }^{398}$ Hier stelt het Hof evenwel dat de afwezigheid van een aanduiding nopens het moreel element in de betrokken bepalingen van het Milieuvergunningsdecreet impliceert dat is vereist dat de beklaagde met algemeen opzet heeft gehandeld. Dit standpunt is niet zonder belang omdat zowel het Openbaar Ministerie als het Hof de stelling delen dat het beroep door de beklaagde op de mildere strafwet (artikel $5 \mathrm{BSw}$ ), slechts kan worden gehonoreerd bij delicten waarvoor geen algemeen (of bijzonder) opzet is vereist. Welnu, conform de heersende rechtsleer is bij stilzwijgen van de bijzondere wetgever inderdaad geen algemeen opzet vereist, maar volstaat onachtzaamheid. Het Hof volgt evenwel deze leer niet en oordeelt dat de overtreden bepalingen algemeen opzet voorschrijven, hetgeen in casu ook was tenlastegelegd, zodat derhalve het verweer van beklaagde geen kans van slagen heeft.

Dat de wetgever van oordeel is dat een enkele veroordeling van de natuurlijke persoon slechts mogelijk is bij een 'zwaarste fout' en dat cumulatie slechts mogelijk is bij bijzondere opzetdelicten doet blijkbaar weinig ter zake. Belangrijk is dan ook de uitspraak van het Hof dat de rechter zich ten aanzien van de interpretatie van artikel 5 BSW niet moet laten leiden door de wil van de wetgever:

\begin{abstract}
'De rechter is bij deze beoordeling van de inhoud van het begrip wetens en willens, dat voldoende duidelijk is, niet gebonden door wat desbetreffend werd gesteld in de memorie van toelichting bij het wetsvoorstel of in de voorbereidende werken, dat overigens niet eenduidig is. Voor het misdrijf omschreven in de telastelegging brengt de toepassing van het nieuw artikel 5 van het Strafwetboek niet met zich mee dat de beklaagde, voor zover de telastelegging bewezen zou zijn, niet zou kunnen worden veroordeeld of slechts zou kunnen worden veroordeeld mits vaststelling dat hij de zwaarste fout heeft gepleegd.'
\end{abstract}

Met andere woorden, het Hof legt de cumulatieregeling zoals deze door de wetgever lijkt te zijn bedoeld naast zich neer. Het Hof stelt ondubbelzinnig dat een cumulatie ook mogelijk is wanneer de natuurlijke persoon bewust en vrijwillig heeft gehandeld en niet alleen bij delicten waar opzet bestanddeel uitmaakt van het delict. Dit standpunt heeft het Gentse Hof overigens in latere arresten herhaald. ${ }^{399}$ Uit deze eerste rechtspraak blijkt duidelijk de ontevredenheid met het door de wetgever gecreëerde systeem, omdat het volgens het Gentse Hof niet noodzakelijk is dat de overtreden wet een bijzonder opzet voorschrijft om een cumulatie mogelijk te maken; cumulatie is reeds mogelijk bij algemeen opzet (het wetens en willens handelen). Vanuit handhavingsoptiek is dit standpunt zeer verdedigbaar. Het probleem is evenwel dat deze interpretatie strijdig lijkt met de bedoelingen van de

398. Dupont, L. en Verstraeten, R., o.c., 1990, 263-264.

399. Zie Gent, 14 januari 2000, inzake Openbaar Ministerie tegen Meersmans en NV De Clercq, arrest nr. 864940, ongepubliceerd en Gent, 10e Kamer, inzake Openbaar Ministerie tegen Verstraete, NV Masureel, NV Bleko en NV Veredeling, arrest nr. 86991 van 28 januari 2000, ongepubliceerd. 
wetgever en dat het Gentse Hof daar geen problemen mee heeft. De vraag rijst thans hoe de andere Hoven en natuurlijk het Hof van Cassatie de cumulatieregeling zullen toepassen. ${ }^{400}$

In de visie van het Gentse Hof volstaat dat de verdachte wetens en willens het feit heeft gepleegd. Wel moet worden opgemerkt dat in deze zaak de beklaagde werd vrijgesproken omdat hij zich met succes kon beroepen op noodtoestand:

'De beklaagde beroept zich op de noodtoestand. Binnen het bedrijf zouden de best mogelijk technieken zijn toegepast maar de toenmalige administratieve omstandigheden (tijdelijke vergunning voor beperkte duur, voorgenomen maar nog onzekere herziening van het gewestplan) zouden het economisch onverantwoord hebben gemaakt de verder noodzakelijke investeringen, te weten de bouw van een volledige waterzuiveringsinstallatie, ter plaatse te realiseren. Hij toont aan dat de kosten van dergelijke installatie reeds in 1993 op minimaal 13 miljoen werden geraamd; meer recente ramingen maken melding van een bedrag van minimaal 34 miljoen. In de gegeven zeer bijzondere juridisch-administratieve context zou het economisch niet verantwoord zijn geweest deze belangrijke investeringen te doen om wat reeds tot een minimum beperkte inbreuken wordt genoemd te vermijden waardoor het bedrijf voor het probleem werd gesteld van zijn voortbestaan en zijn verantwoordelijkheid tegenover ondermeer de werknemers en de klanten. De door de beklaagde aangehaalde zeer specifieke en in de tijd beperkte omstandigheden maken het bestaan van noodtoestand in de periode waarin de feiten zich situeren enigszins geloofwaardig. Het in deze omstandigheden vereiste tegenbewijs van de onjuistheid van de ingeroepen rechtvaardigingsgrond wordt niet geleverd. Dit brengt mee dat de beklaagde dient te worden vrijgesproken en de gedaagde buiten de zaak moet worden gesteld.'

\section{DE STRAFRECHTELIJKE TOEREKENING VAN DOOR OVERHEDEN GEPLEEGDE MILIEUDELICTEN}

Wat ons natuurlijk vooral interesseert is de positie van overheden in het Belgische strafrecht. Zoals reeds werd opgemerkt, heeft de wetgever in het nieuwe artikel 5 lid 4 BSw, naast O.C.M.W.'s, overheden van strafrechtelijke aansprakelijkheid uitgesloten. Het gaat daarbij om de federale staat, de gewesten, de gemeenschappen, de provincies, de Brusselse agglomeratie, de gemeenten, de binnengemeentelijke territoriale organen, de Franse gemeenschapscommissie, de Vlaamse gemeenschapscommissie en de gemeenschappelijke gemeenschapscommissie. De principiële uitsluiting van overheden van strafrechtelijke aansprakelijkheid kan sterk worden bekritiseerd. In deze paragraaf wordt

400. Zie over de toepassing van nieuw artikel 5 BSw reeds een eerste arrest van het Hof van Casstie van 3 oktober 2000 , waarin is bepaald dat aan dit artikel geen terugwerkende kracht is toegekend. Gepubliceerd op de website van het Hof van Cassatie:

http://www.cass.be/juris/judn.htm. 
aan de hand van illustraties uit de rechtspraak daarom nader stil gestaan bij enkele bezwaren tegen de onmogelijkheid overheden strafrechtelijk aansprakelijk te stellen, in het bijzonder voor door hen gepleegde milieudelicten. Zo wordt gaandeweg duidelijk dat de rechtspolitieke keuze van de Belgische wetgever om overheden van de werking van het strafrecht uit te sluiten niet goed is doordacht. ${ }^{401}$

\section{Strafrechtelijke toerekening aan organen}

De niet-strafbaarheid van overheden heeft tot gevolg dat noodgedwongen moet worden teruggegrepen naar het oude systeem. Daar waar andere rechtspersonen thans rechtstreeks strafrechtelijk kunnen worden aangepakt, blijft voor overheden onverkort het oude adagium Societas delinquere potest, sed non punire potest gelden. Dit betekent dat wanneer overheden zich schuldig maken aan een (milieu)delict, net als voorheen, steeds moet worden gezocht naar natuurlijke personen aan wie het strafbaar feit kan worden toegerekend. De talrijke moeilijkheden die voortvloeien uit het ontbreken van de strafrechtelijke aansprakelijkheid van de rechtspersoon, die uiteindelijk hebben geleid tot de invoering van deze aansprakelijkheid, blijven dus voor de bestrijding van overheidscriminaliteit bestaan. Reeds in één van de eerste uitspraken waarin het Hof van Cassatie de regel formuleerde dat rechtspersonen strafbare feiten kunnen plegen stond niet een privaatrechtelijke maar een publiekrechtelijke rechtspersoon centraal: de verdachte rechtspersoon in het arrest van 16 december 1948 is namelijk de Belgische staat. ${ }^{402}$ In deze zaak moest worden nagegaan of de civielrechtelijke vordering tot schadevergoeding jegens de staat - ingesteld door de weduwe van het slachtoffer - wegens een fout, gesteund was op een strafrechtelijk gesanctioneerd delict. Essentieel daarbij was natuurlijk de beantwoording van de vraag of de Belgische staat, als rechtspersoon, wel een misdrijf kon begaan. Het Hof van Cassatie oordeelde dat

'de daad, welke in de sfeer zijner bevoegdheden door het orgaan van een rechtspersoon (in zake de Belgische Staat) wordt begaan, de daad is van de rechtspersoon zelf, en (...) de ongeoorloofde daad, welke een misdrijf uitmaakt, niet van aard verandert door het feit alleen dat de rechtspersoon het voorwerp niet kan zijn van een strafrechtelijke sanctie en enkel tot burgerlijke schadevergoeding gehouden is.'

401. Zie hierover ook Deruyck, F., 'De strafrechtelijke verantwoordelijkheid voor door publiekrechtelijke rechtspersonen gepleegde misdrijven', in Milieuaansprakelijkheid van gemeenten, Antwerpen, Kluwer, 1998, 121-135,; Van Garsse, S., 'De strafrechtelijke verantwoordelijkheid van publiekrechtelijke rechtspersonen', C.D.P.K., 2000, 347-359.

402. Cass., 16 december 1948, J.T., 1949, 148. Vaak wordt dit arrest in de literatuur besproken als het eerste arrest waarin het oude adagium 'societas delinquere potest' werd verlaten. Maar zoals onder meer Deruyck in zijn proefschrift terecht opmerkt moet het keerpunt in de rechtspraak twee jaar eerder worden gesitueerd: in Cass., 8 april 1946, A.C., 1946, 137 overweegt het Hof van Cassatie reeds 'dat terecht het vonnis beslist dat, wanneer een misdrijf begaan wordt door een vennootschap, zedelijk wezen, de physische persoon door middel van welke zij handelt (...) de dader van het misdrijf is.' Zie Deruyck, F., o.c., 1996, 9-10. 
Dit arrest was de eerste cassatieuitspraak omtrent de strafrechtelijke positie van publiekrechtelijke rechtspersonen. De regel dat overheden strafbare feiten kunnen plegen maar daarvoor niet kunnen worden vervolgd zodat moet worden gezocht naar natuurlijke personen vinden we terug in een aantal uitspraken van feitenrechters.

Een eerste belangrijke categorie van mogelijke aansprakelijken zijn de zogenaamde 'organen' of leidinggevende functionarissen van de rechtspersoon. Een eerste illustratie van deze toerekening en de problemen die daarbij kunnen rijzen, vinden we in een arrest van het Hof van Beroep te Antwerpen van 22 november 1984. Het O.C.M.W. te Brasschaat had de prijzenwet overtreden door in de rustoorden van het O.C.M.W. te hoge dagprijzen aan te rekenen. Voor deze feiten werd de voorzitter van het O.C.M.W. vervolgd. In casu besliste het Hof echter dat de voorzitter niet aansprakelijk kon worden gehouden nu

'de beslissingen van het O.C.M.W. door de Raad voor Maatschappelijk Welzijn worden genomen en niet door de voorzitter of door de secretaris (...) en dat de voorzitter ook in feite geen beslissingsmacht heeft aangaande het bepalen van de dagprijzen in de rustoorden van het O.C.M.W. ${ }^{403}$

Interessant aan deze uitspraak is vooral dat de vrijspraak het gevolg is van het feit dat de voorzitter feitelijk geen beslissingsmacht bleek te hebben inzake de besluitvorming die aan het strafbaar feit ten grondslag lag. De prijsverhoging was een collectieve beslissing, genomen door de Raad voor Maatschappelijk Welzijn. Ook is duidelijk dat het niet alleen onmogelijk maar tevens inopportuun is dergelijke collectieve beslissingen aan individuen toe te rekenen. Desalniettemin zal dit nadeel dus blijven bestaan daar artikel 5 lid 4 BSw O.C.M.W.'s van strafrechtelijke verantwoordelijkheid heeft uitgesloten.

Van een zelfde problematiek getuigt een arrest van het Hof van Beroep te Brussel van 24 april 1985. In deze zaak had een intercommunale vereniging de strafwet overtreden. De beklaagden waren twee bestuursleden van deze publiekrechtelijke rechtspersoon. Hoewel de rechter in casu enkel een oordeel kon vellen over de gegrondheid van de civielrechtelijke schadeloosstelling van de burgerlijke partij - de strafvordering was inmiddels al verjaard - is deze zaak interessant omdat natuurlijk moest worden nagegaan of de beklaagden al dan niet de ten laste gelegde feiten hadden gepleegd. De overwegingen van het Hof illustreren op treffende wijze de problematiek:

'Overwegende dat in casu de strafbare feiten (...) bestaan uit verschillende, collegiaal genomen, beslissingen van de raad van beheer van de intercommunale S.; (...) dat uit de overgelegde notulen enkel het collegiaal karakter van de beslissingen in kwestie blijkt; dat het individueel stemgedrag niet gerapporteerd wordt; dat de notulen evenmin eenstemmigheid vermelden; (...) dat de strafrechtelijke verantwoordelijkheid van beklaagden niet voortvloeit uit het enkele feit dat zij, in welke functie dan ook, deel uitmaakten van het college dat ten deze,

403. Antwerpen, 22 november $1984, R W, 1985-86,1850$ met noot De Swaef, $M$. 
namens de rechtspersoon, de eventueel strafrechtelijk te beteugelen beslissing nam; dat ten aanzien van de diverse personen die aanwezig waren op het ogenblik dat dit college, met een niet bekende meerderheid, deze beslissing nam, geen individuele gelijke verdeling van collectieve strafrechtelijke aansprakelijkheid bestaat. ${ }^{404}$

Door gebrek aan bewijs van een daadwerkelijke feitelijke betrokkenheid van de beklaagden aan het misdrijf kon dit niet aan hen worden toegerekend. Ook in dit geval levert het bepalen door de rechter van de natuurlijke persoon die de strafrechtelijke verantwoordelijkheid moet dragen geen oplossing en leidt derhalve tot straffeloosheid.

Een voorbeeld van een veroordeling kan worden gevonden in een uitspraak van de rechtbank te Mons. In deze zaak werd een burgemeester vervolgd voor het uitbaten van een stortplaats in strijd met de vergunningplicht neergelegd in het Waalse afvaldecreet van 5 juli 1985. De feitenconstellatie is bijzonder interessant. Allereerst had de gemeenteraad onder zijn voorzitterschap in strijd met het Waalse afvaldecreet een besluit uitgevaardigd dat toestemming gaf tot het storten van stenen en aarde op de betreffende site. Vervolgens liet de burgemeester, ondanks talrijke waarschuwingen van verschillende inspectiediensten, gedurende meer dan 5 jaar na daadwerkelijk bestuurlijke maatregelen te nemen om een einde te maken aan deze illegale stortingen. Formeel vaardigde de burgemeester weliswaar een politieverordening uit die eenieder verbood de stortplaats te betreden, maar in de praktijk werd deze niet gehandhaafd zodat rustig verder werd gestort. Wat de burgemeester op strafrechtelijk vlak wordt verweten komt dus neer op een opzettelijk gebrekkige handhaving. Het gaat hier feitelijk om een illegale gedoogsituatie. De rechtbank veroordeelt de burgemeester voor het ten laste gelegde en laat in het bijzonder meewegen dat de verdachte als burgemeester persoonlijk verantwoordelijk is voor de correcte naleving van de milieuwetgeving binnen zijn gemeente:

'Attendu qu'en effet vain le prévenu conteste sa responsabilité personelle; Qu'en effet, d'abord il était personnellement responsable de l'exécution du décret du Conseil régional wallon du 5 juillet 1985, puisqu'en sa qualité d'agent des pouvoirs centraux au sein de la commune, il était personnellement chargé de l'exécution des lois, décrets et règlements de l'État, de la Communauté, de la Région et de la province et, dans cette fonction, il devait veiller à l'intérêt général, lequel se situe au-delà de l'intérêt local;

Qu'ensuite, c'est en tant que premier responsable de la commune que: il donna des directives à l'ouvrier communal qui travaillait sur le site du Walestru, il présida le conseil communal du 6 juin 1988, et il signa l'arrêté de cette même date qui autorisa les déversements de déchets pierreux et de terre; 
Qu'enfin, nonobstant son pouvoir de police, il s'abstint délibérément de prendre des mesures effectives pour éviter l'utilisation du site du Walestru comme décharge; ${ }^{, 405}$

De verdachte beroept zich op een schulduitsluitingsgrond, namelijk onoverkomelijke rechtsdwaling, die zou voortvloeien uit het feit dat hij er vanuit kon gaan dat het omstreden gemeentebesluit dergelijk stortingen wettelijk toeliet. Deze redenering wordt begrijpelijkerwijs door de rechtbank afgewezen:

\begin{abstract}
'Attendu que c'est erronément que le prévenu se prévaut de l'autorisation de la loi ou de l'autorité;

Qu'effectivement, il ne peut se retrancher derrière l'arrêté du conseil communal du 6 juin 1988, puisqu'il présida le conseil communal qui se tint à cette date et qu'il signa cet arrêté en sachant qu'il s'agissait d'une norme inférieure et non conforme au décret du 5 juillet 1985 rélatif aux déchets, décret dont il était par ailleurs, ainsi que rappelé ci-avant, personnelement responsable de l'exécution; [...]

Attendu que pour ces mêmes motifs, et compte tenu en outre de son degré de formation intellectuelle et de compétence, de la netteté des differences mises en garde qui lui furent adressés par les autorités compétentes, et de ce qu'il n'agit pas en tant que personne raisonnable et prudente, le prévenu ne peut davantage invoquer l'erreur invincible;'
\end{abstract}

Deze zaak illustreert duidelijk de gevolgen van de niet-strafbaarheid van overheden. Hoewel de burgemeester als orgaan van de gemeente hier een belangrijke verantwoordelijkheid heeft gehad, kan toch worden betoogd dat het zowel efficiënter als rechtvaardiger zou zijn geweest indien de gemeente als dusdanig aansprakelijk kon worden gesteld mede gelet op de betrokkenheid van de gemeenteraad.

\title{
2. Cumulatieve strafrechtelijke toerekening aan leidinggevenden en ondergeschikten
}

In het milieurecht is er een aantal gevallen waarin niet (alleen) leidinggevenden maar (ook) ondergeschikten strafrechtelijk vervolgd worden voor milieudelicten gepleegd door de overheden waartoe zij behoren. Een boeiende casus speelde voor de correctionele rechtbank te Brugge. De verdachte overheid, de gemeente Blankenberge, had de milieuwetgeving overtreden door het wederrechtelijk storten van afval op een niet-vergunde gemeentelijke stortplaats. Voor deze feiten werden de vierde schepen van de stad Blankenberge, bevoegd voor de eigenlijke stortingen, en een tweetal ondergeschikten vervolgd. Opmerkelijk is dat de eerste schepen, die Leefmilieu, Stedenbouw en Ruimtelijke Ordening onder zijn bevoegdheid bleek te hebben, waardoor hij ook beslissings-bevoegdheid had voor wat betreft de vergunningsaanvragen van de stortplaats, niet werd gedaagd. Ook was in eerste instantie tegen de burgemeester een strafvervolging ingesteld maar deze werd

405. Mons, 26 novembre 1996, Aménagement-Environnement, 1997, 143. 
ingevolge zijn parlementaire onschendbaarheid geschorst. Verder is van belang dat de gemeente Blankenberge was gedaagd om zich als werkgever civielrechtelijk te horen veroordelen voor de betaling van de geldboeten. Deze civielrechtelijke aansprakelijkheid was neergelegd in artikel 60 van het Vlaamse afvalstoffendecreet van 2 juli 1981. Zoals bekend, kan deze civielrechtelijke aansprakelijkheid van de rechtspersoon voor de vermogensstraffen, die ten aanzien van de door de rechtspersoon handelende personen worden opgelegd, de facto worden beschouwd als een verdoken strafrechtelijke aansprakelijkheid van de rechtspersoon. De rechtbank besliste echter, gelet op de rechtspraak van het Arbitragehof, ${ }^{406}$ dat van artikel 60 van het afvalstoffendecreet geen gebruik kon worden gemaakt nu dit artikel afweek van de regels vastgelegd door Boek I van het strafwetboek en derhalve de onderscheiden bevoegdheidsregels van de Staat, de gemeenschappen en de gewesten had geschonden. Van een civielrechtelijke 'veroordeling' van de Stad Blankenberge moest dus worden afgezien nu

'het betrekken van de Stad Blankenberge, publiekrechtelijke rechtspersoon, als burgerlijk verantwoordelijke op strafgebied (...) op geen andere bijzondere wetsbepaling kan worden gesteund. ${ }^{407}$

De rechtbank overweegt verder dat moet worden nagegaan

'indien het decreet niet werd nageleefd door de (in casu publiekrechtelijke) rechtspersoon, aan welke fysische persoon dit strafrechtelijk kan worden toegerekend (...) deze strafrechtelijke verantwoordelijke(n) kunnen zowel de organen of de aangestelden van deze rechtspersoon zijn.'

De schepen en de ondergeschikte ambtenaren werden respectievelijk als dader en mededaders veroordeeld. In dit vonnis zien we een mooi voorbeeld van cumulatieve aansprakelijkheid van leidinggevenden en ondergeschikten bij overheden. Dat bepaalde politiek verantwoordelijken de strafrechtelijke dans waren ontsprongen doet evenwel bepaalde vragen rijzen.

406. Arrest Arbitragehof nummer 44 van 23 december 1987, B.S., 27 januari 1988; arrest nummer 50 van 17 maart 1988, B.S., 14 april 1988.

407. Corr. Brugge, 14e kamer, 2 januari 1989 inzake OM t. Alleene e.a., ongepubliceerd. Zie tevens Faure, M., o.c., 1992, 107. In de jaren tachtig was de bevoegdheid voor gewesten om de nietnaleving van hun bepalingen strafrechtelijk te handhaven sterk aan banden gelegd. Artikel 11 van de bijzondere wet van 8 augustus 1980 betreffende de hervorming der instellingen bepaalt immers dat, binnen de grenzen van de bevoegdheden van de Gewesten en de Gemeenschappen, decreten de niet-naleving van hun bepalingen strafbaar kunnen stellen en de straffen wegens de niet-naleving kunnen bepalen overeenkomstig Boek I van het Strafwetboek. Op grond van dit artikel werden dan ook verschillende decretale bepalingen, waaronder artikel 60 van het afvalstoffendecreet, wegens bevoegdheidsoverschrijding vernietigd. Het door de bijzondere wet van 16 juli 1993 gewijzigde artikel 11 biedt de gewesten veel meer speelruimte om milieumisdrijven strafrechtelijk aan te pakken. Zie Deketelaere, K., 'De voorstellen van de interuniversitaire commissie tot herziening van het milieurecht in het Vlaamse Gewest inzake de aansprakelijkheid voor milieuschade', in Deketelaere, M., Deltour, B., Gille, B. en Deketelaere, $\mathrm{K}$. (red.), Recente ontwikkelingen inzake de aansprakelijkheid voor milieuschade, Brugge, Die Keure, 1993, 58-62. 
Een tweede zaak betreft ook een gemeentelijke stortplaats, namelijk de 'Hooge Maey' te Antwerpen. De stad Antwerpen had door het niet-afdekken van een laag asbestafval de voorwaarden van een afvalstoffenverwijderingsvergunning inzake sanering geschonden. In deze zaak stonden drie beklaagden terecht. Politiek verantwoordelijken werden echter niet gedagvaard. ${ }^{408}$ De hoofdbeklaagde was een verantwoordelijke directeur van de Dienst voor Stadsreiniging, die de hiërarchisch hoogste ambtenaar van de dienst was. Hij adviseerde het college van burgemeester en schepenen nopens de voorwaarden van de stortaanvragen en was aan het college ter zake verantwoording verschuldigd. De twee andere beklaagden waren ondergeschikt aan de directeur. De rechtbank oordeelde dat de drie beklaagden over dezelfde materie beslissingsbevoegd waren - zij het op een verschillend beleidsniveau - en veroordeelde hen dienovereenkomstig voor de bewezen feiten. Interessant is echter dat ten aanzien van bepaalde onderdelen van de tenlastelegging de beklaagden werden vrijgesproken. Enerzijds konden de ondergeschikte ambtenaren voor een aantal feiten

\section{'niet strafrechtelijk aansprakelijk (...) worden gesteld voor een aan hun advies tegenstrijdige beslissing van hun hiërarchische overste aan wie zij gehoorzaamheid zijn verschuldigd'.}

Anderzijds was het niet mogelijk de hiërarchisch hogere ambtenaren te veroordelen voor die feiten waaraan beslissingen ten grondslag lagen die waren
'genomen op grond van onjuiste adviezen van hun ondergeschikte diensthoofden, welke juist waren aangesteld om hen over hun departe- ment verantwoording en advies te geven. ${ }^{409}$

Dit vonnis illustreert duidelijk de toerekeningsproblematiek die voortvloeit uit het feit dat leidinggevenden en ondergeschikten zowel elkaars aansprakelijkheid als elkaars straffeloosheid kunnen determineren.

\section{E. WAAROM ZIJN OVERHEDEN NIET STRAFRECHTELIJK VERANTWOORDELIJK?}

Aan de hand van bovenstaande voorbeelden kan worden vastgesteld dat door overheden van strafrechtelijke verantwoordelijkheid uit te sluiten de toerekening van door hen gepleegde delicten aan natuurlijke personen vaak een precaire, ineffectieve en ingewikkelde aangelegenheid zal blijven zodat in een aantal gevallen vrijspraak in de rede ligt. In die gevallen waar wel een naturrijke persoon wordt veroordeeld, rijst soms de vraag of een veroordeling van de overheid - al dan niet gecumuleerd met een aansprakelijkheid van de betrokken ambtenaar - niet beter zou zijn geweest. De via artikel 5 lid 4 BSw ingevoerde niet-strafbaarheid van overheden laat helaas dezelfde onwenselijke situatie bestaan zoals die reeds aanwezig was vóór de wet van 4 mei 1999.

409. Corr. Antwerpen, 25e-bis kamer, 17 juni 1991 inzake OM t. Herreman e.a., ongepubliceerd. 
De Belgische minister van Justitie voert ter rechtvaardiging van de niet-strafbaarheid van overheden slechts één argument aan, namelijk dat overheden bestaan uit democratisch verkozen organen ${ }^{410}$. Hoewel in een afzonderlijk hoofdstuk op de mogelijke argumenten voor uitsluiting van overheden van het strafrecht dieper wordt ingegaan, kan worden opgemerkt dat dit toch wel een zeer eenzijdige en povere motivering is. Bovendien was de politieke druk om deze wet zo snel mogelijk door het parlement door te krijgen - net voor het einde van de legislatuur van Dehaene II - zo groot dat nauwelijks over dit punt werd en kon worden gediscussieerd. Het feit dat overheden uit democratische organen bestaan, vormt nauwelijks een afdoend argument voor een niet-strafbaarheid van overheden. De redenering is waarschijnlijk dat het bestaan van een democratische controle binnen overheden zich verzet tegen een strafrechtelijke controle. Dat in bepaalde gevallen van strafbaar overheidshandelen prioriteit moet worden gegeven aan de politieke, democratische controle is ongetwijfeld verdedigbaar. Maar dat vanwege dergelijke controle een strafrechtelijke verantwoordelijkheid per definitie is uitgesloten, is een ander verhaal. ${ }^{411}$ Controle door democratische organen heeft immers, zoals uit bovenstaande rechtspraak blijkt, nooit verhinderd dat de Belgische strafrechter het handelen of nalaten van de ambtsdragers, die optreden binnen de overheden, zelf op hun strafbaarheid vermag te toetsen. Niet valt in te zien waarom dan voor de overheden zelf het democratische karakter van hun organen of de aanwezigheid van politieke of bestuurlijke verantwoordingsfora wel meteen de strafrechtelijke aansprakelijkheid zou uitsluiten.

\section{F. DE CIVIELRECHTELUKE AANSPRAKELUKHEID VAN GEMEENTE EN PROVINCIE: EEN BEDENKELIJK ALTERNATIEF.}

De door de wetgever ingevoerde niet-strafbaarheid van overheden wordt in een wel heel bijzonder licht geplaatst, wanneer we vaststellen dat de uitsluiting van overheden van de werking van het strafrecht, deels wordt gecompenseerd doordat op dezelfde datum (4 mei 1999) ook een wet betreffende de burgerrechtelijke aansprakelijkheid van burgemeesters, schepenen en leden van de bestendige deputatie werd afgekondigd. Deze wet brengt allereerst wijzigingen aan in de nieuwe gemeentewet. Er wordt een artikel 271bis ingevoegd dat bepaalt dat de burgemeester of de schepenen waartegen een vordering tot schadevergoeding is ingesteld voor het burgerlijk gerecht of het strafgerecht, de staat of de gemeente in het geding kan betrekken.

Cruciaal is het nieuwe artikel 271ter dat bepaalt dat behalve in geval van herhaling, de gemeente burgerrechtelijk aansprakelijk is voor het betalen van de geldboete waartoe de burgemeester en de schepenen veroordeeld zijn wegens een delict dat ze hebben begaan bij de normale uitoefening van hun ambt. Immers, de niet-strafbaarheid van gemeenten sluit niet uit dat burgemeesters en schepenen zelf nog steeds strafrechtelijk aansprakelijk worden gesteld, ook voor milieudelicten die binnen het overheidskader zijn gepleegd, zoals het illegaal storten van afval. Het nieuwe artikel 271ter heeft dus tot doel om via een civielrechtelijke aansprakelijkheid de gemeente toch de strafrechtelijk geldboete te laten betalen,

410. Parl.St., Senaat, 1998-1999, 1-1217/6, 7.

411. Zie hoofdstuk V. 
die oorspronkelijk aan de veroordeelde natuurlijke persoon is opgelegd, voor zover geen sprake is van herhaling en het delict is gepleegd bij de normale uitoefening van het ambt. Met andere woorden, een gemeente mag weliswaar niet rechtstreeks strafrechtelijk aansprakelijk worden gesteld, maar kan blijkbaar wel civielrechtelijk worden veroordeeld tot het betalen van een 'strafrechtelijke' geldboete.

Het tweede lid van artikel 271 ter van de gemeentewet bepaalt dat de gemeente regres kan uitoefenen tegen de veroordeelde burgemeester of schepen, maar dat zulks is beperkt 'tot de gevallen van bedrog, zware schuld of lichte schuld die bij hen gewoonlijk voorkomt'.

Gelijkaardige bepalingen werden door de wet van 4 mei 1999 ook ingevoerd in de provinciewet. Het moge duidelijk zijn dat een civielrechtelijke aansprakelijkheid van gemeente, respectievelijk provincie voor het betalen van de strafrechtelijk geldboete waartoe burgemeester, schepenen of leden van de bestendige deputatie worden veroordeeld wegens delicten die zij zouden hebben begaan bij de normale uitoefening van hun ambt, in de praktijk vrijwel neerkomt op een verdoken strafrechtelijke aansprakelijkheid van deze overheden zelf. Hierdoor komt des te meer de argumentatie van de niet-strafbaarheid van overheden op de helling te staan. Bovendien rijst de vraag waarom deze nieuwe regeling uitsluitend is ingevoerd voor gemeenten en provincies en niet ook voor de andere overheden die van de werking van het strafrecht zijn uitgesloten. Daarnaast kan worden bekritiseerd dat deze civielrechtelijke aansprakelijkheid van gemeente en provincie slechts opgaat voor de geldboete waartoe burgemeester, schepenen of leden van de bestendige deputatie worden veroordeeld; waarom zou dit systeem niet mogen gelden in gevallen waar lagere functionarissen zijn veroordeeld voor delicten gepleegd bij de normale uitoefening van hun tak?

\section{G. CONCLUSIE}

Thans is in België de situatie ontstaan dat bij (milieu)delicten, die door overheden worden gepleegd, nog steeds moet worden gezocht naar daarvoor verantwoordelijke natuurlijke personen. Zoals uit de rechtspraak blijkt, kunnen dit al naargelang de casuspositie zowel leidinggevende als ondergeschikte functionarissen zijn.

In de eerste plaats ontstaat hierdoor een ongelijkheid tussen enerzijds de strafrechtelijke positie van natuurlijke personen binnen overheden en anderzijds de strafrechtelijke positie van natuurlijke personen binnen andere rechtspersonen. Voor deze laatste categorie bepaalt het tweede lid van artikel $5 \mathrm{BSw}$ immers dat wanneer de rechtspersoon verantwoordelijk wordt gesteld uitsluitend wegens het optreden van een geïdentificeerde natuurlijke persoon, deze laatste alleen strafrechtelijk verantwoordelijk kan worden gesteld indien deze de zwaarste fout heeft begaan. Daarnaast kan een natuurlijke persoon slechts samen met de rechtspersoon worden veroordeeld indien hij wetens en willens de fout heeft gepleegd. Deze discutabele beperking van de aansprakelijkheid van de natuurlijke persoon is niet van toepassing op natuurlijke personen binnen overheden. Daar overheden van iedere strafrechtelijke verantwoordelijkheid zijn uitgesloten, zal telkens in voorkomend geval moeten worden uitgeweken naar een strafvervolging van natuurlijke personen, zij het leiding- 
gevende of ondergeschikte functionarissen, ook in die gevallen waar feitelijk de 'fout' of de 'schuld' meer ligt bij de collectiviteit als geheel dan bij een of meer aanwijsbare individuen. Indien een bedrijf illegaal afval loost, dan zal een bedrijfsleider of enig andere verantwoordelijke natuurlijke persoon slechts kunnen worden veroordeeld indien niet bij het bedrijf als dusdanig, bijvoorbeeld door een falende organisatie, maar bij deze natuurlijke persoon zelf de zwaarste fout aanwezig is. Indien nu een gemeente een zelfde delict pleegt, dan zal steeds noodgedwongen een natuurlijke persoon moeten worden gevonden aan wie het strafbare feit kan worden toegerekend. Zelfs indien men betoogt dat vanwege hun specifiek publiekrechtelijk karakter overheden niet op gelijke voet staan met andere (publiekrechtelijke) rechtspersonen en zij daarom buiten het toepassingsgebied van het strafrecht moeten worden gehouden, kan deze redenering moeilijk worden volgehouden in die gevallen waar overheden zich niet anders gedragen dan particulieren. Deze ongelijkheid zal in de praktijk natuurlijk het sterkst naar voren komen in die domeinen waarin overheden met bedrijven samenwerken. Neem bijvoorbeeld de situatie waarin een gemeente aan een onderneming de opdracht uitbesteedt om een vaarwater uit te baggeren terwijl de gemeente hiervoor geen vergunning heeft of het baggeren in strijd met het recht geschiedt. Men krijgt dan de opmerkelijke situatie dat het bedrijf mogelijk wel en de gemeente niet voor het gepleegde feit kan worden vervolgd. Meer algemeen betekent dit dat wanneer een overheid de wet overtreedt en daartoe de hulp zoekt van een onderneming, de overheid strafrechtelijk vrijuit gaat, terwijl het bedrijf en mogelijk zelfs zijn bestuurders en werknemers een straf riskeren. Bovendien rijst de vraag of in voorkomend geval van strafbare samenwerking tussen een overheid en een privaatrechtelijke rechtspersoon een strafvervolging van deze laatste op grond van deelneming wel mogelijk is. Immers, nu in België - anders dan in Nederland - niet de strafvervolging van overheden is uitgesloten, maar de strafrechtelijke verantwoordelijkheid als dusdanig, staat ook een strafrechtelijke verantwoordelijkheid van de mogelijke deelnemers aan het door de overheid gepleegde feit mogelijk op de helling, want daarvoor is nu net een strafbaar hoofdfeit (dus ook een strafbare hoofddader) vereist. ${ }^{412}$ Impliceert de principiële niet-strafbaarheid van de overheid immers niet dat ook de privaatrechtelijke rechtspersoon als deelnemer straffeloos zal blijven?

Er is trouwens niet alleen een discriminatie tussen de strafrechtelijke aanpak van crimineel overheidshandelen en de strafrechtelijke controle op criminele gedragingen van andere rechts-personen. Wegens de principiële niet-strafbaarheid van overheden creëert artikel 5 lid $4 \mathrm{BSw}$ ook een ongelijkheid tussen overheden en de functionarissen die binnen en namens die overheden optreden. De strafrechtelijke verantwoordelijkheid van overheidsfunctionarissen is immers als dusdanig niet door de wetgever uitgesloten. Hoewel strafrechtsdogmatisch een niet-strafbaarheid van overheden een strafrechtelijke verantwoordelijkheid van de natuurlijke persoon onverlet laat, is het inconsequent dat de overheidsorganisatie niet, maar de functionarissen wel strafrechtelijk verantwoordelijk kunnen worden gesteld voor feiten die binnen overheidsverband zijn gepleegd. Is het dan niet moeilijk te begrijpen dat een gemeente niet, maar een schepen of een burgemeester wel kan worden vervolgd voor bijvoorbeeld het illegaal uitbaten van een stortplaats? 
Zoals gezien, wordt de uitsluiting van overheden van de werking van het strafrecht uitsluitend gerechtvaardigd door het feit dat deze publiekrechtelijke rechtspersonen bestaan uit organen die democratisch zijn verkozen. Maar geldt dit argument dan niet evenzeer, zo niet meer, voor deze organen zelf? Het is natuurlijk grotendeels koffiedik kijken hoe, in het licht van artikel 5 lid $4 \mathrm{BSw}$, het openbaar ministerie en de strafrechter zullen omgaan met de vervolging van verantwoordelijke functionarissen voor in overheidsverband gepleegde delicten. Blijft alles bij het oude en zal het strafbare feit dus net als vroeger aan de betrokken natuurlijke persoon worden toegerekend, of zal men daarentegen trachten de niet-strafbaarheid van overheden in de praktijk ook tot bepaalde natuurlijke personen uit te breiden? Beide uitkomsten zijn onwenselijk. In het ene geval is er een ongelijke behandeling tussen overheden en de daarin optredende functionarissen. In het andere geval wordt de (in vergelijking met Nederland en Frankrijk) zeer ruime straffeloosheid van crimineel overheidshandelen nog verder uitgebreid. Daarnaast is de ingevoerde civielrechtelijke aansprakelijkheid van gemeente en provincie voor strafbare feiten, gepleegd door burgemeester, schepenen en leden van de bestendige deputatie bij de normale uitoefening van hun ambt, een zeer bedenkelijk alternatief voor de onmogelijkheid hen rechtstreeks strafrechtelijk aansprakelijk te stellen.

\section{§ 5. Duitsland}

\section{A. INLEIDING}

Het Duitse strafrecht kent niet de strafrechtelijke aansprakelijkheid van de rechtspersoon. De Duitse wetgever voorzag slechts éénmaal in strafsancties tegen de rechtspersoon. § 393 van de Reichsabgabenordnung van 22 mei 1931 bepaalde dat wanneer in bedrijfsmatig kader fiscale delicten werden gepleegd, de geldstraffen aan de rechtspersoon zelf opgelegd konden worden 'sofern nach dem Straftatbestand ein Verschulden einer natürlichen Person nicht festgetsellt zu werden braucht. ${ }^{.13}$ Deze regeling werd in 1967 opgeheven. ${ }^{414}$ Buiten dit curiosum en enkele van de geallieerden afkomstige bepalingen uit het Besatzungsstrafrecht heeft de Duitse Bondsrepubliek nooit de strafbare rechtspersoon gekend. ${ }^{415}$ Ook bij de laatste hervorming van het algemeen strafrecht, wat in 1975 resulteerde in het nieuwe algemeen deel van het Strafgesetzbuch, werd de invoering van de strafrechtelijke aansprakelijkheid van de rechtspersoon afgewezen.

De strafrechtelijke aansprakelijkheid van de rechtspersoon wordt fundamenteel in strijd geacht met de basisbeginselen van het strafrecht. Het voornaamste bezwaar tegen de strafbaarheid van de rechtspersoon is het schuldbeginsel. De rechtspersoon kan niet het moreel element van het delict vervullen, met andere woorden de rechtspersoon is niet schuldbekwaam:

413. Korte, M., Juristische Person und strafrechtliche Verantwortung, Bonn, 1991, 13; Deruyck, F., o.c., 1996, 159-160.

414. Erstes Gesetz zur Änderung strafrechtlicher Vorschriften der Reichsabgabeordnung van 10 augustus 1967, BGBl, 1967, I, 877.

415 Deruyck, F., o.c., 1996, 160; Jescheck, H.H., 'Die strafrechtliche Verantwortlichkeit der Personenverbände', ZStW, 1953, 217. 


\begin{abstract}
'Strafende Gerechtigkeit ist an die Bedingungen einens Schuldvorwurfs gebunden, der, so wie er formuliert ist, sinnvollerweise nur an einzelne natürliche Personen gerichtet werden kann. ${ }^{.416}$
\end{abstract}

Maar ook de handelingsbekwaamheid van de rechtspersoon wordt op strafrechtelijk vlak ontkend. De rechtspersoon kan evenmin het materieel element van een delict vervullen:

\begin{abstract}
'Handlungsfähig im strafrechtlichen Sinne sollen daher nur natürliche Personen sein. Da die juristische Person erst durch ihre Organe künstlich handlungsfähig werde, soll ihr die natürliche und damit strafrechtliche relevante Handlungsfähigkeit fehlen. ${ }^{, 417}$
\end{abstract}

Het klassieke adagium Societas delinquere non potest geldt daarom nog steeds als leidinggevend principe.

De onmogelijkheid rechtspersonen strafrechtelijk aansprakelijk te stellen, heeft tot gevolg dat evenmin overheden of andere publiekrechtelijke rechtspersonen via het strafrecht kunnen worden aangepakt. Uit de afwezigheid van de strafrechtelijke verantwoordelijkheid van de rechtspersoon mag echter niet worden afgeleid dat binnen bedrijfsmatig kader gepleegde en meer in het bijzonder door overheden begane delicten straffeloos blijven. Het Duitse recht kent hoofdzakelijk twee manieren om door rechtspersonen veroorzaakte milieuverstoring punitief aan te pakken. Allereerst kunnen rechtspersonen voor dergelijke delicten rechtstreeks gesanctioneerd worden, maar dan niet via het klassieke strafrecht, doch via het zogenaamde Ordnungswidrigkeitenrecht. De basiswet van het Ordnungswidrigkeitenrecht, het Ordnungswidrigkeitengesetz (OWiG), voorziet namelijk in een overkoepelende bepaling betreffende de sanctionering van door rechtspersonen begane delicten. De rechtspersoon kan via $\S 30 \mathrm{OWiG}$ een geldboete worden opgelegd. In paragraaf B wordt onderzocht of $\S 30 \mathrm{OWiG}$ ook van toepassing is op overheden die milieudelicten plegen.

Naast de rechtsstreekse sanctionering van de rechtspersoon via het OwiG is er nog de mogelijkheid de individuele natuurlijke personen door dewelke de verdachte overheid optreedt strafrechtelijk aansprakelijk te stellen. De afwezigheid van de strafrechtelijke aansprakelijkheid van de rechtspersoon laat onverlet dat de achter de rechtspersoon schuilgaande natuurlijke personen wel strafrechtelijk kunnen worden vervolgd. In paragraaf

416. Heine, H., 'Vom individueller zu kollektiver Verantwortlichkeit. Einige Grundfragen der aktuellen Kriminalpolitik', in Arnold, J., Burkhardt, B., Gropp, W. en Koch, H.G. (Hrsg.), Grenzüberschreitungen. Beiträge zum 60. Geburtstag von Albin Eser, Freiburg im Breisgau, 1996, 51.

417. Korte, M., o.c., 1991, 16; zie tevens Bruns, H.J., 'Anmerkung zum Urteil des BGH vom 27. Oktober 1953', JZ, 1954, 251; Engisch, K., 'Empfiehlt es sich die Strafbarkeit der juristischen Person gesetzlich vorzusehen?' in Verhandlungen des 40. DJT, Band II, Tübingen, 1954, E 24; Jescheck, H.H., en Weigend, Th., Lehrbuch des Strafrechts. Allgemeiner Teil, Berlijn, Duncker \& Humboldt, 1996, 227. 
C wordt bekeken in hoeverre functionarissen strafrechtelijk aansprakelijk kunnen worden gesteld voor door overheden begane milieuverontreiniging. $\mathrm{lk}$ eindig dit hoofdstuk met enkele slotbedenkingen waarbij de voor- en nadelen van het Ordnugswidrigkeitenrecht en de individuele strafrechtelijke aanpak nog eens op een rij worden gezet (D).

Bemerk dat de strafrechtelijke aansprakelijkheid van ambtsdragers en ambtenaren voor milieuverontreiniging in de Duitse strafrechtsliteratuur veel aandacht krijgt. ${ }^{418}$ Het is dan interessant om vast te stellen dat de rechtsleer vrijwel uitsluitend geïnteresseerd is in de zogenaamde indirekte vormen van Amtsträgerstrafbarkeit; dat wil zeggen, de strafrechtelijke aansprakelijkheid van milieuambtenaren voor wederrechtelijke vergunningverlening enerzijds en gebrekkig toezicht anderzijds. De strafrechtelijke aansprakelijkheid van ambtenaren voor rechtstreeks door overheden begane milieudelicten, zoals illegale lozingen, wordt vreemd genoeg slechts summier behandeld. De meeste schrijvers volstaan met de vaststelling dat de strafrechtelijke aanpak van vervuilende overheden niet veel verschilt van de aansprakelijkheid voor milieudelicten gepleegd door private ondernemingen. In tegenstelling tot in Nederland is in Duitsland rechtstreekse milieuverstoring door overheden nauwelijks geproblematiseerd. De Duitse literatuur bespreekt dan ook summier de relevante rechtspraak en bestempelt deze gevallen als onproblematisch en concentreert zich vooral op de 'Amtsträgerstrafbarkeit für Erteilung fehlerhafter Verwaltungsakte'.419 Uit de geringe belangstelling van de doctrine voor de directe Amtsträgerstrafbarkeit mag echter niet worden afgeleid dat de praktijk zich niet uitvoerig met deze kwestie zou bezighouden. Het aantal strafrechtelijke veroordelingen van ambtenaren voor door overheden begane milieuverstoring is zeer groot in verhouding tot de belangstelling in de literatuur. In het licht van een rechtsvergelijkende studie, moet men er zich voor hoeden geen vertekend beeld te geven van het Duitse recht door zich hoofdzakelijk te concentreren op de meningen in de literatuur. Daarom staat in deze paragraaf zo uitgebreid de bespreking van de Duitse rechtspraak centraal hetgeen ons meteen ook toelaat vast te stellen hoe vanuit rechtsvergelijkend gezichtspunt verschillend wordt omgegaan met min of meer gelijkaardige casusposities.

\section{B. DE AANSPRAKELIJKHEID VAN OVERHEDEN VIA HET ORDNUNGSWIDRIGKEITENRECHT}

\section{Algemeen}

De Ordnungswidrigkeiten staan vooral bekend als administratieve delicten, de opvolgers van de vroegere strafrechtelijke overtredingen (Übertretungen). Met de invoering van het

418. Zie hierover reeds hoofdstuk I.

419. Rogall, K., Die Strafbarkeit von Amtsträgern im Umweltbereich, Berlijn, 1991, 147: 'Die Falle des Anlagenbetriebs durch Amtsträger bieten im Ergebnis keine besonderen strafrechtliche Probleme. In ihrer Betreiberfunktion sind Amtsträger für umweltschädigendes Verhalten in gleicher Weise verantwortlich wie Private.' Rogalls werk kan worden beschouwd als één van de belangrijkste studies over 'Amtsträgerstrafbarkeit'. Het is veelzeggend dat in dit 320 pagina's tellende boek het onderzoek naar de 'Amtsträgerverantwortlichkeit in den Fällen des Anlagenbetriebs' amper 5 pagina's bestrijkt. 
nieuwe algemeen deel van het Strafgesetzbuch, dat op 1 januari 1975 van kracht werd, werd afstand genomen van de klassieke driedeling van misdaden (Verbrechen), wanbedrijven (Vergehen) en overtredingen (Übertretungen). Deze laatste groep werd grotendeels gedepenaliseerd en omgevormd tot Ordnungswidrigkeiten. ${ }^{420}$ Dit betekent echter geenszins dat het toepassingsgebied van deze administratieve delicten zou beperkt zijn tot de 'kleine' criminaliteit. Het belang van de Ordnungswidrigkeiten moet grotendeels worden gesitueerd in de economische criminaliteit. De term Ordnungswidrigkeit duikt trouwens voor het eerst op in een wet van 1949 betreffende het economisch strafrecht. ${ }^{421}$

In 1952 ontstond het eerste Ordnungwidrigkeitengesetz, dat later werd vervangen door het Ordnungswidrigkeitengesetz van 24 mei 1968 (OWiG). Hoewel deze wet inmiddels al verscheidene keren is gewijzigd, geldt zij nog steeds als de basiswet van het Ordnungswidrigkeitenrecht. Met deze wet kreeg het Ordnungswidrigkeitenrecht een algemeen deel, dat sterk gelijkt op het algemeen deel van het Strafgesetzbuch. Dat blijkt reeds uit de in $\S 1$ OWiG gegeven definitie van een Ordnungswidrigkeit die sterk overeenkomt met de omschrijving van een strafbaar feit:

'Eine Ordnungswidrigkeit ist eine rechtswidrige und vorwerfbare Handlung, die den Tatbestand eines Gesetzes verwirklicht, das die Ahndung mit einer Geldbuße zuläßt'.

De Ordnungswidrigkeit kent dus net als de Straftat de drie elementen van delictstypiciteit, wederrechtelijkheid en verwijtbaarheid. Dit laatste element heeft zelfs een gelijke inhoud als het strafrechtelijke begrip 'Schuldhaft'. ${ }^{422}$ Ook andere strafrechtstypische rechtsfiguren zijn in de loop der tijd door het Ordnungswidrigkeitenrecht overgenomen. Zo kent het OWiG opzet en culpa $(\S 10)$, poging ( $\S 13)$, noodweer $(\S 15)$ en noodtoestand $(\S 16)$, die vrijwel identiek zijn met de bepalingen uit het Strafgesetzbuch. In die zin is het zeker niet ongepast het Ordnungswidrigkeitenrecht als een quasi-strafrecht, een bestuursstrafrecht ${ }^{423}$ of als een 'kleines Strafrecht' aan te duiden. ${ }^{424}$ In de Duitse literatuur worstelt men nog steeds met de vraag wat nu het fundamentele onderscheid uitmaakt tussen het echte strafrecht en het Ordnungswidrigkeitenrecht. ${ }^{425}$ Traditioneel tracht men het verschil in sociaal-ethische zin te verklaren. Het strafrecht zou dan in de eerste plaats betrekking hebben op justitieel onrecht, op de sanctionering van de overtreding van normen die sterk verband houden met ethische overtuigingen die leven binnen de maatschappij. Het Ordnungswidrigkeitenrecht zou dan veeleer verwijzen naar administratief onrecht, de

420. Klassiek voorbeeld van overtredingen die tot Ordnungswidrigkeiten werden getransformeerd zijn de verkeersdelicten. Zie Deruyck, F., L.c., 1990-1991, 1258.

421. Jescheck, H.H., l.c., 1953, 215-216; F. Deruyck, o.c., 1996, 161.

422. Göhler, E., Ordnungswidrigkeitengesetz, München, C.H. Beck'sche Verlags-Buchhandlung, 1995 , Vor $\S 1$, Nr. 30.

423. Zie o.m. De Doelder, H. en Rogier, L.J.J. (red.), Opstellen over bestuursstrafrecht, Amhem, Gouda Quint, 1994.

424. Aldus Deruyck, F., o.c., 1996, 161.

425. Boujong, K. en Cramer, P., Karlsruher Kommentar zum Gesetz über Ordnungswidrigkeiten, München, C.H. Beck'sche Verlags-Buchhandlung, 1989, Nr. 50-111. 
sanctionering van waardenneutrale normen die slechts tot doel hebben de maatschappij te ordenen. ${ }^{426}$ Toch blijft het vinden van een materieel criterium een moeilijke zaak en is het onderscheid tussen de twee rechtsgebieden vrij diffuus en aan verandering onderhevig. De vraag wat uiteindelijk als Ordnungswidrigkeit wordt bestempeld, lijkt soms eerder een pragmatische gelegenheid van efficiënte wetgeving en handhaving te zijn dan een kwestie van rechstheoretische bespiegeling. Wellicht dat het daarom meer in de rede ligt ervan uit te gaan dat aan het Ordnungswidrigkeitenrecht veeleer een proces van uniformisering en dejustitialisering ten grondslag ligt dan een strategie van doordachte depenalisering.

Fundamenteel verschil met het strafrecht blijft wel de afwezigheid van de vrijheidsbenemende straf. Het OWiG kent eigenlijk maar één sanctie: de Geldbuße, die als ze wordt opgelegd aan een rechtspersoon Verbandsgeldbuße wordt genoemd. Deze sanctie is neergelegd in $\S 30 \mathrm{OWiG}$. Het lijkt niet overbodig de tekst van $\S 30 \mathrm{OWiG}$ weer te geven.

\section{$\S 30$ OWiG:}

'(1). Hat jemand

1. als vertretungsberechtiges Organ einer juristischen Person oder als Mitglied eines solchen Organs

2. als Vorstand eines nicht rechtsfähigen Vereins oder als Mitglied eines solchen Vorstandes

3. als vertretungsberechtiger Gesellschafter einer Personenhandelsgesellschaft oder

4. als Generalbevollmächtiger oder in leitender Stelle als Prokurist oder Handlungsbevollmächtiger einer juristischen Person oder einer in Nummer 2 oder 3 genannten Personenvereinigung eine Straftat oder Ordnungswidrigkeit begangen, durch die Pflichten, welche die juristische Person oder die Personenvereinigung treffen, verletzt worden sind oder die juristische Person oder die Personen-vereinigung bereichert worden ist oder werden sollte, so kann gegen diese eine Geldbuße festgesetzt werden.

(2) Die Geldbuße beträgt:

1. im falle einer vorsätzlichen Straftat bis zu einer Million Deutsche Mark,

2. im falle einer fahrlässigen Straftat biszu fünfhunderdtausend Deutsche Mark.

426. Rechtshistorisch is dit idee terug te voeren tot de begin deze eeuw door Goldschmidt ontwikkelde strafrechtstheorie. Hij zag een wezensonderscheid tussen Verfassungsstrafrecht of Justizstrafrecht enerzijds en Verwaltungsstrafrecht anderzijds. Het Oostenrijkse Ordnungswidrigkeitenrecht wordt trouwens nog steeds aangeduid als Verwaltungsstrafrecht. Zie Goldschmidt, J., Das Verwaltungsstrafrecht. Eine Untersuchung der Grenzgebiete zwischen Strafrecht und Verwaltungsstrafrecht auf rechtsgeschichtlicher und rechtsvergleichender Grundlage, Berlin, 1902. Het Bundesverfassungsgericht ziet als wezenlijk kenmerk voor de echte 'Kriminalstrafe' het 'sozialethisches Unwerturteil'; zie o.m. BVerfGE 27, 18, 29 in NJW, 1969, 1619 en 1621. 
Im Falle einer Ordnungswidrigkeit bestimmt sich das Höchstmaß der Geldbuße nach dem für die Ordnungswidrigkeit angedrohten $H$ öchstmaß der Geldbuße.

(3) § 17 Abs. 4 und § 18 gelten entsprechend.

(4) Wird wegen der Straftat oder Ordnungswidrigkeit ein Straf- oder Bußgeldverfahren nicht eingeleitet oder wird es eingestelt oder wird von Strafe abgesehen, so kann die Geldbuße selbständig fetsgesetzt werden. Dies gilt jedoch nicht, wenn die Straftat oder Ordnungswidrigkeit aus rechtlichen Gründen nicht verfölgt werden kann; § 33 Abs. 1 Satz 2 bleibt unberührt.

(5) Die Festzetzung einer Geldbuße gegen die juristischen Person oder Personenvereinigung schließt es aus, gegen sie wegen derselben Tat den Verfall nach den $\S \S 73$ oder 74 des Strafgesetzbuches oder nach 29a anzuordnen.'

Uit de tekst van $\S 30$ OWiG blijkt al meteen dat de Verbandsgeldbuße veel meer is dan de gewone Geldbuße, de normale bestuurlijke boete die uitsluitend de Ordnungswidrigkeiten sanctioneert. Volgens $\S 30$ (1) OWiG kan aan een rechtspersoon een Verbandsgeldbuße worden opgelegd wanneer een bepaalde natuurlijke persoon zich schuldig maakt aan een Straftat of een Ordnungswidrigkeit. Dat ook de overtreding van in het Strafgesetzbuch neergelegde Straftaten kunnen leiden tot de oplegging van een Verbandsgeldbuße wordt vaak over het hoofd gezien. Nu dogmatisch gezien niet wordt uitgegaan van een door de rechtspersoon gepleegde inbreuk, maar van een overtreding begaan door een bepaalde natuurlijke persoon binnen de rechtspersoon, komen alle Straftaten en Ordnungswidrigkeiten voor sanctionering door een Verbandsgeldbuße in aanmerking. Dit betekent dat - mits ook aan de andere zo nader te bespreken voorwaarden van $\S 30 \mathrm{OWiG}$ is voldaan - aan een rechtspersoon een geldboete kan worden opgelegd wanneer bepaalde natuurlijke personen de milieudelicten van $\S \S 324$ e.v. StGB begaan. De milieustrafbepalingen van het StGB zijn dus via het OWiG rechtstreeks handhaafbaar. Deze niet onbelangrijke eigenaardigheid illustreert opnieuw dat het onderscheid tussen Straftaten, die met strafrechtelijke sancties worden gesanctioneerd, en Ordnungswidrigkeiten, waarvoor geldboetes worden opgelegd, niet helemaal zuiver is. ${ }^{427}$ De Verbandsgeldbuße kan dan ook niet worden vergeleken met de administratieve boetes naar Belgisch of Nederlands recht. ${ }^{428}$ Daar komt nog bij dat deze Verbandsgeldbuße vaak wordt opgelegd door de strafrechter.

\section{Materiële voorwaarden van de oplegging van de Verbandsgeldbuße}

Een eerste materiële vereiste is dat de inbreuk - Straftat of Ordnungswidrigkeit - door een bepaalde natuurlijke persoon moet zijn gepleegd. De kring van natuurlijke personen wier overtreding aanleiding kan zijn voor de oplegging van een Verbandsgeldbuße is uitgebreid door het Einundreißigste Strafrechtsänderungsgesetz - Zweite Gesetz zur Bekämpfung der

427. Alwart, H., 'Strafrechtliche Haftung des Unternehmens - vom Unternehmenstăter zum Tăterunternehmen', ZStW, 1993, 765.

428. Deruyck, F., o.c., 1996, 165. 
Umweltkriminalität van 27 juni 1994, die ook de milieustrafbepalingen gevoelig heeft veranderd.

Vóór de wijziging in 1994 diende volgens $\S 30$, 1ste lid OWiG de natuurlijke persoon een 'vertretungsberechtiges Organ einer juristischen Person' of een lid van dit orgaan, een 'Vorstand eines nicht rechtsfähigen Vereins' of een lid van dit bestuur, of nog een 'vertretungsberechtiger Gesellschaft einer Personenhandelsgesellschaft' te zijn. Net zoals in artikel 121-2 van de Franse Code pénal betrof het dus bestuurders en wettelijke vertegenwoordigers van de rechtspersoon. ${ }^{429}$ Dat uitsluitend organen en vertegenwoordigers in aanmerking konden komen, had als belangrijk nadeel dat inbreuken begaan door lager personeel maar ook door 'gewillkürte Vertreter' of bijzondere gevolmachtigden, zoals een Prokurist, niet resulteerden in de oplegging van een Verbandsgeldbuße. Aldus kon door een bepaalde organisatie van de rechtspersoon de toepassing van $\S 30 \mathrm{OWiG}$ worden omzeild. Als noodoplossing werd dan beroep gedaan op $\S 130$ OWiG. Deze bepaling sanctioneert het gebrekkig toezicht binnen de rechtspersoon, de zogenaamde 'Aufsichtspflichtverletzung'. Wanneer aldus een gevolmachtigde een inbreuk had begaan kon weliswaar deze inbreuk zelf geen Verbandsgeldbuße uitlokken, maar kon wel het gebrek aan toezicht in hoofde van de bestuurder of vertegenwoordiger als zelfstandige inbreuk worden beschouwd. Via $\S 130 \mathrm{OWiG}$ was het mogelijk het beperkte toepassingsgebied van de Verbandsgeldbuße naar inbreuken begaan door lager personeel uit te breiden. In de praktijk bleek deze bepaling niet zo succesvol omdat vaak moeilijk kon worden bewezen of door een zorgvuldige controle inderdaad de inbreuk niet zou zijn gepleegd. ${ }^{430}$ Het Strafrechtsänderungsgesetz van 1994 kwam tegemoet aan deze praktische problemen door aan de groep van natuurlijke personen de 'Generallbevolmächtigter', de 'Prokurist' en de 'Handlungsbevollmächtigter' toe te voegen. Toch is deze uitbreiding niet in staat om alle gesignaleerde bezwaren op te lossen. Belangrijk probleem blijft immers dat de aangeduide natuurlijke personen een leidinggevende functie (leitende Stelle) moeten bekleden. De door de rechtsleer voorgestelde uitbreiding tot iedere natuurlijke persoon die namens de rechtspersoon optreedt, is door de wetgever niet overgenomen. ${ }^{431}$ Dit zou een te ruime aansprakelijkstelling van de rechtspersoon tot gevolg hebben. Voor wat Straftaten of Ordnungswidrigkeiten begaan door lagere personeel betreft, is de omweg van $\S 130 \mathrm{OWiG}$ dus nog steeds van belang. Daarbij mag niet worden vergeten dat het bewuste Strafrechtsänderungsgesetz ook de voorwaarden van $\S 130$ OWiG enigszins heeft versoepeld. De vroegere eis dat het falende toezicht 'hätte verhindert werden können' is omgevormd in 'verhindert oder wesentlich erschwert worden wäre'.432 Men hoopt aldus de bewijsvoering te vergemakkelijken.

Een tweede materiële voorwaarde heeft betrekking op de vraag wanneer de door de natuurlijke persoon gepleegde inbreuk kan worden beschouwd als een schending die een

429. Müller, E., Die Stellung der juristischen Person im Ordnungswidrigkeitenrecht, Köln, 1985, 61; Deruyck, F., o.c., 1996, 209-210.

430. Boujong, K. en Cramer, P, o.c., 1989, §30, Nr. 87.

431. Zie o.m. Jescheck, H.H., 'Zur Frage der Strafbarkeit von Personenverbănden', DÖV, 1953, 543. Deruyck, F., l.c., 1990-1991, 1262.

432. Deruyck, F., o.c., 1996, 212. 
sanctionering van de rechtspersoon rechtvaardigt. Met andere woorden, wanneer kan de inbreuk worden beschouwd als Verbandsunrecht. Het spreekt voor zich dat niet iedere inbreuk van de natuurlijke persoon een Verbandsgeldbuße kan uitlokken. Dat een rechtspersoon niet aansprakelijk moet worden gesteld voor inbreuken die niet in zijn belang zijn gepleegd, is daarbij een begrijpelijk uitgangspunt. In tegenstelling tot het Franse systeem koos de Duitse wetgever niet voor een opsomming van voor bestraffing van de rechtspersoon in aanmerking komende delicten. Er is duidelijk geopteerd voor een algemene omschrijving. $\S 30$ (1) lid OWiG bepaalt dat de inbreuk voor een Verbandsgeldbuße in aanmerking komt wanneer ofwel deze tot gevolg heeft dat bepaalde plichten van de rechtspersoon niet zijn nagekomen, ofwel dat het de rechtspersoon moet hebben verrijkt of dit tenminste beoogde. Wat de eerste voorwaarde betreft, moet het gaan om plichten die de 'juristische Person oder die Personenvereinigung treffen'. Dit betekent dat het gaat om 'betriebsbezogen Pflichten'; plichten die rechtstreeks zijn gerelateerd aan de specifieke werkingssfeer van de rechtspersoon. ${ }^{433}$ Daarbij kan - naast de in $\S 130$ OWiG zelf neergelegde Aufsichtspflicht - worden gedacht aan plichten die voortvloeien uit bepaalde hoedanigheden van rechtspersonen, zoals die van werkgever, vervoerder, ondernemer en dergelijke meer. ${ }^{434}$ Daarnaast is het mogelijk te spreken van Verbandsunrecht wanneer de inbreuk tot gevolg heeft dat hierdoor de rechtspersoon effectief werd verrijkt, ofwel de verrijking werd beoogd. Onder verrijking wordt zowel rechtstreekse als onrechtstreekse verrijking begrepen. ${ }^{435}$ Daarbij is van belang dat bij de effectieve verrijking deze niet moet zijn nagestreefd, terwijl dit voor de beoogde verrijking vanzelfsprekend wel het geval is. ${ }^{436}$ Ook hoeft de verrijking niet het rechtstreekse resultaat zijn van de inbreuk op een betriebsbezogen Pflicht. De enige vereiste is een causaal verband tussen de inbreuk en de verrijking. ${ }^{437}$ Dit zogenaamde baat-criterium beperkt wel meteen weer de reikwijdte van het toepassingsgebied van $\S 30 \mathrm{OWiG}$, nu niet met ieder delict een verrijking wordt bereikt of beoogd.

\section{Procedurele voorwaarden van de oplegging van de Verbandsgeldbuße}

Hoe worden deze materiële condities nu procedureel vertaald? Zoals vastgesteld, moet door een natuurlijke persoon een inbreuk zijn gepleegd die - kort gezegd - de rechtspersoon ten goede komt. De Verbandsgeldbuße kan dan conform $\S 30 \mathrm{OWiG}$ op tweeërlei wijze worden opgelegd. Allereerst is er de mogelijkheid dat in de loop van de procedure - hetzij een Strafverfahren, hetzij een Bußgeldverfahren - tegen de natuurlijke persoon de Verbandsgeldbuße wordt opgelegd. Men spreekt dan van een samengevoegde procedure (verbundenes Verfahren). ${ }^{438}$ Daarnaast is het mogelijk dat tegen de natuurlijke persoon geen vervolging wordt ingesteld en een zelfstandige procedure (selbständiges Verfahren) tegen de rechtspersoon wordt gevoerd. Volgens de tekst van $\S 30$ OWiG dient de samengevoegde procedure de regel te zijn, aangezien de zelfstandige procedure slechts in

433. Boujong, K. en Cramer, P., o.c., $§ 30,1989$, Nr. 92.

434. Idem, Nr. 90-91.

435. Idem, $\mathrm{Nr}$. 100-103.

436. Idem, Nr. 96-103.

437. Idem, Nr. 104-107.

438. Göhler, E., o.c., 1995, § 30, Nr. 28; Boujong, K. en Cramer, P., o.c., 1989, § 30, Nr. 148 e.v. 
drie limitatief opgesomde gevallen mogelijk is; namelijk, wanneer de bevoegde administratieve overheid of de 'Staatsanwaltschaft' besluit geen procedure naar aanleiding van een Ordnungswidrigkeit of een Straftat tegen de natuurlijke persoon in te stellen, wanneer de vervolging tegen de natuurlijke persoon wordt gestaakt en ten slotte wanneer de strafrechter op grond van $\S 60 \mathrm{StGB}^{439}$ van elke bestraffing afziet $(\S 30(4) \mathrm{OWiG}){ }^{440} \mathrm{In}$ de praktijk blijkt echter dat meestal zelfstandige procedures tegen de rechtspersoon worden gevoerd. ${ }^{441}$ Dit is eigenaardig want de zelfstandige procedure heeft enkele belangrijke nadelen. Hoewel in deze procedure de natuurlijke persoon niet wordt vervolgd en dus ook niet bekend hoeft te zijn, moet toch steeds worden bewezen verklaard dat de inbreuk is begaan door een persoon die behoort tot de in $\S 30$ OWiG genoemde kring en dat de inbreuk op wederrechtelijke en schuldige wijze is begaan. Deze bewijsrechtelijke voorwaarden bemoeilijken in sterke mate de effectiviteit van de zelfstandige procedure. ${ }^{442}$

De samengevoegde procedure kan steeds, als aan de materiële voorwaarden is voldaan, worden ingesteld. Indien de natuurlijke persoon een Ordnungswidrigkeit heeft begaan dan wordt voor de bevoegde administratieve overheid tegen hem een Bußgeldverfahren ingesteld. Het is deze overheid die dan ook aan de rechtspersoon de Verbandsgeldbuße oplegt. Bestaat de inbreuk van de natuurlijke persoon echter in een Straftat, dan wordt door het openbaar ministerie voor de strafrechter een Strafverfahren ingesteld. Het is dezelfde strafrechter die aan de opgeroepen rechtspersoon de Verbandsgeldbuße oplegt. ${ }^{443}$ Het is dan interessant om vast te stellen dat hoewel de iure Duitsland niet de strafrechtelijke aansprakelijkheid van de rechtspersoon kent, via de omweg van $\S 30 \mathrm{OWiG}$, de rechtspersoon wel degelijk de facto door de strafrechter kan worden bestraft.

Dit opmerkelijk gegeven geldt uiteraard evenzeer in de zelfstandige procedure. Is de betreffende inbreuk een Straftat, dan wordt de Verbandsgeldbuße door de strafrechter opgelegd. Ofwel gebeurt dit wanneer de reeds tegen de natuurlijke persoon ingestelde strafvervolging wordt gestaakt, ofwel wanneer de strafrechter van straf afziet, ofwel tenslotte wanneer het nooit tot een strafvervolging van de natuurlijke persoon is gekomen en door het OM tegen de rechtspersoon een Verbandsgeldbußverfahren bij de strafrechter wordt ingesteld. ${ }^{444}$ In alle drie de gevallen is het steeds de strafrechter die de rechtspersoon sanctioneert.

439. $\S 60$ StGB: 'Das Gericht sieht von Strafe ab, wenn die Folgen der Tat, die den Tăter getroffen haben, so schwer sind, daß die Verhăngung einer Strafe offensichtlich verfehlt wäre. Dies gilt nicht, wenn der Täter für die Tat eine Freiheitsstrafe von mehr als einem Jahr verwirkt hat.' Nu deze mogelijkheid tot afzien van straf slechts zelden wordt gebruikt, is deze mogelijkheid tot zelfstandige oplegging van de Verbandsgeldbuße bijna van geen praktisch belang.

440. Boujong, K. en Cramer, C., o.c.,1989, § 30, Nr. 149-157.

441. Deruyck, F., o.c., 1996, 165.

442. Schrott, H.J., 'Der Regelungsgehalt des 2. Gesetzes zur Bekämpfung der Wirtschaftskriminalität im Bereich des Ordnungswidrigkeitenrechts', Wistra, 1986, 164; Schünemann, B., Unternehmenskriminalität und Strafrecht, Köln, Carl Heymanns Verlag, 1979, 164-165.

443. Göhler, E., o.c., 1995, § 30, Nr. 43.

444. Gobler, E., o.c., 1995, § 30, Nr. 43. 
Bij dit alles mag niet uit het oog worden verloren dat het instellen van twee afzonderlijke procedures, namelijk één tegen de natuurlijke persoon en één tegen de rechtspersoon, niet is toegestaan. Dit betekent dat wanneer reeds een procedure tegen de natuurlijke persoon is gevoerd en deze resulteert in een einduitspraak - afgezien van de uitspraak bewezenverklaring zonder strafoplegging - geen zelfstandige oplegging van de Verbandsgeldbuße meer mogelijk is. Is de natuurlijke persoon dus reeds veroordeeld in de ene of andere procedure, dan kan niet alsnog de rechtspersoon worden bestraft. ${ }^{445}$

Nog een opmerking over de Verbandsgeldbuße zelf. In $\S 30$ (2) OWiG wordt een maximumgrens bepaald. Voor opzettelijke delicten is het maximum 1 miljoen DM. Voor culpose delicten is dit 0,5 miljoen DM. Deze maxima zijn niet absoluut. Om de hoogte van het boetebedrag in een concreet geval te kennen, is ook § $17 \mathrm{OWiG}$, waar $\S 30$ (3) OWiG naar verwijst, van belang. Deze bepaling luidt als volgt:

'Die Geldbuße soll den wirtschaftlichen Vorteil, den der Täter aus der Ordnungswidrigkeit gezogen hat, übersteigen. Reicht das gesetzlichen Höchstgemaß hierzu nicht aus, so kann es überschritten werden.'

Deze bepaling koppelt de geldboete aan de ontneming van het illegale voordeel en maakt het aldus mogelijk de in $\S 30 \mathrm{OWiG}$ vastgelegde maximumgrens van het boetebedrag te overschrijden wanneer de ontneming van het wederrechtelijk verkregen voordeel daartoe noopt. De Duitse Verbandsgeldbuße krijgt hierdoor een bijzonder karakter. Er is geen scheiding gemaakt tussen de geldboete als straf en de ontneming als maatregel. De boete draagt beide elementen in zich. ${ }^{446}$ De functie van de geldboete is dus niet alleen punitief, maar tegelijk ook herstellend. ${ }^{447}$

\section{Zijn overheden op grond van $\$ 30$ OWiG sanctioneerbaar?}

De rechtsleer is het er unaniem over eens: $\S 30 \mathrm{OWiG}$ richt zich tot alle rechtspersonen, dus ook tot publiekrechtelijke rechtspersonen waartoe eveneens de overheden behoren. Het begrip 'juristische Person' wordt zeer ruim uitgelegd:

'Juristische Personen sind alle Organisationen mit eigener Rechtspersönlichkeit, gleichgültig, ob sie dem Privatrecht (...) oder dem öffentlichen Recht (Körperschaften, selbständige Anstalten und Stiftungen)

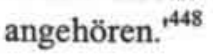

445. Boujong, K. en Cramer, P., o.c., 1989, §30, Nr. 163.

446. Zie hierover Roef, D., 'Voordeelsontneming via het Ordnungswidrigkeitenrecht', in Faure, M. en De Roos, Th., De berekening van het wederrechtelijk verkregen voordeel uit milieudelicten, Den Haag, Sdu, 1998, 139-159.

447. Boujong, K. en Cramer, P., o.c., 1989, § 30, Nr. 131: 'Die Gelduße soll vor allem dazu dienen, unrechtmäßige Gewinne abzuschöpfen und unlauterem Gewinnstreben vorzubeugen. Aus diesem Grunde erklärt $\S 30$ Abs. 3 die Regelung des $\S 17$ Abs. 4 für entsprechend anwendbar, wonach die Geldbuße den aus der Tat gezogenen wirtschaftlichen Vorteil überschreiten soll.'

448. Boujong, K. en Cramer, P., o.c., 1989, § 9, Nr. 21 en $\S 30$, Nr. 45. 
Als argument voor de toepasselijkheid van $\S 30 \mathrm{OWiG}$ op overheden wordt aangevoerd dat zij nu eenmaal ook rechtspersonen zijn, en dat de memorie van toelichting bij het ontwerp van $\S 30$ OWiG desbetreffend stilzwijgt. ${ }^{449}$ Daarnaast ziet een belangrijk deel van de Duitse doctrine de mogelijkheid om ook aan publiekrechtelijke rechtspersonen een Verbandsgeldbuße op te leggen als een crimineel-politieke noodzaak. Cramer vat het als volgt samen:

'mit der Übernahme eines erheblichen Teils der Versorgung der Bevölkerung und der Daseinsfürsorge (Wasserwerke, Energieversorgung, Klär- und Müllanlagen) durch staatliche Stellen und infolge der stetig wachsenden Teilnahme des Staates am Wirtschaftsleben ist die Gefahr gewachsen, daß von Organen der JPen des öffentlichen Rechts Zuwiderhandlungen begangen werden, die in der privaten Wirtschaft nach $\S 30$ zur Festsetzung einer Geldbuße führen würden. ${ }^{450}$

Dit betekent dat niets zich er tegen verzet de overtreding door overheden van milieuvoorschriften neergelegd in $\S \S 324$ e.v. StGB, het Wasserhaushaltsgesetz of andere milieuwetgeving via het OWiG te handhaven: 'die Organe einer JP des öffentlichen Rechts sollen durch die präventive Wirkung des $\S 30$ zum rechtmäßigen Handeln angehalten werden. ${ }^{451}$

Kijken we meer specifiek naar de toepassingsvoorwaarden van $\S 30$ OWiG dan lijken er inderdaad geen ernstige bezwaren te zijn om deze bepaling ook op overheden toe te passen. Wat de eerste materiële voorwaarde betreft kunnen als natuurlijke personen worden aangeduid alle leidinggevende functionarissen van de betrokken overheid, inclusief de organen. Problematisch blijft wel - net als bij ondernemingen - de situatie waarin lagere ambtenaren de inbreuk begaan. De overheid zal dan slechts via een schending van $\S 130$ OWiG kunnen worden gesanctioneerd. Ook de tweede materiële voorwaarde lijkt geen problemen op te leveren. Voorbeelden van betriebsbezogen Pflichten in hoofde van overheden zijn in de milieusfeer afvalverwerking en afvalwaterzuivering. Wanneer aldus een bepaalde ambtenaar een milieudelict begaat, daarbij een van deze plichten schendt en hij niet in eigenbelang handelt, is een Verbandsgeldbuße best denkbaar. Ook aan het baatcriterium zal in bepaalde gevallen zijn voldaan. Zo kan worden gedacht aan de situatie waarin een gemeente om kosten te besparen op wederrechtelijk wijze afvalwater loost door gebruik te maken van een verouderde zuiveringsinstallatie. Niet alleen is dan de Abwasserbeseitigungspflicht geschonden, maar is er ook sprake van een indirecte verrijking of in ieder geval een beoogde verrijking.

449. Deruyck, F., o.c., 1996, 177.

450. Boujong, K. en Cramer, P, o.c., 1989, § 30, Nr. 46; Weber, U., Strafrechtliche Verantwortlichkeit von Bürgermeistern und leitenden Verwaltungsbeambten im Umweltrecht, Stuttgart, 1988, 29.

451. Boujong, K. en Cramer, P., o.c., 1989, § 30, Nr. 48. 
Hoewel deze theoretisch zuivere uitgangspunten nauwelijks worden betwist, geeft de praktijk een totaal ander beeld. Tot op heden heeft - voor zover mij bekend - geen enkele strafrechtelijke inbreuk binnen overheidskader begaan, geleid tot een oplegging van een Verbandsgeldbuße aan het betrokken overheidslichaam. Er zijn slechts enkele zaken gepubliceerd waarin overheden daadwerkelijk een Verbandsgeldbuße opgelegd kregen en dat naar aanleiding van een Ordnungswidrigkeit. Zo werd een Landkreis tot een geldboete van 5.600 DM veroordeeld omdat deze uit kostenbesparingen belastingaanslagformulieren niet via de post maar via ingehuurde bodes had laten bezorgen. ${ }^{452}$ In een andere zaak kreeg een gemeente vanwege een gelijkaardige inbreuk een boete van $10.000 \mathrm{DM}$ opgelegd. ${ }^{453}$

Er kunnen verschillende verklaringen voor deze opmerkelijke situatie worden gegeven. Allereerst wordt, niettegenstaande de principiële toepasbaarheid van $\S 30 \mathrm{OWiG}$ op overheden, het nut van het opleggen van geldboeten aan overheden sterk betwijfeld. Dit zou niet in overeenstemming zijn met de specifieke functie van de Verbandsgeldbuße: 'nach dem Zweck, der mit der Geldbuße gegen JPen erstrebt wird (...), wird es jedoch selten in Betracht kommen, gegen JPen des öR eine solche Sanktion festzusetzen. ${ }^{\text {,454 }}$ Deze functie is deels repressief en deels het ontnemen van het wederrechtelijk verkregen voordeel. Men gaat ervan uit dat deze functie toch eerder past bij ondernemingen en daarom slechts in de sfeer van ondernemingscriminaliteit effectief kan zijn. Dit uitgangspunt hangt sterk samen met de ratio van deze sanctie. Bij de totstandkoming van het OWiG werd de Verbandsgeldbuße bijna uitsluitend op grond van economische motieven gerechtvaardigd. De centrale gedachte was dat indien geldboeten alleen aan natuurlijke personen zouden kunnen worden opgelegd dit enerzijds zou leiden tot uitzonderlijk lage boetes, want afgestemd op de beperkte draagkracht van de natuurlijke persoon, en anderzijds een concurrentievoordeel voor bedrijven tot gevolg zou hebben. Op basis van deze economische overwegingen werd een Verbandsgeldbuße noodzakelijk geacht. ${ }^{455} \mathrm{Nu}$ worden juist deze louter economische maar daarom tegelijk ook eenzijdige en beperkte grondslagen van de Verbandsgeldbuße gezien als een hinderpaal om geldboeten aan overheden op te leggen. Het is echter wel noodzakelijk te beseffen dat hiermee het principe dat ook overheden onder het toepassingsgebied van $\S 30 \mathrm{OWiG}$ vallen, niet overboord wordt gegooid. $\mathrm{Er}$ worden in de Duitse literatuur geen theoretische of dogmatische argumenten aangevoerd die een dergelijke conclusie zouden rechtvaardigen.

452. OLG Frankfurt, 30 januari 1976, NJW 1976, 1276.

453. OLG Hamm, 27 februari 1979, NJW 1979, 1312.

454. Göhler, E., o.c., 1995, §30, Nr. 2.

455. De Verbandsgeldbuße 'soll namentlich einen Ausgleich dafür ermöglichen, daß der juristischen Person, die nur durch ihre Organe zu handeln imstande ist, zwar die Vorteile dieser in ihrem Interesse vorgenommenen Betätigung zufließen, da $\mathrm{B}$ sie aber beim Fehlen einer Sanktionsmöglichkeit nicht den Nachteilen ausgesetzt wäre, die als Folge der Nichtbeachtung der Rechtsordnung im Rahmen der für sie vorgenommen Betätigung eintreten können. Die juristischen Person wäre dann gegenüber der natürlichen Person bessergestellt.' Regierungsentwurf eines Gesetzes über Ordnungswidrigketen, BT-Drucks. V/1269, 59, aangehaald in Rösenkötter, G., Das recht der Ordnungswidrigkeiten, München, C.H. Beck'sche Verlagsbuchhandlung, 1988, 129. 
Een tweede verklaring ligt in het argument dat de oplegging van een Verbandsgeldbuße schadelijke neveneffecten zou hebben. De geldboete wordt als onrechtvaardig beschouwd omdat uiteindelijk de gemeenschap wordt gestraft.

\begin{abstract}
'Allerdings wird von der Möglichkeit der Verhängung von Geldbußen gegen Gemeinden usw. praktisch kein Gebrauch gemacht, weil die Sanktion letzerlich die steuer-und gebührenpflichtigen Bürger in Gestalt von Abgabenerhöhungen treffen würde. ${ }^{.456}$
\end{abstract}

Of dit een overtuigend argument is, kan worden betwijfeld, want de gemeenschap wordt ook bezwaard via bijvoorbeeld een civielrechtelijke aansprakelijkheid van de overheid. De redenering is dan weer wel voor een deel te begrijpen in het licht van de eenzijdige economische sturingsfunctie van de Verbandsgeldbuße.

Een laatste mogelijke verklaring ligt in de complexiteit van het OWiG zelf. Ondanks de wijzigingen door het Strafrechtsänderungsgesetz van 1994 blijft het OWiG een lastige wet, die niet steeds even efficiënt blijkt te zijn. Daar komt nog bij dat, zoals in de volgende paragraaf zal worden aangetoond, het $\mathrm{OM}$ voorrang geeft aan de vervolging van individuele ambtenaren. Dan is het licht te begrijpen dat niet alsnog de overheid zelf wordt beboet. In de eerste plaats niet omdat na een vervolging van natuurlijke personen een afzonderlijke procedure tegen een rechtspersoon niet mogelijk is. En in de tweede plaats niet omdat binnen het Ordnungswidrigkeitenrecht de wettelijke uitzondering van de zelfstandige procedure, waarbij de natuurlijke persoon buiten spel blijft, in de praktijk de regel blijkt te zijn. Daar rijst trouwens nog een ander praktisch probleem, dat de laatste jaren binnen de sfeer van ondernemingscriminaliteit wordt gesignaleerd. De strafrechtspraktijk blijkt zich meer en meer te concentreren op inbreuken begaan door lager personeel veeleer dan op inbreuken begaan door leidinggevenden. Dit heeft zijn gevolgen in de toepassingen van het Ordnungswidrigkeitenrecht. Zoals gezien, kan slechts een Verbandsgeldbuße worden opgelegd indien de inbreuk is gepleegd door de in $\S 30 \mathrm{OWiG}$ aangeduide personen. Wanneer nu de strafvervolging zich primair gaat richten op de lagere niveaus van de corporatie, dan heeft dit meteen als consequentie dat de toepasselijkheid van $\S 30$ OWiG wordt beperkt.

'Eine strafrechtliche Praxis, die mit Nachdruck Vertreter im unteren Bereich verfolgt, wirkt im hinblick auf das Ziel einer Bekämfung der Verbandskriminalität kontraproduktiv, da sie auf diese Weise praktisch die Möglichkeit der Verhängung von Verbandsgeldbußen einengt. ${ }^{\text {.457 }}$

Met andere woorden, hoe intensiever de strafrechtelijke vervolging van niet-leidinggevende personen, hoe geringer de bruikbaarheid van het OWiG. Dergelijke gang van zaken heeft ongetwijfeld repercusies op de aanpak van overheidscriminaliteit.

456. Weber, U., o.c.,1998, 29.

457. Marxen, K., 'Die strafrechtliche Organ- und Vertreterhaftung - eine Waffe im Kampf gegen die Wirtschaftskriminalităt?', $/ Z, 1988,291$. 
Samengevat kan worden geconcludeerd dat met het OWiG in de Duitse Bondsrepubliek een afdoening van door rechtspersonen gepleegde delicten is ontwikkeld die de strafrechtelijke aansprakelijkheid van de rechtspersoon zeer dicht benadert. ${ }^{458}$ Dit Ordnungswidrigkeitenrecht is theoretisch ook op overheden van toepassing, ook wanneer delicten zijn begaan binnen het kader van de hun opgelegde overheidstaak (bijvoorbeeld afvalverwerking). In de praktijk heeft het $\mathrm{OWiG}$ echter nauwelijks betekenis. Door de complexiteit van het OWiG enerzijds en de beperkte functie van de enige sanctie, de Verbandsgeldbuße, anderzijds concentreert de bestrijding van door overheden begane milieudelicten zich op de zuiver strafrechtelijke vervolging van de individuele verantwoordelijke ambtenaren. Hoe dit in zijn werk gaat en welke problemen daarbij kunnen rijzen, wordt in de nu volgende paragraaf onderzocht.

\section{DE STRAFRECHTELIJKE AANSPRAKELUKHEID VAN AMBTENAREN: DE 'ORGAN- UND VERTRETERHAFTUNG'.}

\section{Algemeen}

In gevallen waar overheden rechtstreeks het leefmilieu verstoren biedt het Ordnungswidrigkeitenrecht reeds een eerste (theoretische) mogelijkheid om punitief tegen hen op te treden. Dit 'kleines Strafrecht' is in de praktijk niet de meest gebruikelijke weg om milieudelicten 'strafrechtelijk' aan te pakken. In de eerste plaats gaat de aandacht daarom uit naar de vervolging van de verantwoordelijke organen en ambtenaren van de onderscheiden overheden. Net als bij de strafrechtelijke aansprakelijkheid van particulieren (organen, werknemers of aangestelden) voor milieucriminaliteit in bedrijfsmatig kader gepleegd, dient ook de strafbaarheid van de ambtenaar aan de klassieke dogmatische vereisten te voldoen.

Belangrijke voorwaarde voor de vervolgbaarheid en strafbaarheid van de ambtenaar is dat de strafbepaling tot de ambtenaar moet zijn gericht. De ambtenaar moet normadressaat zijn. ${ }^{459}$ Dit is niet steeds het geval. Net zoals in Nederland zijn ook de Duitse milieustrafbepalingen onder te verdelen in gemene delicten en kwaliteitsdelicten. De gemene delictsomschrijvingen van $\S \S 324$ en 326 StGB richten zich tot eenieder en zijn op het vlak van normadressaatschap dus vrij onproblematisch: zij kunnen door individuele ambtenaren worden overtreden. Wanneer een gemeente op illegale wijze afvalwater loost kan de daarvoor verantwoordelijke ambtenaar vrij gemakkelijk een overtreding van $\S 324$ StGB ten laste worden gelegd.

Problematisch zijn vooral de kwaliteitsdelicten $\S \S 325,327,328,329$ StGB. Deze delicten kunnen immers slechts door hen worden gepleegd, die aan bepaalde kwaliteiten voldoen, zoals het zijn van vergunninghouder of het exploiteren van een inrichting. Deze kwaliteiten behoren niet toe aan de individuele ambtenaren of organen, maar behoren toe aan de 
overheden, de publiekrechtelijke rechtspersonen. ${ }^{460}$ Het zijn deze laatsten die vergunningplichtig zijn of die bijvoorbeeld een afvalverwerkingsbedrijf exploiteren. Dit heeft tot gevolg dat de overheid-rechtspersoon dan de enige normadressaat is. ${ }^{461}$ Deze normadressaat kan echter vervolgd noch bestraft worden, nu het Duitse strafrecht niet de strafrechtelijke aansprakelijkheid van (privaatrechtelijke of publiekrechtelijke) rechtspersonen kent. Langs de andere kant blijven de ambtenaren als eigenlijke plegers van het milieudelict, straffeloos omdat zij geen normadressaat zijn. ${ }^{462}$ Ambtenaren kunnen evenmin worden vervolgd als deelnemers, bijvoorbeeld als medeplichtigen, omdat ook dan een door de rechtspersoon gepleegd strafbaar gronddelict is vereist. Het spreekt voor zich dat een dergelijke aansprakelijkheidslacune een nefaste invloed zou hebben op een efficiënte strafrechtelijke handhaving van het milieurecht. Om dit probleem op te lossen - dat vanzelfsprekend ook bestaat op het niveau van particuliere ondernemingen - kent het Duitse strafrecht de figuur van de zogenaamde Organ und Vertreterhaftung, neergelegd in $\S 14$ $\mathrm{StGB}$. Het is aangewezen de tekst van $\S 14 \mathrm{StGB}$ weer te geven:

\section{$\S 14 \mathrm{StGB}:$}

\section{Handelt jemand}

1. als vertretungsberechtigtes Organ einer juristischen Person oder als Mitglied eines solchen Organes,

2. als vertretungsberechtigtes Gesellschafter einer Personenhandelsgesellschaft oder

3. als gesetzlicher Vertreter eines anderen,

so ist ein Gesetz, nach dem besondere persönliche Eigenschaften, Verhältnisse oder Umstände (besondere persönliche Merkmale) die Strafbarkeit begründen, auch auf den Vertreter anzuwenden, wenn diese Merkmale zwar nicht bei dem Vertretenen vorliegen.

II. Ist jemand von dem Inhaber eines Betriebes oder einem sonst dazu Befugten

1. beauftragtet, den Betrieb ganz oder zum Teil zu leiten, oder

2. ausdrücklich beauftragt, in eigener Verantwortung Aufgaben wahrzunehmen, die dem Inhaber des Betriebes obliegen, und handelt er auf Grund diese Auftrages, so ist ein Gesetz, nach dem besondere persönliche Merkmale die Strafbarkeit begründen, auch auf den Beauftragten anzuwenden, wenn diese Merkmale zwar nicht bei ihm, aber bei dem Inhaber des Betriebes vorliegen. Dem Betrieb im Sinne des Satzes 1 steht das Unternehmen gleich. Handelt jemand auf Grund eines entsprechendes

460. Scholl, F., Strafrechtliche Verantwortlichkeit von Gemeinde-, Kreisräten und Mitgliedern der Zweckverbandssammlungen im Umweltrecht $-\S \S 324,326$ Abs. 1, 327 Abs. 2 Nr. 3 StGB, Schorndorf, 1996, 137.

461. Rogall, K., o.c., 1991, 148.

462. Müller, W., 'Zur Haftung der Amtsträger und politischen Mandatsträger im Umweltstrafrecht', $U P R, 1990,367$. 
Auftrages für eine Stelle, die Aufgaben der öffentlichen Verwaltung wahrnimmt, so ist Satz 1 sinngemäB anzuwenden.

III. Die Absätze 1 und 2 sind auch dann anzuwenden, wenn die Rechtshandlung, welche die Vertretungsbefugnis oder das Auftragsverhältnis begründen sollte, unwirksam ist.

Deze in 1968 ingevoerde bepaling maakt het mogelijk bepaalde natuurlijke personen strafrechtelijk aansprakelijk te stellen wanneer normen zijn overtreden die niet tot hen maar tot anderen, meestal rechtspersonen, zijn gericht. ${ }^{463}$

$\S 14$ StGB viseert twee situaties. Enerzijds is er de 'Organ- und Vertreterstrafbarkeit' van § $14 \mathrm{I} \mathrm{nr.} 1 \mathrm{StGB}$, die betrekking heeft op de strafrechtelijke aansprakelijkheid van de organen en vertegenwoordigers van rechtspersonen. Daarnaast is er de Beauftragtenverantwortlichkeit van $\S 14 \mathrm{II} \mathrm{nr}$. 1 en 2, die de strafrechtelijke aansprakelijkheid regelt van natuurlijke personen die ofwel leiding geven aan (onderdelen van) een onderneming ofwel uitdrukkelijk gevolmachtigd zijn bepaalde opdrachten van de onderneming op eigen verantwoordelijkheid waar te nemen.

Er moet worden beklemtoond dat $\S 14 \mathrm{StGB}$ niet een strafrechtelijke aansprakelijkheid van organen of andere natuurlijke personen creëert voor delicten gepleegd door de rechtspersoon. Omdat rechtspersonen geen strafbare feiten kunnen plegen, kunnen via $\S 14 \mathrm{StGB}$ natuurlijke personen ook niet worden vervolgd voor het daderschap van de rechtspersoon. § 14 StGB schept enkel meer mogelijkheden bepaalde natuurlijke personen voor eigen daderschap te vervolgen door de reikwijdte van tot de rechtspersoon gerichte normen uit te breiden. Dogmatisch gezien is er dus geen sprake van een strafrechtelijke aansprakelijkheid voor daden van een ander. Dit is een belangrijk verschil met de oude Belgische situatie waar de rechtspraak wel aanvaardde dat organen of andere natuurlijke personen kunnen worden vervolgd voor het daderschap van de corporatie. De opzet van $\S 14 \mathrm{StGB}$ is daarom evenmin gelijk aan die van artikel 51 lid $2 \mathrm{nr}$. $2 \mathrm{Sr}$ waar de feitelijke opdracht- of leidinggever aansprakelijk kan worden gesteld voor het daderschap van de rechtspersoon. De ratio van $\S 14$ StGB kan wellicht het best worden vergeleken met enkele oude bepalingen uit het Nederlandse bijzonder strafrecht. Zo hanteerde $41 \mathrm{WVW}$ lange tijd een fictie door te bepalen dat in de gevallen waar wegens overtreding straf wordt bedreigd tegen eigenaren of houders van motorrijtuigen, de leden van het bestuur als eigenaren of houders moeten worden aangemerkt, indien een rechtspersoon die kwaliteiten bezit. Deze fictie dateert nog van een tijd waarin enerzijds daderschap van de rechtspersoon in Nederland nog niet werd aanvaard, terwijl anderzijds leden van een bestuur de delictsomschrijving niet konden vervullen omdat ze geen normadressaat waren. ${ }^{464}$

463. $\S 14$ StGB werd via het Einführungsgesetz zum Gesetz über Ordnungswidrigkeiten (24 mei 1968 ) als $\S 50$ a StGB ingevoerd. Daaruit blijkt reeds de crimineel-politieke verwevenheid van $\S$ 30 OwiG en $\$ 14$ StGB.

464. Torringa, R.A., o.c., 1984, 13. 
Kort samengevat: $\S 14 \mathrm{StGB}$ heeft tot doel de groep normadressaten of de zogenaamde 'Täterkreis' uit te breiden tot die natuurlijke personen die als orgaan, vertegenwoordiger, leidinggever of gevolmachtigde in opdracht van rechtspersonen, de primaire normadressaten, handelen. ${ }^{465}$ Toerekening van het gepleegde feit aan bepaalde natuurlijke personen wordt dan mogelijk doordat $\S 14 \mathrm{StGB}$ via

'eine "Überwalzung" der besonderen Tätermerkmale auf Personen erweitert, die in einem bestimmten Vertretungs- oder Auftragsverhältnis für den primären Normaddresaten handeln. ${ }^{.466}$

Over het precieze toepassingsgebied van $\S 14$ StGB zijn de meningen enigzins verdeeld. Sommige auteurs leiden uit de doelstelling van $\S 14$ StGB af dat deze bepaling uitsluitend bij kwaliteitsdelicten kan worden gehanteerd. $\S 14 \mathrm{StGB}$ zou dus niet van toepassing zijn bij delictsomschrijvingen die door eenieder kunnen worden vervuld, zoals bij $\S 324 \mathrm{StGB}$ :

'Wer eine Gewässerverunreinigung unbefugt bewirkt ( $\$ 324$ StGB), haftet auschließlich nach dem Maß seiner Kausalität und seines Vorzatzes, auf $\S$ 14 StGB kommt es nicht an. ${ }^{.467}$

Andere schrijvers menen daarentegen dat zelfs bij een overtreding van een gemeen milieudelict een strafrechtelijke aansprakelijkheid uitsluitend mogelijk is op grond van $\S 14$ StGB. Zo omschrijft Müller de dogmatische verhouding tussen $\S 14$ en $\S 324$ StGB als volgt:

'der Genehmigungsakt richtet sich an die kommunale Körperschaft als Betreiberin der Kläranlage, so daß auch hier die Anwendung des $\S 14$ StGB Abs. $1 \mathrm{Nr} .1 \mathrm{StGB}$ geboten ist, um die täterschaftliche Verantwortung der Organe, also der Bürgermeisters (...) zu begründen. ${ }^{468}$

Tegen deze opvatting kan het een en ander worden ingebracht. De 'Genehmigungsakt' moet immers worden gezien als een rechtvaardigingsgrond voor het 'unbefugt' lozen van afvalwater en niet als een bestandeel van de delictsomschrijving die het normadressaatschap zou determineren. De rechtspersoon is weliswaar enig vergunningadressaat, maar daar gaat het bij $\S 14$ StGB niet om; van belang is of de strafnorm zich al dan niet uitsluitend tot rechtspersonen richt. Aangezien § 324 StGB het rechtsgoed 'water' op absolute wijze beschermt, is deze norm - waarvan de wederrechtelijke overtreding kan worden gedekt door een vergunning - tot eenieder gericht.

465. Schünemann, B., 'Die Bedeutung der "Besonderen persőnlichen Merkmale" für die strafrechtliche Teilnehmer- und Vertreterhaftung', Jura, 1980, 568.

466. Schönke, A., Schröder, H. en Lenckner, Th., Strafgesetzbuch, München, C.H. Beck'sche Verlags-Buchhandlung, 1991, § 14, Nr. 1.

467. Rudolphi, H.J., Horn, ,E. en Samson, E., Strafgesetzbuch. Systematischer Kommentar, 1989, § 14, Nr. 46.

468. Müller, W., l.c., 1990, 368. Zie tevens Weber, U., o.c., 1988, 25-26. 
'Ein Gewässer kann jeder Betriebsangehörige selbst verunreinigen. Irgendwelche besonderen Anforderungen an die tatbestandmäBige Ausführung bestehen nicht. Die Betriebsangehörigen sind damit unabhängig von ihrer Einbindung in eine rechtliche verselbständigte Organisationsform (...) normaddresaten der $\S \S 324,326$ Abs. 1 StGB. ${ }^{.469}$

De eis dat ook bij gemene delicten $\S 14$ StGB toepassing moet vinden is gelet op de ratio van deze bepaling onlogisch en bovendien strijdig met de bedoelingen van de wetgever. Ook de rechtspraak is niet geheel zuiver wat de toepassing van $\S 14$ StGB betreft. In sommige uitspraken wordt een strafrechtelijke aansprakelijkheid voor schending van $\S 324$ $\mathrm{StGB}$ op grond van $\S 14 \mathrm{StGB}$ vastgesteld. ${ }^{470}$

\section{Het belang van $\$ 14$ StGB voor de strafrechtelijke aansprakelijkheid van ambtenaren}

Voor de strafrechtelijke aansprakelijkheid van ambtenaren is $\S 14$ StGB in tweeërlei opzichten van bijzonder belang.

Allereerst is daar de Organ- und Vertreterhaftung van § $14 \mathrm{I} \mathrm{nr.} 1 \mathrm{StGB}$. De daarin vervatte term 'rechtspersoon' wordt breed uitgelegd en betreft zowel rechtspersonen naar privaat als naar publiek recht:

'Juristische Personen sind alle sozialen Organisationen mit eigener Rechtspersönlichkeit, gleichgültig, ob sie dem Privatrecht (eingetragener Verein, rechtsfähige Stiftung, Gesellschaften des Aktienrechts, GmbH, Genossenschaft) oder dem öffentlichen Recht (Körperschaften, selbständigen Anstalten und Stiftungen) angehören. ${ }^{471}$

Deze ruime interpretatie maakt het mogelijk organen en vertegenwoordigers van publiekrechtelijke rechtspersonen rechtstreeks te vervolgen. Er wordt ook geen onderscheid gemaakt tussen de verschillende categorieën publiekrechtelijke rechtspersonen. Zowel overheidsondernemingen, openbare instellingen als openbare lichamen vallen onder het toepassingsgebied van de Organ- und Vertreterhaftung. Hoofdvraag is steeds welke natuurlijke personen binnen een overheid kunnen worden aangemerkt als orgaan of vertegenwoordiger. Daartoe moet telkens worden gekeken naar de toepasselijke bestuursrechtelijke regeling. ${ }^{472}$ Voor gemeenten betekent dit dat op grond van de gemeentewet de verantwoordelijke organen kunnen worden vastgesteld: dit zijn dan de burgemeester, de wethouders en de leden van de gemeenteraad.

469. Scholl, F., o.c., 1996, 138.

470. Zie het hierna te bespreken OLG Köln, 17 mei 1988, NJW 1988, 2119.

471. Schönke, A., Schröder, H. en Lenckner, Th., o.c., 1991, § 14, Nr. 15.

472. Idem, Nr. 42; Rogall, K., o.c., 1991, 149. 
In de tweede plaats is, voor wat de Beauftragtenverantwortlichkeit aangaat, de laatste zin van $\S 14 \mathrm{StGB}$ II Nr. 2 van belang. Daarin wordt bepaald dat wanneer een natuurlijke persoon (meestal een ambtenaar) een opdracht van een bestuurlijke instantie waarneemt de eerste zin van $\S 14 \mathrm{II} \mathrm{Nr}$. 2 StGB van toepassing is. Deze laatste bepaling voorziet in een strafrechtelijke aansprakelijkheid van natuurlijke personen die de opdracht hebben gekregen (een afdeling binnen) een bedrijf te leiden of die uitdrukkelijk zijn gevolmachtigd op eigen verantwoordelijkheid opdrachten namens een bedrijf te vervullen. De bedoeling van $\S 14 \mathrm{II} \mathrm{Nr}$. 2, S. 3 StGB is duidelijk: leidinggevende ambtenaren binnen een bestuurlijke organisatie moeten aan dezelfde normen onderworpen worden als leidinggevenden binnen een particuliere onderneming. Zo wordt vermeden dat overheidsinstellingen een niet te rechtvaardigen concurrentievoordeel zouden hebben boven particuliere bedrijven. ${ }^{473}$ Deze gelijkstelling gaat zeer ver. Want onder 'Verwaltungsstelle' moet worden verstaan 'alle Stellen, die "Aufgaben der öffentlichen Verwaltung" wahrnehmen'. Dus niet alleen openbare diensten of overheidsondernemingen maar ook de zogenaamde Körperschaften (openbare lichamen), waaronder gemeenten en deelstaten, vallen onder de reikwijdte van genoemde bepaling. ${ }^{474}$ Het is dan interessant om vast te stellen dat de toepasselijkheid van $\S 14 \mathrm{StGB}$ op overheden uitdrukkelijk wordt gemotiveerd door economische overwegingen, meer bepaald het tegengaan van een ongerechtvaardigd concurrentievoordeel, terwijl dit argument blijkbaar in de praktijk niet wordt gebruikt om de toepassing van $\S 30 \mathrm{OWiG}$ op overheden een rol van betekenis te laten spelen.

$\S 14$ II Nr. 2, S. 3 StGB is vooral van praktisch belang bij grotere gemeenten waar overheidstaken (zoals afvalverwerking, waterzuivering) worden gedelegeerd aan afzonderlijke openbare diensten die gekenmerkt worden door een min of meer eigen zelfstandige organisatie. $^{475}$

Bemerk dat een aansprakelijkheid van ambtenaren op grond van § 14 II Nr. 2 StGB niet de aansprakelijkheid hoeft uit te sluiten van de verantwoordelijke organen van de overheid op grond van § 14 I Nr. 1 StGB. De Beauftragtenverantwortlichkeit kan best samengaan met de Organstrafbarkeit. Indien de aansprakelijkheid van de een de aansprakelijkheid van de ander onmogelijk zou maken, zou immers het gevaar bestaan dat met name binnen grotere overheden de vervolging zich enkel zou concentreren op lagere niet politiek verantwoordelijke ambtenaren hetgeen zou resulteren in een bijna principiële straffeloosheid van de delegerende of opdrachtgevende organen. De 'Verwaltungsspitze' zou vrijwel steeds vrijuit gaan. Voor een cumulatieve aansprakelijkheid moet wel telkens worden bekeken in welke mate de organen daadwerkelijk op de hoogte waren van en hadden kunnen ingrijpen tegen het door de 'Beauftragten' gepleegde feit. ${ }^{476}$ Een cumulatieve vervolging van 'Organ' en 'Beauftragte' heeft zich in de praktijk echter nog niet voorgedaan. Dit is trouwens niet

473. Schönke, A., Schröder, H. en Lenckner, Th., o.c., 1991, § 14, Nr. 42.

474. Idem, Nr. 42.

475. Weber, U., o.c., 1988, 26.

476. 'Im Fall der Kenntnis oder der Billigung des Tuns des Dezernenten durch den Bürgermeister bleibt auch er selbst Tatverantwortlicher.' Müller, W., l.c., 1990, 368. Zie tevens Weber, U., o.c., 1988, 27. 
alleen het geval bij de 'Amtsträgerstrafbarkeit'. Ook bij ondernemingscriminaliteit komt cumulatieve vervolging nauwelijks voor en is zelfs eerder een tendens waarneembaar om vooral lager personeel te vervolgen hetgeen een straffeloosheid van de top lijkt te bevorderen. Marxen merkt hierover op:

\begin{abstract}
'Ein Ausbau der Vertreterhaftung in diesem unteren Bereich wird eine weitere Verringerung der Haftung im oberen Berreich der Betriebshierarchie mit sich führen. Kriminelle Verbandsdispositionen die für die Wirkungsfrage von entscheidender Bedeutung sind, entstehen jedoch in der Regel in der Verbandsspitze..$^{477}$
\end{abstract}

Hij relativeert dan ook de effectiviteit van de Organ- und Vertreterhaftung. Met name ook omdat de individuele strafrechtelijke aanpak via $\S 14 \mathrm{StGB}$ geen recht doet aan het veelal uitgesproken collectieve karakter van criminaliteit begaan binnen het overheidskader.

'Ferner darf nicht erwartet werden, daß die Bestrafung einer Einzelperson etwas an der Verbandsdisposition ändert (...) Maßnahmen zur Bekämpfung der Verbandskriminalität müßten auf die Verbandsdisposition selbst einwirken. Strafen, auch Freiheitsstrafen gegen einzelne Organe und Vertreter, richten da nur wenig aus. ${ }^{.478}$

\title{
3. De 'Amtsträgerstrafbarkeit' in de rechtspraak: de belangrijkste knelpunten
}

Hoe naar Duits recht ambtenaren strafrechtelijk aansprakelijk kunnen worden gesteld voor milieuverstoring binnen het kader van een overheid gepleegd, kan nu worden geîllustreerd aan de hand van enkele interessante uitspraken. In de jurisprudentie vinden we zowel voorbeelden van Amtsträgerstrafbarkeit bij overtreding van gemene milieudelicten als voorbeelden van Amtsträgerstrafbarkeit bij overtreding van kwaliteitsdelicten. Vooral bij deze laatste groep treedt het belang van $\S 14 \mathrm{StGB}$ op de voorgrond. In plaats van een chronologisch overzicht te geven, lijkt het beter om de huidige stand van de rechtspraak aan de hand van enkele concrete vraagstukken te illustreren.

Ook het Bundesgerichtshof heeft zich over deze netelige kwestie uitgesproken. Gelet op het belang van deze hoogstrechterlijke beslissing wordt deze in een afzonderlijke paragraaf besproken.

a. Strafrechtelijke aansprakelijkheid van burgemeesters.

Een eerste categorie van mogelijke aansprakelijken binnen een overheid zijn de organen van het overheidslichaam. Daar tot op heden uitsluitend de criminele betrokkenheid van gemeenten tot concrete strafzaken heeft geleid, is met name de strafrechtelijke aansprake-

477. Marxen, K., l.c., 1988, 290.

478. Idem. 
lijkheid van burgemeesters, wethouders en gemeenteraadsleden van belang. Laten we beginnen met enkele zaken waar de vervolging van burgemeesters centraal staat.

Illustratief is een arrest van het Landesgericht München van 1985. Ruim vijf jaar lang had een gemeente via een verouderde zuiveringsinstallatie afvalwater geloosd. Dit had niet alleen een sterke vervuiling van het oppervlaktewater maar ook een aanzienlijke vissterfte tot gevolg. De gemeentelijke lozingsvergunning was reeds vanaf 1978 verstreken zodat de lozing niet langer door een rechtsgeldige vergunning werd gedekt. In eerste aanleg werd de burgemeester als orgaan van de gemeente aansprakelijk gesteld voor de verontreiniging en dientengevolge voor overtreding van $\S 324 \mathrm{StGB}$ tot een geldboete veroordeeld. Nu het gaat om een overtreding van het gemene milieudelict $\S 324$ StGB is voor een aansprakelijkstelling § $14 \mathrm{StGB}$ niet noodzakelijk. Interessant is dat in hoger beroep de burgemeester zich beroept op twee rechtvaardigingsgronden. Enerzijds wordt aangevoerd dat er sprake was van bestuurlijk gedogen omdat de hogere bestuurlijke autoriteit in kwestie (het Landsratamt) niet heeft ingegrepen. Hierdoor zou de wederrechtelijkheid van het feit zijn opgeheven. Anderzijds was er volgens de burgemeester sprake van noodtoestand: er zou in afwachting van een nieuwe vergunning bestuurlijk gezien geen andere mogelijkheid hebben opengestaan dan tijdelijk (vijf jaar !) te lozen zonder rechtsgeldige vergunning.

Van gedogen kan volgens het Landesgericht (LG) geen sprake zijn omdat

'das Landsratsamt hatte bis zu einem nicht exakt feststellbaren Zeitpunkt gar nicht bemerkt, daß der ursprüngliche Genehmigungsbescheid abgelaufen war und daß deshalb eine Entscheidung über die weitere Genehmigung oder über die Untersagung der Gewässerbenutzung seitens der Rechtsaufsichbehörde angebracht wäre. ${ }^{, 479}$

De redenering is eenvoudig en duidelijk. Als het bestuur in kwestie niet op de hoogte is van de overtreding, kan het dus ook geen gebruik maken van zijn handhavingsbevoegdheden en is het zinloos te spreken van gedogen.

Ook het beroep op noodtoestand wordt verworpen. Allereerst merkt het LG op dat

'nicht rechtzeitig im Hinblick auf den Ablauf der ursprünglichen Genehmigung ein neuer Benutzungsantrag seitens der Gemeinde bzw. des für die Gemeinde verantwortliche handelnden Angeklagten gestellt worden ist. ${ }^{480}$

De omstandigheid dat niet tijdig een nieuwe vergunning werd aangevraagd getuigt inderdaad niet van de nodige ijver om het lozingsprobleem zo snel mogelijk op te lossen.

480. Idem. 
Daarnaast duurde de bouw van de nieuwe zuiveringsinstallatie onaanvaardbaar lang doordat deze nodeloos werd belemmerd door bureaucratische vertragingsmanoeuvres:

'Die Plannung für die Neuanlage wurde erst verspätet in Angriff genommen und dann nicht mit dem nötigen Nachdruk im Hinblick auf die vom Angeklagten selbst als höchst bedenklich eingestufte laudende Belastung des Baches durch die alte Anlage vorangetrieben. So schwankte die Gemeinde im Verlauf des mehrjährigen Planungsverfahrens hin und her zwischen unterschiedlichen Planungsgrößen. ${ }^{481}$

Interessant zijn ook de overwegingen van het LG met betrekking tot de schuldvraag:

'Den Angeklagten trifft der Schuldvorwurf fahrlässigen Handelns. Es bedarf keiner Ausführungen, daB der Benutzer eines Gewässers die verkehrsübliche Sorgfalt außer acht läßt, wenn er sich nach dem Ablauf eines befristeten Genehmigungsbescheides nicht rechtzeitig um eine weitere Legalisierung der Gewässerverunreinigung durch die entsprechende Antragstellung bei den zuständigen Behörden bemüht. ${ }^{482}$

Ook de omstandigheid dat de verdachte niet zomaar een burger is maar een burgemeester die een belangrijke politieke verantwoordelijkheid en voorbeeldfunctie heeft, blijkt voor het LG niet zonder belang te zijn:

'Für einen erfahrenen Kommunalpolitiker wie den Angeklagten, der seit Ende 1970 als Bürgermeister tätig ist, stellt es auch ein Außerachtlassen der ihm bei seinen Fähigkeiten und Kenntnissen zumutbaren Sorgfaltspflicht dar, wenn er beim Betrieb einer Kläranlage, an der es nach eigenen Angaben "brennt", verzörgerlich und nicht mit dem nötigen Nachdruck und unentschlossen die nötigen Planungsarbeiten für eine Neuanlage durchführen läßt und nicht durch ein Ausschöpfen aller tatsächlichen und rechtlichen Möglichkeiten darauf bedacht ist, die bei der Abwasserbeseitigung nun einmal unvermeidliche Beeintrachtungen der Wässerqualität so gering wie möglich zu halten. ${ }^{483}$

Een voorbeeld van hoe ruim sommige strafrechters de Organstrafbarkeit formuleren, is een uitspraak van 1985 van het Amtsgericht Cochem. In deze zaak werd een burgemeester veroordeeld voor het uitbaten van een illegale stortplaats (overtreding van § 327 II Nr. 2 $\mathrm{StGB})$. De feiten van deze zaak zijn bijzonder interessant omdat niet alleen de burgemeester maar de hele gemeenteraad bij het delict betrokken was. De gemeente P. had in 1979 van de Landkreis de opdracht gekregen de gemeentelijke stortplaats binnen een termijn van 4 jaar te sluiten en te saneren. In 1984 was nog geen enkele saneringsmaatregel 
uitgevoerd. De enige door de burgemeester genomen maatregel om het terrein met berken af te bakenen mislukte daar deze bomen wegens de sterk vervuilde bodem binnen korte tijd afstierven. Door de burgemeester werd ook verscheidene keren de problematiek van de illegale stortplaats aan de gemeenteraad voorgelegd. Voor zijn voorstel om rondom de stortplaats in ieder geval een behoorlijke schutting te laten plaatsen, bleek echter geen meerderheid te vinden. Om de politieke vrede te bewaren, besloot hij de door hem voorgestelde maatregel maar niet in stemming te brengen, zodat uiteindelijk ieder formeel besluit aangaande de stortplaats achterwege bleef.

Het Amtsgericht (AG) oordeelde dat

'Der Angekl., der als Ortsbürgermeister von P. gemäß § $47 \mathrm{GemO}$ Repräsentativorgan der Gemeinde ist, hat sich nach $\S 327$ II Nr. 2, 14 StGB strafbar gemacht, da die Gemeinde P. unerlaubt entgegen einer vollziehbaren Verfügung eine Abfallbeseitigungsanlage "betrieben" hat (...) Dieses Betrieben wird dem Angekl. nach § $14 \mathrm{Nr}$. 1 StGB zugrechnet, da er als Bürgermeister gemäß § 47 I 1 GemO Repräsentativorgan der Gemeinde ist, die er vertritt ${ }^{484}$

Dit is een mooi voorbeeld van hoe bij overtreding van een kwaliteitsdelict de voor de milieuverstoring verantwoordelijke ambtenaren op grond van $\S 14$ StGB strafrechtelijk kunnen worden aangepakt. $\S 327 \mathrm{II} \mathrm{Nr}$. 2 StGB is gericht tot diegene die zonder vergunning een afvalverwerkingsbedrijf exploiteert. Normadressaat is dus de gemeente. Via $\S 14$ StGB wordt het alsnog mogelijk de burgemeester, bestuursrechtelijk het vertegenwoordigend orgaan van de gemeente, als normaddresaat aan te duiden en derhalve te vervolgen voor het gepleegde feit. Het AG voegt daar bovendien nog aan toe:

'Daß er selbst sich mit dem Weiterbetrieb möglicherweise nicht identifiziert und sogar einzelne Personen, die illegal abgelagert hatten, angezeigt hat, ist für die Zurechnung des Betriebs über $\S 14$ I StGB ohne Bedeutung. ${ }^{.485}$

Het AG gaat uitvoerig in op de rol van de gemeenteraad. Hoewel mede door het ontbreken van enige formele besluitvorming - waaruit individueel stemgedrag zou kunnen worden afgeleid - geen enkel gemeenteraadslid kon worden vervolgd, laat het AG niet na in niet te miskennen bewoordingen de gemeenteraad in zijn geheel als medeverantwoordelijke aan te wijzen:

'Den zuständigen Organen der Gemeinde und zwar sowohl dem Angekl., der als Bürgermeister Repräsentativorgan der Gemeinde ist, als auch dem Gemeinderat, der für die gemeindeinterne Willensbildung zuständig ist, war bekannt und bewußt, daß auf dem Gebiet der ehemaligen Müllkippe

484. AG Cochem, 5 juli 1985, NStZ 1985, 506 .

485. Idem. 


\begin{abstract}
Ablagerungen weiterhin vorgenommen wurden. Da auch der Gemeinderat und nicht nur der Angekl. wußte (..) daß auf dem Gelände der ehemaligen Müllkippe weiterhin abgelagert wurde, hat der Gemeinderat und damit die vom Angekl. vertretene Gemeinde diese fortgesetzte Ablagerung gedultet. $^{.486}$
\end{abstract}

Dat de gemeenteraad het blijkbaar niet nodig vond ter zake noodzakelijke maatregelen te nemen wordt sterk afgekeurd:

'Daß der Gemeinderat bei seinen Beratungen den entsprechenden Vorschlägen des Angekl. seine Zustimmung verweigerte und sich auf verbale $\mathrm{Maßnahmen}$ beschränkte, zeigt jedoch, daß eine ernsthafte Beeindigung der Ablagerungsmöglichkeit nicht gewollt war. ${ }^{487}$

De burgemeester voert deze politieke patstelling vervolgens aan als strafuitsluitingsgrond. Iedere poging om de illegale stortplaats te saneren stuitte immers op onoverkomelijk politiek verzet vanwege de gemeenteraad. Als burgemeester stond hij voor een voldongen feit. Het AG aanvaardt deze redenering echter niet. De verdachte beschikte immers over voldoende feitelijke én juridische mogelijkheden om dit verzet van de gemeenteraad te breken. Zo had hij bijvoorbeeld wel een stemming kunnen uitlokken en vervolgens de rechtmatigheid van het negatieve raadsbesluit kunnen laten toetsen door het daartoe bevoegde hoger bestuursorgaan (in casu de Kreisverwaltung Cochem-Zell) dat vervolgens de noodzakelijke bestuurlijke maatregelen had kunnen opleggen. Bovendien had de verdachte

'sogar ohne einen ablehnenden Beschluß die Aufsichtsbehörde informieren können, um deren Entscheidung herbeizufuhren. ${ }^{488}$

Daarnaast waren er ook nog voldoende andere maatregelen mogelijk om een einde te maken aan de illegale situatie.

'Daß er sie und insb. die Herbeiführung eines Beschlusses des Gemeinderates aus falsch verstandenem Harmoniestreben unterlieB, ist ihm vorzuwerfen. ${ }^{489}$

Net als in de vorige uitspraak speelt ook hier verdachtes hoedanigheid van burgemeester en de daarmee verbonden politieke deskundigheid en verantwoordelijkheid een aanzienlijke rol bij de beantwoording van de schuldvraag. Een beroep op dwaling aangaande de bestuursrechtelijke mogelijkheden om daadwerkelijk in te grijpen heeft dan ook geen kans van slagen: 
'Der Angekl. ist als Bürgermeister Ehrenbeamter der Gemeinde P. (...) Daher gilt für ihn als ehrenamtlicher Bürgermeister wie auch allgemein für Ratsmitglieder, daß sie sich die zu Führung ihres Amtes erfordlichen Rechts-und Verwaltungskenntnisse zu beschaffen haben (...) Hätte der Angekl. in der Gemeindeordnung nachgelesen, in deren Besitz er war, wie er in der Hauptverhandlung eingeräumt hat oder hätte er zumindest eine Auskunft eingeholt, wäre er darauf hingewesen worden, daß er durchaus Möglichkeiten nach der Gemeindeordnung hatte, den Gemeinderat zu einem Beschluß zu veranlassen oder selbst die Frage rechtlich kläre zu lassen. ${ }^{490}$

\section{b. Strafrechtelijke aansprakelijkheid van gemeenteraadsleden}

Zoals in voorgaande uitspraak duidelijk naar voren komt, is het denkbaar dat een milieudelict mede het resultaat is van een besluit van de gemeenteraad. In welke mate gemeenteraadsleden dan strafbaar zijn voor het gepleegde feit is niet helemaal duidelijk. De rechtspraak heeft ter zake nog geen standpunt ingenomen. ${ }^{491}$ Daaruit mag echter niet worden afgeleid dat deze vraag uitsluitend een theoretisch belang zou hebben. Buiten de sfeer van het milieustrafrecht is het immers wel reeds tot een strafvervolging van gemeenteraadsleden gekomen. Belangrijk voorbeeld is een uitspraak van het LG Paderborn. ${ }^{492}$ In deze zaak ging het om de strafrechtelijke aansprakelijkheid van enkele gemeenteraadsleden en de burgemeester wegens dood door schuld ( $\$ 222 \mathrm{StGB})$. Uit deze zaak kunnen tot op zekere hoogte ook conclusies worden afgeleid voor het milieustrafrecht. Wat waren de feiten? In 1984 viel in een gemeente een kind per ongeluk in een niet afgesloten waterput. Naar aanleiding van dit incident besloot de gemeenteraad de put volledig af te dekken. In 1985 leidde gemeentelijke verkiezingen tot een andere politieke samenstelling van de gemeenteraad. Deze nieuw verkozen raad bestempelde het ongelukkige voorval als een eenmalig ongeval en besloot vervolgens met 31 stemmen tegen 1 de put terug te openen. De burgemeester had geen bezwaren tegen deze beslissing. Het gemeenteraadsbesluit had echter dramatische gevolgen; in 1989 viel opnieuw een kind in de nu niet langer afgesloten waterput en verdronk. Voor dit feit werd de burgemeester door het LG Paderborn veroordeeld. Hem werd strafbare nalatigheid verweten door niet tegen het raadsbesluit in administratief beroep te gaan. Interessant is vooral dat door het openbaar ministerie tegen alle 31 gemeenteraadsleden een gerechtelijk vooronderzoek werd ingesteld. Het kwam uiteindelijk tot een vervolging van 11 gemeenteraadsleden. Conform 153 tweede lid StPO werd wel door het LG Paderborn de vervolging tegen betaling van een geldboete gestaakt. ${ }^{493}$

490. Idem.

491. Pfohl, M., 'Strafbarkeit von Amtstrăgern wegen Duldung unzureichender Abwasserreinigungsanlagen', $N J W, 1994,420$.

492. LG Paderdorn, 9 oktober 1991, Az. 2 Kls 10 Js $927 / 89$ (ongepubliceerd), besproken in Scholl, F., o.c., 1996, 181-182.

493. Overeenkomstig $\S 153$ lid 1 StPO kan voor bagatelzaken het openbaar ministerie, met toestemming van de strafrechter, van vervolging afzien. Dit is het zogenaamde sepot 'wegen 
Uit deze zaak blijkt reeds dat het best denkbaar is dat tegen gemeenteraadsleden een strafvervolging wordt ingesteld voor delicten die het gevolg zijn van een door hen genomen besluit. Daarbij is van belang te weten dat de leden van de gemeenteraad geen zogeheten 'Indemnität' genieten. Dit belet tegen bepaalde volksvertegenwoordigers strafvervolging in te stellen voor door hen genomen besluiten. Deze bijzondere vervolgingsuitsluitingsgrond is echter alleen van toepassing op leden van de Bundes- en Landesparlemente. ${ }^{494}$ Gemeenteraadsleden kunnen dus zonder problemen worden vervolgd.

Mede naar aanleiding van de uitspraken van het AG Cochem en het LG Paderborn heeft de rechtsleer zich gebogen over de vraag hoe nu de criminele betrokkenheid van gemeenteraadsleden bij milieuverstoring strafrechtelijk zou kunnen worden vertaald. Deze criminele betrokkenheid kan verschillende vormen aannemen. Zo is de situatie denkbaar dat de gemeenteraad bij meerderheid een besluit neemt dat strijdig is met de milieuwetgeving. Bijvoorbeeld in het geval waarin de wet verplicht tot de aanpassing van een zuiveringsinstallatie maar de gemeenteraad vanwege de hoge kosten besluit daartoe niet over te gaan. Ook is het mogelijk dat de gemeenteraad weigert op een bepaald punt een besluit te nemen. Het probleem van de strafrechtelijke aansprakelijkheid van gemeenteraadsleden doet dan verschillende vragen rijzen.

Allereerst rijst de vraag in welke mate gemeenteraadsleden vallen onder het toepassingsgebied van $\S 14$ StGB. Dit is met name van belang wanneer zij betrokken zijn bij kwaliteitsdelicten. In de eerste plaats moet worden onderzocht of gemeenteraadsleden kunnen worden beschouwd als orgaan of vertegenwoordiger van de gemeente in de zin van $\S 14$ I Nr. 1 StGB. Volgens deze bepaling vallen ook de samenstellende leden van een meerhoofdig orgaan onder het toepassingsgebied van $\S 14 \mathrm{StGB}^{495}$ Van belang is dus te weten of de gemeenteraad een vertegenwoordigend orgaan is in de zin van § $14 \mathrm{I} \mathrm{Nr} 1$ $\mathrm{StGB}$. Welnu, als orgaan in de zin van genoemde bepaling kan enkel worden beschouwd een orgaan dat de rechtspersoon zowel naar binnen als naar buiten vertegenwoordigen kan. Het is daarbij essentieel dat beslissingsbevoegdheid en vertegenwoordingsbevoegdheid in

Geringfügigheit'. In het verlengde daarvan kan in het Duitse strafprocesrecht de strafrechter, bij wie de zaak reeds aanhangig is, in een aantal gevallen met toestemming van het openbaar ministerie en de beklaagde besluiten de vervolging te staken. $\S 153$ lid 2 bepaalt: Ist die Klage bereits erhoben, so kann das Gericht in jeder Lage des Verfahrens (...) mit Zustimmung der Staatsanwaltschaft und des Angeschuldigten das Verfahren einstellen.' § 153 lid 2 StPO laat in die zin een bijzondere vorm van sepot toe in het geval de vervolging reeds is aangevangen. Zie hierover Kleinknecht, T. en Meyer-Gossner, L., Strafprozeßordnung, München, Beck'sche Verlags-Buchhandlung, 1993, § 153, Nr. 2 e.v..

494. De indemniteit is neergelegd in $\S 36$ StGB: 'Mitglieder des Bundestages, der Bundesversammlung oder eines Gesetzgebungsorgans eines Landes dürfen zu keiner Zeit wegen ihrer Abstimmungen oder wegen einer Aüßerung, die sie in der Körperschaft oder in einem ihrer Ausschüsse getan haben, außerhalb der Körperschaft zur Verantwortung gezogen werden. Dies gilt nicht für verleumderische Beleidigungen.'

495. Scholl, F., o.c., 1996, 132; Schönke, A., Schröder, H. en Lenckner, Th., o.c., 1989, § 14, Nr. 18: 'Danach ist jedes Mitglied des Organs (...) Normadressat, und zwar unabhăngig davon, ob und wie die Zustăndigkeiten intern aufgeteilt sind.' 


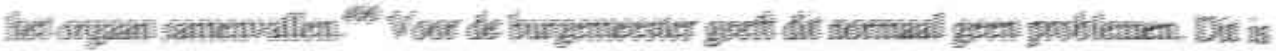

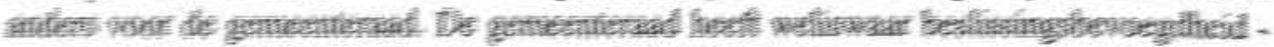

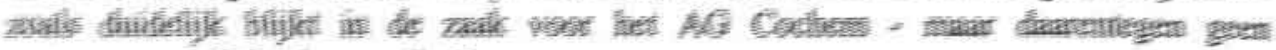

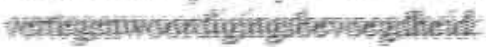

\title{
Die Ratomitglideler sind wwar Mitglioder des in Innementhilinis

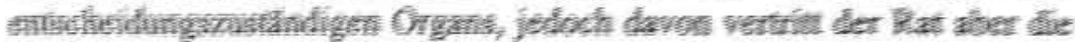 Commune fiche newh aulent
}

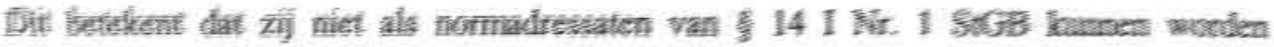
besthoswd. Derhalve bligft uitsivitend de mogelijkheid open de gemeentereadalolen an te

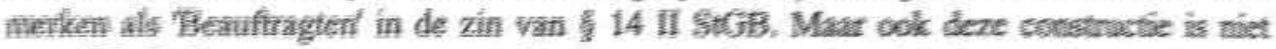
wogelijk. Leden van de gencenteraad kunnen niet als gevolmachtiglen wordes beschouwd omflat hun bevoegdieden rechtstresks voortvloeien uit de wet:

\begin{abstract}
Die Ratamitglieder sind nicht dem Personenkreis des 14 Abs. 2 SeGB zumiordnen, weil sich ihre Entscheidungskompetenz originär aus den gesetzlichen Zuständigkeitsregeln der Kommunalverfassungen ergibt. Eine Verantwortungedelegation zwischen dem vertretungsberechtigen Bürgermeister, Kreistat (...) und Ratsgremium findet nicht statt.
\end{abstract}

Dit gegeven dwingt tot de interessante conclusie dat een gemeenteraadslid niet als pleger van een kwaliteitsmilieudelict, bijvoorbeeld overtreding van $\S 327 \mathrm{StGB}$, kan worden vervolgd. ${ }^{499}$ Wel blijft steeds de mogelijkheid open dat zij als deelnemers kunnen worden vervolgd. Voor deelneming is immers niet noodzakelijk dat de verdachte normadressaat is van de overtreden bepaling. ${ }^{500}$

In de praktijk zal dus vooral de strafrechtelijke aansprakelijkheid van gemeenteraadsleden bij gemene milieudelicten van belang zijn. Hierbij is immers $\$ 14 \mathrm{StGB}$ niet noodzakelijk. Gemeenteraadsleden zijn rechtstreeks aan te merken als normadressaten van $\S 324$ en 326 StGB. Dit betekent echter allesbehalve dat de toerekening van deze milieudelicten aan de gemeenteraadsleden probleemloos zal verlopen. Er rijzen immers andere problemen. Zo rijst de vraag hoe strafrechtelijk moet worden omgegaan met het gegeven dat de gemeenteraad slechts als geheel kan handelen en besluiten kan maken. De gemeenteraad kan alleen als 'Gesamtgremium' optreden, en niet via haar afzonderlijke leden:

496. Schönke, A., Schröder, H. en Lenckner, Th., o.c., 1989, § 14, Nr. 16.

497. Scholl, F., o.c., 1996, 134.

498. Idem, 136.

499. In de zaak voor het AG Cochem zou het dus niet mogelijk zijn geweest een raadslid voor het gepleegde feit als dader te vervolgen.

500. Scholl, F., o.c., 1996, 136. 
'Jeder Beschluß kommt durch alle Mitglieder zustande. Deshalb besteht grundsätzlich immer eine Generalverantwortlichkeit des Gemeinderats (...) als Ganzes. ${ }^{\text {,501 }}$

Dit betekent dat op de gemeenteraad als geheel de gemeentelijke Betriebspflichten rusten. Ook in gevallen waar de gemeenteraad bepaalde taken aan anderen (bijvoorbeeld commissies) overdraagt blijft de uiteindelijke verantwoordelijkheid bij de gemeenteraad als geheel liggen. Nu rijst hier een bijzonder probleem met betrekking tot de strafrechtelijke kwalificatie van het door de gemeenteraad genomen besluit. Immers, de collectieve politieke verantwoordelijkheid van de gemeenteraad moet noodzakelijkerwijs naar een strafrechtelijke aansprakelijkheid van individuele raadsleden worden vertaald, nu noch de gemeente als rechtspersoon, noch de raad als orgaan kunnen worden vervolgd. In den regel gaat de rechtsleer ervan uit dat zowel in de situatie waar een negatief meerderheidsbesluit van de gemeenteraad voorligt als in de situatie waar de gemeenteraad bij meerderheid weigert een besluit te nemen - ook de weigering een besluit te nemen is een besluit - er strafrechtsdogmatisch gezien in hoofde van ieder gemeenteraadslid, dat voor het negatieve besluit heeft gestemd, sprake is van daderschap door positief handelen. De burgemeester die tegen het besluit niet optreedt kan hoogstens daderschap door nalaten worden verweten. ${ }^{502}$ Cruciale vraag is echter wanneer het besluit van de gemeenteraad als oorzaak van het opgetreden delictsgevolg kan worden aangewezen. We betreden hier het netelige vraagstuk van de causaliteit.

Om de causaliteit te kunnen vaststellen dienen achtereenvolgens twee stappen te worden gezet. Daar strafrechtelijk moet worden uitgegaan van het stemgedrag van ieder afzonderlijk gemeenteraadslid moet eerst worden onderzocht of zijn stem causaal is voor het genomen besluit. Vervolgens moet worden nagegaan of het besluit als geheel causaal is voor de ten laste gelegde milieuverstoring. Van belang is vooral de eerste causaliteitsvraag. Zonder op de zeer verscheidene in de Duitse literatuur verdedigde causaliteitstheorieën in te gaan, kan hier worden volstaan met de opmerking dat de heersende rechtsleer en rechtspraak causaliteitsvragen beantwoorden aan de hand van de zogeheten 'Bedingungstheorie' of 'Äquivalentztheorie'. Centraal uitgangspunt is de conditio sine qua non-formule. Deze komt op het volgende neer: een gedraging (handelen of nalaten) veroorzaakt een gevolg, als zij niet kan worden weggedacht zonder dat het gevolg wegvalt. De gedraging is in die zin conditio sine qua non (c.s.q.n.) voor het opgetreden gevolg. Dit is logisch: heeft een bepaalde gedraging bijgedragen tot het gevolg, dan impliceert dit dat zonder deze gedraging het gevolg niet of in ieder geval slechts in mindere mate zou zijn opgetreden. ${ }^{503}$ Passen we deze c.s.q.n.-formule nu toe op de strafrechtelijke aansprakelijkheid van gemeenteraadsleden dan komen we tot enkele opmerkelijke bevindingen. Laten we eerst het voorbeeld nemen waar bijvoorbeeld van de 13 gemeenteraadsleden 7 tegen een noodzakelijke aanpassing van de zuiveringsinstallatie stemmen en 6 voor. Dit

501. Idem, 153.

502. Pfohl, M., l.c., 1994, 420.

503. Scholl, F., o.c., 1996, 211; Jescheck, H.H. en Weigend, Th., o.c., 1996, 279-280. Zie tevens Remmelink, J., o.c., 1995, 175-176. 
geeft geen onoverkomelijke causaliteitsproblemen. Volgens de c.s.q.n. formule is het mogelijk het stemgedrag van de meerderheid als causaal aan te merken voor de illegale verontreiniging. Iedere 'weggedachte' meerderheidsstem is noodzakelijk voor het genomen besluit. Het besluit kan op zijn beurt als oorzaak van de verontreiniging worden aangemerkt. ${ }^{504}$ Laten we nu het voorbeeld nemen waar de voltallige gemeenteraad een wederrechtelijk besluit neemt. Er zijn geen tegenstemmen en er zijn evenmin onthoudingen. Denkt men nu één van de stemmen weg, dan dwingt dit tot de conclusie dat het besluit ook zou zijn genomen zonder deze 'weggedachte' stem. Uiteindelijk is geen enkele afzonderlijke stem oorzakelijk voor het genomen besluit. Iedere stem die kan worden weggedacht laat immers het meerderheidsbesluit onaangetast. ${ }^{505}$ Dit heeft tot gevolg dat geen enkel gemeenteraadslid in een dergelijk geval kan worden vervolgd voor het gepleegde milieumisdrijf, terwijl er toch duidelijk sprake is van een unaniem wederrechtelijk besluit! Deze opmerkelijke situatie doet zich trouwens niet alleen voor bij unanieme besluitvorming, maar is reeds aanwezig vanaf het moment dat de meerderheid meer is dan de helft plus één. De enige mogelijkheid die dan nog over blijft is de vervolging van het gemeenteraadslid wegens poging tot het milieudelict ( $\$ 324 \mathrm{II} \mathrm{StGB}$ en $\S 326 \mathrm{II} \mathrm{StGB)})^{506}$ Het hoeft geen betoog dat een dergelijke vervolging in de praktijk niet vlug zal voorkomen. Bij culpose verontreiniging is vervolging reeds dogmatisch bij voorbaat uitgesloten: voor strafbare poging is immers ook naar Duits recht opzet vereist. ${ }^{507}$

Om aan deze toch wel bevreemdende straffeloosheid tegemoet te komen wordt in de literatuur inspiratie geput uit ervaringen van de rechtspraak met ondernemingscriminaliteit. Het spreekt voor zich dat dergelijke causaliteitsproblemen ook voorkomen bij delicten die binnen bedrijfsmatig kader zijn gepleegd. Welnu, het Bundesgerichtshof (BHG) lijkt op dit vlak een belangrijke opening te hebben gecreëerd. In het zogenaamde 'Lederspray-Urteil' heeft het BGH immers uitgemaakt dat

'wo mehrere Beteiligte unabhängig voneinander den tatbestandsmäßigen Erfolg erst durch Gesamtheit ihrer Handlungsbeiträge herbeiführen, jeder einezelne Beitrag im Haftungsbegründenden Sinne ursächlich ist. ${ }^{508}$

Deze formule, die meer toegespitst is op het collectieve karakter van het besluitvormingsproces binnen organen van een rechtspersoon, zou het mogelijk maken alsnog ieder gemeenteraadslid afzonderlijk strafrechtelijk aansprakelijk te stellen ${ }^{509}$ Of dit in de praktijk tot meer vervolgingen van gemeenteraadsleden zal leiden, is nog maar de vraag. Al bij al blijft de individuele strafrechtelijke aansprakelijkheid van gemeenteraadsleden een complexe en vrij gekunstelde constructie die nauwelijks een afdoende antwoord kan bieden op de vraag naar een effectieve sanctionering van door de gemeenteraad veroorzaakte milieudelicten. Daarvoor is deze betrokkenheid nu eenmaal té collectief.

504. Pfohl, M., l.c., 1994, 420.

505. Scholl, F., o.c., 1996, 211; Pfohl, M., l.c., 1994, 420.

506. Scholl, F., o.c., 1996, 211.

507. Jescheck, H.H. en Weigend, Th., o.c., 1996, 516.

508. BGH, 6 juli 1990, NStZ 1990, 588.

509. Pfohl, M., l.c., 1994, 420. 


\section{c. Strafrechtelijke aansprakelijkheid van niet-organen (Beauftragten)}

Hierboven werd reeds duidelijk gemaakt dat binnen een overheid gepleegde strafbare feiten niet alleen tot de strafrechtelijke aansprakelijkheid van de zogenaamde organen van het overheidslichaam hoeven te leiden. Ook andere functionarissen die niet de functie van orgaan bekleden, kunnen aansprakelijk worden gesteld. Bij grotere gemeenten moet dan worden gedacht aan ambtenaren die binnen bepaalde overheidsdiensten (afvalverwerking, water-zuivering) bijzondere bevoegdheden en verantwoordelijkheden krijgen toebedeeld.

Een opmerkelijk voorbeeld is een arrest van het Oberlandesgericht Köln van 1988. In deze zaak werd door een gemeente drie jaar lang door chloor en aluminiumsulfaat verontreinigd zwembadwater in een rivier geloosd. De gemeente had om financiële redenen nagelaten de afvoer van het zwembad aan te sluiten op de gemeentelijke riolering die verbonden was met de zuiveringsinstallatie. Hierdoor kon het sterk vervuilde zwembadwater niet naar behoren worden gezuiverd. Ook in deze zaak had de verontreiniging zeer schadelijke gevolgen: tot op een afstand van $1,5 \mathrm{~km}$ was de vispopulatie volledig vernietigd. Voor deze feiten werden uiteindelijk twee leidinggevende ambtenaren vervolgd. De eerste verdachte was de wethouder die politiek verantwoordelijk was voor de openbare dienst die het zwembad uitbaatte; de tweede verdachte was de directeur van deze dienst. Interessant aan deze zaak is dat beide verdachten via $\S 14$ II StGB als 'Beauftragten einer Verwaltungsstelle' werden veroordeeld. Nu het hier gaat om een overtreding van een gemeen delict was een strafrechtelijke aansprakelijkheid via § 14 StGB niet noodzakelijk. De verdachte ambtenaren kunnen immers zelf als primaire normadressaten worden beschouwd en aldus voor de wederrechtelijke verontreiniging aansprakelijk worden gesteld. Niettemin oordeelde het Oberlandesgericht (OLG) dat

'Wenn im Rahmen staatlicher Tätigkeit - wie hier beim Betreiben eines Schwimmbads - eine rechtswidrige Tat nach $\S 324$ StGB begangen wird, so kann sich die strafrechtliche Haftung von Amtsträgern aus $\S 14$ II 3 StGB ergeben. ${ }^{510}$

Opmerkelijk is ook dat de exploitatie van het stedelijk zwembad wordt gezien als een overheidstaak. De omstandigheid dat het delict is gepleegd bij de uitvoering van een overheidstaak laat blijkbaar de strafrechtelijke vervolgbaarheid en aansprakelijkheid volledig onaangetast.

Van belang is het gegeven dat de gemeente via een verordening had bepaald dat riolering enkel nog mocht plaatsvinden via een aansluiting op de gemeentelijke zuiveringsinstallatie. Het OLG neemt dan ook als uitgangspunt dat voor de gemeente geen andere regels kunnen gelden als voor haar burgers: 
'Nachdem die Stadt K. Anschluß- und Benutzungsdwang durch Satzung angeordnet hatte, mußte sie auch das von ihr betriebene Freibad an die dort geschaffene Kanalisation anschließen. Für die Stadt galt als Grundstückeigentümer nicht anderes als für die Bürger der Stadt. Der Umstand, daß die Stadt nicht gegen sich selbst einen Hernziehungsbescheid erlassen konnte, gab ihr nicht das Recht, den AnschluB an die Kanalisation beliebig lange hinauszuzögern. Nach Fertigstellung des Kanals mußte sie aufgrund ihrer eigenen Satzung auch das Freibad anschlieBen. $^{.511}$

Vervolgens wijst het OLG de eerste verantwoordelijken aan, hoewel dezen in casu niet terecht stonden:

'Bei Einleitung schadstoffhaltiger Abwässer in ein Gewässer durch eine öffentlichrechtliche Körperschaft sind grundsätzlich deren für den Bereich Abwasser zuständigen Dezernenten verantwortlich. ${ }^{512}$

Het arrest benadrukt dat de primaire verantwoordelijkheid voor de verontreiniging niet rust op de verdachten maar op de leidinggevende ambtenaren van de gemeentelijke waterzuiveringsdienst. In het arrest worden de verdachten dan ook consequent aangeduid als 'Mitverantwortlichen'. Hoewel de verdachte ambtenaren volgens het OLG formeel geen bevoegdheden hadden op het vlak van afvalwaterzuivering en zelfs niet tot de vereiste aansluiting konden besluiten, kunnen zij toch als plegers van het strafbare feit worden aangemerkt omdat de lozing van het vervuilde water onlosmakelijk verbonden is met de exploitatie van het zwembad. Wie volledige verantwoordelijkheid draagt voor de exploitatie van een zwembad, is op zijn minst medeverantwoordelijk voor de verplichte aansluiting van het zwembad aan de riolering. Het OLG voegt daar zelfs nog aan toe dat

'Auch wenn das Schwimmbad ordnungsgemäß an die Kanalisation angeschlossen gewesen wäre, hätten die Angekl. eine Mitverantwortung für die Abwässer gehabt, da sie für die Einsatz der Chemikalien zuständig und mithin dafür verantwortlich waren, da $B$ diese Chemikalien nicht Gefahren verursachten, sei es auch nur durch unmittelbare Einleitung über die Kanalisation in ein Gewässer. ${ }^{513}$

De strafrechtelijke aansprakelijkheid van de Beauftragten vloeit voort uit daderschap door nalaten. Er is dus sprake van een oneigenlijk omissiedelict:

'Der Vorwurf gegen die Angekl. kann sich nur darauf stützen, daß sie es unterlassen haben dafür zu sorgen, daß das Schwimmbad an die 
Kanalisation angeschlossen wurde und damit die Verunreinigung des LBachs vermieden worden wäre. ${ }^{514}$

Nu rijst hier de vraag in welke mate beide verdachten een bijzondere zorgplicht hadden. Het oneigenlijke omissiedelict en de causaliteit van het nalaten zijn immers sterk verweven met de vraag van de zorgplicht. Nu de zorgplichtenproblematiek ook uitgebreid in andere uitspraken aan bod komt, is het wenselijk dit vraagstuk afzonderlijk te behandelen.

d. Milieudelicten gepleegd door nalaten: het probleem van de vereiste zorgplicht

\section{(1) Algemeen}

De Duitse wetgever heeft uitdrukkelijk in $\S 13 \mathrm{StGB}$ het daderschap door nalaten geregeld. $\S 13$ StGB luidt als volgt:

'Wer es unterläßt einen Erfolg abzuwenden, der zum Tatbestand eines Strafgesetzes gehört (...) ist strafbar, wenn er rechtlich dafür einzustehen hat, daß der Erfolg nicht eintritt, und wenn das Unterlassen der Verwirklichung des gesetzlichen Tatbestandes durch ein Tun entspricht.'

Essentieel bij daderschap door nalaten is de eis dat de aansprakelijke persoon een bepaalde rolverantwoordelijkheid of hoedanigheid (Garantenstellung) moet hebben en daarmee een bijzondere zorgplicht (Garantenpflicht) ten aanzien van het strafrechtelijk beschermde ecologische rechtsgoed:

'Alle Erfolgsabwendungspflichten beruhen auf dem Grundgedanken, da $B$ eine bestimmte Person in besondere Weise zum Schutz des gefährdeten Rechtsgutobjekts aufgerufen ist und $\mathrm{da} \beta$ sich alle übrigen Beteiligten auf den aktiven Einsatz dieser Person verlassen und verlassen dürfen. ${ }^{515}$

Functioneel gezien kunnen zorgplichten in twee categorieën worden onderverdeeld. ${ }^{516}$ Enerzijds zijn er de zogeheten Obhutspflichten. Dit zijn zorgplichten die tot doel hebben bepaalde rechtsgoederen te beschermen. De zorgplichthouder heet dan Schutz- of Beschützergarant. Hij heeft de plicht schendingen van de aan hem toevertrouwde rechtsgoederen te voorkomen. Klassieke Schutzgaranten zijn de ouders ten opzichte van hun kinderen en de leraar ten opzichte van zijn leerlingen. Anderzijds zijn er de zogenaamde Beherrschungs- of Sicherungspflichten. Dit zijn zorgplichten die tot doel hebben toezicht te houden op bepaalde gevaarzettingen (Gefahrenquellen) zodat deze geen ongeoorloofde inbreuk veroorzaken op rechtsgoederen. De zorgplichtdrager wordt dan

514. Idem.

515. Jescheck, H.H. en Weigend, Th., o.c., 1996, 620.

516. Deze klassieke tweedeling is terug te voeren tot de 'Funktionenlehre' van Armin Kaufmann. Zie Kaufmann, A., Die dogmatik der Unterlassungsdelikte, Göttingen, 1959. Zie tevens over oorsprong en rechtstheoretische uitgangspunten van deze indeling: Androulakis, N., Rechtsproblematische Studien über die unechten Unterlassungsdelikte, München, 1962. 
aangeduid als Überwachungsgarant. Het is zijn plicht een aan hem toevertrouwde Gefahrenquelle te bewaken. Klassieke Überwachungsgaranten zijn exploitanten van gevaarlijke inrichtingen en houders van gevaarlijke dieren ${ }^{517}$ De ene zorgplichthouder heeft 'Schutzpflichten in bezug auf bestimmte Rechtsgüter', de andere heeft 'Verantwortlichkeit für bestimmte Gefarenquellen'. ${ }^{518}$ Beide zorgplichten vormen in die zin elkaars spiegelbeeld. Daar waar de Schutzgarant moet instaan voor de bescherming van één bepaald rechtsgoed tegen alle mogelijke gevaren, moet de Überwachungsgarant één bepaalde Gefahrenquelle bewaken ter bescherming van alle rechtsgoederen. ${ }^{519} \mathrm{De}$ reikwijdte van beide zorgplichten is daarom zeer verschillend. De Schutzgarant heeft in beginsel een zwaardere verantwoordelijkheid dan de Überwachungsgarant omdat hij een rechtsgoed moet beschermen tegen iedere vorm van bedreiging terwijl de Überwachungsgarant uitsluitend zorg moet dragen voor de controle van en het toezicht op één Gefahrenquelle. $^{520}$

Zorgplichten zijn steeds ook rechtsplichten. Om van een strafrechtelijk relevante zorgplicht te kunnen spreken is met andere woorden steeds een bijzondere rechtsgrond vereist. ${ }^{521}$ Zorgplichten zonder enige rechtsgrond zouden immers tot een onwenselijke uitbreiding van de strafbaarheid leiden.

'Voraussetzung einer Strafbarkeit wegen Unterlassens ist daher die rechtsverbindliche Verpflichtung zu einem bestimmtten Verhalten. ${ }^{.522}$

Dit is ook uitdrukkelijk in de strafwet neergelegd waar $\S 13 \mathrm{StGB}$ eist dat hij die nalaat enkel strafbaar is 'wenn er rechtlich dafür einzustehen hat, daß der Erfolg nicht eintritt'(cursief, DR).

Naargelang de rechtsbron kunnen zorgplichten in drie categorieën worden verdeeld. In de eerste plaats kunnen zorgplichten hun oorsprong vinden in de wet. Daarnaast is de overeenkomst een rechtsbron van zorgplichten. Een derde juridische bron van zorgplichten is het voorafgaand gevaarlijk handelen of de zogenaamde Ingerenz. Deze zorgplicht vloeit voort uit het algemene verbod anderen schade te berokkenen, het nemine laedem-beginsel:

'Wer die Gefahr herbeiführt, daß andere geschädigt werden (Ingerenz), müss dafür sorgen, daß sich diese nicht in einen tatbestandmäßigen Erfolg umsetzt. $^{523}$

517. Otto, H. en Brammsen, J., 'Die Grundlagen der strafrechtlichen Haftung des Garanten wegen Unterlassens', Jura, 1985, 530-542 en 592-602; Arzt, G., 'Zur Garantenstellung beim unechten Unterlassungsdelikt', $J A, 1980,553-561$ en 647-654.

518. Jescheck, H.H. en Weigend, Th., o.c., 1996, 621-625.

519. Schönke, A. , Schröder, H. en Stree, W., Strafrecht, München, Beck'sche Verlags-Buchhandlung, $1991, \S 13$, Nr. 9.

520. Jescheck, H.H. en Weigend, Th., o.c., 1996, 625.

521. Idem, 621.

522. Otto, H. en Brammsen, J., l.c., 1985, 532. OLG Düsseldorf, 7 maart 1989, MDR 1989, 932: 'Die Garantenstellung muß stets eine rechtliche Pflicht zum Handeln begründen, die bloße tatsåchliche Möglichkeit oder sittliche Pflicht Erfolgsverhinderung genugt nicht.' 
Essentieel daarbij is wel - ter vermijding van een oeverloze aansprakelijkheid - dat de Ingerenz-zorgplichtschending bestaat in een inbreuk op een norm, die ertoe strekt het geschonden rechtsgoed te beschermen.

Kortom, iedere Obhutspflicht of Sicherungspflicht moet, om strafrechtelijk relevant te zijn, een rechtsbron hebben: wet, overeenkomst of voorafgaand gevaarlijk handelen. ${ }^{524}$

Rijst de vraag of ambtenaren die door nalaten rechtstreeks het leefmilieu vervuilen, nu moeten worden beschouwd als Schutzgaranten of als Überwachungsgaranten en wat de precieze draagwijdte is van de op hen rustende zorgplichten. Dit is vooral van belang in die gevallen waar gemeenten hun afvalwaterzuiverings- of afvalverwerkingsplicht veronachtzamen door niet op te treden tegen lozingen of stortingen die door derden zijn gepleegd.

Allereerst mag niet worden vergeten dat in dit hoofdstuk uitsluitend het nalaten van 'gewone' gemeenteambtenaren wordt besproken en niet het passief blijven van vergunningverlenende (Genehmigungsbehörden) of toezichthoudende ambtenaren (Aufsichtsbehörden). Bij deze laatsten gelden andere ratio's en uitgangspunten ter vaststelling van de zorgplichten. Bij hen is immers van belang dat zij wettelijk niet alleen meer maar ook andere bevoegdheden ter behartiging van het leefmilieu hebben dan de gewone ambtenaren. De bevoegdheden tot respectievelijk vergunningverlening en toezicht en controle zijn rechtstreeks aan het leefmilieu gerelateerd. Daar aan deze echte milieuambtenaren het leefmilieu als het ware door de wetgever is toevertrouwd, worden zij door rechtspraak en rechtsleer over het algemeen beschouwd als Schutzgaranten van de ecologische rechtsgoederen ${ }^{525}$ In dit hoofdstuk gaat de aandacht echter uitsluitend naar ambtenaren van gemeenten die als 'Anlagebetreiber' aangesproken worden. Met betrekking tot deze ambtenaren kan moeilijk worden verdedigd dat zij ten opzichte van het leefmilieu Schutzgaranten zijn, dat wil zeggen dat op hen de rechtsplicht rust om de ecologische rechtsgoederen in beginsel te beschermen tegen alle ongeoorloofde inbreuken. Als zij al een zorgplicht hebben dan moet deze zijn gerelateerd aan bestuurlijke plichten die binnen de voor hen typische bevoegdhedensfeer vallen. ${ }^{526} \mathrm{Zo}$ zal in het geval van waterverontreiniging de grondslag van de strafrechtelijke zorgplicht moeten worden gevonden in de gemeentelijke Abwasserbeseitigungspflicht die is neergelegd in het Wasserhaushaltsgesetz. De zorgplichten zijn dus primair uit deze bijzondere 'Betreibspflichten' af te leiden. Het zijn

523. Jescheck, H.H. en Weigend, Th., o.c., 1996, 625.

524. De rechtspraak erkent ook nog een vierde rechtsbron, die echter voor de Amtsträgerstrafbarkeit van minder belang is. Dit is de rechtsbron van de zogenaamde 'enge Gemeinschaftsbeziehungen'. Zo wordt aanvaard dat gidsen van gevaarlijke bergtochten een bijzondere Obhutspflicht hebben ten opzichte van de door hen begeleidde personen. Ook samenwonenden hebben ten opzichte van elkaar een zorgplicht. Zie Jescheck, H.H. en Weigend, Th., o.c., 1996, 622-623.

525. Winkelbauer, W., 'Die strafrechtliche Verantwortung von Amtsträgern im Umweltstrafrecht', NStZ 1986, 151; Hom, E.,'Strafbares Fehlverhalten von Genehmigungs- und Aufsichtsbehörden', NJW 1981, 6.

526. Scholl, F., o.c., 1996, 177. 
deze plichten die de rechtsgrond vormen van de milieustrafrechtelijke zorgplichten. ${ }^{527}$ Vanuit het perspectief van de functionele tweedeling van zorgplichten betekent dit dat deze ambtenaren als Überwachungsgarant moeten worden beschouwd; zij hebben een rechtsplicht toezicht te houden op bepaalde Gefahrenquellen die hun oorsprong vinden in voor het leefmilieu hinderlijke taken die aan de overheden wettelijk zijn opgedragen. Dit impliceert dat ambtenaren die op één of andere wijze verantwoordelijkheid dragen voor de exploitatie van bijvoorbeeld gemeentelijke zuiveringsinstallaties ervoor moeten zorgen dat deze inrichtingen geen ongeoorloofde inbreuken op de ecologische rechtsgoederen veroorzaken. ${ }^{528}$ In tegenstelling tot milieuambtenaren hebben de organen van een gemeente en ambtenaren werkzaam binnen bepaalde overheidsdiensten dus in beginsel geen Obhutspflichten maar Sicherungspflichten.

Met betrekking tot de omvang van de zorgplichten is nog van belang dat de uit de (Überwachungs)garantenstellung voortvloeiende strafrechtelijke zorgplichten niet verder kunnen reiken dan de bestuursrechtelijke plichten, waarin deze strafrechtelijke zorgplichten hun oorsprong vinden. ${ }^{529}$ Ook hier komt de administratieve afhankelijkheid om de hoek kijken. Dit betekent dat in een concreet geval steeds moet worden nagegaan aan welke bestuursrechtelijke normen de betrokken ambtenaar onderworpen is en in welke mate hij terzake nog beschikt over freies Ermessen. Dit laatste probleem moet echter niet worden overschat. In de meeste gevallen zal de keuzevrijheid van de ambtenaar niet zo groot zijn omdat de aan de gemeente verleende vergunningen de omvang van de zorgplicht bepalen, nu daarin door middel van voorwaarden nader is vastgelegd aan welke normen de gemeente zich dient te houden. Het probleem van freies Ermessen speelt dan vaak niet meer, omdat dit reeds door de vergunningverlenende overheid is ingevuld. Voor de vergunninghoudende overheid geldt - net als bij een onderneming - een principiële gebondenheid aan de vergunningsvoorwaarden:

'Raum für politische Abwägungen bestehen in diesem Bereich nicht. Die maßgeblichen Entscheidungen werden allein von den zuständigen Umweltbehörden getroffen. ${ }^{.530}$

Rechtspraak

Hoe verhouden deze algemene uitgangspunten zich nu met de rechtspraak? Werpen we opnieuw een blik op bovenvermelde zwembad-casus dan blijkt meteen dat de rechtspraak niet altijd even duidelijk met het onderscheid tussen Schutzgaranten en Überwachungsgaranten omgaat. Het LG had in deze zaak beide ambtenaren veroordeeld op grond van een

527. Idem, 155 .

528. 'Aus diesem Grunde machen sich etwa die zuständigen Gemeindebehörden einer Gewăsserverunreinigung bzw. Abfallbeseitigung durch Unterlassen strafbar, wenn sie nicht durch Sicherungsmaßnahmen verhindern, dass auf der von der Gemeinde betriebenen Müllkippe unerlaubt Sondermüll abgelagert wird, der das Grundwasser verunreinigt.' Winkelbauer, W., l.c., $1986,151$.

529. Pfohl, M., l.c., 1994, 418.

530. Scholl, F., o.c., 1996, 251. 
schending van een Sicherungspflicht. Volgens het LG moeten beide ambtenaren dus worden beschouwd als Überwachungsgaranten. Meer bepaald hebben zij de rechtsplicht om toezicht te houden op het zwembad als Gefahrenquelle geschonden. Dit lijkt inderdaad een juiste benadering. Interessant is echter dat het OLG dit standpunt verlaat en oordeelt dat hier niet zozeer sprake is van een schending van een Sicherungspflicht maar van een Obhutspflicht:

'Die Angeklagten waren (...) "Schutzgaranten". Wegen der Verantwortung für den Einsatz von Chemikalien (...) mußten beide Angekl. dafür sorgen, daß durch den Einsatz der Chemikalien keine Gefahren verursacht wurden. $\mathrm{Zu}$ den daraus folgenden Sorgfaltspflichten gehörte auch die Prüfung, ob die Abwässer, die diese Chemikalien enthielten, ordnungsgemäß über die Kanalisation abgeführt wurden., ${ }^{531}$

In deze overweging zit een duidelijke tegenspraak waar het OLG stelt dat de verdachten enerzijds Schutzgaranten zijn en dat zij anderzijds ervoor hadden moeten zorgen dat door het gebruik van chemische stoffen geen 'gevaren' zouden ontstaan. Dit is typisch een beschrijving van een Sichenungspflicht en niet van een Obhutspflicht!

Meer in concreto rijst nu de vraag naar de reikwijdte van de zorgplicht. Deze vraag is van belang omdat een zorgplicht feitelijk en juridisch wordt beperkt door de beslissingsruimte die de zorgplichthouder in een concreet geval heeft. ${ }^{532}$ Of zoals het OLG zelf vooropstelt:

'Grundsätzlich braucht allerdings jemand, dem bestimmte Pflichten übertragen sind, für die Erfüllung dieser Pflichten nur soweit einzustehen, als ihm konkret tatsächlich und rechtlich Entscheidungsmacht eingeräumt ist. $^{533}$

In casu was die ruimte voor beide verdachten echter niet groot. De wederrechtelijke verontreiniging kon enkel op twee manieren worden verhinderd. Ofwel moest het zwembad worden aangesloten op de daarvoor aangewezen riolering, ofwel diende men onmiddellijk tot de sluiting van het zwembad over te gaan. Het OLG concludeert dat, hoewel de verdachten formeel niet de bevoegdheid hadden om tot een van beide opties te besluiten, de feiten toch aan hen kunnen worden toegerekend. De loutere omstandigheid dat niet de verdachten maar andere ambtenaren ter zake bevoegd waren, doet geen afbreuk aan de op hen rustende zorgplicht want

'Auch wenn sie die erforderliche Entscheidung über den Kanalisationschluß oder - als einzige Alternative - die Stillegung des Schwimmbads nicht selbst treffen konnten, mußten sie als diejenigen, die durch den

531. OLG Köln, 17 mei 1988, NJW 1988, 2121.

532. Steindorf, Strafgesetzbuch. Leipziger Kommentar, Berlin, 1988, Vor $§ 324$ StGB, Nr. 45.

533. OLG Köln, 17 mei 1988, NJW 1988, 2121. Zie tevens OLG Frankfurt 22 mei 1987, NStZ 1987, 509. 


\begin{abstract}
Einsatz von Chemikaliën die Gefahren von Gewässerbeeintrachtigung schafften, bei den für den Kanalanschluß zuständigen Amtsträgern auf die entsprechende Maßnahmen hinwirken. ${ }^{534}$
\end{abstract}

Het is duidelijk dat in deze zaak de grenzen van de strafrechtelijke aansprakelijkheid ruim zijn getrokken. Zo kan worden vastgesteld dat wanneer ambtenaren zelf geen beslissingsbevoegdheid hebben om aan een illegale situatie daadwerkelijk een einde te maken, op hen als garanten nog steeds een zorgplicht rust om hierover de primaire verantwoordelijken te informeren en hen aan te sporen de nodige maatregelen te nemen. Ook wordt in deze uitspraak vlug voorbijgegaan aan de vaststelling van de precieze rechtsgrond van de zorgplicht.

Het loutere feit dat ambtenaren bepaalde zorgplichten hebben geschonden, hoeft nog niet te betekenen dat zij ook aansprakelijk kunnen worden gesteld voor het ten laste gelegde feit. Dit zou in extremis leiden tot een strafrechtelijke risico-aansprakelijkheid. Het feit moet aan de zorgplichtdrager kunnen worden toegerekend. Daartoe moet steeds worden bekeken of het niet vervullen van bepaalde plichten in oorzakelijk verband staat met het opgetreden delictsgevolg. Is dat niet het geval dan kan door het ontbreken van enige causaliteit het strafbare feit niet worden toegerekend. Als regel geldt dat een schending van bepaalde zorgplichten als (mede)oorzaak van het opgetreden gevolg kan worden beschouwd of als schakel uit de causale keten kan worden gezien, indien zonder deze schending het gevolg naar alle waarschijnlijkheid niet zou zijn ingetreden. ${ }^{535}$ In casu rijst de vraag of niet al te vlug een causaal verband tussen de schending van de zorgplicht en het opgetreden gevolg werd verondersteld. Had niet veeleer moeten worden bekeken of de primaire verantwoordelijken anders zouden hebben gehandeld indien de verdachte ambtenaren hun zorgplicht wel naar behoren hadden vervuld? In ieder geval lijkt ter zake een deugdelijke motivering te ontbreken: ${ }^{536}$

'Das Unterlassen dieser Hinwirkung muß auch als kausal für die Gewässerverunreiniging i.S. von § $324 \mathrm{StGB}$ angesehen werden. Das $L G$ hat zwar nicht ausdrücklich fetsgestellt, daß auf eine Initiative der Angekl. hin ein Kanalanschluß erfolgt und damit der tatbestandmäßige Erfolg vermeiden worden wäre; doch kann dies dem Inbegriff der Urteilsgründe entnommen werden, zumal die Stadt $\mathrm{K}$. drei Monate nach dem Fischsterben im L-Bach das Freibad an den kanal angeschlossen hat ${ }^{537}$

\title{
534. Idem.
}

535. Vgl. Dahs, H., 'Zur strafrechtlichen Haftung des Gewässersschutzbeauftragten nach § 324 StGB', NStZ 1986, 101: 'Für eine Verurteilung des Gewässerschutzbeauftragten nach § 324 StGB muß das Gericht zu der zweifelsfreien Ûberzeugung gelangen und diese auch in nachprüfbarer Weise im Urteil darlegen, daß z. B. eiene betriebsinterne Initiative des Beauftragten gegenüber der Betriebsleiter oder die Anregung eines Änderungsantrages an die Wasserbehörde Erfolg gehabt und zu einem ebenfalls konkret festzustellenden Zeitpunkt weitere Verstöße hătte.'

536. Hange, S., 'Verantwortlichkeit für Kanalisationsanschluß eines Schwimmbades', NJW 1989, 122.

537. OLG Köln, 17 mei 1988, NJW 1988, 2121. 
Van een gelijkaardige situatie was sprake in een uitspraak van het OLG Stuttgart van 1988. In deze zaak had het hoofd van een gemeentelijke zuiveringsinstallatie nagelaten een nachtelijke bedrijfsstoomis te melden en de in de dienstvoorschriften neergelegde maatregelen te treffen die noodzakelijk waren om de zo ontstane vervuiling tot een minimum te beperken.

De ambtenaar wordt door het OLG veroordeeld omdat

'der Angekl. aufgrund seiner Garantenstellung als Leiter der Klärwerks
nach § 13 I StGB rechtlich dafür einzustehen hatte, daß aus diesem keine
ungeklärten Abwässer in den Neckar flossen und diesen verunreinigten
(..) Es wäre seine Pflicht gewesen, sofort nach seiner Alarmierung das
Klärwerk aufzusuchen, sich zu informieren und das zuständigen
Wasserwirtschaftsamt $\mathrm{K}$. über die Betriebsstörung zu informieren. ${ }^{538}$

Met andere woorden, de ambtenaar wordt een schending van een Sicherungspflicht verweten. Als hoofd van de zuiveringsinstallatie is hij Überwachungsgarant en dient hij erover te waken dat deze milieugevaarlijke inrichting geen ongeoorloofde vervuiling van het water veroorzaakt.

Zoals gezegd, moet iedere zorgplicht een juridische basis hebben. In casu vindt de zorgplicht zijn oorsprong in de arbeidsovereenkomst.

'Eine solche Handlungsweise war ihm aufgrund seiner durch Arbeitsvertrag begründeten Stellung als Leiter des Klärwerks und der damit verbundenen Verantwortung trotz der nächtlichen Stunde auch zumutbar. ${ }^{539}$

Belangrijk is ook de precieze draagwijdte van de zorgplicht. De vraag rijst met welke maatstaf het nalaten moet worden gemeten om te kunnen spreken van een verwijtbaar en strafbaar nalaten. Het OLG stelt dat bij de invulling van de zorgplicht de persoonlijke bekwaamheden, kennis en levenservaring van de verdachte alsook omgevingsafhankelijke factoren een belangrijke rol kunnen spelen. Tegelijk moet worden gekeken naar de ernst van de inbreuk. Nu het hier gaat om een ernstige en vermijdbare vervuiling concludeert het OLG:

'Im Hinblick auf die Bedeutung des Rechtsguts "Gewässer" und den heute erreichten Informationsstand über die Gefahren einer Gewässerschädigung ist jedoch ein strenger Sorgfaltsmaßtab anzulegen; zu fordern ist die Sorgfalt eines umweltbeußten Rechtsgenossen (...) Den Maßstab der aufzuwendenden Sorgfalt bildeten hier die Stellung des Angekl. als

538. OLG Stuttgart, 2 december 1988, NStZ 1989, 123.

539. Idem. 
Leiter des Klärwerks sowie die ihm für seine Tätigkeit von der Gemeinde erteilten Dienstanweisungen. ${ }^{.540}$

Voor een nadere invulling van de zorgplicht is dus niet alleen de wet of de overeenkomst van belang, maar ook de op dat moment geldende dienstvoorschriften. Het door de ambtenaar aangevoerde gebrek aan kennis en bekwaamheden om de bedrijfsstoornis zelf op te lossen kan volgens het OLG niet worden gezien als een strafuitsluitende of strafverminderende omstandigheid. Had de ambtenaar de 'sogar einem Laien verständlicher' dienstinstructies opgevolgd dan had hij de bevoegde instanties op tijd kunnen verwittigen zodat de verontreiniging tot een minimum beperkt zou zijn gebleven.

Der Angekl. hätte sich zu sofortigen Alarmierung fachkundiger Behörden umso mehr gedrängt sehen müssen, als er sich aufgrund seiner mangelnden Fachkenntnisse über die Einzelheiten der Funktionsweise der Kläranlage ein Urteil über den Grad der Gefahr und die Klärkraft der Anlage nicht zutrauen durfte (...) Dieser Verstoß gegen die Sorgfaltsplicht eines Klärwerksleiters ist ihm persönlich vorwerfbar. ${ }^{541}$

Ook op burgemeesters rust een strenge zorgplicht. Zo werd in een uitspraak van het LG Koblenz een burgemeester veroordeeld voor het onbevoegd verwerken en opslaan van afval ( 326 I Nr. $3 \mathrm{StGB}$ ) en het exploiteren van een illegale stortplaats (§ $327 \mathrm{II}$ Nr. 2 $\mathrm{StGB}$ ) omdat hij had nagelaten bestuurlijke maatregelen te nemen tegen illegale stortingen. ${ }^{542}$

Het LG oordeelt:

'Es ist heute unbestritten, daß sich auch Amtsträger grundsätzlich einer Umweltstraftat schuldig machen können (...) Maßgebliches Problem ist das der Garantenstellung und der sich daraus ergebenden Garantenpflicht. Während bezüglich der Fachbehörden überwiegend die Auffassung vertreten wird, daß bei diesen zwar eine Garantenstellung gegeben sei (...) ist dieses Problem bei "allgemeinen" Amtsträgern wie etwa einem Oberbürgermeister als mehr oder minder ungeklärt anzusehen $(. . .)^{543}$

Interessant in deze zaak is vooral dat de rechtsgrond van de zorgplicht volgens de strafrechter niet moet worden gesitueerd in de op de gemeente rustende 'Betreiberpflichten', maar in het eigendomsrecht van de gemeente.

'Ein Garantenstellung ergibt sich indessen (...) aus dem Umstand, daß es sich bei der fraglichen Parzelle um ein im Gemeindeeigentum stehendes

540. Idem.

541. Idem.

542. Zie tevens de reeds besproken uitspraken van het LG München II en het AG Cochem.

543. LG Koblenz, 12 december 1986, NStZ, 1987, 281. 
Grundstück handelt und der Angesch. Organ der Ortsgemeinde O. i.S. des $\S 14$ Nr. 1 StGB ist. Eine Verwirklichung des $\$ 326$ I Nr. 3 StGB durch Unterlassen kann sich aus dem Grundsatz der Verantwortung für Gefahrenquellen ergeben, der allgemein erkannt ist (...) Dieser allgemeine, d.h. auf jeden Eigentümer eines Grundstücks mit Besitzwillen (...) trifft auch eine juristische Person, insb. aber eine Kommunalkörperschaft und damit deren handelndes bzw. eine gebote handlung unterlassendes Organ. ${ }^{544}$

De overtreding van $\S 326 \mathrm{StGB}$ bestaat dus in de schending van een Sicherungspflicht die zijn grondslag vindt in het feit dat de gemeente eigenaar is van de grond waarop de illegale stortingen hebben plaatsgevonden. De juridische basis voor de Überwachungsgarantenstellung is met andere woorden de Eigentumsstellung van de gemeente. Het eigendomsrecht is inderdaad een algemeen erkende rechtsgrond van Sicherungspflichten. ${ }^{545}$ Dit vloeit voort uit het feit

'daß dem Eigentümer zustehenden Eigentümsschutzansprüche nach $\S \S$ 1004 BGB (...) bewirken, daß die potentiell Gefährdeten die Sachgefahr nicht eigenmächtig beseitigen können. Der Rechtsverkehr ist deshalb darauf angewiesen, daß der Sachherr die von der Sache ausgehenden Gefahren selbst beseitigt oder erst gar nicht entstehen läßt. ${ }^{546}$

Dit verklaart ook waarom het LG beroep doet op $\S 14$ StGB. Dit is op het eerste gezicht vreemd omdat $\S 326 \mathrm{StGB}$ een gemeen milieudelict is. In deze casus kan echter enkel via § 14 StGB een strafrechtelijke aansprakelijkheid van de burgemeester worden vastgesteld omdat $\S 326 \mathrm{StGB}$ is overtreden door de schending van een zorgplicht die zijn oorsprong vindt in het eigendomsrecht. Dit eigendomsrecht en daarmee ook de zorgplicht behoort niet toe aan de organen van de gemeente. Hierdoor krijgt het gemene delict het karakter van een kwaliteitsdelict. De burgemeester heeft een zorgplicht geschonden waarvan alleen de gemeente adressaat kan zijn. $\S 14 \mathrm{StGB}$ is dus nodig om alsnog het orgaan aansprakelijk te kunnen stellen. Hiermee wordt duidelijk dat $\$ 14 \mathrm{StGB}$ ook bij gemene milieudelicten van groot belang is in situaties waar de delictsomschrijving wordt overtreden door het schenden van bepaalde zorgplichten die tot de rechtspersoon zijn gericht.

De burgemeester wordt daarnaast ook veroordeeld voor de exploitatie van een illegale stortplaats. De plek waarop werd gestort kan immers worden gezien als een 'Anlage' in de zin van $327 \mathrm{StGB}::^{547}$

544. Idem.

545. Jescheck, H.H. en Weigend, Th., o.c., 1996, 627; Schōnke, A., Schro̊der, H., Stree, W., o.c., $1991, \S 13$, Nr. 43.

546. Scholl, F., o.c., 1996, 157.

547. De rechtspraak erkent een ruim Anlage-begrip. Zie o.m. BayObLG 19 november 1991, JR 1992, 516. 
'Eine "wilde" Müllkippe kann eine ungenehmigte Abfallbeseitigungsanlage sein, wenn sie die Merkmale aufweist, die einer genehmigungsfähigen Anlage innewohnen (...) Die Anlage wird auch durch den Angesch. als Organ der Eigentümerin betrieben, und zwar durch Unterlassen. $^{548}$

Ook deze uitspraak is een treffende illustratie van hoe ruim sommige strafrechters de strafrechtelijke aansprakelijkheid van ambtenaren formuleren.

Samengevat kan worden vastgesteld dat gemeenteambtenaren vrij eenvoudig voor milieuverstoring die (mede) het gevolg is van een nalatigheid en een schending van een zorgplicht kunnen worden veroordeeld. De op de ambtenaren rustende zorgplichten moeten worden beschouwd als Sicherungspflichten. Als Überwachungsgarant dienen zij ervoor te waken dat de inrichtingen die onder hun 'Sachherrschaft' vallen niet de oorzaak worden van ongeoorloofde verstoring van het leefmilieu. Ook kan worden opgemerkt dat de rechtspraak nauwelijks problemen heeft met de vaststelling van de rechtsbron van de zorgplichten.

\section{e. De problematiek van de noodtoestand}

Een vaak voorkomend probleem is dat gemeenten de milieustrafwet overtreden ten gevolge van een noodsituatie, een conflict van plichten en belangen. Verschillende casusposities zijn mogelijk. Klassiek is het conflict tussen het naleven van de milieuwetgeving, bijvoorbeeld afvalwaterzuivering, en de financiële draagkracht van de overheid. Een belangrijk punt is dat de gemeentelijke taak van afvalwaterzuivering een bijzonder kostelijke aangelegenheid is en tot financiële problemen aanleiding kan geven ${ }^{549} \mathrm{De}$ totale kosten van afvalwaterzuivering voor een middelgrote gemeente van 90.000 inwoners bedragen gemiddeld 38 miljoen DM. Soms kan dit bedrag oplopen tot 200 miljoen DM. ${ }^{550}$ Het hoeft dan nauwelijks nog een betoog dat gemeenten, wanneer zij voor waterverontreiniging strafrechtelijk worden aangesproken, zich trachten te beroepen op noodtoestand. De vraag rijst dan hoe de strafrechter met dit conflict tussen milieubescherming en meer econmische belangen omgaat.

Daarnaast is er de noodsituatie waarin een conflict ontstaat tussen enerzijds de waterrechtelijke plicht het afvalwater te zuiveren en anderzijds het strafrechtelijke gebod dit op zodanige wijze te doen dat er geen strafbaar feit wordt gepleegd. Soms kan een gemeente echter terechtkomen in een situatie waarin op geen andere wijze het afvalwater

548. LG Koblenz, 22 december 1986, NStZ 1987, 282.

549. Pfohl, M., l.c., 1994, 430.

550. Scholl, F., o.c., 1996, 9. Deze indrukwekkende kostenplaatjes hoeven op zich nog niets te betekenen. Het is best mogelijk dat een financieel zwakke gemeente meer problemen ervaart met de bouw van een relatief kleine zuiveringsinstallatie dan een financieel sterke gemeente die overgaat tot de bouw van een grote installatie en een volledig nieuw rioleringsnetwerk. Problematisch is vooral de situatie in de nieuwe deelstaten. De totale kosten om waterzuivering te laten voldoen aan de huidige milieunormen wordt geschat op zo'n 200 miljard DM. 
kan worden gezuiverd dan door het plegen van een strafbaar feit. Dit is bijvoorbeeld het geval wanneer de zuiveringsinstallatie sterk is verouderd en de lozingen in die zin ook niet langer worden gedekt door een vergunning. De zo ontstane wederrechtelijke en dus in beginsel strafbare vervuiling zou dan slechts kunnen worden vermeden door de installatie te sluiten. Een dergelijke sluiting is echter enerzijds onmogelijk omdat dit in strijd is met de Abwasserbeseitigungspflicht en anderzijds onwenselijk omdat dit een nog zwaardere vervuiling tot gevolg kan hebben. Ook dan rijst de vraag in welke mate gemeenten, respectievelijk de verantwoordelijke ambtenaren, zich kunnen beroepen op noodtoestand.

Financiële problemen als rechtvaardigingsgrond

De rechtvaardigingsgrond noodtoestand is door de Duitse wetgever expliciet in § $34 \mathrm{StGB}$ neergelegd:

\begin{abstract}
'Wer in einer gegenwärtigen, nicht anders abwendbaren Gefahr für Leben, Leib, Freiheit, Ehre, Eigentum oder ein anderes Rechtsgut eine Tat begeht, um die Gefahr von sich oder einem anderen abzuwenden, handelt nicht rechtswidrig, wenn bei Abwägung der widerstreitende Interessen, namentlich der betroffenen Rechtsgüter und des Grades der ihnen drohenden Gefähren, das geschützte Interesse das beeinträchtigte wesentlich überwiegt. Dies gilt jedoch nur, soweit die Tat ein angemessen Mittel ist, die Gefahr abzuwenden.'
\end{abstract}

Essentiële vereiste voor een rechtvaardigende noodtoestand is dat voor de dader, die zich in uitzonderlijke omstandigheden bevindt, de naleving van de strafwet - hier de $\S \S 324$ StGB e.v. - onmogelijk is, daar naleving de schending van een hoger rechtsgoed of belang - hier het vermogensbelang van de gemeente - zou betekenen. ${ }^{551} \mathrm{Bij}$ de vraag in welke mate een gemeente zich bij financiële problemen op noodtoestand kan beroepen moet wel in het oog worden gehouden dat de noodtoestand in het milieustrafrecht een beperkte draagwijdte heeft. De bescherming van de ecologische belangen of rechtsgoederen is in een administratief afhankelijk milieustrafrecht gebaseerd op een vergunningenstelsel. Dit betekent allereerst dat de wetgever destijds expliciet rekening heeft gehouden met het feit dat de naleving van de milieuwetgeving voor de betrokkenen een zware financiële last tot gevolg heeft. Daarnaast heeft ook de vergunningverlenende overheid bij het vaststellen van de vergunningsvoorwaarden rekening gehouden met de economische haalbaarheid van de opgelegde voorwaarden. In een administratief afhankelijk milieustrafrecht geldt daarom als uitgangspunt dat de oplossing van conflicten tussen enerzijds het belang van een zuiver leefmilieu en anderzijds meer socio-economische belangen exclusief is uitbesteed aan de daarvoor bevoegde milieuinstanties. ${ }^{552}$ Dit impliceert dat de belangenafweging ex post, die van de strafrechter bij een beroep op noodtoestand wordt verlangd, ex ante reeds door het

551. Zie over de noodtoestand: Jescheck, H.H. en Weigend, Th., o.c., 1996, 357-356; Roxin, C., Strafrecht Allgemeiner Teil. Grundlagen der Aufbau der Verbrechenslehre, München, C.H. Beck'sche Verlags-Buchhandlung, 1994, 586-646.

552. Scholl, F., o.c., 1996, 81 . 
bestuur is gemaakt. De strafrechter heeft weinig ruimte om in een concrete zaak alsnog een belangenafweging te maken. Dit betekent dat slechts in hoogst uitzonderlijke gevallen en na een nauwkeurig onderzoek op grond van noodtoestand kan worden vrijgesproken. In de eerste plaats moet worden getoetst of het voor de dader werkelijk onmogelijk was om de vergunningsvoorwaarden na te leven. Daarnaast moet komen vast te staan dat de dader over geen ander alternatief beschikte om de vervuiling tegen te gaan. Dit uitgangspunt leidt ertoe dat alleen formeel rechtsgeldige vergunningen de wederrechtelijkheid van lozingen kunnen wegnemen. De wederrechtelijkheid moet worden gedekt door een 'wirksame Verwaltungsakt'. Of zoals in een principiële uitspraak van het OLG Frankfurt treffend wordt gesteld:

'Befugt soll nach dem Willen des Gesetzgebers eine Verschlechterung der Gewässereigenschaften sein, wenn sie ein objektives Unwerturteil nicht verdient, weil sie von der Rechtsordnung ausnahmsweise gestattet wird; d.h. jede gestatungsbedürftige, aber nicht gestattete Einwirkung auf ein Gewässer ist schlechthin rechtswidrig; erst die behördliche Gestattung begründet die Befügnis'(...) Somit ist nicht gerechtfertigt, wer Abwasser ohne Erlaubnis in ein Gewässer einleitet oder wer die erteilte Erlaubnis überschreitet (...) Der Berücksichtigung materieller Betreiberpflichten würde jedoch das dem $\S 324$ StGB zugrundeliegende Prinzip des absoluten Gewässerschutzes, wonach jede nachteilige Veränderung des Gewässers, wenn sie nicht gerechtfertigt ist, objektiv strafwürdiges Unrecht bedeuten, zuwiderlaufen. Dem entspricht der Standpunkt, daß die bloße Erlaubnisfähigkeit nicht rechtfertigend wirkt, vielmehr der formale Gestattungsakt erforderlich ist.(Cursief, DR) ${ }^{553}$

Zoals gezegd, houdt ook de milieuadministratie bij de vergunningverlening rekening met de financiële moeilijkheden van de gemeente. Toch kan zich de situatie voordoen dat de vergunningsvoorwaarden zo exorbitant zijn dat ze strijdig zijn met de wet. Zal dan een beroep op het economische belang van de gemeente niet meer kans van slagen hebben omdat toch moeilijk de naleving van onwettige voorschriften kan worden verlangd? Dient de strafrechter de vergunning dan niet als onwettig te bestempelen? Met deze vraag raken we de problematiek van strafrechtelijke toetsing van administratieve rechtshandelingen, een vraagstuk dat uiteraard uitgebreid in hoofdstuk VII zal besproken worden. Momenteel kan worden volstaan met de opmerking dat naar Duits recht de strafrechtelijke toetsing zeer beperkt is. De heersende leer en rechtspraak nemen aan dat de eenheid tussen het bestuursrecht en het strafrecht formeel behouden dient te blijven. Dat wil zeggen dat iedere formeel rechtsgeldige vergunning door de strafrechter moet worden gerespecteerd ook al is hij materieel gezien onrechtmatig. ${ }^{554}$ De vergunninghouder moet ook de voorschriften van

553. OLG Frankfurt 22 mei 1987, JR 1988, 169. Dit impliceert tevens dat ook (actief) gedogen niet de wederrechtelijkheid vermag uit te sluiten. Wel kan dit in bepaalde omstandigheden aanleiding geven tot onoverkomelijke dwaling in hoofde van de vergunningplichtige. Zie o.m. Hallwaß, C., Die behördliche Duldung als Unrechtsausschließungsgrund im Umweltstrafrecht, 1987.

554. Rudolphi, H.J., 'Primat des Strafrechts im Umweltschutz?', NStZ 1984, 197; Horn, E., 1.c., 1981, 3; Zeitler, S., Die strafrechtliche Haftung für Verwaltungsentscheidungen nach dem neuen 
een wederrechtelijke vergunning volgen. Schendingen van materieel wederrechtelijke vergunningen zijn strafbaar en dit tot op het moment dat de vergunning is ingetrokken of nietig is verklaard. Dus zelfs in het geval waarin de naleving van onwettige vergunningsvoorwaarden voor de gemeente financieel onhaalbaar is, is er voor de strafrechter geen ruimte voor een eigen belangenafweging en dus ook niet voor de inwilliging van noodtoestand. Dan rijst de opmerkelijke vraag of de vergunningverlener niet als medepleger of als medeplichtige strafrechtelijk aansprakelijk zou moet worden gesteld voor de door de vergunninghoudende overheid veroorzaakte verontreiniging. Zo wordt duidelijk dat beide vormen van Amtsträgerstrafbarkeit best naast elkaar kunnen voorkomen.

$\mathrm{Nu}$ in beginsel uitsluitend formele vergunningen de wederrechtelijkheid kunnen opheffen, is er nauwelijks nog ruimte voor een beroep op noodtoestand. ${ }^{555}$ In de praktijk wordt noodtoestand dan ook slechts aanvaard in onvoorzienbare situaties, zoals bij rampen en onvermijdbare bedrijfsongevallen. ${ }^{556}$ Vanzelfsprekend kan ook geen beroep worden gedaan op noodtoestand wanneer de overheid door eigen schuld op onrechtmatige wijze in de noodsituatie is terechtgekomen (actio illicita in causa). ${ }^{557}$

Bij dit alles mag bovendien niet uit het oog worden verloren dat gemeenten die zich in financiële moeilijkheden bevinden, wettelijk verplicht zijn een lening aan te gaan om zo alsnog met de bouw of aanpassing van zuiveringsinstallaties te kunnen beginnen. Dit vloeit rechtstreeks voort uit de waterrechtelijke regelgeving. ${ }^{558}$ In de meeste deelstaten bestaan bovendien zogenaamde 'Förderrichtlinien Wasserwirtschaft' die voor gemeenten de mogelijkheid scheppen om voor de aanpassing van zuiveringsinstallaties overheidssubsidies aan te vragen. De wetgever heeft dus duidelijk rekening gehouden met de uitzonderlijke financiële moeilijkheden waartoe de waterzuiveringsplicht kan leiden. Een dergelijk systeem verklaart dan ook dat een strafuitsluiting wegens financiële problemen in de Duitse Bondsrepubliek nauwelijks toepassing vindt. Zo werd in een uitspraak van het AG Wertheim een ambtenaar veroordeeld omdat

'die Kanalisation eines Stadteils schadhaft geworden ist und der Beamte aus Kostenersparnisgründen nicht für eine einwandfreie Rohrumleitung der schadhaften Stelle während der Reparaturarbeiten sorgt, sondern nur derart unzureichende Maßnahmen triffte, daß das Abwasser des Stadteils weitestgehend ungeklärt in einen Bach fließt. ${ }^{559}$

Umweltstrafrecht. Dargestellt an dem $\S 324$ StGB, Tübingen, 1982, 70; Herrmann, J., 'Die Rolle des Strafrechts beim Umweltschutz in der Bundesrepublik Deutschland', ZStW, 1979, 292; Hübenett, C., Rechtswidrige behördliche Genehmigung als Rechtferdigungsgrund - ein gelöstes strafrechtliches Problem? Dargestellt an § 324 StGB (Gewässerverunreinigung), Bonn, 1986.

555. Müller, W., l.c., 1990, 36.

556. Schönke, A., Schröder, H., Cramer, P., o.c., § 324, Nr. 13.

557. Müller, W., L.c., 1990, 369.

558. Meer bepaald $\S 7$ a WHG samen met het in 1989 ingevoerde Allgemeine RahmenVerwaltungsvorschrift über Mindestanforderungen an das einleiten von Abwasser in Gewässer (Rahmen-AbwasserVwV). Zie Pfohl, M., l.c., 1994, 418 en 420; Scholl, F., o.c., 1996, 82.

559. AG Wertheim, 4 november 1987 (ongepubliceerd), aangehaald in Weber, U., o.c., 1988, 31. 
De noodtoestand kan ook bestaan in een conflict tussen enerzijds de waterrechtelijke plicht het afvalwater te zuiveren en de strafrechtelijke plicht dit op niet-wederrechtelijke wijze te doen. Zoals we bij de bespreking van de Nederlandse situatie hebben gezien, werd tot het Tweede Pikmeer-arrest geoordeeld dat de strafrechter dergelijk conflict niet mocht beoordelen omdat hij dan de bestuurlijke belangenafweging zou toetsen. Sinds Pikmeer II is een strafrechtelijke toetsing wel mogelijk en zal deze moeten plaatsvinden op het niveau van de rechtvaardigingsgronden. Een uitstap naar het Duiste recht is dus ook op dit punt interessant, daar volgens de Duitse rechtspraak niets zich verzet tegen een dergelijke toetsing.

Illustratief voor deze problematiek is een omstreden en complexe uitspraak van het OLG Saarbrücken van 1991. De gemeente W. loosde sinds de jaren ' 80 afvalwater via een verouderde collector, die oorspronkelijk enkel was bedoeld voor de afvoer van regenwater. Deze collector was weliswaar aangesloten op een zuiveringsinstallatie maar had door verstopping niet langer een voldoende afwateringscapaciteit. De lozing was evenmin gedekt door een geldige vergunning. In 1982 werd de gemeente door de Wasserbehörde verschillende keren aangemaand een lozingsvergunning aan te vragen. Ook werd in samenspraak met de Wasserbehörde besloten tot de bouw van een nieuwe collector en een aangepast afvoerkanaal. De totale kostprijs werd voor de gemeente op 12 miljoen DM geschat. In 1984 werd aan een deskundigenbureau de opdracht gegeven de gemeente te adviseren over de bouw van het nieuwe rioleringsnetwerk alsook over de inhoud van de vergunningsaanvraag. Pas in 1988 was het deskundigenrapport klaar. Een jaar later werd gestart met de vergunningsprocedure. In totaal duurde het ruim 7 jaar alvorens de vergunning werd aangevraagd. Het openbaar ministerie besluit uiteindelijk de burgemeester voor de illegale lozingen te vervolgen. Zowel het AG als het OLG spreken de verdachte vrij van de hem ten laste gelegde overtreding van $\S 324$ StGB.

Volgens het OLG kan de wederrechtelijke lozing als dusdanig niet aan de verdachte worden toegerekend. Er was geen sprake van een handelen (ein positives Tun) in hoofde van de verdachte dat in oorzakelijk verband zou staan met het opgetreden delictsgevolg:

'Handeln setzt (...) als konstitutives Element ein auf einem Willensentschluß beruhendes Eingreifen in die Außenwelt durch das Auslösen einer Kausalkette voraus, d.h. die Veranderung eines zuvor bestehenden faktischen Zustands oder Gescheheniss. In diesem Sinne gehandelt hätte der Angekl., wenn sein konkretes Verhalten die Ursache für eine ohne dieses Verhalten nicht eingetretene Gewässerverunreinigung gewesen wäre. Dies ist, da er in Person kein Abwasser (...) eingeleitet hat, offensichtlich nicht der Fall. ${ }^{560}$ 
Volgens het OLG ontbrak bovendien enig wilsbesluit in hoofde van de verdachte omdat op de gemeente op grond van het Wasserhaushaltsgesetz (WHG) nu eenmaal een 'Abwasserbeseitigungspflicht' rust waaraan hij zich niet kan onttrekken. Nu moet deze afvalwaterzuiveringsplicht worden uitgevoerd op een wijze die het water niet ongeoorloofd verontreinigt. De gemeente is daarvoor op de zuiveringsinstallaties aangewezen. Maar doordat de bestaande installatie in casu niet langer de verontreiniging kon tegengaan, was, in afwachting van een vergunning en de bouw van een nieuwe installatie, de illegale lozing onvermijdelijk. Het OLG komt dan ook tot de volgende slotsom:

\begin{abstract}
'Die Gemeinde und damit der Bürgermeister als ihr Organ sehen sich also einer Situation gegenüber, in der sie ihre Verpflichtung zur Abwasserbeseitigung nur unter Verletzung des Verbots der Gewässerverunreinigung erfüllen können mit der Folge, daß wegen der Unabdingbarkeit der Erfüllung der Verpflichtung zur Abwasserbeseitigung ein Versto $B$ der Gewässerverunreinigung notwendigerweis unvermeidbar ist (...) Die Gemeinde bzw. der für sie handelnde Bürgermeister können sich ihrer gesetzlichen Abwasserbeseitigungspflicht nicht entziehen. Sie müssen dieser Pflicht genügen, auch wenn sich hieraus möglicher - oder notwendigerweis ein Versto $\beta$ gegen $\S 324$ StGB ergibt. Es fehlt demzufolge schon an dem auf freier Willensentscheidungs beruhenden Entschluß zur Vornahme einer erfolgsverursachenden Handlung. ${ }^{561}$
\end{abstract}

Daar de gemeente/burgemeester zich niet van de plicht tot afvalwaterzuivering konden onttrekken, is de vervuiling niet het resultaat van enig wilsbesluit van de verdachte en is er dus ook geen strafbaar feit gepleegd.

Het OLG maakt hier duidelijk zelf een afweging tussen twee op de gemeente rustende verplichtingen. Enerzijds de bestuursrechtelijke verplichting het afvalwater 'so $\mathrm{zu}$ beseitigen, daß das Wohl der Allgemeinheit nicht beeinträchtigt wird' (§ 18a I 1 WHG) en anderzijds de strafrechtelijke verplichting dit afvalwater niet 'unbefugt' te lozen ( $§ 324$ StGB). De bestuursrechtelijke norm krijgt in casu voorrang op de strafrechtelijke norm. Meteen rijst de vraag of het OLG hier niet een verkeerde afweging heeft gemaakt. Volgens het OLG is de lozing niet strafbaar omdat deze zou hebben plaatsgevonden ten dienste van het algemeen belang ( $\S 18 \mathrm{a}$ I 1 WHG). Verscheidene auteurs merken terecht op dat het OLG hiermee miskent dat § 18a I 1 WHG niet los kan worden gezien van de in § 2 WHG neergelegde vergunningvereiste. Het door het OLG aangevoerde algemeen belang moet immers iedere keer concreet worden ingevuld. Deze concrete invulling moet primair de uitkomst zijn van een vergunningsprocedure waarbij ex ante door de vergunningverlenende instantie een belangenafweging moet worden gemaakt en niet door de vergunningplichtige en evenmin ex post door de strafrechter:

'Eine gemeinwohlverträgliche Abwasserbeseitigung i. S. des $\S 18 \mathrm{a} I$ WHG setzte im Falle von Gewässerverunreinigungen dann jedenfalls

561. Idem. 
einen Genehmigungsantrag (wenn schon nicht die Genehmigung selbst) voraus. ${ }^{562}$

Met deze uitspraak heeft het OLG eigenlijk het vergunningensysteem volledig opzij gezet. De lozing is volgens het OLG geen strafbaar feit, niet omdat er een wirksame Verwaltungsakt voorligt, maar omdat het WHG zelf rechtstreeks de strafbaarheid zou uitsluiten.

De meer inhoudelijke kant van de afweging is ook het vermelden waard. Voor de gemeente/burgemeester bestonden er slechts twee alternatieven om een einde te maken aan de illegale lozingen. Ofwel moest zo snel mogelijk de afvalwaterzuivering worden aangepast aan de huidige stand der techniek zodat kon worden geloosd conform (de nog te verlenen) vergunning. Ofwel moest worden gekozen voor de meest drastische oplossing: sluiting van de zuiveringsinstallatie. Wat de eerste oplossing betreft, kan, gelet op de feiten (zoals beoordeeld door het OLG !), de burgemeester niets worden verweten:

'Nach seinem Amtsantritt hat der Angekl. alles in seiner Macht stehende getan, um weitere Gewässerverunreinigungen schnellstmöglich zu unterbinden, so daß er den Tatbestand des § 324 StGB nicht durch Unterlassen verwirklicht hat (...) Aus (dem) Verhalten des Angekl. folgt, daß er sowohl dem Umfang als auch der Eilbedürftigkeit der notwendigen $\mathrm{Maßnahmen} \mathrm{hinreichend} \mathrm{Genüge} \mathrm{getan} \mathrm{und} \mathrm{nichts} \mathrm{unterlassen} \mathrm{hat,} \mathrm{was} \mathrm{zu}$ wirksamen oder schnelleren Beeindigung des von ihm vorgefundenen $\mathrm{Zu}$ standes geeignet wäre. ${ }^{563}$

Hiertegen kan worden ingebracht dat niettemin de verdachte eerder een vergunning had kunnen aanvragen: tussen het uitgebrachte deskundigenadvies en de aanvraag van de vergunning zat immers nog een vol jaar. ${ }^{564}$ Volgens het OLG zou dit echter geen verschil hebben uitgemaakt:

'Der Angekl. war zwar gehalten, die erfordliche ( $\S \S 2,3$ I Nrn 4, 7, 8 WassHG) wasserrechtliche Einleitungserlaubnis zu beantragen. Daß er dies unterlassen hat, ist für den eingetretenen Erfolg jedoch nicht ursächlich: Hätte er pflichtgemäß einen solchen Antrag gestellt, so hätte sich weder hierdurch noch durch eine erteilte Erlaubnis an der Gewässerverunreinigung und damit am Eintritt des tatbestandsmäßigen Erfolgs etwas geändert. ${ }^{1565}$

Deze redenering overtuigt niet helemaal:

562. Hoyer, A.,'Gewăsserverunreinigung durch Bürgermeister', NStZ, 1992, 388.

563. OLG Saarbrücken, 27 juni 1991, NJW 1991, 3045.

564. Aldus Hoyer, A., I.c., 1992, 388.

565. OLG Saarbrücken, 27 juni 1991, NJW 1991, 3045. 
'Das OLG Saarbrücken verkennt dabei die Möglichkeiten der Wasserbehörde, die aus ihrer Sicht notwendigen Maßnahmen unter Umständen zwangsweise durchzusetzen....566

Het is best denkbaar dat de Wasserbehörde de vereiste spoed waarmee met de bouw van het rioleringssysteem zou moeten worden begonnen anders zou hebben ingeschat en dientengevolge via dwangmaatregelen tegen het passief blijven van de gemeente zou zijn opgetreden.

Het tweede alternatief, sluiting van de zuiveringsinstallatie, lijkt inderdaad een nuloptie. In tegenstelling tot bij particuliere ondernemingen zou dit een te grote inbreuk betekenen op $\S$ 18 WHG en meer algemeen op het beginsel van de continuïteit van de openbare dienst. ${ }^{567}$ Dergelijke maatregel zou trouwens een veel sterkere verontreiniging tot gevolg hebben dan het (tijdelijk) lozen via de verouderde installatie. ${ }^{568}$ Het OLG concludeert dan ook

'daß der Angekl. (...) die z. B. bei privaten Unternehmen mögliche Hanlungsalternative des Unterlassens der Einleitung von Abwässern etwa durch Stillegung des gesamten Betriebes oder der Einstellung des für die Gewässerverunreinigung ursächlichen Teiles des Betriebes nicht hat.'

Ook de wijze waarop de afweging wordt gemaakt, doet de nodige vragen rijzen. Inhoudelijk bekeken gaat het hier duidelijk om een rechtvaardigingsgrond.

'Die Lösung des Konflikts zwischen dem Interesse an natürlicher Wasserreinheit und den Bedürfnissen der Gewässernutzung ist insoweit (...) den Wasserbehörden übertragen und gegenüber $\S 34$ als spezielle gesetzliche Konkretisierung des Notstandes zu verstehen. ${ }^{1569}$

Het is dan interessant om vast te stellen dat het OLG de belangenafweging niet maakt bij de wederrechtelijkheidsvraag maar bij de kwalificatievraag, bij de vraag of het ten laste gelegde feit voldoet aan de delictsomschrijving. Volgens het OLG is de bestuursrechtelijke plicht neergelegd in het WHG niet zozeer als een strafrechtelijke rechtvaardigingsgrond aan te merken, maar moet deze worden gezien als een kwalificatieuitsluitingsgrond. Doordat de verdachte zich niet heeft kunnen onttrekken aan de waterrechtelijke zuiveringsplicht beantwoordt de gedraging niet langer aan de delictsomschrijving van $\S 324 \mathrm{StGB}$. Er is daardoor geen sprake meer van een delictstypische gedraging. Aan een onderzoek van de wederrechtelijkheid van de gedraging komt het OLG dan ook niet meer toe. Het OLG haalt hier 'Tatbestandsebene' en 'Rechtswidrigkeitebene' door elkaar. § 324 StGB beschermt op absolute wijze de zuiverheid van het water. Dit impliceert dat volgens $\S 324 \mathrm{StGB}$ de

566. Scholl, F., o.c., 1996, 76.

567. Müller, W., L.c., 1990, 369.

568. Weber, U., o.c., 1988, 30; Scholl, F., o.c., 1996, 87.

569. Lackner, K. en Kühl, K., Strafgesetzbuch mit Erläuterungen, München, Beck'sche VerlagsBuchhandlung, 1995, $§ 324$, Nr. 14. 
enkele verontreiniging of nadelige verandering van de eigenschappen van het water moet worden gezien als een gedraging die beantwoordt aan de delictsomschrijving. Met de feitelijke verontreiniging

'ist der Tatbestand gegeben, wenn der Täter den genannten Erfolg herbeiführt. Von hier aus betrachtet kann dem Merkmal "unbefugt" die Funktion eines allgemeinen Verbrechensmerkmals der Rechtswidrigkeit zuerkannt werden. ${ }^{570}$

Zelfs indien men aanvaardt dat de verdachte geen andere mogelijkheid openstond dan op grond van het WHG de illegale lozingen te laten voortduren, dan laat dit onverlet dat dogmatisch gezien nog steeds wel sprake is van een verontreiniging die beantwoordt aan de delictsomschrijving:

'Wer aktiv einen Straftatbestand verwirklicht, handelt tatbestandmäßig auch dann, wenn er dazu rechtlich verpflichtet ist (...) seine Handlungspflicht läßt nur die Widerrechtlichkeit des Handelns entfallen. ${ }^{571}$

De door het OLG gemaakte afweging verwijst naar een typisch rechtvaardigingsprobleem en had dus uitsluitend mogen plaatsvinden bij de beantwoording van de wederrechtelijkheidsvraag. Waarom het OLG dergelijke afweging maakt bij de behandeling van de kwalificatievraag is uit het arrest niet op te maken. Sommige auteurs suggereren dat het OLG zo een daadwerkelijk wederrechtelijkheidsoordeel heeft willen omzeilen:

'Hätte das OLG erkannt, daß auch eine Pflicht zu verunreinigender Abwasserbeseitigung allenfals rechtfertigend wirken kann, so wäre es auf das Problem gestoßen, ob die Gewässerverunreinigung bereits bei materiell "guten Gründen" (dem Interesse der Allgemeinheit an geordneter Abwasserentsorgung) oder erst bei formell vorliegender Genehmigung (bzw. jedenfalls gestelltem Genehmigungsantrag) gerechtfertigt erscheint. ${ }^{572}$

Het OLG heeft feitelijk een noodtoestand beoordeeld, echter niet bij het wederrechtelijkheidsoordeel, maar ten onrechte bij de kwalificatievraag. ${ }^{573} \mathrm{Zo}$ wordt

570. Schönke, A. , Schröder, H. en Cramer, P., o.c., 1991, $\S \S 324, \mathrm{Nr} .14$.

571. Hoyer, A., l.c., 1992, 388.

572. Idem.

573 In dit verband kan worden opgemerkt dat ook in het Belgische milieustrafrecht niet zuiver wordt omgegaan met de plaats van de noodtoestand. Zo oordeelde het Hof van Beroep te Gent ( 27 juni 1985, R.W., 1986-87, 1691, met noot Vandeplas) dat het niet naleven van een vergunning wegens financiële moeilijkheden kan worden aangemerkt als afwezigheid van alle schuld (AVAS). Het probleem van de noodtoestand hoort echter thuis bij het leerstuk van de wederrechtelijkheid en niet bij de daaropvolgende schuldvraag en nog minder bij de daaraan voorafgaande kwalificatievraag. Zie voor een uiterst heldere bespreking van deze problematiek in het Belgische milieustrafrecht Faure, M., 'Financiële problemen als rechtvaardigingsgrond voor milieuverontreiniging?', $R W, 1988-89,286-297$. 
duidelijk dat het OLG wellicht al te makkelijk tot een vrijspraak is gekomen. ${ }^{574}$ Of het OLG tot een gelijk oordeel zou zijn gekomen, moest het de dogmatisch juiste weg hebben gevolgd, is dus maar de vraag.

Kan in zijn algemeenheid nog worden opgemerkt dat niet al te vlug uit het enkele conflict tussen de Abwasserbeziehungspflicht en het strafrechtelijke gebod het water niet 'unbefugt' te vervuilen een rechtvaardigende noodtoestand mag worden afgeleid. De gemeente moet daadwerkelijk al het mogelijke hebben gedaan om de verontreiniging zo goed mogelijk te verhinderen of te verminderen. In voorkomend geval moet daarom steeds worden onderzocht of er geen andere maatregelen dan een sluiting van de installatie mogelijk zijn die de verontreiniging kunnen verminderen. Zo kan bijvoorbeeld worden gedacht aan de tijdelijke afvoer van het vervuilde water in een reservebekken. ${ }^{575}$ Over het algemeen leiden dergelijke conflicten niet meteen tot 'alles of niets' situaties: er is meestal een aantal overgangsmaatregelen die de gemeente in staat kunnen stellen om in afwachting van een legalisering tegen de verontreiniging op te kunnen treden. ${ }^{576}$ Het feit dat dergelijke maatregelen de gemeente in financiële moeilijkheden zouden kunnen brengen, mag, zoals gezien, geen rechtvaardiging zijn om er geen gebruik van te maken.

\section{Het standpunt van het Bundesgerichtshof}

In 1992 werd het vraagstuk van de strafrechtelijke aansprakelijkheid van ambtenaren op de spits gedreven toen voor het eerst het Bundesgerichtshof (BHG) de kans kreeg zich over deze gevoelige materie uit te spreken. Ook in deze zaak wordt in het bijzonder aandacht besteed aan de verhouding tussen de waterrechtelijke zuiveringsplicht en de strafrechtelijke plicht het water niet 'unbefugt' te verontreinigen. Ook de zorgplichtenproblematiek komt in dit arrest uitvoerig aan bod.

Wat waren de feiten? Eind jaren zeventig besluit de burgemeester van de Hessische gemeente B. tot de bouw van een nieuwe centrale zuiveringsinstallatie. Ook worden plannen gemaakt om de rioleringen van een vijftal deelgemeenten aan deze installatie aan te sluiten. Eind 1984 wordt met de bouw van de zuiveringsinstallatie en het rioleringssysteem begonnen. Doordat de totale werkzaamheden bijna zes jaar in beslag namen - eind 1990 werd de laatste deelgemeente aangesloten - ontstond wel het tijdelijke probleem dat gedurende de overgangsperiode (1984-1990) het afvalwater van de nog niet aangesloten deelgemeenten niet via de zuiveringsinstallatie kon worden gezuiverd. Om de aldus veroorzaakte verontreiniging zo veel mogelijk te beperken werd door de Landrat in de aan de gemeente verleende lozingsvergunning de voorwaarde neergelegd dat de gemeentelijke lozingen enkel mochten plaatsvinden nadat de betrokken grondeigenaren zelf hun afvalwater hadden gezuiverd. Ter uitvoering van deze vergunningsvoorwaarde werd door

574. Groß, U. en Pfohl, M., 'Zur Strafbarkeit von Bürgermeister im Bereich kommunaler Abwasserreinigungsanlagen - Zugleich Anmerkung zu OLG Saarbrücken, NStZ 1991, 531', NStZ, 1992, 121: 'hier fallt zunächst auf, mit welcher Großzügigkeit des OLG aus den ihm zur Verfügung stehenden tatsăchlichen Feststellungen seine Schlußfolgerungen zieht.'

575. Scholl, F., o.c., 1996, 88.

576. Groß, U. en Pfohl, M., l.c., 1991, 119 en 121. 
de gemeente in een verordening bepaald dat, in afwachting van de ingebruikname van de centrale zuiveringsinstallatie, de nog niet aangesloten grondeigenaren zelf kleine zuiveringsinstallaties moesten bouwen. Mede door de relatief hoge kosten van dergelijke installaties (ongeveer $7000 \mathrm{DM}$ ) stuitte deze verordening op veel verzet van de betrokkenen zodat in 1985 nog steeds een honderdtal grondeigenaren niet beschikte over de noodzakelijke installaties. Eind 1986 werd door het openbaar ministerie tegen deze grondeigenaren gerechtelijk vooronderzoek ingesteld. De meeste zaken werden vervolgens wel (onder voorwaarden) getransigeerd. Het kwam echter wel tot een vervolging van de burgemeester. Het Landesgericht Darmstadt veroordeelde de burgemeester voor opzettelijke en wederrechtelijke waterverontreiniging nu hij had nagelaten de door de grondbezitters veroorzaakte vervuiling door bestuursdwang te hebben verhinderd. Het BGH houdt deze uitspraak vervolgens in stand.

Allereerst herhaalt het BGH het principe dat, nu het hier gaat om een gemeen delict, § 324 StGB ook door bestuursfunctionarissen rechtstreeks kan worden overtreden.

\begin{abstract}
'Bei Amtsträgern einer Gemeinde besteht deshalb eine strafrechtliche Verantwortlichkeit für Gewässerverunreinigungen insoweit, als die Gemeinde selbst Anlagen (wie etwa Krankenhäuser, Schimmbäder, Kraftwerke, Mülldeponien oder Kläranlagen) betreibt und dabei Abwässer in den Vorfluter leitet, die das Gewässer verunreinigen. In dieser Hinsicht nehmen die für sie handelnden Personen innerhalb des Kreises der Täter keine Sonderstellung ein. ${ }^{.577}$
\end{abstract}

Vervolgens staat het BGH stil bij de strafrechtelijke kwalificatie van de criminele betrokkenheid van de burgemeester bij het milieudelict. In de meeste tot hiertoe besproken gevallen is steeds sprake van een aansprakelijkheid van functionarissen voor milieudelicten die rechtstreeks door de gemeenten zelf waren gepleegd; gemeenten die eigenhandig afvalwater lozen of wederrechtelijk een stortplaats uitbaten. Deze zaak lijkt enigszins af te wijken van de klassieke 'Betreiberfälle' omdat hier veeleer sprake is van een onrechtstreekse criminele betrokkenheid van de gemeente. Want hoewel enerzijds de overheid als de uiteindelijke vervuiler kan worden beschouwd - het is immers de gemeente die daadwerkelijk het afvalwater loost - moet anderzijds de directe oorzaak van de verontreiniging toch bij de grondeigenaren worden gezocht. Rijst de vraag met welke vorm van Amtsträgerstrafbarkeit - directe of indirecte aansprakelijkheid - we hier te maken hebben. Uit de vroegere rechtspraak kan worden afgeleid dat dergelijke situaties worden gezien als klassieke 'Betreiberfälle'. ${ }^{578}$ Het BGH oordeelt als volgt:

'Zwar war die Stadt Direkteinleiterin, und zwar als Trägerin der Teilortkanalisationen, also derjenigen Anlagen, die das nicht vorgeklärte Abwasser aufnahmen, um es den Vorflutern zuzuleiten. Das Einleiten der von den Eigentümern "übernommenen" Abwässer vermochte aber eine 
strafrechtliche Verantwortlichkeit nich zu begründen. Als Gegenstand des Vorwurfs einer nach $\S 324$ Abs. 1 StGB strafbaren Gewässerverunreinigung kam es nicht in Betracht. Denn insoweit bestand für die Stadt keine rechtmäßige Verhaltensalternative: Sie hätte, da sie mangels entsprechender Einrichtungen das in ihre Kanalisation geflossene Abwasser nicht selbst vorklären konnte, die Einleitung in die Vorfluter überhaupt unterlassen müssen, was ihr aber ohne Verstoß gegen ihre Abwasserbeseitigungspflicht nicht möglich gewesen wäre.'(cursief, DR) $)^{579}$

Er is geen wederrechtelijke handeling in hoofde van de burgemeester omdat de gemeente als rechtstreekse en uiteindelijke 'Einleiter' waterrechtelijk verplicht was het afvalwater afkomstig van de grondeigenaren te lozen. Een weigering van de burgemeester dit afvalwater te lozen zou betekenen dat hij zich op onrechtmatige wijze zou onttrekken van de plicht tot Abfallwasserbeseitigung. Met andere woorden, gelet op het dwingende karakter van de waterrechtelijke plichten, kan de burgemeester niet een overtreding van § 324 StGB door een positief handelen (door commissie) worden ten laste gelegd. In die zin volgt het BGH min of meer de redenering van de reeds vermelde uitspraak van het OLG Saarbrücken. Belangrijk verschil is echter dat in de uitspraak van het OLG de voorrang van de waterrechtelijke plicht boven de strafrechtelijke norm een straffeloosheid van de ambtenaar tot gevolg had. ${ }^{580}$ Het BGH gaat hier echter verder en acht de burgemeester alsnog strafrechtelijk aansprakelijk op grond van het feit dat

'es der Angklagte als Organ der Gemeinde unterließ, die Grundstückseigentümer an der Einleitung nicht vorgeklärten Abwassers in die Teilortkanalisationen zu hinderen. Für diese Unterlassung muß er strafrechtlich einstehen. Im Rahmen des $\S 324$ StGB Abs. 1 StGB besteht strafrechtliche Verantwortlichkeit nicht nur für positives Tun, sondern auch für Unterlassen. ${ }^{581}$

De burgemeester kan weliswaar geen wederrechtelijk handelen worden verweten, maar wel een wederrechtelijk nalaten, dat erin bestaat niet te hebben opgetreden tegen de grondeigenaren.

Hoewel de overwegingen van het BGH op het eerste gezicht suggereren dat het hier gaat om een Amtsträgerstrafbarkeit voor het niet ingrijpen tegen milieuverstoring door derden gepleegd, gaat het in casu wel degelijk om een strafrechtelijke aansprakelijkheid van de burgemeester voor een (door de gemeente) zelf gepleegde verontreiniging, zij het door omissie. In de literatuur wordt dan ook algemeen aangenomen dat het hier niet gaat om een aansprakelijkheid wegens 'nichteinschritten gegen rechtwidriger Umweltverletzungen Dritter' maar om een 'Betreiberfall', zij het een bijzondere variant daarvan:

579. BGH 19 augustus 1992, BGHSt (38) 1992, 330.

580. Michalke, R., 'Die Strafbarkeit von Amtstrågern wegen Gewåsserverunreinigung ( $\$ 324$ StGB) und umweltgefăhrdender Abfallbeseitigung ( $\$ .326 \mathrm{StGB})$ in neuem Licht', NJW, 1994, 1694.

581. BGH 19 augustus 1992, BGHSt (38) 1992, 331 . 
'der entscheidene Fall mußte sich als "Betreiberfall" darstellen, weil die Gemeinde über die Teilortkanalisation Direkteinleiterin und ihr Bürgermeister für den Betrieb der Teilortkanalisation verantwortlich war. Für die Teilortkanalisation hatte der Landrat der Gemeinde - wie einem privaten Anlagenbetrieber - eine wasserrechtliche Einleiterlaubnis erteilt. Der Bürgemeister war somit als Amtsträger der Stadt für den ordnungsgemäßen Betrieb der Anlage (Teilortskanalisation) verantwortlich. Da die Einleiteerlaubnis unter der Auflage erteilt wurde, daß nur vorgeklärtes Abwasser eingeleitet wird, hatte der Bürgermeister auch für die Einhaltung dieser Auflage Sorge zu trägen. ${ }^{582}$

De burgemeester moet worden beschouwd als pleger van het delict omdat hij door het niet treffen van noodzakelijke maatregelen de voorwaarden van de vergunning heeft geschonden; tot deze voorwaarden behoort de eis om uitsluitend voorgezuiverd afvalwater te lozen. Nu hij heeft nagelaten de grondeigenaren te verplichten hun afvalwater te zuiveren, overtreedt hij de vergunningsvoorwaarden en daarmee $\S 324 \mathrm{StGB}$. De verontreiniging is dus niet slechts veroorzaakt door een kwalificatieoverschrijdend nalaten een nalaten dat 'tatbestandmäßig' is -; nu tevens de vergunning is overtreden is er tevens een wederrechtelijk nalaten. ${ }^{583}$ De ten laste gelegde verontreiniging wordt dan vervolgens als een oneigenlijk omissiedelict rechtstreeks aan de burgemeester toegerekend. Hij wordt dan ook niet veroordeeld als medepleger van of als deelnemer aan, maar als pleger (dader) van het milieudelict. ${ }^{584}$

Zoals gezien, is een cruciaal element van daderschap door nalaten de aanwezigheid van een bijzondere zorgplicht om het delictsgevolg af te wenden. Rijst dus de vraag of in hoofde van de verdachte een bijzondere zorgplicht aanwezig was. ${ }^{585}$ Het BGH laat hierover geen twijfel bestaan:

'Er nimmt eine Garantenstellung ein, kraft derer ihn die Verpflichtung trifft, rechtswidrige Gewässerverunreinigungen abzuwenden, die dadurch entstehen, daß ortsansässige Grundstückeigentümer nicht vorgeklärte

582. Michalke, R., l.c., 1994, 1694. Zie tevens Jung, H., 'Garantenstellung des Bürgermeisters für Abwasserbeseitigung', $J u S, 1993,347$ : 'Die Entscheidung is von großer Tragweite fur den Gesetzesvollzug im Bereich des Umweltrechts. Trotzdem wird man sie nicht dem Bereich der Amtsträgerverantwortlichkeit in Fällen des Nichteinschreitens gegen Umweltstraftaten Dritter zuordnen dürfen. Vielmehr geht es - ungeachtet der gegenteiligen Feststellung des 2. Strafsenats - letzlich doch um eine Variationsform der unmittelbaren strafrechtlichen Verantwortlichkeit des Amtsträgers für die ordnungsgemäße Beseitigung von Abwässern.'; Schall, H., 'Zur Strafbarkeit von Amtsträgern in Umweltverwaltungsbehörden - BGHSt 38, 325', JuS, 1993, 720.

583. Zie over kwalificatieoverschrijdend en wederrechtelijk nalaten Remmelink, J., o.c., 1995, 166.

584. Nestler, C., 'Die strafrechtliche Verantwortlichkeit eines Bürgermeisters für Gewässerverunreinigungen der Bürger', GA, 1994, 527.

585. BGH 19 augustus 1992, BGHSt (38) 1992, 332; 'Nach dem zu beurteilenden Sachverhalt steht allein zur Entscheidung, ob der Bürgermeister einer hessischen Gemeinde für Gewăsserverunreinigungen im Rahmen der Abwasserbeseitigung als Garant strafrechtlich haftet.' 


\begin{abstract}
Abwässer der Ortskanalisation zuführen und damit den Vorfluter verschmutzen. Grund dieser Garantestellung ist eine entsprechende Pflicht der Gemeinde, deren Erfüllung dem Bürgermeister zufolge seiner dienstlichen Aufgaben als Amtsträger der Gemeinde obliegt. ${ }^{586}$
\end{abstract}

De strafrechtelijke zorgplicht vloeit dus voort uit de bestuursrechtelijke regelgeving, waaronder het Wasserhaulthaltsgezetz en het Hessische Wassergesetz. De zorgplicht bestaat erin het afvalwater op zodanige wijze te zuiveren dat 'daß das Wohl der Allgemeinheit nicht beeinträchtigt wird' ( $§ 18$ a Abs. 1 Satz 1 WHG) ${ }^{587}$ Dit betekent dat

\begin{abstract}
'Jedermann, also auch die Gemeinde, ist verpflichtet, bei Maßnahmen, mit denen Einwirkungen auf ein Gewässer verbunden sein können, die nach den Umständen erforderliche Sorfalt anzuwenden, um eine Verunreinigung des Wassers oder eine sonstige nachteilige Veränderung seiner Eigenschaften zu verhüten (...) Aus der Gesamtheit dieser Regelungen ergibt sich, daß die Gemeinde grundsätzlich verpflichtet ist, das in ihrem Gebiet anfallende Abwasser schadlos, also ohne vermeidbare Beeinträchtigungen der Gewässer, zu beseitigen. ${ }^{588}$
\end{abstract}

Interessant is dat het BGH benadrukt dat de plicht tot afvalwaterzuivering hier niet in conflict treedt met het strafrechtelijke verbod neergelegd in § 324 StGB: integendeel, de waterrechtelijke plichten hebben juist tot doel het door $\S 324$ StGB beschermde rechtsgoed (zuiver water) te beschermen:

'Diese verwaltungsrechtlichen Pflicht dient - zumindest auch - dem Schutz des in $\S 324$ StGB mit Strafandrohung bewehrten Rechtsguts und stimmt insoweit mit dem strafrechtlichen Normgebot überein. ${ }^{1589}$

Waar het OLG Saarbrücken nog spreekt van een belangenstrijd en zelfs van een bovengeschiktheid van de waterrechtelijke plichten, verdedigt het BGH de administratieve afhankelijkheid waarbij de bestuursrechtelijke normen de strafrechtelijke normen niet opzij zetten maar juist aanvullen. Het BGH beklemtoont ook dat de administratieve afhankelijkheid van het milieustrafrecht moet worden gezien als een Verwaltungsaktsakkzessorietät en niet als een Verwaltungsrechtsakkzessorietät. ${ }^{590}$ Als uitgangspunt geldt dus dat het strafrechtelijke verbod van $\S 324$ StGB nader moet worden ingevuld door het bestuursrechtelijke vergunningenstelsel. Dit impliceert dat een verontreiniging slechts 'befugt' is wanneer deze wordt gedekt door en plaatsvindt conform een rechtsgeldige vergunning:

586. Idem.

587. Nestler, C., l.c., 1994, 525.

588. BGH 19 augustus 1992, BGHSt (38) 1992, 333-334.

589. Idem, 334.

590. Knopp, L., 'Zur Strafbarkeit von Amtsträgern in Umweltverwaltungsbehörden unter besonderer Berücksichtigung der BGH-Rechtsprechung', DÖV, 1994, 678. 
'Die Pflicht der Gemeinde, im Bereich der ihr zugeweisenen Abwasserbeseitigung dafür zu sorgen, daß Gewässerverunreinigungen unterblieben, reicht dabei soweit, wie die verunreinigenden Einwirkungen auf das Gewässer verwaltungsrechtlich unstatthaft, also nicht durch eine entsprechende Erlaubnis der Wasserbehörde gedeckt sind.'

$\mathrm{Nu}$ er door de Landrat uitsluitend een lozingsvergunning was verleend voor voorgezuiverd afvalwater, is de verontreiniging in casu 'unbefugt':

'Hier lag für die Einleitung nicht vorgeklärten Abwassers eine Erlaubnis der Wasserbehörde nicht vor. Denn die Erlaubnisbescheide des Landrats enthielten jeweils die Bedingung, da $\beta$ den Kanälen nur vorgereinigtes Abwasser zugeführt werden dürfe. Soweit diese Bedingung nicht erfüllt wurde, war daher die Einleitung unstatthaft.'

Met andere woorden, de strafrechtelijke zorgplicht van de burgemeester om waterverontreiniging te vermijden is rechtstreeks uit de lozingsvergunning af te leiden. Nu door het lozen van niet voorgezuiverd afvalwater de vergunningsvoorwaarden zijn overtreden, is daarmee ook de zorgplicht geschonden.

Het BGH gaat vervolgens over tot de vaststelling van de concrete inhoud van de zorgplicht:

\begin{abstract}
'Angesichts dieser Rechtslage verdichtete sich die allgemeine Pflicht der Gemeinde, Gewässerverunreinigungen zu verhüten, hier für die Stadt zu dem Handlungsgebot, diejenigen Grundstückeigentümer, die den Teilortkanalisationen nicht vorgeklärtes Abwasser zuführten, an den Fortsetzung dieses Tun zu hindern. Denn einerseits durfte die Stadt solches Abwasser nicht in die Gewässer einleiten; andererseits war es ihr aber nicht möglich, das in ihre Kanalisation gelangte Abwasser selbst vorzuklären oder dessen Abfluß in den Vorfluter aufzuhalten. Demzufolge konnte sie ihre Pflicht zur Verhütung rechtswidriger Gewässerverunreinigungen nur dadurch erfüllen, daß sie bereits die Einleitung des nicht vorgklärten Abwassers in ihre Kanalisation unterband. ${ }^{.591}$
\end{abstract}

$\mathrm{Nu}$ had de gemeente ter uitvoering van deze zorgplicht weliswaar bij verordening bepaald dat de grondeigenaren zelf zuiveringsinstallaties moesten bouwen, maar het BGH acht deze maatregel niet voldoende.

'Vielmehr hatte sie darüber hinaus die Grundstückeigentümer auch zur befolgung der genannten Pflicht anzuhalten und deren Erfüllung notfalls im Wege des Verwaltungszwangs durchzusetzen (...) Die Pflicht (...), Gewässerverunreinigungen durch (...) Einleitung ungeklärten Abwasser zu verhindern, schloß (...) auch das Gebot ein, die zuwiderhandelnden 
Grundstückeigentümer ausfindig zu machen, weil nur so ihr Verhalten unterbunden werden konnte ${ }^{, 592}$

De burgemeester had beter zorg moeten dragen voor de bestuurlijke handhaving van de verordening. Meer in het bijzonder had hij een onderzoek moeten instellen tegen de grondeigenaren en in dat geval bestuursdwang moeten toepassen.

Deze laatste overweging is niet onproblematisch. De bestuursdwangbevoegdheid is immers een vrije bevoegdheid. Dit betekent dat de wet niet tot toepassing ervan verplicht, maar aan het bestuursorgaan ruimte geeft om na afweging van de in het geding zijnde belangen al dan niet tot toepassing van de bestuursdwang over te gaan. Het BGH oordeelt echter dat in casu niet langer sprake kan zijn van een vrije bevoegdheid:

'Sie war verpflichtet, von dieser Möglichkeit erforderlichenfalls auch Gebrauch zu machen. Einen Ermessensspielraum hatte sie insoweit nicht. Ein Entschliesungsermessen stand ihr nicht $\mathrm{zu}$, weil sie an die Erlaubnisbescheide des Landrats, die ihre Pflicht zur schadlosen Abwasserbeseitigungs konkretisierten, gebunden war. Ebensowenig besa $\beta$ sie, was die zu ergreifenden Maßnahmen anbetraf, ein Auswahlermessen. Denn weitere Gewässerverunreinigungen ließen sich nur durch - notfalls zwangweise - Einwirkung auf die Grundstückseigentümer verhüten. ${ }^{593}$

Rijst de vraag of het BGH het discretionaire karakter van de bestuursdwangbevoegdheid niet miskent en derhalve op de stoel van het bestuur is gaan zitten door als strafrechter te bepalen wanneer en hoe er bestuursrechtelijk moet worden gehandhaafd. Het is inderdaad zo dat de gemeente - en daarmee ook de burgemeester - op grond van de door de Landrat vastgelegde vergunningsvoorwaarden geen beoordelingsruimte meer heeft met betrekking tot de vraag of de grondeigenaren al dan niet verplicht zijn zuiveringsinstallaties te bouwen: dit vloeit rechtstreeks voort uit de vergunningseis dat uitsluitend voorgezuiverd afvalwater mag worden geloosd. Maar betekent dit ook dat de gemeente geen beoordelingsruimte meer heeft met betrekking tot de te nemen handhavingsmaatregelen? Is ook op het niveau van de handhaving sprake van een 'Reduzierung des Eingriffsermessen auf Null? ? ${ }^{594}$ De overweging van het BGH dat 'weitere Gewässerverunreinigungen ließen sich nur durch notfalls zwangsweise - Einwirkung auf die Grundstückeigentümer verhüten' voldoet volgens sommige auteurs niet als verklaring waarom de burgemeester verplicht zou zijn geweest door middel van bestuursdwang en niet via andere middelen op de betrokkenen in te werken:

594. Jung, H., l.c., 1993, 347. 
De strafrechtelijke aansprakelijkheid van overheden

\begin{abstract}
'Aus dem Verwaltungsrechtliche Gebot, durch Einwirken auf die Bürger die Verunreinigungen zu verhindern, ergab sich noch kein zwingendes Gebot zur Vornahme von Ermittlungen'..$^{595}$
\end{abstract}

\title{
D. CONCLUSIE.
}

Naar Duits recht kunnen milieudelicten begaan door overheden in beginsel op tweeërlei wijze worden aangepakt. Allereerst is er de mogelijkheid overheden rechtsreeks te sanctioneren via de oplegging van de in het OWiG neergelegde Verbandsgeldbuße. Deze mogelijkheid wordt in de literatuur sterk bepleit, maar is in de praktijk eigenlijk niet bestaande. De voorkeur gaat duidelijk naar de vervolging van de individuele bestuursfunctionarissen. Via $\S 14 \mathrm{StGB}$ worden functionarissen vervolgd voor milieudelicten die binnen overheidskader zijn begaan. In de eerste plaats worden meestal burgemeesters veroordeeld voor de gepleegde milieudelicten. Daarnaast worden ook geregeld andere leidinggevende functionarissen vervolgd. De vervolging van gemeenteraadsleden is uiterst complex en moeilijk te plaatsen binnen de klassieke strafrechtsdogmatische causaliteitsregels. In de praktijk zijn dan ook geen gevallen bekend waarin gemeenteraadsleden voor milieuverstoring worden veroordeeld. Een cumulatieve vervolging van organen en ambtenaren komt evenmin voor.

$\S 14 \mathrm{StGB}$ is primair van belang bij de bestraffing van inbreuken op kwaliteitsdelicten. Maar ook bij gemene milieudelicten treedt het belang van deze bepaling sterk op de voorgrond wanneer deze delictsomschrijvingen worden overtreden via de schending van zorgplichten die zich specifiek tot de rechtspersoon richten.

Er kan worden vastgesteld dat de rechtspraak vrij soepel omgaat met de strafrechtelijke aansprakelijkheid van functionarissen. Allereerst wordt probleemloos aanvaard dat functionarissen strafrechtelijk aansprakelijk zijn in die gevallen waar het milieu rechtstreeks door overheden binnen de uitvoering van een overheidstaak wordt vervuild. In sommige uitspraken blijkt de enkele omstandigheid dat het delict werd gepleegd door een ambtenaar in de uitvoering van zijn overheidstaak zelfs een aanzienlijke invloed te hebben op de beantwoording van de schuldvraag. Er worden over het algemeen zeer hoge eisen gesteld aan het behoorlijk functioneren van ambtenaren die voor het leefmilieu een zekere verantwoordelijkheid en voorbeeldfunctie hebben. In de tweede plaats wordt moeiteloos aangenomen dat ambtenaren ook strafrechtelijk aansprakelijk kunnen worden gesteld voor milieuverontreiniging die het resultaat is van nalatigheid, meer bepaald de schending van een bepaalde zorgplicht. De toepasselijke zorgplichten zijn aan te merken als Sicherungspflichten en berusten op de gedachte dat de ambtenaar als Überwachungsgarant een bijzondere plicht heeft de milieuhinderlijke inrichtingen en activiteiten die onder zijn bevoegdheid vallen te bewaken. De inhoud van deze zorgplichten wordt ruim ingevuld. Bovendien blijkt vrij makkelijk te worden omgegaan met de rechtsgrond waarin de zorgplicht zijn oorsprong hoort te vinden. Ook hier zijn de eisen gesteld aan de ambtenaar vrij groot. Zo wordt onder meer geëist dat in situaties waar ambtenaren zelf geen formele

595. Nestler, C., l.c., 1994, 518. 
bevoegdheden hebben om aan een illegale milieuverstoring een halt toe te roepen, zij alsnog de plicht hebben in te werken op die instanties die wel over de noodzakelijke bevoegdheden, kennis en middelen beschikken om de milieuverstoring tegen te gaan of te verminderen.

Ook in situaties waar de milieuverstoring het gevolg is van een noodsituatie is de rechtspraak streng. Het bijna waterdichte bestuursrechtelijke vergunningensysteem enerzijds en de verplichting om waar nodig alternatieve financiële bronnen aan te boren anderzijds, maken het vrijwel onmogelijk dat overheden zich met succes kunnen beroepen op financiële noodtoestand. In gevallen waar de noodsituatie voortvloeit uit een conflict tussen waterrechtelijke plichten enerzijds en strafrechtelijke normen anderzijds wordt pas na een zorgvuldige en strenge toetsing een strafuitsluitende noodtoestand aanvaard.

Inmiddels is erkend dat de strafrechtelijke aansprakelijkheid van ambtenaren ook bestaat wanneer zij niet optreden tegen milieuverontreiniging veroorzaakt door derden. Meer zelfs, dergelijk niet-handelen kan worden gezien als een schending van een op de overheid rustende 'Betriebspflicht' en moet dus worden aangemerkt als een bijzondere variant van het klassieke geval waarin een overheid zelf rechtstreeks het leefmilieu vervuilt. Deze uitbreiding van de klassieke Amtsträgerstrafbarkeit werd uitdrukkelijk bevestigd door het Bundesgerichtshof.

Dit schijnbare succes van de individuele strafrechtelijke afdoening van door overheden begane milieudelicten, moet volgens mij niet worden overschat. Zo rijst de vraag of dergelijke aanpak wel in staat is om voldoende prikkels te geven voor de overheid om de mogelijke milieuschadelijke effecten van haar handelen te verminderen, dan wel geheel te voorkomen. Ook rijst de vraag of met deze aanpak ook niet de rechtsbescherming te veel wordt uitgehold.

Allereerst kan worden opgemerkt dat het groot aantal veroordelingen veeleer het gevolg is van een praktische noodzaak dan van een welbewuste crimineel-politieke keuze of een afgewogen beleid. Er werd vastgesteld dat het enige alternatief, de oplegging van de Verbandsgeldbuße aan de overheid zelf, praktisch geen toepassing vindt omdat dit onverzoenbaar zou zijn met de ratio van deze sanctie. Dit uitgangspunt verplicht het openbaar ministerie en de strafrechter de aandacht te richten op de individuele verantwoordelijke ambtenaar. In gevallen waar de ontstaansgeschiedenis van het gepleegde delict duidelijk kan worden teruggevoerd tot de gedragingen en de verantwoordelijkheden van een of meerdere aanwijsbare naturlijke personen, kan de individuele strafrechtelijke aansprakelijkheid wellicht een afdoende afschrikkend effect hebben. Uit de meeste besproken uitspraken kan echter worden afgeleid dat de milieudelicten waarvoor de ambtenaren werden veroordeeld veeleer, of op zijn minst evenzeer, hun oorsprong vinden in collectieve tekortkomingen en nalatigheden. Illustratief hiervoor zijn de uitspraken van het AG Cochem en het OLG Köln waar duidelijk andere ambtenaren of organen (bijvoorbeeld de gemeenteraad) zoniet de organisatie als geheel hebben gefaald en in die zin een belangrijk aandeel hebben in de milieuverstoring. De uiteindelijk veroordeelde ambtenaren hebben veelal de kans gekregen de milieuwet te overtreden omdat bij het 
overheidslichaam zelf alle voorwaarden aanwezig waren die het delict mogelijk maakten, zoals gebrekkige organisatie en controle (OLG Köln), onoirbare partijpolitieke motivaties (AG Cochem) en gebrekkige financiën (OLG Köln en OLG Saarbrücken). Het is dan licht te begrijpen dat daar waar aan het individuele falen van de betrokken ambtenaar een gedeelde of collectieve verantwoordelijkheid ten grondslag ligt, een loutere bestraffing van deze ambtenaar niet volstaat en eigenlijk fundamenteel onrechtvaardig is. Het getuigt bovendien niet van een efficiënte en effectieve strafrechtelijke handhaving wanneer een collectieve verantwoordelijkheid wordt gereduceerd tot de aansprakelijkheid van een of meerdere individuen.

Het probleem of het overheidslichaam zelf dan wel de individuele ambtenaar moet worden gesanctioneerd speelt niet alleen in termen van verwijtbaarheid en schuld, maar tevens op het vlak van de effectiviteit van de uiteindelijk opgelegde sanctie. Wat de geldboete betreft, maakt het in beginsel geen verschil wie van beide de monetaire sanctie krijgt opgelegd, zolang deze maar hoog genoeg is en vrij overdraagbaar. Ofwel verhaalt het overheidslichaam de aan haar opgelegde boete op de verantwoordelijke ambtenaar, ofwel vraagt de ambtenaar vergoeding aan de overheidsinstantie van de door hem betaalde boete. ${ }^{596}$ Echter, deze economische redenering gaat slechts op wanneer ook de aan de ambtenaar opgelegde boete overeenstemt met de ernst van en de schade veroorzaakt door het gepleegde feit. Dat is niet het geval. De aan ambtenaren opgelegde boetes zijn bijzonder laag omdat zij conform $\S 40 \mathrm{StGB}$ worden afgestemd op de financiële draagkracht van de betrokkene. ${ }^{597}$

'Die Finanzkraft des vertretenen Unternehmens (of overheidslichaam, DR) oder die Höhe des angerichteten Schadens sind für den Berechnungsvorgang unerheblich, der die Summe der zu zahlenden Geldstrafe endgültig festlegt (...) Vor diesem Hintergrund müssen die von Organen und Vertretern zu zahlenden Geldsummen in der öffentlichkeit lächerlich wirken. ${ }^{598}$

Het spreekt voor zich dat van een aan de bestuursfunctionarissen opgelegde boete, die geen optimale vermogenssanctie uitmaakt en die daarnaast nog verhaalbaar is op de overheid nauwelijks enige afschrikkende werking kan uitgaan.

596. Faure, M., Oudijk, H. en Koopmans, l.c., 1992, 20.

597. In $\$ 40 \mathrm{StGB}$ is een zogeheten 'Tagessatz'- systeem neergelegd. De geldstraf wordt berekend aan de hand van een boetetarief van minimum 5 en maximum 360 volle 'Tagessătze'. Eén 'Tagessatz' bedraagt minimum 2 en maximum 10.000 DM. Dit betekent dat de uiteindelijke geldstraf minimum $10 \mathrm{DM}(5 \times 2 \mathrm{DM})$ en maximum $3600000 \mathrm{DM}(360 \times 10.000 \mathrm{DM})$ kan bedragen. Belangrijk is echter het tweede lid van $\S 40$ StGB dat stelt: 'Die Höhe eines Tagessatzes bestimmt das Gericht unter Berücksichtigung der persönlichen und wirtschaftlichen Verhältnisse des Tăters. Dabei geht es in der Regel von dem Nettoeinkommen aus, das der Tăter durchschnittlich an einem Tag hat oder haben könnte.' In de praktijk krijgen ambtenaren lage geldboetes opgelegd. Zo bedroeg de boete opgelegd in de uitspraak van het OLG Stuttgart 2400 DM. Zie OLG Stuttgart, 2 december 1988, NStZ 1989, 123.

598. Marxen, K., l.c., 1988, 289. 
De tekortkomingen van de individuele aanpak komen des te sterker naar voren wanneer blijkt dat de betrokken ambtenaren zelden een gevangenisstraf krijgen opgelegd. Het gegeven, dat enerzijds ambtenaren uitsluitend lage monetaire sancties krijgen opgelegd en dat anderzijds van de mogelijkheid om via het $\mathrm{OWiG}$ aan de overheid hoge geldboetes op te leggen geen gebruik wordt gemaakt, dwingt tot de conclusie dat de huidige strafrechtelijke aanpak instrumenteel gezien geen ideale oplossing kan zijn.

Niet alleen instrumenteel gezien is het een en ander op het Duitse systeem aan te merken. Ook vanuit het oogpunt van de rechtsbescherming kan uit het Duitse recht een belangrijke les worden getrokken. $\mathrm{Nu}$ de aandacht uitsluitend uitgaat naar de aansprakelijkheid van individuele ambtenaren, ook in die gevallen waar eerder sprake is van een collectieve (mede)schuld, is het gevaar aanwezig dat rechtsbeschermende garanties worden uitgehold. Illustratief hiervoor is de wijze waarop de rechtspraak omgaat met de vaststelling van de rechtsgrond van de zorgplichten en de daarmee samenhangende causaliteitsvraag. Aan de rechtsgrond van de zorgplichten wordt niet altijd even strenge eisen gesteld. ${ }^{599}$ Men krijgt de indruk dat soms naar een sociaal wenselijk uitkomst toe wordt geredeneerd. Dit lijkt me een gevaarlijke evolutie. Een rechtsgrond moet immers niet alleen legitimeren, maar tegelijk ook limiteren. In de Duitse jurisprudentie blijkt echter van de rechtsgrond nauwelijks nog een begrenzende werking uit te gaan, vooral wanneer kan worden vastgesteld dat in bepaalde gevallen zorgplichten de ambtenaar ook verplichten in te grijpen tegen inbreuken gepleegd door derden. Dergelijke evolutie loopt dan het risico uit te monden in een bijna oeverloze aansprakelijkheid. Dit doet opnieuw de vraag rijzen of dergelijke grenzeloze strafbaarheid ook instrumenteel gezien nog wel enige waarde heeft. Rudolphi wijst in zijn noot op een omstreden uitspraak van het BGH, waarin ook uiterst soepel met de zorgplicht van een ambtenaar werd omgegaan, terecht op het volgende gevaar:

'Der Staat würde mit seinen Organen und Amtsträgern zum allumfassende Garanten avancieren und trüge damit auch in der Person seiner jeweils zuständigen Organe und Amtsträger die strafrechtliche Verantwortung dafür, daß die Rechtsgüter der Bürger nicht durch Straftaten Dritter oder auf andere Weise beeinträchtigt werden. Dies führt (...) zu einer nicht mehr akzeptabelen Verteilung der Verantwortlichkeiten zwischen Staat und Bürger. ${ }^{1600}$

599. Dit is trouwens een tendens die in gans het ondernemingsstrafrecht kan worden waargenomen. Heine merkt hierover op: 'Die Gerichte stellen zunăchst eher ratlos fest, daß in der modernen Industriegesellschaft für den einzelnen jedenfalls neue Sorgfaltspflichten entstanden seien wenngleich Art und Umfang weinig geklärt waren.' Heine, G., 'Vom individueller zu kollektiver Verantwortlichkeit. Einige Grundfragen der aktuellen Kriminalpolitik', in Arnold, J., Burkhardt, B., Gropp, W. en Koch, H.G., (Hrsg.), Grenzüberschreitungen, 1996, 56.

600. Rudolphi, H.J., 'Anmerkung zum BGH 15 juli 1986', JR, 1987, 336. In deze zaak werd een 'Leiter des Ordnungsamtes der Stadt P.' wegens medeplichtigheid aan de uitbating van een bordeel veroordeeld omdat hij had nagelaten bestuursrechtelijke dwangmaatregelen te nemen (intrekking van de exploitatievergunning) tegen de uitbater van een seksclub. 
Kortom, in het Duitse milieustrafrecht wordt getracht de afwezigheid van de strafrechtelijke aansprakelijkheid van de (publiekrechtelijke) rechtspersoon én de weigering gebruik te maken van de meer collectieve aanpak via $\S 30 \mathrm{OWiG}$, te compenseren door een stelselmatige uitbreiding van de individuele 'Amtsträgerstrafbarkeit'. Of een dergelijke aanpak zowel instrumenteel gezien als vanuit het perspectief van de rechtsbescherming navolging verdient, valt evenwel te betwijfelen.

\section{§6. Rechtsvergelijkende conclusies}

Rechtsvergelijkend kan worden vastgesteld dat zowel Frankrijk als Nederland het vraagstuk van de strafrechtelijke aansprakelijkheid van publiekrechtelijke rechtspersonen inhoudelijk op min of meer gelijke wijze hebben aangepakt. Beide stelsels hebben gekozen voor een drievoudige oplossing. In de eerste plaats geldt voor de staat een absolute immuniteit. In de tweede plaats is er voor de lagere overheden een gedeeltelijke immuniteit die slechts bestaat wanneer de overheid in kwestie een misdrijf pleegt bij de uitoefening van een typische onvervreemdbare overheidstaak. Daarvan is sprake indien het gaat om gedragingen die uitsluitend door bestuursfunctionarissen kunnen worden verricht (Nederland) of gedragingen die niet aan private (rechts)personen kunnen worden gedelegeerd (Frankrijk) hetgeen feitelijk min of meer op hetzelfde uitgangspunt neerkomt. Tenslotte blijven andere publiekrechtelijke rechtspersonen, zoals openbare instellingen, in beginsel strafrechtelijk aansprakelijk. Naast deze opmerkelijke gelijkenissen is er echter een aantal verschillen. Allereerst wordt naar Frans recht in tegenstelling tot in Nederland niet de vervolgbaarheid van bepaalde publiekrechtelijke rechtspersonen uitgesloten, maar de strafrechtelijke aansprakelijkheid. Een ander niet onbelangrijk verschil bestaat hierin dat Frankrijk heeft geopteerd voor een wettelijke regeling, terwijl naar Nederlands recht werd gekozen voor een buitenwettelijke oplossing. Indien men al voorstander zou zijn van een (gedeeltelijke) straffeloosheid van overheden dan verdient een wettelijke regeling de voorkeur. Het lijkt allesbehalve wenselijk en verstandig dergelijke vooral ook politiek gevoelige kwesties die de kern van de rechtsstaat en het strafrecht raken in de eerste plaats aan de rechtspraak over te laten. In Nederland is dan ook terecht vaak kritiek geuit op het buitenwettelijk karakter van de overheidsimmuniteit.

In België stellen we vast dat sinds de Wet van 4 mei 1999 overheden niet strafrechtelijk verantwoordelijk kunnen worden gesteld voor de door hen gepleegde delicten. Het nieuwe artikel 5 van het Belgische strafwetboek sluit evenals Frankrijk de centrale overheid en decentrale overheden uit van strafrechtelijke aansprakelijkheid, maar in tegenstelling tot de Franse en ook de Nederlandse situatie wordt niet gedifferentieerd in typen overheden, noch in soorten overheidsgedragingen. Er is dus geen onderscheid gemaakt in de hoedanigheid waarin de overheid optreedt, hetgeen een discriminatie doet ontstaan met particuliere bedrijven. Dat zal vooral parten spelen in situaties waarin overheden met bedrijven samenwerken en binnen dat kader een strafbaar feit wordt gepleegd. De overheid zal straffeloos blijven terwijl het bedrijf (of de bedrijfsleiders) een straf riskeren. Voor de strafrechtspraktijk betekent dit dat in het geval van een door een overheid gepleegd milieudelict, nog steeds moet worden gezocht naar een natuurlijke persoon binnen de overheidsorganisatie waaraan het delict kan worden toegerekend. Aan de hand van een 
analyse van de rechtspraak werd vastgesteld dat zo'n individualistische benadering zeer ingewikkeld is en in de meeste gevallen geen recht doet aan de collectieve of organisatorische verwijtbaarheid die aan het delict ten grondslag ligt. Juist vanwege deze nadelen is in België de strafbaarheid van de rechtspersoon ingevoerd. Door het uitsluiten van overheden van deze strafbaarheid blijven voor de bestrijding van overheidscriminaliteit deze nadelen bestaan. Bovendien ontstaat zo het gevaar dat de strafrechtelijke aansprakelijkheid deresponsabiliserend werkt omdat veelal de ambtenaren op de 'werkvloer' dreigen te worden aangepakt.

Dat een individualistische aanpak inderdaad niet altijd even ideaal is, bleek ook duidelijk bij de bespreking van het Duitse stelsel. In Duitsland wordt getracht de afwezigheid van de strafrechtelijke aansprakelijkheid van de (publiekrechtelijke) rechtspersoon én de weigering gebruik te maken van de meer collectieve aanpak via $\S 30 \mathrm{OWiG}$, te compenseren door een stelselmatige uitbreiding van de individuele 'Amtsträgerstrafbarkeit'. Er wordt voornamelijk gebruik gemaakt van zorgplichten waarvan de rechtsbeschermende draagkracht kan worden betwijfeld. Het hoeft dan ook niet te verbazen dat deze aanpak in de literatuur wordt bekritiseerd.

Uit de Duitse en Belgische situatie blijkt duidelijk wat de moeilijkheden zijn bij afwezigheid van een strafbaarstelling van overheden. Er moet dan noodgedwongen worden gezocht naar verantwoordelijke natuurlijke personen binnen de overheidsorganisatie hetgeen zowel inefficiënt is als vanuit de optiek van de rechtsbescherming van de individuele verdachten onrechtvaardig.

Een ander opmerkelijk gegeven betreft de strafrechtelijke positie van leidinggevende ambtenaren. In Nederland genieten leidinggevende ambtenaren een zelfde immuniteit als de overheden waartoe zij behoren. Wel kunnen (ook leidinggevende) ambtenaren nog steeds uit hoofde van eigen daderschap worden vervolgd, maar dit zal in de praktijk nauwelijks voorkomen al was het maar omdat talrijke normen zich uitsluitend richten tot de rechtspersoon. In Frankrijk blijft de aansprakelijkheid van iedere natuurlijke persoon, dus ook van de leidinggevende functionaris, bestaan nu die aansprakelijkheid rechtstreeks voortvloeit uit het eigen daderschap en niet afhangt van de strafbaarheid van de rechtspersoon. Hoewel het dogmatische uitgangspunt verschillend is, hebben in de praktijk beide landen min of meer hetzelfde stelsel: leidinggevende ambtenaren zijn vervolgbaar voor zover zij zelf het strafbare feit hebben gepleegd. In dit verband is ook de Belgische situatie zeer markant. Omdat in België de strafrechtelijke aansprakelijkheid van overheden ontbreekt, is de rechtspraak wel genoodzaakt het strafbare feit toe te rekenen aan de verantwoordelijke ambtenaren. Dit kunnen in de praktijk zowel leidinggevende als ondergeschikte (uitvoerende) ambtenaren zijn. Het is dan aardig om vast te stellen dat in België, ondanks het ontbreken van de strafrechtelijke aansprakelijkheid van overheden, het in beginsel steeds mogelijk blijft leidinggevende ambtenaren, zelfs ambtsdragers zoals burgemeesters, strafrechtelijk aan te pakken voor daden van de rechtspersoon. Met betrekking tot de toerekening aan deze 'leidinggevenden' wordt trouwens geen onderscheid gemaakt naargelang de categorie van de publiekrechtelijk rechtspersoon waarbinnen de ambtenaar functioneert of de aard van de activiteit die door deze rechtspersoon werd 
verricht. Opmerkelijk is ook dat in België de uitsluiting van gemeenten en provincies van de werking van het strafrecht, wordt gecompenseerd door een civielrechtelijke aansprakelijkheid van deze overheden voor de strafrechtelijk geldboete die aan burgemeester, schepenen en leden van de bestendige deputatie wordt opgelegd in gevallen waar het strafbaar feit is gepleegd bij de normale uitoefening van hun ambt. 


\section{De immuniteitscriteria}

\section{$\S 1$. Inleiding}

Ondanks de uitvoerige motivering van het Tweede Pikmeer-arrest blijft een aantal zaken tot op heden onopgehelderd. In het bijzonder moet worden onderzocht wat nu precies de ratio is van de thans bestaande immuniteitscriteria en welke theoretische alsook praktische problemen daarmee zijn verbonden. In dit hoofdstuk wordt eerst het buitenwettelijke karakter van de vervolgingsuitsluitingsgronden voor overheden besproken in het licht van de reeds bestaande klassieke wettelijke vervolgingsuitsluitingsgronden voor bepaalde overheidsfunctionarissen ( $(2)$. Vervolgens wordt nader stilgestaan bij de betekenis van het subjectcriterium ( $(3)$ en het taakcriterium ( $(4)$. Ik eindig met een pleidooi voor een materieelrechtelijke oplossing van de problematiek op het niveau van de rechtvaardigingsgronden (§ 5).

\section{$\S 2$. Het buitenwettelijke karakter van de vervolgingsuitsluitingsgrond}

De strafrechtelijke immuniteit voor overheden, zoals die door de Hoge Raad wordt geformuleerd, is niet in de wet geregeld. Het is het resultaat van een zuiver jurisprudentiële ontwikkeling. Er kan slechts met moeite een basis voor deze immuniteiten worden gevonden in de MvT bij artikel $51 \mathrm{Sr}$. Dat geldt in het bijzonder voor het subjectcriterium en voor de absolute immuniteit van de staat. Het subjectcriterium en de staatsimmuniteit kunnen nauwelijks worden teruggevoerd tot de bedoelingen van de wetgever. We kunnen dus stellen dat de rechtspraak twee buitenwettelijke vervolgingsuitsluitingsgronden heeft ontwikkeld: een beperkte immuniteit voor openbare lichamen en een onbeperkte immuniteit voor de centrale overheid. Dit buitenwettelijke karakter van de immuniteiten staat op gespannen voet met een aantal strafvorderlijke en rechtsstatelijke uitgangspunten.

De vervolging van strafbare feiten is de uitsluitende bevoegdheid van het openbaar ministerie. ${ }^{601}$ Vervolging is mitsdien een overheidstaak, die door de wet aan het openbaar ministerie is geattribueerd. Enige beperking op deze monopoliesituatie kan dus in beginsel 
alleen langs wettelijke weg tot stand komen. Dat was althans de bedoeling bij de totstandkoming van het huidige wetboek van strafvordering. ${ }^{602}$ Met andere woorden, de vraag naar uitzonderingen op het vervolgingsrecht van het openbaar ministerie moet in beginsel worden beantwoord op basis van de wet hetgeen impliceert dat ook vervolgingsuitsluitingsgronden principieel een wettelijke basis moeten hebben. Kijken we naar de klassieke beperkingen en uitzonderingen op de vervolging dan blijkt inderdaad steeds sprake te zijn van een wettelijk basis.

Zo heeft de wetgever allereerst een aantal vervolgingsbeperkingen, zoals de artikelen 2-8, art. $68 \mathrm{Sr}$ e.v. en art. $255 \mathrm{~Sv}$ en een aantal bijzondere vervolgingsuitsluitingsgronden, zoals de artikelen 53 en 54, art. 77a en de artikelen 316, 319, 324, 338, 353 Sr., in het leven geroepen. Daarnaast heeft de wetgever nog een aparte groep staatsrechtelijke vervolgingsuitsluitingsgronden gecreëerd. Deze laatste groep van vervolgingsuitsluitingsgronden wordt zelfs van zodanig primordiaal belang beschouwd dat ze in de Grondwet is opgenomen. De (Grond)wetgever heeft daarbij bewust gekozen voor een tweeledig stelsel.

Enerzijds heeft hij bepaald dat ten aanzien van bepaalde personen de strafvordering niet kan worden uitgeoefend. Het betreft hier personen die het stelsel van de immuniteiten genieten. ${ }^{603}$ Anderzijds heeft de (grond)wetgever een systeem, verwant doch niet identiek aan de immuniteiten, gecreëerd voor bepaalde groepen van personen die, vanwege hun functie, aan bijzondere procedureregels worden onderworpen. ${ }^{604}$

De eerste groep vervolgingsuitsluitingsgronden, de 'echte' immuniteiten, is uitsluitend van toepassing op de Koning (artikel 42 lid $2 \mathrm{Gw}$ ), de volksvertegenwoordigers (artikel 71 $\mathrm{Gw})^{605}$ en analoog aan artikel $71 \mathrm{Gw}$ tevens op de leden van de gedeputeerde staten (artikel 22 en artikel 57 Provinciewet), de leden van het college van burgemeester en wethouders (artikel 22 en artikel 57 Gemeentewet) en de staatsraden (artikel 122 Wet op de Raad van State). Ten aanzien van hen heeft het openbaar ministerie geen vervolgingsbevoegdheid.

Tot de groep personen die onderworpen is aan speciale procedureregels behoren in het bijzonder ministers en staatssecretarissen (artikelen 42, 46 en $119 \mathrm{Gw}$ ) voor wat betreft de door hen gepleegde ambtsmisdrijven (artikel 355 e.v. Sr). Als vervolgingsinstantie is door de Wet Ministeriële Verantwoordelijkheid (WMV) niet het openbaar ministerie maar de

602. Krabbe, H.G.M., 'De ontvankelijkheid van het $\mathrm{OM}$ en de beginselen van een goede procesorde', in Knigge, G. (red.), o.c., 67.

603. Deze personen vallen weliswaar onder de toepassing van de strafwet, maar de strafvervolging kan niet tegen hen worden ingesteld.

604. Deze personen zijn dus niet 'immuun' tegen strafvervolgingen. Zij worden enkel, omwille van hun bijzondere status, aan een andere procedure onderworpen.

605. Leden der volksvertegenwoordiging genieten een beperkte immuniteit. Zij zijn niet vervolgbaar voor hetgeen zij in de vergadering hebben gezegd of schriftelijk aan haar hebben overgelegd. Artikel $71 \mathrm{GW}$ geldt tevens voor de in de Kamer optredende ministers, staatssecretarissen en andere personen die deelnemen aan de beraadslaging. Volledigheidshalve kunnen ook nog de leden van de Sociaal Economische Raad worden vermeld (artikel 21 Wet op de Bedrijfsorganisatie) en de leden van het algemeen bestuur van de Waterschappen (artikel 39 Waterschapswet). Zie Remmelink, J., o.c., 1995, 577 e.v. 
Kroon en de Tweede Kamer aangeduid (artikel 4); de Procureur-Generaal bij de Hoge Raad oefent de vervolging immers enkel op last van deze instanties uit (artikel 483 lid 3 Sv). De Hoge Raad vervult hierbij als 'forum privilegiatum' de rol van strafrechter (artikel $92 \mathrm{RO}$, artikelen 483-485 Sv en artikel $4 \mathrm{WMV}$ ).

Dit tweeledig stelsel toont duidelijk aan dat enkel op basis van de (grond)wet ten aanzien van bepaalde personen, die expliciet zijn aangeduid, de strafvervolging niet of slechts op een door de wet bepaalde wijze kan worden uitgeoefend. ${ }^{606}$ Met dit stelsel strookt nauwelijks het creëren van strafrechtelijke immuniteiten anders dan door de (Grond)wet.

Nu zou daartegen kunnen worden ingebracht dat de wet niet de enige schepper is van rechtsgronden van niet-ontvankelijkheid van het $\mathrm{OM}$. Er kan immers worden gewezen op de in de rechtspraak ontwikkelde beginselen van een goede procesorde. Deze beginselen kunnen in zekere zin ook als buitenwettelijke vervolgingsuitsluitingsgronden worden beschouwd. Waarom zouden de door de Hoge Raad voor overheden ontwikkelde buitenwettelijke vervolgingsuitsluitingsgronden dan niet passen binnen ons strafrechtelijk systeem?

Allereerst moet worden opgemerkt dat de Hoge Raad wel uiterst voorzichtig is te werk gegaan met de erkenning van de beginselen van een goede procesorde ${ }^{607}$ Immers, het oordeel over de vervolging kan niet zomaar, zonder enige legitimatie in de wet, aan de rechter worden overgelaten. ${ }^{608}$ Dit verklaart dan ook dat deze beginselen niet toelaten dat de strafrechter de vervolgingsbeslissing 'overdoet' en daarmee geheel op de stoel van het OM gaat zitten. ${ }^{609}$ Bovendien kan worden verdedigd dat de beginselen van een goede proces-orde als mogelijke gronden van niet-ontvankelijkheid wel van een fundamenteel ander karakter zijn dan vervolgingsuitsluitingsgronden. Deze laatste categorie duidt de uitzonde-ringen aan op de regel, dat wie volgens de wet strafbare feiten kan plegen ook door het OM moet kunnen worden vervolgd. De (grondwettelijke) status van bepaalde daders staat hier zo centraal dat aan het $\mathrm{OM}$ a priori zijn vervolgingsbevoegdheid wordt ontnomen of beperkt. De beginselen van een goede procesorde daarentegen zijn gerelateerd aan het opportuniteitsbeginsel en zijn bedoeld om de zorgvuldigheid van de vervolging(sbeslissing) te kunnen toetsen. De wijze van vervolgen of strafprocessueel handelen staat hier centraal. Hier heeft het $\mathrm{OM}$ a priori wel een vervolgingsbevoegdheid, anders zou de uitoefening ervan niet aan de beginselen kunnen worden getoetst. Kortom, geen enkel beginsel van een goede procesorde spreekt zich op algemene wijze uit over wie niet en wie wel kan worden vervolgd. Vervolgingsuitsluitingsgronden en met name de 'echte' immuniteiten doen dat juist wel. Mijn stelling is dan ook dat wie niet en wie wel mag worden vervolgd geen vraag is die in zijn algemeenheid door de rechter

606. Deze immuniteiten zijn niet alleen limitatief opgesomd, maar tevens restrictief in hun interpretatie. Zo kan bijvoorbeeld uit de immuniteit van de kroondrager niet de immuniteit van andere leden van het koningshuis worden afgeleid. Remmelink, J., o.c., 1995, 577.

607. Zie Krabbe, H.G.M., 'De ontvankelijkheid van het $\mathrm{OM}$ en de beginselen van een goede procesorde', in Knigge, G. (red.), o.c., 68.

608. Corstens, G.J.M., o.c., 1999, 59 e.v.

609. Idem, 72. 
buitenwettelijk mag en kan worden beantwoord. Enkel de wet behoort in ons zorgvuldig uitgebalanceerd immuniteitensysteem hierover uitsluitsel te geven. Door het creëren van een nieuwe buitenwettelijke vervolgings-uitsluitingsgrond is de Hoge Raad niet alleen op de stoel van het OM, maar tevens in de zetel van de (grond)wetgever gaan zitten.

Niet alleen het buitenwettelijke karakter van de voor overheden bestaande vervolgingsuitsluitingsgronden is problematisch. Ook de reikwijdte van deze vervolgingsuitsluitingsgronden doet in het licht van de klassieke immuniteiten de nodige vragen rijzen. Het aantal wettelijke vervolgingsuitsluitingsgronden, die in geen enkel geval, op geen enkele wijze strafvervolging om rechtsstatelijke of overheidspolitieke redenen mogelijk maken, is uiterst klein en daarenboven secuur geregeld. De meeste immuniteiten zijn daarbij ook nog beperkt in hun werking. ${ }^{610} \mathrm{De}$ (grond)wetgever heeft bovendien de voorkeur gegeven aan een systeem dat voor bepaalde categorieën van personen, vanwege hun overheidsfunctie, bijzondere procedureregels creëert dan aan een stelsel dat de vervolging en dus ook de strafbaarheid voor die personen gewoonweg uitsluit. ${ }^{611}$ Met andere woorden, niet alleen heeft de Hoge Raad met betrekking tot overheden buitenwettelijke vervolgingsuitsluitingsgronden gecreëerd, deze vervolgingsuitsluitingsgronden gaan ook nog veel verder dan de reeds bestaande wettelijke vervolgingsuitsluitingsgronden waarop functionarissen die deel uitmaken van deze overheden beroep kunnen doen. Het is dan moeilijk te begrijpen waarom overheden makkelijker en in een groter aantal gevallen strafrechtelijke immuniteit zouden moeten genieten dan de functionarissen die tot deze overheden behoren. Zo is onbegrijpelijk dat een minister zelfs geen echte immuniteit geniet, maar uitsluitend omwille van zijn overheidsfunctie aan een bijzondere strafrechtelijke procedure kan worden onderworpen (artikel 42, 46 en $119 \mathrm{Gw}$ ), terwijl de staat waartoe hij als orgaan behoort in geen geval kan worden vervolgd. Evenzeer is moeilijk vol te houden dat een gemeente zich kan beroepen op strafrechtelijke immuniteit wanneer het strafbaar feit is gepleegd bij de uitvoering van een exclusieve bestuurstaak, terwijl bijvoorbeeld de leden van het college van burgemeester en wethouders slechts immuniteit genieten voor hetgeen zij in de vergadering hebben gezegd of schriftelijk hebben overgelegd (artikel 22 en artikel 57 Gemeentewet).

\section{§3. Het subjectcriterium}

\section{A. INLEIDING}

Met het Rijksuniversiteit Groningen-arrest heeft de Hoge Raad de strafrechtelijke immuniteit beperkt tot openbare lichamen in de zin van hoofdstuk $7 \mathrm{Gw}$. Een begrenzing die niet terug te vinden is in de MvT bij artikel $51 \mathrm{Sr}$ en die evenmin door de Hoge Raad wordt gemotiveerd. Van Veen merkt in zijn noot op dit arrest daarover het volgende op:

610. Zie o.a. artikel $71 \mathrm{GW}$ dat aan de leden der volksvertegenwoordiging een beperkte immuniteit toebedeelt.

611. Zie nogmaals de Wet op de ministeriële verantwoordelijkheid. 
'Met deze belangrijke uitspraak beperkt de HR dus de mogelijkheid van niet vervolgbaarheid van publiekrechtelijke rechtspersonen tot de in hoofdstuk 7 van de Grondwet opgenomen openbare lichamen. De reden voor deze enge begrenzing lijkt mij ingegeven in de conclusie van de AG. Uitzonderingen op de algemene strafbaarstelling van de rechtspersoon in art. $51 \mathrm{Sr}$ dienen zo beperkt mogelijk te blijven om aan de strekking van die bepaling te voldoen. ${ }^{612}$

Dit is een vrij pragmatische uitleg waarbij de keuze voor het criterium uitsluitend lijkt te zijn ingegeven door de simpele redenering: hoe minder uitzonderingen hoe beter. ${ }^{613}$ Ook na Pikmeer II blijft de Hoge Raad zonder enige nadere toelichting uitgaan van de beperking van de immuniteit tot openbare lichamen. In deze paragraaf wordt gezocht naar de mogelijke ratio van dit subjectcriterium. Twee vragen staan hierbij centraal:

a. Wat is te verstaan onder openbare lichamen in de zin van hoofdstuk 7 Grondwet en hoe verhouden deze zich tot andere publiekrechtelijke rechtspersonen (A)?

b. Levert deze differentiatie een bruikbaar criterium op voor de strafrechtelijke immuniteit (B)?

\section{B. PUBLIEKRECHTELIJKE RECHTSPERSONEN EN OPENBARE LICHAMEN}

\section{Privaatrechtelijke, publiekrechtelijke en 'strafrechtelijke' rechtspersonen}

Met de wijziging van artikel $51 \mathrm{Sr}$ in 1976 werd de rechtspersoon in het strafrecht een volwaardig rechtssubject: strafbare feiten kunnen worden begaan door natuurlijke personen en rechtspersonen. Om te bepalen wat in de zin van artikel $51 \mathrm{Sr}$ onder rechtspersoon moet worden verstaan, moet in de eerste plaats aansluiting bij het civiele recht worden gevonden. In de eerste drie artikelen van Boek $2 \mathrm{BW}$ heeft de wetgever aangegeven welke rechtspersonen er bestaan. Er worden drie categorieën genoemd: publiekrechtelijke rechtspersonen, kerkgenootschappen en privaatrechtelijke rechtspersonen. Met betrekking tot publiekrechtelijke rechtspersonen bepalen de eerste twee leden van artikel 2:1 BW het volgende:

'1. De staat, de provincies, de gemeenten, de waterschappen, alsmede alle lichamen waaraan krachtens de Grondwet verordenende bevoegdheid is verleend, bezitten rechtspersoonlijkheid.

2. Andere lichamen, waaraan een deel van de overheidstaak is opgedragen bezitten slechts rechtspersoonlijkheid, indien dit uit het bij of krachtens de wet bepaalde volgt.'

612. Van Veen, Th. in zijn noot onder HR 10 november 1987, NJ 1988, 303.

613. Vgl. Peters, J.A.F., Publiekrechtelijke rechtspersonen, Deventer, W.E.J., Tjeenk Willink, 1997, 165 . 
Het begrip 'publiekrechtelijke rechtspersoon' kan verwarring scheppen omdat daaruit zou kunnen worden afgeleid dat er zoiets bestaat als rechtspersoonlijkheid naar publiekrecht onderscheiden van rechtspersoonlijkheid naar privaatrecht. Er bestaat slechts rechtsperoonlijkheid in de zin van privaatrechtelijke rechtssubjectiviteit. Publiekrechtelijke rechtspersonen en privaatrechtelijke rechtspersonen genieten een zelfde privaatrechtelijke rechtssubjectiviteit: het zijn beide zelfstandige subjecten in het privaatrecht. De toevoeging publiekrechtelijk of privaatrechtelijk voegt niets toe aan de rechtspersoonlijkheid. Wat deze rechtspersonen van elkaar onderscheidt is de inrichting van de organisatie waaraan rechtspersoonlijkheid is toegekend. ${ }^{614}$ De organisatorische inrichting van de publiekrechtelijke rechtspersoon wordt beheerst door regels van het publiekrecht, die van privaatrechtelijke rechtspersonen door privaatrechtelijke regels. ${ }^{615}$ Het is dan ook enigszins verwarrend dat hier en daar het begrip 'rechtspersoonlijkheid naar publiekrecht' wordt gebruikt. Het publiekrecht kent eigenlijk geen eigen type rechtspersoonlijkheid. ${ }^{616}$ Dat is ook niet nodig omdat de rechtspersoonlijkheid ertoe dient om (overheids)organisaties te laten deelnemen aan het privaatrechtelijke rechtsverkeer. Zo verstaat artikel 1:1 Awb onder een a-bestuursorgaan 'een orgaan van een rechtspersoon die krachtens publiekrecht is ingesteld.' Met deze omschrijving wordt in de eerste plaats verwezen naar de 'openbare lichamen' en in de tweede plaats naar andere bijzondere publiekrechtelijke rechtspersonen die rechtstreeks bij of krachtens de wet zijn ingesteld (zoals openbare universiteiten). ${ }^{617}$ Met andere woorden, 'de rechtspersonen naar publiekrecht' zijn geen andere rechtspersonen dan dewelke in artikel 2:1 BW worden aangeduid.

Het publiekrecht kent geen eigen type rechtspersoonlijkheid maar wel een eigen type rechtssubjectiviteit. Het gaat dan in beginsel om de bestuursorganen die in de Awb zijn aangeduid: zij zijn publiekrechtelijke rechtssubjecten in de zin dat zij naar publiekrecht houders zijn van rechten en plichten. Zij zijn echter geen rechtspersonen. Die rechtspersoonlijkheid - de privaatrechtelijke rechtssubjectiviteit - wordt aan de openbare lichamen verleend waartoe die organen behoren. Zo is de gemeente een publiekrechtelijke rechtspersoon en zijn haar (bestuurs)organen publiekrechtelijke subjecten. Het is belangrijk dit verschil voor ogen te houden niet alleen om terminologische verwarring te vermijden maar vooral omdat de strafrechtelijke aansprakelijkheid neergelegd in artikel $51 \mathrm{Sr}$ aansluit bij de privaatrechtelijke rechtspersoonlijkheid en niet bij de publiekrechtelijke rechtssubjectiviteit. Anders gezegd, het zijn rechtspersonen die strafbare feiten kunnen plegen en daarvoor

614. Stroink, F.A.M., Algemeen bestuursrecht. Een inleiding, Zwolle, W.E.J. Tjeenk Willink, 1996, 89.

615. Net zoals de organisatorische inrichting van kerkgenootschappen wordt beheerst door regels van het canonieke recht.

616. Zie ook de Lange, R., 'Openbare lichamen, rechtspersonen en bestuursorganen: kortsluiting in het publiekrecht?', in Vucán, R.L. (red.), De Awb-mens: boeman of underdog? Opstellen aangeboden aan Leo Damen, Nijmegen, Ars Aequi, 1996, 139.

617. Van Wijk, H.D. en Konijnenbelt, W., Hoofdstukken van bestuursrecht, Den Haag, Elseviers Bedrijfsinformatie, 1999, 100-101. 
strafrechtelijk aansprakelijk kunnen worden gesteld en niet hun organen ${ }^{618}$ Deze laatsten hebben immers geen rechtspersoonlijkheid en dus strikt gezien ook geen 'strafrechtelijke' rechtssubjectiviteit. Meteen moet hieraan worden toegevoegd dat in een aantal gevallen bestuursorganen als zodanig toch strafrechtelijk aansprakelijk kunnen worden gesteld. In de eerste plaats kan een bestuursorgaan strafrechtelijk aansprakelijk worden gesteld wanneer deze ook een 'natuurlijke persoon' is, zoals burgemeesters en (andere) ambtenaren die krachtens attributie, delegatie of mandaat bevoegd zijn tot het uitoefenen van bestuursbevoegdheden. In de tweede plaats bestaan er bestuursorganen die in tegenstelling tot de organen van een openbaar lichaam wel een eigen rechtspersoonlijkheid hebben. Het gaat dan om zogenaamde zelfstandige bestuursorganen (zbo's) waaraan rechtspersoonlijkheid is toegekend. Zbo's kunnen worden omschreven als 'buiten de gewone departementale organisatie vallende overheidsinstanties waaraan (krachtens attributie of delegatie) bestuursbevoegdheden zijn toegekend'. ${ }^{619}$ Zbo's hebben publiekrechtelijke bevoegdheden maar het zijn geen openbare lichamen. Het betreft organen die los van het organisatorische verband van een openbaar lichaam publiekrechtelijke bevoegdheden uitoefenen. Enkele klassieke voorbeelden van zbo's zijn de Kiesraad, de Verzekeringskamer, de bedrijfsverenigingen, de Ziekenfondsraad, het Commissariaat voor de Media en de Stichting Toezicht Effectenverkeer. ${ }^{620} \mathrm{Nu}$ kan aan zbo's rechtspersoonlijkheid worden toegekend. Zbo's zijn dus in principe steeds strafrechtelijk vervolgbaar indien aan hen rechtspersoonlijkheid is verleend.

De privaatrechtelijke subjectiviteit - en indirect dus ook de strafrechtelijke subjectiviteit van publiekrechtelijke rechtspersonen vindt dus haar wettelijke grondslag in artikel 2:1 BW. Deze bepaling heeft een tweeledige opbouw. Het eerste lid van artikel 2:1 BW bepaalt dat de staat, provincies, gemeenten, waterschappen en alle openbare lichamen met verordenende bevoegdheid krachtens de Grondwet rechtspersonen zijn. Daarnaast stelt het tweede lid van artikel 2:1 BW dat bij wet rechtspersoonlijkheid aan lichamen kan worden toegekend, indien daaraan een overheidstaak is opgedragen. Daarbij moet worden aangetekend dat met 'lichamen' niet alleen openbare lichamen worden bedoeld maar alle overheidsinstellingen. Uit de parlementaire geschiedenis van het nieuw Burgerlijk Wetboek blijkt duidelijk dat de regering een ruime uitleg van 'lichamen' voor ogen had:

'Door uitsluitend het woord "lichamen" te gebruiken, is het duidelijk dat hier de met het spraakgebruik overeenstemmende zeer ruime betekenis van deze term is bedoeld. Vermelding van het woord "openbare" komt

618. Dat over de gebruikte terminologie niet steeds evenveel duidelijkheid en eenduidigheid bestaat, kan worden geillustreerd aan de hand van de reeds besproken kabinetsnota die spreekt over 'de strafrechtelijke aansprakelijkheid van overheidsorganen': "'De overheid" is een veelvormig en veelkoppig fenomeen. Onder overheidsorganen verstaat het kabinet in deze notitie alle personen, lichamen, diensten, departementen enz. die zijn belast met de uitvoering van een publieke taak.' TK 1996-1997, 25 249, nr. 2, 2.

619. Van Wijk, H.D. en Konijnenbelt, W., o.c., 1999, 119-120.

620. Zie voor een overzicht van zbo's Munneke, H.F., Ten Berge, J.B.J.M., Stroink, F.A.M., Haighton, P. en den Hoed, P., Organen en rechtspersonen rondom de centrale overheid, WRRserie Voorstudies en Achtergronden van de WRR, V35, 's Gravenhage, 1983. 
ondergetekende niet gewenst voor. Voor zover dat woord in dit verband enige betekenis zou hebben, zou het kunnen leiden tot een te enge uitleg van de bepaling. ${ }^{621}$

Overheidsorganisaties zijn dus rechtspersonen hetzij rechtstreeks op basis van artikel 2:1, eerste lid, BW, hetzij onrechtstreeks op grond van een bijzondere wettelijke regeling (publiekrecht) waarnaar artikel 2:1, tweede lid, BW verwijst. ${ }^{622}$

\section{Wat zijn openbare lichamen?}

Wat is nu de verhouding tussen openbaar lichaam in de zin van hoofdstuk $7 \mathrm{Gw}$ en publiekrechtelijke rechtspersoon in de zin van artikel 2:1 BW?

Binnen de categorie publiekrechtelijke rechtspersonen aangeduid in artikel 2:1 BW vormen de openbare lichamen een afzonderlijke subcategorie: zij zijn een species van de soort publiekrechtelijke rechtspersoon evenals deze laatste weer een species is van de rechtspersoon. Er bestaat dus een verband tussen artikel 2:1 BW en hoofdstuk $7 \mathrm{Gw}$. Zo geeft artikel 2:1, eerste lid, BW rechtspersoonlijkheid aan de staat, provincies, gemeenten, waterschappen en alle openbare lichamen die krachtens de Grondwet verordenende bevoegdheid bezitten, zelfs als er geen afzonderlijke wetsbepaling zou bestaan die hun rechtspersoonlijkheid toekent. Artikel 2:1, eerste lid, BW correspondeert daarmee in grote lijnen met hoofdstuk $7 \mathrm{Gw}$.

Hoofdstuk $7 \mathrm{Gw}$ regelt de instelling, de opheffing, de inrichting en de bevoegdheden van openbare lichamen. Het noemt uitdrukkelijk als openbaar lichaam: gemeente en provincie (artikelen 123-132), waterschap (artikel 133), openbare lichamen voor beroep en bedrijf (artikel 134), en tenslotte andere openbare lichamen (artikel 134). Onder deze laatste kan bijvoorbeeld worden gedacht aan de Nederlandse Orde van Advocaten, de Arbeidsvoorzieningsorganisatie, het Jachtfonds, de Loodsencorporatie. ${ }^{623}$ Artikel $135 \mathrm{Gw}$ geeft ook nog de mogelijkheid tot de instelling van nieuwe openbare lichamen via een gemeenschappelijke regeling tussen twee openbare lichamen, 'in welk geval art. 134, tweede en derde lid, van toepassing is.' Artikel 8 Wet Gemeenschappelijke Regelingen bepaalt dat bij gemeenschappelijke regeling een openbaar lichaam 'kan' worden ingesteld. Een gemeenschappelijke regeling kan ook andere vormen aannemen zoals een samenwerking tussen burgemeesters als korpsbeheerders. ${ }^{624}$ Een klassiek voorbeeld van een via gemeenschappelijke regeling ingesteld openbaar lichaam is de regionale brandweer.

Hoofdstuk $7 \mathrm{Gw}$ mag dan wel een opsomming geven van openbare lichamen, niet duidelijk is wat nu onder een openbaar lichaam moet worden verstaan. In de literatuur worden

621. Van Zeben, C.J. e.a. (red.), Parlementaire geschiedenis van het nieuwe Burgerlijk Wetboek. Boek 2. Rechtspersonen, Deventer/Antwerpen z.j., 64; Zie tevens Peters, J.A.F., o.c., 1997, 56.

622. Peters, J.A.F., 'Wordt vervolgd? Over de criteria gebruikt bij het beleid inzake vervolging van overheden', NTB, 1997, 379.

623. Zie voor een opsomming tevens Brants, C.H. en De Lange, R., o.c., 1996, 27.

624. Brants, C.H. en De Lange, R., o.c., 1996, 27. 
verschillende kenmerken van openbare lichamen aangeduid. Een klassieke omschrijving is dat een openbaar lichaam een publiekrechtelijke rechtspersoon is 'die leden kent - desnoods in rudimentaire vorm - en een bestuur dat binnen die rechtspersoon zekere publiekrechtelijke bevoegdheden bezit. ${ }^{625}$ Aan de organen van het openbaar lichaam zijn deze publiekrechtelijke bevoegdheden bij of krachtens de wet toebedeeld. Het organisatorische verband en de werkingssfeer waarbinnen deze organen hun bevoegdheden uitoefenen is dan het openbaar lichaam:

\begin{abstract}
'Het openbaar lichaam begrenst - territoriaal of functioneel - de bevoegdheden van de organen. Een bevoegdheid van een orgaan gaat dan niet verder dan het "openbaar lichaam waartoe het behoort". Bezien vanuit een openbaar lichaam hebben de organen die tot dat lichaam behoren gemeen dat hun bevoegdheden zijn beperkt tot dat openbaar lichaam. Een openbaar lichaam kan daarom als een "groep van ambten en functies" of "ambtenkring" worden gekarakteriseerd: het vormt de samenhang waarin een aantal publiekrechtelijke ambten verenigd is. ${ }^{1626}$
\end{abstract}

Dit betekent niet dat een openbaar lichaam publiekrechtelijke rechtssubjectiviteit heeft: het is uitsluitend de organisatorische samenhang voor de publiekrechtelijke rechtssubjecten, de organen. Men zou dus kunnen stellen dat het begrip 'openbaar lichaam' een knooppunt vormt van publiekrechtelijk organisatierecht, publiekrechtelijke rechtssubjectiviteit en privaatrechtelijke rechtssubjectiviteit in de zin dat een openbaar lichaam een privaatrechtelijke rechtssubject (een rechtspersoon) kan zijn waarbinnen publiekrechtelijke rechtssubjecten (organen) hun bevoegdheden uitoefenen.

$\mathrm{Nu}$ is het van belang voor ogen te houden dat een verordenende bevoegdheid geen noodzakelijke voorwaarde is voor de kwalificatie van openbaar lichaam in de zin van hoofdstuk $7 \mathrm{Gw}$. Artikel 134, tweede lid, GW stelt immers:

'De wet regelt de taken en de inrichting van deze openbare lichamen, de samenstelling en bevoegdheid van hun besturen, alsmede de openbaarheid van hun vergaderingen. Bij of krachtens de wet kan (cursief, DR) aan hun besturen verordenende bevoegdheid worden verleend.'

Dit betekent dat er twee categorieën openbare lichamen bestaan: openbare lichamen met verordenende bevoegdheid en die zonder verordenende bevoegdheid. ${ }^{627}$ Heeft het openbaar lichaam een verordenende bevoegdheid, de competentie tot regelgeving, dan gaat het dus om een publiekrechtelijke rechtspersoon in de zin van het eerste lid van artikel 2:1 BW. Deze openbare lichamen bezitten krachtens artikel 2:1, eerste lid, BW rechtspersoonlijkheid. Heeft het openbaar lichaam geen verordenende bevoegdheid dan vloeit de

625. Van Wijk, H.D. en Konijnenbelt, W., o.c., 1999, 120.

626. Peters, J.A.F., 'Zbo's, verzelfstandiging en privatisering', NTB, 1997, 139; Peters, J.A.F., o.c., $1997,82$.

627. Zie tevens Peters, J.A.F., o.c., 1997, 55. 
rechtspersoonlijkheid voort uit de bijzondere instellingswet waarnaar het tweede lid van artikel 2:1 BW verwijst. Anders dan artikel 2:1, eerste lid, BW geeft dit artikel geen rechtstreekse wettelijke grondslag voor rechtspersoonlijkheid. Die moet worden gevonden in de bijzondere wettelijke regeling. ${ }^{628}$

Deze beknopte vergelijking tussen openbaar lichaam in de zin van hoofdstuk $7 \mathrm{Gw}$ en publiekrechtelijke rechtspersoon in de zin van artikel 2:1 BW laat reeds duidelijk zien dat er weliswaar een relatie tussen beide bestaat, maar er is zeker geen gelijkheid. Zetten we de belangrijkste punten even systematisch op een rij.

In de eerste plaats gaat het bij publiekrechtelijke rechtspersonen om meer dan alleen openbare lichamen. Openbare lichamen vormen immers een subcategorie van de publiekrechtelijke rechtspersonen. Er zijn talrijke voorbeelden van publiekrechtelijke rechtspersonen te vinden die niet tegelijk openbaar lichaam zijn. Zo zijn openbare universiteiten en politieregio's publiekrechtelijke rechtspersonen (in de zin van artikel 2:1, tweede lid, $\mathrm{BW})$, maar geen openbare lichamen. ${ }^{629}$

In de tweede plaats zijn openbare lichamen in de praktijk steeds ook publiekrechtelijke rechtspersonen, maar ze behoeven dat niet te zijn. Net zomin als de kwalificatie openbaar lichaam nodig is voor het hebben van rechtspersoonlijkheid, is deze laatste een vereiste voor het zijn van een openbaar lichaam. ${ }^{630}$ Beide begrippen dekken een verschillende lading: openbaar lichaam heeft te maken met publiekrechtelijke organisatie(recht), rechtspersoonlijkheid met privaatrechtelijke rechtssubjectiviteit. Dat er geen openbare lichamen bestaan zonder rechtspersoonlijkheid heeft veeleer te maken met pragmatische redenen die verband houden met de noodzaak openbare lichamen te laten deelnemen aan het privaatrechtelijke rechtsverkeer. Theoretisch zou de strafrechtelijke vervolgbaarheid van openbare lichamen dus problematisch kunnen worden indien men te maken krijgt met een openbaar lichaam zonder rechtspersoonlijkheid. Het ontbreken van de rechtspersoonlijkheid maakt dan de strafvervolging onmogelijk. Maar in de praktijk bestaan deze openbare lichamen zonder rechtspersoonlijkheid niet. Duidelijk is wel dat de rechtspersoonlijkheid aan de kwalificatie 'openbaar lichaam' niets toevoegt of afdoet. Wat wel is uitgesloten zijn openbare lichamen met verordenende bevoegdheid die niet tegelijk rechtspersonen zijn: de rechtspersoonlijkheid vloeit dan steeds rechtstreeks voort uit artikel 2:1, eerste lid, BW.

In de derde plaats heeft een openbaar lichaam slechts rechtspersoonlijkheid indien het openbaar lichaam (beter: een orgaan van dat lichaam) verordenende bevoegdheid heeft (artikel 2:1, eerste lid, BW) of een bijzondere wet deze rechtspersoonlijkheid toekent

628. Art. 2:1, tweede lid, BW spreekt trouwens van rechtspersoonlijkheid die bij of krachtens de wet is verleend hetgeen betekent dat de bevoegdheid om rechtspersoonlijkheid toe te kennen bij wet kan worden gedelegeerd. Peters, J.A.F., o.c., 1997, 57.

629. De politieregio is rechtspersoon op basis van artikel 21, vierde lid, Politiewet 1993. Zie voor andere voorbeelden Peters, J.A.F., o.c., 1997, 63.

629. Peters, J.A.F., o.c., 1997, 106-108.

630. Idem. 
(artikel 2:1, tweede lid, BW). Een voorbeeld van een openbaar lichaam zonder verordenende bevoegdheid is de Arbeidsvoorzieningsorganisatie. Deze wordt aangemerkt als openbaar lichaam in artikel 2, eerste lid, Arbeidsvoorzieningswet. Rechtspersoonlijkheid is toegekend op basis van artikel 2, tweede lid van deze wet. Om het allemaal nog complexer te maken, bestaan er ook openbare lichamen waarbij de rechtspersoonlijkheid zowel op artikel 2:1, eerste lid, BW als op een bijzondere wettelijke grondslag - waar artikel 2:1, tweede lid, BW naar verwijst - is gebaseerd. Zij bevinden zich als het ware tussen het eerste en tweede lid van artikel 2:1 BW. ${ }^{631}$ Dit geldt voor de Nederlandse orde van advocaten. Art. 17, eerste lid, Advocatenwet duidt deze organisatie aan als een openbaar lichaam. Artikel 28 Advocatenwet spreekt ook van een verordenende bevoegd-heid van een der organen (college van afgevaardigden). Daarnaast bepaalt artikel 17, derde lid, Advocatenwet dat de orde rechtspersoonlijkheid bezit. Deze laatste bepaling is eigenlijk overbodig nu de rechtspersoonlijkheid voortvloeit uit artikel 2:1, eerste lid, BW. Het is aardig om vast te stellen dat de Nederlandse orde van advocaten als openbaar lichaam voldoet aan het eerste strafrechtelijke immuniteitscriterium.

$\mathrm{Er}$ is met betrekking tot de rechtspersoonlijkheid van openbare lichamen nog een andere merkwaardigheid, die mogelijk onverwachte gevolgen kan hebben voor de strafrechtelijke aansprakelijkheid van overheidsinstellingen. Het gaat dan om regiovorming van de overheidsorganisatie. Binnen de inrichting van een openbaar lichaam, dat rechtspersoonlijkheid heeft, kunnen territoriale onderverdelingen worden gemaakt in de vorm van regio's. Aan deze regio's kan bij bijzondere wet rechtspersoonlijkheid worden toebedeeld. Maar dat kan ook achterwege blijven. ${ }^{632}$ Voorbeelden van openbare lichamen die zijn onderverdeeld in regio's met eigen rechtspersoonlijkheid zijn de Nederlandse orde van advocaten en de Nederlandse loodsencorporatie. Een voorbeeld van een openbaar lichaam dat is onderverdeeld in regio's zonder rechtspersoonlijkheid is de Arbeidsvoorzieningsorganisatie. Deze bestuursorganisatorische verschillen binnen openbare lichamen leiden op strafrechtelijk vlak tot inconsistenties. Zo is de Nederlandse orde van advocaten een openbaar lichaam met rechtspersoonlijkheid en zijn haar organen a-organen in de zin van artikel 1:1 Awb, want 'organen van een rechtspersoon die krachtens publiekrecht is ingesteld'. Nu kent de Nederlandse orde van advocaten ook regionale onderdelen (orden) die per arrondissement zijn ingesteld. Deze hebben een eigen bestuur dat rechtstreeks is gekozen door de leden van het desbetreffende arrondissement (artikel 22 Advocatenwet). Aan de orden in de arrondissementen wordt ex artikel 17, derde lid, Advocatenwet rechtspersoonlijkheid toegekend. Ook de organen van deze orden zijn aan te merken als a-organen in de zin van artikel 1:1 Awb. Het grote verschil is echter dat deze orden in het arrondissement geen openbaar lichaam zijn; alleen de Nederlandse orde van advocaten is een openbaar lichaam. ${ }^{633}$ Dit betekent dat uitsluitend de Nederlandse orde van advocaten op het subjectcriterium beroep kan doen en niet de orden in de arrondissementen. Kijken we naar de Arbeidsvoorzieningsorganisatie waarvan het territoriale gebied ook in regio's is onderverdeeld (hoofdstuk II, Afdeling 2 van de Arbeidsvoorzieningswet) dan krijgen we

631. Idem, 62.

632. Idem, 70-71.

633. Idem, 71 . 
een ander beeld. Aan deze regio's is geen rechtspersoonlijkheid toegekend. De regio's behoren tot de rechtspersoonlijkheid van de Arbeidsvoorzieningsorganisatie zijnde een openbaar lichaam, hetgeen betekent dat zij indirect voldoen aan het subjectcriterium. Moet worden toegegeven dat het hier om uitzonderlijke voorbeelden gaat, maar daarmee wordt wel duidelijk wat de onbedoelde strafrechtelijke gevolgen zijn van het toekennen van rechtspersoonlijkheid enerzijds en de kwalificatie openbaar lichaam anderzijds.

\section{De bijzondere positie van de staat}

Door artikel 2:1, eerste lid, BW is aan de staat rechtspersoonlijkheid toegekend. De staat is echter niet genoemd als openbaar lichaam in hoofdstuk $7 \mathrm{Gw}$. Volgens Hennekens kan uit de Grondwet niet worden afgeleid dat de staat een openbaar lichaam is. ${ }^{634} \mathrm{Er}$ zijn wel verschillende wetten waarin de staat als openbaar lichaam wordt aangeduid. ${ }^{635}$ Andere wetten duiden het Rijk als openbaar lichaam aan ${ }^{636}$ Nog andere regelingen spreken dan weer over de staat als publiekrechtelijk lichaam. ${ }^{637}$ Niettegenstaande de terminologische verwarring is in ieder geval duidelijk dat de staat een publiekrechtelijke rechtspersoon is.

De eigen rechtspersoonlijkheid van de staat heeft een belangrijke consequentie voor de strafrechtelijke positie van andere overheidsinstellingen. De rechtspersoonlijkheid van de staat impliceert immers dat uiteindelijk alle overheidsinstellingen rechtspersoonlijkheid bezitten. Is aan een overheidsorganisatie - in de praktijk gaat het dan vooral om zbo's - geen zelfstandige rechtspersoonlijkheid verleend op grond van artikel 2:1, eerste lid, BW of een bijzondere instellingswet (artikel 2:1, tweede lid, BW) dan behoort deze automatisch tot de staat en maakt deze derhalve ook deel uit van diens rechtspersoonlijkheid. Of een bepaalde overheidsorganisatie een eigen rechtspersoonlijkheid krijgt toebedeeld, hangt voornamelijk af van de mate waarin het nodig wordt geacht dat deze als een apart subject deel moet kunnen nemen aan het privaatrechtelijke rechtsverkeer. Is dat niet nodig of wenselijk dan zal deze overheidsinstelling geen rechtspersoon zijn en automatisch behoren tot de rechtspersoon de staat. Deze zuiver privaatrechtelijke eigenaardigheid heeft op strafrechtelijk vlak grote gevolgen hoewel de erkenning van rechtspersoonlijkheid geen uitstaans heeft met strafrechtelijke regels of ratio's. ${ }^{638}$ De staat geniet een absolute immuniteit. Andere overheidsorganisaties genieten slechts een partiële immuniteit voor zover zij ook openbaar lichaam zijn en het delict is gepleegd bij de uitvoering van een exclusieve bestuurstaak. Dit betekent dat toekenning van rechtspersoonlijkheid aan een overheidsorganisatie meteen tot gevolg heeft dat het niet langer de immuniteit geniet die de staat heeft. Of deze overheidsorganisatie met eigen rechtspersoonlijkheid alsnog beroep kan doen op (partiële) immuniteit zal dan in eerste instantie afhangen van de vraag of het ook

634. Hennekens, H., l.c., 1991, 330.

635. Art. 15, eerste lid onder c. Wet op belastingen van rechtsverkeer; art. 11, derde lid, Vreemdelingenwet; art. 14a, eerste lid, Wet tot behoud van cultuurbezit. Zie Brants, C.H. en De Lange, R., o.c., 1996, 28.

636. Zo bijvoorbeeld art. 141 Onteigeningswet en art. 31 a derde lid Wet op de Ruimtelijke ordening. Zie voor andere voorbeelden Brants, C.H. en De Lange, R., o.c., 1996, 29.

637. Bijvoorbeeld art. 20 Tracéwet en art. 17, eerste lid, Invaliditeitswet.

638. Peters, J.A.F., L.c., 1997, 385. 
nog een openbaar lichaam is. Dit leidt tot ongerijmdheden. Het is nu mogelijk dat een overheidsorganisatie die geen rechtspersoon is een grotere immuniteit geniet dan een openbaar lichaam. Zo bezit de Registratiekamer en het Staatsbosbeheer - beide zbo's - geen eigen rechtspersoonlijkheid, vallen dus onder de rechtspersoonlijkheid van de staat en zijn daardoor niet vervolgbaar. Daarentegen is een politieregio wel een rechtspersoon (sui generis), maar geen openbaar lichaam en is derhalve altijd vervolgbaar.

Uit het voorgaande blijkt dat in hoofdstuk $7 \mathrm{Gw}$ verschillende soorten openbare lichamen zijn opgesomd waarvan sommigen verordenende bevoegdheden hebben en anderen niet. Gelet op de enkele verwijzing naar hoofdstuk $7 \mathrm{Gw}$ door de Hoge Raad moet worden besloten dat al deze openbare lichamen in aanmerking kunnen komen voor immuniteit mits ook aan het later te bespreken taakcriterium is voldaan. Ook al lijkt het aannemelijk dat de Hoge Raad in de eerste plaats die openbare lichamen bedoelt die in de Grondwet expliciet bij naam zijn genoemd, het blijft een feit dat ook de 'andere' openbare lichamen ex artikel $134 \mathrm{Gw}$ openbare lichamen zijn in de zin van hoofdstuk $7 \mathrm{Gw}$. De vraag is nu of gelet op het voorgaande, dit subjectcriterium enigerlei betekenis heeft voor de beoogde begrenzing van strafrechtelijke (on)vervolgbaarheid van publiekrechtelijke rechtspersonen.

\section{DE RATIO VAN HET SUBJECTCRITERIUM}

\section{Verordenende bevoegdheid}

Een eerste mogelijke verklaring voor het subjectcriterium kan liggen in het feit dat de Hoge Raad een onderscheid wil maken tussen publiekrechtelijke rechtspersonen met verordenende bevoegdheid en publiekrechtelijke rechtspersonen zonder dergelijke bevoegdheid. Zo veronderstelt Hennekens dat de Hoge Raad in de eerste plaats het strafrecht wil uitsluiten voor die openbare lichamen met wetgevende ambten. ${ }^{639}$ Mede gelet op het feit dat de casus die voor de Hoge Raad komen vrijwel steeds openbare lichamen met verordenende bevoegdheden betreffen, zoals gemeenten en provincies, is deze verklaring zeer aannemelijk. ${ }^{640}$ Des te meer wanneer de grondwetsgeschiedenis van hoofdstuk $7 \mathrm{Gw}$ uitwijst dat dit hoofdstuk in de eerste plaats is bedoeld om een grondslag te bieden voor de verordenende bevoegdheid. ${ }^{641}$ Toch is deze verklaring niet helemaal sluitend. In de eerste plaats spreekt de Hoge Raad niet over 'verordenende bevoegdheid' als onderscheidend criterium. Er wordt alleen verwezen naar openbare lichamen in de zin van hoofdstuk $7 \mathrm{Gw}$ en (daarnaast) het aangescherpte taakcriterium. Zoals gezien, is de verordenende bevoegdheid ex artikel 134, tweede lid, Gw slechts facultatief. ${ }^{642}$ Er zijn openbare lichamen met en openbare lichamen zonder verordenende bevoegdheid. Een gemeente is een klassiek voorbeeld van een openbaar lichaam met verordenende bevoegdheid. De regionale brandweer is een openbaar lichaam, oefent tevens een

639. Zie Hennekens, H., l.c., 1991, 330.

640. In gelijke zin Brants, C.H. en De Lange, R., o.c., 1996, 28.

641. Idem.

642. Van Wijk, H.D. en Konijnenbelt, W., o.c., 1999, 120; Goorden, C.P.J., Rechtsbevoegdheid in het bestuursrecht; Een rechtsvergelijkende studie naar het bevoegdhedenvraagstuk in het bestuursrecht, Zwolle, W.E.J. Tjeenk Willink, 1990, 27. 
overheidstaak uit, maar bezit geen verordenende bevoegdheid. ${ }^{643}$ De Nederlandse orde van advocaten is dan weer een voorbeeld van een openbaar lichaam met verordenende bevoegdheid. Zij beantwoorden allemaal aan het subjectcriterium. Het al dan niet hebben van regelgevende bevoegdheden doet hieraan geen afbreuk.

Daarnaast bestaan er publiekrechtelijke rechtspersonen die geen openbaar lichaam zijn maar die wel degelijk beschikken over verordenende bevoegdheden. Dit geldt voor bepaalde zelfstandige bestuursorganen. Deze zijn vaak ook rechtspersonen maar geen openbaar lichaam en kunnen beschikken over - zij het meestal beperkte - verordenende bevoegdheden. Doordat zij de kwalificatie openbaar lichaam missen kunnen zelfstandige bestuursorganen, indien zij ook rechtspersoon zijn, strafrechtelijk worden vervolgd.

Bovendien, indien de Hoge Raad inderdaad de immuniteit zou willen beperken tot openbare lichamen met regelgevende bevoegdheid en dan meer bepaald tot de klassieke decentrale overheden, is dan een verwijzing naar artikel 2:1, eerste lid, BW niet logischer en eenvoudiger? Dit artikel noemt uitsluitend de staat, gemeenten, provincies, de waterschappen en alle openbare lichamen waaraan krachtens de Grondwet verordenende bevoegdheid is verleend. Als de Hoge Raad openbare lichamen met verordenende bevoegdheid had willen uitsluiten van strafvervolging, dan zou een verwijzing naar dit artikel meer voor de hand hebben gelegen. Artikel 2:1, eerste lid, BW past ook meer binnen het kader van artikel $51 \mathrm{Sr}$ waar voor de strafrechtelijke rechtspersoonlijkheid toch in de eerste plaats aansluiting wordt gezocht bij het civiele recht of het Burgerlijk Wetboek.

\section{Gemeenschapsverband en publiekrechtelijke controlemechanismen}

Een meer voor de hand liggende verklaring heeft niet zozeer te maken met de 'publiekrechtelijke bevoegdheden' waarover openbare lichamen beschikken, maar wel met de 'publiekrechtelijke organisatorische inrichting' van het openbaar lichaam. ${ }^{644}$ Een openbaar lichaam is een organisatorisch verband waarbinnen bestuursorganen functioneren. Een openbaar lichaam kan worden gezien als een territoriale en functionele begrenzing van publiekrechtelijk bevoegdheden die door haar organen worden uitgeoefend. ${ }^{645} \mathrm{De}$ uitoefening van deze bevoegdheden is beperkt tot het openbaar lichaam waartoe de bestuursorganen behoren en in die zin vormt het openbaar lichaam een democratisch gestuurde organisatorische samenhang waarin een aantal ambten verenigd is. ${ }^{646}$ Daarom wordt het openbaar lichaam ook vaak aangeduid als een gemeenschap van 'leden' of 'ingezetenen'. ${ }^{647}$ Kenmerkend is dat het openbaar lichaam vatbaar is voor democratisering omdat de 'leden' van die gemeenschap op het bestuur van het openbaar lichaam invloed en

643. Vgl. Brants, C.H. en De Lange, R., o.c., 1996, 28.

644. Peters, J.A.F., l.c., 1997, 384.

645. Aldus Peters, J.A.F., o.c., 1997, 82.

646. Hennekens, H.Ph.J.A.M., Van Geest, H.J.A.M. en Fernhout, R., Decentralisatie, Nijmegen, Ars Aequi, 1995, 30.

647. Van Wijk, H.D. en Konijnenbelt, W., o.c., 1999, 120; Goorden, C.P.J., o.c., 1990, 24 e.v.; Kortmann, C.A.J.M., Constitutioneel recht, Deventer, 1994, 495. 
zeggenschap kunnen uitoefenen. ${ }^{648}$ Dit alles hangt sterk samen met de decentralisatie binnen het Nederlandse bestuursorganisatie. Zoals Peters beeldend samenvat:

'openbare lichamen zijn de bouwstenen voor de decentrale opbouw van ons staatsverband. Binnen die opbouw biedt het openbaar lichaam een organisatorische grondslag voor het democratische aspect van de democratische rechtsstaat. ${ }^{169}$

Wat de Hoge Raad blijkbaar met het subjectcriterium voor ogen heeft zijn dan niet zozeer de publiekrechtelijke bevoegdheden van openbare lichamen maar het feit dat de uitoefening van deze bevoegdheden in een openbaar lichaam op democratische wijze zijn gelegitimeerd. Ook de Belgische wetgever verwijst in de MvT bij de Wet tot invoering van de strafrechtelijke verantwoordelijkheid van de rechtspersoon naar de democratische organisatie van bepaalde publiekrechtelijke rechtspersonen als (enig) argument voor de uitsluiting van deze rechtspersonen van de werking van het strafrecht. Door de immuniteit te beperken tot openbare lichamen wil de Hoge Raad mogelijk tot uitdrukking brengen dat voorrang moet worden verleend aan de politieke en democratische controlemechanismen die binnen openbare lichamen aanwezig zijn. ${ }^{650}$ Dit zou dan de verbindende factor kunnen zijn tussen de immuniteit van een openbaar lichaam en die van de staat. Hoewel de Hoge Raad in het Volkel-arrest niet spreekt over het subjectcriterium wordt de absolute immuniteit wel gemotiveerd door te verwijzen naar het parlementaire stelsel van politieke controle, in het bijzonder de ministeriële verantwoordelijkheid. De staat is een publiekrechtelijke organisatorische eenheid waarbinnen, net als bij een openbare lichaam in de zin van hoofdstuk $7 \mathrm{Gw}$, democratische en politieke verantwoordingsmechanismen centraal staan. Zo bekeken sluiten de Hoge Raad-uitspraken over openbare lichamen enerzijds en de staat anderzijds inhoudelijk bij elkaar aan. ${ }^{651}$ Onduidelijk blijft wel waarom bij de staat het taakcriterium niet wordt gehanteerd en bij de (andere) openbare lichamen wel.

Hoe aannemelijk deze uitleg van het subjectcriterium ook mag zijn, toch passen hier enkele kanttekeningen.

In de eerste plaats is niet binnen alle openbare lichamen de democratisch-politieke legitimatie en controle even belangrijk of heeft deze een zelfde lading. Dit betekent dat de strafrechtelijke immuniteit niet altijd even overtuigend aan de hand van het subjectcriterium kan worden onderbouwd. Zo stelt de democratische basis van de Arbeidsvoorzieningsorganisatie niet zo veel voor. ${ }^{652}$ De Arbeidsvoorzieningsorganisatie is krachtens artikel 2,

648. Volgens De Haan is bij een openbaar lichaam 'steeds sprake van een publiekrechtelijke gemeenschap van personen met eigen taken en bevoegdheden en met een bestuur, op de samenstelling waarvan deze personen in beginsel invloed kunnen uitoefenen.' De Haan, P., Drupsteen, Th.G. en Fernhout, R., Bestuursrecht in de sociale rechtsstaat. Deel 1. Ontwikkeling, Organisatie, Instrumentarium, Deventer, Kluwer, 1996, 148.

649. Peters, J.A.F., o.c., 1997, 83.

650. Peters, J.A.F., l.c., 1997, 384-385.

651. Vgl. Peters, J.A.F., o.c., 1997, 166.

652. Vgl. Peters, J.A.F., l.c., 1997, 385. 
eerste lid, Arbeidsvoorzieningswet een zelfstandig openbaar lichaam dat geen 'ingezeten' heeft. ${ }^{653}$ Toch voldoet deze organisatie aan het subjectcriterium: het is een openbaar lichaam in de zin van hoofdstuk $7 \mathrm{Gw}$. De politieke controle op de Nederlandse orde van advocaten is niet bestaande. De democratische legitimatie van de Nederlandse orde van advocaten is weliswaar aanwezig, in de vorm van het college van afgevaardigden en de leden van de algemene vergadering, maar het hoeft nauwelijks betoog dat deze democratische inbedding van het openbaar lichaam niet te vergelijken is met de democratische basis van decentrale overheden. Toch voldoet ook deze instelling aan het subjectcriterium. Natuurlijk moet om beroep te kunnen doen op de strafrechtelijke immuniteit ook steeds zijn voldaan aan het taakcriterium en daarvan zal in hoofde van bijvoorbeeld de Nederlandse orde van advocaten geen sprake zijn. Binnen de orde worden immers geen overheidstaken verricht die niet anders dan door bestuursfunctionarissen kunnen worden verricht. Maar dit doet wel meteen de vraag rijzen wat het verband is tussen beide criteria en wat de toegevoegde waarde kan zijn van het subjectcriterium. Enerzijds bestaan er publiekrechtelijke rechtspersonen die geen openbaar lichaam zijn maar wel degelijk overheidstaken uitvoeren. Anderzijds zijn er openbare lichamen die geen overheidstaken uitvoeren of in ieder geval geen taken die niet anders dan door bestuursfunctionarissen kunnen worden verricht.

In de tweede plaats bestaan er publiekrechtelijke rechtspersonen die onderhevig zijn aan publiekrechtelijke controlemechanismen hoewel ze geen openbaar lichaam zijn. Zij zijn dan ook niettegenstaande het bestaan van publiekrechtelijke controle in alle gevallen strafrechtelijk vervolgbaar zelfs indien het gaat om overheidstaken die niet anders dan door bestuursfunctionarissen kunnen worden verricht. Zo is bijvoorbeeld een politieregio een rechtspersoon én onderworpen aan politieke controle maar het is geen openbaar lichaam en daarom vervolgbaar. De publiekrechtelijke controle op de politieregio vloeit rechtstreeks voort uit de democratische inbedding van de politie die onder meer gestalte krijgt in de plicht van de korpsbeheerder (de burgemeester van één van de regiogemeenten) verantwoording af te leggen aan het regionaal college (artikel 30, eerste lid, Politiewet 1993). Een ander aspect van de politieke controle op politieregio's bestaat in de ministeriële verantwoordelijkheid. Niettegenstaande de aanwezigheid van een publiekrechtelijke controle is een politieregio toch strafrechtelijk vervolgbaar zelfs indien er sprake zou zijn van een misdrijf gepleegd bij de uitoefening van een primaire (!) overheidstaak (bijvoorbeeld handhaving van de rechtsorde krachtens artikel 3 Politiewet) die uitsluitend door bestuursfunctionarissen (bijvoorbeeld opsporingsambtenaren) kan worden verricht. Bovendien kan men zich afvragen of de politieke controle op de politieregio maatschappelijk en rechtsstatelijk gezien niet belangrijker is dan bijvoorbeeld de publiekrechtelijke controle op een organisatie als het Jachtfonds, hoewel deze laatste een openbaar lichaam is en zelfs via haar ledenvergadering verordenende bevoegdheid heeft. ${ }^{654}$ Is het dan niet

653. Zie rapport van het voorstel van de Wet houdende instelling van de Arbeidsvoorzieningsorganisatie en regelen op het gebied van de arbeidsvoorziening of Arbeidsvoorzieningswet, TK 1987-1988, 20569.

654. De verordenende bevoegdheid vloeit voort uit art. 16 Loodsenwet. 
vreemd dat een politieregio geen en het Jachtfonds wel een beroep kan doen op het subjectcriterium?

In de derde plaats kan nogmaals worden gewezen op de belangrijke rol van zelfstandige bestuursorganen in de Nederlandse overheidsorganisatie. Zoals gezegd, zbo's zijn buiten de gewone departementale organisatie vallende overheidsinstellingen waaraan publiekrechtelijke bevoegdheden zijn toegekend, waaronder vaak ook verordenende bevoegdheden. Zbo's zijn geen openbare lichamen maar kunnen wel rechtspersoonlijkheid hebben. Sommige zbo's zijn publiekrechtelijke rechtspersonen, dat wil zeggen dat zij hun rechtspersoonlijkheid ontlenen aan een instellingswet, als bedoeld in artikel 2:1, tweede lid, BW. Een voorbeeld hiervan is het Commissariaat voor de Media waaraan rechtspersoonlijkheid is toegekend krachtens artikel 9, eerste lid, Mediawet. Andere zbo's zijn privaatrechtelijke rechtspersonen, dat wil zeggen dat zij niet alleen privaatrechtelijke rechtssubjectiviteit hebben maar ook organisatorisch naar privaatrechtelijke regels zijn ingericht. Een bekend voorbeeld hiervan is de Stichting Toezicht Effectenverkeer (STE). De STE is een zbo en een privaatrechtelijke rechtspersoon. Nog andere zbo's hebben helemaal geen rechtspersoonlijkheid en vallen daarmee automatisch onder de rechtspersoonlijkheid van de staat. Een voorbeeld hiervan is de Registratiekamer. Een enkele keer heeft een zbo geen rechtspersoonlijkheid zonder dat het meteen valt onder de rechtspersoonlijkheid van de staat omdat het orgaan dan behoort tot de rechtspersoonlijkheid van een openbaar lichaam. Bij mijn weten is dit alleen het geval met het Centraal Bestuur voor de Arbeidsvoorziening (CBA). Dit is een zbo binnen een openbaar lichaam, namelijk de Arbeidsvoorzieningsorganisatie. ${ }^{655}$ Welnu, heeft een zbo rechtspersoonlijkheid dan is het in alle gevallen strafrechtelijk vervolgbaar. Heeft een zbo geen rechtspersoonlijkheid, dan geniet het orgaan derhalve de absolute immuniteit die aan de staat is toebedeeld. ${ }^{656}$ Daarbij verdient aantekening dat de mate van publiekrechtelijke controle op deze qua organisatievorm zeer verschillende zbo's blijkbaar niet relevant is voor de strafrechtelijke vervolgbaarheid terwijl dit nu net een belangrijke motivatie lijkt te zijn om openbare lichamen partieel en de staat absoluut van strafvervolging uit te sluiten. Dit leidt tot ongerijmde uitkomsten. Ontbreekt de rechtspersoonlijkheid, dan is het zbo onvervolgbaar ook al is er slechts sprake van een beperkte publiekrechtelijke controle en is derhalve de motivatie voor immuniteit weggevallen. Is an een zbo wel rechtsper-

655. Zie Van Hukkelhoven, M.M.G., 'De zelfstandigheid van de Arbeidsvoorzieningsorganisatie', Bestuurskunde, 1994, 13-20. Boxum ziet de Arbeidsvoorzieningsorganisatie blijkbaar zelf als een zelfstandig bestuursorgaan. Boxum, J.L., o.c., 1994, 257. Dat lijkt mij niet juist. Een openbaar lichaam kan niet tegelijk een orgaan zijn en omgekeerd. De terminologische verhouding tussen lichaam en orgaan duidt hier reeds op. $\mathrm{Er}$ mag niet worden vergeten dat de termen openbaar lichaam en (zelfstandig) bestuursorgaan verschillende ladingen dekken. Openbaar lichaam heeft te maken met publiekrechtelijke organisatie en bestuursorgaan verwijst naar publiekrechtelijke rechtssubjectiviteit en bevoegdheden. Het CBA is dus een zbo behorende tot het openbare lichaam de Arbeidsvoorzieningsorganisatie. Het is dus duidelijk dat zelfstandige bestuursorganen geen openbare lichamen kunnen zijn, maar ze kunnen er blijkbaar wel onderdeel van uitmaken.

656. Of, zoals bij het $\mathrm{CBA}$, is het mogelijk dat het zbo de partiele immuniteit geniet waarop het openbaar lichaam waartoe het zbo behoort mogelijk beroep zou kunnen doen. 
soonlijkheid toebedeeld dan is deze steeds vervolgbaar ook al is er sprake van publiekrechtelijke controle.

$\mathrm{Nu}$ kan worden opgemerkt dat de publiekrechtelijke controle op zbo's niet veel voorstelt terwijl dit wel een cruciaal gegeven is bij zowel openbare lichamen als bij departementale overheidsinstellingen die geen zbo zijn. In die zin zou het onderscheid op strafrechtelijk vlak tussen zbo's met rechtspersoonlijkheid enerzijds en openbare lichamen en de staat anderzijds toch nog te rechtvaardigen zijn. Zbo's ontberen inderdaad de democratisch legitimerende basis die het openbaar lichaam als organisatie zou kenmerken en evenmin strekt zich over hen de ministeriële verantwoordelijkheid uit. Eén van de belangrijkste redenen om zbo's op te richten is immers om een aantal overheidstaken juist te onttrekken aan de ministeriële verantwoordelijkheid. ${ }^{657}$ Maar in de praktijk valt de beperking van ministeriële verantwoordelijkheid op zbo's best wel tegen. De politieke invloed en controle van een minister - en daarmee ook de parlementaire controle - op zbo's wordt door verschillende factoren bepaald waaronder de aard van de bevoegdheden die aan de zbo's zijn toebedeeld en de wijze waarop de verhouding tussen het zbo en de departementtop concreet gestalte heeft gekregen. ${ }^{658}$ Er bestaat een spectrum van ministeriële beïnvloedingsmogelijkheden op zbo's waarbij aan het ene uiterste de verzelfstandiging van het bestuursorgaan de volledige afwezigheid van ministeriële verantwoordelijkheid tot gevolg heeft en aan het andere uiterste de verzelfstandiging zelfs leidt tot een intensivering van deze verantwoordelijkheid. ${ }^{659}$ Zo heeft de minister, ter voorkoming van ongeoorloofde belangenverstrengeling, geen invloed op de Kiesraad en de Verzekeringskamer. ${ }^{660}$ Daarentegen heeft de minister een aangescherpte invloed op zbo's als het Kadaster en de Luchtverkeersbeveiligingsorganisatie. ${ }^{661}$ Van Nus wijst er ook op dat de ministeriële controle op bijvoorbeeld De Nederlandsche Bank, het Centraal Fonds voor de

657. Scheltema, M. en Lubberdink, H.G., 'Ministeriële verantwoordelijkheid en parlementaire controle', in Parlementaire controle en democratie in de verzorgingsstaat, staatsrechtcongres, Utrecht, 1980, 8-11; Lubberdink, H.G., De betekenis van de ministeriële verantwoordelijkheid voor het openbaar bestuur, Deventer, Kluwer, 1982, 153-181; Boxum, J.L., 'Zelfstandige bestuursorganen en de greep van ministers op de bestuurlijke organisatie', in Engels, J.W.M., Lambers, C., Niemeijer, E., Scheltema, E., Schuiling, K.F., Vis, B.C. en Vuçsán, R.L. (red.), De rechtsstaat herdacht, Zwolle, W.E.J. Tjeenk Willink, 1989, 257 e.v.; Boxum, J.L., 'Ministerièle verantwoordelijkheid en zelfstandige bestuursorganen, in Elzinga, D.J. (red.), De ministeriële verantwoordelijkheid in Nederland, Zwolle, W.E.J. Tjeenk Willink, 1994, 257-278.

658. Boxum, J.L., 'Ministeriêle verantwoordelijkheid en zelfstandige bestuursorganen', in Elzinga, D.J. (red.), o.c., 1994, 263-269.

659. Idem, 271.

660. Sinds 1 september 1992 de Stichting Verzekeringskamer. De Verzekeringskamer is dus niet langer een publiekrechtelijke rechtspersoon, maar een privaatrechtelijke rechtspersoon. Zie Wet houdende regelen m.b.t. de verzelfstandiging van de Verzekeringskamer, Stbl., 1992, 372.

661. De aanscherping van de ministeriële verantwoordelijkheid op dergelijke zbo's moet worden begrepen in de zin dat verzelfstandiging tot gevolg heeft dat voor bepaalde onderwerpen de minister zich niet langer mag bemoeien terwijl hij voor andere onderwerpen zich juist moet bemoeien. Met andere woorden, door de verzelfstandiging wordt de beperking van de ministeriēle zeggenschap in zijn geheel beoogt mede om op bijzondere gebieden een intensivering van departementale beïnvloeding te bewerkstelligen. Aldus Boxum, J.L., 'Ministeriële verantwoordelijkheid en zelfstandige bestuursorganen', in Elzinga, D.J. (red.), o.c., 1994, 271-272. 
Volkshuisvesting en het Centraal Bestuur voor Arbeidsvoorziening zeer ver gaat. ${ }^{662}$ Wat het CBA betreft - een zbo binnen het openbaar lichaam Arbeidsvoorzieningsorganisatie heeft de ministeriële verantwoordelijkheid lange tijd zelfs een zeer ambigu karakter gehad doordat de minister slechts beperkte bevoegdheden had ten opzichte van het zbo, maar hij tegelijk wel lid was van het bestuur. ${ }^{63}$

Er is bij zbo's daarom niet altijd automatisch sprake van een inkrimping van ministeriële verantwoordelijkheid en parlementaire controle. ${ }^{664}$ Ook in gevallen waar een zbo in een privaatrechtelijke vorm is gegoten is niet steeds de publiekrechtelijke controle ingeperkt. Dit is het geval met de Stichting Toezicht Effectenverkeer (STE). De stichtingsvorm blijkt te zijn gekozen om de besluitvorming binnen het zbo onafhankelijk te doen zijn van ledenen aandeelhoudersvergadering, wat gelet op de taakstelling van de STE (toezicht op naleving van effectenwet- en regelgeving) begrijpelijk is. Mede door de (verregaande) regelgevende bevoegdheden van de STE zijn de beïnvloedingsmogelijkheden van de minister van financiën behoorlijk groot. ${ }^{665}$ Toch belet de doelstelling van de STE (een primaire overheidstaak!), noch de ruime regelgevende bevoegdheden en evenmin de publiekrechtelijke controle op de STE een mogelijke strafvervolging. Dit is vreemd nu zowel de aanwezigheid van publiekrechtelijke controlemechanismen als de uitoefening van overheidstaken de ratio's blijken te zijn van de strafrechtelijke immuniteit.

\section{CONCLUSIE}

Concluderend kan worden gesteld dat het niet eenvoudig is de werkelijke ratio van het subjectcriterium 'openbaar lichaam' te achterhalen. Noch het 'gemeenschapsverband' of het hebben van 'ingezeten', noch een verordenende bevoegdheid en evenmin de aanwezigheid van publiekrechtelijke controle verklaart op bevredigende wijze een onderscheid tussen een

662. Van Nus, J.G.J., Overheidstoezicht op afstand. Verzelfstandiging van toezichthoudende taken naar zelfstandige bestuursorganen verkend, Maklu, Antwerpen-Apeldoorn, 1995, 73-74.

663. Hoewel de besluitvorming het gevolg is van een compromisvorming en de minister zich moet neerleggen bij een meerderheidsbesluit. Zie Boxum, J.L., 'Ministeriële verantwoordelijkheid en zelfstandige bestuursorganen', in Elzinga, D.J. (red.), o.c., 1994, 273.

664. Aldus van Gunsteren, H.R., 'Zbo's en het vraagstuk van politieke en bestuurlijke verantwoordelijkheid', in WRR, Studiemiddag zelfstandige bestuursorganen, 12 november 1985, serie voorstudies en achtergronden V54, 's Gravenhage, 1986, 35.

665. Ingevolge art. 18, Wet toezicht effectenverkeer (Wte) kan de STE 'met het oog op een adequate functionering van de effectenmarkten en de positie van de beleggers op die markten voorschriften geven aan de houders van een effectenbeurs met betrekking tot de voor die effectenbeurs te hanteren regels, hun toepassing of de controle op de naleving van deze regels.' Hiermee is aan de STE, een privaatrechtelijke rechtspersoon(!), een verordenende bevoegdheid toebedeeld die samen met de strafbaarstelling krachtens art. 1, aanhef sub 2, WED, zeer ver gaat. De STE heeft in die zin een machtspositie gekregen die op een lijn gesteld kan worden met die van een openbaar lichaam als een gemeente of een provincie. Uit deze bestuursbevoegdheden van de STE vloeit voor de minister een algemene instructiebevoegdheid voort. In voorkomend geval kan hij de aan de STE gedelegeerde bevoegdheid intrekken om vervolgens zelf controlevoorschriften uit te vaardigen. Zie Van Nus, J.G.L., o.c.,1995, 619-620; Vgl. Doorenbos, D.R., Financieel strafrecht. Een studie inzake strafrechtelijk gesanctioneerde voorschriften uit de bank-en effectenwetgeving, Deventer, Kluwer, 1992, 250. 
openbaar lichaam en andere publiekrechtelijke rechtspersonen. Er bestaan zelfs privaatrechtelijke rechtspersonen, zoals de STE, die qua bestuursbevoegdheden en publiekrechtelijke controle best op een lijn kunnen worden gesteld met bepaalde openbare lichamen. Duidelijk is wel dat de kwalificatie 'openbaar lichaam' van bepaalde overheidsinstellingen tamelijk willekeurig heeft plaatsgevonden. Het is moeilijk te verklaren waarom Kamers van Koophandel en universiteiten geen openbaar lichaam zijn en het Jachtfonds en de Nederlandse orde van Advocaten wel openbaar lichaam zijn. ${ }^{666}$ Het is dan ook moeilijk te begrijpen dat zo'n belangrijke kwestie als strafvervolging van publiekrechtelijke rechtspersonen afhankelijk wordt gemaakt van een louter formeel en tamelijk arbitrair bestuursorganisatorisch criterium. Waarom zou een politieregio zich niet kunnen beroepen op strafrechtelijke immuniteit en de Rekenkamer wel? Voor de strafvervolging is evenzeer de toebedeling van rechtspersoonlijkheid aan overheidsinstellingen problematisch. Het al dan niet beschikken over een eigen rechtspersoonlijkheid bepaalt immers rechtstreeks of overheidsorganisaties (zoals zbo's) onder de immuniteit van de staat vallen.

Los van deze kritiek, rijst tenslotte de vraag welke rol het subjectcriterium nog kan spelen na Pikmeer II. Ervan uitgaande dat het subjectcriterium zijn verklaring vindt in het verband tussen de organisatorische inrichting van een openbaar lichaam en het bestaan van publiekrechtelijke controle- en verantwoordingsmechanismen is het interessant vast te stellen dat de Hoge Raad in het Pikmeer II-arrest heeft uitgemaakt dat het stelsel van politieke verantwoordelijkheid noch dat van bestuurlijk toezicht in strijd is met de strafrechtelijke vervolgbaarheid. Beide verantwoordelijkheidsmechanismen nemen een eigen plaats is. Met deze stellingname neemt de Hoge Raad afstand van de oorspronkelijke ratio van de strafrechtelijke immuniteit. Hiermee komt het nut van het subjectcriterium duidelijk op de helling te staan en lijkt het te zijn ingegeven door een louter willekeurige differentiatie in typen publiekrechtelijke rechtspersonen. Het subjectcriterium kan zeker na Pikmeer II geen deugdelijke basis bieden voor de begrenzing van strafrechtelijke vervolgbaarheid. Bovendien mag niet worden vergeten dat in de praktijk bij de beoordeling van de ontvankelijkheidsvraag het subjectcriterium vaak voorafgaat aan het taakcriterium. Zoals Peters terecht opmerkt: 'Bij deze cumulatie bepaalt de zinnigheid van het eerste criterium de relevantie en het effect van het volgende criterium. ${ }^{667}$ Door hardnekkig en zonder (toereikende) motivering vast te houden aan het subjectcriterium ondermijnt de Hoge Raad zelf de bruikbaarheid van het taakcriterium. Immers, is een (publiekrechtelijke) rechtspersoon geen openbaar lichaam dan is een beroep op immuniteit bij voorbaat uitgesloten ook al is het delict mogelijk gepleegd bij de uitoefening van een overheidstaak die alleen door bestuursfunctionarissen kan worden verricht. Dat brengt dan niet alleen een nadere verklaring van het subjectcriterium met zich mee, maar tevens een nadere motivering van het taakcriterium alsook van het verband tussen beide criteria. ${ }^{668}$

666. Brants en De Lange noemen deze kwalificatie dan ook terecht 'grillig'. Brants, C.H. en De Lange, R., o.c., 1996, 32.

667. Peters, J.A.F., l.c., 1998, 33 ,

668. Idem, 34 . 


\section{§4. Het taakcriterium}

\section{A. INLEIDING}

Reeds in het Verkeersdrempel-arrest heeft de Hoge Raad de vervolgbaarheid van overheden afhankelijk gemaakt van de hoedanigheid waarin de verdachte overheid optreedt. In tegenstelling tot het subjectcriterium kan hiervoor wel een basis worden gevonden in de Memorie van Toelichting bij artikel $51 \mathrm{Sr}$ :

'De meest voor de hand liggende differentiatie is dan wel die waarbij onderscheid wordt gemaakt al naar gelang het strafbare feit is te plaatsen in het verband van de algemene of specifieke bestuurstaak waarmee het publiekrechtelijke lichaam is belast dan wel is gepleegd binnen het kader van een ondernemingsactiviteit die ook door particulieren wordt of kan worden verricht. In het eerste geval, dus wanneer het publiekrechtelijk lichaam als bestuurder heeft gehandeld, zal de verantwoording behoren te geschieden aan de instellingen en organen die daartoe in het staats- en administratieve recht in het bijzonder zijn aangewezen [...] In het tweede geval, wanneer de publiekrechtelijke rechtspersoon als ondernemer heeft gehandeld, bestaat er geen voldoende grond haar anders te bejegenen dan privaatrechtelijke rechtspersonen die dezelfde of vergelijkbare ondernemingsactiviteiten verrichten [...] Daartegen behoeft dan ook geen bezwaar te bestaan omdat in deze gevallen niet de rol van de overheid als bestuurder en drager van het publiek gezag maar als ondernemer in het geding is. $^{.669}$

De rechtspraak van de Hoge Raad overschouwend, zien we dat het taakcriterium niet steeds dezelfde inhoud heeft gehad en dat ook verschillende bewoordingen worden gebruikt om dit criterium te omschrijven. Zo was in het Verkeersdrempel-arrest reeds sprake van immuniteit indien de overheidshandeling was gepleegd 'ter uitvoering van een overheidstaak'. In de latere arresten werd bepaald dat een dergelijke algemene en vage aanduiding van een overheidstaak niet volstaat. Het moet steeds gaan om 'een bestuurstaak op basis van een wettelijke verplichting', een 'bij of krachtens de wet aan de verdachte in het bijzonder opgedragen overheidstaak' of 'een in de wet opgedragen bestuurstaak'. Wegens de toenemende kritiek op de vergaande onvervolgbaarheid van overheden heeft de Hoge Raad in Pikmeer II dit taakcriterium nog meer aangescherpt. Immuniteit is alleen nog mogelijk

'als de desbetreffende gedragingen naar haar [hun] aard en gelet op het wettelijke systeem rechtens niet anders dan door bestuursfunctionarissen kunnen worden verricht in het kader van de uitvoering van de aan het openbaar lichaam opgedragen bestuurstaak'. ${ }^{670}$

670. HR 6 januari 1998, $N J 1998,367$ (r.o. 5.7). 
De achterliggende reden van zowel het oude als het aangescherpte taakcriterium moet worden gezocht in een poging dat wat 'strikte' overheidsgedragingen van gedragingen van particulieren onderscheidt te omschrijven. Het taakcriterium heeft dus tot doel een onderscheid te maken tussen overheid 'als zodanig' en overheid 'op gelijke voet met een particulier', acta imperii versus acta iure gestionis. Dergelijke differentiatie is niet nieuw en allerminst typisch strafrechtelijk. Het vindt onder meer zijn grondslag in een inmiddels bijna twee eeuwen lang gevoerde discussie over het onderscheid tussen publiek- en privaatrecht, de plaats van de overheid binnen deze twee rechtsgebieden en in het bijzonder de vraag in hoeverre de overheid voor een onrechtmatige daad civielrechtelijk aansprakelijk kan worden gesteld. ${ }^{671}$ In deze paragraaf worden daarom achtergrond en betekenis van dit taakcriterium nader onderzocht. In de eerste plaats wordt kort aandacht besteed aan de civielrechtelijke herkomst van de differentiatie tussen overheid als zodanig en overheid als particulier (B). Vervolgens komen enkele bezwaren tegen dergelijk onderscheid aan de orde en wordt verdedigd dat de overheid wezenlijk altijd als overheid optreedt ook wanneer deze zogenaamde privaatrechtelijke handelingen verricht (C). Tenslotte wordt bekeken of het taakcriterium, in het bijzonder de in Pikmeer II geformuleerde aanscherping, de strafrechtelijke onvervolgbaarheid van openbare lichamen voldoende kan rechtvaardigen (D).

671. Het onderscheid tussen overheid als zodanig en overheid als bijzondere (rechts)persoon heeft zijn historische wortels in de zogenaamde fiscusleer ten tijde van de absolutistische staten (of politiestaten). Deze leer moest een uitkomst bieden voor de vraag of voor de burger bij de gewone gerechten voorziening mogelijk is tegen optreden van de overheid in aangelegenheden van 'politie' (bestuur) met name in die gevallen waar door of namens de overheid aan de burger vermogensschade wordt veroorzaakt. Het woord 'fiscus' heeft dus binnen die historische context een ruimere en ook andere betekenis dan belastingfiscus. Teunissen merkt hierover op dat de fiscus-leer moet worden gezien als een procesrechtelijke doel-constructie om toch rechterlijke voorziening mogelijk te maken tegen onrechtmatige overheidsdaden in aangelegenheden van wat wij nu bestuur zouden noemen: 'die leer komt erop neer dat, voorzover het optreden van de overheid vermogensrechtelijke gevolgen heeft voor burgers, zij als fiscus opereert en hij in die hoedanigheid - op gelijke voet als andere vermogensrechtelijke subjecten - voor de gewone gerechten zou kunnen worden aangesproken.' Daar waar de overheid bij de uitoefening van 'politie' vermogensschade heeft veroorzaakt en in die zin de rechten van haar onderdanen heeft geschonden wordt dan niet tegen de overheid 'als soeverein', maar tegen de overheid 'als fiscus' een voorziening ingesteld. Later met de opkomst van de negentiende eeuwse rechtsstaten wordt de staat-fiscus gaandeweg gelijkgesteld met de burger, de particulier en wordt zo ook de staatfiscus materieel gelijkgeschakeld met de staat 'in privaatrechtelijke hoedanigheid'. Teunissen, J.M.H.F., Het burgerlijk kleed van de staat. Beschouwingen over de tweewegenleer, W.E.J. Tjeenk Willink, Zwolle, 1996, 64. Aan de oorspronkelijke zuiver procesrechtelijke ratio's van het onderscheid worden later materieelrechtelijk consequenties verbonden. Het is nu niet de bedoeling op deze boeiende rechtshistorische kwestie nader in te gaan. Duidelijk is wel dat al vóór de opkomst van de rechtsstaat het onderscheid tussen overheid 'als zodanig' en overheid 'als particulier' zijn oorsprong heeft in het vraagstuk van rechtsbescherming van de burger tegen de overheid. De vraag rijst dan of dit onderscheid enige betekenis kan hebben binnen het strafrechtelijke domein waar een geheel ander vraagstuk centraal staat, namelijk de strafrechtelijke handhaving van de rechtsorde tegen overheidscriminaliteit. De verhouding burger-overheid speelt hierbij geen rol. 


\section{B. DE OVERHEIDSHOEDANIGHEID IN HET PERSPECTIEF VAN DE ONRECHTMATIGE OVERHEIDSDAAD}

De wijze waarop de overheid optreedt - als zodanig of als bijzonder persoon - heeft in de geschiedenis van de onrechtmatige overheidsdaad een belangwekkende rol gespeeld, zij het niet steeds op een gelijke manier. Dit onderscheid in overheidshandelen heeft in eerste instantie voor een korte tijd de bevoegdheid van de gewone rechter bepaald en later een betekenis gekregen op het niveau waar het mijns inziens ook op strafrechtelijk vlak thuishoort, namelijk op het vlak van de invulling van de onrechtmatigheid van het omstreden overheidshandelen. Dat heeft dan weinig meer van doen met de vraag of de rechter bevoegd is het overheidsoptreden 'als zodanig' te toetsen maar met de zuiver materieelrechtelijke vraag wanneer dergelijk handelen een onrechtmatigheid oplevert. Uit hiernavolgend kort historisch overzicht blijkt tevens dat stilaan voor de vaststelling van de onrechtmatigheid van overheidshandelen bepalend is geworden niet zozeer in welke hoedanigheid de overheid optreedt, maar wel de mate van beleids- of beoordelingsvrijheid die aan het bestuur is toebedeeld en de wijze waarop het bestuur van deze vrijheid gebruik heeft gemaakt. Dit is ook het punt waar het in de strafrechtelijke aansprakelijkheid van overheden om zou moeten gaan, namelijk is de verdachte overheid bij de uitoefening van haar overheidstaak binnen de grenzen van wet en recht gebleven, en niet de vraag of het $\mathrm{OM}$ al dan niet ontvankelijk is wegens de hoedanigheid waarin de overheid het strafbaar feit heeft gepleegd.

Bemerk dat onderstaande beschouwingen slechts de grote lijnen weergeven van het leerstuk van de onrechtmatige overheidsdaad met als enige doel duidelijk te maken hoe groot de discrepantie is tussen wat de burgerlijke rechter en wat de strafrechter kan doen met betrekking tot de toetsing van onrechtmatig overheidsoptreden. ${ }^{672}$

\section{De overheidshoedanigheid in relatie tot de bevoegdheid van de gewone rechter}

Het onderscheid tussen overheid als zodanig en overheid als particulier speelde eind vorige eeuw voor het eerst een cruciale rol bij de vraag of de gewone (civiele) rechter in schadevergoedingsacties tegen de overheid wel bevoegd kon zijn. Klassiek is het Vrouwe Elske of Potmarge-arrest. Deze zaak had betrekking op een eis tot schadevergoeding van de eigenaar van het schip 'Vrouwe Elske', dat schade opliep door in te varen op een paal staande in gemeentewater Potmarge (Leeuwarden). De eigenaar achtte de gemeente hiervoor verantwoordelijk, daar op grond van artikel 179 onder $\mathrm{h}$ gemeentewet de gemeente de plicht had voor het onderhoud en de veiligheid van het openbaar vaarwater te zorgen. De Hoge Raad kwam tot het oordeel dat private personen aan het publiek recht alleen geen rechtsgrond kunnen ontlenen om de overheid tot zorg voor de veiligheid van een openbaar water te verplichten, en evenmin om tegen die overheid een onrechtmatige daadsactie in te stellen wegens nalatigheid in die zorg:

672. Zie over het leerstuk van de onrechtmatige overheidsdaad: Van Maanen, G.E. en De Lange, R., Onrechtmatige overheidsdaad, Deventer, W.E.J. Tjeenk Willink, 2000. 
'dat mitsdien deze vordering haren rechtsgrond zuiver en alleen vindt in het publiek recht, krachtens hetwelk de gemeente door hare regeeringsorganen optreedt als overheid, uitoefenende het openbaar gezag, waarvoor zij, als zoodanig, niet privaatrechtelijk verantwoordelijk is, en krachtens welk recht tusschen haar en private personen geen civiele rechtsband ontstaat; (...) Overwegende dat alzoo, daar in deze van geene nalatigheid in eenigerlei burgerlijkrechtelijke verplichting is gebleken, ten onrechte bij het arrest de bepalingen der artt. 1401 en 1402 B.W. toepasselijk zijn verklaard $(\ldots)^{, 673}$ (cursief, DR)'

In $1898 \mathrm{kwam}$ de Hoge Raad in het Rhedense koe-arrest tot een vergelijkbare uitspraak. In deze zaak ging het om een ontsnapte koe, die op last van de burgemeester van de gemeente Rheden werd doodgeschoten. De eigenaar van de koe achtte dit optreden onrechtmatig en stelde een vordering tot schadevergoeding in. De Hoge Raad oordeelde

\section{'...dat de al of niet rechtmatigheid van zoodanige daad van het openbaar gezag als in deze heeft plaatsgehad, uitsluitend aan het publiekrecht kan worden getoetst, en niet kan worden beoordeeld naar de bepalingen van het burgerlijk recht, als regelende de rechten en verplichtingen van bijzondere personen... ${ }^{674}$}

Ook hier meende de Hoge Raad tot niet-ontvankelijkverklaring van de vordering tot schadevergoeding te moeten overgaan om de eenvoudige reden dat een overheid, die een overheidstaak uitvoert, een overheid 'als zodanig', niet naar de bepalingen van het burgerlijk recht kan worden verantwoordelijk gesteld. Hoewel in beide zaken formeel een niet-ontvankelijkheidsoordeel werd uitgesproken, moet voor ogen worden gehouden dat de Hoge Raad de burgerlijke rechter onbevoegd achtte van de vorderingen kennis te nemen. ${ }^{675}$

Niettegenstaande deze arresten moeten worden gesitueerd in het leerstuk van onrechtmatige overheidsdaad en dus hun oorsprong vinden in het vraagstuk van de rechtsbescherming van de burger tegen overheidsoptreden is de gelijkenis met de uitspraken van de Hoge Raad inzake de strafrechtelijke aansprakelijkheid van overheden bijzonder treffend. ${ }^{676}$ Honderd jaar na dato wordt niet de burger maar het OM nietontvankelijk verklaard wanneer het gaat om zogeheten strikte overheidstaken. De

673. HR 29 mei 1896, W 6817.

674. HR 21 april 1898, W 7116.

675. Van Wijk, H.D. en Konijnenbelt, W., o.c., 1999, 675.

676. Tot deze conclusie komt ook Tak, A.Q.C., De overheid in het burgerlijk recht, 's Gravenhage, VUGA, 1997, 379-380: 'in de civiele jurisprudentie rond de eeuwwisseling lijkt de benadering ook opvallend veel op die van Kerosine, Volkel en Pikmeer. Zoals we zagen bij [...] het arrest inzake "Vrouwe Elske" of Potmarge van 1896, werd daarbij door de Hoge Raad de overheid voor de uitoefening van openbaar gezag ook niet civielrechtelijk aansprakelijk geacht. Krachtens publiekrecht bestond tussen overheid en private personen geen civiele rechtsband, zodat daaraan niet alleen geen civiele aanspraken op een handelen of een nalaten konden worden ontleend, maar evenmin schadevergoedingsaanspraken. Deze uitsluiting van civielrechtelijke aansprakelijkheid gold echter alleen de overheid die handelde "als zodanig" '. 
achterliggende reden lijkt eigenlijk min of meer dezelfde: het is de strafrechter, evenals vroeger zijn burgerrechtelijke collega, niet toegestaan overheidshandelen te toetsen. In dat opzicht is het interessant vast te stellen dat genoemde civielrechtelijke uitspraken inzake de toepasselijkheid van (oud) artikel $1401 \mathrm{BW}$ op onrechtmatig overheidshandelen historisch gezien eerder moeten worden beschouwd als incidentele afwijkingen van de toen bestaande jurisprudentie en niet zozeer als een voortzetting daarvan. ${ }^{677}$ De vraag of de gewone rechter bevoegd is om van een onrechtmatige daadsactie bij overheidsdaden kennis te nemen werd in de negentiende eeuw vrijwel steeds positief beantwoord. ${ }^{678}$ Deze bevoegdheid werd ontleend aan artikel 165 van de Grondwet van 1815:

'Alle twistgedingen over eigendom of daaruit voortspruitende regten, over schuldvordering of burgerlijk regten, behooren bij uitsluiting tot de kennis van de regterlijke magt.'

Bij gebrek aan een algemene bestuursrechtelijke rechtsbescherming leidde de gewone (burgerlijke) rechter uit deze bepaling een zeer ruime bevoegdheid af om overheidsoptreden te beoordelen. ${ }^{679}$ Een onderscheid tussen privaatrechtelijke en publiekrechtelijke geschillen werd niet gemaakt. Dat de overheid 'als zodanig' in de negentiende eeuw nooit civielrechtelijk aansprakelijk kon worden gesteld is dus een misvatting. Van Maanen merkt hierover in zijn historische analyse van de onrechtmatige overheidsdaad het volgende op:

'De wijd verbreide opvatting in de literatuur, zoals bijvoorbeeld bij Hartkamp verwoord en bij Huijgen verondersteld wordt, dat voor 1900 de overheid als zodanig in het geheel niet aansprakelijk kon worden gesteld voor - publiekrechtelijk - onrechtmatig handelen blijkt te ongenuanceerd; dat kon zeer wel, niet slechts in situaties waarin de overheid op gelijke voet deelnam aan het maatschappelijk verkeer als een particulier, maar ook in gevallen waarin het typisch, algemeen overheidshandelen betrof. De burger kon de overheid niet aanspreken op het niet-vervullen van zijn zorgplicht voor het algemeen belang. Slechts in gevallen waarin die zorg zich had geconcretiseerd in specifieke taken en de overheid in de vervulling van die taken tekort schoot, kon de overheid aansprakelijk zijn tegenover de burger die als gevolg daarvan schade had geleden.' ${ }^{680}$

677. Zie onder meer Van der Hoeven, J., De drie dimensies van het bestuursrecht; Ontstaan en vorming van het Nederlandse algemene bestuursrecht, VAR-reeks 100, Samson/H.D. Tjeenk Willink, Alphen aan den Rijn, 1989, 124; Van Maanen, G.M., De wonderbaarlijke geschiedenis van de onrechtmatige overheidsdaad in de $19 e$ en $20 e$ eeuw, Ars Aequi Cahiers Rechtsvergelijking en rechtsgeschiedenis, deel 5, Ars Aequi Libri, Nijmegen, 1996; Teunissen, J.M.H.F., o.c., 1996, 163-165; Tak, A.Q.C., o.c., 1997, 331-337 en 364-365.

678. Zie tevens Tak, A.Q.C en Bakker, R.E., 'De centrale rol van het willekeurverbod bij de toetsing van overheidshandelen', in Heringa, A.W. en Verheij, N., Publiekrechtelijke bewegingen, Deventer, Kluwer, 1990, 208-209.

679. Zie voor jurisprudentie De Vries, C.W., 'Het arrest van den Hoogen Raad van 31 december 1915 , W.v.h.R. no. 9974, aangaande de bevoegdheid van de rechterlijk macht krachtens art. 2 der Wet op de Rechterlijke Organisatie', RMThemis, 1917, 337 e.v.

680. Van Maanen, G., o.c., 1996, 54. Zie tevens Tak, A.Q.C., o.c., 1997, 364-365. 
Doorslaggevend in de rechtspraak vóór 1896 is dus of het gaat om feitelijk concreet overheidshandelen in het kader van de uitoefening van een specifieke overheidstaak ongeacht of dat handelen burgerrechtelijk is - en of dat handelen schade veroorzaakt aan een subjectief privaat vermogensbelang. Indien het een tekort schieten betreft van algemene publiekrechtelijke verplichtingen van de overheid, dan kan daaruit geen rechtsgrond voor een actie uit onrechtmatige daad worden afgeleid. Als het gaat om concrete werkzaamheden die schade veroorzaken dan is de aansprakelijkstelling van de overheid in beginsel geen probleem. Dit onderscheid ligt volgens van Maanen in de (toenmalige) opvatting dat de zelfstandige beleidsvrijheid van de overheid in het geding zou komen indien private personen ter zake van algemene taken de overheid bij de burgerlijke rechter ter verantwoording zouden kunnen roepen. $\mathrm{Bij}$ de concrete uitvoering van deze taken zou die vrijheid een minder belangrijke rol spelen. ${ }^{681}$ Het is dus van belang dat het onderscheidend criterium niet zozeer leek te liggen in de overheidshoedanigheid alswel in de mate van beleidsvrijheid:

'Alle juridische subtiliteiten weggedacht komt het erop neer dat de overheid bij het vaststellen van het algemene beleid niet door individuele burgers op de vingers gekeken wil worden. ${ }^{.682}$

Illustratief voor de ruime bevoegdheid van de burgerlijke rechter is een arrest van de Hoge Raad van 1863 waarbij de Zuidplaspolder (een openbaar lichaam) tot het betalen van schadevergoeding werd veroordeeld wegens schade die deze aan een schipper had toegebracht door een dam te leggen in een bij deze overheid in beheer zijnde ringvaart - in Pikmeer I-termen duidelijk een overheidstaak - zodat daarmee de openbare vaarweg was versperd. Het cassatiemiddel, dat daartegen geen onrechtmatige daadsactie kon worden ingesteld, wordt door de Hoge Raad als volgt verworpen:

'dat art. $1401 \mathrm{BW}$ toekent vergoeding der schade, toegebragt, door elke onregtmatige daad; dat daaronder is begrepen elk ook door een openbaar bestuur gepleegde daad, waartoe het is onbevoegd en waardoor het schade heeft veroorzaakt, hoedanige onbevoegdheden geleden schade in casu zijn uitgemaakt, en dat dus gezegd artikel terecht is toegepast; dat hetzelfde geldt ten aanzien van art. $1402 \mathrm{BW}$, hetwelk heeft eene even algemeene strekking en alleen vordert nalatigheid of onvoorzigtigheid en door een van beide veroorzaakte schade, terwijl èn nalatigheid èn daardoor geleden schade door het Hof zijn aangenomen. ${ }^{683}$

Met het Vrouwe Elske- en Rhedense Koe-arrest wordt de bevoegdheid van de burgerlijke rechter meer dan ooit ingeperkt. In deze arresten acht de Hoge Raad alleen nog bij nalatigheid in burgerrechtelijke verplichtingen van de overheid, dus verplichtingen 'evenals

681. Van Maanen, G., o.c., 1996, 75.

682. Idem.

683. HR 22 mei en 26 juni 1863, W. 2499 (Zuidplaspolder). 
elk privaat persoon', een actie uit onrechtmatige daad toelaatbaar. Naar alle waarschijnlijkheid is de ommekeer van de Hoge Raad te wijten aan het feit dat op het einde van de vorige eeuw op basis van de voorstellen van de commissie-Kappeyne van de Copello (1894) plannen waren gemaakt voor een algemene bestuursrechtspraak. ${ }^{684} \mathrm{Nu}$ deze plannen uitbleven tot en met de invoering van respectievelijk de BAB, de Arob en (uiteindelijk) de Awb betekende deze rechtspraak niet alleen een keerpunt maar ook een dieptepunt in de rechtsbescherming van de burger tegen de overheid. ${ }^{685}$ Wegens het ontbreken of beter het uitblijven van administratieve rechtspraak wordt in 1915 met het arrest Guldemond/Noordwijkerhout, in ieder geval voor wat betreft het bevoegdheidsvraagstuk, definitief afstand genomen van het onderscheid tussen overheid als zodanig en overheid als bijzondere persoon en wordt in die zin de algemene bevoegdheid van de gewone rechter om over overheidsoptreden te oordelen (her)bevestigd:

'dat art. 163 van de Grondwet van 1815, ten einde te breken met het stelsel der Fransche Administratie, waarbij deze de beslissing aan zich trok van alle geschillen, waarin de belangen van de Staat met die van andere personen in botsing kwamen, in beginsel vaststelde: "Alle twistgedingen over eigendom of daaruit voortspruitende regten, over schuldvordering of burgerlijk regten behooren bij uitsluiting tot de kennis van de regterlijke magt." - en dat als uitvloeisel van dit grondwettelijk voorschrift art. 2 R.O. van 18 April 1827 is opgenomen;

O., dat niet kan worden aangenomen, dat bovenaangehaald Grondwetsartikel eene zuivere onderscheiding wilde maken tussen privaatrechtelijke en publiekrechtelijke geschillen, welke onderscheiding in 1815 nagenoeg onbekend was, doch dat blijkens de woorden "bij uitsluiting", daarbij de gedachte heeft voorgezeten, om de macht der Administratie te beperken, en de in dat artikel genoemde rechten onvoorwaardelijke te stellen onder de hoede der rechterlijke macht;

O., dat derhalve niet het publiek- of privaatrechtelijk karakter van het geschil, maar het te beschermen recht de uitsluitende bevoegdheid der rechterlijke macht zou bepalen, gelijk nader blijkt uit den Franschen tekst van dit Grondwetsartikel: "Les contestations qui sont pour objet la proprieté ou les droits qui en derivent etc."'"686

Volgens vaste rechtspraak van de Hoge Raad verklaart sindsdien de burgerlijke rechter zich bevoegd mits de eiser zich maar beroept op een subjectief burgerlijk recht. Doorslaggevend voor de bevoegdheid van de rechter is niet langer de vraag of de rechtsbetrekking, de vinculum iuris, of de grondslag van de vordering, het fundamentum petendi, privaatrechtelijk is, maar de aard van het voorwerp van het geschil, het objectum litis, dat wordt bepaald door de vraag van de eiser om beschermd te worden in een burgerlijk recht. Of de

684. Zie hierover Teunissen, J.M.H.F., o.c., 1996, 164; Tak, A.Q.C., o.c., 1997, 336.

685. Zie hierover Van Maanen, G., o.c., 1996, $46-47$ en Tak, A.Q.C., o.c., 1997, 335-336.

686. HR 31 december 1915, $N J$ 1916, 407; AB Klassiek nr. 3 (Guldemond/Noordwijkerhout). 
burgerlijke rechter bevoegd is kennis te nemen van vorderingen tegen de overheid is sinds Guldemond/Noordwijkerhout onbetwist. ${ }^{687}$

Deze ruime bevoegdheidsopvatting van de civiele rechter levert natuurlijk wel problemen op indien tegen het omstreden besluit of handeling een bijzondere bestuursrechtelijke voorziening openstaat (probleem van dubbele competentie), zodat in beginsel twee instanties zouden kunnen worden geroepen een oordeel te vellen over hetzelfde overheidshandelen. Dit positief competentieprobleem werd door de Hoge Raad opgevangen via de ontvankelijkheidsvraag. Is de burgerlijke rechter bevoegd, hetgeen het geval is eens de eiser een burgerlijk recht heeft gesteld, dan verklaart hij de vordering alsnog niet-ontvankelijk indien en voor zover er tegen het betwiste besluit of handeling een bijzondere met de nodige rechtswaarborgen omringde rechtsgang openstaat of opengestaan heeft. De burgerlijke rechter is dus aanvullende rechter. ${ }^{688}$ Men kan alleen op hem beroep doen voor zover er geen adequate rechtsbescherming kan worden geboden met behulp van een administratiefrechtelijke rechtsgang. ${ }^{689}$

Op basis van deze korte civielrechtelijke uitstap is het reeds mogelijk enkele voorlopige conclusies te trekken over de bevoegdheid van de gewone rechter, dus ook de strafrechter, overheidshandelen te beoordelen. In de eerste plaats wordt duidelijk dat de overheidshoedanigheid (al lang) geen beletsel meer is voor de bevoegdheid van de gewone rechter om over overheidshandelen te oordelen. De burgerlijke rechter haalt deze bevoegdheid uit de Grondwet (huidig artikel $112 \mathrm{Gw}$ ). Dit uitgangspunt geldt niet minder voor de strafrechter. Hij is immers bevoegd te oordelen over strafbare feiten op basis van artikel $113 \mathrm{Gw}$. In de tweede plaats zien we dat de burgerlijke rechter in bepaalde gevallen een civiele vordering niet-ontvankelijk verklaart vanwege een concurrentieprobleem met de administratieve rechter. Een dergelijk competentieconflict op het vlak van de rechtsbescherming bestaat echter niet tussen de administratieve rechter en de strafrechter en kan dus ook geen reden zijn om strafrechtelijke controle uit te sluiten door het OM a priori nietontvankelijk te verklaren als het gaat om zogezegd strikt overheidshandelen. De ratio van de niet-ontvankelijkheid van het OM kan moeilijk liggen in het feit dat de taak van de strafrechter conflicteert met de taak van de administratieve rechter. Beide rechters hebben een zelfstandige van elkaar onderscheiden functie.

687. Voorbeelden van latere jurisprudentie: HR 9 november 1973, $N J$ 1974, 91 (Limmen/Houtkoop); HR 23 juni 1989, NJ 1991, 673 met noot Scheltema (CGN/Nieuwegein II); HR 5 februari 1993, AB 1993, 239 met noot Van der Burg (Welzijnsconvenant Rotterdam; HR 28 februari 1992, AB $1992,301)$. Uiteindelijk heeft de onbegrensde bevoegdheidsgrondslag voor civiele vorderingen er zelfs toe geleid dat, omgekeerd, ook de overheid ter behartiging van publieke belangen via art. 6:162 BW dwingend kan optreden tegen haar burgers. Zie onder meer HR 14 april 1989, $N J$ 1990, 712 (Benckiser); HR 18 februari 1994, Rawb 1995, nr. 47 (Kabayel). Voor een helder kritisch commentaar op deze ontwikkeling zie Teunissen, J.M.H.F en Tak, A.Q.C., 'Recht ist was der Umwelt nutzt?', NJB, 1994, 610-612.

688. Van Wijk, H.D. en Konijnenbelt, W., o.c., 1997, 677.

689. HR 22 februari 1957, $N J$ 1957, 310 (Schel- en Deuropeners); HR 25 november 1977, $N J 1978$, 255 (Loosdrechtse plassenschap); HR 17 juni 1983, NJ 1984, 148 met noot Scheltema (afgifte visum); 19 maart 1982, NJ 1983, z77 met noot Scheltema (Rozenberg/Heldemond); HR 9 oktober 1987, $A B$ 1987, 148 met noot Van der Burg (nieuwe samenleving) 
Het onderscheid tussen overheid als zodanig en overheid als particulier had sinds 1915 nog niet alle belang verloren. Het speelde weliswaar geen rol meer bij het bevoegdheidsvraagstuk, evenmin bepaalde het de ontvankelijkheid van de eiser, het bleef wel geruime tijd een rol spelen bij de vraag of het schadeveroorzakende overheidsoptreden onder het civielrechtelijke onrechtmatigheidsbegrip te brengen is. Deze vraagstelling is ook vanuit strafrechtelijk oogpunt van belang omdat, zoals gezien, de literatuur reeds lang bepleit dat een differentiatie in overheidshandelen niet zozeer behoort een rol te spelen bij de ontvankelijkheid van het OM, maar bij de vraag of de ten laste gelegde gedraging als wederrechtelijk (strafrechtelijk onrechtmatig) moet worden beschouwd. Wat nietexclusieve overheidstaken betreft, heeft de Hoge Raad inmiddels, sinds Pikmeer II, de mogelijkheid geopend strafbare overheidsgedragingen te toetsen.

Zoals bekend heeft de Hoge Raad met het beroemde Lindenbaum/Cohen-arrest de onrechtmatigheidsgronden uitgebreid met 'strijd met de zorgvuldigheid die in het maatschappelijk verkeer betaamt ten aanzien van eens anders persoon of goed'. ${ }^{690}$ Welnu, deze uitbreiding werd in het begin door de Hoge Raad niet op de overheid van toepassing verklaard, wanneer deze 'als zodanig' en niet 'op gelijke voet als een particulier' was opgetreden. Zo oordeelde de Hoge Raad in het Strooppot-arrest dat de zorgvuldigheidsnorm
'Slechts ziet op het verkeer tussen bijzondere personen onderling, daaronder begrepen het verkeer, waaraan de Overheid op gelijken voet als een bijzonder persoon deelneemt, zoodat voormelde norm niet beheerscht die gevallen, waarin aan de Overheid niet anders of meer wordt verweten, dan dat zij door tekort te schieten in haar verplichtingen om de taak, die op haar als zoodaanig rust naar behooren te vervullen, belangen heeft gekrenkt. $^{.691}$

Uit latere rechtspraak blijkt dat de grens tussen beide soorten overheidshandelingen niet altijd even duidelijk te trekken is. Men krijgt ook stellig de indruk dat het begrip 'overheid handelende op gelijke voet als een bijzonder persoon' omwille van de rechtsbescherming ruimer wordt opgevat of in ieder geval, al naar gelang de voorliggende casus, 'anders' wordt ingevuld. Zo werd in het Meerboei-arrest de gemeente Amsterdam aansprakelijk geacht voor de schade die aan een schip was toegebracht door een kapotte boei in de Minervahaven:

'dat immers het wettelijk begrip "onrechtmatige daad" omvat niet slechts een handelen of nalaten, dat inbreuk makt op eens anders recht of in

690. HR 31 januari 1919, $N J$ 1919, 161. De onrechtmatigheidsgronden zijn nu opgenomen in art. 6:162 BW.

691. HR 29 juni $1928, N J 1928,684$. 
strijd is met des daders rechtsplicht, maar ook een handelen of nalaten, dat indruischt tegen de zorgvuldigheid, welke in het maatschappelijk verkeer betaamt ten aanzien van eens anders persoon of goed; dat ook de Overheid zich kan schuldig maken aan zoodanig handelen of nalaten, wanneer zij aan dat verkeer deelneemt op gelijken voet als een bijzonder persoon door handelingen te verrichten, die naar haar aard niet slechts door de Overheid maar ook door een bijzonder persoon kunnen worden verricht;

dat dit het geval is, wanneer een gemeente, zij het ter vervulling van haar Overheidstaak, in een voor het publiek toegankelijk water boeien beschikbaar stelt om schepen daaraan te meren. ${ }^{692}$

Het beschikbaar stellen van boeien is blijkbaar een handeiing verricht op gelijken voet als een particulier, terwijl de overheidshandeling in de Strooppot-casus, het bevaarbaar houden van een openbaar vaarwater, moet worden beschouwd als iets dat alleen door de overheid kan worden verricht. Interessant, ook vanuit strafrechtelijk oogpunt, is dat volgens de Hoge Raad het hier gaat om een handeling ter uitvoering van een overheidstaak, maar die 'naar haar aard' ook door particulieren kan worden verricht zodat de maatschappelijke zorgvuldigheidsnorm van toepassing is. We zien dat hier min of meer een gelijk criterium wordt gehanteerd als in Pikmeer II: kan de betwiste gedraging worden verricht door een particulier en niet slechts door de overheid zelf.

De overheid is dus, wanneer er niet over een inbreuk op een subjectief burgerlijk recht wordt geklaagd, maar over de schending van een maatschappelijke zorgvuldigheidsnorm, niet aansprakelijk wanneer zij 'als zodanig' is opgetreden en dat is het geval wanneer een gedraging in het geding is die niet anders dan door de overheid kan worden uitgevoerd. De uitsluiting van de norm van 'maatschappelijke zorgvuldigheid' op dergelijk overheidshandelen is enigszins begrijpelijk gelet op het typisch materieel burgerrechtelijk karakter van deze onrechtmatigheidsnorm. Onrecht dat zijn basis vindt in de publieke taakvervulling kan moeilijk aan de hand van het criterium van maatschappelijke onzorgvuldigheid worden beoordeeld. ${ }^{693}$ De Hoge Raad bleek dan ook vlug bij zuiver overheidshandelen een andere ongeschreven maatstaf te hanteren, namelijk of de overheid 'bij afweging van alle in aanmerking komende belangen in redelijkheid tot haar beslissing of handeling had kunnen komen.' Hiermee ontsnapt de overheid als zodanig niet langer aan de rechterlijke controle en wordt stilaan bepalend de toetsing van de beleids- en beoordelingsvrijheid van het bestuur aan geschreven en ongeschreven recht (algemene beginselen van behoorlijk bestuur).

692. HR 5 mei 1933, $N J$ 1933, 875 met noot Meijers (Meerboei).

693. Meijers, E.M., 'De onrechtmatige overheidsdaad', deel II, WPNR, 1925, 2884, 241-244; Van Maarseveen, H.Th.J.F., 'Een opmerking over de onrechtmatige overheidsdaad', NJB, 1954, 914920; Teunnisen, J.M.H.F., o.c., 1996, 167-169. 


\section{De toetsing van zuiver overheidshandelen en de beleidsvrijheid}

Een pril begin van toetsing van zuiver overheidshandelen aan bestuursrechtelijke normen door de burgerlijke rechter kan worden gevonden in het De Boer-arrest. Deze zaak gaat over een dienstplichtige militair in de mobilisatietijd die de staat aansprakelijk wilde stellen voor zijn blijvende invaliditeit ontstaan door het gebrekkige regime van huisvesting en verzorging waaraan hij onderworpen is geweest. De Hoge Raad oordeelt

'dat in deze slechts dan onrechtmatig in den zin van artikel $1401 \mathrm{BW}$ is gehandeld, indien de invaliditeit van De Boer is veroorzaakt door een gedragslijn te zijnen aanzien, die redelijkerwijs niet meer is te beschouwen als uitvloeisel van afweging door de militaire organen van de hun toevertrouwde belangen, doch die kennelijk slechts wijst op door de omstandigheden niet te verontschuldigen misbruik van bevoegdheid.'

Daarvan was in casu volgens de Raad geen sprake. Wel wordt uitdrukkelijk vastgesteld, dat, wanneer er door de omstandigheden een niet te verontschuldigen misbruik van bevoegdheid zou hebben bestaan, aansprakelijkheid voor de geleden schade in de rede ligt. ${ }^{694}$

In het Heldenkermis-arrest ${ }^{695}$ en het Zandvoortse Woonruimtevordering-arrest ${ }^{696}$ zet de Hoge Raad de toetsing via een controle op détournement de pouvoir nog voort. In beide arresten wordt de leer van het 'freies Ermessen' erkend. Dit betekent dat de wettelijke omschrijving van de overheidstaak, de aard van de taak alsook de omstandigheden waarin deze moet worden vervuld voor de overheid in kwestie een vrijheid impliceren om naar eigen inzicht te handelen. ${ }^{697}$ Met het Doetinchemse Woonruimtevordering-arrest blijkt het 'freies Ermessen' niet absoluut te zijn en wordt de toetsing ervan via de willekeurformule tot uitdrukking gebracht:

'dat voor tussenkomst van den rechter zou kunnen zijn, indien de vordering als een daad van willekeur zou zijn aan te merken; dat deze figuur zich voordoet, als moet worden aangenomen, dat de vorderende autoriteit bij afweging van de in aanmerking komende belangen in redelijkheid niet tot een vordering had kunnen komen, en dus afweging van die belangen geacht moet worden niet te hebben plaats gehad. ${ }^{698}$

Aanvankelijk werd nog aangenomen dat vrij overheidshandelen, dus wanneer sprake is van beleidsvrijheid, niet rechtstreeks kon worden getoetst aan de algemene beginselen van

694. Vgl. Van Oordt, W.C., Overheidsaansprakelijkheid in Belgiě en Nederland. Een rechtsvergelijkende studie, Amhem, G.W. van der Wiel \& Co, 1963, 63.

695. HR 29 maart 1940, NJ 1940, 1128.

696. HR 14 januari 1949, $N J 1949,557$.

697. Tak, A.Q.C. en Bakker, R.E., 'De centrale rol van het willekeurverbod bij de toetsing van overheidshandelen', in Heringa, A.W. en Verheij, N. (red.), o.c., 1990, 211.

698. HR 25 februari 1949, NJ 1949, 558. 
behoorlijk bestuur (a.b.b.b.'s), hetgeen betekende dat alleen onder bepaalde omstandigheden een schending van a.b.b.b.'s willekeur kon opleveren. Aan willekeur kon, sinds het Doetinchemse Woonruimtevordering-arrest, immers wel worden getoetst:

'...dat een rechtstreeks toetsen aan de algemene beginselen van behoorlijk bestuur, zoals art. 5 Wet Administratieve rechtspraak bedrijfsorganisatie deze ten aanzien van de daarin bedoelde handelingen en besluiten opdraagt aan den daar aanwezigen administratieven rechter, daarom in het bijzonder ten aanzien van de belangenafweging waarop een woonruimtevordering berust, buiten ten dezen aanzien voor den burgerlijken rechter bestaande taak valt, al is dan niet uitgesloten dat die beginselen binnen het kader van de beoordeling van de vraag of de vorderende autoriteit in redelijkheid tot zijn besluit heeft kunnen komen, onder omstandigheden in het oordeel van den rechter zullen kunnen worden betrokken... ${ }^{.699}$

Deze rechterlijke terughoudendheid is bekend geworden onder de noemer 'marginale toetsing'. Met het Amsterdam/lkon-arrest kwam echter een einde aan deze restrictieve toetsing en werd een rechtstreeks toetsing van alle overheidshandelen door de burgerlijke rechter aan de a.b.b.b.'s volledig aanvaard:

'Een overheidslichaam behoort bij het uitoefenen van zijn bevoegdheden uit een erfpachtbeschikking de algemene beginselen van behoorlijk bestuur - en derhalve ook het gelijkheidsbeginsel als een van die beginselen - in acht te nemen. Voor zover het slot van het onderdeel onder a, betoogt dat het gelijkheidsbeginsel hier slechts aan de orde zou kunnen komen in het kader van de toepassing van een aan de overheid meer ruimte latende redelijkheidsmaatstaf en daarom hier een zwakkere werking dan in het bestuursrecht zou hebben, gaat het uit van een onjuiste rechtsopvatting ${ }^{1700}$

In dit verband past het op te merken dat het eigenlijk niet helemaal juist is te spreken van marginale toetsing door de burgerlijke rechter. De rechter toetst alleen de rechtmatigheid en niet de doelmatigheid van een overheidshandeling: hij toetst steeds aan het objectieve recht. Marginale toetsing is verwarrend omdat het suggereert dat er geen volle toetsing aan het recht plaatsvindt door de rechter. Dat is niet het geval. Reeds vóór Amsterdam/lkon toetste de burgerlijke rechter 'vol' aan het recht, zij het niet aan alle rechtsnormen. Voor een duidelijk begrip van wat de rechterlijke controle inhoudt, is het daarom wellicht beter de term 'marginale toetsing' te laten vallen. Zoals Tak terecht opmerkt:

699. HR 4 januari 1963, $N J 1964,202-204$ (Landsmeer-arresten).

700. HR 27 maart 1987, $N J$ 1987, 727. Zie reeds HR 27 juni 1987, $N J$ 1987, 726 (Tolkentarieven); Zie ook HR 12 januari 1990, $A B$ 1991, 430 met noot Van Ommeren (Staat/Appels); HR 24 april 1992, $A B$ 1992, 542 (Zeeland/Hoondert). 
'Het onbegrip "marginale toetsing" heeft al te lang het juiste zicht belemmerd op de rechterlijke taak tot toetsing van overheidshandelingen. Toetsing aan het recht dient volledig te zijn; slechts ten aanzien van de vraag of iets vatbaar is voor rechterlijke controle kan terughoudendheid gepast zijn. ${ }^{701}$

Duidelijk is geworden dat waar aanvankelijk de burgerlijke rechter zich van een beoordeling onthoudt en vervolgens zich terughoudend opstelt (willekeurtoets), hij nu ook het vrije overheidshandelen volledig toetst aan het recht, inclusief aan de a.b.b.b.'s. Civielrechtelijke aansprakelijkheid van de overheid omvat mede aansprakelijkheid voor schade ontstaan uit handelingen die bij uitstek op het terrein van de publieke takuitoefening liggen en waarbij de overheid over een beleidsvrijheid beschikt. Daarmee staat in schril contrast de onmogelijkheid van het $\mathrm{OM}$ om strafbare feiten gepleegd door de overheid binnen de uitvoering van zogenaamde 'strikte' overheidstaken te vervolgen om daarover van de strafrechter een onrechtmatigheidsoordeel te verkrijgen. Niet valt in te zien waarom de burgerlijke rechter inmiddels wel dergelijk overheidsoptreden aan het recht kan toetsen en de strafrechter niet.

\section{EEN ZUIVERDER UITGANGSPUNT: DE OVERHEID TREEDT ALTIJD OP 'ALS ZODANIG'}

Hoewel reeds op basis van het voorgaande is gebleken dat de zogenaamde twee petten van de overheid in de praktijk geen beletsel hoeven te zijn voor rechterlijke controle, derhalve evenmin voor strafrechtelijke controle, is het aardig nader te bekijken of een onderscheid tussen overheid als zodanig en overheid als bijzondere persoon ook op theoretische gronden vol te houden is. Anders en in termen van de Pikmeer-rechtspraak geformuleerd, rijst de vraag of niet iedere gedraging van de overheid uiteindelijk wordt verricht ter uitvoering van een overheidstaak en haar grondslag moet vinden in een publiekrechtelijke bevoegdheid zodat ter afbakening van de vervolgbaarheid enig onderscheid in overheidshoedanigheid uiterst formalistisch en betwistbaar is.

De kwestie wanneer een overheidslichaam bij een bepaalde handeling 'als zodanig' is betrokken, werd in de loop der tijd verschillend beantwoord. ${ }^{702}$ Zoals reeds opgemerkt, zijn de criteria waarmee men het onderscheid in twee soorten overheden heeft willen onderbouwen onlosmakelijk verbonden met de maatstaven waarmee men de regels van

701. Tak, A.Q.C., o.c., 1997, 367 en 36-38. Scheltema drukt het als volgt uit: 'Het is verwarrend dat in dit verband nog wel het begrip "marginale"toetsing wordt gebruikt. Soms wordt daarmee bedoeld dat de rechter de beleidsvrijheid van het bestuur moet respecteren, zodat de beoordeling van de rechter een andere moet zijn dan die van het bestuur. Dat laatste is - indien inderdaad beleidsvrijheid bestaat - juist. Maar dat neemt niet weg dat ook dan het bestuur aan het recht gebonden is en tot dat recht behoren ook de beginselen van behoorlijk bestuur. Wanneer de rechter nagaat of het bestuur het recht heeft gerespecteerd, zal hij dus niet "marginaal" aan de wet of aan die beginselen toetsen, maar direct en zonder enige terughoudendheid.' Scheltema, M., l.c., 1993, 32.

702. Zie voor een uitstekend (historisch) overzicht terzake: Simon, H., Publiekrecht of Privaatrecht? Een geschiktheidsonderzoek aan de hand van het nutsmaximalisatiebeginsel toegespitst op het gebruik van het privaatrecht door het bestuur, Zwolle, W.E.J. Tjeenk Willink, 1993, 73-84. 
publiekrecht van die van privaatrecht heeft willen onderscheiden. Een ook vanuit strafrechtelijk oogpunt interessante benadering kan bijvoorbeeld worden gevonden in de opvatting van Van Praag. Van Praag neemt als uitgangspunt dat publiekrechtelijk slechts die verhouding is waarbij de overheid 'als zodanig' partij is, of, zoals hij nader uitwerkt, een verhouding voortspruitende uit rechtshandelingen, waarvan het voorwerp de overheidstaak van een overheidslichaam inhoudt. ${ }^{703}$ In zijn visie is het criterium ter beantwoording van de vraag of een rechtsverhouding publiek- dan wel privaatrechtelijk is, of de overheid als zodanig dan wel op gelijke voet met een bijzondere persoon handelt, gelegen in de vraag of het object van de rechtsverhouding al dan niet een overheidstaak uitmaakt.

Hier kan duidelijk een verband worden gelegd met het door de strafkamer van de Hoge Raad ontwikkelde taakcriterium. Ook de Hoge Raad neemt immers de 'echte' overheidstaak als cruciaal criterium voor een differentiatie tussen overheid als zodanig en overheid als bijzondere persoon. Het standpunt van Van Praag is echter fel bekritiseerd geworden. ${ }^{704} \mathrm{Zo}$ vraagt Scheltema zich af hoe men in concreto kan vaststellen wanneer de overheid inderdaad als zodanig optreedt. ${ }^{705}$ Scheltema ziet deze vraag niet beantwoord aan de hand van de rechtsverhouding, maar aan de hand van de rechtsregel, namelijk door na te gaan of het publiekrecht, dan wel het privaatrecht toepasbaar is. De toepasselijkheid van bepaalde rechtsregels kan alleen via het objectieve recht worden bepaald omdat er geen rationeel, aan de innerlijke waarde van de geregelde materie gerelateerd, criterium te vinden is.

'Of zekere verhouding publiek-, dan wel privaatrechtelijk is, moet in laatste instantie door het positieve recht worden uitgemaakt (...) Een verhouding is dan privaatrechtelijk en m.a.w. onderworpen aan het privaatrecht, wanneer het objectieve privaatrecht meer of minder uitdruk-

703. Van Praag, L., Op de grenzen van publiek-en privaatrecht, 's-Gravenhage, 1930, 9.

704. Zie o.m. Scheltema, F.G., 'Het grensterrein van publiek en privaatrecht', RMThemis, 1927, 233265. Scheltema heeft het betoog van Van Praag bestreden onder meer door er op te wijzen, dat de overheid altijd 'als overheid' optreedt, dat wil zeggen ter behartiging van een publieke taak. Zie ook Vegting, M.G., Het Algemeen Nederlands Administratiefrecht, deel II, Alphen aan den Rijn, 1957, 3-78 en Van der Hoeven, J., 'De magische lijn. Verkenningen op de grens van publiek- en privaatrecht', in Honderd jaar rechtsleven, Zwolle, W.E.J. Tjeenk Willink, 1970, 201-219. Deze laatste merkt onder andere op: 'L. van Praag heeft (...) betoogd, dat het onderscheid tussen deze beide rechtsgebieden dient te worden gevonden in het optreden van de overheid, al of niet "als zodanig"'(...) Met anderen meen ik dat dit ten onrechte geschiedt. Het komt mij voor, dat een gedachtegang als die, welke wordt verdedigd door Van Praag, voortvloeit uit de doorwerking van een monistische soevereiniteitsgedachte, die het criterium voor de speciale behandeling welke het recht toekent aan sommig overheidshandelen zoekt in de kwaliteit van het handelend orgaan en niet in de door de rechtsorde erkende strekking van de bewuste handeling.

705. Zie onder meer ook Kobussen, M., De vrijheid van de overheid. Een vergelijking van de privaatrechtelijke en bestuursrechtelijke beoordelingskaders om te komen tot een beantwoording van de vraag of, en in hoeverre het privaatrecht voor de overheid remplaçant kan zijn voor het bestuursrecht, Zwolle, W.E.J. Tjeenk Willink, 1991, 31: 'Waaruit precies die bijzondere aard (van een publiekrechtelijke verhouding, DR) bestaat, wordt in het werk van Van Praag niet geheel duidelijk. Behartiging van algemeen belang is niet (alleen) het onderscheidend criterium, omdat dit volgens hem door middel van "privaatrechtelijke" overeenkomsten kan worden behartigd.' 
kelijk die verhouding regelt; zij is publiekrechtelijk, wanneer het objectieve publieke recht zich harer heeft aangetrokken. ${ }^{706}$

Hoe spitsvondig deze redenering ook moge zijn, veel soelaas brengt ze niet. Men komt onvermijdelijk in een vicieuze cirkel terecht waarbij de overheid als zodanig optreedt als het publiekrecht van toepassing is en het publiekrecht (slechts) van toepassing is als de overheid als zodanig optreedt. ${ }^{707}$

In het algemeen kan worden vastgesteld dat de pogingen in de doctrine om een onderscheidend criterium te vinden tussen overheid als zodanig en overheid als particulier geen van alle echt zijn geslaagd:

'Voor een niet onbelangrijk deel moet worden geconstateerd dat het resultaat bestaat uit cirkelredeneringen. Voor het overige blijken de pogingen de maatschappelijke werkelijkheid niet geheel te dekken en/of niet volledig bestand tegen wetenschappelijke kritiek. ${ }^{708}$

Het lijkt mij daarom verstandiger enig principieel onderscheid tussen de overheid als zodanig en overheid als bijzondere persoon - op welke wijze ook ingevuld - wat betreft de toepasselijkheid van het recht op het overheidshandelen, derhalve ook strafrecht, af te wijzen. In de eerste plaats omdat een dergelijk onderscheid zowel theoretisch als praktisch nauwelijks op eenduidige wijze kan worden gemaakt. In de tweede plaats omdat het zuiverder is ervan uit te gaan dat uiteindelijk de overheid steeds 'als zodanig' optreedt en, wegens haar natuur, nooit anders dan 'als zodanig' kan optreden.

Met welk overheidsoptreden men ook te maken krijgt, steeds dient als uitgangspunt te worden genomen dat de overheid slechts

'... één alomvattende taak heeft: het behartigen van het algemeen belang. Daarin onderscheidt zij zich van haar "onderdanen", die dit belang wel kunnen en mogen behartigen, doch dat niet behoeven te doen. De overheid behoort evenwel steeds haar hiervoor genoemde taak te vervullen, mag ten dien aanzien nimmer verstek laten gaan. $\mathrm{Zij}$ mag zich

706. Scheltema, F.G., l.c., 1927, 233. De kritiek van Scheltema op de opvatting van Van Praag is tevens een kritiek van algemene aard en geldt tot op zekere hoogte ook voor andere pogingen om een inhoudelijk onderscheid tussen soorten overheden te maken. Immers, steeds komt hetzelfde probleem naar voren namelijk dat de hoedanigheid waarin de overheid optreedt afhankelijk wordt gemaakt van de vraag in welke rechtsverhouding de overheid is betrokken en dat vraagt inhoudelijke maatstaven, waarover meer meningsverschil dan eenstemmigheid te vinden is. Zie ook Tak, A.Q.C., Overheidsbestuur en privaatrecht, Alphen aan den Rijn, Samsom Uitgeverij, $1978,76$.

707. Kobussen, M., o.c., 1991, 32.

708. Tak, A.Q.C., 'Drie magische lijnen', Ars Aequi, 1987, 281. 
niet van haar hermelijnen mantel ontdoen. Anders gezegd: zij treedt, ipso facto, "als zodanig" op. 709

In feite gaat het om de vraag naar het doel en de legitimatie van het bestaan van een overheid. De overheid heeft slechts één bestaansreden en dus één taak, te weten het behartigen van het algemene belang. $\mathrm{Nu}$ is dit begrip erg vaag en tijd- en plaatsgebonden. We hebben reeds vastgesteld dat het een belangrijk machtswoord kan zijn, dat bijvoorbeeld in het Volkel-arrest wordt aangegrepen als rechtvaardiging voor de staatsimmuniteit. Maar het is belangrijk te beseffen dat de invulling van het algemeen belang geschiedt niet op een statische maar dynamische wijze. Sommigen zijn dan ook de mening toegedaan dat wat met algemeen belang kan worden aangeduid veeleer dient te worden beschouwd als een groepsbelang of een gemeenschappelijk belang. ${ }^{710} \mathrm{Er}$ kan wellicht ook veeleer worden gesproken van verschillende 'algemene belangen' dan van één algemeen belang. Als criterium kan dan worden genomen al de belangen waarvan het niet wenselijk of mogelijk is dat zij (in beginsel) door particulieren worden behartigd. ${ }^{711}$ Waarbij wel moet worden opgemerkt dat ook hier met enige marge rekening moet worden gehouden. In zekere zin zou men kunnen stellen dat de 'eigenbelangen' van de overheid noodzakelijkerwijs gemeenschapsbelangen zijn, waarvan de belangen niet gelijk kunnen en mogen zijn aan de belangen van bepaalde particulieren. Zeker is in ieder geval dat de vaststelling van de overheid, dat bepaalde belangen door haar moeten worden behartigd - wat niet hoeft te betekenen dat particulieren a priori deze behartiging wordt ontnomen - deze belangen tot algemene belangen maakt en dat de vaststelling zelf een zaak van algemeen belang is. Daarbij aansluitend is 'het optimaal vervullen en behartigen van al deze taken en belangen (...) in wezen het algemeen belang. ${ }^{, 712}$

De onbepaaldheid van het algemeen belang belet evenmin dat de overheid dit belang telkens moet kunnen behartigen. Het doet ook geen afbreuk aan het uitgangspunt dat de overheid geen eigen belangen kan hebben en dat het dus een contradictio in terminis is te beweren dat de overheid als een particulier, dus uit een bijzonder (eigen)belang, zou kunnen handelen. $^{713}$

Het uitgangspunt dat fundamenteel de overheid altijd als overheid optreedt, laat natuurlijk onverlet dat deze overheid niet alleen overheidsbevoegdheden ${ }^{714}$ kan uitoefenen; zij kan ook (als publiekrechtelijke rechtspersoon) naar burgerlijk recht aan het rechtsverkeer

709. Spier, J., Overeenkomsten met de overheid, Deventer, 1981, 10.

710. Zie Kleerekoper, S., De fictie van het algemeen belang, Deventer, Kluwer, 1964, 14.

711. Tak, A.Q.C., o.c., 1978, 88 e.v.

712. Idem, 87 .

713. Ackermans-Wijn, J.F.C., Contracten met de overheid, Deventer, Kluwer, 1989, 48: 'Kernpunt is m.i. dat de overheid geen eigen belang heeft, maar altijd gehouden is het algemeen belang te dienen. Deze verplichting vloeit voort uit de aard van het overheidsgezag. Buiten de behartiging van het algemeen belang heeft de overheid geen taak, ja zelfs geen bestaansrecht.'

714. Overheidsbevoegdheid kan wellicht het best worden omschreven als de bevoegdheid positief recht vast te stellen en te handhaven. Zie Stroink, F.A.M. en Steenbeek, J.C., Inleiding in het staats- en bestuursrecht, Alphen aan den Rijn, Samsom, 1993, 30 e.v. 
deelnemen. Om een inmiddels overbekend voorbeeld aan te halen: een gemeente kan potloden kopen. ${ }^{715}$ Een overheid kan privaatrechtelijk handelen, kan gebruik maken van privaatrechtelijke rechtsfiguren. Maar dat betekent nog niet dat hiermee de overheid niet langer handelt binnen het kader van haar publieke taak of daarmee optreedt 'op gelijke voet als een bijzondere persoon'. Daarmee houdt verband de precaire vraag of de overheid naast overheidsbevoegdheden ook privaatrechtelijke bevoegdheden heeft. Zoals bekend gaat de Hoge Raad er vanuit, dat een overheid haar publieke taak, behalve door middel van het publiekrecht,

\begin{abstract}
'ook mag behartigen door gebruik te maken van haar in beginsel krachtens het privaatrecht toekomende bevoegdheden, zoals aan het eigendomsrecht ontleende bevoegdheden, de bevoegdheid een overeenkomst naar burgerlijk recht te sluiten of de bevoegdheid een vordering op grond van een jegens haar gepleegde onrechtmatige daad bij de burgerlijke rechter in te stellen. ${ }^{716}$
\end{abstract}

Welnu, zelfs indien de overheid over privaatrechtelijke bevoegdheden beschikt - wat kan worden betwijfeld -, dan nog blijft staan dat dit gebeurt ter uitoefening van haar publieke taak. Zo zal de aankoop van potloden (computers is meer van deze tijd) bijvoorbeeld geschieden binnen het kader van het verlenen van vergunningen of het opstellen van processen-verbaal, hetgeen (ook in termen van Pikmeer II) exclusieve overheidstaken zijn. Maar meer fundamenteel kan worden betwist of overheidslichamen net als particulieren beschikken over in beginsel aan hen toekomende privaatrechtelijke bevoegdheden. Tak zegt hierover het volgende:

'De vraag naar het axioma van 'Windmill', waar de gemene rechtsleer sinds haar ontstaan evenwel aan voorbij gaat, is de vraag naar de publiekrechtelijke toelaatbaarheid van privaatrechtelijk handelen door de overheid. De vraag naar de bevoegdheid van de overheid tot privaatrechtelijk handelen wordt door de gemene rechtsleer uitsluitend beantwoord vanuit het BW (art. 2:1). Publiekrechtelijk legt deze bepaling

715. Stroink zegt hierover het volgende: 'Nu ligt de zaak van de potloodkopende Staat vrij eenvoudig, maar dit is niet altijd zo. In vele gevallen heeft de privaatrechtelijk optredende overheid een grote feitelijk machtspositie en soms zelfs een monopoliepositie (denk bijvoorbeeld aan verkoop van grond of erfpachtcontracten). Recentelijk heeft de HR de neiging dit privaatrechtelijk overheidsoptreden te laten beheersen door algemene beginselen van behoorlijk bestuur, of wellicht beter uitgedrukt, open privaatrechtelijke begrippen in te kleuren met beginselen van behoorlijk bestuur (zie HR 13 maart 1981, NJ 1981, 346 (Ockenburg) en HR 27 maart 1987, AB 1987, 273 (Ikon erfpacht). Hier wordt geanticipeerd op art. 3:14 BW dat luidt: 'een bevoegdheid die iemand krachtens het burgerlijk recht toekomt, mag niet worden uitgeoefend in strijd met geschreven of ongeschreven regels van het publiekrecht.' Ook de Algemene wet bestuursrecht bevat een soortgelijke bepaling (art. 3:1, lid 2). Een ander punt is dat dergelijke overeenkomsten geld kosten, dat wil zeggen gefinancierd worden uit de algemene middelen.' Stroink, F.A.M. en Steenbeek, J.C., o.c., 1993, 41.

716. HR 26 januari 1990, $N J$ 1991, 393 met noot Scheltema, M.; zie tevens Hennekens, H., 'Gebruik van privaatrechtelijke bevoegdheden dat publiekrechtelijke regeling doorkruist', in $A B$ Klassiek, Zwolle, 1991, 212-224. 
echter geen enkel gewicht in de schaal voor de beantwoording van de bevoegdheidsvraag. ${ }^{717}$

Vanuit rechtsstatelijk oogpunt moet de vraag naar de bevoegdheid tot privaatrechtelijk handelen voor particulier en voor overheid verschillend worden beantwoord. In een rechtsstaat staan de beginselen van algemene burgerlijke vrijheid, de legaliteitseis (de heerschappij van de wet), het democratiebeginsel en de machtenscheiding centraal. ${ }^{718}$ Dit impliceert onvermijdelijk dat de overheid slechts bevoegdheden heeft, in tegenstelling tot in een politiestaat, op basis van het objectieve recht. Het is het objectieve recht dat de overheidsbevoegdheid creëert en begrenst. Deze begrenzing is noodzakelijk teneinde de vrijheid van de burger te waarborgen ${ }^{719}$ :

'Bij de overheid is slechts sprake van bevoegdheid voor zover die uit de volkswil positief en met voldoende zekerheid voor de burger blijkt, en is iedere bevoegdheidsuitoefening volledig onvrij, immers geheel gedetermineerd door het doel waarvoor zij is verleend: het specifieke gemeenschapsbelang dat met die bevoegdheidsuitoefening moet worden behartigd. Reeds hierom is derhalve toekenning van welke privaatrechtelijke bevoegdheid dan ook aan de overheid onmogelijk..$^{720}$

Daartegenover staat dat bij de burger, de particulier, de privaatrechtelijke bevoegdheden voortvloeien uit zijn algemene wils- en handelingsvrijheid. Bij particulieren worden deze bevoegdheden voorondersteld en wordt hun vrijheid om die bevoegdheden naar eigen goeddunken te hanteren slechts begrensd door de soortgelijke bevoegdheden van de andere burgers, met andere woorden voor zover uit de wet of de gelijkaardige rechten van anderen

717. Tak, A.Q.C., 'Overheid en Burgerlijk Wetboek', Recht en Kritiek, 1993, 178.

718. 'Machtsuitoefening geschiedt in onze rechtsorde volgens het patroon van de democratische rechtsstaat. De beginselen van democratie en rechtsstaat formuleren grenzen voor het overheidsoptreden en bepalen minimumvoorwaarden waaraan het optreden moet voldoen. De democratische beginselen omvatten de basis met betrekking tot de wijze waarop constitutionele vertegenwoordiging tot stand komt. De rechtsstatelijke beginselen stellen een meer inhoudelijke begrenzing aan het overheidsoptreden, waarbij met name kan worden gedacht aan het legaliteitsbeginsel en de waarborging van de grondrechten.' Peters, J.A.F., l.c., 1997, 79. Zie tevens Burkens, M.C., Beginselen van de democratische rechtsstaat, Zwolle, W.E.J. Tjeenk Willink, 1990, 12

719. Teunissen, J.H.M.F. en Tak, A.Q.C., L.c., 1994, 609 e.v.

720. Tak, A.Q.C., l.c., 1993, 178. Anders zie o.a. Stroink, F.A.M. en Steenbeek, J.C., o.c., 1993, 3043; Zelfs Bloembergen, die er vanuit gaat dat de overheid wel privaatrechtelijke bevoegdheden heeft, acht een onderscheid in twee soorten overheden een fictie; 'De overheid neemt nu eenmaal in de samenleving een bijzondere positie in, én omdat zij bij uitstek de behartiger van het algemene belang is én omdat zij over allerlei bijzondere bevoegdheden beschikt. Naar mijn mening kan zij die bijzondere positie wel voor een groter of kleiner deel, maar nooit helemaal afleggen als zij in het privaatrecht optreedt, zelfs niet als zij potloden koopt. Zij neemt eigenlijk nooit helemaal "op gelijke voet als een bijzonder persoon" aan het maatschappelijk verkeer deel.' (cursief DR) Bloembergen, A.R., 'Overheidsprivaatrecht: schets van een algemeen deel', WPNR-special, 1992, 952. 
geen beperkingen voortvloeien. ${ }^{721}$ Deze burgerlijke wils- en handelingsvrijheid vormt het uitgangspunt van het Burgerlijk Wetboek. In het Burgerlijk Wetboek worden dan ook geen bevoegdheden gecreëerd of verleend. Het enige wat de wetgever in het Burgerlijk Wetboek heeft gedaan is de bevoegdheden, of het gebruik ervan, erkennen en normeren. Indien het privaatrecht de bevoegdheden van de bijzondere (rechts)persoon als uitvloeisel van zijn algemene wils- en handelingsvrijheid normeert en beschermt, dan kunnen deze bevoegdheden niet aan de overheid toekomen:

'Dé basisgedachte van de rechtsstaatsfilosofie, en van het moderne privaatrecht, was immers de algemene en gelijke vrijheid van de mens zowel tegenover niet-statelijke als statelijke machten. Beperkingen van die vrijheid zijn slechts mogelijk op basis van de wet of de eigen, vrije wil. ${ }^{722}$

Overheden ontberen dus elke vorm van eigen, vrije wil. De overheid heeft geen natuurlijke bevoegdheden, kent niet de individuele wil en de daaraan gekoppelde vrijheid, zoals die in het privaatrecht wordt vooropgesteld.

'De overheid heeft slechts een door het algemeen belang geobjectiveerde wil, een ambtswil. Haar wil is niet de persoonlijke wil van de toevallige ambtsdrager, doch de door het gemeenschapsbelang gevorderde toepassing van de publiekrechtelijke bevoegdheid conform de daarvoor geldende geschreven en ongeschreven regels van het publieke recht'. ${ }^{723}$

Een ander fundamenteel verschil met het handelen van particulieren is dat het overheidshandelen niet wordt gekenmerkt door het wederkerigheidsprincipe. In de eerste plaats kenmerkt eenzijdigheid de bevoegdheidsuitoefening van de overheid. Die eenzijdigheid houdt in dat de overheid enkel kan optreden op basis van door het objectieve recht

721. Ook bij Van Der Hoeven herkennen we dezelfde visie: 'De doelstelling van alle handelen ter behartiging van een publieke taak is: het dienen van het - of van een gemeenschapsbelang. Dat belang kan ruim of beperkt zijn, het kan al of niet uitdrukkelijk zijn omschreven, de inhoud van dat belang kan al dan niet worden bepaald of geconcretiseerd door de handelende personen of organen zelf of door een wetgever zijn geformuleerd. Maar het is de rechtsplicht, dat - ongeacht de formulering van de toepasselijke rechtsregel - de oordeelsvrijheid die zij laat, door hem die handelt uitsluitend wordt gebruikt om optimale dienst aan het door hem te behartigen belang te verwerkelijken. Uiteraard binnen de bestaande rechtsorde: het blijven binnen die rechtsorde is trouwens zèlf een gemeenschapsbelang van de eerste orde (...) Omgekeerd is de burger - en zijn vrij gevormde beroepen - bij zijn handelen vrij, het door hem te behartigen belang zelf te kiezen, mits hij slechts blijft binnen de geldende rechtsorde. Voorzover die rechtsorde dat veroorlooft, mag hij trachten zichzelf of een ander te bevoordelen, mag hij zich van eigendommen ontdoen door die weg te schenken, te vervreemden of te vernietigen, mag hij willekeurig zijn goed gebruiken ter begunstiging van zichzelf of van door hem zelf (willekeurig) gekozen anderen, terwijl hij anderen die begunstiging onthoudt.' Van der Hoeven, J., 'De magische lijn. Verkenningen op de grens van publiek- en privaatrecht', o.c., 1970, 217.

722. Teunissen, J.M.F.H. en Tak, A.Q.C., L.c., 1994, 609.

723. Tak, A.Q.C., l.c., 1993, 180. 
gecreëerde en duidelijk afgebakende bevoegdheden, uitsluitend ter behartiging van het algemene belang.

'In een rechtsstaat is o.i. juist de eenzijdigheid een kenmerk van het overheidsoptreden en een waarborg voor de burgers (...) Wederkerigheid van rechtsbetrekkingen was een kenmerk van het feodale bestel, waarin 'overheidsrechten' werden beschouwd als "zaken in de handel" en welk bestel niet uitging van het beginsel van de vrijheid en gelijkheid van ieder mens. ${ }^{.724}$

Kortom, zelfs wanneer dé overheid privaatrechtelijk handelt, kan niet echt sprake zijn van een overheid die handelt op gelijke voet als een particulier. ${ }^{725}$ Een overheid, die contracteert of feitelijke handelingen verricht, treedt weliswaar niet op als een overheid die positief recht creëert maar dat maakt nog niet dat deze privaatrechtelijke bevoegdheden heeft of daardoor meteen op gelijke voet komt te staan met een bijzondere (rechts)persoon. Natuurlijk is er geen fundamenteel bezwaar dat de overheid gebruik maakt van privaatrechtelijke rechtsfiguren. Het zuiverste uitgangspunt blijft echter dat ook het privaatrechtelijk handelen van een overheidslichaam rechtsstatelijk enkel mag geschieden op basis van door het objectieve recht verleende publiekrechtelijke bevoegdheden. ${ }^{726}$ Daarbij kan de overheid zich nooit van de publieke taakvervulling losmaken, en dat geldt zelfs indien men zou aanvaarden dat de overheid wel privaatrechtelijke bevoegdheden heeft. Dit in tegenstelling tot een particulier (rechts)persoon die zijn privaatrechtelijke bevoegdheid kan uitoefenen ter behartiging van zowel individuele als algemene belangen. ${ }^{727}$ Teunissen en Tak voegen hieraan toe:

724. Teunissen, J.M.F.H. en Tak, A.Q.C., L.c., 1994, 614-615.

725. Bij de aankoop van potloden valt dit wellicht niet meteen op, maar wat indien het om het bestellen van (materiaal tot het bouwen van) kerncentrales zou gaan: 'Zij (de overheid, DR) zou (ineens) tot de overtuiging kunnen komen dat die dingen gevaarlijk zijn. Of het parlement zou zijn veto uit spreken. Gezien de zeer gewichtige algemene belangen die met aanschaf of annulering verbonden zijn speelt haar bijzondere positie ten deze een rol van betekenis.', aldus Spier, J., o.c., 1981, 11. Die bijzondere positie geldt echter voor alle overeenkomsten die de overheid afsluit. Dat bij bepaalde alledaagse eenvoudige contracten zich in de praktijk weinig moeilijk-heden zullen voordoen en daarbij het verschil met een met een particulier afgesloten overeenkomst zich nauwelijks zal laten voelen, doet hier niets aan af. Spier wijst er op, mijns inziens volkomen terecht, dat zelfs bij die zogenaamde 'routineuze' overeenkomsten de overheid zichzelf en haar algemene belangen behartiging niet kan wegeijferen: 'Stel dat de Staat bij de NV B een miljoen potloden koopt. Op zekere dag ontdekt een volijverig kamerlid dat het hout uit een land komt waar de mensenrechten met voeten worden getreden. De kamer spreekt, in meerderheid, uit dat de Staat "van de overeenkomst af moet". Hoewel de Regering staatsrechtelijk niet verplicht is zo'n motie uit te voeren, is het op zichzelf wenselijk dat ze dat kan als ze dat wil. Dat nu brengt mee dat het, zelfs bij een op het eerste gezicht volkomen alledaagse overeenkomst, wenselijk is dat de overheid niet kan worden gedwongen haar contractuele verplichtingen na te komen.' Spier, J., o.c., 1981, 181.

726. 'Als de overheid zich beweegt in het privaatrecht, behoort zij niet alleen onderworpen te zijn aan de beginselen van behoorlijk bestuur, maar ook aan de even wezenlijke beginselen van de (democratische) rechtsstaat.' Bloembergen, A.R., L.c., 1992, 956.

727. Zie Kobussen, M., 'Een privaatrechtelijke legaliteitseis?', NTB, 1989, 97-109. 
'Dat aan de "overheid" is opgedragen om bepaalde openbare belangen te behartigen, impliceert evenwel ook dat zij (...) potloden voor haar ambtenaren moet kopen. Men moet immers aannemen dat het objectieve recht aan de "overheid" bepaalde bevoegdheden niet heeft toegekend, zonder haar daarbij de mogelijkheid te bieden zich de middelen te verschaffen om die bevoegdheden te kunnen uitoefenen. Dat ten behoeve van de uitoefening gebruik kan worden gemaakt van in het BW geregelde rechtsvormen, is m.a.w. een annexe, accessoire bevoegdheid (een "implied power", zo men wil). Kortom: "de overheid" beschikt niet over "privaatrechtelijke bevoegdheden" ter behartiging van openbare belangen, maar kan gebruik maken van in het BW geregelde rechtsvormen waar dat nodig is in het kader van de uitoefening van publiekrechtelijke bevoegdheden..$^{728}$

Concluderend kan worden gesteld dat, hoe men ook kijkt naar de overheid die privaatrechtelijk handelt, een fundamenteel onderscheid tussen overheid als zodanig en overheid als particulier niet alleen moeilijk, maar ook zeer discutabel is. Een overheid treedt uiteindelijk steeds op 'als zodanig' zelfs wanneer hij handelingen verricht als een bijzondere (rechts)persoon. Welke activiteiten de overheid ook verricht, of die nu bestaan uit beschikken, feitelijk handelen, dan wel privaatrechtelijk handelen, zij verricht deze steeds in het kader van de uitoefening van haar publiekrechtelijke bevoegdheden en dit ter uitvoering van haar publieke taak. Strafrechtelijk betekent dit dat eigenlijk niet relevant moet zijn wat voor type gedraging is verricht (een beschikking, feitelijke handeling of privaatrechtelijke handeling), want iedere overheidsgedraging geschiedt uiteindelijk ter uitvoering van een publiekrechtelijke bevoegdheid. Van belang dient veeleer te zijn of de overheidsgedraging een strafbaar feit constitueert. Het enkele feit dat een bepaalde overheidsgedraging binnen 'het kader van een wettelijke overheidstaak is verricht' (criterium vóór Pikmeer II) of 'binnen het kader van een overheidstaak die slechts door de overheid kan worden verricht' (criterium sinds Pikmeer II) is zuiver formalistisch en kan, evenmin als 'het algemeen belang' (Volkel), als dusdanig het plegen van een strafbaar feit rechtvaardigen. Relevant dient veeleer te zijn, evenals in het bestuursrecht en het civiele recht, of de overheidsgedraging in kwestie berust op een publiekrechtelijke bevoegdheid en of deze bevoegdheid rechtmatig is uitgeoefend.

\section{DE WANKELE BASIS VAN HET TAAKCRITERIUM IN PIKMEER II}

$\mathrm{Nu}$ aan de hand van het voorgaande duidelijk is geworden dat enerzijds een onderscheid tussen overheid als zodanig en overheid als particulier moeilijk kan worden volgehouden en dat anderzijds de lege lata de erkenning van beleidsvrijheid rechterlijke controle niet in de weg hoeft te staan, rijst de vraag wat de preciese inhoud en ratio kan zijn van het in Pikmeer II aangescherpte taakcriterium.

728. Teunissen, J.M.H.F. en Tak, A.Q.C., l.c., 1994, 610. 


\section{Het exclusiviteitselement: een schijnoplossing?}

Cruciaal voor de huidige overheidsimmuniteit is dat de ten laste gelegde gedraging er een moet zijn die, binnen het kader van de uitvoering van een wettelijk opgedragen overheidstaak, naar haar aard en gelet op het wettelijke systeem rechtens alleen door bestuursfunctionarissen kan worden verricht. Er wordt dus een nadere differentiatie gemaakt binnen de categorie van wettelijke overheidstaken, namelijk enerzijds die taken waarvan de uitvoering aan particulieren kan worden uitbesteed en anderzijds die taken waarvan de uitvoering uitsluitend door bestuursfunctionarissen kan worden verricht. Eigenlijk wordt niet zozeer een onderscheid gemaakt tussen typen wettelijke overheidstaken, als wel tussen vormen van uitoefening of uitvoering van wettelijke overheidstaken.

Zoals reeds is besproken, heeft de Hoge Raad de aanscherping aangebracht omdat de criteria die tot dan toe werden toegepast tot onrechtvaardige uitkomsten aanleiding gaven, onder meer omdat in de praktijk zich vormen van takkuitoefening hebben ontwikkeld die meebrengen dat taken die aan openbare lichamen zijn toevertrouwd niet door henzelf maar door privaatrechtelijke rechtspersonen worden verricht. De Raad verwijst onder meer naar het ophalen van afvalstoffen, het onderhoud van wegen en waterwegen, bodemsanering, de gelegenheid bieden tot parkeren. Het nieuwe taakcriterium wordt dan ook, niettegenstaande principiële kritiek, gezien als een grote verbetering in vergelijking met de vroegere rechtspraak. ${ }^{729}$ Er wordt geconcludeerd dat met deze uitspraak een sterke beperking van de immuniteit is aangebracht. Zaken die tot nu toe steeds niet-ontvankelijk zijn verklaard, zijn met het nieuwe criterium nu wel vervolgbaar. Zo stellen Hendriks en De Lange:

'op milieugebied zijn er naar onze mening nauwelijks nog situaties denkbaar waarbij lagere overheden zich nu nog op immuniteit kunnen beroepen [...] De Hoge Raad komt zelf met de bodemsaneringen en het bouwrijp maken van gronden als voorbeelden van taken, waarvoor de zorg aan het openbaar bestuur is opgedragen dan wel die een openbaar lichaam zich heeft aangetrokken, en die nu ook door privaatrechtelijke personen worden verricht. De lijst kan vervolgens worden aangevuld met het uitbaggeren van vaarwegen, het exploiteren van slibdepots, en de afvalverwijdering. ${ }^{730}$

Niettemin kan op het aangescherpte taakcriterium de nodige kritiek worden geleverd. Een eerste punt van kritiek is dat niet duidelijk is op welke wijze het aangescherpte takcriterium moet worden uitgelegd. Er lijken verschillende interpretaties mogelijk. Zo suggereert Hennekens dat er geen immuniteit meer bestaat voor openbare lichamen, omdat volgens hem de Hoge Raad de immuniteit beperkt tot publiekrechtelijke rechtshandelingen

730. Hendriks, L.E.M. en De Lange, A., L.c., 1998, 44. 
en die handelingen zijn als zodanig niet strafbaar gesteld. ${ }^{731}$ Met andere woorden, de door de Hoge Raad geformuleerde uitzondering op strafvervolging van openbare lichamen is geen uitzondering want gedragingen die uitsluitend door bestuursfunctionarissen kunnen worden verricht, zijn publiekrechtelijke rechtshandelingen, die sowieso niet vervolgd kunnen worden omdat ze niet strafbaar zijn gesteld. Het taakcriterium is dus een lege doos. De wijze waarop de immuniteitsregel is geformuleerd, lijkt deze interpretatie te ondersteunen, want immuniteit geldt volgens de Hoge Raad slechts voor 'gedragingen die rechtens alleen door bestuursfunctionarissen kunnen worden verricht', en dat zijn publiekrechtelijke rechtshandelingen. De immuniteit lijkt dus voornamelijk betrekking te hebben op de uitoefening van de beschikkingsbevoegdheid van de bestuursorganen die deel uitmaken van de openbare lichamen. Toch is deze uitleg problematisch, want dit zou betekenen dat de Hoge Raad iets heeft gecreëerd dat geen enkele betekenis heeft. Het heeft immers weinig zin immuniteit toe te kennen voor gedragingen die niet strafbaar zijn gesteld. Deze interpretatie lijkt daarom niet in overeenstemming met de manier waarop de Hoge Raad het arrest heeft gemotiveerd. De Hoge Raad moet wellicht iets anders hebben bedoeld. Een tweede, meer zinvolle interpretatie dient zich dan aan. De Hoge Raad heeft waarschijnlijk bedoeld vervolging uit te sluiten voor feiten die binnen het kader van exclusieve bestuurstaken worden begaan, dat wil zeggen, feiten die zijn begaan door middel van gedragingen, die slechts door bestuursfunctionarissen kunnen worden verricht. De (aangescherpte) immuniteit verwijst dan niet naar de publiekrechtelijke rechtshandelingen zelf, want die zijn niet strafbaar, maar naar strafbare feitelijke gedragingen die daarbij of daardoor zijn tot stand gekomen. ${ }^{732}$ Zo geeft Krol, hoofd centrale juridische zaken van de gemeente Nijmegen, als (theoretisch) voorbeeld een gemeente die een subsidie verleent aan een criminele organisatie. De subsidieverlening is als zodanig niet strafbaar (en alleen al om die reden niet vervolgbaar), maar deze kan wel onderdeel zijn van een strafbare gedraging (bvb. art. $140 \mathrm{Sr}$ ) ${ }^{733}$ Volgens de uitleg van Hennekens zou de subsidieverlenende overheid wel vervolgbaar zijn omdat de immuniteit slechts betrekking heeft op de (niet-strafbare) subsidieverlening, maar niet op de deelname aan een feit dat wel strafbaar is en dat door middel van de subsidieverlening wordt gepleegd. Dit betekent echter dat openbare lichamen in beginsel steeds vervolgbaar zijn, wat niet de bedoeling is geweest van de Hoge Raad. Om te bepalen of de gemeente vervolgbaar is, moet worden bekeken of subsidieverlening een gedraging is die naar haar aard en gelet op het wettelijk systeem rechtens alleen door bestuursfunctionarissen kan worden verricht. Is dat het geval, dan is er immuniteit, niet voor de subsidieverlening, maar voor het strafbaar feit dat daarbij of daardoor is gepleegd. Het aangescherpte taakcriterium is dus niet zonder inhoud. ${ }^{734} \mathrm{Zo}$ rijst bijvoorbeeld op milieustrafrechtelijk gebied de vraag of een openbaar lichaam kan worden vervolgd wanneer deze een onrechtmatige vergunning heeft verleend. Het in strijd met wettelijke voorschriften afgeven van een vergunning (denk aan te soepele emissie-

731. Hennekens, H.Ph.J.A.M.. 'De gemeente als rechtspersoon', Gemeentestem, 1998, 435. Zie ook zijn annotatie onder Pikmeer II, Gemeentestem, 1998, 3. Ook milieuofficier De Lange is deze mening toegedaan, zie Van der Jagt, J.A.E., o.c., 2000, 265.

732. Zie hierover Van der Jagt, J.A.E., o.c., 2000, 145-147.

733. Zie interview met Krol, gepubliceerd in Van der Jagt, J.A.E., o.c., 2000, 236-237.

734. Idem, 145-146. Zie ook het daarin gepubliceerde interview met Corstens, raadsheer in de Hoge Raad, 248. 
voorwaarden) is niet strafbaar gesteld. Het is evenwel denkbaar dat de vergunningverlening onderdeel uitmaakt van een milieudelict, bijvoorbeeld overtreding van de artt. 173a en $173 \mathrm{~b} \mathrm{Sr}$, dat door de vergunninghouder is gepleegd. Ook is denkbaar (zoals bij de ramp in Enschede) dat een onrechtmatige vergunningverlening mede aan de basis ligt van een commuun delict, zoals dood door schuld (art. $307 \mathrm{Sr}$ ) of het veroorzaken van brand door schuld (art. $158 \mathrm{Sr}$ ). De vraag rijst dan of de vergunningverlenende overheid kan worden vervolgd op grond van deelneming aan het door derden gepleegde delict. De deelnemingsbepalingen (artt. 47 e.v. Sr) zorgen er immers voor dat niet alleen het volledig aan een delictsomschrijving in al haar bestanddelen beantwoordde gedrag strafbaar is (het plegen), maar ook andere gedragingen die aan de totstandkoming van het grondfeit hebben bijgedragen, namelijk indien deze gedragingen kunnen worden aangemerkt als doen plegen, medeplegen, uitlokken van of medeplichtigheid aan dit delict.

\section{Wat valt onder het taakcriterium?}

Naast de onduidelijkheid over de reikwijdte van de immuniteit, is een tweede punt van kritiek dat onbeantwoord blijft wat nu een exclusieve bestuurstaak is. Door de Hoge Raad wordt uitgegaan van een zuiver formeel criterium. In de berichtgeving in de media rondom het Pikmeer II-arrest werd als voorbeeld de uitgifte van paspoorten genoemd. Dit is inderdaad een voorbeeld van een exclusief door ambtenaren uitgevoerde bestuurstaak. Maar het illustreert tegelijk ook de moeilijkheid van het criterium. Zo kan de overheid het antecedenten-onderzoek bij een paspoortaanvraag aan een privaatrechtelijke rechtspersoon uitbesteden en slechts na een dergelijk door particulieren verricht onderzoek het paspoort verstrekken. ${ }^{735}$ Natuurlijk laat dit onverlet dat de uitgifte van een paspoort nog steeds door de overheid geschiedt - het blijft een gedraging die rechtens alleen door de overheid kan worden verricht -, maar het laat wel zien hoe de facto de uitoefening van overheidsgezag met een beroep op 'derden' is verweven.

Bezien we het exclusiviteitselement in relatie tot het subjectcriterium, dan lijkt de conclusie gerechtvaardigd dat de Hoge Raad hier in de eerste plaats bestuurshandelingen, daden van bestuur oftewel publiekrechtelijke bevoegdheidsuitoefening ${ }^{736}$ op het oog heeft ${ }^{737}$. Er kan met name worden gedacht aan de uitoefening van de beschikkingsbevoegdheid van de bestuursorganen die deel uitmaken van de openbare lichamen. Zoals gezegd gaat het hier om typische overheidsdaden die per definitie steeds zijn te plaatsen binnen de uitvoering van een wettelijke overheidstaak. Daar kan ten overvloede nog aan worden toegevoegd dat

\section{Zie Peters, J.A.F., l.c., 1998, 33.}

736. Soms wordt ook gesproken van overheidsbevoegdheid, bestuursbevoegdheid of bestuursrechtelijke bevoegdheid. Zie Stroink, F.A.M. en Steenbeek, J.G., o.c., 1993, 30; Goorden, C.P.J., o.c., 1990, 53-79; Nicolaï, P., Olivier, B.K., Damen. L.J.A. en Troostwijk, H. (red.), Bestuursrecht, Amsterdam, 1992, 4. Gelet op de verschillende begrippen, is er niet steeds eenduidigheid over wat zij inhoudelijk precies betekenen. $\mathrm{kk}$ volg in deze de ruime benadering van publiekrechtelijke bevoegdheid, zoals die o.m. door Stroink en Steenbeek is weergegeven, namelijk de bevoegdheid om positief recht vast te stellen en te handhaven. Zie Stroink, F.A.M. en Steenbeek, J.G., o.c., 1993, 30.

737. Tot deze conclusie kwam de literatuur ook reeds vóór het Tweede Pikmeer-arrest. Zie o.m. Brants, Chr. en De Lange, R., o.c., 1996, 28; Hennekens, H., L.c., 1991, 330. 
uit een algemene publieke of publiekrechtelijke taak geen bestuursbevoegdheid mag worden afgeleid. ${ }^{738}$

In milieustrafrechtelijke context lijkt de verlening van milieuvergunningen dus onder het taakcriterium te vallen. Kijken we zuiver formeel naar het 'wettelijk systeem', dan zien we bijvoorbeeld in artikel 8.2 van de Wet Milieubeheer (Wm) dat het college van burgemeester en wethouders het tot verlening van de Wm-vergunning bevoegde gezag is, tenzij bij amvb gedeputeerde staten of de minister van VROM als zodanig zijn aangewezen. Zo bekeken is het afgeven van een Wm-vergunning een overheidsgedraging die rechtens slechts door het bevoegde overheidsgezag kan worden uitgeoefend. Een onrechtmatige vergunningverlening mag strafrechtelijk dus niet worden gecontroleerd, ook al is het denkbaar dat dit een bestanddeel uitmaakt van een strafbaar feit. Een zelfde conclusie lijkt dan te gelden voor de handhaving. Alleen al om redenen van consistentie lijkt dit voor de hand te liggen: als vergunningverlening onder het taakcriterium valt, waarom zou dan de handhaving van overheidswege op de naleving van de vergunning(svoorwaarden) daar buiten vallen? Laten we kijken naar het handhavingsinstrument bij uitstek, de bestuursdwang. Artikel 5:21 Awb definieert bestuursdwang als

'het door feitelijk handelen door of vanwege een bestuursorgaan optreden tegen hetgeen in strijd met bij of krachtens enig wettelijk voorschrift gestelde verplichtingen is of wordt gedaan, gehouden of nagelaten.'

Bestuursdwang is een feitelijk handelen dat niet alleen door een bestuursorgaan, maar ook vanwege een bestuursorgaan kan worden verricht. Dat laatste is veelal het geval hetgeen betekent dat de bestuursdwang kan worden uitgevoerd door anderen dan het bestuursorgaan, ook door private ondernemingen, zoals bouw- en sloopbedrijven. ${ }^{739}$ Dit betekent echter niet dat bestuursdwang een gedraging is die, omdat zij door derden feitelijk kan worden verricht, strafrechtelijk vervolgbaar zou zijn. Ter beoordeling van de overheidsexclusiviteit van de bestuursdwang moet immers worden gekeken naar diegene die rechtens de bestuursdwangbevoegdheid uitoefent en dat is steeds de overheid. Dat blijkt bijvoorbeeld uit artikel 5:28 Awb:

738. In de literatuur wordt een publieke taak van een publiekrechtelijke taak onderscheiden. Een publieke taak kan worden omschreven als iedere taak waarbij het algemeen belang is betrokken, hetgeen zeer ruim is. Een publieke taak is publiekrechtelijk wanneer deze een publiekrechtelijke grondslag heeft in een democratisch gelegitimeerd besluit van de statelijke organen (m.a.w. een wettelijke grondslag). Met 'wettelijke overheidstaak' lijkt de Hoge Raad dus te refereren naar het begrip publiekrechtelijke taak, een publieke taak met wettelijke grondslag. In het Verkeersdrempel-arrest volstond nog als criterium 'overheidstaak', hetgeen ruimer is en verwijst naar het begrip publieke taak. Zie Schreuder, C.A., Publiekrechtelijke taken, private rechtspersonen, Deventer, Kluwer, 1994, 33; Schlössels, R.J.N., Het specialiteitsbeginsel. Over de structuur van bestuursbevoegdheden, wetmatigheid van bestuur en beleidsvrijheid, Den Haag, Sdu, 1998, 49-52.

739. Vgl. Van der Meulen, B.M.J., 'Handhaving', in Van der Linden, E.C.H.J. en Tak, A.Q.C. (red.), Eenzijdig en wederkerig?, Deventer, Kluwer, 1995, 236. 
'Om aan een beslissing tot toepassing van bestuursdwang uitvoering te geven, hebben personen die daartoe zijn aangewezen door het bestuursorgaan dat bestuursdwang toepast, toegang tot elke plaats, voor zover dat redelijkerwijs voor de vervulling van de taak nodig is.'

Het is het bestuursorgaan dat zowel beslist tot toepassing van bestuursdwang als deze de iure toepast. ${ }^{740}$ Dat de feitelijke uitvoering daarvan vervolgens óf door het bestuursorgaan óf op basis van ambtelijke aanstelling en opdracht óf op basis van civielrechtelijke overeenkomst kan worden verricht, verandert niets. Relevant is wie rechtens de overheidsgedraging kan stellen en dat is het bestuursorgaan. Strafrechtelijk betekent dit dat een overheid die op wederrechtelijke wijze een strafbaar feit (bijvoorbeeld een illegale lozing) gedoogt, niet als deelnemer aan dat feit kan worden vervolgd: het al dan niet inzetten van het bestuursrechtelijke handhavinginstrumentarium behoort immers uitsluitend tot de overheid. ${ }^{741}$ Ook in situaties waarin wel bestuursdwang wordt toegepast maar tijdens de feitelijke uitvoering een strafbaar feit wordt gepleegd, bijvoorbeeld een dodelijk ongeluk ten gevolge van een onzorgvuldig slopen, lijkt vervolging onmogelijk omdat de betreffende strafbare gedraging is gepleegd in het kader van de uitvoering van een exclusieve bestuurstaak, die rechtens niet anders dan door bestuursfunctionarissen kan worden verricht. Het blijft dan wel ongerijmd dat een private onderneming die feitelijk de sloopwerkzaamheden heeft verricht niettemin vervolgd zou kunnen worden daar deze geen openbaar lichaam is in de zin van hoofdstuk $7 \mathrm{Gw}$.

In ieder geval, het bovenstaande maakt duidelijk dat het moeilijk blijft te bepalen wat een exclusieve bestuurstaak is en wat niet. Uit de literatuur blijkt dan ook dat ten aanzien van een aantal taken niet duidelijk is of ze al dan niet onder het taakcriterium vallen. Zo zijn volgens Viering en Widdershoven politie- en toezichtstaken exclusieve bestuurstaken, zodat wanneer binnen dat kader strafbare feiten worden gepleegd immuniteit voorligt. ${ }^{742}$ Corstens daarentegen ziet vergunningverlening wel, maar politietaken, toezichtstaken én handhavingstaken niet als exclusieve bestuurstaken ${ }^{743}$ Dit is vreemd want een aantal toezichtstaken kunnen slechts door de overheid worden verricht en anderzijds wordt vergunningverlening niet steeds exclusief aan openbare lichamen uitbesteed.

Het moge dus duidelijk zijn dat tegen het exclusiviteitselement als vervolgingscriterium een aantal belangrijke bedenkingen kan worden gemaakt.

In de eerste plaats blijft het een in hoofdzaak formeel criterium. Blijkbaar gaat de Hoge Raad er nog steeds van uit dat bij dit soort overheidsdaden - in tegenstelling tot andere overheidsdaden - de rechtvaardiging tot het plegen van strafbare feiten wel reeds op

740. Idem, 235.

741. Jurgens, G.T.J.M., Bestuurlijk gedogen. Aanvaardbaarheid en gevolgen van bestuurlijk gedogen in het milieurecht en het ruimtelijk recht, Zwolle, W.E.J. Tjeenk Willink, 1996, 240-242.

742. Viering, M.L.W.M. en Widdershoven, R.J.G.M., 'De strafrechtelijke positie van de overheid na Pikmeer II, in Elzinga, D.J. en De Jong, H.M. (red.), Strafbaarheid van overheden, Deventer, W.E.J. Tjeenk Willink, Publikaties van de Staatsrechtskring deel 15, 1998, 76.

743. Zie Van der Jagt, J.A.E., o.c., 2000, 248. 
voorhand bestaat en zij dus daarom niet strafrechtelijk mogen worden gecontroleerd. De vraag rijst waarin die zogenaamde rechtvaardiging dan wel bestaat en waarop die is gebaseerd. Openbare lichamen kunnen via wederrechtelijke vergunningverlening of onzorgvuldige handhaving rechtstreeks bijdragen tot milieuverstoring. In dat opzicht kan moeilijk worden volgehouden dat het in strijd met wet en recht verlenen van vergunningen of een onzorgvuldige controle en toezicht op milieuverstoring reeds op voorhand gerechtvaardigd zou zijn alleen maar omdat het een taak 'des overheids' is, omdat alleen een bestuursfunctionaris rechtens deze handelingen kan uitoefenen. ${ }^{744}$ Dit gaat uit van een naïeve vooronderstelling dat overheden en ambtenaren neutrale belangeloze instrumenten zouden zijn die steeds en altijd conform het recht optreden. In plaats van een formele benadering van wat als een exclusieve bestuurstaak moet worden aangemerkt, zou een meer materiële invulling wellicht meer te verkiezen zijn. Met andere woorden, de vraag is of het wel juist is om aan de hand van een dergelijk formeel criterium te bepalen wat een exclusieve bestuurstaak is en wat niet. Volgt men een meer materiële benadering dan is niet doorslaggevend de vraag of de wetgever de uitvoering van bepaalde taken exclusief aan de overheid heeft opgedragen - dat is immers in belangrijke mate een tijdsgeboden kwestie -, maar de vraag of de overheid verantwoordelijkheid draagt voor de uitvoering van de haar in de wet opgedragen taak. ${ }^{745}$ Dat is een meer zinvol, want inhoudelijk criterium. Natuurlijk is de consequentie hiervan nu net datgene wat de Hoge Raad heeft willen vermijden, namelijk dat veel overheidsgedragingen dan onder de immuniteit vallen. Langs de andere kant is het wel zo dat met het formele criterium slechts in zo weinig gevallen van een exclusieve overheidstaak kan worden gesproken, dat nauwelijks nog strafrechtelijke immuniteit kan worden aangenomen. Dan heeft het criterium nog maar weinig inhoud. De cruciale vraag hoort daarom niet zozeer te zijn wat een exclusieve bestuurstaak is, maar waarom strafrechtelijke controle op de uitvoering van exclusieve overheidstaken zou moeten worden uitgesloten.

In de tweede plaats rijst de vraag of overheidsdaden als vergunningverlening en handhaving zodanige handelingen betreffen dat zij uitsluitend door overheden, meer bepaald openbare lichamen, kunnen worden uitgeoefend. Met andere woorden, hoe exclusief zijn exclusieve bestuurstaken? Meer in het bijzonder rijst dus de vraag hoe de aanscherping moet worden beoordeeld. In abstracto bekeken, verzet niets zich tegen de idee dat zelfs het verlenen van (milieu)vergunningen een handeling is die door bijzondere (rechts)personen kan worden verricht. Binnen het huidige overheidsbeleid en de bestaande regelgeving geschiedt de milieuvergunningverlening en de handhaving inderdaad alleen door overheden, maar dat kan in de toekomst best anders liggen. Vergunningverlening is een overheidsbevoegdheid die best kan worden uitbesteed aan publiekrechtelijke rechtspersonen die geen openbaar lichaam zijn of zelfs aan privaatrechtelijke organisaties. Op andere terreinen behoren bepaalde publiekrechtelijke bevoegdheden als vergunningverlening en toezicht (zelfs strafvorderlijke opsporingsbevoegdheden) reeds tot het takenpakket van privaatrechtelijke organisaties. Het Commissariaat voor de Media, de Verzekeringskamer, de Stichting Toezicht Effectenverkeer en talrijke kwaliteitscontrole-

744. Brants, Chr., l.c., 1998, 339; Roef, D., l.c., 1996, 280-281.

745. Vgl. Van der Jagt, J.E.A., o.c., 2000, 150. 
instellingen zoals de Stichting Nederlandse Vleeswaren Kontrole hebben vergunningverlenende en (soms vergaande) toezichthoudende bevoegdheden. ${ }^{746} \mathrm{Het}$ feit dat dergelijke organisaties ook als bestuursorgaan in de zin van de Awb kunnen worden aangemerkt, maakt duidelijk hoe vaag het onderscheid publiek-privaat is geworden. In hoeverre kan dan bij vergunningverlening en handhaving nog worden gesproken van exclusiviteit? Daarnaast mag niet worden vergeten dat aan vergunningverlening vaak een proces voorafgaat, zoals een onderzoek of de aanvrager voor de vergunning in aanmerking komt. Dat is echter geen exclusieve bestuurstaak. Dit voorwerk gebeurt immers veelal door anderen dan de vergunningverlenende overheid. Maakt dit voorwerk bestanddeel uit van een strafbaar feit bijvoorbeeld in het geval van een deskundigenadvies, dat meer emissies toestaat dan wettelijk is geoorloofd -, dan is dit vervolgbaar. De vergunningverlening gebaseerd op het verkeerde advies kan echter niet worden vervolgd. In hoofdstuk VII komen we uitgebreid op deze problematiek terug.

Een belangrijk punt van kritiek blijft dat de Hoge Raad geen of onvoldoende rekening heeft gehouden met het feit dat vele 'zuivere' overheidstaken (kunnen) worden verzelfstandigd, geprivatiseerd, gemandateerd of anderszins uitgevoerd door privaatrechtelijke organisaties, die in de zin van Pikmeer II als particulieren kunnen worden beschouwd. De Hoge Raad wijst daar zelf op, maar ziet blijkbaar geen contradictie met de nieuwe aanscherping. Daaruit blijkt duidelijk dat niet is gekozen voor een principiële oplossing, maar voor een compromis onder druk van de kritiek op de bestaande jurisprudentie. Bovendien gaat het gelijkheidsargument van de Hoge Raad maar ten dele op. De ongelijkheid is slechts opgeheven in de zin dat overheidsdaden die ook door bijzondere (rechts)personen kunnen worden verricht niet langer onvervolgbaar zijn. Maar de ongelijkheid blijft nog wel bestaan voor die categorie overheidsorganisaties die niet behoren tot een openbaar lichaam terwijl ze wel met daden van openbaar gezag, met bestuursbevoegdheden zijn belast. Er kan worden verwezen naar de reeds besproken zbo's. Deze zijn steeds vervolgbaar indien zij over een eigen rechtspersoonlijkheid beschikken, want ze zijn dan geen openbaar lichaam. Of ze zijn in geen enkel geval vervolgbaar indien zij eigen rechtspersoonlijkheid ontberen en aldus behoren tot de rechtspersoonlijkheid van de staat. Kortom, het aangescherpte takeriterium is enigszins arbitrair zolang het gekoppeld blijft aan het subjectcriterium.

\section{De (achterhaalde) ratio van het taakcriterium}

Niet alleen de bruikbaarheid of toepasselijkheid van het taakcriterium kan worden betwijfeld, ook de ratio ervan is nu voor een groot deel zoek. De grondslag voor het taakcriterium kan eigenlijk alleen maar liggen in het klassieke argument dat de strafrechter geen beleidsvrije overheidsdaden mag beoordelen vanwege het primaat van nietstrafrechtelijke controlemechanismen. Dit argument is in Pikmeer II door de Hoge Raad zelf terecht verlaten door voorop te stellen dat de strafrechtelijke vervolging van decentrale overheden op zichzelf niet strijdig is met het stelsel van politieke en bestuurlijke controle. $\mathrm{Nu}$ de Hoge Raad expliciet breekt met het uitgangspunt dat strafrechtelijke controle

746. Zie voor een grondige bespreking van deze zbo's, Van Nus, J.G.J., o.c., 1995, 397-453 en 501 669. 
onverzoenbaar is met politieke en bestuurlijke controle, behoeft het taakcriterium, nog meer dan voorheen, een nadere motivering.

Indien de ware toedracht van de aanscherping van het takcriterium inderdaad niet zou liggen in een pragmatisch compromis, maar in de principiële kwestie dat de strafrechter de beoordelings- en beleidsvrijheid van de overheid niet mag toetsen aan het recht, dan dekt het taakcriterium niet de volle lading. Waarom niet? Omdat enerzijds niet alle gedragingen, die rechtens alleen door bestuursfunctionarissen kunnen worden uitgeoefend, automatisch beoordelings- en beleidsvrijheid met zich meebrengen en omdat er anderzijds overheidsdaden bestaan die weliswaar door derden kunnen worden verricht maar waaraan uiteindelijk ook een discretionaire bevoegdheidsuitoefening van de overheid ten grondslag kan liggen.

Een voorbeeld van het eerste kan worden gevonden in vergunningverlening. Zoals gezien is het huidige taakcriterium van toepassing op de vergunningverlening. $\mathrm{Nu}$ is vergunningverlening vaak een discretionaire bevoegdheid waarbij de bevoegde overheid beschikt over een vrij ruime beoordelings- en beleidsvrijheid. Vergunningen zijn in die zin vaak vrije beschikkingen. Maar dat is niet steeds het geval. Zo is de bouwvergunning in hoge mate een gebonden beschikking. ${ }^{747}$ De beperkte beleidsruimte komt tot uiting in de eerste zinsnede van artikel 44 Ww: De bouwvergunning mag alleen en moet worden geweigerd, indien...'. Dit impliceert dat de bouwvergunning moet worden verleend indien aan de wettelijke voorwaarden is voldaan en moet worden geweigerd indien dat niet het geval is. In artikel $44 \mathrm{Ww}$ zijn vijf toetsingsgronden opgenomen, namelijk het Bouwbesluit, de bouwverordening welstandseisen, het bestemmingsplan of de krachtens dit plan gestelde eisen en de Monumentenwet of de op basis daarvan vastgestelde monumentenverordeningen. Wanneer nu een gemeente (het bestuursorgaan B\&W) in strijd met de wet een vergunning aflevert en zo duidelijk deelneemt aan het illegaal bouwen of instandhouden van een bouwwerk, zie ik niet in waarom het de strafrechter niet zou zijn toegestaan de wederrechtelijkheid van die vergunning vast te stellen, mede gelet op het gebonden karakter van de bouwvergunning. De hoge corruptiegevoeligheid van het verlenen van bouwvergunningen kan het belang van een strafrechtelijke controle alleen maar onderstrepen. ${ }^{748}$

Daarnaast zijn er overheidsdaden die weliswaar door derden kunnen worden verricht, maar waaraan uiteindelijk evengoed evenals bij exclusieve overheidsdaden (daden van bestuur), een zekere beoordelings- en beleidsvrijheid ten grondslag liggen. In die zin kan worden betoogd dat, indien de strafrechtelijke controle van de beslissingsnuimte van het bestuur inderdaad het werkelijke probleem is, de lijn dan ook moet worden doorgetrokken naar alle beslissingen van de overheid waar deze ruimte een belangrijke rol speelt. Het is dus

747. Struiksma, J., 'De bouwvergunning', in Michiels, F.C.M.A. en Van der Schans, E., Bestuursrechtelijk bouwrecht, Den Haag, 1996, B-28.

748. Zie hierover het onderzoek van Hoitink, J.E., Hille, M.G.F en Janssen, A.F.J.M., 'Handhaving van de bouwvergunningvereiste. Een onderzoek naar het contra legem verlenen van bouwvergunningen', in Commissie bestuursrechtelijke en privaatrechtelijke handhaving, Handhaven op niveau, Zwolle, W.E.J. Tjeenk Willink, 1998, 353-378. 
willekeurig te stellen dat rechterlijke toetsing van overheidshandelen alleen maar ontoelaatbaar is wanneer het gaat om daden die alleen door de overheid kunnen worden verricht, zoals de uitoefening van de beschikkingsbevoegdheid. Anders gezegd, het taakcriterium is niet in staat de grens te trekken tussen die overheidsgedragingen waar discretionaire bevoegdheid wel speelt en waar deze minder speelt of vrijwel afwezig is. Indien men strafrechtelijke toetsing van bestuurlijke belangenafweging aan het recht wil vermijden, dan is het zuiverder het criterium van de niet-vervolgbaarheid te leggen bij de (discretionaire) beslissing van de overheid die aan een overheidsgedraging ten grondslag ligt en niet bij wie rechtens deze gedraging kan uitvoeren. Bekeken vanuit een strafrechterlijk controleverbod heeft het weinig zin een formeel onderscheid te maken tussen bijvoorbeeld beschikkingen, feitelijke handelingen en privaatrechtelijke rechtshandelingen, want bij al deze overheids-gedragingen kan een zekere mate van bestuurlijke beslissingsruimte gemoeid zijn. Vanuit het perspectief dat bestuurlijke belangenafweging niet strafrechtelijk zou mogen worden getoetst is het vroegere taakcriterium (dus dat van vóór Pikmeer II) eigenlijk zelfs zuiverder. Nu is het inconsistent dat een gemeente die besluit om zonder vergunning vogelnesten te verwijderen wel vervolgbaar is, maar de overheid die wederrechtelijk een vergunning tot verwijdering van vogelnesten verleent niet vervolgbaar is terwijl in beide gevallen sprake is van een strafbaar feit, een (onrechtmatige) uitoefening van discretionaire bevoegdheid en het enige verschil hierin bestaat dat het verwijderen van vogelnesten door eenieder kan worden verricht en het verlenen van een vergunning alleen door de overheid. De strafwaardigheid is echter in beide gevallen gelijk: op wederrechtelijke wijze worden vogelnesten verwijderd. Kan dan niet met evenveel verve worden verdedigd dat ook het plaatsen van een geluidswal ${ }^{749}$, het vellen van een houtopstand ${ }^{750}$, het storten van slib $^{751}$ en het verbranden van riet $^{752}$ onvervolgbaar moet blijven, zoals vóór Pikmeer II het geval was, omdat de beslissing om dergelijke handelingen te verrichten alleen door de daartoe bevoegde overheden rechtens kan worden gemaakt en het irrelevant is wie deze gedragingen uiteindelijk uitvoert?

Kortom, eens wordt aanvaard dat de strafrechter 'vrij' overheidshandelen aan het objectieve recht kan toetsen, dan is het niet langer verdedigbaar dat in bepaalde gevallen wel strafrechtelijke controle mogelijk is en in andere gevallen niet.

Tenslotte kan opnieuw worden herhaald dat de aanwezigheid van beslissingsruimte voor bestuursorganen rechterlijke toetsing door de administratieve en civiele rechter niet in de weg staat. Dat dit voor de strafrechter wel zo is, blijft moeilijk te verzoenen met het bestaande systeem van rechterlijke controle op overheidshandelen.

749. Hof Amhem 22 mei 1989, MenR 1989, nr. 81 .

750. HR 9 juni 1992, $N J 1992,794$.

751. HR 23 april 1996, NJ 1996, 513 (Pikmeer 1).

752. HR 23 april 1996, NJ 1996, 512. 


\section{§ 5. De materieelrechtelijke oplossing}

Het is duidelijk dat sinds Pikmeer II de mogelijkheid om overheden te vervolgen is uitgebreid. De strafrechtelijke immuniteit is in ieder geval wat openbare lichamen betreft, beperkt tot strafbare feiten die zijn gepleegd bij de uitvoering van een specifieke wettelijke bestuurstaak die uitsluitend door bestuursfunctionarissen kan worden verricht. In andere gevallen staat voor deze lichamen een beroep op het stelsel van rechtvaardigingsgronden open. Met dit arrest heeft de Hoge Raad tevens uitdrukkelijk afstand genomen van het oorspronkelijke standpunt dat politieke en bestuursrechtelijke controlemechanismen een strafrechtelijke aansprakelijkheid in de weg zouden staan.

Niettegenstaande het aantal gevallen waarin decentrale overheden een strafrechtelijke immuniteit genieten nu in de praktijk sterk is beperkt, is duidelijk gebleken dat dit geen zuivere oplossing is van de problematiek.

In de eerste plaats blijft de vervolgbaarheid van de staat problematisch. Nog steeds geldt de absolute immuniteit zoals die is geformuleerd in het Volkel-arrest. Met Pikmeer II is de discrepantie tussen strafvervolging van decentrale overheden en de centrale overheid alleen maar groter geworden. In het Volkel-arrest wordt de absolute immuniteit van de staat immers gemotiveerd door de onverzoenbaarheid van strafrechtelijke controle met parlementaire controle en ministeriële verantwoordelijkheid. Nu de Hoge Raad in Pikmeer II stelt dat politieke en bestuurlijke controle zich niet verzetten tegen een strafrechtelijke aansprakelijkheid van decentrale overheden, behoeft de bijzondere positie van de staat een nadere en ook een andere motivering. Zolang deze ontbreekt is er geen reden de staat strafrechtelijk anders te bejegenen dan decentrale overheden. ${ }^{753}$

In de tweede plaats is het subjectcriterium onduidelijk en is de ratio daarvan grotendeels achterhaald. Ervan uitgaande dat het subjectcriterium zijn verklaring vindt in het verband tussen de organisatorische inrichting van een openbaar lichaam en het bestaan van publiekrechtelijke controle- en verantwoordingsmechanismen moet worden geconcludeerd dat de bestaansreden van het subjectcriterium duidelijk op de helling is komen te staan nu in Pikmeer II is bepaald dat het stelsel van politieke verantwoordelijkheid en dat van bestuurlijk toezicht niet in strijd zijn met de strafrechtelijke vervolgbaarheid. Het lijkt uitsluitend te zijn ingegeven door een louter willekeurige differentiatie in typen publiekrechtelijke rechtspersonen die tot ongerijmde uitkomsten aanleiding geeft. Het subjectcriterium biedt geen deugdelijke basis voor de begrenzing van strafrechtelijke vervolgbaarheid. Indien de Hoge Raad uitsluitend met het openbaar lichaam-criterium de uitsluiting van decentrale overheden met verordenende bevoegdheid op het oog heeft hetgeen aannemelijk lijkt -, dan zou als subjectcriterium beter kunnen worden gekozen voor de in artikel 2:1, eerste lid, BW genoemde rechtspersonen. Dit artikel noemt

753. Er zijn ook andere argumenten tegen de strafrechtelijke aansprakelijkheid van de staat. Zo wordt bijvoorbeeld betoogd dat de staat onmogelijk strafrechtelijk kan worden vervolgd, omdat dit zou betekenen dat de staat zichzelf vervolgt. Of dergelijke argumenten valabel zijn, wordt in hoofdstuk $\mathrm{V}$ besproken. 
uitsluitend de staat, gemeenten, provincies, de waterschappen en alle openbare lichamen waaraan krachtens de Grondwet verordenende bevoegdheid is verleend. Artikel 2:1, eerste lid, BW past ook meer binnen het kader van artikel $51 \mathrm{Sr}$ waar voor de strafrechtelijke rechtspersoonlijkheid toch in de eerste plaats aansluiting wordt gezocht bij het civiele recht of het Burgerlijk Wetboek.

In de derde plaats is ook het (aangescherpte) taakcriterium niet in staat onvervolgbaarheid van overheden te rechtvaardigen. Met dit criterium wil de Hoge Raad een onderscheid maken tussen handelen van de overheid 'als zodanig' en handelen van de overheid 'op gelijke voet met een particulier'. Zowel op theoretisch als op praktisch vlak kan een principiële differentiatie tussen overheid als zodanig en overheid als particulier worden in vraag gesteld. Bovendien blijkt dat de erkenning van beslissingsruimte in hoofde van de overheid rechterlijke controle niet in de weg hoeft te staan. Uitgangspunt was steeds dat de controle op bestuurstaken moest plaatsvinden via het bestuurlijk toezicht en niet (ook) via de strafrechtelijke handhaving. Nu enerzijds de Hoge Raad van dit standpunt terecht afstand heeft genomen en anderzijds de administratieve en civiele rechter beleidsvrij overheidshandelen kunnen toetsen, blijft onbeantwoord wat de meerwaarde is van het taakcriterium.

Meer fundamenteel kan worden besloten dat met het huidige tweesporen-systeem vervolgingsuitsluitingsgrond naast rechtvaardigingsgronden - de oorspronkelijke grondslag en bestaansreden van strafrechtelijke onvervolgbaarheid van overheden zoek zijn. De vóór Pikmeer II bestaande immuniteiten werden hoofdzakelijk gemotiveerd door de vooronderstelling dat strafbare feiten eigenlijk reeds op voorhand zijn gerechtvaardigd wanneer ze zijn gepleegd in het kader van een wettelijke overheidstaak. Het is echter duidelijk dat noch het algemeen belang, noch de kwalificatie overheidstaak als dusdanig het plegen van strafbare feiten kunnen rechtvaardigen. Dat wordt nu door de Hoge Raad ook met zoveel woorden toegegeven. Of een strafbaar feit, gepleegd in het kader van een overheidstaak, in concreto gerechtvaardigd is, moet blijken uit de door de overheid gemaakte belangenafweging die door de strafrechter moet worden getoetst. Deze materiële beoordeling van de strafrechtelijke rechtmatigheid van overheidsgedragingen gebeurt strafprocessueel aan de hand van de rechtvaardigingsgronden. Het is dan vreemd dat een strafrechtelijke controle uitgesloten blijft wanneer het gaat om openbare lichamen die exclusieve overheidsdaden verrichten, dat wil zeggen, daden die alleen door bestuursfunctionarissen kunnen worden uitgeoefend. Blijkbaar gaat de Hoge Raad er nog steeds van uit dat bij dit soort overheidsgesties de rechtvaardiging tot het plegen van strafbare feiten wel reeds op voorhand bestaat en zij dus daarom niet strafrechtelijk mogen worden gecontroleerd. In dat licht is het interessant dat ook de Raad van State in zijn advies over de strafrechtelijke aansprakelijkheid van overheidsorganen kritiek heeft op het taakcriterium, mede omdat het niet voldoende differentiërend vermogen heeft:

'Op het eerste gezicht lijkt deze formulering [van het taakcriterium, DR] aan te sluiten bij het bekende uitgangsput dat de immuniteit nodig en gerechtvaardigd is voor de uitoefening van openbaar gezag, zij het dat een materiële omschrijving van het handelen in de plaats treedt van een 
aanduiding van de herkomst daarvan. Die wijziging biedt voor de praktijk evenwel geen goed hanteerbaar criterium. Een onderscheid van overheidshandelen naar gelang de aard daarvan is niet goed mogelijk. Of een taak door de overheid wordt verricht hangt niet af van de aard van het desbetreffende handelen. Een tak die "niet anders dan door bestuursfunctionarissen" verricht kan worden is nauwelijks aan te wijzen. Of dit gebeurt is het resultaat van een politieke keuze en is vastgelegd in wetgeving. ${ }^{754}$

Met andere woorden, volgens de Raad van State is een onderscheid naar aard van de overheidsgedraging niet wenselijk. De Raad van State verbindt daaraan echter wel de conclusie dat overheden daarom in beginsel van strafvervolging moeten worden uitgesloten. De Raad van State is het dus niet eens met de door de Hoge Raad gecreëerde verruiming van strafvervolging.

Gelet op de onduidelijkheid en onbruikbaarheid van de immuniteitscriteria is er mijns inziens geen afdoende reden meer om vast te houden aan de onvervolgbaarheid van overheden. Er kan beter volledig worden gekozen voor een materiële benadering van de problematiek. Dat is vanuit strafrechtelijk oogpunt ook de meest aangewezen weg. Aan de door overheden gepleegde strafbare feiten ligt vaak een conflict van belangen of wettelijke voorschriften ten grondslag. De vraag is steeds of de gemaakte belangenafweging rechtmatig is. Om te kunnen beoordelen of het gepleegde feit moet worden aangemerkt als een strafbaar dus wederrechtelijk feit is het noodzakelijk dat de strafrechter de bestuurlijke belangenafweging aan het recht toetst. Natuurlijk zal dergelijke toetsing steeds beperkt zijn wanneer in hoofde van het bestuur sprake is van een beoordelings- of beleidsvrijheid. Maar de strafrechter kan dan evenals de administratieve en burgerlijke rechter het overheidshandelen op zijn rechtmatigheid toetsen. In de praktijk betekent dit dat de overheid in kwestie beroep zal kunnen doen op de rechtvaardigingsgrond 'wettelijk voorschrift' (artikel $42 \mathrm{Sr}$ ) en de rechtvaardigingsgrond 'overmacht in de zin van noodtoestand' (artikel $40 \mathrm{Sr}$ ).

Voor een beroep op artikel $42 \mathrm{Sr}$ moet aan een aantal vereisten zijn voldaan. Allereerst moet er natuurlijk sprake zijn van een wettelijk voorschrift. Daaronder valt ieder voorschrift, uitgaande van enige macht, waaraan wetgevend vermogen is verleend, krachtens die bevoegdheid gemaakt. ${ }^{755}$ Daarnaast moet er 'ter uitvoering van' een wettelijk voorschrift zijn gehandeld. Dit betekent dat gevolg moet zijn gegeven aan een wettelijke taak of plicht. Het enkele gebruik maken van een wettelijke bevoegdheid valt niet onder de werking van artikel $42 \mathrm{Sr}^{756}$ Voor de overheid in kwestie is dus van belang in welke mate de strafbare gedraging is verbonden met een bepaalde wettelijke overheidstaak. Dit beroep op het wettelijk voorschrift zal evenwel slechts als een rechtvaardigingsgrond mogen worden aangenomen indien is voldaan aan de eisen van proportionaliteit en subsidiariteit. Wat moet

754. TK 1999-2000, $25294, \mathrm{~A}, 6$.

755. Zie Cleiren, C.P.M. en Nijboer, J.F. (red.), Strafrecht, Tekst en Commentaar, Deventer, Kluwer, 1997, 233; Van der Jagt, J.A.E., o.c., 2000, 202.

756. Kelk, C., Studieboek materieel strafrecht, Arnhem, Gouda Quint, 1998, 285. 
worden beoordeeld is of de overheid redelijkerwijs verplicht was om op te treden. Bij die beoordeling zal moeten worden rekening gehouden met het karakter, de doelstelling of het gewicht van de in geding zijnde voorschriften. ${ }^{757}$ Wat de subsidiariteitseis betreft moet de verhouding tussen doel en middel worden nagegaan. Het is de wijze van optreden dat moet worden beoordeeld. Het optreden moet zodanig zijn dat er geen andere even deugdelijke middelen aanwezig waren om in het desbetreffende geval het doel te bereiken. Meer in concreto zal deze vraag zich voornamelijk toespitsen of in casu de overheid niet voor de legale weg had kunnen kiezen, zoals bijvoorbeeld het aanvragen van een vergunning voor de in beginsel strafbare gedraging. Indien deze legale weg openstond, is er in beginsel geen reden om van de door het bevoegde gezag gegeven voorschriften af te wijken.

In het verlengde van deze rechtvaardigingsgrond is het interessant of de overheid zich wellicht op de schulduitsluitingsgrond rechtsdwaling kan beroepen, bijvoorbeeld vanwege de complexiteit van de milieuwetgeving of omdat men meent conform een wettige vergunning te handelen, terwijl deze onrechtmatig is. Dat lijkt mij gelet op de hoedanigheid van de dader - het betreft de overheid zelf - en de daaruit voortvloeiende vereiste deskundigheid en Garantenstellung moeilijk denkbaar. In de Belgische en Duitse rechtspraak hebben we dan ook kunnen vaststellen dat een beroep op rechtsdwaling niet wordt gehonoreerd. $^{758}$

Wat een beroep op wettelijk voorschrift betreft, is het van belang op te merken dat reeds begin deze eeuw de strafrechter overheidshandelen aan deze rechtvaardigingsgrond toetste. Natuurlijk stonden telkens ambtenaren terecht vermits de (publiekrechtelijke) rechtspersoon niet kon worden vervolgd. Niettemin is duidelijk dat in deze oude rechtspraak dezelfde vragen naar voren komen als dewelke nu bij de vervolging van overheden moeten worden beantwoord en dat toen blijkbaar geen bezwaren bestonden het overheidsoptreden strafrechtelijk te controleren. Illustratief is een arrest van de Hoge Raad uit 1940. In deze zaak werd een hoofddirecteur-ingenieur van Rijkswaterstaat veroordeeld wegens het bouwen van een aanlegsteiger zonder de daartoe vereiste vergunning. ${ }^{759}$ Hij beriep zich op artikel $42 \mathrm{Sr}$, in het bijzonder op artikel 15 Rivierenwet, op grond waarvan de centrale overheid ter bescherming van het openbaar rivier- of stroombelang bevoegd was om rivierwerken te veranderen. De uitoefening van deze bevoegdheid zou volgens de verdachte als de uitvoering van een wettelijk voorschrift moeten worden beschouwd zodat het ten laste gelegde niet wederrechtelijk is. De Hoge Raad oordeelde echter dat

'noch in deze wet noch in eenig andere aan het Rijk of zijn ambtenaren een verplichting is opgelegd om [dergelijke] werken tot stand te brengen $^{760}$

757. Van der Jagt, J.A.E., o.c., 2000, 203.

758. Zie hierover meer in het bijzonder Faure, M., 'Strafuitsluitingsgronden in het milieustrafrecht', TMR, 1998, 188-209.

759. Zie Brants, C.H. en De Lange, R., o.c., 1996, 37 e.v.

760. HR 14 oktober $1940, N J 1941,165$. 
zodat een beroep op een wettelijk voorschrift niet kan worden gehonoreerd. Het kan niet zo zijn dat de enkele uitoefening van een overheidsbevoegdheid een wettelijk neergelegde vergunningplicht kan opzij zetten, tenzij hiervoor gegronde redenen zijn, die dan in het kader van de rechtvaardigingsgronden moeten worden beoordeeld ${ }^{761}$ Indien nu, bijna 60 jaar later, voor een gelijkaardig feit Rijkswaterstaat zou worden vervolgd, zou naar alle waarschijnlijkheid beroep worden gedaan op de absolute immuniteit die de staat geniet. De strafrechtelijke immuniteit is dus niet alleen vreemd in het licht van de bestaande mogelijkheden van rechterlijke controle door administratieve en civiele rechter, het is ook een stap terug in vergelijking met wat de strafrechter kon doen vóór de invoering van de strafbaarheid van de rechtspersoon in het Strafwetboek.

Wat een beroep op noodtoestand betreft, moet worden opgemerkt dat dit slechts in uitzonderlijke gevallen kan worden gehonoreerd. Van belang is dat sprake moet zijn van een gedraging die voortvloeit uit een concrete nood, die het gevolg is van een conflict tussen twee rechtsbelangen. ${ }^{762}$ Van noodtoestand kan alleen sprake zijn indien de overheid zich in een zodanig uitzonderlijke situatie bevindt dat de naleving van de strafwet onmogelijk wordt. Een beroep op noodtoestand door de overheid in kwestie zal zich vooral voordoen indien deze meent dat de naleving van de strafwet onmogelijk was vanwege financieel-economische omstandigheden. Immers, aan het plegen van strafbare feiten liggen ook bij overheden vaak financiële motieven ten grondslag, meer bepaald het vermijden van kosten. Het spreekt voor zich dat in een dergelijk geval een beroep op noodtoestand moet worden uitgesloten. In de eerste plaats is reeds door de wetgever bij het opstellen van de milieuvoorschriften rekening gehouden met de financieel-economische aspecten. Daarnaast is het belangenconflict tussen milieubescherming en andere, meer economische belangen niet alleen door de wetgever beslecht. Ook bij het uitreiken van een vergunning heeft de administratieve overheid rekening kunnen houden met de economische haalbaarheid van de opgelegde voorschriften. Dit betekent dat een beroep op noodtoestand alleen maar kan worden toegestaan indien sprake is van exceptionele en onverwachte situaties waarmee door wetgever en de vergunningverlenende overheid geen rekening kon worden gehouden. En ook in die gevallen zal natuurlijk steeds moeten worden getoetst aan de eisen van proportionaliteit en subsidiariteit.

Samengevat kan worden gesteld dat de gedeeltelijke aanvaarding door de Hoge Raad van het stelsel van de rechtvaardigingsgronden dient te worden uitgebreid tot alle overheidsgedragingen, ook die gedragingen die uitsluitend door bestuursfunctionarissen kunnen worden verricht. Dat dit best mogelijk is, werd reeds in hoofdstuk III duidelijk geillustreerd, bij de bespreking van de Belgische en de Duitse rechtspraak. Zowel de Duitse als de Belgische rechtspraak aanvaarden een strafrechtelijke aansprakelijkheid van functionarissen indien zij bij de uitvoering van exclusieve bestuurstaken strafbare feiten plegen. Uitzonderingen hierop worden slechts aanvaard indien een rechtvaardigingsgrond voorligt. Zoals besproken ligt het grote probleem in deze twee landen op een ander vlak: in geen van beide rechtsstelsels kent men een strafrechtelijke aansprakelijkheid van de

762. Kelk, C., o.c., 1998, 267; Van der Jagt, J.A.E., o.c., 2000, 207. 
overheid zelf, hetgeen leidt tot een (soms) verregaande individualisering van collectieve verantwoordelijkheden. 
Hoofdstuk V

\section{Argumenten voor en tegen een strafrechtelijke immuniteit van overheden}

\section{§ 1. Inleiding}

In dit hoofdstuk staat een bespreking van de belangrijkste argumenten voor en tegen de strafrechtelijke immuniteit van overheden centraal. De argumenten voor de strafrechtelijke immuniteit van overheden kunnen worden verdeeld in enerzijds argumenten voor een strafrechtelijke immuniteit van overheden in het algemeen en anderzijds argumenten voor een strafrechtelijke immuniteit van de staat in het bijzonder. Hoewel reeds in vorige hoofdstukken enkele argumenten terloops aan bod zijn gekomen, is het wenselijk een aantal zaken op een meer systematische en samenvattende wijze te belichten. Daarbij wordt niet alleen aandacht besteed aan de discussie zoals die in de literatuur wordt gevoerd, maar ook aan de recente standpuntbepaling van minister van Justitie Korthals. Deze standpuntbepaling is voor het eerst verwoord in een brief die Korthals op 11 november 1999 aan de Tweede Kamer zond naar aanleiding van een advies van de Raad van State, waar zijn ambtsvoorganger Sorgdrager om had gevraagd nadat de Hoge Raad het Tweede Pikmeer-arrest had gewezen. ${ }^{763}$ In dat advies komt de Raad van State tot de conclusie dat uitbreiding van de strafrechtelijke aansprakelijkheid van openbare lichamen geen overweging verdient. Van belang is vooral dat de Raad van State nog verder gaat: er moet een wettelijke regeling van de immuniteit komen, met als uitgangspunt dat het optreden van openbare lichamen in zijn geheel van strafrechtelijke controle wordt uitgesloten. ${ }^{764} \mathrm{De}$ Raad van State keert zich dus tegen de beperking van de immuniteit, zoals die door de Hoge Raad in het Tweede Pikmeer-arrest is neergelegd. Het is dan interessant om te zien hoe de minister enerzijds dit onderdeel van het advies verwerpt - door zich te verschuilen achter de uitspraak van de Hoge Raad -, maar anderzijds de argumenten van de Raad van State voor de ongeclausuleerde immuniteit van de staat gretig en kritiekloos overneemt. Naar aanleiding van dit standpunt van de minister heeft op 25 mei 2000 in de Tweede Kamer een Algemeen Overleg plaatsgevonden waar de strafrechtelijke immuniteit van de

763. De adviesaanvraag werd op 8 mei 1999 verzonden. Het advies is gedateerd 28 april 1999 en is als bijlage bij de brief van de minister gevoegd: TK 25294 , $\mathrm{nr}$. 10, A.

764. Zie hierover De Roos, Th.A., 'Geen strafrechtelijke aansprakelijkheid voor de Staat? Minister Korthals als Oblomow', Ars Aequi, 2000, 92 e.v. 
staat beproken is. ${ }^{765}$ Tijdens dit Algemeen Overleg bleek, dat veel van de aanwezige leden van de Vaste Commissie voor Justitie een voorkeur uitspraken voor het wettelijk mogelijk maken van de vervolging van de staat. Dat is voor de minister van Justitie reden geweest om in een brief van 22 september 2000 opnieuw het kabinetstandpunt te verdedigen dat de immuniteit van de staat, zoals die door de Raad van State wordt bepleit, moet blijven bestaan. ${ }^{766}$ Daarmee is (voorlopig) een einde gekomen aan de politieke discussie inzake de strafrechtelijke aansprakelijkheid van overheden.

Bemerk dat het van belang is voor ogen te houden dat de meeste argumenten hoofdzakelijk worden aangevoerd om de immuniteit te rechtvaardigen in gevallen waarin binnen het kader van exclusieve bestuurstaken strafbare feiten worden gepleegd. De vervolging van overheden in alle andere gevallen, dus wanneer zij geen exclusieve bestuurstaak uitvoeren, wordt - met uitzondering van de staat - in Nederland sinds Pikmeer II niet langer uitgesloten. $\mathrm{Nu}$ is het evenwel zo dat een aantal argumenten evenveel overtuigingskracht heeft in situaties waarin overheden een strafbaar feit plegen bij de uitvoering van een ondernemingsactiviteit of zelfs een niet-exclusieve bestuurstaak. Dat is dan ook voor de Raad van State een belangrijk argument om strafvervolging volledig onmogelijk te maken. Zo is bijvoorbeeld het bezwaar dat met de sanctionering van de overheid de gemeenschap wordt gestraft evenzeer valabel wanneer deze overheid handelt als een particulier als wanneer deze een typische bestuursdaad verricht. Indien men principiële bezwaren heeft tegen de bestraffing van overheden dient men logischerwijs in geen enkel geval een strafvervolging van overheden te aanvaarden en verdient onmiskenbaar het Belgische systeem (of het advies van de Nederlandse Raad van State) de voorkeur om alle overheden, ongeacht de hoedanigheid waarin deze optreden, van strafrechtelijke controle uit te sluiten.

De opbouw van dit hoofdstuk is als volgt. Allereerst passeren enkele algemene argumenten tegen de strafvervolging van overheden de revue ( $\left.\$ 2_{2}-5\right)$. Daarna komen enkele specifieke argumenten tegen de strafvervolging van de staat aan bod ( $\$ \S 6-8)$. Vervolgens wordt aan enkele argumenten voor de strafvervolging van overheden aandacht besteed ( $\S \S$ 9 - 12). Tot slot volgen enkele conclusies ( $(13)$.

\section{§ 2. Machtenscheiding}

Volgens de leer van de machtenscheiding zou een strafvervolging van overheden niet toelaatbaar zijn omdat het niet opportuun is dat aan de strafrechter een oordeel wordt gevraagd over de gedragingen van overheden. Dit geldt dan in het bijzonder voor die overheidsgedragingen waar beoordelings- of beleidsvrijheid centraal staan, de zogenaamde discretionaire bevoegdheden. Hoewel de Hoge Raad nooit expliciet naar de trias politica als argument tegen strafvervolging van overheden heeft verwezen, is de literatuur het er wel over eens dat dit een belangrijke rol moet hebben gespeeld in de (gedeeltelijke) uitsluiting van overheden van strafvervolging. Het kabinet daarentegen refereert wel expliciet aan de machtenscheiding om overheden in bepaalde situaties van strafvervolging uit te zonderen. 
In de naar aanleiding van het Eerste Pikmeer-arrest verschenen nota 'Strafrechtelijke aansprakelijkheid van overheidsorganen' wordt gesteld:

'De aan overheidsorganen toekomende beleids- of beoordelingsvrijheid betekent, mede gelet op het aan het Nederlandse staatsrecht ten grondslag liggende beginsel van scheiding en spreiding van macht en bevoegdheid, dat de rechter bij de beoordeling van de wijze waarop een overheidsorgaan van die vrijheid gebruik heeft gemaakt, enige terughoudendheid betracht. Dit geldt zowel voor de strafrechter als voor de bestuursrechter en de civiele rechter. ${ }^{767}$

Tegen het argument van de machtenscheiding kunnen niet alleen principiële bezwaren worden aangevoerd (A). Het is ook mogelijk om op basis van deels historische en deels rechtsvergelijkende gronden de ondeugdelijkheid van dit argument aan het licht te brengen. Zo wordt in België uit de trias politica niet een verbod van (straf)rechtelijke controle op overheidshandelen afgeleid, maar een zelfs in de Grondwet neergelegde plicht van de (straf)rechter om overheidsgedragingen te toetsen (B). Aan de hand van een korte historische bespreking van de Belgische kijk op rechterlijke toetsing wordt duidelijk dat een absolute visie op de machtenscheiding eerder blijk kan geven van een zeker machtscentralisme, dan van een via het beginsel van de trias politica te verwezenlijken bescherming van de rechtsorde.

\section{A. ALGEMENE BEZWAREN TEGEN HET ARGUMENT VAN DE MACHTENSCHEIDING}

In de eerste plaats hangt de draagwijdte van het argument af van de wijze waarop men de trias politica interpreteert. Doorgaans kan men twee opvattingen van elkaar onderscheiden: een strikte scheiding der machten of een evenwicht der machten. Ziet men de machtenscheiding als een strikte scheiding tussen zowel organen als functies, hetgeen betekent dat alle organen (wetgevende, uitvoerende en rechterlijke macht) slechts één functie vervullen en zich niet mogen moeien met de manier waarop de andere organen hun functie uitoefenen, dan is er inderdaad geen ruimte voor rechterlijke controle van bestuurlijk handelen. ${ }^{768}$ Het hoeft nauwelijks betoog dat deze visie op de scheiding der machten volledig is achterhaald. ${ }^{769}$ Bovendien is in zo'n opvatting iedere rechterlijke controle ontoelaatbaar en niet slechts die van de strafrechter. Hoewel in Nederland geen duidelijke staatsrechtelijke onderbouwing bestaat van de precieze verhouding tussen de onderscheiden staatsmachten, kan worden vastgesteld dat de trias politica veeleer als checks and balances, als een evenwicht der machten wordt bekeken, dan als een echte scheiding der machten. ${ }^{770}$ Indien men machtenscheiding ziet als een machtsevenwicht dan lijkt niets zich tegen een beoordeling van gedragingen van overheden door een rechter te

767. TK 1996-1997, 25294 , nr. 2, 3 .

768. Vgl. Brants, C.H. en De Lange, R., o.c., 1996, 82.

769. Zie o.a. Witteveen, W.J., Evenwicht der machten, Zwolle, W.E.J. Tjeenk Willink, 1991, 65 e.v.

770. Zie tevens noot 't Hart, A.C. onder HR 23 april 1996, NJ 1996, 513; Witteveen, W.J., De geordende wereld van het recht. Een inleiding, Amsterdam, University Press, 1996, 258-298. 
verzetten. ${ }^{771}$ Begaat een overheid een strafbaar feit, zoals een milieudelict, dan is een vervolging en berechting van deze overheid vanuit het idee van machtsevenwicht verdedigbaar omdat zo door een onafhankelijke strafrechter het overheidshandelen op zijn strafwaardigheid kan worden beoordeeld.

In de tweede plaats laat de leer van de machtenscheiding onverlet dat ambtsdragers, dus personen in overheidsfunctie, voor in kwaliteit gepleegde strafbare feiten toch vervolgbaar en strafbaar blijven. Dit is bijvoorbeeld wat ministers en staatssecretarissen betreft expliciet tot uitdrukking gebracht in de artikelen 42,46 en $119 \mathrm{Gw}$ voor wat betreft de door hen gepleegde ambtsmisdrijven (artikel 355 e.v. Sr). Als vervolgingsinstantie is door de Wet Ministeriële Verantwoordelijkheid (WMV) niet het openbaar ministerie maar de Kroon en de Tweede Kamer aangeduid (artikel 4); de Procureur-Generaal bij de Hoge Raad oefent de vervolging immers enkel op last van deze instanties uit (artikel 483 lid $3 \mathrm{~Sv}$ ). De Hoge Raad vervult hierbij als 'forum privilegiatum' de rol van strafrechter (artikel $92 \mathrm{RO}$, artikelen 483-485 Sv en artikel $4 \mathrm{WMV}$ ). Indien ministers worden verdacht van een misdrijf, ook wanneer het strafbare feit is gepleegd binnen de uitoefening van hun overheidsfunctie, leidt dit niet tot een immuniteit van de ambtsdrager in kwestie maar wordt voorzien in een bijzondere procedure. In die zin mag niet worden vergeten dat ook bij de vervolging van individuele ambtsdragers vaak een oordeel van de strafrechter wordt gevraagd over het handelen van de overheden waartoe zij behoren. Het zou mijns inziens in strijd zijn met het gelijkheidsbeginsel indien men voor een overheid een strafrechtelijke immuniteit aanvaardt, terwijl wat de organen van de rechtspersoon betreft expliciet niet voor een immuniteit wordt gekozen. Als ambtsdragers en ambtenaren voor in kwaliteit verrichte strafbare feiten vervolgbaar blijven, valt moeilijk in te zien waarom de overheden waarbinnen deze functionarissen functioneren wel een immuniteit zouden moeten genieten. $^{772}$

Daarnaast kan nog worden opgemerkt dat het aantal strafrechtelijke immuniteiten voor natuurlijke personen, dat wil zeggen, die categorie van vervolgingsuitsluitingsgronden, die in geen enkele geval, op geen enkele wijze strafvervolging om rechtsstatelijke redenen mogelijk maken, uiterst klein zijn en daarenboven secuur zijn geregeld. De meeste immuniteiten zijn daarnaast ook nog materieel beperkt in hun werking. Het is duidelijk dat de (grond)wetgever veeleer de voorkeur heeft gegeven aan een systeem dat voor bepaalde categorieën van personen, ter bescherming van hun overheidsfunctie, bijzondere procedureregels creëert, dan aan een stelsel dat de vervolging voor die personen gewoonweg uitsluit. ${ }^{773}$

Bovendien belet de trias politica niet dat zowel de administratieve rechter alsook de civiele rechter overheidshandelen kunnen controleren. Het argument van de machtenscheiding betreft dan ook niet zozeer de kwestie of een rechter, waaronder vanzelfsprekend ook de strafrechter, overheidsoptreden mag toetsen, maar of deze toetsing niet te ver gaat in de zin

771. Van Strien, A.L.J., o.c. 1996, 58.

772. Zie Hennekens, H., l.c, 1991, 330; Roef, D., l.c., 1995, 342.

773. Zie Roef, D., l.c., 1995, 338-339. 
dat de rechter de politieke beslissing, de doelmatigheid van het omstreden handelen zou controleren. Dat moet inderdaad worden vermeden. Zolang de rechter zich echter houdt aan de toetsing van de rechtmatigheid, kan evenwel uit de trias politica geen valabel argument worden afgeleid voor een verbod van rechterlijke controle. Integendeel, vanuit het perspectief van bewaking van de rechtsorde en het vermijden van machtsmisbruik ligt een rechterlijke controle in de rede.

Bovendien wordt thans aanvaard dat het openbaar lichaam wel strafrechtelijk ter verantwoording kan worden geroepen indien deze geen exclusieve bestuurstaak uitvoert, of wanneer deze op gelijke voet als een particulier aan het maatschappelijk verkeer deelneemt. De leer van de trias politica staat dus bij de andere rechters niet, en sinds Pikmeer II in de meeste gevallen ook niet langer bij de strafrechter ter discussie.

\section{B. DE MACHTENSCHEIDING ALS EEN ARGUMENT VOOR STRAFRECHTELIJKE CONTROLE: DE BELGISCHE KIJK OP RECHTERLIJKE TOETSING}

Dat de machtenscheiding geen overtuigend argument hoeft te zijn tegen strafrechtelijke controle op overheidshandelen, kan op historische en rechtsvergelijkende wijze worden verduidelijkt door terug te grijpen naar het Belgische recht. Ik verwijs uitdrukkelijk naar het Belgische recht omdat in de Belgische Grondwet (BGw) is neergelegd dat het de rechter niet alleen is toegestaan, maar dat hij zelfs verplicht is om bestuurlijke rechtshandelingen op wet- en rechtmatigheid te toetsen. Het gaat om artikel 159 BGw (oud artikel $107 \mathrm{BGw}$ ):

'De hoven en rechtbanken passen de algemene, provinciale en plaatselijke besluiten en verordeningen alleen toe voor zover zij met de wetten overeenstemmen.'

Oorspronkelijk werd de rechterlijke toetsing via toepassing van artikel $159 \mathrm{BGw}$ beperkt geïnterpreteerd in de zin dat in dit artikel slechts een exceptie van onwettigheid zou besloten liggen hetgeen inhoudt dat een administratieve beslissing niet rechtstreeks, maar slechts bij wijze van verweer voor de gewone rechter zou kunnen worden aangevochten. Deze enge opvatting vindt echter geen steun in het recht. ${ }^{774}$ Rechtshistorisch zijn geen dragende argumenten te vinden om de rechterlijke controle te beperken tot een incidenteel verweermiddel. Heden ten dage is dan ook de communis opinio dat artikel 159 BGw zich niet tegen een rechtstreekse aanvechting van bestuurlijke beslissingen verzet. Integendeel, deze ruime opvatting is volledig in overeenstemming met de dwingende bewoordingen van het grondwetsartikel zelf. Artikel $159 \mathrm{BGw}$ is van openbare orde en heeft een imperatieve en algemene draagwijdte. ${ }^{775}$ Het is dus niet alleen een mogelijkheid maar de plicht van de

774. Reeds Bourquin komt begin deze eeuw - toen de restrictieve benadering de heersende leer was tot de conclusie dat 'rien, (...) ni dans le texte de l'article 107, ni dans son origine historique, ni dans le commentaire que les travaux préparatoires nous en donnent, ne lui assigne nécessairement une portée limitative.' Bourquin, M., La protection des droits individuels contre les abus de pouvoir de l'autorité administrative en Belgique, Brussel, 1912, 58.

775. Cass., 3 maart 1972, $R W$ 1971-72, 1638, Conclusie Procureur-Generaal Ganshof van der Meersch. 
rechter om administratieve rechtshandelingen op hun rechtmatigheid te toetsen. ${ }^{776}$ Deze plicht geldt evenzeer voor de strafrechter.

Historisch moet dit artikel worden begrepen als een reactie tegen enerzijds de Franse revolutionaire strikte opvatting van de machtenscheiding (1) en de daaraan gekoppelde immuniteit van ambtenaren (2) en anderzijds de besluitenregering van Willem I onder dewelke de Raad van State in belangrijke mate functioneerde als een machtsinstrument in handen van de Koning (3).

\section{Absolute machtenscheiding, Montesquieu en het Franse revolutionaire systeem}

Zoals bekend, brak de Franse revolutie met de monopolistische macht van de Koning. De soevereine wil van de absolute vorst werd vervangen door de voluntaristisch opgevatte soevereiniteit van het volk, de zogeheten 'volonté générale'. De wetgevende macht werd als de incarnatie van de soevereiniteit van de natie beschouwd hetgeen logischerwijs resulteerde in het in de Grondwet van 1791 uitdrukkelijk neergeschreven primaat van de wet. ${ }^{777}$ De Franse revolutionaire Grondwetgevende vergadering was duidelijk voorstander van een absolute scheiding der machten:

'Toute société dans laquelle (...) la séparation des pouvoirs (n'est pas) déterminée, n'a point de constitution. ${ }^{.778}$

Dit had tot gevolg dat het de rechter verboden was om van administratieve rechtshandelingen kennis te nemen. Artikel 13, titel II van de wet van 16-14 augustus 1790 stelde dat

'Les fonctions judiciaires sont distinctes et demeurent toujours séparées des fonctions administratives. Les juges ne pourront, à peine de forfaiture, troubler de quelque manière que ce soit les opérations des corps administratifs, ni citer devant eux les administrateurs pour raison de leur fonctions.'

776. Zie reeds een uitspraak van Cass., 15 juni 1885, Pas., I, 183: ' (...), la question de savoir si les règlements communaux dont l'exécution était poursuivie étaient conformes la loi, si elle n'était soulevée par les parties, s'imposait d'office, (...)'. Zie tevens principieel Cass., 10 maart 1955, $R W$ 1955-1956, 529; Cass., 21 november 1963, Pas., 1964, I, 309. De ambtshalve opwerping van schending van artikel $159 \mathrm{BGw}$ vond trouwens in strafzaken veel eerder plaats dan in civiele zaken. Dit is te verklaren door de afwezigheid van de verplichte wettelijk motivering van de voorziening in cassatie in strafzaken. In civiele zaken daarentegen moet het verzoekschrift tot cassatie op straffe van nietigheid de wettelijke bepalingen vermelden, waarvan de schending wordt aangevoerd. Gebeurt dit niet, dan verklaart het Hof van Cassatie het middel niet ontvankelijk en kan het Hof, in tegenstelling tot in strafzaken, nooit ambtshalve een middel, zelfs al is het van openbare orde, opwerpen.

777. Alen, A., Rechter en bestuur in het Belgische publiekrecht. De grondslagen van de wettigheidskontrole, Antwerpen, Kluwer, 1984, 481.

778. Aldus artikel 16 van de Déclaration van 26 augustus 1789 . Zie eveneens artikel 22 van de Déclaration in de Grondwet van 1795: 'La garantie sociale ne peut exister si la division des pouvoirs n'est pas établie, si leurs limites ne sont pas fixées, (...)'. 
Het absolute primaat van de wet enerzijds, het verbod van rechterlijke controle van bestuurlijk handelen anderzijds en tenslotte nog de afwijzing van bijzondere administratieve rechtbanken resulteerde in een stelsel waarin de bestuurlijke overheden zelf de rechtmatigheid van hun handelingen beoordeelden (administration-juge).

Het is van belang even stil te staan bij de voornaamste ratio's van deze absolute opvatting omtrent de scheiding der machten. Enerzijds omdat hiermee de ontstaansgeschiedenis en de rechtsstatelijke betekenis van artikel $159 \mathrm{BGw}$ duidelijk wordt, anderzijds omdat in het politieke debat over de strafrechtelijke aansprakelijkheid van overheden veelal een absolute visie op de scheiding der machten wordt verdedigd die op enkele punten opvallend veel gelijkenis vertoont met die van de revolutionairen. $\mathrm{Nu}$ een strikte machtenscheiding als argument wordt gebruikt tegen de vervolging van overheden kan een korte bespreking van de historische oorsprong van deze opvatting tegen de achtergrond van de totstandkoming van artikel $159 \mathrm{BGw}$ wellicht een bijkomend kritisch licht werpen op de draagwijdte en de overtuigingskracht van het argument van de machtenscheiding.

Om te beginnen moet worden vooropgesteld dat de revolutionaire absolute opvatting van de trias politica niet primair was gelegen in de bescherming van de individuele burger tegen het optreden van de overheid en het was al helemaal niet bedoeling de rechter een voldoende onafhankelijke positie te garanderen. De belangrijkste reden was veeleer gelegen in de bezorgdheid bij het nieuwe revolutionaire bestuur voor een terugkeer naar de bemoeiingen van de rechter in bestuurlijke aangelegenheden zoals dit het geval was tijdens het Ancien Régime met de rechtsprekende Parlementen. ${ }^{779}$ De strikte scheiding tussen rechterlijke macht en uitvoerende macht wilde dus voorkomen dat 'de rechters, aan wiens revolutionaire trouw soms wel eens getwijfeld werd door de overheid, het revolutionaire bestuur zouden kunnen tegenwerken. ${ }^{780}$

Interessant is ook dat de revolutionaire opvatting omtrent de scheiding der machten rechtstheoretisch slechts ten dele is terug te voeren op Montesquieu. Meer zelfs, de Grondwet van 1791 maakte een halfslachtige, want veel striktere toepassing van Montesquieu's ideeën. Daar waar Montesquieu het begrip 'scheiding', dat hij zelf trouwens niet hanteerde, slechts in relatieve zin interpreteerde en geen samenwerking tussen machten uitsloot, koesterde de Grondwetgevende vergadering een absolute opvatting van dit begrip met als gevolg dat elke inwerking van de ene macht op de andere macht ontoelaatbaar werd geacht. ${ }^{781}$ Montesquieu begreep zeer goed dat, wil men het staatsgezag zo organiseren dat machtscentralisme onmogelijk wordt, een wederzijdse beperking van de machten door het installeren van een trias politica noodzakelijk is, maar evenzeer realiseerde hij zich dat een machtenscheiding slechts werkbaar is en machtswillekeur kan tegengaan wanneer een onderlinge samenwerking tussen de machten niet wordt uitgesloten. Hij was geen voorstander van schotten tussen de machten. Een strikte scheiding tussen de machten zou

779. Laferrière, A., Traité de la jurisdiction administrative, 1896, I, 180 e.v.

780. Baert, K., 'De rechter en de overheid', TBP, 1981, 43.

781. Aldus Alen, A., o.c., 1984, 519. 
evenzeer als machtscentralisme ten koste gaan van de rechtsbescherming en zou tot onverantwoordelijkheid leiden van de machten. ${ }^{782}$ Het hoofddoel van Montesquieu's invulling van de trias politica was de voorkoming van despotisme, het herstellen en verzekeren van evenwicht tussen de machten en standen en de bescherming van de vrijheid van het individu. Het feit dat Montesquieu een rechterlijke controle op bestuurlijk handelen zou hebben willen uitsluiten lijkt niet zozeer gelegen in de verwerping van het principe van rechterlijke toetsing als wel in zijn opvatting omtrent de beperkte functie van de rechterlijke macht in relatie tot het toepassen van de wet. ${ }^{783}$ In die zin is het zelfs maar de vraag of hij de rechterlijke macht als gelijkwaardig aan de andere machten beschouwde. Hoewel volgens Montesquieu de rechter de burger moest beschermen en daarom onafhankelijk diende te zijn van de twee andere machten lijkt tegelijk de rechterlijke macht een ondergeschikte want slechts juridische functie te hebben. Met andere woorden, Montesquieu erkent enerzijds formeel drie onafhankelijke organieke machten, maar anderzijds noemt hij de rechterlijke macht materieel een 'puissance nulle' doordat deze in tegenstelling tot de twee andere machten geen politieke macht krijgt toebedeeld en (slechts) in die zin moest de rechterlijke functie als uitsluitend uitvoerend worden beschouwd. ${ }^{784}$ Aldus kon hij de beroemde woorden schrijven dat de rechter slechts is 'la bouche qui prononce les paroles de la loi'. Aan de basis van deze (vaak eenzijdig geciteerde) uitspraak ligt zijn visie over de eenduidige betekenis van de wet die geen interpretatie behoeft en die de rechter dus automatisch met wegcijfering van zijn persoonlijkheid moest toepassen. ${ }^{785}$ De beperkte rol van de rechter vloeit bij Montesquieu niet voort uit een verbod om overheidshandelingen te toetsen, dus uit een ondergeschiktheid aan het bestuur, maar hangt

782. Idem, 181.

783. Idem, $179-180$.

784. Idem, 516-517.

785. Tegelijk moet deze stelling aan de hand van verschillende studies worden genuanceerd. Het is nog maar de vraag of Montesquieu in alle gevallen van de rechter een automatische wetstoepassing verlangde. Volgens sommigen zou de beroemde uitspraak van Montesquieu - de rechter is slechts 'la bouche de la loi'- slechts verwijzen naar de voor de burger noodzakelijke rechtszekerheid en dan met name voor wat de strafrechtspraak aangaat. Zie o.m. Belaid, S., Essai sur le pouvoir créateur et normatif du juge, Parijs, 1974, 44 en Cotta, S., 'Montesquieu, la séparation des pouvoirs et la Constitution fédérale des Etats-Unis', Rev. hist. pol. const., 1951, 233. Anderen gaan nog verder en verdedigen de stelling dat Montesquieu helemaal niet de rechterlijke functie eng interpreteerde. Zo verwerpt Schonfeld de opvatting dat Montesquieu de rechter slechts zou zien als een 'juge-automate' op grond van de vaststelling dat Montesquieu niet alleen goed op de hoogte was van de Engelse 'judge-made law' maar zich ook liet inspireren door schrijvers die voorstander waren van een rechterlijke toetsingsbevoegdheid. Daar waar Montesquieu de rechter voorschrijft slechts de letter van de wet te volgen, zou slechts het (jury)strafrecht zijn bedoeld. Zie de studie van Schonfeld, K.M., Montesquieu en 'La bouche de la loi', Leiden, 1979. Ook Witteveen onderschrijtt recentelijk een originele interpretatie van Montesquieu's opvatting van de rechterlijke functie: 'Montesquieu lijkt op het eerste gezicht een onderdanige opvatting van de rechtspraak te verdedigen, een extreem ideaal van wetsgebondenheid voor te staan (...) Daartegenover kan erop gewezen worden dat Montesquieu een in zijn tijd gangbare metafoor gebruikt als hij de rechter de mond van de wet noemt en het recht als een sprekende persoon opvat. Wie de mond is, bepaalt wat de woorden betekenen. Dat wijst op een veel actievere rechtsvormende rol dan openstaat voor een 'onbezield wezen'. Zie hierover Witteveen, W., o.c., 1996, 262. 
samen met het ideaal van gebondenheid van de rechter aan de wet. Een wetsgebondenheid die trouwens ook van het bestuur werd verwacht.

Het is duidelijk dat de Franse Grondwetgever door een absolute opvatting van de trias politica van de ideeën van Montesquieu zeer selectief gebruik heeft gemaakt. ${ }^{786}$ Dit laat zich grotendeels verklaren door de omstandigheid dat het revolutionaire rechtsdenken primair tot doel had een totaal nieuwe maatschappelijke constellatie in te voeren, terwijl Montesquieu's gedachtegoed getuigt van een meer conservatief rechtsdenken dat gericht was op het bijsturen van de al bestaande maatschappelijke orde met als doel machtswillekeur te vermijden. ${ }^{787}$ Montesquieu's rechtsbegrip is in die zin relationeel te noemen, dat wil zeggen dat in zijn opvatting het recht niet in de eerste plaats een bevelsconstructie is die eenzijdig wordt opgelegd door de staat aan de maatschappij: het recht moest in zijn visie eerder een kunstmatig kader scheppen dat de machtsuitoefening mogelijk maakt, maar deze tegelijk ook limiteert en controleert. ${ }^{788}$ Bij Montesquieu ging het helemaal niet om de omverwerping van het bestaande regime maar was de trias poitica vooral bedoeld als een 'hervorming' van de maatschappelijke structuur teneinde die institutionele voorwaarden te scheppen die het mogelijk maakten een nieuw machtsevenwicht te creëren. Montesquieu ging ervan uit dat door het waarborgen van bepaalde institutionele netwerken en juridische structuren vrijheid, autonomie en mondig burgerschap konden worden verwezenlijkt en dat zo evenwichtige verhoudingen tussen de verschillende maatschappelijke groepen en belangen konden worden gerealiseerd. ${ }^{789}$ Het was de intentie van Montesquieu om door middel van zijn leer van trias politica de balans tussen de verschillende machtsstructuren te herstellen door deze te begrenzen teneinde zo de vrijheid en zelfontplooiing van het individu te kunnen garanderen. De revolutionaire ambities van de derde stand, de burgerij, daarentegen waren meer sociaal-economisch dan juridisch van aard. ${ }^{790}$ Werkelijke vrijheid en autonomie zouden slechts mogelijk zijn door de fundamenten van de maatschappelijke orde zelf te herscheppen door een andere politieke wil en een op die andere wil gebaseerde machtsuitoefening. ${ }^{791}$ De revolutionaire opvatting van het recht was niet relationeel maar imperativistisch, hetgeen betekent dat het recht ondergeschikt werd gemaakt aan een maakbaarheidsidee:

'het recht als vorm van machtsuitoefening die zo doeltreffend mogelijk moest worden ingezet om een nieuwe maatschappelijke orde door te voeren. ${ }^{792}$

Juridische structuren en begrippen werden zo ideologisch én instrumentalistisch verbonden met het revolutionaire project van een nieuwe sociale orde die zijn legitimatie moest vinden in het algemene belang van de 'volonté génerale' - theoretisch onderbouwd via een beperkte

786. Zie tevens Witteveen, W., o.c., 1996, 263.

787. Zie hierover Foqué, R. en 't Hart, A.C., o.c., 1990, 155-180.

788. Zie hoofdstuk II.

789. Foqué, R. en 't Hart, A.C., o.c., 1990, 161.

790. Vgl. Arendt, H., On Revolution, New York, 1973, 75-84.

791. Foqué, R. en 't Hart, A.C., o.c., 1990, 162.

792. 't Hart, A.C., o.c., 1994, 201. 
interpretatie van Rousseau's maatschappelijk contract - en het ideaal van een samenleving van gelijke 'citoyens'. In die zin bleef de structurele positie en theoretische fundering van de staatsmacht echter in wezen onveranderd. Was deze macht in het Ancien Régime een wilsuiting van één soevereine machthebber vertegenwoordigd in de fysieke persoon van de Koning, dan bleef de staatsmacht met de revolutie nog steeds één wilsuiting zij het van een andere soevereine machthebber ditmaal belichaamd in de extreem fictieve persoon van het volk. Het oude machtscentralisme werd vervangen door een nieuw machtscentralisme. Met andere woorden, met het verdwijnen van de absolute vorst werd de wil van een persoon vervangen door een gepersonifieerde wil. ${ }^{793}$ Opvallend in dit opzicht is dat de scheiding der machten, dat, zoals uitgedacht door Montesquieu, tot doel had elke vorm van absolutisme te verhinderen, door de revolutionairen werd ingezet als een bij uitstek despotisch instrument ter verwezenlijking van het revolutionaire maakbaarheidsproject en vooral als een 'machine de guerre' tegen de Koning en de Parlementen ten voordele van de volkssoevereiniteit zoals deze werd belichaamd in het wetgevende lichaam. ${ }^{794}$ Dit betekende echter dat het ene despotisme, dat van de Vorst, werd ingeruild voor een ander despotisme, dat van het Volk.

Het Franse revolutionaire recht was dus gekenmerkt door een zekere ambiguitteit. Enerzijds werd het absolute primaat van de wet gevestigd als reactie tegen de absolute monarchie en anderzijds werd een absolute scheiding der machten voorgestaan vanuit een duidelijk wantrouwen tegenover de rechterlijke macht in haar verhouding tot de revolutionaire doelstellingen van het bestuur. In de praktijk had dit als belangrijke consequentie dat het primaat van het legaliteitsbeginsel in concreto niet kon worden gegarandeerd. De overheden beoordeelden zelf de rechtmatigheid van hun handelingen waardoor een degelijke rechtsbescherming niet werd verwezenlijkt.

\section{Absolute machtenscheiding en immuniteit van ambtenaren}

Een tweede consequentie - een niet onbelangrijke in het licht van de strafvervolging van overheden - van de revolutionaire theorie van de scheiding tussen de administratieve en rechterlijke overheden was de immuniteit van overheidsambtenaren. Het is interessant om vast te stellen dat in de revolutionaire periode het bestuur zich een controle- en vetorecht op de vervolging tegen haar ambtenaren voorbehield. Dit voorrecht stond bekend als de 'garantie administrative'. ${ }^{795}$ Dit was eigenlijk een voortzetting van de 'garantie constitutionnelle' tijdens het Ancien Régime waar de beoordeling van lagere ambtenaren was voorbehouden aan hogere ambtenaren. Werd oorspronkelijk nog een onderscheid gemaakt tussen uit eigen hoofde gepleegde delicten (persoonlijke delicten) en delicten begaan in de uitoefening van een bestuurstaak (bestuursdelicten), veralgemeende de wet van 7-14 oktober 1790 het verbod om ambtenaren voor de rechter te brengen:

793. Idem, 171.

794. Godechot, J., Les institutions de la France sous la Révolution et l'Empire, Parijs, 1968, 45.

795. Alen, A., o.c., 1984, 540; Cambier, C., Principes du contentieux administratif, I, Brussel, 1961, $75-76$. 
'(...) aucun administrateur ne peut être traduit devant les tribunaux, pour raison de ses fonctions publiques, à moins qu'il n'y ait été renvoyé par l'autorité supérieure, conformément aux lois. ${ }^{796}$

De daaropvolgende Grondwetten bevestigden deze (civielrechtelijke én strafrechtelijke) immuniteit. Met de Grondwet van het jaar VIII werd de voor de vervolging van ambtenaren noodzakelijke machtiging door de hiërarchisch hogere overheid vervangen door een machtiging van de Conseil d' Etat:

'Les agents du Gouvernement, autres que les ministres, ne peuvent être poursuivis pour des faits relatifs à leurs fonctions, qu'en vertu d'une décision du conseil d'état en ce cas, la poursuite a lieu devant les tribunaux ordinaires. ${ }^{797}$

Daarmee ging een dubbele uitbreiding van de 'garantie administrative' en dus ook van de strafrechtelijke immuniteit gepaard. Enerzijds gold de immuniteit niet langer uitsluitend voor de ambtenaren van de gemeente, het district en het departement, maar voor alle overheidsdienaren, alle 'agents du Gouvernement', dat wil zeggen 'ceux qui, dépositaires d'une partie de son autorité, agissent directement en son nom et font partie de la puissance publique.' Tegelijk werd de immuniteit uitgebreid in de zin dat deze niet alleen betrekking had op 'délits d'administration', maar eveneens op alle 'faits relatifs aux functions'. ${ }^{798}$ Dit had in de praktijk tot gevolg dat niet zozeer de bestuurlijke rechtshandeling werd beschermd, maar dat veeleer ook de persoon en de functie van de 'ambtenaar' als zodanig van iedere rechterlijke controle werd gevrijwaard. De 'garantie administrative' was grotendeels verworden tot een 'garantie personnelle'. ${ }^{799}$ Voor de strafvervolging betekende dit dat vanaf het moment dat een ambtenaar verdacht werd van een delict gepleegd in de uitoefening van zijn functie de 'garantie administrative' van toepassing was. De immuniteit bleek ondertussen niet langer te zijn gebaseerd op de scheiding tussen rechterlijke en uitvoerende macht, maar vooral op de wens het overheidsgezag zo veel mogelijk onaantastbaar te houden door de ambtenaren te beschermen tegen iedere vorm van rechterlijke controle en inmenging.

Terwijl de 'garantie administrative' in Frankrijk pas in 1870 per wetgevend decreet werd afgeschaft, verwierp het Verenigde Koninkrijk der Nederlanden reeds met de aanvaarding van de Grondwet van 1815 dit voorrecht. ${ }^{800}$ De Belgische Grondwetgever kon zich echter nog goed de misbruiken van het Franse systeem herinneren en besloot via artikel $24 \mathrm{BGw}$ (het huidige artikel $31 \mathrm{BGw}$ ) iedere mogelijke terugkeer tot een vervolgingsimmuniteit definitief uit te sluiten. Artikel $24 \mathrm{BGw}$ bepaalt immers dat

796. Alen, A., o.c., 1984, 542.

797. Idem, 543.

798. Idem.

799. Bernard, P., 'De la responsabilité des fonctionnaires publics', Rev. crit. législ. jur., 1876, 537.

800. Alen, A., o.c., 1984, 545 . 
'geen voorafgaand verlof (...) nodig (is) om vervolgingen in te stellen tegen openbare ambtenaren wegens daden van hun bestuur, behoudens wat ten opzichte van ministers is bepaald.'

Hieruit volgt dat de Belgische Grondwetgever vanuit de trias politica de principiële vervolgbaarheid van ambtenaren voorstond hetgeen vanzelfsprekend impliceerde dat de strafrechter de bevoegdheid moest hebben om tot de beoordeling van ambtelijk handelen te kunnen overgaan. In strafrechtelijke zin vormt daarom artikel $159 \mathrm{BGw}$, dat de rechterlijke controle op overheidshandelen instelt, tevens een sluitstuk van artikel $31 \mathrm{BGw}$, dat het beginsel van de principiële vervolgbaarheid van ambtenaren grondwettelijk heeft verankerd en waarbij afstand is genomen van het despotische instrument van de 'garantie administrative'.

Samengevat kan dus worden vastgesteld dat historisch gezien artikel 159 BGw niet alleen moet worden begrepen als een reactie op de onbevoegdheid van de civiele rechter een rechtmatigheidsoordeel te vellen over overheidshandelingen naar aanleiding van een conflict tussen overheid en burger, maar dat deze ook moet worden gezien als een reactie tegen de onmogelijkheid ambtenaren voor de rechter te brengen.

Het voorgaande brengt ons reeds bij een belangrijke dubbele vaststelling in relatie tot een strikte interpretatie van de machtenscheiding als argument tegen de strafrechtelijke aansprakelijkheid van overheden en ambtenaren. Enerzijds kan worden verdedigd dat een absolute scheiding der machten rechtstheoretisch niet te herleiden is tot Montesquieu; zijn opvattingen omtrent de trias politica kunnen eerder worden begrepen binnen de context van een relationeel rechtsbegrip. In die zin was hij voorstander van een gematigde machtenscheiding, dat wil zeggen een machtenverhouding van poids et contrepoids. Anderzijds is het argument van een strikte machtenscheiding rechtsstatelijk gezien enigszins verdacht wanneer historisch blijkt dat een dergelijke absolute visie niet zozeer voortvloeit uit de intentie samenleving en burger te beschermen tegen de overheid als wel dat deze veeleer is gelegen in de wens om de maatschappelijke projecten van de overheid zo kritiekloos mogelijk te implementeren. In die zin kan worden betoogd dat de gematigde machtenscheiding, zoals die is uitgedacht door Montesquieu en duidelijk is neergelegd in de Belgische Grondwet, niet alleen een rechterlijke controle op bestuurlijk handelen toelaat maar logischerwijs voorschrijft. Een dergelijk machtsevenwicht is een noodzakelijk complement van het legaliteitsbeginsel, is verankerd in een relationeel rechtsdenken gericht op de bescherming van maatschappij en burger en de kritische kanalisering van de bestuurlijke macht. Langs de andere kant getuigt een absolute visie op de machtenscheiding van een imperativistisch rechtsdenken waar juridische structuren worden herleid tot bevelsconstructies en op die manier getracht wordt de overheid zoveel mogelijk vrijheid te geven. Een dergelijke machtenscheiding is dan niet langer een instrument van bevrijding en machtscontrole maar kan verworden tot een instrument van onderdrukking. Vanuit deze vaststelling lijkt het me niet ongepast te concluderen dat een absolute visie op de scheiding der machten als argument tegen een strafrechtelijke aansprakelijkheid van de overheid getuigt van een uitholling van het oorspronkelijke machtskritische karakter van het beginsel van de trias politica. Immers, een machtenscheiding die primair de bescherming van de 
maatschappij en controle van overheidshandelen op het oog heeft, bemoeilijkt vanuit zuiver instrumentalistische doelmatigheidsoverwegingen onnodig de politieke en contra-juridische inzetbaarheid van het recht als machtsinstrument.

\section{Artikel 159 BGW als reactie tegen de Besluitenregering van Willem I}

Met de Grondwet van 1814 en later nog meer uitgesproken met die van 1815 werd door het Koninkrijk der Nederlanden afstand genomen van het Franse stelsel van de 'administrationjuge'. De Raad van State werd niet als rechtsprekend orgaan maar als adviesorgaan van de Koning ingesteld. Ook werd de al eerder genoemde 'garantie administrative' afgeschaft.

Belangrijk met betrekking tot het argument van de absolute machtenscheiding is de opneming in de toenmalige Grondwet van artikel 165, dat, gelet op zijn algemene bewoordingen, uitsluitend de gewone rechter bevoegd maakte om kennis te nemen van de in het artikel genoemde geschillen, ook wanneer het bestuur hierin betrokken was. Dit artikel 165 luidde als volgt:

'Alle twistgedingen over eigendom of daaruit voortspruitende regten, over schuldvordering of burgerlijke regten, behooren bij uitsluiting tot de kennis van de regterlijke magt.'

Artikel 165 van de Grondwet hanteerde als criterium van de rechterlijke competentie niet, zoals het Franse stelsel, de verhouding tussen de partijen, maar wel het objectum litis, het voorwerp van het rechtsgeschil. ${ }^{801}$ Het zal wellicht niet verbazen dat dit artikel op vraag van twee Belgische leden (J.F. Gendebien en O. Leclerq) van een subcommissie van de Grondwetscommissie in de Grondwet van 1815 is opgenomen. Het feit dat de Belgen gedurende een acht maal langere inlijving bij Frankrijk veel sterker dan het Noorden de nadelen van het Franse systeem hebben ondervonden kan in verband met de ontstaansgeschiedenis van artikel 165 niet worden onderschat. Drion merkt in dat verband op dat de woorden 'bij uitsluiting' in artikel 165 moeten worden gelezen als 'bij uitsluiting van de administratieve of executieve macht'; het artikel moet dus worden begrepen tegen de achtergrond van de bij de Belgen aanwezige afkeer van het Franse conflictensysteem. De secretaris van de Grondwetscommissie J.D. Meyer vatte de betekenis van artikel 165 dan ook als volgt samen:

'De Grondwet heeft dit verband (met het Franse conflictensysteem, DR) geheel verbroken. Aan de Raad van State is (...) alle regtsmacht ontnomen (...); alle conflicten van jurisdictie van de zijde van het bestuur is verboden; de regterlijke magt is bij uitsluiting belast met het beoordelen van alle geschillen over eigendom of burgerlijke regten der onderdanen. (Artikel 165 verzekert, DR) de inwoners tegen alle misbruik van gezag (...) Er blijft dan niets over, dan de regterlijke magt alleen, die de burgers

801. Zie tevens hoofdstuk IV. 
eene noodzakelijke waarborg tegens de aanmatigingen der besturen kan verzekeren en deze waarborg is bij de Grondwet erkend'. ${ }^{802}$

De kwestie van de rechterlijke controle leidde echter al vlug tot een ware machtsstrijd tussen de administratieve overheid, die van oordeel was dat de rechter niet de conformiteit van het bestuurlijk handelen aan de wet mocht beoordelen, en de rechterlijke macht die niet aarzelde haar nieuwe grondwettelijke taak uit te oefenen. Uit de rechtspraak van 1815 tot aan het Conflictenbesluit kan duidelijk worden vastgesteld dat de rechterlijke macht zich niet onbevoegd achtte om over de rechtmatigheid van overheidsverrichtingen te oordelen, tenzij een wet anders bepaalde. ${ }^{803}$ Deze confrontatie leidde uiteindelijk tot een overwinning van de uitvoerende macht op de rechterlijke macht hetgeen resulteerde in de herinvoering van het Franse conflictenstelsel via (hoofdzakelijk) het Conflictenbesluit van 5 oktober 1822 van Willem I. Dit besluit verklaarde in artikel 1 de rechterlijke macht uitdrukkelijk onbevoegd om een wettigheidscontrole uit te oefenen. Deze wettigheidscontrole was voorbehouden aan de Koning.

Uit het voorgaande kan worden vastgesteld dat het Franse stelsel van 'administration-juge' werd afgeschaft met de Grondwet van 1815, doch in 1822 opnieuw werd hersteld via het Conflictenbesluit en dat de Belgische Grondwetgever tegen deze herinvoering van het Franse systeem reageerde door de opneming van artikel 159 in de Belgische Grondwet. Artikel $159 \mathrm{BGw}$ moet tegen een historische achtergrond worden gezien als een reactie tegen de door het Conflictenbesluit ingevoerde praktijken die voor de Belgen een onaangename reminiscentie waren van het Franse systeem. In de woorden van de historicus de Gerlache was de Belgische Grondwet van 1831

'dans les intentions du Congrès et dans l'opinion du peuple belge, selon la lettre en l'esprit, une oeuvre de réaction contre quarante ans de tyrannie. ${ }^{.804}$

De Belgische Grondwet brak definitief met deze 'tirannie' van de uitvoerende macht door het legaliteitsbeginsel centraal te stellen, de residuaire bevoegdheid niet bij de Koning maar bij de wetgever te leggen en te eisen dat elk optreden van de Koning steun in de wet moet vinden en met de wet in overeenstemming moet zijn. Artikel 159 BGw was dus voornamelijk bedoeld om een zuivere machtenverhouding te handhaven en om via het instrument van onafhankelijke rechterlijke controle het gezag en de voorrang van de wet te versterken. Alen merkt in dit verband op dat de fundamentele kenmerken van de Belgische visie op de machtenscheiding als checks and balances in artikel $159 \mathrm{BGw}$ goed tot uiting komen:

802. Aangehaald door Drion, J,, Administratie contra de rechter tot de intrekking van het conflictenbesluit, 's Gravenhage, 1950, 90-91.

803. Zie voor een bespreking van deze rechtspraak Alen, A., o.c., 1984, 762-766.

804. Aangehaald in Alen, A., o.c., 1984, 803. 
'een rotsvast vertrouwen in de wetgever; een zeer diepgaand wantrouwen in de uitvoerende macht; een sterk geloof in de gewone rechter om de burger tegen de administratieve overheid te beschermen. ${ }^{.805}$

Uit het bovenstaande blijkt duidelijk dat in België noch de vervolging van ambtenaren voor onrechtmatige bestuursdaden, noch de rechterlijke toetsing van bestuurlijke handelen als strijdig met de scheiding der machten wordt gezien maar eerder als een rechtstreekse en ideale vertolking daarvan werd beschouwd met als doel de handhaving van het legaliteitsbeginsel en de bescherming van de individuele vrijheden en rechten tegen administratieve willekeur. Artikel $159 \mathrm{BGw}$ moet worden begrepen als een afwijzing van een absolute scheiding der machten en kan in die zin worden gezien niet als een inbreuk op maar als een herstel van de machtenscheiding zoals Montesquieu die oorspronkelijk had vooropgesteld.

In het algemeen kan derhalve worden geconcludeerd dat de machtenscheiding geen overtuigend argument is voor het uitsluiten van overheidshandelen van de werking van het strafrecht. Het kan net zo goed worden gezien als een argument voor strafrechtelijke controle. In dit licht is dan ook het huidige Belgische systeem waarin alle overheden van de werking van het strafrecht worden uitgesloten een monstrum en wijkt dit sterk af van de in de Belgische Grondwet neergelegde visie op de trias politica en de strafrechtelijke controle van overheidsgedragingen. Het is ironisch dat juist in België overheden buiten de werking van het strafrecht zijn geplaatst.

\section{§3. Doorkruising van politieke en bestuurlijke controle}

Een volgend argument tegen de strafvervolging van overheden is dat de politieke en bestuurlijke controlemechanismen niet door het strafrecht mogen worden doorkruist. ${ }^{806}$ Hierbij moet in de eerste plaats worden gedacht aan de (politieke) controle door gekozen organen. Op gemeentelijk niveau bijvoorbeeld moeten burgemeesters en wethouders verantwoording afleggen aan de gemeenteraad (artikel 169 lid 1 Gemeentewet). In de tweede plaats moet worden gedacht aan de (bestuurlijke) controle door (hogere) bestuursorganen. Zo kan een besluit van het gemeentebestuur aan goedkeuring van gedeputeerde staten onderhevig zijn (artikel 259 lid 1 Gemeentewet en afdeling 10.2.1. Algemene wet bestuursrecht). Een strafrechtelijke controle op overheidsgedragingen zou op de politieke en bestuurlijke controle een negatieve werking hebben ${ }^{807}$ Ook de Raad van State voert in zijn advies aan dat de beperking of opheffing van de immuniteit het functioneren van overheden kan frustreren doordat een strafrechtelijke controle een ongewenste juridisering in de hand werkt. De minister van justitie is het hiermee niet eens:

805. Idem, 1741 .

806. Brants, C.H. en De Lange, R., o.c., 1996, 80-82; Elzinga, D.J., 'Heethoofdige reacties op het Pikmeerarrest', $B B, 1997,39$.

807. Van Veen, Th.W., 'De strafrechtelijke aanprakelijkheid van de overheid', RMThemis, 2000,166 . 
'Niet zozeer de besluitvorming omtrent de te behartigen taken als wel de bij de daadwerkelijke uitvoering van feitelijk behartigde taken gepleegde strafbare feiten staan bij de strafrechter ter discussie. ${ }^{808}$

Er zijn evenwel nog andere, meer overtuigende bezwaren tegen dit argument aan te voeren. Controle door vertegenwoordigende organen of (hogere) bestuursorganen hebben immers nooit verhinderd dat de strafrechter het handelen of nalaten van de ambtsdragers, die optreden binnen de overheden, zelf op strafbaarheid vermag te toetsen. Zo dienen op gemeentelijk niveau burgemeester en wethouders politiek verantwoording af te leggen aan de gemeenteraad. Een dergelijk systeem bestaat tevens op provinciaal niveau. Deze verantwoordingsmechanismen beletten niet dat daarnaast ook de strafrechtelijke aansprakelijkheid van in de overheid optredende ambtsdragers, meestal de leidinggevenden binnen de organisatie, mogelijk blijft. Niet valt in te zien waarom dan voor de overheden zelf de aanwezigheid van andere (bestuurlijke) verantwoordingsfora wel de strafrechtelijke aansprakelijkheid a priori zou uitsluiten. ${ }^{809}$

Een ander punt van kritiek op dit argument is dat er wordt vanuit gegaan dat de bestuurlijke en politieke controle voldoende effectief zijn. ${ }^{810} \mathrm{Zij}$ zouden strafrechtelijk optreden tegen overheden overbodig maken. Kijken we naar de democratische controlemechanismen, dan blijken deze echter niet steeds voldoende in staat te zijn het plegen van strafbare feiten te sanctioneren, laat staan te voorkomen. De reeds besproken Voorburgse reigersnesten-casus en de Nijmeegse vuile grond-affaire zijn hiervan pijnlijke illustraties. De democratische controle zal zeker niet altijd tot een adequate sanctionering van het strafbare overheidshandelen leiden. Immers, het enkele gegeven dat een politiek meerderheid van het controlerende orgaan (bijvoorbeeld de gemeenteraad) een bepaalde gedraging afkeurt, betekent nog niet dat daaruit de gepaste maatregelen of sancties voortvloeien. Daarvoor is politieke controle trouwens ook niet primair bedoeld. Democratische controle inschakelen om te oordelen over strafbaar gedrag, impliceert dat deze controle zelf ook 'punitiever' ingesteld moet worden, hetgeen mij niet echt mogelijk noch wenselijk lijkt. Het politieke debat moet in de eerste plaats een politiek debat blijven en geen strafrechtelijke doelstellingen gaan overnemen waartoe het niet geschikt is al was het maar omdat het de nodige onafhankelijkheid beschikt. Bij de beoordeling van strafbare gedragingen dienen geen politieke motieven voorop te staan.

Daarnaast kan worden herhaald dat zelfs een democratische controle die wel steeds zou werken, geen vruchtbaar alternatief kan zijn voor strafrechtelijke controle, omdat democratische legitimatie van overheidsgedragingen niet automatisch kan worden gelijkgeschakeld met rechtsstatelijke legitimatie. Bij het uitoefenen van politieke controle vindt er een andere toetsing plaats dan wanneer de strafrechter over het desbetreffende handelen een oordeel moet geven. Politieke en bestuurlijke toetsing is niet gelijk aan de

808. TK $25294, \mathrm{nr} .10$, a, 9.

809. Hennekens, H., L.c., 1991, 331; Roef, D., L.c., 1996, 1116.

810. Elzinga, D.J., l.c., 1997, 39. 
rechtmatigheidstoetsing die de strafrechter verricht. ${ }^{811}$ Daarmee hangt samen dat kan worden betwijfeld of politieke en bestuurlijke controle een zodanige legitimerende werking heeft dat de schending van een strafrechtelijke norm niet meer vervolgd hoeft te worden, omdat de goedkeuring van een besluit door bijvoorbeeld de gemeenteraad niet meer doet dan het bieden van legitimatie jegens degene die het vertegenwoordigt. ${ }^{812}$ Ook moet in de praktijk rekening worden gehouden met de wijze waarop binnen een overheidsorganisatie verantwoordelijkheden zijn verdeeld. Zo stelt de democratische controle bij mandaatregelingen en gemeenschappelijke regelingen niet zo veel voor. Het is immers de democratie, d.w.z. de raden van de aangesloten gemeenten, die op enig tijdstip hebben besloten een mandaat te geven of een gemeenschappelijke regeling op te richten met de daarbij behorende besluitvorming. Niettemin zijn deze gemeenschappelijke regelingen als 'openbare lichamen' niet vervolgbaar indien hun gedragingen te plaatsen zijn binnen het aangescherpte taakcriterium.

Wat bestuurlijk toezicht op milieuverstorende decentrale overheden betreft, kan nog worden opgemerkt dat deze evenmin steeds in staat is naar behoren een strafrechtelijke controle te vervangen. Zoals mede uit het rapport van de Cie Michiels blijkt kunnen er heel wat vraagtekens worden geplaatst bij de effectiviteit van preventief en repressief toezicht. $^{813}$ Daarnaast zou een gebruik van dit bestuurlijke toezicht op de strafbare overheidsgedragingen ertoe leiden dat de functie van dit toezicht volledig verandert.

Daarnaast kan men in zijn algemeenheid de vraag stellen of louter politieke en staatsrechtelijke controle op afdoende wijze in staat zijn overheden aan te sporen de wet na te leven. Zo meent de Hoge Raad in het Volkel-arrest dat wanneer de staat een strafbaar feit pleegt daarvoor in eerste instantie ministers politiek verantwoording dienen af te leggen. Malafide praktijken zoals die aan de Volkel-casus ten grondslag lagen, kunnen inderdaad via parlementaire vragen aan de orde worden gesteld. Of ministers (of staatssecretarissen) daarvoor tot het nemen van maatregelen laat staan tot aftreden kunnen worden gedwongen - afgezien van de vraag of dit in dergelijke kwesties wel wenselijk is - valt zeer te betwijfelen.

Bovendien wordt het doorkruisingsargument niet aangevoerd wanneer overheden strafbare feiten plegen buiten de behartiging van een exclusieve bestuurstaak. Niettemin doorkruist ook dan de strafvervolging de politieke en bestuurlijke controle. Daarnaast kan opnieuw worden herhaald dat het bestaan van politieke en bestuurlijke controle niet belet dat de civiele rechter en de bestuursrechter overheidsgedragingen beoordelen. Het is in die zin dan ook van belang in herinnering te brengen dat dit argument met het Tweede Pikmeer-arrest veel van zijn geldingskracht heeft verloren. In deze uitspraak heeft de Hoge Raad immers uitdrukkelijk bepaald dat strafrechtelijke controle niet onverzoenbaar is met het bestaan van politieke en bestuurlijke controlemechanismen.

811. Hendriks L.E.M. en De Lange, A., L.c., 1998, 42; Van Kuijck, Y. en De Lange, A., 'Strafvervolging van overheden', Opportuun, 1997, nr. 7, 12; Van der Jagt, J.E.A., o.c., $2000,54$.

812. De Lange, A., l.c., 1995, 445; Van der Jagt, J.E.A., o.c., 2000, 55.

813. Commissie bestuursrechtelijke en privaatrechtelijke handhaving, o.c., 1998, 151. 
Ten aanzien van het doorknuisingargument past wel een relativerende opmerking. Dat politieke en bestuurlijke controle bij de handhaving van het milieurecht vaak te kort schieten, betekent niet dat het de taak is van het strafrecht dit tekort te herstellen. Net zomin als de bestuurlijke en politieke controle de functies van strafrechtelijke controle kunnen overnemen, is het evenmin wenselijk dat de strafvervolging van overheden de functies van bestuurlijke en politieke controle gaat overnemen. Dit betekent dat het functioneren van bestuurlijke en politieke controlemechanismen in de eerste plaats binnen deze mechanismen zelf moet worden verbeterd, zodat het strafrecht vooral zijn werking kan doen in die gevallen waar zelfs een behoorlijke bestuurlijke en politieke controle niet in staat zijn om op gepaste wijze op de door de overheid gepleegde strafbare feiten te reageren. Met andere woorden, ondanks het primaat van politieke en bestuurlijke controle, dient aanvullend optreden langs strafrechtelijke weg niet bij voorbaat te worden uitgesloten.

\section{§4. Vertrouwensverlies}

Het argument dat door een strafvervolging van overheden het vertrouwen in de overheid geschokt zou raken is niet overtuigend. ${ }^{814}$ Het komt mij meer schokkend over indien overheden voor het schenden van de eigen rechtsregels niet vervolgd en gestraft kunnen worden. ${ }^{815}$ In een rechtsstaat is het vanzelfsprekend dat de overheid steeds gebonden dient te zijn aan de regels van het (eigen) recht. Het zogenaamde vertrouwensverlies ontstaat bovendien niet door de vervolging, maar door het daaraan voorafgaand overtreden van de strafwet en door het niet respecteren van de belangen en rechtsgoederen die door het (straf)recht worden beschermd. Wat een overheid door het met de voeten treden van de wet aan geloofwaardigheid heeft kwijtgespeeld, kan niet nogmaals door de vervolging en bestraffing worden tenietgedaan. De burger mag juist van de overheid verwachten dat zij zich aan de eigen rechtsregels houdt. De voorbeeldfunctie van de overheid speelt hierbij een belangrijke rol. Indien blijkt dat overheden niettemin de (eigen) regels kunnen overtreden zonder daarvoor vervolgd te kunnen worden louter en alleen omdat het een gedraging 'des overheids' is, ondergraaft dit niet alleen het vertrouwen van de burger in de overheid, maar ook de legitimiteit van het handelen van de overheid. ${ }^{816}$ Daarnaast heeft ook dit argument evenveel geldingskracht wanneer overheden strafbare feiten plegen binnen het kader van ondernemingsactiviteiten.

814. Kist, F.C., o.c., 1966, 66.

815. Roef, D., l.c., 1995, 343-344; Roef, D., l.c., 1996, 1116; Hendriks, L.E.M. en De Lange, A., l.c., $1998,43$.

816. Hendriks, L.E.M. en De Lange, A., l.c., 1998, 43; Brants, Chr., l.c., 1998, 328. 


\title{
§ 5. Continuïteit van de openbare dienst en bestraffing van de gemeenschap
}

De bestraffing van overheden is volgens de tegenstanders een schending van het algemeen rechtsbeginsel van de continuïteit van de openbare dienst. ${ }^{817}$ Dit argument werd tijdens de parlementaire bespreking van artikel 121-2 CP door de Franse Raad van State aangevoerd:

\begin{abstract}
'Il n'est pas concevable (...) qu'elles (les personnes morales de droit public, DR) soient soumises à des mesures qui, comme la dissolution judiciaire, ont pour effet de porter atteinte à la continuité du service public. ${ }^{818}$
\end{abstract}

Dit beginsel hangt ook zeer nauw samen met de uitvoeringsimmuniteit. ${ }^{819}$ Met een beroep op dit rechtsbeginsel heeft bijvoorbeeld de Belgische rechtspraak herhaaldelijk de uitvoeringsimmuniteit bevestigd. ${ }^{820}$ Aan dit terechte bezwaar kan worden tegemoetgekomen door de toepassing van bepaalde straffen, zoals de ontbinding of de onderbewindstelling op overheden uit te sluiten. Voor deze oplossing heeft uiteindelijk ook de Franse wetgever gekozen ${ }^{821}$ Het is dus niet nodig daartoe voor overheden het middel van strafrechtelijke immuniteit uit de kast te halen. Bovendien geldt ook dit argument voor alle gevallen waarin overheden strafbare feiten plegen en niet slechts wanneer het delict zou zijn gepleegd bij de uitvoering van een exclusieve overheidstaak. Het beginsel van de continuïteit van de openbare dienst verzet zich eigenlijk tegen iedere vorm van strafbaarstelling van overheden. Eens men aanvaardt dat in bepaalde gevallen overheden wel kunnen worden bestraft, valt daarmee meteen ook de overtuigingskracht van dit argument weg.

817. Picard, E., 'La responsabilité pénale des personnes morales de droit public: fondements et champ d'application', Rev. Soc., 1993, 271.

818. Eerste plenaire bespreking in de Senaat, Franse Parl. Hand., Sénat, 2ième S.O., 1988-89, zitting van 10 mei 1989, 624. Tevens aangehaald in Deruyck, F., o.c., 1996, 1184.

819. Guirimand, D., 'La responsabilité pénale des personnes morales. La mise en oeuvre du nouveau dispositif, Droit Social, 1994, 648; Zie over het algemeen rechtsbeginsel van de continuïteit van de openbare dienst: Claeys-Bouuaert, Ph., 'Algemene beginselen van het recht - Vijftien jaar rechtspraak van het Hof van Cassatie', $R W$ 1986-87, 995; Mast, A. en Dujardin, J., o.c., 1994, 7679.

820. Cass., 21 april 1966, Pas., 1966, I, 1060; Cass., 26 juni 1980, $R W$ 1980-1981, 1661. Tegelijk kan, wat het Belgsiche recht betreft, worden vastgesteld dat de uitvoeringsimmuniteit niet langer een absolute geldingskracht heeft: zie o.m. Beslagrechter Brussel, 20 december 1990, $R W 1991$ 92, 299, met noot Van Volsem, F. en Van Heuven, D., 'Nogmaals over de uitvoeringsimmuniteit van publiekrechtelijke rechtspersonen'. Bovendien is in België door de wet van 30 juni 1994 een nieuw artikel 1412bis ingevoegd in het Gerechtelijk Wetboek dat de absolute uitvoeringsimmuniteit van publiekrechtelijke rechtspersonen enigzins doorbreekt. Artikel 1412 bis $\S 2 \mathrm{Ger}$. W. erkent expliciet de mogelijkheid beslag te leggen op alle goederen die 'kennelijk niet nuttig' zijn voor de uitoefening van de taak van de overheid of voor de continuitteit van de openbare dienst. Zie Brijs, S., Nieuwe wetgeving: de absolute uitvoeringsimmuniteit van de overheid doorbroken', $R W, 1994-95,625-633$.

821. Deruyck, F., o.c., 1996, 185. 
Met het voorgaande hangt het argument samen dat de bestraffing van overheden als ongepast moet worden beschouwd omdat uiteindelijk de gemeenschap voor de opgelegde sanctie moet opdraaien. ${ }^{822}$ Dit argument werd ook in het advies van de Raad van State aangevoerd. Volgens de Raad heeft een bestraffing van overheidsgedragingen

'geen effectieve functie; de resulterende lasten moeten uiteindelijk worden opgebracht door de justitiabelen die nu juist beschermd moeten worden door de strafrechtelijke handhaving. ${ }^{1823}$

Daartegen kan in de eerste plaats worden aangevoerd dat dit bezwaar niet eigen is aan een strafrechtelijke aansprakelijkheid. Ook bij de civielrechtelijke aansprakelijkheid en de oplegging van bestuursrechtelijke sancties komt de rekening - om het plastisch uit te drukken - op het bord van de burger. Bovendien moet men dan in alle gevallen overheden strafrechtelijk immuun verklaren, omdat anders in die gevallen waar overheden wel kunnen worden vervolgd, bij activiteiten die ook door particulieren kunnen worden verricht, de straf ook aan de gemeenschap wordt opgelegd. Bovendien gaat dit argument uit van een eenzijdige benadering van straffen en beboeten. Er kunnen ook andere straffen of maatregelen worden opgelegd, zoals het herstel van de schade (art. 8 sub c WED). Daarnaast is een veroordeling, zeker bij strafbaar overheidshandelen, meer dan het louter opleggen van een sanctie. Centraal staat vooral de machtsnormerende én vergeldende functie van de veroordeling. Het is interessant dat ook de minister van Justitie de argumentatie van de Raad naast zich neer legt en erop wijst dat het strafrechtelijk sanctiearsenaal wel degelijk een functie heeft tegenover wetsovertredende overheden. Hij stelt onder meer:

\begin{abstract}
'Voor strafrechtelijke sancties die ten doel hebben de ongerechtvaardigde verrijking die uit gepleegde delicten voortvloeit teniet te doen, bestaat zo in ieder geval grond [en] tenslotte zij opgemerkt dat het strafrecht en de strafrechtstoepassing ook een normvormende en een normbevestigende functie hebben ${ }^{824}$
\end{abstract}

\title{
§ 6. De ongelijkheid tussen de staat en decentrale overheden
}

De argumenten voor strafrechtelijke immuniteit van de staat verdienen afzonderlijk aandacht. Met de immuniteit van de staat wordt immers het vraagstuk van de strafrechtelijke aansprakelijkheid van overheden op de spits gedreven. Reeds werd vastgesteld dat zowel Frankrijk, België als Nederland hebben gekozen voor een absolute immuniteit van

822. Strijards, G.A.M., o.c., 1988, 66. Dit bezwaar is wellicht het meest overtuigend verwoord door Picard: 'lorsque la personne coupable puis réprimée, constitue une personne publique, les victimes des deux maux risquent, à chaque fois, d'être les mêmes. (...) Par exemple, il ne suffira pas aux habitants de la commune (...) ayant subi pendant des mois ou des années la pollution causée par une installation de chauffage urbain: il leur faudra encore supporter (...) l'ammende!' Picard, E., l.c., 1993, 272.

823. TK 1999-2000, 25294, A, 7.

824. TK 1999-2000, 25294, A, 8-9. 
de staat. Allereerst kan worden opgemerkt dat áls in een absolute strafrechtelijke immuniteit moet worden voorzien het niet opportuun is deze te beperken tot de staat als dusdanig ${ }^{825}$. Ook decentrale overheden moeten zich in navolging van de staat dan kunnen beroepen op een absolute immuniteit. Een absolute en exclusieve immuniteit die alleen geldt voor de centrale overheid vormt een te grote inbreuk op het gelijkheidsbeginsel. Het is nauwelijks te rechtvaardigen dat bijvoorbeeld een milieuverstorende handeling in het kader van een gemeentelijke activiteit zou kunnen leiden tot een strafvervolging, terwijl een gelijkaardige activiteit in hoofde van een ministerie de strafrechtelijke aansprakelijkheid zou uitsluiten. Daarnaast geldt het uitgangspunt van deze immuniteit, zoals die door de Hoge Raad wordt geformuleerd, namelijk dat de handelingen van de staat geacht moeten worden te strekken tot de behartiging van het algemeen belang, in beginsel voor iedere overheid. Met welk overheidsoptreden men ook te maken krijgt, steeds dient als uitgangspunt te worden aangenomen dat een overheid slechts één bestaansreden heeft: het behartigen van het algemeen belang. Het is met andere woorden haast een contradictio in terminis dat de staat als uit een bijzonder (eigen)belang zou kunnen handelen. De staat verschilt hierin echter niet van een gemeente of een provincie.

De behartiging van het algemeen belang kan niet de rechtvaardiging zijn voor een aparte strafrechtelijke positie voor de staat. Bovendien kan, redenerende vanuit het gelijkheidsbeginsel, de vraag worden gesteld waarom openbare instellingen of zelfs privaatrechtelijke rechtspersonen op het moment dat zij het algemeen belang behartigen niet evenveel beroep zouden kunnen en mogen doen op een vervolgingsuitsluitingsgrond. ${ }^{826}$ Het algemeen belang kan dus niet een verschil in strafrechtelijk optreden tussen soorten publiekrechtelijke rechtspersonen rechtvaardigen en al helemaal niet het plegen van strafbare feiten.

Tegen de strafrechtelijke aansprakelijkheid van de staat kunnen hoofdzakelijk twee argumenten worden aangevoerd. Allereerst, het argument van de identiteit tussen de vervolgende instantie, het openbaar ministerie (OM), en de vervolgde persoon (de staat). Dit argument situeert zich op het processuele niveau. Ten tweede, het argument dat bestraffing van de staat zinloos zou zijn omdat uiteindelijk bij het opleggen van een straf de staat aan zichzelf betaalt. ${ }^{827}$ Dit zogenaamde vestzak-broekzak-argument situeert zich op het sanctionele niveau.

825. Roef, D., l.c, 1995, 341; Deruyck, F., o.c., 1996, 187.

826. De gevallen waar aan privaatrechtelijke rechtspersonen bepaalde overheidstaken, dus taken van algemeen belang, en bijbehorende beschikkingsbevoegdheden worden opgedragen, zijn talrijk. Zie voor een zeer volledige opsomming naar Nederlands recht: Ackermans-Wijn, o.c., 1989, 28. Ook de Belgische wetgever doet bij de inrichtingen van openbare diensten vaak beroep op vormen waarin privaatrechtelijke instellingen tot stand komen. Illustratief in dit verband is een arrest van de Belgische Raad van State waarin terecht wordt vastgesteld 'dat het in een steeds groter wordend aantal domeinen steeds veelvuldiger voorkomt dat diensten die geacht worden van openbaar nut te zijn maar die beroepshalve worden verstrekt, verleend worden in het raam van organisaties die de vorm aannemen van een vereniging zonder winstoogmerk.' R.V. St. Van Damme, Nr. 17192 van 7 oktober 1975, aangehaald in Mast, A. en Dujardin, J., o.c., 1994, 70.

827. Zie o.a. Strijards, G.A.M., o.c., 1988, 41 . 


\section{§ 7. De staat vervolgt zichzelf en de eenheid van de regering}

Het argument van identiteit tussen vervolgde en vervolger lijkt op het eerste gezicht gefundeerd. De Raad van State formuleert in zijn advies aan het kabinet dit argument als volgt:

'opheffen van de immuniteit [zou] neerkomen op de figuur van de staat die zichzelf vervolgt, beoordeeld en bestraft; rechter en openbaar ministerie zijn immers ook organen van de rijksoverheid. ${ }^{828}$

In het verlengde van dit argument is voor de Raad van State doorslaggevend het bezwaar dat met de vervolging van de staat de eenheid van regering en beleid op het spel staan, wat bij de vervolging van decentrale overheden niet het geval is. Op dit punt is de minister opeens akkoord met het advies van de Raad van State:

'De specifieke positie van de Staat brengt naar mijn mening inderdaad de wenselijkheid van algehele immuniteit van strafvervolging met zich mee. Hiervoor pleit vooral het aspect van - wat door de Raad van State wordt aangeduid als - de eenheid van de regering. Strafvervolging impliceert de betrokkenheid van de minister van Justitie. Het erkennen van de mogelijk-heid van vervolging van de Staat zou de positie van de minister van Justitie als lid van de regering aanmerkelijk compliceren. Enerzijds ligt het, zo kan met de Raad worden geoordeeld, niet voor de hand de ministerraad te betrekken bij beslissingen inzake de vervolging van de Staat; anderzijds schept een autonome verantwoordelijkheid van de minister van Justitie bijzondere staatsrechtelijke problemen. De Raad vestigt er terecht de aandacht op dat ook toetsing en beoordeling van het vervolgingsbeleid in deze door de Staten-Generaal vraagtekens oproept. De eenheid van het regeringsbeleid kan bij deze toetsing moeilijk een ijkpunt vormen. ${ }^{.829}$

Dit argument is niet overtuigend genoeg om een absolute immuniteit te rechtvaardigen. De argumentatie zou zijn dat het $\mathrm{OM}$ de staat niet kan vervolgen omdat het $\mathrm{OM}$ op basis van de Wet Rechterlijke Organisatie (RO) ondergeschikt is aan de minister van Justitie. Ik ben het daar niet volledig mee eens. Allereerst is het een denkfout uit een zogenaamde ondergeschiktheid aan de minister van Justitie meteen een ondergeschiktheid aan de publiekrechtelijke rechtspersoon 'de staat' af te leiden. Bovendien is een dergelijke uitleg van de $\mathrm{RO}$ ook te eenzijdig. $\mathrm{Zij}$ gaat er immers van uit dat het $\mathrm{OM}$ in alle gevallen kan

828. TK 1999-2000, 25294 , nr. 10, A, 2.

829. TK 1999-2000, 25 294, nr. 10,1-2. Dit argument werd door de minister herhaald in de standpuntbepaling van 22 september 2000: TK 2000-2001, 25 294, nr. 12, 3. De minister voegt daar nog aan toe dat een vervolging van de staat niet alleen het kabinetsberaad compliceert, maar dat een dergelijke gang van zaken 'het vertrouwen van de bevolking in de overheid kan schaden.' En een immuniteit vanwege de eenheid van de regering zou dit vertrouwen dan niet schenden? 
worden herleid tot een departementale buitendienst van het ministerie van Justitie en dat een $\mathrm{OvJ}$ niet meer dient te zijn dan een bestuursambtenaar. ${ }^{830}$ Een OvJ is mijns inziens veel meer dan een bestuursambtenaar. Hij heeft tevens een magistratelijke opdracht. ${ }^{831} \mathrm{Op}$ welke functie de nadruk ligt, hangt af van de context waarbinnen de OvJ optreedt. ${ }^{832} \mathrm{De}$ magistratelijke taak van het $\mathrm{OM}$ en de daarmee gepaard gaande onafhankelijkheid is juist het grootst wanneer het gaat om beslissingen van al of niet vervolgen, en zeker wanneer overheidshandelen in het geding is. Artikel $127 \mathrm{RO}$ moet dan ook steeds worden uitgelegd in de context van artikel $124 \mathrm{RO}$. Artikel $124 \mathrm{RO}$ draagt het OM niet enkel handhaving van de wetten op maar bovenal handhaving van het recht. ${ }^{833}$ Dat betekent dat het OM zich primair dient te richten op het dienen van de rechtsorde. Dat zou meer moeten behelzen dan een kritiekloze implementatie van het beleid dat een bepaalde overheid heeft ontwikkeld. Daarin ligt mogelijk de meerwaarde van het $\mathrm{OM}^{834}$ Het OM kan die meerwaarde echter slechts verwerkelijken indien hij over voldoende machtskritische onafhankelijkheid beschikt. Een onafhankelijkheid die het OM in staat stelt om een overheid die strafrechtelijke normen overtreedt te kunnen vervolgen:

'De rechtsgemeenschap is uitsluitend gediend met een openbaar ministerie dat voldoende zelfstandigheid bezit om in een onpartijdige proceshouding tegen normschendingen ook van enige overheid op te treden. ${ }^{835}$

De zorg voor een adequate rechtshandhaving moet dan ook worden beschouwd als de handhaving van de rechtsstaat, waarin het $\mathrm{OM}$ bij de behandeling van een geding voldoende onpartijdig kan zijn en in de eerste plaats verantwoording is verschuldigd aan de rechter. Kortom, OvJ's zijn bij rechtshandhaving niet slechts gens $d u$ roi, zelfs geen gens du loi: zij zijn bovenal gens du droit. ${ }^{836} \mathrm{Het} \mathrm{OM}$ dient idealiter in onze rechtsstaat het recht in de staat, niet de staat in het recht te vertegenwoordigen. Het is interessant in dit verband opnieuw te verwijzen naar een uitspraak van een voormalig minister van Justitie:

'Ik meen dat er slechts één gebied is waarop de minister van justitie grote terughoudendheid moet betrachten in de uitoefening van zijn beïnvloedingsmogelijkheden. Hier kan het feit dat het openbaar ministerie deel uitmaakt van de rechterlijke macht van bijzondere betekenis zijn. $I k$ doel op gevallen waarin de overheid of een overheidsfunctionaris, dan

830. Vgl. Lubberdink, H.G., De betekenis van de ministeriële verantwoordelijkheid voor de organisatie van het openbaar bestuur, Deventer, 1982, 70.

831. Zie Ficq, C.R.L.R.M., 'De officier van jusititie, magistraat (of bestuursambtenaar?)', Trema, 1991, 158-166; Remmelink, J., 'De officier van justitie, magistraat of bestuursambtenaar?', Trema, 1991, 167-179; De Doelder, H., 'Van Paasbrief tot herfstweer. Over de begroting van Justitie', $D D, 1993,911-921$.

832. Schalken, T.M., 'Het taboe van art. 5 RO', Trema, 1991, 179 e.v.

833. Zie 't Hart, o.c., 1994, 141-163.

834. Zie De Doelder, H. en 't Hart, A.C., 'De meerwaarde van het OM', Trema, 1990, 250-252.

835. Meijers, I.C.M., 'Het einde van de onpartijdigheid, van openbaar ministerie tot departementale vervolgingsdienst', Trema, 1991, 174.

836. Vgl. Stolwijk, S.A.M., 'Minister van Justitie, Openbaar Ministerie en artikel 5 RO', in Magistraat met beleid: de Officier van Justitie en zijn omgeving, 1992, 35. 
wel een natuurlijk persoon of rechtspersoon die een gewichtige maatschappelijke functie vervult, als verdachte in een strafrechtelijk onderzoek betrokken wordt...'(cursief, DR) ${ }^{837}$

Dogmatisch gezien is dit argument dus niet doorslaggevend. Vanuit praktisch oogpunt kunnen zich echter wel problemen voordoen. Corstens geeft als voorbeeld de lastige positie waarin het $\mathrm{OM}$ zou verkeren als deze wordt geconfronteerd met een beslissing van de ministerraad dat er niet vervolgd moet worden ${ }^{838}$ Daar wijst immers ook de Raad van State op. $^{839}$ Dergelijke (zeldzame) praktische moeilijkheden rechtvaardigen echter nog geen absolute vervolgingsuitsluitingsgrond. Zij wijzen niet op de vraag of de staat moet kunnen worden vervolgd maar op het probleem hoe de staat moet worden vervolgd. Dat probleem zou kunnen worden opgelost door het creëren van een aparte procedure al dan niet analoog aan de procedure voor ministers en staatssecretarissen ${ }^{840}$ Toch lijkt mij zelfs een dergelijke procedure niet echt wenselijk. De meeste gevallen waar de staat in het geding is betreffen strafbare feiten die door overheidsinstellingen worden begaan, die ver zijn verwijderd van de centrale leiding van de staat, de departementele top. De Vliegbasis Volkel-casus is daarvan een voorbeeld. Bovendien betreft het in veel gevallen weliswaar geen bagateldelicten, maar wel het type milieudelicten waarbij men zich kan afvragen of voor de vervolging van dergelijke delicten een zware procedure wenselijk is. Kortom, indien het strafbaar feit gepleegd binnen de rechtspersoon 'de staat' niet tevens een door een minister of staatssecretaris gepleegd ambtsdelict oplevert, kan volgens mij worden volstaan met de gewone strafrechtelijke procedure. In de woorden van de Roos:

'Zo overtuigend als de ministeriële brief is in de kritiek op de Raad van State, zo onbevredigend en mager is de onderbouwing van de wenselijkheid van de immuniteit van de centrale overheid. De taakverdeling tussen centrale en decentrale overheden is immers vaak nogal toevallig, en bovendien aan voortdurende verandering onderhevig. Bovendien - zoals de Raad van State het - nu eens terecht - formuleert, worden de overheden 'voor de uitvoering van hun taken steeds meer van elkaar afhankelijk'. Inderdaad kleven aan de invoering van specifieke procedures veel nadelen, maar daaraan bestaat geen behoefte. De door de minister in gretige navolging van de Raad van State geschetste problemen zijn namelijk niet van een zodanige aard en omvang, dat immuniteit dermate onwenselijk wordt dat het door de minister zelf sterk benadrukte belang van de rechtsgelijkheid het onderspit zou moeten delven. ${ }^{.841}$

837. Korthals Altes, F., 'De verhouding tussen minister van justitie en het openbaar ministerie', Trema, 1988, 372.

838. Corstens, G., l.c., 1994, 2807.

839. TK 1999-2000, $25294,10$.

840. Hennekens, H., L.c., 1990, 331.

841. De Roos, Th.A., I.c., 2000, 96. 


\section{§ 8. Het vestzak-broekzak-argument}

Een tweede bezwaar tegen strafvervolging van de staat betreft een argument tegen de sanctionering van de staat. De aan de staat op te leggen straf zal meestal bestaan uit het betalen van een geldboete. Deze bestraffing wordt echter zinloos geacht, omdat uiteindelijk de staat aan zichzelf betaalt. ${ }^{842}$ De minister van Justitie neemt ook dit argument van de Raad van State klakkeloos over:

'De Staat is zowel vervolger als vervolgde, zij betaalt boetes aan zichzelf. Het kabinet stelt zich mede in dat licht de vraag of het met strafrechtelijke doelstellingen verenigbaar is om afkeuring van gedragingen die aan de Staat worden toegerekend langs deze weg tot uitdrukking te brengen. $\mathrm{Bij}$ het nastreven van strafrechtelijke doelstellingen neemt de mogelijkheid daartoe straffen en maatregelen op te leggen een centrale plaats in. Een kernprobleem bij vervolging van de Staat is, dat straffen en maatregelen op zichzelf bezien nauwelijks effect kunnen sorteren. Vrijheidsbenemende straffen en maatregelen alsmede dienstverlening komen niet in aanmerking [geldt dit argument niet voor alle rechtspersonen? DR]. Een geldboete betaalt de Staat aan zichzelf. Uit de in artikel $28 \mathrm{Sr}$ bedoelde rechten kan de Staat niet ontzet worden [decentrale overheden evenmin ! DR] . Bij verbeurdverklaring, onttrekking aan het verkeer en de ontnemingsmaatregel komt het verkregene ten bate van de Staat. Openbaarmaking van de rechterlijke uitspraak dient tot waarschuwing van hen die later met de veroordeling in betrekking zouden treden; bij de Staat kan die ratio zich niet voordoen. Oplegging van een schadevergoedingsverplichting of, in economische strafzaken, een herstelverplichting kan ook langs civielrechtelijke weg worden bereikt; waar andere straffen en maatregelen niet met vrucht kunnen worden opgelegd, kan proceseconomie geen reden zijn om toepassing van deze maatregelen in het strafrecht mogelijk te maken. Zinvolle strafrechtelijke sanctionering van de Staat behoort derhalve nauwelijks tot de mogelijkheden. ${ }^{843}$

Dit zogenaamde vestzak-broekzak-argument is niet helemaal overtuigend. Men kan het opleggen van een straf aan de staat niet voorstellen als een aan zichzelf betalende staat ${ }^{844}$ of als een man die zichzelf kastijdt ${ }^{845}$. Dat is al te simplistisch. De staat is geen éénmanszaak of een ondeelbare eenheid. De staat is als publiekrechtelijke rechtspersoon een complexe uit afzonderlijke delen bestaande organisatie en een door het recht gestructureerd

842. Zie Torringa, R.A., o.c., 1984, 158. Van Strien heeft dit standpunt ook verdedigd, maar is daar later op terug gekomen: Van Strien, A.L.J., o.c., 1996, 59.

843. TK 2000-2001, 25294 , nr. 12, 2.

844. Zie Torringa, R.A., o.c., 1984, 158.

845. Strijards, G.A.M., o.c., 1988, 60. 
geheel van afzonderlijke functies en departementen ${ }^{846}$. Daarbij is het de gewoonste zaak van de wereld dat financiën van het ene departement naar het andere verschuiven.

\begin{abstract}
The reality of the Crown paying a fine to itself is that one government department, with its own seperate accounts, accounts for the fine to another government departement. If the accounts of government are to reflect the true costs and benefits of running each department - and surely this is a prerequisite to efficient management - then the recording of a judicially imposed fine as an item in the outgo of one departement and the income of another seems an entirely proper procedure..$^{847}$
\end{abstract}

Zo is het tevens volkomen normaal en zinvol dat de staat aan zichzelf belastingen betaalt. ${ }^{848}$ De 'ondeelbare' staat heeft zeker politiek-psychologisch zijn waarde maar strookt niet met de realiteit. Bovendien belet het vestzak-broekzak-argument niet dat de staat aan zichzelf administratieve sancties kan opleggen. Ook zal in de praktijk de boete die aan het ministerie van Justitie door een ander departement zal moeten worden betaald voor deze laatste wel degelijk een financiële aderlating uitmaken. De straf kan beslist preventief werken. Dat in Nederland, althans tot voor het Volkel-arrest, de staat geregeld via het 'aan zichzelf' betalen van transacties een openbare strafvervolging heeft willen vermijden is daarvan een veelzeggende illustratie. ${ }^{849}$

Daarnaast behoeft het sanctiepakket van de strafrechter zich niet tot het opleggen van boetes te beperken. Zo zou men inderdaad ook voor het herstel van de schade kunnen opteren. Bovendien betreft een strafrechtelijke aansprakelijkheid niet alleen een sanctionering maar ook steeds een normering die van de symbolische en afkeurende uitstraling van een veroordeling uitgaat. ${ }^{850}$ Deze normering kan bijdragen tot een verscherpte interne en externe controle op de staat en aldus zorgen voor een bevestiging van de checks and balances enerzijds en de legitimiteit van het overheidshandelen anderzijds. $^{851}$

'De normvormende en normbevestigende functie van het strafrecht moet ook ten aanzien van de rijksoverheid uit de verf kunnen komen. Dat zou de geloofwaardigheid van de overheid in het algemeen bij de burger ten goede komen. ${ }^{852}$

846. Mast, A. en Dujardin, J., o.c., 1994, 77.

847. Hogg, P.W., Liability of the Crown, Sydney, 1971, 178-179.

848. Zie o.a. HR 9 november 1973, $N J 1974,351$ en 352.

849. Zie Kleiman, W.M., Van den Berg, E.A.I.M. en Van der Linden, E.J.A., o.c., 1995.

850. 't Hart, A.C., l.c., 1996, 2830.

851. Brants, C.H. en De Lange, R., o.c., 1996, 87-89.

852. De Roos, Th.A., l.c., 2000, 96. 


\section{§9. Individuele strafrechtelijke aanpak volstaat niet}

Een eerste belangrijk argument tegen een strafrechtelijke immuniteit (of voor strafvervolging) is zuiver instrumenteel van aard en verwijst rechtstreeks naar een meer effectieve strafrechtelijke handhaving van de milieuwetgeving. Evenals bij privaatrechtelijke rechtspersonen is het gevolg van de onmogelijkheid overheden strafrechtelijk aan te pakken, dat moet worden uitgeweken naar de vervolging van personen door dewelke de rechtspersoon (de overheid) optreedt. Aan de hand van onder meer de Duitse en Belgische situatie werd reeds vastgesteld tot welke problemen dit aanleiding kan geven. Het zal in de praktijk veelal moeilijk te bewijzen zijn welke natuurlijke persoon daadwerkelijk schuld heeft aan de gedraging van de rechtspersoon. In dat opzicht is dan ook het advies van de Raad van State af te keuren dat een strafrechtelijke aansprakelijkheid van overheden niet wenselijk is omdat een uitbreiding van de individuele strafrechtelijkheid, bijvoorbeeld via een uitbreiding van de deelnemingsregeling, voor een oplossing kan zorgen:

\section{'Indien zich een specifiek probleem voordoet op het punt van de aansprakelijkheid van de bestuurlijke of ambtelijke top van openbare lichamen, dan ware de oplossing te zoeken in uitbreiding van de (mede)aansprakelijkheid of medeplichtigheid van de bestuurlijke en ambtelijke top bij ambtsdelicten. ${ }^{1853}$}

Dat is niet een realistische oplossing. Men verliest te veel het vaak organisatorische of collectieve karakter van overheidshandelen uit het oog. Bovendien is ook criminaliteit gepleegd door overheden vaak ondernemingscriminaliteit en de maatschappelijke kost is hierbij vrij groot. Door de milieuregels niet na te leven kunnen overheden veel geld besparen. ${ }^{854}$ Wil het strafrecht ook bij milieucriminaliteit gepleegd door overheden zijn volledige preventieve en sturende werking hebben dan moeten de sancties meer zijn dan de loutere verdiscontering van de schade. Dat betekent dat een strafrechtelijke aansprakelijkheid van het individu niet voldoende prikkels zal verschaffen nu de optimale sanctie vaak het individuele vermogen overschrijdt. ${ }^{855}$ Ook is de veroorzaakte schade, vooral bij milieudelicten, vaak jaren later pas vast te stellen. Ondertussen kunnen zoveel personele wisselingen bij de verdachte overheid zijn doorgevoerd, dat praktisch gezien alleen de overheid aansprakelijk kan worden gesteld.

Daarnaast mag niet worden vergeten dat de betrokken ambtenaren in bepaalde gevallen de kans krijgen strafbare feiten te plegen juist omdat bij het overheidslichaam de criminogene voorwaarden aanwezig zijn die het delict mogelijk maken of intern ongesanctioneerd laten. Hierbij kan gedacht worden aan klassieke kwalen zoals gebrekkige organisatie ${ }^{856}$ en

853. TK 1999-2000, $15294, \mathrm{~A}, 4$.

854. Zo heeft de gemeente Nijmegen tussen 1990 en 1995 wellicht 60 miljoen gulden bespaard door vervuilde grond niet volgens de wettelijke regels af te voeren. Het OM heeft besloten, gelet op de rechtspraak van de Hoge Raad, niet tot vervolging over te gaan. Zie Trouw 21 januari 1997.

855. Faure, M., Oudijk, H. en Koopmans, I., L.c., 1992, 21.

856. Brants, C.H. en De Lange, R., o.c., 1996, 88-89. 
controle, de afwezigheid van duidelijke hiërarchische verhoudingen en een onoirbare vermenging van private en publiek belangen. In die context kan worden verwezen naar de sterk veranderde rol van de overheid en de ambtenaar in het maatschappelijk veld. Overheden zijn in onze maatschappij verweven met het particuliere economische en sociale leven. Criminaliteit gepleegd binnen het kader van een overheid vestigt rechtstreeks de aandacht op de kwetsbaarheid van de relatie tussen overheid en burger omdat het wijst op een toenemend conflict tussen het publiek en het privaat toelaatbare. Wat privaat een deugd kan zijn, blijkt publiek vaak een zonde. ${ }^{857} \mathrm{Er}$ is een vervaging tussen de publieke moraal en de private commerciële moraal. ${ }^{858}$ Binnen de organisatie van een overheid geeft. dit aanleiding tot onduidelijke hybride, zoniet 'normloze' situaties. ${ }^{859}$ Door een samenspel van ontwikkelingen en tendensen is de ambtenaar, de klassieke belangeloze dienaar van de publieke taak, niet meer in de situatie dat hij veilig kan terugvallen in de voorgeschreven sociale rol zoals die in de Weberiaanse bureaucratietheorie model stond. Op overheidsniveau gaat meer en meer een andere logica dan de redelijk eenduidige loyaliteit met het algemeen belang en het respecteren van hiërarchie een cruciale rol spelen. In de praktijk moet men met het bedrijfsleven wedijveren, met belangengroepen en lobbies compromissen bereiken. ${ }^{860}$ Vanuit dit perspectief volstaat het dan ook niet de aansprakelijkheid te reduceren tot de verantwoordelijkheid van een of meerdere individuen:

\begin{abstract}
'this reductionism is unrealistic; both corporate and individual blameworthiness are alive, well and living intentionally (...) Thus, where a corporate system is blamed for criminogenic group pressures, that blame is directed not at individual actors but rather toward an institutional set-up from which the standards of organisational performance expected are higher than those expected of any personnel. ${ }^{861}$
\end{abstract}

Ook is het juridisch-technisch vaak moeilijk het gepleegde feit aan een individuele ambtenaar ten laste te leggen omdat talrijke milieunormen nu eenmaal gericht zijn tot rechtspersonen. Gewone ambtenaren zijn vaak geen normadressaat in het ordeningsstrafrecht. Ook dit bemoeilijkt de toerekening van criminele feiten aan een of meerdere individuen.

857. Roef, D. en De Roos, Th.A., 'Strafrecht als discussie - over corruptie', in Bestuurlijke integriteit: ervaringen en perspectieven Themanummer Bestuurswetenschappen, 1995, 412.

858. Van Vugt, G.W.M. en Boet, J.F., Zuiver handelen in een vuile context. Over (grensoverschrijdende) afvalstromen, milieucriminaliteit en integer handelen in het openbaar bestuur, Amhem, Gouda Quint, 1994, 65-66.

859. Bovens, M.A.P., 'Ambtelijke verantwoordelijkheid', in de Jong, P. (red.), Verantwoordelijkheid en verantwoording in het openbaar bestuur, 's Gravenhage, 1995, 133-144.

860. Roef, D. en De Roos, Th.A., l.c., 1995, 412-413.

861. Fisse, B., 'Controlling Governmental Crime: issues of individual and collective liability', in Gabrosky, P. (ed.), Government Illegality, Canberra, 1986, 122-123. 


\section{$\S 10$. Rechtsbescherming en rechtsgelijkheid}

Niet alleen instrumenteel gezien getuigt een louter individuele benadering van overheidscriminaliteit van weinig realisme; ook vanuit het standpunt van bescherming van het individu is veel te zeggen voor een aansprakelijkheid van de overheid als collectiviteit. Het louter aanpakken van de foute functionaris verwijdert wellicht de zwakste schakel uit de overheidsketen, maar doet tevens uit het oog verliezen dat mogelijk de keten zelf niet deugt. Het risico is niet denkbeeldig dat één ambtenaar als zondebok wordt opgeofferd. Een immuniteit van overheden én leidinggevers verplicht het $\mathrm{OM}$ immers de aandacht te richten op de gewone (uitvoerende) ambtenaar. ${ }^{82}$ Dit risico is thans vooral in België zeer groot, daar overheden in alle gevallen van strafvervolging zijn uitgesloten.

Een strafrechtelijke immuniteit voor overheden is vanuit een breder rechtsbeschermingsperspectief ook in strijd met het gelijkheidsbeginsel; in ieder geval daar waar overheden activiteiten verrichten gelijk aan particulieren zal een immuniteit tot rechtsongelijkheid leiden en een niet gepaste voorsprong op het particuliere bedrijfsleven creëren. Daaruit kan een argument worden afgeleid om de strafrechtelijke aansprakelijkheid enkel uit te sluiten voor exclusieve overheidstaken. Dat is, met uitzondering van de staat, ook het Franse en Nederlandse systeem. Tegen dit criterium kan dan weer, zoals gezien, worden aangevoerd dat het theoretisch niet zuiver is en praktisch niet steeds hanteerbaar.

Waar de, in vergelijking met privaatrechtelijke rechtspersonen, ongelijke of zelfs bovengeschikte positie van overheden als rechtvaardiging wordt gezien voor een immuniteit, kan met evenveel verve die ongelijkheid worden aangevoerd als een extra argument vóór strafrechtelijke aansprakelijkheid. De strafrechtelijke aansprakelijkheid van privaatrechtelijke rechtspersonen in het milieustrafrecht refereert aan het leefmilieu als (strafrechtelijk) beschermd rechtsgoed. Indien overheden zich aan milieudelicten schuldig maken is echter niet alleen het leefmilieu in het geding, maar staat ook de bestuurlijke integriteit op het spel. Het gaat bij door de overheid gepleegde milieudelicten dus niet alleen om de bescherming van het leefmilieu maar ook om de rechtmatigheid van het overheidshandelen als zodanig. Zo is het best verdedigbaar dat de ongelijkheid tussen publiek en privaat eerder moet worden uitgelegd als een argument voor dan een bezwaar tegen de strafrechtelijke controle. In die zin moet ook de voorbeeldfunctie van overheden sterk worden benadrukt.

\section{§11. Strafvervolging als correctief op de administratieve afhankelijkheid}

Binnen het kader van het milieurecht kan een argumentatie voor de strafrechtelijke aansprakelijkheid van overheden tevens worden gevonden in de administratieve afhankelijkheid van het milieustrafrecht. In het milieustrafrecht worden de ecologische rechtsgoederen zoals zuiver oppervlaktewater, schone bodem en schone lucht niet

862. Idem, 124: 'Individualism urges the reallocation of scarce enforcement resources to prosecuting larger numbers of corporate personnel, an enforcement strategy which is inegalitarian in tendency'. 
rechtstreeks maar via opgelegde administratieve plichten beschermd. Deze administratieve plichten worden door de onderscheiden milieuoverheden vastgelegd. Een dergelijk stelsel, waarbij kan worden gesproken van een zekere 'afdanking' van de strafwetgever, vindt zijn voornaamste rechtvaardiging in het streven naar een doelmatig en doeltreffend milieubeleid. Milieuoverheden spelen aldus een cruciale rol bij het vastleggen van de strafbaarstelling alsook bij de handhaving ervan ${ }^{863} \mathrm{De}$ administratieve overheden hebben een belangrijke bevoegdheid om te beslissen welke vervuiling wordt vervolgd en welke onbestraft blijft. ${ }^{864} \mathrm{Nu}$ zijn juist in een bestuursondersteunend rechtsgebied als het milieurecht, waar overheden zelf via de verantwoordelijke bewindslieden vorm en inhoud geven aan regelgeving enerzijds en handhaving anderzijds, voldoende redenen aanwezig om deze overheden te vervolgen wanneer zij zelf milieudelicten plegen. Met name in die gevallen waar de overheid rechtstreeks het milieu vervuilt of onrechtstreeks via wederrechtelijke vergunningverlening milieuverontreiniging veroorzaakt of in stand houdt, rijst sterk de vraag naar de strafrechtelijk aansprakelijkheid van die overheid. De mogelijkheid van strafrechtelijke aansprakelijkheid van overheden kan dan worden benaderd als een tegengewicht voor de huidige administratieve afhankelijkheid. De verantwoordelijkheid die overheden in het milieurecht hebben, kan pas echt ernstig worden genomen indien tegelijk haar spiegelbeeld, aansprakelijkheid, effectueerbaar blijft.

\section{§ 12. Machtskritische herijking van het (milieu)strafrecht}

Een laatste overweging overstijgt het zuiver instrumentele en het belang van het leefmilieu. Het betreft meer een algemene heroriëntering van het (milieu)strafrecht. Het strafrecht kan traditioneel worden beschouwd als een poging de anti-despotische Verlichtingsidealen juridisch-maatschappelijk te verwezenlijken. Die hervormingsidealen, zoals we die onder meer aantreffen bij Montesquieu en Becarria, kunnen als volgt worden samengevat. $\mathrm{Zij}$ omvatten enerzijds een streven naar een bescherming van maatschappij en burger tegen een onzekere, arbitraire en ongelimiteerde machtsuitoefening en anderzijds zijn zij gericht op de verwezenlijking van een samenleving waarin zelfontwikkeling, mondig burgerschap en de daartoe noodzakelijke vrijheid van het individu centraal staan. Het strafrecht wordt in die zin traditioneel gekenmerkt door een rechtsbeschermende (machtskritische) en een instrumentele (ordenende, sturende) functie, die als twee zijden van één medaille onverbrekelijk met elkaar zijn verbonden; beide functies houden elkaar wederkerig in de ban. $^{865}$

De rechtsbeschermende taak, gedragen door het democratische ideaal een vrije samenleving te waarborgen, houdt niet alleen bescherming van de burger tegen de overheid in, maar impliceert tevens een bescherming tegen elke inbreuk op menselijke vrijheid in denken en handelen, dus ook een bescherming van de samenleving tegen criminaliteit. ${ }^{866}$ Dit reeds in hoofdstuk II besproken uitgangspunt dient met name te gelden wanneer

863. Zie hierover hoofdstuk II.

864. Faure, M., l.c, 1991-92, 937-950.

865. Foqué, R. en 't Hart, A.C., o.c., 1990; Gutwirth, S., o.c., 1994, 336-360.

866. 't Hart, A.C., o.c., 1994, 235-265. 
criminaliteit wordt gepleegd of ondersteund door de overheid. Een beschermend recht dat de instrumentaliteit van maatschappelijke sturing en ordening echter buiten haar eigen werkingssfeer plaatst, kan niet meer zijn dan een ethische utopie; zij kan de rechtsbescherming de facto garanderen noch handhaven. Anderzijds kan de maatschappelijk ordenende taak van het strafrecht, die zich vooral of zelfs uitsluitend concentreert op de sanctionering van criminaliteit gepleegd door de burger, leiden tot maatschappelijke gijzeling en onvrede indien het individu en de vaak precaire verhoudingen tussen (groepen) individuen niet tegelijk worden beschermd tegen mogelijke excessen van een ordenende en sturende overheid.

We hebben reeds verschillende keren vastgesteld dat de oriëntatie op machtskritische beginselen, die relatief zelfstandig zijn ten aanzien van het conflictoplossende gebruik van het strafrecht, de laatste decennia enigszins op de achtergrond zijn geraakt. Het doel van de straf, sturing van de maatschappelijke orde en bescherming tegen criminaliteit, is steeds meer op de voorgrond komen te staan. Met name in het ordeningsrecht en dus ook in het milieurecht wordt het strafrecht vaak uitsluitend als een maatschappelijk sturingsmedium beschouwd. Het machtskritische aspect van het strafrecht, dat door middel van de macht van het recht voortdurend het recht van de macht moet kunnen kanaliseren, wordt hierdoor vaak ter wille van de vervolmaking van het uitgestippelde milieubeleid geminimaliseerd. Dit heeft onder meer tot gevolg dat de zwakke plekken van de overheidsmacht niet centraal komen te staan in het milieubeschermingsproject van de overheid. Het spreekt voor zich dat in die optiek milieuoverheden niet meteen in het klassieke boefbeeld passen. Mijns inziens is de strafrechtelijke aansprakelijkheid van overheden daarom niet alleen van belang voor een betere en meer rechtvaardige bescherming van het leefmilieu. Dat is in de kern een louter instrumentele overweging. De mogelijkheid tot het strafrechtelijk vervolgen van overheden is tevens van belang om het machtskritische en bestuursonafhankelijke aspect van het strafrecht te bewaken. Dergelijke accentverschuiving naar het machtskritische beschermt ons tegen de naïeve vooronderstelling van een eenzijdig naar de burger georiënteerd strafrecht, dat enerzijds een samenhangend conflictloos overheidsbeleid mogelijk zou zijn en dat anderzijds overheden en ambtenaren neutrale belangeloze instrumenten zouden zijn. Dat betekent dat het optreden van overheden geloofwaardig en betrouwbaar zal moeten zijn ten aanzien van de gerechtvaardigde en legitieme verwachtingen die overheid en burgers ten opzichte van elkaar hebben. Daarin past niet een conceptie van een overheid die boven de strafwet staat. ${ }^{867}$ Vanuit dit perspectief dient het (milieu)strafrecht steeds de ruimte en de mogelijkheid te hebben overheden zelf aan te sporen hun taak naar behoren uit te voeren.

\section{$\S 13$. Conclusies}

Als voornaamste argumenten voor een strafrechtelijke immuniteit van overheden worden de machtenscheiding en de doorkruising van politieke en bestuurlijke controle aangevoerd. Afgezien van het gegeven dat deze argumenten ook zouden kunnen worden gebruikt bij

867. Vgl. Foqué, R.M.G.E., 'De legitimiteit van het huidige strafrechtssysteem', in De Doelder, H., Foqué, R.M.G.E. en Gerding, R.A.F. (red.), o.c., 1994, 19-20. 
strafbare feiten gepleegd bij een niet-exclusieve bestuurstaak, is duidelijk geworden dat zij niet in die mate overtuigend zijn dat ze een uitsluiting van overheden van de werking van het strafrecht kunnen rechtvaardigen. Een belangrijke rode draad in veel van de argumenten is dat het primaat moet liggen bij niet-strafrechtelijke controlemechanismen, zoals bestuurlijk toezicht of politieke controle. In het vorige hoofdstuk is er reeds op gewezen dat de bij overheden aanwezige beslissingsruimte geen beletsel hoeft te zijn voor rechterlijke en dus ook niet voor strafrechterlijke controle.

Dat het primaat bij andere controlemechanismen zou moeten liggen, kan wel rechtvaardigen dat niet onbehoedzaam met strafvervolging moet worden omgegaan. Dit moet bij de opportuniteit van de vervolging worden beoordeeld. Bij de beantwoording van de vraag welke controle op een door een overheid gepleegd strafbaar feit wenselijk is, lijkt mij inderdaad een vruchtbaar uitgangspunt dat de politieke, bestuurlijke en bestuursrechtelijke controle het primaat moet hebben. Zo kan men overwegen om (alsnog) niet te vervolgen indien naar aanleiding van de verboden gedraging een zorgvuldige bestuurlijke procedure loopt. Al naargelang de uitkomst van deze procedure kan desnoods worden vervolgd, geseponeerd of een transactie worden aangeboden. Maar het moge duidelijk zijn dat een bestuurlijke en politieke controle als dusdanig geen argument is voor een strafrechtelijke immuniteit, waardoor strafrechtelijke controle al bij voorbaat is uitgesloten, met name in gevallen waar alternatieve controlemechanismen hun beoogde werking missen of waar evident onrecht is gepleegd. De beperkingen van politieke, bestuurlijke en bestuursrechtelijke controle kunnen vanwege het karakter van deze instrumenten niet in die zin worden opgelost dat zij strafrechtelijke controle volledig overbodig maken.

Wat de staat betreft, kan worden geconcludeerd dat de argumenten voor strafrechtelijke immuniteit allemaal één ding gemeen hebben: namelijk het gegeven dat de staat als een bijna mythisch ondeelbaar geheel wordt waargenomen. Sommigen verklaren de immuniteit zelfs vanuit het adagium The King can do no wrong. ${ }^{868}$ Een mooie illustratie van de wijze waarop de staat als een monolitisch blok ten tonele wordt gevoerd kan worden gevonden in een uitspraak van Schalken, die trouwens geen voorstander is van de immuniteit:

'de vervolgbaarheid valt theoretisch moeilijk te funderen: de Staat als rechtsprekend orgaan bestraft de Staat als bestuurlijk orgaan voor wat hij deed in strijd met de regels die de Staat als wetgevend orgaan heeft vastgesteld, terwijl de Staat ook nog eens als executeur van het tegen zichzelf uitgesproken strafvonnis moet optreden ${ }^{869}$

Eigenlijk wordt in één zin treffend (de ratio van) de machtenscheiding weergegeven en wordt hier dus eerder een argument voor dan tegen vervolgbaarheid van de staat vertolkt. In zijn algemeenheid strookt een monolitische voorstelling van de staat, als rechtvaardiging voor staatsimmuniteit, niet met het recht, noch met de maatschappelijke realiteit. Immers,

868. Mulder, G.E., noot onder HR 27 oktober 1981, NJ 1982, 474 (Verkeersdrempels). De annotator geeft wel toe dat hij 'onervaren is in het staatsrecht'.

869. Schalken, T., noot onder HR 23 oktober 1990, $N J 1990,496$. 
met een zelfde argumentatie dient dan ook te worden uitgesloten dat de staat zichzelf civielrechtelijk aansprakelijk stelt, of aan zichzelf belastingen betaalt. ${ }^{870}$

De 'ondeelbaarheid' van de staat speelt in het strafrecht voornamelijk parten omdat de strafrechtelijke aansprakelijkheid van overheden via artikel $51 \mathrm{Sr}$ is gekoppeld aan een civielrechtelijk gekleurd rechtspersoonlijkheidsbegrip. Het is de rechtspersoon 'de staat' die moet worden vervolgd indien binnen haar organisatie door een andere 'entiteit', die geen rechtspersoonlijkheid bezit, een strafbaar feit wordt begaan. Dat dit leidt tot ongerijmdheden is eerder geîllustreerd aan de hand van de zbo's. Hebben zbo's een eigen rechtspersoonlijkheid, dan zijn deze altijd vervolgbaar, zelfs wanneer het gaat om strikte overheidstaken. Kennen zbo's om wat voor reden ook geen rechtspersoonlijkheid dan genieten zij ten alle tijde de immuniteit van de staat waartoe zij automatisch behoren. Er kan dan ook worden betoogd dat voor een strafrechtelijke aanpak en controle van publiekrechtelijke organisaties, die tot 'de staat' behoren, rechtsstatelijk realisme moet primeren. Dit betekent dat men de strafrechtelijke blik niet langer op de rechtspersoonlijkheid van de staat dient te richten, maar op de publiekrechtelijke organisaties, die als zelfstandige strafrechtelijke rechtssubjecten moeten worden beschouwd. Dit niet zozeer omdat het absoluut onmogelijk zou (moeten) zijn om de staat als dusdanig te vervolgen of te bestraffen. Nogmaals, de argumenten contra vervolging en bestraffing van de staat zijn niet steeds even overtuigend, maar omdat zo veel meer recht wordt gedaan aan de maatschappelijke realiteit alsook aan de legitieme doelstellingen die het strafrecht bij de aanpak van overheidscriminaliteit moet kunnen vervullen. Nemen we de Volkel-casus als voorbeeld, dan is het duidelijk dat in deze zaak niet zozeer de aansprakelijkheid van de staat als geheel centraal had moeten staan, maar wel die van de vliegbasis Volkel als zelfstandig subject van strafrechtelijke plichten én rechten. Enkel wanneer uit het strafrechtelijk onderzoek blijkt dat er ook op departementeel niveau sprake is van laakbaar gedrag dat als strafwaardig kan worden aangemerkt, bijvoorbeeld wanneer de verantwoordelijke topambtenaren of minister op de hoogte waren van de strafbare feiten, maar daartegen geen maatregelen namen, hoewel zij daartoe gehouden waren, is het wellicht opportuun de staat als dusdanig aan te spreken (of het desbetreffende departement). Stel dat de militaire vliegbasis Volkel een eigen rechtspersoonlijkheid zou hebben, zou dan de staatsimmuniteit ooit zo hevig ter sprake zijn gekomen? Ik meen van niet. Het OM zou naar alle waarschijnlijkheid ontvankelijk zijn verklaard en de strafrechter zou zich vervolgens hebben kunnen uitspreken of de Vliegbasis als pleger van het strafbare feit kon worden aangemerkt. Meteen vallen zo ook de belangrijkste argumenten weg die tot op heden voor de staatsimmuniteit worden aangevoerd. Het gaat dan immers niet meer om de staat. Het strafrechtelijk vraagstuk wordt zo tot zijn werkelijke proporties teruggebracht. Het probleem is echter wel of de huidige redactie van artikel $51 \mathrm{Sr}$ toelaat dat publiekrechtelijke organisaties, die behoren tot de rechtspersoon van de staat, maar zelf geen civielrechtelijke rechtspersoon zijn, gelijk te stellen zijn met het begrip 'rechtspersoon' in de zin van artikel $51 \mathrm{Sr}$. Deze kwestie wordt in het hiernavolgende hoofdstuk besproken, omdat de noodzaak tot een loskoppeling van de strafrechtelijke aansprakelijkheid van de staat van het civielrechtelijke rechtspersoonlijkheidsbegrip veeleer te maken heeft met de wijze waarop het daderschap van deel-

870. Zie hoofdstuk IV. 
organisaties binnen de staat zo goed mogelijk vorm moet krijgen, dan met de principiële vraag, die in dit hoofdstuk centraal staat, of de staat al dan niet onder de werking van het strafrecht moet kunnen vallen. 
Hoofdstuk VI

\section{Het daderschap van overheden voor milieuverstoring}

\section{§1. Inleiding}

Vóór Pikmeer II was het vrijwel onmogelijk overheden strafrechtelijk aansprakelijk te stellen voor milieudelicten. Deze delicten werden immers vaak geacht te zijn gepleegd bij de uitvoering van een overheidstaak. ${ }^{871}$ Omdat dit immuniteitscriterium door de Hoge Raad is geformuleerd als een vervolgingsuitsluitingsgrond kwam men bijgevolg niet tot een oordeel over het al dan niet strafbaar handelen van de overheid. ${ }^{872}$ Zoals besproken, heeft het Pikmeer II-arrest een belangrijke opening gecreëerd in de vervolgbaarheid van decentrale overheden door de immuniteit alleen nog maar te laten bestaan voor bestuurstaken die rechtens uitsluitend door bestuursfunctionarissen kunnen worden verricht. ${ }^{873}$ In de praktijk betekent dit dat decentrale overheden thans vervolgd kunnen worden voor vrijwel alle milieudelicten die ook door particulieren kunnen worden begaan: zo zijn illegale lozingen, het zonder vergunning uitbaten van een stortplaats of uitbaggeren van een vaarwater thans ook in hoofde van decentrale overheden vervolgbaar. ${ }^{874}$

$\mathrm{Nu}$ het OM niet langer voor dergelijke zaken niet-ontvankelijk kan worden verklaard - toch niet om redenen van immuniteit - zal het $\mathrm{OM}$ het tenlastegelegde feit moeten bewijzen en zal de strafrechter moeten beoordelen of de overheid in kwestie als dader van het gepleegde delict kan worden aangemerkt. In het milieustrafrecht rijst dan vanzelfsprekend de vraag wanneer overheden als dader van een milieudelict kunnen worden beschouwd.

In dit hoofdstuk wordt getracht op deze vraag een antwoord te geven. Omdat overheden, net zoals ondernemingen, slechts als rechtspersonen strafrechtelijk kunnen worden aangepakt volgen eerst enkele algemene beschouwingen over de verhouding tussen de strafbaarheid van de rechtspersoon en het schuldbeginsel (§ 2). Vervolgens passeren enkele rechtspersoonlijke daderschapscriteria de revue en worden zij in het licht van het schuldbeginsel geëvalueerd $(\S 3)$. Nu steeds een of andere vorm van verwijtbaarheid aan het

871. Zie hierover de hoofdstukken III en IV.

872. Cfr. Brants, C.H. en De Lange, R., o.c., 1996, 45.

873. Zie hierover de hoofdstukken III en IV.

874. Vgl. Hendriks, L.E.M. en De Lange, A., l.c., 1998, 41-47. 
overheidslichaam dient te worden toegerekend om tot bestraffing over te gaan, wordt tevens aandacht besteed aan het specifieke schuldvereiste in het milieustrafrecht (§ 4). Daarna wordt besproken hoe verschillende daderschapscriteria op de onderscheiden soorten milieudelicten kunnen worden toegepast (§ 5-8). Vervolgens wordt aandacht besteed aan de problematiek van het feitelijk leidinggeven, die naar aanleiding van de Pikmeer-zaak een aantal vragen deed rijzen $(\S 9)$. In paragraaf 10 wordt een tot op heden hypothetische situatie besproken, namelijk hoe het daderschap van de staat zou kunnen worden vastgesteld, eens de absolute immuniteit van de staat zou worden doorbroken. Het probleem van het daderschap van de staat is immers dat we te maken krijgen met een wel zeer grote en complexe organisatie waardoor het lastig wordt strafbare feiten aan deze 'super'-rechtspersoon toe te rekenen. Tot slot volgen enkele samenvattende conclusies (§ 11).

\section{§ 2. De precaire verhouding tussen de strafbaarheid van de rechtspersoon en het schuldbeginsel}

\section{A. GEEN STRAF ZONDER SCHULD (OOK IN EEN RISICOMAATSCHAPPU)}

Uitgangspunt dient te zijn dat voor rechtspersonen, dus ook voor overheden, het beginsel van 'geen straf zonder schuld' moet worden geëerbiedigd wil men niet afglijden naar een objectieve aansprakelijkheid. Dat ook bij een strafrechtelijke aansprakelijkheid van rechtspersonen geen afstand mag worden genomen van het schuldbeginsel houdt in de eerste plaats verband met de notie dat op het niveau van de verwijtbaarheid de voornaamste legitimatie van de straf dient te liggen: omdat er schuld is, is bestraffing door de overheid gelegitimeerd. ${ }^{875}$ Daarin ligt ook de limiterende functie van schuld: slechts waar schuld aanwezig is, mag worden gestraft. Vanuit het standpunt van het rechtssubject wijst dit op de rechtsbeschermende functie van het schuldbeginsel hetgeen zich onder meer processueel vertaalt in de onschuldpresumptie en de eis dat slechts bij een zeker schuldvermoeden bepaalde strafvorderlijke dwangmiddelen kunnen worden gebruikt. ${ }^{876}$

Ook op het niveau van de sanctionering van de rechtspersoon mag de waarde van het schuldbeginsel niet worden onderschat. Voor een uitgebalanceerde toepassing van het strafrecht, dient de 'mate van schuld' voor de strafrechter een belangriike leidraad te zijn voor de straftoemeting, voor de vaststelling van zowel strafsoort als strafmaat. ${ }^{877}$ Reeds bij de parlementaire voorbereiding van het Wetboek van Strafrecht werd door de Tweede Kamer gesteld dat '(...) de mate van schuld in de meeste gevallen door den regter zal moeten worden in aanmerking genomen bij het bepalen van het quantum der straf $(\ldots . .)^{878}$

875. Wemes, L.T., 'Commune delicten betreffende de milieuvervuiling in de sleutel van de schuld', in Faure, M., Oudijk, J.C. en Schaffmeister, D. (red.), o.c., 1991, 215.

876. Kristen, F.G.H., Borgers, M.J. en Koopmans, I.M., 'Schuld in het strafrecht', in Borgers, M.J., Koopmans, I.M. en Kristen, F.G.H. (red.), o.c., 1998, 21-23.

877. Nijboer, J.F., 'Schuldbegrip en schuldbeginsel als oriëntatiepunten in het strafrecht', Recht en kritiek, 1989, 380-381; Wemes, L.T.,'Commune delicten betreffende de milieuvervuiling in de sleutel van de schuld', in Faure, M., Oudijk, J.C. en Schaffmeister, D. (red.), o.c., 1991, 220-221.

878. Smidt I, o.c., 1881, 78. Volgens de Hoge Raad vindt het beginsel 'geen straf zwaarder dan de schuld' geen steun in het recht (HR 10 september 1957, NJ 1958, 5; HR 13 mei 1958, NJ 1958; 
Deze passage is begrijpelijk mede in het licht van het in het Wetboek van Strafrecht neergelegde onderscheid tussen (in de regel doleuse) misdrijven en overtredingen. De rol van schuld bij de straftoemeting is ook met zoveel woorden in het milieustrafrecht zelf neergelegd. De meeste milieudelicten zijn immers ondergebracht onder de WED waarin wordt gedifferentieerd al naar gelang zij opzettelijk zijn begaan of niet. In het eerste geval zijn milieudelicten misdrijven en worden zij met een hogere straf bedreigd dan wanneer zij als een overtreding moeten worden aangemerkt. ${ }^{879}$ Ook de commune milieustrafbepalingen kennen opzettelijke en culpose varianten met daarbij behorende strafmaxima.

Eens men ook voor rechtspersonen aanvaardt dat het schuldbeginsel de kern van een strafrechtelijke aansprakelijkheid moet blijven, moet tegelijk wel worden bedacht dat rechtspersonen zich niet als natuurlijke personen gedragen en dat klassieke strafrechtelijke noties, zoals schuld, daarom niet zomaar ongewijzigd op rechtspersonen kunnen worden toegepast. ${ }^{880}$ In dat opzicht moet hoofdzakelijk met twee zaken rekening worden gehouden.

In de eerste plaats kan opnieuw worden verwezen naar het gegeven dat tengevolge van moderne technologische en industriële ontwikkelingen onze samenleving is geëvolueerd in de richting van een risicomaatschappij, waardoor verantwoordelijkheidsvraagstukken een andere dimensie krijgen ${ }^{881}$ Enerzijds is de opdracht tot risicobeheersing middels uitgebreide controlesystemen naar de overheid toegeschoven. Anderzijds verlangt de risicomaatschappij een grotere mate van zelfdisciplinering in hoofde van burgers en organisaties die een maatschappelijke verantwoordelijkheid dragen met betrekking tot risicovolle activiteiten en processen. Zoals Raes, in navolging van Beck, opmerkt:

'De hoogtechnologische maatschappij dringt een volstrekt andere invulling op van de notie "aansprakelijkheid", omdat men die technologieën niet meer eenvoudig als een "verlengstuk" van de menselijke persoon kan zien. Hun reikwijdte is heel wat ruimer en dieper, zodat de mens veeleer een verlengstuk wordt van de technologie. Maar hoe zit dat dan met het aansprakelijkheidsdenken, waarin het causaal verband tussen fout en schade nog steeds centraal staat? Het probleem is immers dat een kleine fout een buitenproportionele schade kan aanrichten, die men de betrokkene noch moreel, noch materieel volledig kan aanrekenen (...) Het

HR 12 november 1985, $N J$ 1986, 327). Bemerk wel dat gelet op de strafmotivering van straffen de mate van verwijtbaarheid een rol speelt bij de straftoemeting (zie o.m. HR 25 juli 1985, $N J$ 1986, 184). Zie hierover ook Hofstee, E.J., 'Straf naar de mate van schuld?', in Enschedé, Ch.J. e.a. (red.), Naar eer en geweten, Arnhem, 1987, 195-214; Leijten, J.C.M., 'Straf naar de mate van schuld', in Corstens, G.J.M. e.a. (red.), Straffen in gerechtigheid, Amhem, Gouda Quint, 1987, 61-69; Kristen, F.G.H., Borgers, M.J. en Koopmans, I.M., 'Schuld in het strafrecht', in Borgers, M.J., Koopmans, I.M. en Kristen, F.G.H. (red.), o.c., 1998, 19-21.

879. Hendriks, L.E.M. en Wöretshofer, J., o.c., 1995, 23-25.

880. Vgl. Van Strien, A.L.J., 'Het daderschap van de rechtspersoon voor milieudelicten', in Faure, M.G., Oudijk, J.C., Schaffmeister, D. (red.), o.c., 1991, 257-301.

881. Zie hoofdstuk II. 
gevolg van dit alles is dat de relatie tussen (persoonlijke) verantwoordelijkheid en aansprakelijkheid vervaagt. ${ }^{.882}$

Hoewel Raes voornamelijk problemen van civiele aansprakelijkheid en verzekerbaarheid bespreekt, is deze vaststelling, gelet op het schuldbeginsel, ook voor de strafrechtelijke aansprakelijkheid van groot belang.

In de tweede plaats, en dit houdt met het voorgaande rechtstreeks verband, moet voor ogen worden gehouden dat we ook bij overheidscriminaliteit veelal te maken krijgen met wat in de rechtssociologie wordt aangeduid als 'complexe organisaties. ${ }^{883}$ De rechtspersoon 'de staat', bestaande uit verschillende departementen, sub-organisaties en diensten is daarvan wellicht het meest uitgesproken voorbeeld. Maar ook gemeenten kunnen vaak als complexe organisatie worden aangemerkt. Een strafrecht dat zowel effectief als rechtsbeschermend wil zijn, dient uit te gaan van de maatschappelijke realiteit, ${ }^{884}$ en moet met de specifieke aard van deze organisaties en hun activiteiten rekening houden. ${ }^{885}$ Laten we daarom de belangrijkste kenmerken van complexe organisaties op een rij zetten zodat duidelijk wordt welke problemen zich mogelijk bij de strafbaarheid van rechtspersonen (inclusief overheden) kunnen voordoen.

\section{B. COMPLEXE ORGANISATIES}

Complexe organisaties vertonen over het algemeen een combinatie van twee of drie eigenschappen ${ }^{886}$ Allereerst worden dergelijke organisaties gekenmerkt door een zekere grootschaligheid in personeelsbestand, takenpakket of activiteiten. Vervolgens getuigen zij in meer of mindere mate van een differentiatie in werkzaamheden, een hiërarchische gezagsstructuur, een positiebekleding op grond van deskundigheid en een rationele beleidsvoering op basis van en met behulp van regelgeving. Met andere woorden, zij vertonen een 'bureaucratische' organisatiestructuur. Doordat dergelijke organisaties opgedeeld zijn in onderafdelingen, directies en andere 'sub-units' worden zij, met name wanneer er sprake is van complexe produktie- en besluitvormingsprocessen en technologische ontwikkelingen, gekenmerkt door een gebrek aan transparantie. Het is vaak moeilijk exact vast te stellen, soms ook voor leden van de organisatie zelf, welke beslissingen er worden genomen, welke transacties er geschieden, wat voor interacties er met andere complexe organisaties plaats-

882. Raes, K., 'Een samenleving van onverantwoordelijken. Grenzen aan deresponsabilisering', in WODC, Schuld, Justitièle Verkenningen, nr. 5, WODC, Arnhem, 1999, 25-27.

883. Zie hierover o.m. Etzioni, A., A Sociological Reader on Complex Organizations, New York, Holt, Rinehart and Winston, 1969; Lammers, C.J., Organiseren van bovenaf en van onderop. Een beknopte inleiding in de organisatiesociologie, Utrecht, 1993.

884. Vgl. D'Haenens, J., 'Sanctions pénales et personnes morales', RDP, 1975-1976, 741; Deruyck, F., o.c., 1996, 273-274; Deruyck, F., 'Naar een strafrechtelijke aansprakelijkheid van de rechtspersoon in Belgiē', in Faure, M. en Schwarz, K. (red.), o.c., 1998, 45.

885. Van den Heuvel, G.A.A.J., Onderhandelen of straffen. Over organisatie-criminaliteit en overheids-controle, Arnhem, Gouda Quint, 1993, 21-34; Heine, G.,o.c. 1995, 31 -53.

886. Bovens, M.A.P., Verantwoordelijkheid en organisatie: beschouwingen over aansprakelijkheid, institutioneel burgerschap en ambtelijke ongehoorzaamheid, Zwolle, W.E.J. Tjeenk Willink, 1990, 13-15. 
vinden en of er zich daaromtrent onregelmatigheden voordoen. Doen er zich onregelmatigheden voor, dan is het niet altijd even eenvoudig het nodige bewijs te verzamelen op basis waarvan men een complexe organisatie kan aanspreken.

Dat deze kenmerken van complexe organisaties ook bij overheden mede aan de basis kunnen liggen van crimineel gedrag bleek duidelijk uit de reeds besproken Nijmeegse vuile grond-affaire. ${ }^{887}$ Deze zaak illustreert goed hoe complexe organisaties collectief gezien verantwoordelijk kunnen zijn voor strafbare gedragingen terwijl slechts met moeite één of meer individuen daarvoor kunnen worden aangesproken. Meerdere afdelingen en subafdelingen binnen de organisatie van de gemeente Nijmegen waren rechtstreeks of onrechtstreeks betrokken bij de strafbare milieuverstoringen. Niet alleen bleek de communicatie tussen de afdelingen Milieu, Bodem, Weg- en Waterbouw en Volkshuisvesting niet te functioneren, ook de organisatie zelf was zodanig opgezet dat alle criminogene voorwaarden aanwezig waren voor het mogelijk maken van de illegale praktijken. Zo was de afdeling Milieu binnen de gemeentelijke organisatie duidelijk ondergewaardeerd en werd deze politiek noch bestuurlijk ernstig genomen; zij had geen zelfstandige adviesbevoegdheid en was slechts een onderdeel van de afdeling Volkshuisvesting. Deze dienst had echter andere belangen te behartigen dan het leefmilieu zodat bepaalde belangrijke milieugegevens gewoonweg niet naar de gemeenteraad en de bevoegde wethouders werden doorgespeeld. Ook deze organen bleken aan het leefmilieu niet veel belang te hechten en lieten (meer dan) oogluikend toe hoe de milieuregels met de voeten werden getreden. Kortom, zowel de interne organisatie van de gemeente als de wijze waarop voor het leefmilieu belangrijke beslissingen tot stand kwamen, lagen mee ten grondslag aan een bepaalde overheidscultuur die een ideale voedingsbodem bleek te zijn voor de milieuverstorende activiteiten.

Een ander kenmerk van complexe organisaties is dat zij vaak oligopolist of zelfs monopolist zijn. ${ }^{888}$ Dat geldt niet alleen voor privé-organisaties, maar ook voor publieke organisaties. Zo hebben overheden op het vlak van het leefmilieu vrijwel een monopoliepositie zowel wat de vergunningverlening als de handhaving betreft. Dat veroorzaakt een zekere afhankelijkheid bij individuen van deze organisaties. Dit heeft tot gevolg dat individuele buitenstaanders de relaties met complexe organisaties moeilijk kunnen beïnvloeden en dat inzicht in de aard, voorkoming en beperking van de risicodragende activiteiten, zoals bijvoorbeeld milieuvervuilende productieprocessen slechts moeizaam is te verkrijgen. ${ }^{889}$ In tegenstelling tot natuurlijke personen verrichten complexe organisaties activiteiten die uit hun aard risicovoller, grootschaliger en diffuser zijn, hetgeen tot enorme maatschappelijke schadeposten kan leiden. Schadelijke activiteiten van rechtspersonen, bijvoorbeeld ten gevolge van inefficiënt management of bestuur, hebben daarom een veel grotere impact dan de schadeverwekkende handelingen van natuurlijke personen. ${ }^{890} \mathrm{De}$

887. Zie reeds hoofdstuk I.

888. Bovens, M.A.P., o.c., 1990, 22.

889. Bovens, M.A.P., o.c., 1990, 23.

890. Het hoeft trouwens niet steeds te gaan om inefficiënt management of opzet van de kant van dergelijke organisaties. Het probleem bij milieuverstoring is dat het vaak gaat om bepaalde, op zich sociaal en economisch wenselijke activiteiten. Deze wenselijkheid sluit echter niet uit dat 
gevolgen van illegale stortingen (Mellery, Nijmegen), giframpen (Lekkerkerk) en kernongevallen (Harrisburg,Tsjernobyl), om maar enkele tot de verbeelding sprekende voorbeelden te noemen, leiden tot enorme schadeposten. De materiële schade en het menselijke leed lopen niet alleen in de miljoenen (denk maar aan de dioxinecrisis), ze zijn vaak lang onbekend, moeilijk identificeerbaar, onherstelbaar en kunnen geregeld leiden tot de ontwrichting van de lichamelijke en geestelijke gezondheid van hele groepen van mensen ${ }^{891}$ Men kan dus spreken van een zekere feitelijke asymmetrie in onze moderne risicomaatschappij. ${ }^{892}$ Het gaat echter niet om een asymmetrie tussen individuen onderling, maar tussen twee totaal anders functionerende maatschappelijke actoren: individuele burgers en complexe organisaties. ${ }^{893}$

Geconfronteerd met dit onevenwicht tussen natuurlijke personen en (particuliere of publieke) complexe organisaties hebben zowel individuele burgers als de overheid verscheidene instrumenten in het leven geroepen om te voorkomen dat de 'corporate risks $^{1894}$ te zeer uit de hand lopen. Zo zijn er vanuit de burgers op een aantal terreinen, waaronder het milieu, verschillende belangengroepen ontstaan. Deze verenigingen zijn echter op hun beurt dikwijls complexe organisaties. Op het niveau van de overheid wordt vooral getracht via regulering de activiteiten van complexe organisaties te beïnvloeden. ${ }^{895}$

Teneinde de voor het milieu nadelige gevolgen van risicodragende activiteiten van met name bedrijven in te perken, heeft de overheid een uitgebreide milieuregelgeving uitgewerkt. Om de belangen van individuele burgers te beschermen tegen schadeverwekkend gedrag van dergelijke complexe organisaties is enkel regelgeving niet voldoende. De overheid is dan ook overgegaan tot het creëren van een noodzakelijk netwerk van speciale inspecties en instellingen, die de milieuwetgeving nader moet uitwerken en de naleving ervan moet controleren. Bij dit actief en direct overheidsingrijpen krijgt men te maken met wat Bovens een Droste-effect noemt: 'de overheid, zelf een conglo-

deze activiteiten, bijvoorbeeld het produceren van farmaceutica, toch schadelijke gevolgen hebben voor derden. In de (rechts)economische literatuur noemt men deze nadelige effecten 'externaliteiten'. Milieuverontreiniging kan als een klassiek voorbeeld van zo'n externaliteit worden beschouwd. De taak van het recht is dan ook er voor te zorgen dat deze externaliteiten door de ondernemingen worden geïnternaliseerd. Zie hierover Posner, R., Economic Analysis of Law, Boston, Little, Brown and company, 1986, 62.

891. 'Men zou kunnen tegenwerpen dat deze risico's uiteindelijk toch weer het gevolg zijn van de handelingen van natuurlijke personen. Dan vergeet men echter dat pas met de opkomst van complexe organisaties, met hun samenballing van kapitaal en expertise, het mogelijk is gebleken kerncentrales, opwerkingsfabrieken en petrochemische complexen op te zetten en draaiende te houden...' Bovens, M.A.P., o.c., 1990, 23.

892. Coleman, J.S., The Assymetric Society, New York, Syracuse University Press, 1982, 19. Zie over de toenemende collectivisering van ons samenleving en het begrip 'risicomaatschappij' hoofdstuk II.

893. Bovens, M.A.P., o.c., 1990, 24.

894. 'Corporate risks' is een term die door Coleman wordt gebruikt om de risico's van privaatrechtelijke of publiekrechtelijke rechtspersonen aan te duiden, ter onderscheiding van risico's die voortvloeien uit natuurrampen of uit het gedrag van natuurlijke personen. Zie Coleman, J., o.c., 1982, 88-90.

895. Bovens, M.A.P., o.c., 1990, 25-27. 
meraat van complexe organisaties, tracht complexe organisaties te sturen die zelf vaak ook weer uit complexe (deel)organisaties bestaan. ${ }^{.896}$ Wil men dus bijvoorbeeld de afvallozingen van een bedrijf of een gemeente (beiden een complexe organisatie) in zekere mate sturen, dan zal de overheid, in casu het ministerie van leefmilieu (een complexe organisatie), gebruik moeten maken van een milieu-instantie (ook een complexe organisatie), die al dan niet tot vergunningverlening zal overgaan. Om de naleving van de vergunningsvoorwaarden te controleren zal er vervolgens een milieu-inspectiedienst, die zelf ook complex is, worden opgericht. Daarenboven zal vaak het ministerie niet eigenhandig, maar door middel van een departement de vergunningverlenende en toezichthoudende instellingen sturen en controleren. Ook de vergunningplichtige onderneming of gemeente bestaan op hun beurt uit verscheidene afdelingen met een complexe opbouw. Op deze manier krijgt men al vlug te maken met vier of vijf lagen complexe organisaties.

Geconfronteerd met complexe organisaties zijn we duidelijk verwijderd van de negentiende eeuwse 'natuurlijke persoon'-benadering waarbij individuele 'schuld en boete' de kern uitmaken van de strafrechtelijke verantwoordelijkheid.

\section{STRAFRECHTELIJKE AANSPRAKELIJKHEID VAN OF BINNEN DE COMPLEXE ORGANISATIE?}

Bovengeschetste eigenschappen van complexe organisaties bemoeilijken de rechtstreekse toepassing van klassieke aansprakelijkheidsnoties. Met name de invulling van schuld (verwijtbaarheid) wordt een lastig gegeven. In de praktijk moet kunnen worden gegarandeerd dat de verwijtbaarheid kan worden gelegd bij diegenen die daadwerkelijk verantwoordelijk zijn. Voorkomen moet worden dat zij die niet feitelijk verantwoordelijk zijn voor een normschending toch strafrechtelijk aansprakelijk kunnen worden gesteld. Omgekeerd mag de strafrechtelijke aansprakelijkheid niet een zodanige vorm krijgen dat zij die wel feitelijk verantwoordelijk zijn daaraan ontsnappen of dat deze aansprakelijkheid geen instrumentele of rechtsbeschermende werking meer heeft.

Ideaaltypisch dienen zich dan voor een strafrechtelijke aanpak van organisatiecriminaliteit, en dus ook voor overheidscriminaliteit, grosso modo twee benaderingen aan: ofwel past men het strafrecht toe binnen de organisatie van de rechtspersoon door een aansprakelijkstelling van natuurlijke personen; ofwel past men het strafrecht toe op de organisatie van de rechtspersoon door een aansprakelijkstelling van de rechtspersoon als dusdanig. ${ }^{897}$ Beide benaderingen kunnen echter leiden tot zowel een onwenselijke verwatering van het schuldbeginsel als tot een verlies aan effectiviteit omdat bij beide veelal de natuurlijke persoon als dogmatisch vertrekpunt wordt genomen. ${ }^{898}$ De nadelen van de eerste benadering zijn in België maar al te goed gekend. Mede door een eenzijdige

896. Bovens, M.A.P., o.c., 1990, 26.

897. Vgl. Roef, D. en De Roos, Th., 'De strafrechtelijke aansprakelijkheid van de rechtspersoon in Nederland: rechtstheoretische beschouwingen bij enkele praktische knelpunten', in Faure, M. en Schwarz, K. (red.), o.c., 1988, 78-81; Heine, G., o.c., 1995, 307-316.

898. Vgl. Noot van 't Hart bij HR 22 april 1986, NJ 1986, 827. 
menselijke invulling van schuld werd lange tijd een strafrechtelijke verantwoordelijkheid van de rechtspersoon ontkend en liet men het aan de rechtspraak over om de klassieke strafrechtelijke aansprakelijkheidsnoties van materiële en morele toerekening binnen de rechtspersoon toe te passen door het gepleegde delict aan natuurlijke personen toe te rekenen. Zoals in hoofdstuk III werd besproken, werkt deze aanpak niet altijd even goed omdat het veelal niet volstaat collectieve gedragingen van (en binnen) een organisatie eenvoudig te herleiden tot een individuele aansprakelijkheid van één of meerdere natuurlijke personen. In dit verband kan worden verwezen naar het befaamde Petrochim-arrest waar een vrijspraak mede werd gebaseerd op de omstandigheid dat de tenlastegelegde feiten onmogelijk kunnen worden gedacht als 'het individueel en persoonlijk toedoen of de nalatigheid van de organen of de aangestelden van het bedrijf... ${ }^{899}$ Bovendien blijkt een toerekening van corporatieve gedragingen aan individuen niet alleen inefficiënt te zijn, maar heeft dit juist tot gevolg dat de rechtsbeschermende werking van het schuldbeginsel en het daarmee samenhangende beginsel van de persoonlijkheid van de straf worden aangetast. In de praktijk is een rechterlijke toerekening aan natuurlijke personen daarom zowel onrechtvaardig als disfunctioneel. ${ }^{900}$ Onrechtvaardig, omdat in hoofde van de natuurlijke persoon het schuldbeginsel geweld wordt aangedaan; disfunctioneel, omdat geen rekening wordt gehouden met de specifieke kenmerken van organisatorische activiteiten en de aansprakelijkheid zo globaal en abstract dreigt te worden dat de aangesprokenen zich niet langer verantwoordelijk voelen waardoor sancties hun beoogde gedragsbeïnvloeding dreigen te missen. In dat licht werd op de uitsluiting van overheden van strafrechtelijke verantwoordelijkheid in België dan ook om begrijpelijke redenen de nodige kritiek uitgeoefend. ${ }^{901}$ Door overheden gepleegde milieudelicten dienen immers nog steeds rechterlijk aan natuurlijke personen te worden toegerekend. ${ }^{902}$

Nederland kent reeds sinds 1976 de tweede benadering, de toepassing van het strafrecht op de rechtspersoon zelf. Ook Frankrijk (1994) en België (1999) kennen nu de strafrechtelijke aansprakelijkheid van de rechtspersoon. Hoewel deze benadering uitgaat van een meer realistische kijk op organisatiecriminaliteit, schuilt ook hier een mogelijk gevaar. De gelijkschakeling van rechtspersonen met natuurlijke personen in het strafrecht kan immers tot gevolg hebben dat men rechtspersonen gaat beschouwen als een soort 'uit de kluiten gewassen' mensen ${ }^{903}$ De corporatieve gedragingen blijft men dan zien als gelijk aan, of als een verlengstuk van menselijke gedragingen. Zo ontstaat het risico dat men de klassieke strafrechtelijke noties, die oorspronkelijk voor natuurlijke personen zijn uitgedacht, onaangepast aan het bijzondere karakter van organisatorische activiteiten, op rechtspersonen toepast. Daarbij speelt een rol dat veelal normschendingen binnen de organisatie van een

899. Antwerpen, 24 april 1992 (met noot Deruyck, F.), TMR, 1992, 18.

900. Vgl. Roef, D. en De Roos, Th., 'De strafrechtelijke aansprakelijkheid van de rechtspersoon in Nederland: rechtstheoretische beschouwingen bij enkele praktische knelpunten', in Faure, M. en Schwarz, K. (red.), o.c., 1998, 63.

901. Zie o.m. Deruyck, F., 'Naar een strafrechtelijke aansprakelijkheid van de rechtspersoon in Belgiè?', in Faure, M. en Schwarz, K. (red.), o.c., 1998, 37-38.

902. Vgl. Roef, D., 'De strafrechtelijke aansprakelijkheid van publiekrechtelijke rechtspersonen voor milieuverontreiniging', TMR, 1997, 87-103.

903. Bovens, M.A.P, o.c., 1990, 70-71; Roef, D. en De Roos, Th., l.c., 1998, 81. 
rechtspersoon worden voorgesteld als een uitvloeisel van de ingesteldheid en de intenties van de mensen die in of rond de organisatie werkzaam zijn. Maar uit de organisatiecriminologie kunnen we onder meer leren dat het vaak andersom is: de in de corporatie werkende individuen maken zich soms schuldig aan bepaalde criminele feiten juist omdat binnen de organisatie alle daarvoor noodzakelijk criminogene voorwaarden aanwezig zijn. ${ }^{904}$ Dat dit ook bij overheden vaak het geval is, blijkt wel uit de in hoofdstuk III besproken Nederlandse, Duitse en Belgische rechtspraak. Er is vastgesteld dat in veel gevallen het strafbare handelen of nalaten eerder aan de collectiviteit dan aan een of meer individuen moet worden verweten. Strafrechtelijk gezien moet men daarom voor ogen houden dat waar natuurlijke personen in corporatief verband strafbare feiten plegen, schuld in hun hoofde aanwezig kan zijn omdat het reilen en zeilen van de organisatie als geheel of op onderdelen daarvan niet deugt. Zo komt het vooral bij complexe organisaties regelmatig voor dat de beleidsdoelstellingen binnen de verschillende afdelingen van de organisatie met elkaar in strijd zijn hetgeen normschendend gedrag door individuen in de hand kan werken. Bovens merkt in dit verband op:

'Complexe organisaties zijn veelal opgedeeld in divisies, directies en onderafdelingen. De doelstellingen die elk van deze 'sub-units' tracht te bereiken zijn vaak slechts zijdelings gelieerd aan de doelstellingen winstmaximalisatie, omzetvergroting, dienstverlening - van de organisatie als geheel. Het voldoen aan wettelijke verplichtingen (casu quo het voorkomen van winstverminderende sancties) is soms alleen een doelstelling van de top van de organisatie of van de stafafdelingen die zich met juridische zaken bezighouden. Op het niveau van de lagere afdelingen zal men niet vaak uit zichzelf geneigd zijn maatregelen te nemen, elke extra verplichting kost immers tijd en geld en vermindert de mogelijkheden de eigen subdoeleinden na te streven'. ${ }^{905}$

In die zin determineert de collectieve of corporatieve schuld dus evenzeer de individuele schuld als vice versa. ${ }^{906}$ Het is zelfs denkbaar dat natuurlijke personen binnen een

904. Zie hierover reeds Sutherland, E.H., White Collar Crime, the uncut Version, New Haven, Yale University Press, 1983; Stone, C.D., 'The Place of Enterprise Liability in the Control of Corporate Conduct', Yale Law Journal, 1980, 1-77; Van de Heuvel, G.A.A.J., o.c., 1993.

905. Bovens, M.A.P., o.c., 1990, 76. Zie ook Van Strien, A.L.J., o.c., 1996, 92-93.

906. ' $t$ Hart merkt hierover het volgende op: 'Dat hangt samen met de praktische ervaring dat mensen, wanneer zij eenmaal functioneren in het kader van een organisatie, daarbij in sterke mate door die organisatie kunnen worden beỉnvloed en gevormd, waarbij het individuele handelen niet meer los kan worden gezien van de organisatie als context waarbinnen het plaatsvindt. Op theoretisch niveau krijgt dit uitdrukking in het inzicht, dat de stelling dat individuele mensen gezamenlijk organisaties, instellingen, instituties en de Staat maken, maar de halve waarheid vormt: die instellingen enz. scheppen op hun beurt net zo zeer de individuele mens [...] Dat wil nog niet zeggen dat de individuele verantwoordelijkheid opzij moet worden geschoven. Maar tegen deze achtergrond kan wel worden hard gemaakt, dat er zich situaties voordoen waarin het vooropstellen van de vervol-ging van de rechtspersoon meer recht doet aan het werkelijk gebeurde dan het vooropstellen van de vervolging van natuurlijke personen.' Noot van 't Hart bij HR 22 april 1986, $N J 1986,827$. 
rechtspersoon wetens en willens een strafbaar feit plegen doordat de organisatie van de corporatie zelf faalt, bijvoorbeeld door een gebrekkige interne controle of dubbelzinnige instructies. Dit betekent geenszins dat de strafbaarheid van de rechtspersoon moet leiden tot een ontwijken van individuele verantwoordelijkheden en een depreciatie van de individuele strafrechtelijke aansprakelijkheid. In beginsel moet daarom ook een strafrechtelijke aansprakelijkheid van de natuurlijke persoon naast die van de rechtspersoon mogelijk blijven, omdat ieder van hen kan hebben gefaald binnen zijn eigen verantwoordelijkheidssfeer. $^{907}$

Strafrechtsdogmatisch én praktisch gezien is het dus niet alleen onverstandig om individuele strafbaarheidsnoties, zoals schuld, ongewijzigd toe te passen binnen de rechtspersoon, maar men moet ook voorzichtig zijn in het ongewijzigd hanteren van deze noties $o p$ de organisatie als dusdanig. Want ook dan zal het schuldbeginsel als instrumenteel én rechtsbeschermend oriëntatiepunt inhoudelijk nog weinig voorstellen omdat de strafrechtelijke aansprakelijkheid wordt gebaseerd op de beperkte visie dat de rechtspersoon 'schuld' kan hebben zoals een natuurlijke persoon, hetgeen per definitie niet het geval is. Gaat men daar a priori wel van uit, dan blijft men formeel-juridisch weliswaar de klassiek strafrechtelijke eis stellen dat een of andere vorm van verwijtbaarheid aanwezig moet zijn, maar in de praktijk dreigt het risico dat aan het specifieke karakter en de werkelijke inhoud van corporatieve verantwoordelijkheden wordt voorbijgegaan. De Duitse auteur Heine merkt daarover terecht op dat dit kan leiden tot een Nivellierung individualrechtlicher Haftungsprinzipien. ${ }^{908}$ Een verwijtbaarheidsoordeel heeft dan alleen een zuiver symbolisch en normstellend karakter. Maar die normstelling gaat mogelijk aan zijn doel - de sturing van het corporatieve gedrag - voorbij wanneer niet in voldoende mate aansluiting wordt gezocht bij de corporatieve werkelijkheid. Een schuldoordeel, dat te zeer wordt geobjectiveerd of alleen maar normatief wordt ingevuld, blijt in het luchtledige hangen als het geen enkel verband meer heeft met de interne (organisatorische) oorzaken die aan de corporatieve normovertreding ten grondslag hebben gelegen. ${ }^{909}$

\section{INVLOED VAN EN AANDACHT VOOR DE INSTRUMENTELE RATIO'S VAN HET MILIEUSTRAFRECHT}

Voor een behoorlijke formulering van rechtspersoonlijke schuld dient niet alleen te worden gekeken naar bijzondere organisatorische eigenheden van rechtspersonen. Men moet niet alleen rekening houden met de complexe aard van de rechtspersoon-overheid als 'dader', maar ook met het bijzondere karakter van het moderne ordeningstrafrecht. Het is immers in het ordeningsstrafrecht dat een strafrechtelijke aansprakelijkheid van zowel privaatrechtelijke als publiekrechtelijke rechtspersonen de meeste betekenis heeft. In het ordeningsstrafrecht kunnen dan bijzondere ratio's bestaan voor een meer functionalistisch gebruik van het strafrecht, ratio's die niet of veel minder (mogen) gelden in het commune strafrecht.

907. Faure, M. en Roef, D., L.c., 1995-1996, 425; Loth, M.A., Handeling en aansprakelijkheid in het recht, Arnhem, Gouda Quint, 1998, 257.

908. Heine, G., o.c., 1995, 236 e.v.

909. Zie hierover ook Groenhuijsen, M.S., o.c., 1989, 47. 
In het tweede hoofdstuk is duidelijk gemaakt en geillustreerd hoezeer het milieustrafrecht instrumentalistisch is gekleurd. Hoewel de specifieke doelrationele eisen van een vooral op corporaties toegesneden ordeningsstrafrecht nooit een volledig afscheid van de klassieke rechtswaarborgen kunnen rechtvaardigen, betekent dit wel dat ze moeten worden verdisconteerd in de toepassing van de strafrechtsdogmatiek op de (publiekrechtelijke) rechtspersoon en zo een eigen modus operandi kunnen krijgen. Zo blijken de meeste milieumisdrijven geen bijzondere eisen te stellen aan de subjectieve zijde van de delictsomschrijving, zodat in de praktijk aan de vaststelling van schuld vlug zal zijn voldaan. ${ }^{910}$ In de praktijk betekent dit dat niet in alle gevallen strenge eisen kunnen worden gesteld aan de invulling van rechtspersoonlijke schuld. Toch zal uit het hiernavolgende blijken dat men het milieustrafrechtelijk instrumentalisme niet steeds voor lief hoeft te nemen en dat per geval moet worden bekeken in welke mate de beoogde doelstelling van effectievere strafrechtelijke handhaving een uitholling van het schuldbeginsel kan rechtvaardigen.

Het in acht nemen van het eigen rechtskarakter van het ordeningsstrafrecht heeft ook nog een ander belang. Door voldoende rekening te houden met de bijzondere ratio's van de verschillende deelgebieden van het strafrecht kan worden vermeden dat, via de 'omweg' van de strafrechtelijke aansprakelijkheid van de rechtspersoon, klassieke strafrechtelijke leerstukken, zoals opzet en culpa, ook in het commune strafrecht een onnodige vervlakking ondergaan. ${ }^{911}$ Het is nu eenmaal een feit dat in de moderne deelgebieden van het strafrecht, zoals milieustrafrecht, sterke instrumentalistische tendensen heersen, die een minimalisering van klassieke rechtsbeginselen, zoals legaliteit, proportionaliteit en schuld, tot gevolg hebben. ${ }^{912}$ Tot op zekere hoogte is dit begrijpelijk en zelfs gerechtvaardigd. Maar het zou een spijtige zaak zijn indien de strafrechtelijke aansprakelijkheid van de rechtspersoon tot gevolg heeft dat de strafrechtsdogmatiek en -toepassing in hun geheel vervlakken omdat men te weinig rekening houdt met het bijzondere karakter van het ordeningsstrafrecht. ${ }^{913}$ In die zin is een pleidooi voor een zelfstandige betekenis van schuld en van het schuldbeginsel voor de strafbaarheid van rechtspersonen niet alleen gemotiveerd door een efficiënte én machtskritisch verantwoorde aanpak van organisatiecriminaliteit, maar ook door een gepast en noodzakelijk respect voor de grondslagen van het klassieke strafrecht waar toch vooral de rechtsbescherming van het individu moet worden bewaakt.

910. Zie paragraaf 4 van dit hoofdstuk.

911. Zie hierover Roef, D., 'De strafrechtelijke aansprakelijkheid van de rechtspersoon in het milieustrafrecht', in Belgische Vereniging van bedrijfsjuristen, Vereniging van praktijkjuristen in sociaal recht en Vereniging voor arbeidsrecht, o.c., 1999, 74-77.

912. Zie hoofdstuk II.

913. Mede om die reden bepleit Heine voor rechtspersonen, in het bijzonder voor complexe organisaties, een op hen toegesneden bijzondere strafrechtsdogmatiek, een zogenaamd 'zweite Spur'. Er zou naast het Individualstrafrecht een afzonderlijk Verbandsstrafrecht moeten worden gecreěerd. Zie Heine, G., o.c., 1996. Recentelijk wordt de uitholling van schuld in het ordeningsstrafrecht en de mogelijke gevolgen hiervan op de klassieke strafrechtelijke leerstukken ook in Nederland meer bediscussieerd. Zie o.m. Borgers, M.J., Koopmans, I.M., en Kristen, F.G.H. (red.), o.c., 1998 en de Jong, D.H., 'Het strafrechtelijke schuldbegrip: ontwikkeling of ontbinding', $D D, 1999,1-6$. 


\section{§3. Daderschapscriteria in het licht van de schuld}

\section{A. ALGEMEEN}

Voor het daderschap van rechtspersonen, dus ook voor overheden, dienen steeds twee vragen te worden beantwoord. ${ }^{914}$ Allereerst, welke gedragingen kunnen aan de rechtspersoon materieel of objectief worden toegerekend? Er moet dan worden beantwoord welke categorie van gedragingen feitelijk aan de rechtspersoon kunnen worden toegerekend. Men kan zich voorstellen dat niet elke gedraging verricht in het kader van de organisatie ook meteen behoort tot de handelingssfeer van de rechtspersoon. De tweede vraag is wanneer deze gedragingen aan de rechtspersoon moreel of subjectief moeten worden toegerekend? Dit heeft te maken met de vaststelling van verwijtbaarheid in hoofde van de rechtspersoon: slechts die gedragingen die ook te plaatsen zijn binnen de verantwoordelijkheidssfeer van de rechtspersoon kunnen aan de rechtspersoon worden toegerekend. ${ }^{915}$ Er kan immers sprake zijn van een delict gepleegd in de handelingssfeer

914. Voor alle duidelijkheid: ik gebruik het begrip daderschap in de zin van plegen; dader is gebruikt als synoniem van pleger, dat wil zeggen diegene die alle (objectieve en subjectieve) bestanddelen van een delictsomschrijving vervult. Zie hierover van Woensel, A.M., In de daderstand verheven, Amhem, Gouda Quint, 1993, 5 en 7-44. De hier gebruikte gelijkschakeling van dader met pleger heeft niet slechts te maken met terminologie. Daar de vraag naar daderschap (van natuurlijke of rechtspersonen) steeds ook de vraag is in welke mate iemand de bestanddelen van een delicts-omschrijving kan vervullen, betekent dit dat de daderschapscriteria van de rechtspersoon idealiter moeten rekening houden met en moeten anticiperen op de klassieke eis dat voor het plegen van een strafbaar feit steeds sprake moet zijn van een gedraging (handelen of nalaten) alsook van een mate van verwijtbaarheid (schuld). Bovendien wordt zo reeds van in het begin duidelijk dat een eenduidig daderschapscriterium (voor rechtspersonen) per definitie is uitgesloten daar de delictsbestanddelen die moeten worden vervuld per delictsomschrijving verschillen. Derhalve moet dus, zoals hierna blijkt, per type milieudelict worden bekeken hoe het daderschap van de rechtspersoon kan worden vastgesteld. De wettelijke omschrijving van daderschap is natuurlijk ruimer. Artikel $47 \mathrm{Sr}$ ziet als daders mede zij die een delict doen plegen, medeplegen en uitlokken. Zie hierover Remmelink, J., Mr. D. Hazewinkel-Suringa's Inleiding tot de studie van het Nederlandse strafrecht, Arnhem, Gouda Quint, 1995, 426-443. Ik besteed in dit hoofdstuk geen aandacht aan de rechtspersoon/overheid als deelnemer aan een milieudelict. In hoofdstuk VII over de wederrechtelijke vergunningverlening komt dit wel kort aan bod. Een van de vraagstukken die daarin (rechtsvergelijkend) wordt behandeld is immers de kwestie in welke mate milieu-overheden via onzorgvuldige vergunningverlening kunnen worden aangemerkt als deelnemer aan een milieudelict.

915. In termen van de constitutieve elementen van ieder delict vertalen deze toerekeningsvragen zich in de vraag in welke mate rechtspersonen het materieel en het moreel element van een delict kunnen vervullen. In termen van de bestanddelen van een delictsomschrijving: in welke mate rechts-personen de objectieve en de subjectieve bestanddelen kunnen vervullen. In landen die weigerachtig staan tegenover de strafrechtelijke aansprakelijkheid van rechtspersonen vormt met name de veronderstelling dat rechtspersonen het subjectief of moreel element van een delict niet kunnen vervullen, m.a.w. dat zij niet schuldbekwaam zijn, het voornaamste argument om hen van de werking van het strafrecht uit te sluiten. Zoals gezien, betekende dit voor België dat rechtspersonen wel geacht werden strafbaar feiten te begaan, maar dat zij daarvoor, wegens schuldonbekwaamheid, niet konden worden gestraft. Maar zoals o.m. Deruyck terecht opmerkt zat in deze regel een belangrijke tegenspraak want in de erkenning dat een rechtspersoon een strafbaar feit kan plegen (societas delinquere potest) zit reeds een zekere schuldbekwaamheid omdat ieder delict nu eenmaal een schuldelement heeft. Zie Deruyck, F., o.c., 1996, 39 en 236. 
van de rechtspersoon, maar dat betekent nog niet dat de rechtspersoon als geheel daarom verwijtbaar heeft gehandeld. Het is mogelijk dat het verwijt slechts ten aanzien van een natuurlijke persoon dient te worden gemaakt. Het antwoord op deze vraag bepaalt daarom ook de grens tussen het daderschap van de rechtspersoon en het eigen daderschap van de natuurlijke persoon, die werkzaam is binnen de organisatie.

Bemerk dat deze toerekeningsvragen niet alleen voor het daderschap van de rechtspersoon van belang zijn, maar onrechtstreeks ook voor het feitelijk leidinggeven. Feitelijk leidinggeven is immers volgens artikel $51 \mathrm{Sr}$ een accessorium van het daderschap van de rechtspersoon. ${ }^{916}$ Hoe makkelijker het rechtspersoonlijk daderschap wordt vastgesteld, des te eenvoudiger kan men komen tot een strafbaarheid van de feitelijk leidinggever. In de koppeling van feitelijk leidinggeven aan het daderschap van de rechtspersoon zien we opnieuw het belang geillustreerd van de machtskritische eis dat moet worden vermeden dat via de omweg van een (al te makkelijke) strafbaarheid van de rechtspersoon ook de rechtsbescherming van natuurlijke personen wordt uitgehold. Het spreekt voor zich dat met name de vaststelling van de verwijtbaarheid in hoofde van de rechtspersoon problemen kan opleveren. In de praktijk komt het dan ook voor dat de rechter niet altijd even grondig kijkt naar het daderschap van de rechtspersoon vooral wanneer (ook) de feitelijk leidinggever terechtstaat. ${ }^{917}$ Dit kan worden geillustreerd aan de hand van de reeds besproken Pikmeerzaak,

Zoals bekend, werd in de aan Pikmeer I ten grondslag liggende uitspraak van het Hof Leeuwarden het hoofd nieuwe werken van de gemeente Boarnsterhim veroordeeld voor het feitelijk leiding geven aan het zonder vergunning storten van verontreinigde baggerspecie in het Pikmeer. In deze uitspraak zit een belangrijke contradictie op het vlak van de vaststelling van het daderschap van de gemeente. ${ }^{918}$ Enerzijds overweegt het Hof bij de ontvankelijkheidsvraag van het $\mathrm{OM}$, dat de ambtenaar zich niet op de immuniteit kan beroepen omdat hij tegen het besluit van de gemeente in zou hebben gehandeld. De gemeente had namelijk 'na ampele overweging' bewust afgezien van het uitbaggeren van de Groundaem, omdat er voor de afvoer van het slib geen verantwoorde financiële oplossing bestond. Daaruit concludeert het Hof dat de ambtenaar niet heeft gehandeld bij de uitvoering van een gemeentelijke bestuurstaak en dus kan worden vervolgd. ${ }^{919}$ Anderzijds stelt het Hof (impliciet) vast dat de gemeente wel moet worden geacht dader te zijn van het milieudelict waaraan de ambtenaar feitelijk leiding zou hebben gegeven. Dit is een zeer

In Duitsland rijst het probleem van het schuldelement in hoofde van de rechtspersoon niet. Daar wordt immers ook de handelings-bekwaamheid van de rechtspersoon ontkend en $\S 30 \mathrm{OWiG}$ vertrekt derhalve niet van een door de rechtspersoon gepleegde inbreuk, maar van een door een natuurlijke persoon gepleegde Straftat of Ordnungswidrigkeit, zodat het schuldelement bij voorbaat steeds door deze natuurlijke persoon moet zijn vervuld. Zie hierover hoofdstuk III.

916. Remmelink, J., o.c., 1995, 155-157; Van Elst, R., Strafbare rechtspersonen en hun leidinggevers, Ars Aequi Cahiers Strafrecht, deel 8, Nijmegen, 1997, 48-49.

917. Zie bijvoorbeeld HR 1 juni 1993, $N J$ 1994, 53; HR 16 juni 1981, $N J 1981,586$.

918. Zie ook Van Strien, A.L.J, 'Het (bewijs van het) daderschap van de rechtspersoon naar Australisch en naar Nederlands recht', in Faure, M. en Schwarz, K. (red.), o.c., 1998, 137-138.

919. Zoals bekend oordeelde de Hoge Raad anders. Zie hoofdstuk III. 
opmerkelijke constructie. Want de vraag rijst hoe de gemeente als dader kan worden aangemerkt als eerst is gesteld, zij het bij de ontvankelijkheidsvraag, dat de ambtenaar tegen het besluit van de gemeente heeft gehandeld en (volgens het Hof) derhalve buiten de uitvoering van de overheidstaak. Nu hoeft voor daderschap van de rechtspersoon, zoals later blijkt, niet beslissend te zijn dat de gedraging door uitdrukkelijke besluiten worden gebillijkt. Ook een stilzwijgende goedkeuring of een nalaten in te grijpen kan mogelijk het daderschap van de rechtspersoon constitueren. Cruciaal is echter dat toch steeds een band moet worden vastgesteld tussen de verboden gedraging enerzijds en de rechtspersoon anderzijds en daar wordt in deze uitspraak niet expliciet op ingegaan. Een dergelijke band wordt in casu blijkbaar verondersteld aanwezig te zijn. Hier wreekt zich het tekort aan duidelijke daderschapscriteria. Bovendien krijgt de vraag naar het daderschap van de gemeente hier een extra dimensie omdat feitelijk leidinggeven aan het door de gemeente opzettelijk overtreden van artikel 1 derde lid van de Wet verontreiniging oppervlaktewateren werd tenlastegelegd.

Op basis van welke criteria kan de strafrechter nu het daderschap van de rechtspersoon vaststellen? Achtereenvolgens komen de belangrijkste door de rechtspraak ontwikkelde criteria aan bod. Daarbij wordt vooral aandacht besteed aan de vraag in welke mate zij rekening houden met de corporatieve werkelijkheid en of zij recht doen aan de eis dat ook in hoofde van de rechtspersoon-dader sprake moet zijn van een subjectief element of een mate van verwijtbaarheid.

\section{B. GEDRAGINGEN VAN ORGANEN ALS GRONDSLAG VOOR CORPORATIEF DADERSCHAP}

Een eerste mogelijke benadering van rechtspersoonlijk daderschap bestaat erin de rechtspersoon te 'vermenselijken' teneinde zo op analoge wijze het op de natuurlijke persoon toegesneden daderschap op de rechtspersoon toe te passen. De achterliggende redenering is vrij simpel; het strafrecht is in beginsel gebaseerd op persoonlijke en menselijke 'schuld en boete', een rechtspersoon bestaat uit mensen, dus het klassieke schuldbegrip kan vrijwel ongewijzigd op de rechtspersoon worden toegepast. Om inhoud te kunnen geven aan corporatief daderschap ziet men de rechtspersoon als niets anders dan een georganiseerd verband van natuurlijke personen. ${ }^{920}$ De rechtspersoon wordt dan vereenzelvigd met zijn organen - dit zijn niet toevallig ook menselijke begrippen - of andere natuurlijke personen. ${ }^{921}$

De perceptie van de rechtspersoon als soort mens waarbij corporatieve psyche en wil samenvallen met die van natuurlijke personen, herkennen we duidelijk in de orgaanleer.

920. Vgl. Van Strien, A.L.J., o.c., 1996, 77-78.

921. In werkelijkheid verschilt dit niet zo veel van de klassieke visie waar corporatieve schuld wordt ontkend en dus de strafrechtelijke aansprakelijkheid van de rechtspersoon wordt afgewezen. In de klassieke benadering worden de organen (of andere natuurlijke personen) vereenzelvigd met de rechtspersoon. In de vermenselijkende benadering van de rechtspersoon gebeurt eigenlijk het omgekeerde; de rechtspersoon wordt gelijkgeschakeld met zijn organen. Het verschil zit dan hoofdzakelijk in de straf, die in het eerste geval uitsluitend aan natuurlijke personen kan worden opgelegd, en in het laatste geval aan de rechtspersoon zelf. 
Volgens deze theorie is een rechtspersoon dader van een strafbaar feit wanneer een orgaan van de rechtspersoon de wet overtreedt, mits dat orgaan handelde binnen zijn bevoegdheidssfeer. Frankrijk baseert de strafrechtelijke aansprakelijkheid van de rechtspersoon uitdrukkelijk op de orgaantheorie. Artikel 121-1 van de Code pénal bepaalt immers dat rechtspersonen slechts strafbaar zijn indien het feit is gepleegd 'pour leur compte, par leurs organes ou représentants'. De koppeling van rechtspersoonlijk daderschap aan het daderschap van de organen is niet zonder problemen. Het kan leiden tot situaties waar geen strafrechtelijke aansprakelijkheid van de rechtspersoon in de rede ligt indien het orgaan zelf geen reële beslissingsmacht heeft of omdat het orgaan de bevoegdheden nauwkeurig heeft vastgelegd en op verantwoorde wijze heeft gedelegeerd aan deskundige ondergeschikten. De orgaantheorie staat ook veraf van de realiteit van organisatiecriminaliteit in de zin dat wordt vergeten dat in vele gevallen rechtspersonen het 'vuile werk' door derden, zogenaamde stromannen, die de band met de rechtspersoon aan het oog onttrekken, laten opknappen. In fraudezaken komen dergelijke praktijken vaak voor. ${ }^{922}$

De orgaantheorie is in Nederland reeds in 1951 met het ATO-arrest verlaten. De Hoge Raad oordeelde dat voor daderschap van een rechtspersoon niet is vereist dat de uitvoeringshandeling is verricht door een orgaan van de rechtspersoon. ${ }^{923}$ Toch kunnen we in sommige arresten nog overblijfselen zien van een dergelijke vermenselijkende benadering. Een voorbeeld is het Papa Blanca-arrest waar het voor het daderschap vereiste opzet werd bijeengeharkt doordat bestanddelen die bij verschillende natuurlijke personen worden gevonden tezamen de vervulling van de delictsbestanddelen door de corporatie uitmaken. ${ }^{924}$ Van Strien merkt daarover op dat deze benadering problematisch is 'omdat een rechtspersoon lang niet altijd kan worden vereenzelvigd met de natuurlijke personen die deel uitmaken van de rechtspersoon. Een rechtspersoon is namelijk meer - en ook iets anders - dan alleen een verzameling natuurlijke personen. ${ }^{.225}$ De vermenselijking van de rechtspersoon via een gelijkschakeling van de rechtspersoon met de natuurlijke personen is dus geen bruikbaar uitgangspunt voor een adequate formulering van rechtspersoonlijk daderschap. Het hinkt nog te veel na op de klassieke gedachte dat strafrechtelijke aansprakelijkheid hoofdzakelijk gebaseerd moet zijn op duidelijk afgebakende menselijke verantwoordelijkheden. ${ }^{926}$ Het belangrijkste bezwaar is dat, wanneer men organen of natuurlijke personen met het 'bewustzijn' van de rechtspersoon gelijkstelt, men gebruikt makt van fictieve toerekeningsconstructies. De gedachte is immers dat een rechtspersoon zo'n menselijk bewustzijn moet hebben, omdat ook de personen, die deel uitmaken van de (organen van) de rechtspersoon bewustzijn en verantwoordelijkheidsbesef hebben. Deze redenering berust op een denkfout, omdat de analogie die bestaat tussen mensen en hun organen (hoofd en handen) enerzijds en rechtspersonen en hun organen anderzijds volledig wordt vertaald in een identiteit.

922. Faure, M. en Roef, D., l.c., 1995, 420-421.

923. HR 27 februari 1951, NJ 1951, 474 met noot Röling.

924. HR 16 juni $1981, N J 1981,586$.

925. Van Strien, A.L.J., o.c., 1996, 90. Zie tevens noot van 't Hart bij HR 23 februari 1993, NJ 1993, 605.

926. Vgl. Kessler, M., 'Het daderschap van de rechtspersoon. Een pleidooi voor afschaffing van het aanvaardingscriterium', $D D, 1997,233-235$. 
Zoals gezien, heeft ook de Belgische wetgever bij de invoering van de strafrechtelijke verantwoordelijkheid van de rechtspersoon de orgaanleer niet overgenomen. $\mathrm{Er}$ is uitdrukkelijk gekozen voor een benadering waarbij het daderschap van de rechtspersoon niet via de natuurlijke personen hoeft te worden geconstrueerd. Maar er is ook vastgesteld dat in de parlementaire stukken op dit punt grote onduidelijkheid bestaat. Enkele passages wijzen duidelijk in de richting van de achterhaalde orgaantheorie. ${ }^{927}$ In het licht van het klassieke schuldbeginsel heeft de orgaantheorie natuurlijk wel zijn voordelen, omdat het schuldelement in hoofde van leidinggevende natuurlijke personen moet worden bewezen. Maar deze verdienste is slechts schijn wanneer we weten dat schuld in hoofde van de organen de corporatieve schuld niet altijd dekt. Alleen in kleine organisaties met transparante activiteiten is een gelijkschakeling van de rechtspersoon met zijn organen min of meer gerechtvaardigd. In het licht van het specifieke karakter van complexe organisaties zijn op de orgaanleer gë̈nspireerde criteria dan ook niet in alle gevallen bruikbaar.

\section{DE IJZERDRAADCRITERIA: EEN GELIJKSCHAKELING VAN DE RECHTSPERSOON- FUNCTIONARIS MET DE NATUURLIJKE PERSOON-FUNCTIONARIS.}

De antropomorfe benadering van rechtspersoonlijk daderschap kan ook nog op een andere manier plaats vinden. Namelijk niet zozeer door de rechtspersoon te vereenzelvigen met zijn organen of andere natuurlijke personen, maar eerder omgekeerd door de rechtspersoon als geheel gelijk te schakelen met een natuurlijke persoon. Een rechtspersoon wordt dan geacht, net zoals natuurlijke personen, te beschikken over inherente psychische en mentale kwaliteiten waaronder machts- en wilsuitoefening. Het opnemen van corporaties in de soort 'mens' is echter wat Loth noemt een categoriefout. Een corporatie mag dan uit mensen bestaan, het is daarom zelf nog geen mens. ${ }^{928}$ Ook het opnemen van de rechtspersoon in de juridische categorie 'natuurlijke persoon' is foutief. Een natuurlijke persoon is immers alleen een juridische abstractie van de mens. ${ }^{929}$ Natuurlijke personen en rechtspersonen zijn beide juridische abstracties die naast elkaar bestaan en dus niet gelijkgeschakeld mogen worden. ${ }^{930}$

Deze benadering is voor een groot deel verantwoordelijk voor de opvatting dat de in de rechtspraak ontwikkelde IJzerdraadcriteria bij uitstek geschikt zouden zijn voor de invulling van het daderschap van de rechtspersoon. ${ }^{931}$ Toch kan men zich daarbij de nodige vragen stellen.

\section{Zie hoofdstuk III.}

928. Loth, M.A., o.c., 1988, 267.

929. Zie 't Hart, A.C., Mensenwerk? Over rechtsbegrip en mensbeeld in het strafrecht van de rechtsstaat, Mededelingen van de Afdeling Letterkunde van de KNAW, deel $58 \mathrm{nr}$. e, Amsterdam/New York/Oxford/Tokyo, 1995; 't Hart, A.C., De Meerwaarde van het Strafrecht, Den Haag, Sdu, 1997, 155-164.

930. Loth, M.A., o.c., 1988, 265. Zie ook 't Hart, A.C., o.c., 1997, 139-144.

931. Vgl. Kessler, M., l.c., 1997, 238-246. 
De Izerdraadcriteria zijn geformuleerd in het befaamde Izerdraadarrest waarin de Hoge Raad het functioneel daderschap van een natuurlijke persoon moest beoordelen. In deze zaak werd de eigenaar van een exportbedrijf vervolgd omdat één van zijn ondergeschikten, een exportmanager en chef inkoper, een onjuiste opgave had gedaan bij de aanvraag van een vergunning, die vereist was om bepaalde goederen (ijzerdraad) uit te voeren. In cassatie moest uiteindelijk worden beoordeeld wanneer de feitelijke gedragingen van de exportmanager als gedraging van de eigenaar kunnen worden aangemerkt. De Hoge Raad antwoordde met de inmiddels bekende formule dat dit slechts kan wanneer de eigenaar

\begin{abstract}
'erover vermocht te beschikken, of die handelingen al dan niet plaatsvonden, en deze behoorden tot de zodanige, welker plaatsvinden blijkens den loop van zaken door verd. werd aanvaard of placht te aanvaarden. ${ }^{932}$
\end{abstract}

De Uzerdraadcriteria staan daarom ook wel bekend als de beschikkings- en aanvaardingscriteria. Het is duidelijk dat deze criteria uitermate geschikt zijn voor de invulling van het functionele daderschap van de natuurlijke persoon: degene die over de gedraging van een ander vermag te beschikken en deze aanvaardt of placht te aanvaarden, kan worden geacht de gedraging zelf te hebben verricht. ${ }^{933}$ De vraag is echter of deze criteria ook automatisch toepasbaar zijn voor het daderschap van de rechtspersoon. Dat het daderschap van de rechtspersoon kan worden gezien als functioneel daderschap lijkt vanzelfsprekend. ${ }^{934}$ Maar betekent dit ook dat de IJzerdraadcriteria zomaar in alle gevallen toepasbaar zijn op de rechtspersoon? Met het Nicotinezuur-arrest bestond daar nog twijfel over. ${ }^{935} \mathrm{Na}$ de arresten Tweede Visserij ${ }^{936}$ en Discriminerende Disco ${ }^{937}$ kan moeilijk worden betwist dat de rechtspraak (onder meer) de IJzerdraadcriteria gebruikt ter beoordeling van het corporatieve daderschap. Zo werd in laatst genoemd arrest, waar een discotheek (in casu een vennootschap onder firma) werd vervolgd omdat zij middels haar portier aan drie Turken de toegang had geweigerd, bepaald dat van daderschap van een vennootschap onder firma sprake kan zijn

'indien de vennootschap erover vermocht te beschikken of die handelingen al dan niet zouden plaatsvinden en deze behoorden tot de zodanige welker plaatsvinden blijkens de feitelijke gang van zaken door de verdachte werd aanvaard of placht te worden aanvaard.'

Hiermee is het functioneel daderschap van de rechtspersoon gelijkgesteld met dat van de natuurlijke persoon. Deze gelijkschakeling lijkt op het eerste gezicht voor de hand te

932. HR 23 februari 1954, $N J 1954,378$ met noot Röling.

933. Zie voor een grondige analyse van ontstaansgeschiedenis en inhoud van functioneel daderschap van Woensel, A.M., o.c., 1993, 45-105.

934. Vgl. Röling, B.V.A., 'De strafbaarheid van de rechtspersoon', DD, 1980, 1-9; Van Woensel, M., o.c., 1993, 44-106.

935. HR 24 mei 1977, $N J$ 1978, 330. Ook wel Co-op Gelderland-arrest genoemd.

936. HR 1 juli $1981, N J 1982,80$ met noot Van Veen.

937. HR 14 januari $1992, N J 1992,413$, met noot 't Hart. 
liggen, te meer wanneer we zien dat de rechtspraak de IJzerdraadcriteria voornamelijk heeft toegepast bij kleine organisaties. Bij kleine rechtspersonen is de afstand tussen natuurlijke persoon-functionaris en de rechtspersoon-functionaris immers gering. Maar meer algemeen bekeken lossen de IJzerdraadcriteria in een aantal situaties het daderschapsvraagstuk niet op. Met name in complexe organisaties kunnen er problemen rijzen. Wat eigenlijk wordt verdedigd, is dat een rechtspersoon net als een natuurlijke persoon over handelingen van anderen kan beschikken en deze ook kan aanvaarden of plegen te aanvaarden. ${ }^{938}$ Met andere woorden, de gedachte is dat een rechtspersoon zelf beschikkings- en aanvaardingsmacht heeft. Het voordeel van deze benadering is dat de rechtspersoon in ieder geval als een zelfstandige (functionele) dader met een eigen verantwoordelijkheidsbesef wordt erkend. Maar wordt met de IJzerdraadcriteria wel duidelijk gemaakt waarin deze verantwoordelijkheid nu precies bestaat?

Het probleem van rechtspersoonlijk daderschap heeft steeds betrekking op de vraag wanneer de rechtspersoon een strafbaar feit begaat en dus geacht wordt de bestanddelen van een delictsomschrijving te vervullen. Het antwoord dat een rechtspersoon een strafbaar feit begaat wanneer 'de corporatie daarover kan beschikken en deze pleegt te aanvaarden' is echter weinig zeggend omdat het alleen maar de vraag verschuift. ${ }^{939}$ Onduidelijk blijft immers waarin dat rechtspersoonlijk beschikken en aanvaarden zou moeten bestaan: de feitelijke inhoud van het beschikken en aanvaarden is niet gegeven en moet dus nader worden geëxpliciteerd, willen deze criteria meer zijn dan een lege doos, een inhoudsloze metafoor. ${ }^{940}$ Verschillende interpretaties dienen zich dan aan. $\mathrm{Zo}$ is volgens sommigen de beschikkings- of machtsvereiste objectief vast te stellen. Zo meent Torringa dat het volstaat dat de rechtspersoon in kwestie invloed kan uitoefenen, hetgeen betekent dat de omstandigheid dat de rechtspersoon in voorkomend geval tevergeefs maatregelen heeft genomen om de criminele gedraging tegen te gaan geen afbreuk doet aan de vaststelling dat aan het beschikkingscriterium is voldaan. ${ }^{941}$ Een dergelijke benadering maakt het beschikkingscriterium zeer normatief. Voor culpose delicten levert zo'n normatieve uitleg wellicht minder bezwaren op, omdat culpa sterk wordt geobjectiveerd en men uitgaat van een abstracte criteriumfiguur, de normale burger, die als toetssteen wordt gebruikt voor de beoordeling van de gedraging van de justitiabele ${ }^{942}$ Voor doleuse delicten gaat mijns inziens een normatieve uitleg van beschikken veel te ver. Wil men meer recht doen aan het

938. Vgl. Kessler, M., l.c., 1997, 239-241.

939. Vgl. Knigge, G., 'Doen en laten; enkele opmerkingen over daderschap', $D D, 1992,147$.

940. Kessler, M., l.c., 1997, 239.

941. Torringa, R.A., o.c., 1984, 94.

942. Vgl. Groenhuijsen, M.S., 'Schuld en boete. Een beschouwing over strafrechtelijke verantwoordelijkheid', in Bovens, M.A.P. e.a. (red.), Verantwoordelijkheid: Retoriek en Realiteit, Zwolle, W.E.J. Tjeenk Willink, 1989, 45-46; Van Duyne, P.C., 'Schuldig zijn of schuldig verklaard worden. de "goede voerman" in schuld- en rechtvaardigingsgronden', $R \& K, 1991,445$. Ook in het Belgische strafrecht wordt culpa gezien als een vorm van onachtzaamheid of onvoorzichtigheid, die in de rechtspraak wordt gelijkgeschakeld met het aquiliaanse foutbegrip (de nalatigheid van de onrecht-matige daad). De schuld wordt normatief bepaald aan de hand van de bonus pater familias-standaard. Zie o.m. Cass., 19 februari 1998, Arr. Cass., 1987-1988, 795; 1988-1989, 159; Dupont, L. en Verstraeten, R., Handboek Belgisch strafrecht, Leuven, Acco, 1990, 257-260. 
schuldbeginsel dan verdient een meer subjectieve uitleg de voorkeur, hetgeen betekent dat aan het criterium slechts is voldaan indien concreet kan worden vastgesteld dat de rechtspersoon bijvoorbeeld niet de nodige controles heeft uitgevoerd of niet de nodige instructies heeft gegeven ter vermijding van het gepleegde feit. Ook met betrekking tot het aanvaardingscriterium rijst een zelfde probleem. Volgt men hier een objectiverende of normatieve benadering ${ }^{943}$ dan verdwijnt opnieuw de verwijtbaarheid uit het gezichtsveld. Omgekeerd, zal een subjectieve benadering van het aanvaarden in de zin dat aanvaarden steeds opzet impliceert, leiden tot een te strenge invulling van het criterium hetgeen bijvoorbeeld in het milieustrafrecht zou leiden tot ernstige bewijsproblemen daar de meeste milieudelicten in hun delictsomschrijvingen geen opzet en zelfs geen culpa eisen. ${ }^{944}$

Het belangrijkste theoretische bezwaar tegen het gebruik van de IJzerdraadcriteria voor het daderschap van de rechtspersoon is dat dit in de praktijk opnieuw een zekere vereenzelviging van de rechtspersoon met zijn (feitelijke) organen met zich mee kan brengen, zij het meer 'functioneel' dan bij de orgaantheorie. Immers, wil men vermijden dat de IJzerdraadcriteria louter normatief of objectief worden ingevuld, dan zal toch moeten worden bekeken én bewezen welke natuurlijke personen (al dan niet organen) binnen de corporatie in relatie tot het gepleegde feit hun verantwoordelijkheden hebben verzuimd. Anders gezegd, de IJzerdraadcriteria hebben voor de vaststelling van het corporatieve daderschap slechts daadwerkelijk inhoud indien naar de verantwoordelijke natuurlijke personen wordt gezocht, die de enigen zijn die feitelijk kunnen beschikken en aanvaarden. Het resultaat is dan toch dat een of andere vorm van schuld bij de leiding van de organisatie moet worden aangetoond. ${ }^{945} \mathrm{Zo}$ bekeken, heeft dit tot gevolg dat de toepassing van de IJzerdraadcriteria op de rechtspersoon vooral bij complexe organisaties niet veel oplost omdat - tenzij men objectiveert - ook nu moet worden nagegaan, via welke natuurlijke personen de corporatie heeft gehandeld. Alleen werd vroeger - vóór de invoering van de strafrechtelijke aansprakelijkheid van de rechtspersoon - aan deze natuurlijke personen zelf de straf opgelegd, terwijl nu wordt gesteld dat het de rechtspersoon zelf is die als dader van het delict moet worden gestraft.

943. Vgl. Strijards, G.A.M., Aansprakelijkheidsgronden, Zwolle, W.E.J. Tjeenk Willink, 1988, 75 e.v.

944. Zo meent Wortel dat aanvaarden steeds opzet inhoudt, omdat men nu eenmaal niet kan aanvaarden zonder zich van het feit bewust te zijn. Zie Wortel, J., De onderneming in het strafrecht, Lelystad, Vermande, 1987, 52. Daar ben ik het grotendeels mee eens en dat is gelet op de herkomst van de Izerdraadcriteria - de vaststelling van functioneel daderschap in hoofde van een natuurlijke persoon (die van nature over bewustzijn beschikt) - ook volkomen begrijpelijk. Dit betekent evenwel dat het aanvaardingscriterium voornamelijk kan worden toegepast bij functioneel daderschap van de natuurlijke persoon, het feitelijk leidinggeven en bij het daderschap van kleine en transparante rechtspersonen waar de afstand tussen de rechtspersoon en (het bewustzijn van) de natuurlijke persoon-functionaris niet zo groot is. In die gevallen is een subjectieve benadering van aanvaarden namelijk op zijn plaats. In andere gevallen, bijvoorbeeld bij complexe organisaties, is het aanvaar-dingscriterium enkel bruikbaar indien het wordt geobjectiveerd, wat volgens mij niet wenselijk is.

945. Knigge, G., 'Dat deed mijn handje. Enige opmerkingen over het daderschap van de rechtspersoon', in Van Kraaij, M. en Van Veen, A. (red.), Onderneming en strafrecht, Ars Aequi Libri, Nijmegen, 1997, 18. 
Niettemin kan in zijn algemeenheid worden geconcludeerd dat de IJzerdraadcriteria hun waarde hebben, zij het niet voor alle delicten en niet voor alle rechtspersonen. ${ }^{946}$ Nemen we als uitgangspunt dat, in het licht van het schuldbeginsel, de machts- en aanvaardingsvereiste bij voorkeur subjectief moeten worden ingevuld, dan is voor deze criteria voornamelijk een rol weggelegd voor doleuse delicten gepleegd door kleine of middelgrote organisaties.

\section{EEN CIVIELRECHTELIJKE BENADERING: HET MAATSCHAPPELIJK- VERKEERSCRITERIUM}

Juist vanwege de kritiek op de IJzerdraadcriteria, wordt door sommigen voorgesteld om het daderschap van de rechtspersoon te onderbouwen via het civielrechtelijke maatschappelijkverkeerscriterium. $^{947}$

De civiele kamer van de Hoge Raad heeft, ter beoordeling van de vraag of een rechtspersoon een onrechtmatige daad heeft gepleegd, in het Kleuterschool Babbelarrest de orgaantheorie verworpen en voor het maatschappelijk-verkeerscriterium gekozen. In casu werd de gemeente Zwolle aangesproken wegens een door haar gepleegde onrechtmatige daad. ${ }^{948}$ De wethouder van onderwijs had naar aanleiding van het instorten van een kleuterschool de opmerking gedaan dat dit ongeval grotendeels te wijten was aan de aannemer. Als later blijkt dat deze uitlating niet met de feiten overeenstemt, stelt de aannemer een onrechtmatige daadsactie in tegen de gemeente nu hij door deze uitspraak een aantal opdrachten is misgelopen. Het verweer dat de gemeente geen onrechtmatige daad heeft gepleegd nu de wethouder geen orgaan is van de gemeente wordt in cassatie verworpen:

'De gedragingen van een wethouder kunnen immers ook dan een onrechtmatige daad opleveren, wanneer zij in het maatschappelijk verkeer als gedragingen van de gemeente hebben te gelden. ${ }^{949}$

Sindsdien is in de civielrechtelijke jurisprudentie dit criterium enkele keren door de Hoge Raad gebruikt. ${ }^{950}$ Volgens sommige auteurs is het maatschappelijk-verkeerscriterium bij uitstek geschikt voor het strafrechtelijke daderschap van de rechtspersoon. ${ }^{951}$ Het is zelfs een enkele keer door de strafrechter toegepast, bijvoorbeeld in de Pikmeer-zaak. Na eerste terugwijzing door de Hoge Raad (Pikmeer I) oordeelde het Hof te Leeuwarden in een nadere bewijsoverweging dat de verboden gedraging van de ambtenaar (de illegale baggerwerkzaamheden) aan de gemeente Boarnsterhim moet worden toegerekend, omdat deze

946. Vgl. Van Strien, A.L.J., l.c., 1996, 287 en 292-295; Roef, D. en De Roos, Th, o.c., 1998, 91-92.

947. Zie hierover Knigge, G., l.c., 1997, 147.

948. Zie hierover Van Elst, E., o.c., 1997, 27.

949. HR 6 april 1979, NJ 1980, 34.

950. Zie Van Strien, A.L.J., o.c., 1996, 90.

951. Zie Knigge, G, l.c., 1997, 129 en 147; De Doelder, H., 'Criminal Liability of Corporations Netherlands', in De Doelder, H. en Tiedemann, K. (red.), Criminal Liability of Corporations, The Hague-London-Boston, Kluwer Law International, 1996, 291-292 en 300. 
gedragingen in het maatschappelijk verkeer hebben te gelden als gedragingen van de gemeente. ${ }^{952}$

Het nadeel van dit criterium is dat het inhoudelijk weinig zegt. Maatschappelijke verwachtingspatronen over hoe rechtspersonen zouden moeten handelen kunnen een norm stellen of wellicht een vorm van verwijtbaarheid suggereren, maar vullen deze niet in, noch zijn ze voldoende in staat een strafprocessueel beoordelingspunt te leveren om na te gaan wat daadwerkelijk binnen de corporatie is misgegaan. Bovendien kan men meer fundamenteel stellen dat 'hetgeen in het strafrecht met betrekking tot daderschap wordt verstaan onder redelijkerwijs toerekenbaar niet op voorhand altijd hoeft overeen te stemmen met hetgeen in het privaatrecht als redelijkerwijs toerekenbaar wordt beschouwd. ${ }^{953}$ Het maatschappelijk-verkeerscriterium is alleen geschikt om aan te duiden welke gedragingen materieel aan een rechtspersoon kunnen worden toegerekend. Het duidt in die zin een ondergrens aan. ${ }^{954}$ Het is echter niet in staat de morele toerekening, de verwijtbaarheid, naar behoren in te vullen. ${ }^{955}$ Bovendien voegt het weinig toe aan andere criteria. In die gevallen waar bijvoorbeeld aan de IJzerdraadcriteria is voldaan, zal ook steeds een maatschappelijke zorgvuldigheidsnorm zijn geschonden. ${ }^{956}$ In die gevallen waar de IJzerdraadcriteria niet genoeg inhoud kunnen geven aan rechtspersoonlijke schuld, is dat met het maatschappelijk verkeers-criterium nog minder het geval.

\section{E. DE ZORGPLICHTENBENADERING}

Verwant aan het maatschappelijk verkeerscriterium is de zorgplichtenbenadering, die vooral door Nieboer en Strijards is uitgewerkt. ${ }^{957}$ In deze visie dient een rechtspersoon als strafbare dader te worden aangemerkt indien deze bepaalde zorgplichten heeft geschonden. ${ }^{958}$ Nieboer ziet de strafrechtelijke aansprakelijkheid als een juridisch gevolg van een door iemand 'gepleegd verzuim een op hem rustende strafrechtelijke plicht na te komen'. ${ }^{959}$ De op de justitiabele rustende zorgplicht bestaat uit de plicht ervoor te zorgen dat het strafrechtelijk beschermde rechtsgoed niet wordt geschonden. Het is niet de bedoeling van deze studie om de zorgplichtentheorie aan een nadere analyse te onderwerpen, maar in het licht van het daderschap van de rechtspersoon kan wel worden opgemerkt dat deze benadering belangrijke nadelen heeft. Zo is niet duidelijk waaruit die zorgplicht moet bestaan en hoe ver die moet gaan. De cruciale vraag welke gedragingen

952. Zie De Roos, Th.A., L.c., 1997, 228.

953. Noot van 't Hart onder HR 14 januari 1992, $N J 1992,413$.

954. Vgl. Mulder, A. en Doorenbos, D.R, Schets van het economisch strafrecht, Zwolle, W.E.J. Tjeenk Willink, 1995, 67-68.

955. Vgl. Van Woensel, o.c., 1993, 92.

956. Van Strien, A.L.J., l.c., 1996, 287; Roef, D. en De Roos, Th., l.c., 1998, 87.

957. Nieboer, W., Schets van het materieel strafrecht, Arnhem, Gouda Quint, 1991; Strijards, G.A.M., o.c., 1988, 48-57.

958. Vgl. De Vries-Leemans, J.H.J., 'Enkele aspecten van daderschap', in 't Hart, A.C. (red.), Strafrecht in balans. Opstellen over strafrecht aangeboden aan A.C. Geurts, Arnhem, Gouda Quint, 1983, 320; Van Elst, R., o.c., 1997, 28-29.

959. Nieboer, W., o.c., 1991, 18. Zie voor een korte bespreking van de zorgplichtentheorie Van Woensel, A.M., o.c., 1993, 67-81. 
wel en welke niet moeten worden gezien als zorgplichtenschending, m.a.w. wat strafbaar is en wat niet, wordt niet helder beantwoordt. ${ }^{960}$ Het gevaar is niet denkbeeldig dat zo door de strafrechter ex post naar een sociaal wenselijke bestraffing toe wordt geredeneerd zonder dat de werkelijke verwijtbare betrokkenheid van de organisatie wordt beoordeeld ${ }^{961}$ Een ander probleem betreft de herkomst van de zorgplicht. Wil dit criterium enige rechtsbeschermende werking behouden, dan dient niet alleen de inhoud maar ook de rechtsbron van de zorgplicht voor de justitiabele op voorhand duidelijk te zijn. ${ }^{962}$ We hebben gezien dat in Duitsland voor de strafrechtelijke aansprakelijkheid van ambtenaren voor milieuverstoring veelvuldig gebruik wordt gemaakt van zorgplichten. ${ }^{963}$ Ambtenaren worden beschouwd als Überwachungsgaranten, die de plicht hebben bepaalde gevaarzettingen (Gefahrenquellen) te bewaken zodat deze geen ongeoorloofde inbreuk op het beschermde (ecologische) rechtsgoed veroorzaken. Klassiek voorbeeld is de ambtenaar die als Überwachungsgarant van een zuiveringsinstallatie moet worden beschouwd. $\mathrm{Bij}$ de bespreking van de Duitse rechtspraak is echter duidelijk geworden dat aan de rechtsgrond van de zorgplicht niet steeds hoge eisen worden gesteld en dat de zorgplichten vaak zo ruim worden uitgelegd dat ambtenaren ook de strafrechtelijke plicht hebben in te grijpen tegen milieuverstorende handelingen van particulieren, hoewel ze daartoe niet steeds bevoegd zijn. Indien ambtenaren deze plicht schenden dan worden zij - en niet slechts de eigenlijke plegers - geacht zelf het milieudelict te hebben begaan. Heine merkt over deze rechterlijke uitbreiding van strafrechtelijke aansprakelijkheid via zorgplichten op:

'Die Gerichte stellen zunächst eher ratlos fest, daß in der modernen Industriegesellschaft für den einzelnen jedenfalls neue Sorgfaltsplichten entstanden seien -wenngleich Art und Umfang weinig geklärt waren. ${ }^{964}$

De zorgplichtbenadering heeft dus als belangrijk nadeel dat de grenzen van een delictsomschrijving zodanig worden opgerekt dat het aantal strafbare gedragingen waarvoor men aansprakelijk kan worden gesteld te zeer worden verruimd. ${ }^{965}$ Bovendien dient nog steeds, al naargelang de tenlastegelegde schuldvorm (culpa of opzet), het onderscheid tussen culpose en doleuse zorgplichtschendingen te worden verduidelijkt, hetgeen vraagt naar een meer expliciet en concreet verwijtbaarheidsoordeel dat door de louter objectieve schending van de zorgplicht niet kan worden gegeven. Uit de schending van een

960. Vgl. Knigge, G., l.c., 1992, 136. Bemerk dat ik niet de strafrechtstheoretische waarde van de zorgplichtentheorie in twijfel trek. Zij stelt ons zeer zeker in staat om op kritische wijze de grondslagen en uitgangspunten van de klassieke aansprakelijkheidsnoties van ons strafrecht, die we vaak als zo vanzelfsprekend aanvaarden, te belichten. Ik stel alleen in vraag of zorgplichten als concrete daderschapscriteria kunnen fungeren.

961. Vgl. Van Strien, A.L.J., o.c., 1990, 280.

962. Er zijn verschillende bronnen mogelijk. Remmelink noemt het eigendomsrecht, overeenkomsten, het beroep, de gezagsverhouding, de zaakwaarneming en voorafgaand gevaarlijk of crimineel handelen (Ingerenz). Remmelink, J., o.c., 1995, 168. Zie tevens paragraaf 6 van hoofdstuk III.

963. Zie hierover hoofdstuk III.

964. Heine, G., 'Von individueller zu kollektiver Verantwortlichkeit. Einige Grundfragen der aktuellen Kriminalpolitik', in Arnold, J., Burkhardt, B., Gropp, W. en Koch, H-G. (Hrsg.), Grenzüberschreitungen, Freiburg, 1996, 56.

965. Vgl. Van Woensel, A.M., o.c., 1993, 76. 
zorgvuldigheidsnorm kan wellicht culpa worden afgeleid en aldus kan de zorgplichtbenadering zelfs een goede leidraad zijn voor een nadere specificering van de vrij abstracte criteriumfiguur, die als maatstaf bij de vaststelling van culpa wordt gebruikt. Bij doleuse delicten daarentegen lijkt meer vereist dan de vaststelling dat bepaalde zorgplichten zijn geschonden. Dan moet de mate van verwijtbaarheid die in causaal verband staat met de schending bij het bewijs en het rechterlijk oordeel meer naar voren kunnen komen.

\section{F. HET BAAT- OF VOORDEELCRITERIUM}

Een andere vraag is of de bevoordeling van de rechtspersoon een algemeen criterium mag zijn voor het daderschap van de rechtspersoon. ${ }^{966}$ Het lijkt mij niet overbodig daar even bij stil te staan daar overheidscriminaliteit vaak uit kostenbesparing wordt gepleegd. Uit het Vroom \& Dreesman-arrest kan worden afgeleid dat een rechtspersoon dader is van een crimineel feit wanneer de rechtspersoon voordeel haalt uit de gepleegde gedraging. In deze zaak had de chef van de meubelafdeling van de V\&D een huiskamerameublement verkocht tegen een te hoge prijs. Hoewel er in het bedrijf een directie-instructie bestond die verbood boven de wettelijk vastgestelde maximumprijs te verkopen, werd V\&D toch veroordeeld. De Hoge Raad overwoog dat de rechter het daderschap van de rechtspersoon bewezen kon verklaren omdat de verkoop van het ameublement 'kon strekken om de NV in haar bedrijf dienstig te zijn'. ${ }^{967}$ Ook in de literatuur is de baattrekking door de rechtspersoon als mogelijk daderschapscriterium geregeld ter sprake gekomen. Fokkens spreekt hierover door aan het Nicotinezuur-arrest ${ }^{98}$ de conclusie te verbinden, dat er sprake is van daderschap van een rechtspersoon als de ondergeschikte uit hoofde van zijn functie ten bate van het bedrijf heeft gehandeld. ${ }^{969}$ Ook Pompe en Strijards zijn die mening toegedaan. ${ }^{970}$

Het lijkt mij weinig aantrekkelijk om de baattrekking door de rechtspersoon als afzonderlijk criterium voor daderschap aan te nemen. Het zou leiden tot een niet te rechtvaardigen ongelijkheid tussen de natuurlijke persoon als dader en de rechtspersoon als dader. Waarom zou een rechtspersoon slechts dader zijn als hij zichzelf bevoordeelt en de natuurlijke persoon niet? $?^{771}$ Natuurlijk kan het bevoordelingsaspect wel een aanwijzing zijn voor het aannemen van daderschap omdat de baattrekking die voortvloeit uit de criminele gedraging in ieder geval erop wijst dat er binnen de doelstelling en belangenwaarneming van de rechtspersoon is gehandeld. De baattrekking kan daarom vooral een indicatie opleveren dat het gepleegde feit materieel aan de rechtspersoon zou kunnen worden toegerekend. Het zegt echter weinig over de kwestie of ook moreel aan de rechtspersoon kan worden toegerekend, of er verwijtbaar is gehandeld. In vergelijking met de andere criteria heeft het baatcriterium dus weinig toegevoegde waarde. ${ }^{972}$

966. Vgl. Van Elst, R., o.c., 1997, 26.

967. HR 27 januari 1948, $N J 1948,197$ met noot Pompe.

968. HR 24 mei 1977, NJ 1979, 330.

969. Fokkens, J.W., 'De rechtspersoon als dader', $D D, 1980,401$.

970. Zie Pompe's noot onder het V\&D-arrest en Strijards, G.A.M., Hoofdstukken van materieel strafrecht, Utrecht, Lemma, 1992, 100.

971. Torringa, R.A., o.c., 1984, 96.

972. Roef, D. en De Roos, Th., l.c., 1998, 87. 
Kan nog worden opgemerkt dat de vaststelling, dat een functionaris binnen de overheidsorganisatie een delict heeft gepleegd uitsluitend ter bevoordeling van een ander dan de organisatie, een duidelijk indicatie is dat de handeling als zodanig buiten de doelstelling en belangen van de overheid staat. In dat geval is de rechtspersoon slechts gebruikt voor de verwezenlijking van illegale doelstellingen van bepaalde natuurlijke personen. Hiervoor kan de overheid niet ter verantwoording worden geroepen.

\section{G. DE BEDRUFSVOERING VAN DE RECHTSPERSOON ALS CRITERIUM}

Een ander daderschapscriterium is de bedrijfspolitiek of de bedrijfsvoering van de rechtspersoon. Is de strafbare gedraging gepleegd in het kader van de bedrijfsvoering of bedrijfspolitiek dan is het feit toe te rekenen aan de rechtspersoon. In (oud) artikel 15 lid 2 WED werd reeds als één van de daderschapscriteria het handelen in de sfeer van de rechtspersoon' vastgelegd. ${ }^{973}$ Door sommigen wordt dit bedrijfsvoeringcriterium uitgelegd als een toepassing van het IJzerdraad-aanvaardingscriterium. ${ }^{974}$ Het feit dat een delict is begaan bij de uitoefening van de bedrijfspolitiek zou aanvaarden door de rechtspersoon impliceren. Indien men aan aanvaarden nog enige subjectieve inhoud wil geven, gaat dit volgens mij veel te ver. Er zijn genoeg voorbeelden te bedenken waar werknemers verboden gedragingen kunnen verrichten binnen de bedrijfsvoering, de normale activiteit van de rechtspersoon, zonder dat dit meteen hoeft te betekenen dat de organisatie van de rechtspersoon als dusdanig iets te verwijten valt.

Een eerste nadeel van dit criterium bestaat hierin dat niet duidelijk is wat moet worden verstaan onder de bedrijfspolitiek van de rechtspersoon. Over de vaststelling van de corporatieve bedrijfsvoering liepen de meningen in de literatuur dan ook uiteen. Zo was Röling voorstander van een meer formeel-juridische benadering waarbij het corporatieve handelen, kort gezegd, moet worden gezien als het handelen conform de statutaire doelstellingen van de rechtspersoon. ${ }^{975}$ Mulder daarentegen was meer voorstander van een sociaal-feitelijke invulling van het criterium waarbij de reëel gevoerde bedrijfspolitiek centraal staat. ${ }^{976}$ Het moge duidelijk zijn dat een sociaal-feitelijke benadering sterk de voorkeur verdient omdat anders enkel gedragingen die beantwoorden binnen het statutaire doel van de rechtspersoon voor daderschap van de rechtspersoon in aanmerking komen. Een louter formele benadering van de bedrijfspolitiek beantwoordt niet aan de realiteit van organisatiecriminaliteit en is dus niet in staat de strafrechtelijke aansprakelijkheid van de rechtspersoon in voldoende mate te operationaliseren. ${ }^{977}$ Ook bij overheden verdient een sociaal-feitelijke interpretatie van de 'bedrijfsvoering' de voorkeur, omdat anders enkel

973. Zie hierover Torringa, R.A., o.c., 1984, 54.

974. Zo bijvoorbeeld Hendriks, L.E.M. en Wöretshofer, J., o.c., 1995, 104-105; Brants, Chr., l.c., 1998, 522 en Van Elst, R., o.c., 1997, 34.

975. Röling, B.V.A., 'De strafbaarheid van de rechtspersoon', TvS, 1957, 4.

976. Mulder, A., Schets van het economische strafrecht, Zwolle, W.E.J. Tjeenk Willink, 1975, 78 en 66.

977. Zie o.m. Torringa, R.A., o.c., 1984, 84-86; Vellinga-Schootstra, F., Vellinga W.H. en Van Strien, A.L.J., 'Het daderschap van de rechtspersoon', in Van der Neut, J.L. (red.), o.c., 1993, 44-45. 
gedragingen die voortvloeien uit de aan overheden wettelijk opgedragen (overheids)taken voor daderschap van de overheid in aanmerking zouden kunnen komen. Zo zou men verwachten dat bankieren niet tot de normale bedrijfsvoering hoort van een overheid, maar indien nu blijkt dat een overheid zich daarmee toch bezig houdt dan is toch sprake van een reëel gevoerde bedrijfspolitiek. Het bedrijfsvoeringscriterium heeft dus enkel waarde indien de werkelijk uitgevoerde activiteiten en daarbij passende 'policies' als uitgangspunt voor strafrechtelijke toerekening worden genomen. Maar daarmee is nog weinig gezegd over de mogelijke verwijtbare betrokkenheid van de rechtspersoon. Zo kan uit het enkele feit dat een overheid 'bankiert', en dit dus behoort tot de bedrijfsvoering van de overheid, niet meteen worden afgeleid dat een binnen het kader van deze bedrijfsvoering gepleegd delict (bv. fraude of valsheid in geschrifte) ook aan de overheid kan worden toegerekend.

Het hoofdbezwaar tegen het bedrijfsvoeringscriterium is dat dit evenals het baat- en maatschappelijk-verkeerscriterium weinig zegt over de verwijtbaarheid van de corporatieve gedraging. ${ }^{978}$ In die zin is het criterium vooral zinvol ter beantwoording van de materiële toerekeningsvraag. Het maakt immers wel duidelijk welke gedraging binnen de handelingssfeer van de rechtspersoon valt en welke niet, wat een factum alienum is en wat niet. De rechtspersoon aansprakelijk stellen voor delicten gepleegd in uitoefening van activiteiten ook als deze niet geschieden binnen de bedrijfsvoering rekt de materiële toerekening te veel op. Het geeft dus een belangrijke ondergrens aan, maar meer niet.

Een bekend milieustrafrechtelijk voorbeeld van het gebruik van het bedrijfsvoeringscriterium is het Furazolidon-arrest. Orphahell BV werd vervolgd voor het via een pijp zonder vergunning lozen van een schadelijke stof (furazolidon) in het oppervlaktewater. In cassatie werd de veroordeling door het Hof betwist omdat de rechter geen gebruik had gemaakt van de IJzerdraadcriteria. De Hoge Raad acht echter het daderschap van de rechtspersoon reeds bewezen omdat het ging om de lozing van een stof

'die tijdens de normale productieprocessen in het bedrijf van de verdachte pleegt te ontstaan en die in het kader van de normale bedrijfsvoering gedurende een aantal dagen via een lozingspijp van het bedrijf plaatsvond in een bij dit bedrijf gelegen sloot. ${ }^{979}$

De Hoge Raad stelde niet de eis dat uit de bewijsmiddelen moet blijken dat de verboden gedraging werd aanvaard. ${ }^{980}$ Sommige auteurs trekken hieruit de conclusie dat de Hoge

978. Zie tevens Van Strien, A.L.J, l.c., 1991, 281.

979. HR 23 februari 1993, $N J$ 1993, met noot 't Hart, A.C. Aan het bedrijf was tenlastegelegd dat: 'zij in of omstreeks de periode van 1 tot en met 7 juli 1988, in de gemeente De Ronde Venen, zonder de ingevolge (artikel 1 eerste lid van) de Wet Verontreiniging Oppervlaktewateren vereiste vergunning met behulp van een werk, te weten een pijp, een (rode) vloeistof, althans een samenstel van (vloei)stoffen, zijnde (een) afvalstof(fen), dan wel (een) verontreinigende of schadelijke stof(fen) heeft gebracht in een oppervlaktewater, te weten een sloot gelegen aan de westzijde van de Groot Mijdrechtstraat, door die (vloei)stof via genoemde pijp in bovenbedoelde sloot te laten lopen/druppen.'

980. Van Strien, A.L.J., o.c., 1996, 97. 
Raad met dit arrest een belangrijke stap heeft gezet in de richting van een strafrechtelijke risico-aansprakelijkheid van de rechtspersoon. ${ }^{981}$ Heeft de Hoge Raad inderdaad afstand genomen van de IJzerdraadcriteria en is voor het corporatieve daderschap niet langer een beschikken en aanvaarden vereist? Het is moeilijk uit dit arrest harde conclusies te trekken, maar ik meen van niet. Men moet rekening houden met het concrete geval waarover de Hoge Raad uitspraak moest doen. Nu het hier gaat om een overtreding van een voorschrift van de Wet verontreiniging oppervlaktewateren waarbij in de delictsomschrijving geen subjectieve bestanddelen (opzet of culpa) zijn neergelegd en het $\mathrm{OM}$ evenmin een schuldvorm heeft tenlastegelegd, kan men uit dit arrest geen algemene conclusies trekken over de mate waarin volgens de Hoge Raad corporatieve schuld bij de vaststelling van het daderschap nog een rol speelt. ${ }^{982}$ Duidelijk is wel dat aan het rechtspersoonlijk daderschap, of in ieder geval aan het bewijs daarvan, bij milieuovertredingen geen hoge eisen worden gesteld. De bewijslast voor het openbaar ministerie is vederlicht, maar dit is grotendeels het gevolg van het type delict dat was tenlastegelegd. Deze welhaast objectieve aansprakelijkheid is daarom allicht eerder het gevolg van de tenlastelegging in casu (en het feit dat door de verdachte geen aannemelijk schuldverweer is gevoerd), dan van een door de Hoge Raad beoogde uitvlakking van corporatieve schuld. Niettemin laat deze uitspraak wel zien dat de beoordeling van de verwijtbaarheid in het milieustrafrecht bewijsrechtelijk niet veel hoeft voor te stellen. ${ }^{983}$ Dan is het moeilijk te ontkennen dat wanneer materiële strafbaarheidsvoorwaarden, zoals schuld, nauwelijks een strafprocessuele vaststelling of beoordeling behoeven, een objectieve aansprakelijkheid voor de hand ligt, waarbij eenvoudigweg de veroorzaakte (milieu)schade op zuiver objectieve gronden aan de rechtspersoon wordt toegerekend. Niet van belang is bijvoorbeeld wat de precieze oorzaak van de illegale lozing is geweest of de vraag of de gedraging al dan niet het gevolg is geweest van een

981. Zo o.m. Buruma, Y., 'Veranderingen in het ondernemingsstrafrecht', in Van Kraaij, M. en Van Veen, A., o.c., 1997, 1-2.

982. Vgl. Van Strien, A.L.J., o.c., 1996, 99-100.

983. Begrijp ik haar goed dan ziet Van Strien in het Furzalidon-arrest een pijnlijke illustratie van hoe groot de kloof kan zijn tussen enerzijds de materie̋le strafbaarheidsvoorwaarden en anderzijds het bewijs daarvan (Van Strien, A.L.J., o.c., 1996, 243-244). Ik deel tot op zekere hoogte haar bekommernis (zie o.m. Roef, D. en De Roos, Th., l.c., 1998, 90-91.). Wat inderdaad moet worden vermeden is dat de bewijsrechtelijke eisen in de praktijk zo laag worden dat de kans groot wordt dat een rechtspersoon veroordeeld wordt voor feiten die hem vanuit het perspectief van daderschap en de eisen van het materiële strafrecht (de aanwezigheid van culpa of opzet, e.d.m.) niet zouden mogen worden toegerekend. Maar mijns inziens moet het bestaan van die 'kloof' in dit arrest toch enigszins worden genuanceerd. Van Strien verliest te veel uit het oog dat in deze zaak aan de bewijsvoering niet al te hoge werden gesteld mede omdat het gepleegde delict op materieel strafrechtelijk vlak (en dus qua rechtspersoonlijk daderschap) nu eenmaal niet veeleisend is: het gaat hier om een overtreding van een abstract gevaarzettingsdelict en, zoals later zal blijken, stellen dergelijke delicten ook materieel strafrechtelijk gezien geen strenge eisen - meestal volstaat het handelen zonder vergunning of de schending van een vergunningsvoorschrift -, zodat het eigenlijk voor de hand ligt dat dit 'gemak' zich ook in de bewijsvoering vertaalt. De milieustrafrechtelijke abstracte gevaarzettingsdelicten hebben nu juist als voordeel en ook tot doel dat er op bewijsrechtelijk vlak niet al te veel obstakels zijn. Een dergelijk bewijsrechtelijk deficit kan natuurlijk principieel worden bekritiseerd, maar zo'n kritiek heeft dan veeleer betrekking op het karakter van dergelijke delicten, dan op het feit dat de Hoge Raad in casu geen hoge eisen stelt aan het bewijs. Men kan moeilijk verwachten dat de strafrechter aan bewijs hogere eisen stelt, dan de wetgever noodzakelijk heeft geacht. 
ongewoon voorval, falend management, onduidelijke controles of dubbelzinnige instructies binnen de organisatie van de rechtspersoon. En dat zijn nu juist zaken die men vanuit een instrumenteel oogpunt wil beoordelen, sturen en beïnvloeden. Het gevaar bestaat dan dat op die manier wordt verondersteld dat alles wat gebeurt - of juist niet gebeurt - binnen de bedrijfsvoering niet alleen objectief maar ook automatisch subjectief aan de rechtspersoon moet worden toegerekend en derhalve niet hoeft te worden bewezen verklaard. Gaat men daar als principe van uit, dan is de kloof tussen feitelijke verantwoordelijkheid en juridische aansprakelijkheid wel heel groot hetgeen de instrumentele sturingsmogelijkheden van een strafrechtelijke reactie kan uithollen omdat uiteindelijk niet of weinig rekening wordt gehouden met de mate en wijze van organisatorisch verwijtbare betrokkenheid van de rechtspersoon bij het gepleegde delict. Maar zoals gezegd, het gepleegde delict moet in zijn delictsomschrijving wel zodanig zijn geformuleerd dat zowel materieel strafrechtelijk als strafprocesrechtelijk een dergelijke ook vanuit sturingsperspectief wenselijke beoordeling vereist is. Dat is in het milieustrafrecht niet steeds het geval, en bij de abstracte gevaarzettingsdelicten is dat ook niet echt vereist. Als de (bijzondere) wetgever voor strafbaarheid voldoende acht dat een vergunning is overtreden, dan houdt een zoektocht naar één of andere vorm van organisatorische verwijtbaarheid natuurlijk al vlug op.

\section{H. NIET DE BEDRIJFSVOERING, MAAR DE BEDRIJFSVOERINGSSCHULD ALS CRITERIUM}

De besproken daderschapscriteria geven meestal weinig aandacht aan de bijzondere aard van corporatief handelen en collectieve verwijtbaarheid. Dit kan resulteren in een stelselmatige uitholling van het schuldbeginsel en een evolutie in de richting van een risicoaansprakelijkheid. De enige criteria die wel tot op zekere hoogte rekening houden met één of andere vorm van verwijtbaarheid zijn de IJzerdraadcriteria (beschikken en aanvaarden). Maar deze verschuiven soms het probleem, ofwel omdat zij té normatief worden ingevuld waarbij feitelijke corporatieve verwijtbaarheid nauwelijks een rol speelt - ofwel omdat zij een nadere invulling behoeven via een koppeling aan de mate van bewustheid of verwijtbaarheid in hoofde van de organen (of andere natuurlijke personen), hetgeen niet veel verschilt van de klassieke orgaantheorie. Met de toepassing van de functionele IJzerdraadcriteria op de rechtspersoon verliest men bovendien uit het oog dat er een groot verschil bestaat tussen de natuurlijke persoon als functionaris en de rechtspersoon als functionaris.

Zoals ik reeds elders met de Roos heb betoogd schuilt de grond van het probleem hierin, dat de rechtspersoon soms nog te veel vanuit een menselijke of natuurlijke persoonbenadering wordt waargenomen. ${ }^{984}$ Door een theoretisch en dogmatisch tekort valt men onvermijdelijk terug op de bekende strafrechtelijke aansprakelijkheidsnoties, die op een of andere manier gerelateerd blijven aan menselijke gedragingen, of zoekt men zelfs zijn toevlucht tot buiten-strafrechtelijke aansprakelijkheidsnoties, zoals het maatschappelijkverkeerscriterium. Zolang het gaat om kleine organisaties, zoals bijvoorbeeld kleine bedrijven of gemeenten, met een vrij eenvoudige en doorzichtige interne structuur en besluitvorming, hoeft dat niet veel problemen op te leveren omdat dan de afstand tussen de

984. Roef, D. en De Roos, Th., l.c., 1998, 91-94. 
natuurlijke personen (de interne functionarissen) en de rechtspersoon, tussen individualiseerbare beslissingen enerzijds en corporatief handelen anderzijds niet zo groot is. Problematisch wordt het wanneer de aansprakelijkheid van complexe organisaties moet worden ingevuld omdat het daar veelal gaat om diffuse in tijd gespreide (risicovolle) activiteiten en besluiten. Noch een toepassing van klassieke strafbaarheidsnoties binnen de rechtspersoon, als een toepassing van deze noties op de rechtspersoon zelf, zijn dan voldoende in staat deze verantwoordelijkheidsvraagstukken strafrechtelijk op te lossen. ${ }^{985}$ Heine vat dit treffend als volgt samen:

'Es geht darum, neuartige Probleme der modernen Risiko-Gesellschaften in vertretbarem Umfang justitiabel zu machen. Die strafrechtlichen Schwierigkeiten im Umgang mit technologiegestützten kollektiven Prozessen und Risikolagen ergeben sich vor allem aus dem Verlust einer zeitlich, örtlich, gegenständlich und personal bestimmbaren, konkreten Haftungssituation. Betriebliche Störfälle sind typischer-weise das Ergebnis systemischer Fehlentwicklungen, die sich nicht punktuell auf einzelne Entscheidungen zurückführen lassen, sondern einem meist langjährigen Defizit an Risikobewußtsein und Risikovorsorge entsprechen. Und der Erfolg in der Dimension eines Störfalls läßt sich nicht mehr anhand individueller Opfersitituationen bestimmen, sondern ist selbst ein sich fortsetzender, schadenstiftender Prozeß. Damit stößt das Individualstrafrecht an seine Grenzen. ${ }^{.986}$

Zolang men risico-aansprakelijkheid onverenigbaar acht met de grondbeginselen van het strafrecht is dat op zijn minst een reden voor zorg en nadere studie. Temeer indien men de potentiële schade, die de activiteiten van rechtspersonen kunnen veroorzaken, voor ogen houdt. Maar wanneer men zich realiseert dat de zwaarste strafrechtelijke sanctie (de vrijheidsstraf) niet op de rechtspersoon kan worden toegepast en er bovendien in slaagt een verwijtbaarheidsconcept, dat specifiek past bij de constructie die de rechtspersoon is, te ontwikkelen, kan afglijden naar risico-aansprakelijkheid wel degelijk worden voorkomen.

Bovens heeft overtuigend uiteengezet, onder meer aan de hand van de massamoord te My Lai tijdens de Vietnamoorlog, dat de situatie zich kan voordoen dat de collectiviteit fout zit, terwijl ieder lid van die collectiviteit een min of maar aanvaardbaar excuus kan doen gelden. ${ }^{987}$ Hij wijst erop dat in gevallen als My Lai de collectiviteiten voldoen aan de

985. Heine, G., o.c., 1995, 307.

986. Heine, G., o.c., 1995, 307.

987. Bovens, M.A.P., o.c., 1990, 59. Luitenant Calley werd als enige veroordeeld voor een gang van zaken, een 'policy' van vuile oorlog waarin 'search and destroy-missions' uitstekend pasten, die aan de collectiviteit - het Amerikaanse leger - moesten worden toegerekend. Dat leger bleef echter buiten schot, terwijl de superieuren van Calley op alle niveaus wegkwamen met excuses van de strekking dat Calley hen niet goed had geïnterpreteerd. Pas in maart $1998 \mathrm{kwam}$ de legerstaf van de Verenigde Staten met de erkenning van grote fouten in relatie met de gebeurtenissen in My Lai. Daarmee, zo kan men stellen, is de corporatieve aansprakelijkheid ex post gegeven. Zie tevens Roef, D. en De Roos, Th., l.c., 1998, 91-94. 
criteria voor morele aansprakelijkheid terwijl het op zijn minst twijfelachtig is of dat ook voor individuele leden geldt. Bovens, die in zijn betoog trouwens ook gebruik maakt van het voorbeeld van milieuschandalen en de rol van rechtspersonen daarin ${ }^{988}$, kiest positie tussen de Scylla en de Charibdis die het debat over de corporatieve aansprakelijkheid bedreigen: totale afwijzing van elke corporatieve verantwoordelijkheid enerzijds, de opvatting dat complexe organisaties moeten worden beschouwd als 'full-pledged members of the moral community' anderzijds ${ }^{989}$. Zo komt hij uit bij een derde (tussen)positie: 'sommige morele categorieën zijn niet goed toepasbaar op complexe organisaties, maar andere morele categorieën, waaronder "verantwoordelijkheid", zijn dat wel degelijk ${ }^{190}$. Ook Heine ${ }^{991}$ opteert voor een verwante positie waar hij onderscheid maakt tussen 'Individualstrafrecht' en 'Verbandstrafrecht', en met betrekking tot dit laatste, rekening houdend met de bijzondere eisen van het milieustrafrecht, andere meer op de rechtspersoon toegesneden aansprakelijkheidscriteria aanvaardbaar acht. Zo ontwikkelt hij het concept van de 'Betriebsführungsschuld', dat in zijn voorstelling beantwoordt aan het voor corporaties karakteristieke gegeven dat systeembepaalde, defectueuze ontwikkelingen over langere perioden niet tot individuele beslissingen kunnen en mogen worden herleid. ${ }^{992}$

Tegen de achtergrond van het klassieke schuldbeginsel zou kritiek kunnen worden geuit op een dergelijke 'Lebensführungsschuld' van de rechtspersoon. Maar net zoals men een denkfout maakt door corporatieve verantwoordelijkheid gelijk te schakelen met de verantwoordelijkheid van de natuurlijke persoon of door op de natuurlijk persoon geënte aansprakelijkheidsnoties automatisch op de rechtspersoon toe te passen, maakt men een denkfout door corporatieve schuld te toetsen aan een klassiek niet aan de rechtspersoon aangepast schuldbeginsel. Dan maakt men zich schuldig aan een té formalistische benadering van de strafrechtelijk beginselen, hetgeen uiteindelijk de beoogde rechtsbescherming uitholt. Niet alleen vanwege de instrumentaliteit, maar juist ter wille van de rechtsbescherming van het strafrecht, dient een realistische benadering de voorkeur te hebben. De toenemende collectivering van verantwoordelijkheden in onze (risico)maatschappij nopen daarom tot een creatieve herijking van het schuldbeginsel zonder dat het zijn rechtsbeschermende waarde mag verliezen, hetgeen kan gebeuren indien men blijft vasthouden aan een individualistische kijk op dat beginsel of wanneer men doet alsof er niets is veranderd en zich beperkt tot normatieve criteria. Wel moet men steeds indachtig houden, dat, wil men dergelijk perspectief in rechte op een bevredigende wijze uitwerken, dan tenminste de eis moet worden gesteld dat het criterium van het passen binnen de 'bedrijfsvoeringsschuld' of 'verwijtbare bedrijfspolitiek' serieus wordt genomen, en liefst in de wet of (ten minste in de) rechtspraak tot uitdrukking wordt gebracht. ${ }^{993}$ Dat betekent dat deze 'bedrijfsvoeringsschuld' niet mag worden geobjectiveerd, maar dat steeds uit bewijsmiddelen moet blijken dat welomschreven beslissingspatronen of (en) reeksen van

988. Bovens, M.A.P., o.c., 1990, 74-75 en 79-80.

989. Idem, 70-71.

990. Idem, 71 .

991. Heine, G., o.c., 1995, 307-318.

992. Vgl. Van Strien, A.L.J., o.c., 1996, 81.

993. Vgl. Van Strien, A.L.J., 'Het (bewijs van het) daderschap van de rechtspersoon naar Australisch en naar Nederlands recht', in Faure, M. en Schwarz , K. (red.), o.c., 1998, 123-144. 
beslissingen en praktijken in causaal verband zijn te brengen met de aan de rechtspersoon tenlastegelegde wetsovertredingen. ${ }^{994}$ Dit betekent overigens niet dat uitsluitend 'systemische Fehlentwicklungen' tot corporatieve delicten zouden kunnen leiden. Ook incidentele beslissingen of een abrupte ommezwaai (denk aan een noodsprong onder druk van verrassende negatieve marktontwikkelingen) kunnen dat. In de regel zal er in dergelijke gevallen echter nauwelijks van dogmatische problemen sprake zijn, omdat dergelijke beslissingen meestal wel eenvoudig te herleiden zullen zijn tot de centrale organen en individuen in de corporatie. Het dogmatisch en rechtspolitiek relevante probleem dat zowel theoretisch als praktisch de meeste hoofdbrekens kost, is juist de 'policy' en structurele organisatorische problemen over een langere periode, die veelal een veel onpersoonlijker karakter hebben, terwijl zij niettemin leidt tot onaanvaardbare resultaten die causaal zijn verbonden aan een tekortschieten van de organisatie als geheel (zoals een voortdurend gebrek aan voldoende controle of ondermaatse investeringen in apparatuur, personeel, opleidingen e.d.m.).

\section{§4. Het schuldvereiste in het milieustrafrecht}

\section{A. SCHULDELEMENT EN SCHULDVORMEN BIJ MILIEUDELICTEN}

Voor een behoorlijke formulering van het daderschap van overheden voor milieuverstoring moet niet alleen rekening worden gehouden met de specifieke aard van de rechtspersoon als (complexe) organisatie. Er dient ook aandacht te worden besteed aan het specifieke schuldvereiste in het milieustrafrecht. Die kan immers grondig verschillen met het schuldvereiste in het commune strafrecht. ${ }^{995}$

Net zoals ieder ander delict, veronderstelt een milieudelict de aanwezigheid van een schuldelement, zonder dewelke geen sprake kan zijn van een strafbaar feit. ${ }^{996}$ Een objectieve strafrechtelijke aansprakelijkheid of een risico-aansprakelijkheid moet dus ook

994. Zo heeft Heine voor gevallen van ernstige bedrijfsmatige milieuverstoring de bedrijfsvoeringsschuld als volgt nader uitgewerkt (Heine, G. o.c., 1995, 316):

'Ein Unternehmen, das betriebstypische Risiken dadurch vernachlässigt, daß es

1. die Pflicht, mittels organisatorischer Maßnahmen und innerbetrieblicher Strukturanpassungen lagfristig beriebliche Gefahren-quellen zu sicheren,

2. die Pflicht zur Aufrechterhaltung des Sicherheitsniveaus bei Delegation betrieblicher Kompetenzen,

3. die Pflicht zur Uberwachung und Kontrolle betrieblicher Gefahren

versäumt, wird mit Verbandsstrafe belegt, wenn es zum Eintritt eines erheblichen betrieblichen Störfalls kommt,

Ein erheblicher betrieblicher Störfalls liegt vor bei

1. Tötungen oder schwerer Körperverletzungen von Teilen der Bevölkerung,

2. Gemeingefahren, insbesondere gemeingefăhrlichen Feuerbrünsten oder Explosionen (oder erheblichen. Sachschäden an einer Vielzahl von Gebăuden)

3. Schwerwiegendem Umweltschäden, die nur mit unverhältnismäßigen Schwierigkeiten oder erst nach lăngerer Zeit beseitigt werden kōnnen.'

995. Zie ook hoofdstuk II.

996. Remmelink, J., o.c., 1995, 375. 
in het milieustrafrecht worden uitgesloten. ${ }^{997}$ De aanwezigheid van schuld (verwijtbaarheid) blijkt meestal uit een of andere schuldvorm, namelijk opzet of culpa. Nu kan het schuldelement op verschillende manieren in de delictsomschrijving zijn verwerkt. Zo kan de wetgever ervoor kiezen het subjectief delictsbestanddeel nader te omschrijven ${ }^{998} \mathrm{Het}$ is echter kenmerkend voor het milieustrafrecht dat in de delictsomschrijving meestal geen subjectief bestanddeel is gepreciseerd. Zoals reeds werd opgemerkt, heersen in het milieustrafrecht vaak sterke instrumentalistische tendensen, die een minimalisering van het klassieke schuldbeginsel (en andere beginselen) tot gevolg kunnen hebben. In het milieustrafrecht kennen de meeste strafbepalingen in hun delictsomschrijving daarom geen bijzondere schuldvorm. Uitzonderingen op deze regel zijn de commune milieustrafbepalingen, de artikelen 173a en 173b Sr, en in bepaalde zin ook de zorgplichtbepalingen.

Uit het stilzwijgen van de bijzondere milieuwetgever op het vlak van het schuldvereiste in milieustrafbepalingen kan geenszins worden afgeleid dat bij overtreding van deze bepalingen geen zekere mate van schuld is vereist. Het is van belang voor ogen te houden dat de meeste milieudelictsomschrijvingen onder het regime van de WED zijn gebracht. Hierdoor vindt de strafrechtelijke handhaving van deze bepalingen plaats op basis van artikel 1a WED waarin bijna alle milieudelicten zijn ondergebracht. In artikel la WED zijn de milieudelicten opgedeeld in een drietal categorieën met verschillende strafmaxima. ${ }^{999}$ De eerste categorie bestaat uit de ernstige milieudelicten. De tweede en derde categorie betreffen meestal delicten die het niet nakomen van administratieve plichten strafbaar stellen. Volgens artikel 2 lid 1 WED zijn de milieudelicten van de eerste en tweede categorie misdrijven voor zover ze opzettelijk zijn begaan. Indien dit niet het geval is, zijn ze overtredingen. De delicten van de derde categorie zijn uitsluitend overtredingen (artikel 2 lid 4 WED). De koppeling van milieudelicten aan de WED heeft niet slechts gevolgen voor de kwalificatie van het delict (misdrijf of overtreding), maar ook voor de toepasselijke strafmaat. ${ }^{1000}$

Het is interessant terloops op te merken dat dit systeem, waarbij voor de meeste milieudelicten via de WED een nadere kwalificatie en differentiatie op het vlak van het schuldelement en (derhalve ook) de strafmaat mogelijk is gemaakt, grondig verschilt met bijvoorbeeld het Belgische stelsel. Het Belgische milieustrafrecht bestaat voor een groot

997. Faure, M., o.c., 1992, 21-23.

998. Remmelink, J., o.c., 1995, 193-241.

999. Hendriks, L.E.M. en Wöretshofer, J., o.c., 1995, 23-25.

1000. Op grond van artikel 6 WED worden de milieudelicten van de eerste categorie, voorzover het om misdrijven gaat, bedreigd met een gevangenisstraf van ten hoogste zes jaren of een geldboete van de vijfde categorie (artikel 6 lid sub 1 WED). Gaat het om overtredingen dan is de strafbedreiging hechtenis van ten hoogste een jaar of geldboete van de vierde categorie (artikel 6 lid 1 sub 3 WED). De delicten van de tweede categorie kennen een lichtere strafbedreiging. Worden ze opzettelijk begaan en zijn het dus misdrijven dan is de maximum gevangenisstraf twee jaren of een geldboete van de vierde categorie (artikel 6 lid 1 sub 2 WED). De overtredingen worden bedreigd met een hechtenis van ten hoogste zes maanden en een geldboete van de vierde categorie (artikel 6 lid 1 sub 4 WED). Eenzelfde strafbedreiding geldt voor de overtredingen van de derde categorie (artikel 6 lid 1 sub 4 WED). Zie hierover Hendriks, L.E.M. en Wöretshofer, J, o.c., 1995, 25. 
deel nog uit strafbepalingen die als sluitstuk aan de verschillende bijzondere milieuwetten (en -decreten) zijn toegevoegd. Hoewel het laatste decennium vooral in Vlaanderen het materieel milieurecht grondig is geïntegreerd, is helaas nauwelijks gestreefd naar een integratie van de strafbepalingen. ${ }^{1001}$ Kenmerkend voor vrijwel alle milieustrafbepalingen in België - of het nu gaat om abstracte gevaarzettingsdelicten, concrete gevaarzettingsdelicten of zorgplichtbepalingen - is dat de delictsomschrijvingen geen bijzondere subjectieve bestanddelen kennen. ${ }^{1002}$ Volgens de algemene beginselen van het Belgische strafrecht betekent dit noodzakelijkerwijs dat dogmatisch gezien bijna alle milieudelicten met overtredingen worden gelijkgeschakeld. ${ }^{1003}$ Op het vlak van schuld worden voor overtredingen uit bijzondere wetten echter geen strenge eisen gesteld. De schuld wordt als een feitelijk vermoeden uit het begaan van de materiële wetsinbreuk afgeleid. Tenzij ter zake door de verdachte een geloofwaardig verweer wordt gevoerd, door het aanvoeren van schulduitsluitingsgronden, wordt (schuld aan) het strafbare feit vrijwel automatisch bewezen verklaard. ${ }^{1004}$ Dat is een kwalijke zaak omdat deze delicten soms met zware straffen worden bedreigd. Zo wordt in artikel 50 van het Vlaamse Bodemsaneringsdecreet $(1995)^{1005}$ nog steeds het niet nakomen van bepaalde administratieve verplichtingen, zoals het verhinderen van toezicht, bedreigd met een gevangenisstraf van 1 maand tot 5 jaar en/of een geldboete van 100 tot $10.000 .000 \mathrm{BEF}{ }^{1006}$ Dat is op zich al een forse sanctie, maar ingevolge de opdeciemen dient de geldboete nog met 200 te worden vermenigvuldigd, ${ }^{1007}$ zodat deze minimaal $20.000 \mathrm{BEF}$ en maximaal 2.000.000.000 BEF bedraagt. Er is niet gedifferentieerd al naargelang het delict ecologische rechtsgoederen bedreigt, dan wel alleen administratieve belangen schendt. Evenmin is een onderscheid gemaakt al naargelang het delict opzettelijk of culpoos is begaan. ${ }^{1008}$ Deze ondoordachte strafwetgeving heeft dus tot gevolg dat het mogelijk is iemand te veroordelen tot de maximum gevangenisstraf en/of geldboete zonder dat het $\mathrm{OM}$ enige vorm van schuld hoeft te bewijzen, want dogmatisch gezien is iedere inbreuk niet meer dan een overtreding. Het moge duidelijk zijn dat in vergelijking met België het Nederlandse milieustrafrecht meer

1001. Zie o.m. Deketelaere, K. (red.), Milieurechtstandpunten, nr. 10. Milieurecht in Belgie. Status Questionis Anno 1997, Brugge, die Keure, 1997. Zie hoofdstuk II.

1002. Zie hierover Roef, D., 'De strafrechtelijke aansprakelijkheid van de rechtspersoon in het milieustrafrecht', in Belgische Vereniging voor bedrijfsjuristen, Vereniging van praktijkjuristen en Vereniging voor arbeidsrecht (red.), o.c., 1999, 105-125.

1003. Dupont, L. en Verstraeten, R., o.c., 1990, 263; Roef, D., 'De strafrechtelijke aansprakelijkheid van de rechtspersoon in het milieustrafrecht', in Belgische Vereniging van bedrijfsjuristen, Vereniging van praktijkjuristen en Vereniging voor arbeidsrecht, o.c., 1999, 106-107.

1004. Traest, Ph., Het bewijs in strafzaken, Gent, Mys \& Breesch, 1992, 206-207.

1005. Artikel 50 van het Bodemsaneringsdecreet zoals gewijzigd door het decreet van 26 mei 1998 (BS, 25 juli 1998). Zie hierover Ryckbost, D., 'Bijsturing van het Decreet betreffende de Bodemsanering', TMR, 1998, 334-352.

1006. In het oorspronkelijke artikel was het strafmaximum zelfs $100.000 .000 \mathrm{BEF}$. Vermenigvuldigd met 200 opdeciemen was dat dus 20.000 .000 .000 BEF.

1007. Sedert de wet van 24 december 1994 (BS, 31 december 1993) moeten de geldboeten voor feiten gepleegd vanaf 1 januari 1995 met een factor van 200 te worden vermenigvuldigd.

1008. Faure, M., 'De handhaving van het bodemsaneringsdecreet via toezicht, dwangmaatregelen en strafsancties', in Deketelaere, K. (red.), Milieurechtstandpunten, nr.7. Het decreet betreffende de bodemsanering, Brugge, die Keure, 1995, 215-254. 
recht doet aan het schuldbeginsel door via de WED de zwaarste straffen slechts mogelijk te maken indien het milieudelict opzettelijk is begaan.

Kortom, doorslaggevend voor de vaststelling van het schuldvereiste bij de meeste Nederlandse milieustrafbepalingen is dus de tenlastelegging: kiest het $\mathrm{OM}$ voor een opzettelijke variant of niet. Het OM zal bijgevolg steeds de tenlastegelegde schuldvorm moeten bewijzen. Belangrijk is evenwel dat bij de milieuovertredingen uit de WED een onderscheid moet worden gemaakt tussen enerzijds schuld als voorwaarde voor materiële strafbaarheid (het schuldelement) en anderzijds het bewijs daarvan. Wordt een milieuovertreding tenlastegelegd, dan is het schuldelement eenvoudig te bewijzen door de vaststelling dat aan het materiële bestanddeel is voldaan, hetgeen meestal is beperkt tot handelen zonder of in strijd met een vergunning. Schuld behoeft niet te worden tenlastegelegd of te worden bewezen. Met het bewijs van het materiële feit wordt schuld verondersteld, mits maar de mogelijkheid van verweer openstaat. ${ }^{1009}$ Het verweer zal veelal een beroep op een schulduitsluitingsgrond zijn. Het is dan aan de verdachte om gemotiveerd feiten en omstandigheden aan te voeren waaruit aannemelijk wordt dat de schuld ontbreekt. Ontbreekt dergelijk aannemelijk verweer, dan kan het feit bewezen worden verklaard. Het gaat dus niet om een onweerlegbaar wettelijk schuldvermoeden, wat in strijd zou zijn met de praesumptio innocentiae, maar om een weerlegbaar feitelijk vermoeden, dat met een zekere graad van geloofwaardigheid kan worden betwist. Dit vloeit voort uit het Water en Melk-arrest waarin door de Hoge Raad de schulduitsluitingsgrond afwezigheid van alle schuld is erkend. ${ }^{1010}$ Ook het EHRM acht het gebruik van delictsomschrijvingen waarin schuld door de materiële wetsinbreuk wordt verondersteld slechts toelaatbaar onder de stringente voorwaarde dat dit vermoeden voor de verdachte weerlegbaar moet kunnen zijn. ${ }^{1011}$

\section{B. HET ONDERSCHEID TUSSEN FUNCTIONELE EN NIET-FUNCTIONELE DELICTEN}

Een differentiatie op het vlak van het schuldvereiste gekoppeld aan de aard van het delict hangt ook met andere factoren samen. Zo wordt in de literatuur over het daderschap van de rechtspersoon in het milieustrafrecht een onderscheid bepleit tussen functionele en nietfunctionele delicten. ${ }^{1012}$ Functionele delicten kunnen worden gezien als typische ordeningsstrafrechtelijke delicten. Het zijn delicten uit de sociaal-economische sfeer waarin voorschriften worden gegeven over de manier waarop met bepaalde sociale en economische activiteiten moet worden omgegaan. ${ }^{1013} \mathrm{Zij}$ richten zich niet tot eenieder; het zijn geen gemene delicten maar kwaliteitsdelicten gericht tot bepaalde functionarissen die bedrijfs-

1009. Keijzer, N., 'Enkele opmerkingen over de praesumptio innocentiae in strafzaken', in Enschedé, Ch.J., e.a. (red.), Naar eer en geweten, Amhem, Gouda Quint, 1987, 252-253.

1010. HR 14 februari 1916, $N J$ 1916, 618; Remmelink, J., o.c., 1995, 376; Van Bemmelen, J.M. en Van Veen, Th.W., Ons strafrecht I, Het materiële strafrecht, Algemeen deel, bewerkt door De Jong, D.H. en Knigge, G., Arnhem, Gouda Quint, 1995, 37-39.

1011. EHRM 7 oktober 1988, NJ 1991, 351 (Salabiaku); EHRM 25 september 1992, NJ 1995, 593 (Pham Hoang); Van Bemmelen, J.M. en Van Veen, Th.W., o.c., 1998, 40-41.

1012. Zie o.m. Van Strien, A.L.J., L.c., 1991, 275-278 en 289-295.

1013. Fokkens, J.W., 'De rechtspersoon als dader', DD, 1980, 404; Van Strien, A.L.J., l.c., 1991, 276. 
matig handelen en derhalve een voor het leefmilieu belangrijke risicogroep vormen. $\mathrm{Zij}$ vallen in het milieustrafrecht dan ook veelal samen met de abstracte gevaarzettingsdelicten, de grootste categorie van milieustrafbepalingen, waar het handelen zonder of in strijd met een vergunning strafbaar is gesteld.

Functionele delicten zijn doorgaans het resultaat van gelede normstelling. Zij bevatten meestal zeer concrete zorgvuldigheidsnormen in de door de administratieve overheid vastgelegde regelgevingen en individuele vergunningen. In het licht van de in het legaliteitsbeginsel neergelegde lex certa-vereiste kan worden betoogd dat voor de normadressaat (de vergunninghouder) zeer duidelijk is aan welke regels hij zich dient te houden. ${ }^{1014} \mathrm{Er}$ is een relatief doorzichtige afbakening tussen strafbaar en niet-strafbaar gedrag. Gelet op de kenbaarheid van de norm kan worden verdedigd dat vlugger aan het schuldvereiste is voldaan dan bij niet-functionele delicten. ${ }^{1015}$ Van Strien zegt hierover het volgende:

'Juist bij de functionele delicten zijn immers de maatschappelijke verwachtingspatronen belangrijk. Met het niet voldoen aan dergelijke verwachtingen is in beginsel de verwijtbaarheid al gegeven. Omdat bij de functionele delicten verwachtingspatronen een belangrijke rol spelen bij de afgrenzing van de strafrechtelijke verantwoordelijkheid, zal bij deze delicten sneller schuld (in de zin van verwijtbaarheid) aanwezig kunnen worden geacht dan bij andere delicten. ${ }^{1016}$

Hoewel ik het daar in beginsel mee eens ben, is het toch verstandig steeds per geval te kijken naar de strafbaar gestelde norm, die in de vergunning is neergelegd, in plaats van te veronderstellen dat de norm a priori voor de normadressaat duidelijk is omdat deze nu eenmaal formeel in de vorm van een vergunningsvoorschrift is gegoten. Het komt immers voor dat in een zeer concrete vergunning uiterst vage normen, zoals zorgplichtbepalingen, zijn neergelegd. ${ }^{1017}$ Is dat het geval, dan kan men niet automatisch stellen, dat het hier gaat om een functioneel delict, waarbij minder stringente eisen aan het schuldbeginsel kunnen worden gesteld.

Is duidelijk dat het gaat om een functioneel milieudelict, gepleegd door een functionaris, dan is er inderdaad geen fundamenteel bezwaar dat wordt volstaan met een lichtere graad van schuld. De schuld kan dan worden geobjectiveerd. Een extra argument hiervoor is dat dergelijke delicten vaak behoren tot de overtredingencategorie en een sterk administratief

1014. Vgl. Faure, M.G., 'De gevolgen van de 'administratieve afhankelijkheid' van het milieustrafrecht: een inventarisatie van knelpunten', in Faure, M.G., Oudijk, J.H.C., Schaffmeister, D. (red), o.c., 1991, 94-95.

1015. Zie over de relatie tussen het legaliteitsbeginsel en het schuldbeginsel De Roos, Th.A., Strafbaar-stelling van economische delicten; een crimineel-politieke studie, Arnhem, Gouda Quint, 1987, 75.

1016. Van Strien, A.L.J., l.c., 1998, 142.

1017. Zie voor voorbeelden Visser, M., l.c., 1997, 209-210. 
karakter hebben met een geringe strafbedreiging. ${ }^{1018}$ Voor de vaststelling van het daderschap zou men bij functionele delicten in hoofdzaak kunnen terugvallen op vrij objectieve daderschapscriteria, zoals het criterium van de bedrijfspolitiek. Wat overheden betreft kan nog worden opgemerkt dat zij, vanwege hun verantwoordelijkheden in het milieurecht, bij uitstek moeten worden beschouwd als functionarissen, waarvan verwacht mag worden dat zij de na te leven normen kennen en respecteren. Toch zal ook bij overheden per geval moeten worden gekeken of het tenlastegelegde delict zodanig functioneel van aard is dat een objectivering van schuld gerechtvaardigd is.

Niet-functionele milieudelicten daarentegen kunnen in beginsel door eenieder worden verricht en kennen doorgaans een vagere delictsomschrijving zodat zorgvuldiger met het schuldvereiste moet worden omgegaan. Bovendien kennen zij in hun delictsomschrijvingen eigen subjectieve delictsbestanddelen. Zo moeten de (meeste) zorgplichtbepalingen en de milieustrafbepalingen uit het Strafwetboek, de artikelen 173a en 173b, worden aangemerkt als niet-functionele delicten. Natuurlijk hebben zij een functioneel karakter in die zin dat zij zich voornamelijk tot functionarissen richten, maar de praktijk leert dat de normadressaten zich niet tot hen die bedrijfsmatig handelen beperken. ${ }^{1019}$ Geregeld worden niet-functionarissen voor overtreding van zorgplichtbepalingen vervolgd en veroordeeld ${ }^{1020} \mathrm{Bij}$ nietfunctionele milieudelicten moet dus indringender naar het schuldelement in hoofde van rechtspersonen worden gekeken en dienen wat daderschapscriteria betreft strengere eisen te worden gesteld, juist mede vanwege het feit dat zij ook makkelijk op gewone burgers kunnen worden toegepast.

Samengevat: voor de concrete invulling van het subjectief element in hoofde van de rechtspersoon moet worden bekeken welk milieudelict wordt tenlastegelegd. De meeste milieudelicten kennen geen eigen bijzondere subjectieve bestanddelen (opzet of culpa). Gelet op de koppeling van de milieustrafbepalingen aan de WED, hangt het schuldvereiste grotendeels af van de tenlastelegging van het $\mathrm{OM}$. Legt het $\mathrm{OM}$ een milieuovertreding ten laste dan zal schuld in hoofde van de rechtspersoon niet moeten worden bewezen. Het beginsel van geen straf zonder schuld eist wel dat ter zake door de rechtspersoon een verweer moet kunnen worden gevoerd. Legt het openbaar ministerie daarentegen een milieumisdrijf ten laste dan zal vanzelfsprekend opzet moeten worden bewezen in hoofde van de rechtspersoon. Daarnaast speelt een rol of het delict al dan niet functioneel van aard is, hetgeen idealiter niet alleen in abstracto, maar ook in concreto vanuit het perspectief van

1018. Vgl. Van Strien, A.L.J., l.c., 1998, 142. In ieder geval hebben deze delicten in Nederland een geringe strafbedreiging. Zoals gezien is dat in België allerminst het geval.

1019. Vgl. Buiting, Th.J.B. en Huygen, A.E.H., 'Milieustrafrecht: een ondoordachte chaos', in Van Buuren, P.J.J., Betlem, G. en IJstra, T. (red.), Milieurecht in stelling, Utrechtse opstellen over actuele thema's in het milieurecht, Zwolle, W.E.J. Tjeenk Willink, 1990, 72-95. Schaffmeister, D., 'De strafrechtelijke bescherming van ecologische rechtsgoederen', in Faure, M., Oudijk, J.C. en Schaffmeister, D. (red), o.c., 1991, 187-192.

1020. Zie hierover Visser, M., 'Strafrechtelijke zorgplichtbepalingen over de grens? De strafrechtelijke afdwingbaarheid van milieuzorgplichtbepalingen in Belgiẻ en Nederland', in Faure, M. en Deketelaere, K. (red.), Ius Commune en milieurecht. Actualia in het milieurecht in België en Nederland, Intersentia, Antwerpen-Groningen, 1997, 203-236. 
de dader-rechtspersoon dient te worden bekeken. Hoe functioneler het delict, des te objectiever kan het daderschap worden geformuleerd.

Het bijzondere karakter van het milieustrafrecht en de koppeling van de milieudelicten aan de WED heeft dus duidelijk gevolgen voor het (bewijs van) daderschap van de rechtspersoon. Het daderschap en de mate van aan te tonen rechtspersoonlijke verwijtbaarheid worden bepaald door het type milieudelict (opzettelijk of niet-opzettelijk; functioneel of niet-functioneel) dat wordt tenlastegelegd. Het is dan ook onmogelijk en onwenselijk om eenduidige rechtspersoonlijke daderschapscriteria te formuleren. Dit moet per type delict worden beoordeeld zodat ook op privaatrechtelijke en publiekrechtelijke rechtspersonen een uitgebalanceerde strafrechtstoepassing mogelijk blijft.

\section{§ 5. Daderschap bij abstracte gevaarzettingsdelicten}

\section{A. ABSTRACTE GEVAARZETTINGSDELICTEN: FUNCTIONELE DELICTEN ZONDER SUBJECTIEVE BESTANDDELEN}

Gelet op de sterke administratieve afhankelijkheid van het huidige milieustrafrecht zijn de meest voorkomende milieudelicten de zogenaamde abstracte gevaarzettingsdelicten, die het niet conform een administratieve beschikking handelen strafbaar stellen. ${ }^{1021}$ De strafbaarstelling is niet gericht op een rechtstreekse bescherming van ecologische rechtsgoederen, maar op de schending van administratieve voorwaarden, zoals een vergunning. ${ }^{1022}$ Een typisch voorbeeld van een abstract gevaarzettingsdelict is artikel 1, eerste lid Wet Verontreiniging Oppervlaktewateren:

'Het is verboden zonder vergunning met behulp van een werk afvalstoffen, verontreinigende of schadelijke stoffen, in welke vorm ook, te brengen in oppervlaktewateren.'

Ook artikel 8.1 van de Wet Milieubeheer $(\mathrm{Wm})$ is een abstract gevaarzettingsdelict:

'1. Het is verboden zonder daartoe verleende vergunning een inrichting:

a. op te richten;

b. te veranderen of de werking daarvan te veranderen;

c. in werking te hebben.

2. Het verbod geldt niet met betrekking tot inrichtingen, behorende tot een categorie die bij een algemene maatregel van bestuur krachtens artikel 8.40 , eerste lid, is aangewezen, behoudens in gevallen waarin, krachtens de tweede volzin van dat lid, de bij die algemene maatregel gestelde regels niet gelden voor een zodanige inrichting.' 
Artikel $18.18 \mathrm{Wm}$ bepaalt vervolgens dat het handelen in strijd met een vergunningsvoorschrift verboden is. Hierop staat dezelfde sanctie als bij overtreding van artikel 8.1 Wm. Artikel 18.8 Wm luidt:

'Een gedraging in strijd met een voorschrift dat is verbonden aan een krachtens deze wet verleende vergunning of ontheffing is verboden.'

Het is duidelijk dat deze categorie van delicten bij uitstek kunnen worden aangemerkt als functionele delicten. Zij richten zich tot specifieke functionarissen, die bedrijfsmatig handelen, waarvan mag worden verwacht dat zij beschikken over de nodige kennis en macht om de neergelegde zorgvuldigheidsnormen na te leven. ${ }^{1023}$ Dit geldt natuurlijk ook voor overheden, die vanwege hun maatschappelijke machtspositie en verantwoordelijkheid in het milieurecht de toepasselijke normen, die in de functionele delictsomschrijvingen zijn neergelegd, behoren te kennen. Voor de formulering van het daderschap kan daarom vanwege de kenbaarheid van de norm meestal worden volstaan met vrij objectieve daderschapscriteria.

Daarnaast kennen abstracte gevaarzettingsdelicten in hun delictsomschrijvingen doorgaans geen bijzondere eisen op het vlak van het subjectief element. Doorslaggevend is onder welke categorie deze delicten in de WED zijn ondergebracht en de inhoud van de tenlastelegging: kiest het $\mathrm{OM}$ voor een opzettelijk variant $(\mathrm{C})$ of niet $(\mathrm{B})$.

\section{B. DADERSCHAP BU ABSTRACTE GEVAARZETTINGSOVERTREDINGEN}

Wordt een abstract gevaarzettingsdelict als overtreding tenlastegelegd dan volstaat voor de vaststelling van het daderschap in hoofde van de (publiekrechtelijke) rechtspersoon de loutere overtreding van de strafbepaling: het handelen zonder of in strijd met een vergunning(svoorschrift). De materiële inbreuk veronderstelt een feitelijk vermoeden dat verwijtbaar is gehandeld. Het openbaar ministerie dient geen schuldvorm te bewijzen. De rechtspersoon kan reeds als strafbare dader worden aangemerkt wanneer aan het materiële delictsbestanddeel is voldaan. Dit betekent dat de strafrechtelijke aansprakelijkheid is gegeven zodra er geen rechtvaardigings- of schulduitsluitingsgronden aanwezig zijn. Met andere woorden, in de praktijk moet daderschap van de rechtspersoon worden aangenomen indien er geen strafuitsluitingsgronden zijn. In termen van toerekening volstaat dan ook de loutere vaststelling dat het delict binnen de handelingssfeer van de rechtspersoon is gepleegd. De materiële toerekening indiceert reeds de morele toerekening. In de praktijk is het milieudelict geacht te zijn begaan door de rechtspersoon wanneer dit plaatsvindt binnen de bedrijfsvoering of bedrijfspolitiek van de rechtspersoon. Er kan hier worden verwezen naar het reeds besproken Furazolidon-arrest waar het daderschap van de rechtspersoon werd bewezen omdat het ging om de lozing van een stof in het kader van de normale bedrijfsvoering. ${ }^{1024}$ 
Zwaardere daderschapscriteria, zoals de IJzerdraadcriteria, zijn voor dergelijke milieuovertredingen niet nodig, noch gepast, omdat deze bij voorkeur subjectief en niet louter normatief moeten worden ingevuld. Aantonen dat de rechtspersoon in kwestie over de gedraging heeft beschikt en deze heeft aanvaard of pleegde te aanvaarden, zou voor het openbaar ministerie een te grote bewijslast betekenen; een bewijslast die gelet op de functionele aard van het delict en de geringe strafmaat in het licht van het schuldbeginsel ook niet is vereist. Bovendien zou een toepassing van IJzerdraadcriteria op deze milieuovertredingen leiden tot een te grote objectivering van 'beschikken en aanvaarden', een uitholling die onwenselijk zou zijn indien men deze 'geobjectiveerde' criteria vervolgens zou willen toepassen bij opzetdelicten gepleegd door rechtspersonen of natuurlijke personen-functionarissen. In die zin is de verwerping van het in de Furazolidonzaak gevoerde verweer, dat het Hof niet tot een bewezenverklaring kon komen omdat het niet de IJzerdraadcriteria had toegepast, niet onbegrijpelijk.

De verwijtbaarheid van de rechtspersoon kan aldus worden afgeleid uit de schending van de administratieve plichten, maar er dient, in het licht van het schuldbeginsel, wel ter zake steeds een verweer open te staan. Dit betekent dat via het gevoerde verweer dieper op het daderschap van de rechtspersoon kan worden ingegaan, mits het verweer natuurlijk geloofwaardig is. Wanneer dus de rechtspersoon met een zekere graad van aannemelijkheid de naleving van de voor hem geldende zorgvuldigheidsnorm, waarvan de schending in eerste instantie door het overtreden van het voorschrift wordt vermoed, kan aantonen, zal de strafrechter hem moeten ontslaan van alle rechtsvervolging. ${ }^{1025}$ In de praktijk betekent dit dat de rechtspersoon zich vooral op a.v.a.s, in de zin van onoverkomelijke (rechts)dwaling, of op a.v.a.s., in de zin van verontschuldigbare onmacht, zal beroepen. ${ }^{1026}$ A.v.a.s. is een ongeschreven schulduitsluitingsgrond, die moet worden aangenomen wanneer de dader de wederrechtelijke gedraging niet kon vermijden: het is onvermijdbare verwijtbaarheid. ${ }^{1027}$ Slechts indien de dader zich redelijkerwijs anders heeft kunnen gedragen is er schuld. Wat rechtsdwaling betreft, kunnen we kort zijn. Bedrijven en zeker overheden, die immers zelf een belangrijke verantwoordelijkheid dragen zowel op het vlak van de milieuregulering als de handhaving, kunnen zich nauwelijks beroepen op onwetendheid omtrent de wettelijke vergunningsplicht(en). ${ }^{1028}$ Rechtsdwaling leidt volgens

1025. Legt het $\mathrm{OM}$ in voorkomend geval schuld ten laste en kan door het gevoerde verweer de schending van de vereiste zorgvuldigheidsnorm niet worden bewezen verklaard dan volgt vrijspraak.

1026. De schulduitsluitingsgrond (morele) overmacht kan volgens mij moeilijk worden ingeroepen door een rechtspersoon. Vereist is immers een volledige uitschakeling van de wilsvrijheid.

1027. Pompe, W., Handboek van het Nederlandse strafrecht, Zwolle, W.E.J. Tjeenk Willink, 1959, 126-127; Remmelink, J., o.c., 376.

1028. Zo werd in een Belgische zaak van illegaal gedogen van afvalstortingen door de rechtbank te Mons het door de verdachte burgemeester gevoerde verweer van onoverkomelijke rechtsdwaling terecht verworpen: 'Attendu que c'est erronément que le prévenu se prévaut de l'autorisation de la loi ou de l'autorité; Qu'effectivement, il ne peut se retrancher derrière l'arrêté du conseil communal du 6 juin 1988, puisqu'il présida le conseil communal qui se tint à cette date et qu'il signa cet arrêté en sachant qu'il s'agissait d'une norme inférieure et non conforme au décret du 5 juillet 1985 rélatif aux déchets, décret dont il était par ailleurs, ainsi que rappelé ci-avant, personnelement responsable de l'exécution; [...] Attendu que pour ces mêmes motifs, et compte 
heersende rechtspraak en rechtsleer alleen tot straffeloosheid indien deze onoverkomelijk is, en dat is het geval indien de dader heeft gehandeld zoals iedere redelijk en voorzichtig persoon onder dezelfde omstandig-heden zou hebben gedaan. ${ }^{1029}$

Een beroep op a.v.a.s., in de zin van onverschuldigbare onmacht, lijkt me in een enkel geval wel mogelijk. ${ }^{1030}$ Maar de strafrechter zal slechts verontschuldigbare onmacht ${ }^{1031}$ aannemen wanneer de verdachte iedere reële mogelijkheid heeft gebruikt om het delict te vermijden. ${ }^{1032}$ Een beroep op a.v.a.s. lijkt me bijvoorbeeld denkbaar wanneer de verdachte rechtspersoon als verweer voert dat de organisatie als geheel geen verwijt kan worden gemaakt, omdat in casu slechts een natuurlijke persoon (bijvoorbeeld een ondergeschikte functionaris) binnen de organisatie van de rechtspersoon in strijd met beleid en instructies heeft gehandeld en zich niet heeft gehouden aan de voorgeschreven zorgvuldigheidsnormen. Een dergelijk verweer moet natuurlijk geloofwaardig zijn en gestaafd door concrete feiten en omstandigheden. Een verweer dat niet meer inhoudt dan de ontkenning dat er sprake is van daderschap van de rechtspersoon volstaat niet (zoals ook blijkt uit de Furazolidon-casus). Ik meen dat als uitgangspunt moet gelden dat in een dergelijk geval uit het verweer moet blijken dat de overtreding niet kan worden teruggevoerd tot een disfunctioneren van de rechtspersoon als geheel. ${ }^{1033}$ De vaststelling daarvan zal steeds van de feiten afhangen, maar in concreto zal bijvoorbeeld expliciet door de rechtspersoon moeten worden aannemelijk gemaakt dat er binnen de organisatie alle redelijke maatre-

tenu en outre de son degré de formation intellectuelle et de compétence, de la netteté des differences mises en garde qui lui furent adressés par les autorités compétentes, et de ce qu'il n'agit pas en tant que personnes raisonable et prudente, le prévenu ne peut davantage invoquer l'erreur invincible.' Mons, 26 novembre 1996, Aménagement-Environnement, 1997, 143. Zie ook hoofdstuk III.

1029. Zie o.m. HR 6 december 1988, MenR 1989, nr. 38; Rb. Amsterdam, 26 april 1991, MenR, 1991, nr. 121; Rb. Amsterdam 18 december 1990, MenR 1992, nr. 14. Voor voorbeelden uit het Belgische milieustrafrecht zie Faure, M., 'De onoverkomelijke rechtsdwaling in milieustrafzaken', $R W, 1991-92,937-950$.

1030. A.v.a.s. heeft zijn ontstaansgeschiedenis in het befaamde Water en Melk-arrest (HR 14 februari $1916, N J 1916,681$ ) waarin door de Hoge Raad expliciet is uitgemaakt dat voor ieder delict een schuldelement is vereist, ook wanneer in (bijzondere) wetgeving schuld niet als bestanddeel is opgenomen.

1031. Hendriks, L.E.M. en Wöretshofer, J., o.c., 1995, 134-135.

1032. Remmelink, J., o.c., 1995, 376; Zie voor een toepassing HR 2 februari 1993, NJ 1993, 476, waarin een vennootschap werd vervolgd omdat deze pinda's met een te hoog aflatoxine-gehalte had verkocht. De Hoge Raad aanvaarde het a.v.a.s.-verweer omdat de rechtspersoon 'de maximale van haar te vergen zorg heeft betracht'. A.v.a.s., in de zin van verontschuldigbare onmacht, garandeert eigenlijk dat de plicht om de strafwet na te leven steeds een, zij het strenge, inspanningsverplichting blijft en geen resultaatsverplichting wordt. Het zou in strijd zijn met het schuldbeginsel indien de justitiabele ondanks alle maximaal geleverde zorgvuldigheid toch zou kunnen worden veroordeeld. Dat zou neerkomen op een zuivere risico-aansprakelijkheid waarvan nauwelijks nog een instrumentele werking mag worden verwacht omdat, simpel gezegd, ondanks de inspanningen die door iemand zijn verricht hij bij wetsovertreding toch steeds strafbaar en dus verwijtbaar heeft gehandeld. Een verwijtbaarheidsoordeel in geval van onvermijdbare verwijtbaarheid moet ten alle tijde worden vermeden. Vgl. Kessler, M., 'Afwezigheid van alle schuld in de economische rechtspraak', in Borgers, M.J., Koopmans, I.M. en Kristen, F.G.H. (red.), o.c., 1998, 83 en 86.

1033. Zie tevens Van Strien, A.L.J., o.c., 1996, 111. 
gelen zijn genomen om de wet na te leven of dat alle mogelijke controle is uitgevoerd op productieprocessen, op de uitvoering van beslissingen door de ondergeschikte functionarissen. Wat moet worden vermeden is dat de rechtspersoon straffeloosheid kan bekomen door met een beschuldigende vinger naar het 'personeel' te wijzen, terwijl deze wellicht de verboden gedragingen hebben verricht met (impliciete) toestemming of oogluikende goedkeuring van de leiding van organisatie.

Voor een succesvol beroep op a.v.a.s. door de rechtspersoon lijkt mij daarnaast ook van belang welk voorschrift in concreto is geschonden. Een a.v.a.s.-verweer concentreert zich immers op de vraag welke 'redelijke' maatregelen ter voorkoming van de schending van het voorschrift zijn genomen. Het type voorschrift heeft echter rechtstreeks invloed op de maatregelen die de rechtspersoon had moeten nemen. ${ }^{1034} \mathrm{Zo}$ kan van de rechtspersoon meer maatregelen worden gevergd naarmate de voorschriften specifieker zijn geformuleerd. Zijn deze voorschriften daarentegen vaag, dan is het moeilijker te beoordelen welke maatregelen ter vermijding van het delict hadden genomen moeten worden en zal derhalve indringender op het schuldverweer moeten worden ingegaan. Nu levert dit meestal niet zoveel problemen op daar de vergunningsvoorschriften zeer precies zijn geformuleerd. Maar het is bekend dat in een vergunning wel eens vage normen worden neergelegd. ${ }^{1035}$

Er rijst ook nog een ander probleem bij het a.v.a.s. verweer, namelijk wanneer de rechtspersoon aanvoert dat hij de te vergen maatregelen niet heeft kunnen nemen omdat, naar zijn oordeel, de voorschriften te streng zijn en een abnormale (financiële of personele) inspanningsverplichting eisen van de organisatie. Een dergelijk verweer kan dan de vorm aannemen van een exceptie van onwettigheid ${ }^{1036}$, indien de voorwaarden onrechtmatig zouden zijn opgelegd, of de vorm van een a.v.a.s.-verweer. Dergelijk verweer zal weinig kans van slagen hebben. De strafrechter zal immers in een dergelijk geval de bal terugkaatsen en de verdachte erop wijzen dat hij de voorgeschreven normen maar via administratief bezwaar en beroep had moeten aanvechten. ${ }^{1037}$ Met name bij overheden lijkt een dergelijk verweer niet honoreerbaar: zij hebben immers alle juridische en feitelijke mogelijkheden om de in hun ogen 'te strenge' of wellicht zelfs onrechtmatige voorschriften aan te vechten. Problematisch is wel de situatie waar na het verstrijken van de bezwaar- en beroepstermijnen pas blijkt dat de te nemen maatregelen onhaalbaar zijn. ${ }^{1038} \mathrm{Er}$ zijn ook dan weer twee mogelijke verweren denkbaar. Beroept de verdachte zich in dergelijk geval alsnog op het onrechtmatige karakter van de vergunningsvoorschriften (exceptie van onwettigheid), dan zal naar alle waarschijnlijkheid de strafrechter de formele rechtskracht van deze voorschriften moeten aanvaarden en de verdachte veroordelen voor de

1034. Zie hierover Kessler, M., 'Afwezigheid van alle schuld in de economische rechtspraak', in Borgers, M.J., Koopmans, I.M. en Kristen, F.G.H. (red.), o.c., 1998, 84.

1035. Zie hierover o.m. Visser, M., 'Strafrechtelijke zorgplichtbepalingen over de grens?', in Faure, M. en Deketelaere, K. (red.), o.c., 1996, 209-210.

1036. Zie hierover Faure, M.G., l.c., 1991, 96-110.

1037. Kessler, M., l.c., 1998, 85.

1038. Zie hierover ook Kessler, M., l.c., 1998, 85. 
overtreding van de voorschriften. ${ }^{1039}$ Wat overblijft is een beroep op a.v.a.s., waarvan de aannemelijkheid door de strafrechter zal moeten worden beoordeeld.

\section{DADERSCHAP BJ ABSTRACTE GEVAARZETTINGSMISDRIJVEN}

Indien een abstract gevaarzettingsdelict opzettelijk wordt begaan, gaat het om een misdrijf en zal dus in beginsel meer naar de mate van schuld in hoofde van de rechtspersoon moeten worden gekeken. Bovendien moet het $\mathrm{OM}$ het tenlastegelegde opzet bewijzen. De beoordeling van de rechtspersoonlijke opzet zal dus plaatsvinden bij de bewijsvraag en niet zoals bij de milieuovertredingen bij een mogelijk schuldverweer. Wat kan nu worden verstaan onder rechtspersoonlijk 'opzet' en hoe weerspiegelt zich dat in de vaststelling van het daderschap?

Allereerst moet worden opgemerkt dat de Hoge Raad in 1952 heeft bepaald dat het 'opzet' uit de WED, net als in het commune strafrecht, moet worden gezien als kleurloos opzet. ${ }^{1040}$ Dit betekent voor het milieustrafrecht dat het zonder of in strijd met een vergunningsvoorschrift opzettelijk handelen niet impliceert dat de justitiabele wetenschap heeft van het onrechtmatige karakter van zijn gedraging: het opzet hoeft niet gericht te zijn op de wetsovertreding. ${ }^{1041}$ Het is uitsluitend de gedraging, bijvoorbeeld het uitbaten van een inrichting of een lozing, die opzettelijk moet zijn verricht.

We hebben gezien dat er verschillende manieren bestaan om te bekijken of bij een rechtspersoon sprake is van opzet. De meest gebruikelijke methode is die waarbij het opzet van bepaalde natuurlijke personen aan de rechtspersoon wordt toegerekend. ${ }^{1042}$ Vooral de orgaantheorie gaat hiervan uit, maar ook bij de IJzerdraadcriteria is soms sprake van een toerekening van verwijtbaar handelen van de natuurlijke persoon aan de organisatie als geheel. Daarnaast is er de theorie dat het opzet van de rechtspersoon bij natuurlijke personen kan worden 'bijeengeharkt'. ${ }^{1043}$ Een andere benadering is min of meer losgekoppeld van de natuurlijke persoon en maakt gebruik van maatschappelijke zorgplichten. ${ }^{1044}$ Een

1039. Zie o.m. Koopmans, I.M., o.c., 1996, 137-139. Zie tevens hoofdstuk VII waar uitvoerig bij de formele rechtskracht van vergunningen wordt stil gestaan.

1040. HR 18 maart 1952, NJ 1952, 314 en 314 (Kleurloos opzet).

1041. Zie hierover o.m. Peters, A.A.G., Opzet en schuld in het strafrecht, 1966, 89; Van Bemmelen, J.M. en Van Veen, Th.W., o.c., 1995, 84-85; Remmelink, J., o.c., 1995, 225.

1042. Zie voor een toepassing HR 9 april 1985, NJB 1985, 658.

1043. Torringa, R.A., De rechtspersoon als dader; strafbaar leidinggeven aan rechtspersonen, Arnhem, Gouda Quint, 1984, 33; Vellinga, W.H. en Vellinga-Schootstra, F., 'Het daderschap van de rechts-persoon', o.c., 1993, 46; Zie voor een illustratie HR 16 juni 181, NJ 1981, 586 (Papa Blanca).

1044. Zie voor een toepassing bijvoorbeeld Rb. Den Bosch 2 januari 1990, MenR 1990, 66 waar een bedrijf werd veroordeeld voor het opzettelijk zich ontdoen van chemische afvalstoffen in de zin van artikel $1 \mathrm{Wca}$. Het opzet werd door de rechter o.m. afgeleid uit het feit dat de verdachte 'een groot chemisch bedrijf dat meerdere chemische deskundigen in dienst heeft, klaarblijkelijk welbewust geen enkel onderzoek heeft ingesteld naar de gevolgen voor het milieu van de storting van de onderhavige grote hoeveelheden chemische afvalstoffen, doch het haar er kennelijk om te doen was deze stoffen kwijt te geraken'. Zie hierover ook Hendriks, L.E.M. en Wöretshofer, J., o.c., 1995, 107. 
fundamenteel bezwaar hiertegen is dat de mate van verwijtbaarheid zeer normatief wordt bepaald en dat zo de opzeteis wordt uitgevlakt. ${ }^{1045}$

Ook de Hoge Raad blijkt tot op heden (terecht) moeite te hebben om bij doleuse delicten het daderschap van de rechtspersoon uit de schending van zorgvuldigheidsnormen af te leiden. ${ }^{1046}$

Hoe het opzet van de rechtspersoon gestalte kan krijgen en welke problemen daarbij kunnen rijzen, kan thans worden geillustreerd aan de hand van twee voorbeelden. ${ }^{1047}$

\section{De illegale geluidswal van de gemeente Druten}

Een eerste casus betreft de veroordeling van de gemeente Druten door het Hof Arnhem. ${ }^{1048}$ Aan de gemeente werd verweten het zonder vergunning opzettelijk oprichten van een geluidswal, zijnde overtreding van artikel 33 Afvalstoffenwet, strafbaar gesteld bij artikel 1 jo. artikel 6 WED. ${ }^{1049}$ De gemeente had in casu voor de oprichting van een geluidswal gebruik gemaakt van bouw-, sloop- en ander bedrijfsafval. Het Hof achtte het tenlastegelegde opzet bewezen omdat

'de telastegelegde handelingen zijn verricht door en in opdracht van ambtenaren van de gem. Druten, die geacht moeten worden ter zake kundig te zijn en de wet te kennen.' ${ }^{1050}$

Uit deze bewijsoverweging blijkt dat het opzettelijk handelen van de gemeente kon worden afgeleid uit het feit dat de illegale gedragingen door en in opdracht van de betrokken ambtenaren zijn verricht. Het opzet van de natuurlijke personen is in die zin het opzet van de rechtspersoon. Het opzet van de ambtenaren wordt op zijn beurt afgeleid uit de schending van de maatschappelijke zorgplicht die erin bestaat dat zij 'geacht moeten worden ter zake kundig te zijn en de wet te kennen'. ${ }^{1051}$

In het licht van het voorgaande kan in de eerste plaats enige kritiek worden geleverd op de constructie dat het opzet van de natuurlijke persoon automatisch moet worden gezien als opzet van de rechtspersoon ${ }^{1052}$. We weten dat dit niet steeds zo hoeft te zijn. Wel moet worden toegegeven dat dit in deze casus minder bezwaarlijk is daar het gaat om een organisatie waar de afstand tussen individuele beslissingen en de rechtspersoon gering is.

1045. Vgl. Van Strien, A.L.J, o.c., 1996, 104-105; Roef, D. en De Roos, Th., l.c., 1998, 86-87; noot van 't Hart bij HR 19 november 1991, $N J$ 1992, 250.

1046. HR 19 november 1991, NJ 1991, 250 met noot 't Hart.

1047. Zie voor een diepgravende analyse tevens Van Strien, A.L.J., o.c., 1996, 106-110.

1048. Zie ook hoofdstuk III.

1049. De Afvalstoffenwet is in het kader van de integratie van de milieuwetgeving sinds 1 januari 1994 in de Wet milieubeheer opgenomen. Zie hierover Addink, G.H., Afvalstoffen, Zwolle, W.E.J. Tjeenk Willink, 1996; MenR, 1993/12, Themanummer afvalstoffen.

1050. Hof Arnhem 22 mei 1989, MenR 1989, nr. 81 met noot Tak, P.J.P.

1051. Zie hierover ook Van Strien, A.L.J., o.c., 1996, 106.

1052. Vgl. Van Strien, A.L.J., o.c., 1996, 106; Roef, D. en De Roos, Th., l.c., 1998, 82-83. 
Maar op de casus van bijvoorbeeld de Nijmeegse vuile grond-affaire zou een dergelijke toerekening van opzet onwenselijk kunnen zijn, omdat te weinig wordt gekeken naar de organisatie als geheel.

Meer problematisch is wellicht dat het opzet van de natuurlijke persoon alleen wordt gebaseerd op de schending van een zorgvuldigheidsnorm. Wordt hierdoor niet de vereiste schuldvorm (opzet) te zeer geobjectiveerd? Met van Strien ben ik van oordeel dat dit gevaar inderdaad aanwezig is. Opzet afleiden uit de schending van objectieve zorgvuldigheidsnormen kan ertoe leiden dat de verdachte opzettelijk de tenlastegelegde gedraging heeft verricht, terwijl wellicht de (rechts)persoonlijke opzet, de intentie, afwezig was. ${ }^{1053}$ Daartegen kan evenwel worden aangevoerd dat rekening moet worden gehouden met de aard van het tenlastegelegde delict. Het gaat hier immers om een zeer functioneel getint abstract gevaarzettingsdelict. Het is een delict waarin normen worden voorgeschreven over de wijze waarop met bepaalde voor het leefmilieu schadelijke activiteiten (i.c. het gebruik van afvalstoffen) moet worden omgegaan, die bovendien zijn gericht tot normadressaten die geacht worden ter zake de wettelijke voorschriften te kennen. Men mag inderdaad eisen en verwachten dat een gemeente (en zijn ambtenaren) op de hoogte is (zijn) van de na te leven regelgeving. Daarom zou kunnen worden verdedigd dat er minder bezwaren zijn om bij dergelijke functionele milieudelicten meer objectieve daderschapscriteria toe te passen. Dus wat opzet als materiële strafbaarheidsvoorwaarde betreft, lijkt er minder bezwaar deze schuldvorm bij functionele milieudelicten inderdaad te baseren op zorgvuldigheidsnormen.

Hoewel deze redenering overtuigt, lijkt het toch verstandig dat de vaststelling van de schending van deze normen niettemin bewijsrechtelijk ernstig wordt genomen. Dit betekent dat het $\mathrm{OM}$ de aanwezigheid van opzet niet slechts uit de loutere schending van de geobjectiveerde zorgvuldigheidsnorm zou mogen afleiden, maar dat uit concrete feiten en omstandigheden moet blijken dat deze schending inderdaad in causaal verband staat met het functioneren of het beleid van de organisatie als geheel. Indien het OM meent dat een abstract gevaarzettingsdelict opzettelijk is gepleegd dan dient dit ook te worden bewezen. Anders is er qua (bewijs van) daderschap nauwelijks nog een onderscheid tussen abstracte gevaarzettingsovertredingen en abstracte gevaarzettingsmisdrijven. Een beter uitgangspunt is daarom dat de vereiste opzet in hoofde van de verdachte moet worden beoordeeld en dat is de organisatie zelf. Hier kan, vooral bij complexe organisaties, het concept van de bedrijfsvoeringsschuld een belangrijke rol spelen. Het OM kan dan aanvoeren dat zorgvuldigheidsnormen zijn geschonden omdat (bijvoorbeeld) zekere beslissingspatronen, inefficiënt management of gebrekkige controles in causaal verband staan met de schending. Tegelijk moet het voor de verdachte rechtspersoon steeds mogelijk zijn het bewijs van dit opzet aan te vechten. Dit zal dan de vorm krijgen van een bewijsverweer. De verdachte rechtspersoon kan bijvoorbeeld aanvoeren dat in casu opzet ontbreekt omdat binnen de organisatie alle maatregelen zijn genomen ter vermijding van het delict en een ondergeschikte bijvoorbeeld op eigen houtje heeft gehandeld. 


\section{De grafheuvel en de Rijksuniversiteit Groningen}

Een andere boeiende casus betreft de reeds eerder besproken zaak van de Rijksuniversiteit Groningen (RUG) ${ }^{1054}$ De RUG kon zich niet beroepen op de strafrechtelijke overheidsimmuniteit omdat deze publiekrechtelijke rechtspersoon geen openbaar lichaam is in de zin van hoofdstuk $7 \mathrm{Gw}$. De strafrechter heeft derhalve een oordeel kunnen vellen over de hoofdvraag of de RUG een strafbaar feit heeft gepleegd. De feiten zijn inmiddels bekend: een wetenschappelijk hoofdmedewerker, werkzaam bij het Biologisch Archeologisch Instituut (BAI) van de RUG, had met zijn studenten zonder vergunning een grafheuvel afgegraven. Hij had immers vernomen dat de heuvel binnen zeer korte tijd met de grond gelijk zou worden gemaakt en wou daarom 'op de valreep' tot archeologisch onderzoek overgaan. Het BAI had besloten de graafwerkzaamheden te verrichten ter uitvoering van het door de subfaculteit der Praehistorie goedgekeurde onderzoeksprogramma. Niet de wetenschapper, noch het BAI (dat instituut heeft immers geen rechtspersoonlijkheid), maar de RUG werd voor deze feiten vervolgd. Aan de RUG werd tenlastegelegd dat zij:

'in of omstreeks de maand september 1982, althans in het jaar 1982 te Eext in de gemeente Anloo opzettelijk in strijd met, althans in strijd met artikel van de Monumentenwet, zonder vergunning van de Minister van Onderwijs, Kunsten en Wetenschappen [...] een beschermd monument in de zin van artikel 1 van de bedoelde wet -te weten (een terrein waarin) een grafheuvel [...] (gedeeltelijk) heeft afgebroken en/of in enig opzicht heeft gewijzigd:

J.N.L(..), wetenschappelijk hoofdmedewerker, als archeoloog werkzaam ten behoeve van het Biologisch Archeologisch Instituut te Groningen, een onder haar, verdachte, ressorterend instituut, en aldus werkzaam zijnde in dienstbetrekking van haar, verdachte, heeft in voormelde hoedanigheid in of omstreeks de maand september 1982, althans in het jaar 1982, te Eext in de gemeente Anloo tezamen en in vereniging met een ander of anderen, althans alleen, (opzettelijk) in strijd met artikel 14 van de Monumentenwet, zonder vergunning van de Minister van Onderwijs, Kunsten en Wetenschappen, [...] (opzettelijk) graafwerkzaamheden verricht aan bovenbedoelde grafheuvel, waardoor die grafheuvel (gedeeltelijk) werd ontmanteld en/of afgegraven en aldus het monument (gedeeltelijk) werd afgebroken en/of in enig opzicht werd gewijzigd. ${ }^{1055}$

Deze tenlastelegging werd bewezen verklaard, maar er volgde wel een vrijspraak op het onderdeel waarin was gesteld dat de RUG (en de archeoloog) opzettelijk in strijd met artikel 14 van de Monumentenwet had(den) gehandeld. Kortom, bewezen was verklaard dat de archeoloog opzettelijk graafwerkzaamheden had verricht waardoor de grafheuvel werd afgebroken, en dat (aldus) de RUG artikel 14 van de Monumentenwet had overtreden. 
Annotator van Veen is het met deze uitspraak niet eens omdat volgens hem het opzet van de functionaris ook het opzet is van de rechtspersoon. Hij stelt:

'Daarom acht ik het minder juist dat het hof het opzet van de hoofdmedewerker wel bewezen verklaart en het opzet van de rechtspersoon niet $^{1056}$

Mijns inziens verliest van Veen uit het oog dat in de tenlastelegging twee verschillende opzetvormen centraal staan: namelijk het opzettelijk overtreden van de Monumentenwet en het opzettelijk afgraven van de grafheuvel. ${ }^{1057}$ Aan de RUG werd (primair) het opzettelijk (en subsidiair het) in strijd met artikel 14 Monumentenwet afgraven van de grafheuvel tenlastegelegd. ${ }^{1058}$ Dit betekent dat het aan de RUG primaire tenlastegelegde opzet niet alleen het afgraven beheerst, maar ook de rest van de bestanddelen van de tenlastelegging, dus ook het in strijd met de regel handelen. ${ }^{1059}$ Hier wordt eigenlijk boos opzet tenlastegelegd, want de verdachte rechtspersoon moet wetenschap hebben gehad van de wederrechtelijkheid van de gedraging. Met betrekking tot de archeoloog werd in de tenlastelegging echter gesteld dat hij opzettelijk in strijd met de Monumentenwet opzettelijk de grafheuvel had afgegraven. Slechts het opzet gericht op het afgraven werd bewezen verklaard. Het opzettelijk handelen in strijd met de Monumentenwet kon niet worden bewezen omdat de archeoloog zich met succes op a.v.a.s. had kunnen beroepen. Op basis van een mededeling van een collega had hij (en dus ook het BAI) de overtuiging dat de heuvel geen beschermd monument was. ${ }^{1060}$ De conclusie is vrij duidelijk: indien geen boos opzet in hoofde van de archeoloog kan worden bewezen verklaard, dan kan dat evenmin in hoofde van de RUG. Nu aan de RUG het opzettelijk in strijd met de Monumentenwet afgraven van de heuvel was tenlastegelegd en niet (ook) het opzettelijk afgraven, moest de RUG ten aanzien van het onderdeel 'opzettelijk' geheel worden vrijgesproken. Simpel gezegd en anders dan van Veen concludeert: de rechtspersoon kon in casu moeilijk voor het tenlastegelegde worden veroordeeld, want er was 'meer' opzet aan haar tenlastegelegd dan in hoofde van de archeoloog kon worden bewezen.

Uiteindelijk is de RUG dus veroordeeld niet voor het opzettelijk afgraven, maar voor het afgraven zonder meer, hetgeen ook een inbreuk op artikel 14 Monumentenwet oplevert (wat subsidiair was tenlastegelegd). Laten we nu wat meer inhoudelijk bij het daderschap van de veroordeelde rechtspersoon stilstaan. Allereerst, op grond waarvan heeft het Hof het daderschap van de RUG, het (niet-opzettelijk!) afgraven, bewezen verklaard? Het Hof geeft als bewijsoverweging dat:

1056. Noot Van Veen, Th.W. bij HR 10 november 1987, NJ 1988, 303.

1057. Zie ook Vellinga-Schootstra, F. en Vellinga, W.H., o.c., 1993, 46 en Van Strien, A.L.J., o.c., 1996, 107.

1058. Zie over dergelijke expliciet subsidiaire tenlasteleggingen De Jong, D.H., De macht van de tenlastelegging in het strafproces, Arnhem, Gouda Quint, 1981, 203.

1059. Remmelink, J., o.c., 1995, 201. De gerichtheid van het bestanddeel opzet op de (daaropvolgende) andere bestanddelen wordt schuldverband genoemd.

1060. Zie hierover Van Strien, A.L.J., o.c., 1996, 109-110. 
'a. de bewezen verklaarde afgraving geschiedde onder leiding van en mede door een in verdachtes dienst zijnde wetenschappelijk hoofdmedewerker Lanting, in het kader van zijn dienstbetrekking;

b. die hoofdmedewerker was werkzaam bij het BAI, en zijn werk bestond uit archeologisch onderzoek;

c. onderwijs en wetenschapsbeoefening behoren tot de taak van de universiteit; binnen de universiteit zijn ingevolge art. 8 jo. art 14 WUB de organisatie en coördinatie van onderwijs en wetenschapsbeoefening opgedragen aan de (sub)faculteiten, die aldus een deel van de taak van de universiteit vervullen;

d. de door die hoofdmedewerker c.s. verrichte afgraving geschiedde ter uitvoering van het besluit tot afgraven van het betreffende monument, genomen door het bestuur van het BAI, een vakgroep in de zin van de WUB, welk besluit was gebaseerd op het door de faculteitsraad van de subfaculteit der praehistorie goedgekeurde onderzoeksprogramma en derhalve, gelet op het onder $\mathrm{c}$ overwogene, ter uitvoering van de taak van de universiteit." ${ }^{1061}$

Hiertegen wordt door de verdachte een dubbel verweer gevoerd, namelijk enerzijds dat vanwege de autonomie van de subfaculteit op het gebied van onderzoek en onderwijs de organen van de universiteit geen invloed hebben op de beslissingen van deze subfaculteit; anderzijds dat het vakgroepbestuur en de subfaculteitsraad niet kunnen worden gezien als organen van de universiteit. Kortom, het bewezenverklaarde gaat volgens het verweer eraan voorbij dat de RUG slechts geacht kan worden een strafbaar feit te hebben gepleegd indien haar organen op een of andere manier verwijtbaar betrokken zouden zijn geweest bij het besluit de grafheuvel af te graven. Nu deze organen (1) in casu geen zeggenschap zouden hebben over de subfaculteitsraad en (2) deze laatste weliswaar zeggenschap heeft gehad maar geen orgaan is van de universiteit, kan geen sprake zijn van daderschap in hoofde van de rechtspersoon. Het verweer gaat blijkbaar uit van de orgaantheorie. Daarnaast veronderstelt het verweer dat van daderschap van de rechtspersoon slechts sprake kan zijn indien het orgaan over de tenlastegelegde gedraging kan beschikken: een impliciete verwijzing naar de IJzerdraadcriteria. Het Hof verwerpt beide verweren met als hoofdmotivering dat de bewezenverklaring daarmee niet onverenigbaar is en voegt daar nog aan toe dat de autonomie van de subfaculteit onverlet laat dat de Universiteitsraad c.q. het College van Bestuur bevoegd is besluiten van een subfaculteit te vernietigen c.q. te schorsen wegens strijd met de wet of het algemeen belang, terwijl de subfaculteitsraad ten aanzien van het bestuur van een vakgroep een soortgelijke bevoegdheid heeft. In cassatie wordt door de RUG een gelijkluidend verweer gevoerd, maar de Hoge Raad houdt de veroordeling in stand en verwerpt het middel als volgt:

'Aan het middel ligt de opvatting ten grondslag dat een rijksuniversiteit slechts kan worden aangemerkt als dader van een strafbaar feit indien een van haar hoogste organen (College van Bestuur en Universiteitsraad) over 
het begaan van dat feit zeggenschap heeft gehad. Deze opvatting vindt echter geen steun in het recht. ${ }^{1062}$

De Hoge Raad weerlegt de eis dat organen - in termen van de Ijzerdraadcriteria - over de tenlastegelegde gedragingen 'vermochten te beschikken'. ${ }^{1063}$ Welke conclusies over het daderschap van de rechtspersoon kunnen uit dit arrest worden afgeleid? Dat is moeilijk te beoordelen. Mijns inziens kan hieruit niet worden afgeleid dat de Hoge Raad afstand heeft genomen van de IJzerdraadcriteria. Er moet, net als bij het Furazolidon-arrest, rekening worden gehouden met het type delict dat uiteindelijk werd bewezen verklaard. Het ging hier niet (meer) om een doleus delict, maar om een overtreding. Het enige wat immers door het Hof is bewezenverklaard, is dat er door de RUG zonder vergunning een grafheuvel werd afgegraven, niet dat dit door de rechtspersoon opzettelijk werd begaan. De verwerping van het cassatiemiddel dat (organen van) de rechtspersoon zeggenschap moet(en) hebben gehad over de verboden gedragingen, is in dat licht niet onbegrijpelijk.

\section{Daderschapsproblemen tengevolge van interne organisatiestructuur}

Het RUG-arrest doet wel de vraag rijzen of het enig verschil zou hebben gemaakt indien in hoofde van de rechtspersoon het opzettelijk afgraven van de heuvel zou moeten worden bewezen verklaard. Welke eisen dienen in zo'n geval te gelden voor het daderschap en het bewijs daarvan? Meer algemeen gesteld, is het bij opzetdelicten nog verdedigbaar dat in Hoge Raad-termen 'de organen geen zeggenschap moeten hebben gehad over de strafbare gedragingen', in het bijzonder wanneer blijkt dat ze dat nauwelijks kunnen hebben?

Uit de RUG-casus blijkt dat de organen inderdaad niet verwijtbaar betrokken waren bij de graafwerkzaamheden, noch op beslissingsniveau en zeker niet op uitvoeringsniveau. Het is evenzeer duidelijk dat op basis van de orgaanleer geen opzet bij de RUG had kunnen worden geformuleerd. De organen van de RUG hebben niet de gedraging verricht, noch hebben ze daartoe besloten. Ook de IJzerdraadcriteria zijn moeilijk toepasbaar omdat de rechtspersoon geen of nauwelijks beschikkingsmacht heeft over de door de BAI verrichtte gedragingen. ${ }^{1064}$ Wat hier eigenlijk een hinderpaal opwerpt is niet in de eerste plaats een strafrechtsdogmatisch probleem, maar de interne organisatiestructuur van de rechtspersoon. We hebben hier immers te maken hebben met enerzijds een organisatie met rechtspersoonlijkheid (RUG), die bestaat uit relatief autonome deel-organisaties of subafdelingen zonder rechtspersoonlijkheid (BAI). De strafrechtelijke aansprakelijkheid is echter via artikel $51 \mathrm{Sr}$ gekoppeld aan de rechtspersoonlijkheid. Moest de BAI rechtspersoonlijkheid genieten dan zou de formulering van het daderschap natuurlijk veel minder problemen geven. Nu moet echter een 'sprong' worden gemaakt in termen van verwijtbare betrokkenheid tussen de sub-afdeling en de rechtspersoon als geheel, hetgeen door de bestuurlijke autonomie van de sub-afdeling wordt bemoeilijkt. 
Reeds bij de bespreking van het openbaar lichaam-criterium kwam aan de orde welke nadelen er kleven aan de koppeling van de strafrechtelijke aansprakelijkheid aan het civiele recht. ${ }^{1065}$ Een belangrijk bezwaar is dat de ratio's van civielrechtelijke rechtspersoonlijkheid weinig uitstaans hebben met strafrechtelijke doelstellingen. De rechtspersoonlijkheid heeft als hoofddoel een organisatie - privaat of publiek - de mogelijkheid te geven net als een natuurlijke personen aan het civielrechtelijke rechtsverkeer deel te kunnen nemen. ${ }^{1066}$ Voor het strafrecht gaat het in de eerste plaats om de vraag wie verantwoordelijk moet kunnen worden gesteld voor gepleegde delicten en niet om wie civielrechtelijk rechten en plichten dient te hebben. Dit pleit ervoor om bij de vaststelling van het daderschap niet blind te varen op de civielrechtelijke constructie van de organisatie, maar de maatschappelijke realiteit binnen de rechtspersoon als vertrekpunt te nemen. Bestaat de rechtspersoon uit sub-organisaties die feitelijk gezien zodanig zijn opgebouwd (statutair of wettelijk) dat zij een eigen beschikkingsmacht en besluitvorming hebben, dan kan volgens mij het daderschap daarop worden gebaseerd. Het ligt dus veel meer voor de hand om het daderschap binnen de functionele entiteiten die tot de rechtspersoon behoren te situeren. Voor publiekrechtelijke rechtspersonen is dit zelfs vrij makkelijk toe te passen door eenvoudig de publiekrechtelijke rechtssubjecten binnen de rechtspersoon als uitgangspunt te nemen en niet alleen maar de civielrechtelijke rechtssubjectiviteit (de rechtspersoonlijkheid). Het zijn immers deze publiekrechtelijke organisaties (bestuursorganen) die men wil sturen en wiens gedrag men strafrechtelijk moet beoordelen. Toegepast op de RUG-casus betekent dit dat de 'beschikkingskloof' tussen de organen van de rechtspersonen en de organen van de betrokken faculteit geen probleem hoeft te zijn indien men aanvaardt dat het daderschap kan worden geformuleerd aan de hand van de sub-organisatie, die om puur buitenstrafrechtelijke redenen weliswaar geen eigen rechtspersoonlijkheid heeft, maar binnen de interne organisatie van de rechtspersoon niettemin een autonome, duidelijk afgebakende positie inneemt. We komen hier later op de terug bij de bespreking van het daderschap van de staat. Het is immers met name bij de rechtspersoon 'de staat' dat er zich daderschapsproblemen zullen voordoen ten gevolge van de grootte en de complexiteit van de organisatorische structuur van deze rechtspersoon.

\section{§6. Daderschap bij concrete gevaarzettingsdelicten}

\section{A. Het Falen VAN DE ARTIKELEN 173A EN 173B SR}

Naast abstracte gevaarzettingsdelicten kent het milieustrafrecht ook concrete gevaarzettingsdelicten. Kenmerkend voor deze categorie van milieudelicten is dat op enigerlei wijze wordt vereist dat er sprake is van een emissie die een concreet gevaar vormt voor het beschermde (ecologische) rechtsgoed. ${ }^{1067}$ Is bij abstracte gevaarzettingsdelicten vooral het schenden van administratieve voorschriften strafbaar gesteld, dan zijn concrete gevaarzettingsdelicten meer gericht op de bestraffing van concrete gevaarzettingen die door bepaalde

1065. Zie hoofdstuk IV over het subjectcriterium.

1066. Vgl. Van Strien, A.L.J., o.c., 1996, 40-42.

1067. Waling, C., o.c., 1990, 23; Hendriks, L.E.M. en Wöretshofer, J., o.c., 1995, 38. Faure, M. en Visser, M., o.c., 1999, 227-228. 
gedragingen worden veroorzaakt. Voor strafbaarheid is in beginsel geen schending van een administratief voorschrift vereist, bijvoorbeeld de overtreding van een vergunningsvoorwaarde, maar de naleving van deze administratieve voorschriften sluit over het algemeen de strafbaarheid wel uit. ${ }^{1068}$

De in het Nederlandse milieustrafrecht bekendste voorbeelden van concrete gevaarzettingsdelicten zijn, zoals gezien, de artikelen 173a en 173b Sr. Artikel 173a Sr luidt als volgt:

'Hij die opzettelijk en wederrechtelijk een stof op of in de bodem, in de lucht of in het oppervlaktewater brengt, wordt gestraft:

1. met een gevangenisstraf van ten hoogste twaalf jaren of een geldboete van de vijfde categorie, indien de schuldige weet of ernstige reden heeft om te vermoeden, dat daarvan gevaar voor de openbare gezondheid of levensgevaar te duchten is;

2. met gevangenisstraf van ten hoogste vijftien jaren of een geldboete van de vijfde categorie, indien de schuldige weet of ernstige reden heeft om te vermoeden dat daarvan levensgevaar te duchten is en het feit iemands dood tot gevolg heeft.'

Artikel 173b is de culpose variant. Reeds bij het lezen van deze bepalingen wordt duidelijk hoe ingewikkeld de delictsbestanddelen zijn geformuleerd. Het hoeft niet te verbazen dat in de literatuur kritiek is geuit op de redactie van deze strafbepalingen ${ }^{1069}$ Deze kritiek wordt trouwens bevestigd door het feit dat zij door het OM nauwelijks worden gebruikt. ${ }^{1070} \mathrm{De}$ eis dat sprake moet zijn van een bepaalde emissie is tamelijk evident. De kritiek richt zich dan ook voornamelijk op het uitgangspunt dat niet de ecologische rechtsgoederen worden beschermd, maar de menselijke gezondheid, ${ }^{1071}$ en dat de cumulatieve voorwaarden waaraan moet zijn voldaan uiterst lastig te bewijzen zijn: de schuldige moet immers weten of ernstige reden hebben om te vermoeden dat van die emissie een gevaar voor de openbare gezondheid of levensgevaar van een ander te duchten is. ${ }^{1072}$ Het bewijs van het objectieve gevaar voor de openbare gezondheid speelde een nefaste rol in de bekende zaak tegen Tanker Cleaning Rotterdam (TCR). De leidinggevenden van dit afvalverwerkingsbedrijf werden onder meer voor overtreding van artikel 173a Sr vervolgd, maar het Hof sprak hen hiervan vrij omdat het gevaar voor de openbare gezondheid niet bewezen werd geacht. ${ }^{1073}$

1068. Faure, M. en Visser, M., o.c., 1999, 228. Zie reeds hoofdstuk II.

1069. Zie o.m. Waling, C., o.c., 1990, 25-57; Buiting, Th.J.B. en Huygen, A.E.H., 'Milieustrafrecht: een ondoor-dachte chaos', in Van Buuren, P.J.J, Betlem, G. en Ylstra, T. (red.), o.c., 1990, 72-95; Koopmans, I.M., 'Zeven jaar milieustrafrecht in Nederland: een evaluatie', DD, 1996, 352-356; Faure, M. en Visser, M., o.c., 1999, 227-280 i.h.b. 268-273.

1070. Zie o.m. Van den Berg, E.A.I.M. en Eshuis, R.J.J., o.c., 1996, 87-95.

1071. Zie hierover o.m. Waling, C., o.c., 1990, 15; Koopmans, L.M., l.c., 1997, 352-353 en Faure, M. en Visser, M., o.c., 1999, 232.

1072. Zie hierover Faure, M. en Visser, M., o.c., 1999, 268-272.

1073. Hof 's-Gravenhage, 17 april 1996, $N J$ 1996, 574 (TCR-zaak). Zie ook de daaraan voorafgaande uitspraak van de rechtbank Rotterdam: Rb. Rotterdam, 13 oktober 1995, MenR 1996, nr. 24, met noot De Lange, A; zie ook De Lange, A., 'Herijking van het milieu-strafrecht', in Aalders, M.V.C. en Van Grieken, D. (red.), Bestuursrechtelijke en strafrechtelijke handhaving van het 
Daarnaast wordt het bestanddeel wederrechtelijk zeer administratief afhankelijk uitgelegd als in strijd met een vergunning. Zolang er geen administratieve voorschriften overtreden zijn, is er geen sprake van een wederrechtelijke emissie. ${ }^{1074}$ De macht van de administratieve overheden in termen van invulling van de strafbaarheid is hier dus vrijwel even groot als bij de abstracte gevaarzettingsdelicten. Het is hier niet de plaats om op dit onderdeel van de artikelen 173a en $173 \mathrm{~b} \mathrm{Sr}$ nader in te gaan. ${ }^{1075}$ Terloops kan wel worden aangestipt dat vanwege de vergunningafhankelijke (Verwaltungsaktsakzessorische) invulling van de wederrechtelijkheid, zich allerlei problemen kunnen voordoen. Zo zijn emissies die een gevaar kunnen vormen voor de gezondheid niet langer strafbaar wanneer ze vergunningconform plaatsvinden, wat onder meer de vraag doet rijzen in welke mate wederrechtelijke vergunningen de strafbaarheid kunnen uitsluiten en of de strafrechter in staat is dergelijke vergunningen onverbindend te verklaren zodat de vergunninghouder zich niet langer op deze vergunningen kan beroepen. Zoals reeds in de inleiding tot deze studie werd uiteengezet, worden deze nadelen in de (Duitse) literatuur zelfs aangegrepen als argumenten voor een strafrechtelijke aansprakelijkheid van vergunningverlenende instanties wanneer zij door onzorgvuldige vergunningverlening meewerken aan milieuverstoring, in het bijzonder wanneer daarvan gevaar voor de menselijke gezondheid te duchten is.

Wat ons nu voornamelijk interesseert, is de vraag in welke mate rechtspersonen, in het bijzonder overheden, dader kunnen zijn van deze delicten. Tegelijk moet wel opnieuw worden benadrukt dat deze delicten nauwelijks praktische waarde hebben en het hiernavolgende voornamelijk een theoretische exercitie is.

In de eerste plaats kan worden opgemerkt dat de artikelen 173a en 173b $\mathrm{Sr}$ minder functioneel zijn getint dan de abstracte gevaarzettingsdelicten, hetgeen noopt tot meer aandacht aan het schuldvereiste. Toch zal het functionele karakter van het delict telkens per geval moeten worden bepaald aan de hand van de feiten, die aan de emissie ten grondslag hebben gelegen. Doorslaggevend is de band tussen de verboden gedraging en de functie die de rechtspersoon ten tijde van de gedraging heeft waargenomen. Anders gezegd, de mate waarin bij het plegen van het delict de rechtspersoon als (een voor het leefmilieu gevaarlijke) functionaris is opgetreden determineert het functionele karakter van deze strafbepalingen. Is bijvoorbeeld door een slecht onderhouden gemeentelijke zuiverings-

milieurecht, 1996, 71-83. De TCR-zaak doet ook nog andere milieustrafrechtelijke vragen rijzen, bijvoorbeeld naar de inhoud van het begrip wederrechtelijkheid en de verantwoordelijkheid van de vergunning-verlenende instanties, waar we in hoofdstuk VII op terug zullen komen.

1074. Dat blijkt duidelijk uit de parlementaire voorbereiding: 'Handelt iemand in overeenstemming met zo een vergunning, dan is dit niet wederrechtelijk, [...] Het is billijk dat degeen die handelt in overeen-stemming met de voorschriften die de milieu-autoriteiten in zijn concreet geval hebben gegeven, zich niet daarnaast zorgen hoeft te maken dat hij mogelijk in aanraking zal komen met de strafrechter. De overheid tone tegenover de burger één gelaat. Het kan niet zo zijn wat de milieu-autoriteiten toestaan langs strafrechtelijke weg wordt verboden.' MvT, TK 1984-85, $19020, \mathrm{nr} .103,13$.

1075. Dat gebeurt in hoofdstuk VII waar de problematiek van de wederrechtelijke vergunningverlening wordt besproken. 
installatie sterk verontreinigd afvalwater in het oppervlaktewater terechtgekomen of is er sprake van een illegale gemeentelijk stortplaats dan treedt de gemeente hier duidelijk als leefmilieugevaarlijke functionaris op en kan in beginsel minder streng naar het schuldvereiste worden gekeken dan in situaties waar de gemeente als het ware minder functioneel optreedt. Dat lijkt mij bijvoorbeeld het geval wanneer op het plantsoen van een gemeentelijke bibliotheek de tuinman gebruik maakt van giftige bestrijdingsmiddelen. ${ }^{1076}$ Dat betekent niet dat de gemeente in zo'n situatie niet als strafbare pleger in aanmerking zou kunnen komen, maar wel dat meer indringend naar het schuldvereiste zal moeten worden gekeken dan in de eerste gevallen.

Wat natuurlijk opvalt is dat de artikelen 173a en 173b $\mathrm{Sr}$ in hun delictsomschrijvingen bijzondere subjectieve bestanddelen kennen. In de eerste plaats dient de emissie culpoos of doleus te zijn (B en C). In de tweede plaats is slechts sprake van een strafbaar feit indien de schuldige weet of ernstige reden heeft om te vermoeden dat van de (opzettelijke of culpose) emissie gevaar voor de openbare gezondheid of levensgevaar voor een ander te duchten was (D).

\section{B. CULPOSE EMISSIES}

Legt het $\mathrm{OM}$ aan een rechtspersoon artikel $173 \mathrm{~b} \mathrm{Sr}$ ten laste dan dient idealiter in het daderschap de vereiste culpa te worden verdisconteerd. Het daderschap dient zodanig te worden geformuleerd dat duidelijk wordt dat de rechtspersoon als zodanig uit onachtzaamheid (dus culpoos) een stof op of in de bodem, in de lucht of in het oppervlaktewater heeft gebracht. Het OM zal, anders dan bij de abstracte gevaarzettingsovertredingen, die geen culpa als bestanddeel kennen, deze onachtzaamheid moeten bewijzen. Bij de abstracte gevaarzettingsovertredingen speelt 'schuld' slechts een rol als element van het delict: schuld wordt vermoed aanwezig te zijn door de materiële wetsinbreuk (het materiële feit) en zal slechts bij een mogelijk schuldverweer (a.v.a.s.) ter discussie komen. We hebben gezien dat om die reden sterk geobjectiveerde daderschapscriteria, zoals de bedrijfspolitiek, kunnen volstaan onder de voorwaarde dat de rechtspersoon steeds strafprocessueel de gelegenheid moet krijgen het schuldvermoeden te weerleggen. Bij artikel 173b Sr daarentegen is schuld niet slechts element maar bestanddeel (culpa) en moet het derhalve expliciet bij het bewijs aan de orde komen. Daarbij verdient aantekening dat culpa als dusdanig in de strafrechtspraktijk een sterk geobjectiveerde schuldvorm is. Er wordt uitgegaan van een geabstraheerde criteriumfiguur, de normale burger die als maatstaf in vergelijkbare omstandigheden als waarin de verdachte was geplaatst, wordt geobjectiveerd. ${ }^{1077}$ Hoe kan nu culpa in de rechtspersoonlijke daderschapsfiguur behoorlijk tot zijn recht komen?

Er dienen zich verschillende mogelijkheden aan. Zo kan men culpa psychologisch opvatten en als vertrekpunt nemen dat culpa in hoofde van de rechtspersoon aanwezig is, indien bepaalde natuurlijke personen onvoorzichtig hebben gehandeld. Maar zoals gezien, kleven

1076. Vgl. Van Strien, A.L.J., l.c., 1991, 276.

1077. Vgl. Kristen, F.G.H., Borgers, M.J. en Koopmans, I.M., 'Schuld in het strafrecht', in Borgers, M.J., Koopmans, I.M. en Kristen, F.G.H. (red.), o.c., 1998, 25-26. 
aan deze benadering verschillende bezwaren. In de eerste plaats is het niet wenselijk om bij rechtspersonen de voorkeur te geven aan een psychologische invulling van culpa. In de tweede plaats dekt culpa in hoofde van natuurlijke personen niet automatisch culpa in hoofde van de organisatie. Het is steeds denkbaar dat een individuele functionaris onachtzaam handelt, maar dat de organisatie als geheel zelf geen onachtzaamheid kan worden verweten. Voor rechtspersonen kan daarom beter worden gekeken of deze niet organisatorisch bepaalde zorgplichten hebben geschonden. Van belang daarbij is evenwel dat ook via de zorgplichtenbenadering de organisatie als vertrekpunt moet worden genomen en dat niet slechts naar een of meer natuurlijke personen wordt gekeken. Het is immers mogelijk dat individuen binnen de rechtspersonen zorgvuldigheidsnormen hebben geschonden - en derhalve culpoos hebben gehandeld - maar dat impliceert nog niet dat de rechtspersoon zelf een zorgvuldigheidsnorm heeft geschonden. De rechtspersoon en de daarin werkzame natuurlijke personen hebben immers hun eigen verantwoordelijkheidssfeer. Een voorbeeld kan dit verduidelijken. Stel dat een ondergeschikte ambtenaar binnen een gemeente in strijd met expliciete instructies op een zodanige wijze met gevaarlijke stoffen omgaat dat hierdoor een schadelijke emissie ontstaat, zoals in het bovengeschetste voorbeeld van de tuinman die giftige bestrijdingsmiddelen gebruikt. Wie heeft nu schuld (in de zin van culpa) aan de gedraging? Het antwoord op deze vraag hangt niet slechts af van de concrete feitenconstellatie die aan de gedraging ten grondslag ligt, maar tevens van de zorgvuldigheidsnorm die de strafrechter zal hanteren. Zo kan men verdedigen dat op de rechtspersoon, ondanks het bestaan van uitdrukkelijke instructies, nog steeds een zorgplicht rust een behoorlijke controle op de activiteiten van zijn ondergeschikten uit te voeren. Aan de andere kant kan worden betoogd dat er op de 'redelijke en voorzichtige' ondergeschikte nog steeds een zorgplicht bestaat zich aan de instructies te houden. En indien dit om een of andere reden onmogelijk mocht zijn, kan worden gesteld dat op hem nog steeds een zorgplicht rust de leiding hiervan op de hoogte te brengen. Het is dus duidelijk dat voor de organisatie als geheel en de natuurlijke persoon afzonderlijk andere zorgvuldigheidsnormen kunnen gelden: zij hebben immers hun eigen verantwoordelijkheidssfeer. De vaststelling van culpa in hoofde van de rechtspersoon dient daarom in de eerste plaats niet slechts van de schending van een zorgplicht door een natuurlijke persoon te worden afgeleid. Dat kan een indicatie opleveren dat ook de rechtspersoon onachtzaam is geweest, maar vanzelfsprekend is dit niet, vooral niet wanneer deze natuurlijke persoon tot de lagere uitvoerende echelons van de organisatie behoort. Er is dus niets op tegen om de rechtspersoonlijke culpa vast te stellen aan de hand van de schending van een zorgvuldigheidsnorm, mits deze maar op de organisatie als geheel wordt toegepast en bijgevolg wordt aangetoond dat de schending daarvan inderdaad kan worden toegeschreven aan de organisatie als geheel.

Een mogelijk bezwaar tegen het gebruik van zorgvuldigheidsplichten blijft dat de culpa-eis te zeer wordt geobjectiveerd. Hoewel een objectivering of normativering van culpa minder bezwaren oplevert dan bij opzet, dient toch bij voorkeur uit het bewijs van de schending van de zorgplicht te blijken dat deze vorm van verwijtbaarheid inderdaad in causaal verband staat met de organisatie. Wil de schuld bewezen kunnen worden, dan moet schuld zijn tenlastegelegd en dient het OM derhalve die feiten en omstandigheden aan te geven, die het oordeel wettigen dat de rechtspersoon uit onachtzaamheid heeft gehandeld. Hier kan het concept van de Betriebsführungsschuld een dogmatische onderbouwing en leidraad 
geven: de schending van de zorgplicht moet het gevolg zijn van het organisatorisch disfunctioneren. De enkele vaststelling dat een zorgvuldigheidsnorm is overtreden volstaat in die zin niet om van culpa te kunnen spreken. Immers, er kunnen zich steeds onverwachte 'ongevallen' voordoen, die zelfs door de best functionerende overheden en ondernemingen niet te vermijden zijn. Dit betekent niet dat bij een incident nooit sprake kan zijn van een culpose gedraging. Het betekent wel dat ook bij een 'incident' naar de mate van organisatorisch falen dient te worden gekeken. Als een ongeval (bijvoorbeeld bij transport van verontreinigd slib of in een zuiveringsinstallatie) mede te wijten is aan een gebrekkige controle, dan kan best sprake zijn van een culpose emissie in de zin van artikel 173b Sr. Daarbij komt ook het functionele karakter van het delict mogelijk weer om de hoek kijken: hoe functioneler de verboden gedraging in een concreet geval, des te makkelijker kan sprake zijn een verwijtbare zorgplichtschending en dus van onachtzaamheid.

\section{DOLeUSE EMISSIES}

Legt het $\mathrm{OM}$ aan een rechtspersoon artikel 173a $\mathrm{Sr}$ ten laste dan zal dit vanzelfsprekend voor de vaststelling van het daderschap van de rechtspersoon zowel materieelrechtelijk als bewijsrechtelijk consequenties moeten hebben. Wat moet worden bewezen in een concreet geval is dat de rechtspersoon opzettelijk een stof op of in de bodem, in de lucht of in het oppervlaktewater heeft gebracht. Er moeten concrete feiten en omstandigheden worden aangevoerd waaruit de organisatorische intentie kan worden afgeleid. De meest simpele situaties zijn natuurlijk die gevallen waar door de verantwoordelijke organen van de rechtspersoon opdracht is gegeven tot de verboden gedraging. Maar dergelijke gevallen zijn niet echt problematisch en kunnen reeds via de orgaanleer of IJzerdraadcriteria worden opgelost. Het bezwaar tegen deze constructies is natuurlijk dat deze niet altijd voldoende rekening houden met de zelfstandige betekenis van collectief verwijtbaar handelen, hetgeen hun toepassingsbereik veelal beperkt tot rechtspersonen met een doorzichtige besluitvorming en organisatiestructuur, zoals kleine ondernemingen en gemeenten. Moeilijker is het om opzet in hoofde van de rechtspersoon vast te stellen wanneer het gaat om complexere organisaties en wanneer organen niet via expliciete besluitvorming rechtstreeks bij de verboden gedragingen betrokken zijn, zoals in de Nijmeegse casus het geval was. Een mogelijke oplossing zou dan zijn het opzet af te leiden uit de schending van zorgvuldigheidsnormen, net zoals bij de culpose variant van dit concrete gevaarzettingsdelict. Het nadeel is dan weer dat zo het opzet te normatief wordt benaderd en de intentie mogelijk op de achtergrond verdwijnt. Zo kan uit de schending van de zorgplicht tot het controleren van bepaalde voor het leefmilieu gevaarlijke activiteiten (bijvoorbeeld het vervoer van giftige stoffen) niet meteen worden geconcludeerd dat de organisatie ook de intentie heeft gehad tot het verrichten van de verboden gedraging (de emissie). Het is zelfs denkbaar dat een ondergeschikte wetens en willens, dus opzettelijk, de norm schendt, maar daaruit blijkt nog niet dat de rechtspersoon als geheel opzettelijk heeft gehandeld. Wat nog moet worden vastgesteld in hoofde van de organisatie zelf is een intentionele band tussen de schending van de zorgplicht en de verboden gedraging.

Een mogelijke uitweg kan dan opnieuw worden gevonden in de figuur van de 'Betriebsführungsschuld', die als de 'Lebensführungsschuld' van de organisatie kan worden aange- 
merkt. Wat het OM zal moeten bewijzen is dat er tussen de emissie en de bedrijfsvoeringscultuur een zodanige relatie bestaat dat kan worden gesproken van opzet in hoofde van de organisatie als geheel. Uit bewijsmiddelen moet dan blijken dat bepaalde beslissingspatronen en/of reeksen van praktijken op zodanige wijze aan de verboden gedraging ten grondslag liggen dat kan worden gesteld dat de organisatie als geheel deze gedraging heeft 'gewild'. Zo zal bijvoorbeeld sprake moeten zijn van het stelselmatig nalaten van controles op voor het leefmilieu gevaarzettende activiteiten (zoals stortplaatsen en zuiveringsinstallaties) of het bestaan van dubbelzinnige instructies die formeel weliswaar eisen dat ondergeschikten de wet naleven, maar waarbij in de praktijk niet de (financiële of personele) middelen zijn gecreëerd die hen in staat zouden moeten stellen daadwerkelijk normconform te handelen. Doorslaggevend voor het corporatief opzet is dat sprake moet zijn van een zeker structureel en duarzaam disfunctioneren van de organisatie waaruit blijkt dat de gevolgen (de schadelijke emissies) indien niet gewild dan toch op de koop toe worden genomen. Aldus kan men het onderscheid bewaken tussen culpoos en doleus handelen. Zo kunnen emissies die het gevolg zijn van een eenmalig ongeval in beginsel niet als een opzettelijk emissie worden aangemerkt. ${ }^{1078}$ De culpose variant is dan meer op zijn plaats.

Andere factoren die bij de vaststelling van het organisatorische opzet, als onderscheiden van organisatorische culpa, van belang kunnen zijn, vormen de motieven en de doelstellingen die bij het verrichten van de strafbare gedraging een rol hebben gespeeld. Klassiek strafrechtelijk gezien spelen de motieven in hoofde van de dader in beginsel nauwelijks een rol voor zijn strafbaarheid al was het maar omdat men deze moeilijk kan vaststellen. Het typische van organisaties is echter dat motieven en onoirbare doelstellingen, kortom de Lebensführungssschuld, veel makkelijker en ook objectiever dan bij natuurlijke personen kunnen worden vastgesteld. Door het ondervragen van getuigen, personeelsleden en leidinggevenden alsook een onderzoek naar de houding binnen de organisatie tegenover de verboden gedragingen, kan vrij eenvoudig de corporatieve intentie tot het milieuverstorende gedrag worden vastgesteld. Zo kan in termen van Betriebsführungsschuld worden geconcludeerd dat bijvoorbeeld bij de vuile grond-affaire in de gemeente Nijmegen wel degelijk opzet aanwezig was. Binnen de gemeentelijke organisatie was sprake van een zodanig structureel, systematisch falen en disfunctioneren dat van opzet kan worden gesproken. Met enige moeite zou men zelfs zonder het concept van de bedrijfsvoeringssschuld in klassieke strafrechtelijke zin nog van opzet, in de zin van voorwaardelijk opzet, kunnen spreken. Kan immers niet op basis van de feiten in de vuile grond-affaire worden volgehouden dat uit het geheel van beslissingen, praktijken en gedragingen binnen de organisatie voortvloeit dat de gemeente als geheel zich willens en wetens heeft blootgesteld aan een geenszins als denkbeeldig te verwaarlozen kans dat de verboden gedragingen plaats vinden? ${ }^{1079}$

1078. Dat laat onverlet dat een ongeval met (voorwaardelijk) opzet door een werknemer kan zijn veroorzaakt. Maar dat impliceert nog geen opzet bij de organisatie.

1079. Zie over voorwaardelijk opzet o.m. Van Bemmelen, J.M. en Van Veen, o.c., 1998, 87-91. 
Een belangrijke vereiste voor strafbaarheid bij de artikelen 173a en 173b Sr zijn de bestanddelen die eisen dat de dader weet of ernstige reden heeft om te vermoeden dat van de (culpose of doleuse) emissie gevaar voor de openbare gezondheid of levensgevaar voor een ander te duchten was. Dit is wellicht dé achilleshiel van deze strafbepalingen. ${ }^{1080}$ Dit onderdeel van de delictsomschrijving is een combinatie van zowel objectieve als subjectieve bestanddelen. Wat opvalt is dat bij andere delicten uit titel VII Sr het ontstaan of het te duchten zijn van het gevaar is geobjectiveerd. Voor strafbaarheid is niet vereist dat de dader met het gevaar bekend was of dat had moeten vermoeden. In de artikelen 173a en $173 \mathrm{~b} \mathrm{Sr}$ is de objectieve voorwaarde dat van de emissie gevaar moet te duchten zijn, gekoppeld aan de subjectieve voorwaarde dat de dader dit gevaar kende of in ieder geval ernstige redenen heeft gehad om dit te vermoeden. Door deze koppeling is de effectiviteit van deze bepaling zeer beperkt. ${ }^{1081}$

Wat de objectieve voorwaarde betreft, wordt geëist dat voor strafbaarheid noodzakelijk is dat er gevaar voor de gezondheid van mensen te duchten is. Daadwerkelijk opgetreden gezondheidsschade is niet vereist: het gaat hier immers om een concreet gevaarzettingsdelict en niet om een krenkingsdelict. Of er gevaar is voor de openbare gezondheid moet volgens objectieve maatstaven, dat wil zeggen naar algemene ervaringsregels, worden vastgesteld. ${ }^{1082}$ Daarvoor moet aansluiting worden gezocht bij de stand van wetenschap en techniek. Op basis van wat in de wetenschap ten tijde van het plegen van het delict bekend is, dient het objectief te duchten gevaar van de emissie voor de menselijke(!) gezondheid te worden beoordeeld. ${ }^{1083}$ Bovendien dient dit gevaar aanwezig te zijn op het moment van de emissie en onder de omstandigheden waaronder deze heeft plaatsgevonden. Er zijn dus heel wat bewijsrechtelijke obstakels. ${ }^{1084}$

Nog problematischer zijn de subjectieve bestanddelen. De wetgever heeft hier zowel het doleuse 'weten' als het culpose 'ernstige reden hebben om te vermoeden' als alternatieven in de delictsomschrijving opgenomen. Opvallend is wel dat de strafbedreiging in beide gevallen dezelfde is, terwijl toch kan worden verdedigd dat ingeval van wetenschap aan de dader een ernstiger verwijt kan worden gemaakt en dus ook een hogere straf op zijn plaats is, in het bijzonder wanneer de schadelijke emissie zelf ook nog opzettelijk is gepleegd. ${ }^{1085}$ Het is

1080. Vgl. Faure, M. en Visser, M., o.c., 1999, 245-250.

1081. Vgl. Hendriks, L.E.M. en Wöretshofer, J., o.c., 1995, 42-43; Waling, C., 0.c., 1990, 28; Koopmans, I.M., o.c., 1996, 272-273; Faure, M. en Visser, M., o.c., 1999, 245.

1082. Koopmans, I.M., o.c., 1996, 172.

1083. Waling, C., o.c., 1990, 22; Hendriks, L.E.M. en Wöretshofer, J., o.c., 1995, 41.

1084. Zie bijvoorbeeld Rb. Rotterdam 6 mei 1993, MenR 1994, 49. In deze zaak waarbij voor de ontsmetting van grond een te hoge dosering methylbromide werd gebruikt werd geoordeeld dat het te duchten gevaar onder de omstandigheden van het moment van de emissie niet aanwezig was. Dat dit gevaar, zoals door het OM werd betoogd, wel had kunnen ontstaan door een verandering in (weers)omstandigheden doet hier niet aan af. Zie tevens Hendriks, L.E.M. en Wóretshofer, J., o.c., 1995, 42.

1085. Vgl. Faure, M. en Visser, M., o.c., 1999, 246. 
dus maar de vraag of het OM ooit tot de vervolging van de opzettelijke variant van 'weten' zal willen overgaan. De andere bestanddelen zijn qua bewijs al moeilijk genoeg.

Of het $\mathrm{OM}$ nu overtreding van artikel 173a Sr of van artikel 173b $\mathrm{Sr}$ tenlastelegt, deze subjectieve bestanddelen zullen telkens moeten worden bewezen. Volgens Waling dient het OM te bewijzen dat de dader het potentieel gevaarlijke karakter van de stof kende, of althans ernstige reden heeft gehad om dit te vermoeden. ${ }^{1086}$ Hendriks daarentegen betoogt dat de wetenschap of het vermoeden van het potentieel gevaar van de stof niet volstaat. De tekst van de delictsomschrijving geeft duidelijk aan dat de subjectieve bestanddelen betrekking hebben op het te duchten gevaar van de emissie, het brengen van de stof in de leefmilieucomponenten. ${ }^{1087}$ Met andere woorden, er moet worden bewezen dat de dader wist of ernstige reden had om te vermoeden dat de emissie gevaarlijk was voor de openbare gezondheid. Dit blijft een lastige opgave, ook wanneer de dader een rechtspersoon is. Laten we ons gemakkelijkheidhalve beperken tot de culpose variant, het 'ernstige reden hebben om te vermoeden'. Voor de strafmaat maakt dit immers geen verschil. Hoe moet dit vermoeden nu in hoofde van een organisatie worden aangetoond? Een belangrijk punt is dat moet worden gekeken naar de functie van de dader ten tijde van het plegen van het delict; in welke (beroeps)hoedanigheid pleegde de dader het delict. ${ }^{1088}$ Dit is begrijpelijk omdat de mate van bewustheid van het gevaar afhankelijk is van de mate van deskundigheid en dat is weer afhankelijk van de kwaliteit of functie waarin de dader optreedt. Reeds werd opgemerkt dat voor het schuldvereiste van de artikelen 173a en 173b Sr -en voor het milieustrafrecht als geheel- de functionele aard van het delict van groot belang is: hoe functioneler de gedraging en de dader des te eerder kan sprake zijn van schuld. In die zin kan zelfs worden verdedigd, dat de vaststelling van dit subjectieve bestanddeel zelfs eenvoudiger is bij rechtspersonen dan bij natuurlijke personen. Rechtspersonen (bedrijven, gemeenten, etc...) kunnen doorgaans eerder als voor het leefmilieu risicovolle functionarissen worden aangemerkt en derhalve kan van hen ook vanwege hun maatschappelijke functie verwacht worden dat zij ter zake over de vereiste deskundigheid beschikken om het gevaar van hun activiteiten in te schatten. In de regel kan daarom bij rechtspersonen worden volstaan met een normatieve benadering van het 'ernstige reden hebben om te vermoeden': houdt de organisatie zich binnen de bedrijfsvoering met gevaarlijk stoffen bezig, dan kan daaruit in beginsel worden afgeleid dat binnen de organisatie ingeval van emissie een ernstig vermoeden aanwezig is van het te duchten gevaar van dergelijke emissies. Niettemin dient deze veronderstelling geval per geval bewaarheid te worden, want een voor de openbare gezondheid gevaarlijke emissie kan natuurlijk ook door rechtspersonen worden veroorzaakt die op dit vlak als minder deskundig kunnen worden beschouwd. Dan heeft het gepleegde delict een minder functioneel karakter en kan men zich voorstellen dat aan het bewijs van dit subjectief bestanddeel strengere eisen moeten worden gesteld.

1086. Waling, C., o.c., 1990, 49-59.

1087 Hendriks, L.E.M., Techniek en normstelling in het milieustrafrecht. Een rechtsvergelijkende studie naar de strafrechtelijke handhaving van emissievoorschriften, Zwolle, W.E.J. Tjeenk Willink, 1994, 95-98; Hendriks, L.E.M. en Wöretshofer, J., o.c., 1995, 43. Zie ook Koopmans, I.M., o.c., 1996, 273.

1088. Hendriks, L.E.M. en Wöretshofer, J., o.c., 1995, 43-44. 


\section{§ 7. Daderschap bij zorgplichtbepalingen}

\section{A. AlgemeEN}

Naast de abstracte en concrete gevaarzettingsdelicten is er nog een andere categorie strafrechtelijk handhaafbare bepalingen te vinden in de bijzondere milieuwetgeving. Het betreft de zorgplichtbepalingen. Het gebruik van (strafbaar gestelde) zorgplichtbepalingen is in Nederland zeer populair ${ }^{1089}$. Zorgplichtbepalingen kunnen worden omschreven als: 'een vrij algemeen geformuleerde, tot de burger gerichte (zorg)verplichting die een bepaalde verantwoordelijkheid van de burger markeert en waarvan het de bedoeling is deze juridisch te handhaven. Een zorgplicht bevat een algemene verplichting tot het in acht nemen van een bepaalde graad van zorgvuldigheid met het oog op het door de desbetreffende wet te beschermen belang, en kan zowel betrekking hebben op een handelen als een nalaten van het normadressaat. De wetstechnische vormgeving van een zorgplichtbepaling kan verschillen; het kan gaan om een gebod (een positief geformuleerde verplichting), of om een verbod. De handhaving van de norm kan langs bestuurlijke, strafrechtelijke of privaatrechtelijke weg geschieden, of zelfs via een combinatie van deze methoden. ${ }^{1090}$

Een typisch voorbeeld van een zorgplichtbepaling is artikel 13 Wet Bodembescherming:

'Ieder die op of in de bodem handelingen verricht als bedoeld in de artikelen 6 tot en met 11 en die weet of redelijkerwijs had kunnen vermoeden dat door die handelingen de bodem kan worden verontreinigd of aangetast, is verplicht alle maatregelen te nemen die redelijkerwijs van hem kunnen worden gevergd, teneinde die verontreiniging of aantasting te voorkomen, dan wel indien die verontreiniging of aantasting zich voordoet, de bodem te saneren of de aantasting en de directe gevolgen daarvan te beperken en zoveel mogelijk ongedaan te maken. Indien de verontreiniging of aantasting het gevolg is van een ongewoon voorval, worden de maatregelen onverwijld genomen.'

Reeds bij het lezen van deze bepaling blijkt dat in feite meer dan éen zorgplicht is neergelegd. In de eerste plaats bestaat er de plicht tot het nemen van alle maatregelen die redelijkerwijs van de dader kunnen worden gevergd teneinde de verontreiniging te voorkomen. In de tweede plaats is er de plicht om bij opgetreden verontreiniging de bodem te saneren of de aantasting en de directe gevolgen daarvan te beperken en ongedaan te maken.

1089. Hendriks, L.E.M. en Wöretshofer, J., o.c., 1995, 85-87; Visser, M., 'Strafrechtelijke zorgplichtbepalingen over de grens? De strafrechtelijke afdwingbaarheid van milieuzorgplichtbepalingen in België en Nederland', in Faure, M. en Deketelaere, K. (red.), o.c., 1997, 203-242.

1090. Commissie Toetsing van Wetgevingsprojecten, Advies van de Commissie voor de Toetsing van Wetgevingsprojecten inzake zorgplichtbepalingen, CTW 90/6, 20 augustus 1990, 3. Zie tevens Faure, M. en Visser, M., l.c., 1997, 132-133. 
In de derde plaats is er de plicht, indien de verontreiniging het gevolg is van een ongewoon voorval, de in de eerste en tweede plicht gevergde maatregelen onverwijld te nemen. ${ }^{1091}$

Ook in andere bijzondere milieuwetten komen geregeld (strafbaar gestelde) zorgplichtbepalingen voor. ${ }^{1092}$ Daarnaast worden zelfs in vergunningen zorgplichtbepalingen neergelegd. ${ }^{1093}$

Het is duidelijk dat de delictsomschrijving van deze categorie van milieudelicten zeer vaag is omschreven. Wat hier eigenlijk is strafbaar gesteld, zijn zorgplichten die we tot nu toe voornamelijk zijn tegengekomen in het licht van mogelijk toepasbare daderschapscriteria. Zo hebben we bij de bespreking van het daderschap bij abstracte en concrete gevaarzettingsdelicten vastgesteld, dat een mogelijke benadering om tot (bewijs van) daderschap te komen, bestaat in de vaststelling dat de organisatie bepaalde zorgvuldigheidsnormen niet heeft nageleefd. Tevens is geconcludeerd dat aan zo'n vrij normatieve benadering verschillende bezwaren kleven. Welnu, hier zien we dat de bijzondere wetgever de schending van dergelijke zorgplichten rechtstreeks heeft strafbaar gesteld.

Vanuit de bekende klassieke strafrechtelijke beginselen, zoals het legaliteitsbeginsel en het lex certa-vereiste, kan terecht kritiek worden geleverd op de strafbaarstelling van deze vage normen. ${ }^{1094} \mathrm{Er}$ zijn door de bijzondere wetgever weinig beperkingen gesteld aan de strafrechtelijke aansprakelijkheid. Niettemin zijn deze bepalingen volgens de rechtspraak niet in strijd met het legaliteitsbeginsel. ${ }^{1095}$ Dit is instrumentalisme zonder grenzen. Ter wille van de bescherming van het leefmilieu mogen blijkbaar de klassieke rechtswaarborgen worden opgeofferd. ${ }^{1096}$

Bemerk tevens dat deze zorgplichten niet automatisch als functionele delicten kunnen worden aangemerkt. Zij richten zich tot eenieder en niet slechts tot functionarissen. Bovendien is de norm zo vaag dat niet slechts gedragingen van voor het leefmilieu risicovolle functionarissen (zoals bedrijven) daaronder kunnen vallen, maar iedere gedraging die kan worden beschouwd als potentieel gevaarlijk voor het leefmilieu. ${ }^{1097}$

1091. Zie hierover uitvoerig Visser, M., 'Uitholling van het schuldbeginsel; in Borgers, M.J., Koopmans, I.M. en Kristen, F.G.H. (red.), o.c., 1998, 68-69.

1092. Zo bijvoorbeeld artikel 13, vierde lid (voorheen derde lid) Bestrijdingsmiddelenwet, artikel 2 Wet Milieugevaarlijke Stoffen en artikel 10.3 van de Wet Milieubeheer, hoofdstuk Afvalstoffen. Zie hierover Faure, M. en Visser, M., o.c., 1999, 327-328.

1093. Zie voor voorbeelden Visser, M., l.c., 1997, 209-210.

1094. Zie voor een kritische evaluatie van zorgplichtbepalingen vanuit het oogpunt van de klassieke strafrechtsbeginselen Visser, M., l.c., 1997, 216-236; Faure, M. en Visser, M., o.c., 1999, 339 357.

1095. Zie o.m. Rb. Amsterdam 5 januari 1993, TMA 1993, 77-83, met noot Faure, M. (Cindu).

1096. Zie over de gevaren van doorgedreven instrumentalistische tendensen in het milieustrafrecht Roef, D., 'Strafrecht versus leefmilieu: van geschiktheid naar ondergeschiktheid', TMR, 1995, 466-476; Roef, D., 'Zoektocht naar een meer-zinnige betekenis van het strafrecht voor het leefmilieu', in Gutwirth, S. en Van Maanen, G., De natuur van het milieurecht, Nijmegen, Ars Aequi Libri, 1995, 160-190.

1097. Vgl. Faure, M. en Visser, M., o.c., 1999, 342. 
Zorgplichtbepalingen zijn ook een enkele keer gebruikt in gevallen waar overheden werden vervolgd. Het bekendste voorbeeld is de Volkel-zaak. In deze zaak werd de staat vervolgd wegens overtreding van artikel 14 (huidig artikel 13) Wet Bodembescherming. De rechtbank 's-Hertogenbosch verklaarde het OM ontvankelijk in zijn vervolging, kwam tot een bewezenverklaring en verklaarde de staat schuldig zonder strafoplegging. Zoals bekend, oordeelde de Hoge Raad hier anders over. ${ }^{1098}$

Bekijken we de zorgplichtbepalingen in het licht van het schuldvereiste, dan zien we dat meestal bijzondere subjectieve delictsbestanddelen zijn geformuleerd (B). ${ }^{1099}$ Daarnaast is van belang dat de zorgplichtbepalingen, net als de abstracte gevaarzettingsdelicten, onder de WED zijn ondergebracht. Volgens artikel 2 lid 1 WED is er sprake van een misdrijf indien de zorgplichtbepaling opzettelijk is begaan en is er in de andere gevallen sprake van een overtreding (C). Beperken we ons tot de voor de praktijk belangrijkste zorgplichtbepaling, die van artikel $13 \mathrm{Wbb}$, dan komen we voor het (bewijs van) daderschap van de rechtspersoon tot de volgende vaststellingen.

\section{B. DE SUBJECTIEVE BESTANDDELEN IN ARTIKEL 13 WBB (EN VOLKEL)}

In de eerste plaats kent de delictsomschrijving zelf eigen subjectieve bestanddelen. De in artikel $13 \mathrm{Wbb}$ neergelegde schuldvorm betreft 'weet of redelijkerwijs had kunnen vermoeden'. Net als in de artikelen 173a Sr en 173b Sr is hier sprake van zowel een doleus 'weten' als van een culpoos 'redelijkerwijs had kunnen vermoeden. ${ }^{1100}$ Zoals Visser terecht opmerkt zijn hier dus twee feiten onafhankelijk van elkaar strafbaar gesteld. Het betreft een strafbaarstelling van een doleuse gedraging en één van een culpose gedraging. Daar in artikel $13 \mathrm{Wbb}$ drie zorgplichten zijn neergelegd, zijn in deze bepaling uiteindelijk zes afzonderlijke strafbare zorgplichten neergelegd. ${ }^{1101}$ De subjectieve bestanddelen hebben dus betrekking op alle drie de zorgplichten. Van belang is evenwel dat het 'weten' en het 'redelijkerwijs had kunnen vermoeden' niet slaan op het bestanddeel 'Teder die op of in de bodem handelingen verricht als bedoeld in de artikelen 6 tot en met $11(\ldots)^{11102}$

1098. Zie over de vervolgbaarheid van de staat hoofdstuk III.

1099. Hendriks, L.E.M. en Wöretshofer, J., o.c., 1995, 23-29.

1100. Faure, M. en Visser, M., o.c., 1999, 350.

1101. Zie hierover Visser, M., 'Uitholling van het schuldbeginsel' in Borgers, M.J., Koopmans, I.M. en Kristen, F.G.H. (red.), o.c., 1998, 68.

1102. Terloops zij opgemerkt dat deze verwijzing naar de artikelen 6 tot en met 11 van de Wbb, op basis waarvan bij algemene maatregelen van bestuur nadere voorschriften kunnen worden gesteld, niet van groot belang is voor de mogelijkheid om overtreding van de zorgplicht strafrechtelijk te sanctioneren. Men zou met verve kunnen verdedigen dat artikel $13 \mathrm{Wbb}$ als zelfstandige norm te vaag is om strafbaar te kunnen worden gesteld en dat een nadere invulling van de zorgplicht via algemene maatregelen van bestuur is vereist. Met andere woorden, dat slechts strafrechtelijk kan worden opgetreden indien artikel $13 \mathrm{Wbb}$ is overtreden door schending van de nadere voorschriften. De rechtspraak oordeelt echter anders. In de Kabelbrandenzaak oordeelde de Hoge Raad dat artikel 13 (toen nog artikel 14) Wbb ook strafrechtelijk kan worden gehandhaafd zonder dat eerst sprake moet zijn van nader uitgewerkte uitvoeringsmaatregelen van de bestuurlijke overheid. Zie HR 26 oktober 1993, NJ 1994, 99; Hendriks, L.E.M., 'De Hoge Raad en artikel 14 Wbb', MenR 1994, 139-140; Faure, M. en Visser, M., o.c., 1999, 337-338. 
Nu het onderscheid tussen de doleuse en de culpose gedragingen voor de strafmaat geen rol speelt, hoeft het niet te verbazen dat het $\mathrm{OM}$ in de praktijk kan volstaan met het bewijs van de culpose variant. De conclusie in termen van daderschap van de rechtspersoon ligt dan ook voor de hand. Hier geldt een zelfde redenering als bij de artikelen 173a en 173b Sr, namelijk (1) dat het OM deze schuldvorm moet tenlasteleggen en derhalve moet bewijzen en (2) dat deze schuldvorm (culpa) in hoofde van de dader-rechtspersoon vrij normatief kan worden vastgesteld. Maar vanwege de vaagheid van de norm, lijkt het wel aangewezen dat per geval wordt bekeken in welke mate de rechtspersoon ten tijde van het plegen van het delict als functionaris is opgetreden. Kijken we bijvoorbeeld naar de Volkel-zaak, dan kan daar vrij eenvoudig een 'redelijkerwijs had kunnen vermoeden' worden bewezen. Gelet op de feitenconstellatie - er lekte een aanzienlijke hoeveelheid kerosine uit een tank op de vliegbasis Volkel - kan worden verdedigd dat dit plaatsvindt binnen het kader van een activiteit waarvan mag worden verwacht dat de organisatie, die daar rechtstreeks bij betrokken is (i.c. de militaire vliegbasis), beschikt over de nodige deskundigheid teneinde het potentieel gevaar daarvan in te schatten (temeer omdat dit 'incident' al voor de derde keer plaatsvond). Een organisatie die zich bezig houdt met voor de bodem mogelijk schadelijke activiteiten moet over de kennis en dus zeker over een redelijk vermoeden beschikken dat hierdoor de bodem kan worden verontreinigd of aangetast. ${ }^{1103}$ In Duitse termen kan men stellen dat in de Volkel-casus sprake is van een 'Gefahrenquelle' (de tank) die door de vliegbasis moet worden bewaakt: hier rust op de overheid een Sicherungs- of Beherschungspflicht. Met andere woorden, de overheid treedt hier op als een Uberwachungsgarant. ${ }^{1104} \mathrm{De}$ vaststelling van dit subjectieve bestanddeel is dus tamelijk eenvoudig. ${ }^{1105}$ In hoofde van de staat rijst echter wel een ander probleem. Immers, traditioneel moet het daderschap, en dus ook de vereiste subjectieve bestanddelen, in hoofde van de rechtspersoon worden vastgesteld. De rechtspersoon 'de staat' is echter als geheel bekeken een uiterst complexe en grote organisatie. De vraag rijst of schuldvormen, die weliswaar 'in het veld' of in sub-organisaties van 'de staat' kunnen worden vastgesteld, zomaar aan de rechtspersoon als geheel kunnen worden toegerekend. Maar zoals aangekondigd, komt dit probleem afzonderlijk nog aan bod. ${ }^{1106}$

\section{ARTIKEL 13 WBB ALS MISDRUF EN ALS OVERTREDING}

Via de koppeling aan de WED kan de overtreding van artikel $13 \mathrm{Wbb}$ als misdrijf of als overtreding worden tenlastegelegd. Gaat het om een misdrijf dan moet de zorgplicht-

1103. Zie voor toepassingen van de eisen aan 'het redelijkerwijs had kunnen vermoeden' o.m. HR 15 november 1994, MenR 1995, 10k; HR 20 februari 1996, MenR 1997, 62 en Hof Amsterdam 31 januari 1996, MenR 1996, 38k. Beide laatste zaken illustreren evenwel dat inderdaad geval per geval wordt bekeken of de dader 'redelijkerwijs had kunnen vermoeden' dat zijn handelingen de bodem kunnen verontreinigen en dat dit niet steeds zo eenvoudig kan worden bewezen verklaard. Uit deze rechtspraak blijkt tevens dat de functie waarin de dader optreedt een rol speelt. Zie hierover ook Visser, M., l.c., 1998, 70-72.

1104. Zie hierover meer in bijzonder hoofdstuk III.

1105. Wel moet natuurlijk een verweer mogelijk blijven in gevallen waar men zich binnen de organisatie niet bewust was noch behoorde te zijn van de verontreiniging of aantasting.

1106. Zie paragraaf 10 van dit hoofdstuk. 
overtreding opzettelijk zijn begaan. De eerste vraag is op welke bestanddelen de opzetvereiste betrekking heeft, hetgeen natuurlijk ook voor het (bewijs van) het daderschap van belang is. Volgens Visser is het opzet slechts van toepassing op het eerste onderdeel van de delictsomschrijving, namelijk op het bestanddeel 'Teder die op of in de bodem handelingen verricht als bedoeld in de artikelen 6 tot en met $11{ }^{1}{ }^{1107}$ Immers, indien de opzetvereiste ook de andere (subjectieve) bestanddelen zou betreffen, zou een zogenaamde 'schuldkwadratuur' ontstaan. ${ }^{1108}$ Zo zou zich de merkwaardige situatie voordoen dat men 'opzettelijk redelijkerwijs had moeten vermoeden', hetgeen een contradictie in termen is. Een dergelijke tenlastelegging zou duidelijk innerlijk tegenstrijdig zijn.

Gaat men ervan uit dat opzet alleen de kern van het delict betreft, dan dient het daderschap zodanig te zijn geformuleerd dat kan worden aangetoond dat de rechtspersoon opzettelijk op of in de bodem handelingen verricht als bedoeld in de artikelen 6 tot en met 11 en weet of redelijkerwijs had kunnen vermoeden dat door die (opzettelijk verrichte) handelingen de bodem kan worden verontreinigd. Om bij de Volkel-casus te blijven: bewezen moet worden dat de kerosine opzettelijk op de bodem is terechtgekomen. Zelfs los van het probleem dat het hier gaat om de staat is dit geen makkelijke opgave. Reeds bij de bespreking van artikel 173a Sr is gebleken dat, indien men recht wil doen aan zowel het schuldbeginsel als aan de eigen complexe aard van organisaties, het bepaald geen sinecure is opzet in hoofde van de rechtspersoon te omschrijven. Dit geldt des te meer bij artikel $13 \mathrm{Wbb}$ omdat de handelingen waarop het opzet dient te zijn gericht niet nader zijn omschreven. Het lijkt me dan ook moeilijk, tenzij men de opzetvereiste sterk objectiveert, een rechtspersoon te veroordelen voor het opzettelijk overtreden van deze zorgplichtbepaling. Wellicht dat via het concept van de bedrijfsvoeringsschuld op enigerlei wijze (voorwaardelijk) opzet kan worden aangetoond, maar dat moet dan wel bewijsrechtelijk au serieux worden genomen. $\mathrm{Nu}$ de norm op gespannen voet staat met de lex certa-eis acht ik het noodzakelijk dat zowel het $\mathrm{OM}$ als de strafrechter met grote zorgvuldigheid met het schuldvereiste omgaan. Dit betekent dat daadwerkelijk moet worden gekeken naar het rechtspersoonlijk disfunctioneren en niet alleen maar naar het 'behoren te functioneren' van de organisatie. Achteraf gezien is het altijd eenvoudig vast te stellen welke normen zijn geschonden en hoe de rechtspersoon zich had moeten gedragen. Dat kan zelfs vrij detaillistisch in een tenlastelegging worden omschreven. Maar daar gaat het uiteindelijk niet om. Wat ten laste is gelegd dient ook echt bewezen te worden aan de hand van concrete feiten en omstandigheden. Het volstaat geenszins dat de strafrechter naar wat is tenlastegelegd toe redeneert. Zoals Faure en Visser opmerken:

1107. Visser, M., l.c., 1998, 74-75 en de daarin vermelde literatuur. Wel moet worden opgemerkt dat deze kwestie nog niet geheel is uitgekristalliseerd. De interpretatie van Visser lijkt mij logisch en gerechtvaardigd, maar zij is wel in tegenspraak met het beginsel van het commune strafrecht waar het opzet-bestanddeel slaat op alle daarop volgende bestanddelen, derhalve bij artikel 13 Wbb ook op de subjectieve bestanddelen. Zie hierover Buiting, TH.J.B. en Huygen, A.E.H., 'Milieustraf-recht: een ondoordachte chaos', in Van Buuren, P.J.J. e.a. (red), o.c., 1990, 81-82.

1108. Zie hierover Doorenbos, D.R., 'Schuldkwadratuur. Iets over de betekenis van art. 2, eerste lid WED', $D D, 1990,812$. 
'het lex certa-vereiste dat zich richt op het precieze van de delictsomschrijving voordat het gedrag wordt gesteld, mag natuurlijk niet worden verward met de eis dat na het delict een feit in voldoende precieze bewoordingen dient te worden ten laste gelegd. ${ }^{\prime 109}$

Deze in mijn ogen strafrechtelijke vanzelfsprekendheid wordt door sommige auteurs over het hoofd gezien. ${ }^{1110}$

Kortom, men mag eisen dat $\mathrm{OM}$ en strafrechter met een zelfde zorgvuldigheid met zorgplichtbepalingen omgaan als van de samenleving wordt verwacht bij de naleving daarvan.

Kiest het OM voor de overtredingvariant, dan dient deze slechts de subjectieve bestanddelen die in de delictsomschrijving zelf staan vermeld, te bewijzen. Voor het bestanddeel 'Ieder die op of in de bodem handelingen verricht als bedoeld in de artikelen 6 tot en met $11 \ldots$ '.. speelt schuld dus slechts de rol van element en dient schuld dus niet te worden tenlastegelegd en bijgevolg ook niet te worden bewezen. ${ }^{1111}$ In termen van rechtspersoonlijk daderschap volstaat daarom dat de handelingen zijn verricht binnen de normale bedrijfspolitiek of bedrijfsvoering van de organisatie. In de Volkel-casus is dit vrij duidelijk: de verboden handelingen (het lekken van de kerosine) hebben plaatsgevonden binnen de gewone activiteiten van de vliegbasis. Bemerk wel dat op dit punt steeds een schuldverweer moet kunnen worden gevoerd. De rechtspersoon zou bijvoorbeeld kunnen aanvoeren dat sprake is van a.v.a.s.. Gelet op de vaagheid van de zorgvuldigheidsnorm moet idealiter indringender naar dit verweer worden gekeken dan bij de abstracte gevaarzettingsovertredingen. Bij deze laatste categorie van delicten zijn immers meestal precieze voorschriften overtreden, terwijl dit bij artikel $13 \mathrm{Wbb}$ niet het geval is.

\section{§ 8. Het daderschap bij commune delicten}

\section{A. DE DERESPONSABILISERENDE WERKING VAN COMMUNE DELICTEN}

Bij de strafrechtelijke bestrijding van milieuverstoring kan ook gebruik worden gemaakt van commune delicten, die niet zijn gericht op de bescherming van het leefmilieu. ${ }^{112} \mathrm{Zo}$ is het niet ondenkbaar dat bij milieudelicten ook kan worden vervolgd wegens valsheid in geschrifte (artikel $225 \mathrm{Sr}$ ) en dood of lichamelijk letsel door schuld (artikelen 307 en $308 \mathrm{Sr}$ ).

Voornamelijk artikel $225 \mathrm{Sr}$ wordt in Nederland in milieustrafzaken gebruikt. Valsheid in geschrifte is vooral denkbaar bij afvaldelicten. Vaak zal immers bij afvalzwendel op de vereiste documenten, zoals vrachtbrieven, een onjuiste beschrijving van de afvalstoffen zijn

1109. Faure, M. en Visser, M., o.c., 1999, 346.

1110. Zie bijvoorbeeld Hendriks, L.E.M. en Wöretshofer, J., o.c., 1995, 85-88, die blijkbaar niet veel problemen zien in de kenbaarheid van de zorgplichtbepalingen. Zie tevens hoofdstuk II.

1111. De subjectieve bestanddelen van de delictsomschrijvingen dienen natuurlijk wel steeds te worden tenlastegelegd.

1112. Zie hierover Faure, M. en Visser, M., L.c., 1997, 135; Faure, M. en Visser, M., o.c., 1999, 365396. 
gegeven, teneinde te verhullen dat het bijvoorbeeld om giftig afval gaat. Men kan ook denken aan het vervalsen van vergunningen. ${ }^{1113}$ Een bekend voorbeeld waar bij een milieudelict tevens valsheid in geschrifte werd tenlastegelegd is de genoemde TCR-zaak. Opmerkelijk was evenwel dat de betrokkenen - alleen de feitelijk leidinggevenden werden vervolgd - slechts werden veroordeeld voor het overtreden van artikel $225 \mathrm{Sr}$ (en artikel $\left.140 \mathrm{Sr}^{1114}\right)$, terwijl de overtreding van de specifieke milieustrafbepalingen, de artikelen $173 \mathrm{a}$ en $173 \mathrm{~b} \mathrm{Sr}$, niet kon worden bewezen verklaard. Zoals besproken, was dit grotendeels te wijten aan het in deze strafbepalingen neergelegde bestanddeel dat van de emissie gevaar voor de menselijke gezondheid moet te duchten zijn. ${ }^{1115}$

Hoewel in Nederland bij milieustrafzaken nog nooit het veroorzaken van de dood of lichamelijk letsel door schuld is tenlastegelegd, kan men zich die mogelijkheid best voorstellen, mede gelet op het deficit van de artikelen 173a en 173b Sr. Een vervolging van een rechtspersoon op basis van de artikelen 307 e.v. Sr is bijvoorbeeld denkbaar wanneer bepaalde afvalwaterlozingen schade aan de gezondheid van zwemmers in het ontvangende oppervlaktewater veroorzaken, of wanneer de omgang met gevaarlijke stoffen (bijvoorbeeld asbest) niet alleen milieuschade teweegbrengt, maar ook lichamelijk letsel berokkent. ${ }^{1116}$ Er kan hier worden verwezen naar de Belgische Amoco Fina-zaak waar verschillende werknemers - de strafbaarheid van de rechtspersoon bestond toen nog niet niet alleen werden vervolgd voor het overtreden van de milieuwetgeving, maar ook voor onopzettelijke doding en onopzettelijke slagen en verwondingen (artikel 418 e.v. van het Belgische Strafwetboek). Het Hof van Beroep te Antwerpen had de beklaagden vrijgesproken omdat de delicten niet aan hen individueel konden worden toegerekend, hoewel in casu de onopzettelijke doding en onopzettelijke slagen en verwondingen als dusdanig bewezen waren. ${ }^{1117}$ De vrijspraak was dus het gevolg van het ontbreken van de strafrechtelijke aansprakelijkheid van de rechtspersoon, hetgeen opnieuw illustreert dat een individualistische benadering van in organisatorisch verband verrichte gedragingen niet volstaat.

Bemerk dat ik geen grote voorstander ben van het gebruik van commune delicten in milieustrafzaken. In de literatuur wordt het gebruik van commune delicten bij vervolging voor milieuverstoring verklaard door het theoretisch en praktisch tekort van de milieustrafbepalingen uit het Wetboek van Strafrecht. De artikelen $225 \mathrm{Sr}$ en $140 \mathrm{Sr}$ zijn

1113. Dat was bijvoorbeeld het geval in de zaak van de Antwerpse stortplaats 'Hooge Maey'. In deze milieustrafzaak werd een directeur van de dienst stadsreiniging van Antwerpen ervan beschuldigd tegen betaling van steekpenningen een vervalste vergunning te hebben opgesteld (Antwerpen, 30 september 1988, $R W, 1988-89,509$ ). Zie hoofdstuk III voor een bespreking van deze zaak.

1114. Zie over de betekenis van artikel $140 \mathrm{Sr}$ in milieustrafzaken, in het bijzonder de TCR-zaak Faure, M. en Visser, M., o.c., 1999, 1379.

1115. Zie hierover de noot van De Lange, A. bij Rb. Rotterdam 13 oktober 1995, MenR 1996, nr. 24; Faure, M. en Visser, M., o.c., 1999, 270-272 en 379.

1116. Zie bijvoorbeeld Corr. Mechelen, 3e Kamer, 29 januari inzake OM, Mampaey en Vercauteren t. Van Meersbeeck en NV Kemira, ongepubliceerd.

1117. Antwerpen, 26 maart 1993, TMR 1993, 239. 
makkelijker te bewijzen dan de artikelen 173a en $173 \mathrm{~b} \mathrm{Sr} .{ }^{1118}$ Daarnaast is de strafmaat van de commune delicten vrijwel gelijk aan, of soms zelfs hoger dan die van de milieustrafbepalingen. ${ }^{1119}$ Bovendien zijn opsporingsinstanties en $\mathrm{OM}$ in de praktijk meer vertrouwd met de klassieke commune delicten, dan met de vaak complexe delicten uit het milieustrafrecht. ${ }^{1120}$ Tegen het gebruik van commune delicten ter bestrijding van milieuverstoring pleit voornamelijk dat zo de normbevestigende en responsabiliserende werking van het milieustrafrecht wordt gefrustreerd. Immers, deze commune delicten zijn niet gericht op de bescherming van de ecologische rechtsgoederen, maar op andere maatschappelijke belangen. Door het vervolgen van milieuverstoorders op basis van commune delicten wordt niet voldoende duidelijk gemaakt dat hen een ontoelaatbare verstoring van het leefmilieu wordt verweten. ${ }^{1121}$ De deresponsabiliserende werking van commune delicten is des te nefaster wanneer we zien dat daarop veelal beroep wordt gedaan in de ergste gevallen van milieuverstoring, zoals in de TCR-zaak. Daarnaast zijn deze delicten in beginsel toegesneden op gedragingen van natuurlijke personen. In het bijzonder valsheid in geschrifte lijkt me een delict dat toch bij uitstek slechts door natuurlijke personen kan worden gepleegd: valsheid in geschrifte moet daarom in de eerste plaats aan natuurlijke personen en niet aan de rechtspersoon worden verweten. Het hoeft dan ook niet te verbazen dat wanneer in bedrijfsmatig kader sprake is van milieuverstoring én valsheid in geschrifte, het OM voornamelijk de natuurlijke personen vervolgt, zij het als feitelijk leidinggevers aan het daderschap van de rechtspersoon. ${ }^{1122}$ In dergelijke gevallen wordt vlug aan het daderschap van de rechtspersoon voorbijgegaan en worden verweren die zich richten tegen de bijna automatische vaststelling van het rechtspersoonlijke daderschap niet echt ernstig genomen. Men stelt vast dat men via het rechtspersoonlijke daderschap naar het feitelijk leidinggeven aan valsheid in geschrifte toeredeneert. ${ }^{1123}$ Wat zo bijna volledig uit het zicht verdwijnt is de collectieve verwijtbaarheid van de organisatie in relatie tot de milieuverstoring. Anders gezegd, bestrijding van milieuverstoring op basis van commune delicten neigt tot een individualisering van collectieve verwijtbaarheid, hetgeen vanuit het oogpunt van effectiviteit niet echt wenselijk is, daar bij collectieve verwijtbaarheid een collectieve aansprakelijkheid meer in de rede ligt. Dat dit ook zo door strafrechters wordt ervaren blijkt bijvoorbeeld uit de motivering van de rechtbank in de UNISER-zaak, waar feitelijk leidinggevers terechtstonden voor overtreding van (het oude en toen meer op milieuverstoring

1118. Vgl. o.m. Faure, M., 'Het Nederlandse milieustrafrecht: dringend aan herziening toe!', RMThemis, 1997, 3-12; Faure, M. en Visser, M., o.c., 1999, 393.

1119. Op het overtreden van artikel $140 \mathrm{Sr}$ staat een strafbedreiging van ten hoogste vijf jaren gevangenis-straf of een geldboete van de vierde categorie. Op het overtreden van artikel $225 \mathrm{Sr}$ staat een gevangenisstraf van ten hoogste zes jaren of een geldboete van de vijfde categorie. Zie hierover Faure, M. en Visser, M., o.c., 1999, 392.

1120. Vgl. Faure, M., Preadvies milieustrafrecht, Antwerpen, Maklu, 1990, 54-58.

1121. Vgl. Faure, M. en Visser, M., o.c., 1999, 394.

1122. Zie o.m. naast de TCR-zaak, de UNISER-zaak Rb. Breda, 15 februari 1982, $N J$ 1983, 6 alsook Rb. Breda, 5 juli 1989, MenR 1990, nr. 37, met noot Tideman. Zie tevens De Roos, Th., 'De strafzaak tegen UNISER - een case study', in Van de Bunt, H.G., De Jonge, G. e.a. (red.), De macht van het O.M., Nijmegen, Ars Aequi Libri, 1983, 261- 277.

1123. Zie bijvoorbeeld de UNISER-zaak Rb. Breda, 15 februari 1982, $N J$ 1983, 6. 
gerichte) artikel $174 \mathrm{Sr}$, het bedriegen van afvalproducenten, en overtreding van artikel 225 Sr. ${ }^{1124}$ Ten aanzien van het verwijt van de verdachten merkt de rechtbank op:

'Het verwijt van de verdachten (dat de overheid op het vlak van afvalregulering in gebreke zou zijn gebleven, DR) is trouwens niet ter zake dienende, want zelfs al zou de overheid in gebreke zijn, dan nog kunnen verdachten aan niets het recht ontlenen zich op te werpen als degenen die de industrie van haar afval zullen bevrijden, en die daarbij dan zelf wel zullen uitmaken wat met het afval wel en niet kan en mag gebeuren.

Dit is de kern van het verwijt, dat aan de verdachten gemaakt dient te worden. Zij hebben zich het recht aangemeten eigenmachtig, met voorbijgaan van alle wettelijk bepalingen en bevoegde instanties, uit te maken wat wel en wat niet verantwoord en toelaatbaar is bij de verwerking en verwijdering van chemisch afval.

Waarop berust nu deze aanmatiging? De technische en wetenschappelijke kennis binnen het concern was, gelet op de omvang van het probleem, ten enenmale onvoldoende, evenals de commerciële en economische kennis. De verdachten hebben betoogd, dat zij grote hoeveelheden chemisch afval legaal hebben verwerkt. De Rb. laat zich niet begeven in de vraag, of het grootste deel van het afval nu legaal of illegaal is verwerkt: voor de verwijtbaarheid zijn allereerst de absolute hoeveelheden illegaal verwerkt afval van belang en de risico's die deze verwerking heeft opgeleverd.'

(...)"In de eerste plaats dient Uniser derhalve in deze zaak te worden verweten het verkopen van voor de gezondheid schadelijke waren met verzwijging van het schadelijke karakter. Deze gedraging raakt, zoals hierboven is overwogen, de kern van het verwijt. Daarmee is tevens de vraag beantwoord, of overtreding van art. $174 \mathrm{Sr}$ nog strafwaardig is. Het eraan ten grondslag liggende beginsel -de bescherming van de bevolking tegen schadelijke stoffen- leeft zeker in het rechtsbewustzijn. In dit geval is sprake van een verwijtbare gedraging die onder de omschrijving van het artikel valt. Daarmede is toepassing van het artikel gerechtvaardigd, en bestraffing naar huidige maatstaven.

Naast de overtreding van art. $174 \mathrm{Sr}$ is de overtreding van art. $225 \mathrm{Sr}$ en in nog sterkere mate het bedriegen van afvalproducenten, van secundair belang. ${ }^{1125}$

Wat opvalt is dat in deze motivering duidelijk wordt dat de verwijtbaarheid niet alleen bij de feitelijk leidinggevers zit, maar ook bij Uniser zelf als organisatie en bij de risico's inherent aan de bedrijfsactiviteiten. Daarnaast wijst de rechtbank erop dat de verwijtbaarheid primair ligt bij de omgang met (voor de gezondheid) gevaarlijke stoffen en niet bij de valsheid in geschrifte of de bedrieging van de afvalproducenten. 
Indien nu een overheid in een milieustrafzaak (mede) wordt vervolgd voor commune delicten rijst de vraag hoe het daderschap kan worden vastgesteld op een wijze die recht doet aan de eigen aard van de rechtspersoon en zonder dat het schuldbeginsel te zeer wordt uitgevlakt. Kenmerkend voor deze commune delicten is dat zij, in tegenstelling tot de meeste milieudelicten, bijzondere subjectieve bestanddelen kennen. Dit betekent dat minder snel het daderschap van de rechtspersoon kan en mag worden aangenomen. Het daderschap van de rechtspersoon mag zich hier niet beperken tot pure materiële toerekeningscriteria. De morele toerekening dient idealiter in het daderschap te zijn omschreven. Het corporatieve daderschap moet dus bij deze commune delicten subjectiever worden ingevuld dan bij de milieudelicten, die veelal geen strenge eisen stellen aan het schuldvereiste. Er weze an herinnerd dat dit niet alleen voor een rechtsstatelijk verantwoorde invulling van het rechtspersoonlijk daderschap van belang is, maar ook om te vermijden dat zo, via de omweg van een te zeer geobjectiveerde strafrechtelijke aansprakelijkheid van de rechtspersoon, de klassieke leerstukken en delicten uit het commune strafrecht worden uitgehold. In de volgende paragraaf wordt bekeken of een rechtspersoon zich aan dood of zwaar lichamelijk letsel door schuld kan schuldig maken. ${ }^{1126}$ Dit is niet slechts van theoretisch belang. Zo merken Nijboer en de Koning op dat het in beginsel mogelijk moet zijn om ook overheidsorganisaties strafrechtelijk aansprakelijk te stellen voor dodelijke ongelukken, die te wijten zijn aan een organisatorisch falen. $\mathrm{Zij}$ geven als voorbeeld de Hercules-ramp op de vliegbasis Welschap waar het ongeluk, het niet redden van nog levende passagiers uit het toestel na de fatale landing, voor een deel mogelijk te wijten zou zijn geweest aan coördinatiefouten binnen organisaties, zoals de vluchtleiding van de vliegbasis. ${ }^{1127}$ Daarnaast kan worden verwezen naar de affaire bij de marinewerf in Den Helder waar honderden werknemers aan asbest zijn blootgesteld tijdens werkzaamheden op de werf en in de machinekamers van oorlogsschepen. Het ministerie van defensie heeft inmiddels wel aan een aantal slachtoffers schadevergoeding gegeven. Ook dat is een voorbeeld van binnen een overheidsorganisatie verrichte gedragingen die onder de werking van artikel 307 of $308 \mathrm{Sr}$ zouden kunnen vallen. ${ }^{1128}$ En wat te denken van gevangenissen die zo bruut en onmenselijk omgaan met hun gevangenen dat dit (dodelijke) slachtoffers tot gevolg heeft? Ook dit zou best kunnen worden gecatalogiseerd als door een overheidsorganisatie gepleegd strafbaar feit. De vraagstelling of overheden, en rechtspersonen in het algemeen, zich schuldig kunnen maken aan artikel 307 of artikel $308 \mathrm{Sr}$ overstijgt duidelijk het milieustrafrechtelijke terrein.

1126. Of de rechtspersoon zich ook kan schuldig maken aan valsheid in geschrifte komt niet aan bod, omdat voor dit delict (mijns inziens terecht) hoofdzakelijk natuurlijke personen (als feitelijk leidinggevenden) worden vervolgd. Het is daarom beter om in paragraaf 10 over feitelijk leidinggeven aan valsheid in geschriften aandacht te besteden.

1127. Nijboer, H. en De Koning, A.-M., 'Strafrechtelijke verantwoordelijkheid van de Nederlandse Staat', NJB, 1997, 680-682.

1128. Het Parool 6 juni 1997. Vgl. ook de Cannerberg-affaire in Maastricht, waar in het onderaardse gangenstelsel van de Cannerberg een enorme illegale vuilnisbelt was gegroeid. Ook daar bleek sprake te zijn van een aanzienlijke hoeveelheid asbest in het afval waaraan verschillende mensen zijn blootgesteld: zie Volkskrant 10 april 1997. 


\section{B. HET DADERSCHAP BU DOOD OF ZWAAR LICHAMELIJK LETSEL DOOR SCHULD}

Hoe zal het daderschap van de rechtspersoon kunnen worden geformuleerd indien deze overtreding van artikel 307 of artikel $308 \mathrm{Sr}$ wordt tenlastegelegd. Het gaat om culpose gevolgsdelicten waarin dus een bijzonder subjectief bestanddeel is neergelegd, dat dus ook in het daderschap van de rechtspersoon moeten worden verdisconteerd. Het OM dient de vereiste culpa te bewijzen.

Deze delicten vereisen drie bestanddelen. Er moet sprake zijn van (1) onachtzaamheid of culpa; (2) een bepaald gevolg, namelijk de dood ofwel zwaar lichamelijk letsel; en er moet (3) een causaal verband tussen beide bestaan. ${ }^{1129}$ Hoewel natuurlijk de vaststelling van het oorzakelijk verband reeds belangrijke vragen oproept ${ }^{1130}$, is het nodig hier voornamelijk stil te staan bij de vereiste culpa in hoofde van de rechtspersoon. Kan de rechtspersoon als geheel zich schuldig maken aan artikel 307 of artikel $308 \mathrm{Sr}$ ?

Bij kleine ondernemingen en gemeenten met een eenvoudige en doorzichtige interne structuur, zou men zijn toevlucht kunnen nemen tot de IJzerdraadcriteria omdat de afstand tussen (beslissingen van) de verantwoordelijke natuurlijke personen en de schadeverwekkende activiteiten van de organisatie die de dood of het lichamelijk letsel tot gevolg hebben niet zo groot is. Er moet dan worden vastgesteld of de rechtspersoon over de tenlastegelegde schadelijke gedragingen kon beschikken en deze aanvaardde of placht te aanvaarden. Uit de concrete bewijsmiddelen moet wel blijken dat binnen de rechtspersoon door de verantwoordelijke functionarissen niet de nodige maatregelen zijn genomen ter voorkoming van de schadelijke gedragingen. Met andere woorden, men dient de macht- en aanvaardingsvereiste zo subjectief en rechtspersoontypisch mogelijk in te vullen en niet slechts normatief. Zo wordt tegelijk vermeden dat feiten aan de rechtspersoon worden toegerekend die niet te wijten zijn aan de organisatie zelf, maar veeleer aan zuiver individuele gedragingen.

Problematisch, maar ook interessanter, wordt het wanneer het delict het gevolg is van diffuse in tijd gespreide risicovolle activiteiten verricht door complexe organisaties. De IJzerdraadcriteria zijn op dergelijke rechtspersonen moeilijker toe te passen, tenzij men ze dermate objectiveert dat de verwijtbaarheid nauwelijks nog een rol hoeft te spelen. In dergelijke situaties biedt de op de 'Betriebsführungschuld' gefundeerde daderschap een verantwoorde oplossing en kan een objectieve aansprakelijkheid worden vermeden. Uit de bewijsmiddelen moet blijken dat de vereiste voorzorg niet is betracht omdat welom-

1129. Vgl. Remmelink, J., o.c., 1995, 172; Van Bemmelen, J.M. en Van Veen, Th.W., o.c., 1998, 64 e.v.

1130. Zie hierover Remmelink, J., o.c., 1995, 172 e.v. Er kan hier worden volstaan met de opmerking dat voor causaliteit volgens de heersende leer en rechtspraak niet langer de voorzienbaarheid van het gevolg is vereist, maar of het gevolg aan de dader redelijkerwijs kan worden toegerekend (HR 12 september 1978, NJ 1979, 60; HR 23 december 1980, $N J$ 1981, 534). Bij de redelijke toerekening kan evenwel nog steeds rekening worden gehouden met de voorzienbaarheid van het gevolg. Alleen is de voorzienbaarheid niet de enige factor om tot een redelijke toerekening te kunnen komen. Zie hierover Van Bemmelen, J.M. en Van Veen, Th.W., o.c., 1998, 70-71. 
schreven beslissingen, slecht management of organisatorische praktijken in causaal verband staan met de schadeberokkenende gedragingen, bijvoorbeeld omdat blijkt dat binnen de organisatie niet voldoende aandacht is gegeven of niet genoeg financiële middelen zijn vrijgemaakt ten behoeve van de veiligheid. Door het ondervragen van de personeelsleden en leidinggevenden kan zo in concreto het disfunctioneren van de organisatie worden beoordeeld. ${ }^{1131}$ De enkele vaststelling dat een zorgvuldigheidsnorm is overtreden kan dus niet volstaan ter invulling van de culpa. Immers, er kunnen zich nu eenmaal 'ongevallen' voordoen, die ook voor goed functionerende organisaties onvermijdbaar zijn. Wil de strafrechtelijke aansprakelijkheid hier zijn instrumentele werking behouden, dan moet daadwerkelijk worden gekeken naar het organisatorische falen.

Dat een organisatie als geheel zich wel degelijk kan schuldig maken aan de artikelen 307 en $308 \mathrm{Sr}$, kan worden geíllustreerd aan de hand van een uitspraak van de rechtbank Leeuwarden, waar een ziekenhuis voor dood door schuld werd veroordeeld omdat gebruik was gemaakt van een verouderd en onvoldoende onderhouden narcose-kabinet ten gevolge waarvan een patiènt was overleden. $\mathrm{Zij}$ bleek in plaats van zuurstof lachgas toegediend te hebben gekregen. Uit de motivering van de rechtbank blijkt duidelijk de aanwezige bedrijfsvoeringsschuld, omdat het ziekenhuis aan haar verantwoordelijkheid
'(...)niet voldoende vorm en inhoud heeft gegeven nu de organisatie en werkwijze van de Technische Dienst van dien aard waren dat enerzijds niet is gebleken van een behoorlijk controlesysteem inzake onderhoud en reparaties en het anderzijds mogelijk is gebleken dat een volledig narcose-kabinet uit de administratie is verdwenen, terwijl het wel in gebruik bleef en daarbij van ieder regulier onderhoud verstoken bleef. Voorts bestond voor een situatie als de onderhavige (...) geen behoorlijke schriftelijke instructie of werkafspraak.'

Over de verantwoordelijkheid van de leiding van het ziekenhuis merkt de rechtbank nog het volgende op:
'(...) Het feit dat de onderhavige apparatuur zolang gebruikt kon worden zonder dat dat op leidinggevend niveau binnen de organisatie bekend was, geeft op overduidelijk wijze weer, dat leidinggevende functionarissen in dit opzicht volstrekt onvoldoende zicht hadden op de gang van zaken in het ziekenhuis' ${ }^{1132}$

1131. Vgl. Van Strien, A.L.J., o.c., 1996, 112.

1132. Rb. Leeuwarden 23 december 1987, Tijdschrift voor Gezondheidsrecht 1988, 175, nr. 24, met noot Roscam Abbing, H.D.C. In dezelfde zaak werd overigens ook de anesthesist die het narcose-kabinet bediende voor dood door schuld veroordeeld, hetgeen illustreert dat zowel de organisatie als daarin werkzame natuurlijke personen een afzonderlijke verantwoordelijkheidssfeer kunnen hebben. Zie tevens Wortel, J., 'Ook ondernemingen kunnen door ernstige onzorgvuldigheid een misdrijf begaan', Bb, 1989, 73-76; Van Elst, R., o.c., 1997, 42. 
Het spreekt voor zich dat niet alleen ziekenhuizen zich aan dood door schuld kunnen schuldig maken, maar ook overheidsorganisaties.

\section{§9. Feitelijk leidinggeven}

\section{A. DE AMBIGUE VERHOUDING TUSSEN FEITELIJK LEIDINGGEVEN EN RECHTSPERSOONLUK DADERSCHAP}

Alvorens we de aandacht richten op de rechtspersoon 'de staat' dient aandacht te worden besteed aan het feitelijk leidinggeven. Het feitelijk leidinggeven aan door overheden verrichte verboden gedragingen staat onder meer centraal in de Pikmeer-zaak. Zowel in de eerste als in de tweede door de Hoge Raad vernietigde uitspraak van het Hof Leeuwarden werd het feitelijk leidinggeven van de ambtenaar bewezen verklaard. Zoals bekend heeft de Hoge Raad in Pikmeer I en II zich niet inhoudelijk over het feitelijk leidinggeven uitgesproken. In Pikmeer I werd het OM immers niet-ontvankelijk verklaard in de vervolging van de ambtenaar, daar de feitelijk leidinggever in de immuniteit deelt van het openbaar lichaam aan wiens gedraging hij leiding heeft gegeven. ${ }^{1133}$ In Pikmeer II kwam de Hoge Raad weliswaar tot een herziening van zijn eerdere jurisprudentie, maar werd, gelet op de eisen van een behoorlijke procesorde en de rechtszekerheid, op de ambtenaar nog de oude Pikmeer I-rechtsregel toegepast. De zaak werd vervolgens naar het Hof te Arnhem doorverwezen teneinde te oordelen of de ambtenaar niet voor eigen daderschap kan worden veroordeeld, hetgeen hem subsidiair was tenlastegelegd. ${ }^{1134}$ Terloops weze herhaald dat mij een veroordeling van ambtenaren voor eigen daderschap, in het licht van de immuniteit, niet echt consistent en rechtvaardig lijkt tenzij echt blijkt dat deze tegen uitdrukkelijke instructies (en daarbij passende controle) op eigen houtje heeft gehandeld. Niet consistent, omdat ook dan in veel gevallen het overheidshandelen door de strafrechter moet worden getoetst; onrechtvaardig omdat dit meestal, toch bij grotere gemeenten, betekent dat vooral de lagere uitvoerders worden aangepakt. ${ }^{1135}$ In de Pikmeer-zaak is de inconsistentie natuurlijk verdwenen, nu na Pikmeer II de immuniteit zodanig is beperkt dat zij op de feiten van het Pikmeer-dossier niet langer van toepassing is: de gemeente c.q haar leidinggevers zouden zich voor de illegaal slibstort thans niet langer op een immuniteit kunnen beroepen. Maar of een veroordeling van de ambtenaar wegens eigen daderschap als rechtvaardig kan worden bestempeld durf ik te betwijfelen.

Volgens artikel 51 lid $2 \mathrm{Sr}$ is feitelijk leidinggeven accessoir aan het daderschap van de rechtspersoon. Er kan pas sprake zijn van feitelijk leidinggeven (of opdracht geven) als een rechtspersoon een strafbaar feit begaat. Immers, een functionaris (ambtenaar) kan zijn functie bij de rechtspersoon gebruiken om op eigen houtje een strafbaar feit te plegen. De rechtspersoon staat dan buiten dit strafbare feit en kan derhalve niet als dader worden aangemerkt. De functionaris kan dan slechts voor eigen daderschap worden vervolgd. 
$\mathrm{Nu}$ veronderstelt daderschap dat de dader alle bestanddelen van een delictsomschrijving kan vervullen. Idealiter betekent dit dat ook het daderschap van de rechtspersoon een zodanige vorm moet krijgen dat materieelrechtelijk, maar bovenal bewijsrechtelijk, met de subjectieve bestanddelen moet rekening worden gehouden. Dat dit geen makkelijke, maar ook geen onmogelijke opgave is, is inmiddels wel duidelijk geworden. Tevens is vastgesteld dat aan het (bewijs van) daderschap van de rechtspersoon niet al te hoge eisen worden gesteld, met name in die gevallen waar de feitelijk leidinggever wordt vervolgd. Men krijgt al vlug te maken met cirkelredeneringen, in de zin dat het daderschap van de rechtspersoon eerst wordt afgeleid uit de gedragingen van een natuurlijke persoon om dan vervolgens deze als feitelijk leidinggever aan het (via hem) door de rechtspersoon gepleegde feit te veroordelen. In het Pikmeer-dossier komt dit vooral in het (tweede) arrest van het Hof Leeuwarden goed tot uiting. Het Hof stelt in één moeite vast dat de gemeente het verboden handelen niet heeft goedgekeurd, daarvoor dus niet kan worden vervolgd, daartoe wel via de betrokken ambtenaar opdracht heeft gegeven en derhalve de feiten heeft gepleegd, waarvoor deze ambtenaar als feitelijk leidinggever kan worden veroordeeld daar hij op de hoogte was dat in strijd met de vergunning werd gehandeld. Kortom, de gemeente is niet vervolgbaar want er ligt geen besluit dat de handelingen heeft goedgekeurd, maar is niettemin wel dader omdat de ambtenaar tot die handelingen opdracht heeft gegeven, wat hem maakt tot feitelijk leidinggever aan het via hem door de gemeente (let wel: opzettelijk) gepleegde delict. Zoals reeds is besproken, voegt het Hof als nadere bewijsoverweging daar nog aan toe dat de verboden gedragingen als gedragingen van de gemeente moet worden aangemerkt omdat deze in het maatschappelijk verkeer hebben te gelden als gedragingen van de gemeente. ${ }^{1136}$

Laten we nu inhoudelijk op het feitelijk leidinggeven ingaan. Cruciale vraag is vanzelfsprekend wanneer van feitelijk leidinggeven sprake kan zijn. Wat zijn de voorwaarden van het feitelijk leidinggeven en meer in bijzonder, wat is het schuldvereiste bij feitelijk leidinggeven?

\section{B. DE VOORWAARDEN VAN FEITELIJK LEIDINGGEVEN}

\section{Geen risico-aansprakelijkheid}

Ook voor feitelijk leidinggeven geldt als uitgangspunt dat niet mag worden afgegleden naar een risico-aansprakelijkheid. Het moge duidelijk zijn dat het louter bekleden van een bepaalde leidinggevende functie binnen een (overheids)organisatie niet voldoende is voor een strafrechtelijke aansprakelijkheid. Zo kan voor feitelijk leidinggeven niet volstaan het enkele gegeven dat een bepaalde ambtenaar hoofd is van een gemeentelijke dienst. Indien deze dienst activiteiten verricht die een milieudelict constitueren, dan dient specifiek naar

1136. Vgl. Brants Chr., 'Wordt vervolgd... Het Pikmeer II-arrest', DD, 1998, 331. Deze laatste overweging is bijzonder interessant, want indien het daderschap van een gemeente uitsluitend op basis van het maatschappelijk verkeerscriterium zou worden gebaseerd - wat het Hof weliswaar niet doet - dan zou het illegale slibstort ook als een door de gemeente gepleegd strafbaar feit moeten worden aangemerkt wanneer dit plaatsvond in strijd met uitdrukkelijke instructies. Want ieder gemeentelijke slibstort is naar 'maatschappelijk verkeer' een gedraging van de gemeente. 
het gedrag van deze ambtenaar te worden gekeken om vast te kunnen stellen of hij strafbaar is. Niettemin ziet bijvoorbeeld Remmelink de strafbaarheid van de feitelijk leidinggever als een pure aansprakelijkheidsconstructie. Het gaat slechts 'om de aanwijzing van de hoedanigheid van de aansprakelijkgestelde' ${ }^{\prime 137}$ Dit betekent dat voor feitelijk leidinggeven volstaat dat iemand een zodanige relatie heeft met de rechtspersoon dat hij qua functie als feitelijk leidinggever binnen de organisatie kan worden aangemerkt. ${ }^{1138}$ Centraal staat dan de betrokkenheid bij de organisatie van de rechtspersoon en niet zozeer de verwijtbare betrokkenheid bij de door de rechtspersoon verrichte gedragingen.

Een strafrechtsdogmatisch zuiverder uitgangspunt bestaat erin om feitelijk leidinggeven aan te merken als een bijzondere vorm van deelneming, of zoals 't Hart en de Vries-Leemans het omschrijven: een deelnemingsfiguur sui generis. ${ }^{1139}$ Centraal staat niet de functie - een tamelijk objectief en formeel gegeven - binnen de organisatie, maar het eigen gedrag van de feitelijk leidinggever in relatie tot de gedraging van de rechtspersoon. Met andere woorden, van feitelijk leidinggeven is slechts sprake indien een natuurlijke persoon op verwijtbare wijze betrokken is bij het door de rechtspersoon gepleegde strafbare feit. Eigenlijk vloeit dit reeds met zoveel woorden uit de tekst van de wet voort. Artikel 51 lid 2, onder $2 \mathrm{Sr}$ stelt dat de in de wet voorziene straffen en maatregelen, indien zij daarvoor in aanmerking komen, kunnen worden uitgesproken tegen hen die feitelijk leiding hebben gegeven aan de verboden gedraging.

De vraag rijst waarin deze verwijtbare betrokkenheid in concreto moet bestaan. Bij het opdracht geven is dit minder problematisch: er moet opdracht zijn gegeven tot het gepleegde feit. ${ }^{1141}$ Feitelijk leidinggeven daarentegen is vager en werpt vragen op over de begrenzing van de aansprakelijkheid. Strafrechtsdogmatisch vertaald betekent dit of in hoofde van

1137. Remmelink, J., o.c., 1995, 155.

1138. Vgl. Van Elst, R., o.c., 1997, 53.

1139. 't Hart, A.C. en De Vries-Leemans, M.J.H.J., 'Enige opmerkingen betreffende het feitelijke leiding-geven', in Balkema, J.P. (red.), Gedenkboek honderd jaar Wetboek van Strafrecht, Arnhem, Gouda Quint, 1986, 289-301.

1140. Ook uit de parlementaire voorbereiding kan worden afgeleid dat het moet gaan om een zelfs actieve betrokkenheid bij de verboden gedraging. Volgens de toenmalige minister van justitie Van Agt kan bijvoorbeeld geen sprake zijn van feitelijk leidinggeven indien een bestuurder niet aanwezig is op de bestuurdersvergadering waar een besluit wordt genomen dat aan een strafbaar feit ten grondslag ligt, ook niet wanneer hij later zich tegen dat besluit niet verzet. Zie TK 19751976, 19 mei 1976, 4210. Vgl. ook Kantongerecht Heerlen 2 juni 1947, NJ 1948, 139.

1141. Bemerk dat in de strafrechtspraktijk 'opdracht geven' niet van groot belang is. Meestal wordt zowel feitelijk leidinggeven als opdracht geven tenlastegelegd (zoals in de Pikmeer-casus). In de literatuur wordt verdedigd dat opdracht geven een nauwere en actievere betrokkenheid bij de door de rechtspersoon gepleegde gedraging impliceert dan feitelijk leidinggeven (zie o.m. Vellinga-Schootstra, F., Vellinga, W.H. en Van Strien, A.L.J.., 'Het daderschap van de rechtspersoon', in Van der Neut, J.L. (red.), Daderschap en deelneming, Arnhem, Gouda Quint, 1993, 51). Maar, zoals hierna zal blijken, valt een actieve betrokkenheid ook reeds onder het feitelijk leidinggeven. Van Elst concludeert dat 'kan worden gezegd dat, bij de buidige stand van de rechtspraak, de strafbaarheid van opdracht geven in feite geheel wordt overlapt door de strafbaarheid van feitelijk leidinggeven.' Van Elst, R., o.c., 1997, 66. 
de feitelijk leidinggever sprake moet zijn van opzet of culpa; vragen die we tot nu toe slechts binnen het kader van de strafbaarheid van de rechtspersoon hebben onderzocht.

\section{Het schuldvereiste bij feitelijk leidinggeven}

\section{a. Feitelijk leidinggeven aan de 'bedrijfsvoering'}

In het bovenstaande is vastgesteld dat één van de mogelijke daderschapscriteria voor rechtspersonen bestaat in de bedrijfsvoering of de feitelijk uitgeoefende bedrijfspolitiek. Er is geconcludeerd dat dit daderschapscriterium in het licht van het schuldbeginsel kan worden bekritiseerd, maar dat het niettemin kan volstaan bij de abstracte gevaarzettingsdelicten die als overtreding worden tenlastegelegd. In de literatuur over feitelijk leidinggeven wordt de vraag gesteld of het voor strafbaar feitelijk leidinggeven voldoende is dat de leidinggever actief betrokken is bij de bedrijfsvoering, die aan het door de rechtspersoon gepleegde feit ten grondslag ligt. ${ }^{1142}$ Of moet een (actieve of passieve) betrokkenheid bij de verboden gedraging worden vastgesteld, hetgeen artikel 51, tweede lid, onder $2 \mathrm{Sr}$ lijkt aan te geven?

Dat voor feitelijk leidinggeven een actieve betrokkenheid aan de bedrijfsvoering volstaat, zou kunnen worden afgeleid uit het Witte grammofoonplaten-arrest. In deze zaak werd een directeur van een BV vervolgd wegens het feitelijk leidinggeven aan heling. De BV had samen met een andere BV bootlegs verkocht. In cassatie werd aangevoerd, dat uit de bewijsmiddelen geen actieve betrokkenheid bij de verboden gedraging (de heling) kon worden afgeleid zodat de directeur niet als leidinggever kon worden aangemerkt. De Hoge Raad verwerpt dit verweer en houdt het bewijs van het feitelijk leidinggeven in stand:

'Het Hof heeft zulks in het bijzonder kunnen afleiden uit de verklaring van de verdachte ter terechtzitting voor zover deze inhoudt, dat de inkoop van geluidsdragers voor alle filialen/verkoop-punten van beide BV's gebeurt door de FRS, waarvan de verdachte enig directeur is, er een nauwe samenwerking is tussen FRS en BRS waarbij de zakelijke leiding bij de verdachte berust en dat de in de FRS werkzame inkoper J. da Silva werkt onder zijn - verdachtes - verantwoordelijkheid ${ }^{1143}$

Betekent dit nu dat een actieve betrokkenheid aan de bedrijfsvoering volstaat? Zo ja, dan zijn er geen hoge eisen gesteld aan het schuldvereiste in hoofde van de leidinggever. Het gaat dan om een pure aansprakelijkheidsconstructie. ${ }^{1144}$ Mijns inziens dient voor een zinvol antwoord op deze vraag naar de concrete casus te worden gekeken waarover de Hoge Raad moest oordelen. Wat in deze zaak een belangrijke rol speelt, is dat twee kleine BV's bij de

1142. Zie Van Elst, R., o.c., 1997, 54-55.

1143. HR 2 maart 1982, $N J$ 1982, 446 met noot 't Hart, A.C. Vgl. HR 16 juni 1981, NJ 1981, 568 (Papa Blanca); HR 22 maart 1983, $N J$ 1983, 502. Zie tevens Van Elst, R., o.c., 1997, 54-55; Van Strien, A.L.J., l.c., 1989, 42.

1144. Vgl. Van Strien, A.L.J., l.c., 1989, 43. 
heling betrokken waren. De rechtspersonen kennen een doorzichtige organisatiestructuur en vielen vrijwel samen met de directeurs. Dit betekent dat een actieve betrokkenheid bij de bedrijfsvoering kan volstaan omdat de verboden gedraging nu eenmaal nauw verband houdt met de bedrijfsvoering. ${ }^{1145}$ De afstand tussen de bedrijfsvoering, de verboden gedraging en de leidinggever is zeer klein. $\mathrm{Bij}$ complexere organisaties daarentegen volstaat een actieve - laat staan een passieve - betrokkenheid bij de bedrijfsvoering geenszins: dat zou neerkomen op een risico-aansprakelijkheid.

Wanneer het gaat om feitelijk leidinggeven aan door overheden verrichte verboden gedragingen, dient dus naar de complexiteit van de organisatie te worden gekeken en mag niet worden volstaan met de vaststelling dat de betrokken ambtenaar (of arbeidscontractant) actief betrokken is geweest bij de overheidsactiviteiten waarbinnen het concrete delict is gepleegd. Neem als voorbeeld een gemeente waarbinnen een bepaalde afdeling verantwoordelijk is voor het beheer van een huishoudelijk afvalstortplaats. Het beheer van deze stortplaats behoort tot de 'normale' bedrijfsvoering van de gemeente(lijke dienst). Indien nu blijkt dat door de gemeente chemisch afval is gestort, dan is het in beginsel niet voldoende het feitelijk leidinggeven van het hoofd van de dienst af te leiden uit zijn actieve betrokkenheid bij de bedrijfsvoering. Indien hij tot de verboden gedraging toestemming of opdracht heeft gegeven - hetgeen bijvoorbeeld in de Pikmeer-casus het geval was -, rijst er niet echt een probleem. Problematisch is vooral de situatie waarin niet meteen duidelijk is welke rol de functionaris heeft gespeeld bij de verboden gedraging omdat feitelijk leidinggeven bijvoorbeeld ook door een nalaten kan geschieden (het klassieke door de vingers zien). Wat dan zal moeten worden vastgesteld is op welke wijze de functionaris binnen de bedrijfsvoering (in het voorbeeld: de afvalverwerking) verwijtbaar betrokken is geweest bij de illegale storting.

\section{b. De verwijtbare betrokkenheid bij de verboden gedraging: culpa of opzet?}

Dat in de regel meer eisen moeten worden gesteld aan het schuldvereiste bij feitelijk leidinggeven werd duidelijk in de bekende Slavenburg-beschikkingen.

In de Slavenburg-zaak ging het om de vervolging van een aantal leidinggevende functionarissen van NV Slavenburgs Bank voor door die bank gepleegde delicten, met name valsheid in geschrifte. ${ }^{1146}$ Deze zaak is derhalve ook milieustrafrechtelijk van belang daar artikel 225 Sr soms wordt gebruikt binnen het kader van de bestrijding van milieuverstoring.

Het Hof 's Gravenhage beslist in zijn beschikking in de Slavenburg-zaak, dat er sprake kan zijn van feitelijke leidinggeven indien bewezen kan worden:

1145. Vgl. de noot van 't Hart, A.C. onder HR 7 februari 1984, NJ 1984, 527.

1146. Zie voor een interessante beschouwing over de achtergrond van de Slavenburg-zaak Brants, Chr., 'Slavenburg: een geslaagde transactie?', $R \& K, 1987,7$ e.v.; Brants, Chr., 'Slavenburg en de grenzen van het strafrecht', $R \& K, 1988,26$ e.v. 
'dat verdachte als hoger geplaatste in de vennootschap/rechtspersoon van het plaatsvinden van een of meer verboden gedragingen van de soort als in de kennisgeving van verdere vervolging bedoeld heeft geweten of heeft moeten en kunnen weten en hoewel hij de bevoegdheid en/of de positie had in te grijpen en aan zodanige gedragingen een einde te maken, vervolgens met veronachtzaming van dan wel in strijd met hetgeen redelijkerwijs van hem kon en mocht worden verwacht, heeft nagelaten het plegen en/of het verder plegen van zodanige verboden gedragingen te voorkomen. ${ }^{1147}$

Het Hof kiest duidelijk voor een normatieve benadering: het volstaat dat de verdachte had moeten en kunnen weten dat de verboden gedraging was verricht. Dit betekent dat geen opzet is vereist in hoofde van de leidinggever, maar dat culpa volstaat. ${ }^{1148}$ Op het eerste gezicht is hier iets voor te zeggen indien men ervan uitgaat dat de feitelijk leidinggever als functionaris moet worden aangemerkt en dat op hem in die hoedanigheid een bepaalde zorgplicht rust strafbare feiten binnen zijn organisatie tegen te gaan of te voorkomen. Een fundamenteel bezwaar tegen zo'n zorgplichtbenadering is echter dat de grenzen van de strafrechtelijke aansprakelijkheid verruimd worden. De consequentie van de redenering van het Hof is dat de leidinggever strafbaar is door het enkele feit dat hij niet naar behoren functioneerde binnen zijn organisatie. Slecht management hoeft weliswaar geen bezwaar te zijn voor de aansprakelijkheid van de rechtspersoon, maar dat ook de 'manager' zelf om die reden moet worden bestraft, is volgens mij een te grote inbreuk op het schuldbeginsel. ${ }^{1149}$ Uit het niet behoorlijk functioneren van een functionaris volgt nog niet automatisch een feitelijk leidinggeven aan het strafbaar feit. Deze culpose invulling van het feitelijk leidinggeven wordt door de Hoge Raad in het Eerste Slavenburg-arrest verworpen:

'die opvatting gedraagt zich evenwel niet met een juiste uitleg van art. 51 tweede lid onder $2 \mathrm{Sr}$, aangezien slechts dan kan worden aangenomen (of: gezegd) dat iemand feitelijke leiding aan een verboden gedraging heeft gegeven, indien hij van die gedraging op de hoogte was. ${ }^{1150}$

Hieruit kan worden afgeleid dat voor feitelijk leidinggeven culpa niet volstaat. Volgens de Hoge Raad is opzet op de verboden gedraging noodzakelijk om van feitelijk leidinggeven te kunnen spreken. Simpel gezegd, indien de leidinggevende functionaris niet wist dat de rechtspersoon het strafbare feit beging, is geen sprake van feitelijk leidinggeven. ${ }^{1151}$

In het Tweede Slavenburg-arrest wordt aan deze opzet-eis (of wetenschapseis) nader inhoud gegeven:

1147. Hof 's Gravenhage 21 mei 1985, aangehaald in HR 19 november 1985, $N J$ 1986, 125 (Slavenburg I).

1148. Vgl. Van Elst, R., o.c., 1997, 57.

1149. Vgl. Van Strien, A.L.J., l.c., 1989, 43.

1150. HR 19 november 1985, $N J 1986,126$ met noot 't Hart, A.C.

1151. Vgl. Van Elst, o.c, 1997, 58; Vellinga-Schootstra, F., Vellinga, W.H. en Van Strien, A.L.J., 'Het daderschap van de rechtspersoon', in Van der Neut, J.L. (red.), o.c., 1993, 54. 
'5.1.1. Van feitelijk leiding geven aan verboden gedragingen kan onder omstandigheden sprake zijn indien de desbetreffende functionaris -hoewel daartoe bevoegd en redelijkerwijs gehouden -maatregelen ter voorkoming van deze gedraging achterwege laat en bewust de aanmerkelijke kans aanvaardt dat de verboden gedragingen zich zullen voordoen. In deze situatie wordt de zojuist bedoelde functionaris geacht opzettelijk de verboden gedragingen te bevorderen.

5.1.2. De bewuste aanvaarding van de aanmerkelijke kans als onder 5.1.1. bedoeld kan zich te dezen voordoen, indien hetgeen de verdachte bekend was omtrent het begaan van strafbare feiten door de Bank rechtstreeks verband hield met de in de kennisgeving van verdere vervolging omschreven verboden gedragingen'1152

Wat opvalt is dat de door de Hoge Raad geformuleerde criteria sterk gelijken op de IJzerdraadcriteria van 'beschikken en aanvaarden'. ${ }^{1153}$ Maar in tegenstelling tot de strafbaarheid van de rechtspersoon, is er qua toepassingsbereik van deze criteria voor het feitelijk leidinggeven meer duidelijkheid. In verschillende arresten worden deze Slavenburg-criteria op het feitelijk leidinggeven toegepast. ${ }^{1154}$ De Hoge Raad houdt vast aan de opzet-eis, maar voorwaardelijk opzet is reeds voldoende om feitelijk leidinggeven aan te kunnen nemen. Er wordt dus een minder strenge eis gesteld dan in Slavenburg I. Op de hoogte zijn van het strafbaar feit (echte wetenschap) is veranderd in de aanmerkelijke kans aanvaarden dat de verboden gedragingen zich zullen voordoen. ${ }^{1155}$ Dit doet wel de vraag rijzen naar de reikwijdte van dat voorwaardelijk opzet, meer bepaald tot hoever het beschikken en aanvaarden moet gaan.

\section{Beschikken en aanvaarden in hoofde van de feitelijk leidinggever}

Uit Slavenburg II blijkt dat de feitelijk leidinggever niet op de hoogte hoeft te zijn van het begaan van de concrete tenlastegelegde gedraging. ${ }^{1156}$ Dit is dus een groot verschil met de strikte wetenschapseis van Slavenburg I. Wat is vereist is een verband tussen enerzijds de kennis in hoofde van de feitelijk leidinggever omtrent het begaan van strafbare feiten binnen de organisatie van de rechtspersoon en anderzijds de tenlastegelegde gedraging. Dat hij van deze laatste gedraging niet op de hoogte is, doet niet ter zake. ${ }^{1157}$ Een concrete toepassing hiervan kan worden gevonden in het Klaver Fashion-arrest. De verdachte werd vervolgd voor het feitelijk leidinggeven aan het in dienst nemen van werknemers zonder

1152. HR 16 december 1986, $N J$ 1987, 321. Zie ook HR 16 december 1986, $N J$ 1987, 322; tevens Mulder, A., 'Feitelijke leidinggeven aan de verboden gedraging, indien het strafbaar feit door een rechtspersoon is begaan', TVVS, 1988, 213 e.v.

1153. Zie paragraaf 3 van dit hoofdstuk.

1154. Zie o.m. HR 14 september $1987, N J 1988,45$ (Rijtijden) met noot 't Hart, A.C.

1155. Vgl. Vellinga-Schootstra, F., Vellinga, W.H. en Van Strien, A.L.J., l.c., 1993, 55.

1156. Van Elst, R., o.c., 1997, 60; Torringa, R.A., o.c., 1988, 53 en 56.

1157. Vgl. HR 14 september 1987, NJ 1988, 45 (Rijtijden) met noot 't Hart, A.C. Zie tevens noot van 't Hart, A.C. onder HR 21 januari 1992, NJ 1992, 414. 
werkvergunning. De verdachte voerde als verweer dat hij van enkele in de tenlastegelegde genoemde werknemers niet wist dat zij niet over een werkvergunning beschikten. Dit verweer werd door de Hoge Raad verworpen:

\begin{abstract}
'5.1. Blijkens de bewezenverklaring en de gebezigde bewijsmiddelen heeft het hof kennelijk en niet onbegrijpelijk geoordeeld dat de in de tenlastelegging en bewezenverklaring met "Confectie-atelier "Klaver" Fashion" aangeduide werkgever een vennootschap zonder rechtspersoonlijkheid als bedoeld in art. 51 derde lid $\mathrm{Sr}$ is, te weten de vennootschap onder firma "Klaver"Fashion, met H.K. en de verdachte als de beherend vennoten. Het hof heeft voorts kennelijk en -gelet op de uit de bewijsmiddelen blijkende actieve betrokkenheid van de verdachte bij de bedrijfsuitoefening, met name ook bij de indienstneming van vreemdelingen voor het verrichten van arbeid in het door de vennootschap geëxploiteerde confectie-atelier -niet onbegrijpelijk geoordeeld dat de verdachte als beherend vennoot bevoegd en redelijkerwijs gehouden was maatregelen te nemen ter voorkoming van de bewezen verklaarde verboden gedragingen van de vennootschap, dat hij dit heeft nagelaten en bewust de aanmerkelijke kans heeft aanvaard dat de verboden gedragingen zich zouden voordoen, en dat hij daardoor opzettelijk deze gedragingen heeft bevorderd.
\end{abstract}

5.3. Uitgaande van de onder 5.2. vermelde oordelen heeft het hof, zonder miskenning van art. $51 \mathrm{Sr}$, bewezen kunnen achten dat de verdachte [...] feitelijke leiding heeft gegeven aan de bewezen verklaarde verboden gedragingen van de vennootschap. Anders dan in de toelichting op het middel wordt betoogd kan hieraan niet afdoen dat uit deze bewijsmiddelen niet kan worden afgeleid dat de verdachte met betrekking tot alle in bewezenverklaring genoemde personen wist dat deze zonder de vereiste vergunning van het Ministerie van Sociale Zaken arbeid verrichtten. (Cursief, DR) $)^{1158}$

Van belang is ook dat het vereiste (voorwaardelijke) opzet niet op alle bestanddelen van het tenlastegelegde delict moet zijn gericht, maar slechts op die bestanddelen, die de kem van de delictsomschrijving uitmaken. Zo volstaat voor feitelijk leidinggeven aan artikel $225 \mathrm{Sr}$ dat het opzet moet zijn gericht op het 'valselijk opmaken of vervalsen' en niet ook op het 'als echt en onvervalst gebruiken'. Immers, indien men op de hoogte is van het eerste bestanddeel, heeft men de nodige wetenschap om van leidinggeven aan valsheid in geschrifte te kunnen spreken. ${ }^{1159}$

Cruciaal is evenwel dat het opzet van de feitelijk leidinggever ook aanwezig moet zijn bij delicten die opzet niet in de delictsomschrijving hebben opgenomen. ${ }^{1160}$ Niet mag worden 
vergeten dat het bij feitelijk leidinggeven niet gaat om een aansprakelijkheidsconstructie, maar om een bijzondere deelnemingsfiguur met een eigen schuldvereiste. Zo kon in een zaak waar de verdachte werd vervolgd voor feitelijk leidinggeven aan het door een v.o.f. (aannemingsbedrijf) zonder vergunning ter beschikking stellen van arbeidskrachten het feitelijk leidinggeven niet worden bewezen verklaard omdat uit de bewijsmiddelen niet bleek dat de verdachte op de hoogte was dat de v.o.f. geen vergunning had voor het ter beschikking stellen van arbeidskrachten. ${ }^{1161}$ Het ging hier om een delictsomschrijving zonder enig subjectief bestanddeel en er werd evenmin opzet tenlastegelegd. Niettemin moest wel worden voldaan aan het opzetvereiste in hoofde van de feitelijk leidinggever.

Dit is voor milieustrafzaken van groot belang omdat talrijke delicten geen opzet (of culpa) in hun delictsomschrijving kennen. Wordt dus aan een functionaris feitelijk leidinggeven aan een door een gemeente gepleegd abstract gevaarzettingsdelict tenlastegelegd, dan zal toch steeds - of het OM nu heeft gekozen voor de opzetvariant of niet - moeten worden bewezen dat de verdachte op de hoogte was dat de gemeente handelde in strijd met of zonder vergunning. In het (tweede) arrest van het Hof Leeuwarden stelt het Hof dan ook in de Pikmeer-zaak vast dat de ambtenaar op de hoogte was van het feit dat de gemeente voor de illegale slibstort niet beschikte over de vereiste vergunning.

Kortom, het voor de feitelijk leidinggever vereiste opzet moet worden onderscheiden van het opzet van de rechtspersoon. Indien een rechtspersoon een doleus milieudelict heeft begaan, dan dient het te bewijzen opzet zich uit te strekken over alle bestanddelen (van de delictsomschrijving of de tenlastelegging) die door deze schuldvorm worden beheerst. Het opzet van de feitelijk leidinggever dient zich alleen uit te strekken over de kern van het milieudelict.

Wat het beschikkingscriterium betreft, kan worden opgemerkt dat moet worden aangetoond dat de feitelijk leidinggever een zekere mate van zeggenschap moet hebben gehad met betrekking tot de verboden gedraging. Het volstaat vanzelfsprekend niet dat hij zeggenschap heeft gehad met betrekking tot de bedrijfsvoering van de rechtspersoon. Essentieel is weer een verwijtbaar verband met de verboden gedraging. In Slavenburgtermen is hiervan sprake wanneer de functionaris, hoewel daartoe bevoegd en redelijkerwijs gehouden, maatregelen ter voorkoming van de verboden gedragingen achterwege laat. De vereiste zeggenschap of beschikkingsmacht is dus gekoppeld aan een plicht tot het nemen van maatregelen. De band tussen wetenschap (aanvaarden) en zeggenschap (beschikken) wordt zo duidelijk: als een functionaris wetenschap heeft van bepaalde gedragingen en hij heeft daarover ook zeggenschap, dan vloeit daaruit voort dat hij ook de plicht heeft daartegen iets te ondernemen. ${ }^{1162}$

Van belang hierbij is dat voor de vereiste zeggenschap de functionaris niet moet behoren tot de statutaire of wettelijke (bestuurs)organen van de rechtspersoon. Moest dat wel het geval zijn, dan zou het feitelijke leidinggeven eenzijdig worden bepaald (en beperkt) door

1161. HR 23 juni 1987, $N J$ 1988, 44; vgl. Van Elst, R., o.c., 1997, 61.

1162. Vgl. Van Elst, R., o.c., 1997, 63. 
de officiële organen. Er moet dus sprake zijn van een feitelijke beschikkingsmacht. De juridische constructie doet niet ter zake. ${ }^{1163}$

Dit is ook bij feitelijk leidinggeven aan verboden overheidsgedragingen niet zonder belang. Doordat het moet gaan om een feitelijke zeggenschap kan een overheidsfunctionaris (of zelfs een derde) zich niet verschuilen achter de wettelijke bestuursorganen (bijvoorbeeld B en W) teneinde zijn eigen verantwoordelijkheden te ontlopen. Maar omgekeerd zou het ook zo moeten zijn dat bestuursorganen of leden daarvan, bijvoorbeeld een wethouder of een burgemeester, zich niet alleen maar op het ontbreken van politieke en/of juridische zeggenschap over bepaalde personen of activiteiten kunnen beroepen teneinde op die manier hun feitelijke plicht tot het nemen van maatregelen te ontwijken. Wat moet worden beoordeeld is de daadwerkelijke feitelijke beschikkingsmacht van de functionaris, niet slechts zijn juridische of politieke positie binnen de overheidsorganisatie.

Het is interessant in dat verband te verwijzen naar enkele reeds besproken Duitse uitspraken waar burgemeesters, maar ook andere functionarissen, tevergeefs beroep deden op hun beperkte politieke of juridische mogelijkheden om tegen de verboden gedragingen de nodige maatregelen te nemen. ${ }^{1164}$

De vraag rijst welke maatregelen in een concreet geval van een leidinggever kunnen worden verwacht. Hierover bestaat weinig zekerheid. ${ }^{1165}$ Uit enkele milieustrafzaken kan worden afgeleid dat dit grotendeels wordt bepaald door de feitelijke machtspositie van de verdachte en de structuur van de rechtspersoon. Hoe kleiner en doorzichtiger de organisatie, des te eenvoudiger kan feitelijke zeggenschap worden verwacht én vastgesteld. Een voorbeeld is de zaak Tank Cleaning BV. De rechtbank Amsterdam was van oordeel dat feitelijk leidinggeven kon worden bewezen omdat

'Van feitelijke leidinggeven kan worden gesproken als een daartoe bevoegde en redelijkerwijs gehouden functionaris maatregelen ter voorkoming van een verboden gedraging achterwege laat en aldus bewust de aanmerkelijke kans aanvaardt dat de verboden gedraging zich zal voordoen.

Naar het oordeel van de rechtbank is verdachte als een zodanig functionaris aan te merken nu hij, zoals hij zelf verklaard heeft, als enig directeur van Tanker Cleaning Amsterdam BV de algehele leiding en verantwoordelijkheid dragende weliswaar instructie heeft gegeven toestemming te vragen voor de opslag van de oilslobs, maar dit niet heeft gedaan, wetende dat de partij oilslobs er al aan kwam, daarmede bewust het risico aanvaardend dat voor de opslag van de partij de gevraagde vergunning niet zou worden gegeven.

1163. Vgl. HR 16 juni 1981, NJ 1981, 586 (Papa Blanca) en de conclusie van A-G Biegman-Hartogh. 1164. Zie paragraaf 5 van hoofdstuk III.

1165. Van Elst, R., o.c., 1997, 64. 
Daarenboven is de rechtbank van oordeel dat, wanneer het ministerie van Volksgezondheid, Ruimtelijke Ordening en Milieu toestemming geeft tot afwijking van de bepalingen van een bepaalde vergunning, deze toestemming incidenteel van aard is en uitsluitend van toepassing op de situatie waarin de ontheffing is gevraagd. Tanker Cleaning Amsterdam BV mocht er niet op vertrouwen dat voor de opslag van materiaal als hier bedoeld die toestemming zou worden gegeven. ${ }^{1166}$

Gaat het om complexere organisaties dan is het beschikkingscriterium veel lastiger in te vullen en dreigt mogelijk een te vergaande normativering van de plicht tot het nemen van maatregelen. Wie als feitelijk leidinggever in een complexe organisatie kan worden aangemerkt, hangt voornamelijk af van de vraag binnen welke (sub-)afdeling van de organisatie de verantwoordelijkheid ten overstaan van de verboden gedraging het zwaarste doorweegt. Er dient dan zorgvuldig te worden gekeken naar de interne taakverdeling. De vaststelling van het feitelijke zeggenschap zal daarom in de praktijk reeds bij voorkeur moeten gebeuren bij de (opportunititeits)vraag wie van de mogelijk verantwoordelijke functionarissen als strafbare feitelijk leidinggever voor vervolging in aanmerking komt, terwijl dit bij kleine organisaties meestal bij het bewijs pas ter sprake komt omdat daar de leiding meestal samenvalt met het officiële bestuursorgaan. Bij complexe organisaties kunnen echter ver-schillende personen tegelijk feitelijk leidinggever zijn, al naargelang het echelon of de afdeling waarbinnen de hoofdverantwoordelijkheid met betrekking tot de verboden gedraging kan worden gesitueerd. Dat kan in bepaalde gevallen samenvallen met het niveau van de hogere bestuursorganen, maar dat kan zich ook beperken tot feitelijke machtscentra op lagere niveaus van de organisatie. Dit moet per geval worden uitgezocht. Zo zou men zich kunnen afvragen of in de Pikmeer-zaak niet ook de voor de baggerwerkzaamheden bevoegde wethouder als feitelijk leidinggever in aanmerking had kunnen komen. Een positief antwoord op deze vraag hangt vanzelfsprekend af van de concrete feiten van het dossier, maar de kans is niet denkbeeldig dat in casu de vervolgde ambtenaar tot de illegale slibstort heeft kunnen overgaan omdat dit uiteindelijk voor de politiek verantwoordelijken binnen de gemeente goed uit kwam. Kortom, de vraag wie zeggenschap heeft gehad alsook de omvang van de plicht tot ingrijpen zal mijns inziens steeds feitelijk moeten worden beoordeeld en niet enkel normatief.

\section{$\S 10$. Het daderschap van de staat}

\section{A. DE ONDEELBAARHEID VAN 'DE STAAT'}

Aan het Volkel-arrest ${ }^{1167}$ wordt in deze studie vanuit verschillende invalshoeken aandacht besteed. Het machtswoord van de Hoge Raad, dat de staat voor haar gedragingen niet strafrechtelijk aansprakelijk kan worden gesteld, is zowel in rechtstheoretisch (hoofdstuk II) als rechtsvergelijkend perspectief (hoofdstuk III) aan bod gekomen. Ook bij de bespreking van het subjectcriterium (hoofdstuk IV) als in het licht van de argumenten tegen 
een strafrechtelijke aansprakelijkheid van overheden (hoofdstuk V) wordt dieper ingegaan op de staatsimmuniteit. Er is geconcludeerd dat er geen principiële en overtuigende argumenten zijn om de staat in beginsel van de werking van het strafrecht uit te sluiten. Tevens is vastgesteld dat bij de vraag naar een mogelijke strafvervolging en strafbaarheid van de staat steeds een zelfde probleem om de hoek komt kijken: namelijk haar bijna mythische ondeelbaarheid en de daarmee samenhangende concepten als staatssoevereiniteit.

De 'ondeelbaarheid' van de staat speelt het strafrecht voornamelijk parten omdat de strafrechtelijke aansprakelijkheid van overheden via artikel $51 \mathrm{Sr}$ is gekoppeld aan een civielrechtelijk georiënteerd rechtspersoonlijkheidsbegrip. Het is de rechtspersoon 'de staat' die moet worden vervolgd indien binnen haar organisatie door een andere 'entiteit', die geen rechtspersoonlijkheid bezit, een strafbaar feit wordt begaan. Er is dan ook betoogd dat voor een strafrechtelijke aanpak en controle van publiekrechtelijke organisaties, die tot 'de staat' behoren, rechtsstatelijk realisme moet primeren. Dit betekent dat men de strafrechtelijke blik niet langer op de rechtspersoonlijkheid van de staat dient te richten, maar op de publiekrechtelijke organisaties, die als zelfstandige strafrechtelijke rechtssubjecten moeten worden beschouwd.

Dat het inderdaad wenselijk is om vanuit strafrechtelijk oogpunt de civielrechtelijke sluier van de staat te doorprikken, kan nu verder worden verdedigd en verduidelijkt door nader stil te staan bij het daderschap van de staat, in de veronderstelling dat deze vervolgbaar zou zijn. Meteen wordt zo opnieuw duidelijk dat het voornaamste bezwaar tegen een strafrechtelijke aansprakelijkheid van de staat niet zozeer ligt op het niveau van de vervolgbaarheid, maar veeleer op het vlak van de aansprakelijkheid zelf. ${ }^{1168}$

\section{B. DADERSCHAPSCRITERIA VOOR DE STAAT?}

In de literatuur wordt de staat veelal vergeleken met een concern of een multinational. Wanneer we het toenemend bedrijfsmatig karakter van het overheidshandelen voor ogen houden, gaat deze vergelijking zeker op. ${ }^{1169}$ Maar in tegenstelling tot een multinational ontberen de meeste 'dochterondernemingen' van de centrale overheid eigen rechtspersoonlijkheid, zodat deze niet voor daderschap in aanmerking komen. Brants merkt hierover op:

'Waar de dochterondernemingen van een multinational als functionele eenheden met eigen rechtspersoonlijkheid zijn bekleed en ieder voor zich als dader kunnen worden aangemerkt, is dat bij de staat maar ten dele het geval. Daar worden de ministeries en een zeer groot aantal organisaties, diensten en andere entiteiten, die uiteindelijk onder het overkoepelend gezag van de verschillende departementen vallen en aan wie al dan niet

1168. Wel moet in herinnering worden gebracht dat niet helemaal duidelijk is of de Hoge Raad nu de vervolgbaarheid of de verantwoordelijkheid van de staat heeft uitgesloten. Het arrest kan ook worden uitgelegd als een uitsluiting van strafrechtelijke verantwoordelijkheid zodat om die reden het OM niet ontvankelijk is verklaard. Vgl. Brants, Chr., 'The King can do no wrong. Daderschap, feitelijk leidinggeven en de staat', 1996, 511-513.

1169. Vgl. De Lange, A., l.c., 1995, 441; Fransen, A.M., L.c., 1997, 15. 
gedelegeerde beslissingsmacht op allerlei gebied en eigen beheersbevoegdheid zijn toebedeeld, allemaal gedekt door de paraplu van die ene rechtspersoon "de staat" "1170

Indien nu het daderschap van de staat zou moeten worden vastgesteld, staan we voor een onoverkomelijk obstakel. We krijgen dan immers te maken met een gigantische complexe organisatie, de grootste rechtspersoon die we in Nederland kennen. Reeds is besproken hoe lastig het kan zijn om, mede in het licht van het schuldbeginsel, voor complexe organisaties bruikbare daderschapscriteria uit te denken. De zoektocht naar zinvolle daderschapscriteria wordt bij de staat op de spits gedreven.

Nu moet wel worden bemerkt dat niet in alle gevallen het daderschap van de staat moeilijkheden hoeft op te leveren. Dit hangt grotendeels af van het type delict dat is begaan en dat wordt tenlastegelegd. Beperken we ons tot de hierboven besproken milieudelicten, dan kunnen we stellen dat het daderschap van de staat bij overtreding van de abstracte gevaarzettingsdelicten vrij eenvoudig zou kunnen worden vastgesteld. Het enige dat het OM moet bewijzen is niet meer dan de materiële inbreuk, te weten dat er is gehandeld zonder of in strijd met een vergunning. De strafrechter zou dan het daderschap kunnen bewezen verklaren aan de hand van het in het Furazolidon-arrest gebruikte bedrijfsvoeringscriterium. ${ }^{1171}$ Is het abstracte gevaarzettingsdelict, bijvoorbeeld lozen in strijd met een Wvo-vergunningsvoorschrift, begaan binnen de normale bedrijfspolitiek, dan is er sprake van daderschap. Maar zelfs bij deze delicten kunnen er zich problemen voordoen. Er kan immers door 'de staat' een schuldverweer (a.v.a.s.) worden gevoerd, hetgeen impliceert dat dieper en ook feitelijker op het daderschap van de staat zal moeten worden ingegaan. Dan wreekt zich alsnog de complexiteit van de staat, opgevat als één rechtspersoon. De vraag rijst immers hoe dit schuldverweer inhoudelijk moet worden beoordeeld. De discussie zal zich in zo'n geval hoofdzakelijk concentreren rond de zorgplicht die door de staat had moeten worden nageleefd, de maatregelen die redelijkerwijs ter vermijding van het delict hadden moeten worden genomen. Neemt men de gehele organisatie van de staat als vertrekpunt, dan wordt de vraag naar de gevergde maatregelen zeer abstract en moeilijk te beantwoorden. Indien men het schuldverweer werkelijk ernstig wil nemen, dan moet worden bekeken op welk niveau binnen de organisatie de zorgplicht van toepassing is, wie deze in concreto had moeten naleven en tenslotte of de schending van de zorgplicht aan de

1170. Brants, Chr., l.c., 1996, 520; zie ook Brants, Chr. en De Lange, R., o.c., 1996, 47.

1171. Ook Brants acht dit criterium in sommige gevallen op 'staatsniveau' bruikbaar (zie Brants, Chr., l.c., 1996, 522 e.v.) Zij plaatst dit citerium evenwel binnen de Izerdraadcriteria: beschikken en aanvaarden. Het bedrijfsvoeringscriterium zou volgens haar een toepassing zijn van het aanvaarden door een rechtspersoon. Ik ben het daar niet helemaal mee eens. Op die manier kan men bijna alle criteria onder de Uzerdraadcriteria plaatsen, mits men deze maar ruim genoeg interpreteert. Juist vanwege het gevaar dat Uzerdraadcriteria te zeer worden genormativeerd of geobjectiveerd ben ik voorstander van een bij voorkeur subjectieve invulling van deze criteria, zodat zij hun sturend en rechtsbeschermend vermogen kunnen behouden in die gevallen waar ze wel bij uitstek toepasselijk zijn, zoals bij delicten gepleegd door een natuurlijke persoonfunctioneel dader, bij het feitelijke leidinggeven en bij doleuse delicten begaan door kleine rechtspersonen met een transparante organisatorische structuur en besluitvorming. Zie paragraaf 3 van dit hoofdstuk. 
staat als dusdanig kan worden toegerekend. Dat zijn lastige vragen. Richt men de blik naar de top van de staatsorganisatie, dan moet worden bewezen dat de topambtenaren een zorgplicht hebben geschonden en dus niet de nodige maatregelen hebben genomen ter voorkoming van de verboden gedraging. Indien het strafbaar feit echter is gepleegd binnen een overheidsdienst die ver is verwijderd van de departementele leiding, stuit men op het probleem dat men niet redelijkerwijs kan verwachten dat op het centrale niveau steeds geweten is wat er op de lagere echelons plaatsvindt. Zelfs indien men dat zou eisen of mogen verwachten, moet nog steeds in concreto worden bekeken welke maatregelen genomen hadden moeten worden. De te nemen maatregelen beperken zich in de praktijk meestal tot instructies of controleprocedures, maar de uitvoering daarvan is niet altijd in handen van diegenen die ze uitvaardigen. Het is dan denkbaar dat het a.v.a.s. verweer vlug wordt gehonoreerd, eens duidelijk is gemaakt dat door de lagere publiekrechtelijke organisatie in strijd met departementele instructies is gehandeld.

Zijn abstracte gevaarzettingsdelicten reeds enigszins problematisch, dan is dat voor de andere milieudelicten nog meer het geval. Neem artikel $13 \mathrm{Wbb}$, dat in de Volkel-casus (toen nog artikel $14 \mathrm{Wbb}$ ) als overtreding werd tenlastegelegd. Wat onder meer moet worden bewezen, zijn de in deze zorgplichtbepaling opgenomen subjectieve bestanddelen, meer bepaald het 'redelijkerwijs had kunnen vermoeden'. Zoals gezien is het op het niveau van de vliegbasis zelf niet zo moeilijk vast te stellen of dit bestanddeel is vervuld. Men kan verdedigen dat door de vliegbasis een Sicherungs- of Beherschungspflicht is geschonden. ${ }^{1172}$ Maar er is dan eigenlijk slechts schuld aangetoond op een lager niveau en binnen de organisatie waar de verboden gedraging zich heeft voorgedaan. Voor daderschap van de staat lijkt mij echter meer vereist. Wat moet worden bewezen is schuld in hoofde van de rechtspersoon als geheel. Kan men dan volstaan met het automatisch toerekenen van deze schuld aan de rechtspersoon zelf? Ik meen van niet. Er is in zo'n geval nauwelijks sprake van een 'verwijtbaarheids-verband' tussen de centrale organisatie van de rechtspersoon (het departement, de ministers en staats-secretarissen) en zijn sub-onderdelen. Zo wordt het trouwens ook maatschappelijk niet waargenomen. ${ }^{1173}$ Wie in zo'n geval de strafwet heeft overtreden is niet de staat, maar één van zijn diensten. Bovendien zou de staat de uiteindelijke sanctie krijgen opgelegd, meestal toch een geldboete, terwijl het vanuit sturingsperspectief wellicht geen slecht idee zou zijn indien deze ook daadwerkelijk aan het organisatieonderdeel zelf wordt opgelegd. ${ }^{1174}$

Wordt aan de staat een doleus milieudelict, of wellicht zelfs een commuun delict als dood door schuld tenlastegelegd, dan lijkt mij daderschap in hoofde van de staat een moeilijke constructie, tenzij het gaat om strafbare feiten die op departementeel niveau zijn gepleegd. Zelfs indien men het opzet via een of andere vorm van bedrijfsvoeringsschuld zou willen

1172. Zie hierover meer in het bijzonder hoofdstuk III.

1173. Vgl. Fransen, A.M., l.c., 1997, 15.

1174. Hoewel dat op zich nog geen onoverkomelijk probleem hoeft op te leveren omdat ook binnen andere rechtsgebieden een 'sanctie' of het betalen van een schadevergoeding aan de publiekrechtelijke rechtspersoon wordt opgelegd terwijl het de bestuursorganen of andere publiekrechtelijke organisaties zijn die feitelijk de rechtsregels hebben geschonden. Zie bijvoorbeeld de regeling van artikel 8:72 Awb e.v. 
bewijzen, zal toch meestal deze schuldvorm slechts bij het organisatie-onderdeel waarbinnen het feit zich heeft voorgedaan zelf aanwezig zijn (bijvoorbeeld in de vorm van een stelselmatig disfunctioneren) en niet ook bij de staat als geheel. Anders gezegd, men kan moeilijk het organisatorische falen van één bepaalde dienst of sub-organisatie aan de staat als geheel toeschrijven.

Indien men, ondanks deze problemen, voor de invulling van een strafrechtelijke aansprakelijkheid toch wil vasthouden aan de 'rechtspersoonlijkheid' van de staat, zou men kunnen overwegen om niet de staat zelf te vervolgen, maar een feitelijk leidinggever. Dat zou dan zelfs strafrechtsdogmatisch mogelijk zijn indien de staat onvervolgbaar blijft. Is dit een werkbare oplossing?

\section{FEITELIJK LEIDINGGEVEN BINNEN DE STAAT}

In de literatuur is de vraag geopperd of iemand als feitelijk leidinggever voor een door de staat gepleegd strafbaar feit zou kunnen worden aansprakelijk gesteld. ${ }^{1175}$ Dit is slechts mogelijk indien aan een aantal voorwaarden is voldaan. In de eerste plaats moet de staat zelf dader zijn. Het feitelijk leidinggeven is accessoir an het daderschap van de rechtspersoon. Indien we ervan uitgaan dat de staat pleger van een strafbaar feit kan zijn en door de Hoge Raad dus slechts de vervolgbaarheid is uitgesloten, rijst de vraag of de staatsimmuniteit zich niet evenzeer uitstrekt tot haar leidinggevers. Dat zou de logische consequentie zijn indien we de in Pikmeer I geformuleerde rechtsregel voor ogen houden. Men kan volhouden dat de vervolgbaarheid van rechtspersoon en feitelijk leidinggever zo nauw met elkaar zijn verbonden dat de omstandigheid dat de staat zelf niet kan worden vervolgd omdat deze voor haar gedragingen niet strafrechtelijke aansprakelijk kan worden gesteld, meebrengt dat een strafvervolging evenmin kan worden ingesteld tegen ambtenaren en arbeidscontracten in dienst van de staat, indien deze in die hoedanigheid opdracht hebben gegeven tot of feitelijk leiding hebben gegeven aan de verboden gedraging.

Zelfs indien de feitelijk leidinggever wel vervolgbaar zou zijn, moet een aantal obstakels worden overwonnen. In de eerste plaats moet worden bepaald wie als feitelijk leidinggever binnen de rechtspersoon van de staat kan worden aangemerkt. Is een strafbaar feit gepleegd door een min of meer zelfstandige overheidsdienst, zoals een havenbedrijf of een grondbedrijf, ligt het voor de hand de feitelijk leidinggever niet op departementeel niveau te zoeken, maar binnen zijn eigen organisatie. Maar kan men dan nog beweren dat het gaat om feitelijk leidinggeven aan een gedraging door de staat verricht? Dit is een gewrongen constructie. Zoekt men daarentegen de feitelijk leidinggever op het centrale niveau, dan zal de toepassing van de Slavenburg-criteria een lastige opgave worden. Wat moet worden bewezen is dat de feitelijk leidinggever, bijvoorbeeld een topambtenaar binnen het ministerie van defensie, wetenschap had van en zeggenschap over de verboden gedragingen verricht door de dienst, bijvoorbeeld een militaire vliegbasis, waarbinnen het delict is gepleegd. Bij de Volkel-casus zou dit theoretisch nog mogelijk zijn omdat de

1175. Zie Brants, Chr. en De Lange, R., o.c., 1996, 52 e.v.; Van Veen, Th.W. 'De strafrechtelijke aansprakelijkheid van de overheid', RMThemis, 2000, 163 e.v. 
staat(secretaris) reeds twee maal een transactie had betaald voor soortgelijke feiten en hij moeilijk kan ontkennen dat hij van de strafbare feiten niet op de hoogte was. Maar ik acht het weinig opportuun in een dergelijk geval een topambtenaar als leidinggever te vervolgen, indien de feitelijke verantwoordelijkheid in relatie tot het delict het zwaarst bij de leiding van de deelorganisatie doorweegt.

Kortom feitelijk leidinggeven is niet een bruikbaar alternatief voor de onvervolgbaarheid van de staat, of voor de moeilijkheden die rijzen bij het daderschap van de staat, eens deze wel vervolgbaar zou zijn. Bovendien zou een concentratie op de vervolging van de feitelijk leidinggever de aandacht te veel verleggen van de verantwoordelijkheid van de betrokken overheidsorganisatie zelf naar de individuele verantwoordelijkheid van bepaalde natuurlijke personen. Dit denatureert niet slechts de rechtsfiguur van het feitelijk leidinggeven, maar doet ook geen recht aan de collectieve verwijtbaarheid die aan de door overheidsorganisaties gepleegde delicten veelal ten grondslag ligt. Er blijft mijns inziens dan ook maar één oplossing over, namelijk de publiekrechtelijke deelorganisaties, die opereren binnen 'de staat', erkennen als zelfstandige strafrechtelijke rechtssubjecten.

\section{AFSCHEID VAN DE RECHTSPERSOONLUKHEID VAN DE STAAT IN HET STRAFRECHT?}

Teneinde de civielrechtelijke sluier van de staat te kunnen doorbreken, moet eerst worden bekeken wat de precieze lading is van het begrip 'rechtspersoon' in artikel $51 \mathrm{Sr}$. Er zijn grosso modo twee interpretaties mogelijk van de term 'rechtspersoon' in strafrechtelijke zin: een civielrechtelijke en een meer autonome interpretatie.

De meest aanvaarde uitleg sluit aan bij het civiele recht, zoals onder meer door Remmelink ${ }^{1176}$ en Strijards ${ }^{1177}$ is bepleit. Deze benadering is ook gevolgd door de wetgever, toen de strafrechtelijke aansprakelijkheid van de rechtspersoon in het Wetboek van Strafrecht werd ingevoerd. In de MvT bij artikel $51 \mathrm{Sr}$ wordt gesteld:

'Door de rechtspersoon strafbaar te stellen knoopt het strafrecht aan bij een civielrechtelijk begrip. Een voor een bepaald doel juridisch georganiseerde entiteit wordt voor het recht gelijkgesteld met een natuurlijke persoon $^{1178}$

Wel moet worden opgemerkt dat aansluiting bij het civiele recht niet altijd consequent wordt gevolgd. Zo worden in artikel 51 lid 3 met de 'rechtspersoon' gelijkgesteld de personenvennootschappen, de rederij en het doelvermogen. ${ }^{1179}$ Daarnaast wordt naast deze wettelijke afwijking ook in de praktijk soms afgeweken van het civiele recht. Zo dient volgens Remmelink het strafrecht niet gebonden te zijn aan civielrechtelijke nulliteiten. ${ }^{1180}$

1176. Remmelink, J., o.c., 1995, 145.

1177. Strijards, G.A.M., o.c., 1988, 66 e.v.

1178. TK 1975-1976, 13655 , nr. 1-3, 8.

1179. Zie hierover Van Strien, A.L.J., o.c., 1996, 32-33.

1180. Remmelink, J., o.c., 1995, 146. 
Tot slot is ook het civielrechtelijke begrip rechtspersoon ruimer dan men op het eerste gezicht zou denken, hetgeen impliceert dat ook de 'rechtspersoon' in het strafrecht meer dekt dan de in het BW genoemde rechtspersonen. Van Strien wijst erop dat bepaalde organisaties met een lage organisatorische ontwikkeling, zoals krakersgroepen, in het civiele recht als 'informele vereniging' kunnen worden beschouwd. ${ }^{1181}$

Een belangrijk bezwaar tegen de civielrechtelijke benadering is dat de ratio's van civielrechtelijke rechtspersoonlijkheid weinig uitstaans hebben met strafrechtelijke doelstellingen. De rechtspersoonlijkheid heeft als hoofddoel een organisatie -privaat of publiekde mogelijkheid te geven net als een natuurlijke personen aan het civielrechtelijke rechtsverkeer deel te kunnen nemen. ${ }^{1182}$ Voor het strafrecht gaat het in de eerste plaats om de vraag wie verantwoordelijk moet kunnen worden gesteld voor gepleegde delicten en niet om wie civielrechtelijk rechten en plichten dient te hebben. Dit pleit ervoor om bij een strafrechtelijke aansprakelijkheid niet steeds blind te varen op de civielrechtelijke constructie van de organisatie, maar om veeleer de maatschappelijke realiteit als uitgangspunt te nemen. Voor publiekrechtelijke organisaties wil dit zeggen dat het voor een strafrechtelijke aansprakelijkheid niet doorslaggevend zou mogen zijn of deze nu rechtspersoonlijkheid heeft of niet. De enige mogelijkheid om tot een dergelijke strafrechtsdogmatische constructie te komen, bestaat er dan ook in een autonome invulling te geven aan het begrip rechtspersoon van artikel $51 \mathrm{Sr}$.

Een autonome strafrechtelijke benadering van het begrip 'rechtspersoon' laat de civielrechtelijke koppeling volledig los. Uitgangspunt is dat het begrip rechtspersoon op een zodanige wijze dient te worden uitgelegd dat het in staat is de doelstellingen van het strafrecht naar behoren te effectueren. Hierboven is reeds duidelijk geworden dat een loskoppeling van het civielrechtelijke rechtspersoonlijkheidsbegrip bij de strafrechtelijke aanpak van overheidscriminaliteit grote voordelen zou hebben. Niet alleen voor de staat, maar ook bij andere complexe overheidsorganisaties, zoals grote gemeenten of zelfs universiteiten, zou dit een aantal aansprakelijkheidsvraagstukken kunnen oplossen. Uit de analyse van het Rijksuniversiteit Groningen-arrest bleek reeds dat het daderschap van een universiteit soms moeilijk bewezen zal kunnen worden indien er een te grote beschikkingskloof is tussen bijvoorbeeld een faculteit (of een onderzoeksschool) en de centrale organen van de universiteit, de Universiteitsraad en het College van Bestuur.

Het nadeel van de autonome benadering is evenwel dat moet worden bepaald hoever de interpretatie van het begrip 'rechtspersoon' dient te gaan. Problematisch is immers dat de grenzen van de strafrechtelijke aansprakelijkheid van de rechtspersoon zodanig worden verruimd, dat vrijwel iedere groepering daaronder zou kunnen vallen. Zo meent Demeersseman, een groot voorstander van de autonomie van het strafrecht, dat onder rechtspersoon in strafrechtelijke zin moet worden verstaan alle samenwerkingsverbanden 
met een zekere duurzaamheid. ${ }^{1183}$ Dat gaat volgens mij te ver. Een dergelijke ruime interpretatie creëert onzekerheid over welke entiteiten nu precies onder de werking van het strafrecht vallen en welke niet. Dit staat op gespannen voet met het legaliteitsbeginsel. Burgers, die in samenwerkingsverband werkzaam zijn, dienen op voorhand te weten of zij onder het toepassingsgebied van artikel $51 \mathrm{Sr}$ vallen. Daarnaast wordt de afbakening met artikel $140 \mathrm{Sr}$ wel heel vaag. Vermeden moet worden dat 'de rechtspersoon' zo wordt opgerekt dat er nauwelijks nog een verschil is met een criminele organisatie. Beide artikelen dienen hun eigen criteria van toepasselijkheid te behouden. Van Strien neemt om die reden dan ook een meer realistische en zinvolle tussenpositie in. Zij pleit net als Demeersseman voor een autonome benadering, maar begrenst duidelijker de interpretatie van het begrip rechtspersoon. Vertrekpunt dient te zijn of een samenwerkingsverband als zelfstandige maatschappelijke groepering of entiteit gekenmerkt wordt door een zodanige organisatorische structuur en besluitvorming dat zij zowel intern als naar buiten toe kan worden geacht schuldbekwaam te zijn:

\section{'(...) Samenwerkingsverbanden kunnen m.i. alleen als "rechtspersoon" worden aangemerkt, wanneer deze een tamelijk ver ontwikkelde organi- satie hebben. Er dient minimaal beschikkingsmacht te zijn over de kwestie welke personen of instanties bevoegd zijn bepaalde besluiten te nemen en welke procedure bij deze besluitvorming moet worden gevolgd. Deze zeggenschap hoeft niet gebaseerd te zijn op regels die op schrift zijn gesteld, zij kan ook steunen op feitelijke gebruiken. Verder moeten er ook door leden van de organisatie onderlinge afspraken zijn gemaakt over de taakverdeling ${ }^{\prime 184}$}

Wat kan dit betekenen voor de staat (of andere complexe publiekrechtelijke rechtspersonen)? Een bruikbaar uitgangspunt lijkt mij dat moet worden bekeken of de publiekrechtelijke rechtspersoon bestaat uit sub-organisaties die maatschappelijk gezien zodanig zijn opgebouwd dat zij een eigen beschikkingsmacht en besluitvorming hebben. $\mathrm{Zij}$ kunnen in die zin als zelfstandige strafrechtelijke 'rechtspersonen' worden beschouwd. Het ligt dus veel meer voor de hand om de aansprakelijkheid (en het daderschap) binnen de functionele entiteiten die tot de rechtspersoon van de staat behoren te situeren. Voor publiekrechtelijke rechtspersonen is dit zelfs vrij makkelijk toe te passen door eenvoudig de publiekrechtelijke rechtssubjecten binnen de rechtspersoon als uitgangspunt te nemen en niet alleen maar de civielrechtelijke rechtssubjectiviteit (de rechtspersoonlijkheid). Het zijn immers deze publiekrechtelijke organisaties die men wil sturen en wiens gedrag men strafrechtelijk moet beoordelen.

De vraag rijst of hiervoor een wetswijziging noodzakelijk is. Of is het aan de strafrechter om publiekrechtelijke organisaties, die naar het civiele recht geen rechtspersoonlijkheid kennen, aan te merken als 'rechtspersonen'. Volgens van Strien zou artikel $51 \mathrm{Sr}$ een

1183. Demeersseman, H.A., De autonomie van het materiële strafrecht, Arnhem, 1985, 47 e.v. Zie tevens Van Strien, A.L.J., o.c., 1996, 32.

1184. Van Strien, A.L.J., o.c., 1996, 43. 
autonome interpretatie door de strafrechter niet in de weg staan. Hoewel ik mij in een aantal door haar aangevoerde argumenten kan vinden, lijkt mij een wetswijziging toch wenselijk. ${ }^{1185}$ In de eerste plaats is er de wetsgeschiedenis. Zoals bovenstaande aanhaling uit de MvT bij artikel $51 \mathrm{Sr}$ reeds aantoont, ging de wetgever van een civielrechtelijke benadering uit. Dat blijkt ook uit de redactie van het artikel zelf. Indien het begrip rechtspersoon een autonome betekenis zou hebben, dan had de wetgever geen uitbreiding via artikel 51 derde lid moeten aanbrengen. Het argument van van Strien dat 'de wil van de wetgever' ons niet per se hoeft te binden, is tot op zekere hoogte overtuigend, maar hier gaat het wel om een zeer belangrijke kwestie, die tot een aanzienlijke vemuiming van het aantal rechtssubjecten kan leiden die onder de werking van de strafwet kunnen vallen. Dat de wetgever zich in 1976 zich niet voldoende heeft gerealiseerd dat in het strafrecht andere overwegingen relevant zouden kunnen worden, dan de civielrechtelijke ratio's die aan de rechtspersoonlijkheid ten grondslag liggen, is nog geen reden om thans een legislatieve aanpassing van artikel $51 \mathrm{Sr}$ achterwege te laten, te meer nu in relatie tot het vraagstuk van de strafrechtelijke aansprakelijkheid van overheden de wetgever zich ondertussen wel degelijk bewust is geworden van de problematiek. Daarom geef ik de voorkeur aan een wijziging van artikel $51 \mathrm{Sr}$ door een nieuw vierde lid in te voeren, dat tot doel heeft publiekrechtelijke organisaties die geen eigen rechtspersoonlijkheid kennen, maar wel als een zelfstandige entiteit kunnen worden beschouwd gelijk te schakelen met de rechtspersoon als bedoeld in het eerste lid. ${ }^{1186}$

\section{$\S 11$. Conclusies}

In dit hoofdstuk staat het daderschap van overheden voor milieuverstoring centraal. Duidelijk is geworden dat het niet mogelijk, noch wenselijk is één algemeen geldend daderschapscriterium uit te denken op basis waarvan een publiekrechtelijke (of privaatrechtelijke) rechtspersoon voor milieuverstoring strafrechtelijk aansprakelijk kan worden gesteld. Wil men het rechtspersoonlijke daderschap werkelijk ernstig nemen dan zal men rekening moeten houden met zowel de instrumentele als met de rechtsbeschermende dimensie van het strafrecht. In de praktijk betekent dit dat men expliciet van geval per geval moet kijken naar de aard van de organisatie en het type milieudelict dat in een concreet geval wordt tenlastegelegd. Wat zeker moet worden vermeden, is een objectieve aansprakelijkheid of een aansprakelijkheid waarvan de toerekeningscriteria dusdanig worden geobjectiveerd, dat hun toepassing feitelijk nog maar weinig verschilt van de verworpen leer van de materiële inbreuken. Het gevaar is steeds aanwezig dat de strafrechter naar een sociaal wenselijke uitkomst toe redeneert waardoor niet alleen onrecht wordt gedaan aan de klassieke rechtswaarborgen, maar waarbij het strafrecht ook zijn sturende werking dreigt te verliezen. $^{1187}$

Gelet op de sterke administratieve afhankelijkheid van het milieustrafrecht zijn veel milieudelicten abstracte gevaarzettingsdelicten. Als deze als overtreding worden tenlastegelegd, 
betekent dit dat meestal kan worden volstaan met geobjectiveerde daderschapscriteria. Daarbij is het van belang dat bewijsrechtelijk rekening wordt gehouden met de eigen verantwoordelijkheidssfeer van de rechtspersoon als onderscheiden van die van de daarin werkzame natuurlijke personen. De corporatieve 'schuld' moet uit de concrete bewijsmiddelen blijken, wil men niet afglijden naar een risico-aansprakelijkheid waarbij alles dat binnen de organisatie fout gaat ook automatisch aan de organisatie wordt toegerekend. Kortom, bij de milieuovertredingen kan vrij snel het rechtspersoonlijk daderschap worden aangenomen. Dat aan het schuldvereiste vlug is voldaan heeft niet alleen te maken met de op dit punt eenvoudige delictsomschrijvingen, maar ook met het functionele karakter van de materiële bestanddelen van deze delicten. Zij verwijzen naar sociaaleconomische zorgvuldigheidsnormen waarvan over het algemeen kan worden verwacht dat zij in hoofde van rechtspersonen gekend zijn, hoewel bijvoorbeeld bij zorgplichtbepalingen de kenbaarheid van deze normen veel te wensen overlaat. Deze zijn dermate vaag omschreven dat het tekort op het vlak van de materiële strafbaarheidsvoorwaarden bewijsrechtelijk moet kunnen worden gecompenseerd. Daar is een belangrijke taak weggelegd voor de strafrechter.

Wat de commune delicten betreft, die in geval van milieuverstoring in aanmerking kunnen komen, dienen over het algemeen strengere eisen te worden gesteld aan het rechtspersoonlijke daderschap. Deze delicten zijn immers minder functioneel (sociaal-economisch) gekleurd dan de (meeste) milieudelicten. Zij zijn, met andere woorden, minder op rechtspersoonlijk handelen toegesneden. Daarnaast kennen zij, net als de artikelen 173a en 173b $\mathrm{Sr}$, bijzondere subjectieve bestanddelen, die door het openbaar ministerie moeten worden bewezen. Wil men recht doen aan het schuldbeginsel en het sturingspotentieel van het strafrecht, dan moet bij commune delicten een subjectieve benadering van het daderschap voorop staan. Welk daderschapscriterium in een concreet geval moet worden toegepast hangt ook hier af van de aard van het delict en het type rechtspersoon. Voor commune culpose delicten, zoals dood of zwaar lichamelijk letsel door schuld, moet worden vermeden dat alles wat tijdens de bedrijfsvoering gebeurt automatisch aan de rechtspersoon wordt toegerekend. Gaat het om complexe organisaties en in tijd gespreide risicovolle activiteiten dan kan het daderschap van de rechtspersoon worden gefundeerd op de feitelijke bedrijfsvoeringsschuld, de 'Lebensführungsschuld' van de organisatie, mits deze maar uit de concrete bewijsmiddelen blijkt. Bij kleine of meer transparante organisaties kan in de meeste gevallen worden volstaan met de IJzerdraadcriteria onder de voorwaarde dat zij niet uitsluitend normatief worden ingevuld.

Afzonderlijk aandacht verdient het daderschap van de staat. Een steeds weer terugkerend probleem is dat het strafrecht stuit op de rechtspersoonlijkheid van de staat als uitgangspunt voor strafrechtelijke aansprakelijkheid. Dit strookt niet met de maatschappelijke werkelijkheid en houdt bovendien de argumenten tegen aansprakelijk-heid van de staat onnodig in stand. Een betere oplossing zou erin bestaan de aandacht te richten op die publiekrechtelijke entiteiten, die binnen de staat een eigen organisatorische verantwoordelijkheidssfeer hebben, en die om zuiver buitenstrafrechtelijke redenen geen rechtspersoonlijkheid kennen en daardoor onder de rechtspersoon van de staat vallen. Een wetswijziging is daartoe wel aangewezen. 


\section{Wederrechtelijke vergunningverlening}

\section{§1. Inleiding}

Zoals reeds is uiteengezet, berust een belangrijk argument voor een strafrechtelijke aansprakelijkheid van overheden en hun functionarissen bij de administratieve afhankelijkheid van het milieustrafrecht. Vooral in de Duitse literatuur wordt de Verwaltungsaktsakzessorietät van het milieustrafrecht gezien als een hinderpaal voor een succesvolle strafrechtelijke handhaving van het milieurecht. Milieuoverheden beschikken over een grote verantwoordelijkheid bij het bepalen van de grenzen van de strafbaarheid. De strafbaarheid is namelijk in veel gevallen beperkt tot inbreuken op administratiefrechtelijke plichten en de naleving van de vergunningsvoorwaarden wordt veelal als een kwalificatieuitsluitingsgrond of strafuitsluitingsgrond beschouwd. ${ }^{1188}$ Dit brengt met zich mee dat de bij de vergunningverlening betrokken overheden en functionarissen de milieuverstoring mee kunnen veroorzaken indien zij in strijd met wet en recht zeer soepele vergunningsvoorwaarden zouden voorschrijven. In dergelijk geval worden grotere emissies dan vanuit milieuhygiënisch oogpunt verantwoord zou zijn, gerechtvaardigd door een foutief optreden van de overheid.

Omdat overheden een cruciale rol spelen bij het bepalen van de toelaatbare graad van milieuverstoring, rijst de vraag in hoeverre overheden en functionarissen strafrechtelijk aansprakelijk kunnen worden gesteld voor de als gevolg van onzorgvuldige vergunningverlening veroorzaakte milieuschade. In dat verband kan nog worden opgemerkt dat het probleem vooral rijst wanneer men aanneemt dat de vergunning een absoluut strafuitsluitende werking heeft voor milieuverstoring. Zoals hierna zal blijken, is dit onder meer in de Duitse Bondsrepubliek het geval (daar is het de rechter in beginsel niet

1188. Bemerk dat de strafuitsluitende werking van de vergunning verschillende vormen kan aannemen al naargelang de vergunning bestanddeel uitmaakt van de delictsomschrijving. Indien de vergunning een delictsbestanddeel is, zoals bij de meeste abstracte gevaarzettingsdelicten, is het handelen conform een vergunning bestanddeel- of kwalificatieuitsluitend. Is dat niet het geval, dan gaat het om een rechtvaardigingsgrond. Dit heeft ook gevolgen voor de bewijspositie in het strafproces. Het OM moet de bestanddelen ten laste leggen en bewijzen, wil de rechter kunnen kwalificeren. De rechtvaardigingsgronden worden door de verdediging aangevoerd. Zie hierover o.m. Buiting, Th.J.B., Strafrecht en milieu, Arnhem, Gouda Quint, 1993, 45-71. 
toegestaan de vergunning te toetsen) en daarom is het ook begrijpelijk dat door sommige auteurs, waaronder Tiedemann en Immel, wordt voorgesteld om in de wetgeving uitdrukkelijk voor te schrijven dat de milieustrafbepalingen ook op foutieve vergunningverlening toepasselijk zijn. ${ }^{1189}$ Een strafrechtelijke aansprakelijkheid van de vergunningverlenende instanties zou dan kunnen gelden als een correctief op de straffeloosheid van de milieuverstoorder en de dreiging van een mogelijke strafrechtelijke sanctie zou de milieuoverheden prikkels moeten geven voor een meer zorgvuldige vergunningverlening. ${ }^{1190}$ Bemerk evenwel dat een strafrechtelijke aansprakelijkheid niet alleen van betekenis kan zijn in gevallen waar de vergunningverlenende overheden zelf, door het niet naar behoren vervullen van hun verantwoordelijkheden, bijdragen tot het veroorzaken of instandhouden van een ontoelaatbare graad van milieuverstoring. De strafbaarheid kan zich mogelijk ook uitstrekken tot instanties en personen die een rechtstreekse invloed uitoefenen op de totstandkoming van de inhoud van een vergunning. Zo kan het bestuur bij het bepalen van de vergunningsvoorwaarden van met name complexe installaties of situaties de hulp inroepen van deskundigen, zoals ingenieursbureaus. De ingeschakelde, vaak particuliere instantie handelt dan in opdracht van de vergunningverlenende overheid. Het komt zelfs voor dat instanties met technische expertise in opdracht van de vergunningplichtige onderneming handelen en aan de vergunningverlenende overheid een conceptvergunning leveren. ${ }^{1191} \mathrm{Het}$ spreekt voor zich dat zowel het bedrijf als de ingeschakelde instantie duidelijk belang hebben bij het verkrijgen van de nodige vergunning en dat het risico aanwezig is dat de vergunningsvoorwaarden zo gunstig mogelijk worden voorgesteld met het oog op het bedrijfsbelang. Indien het bestuur vervolgens de aangeleverde conceptvergunning als uitgangspunt neemt, kan bij de afweging van alle relevante belangen in een vergunningprocedure het belang van het bedrijfsleven zeer zwaar doorwegen en dit ten koste van andere belangen zoals het milieubelang of de veiligheid. ${ }^{1192}$ Het advies van externe deskundigen heeft immers een beslissende invloed op de inhoud van de vergunning en dus ook op de strafrechtelijk afdwingbare voorschriften. Het is dan best denkbaar dat een foutieve vergunningverlening noopt tot een strafbaarheid van deze bij de vergunningverlening betrokken externe instanties, indien zij mede verantwoordelijk zijn voor de onrechtmatige inhoud van de vergunning en dus ook voor de daardoor veroorzaakte milieuverstoring. Het eigenaardige is dan wel dat in een dergelijk geval de vergunningverlenende overheid zich veelal zal kunnen beroepen op de strafrechtelijke immuniteit omdat vergunningverlening een exclusieve bestuurstaak uitmaakt, terwijl de externe instantie, die mede verantwoordelijk is voor de onrechtmatige vergunning, wel zal kunnen worden vervolgd. Dergelijke instanties zijn immers vaak particulieren, die zich niet op de strafrechtelijke immuniteit kunnen beroepen en daarnaast is hun gedraging (de adviesverlening) geen exclusieve bestuurstaak. Deze verwevenheid tussen het publieke en het private op het niveau van de

1189. Tiedemann, K., Die Neuordnung des Umweltstrafrechts. Gutachtliche Stellungnahme zu dem Entwurf eines 16. Strafrechtsänderungsgesetzes (Gesetz zur Bekämpfung der Umweltkriminalität), Berlijn, Walter de Gruyter, 1980, 41 e.v.; Immel, B., 'Die Notwendigkeit eines Sondertatbestandes im Umweltstrafrecht - Umweltreue', ZRP, 1989, 105-110.

1190. Faure, M., o.c., 1992, 112-113.

1191. Van Tuijn, J., 'Shell mag van provincie eigen milieuvergunning schrijven', Ingenieurskrant, 3 juni 1993, 3 .

1192. Zie hierover Faure, M. en Visser, M, o.c., 1999, 124-126. 
uitvoering van een exclusieve bestuurstaak, zoals vergunningverlening, illustreert dat de (rest)immuniteit voor overheden niet steeds even bevredigend is. ${ }^{1193}$

In dit hoofdstuk staan de strafrechtelijke gevolgen van wederrechtelijke vergunningverlening centraal. Er wordt echter niet alleen aandacht besteed aan de strafrechtelijke aansprakelijkheid van bij de vergunningverlening betrokken overheden en functionarissen. Dat lijkt mij een te beperkte benadering van de problematiek. De 'macht' van de vergunning in het milieustrafrecht heeft immers een dogmatisch belang dat de strafrechtelijke aansprakelijkheid van overheden overstijgt. Het centrale probleem is in de eerste plaats de positie van de vergunning in het milieustrafrecht. Meer in het bijzonder moet worden onderzocht op welke wijze door de strafrechter met onrechtmatige vergunningen kan worden omgegaan, en dit hoofdzakelijk in relatie tot de milieuverstorende activiteiten van de vergunninghouder. $\mathrm{Zo}_{\mathrm{o}}$ is het van belang te weten in welke gevallen onrechtmatige vergunningen strafuitsluitend kunnen werken. De vraag naar een strafrechtelijke aansprakelijkheid voor wederrechtelijke vergunningverlening is immers het sterkst wanneer de strafrechter gebonden is aan onrechtmatige vergunningen. Pas als op dergelijke vragen een duidelijk antwoord wordt gegeven, kan worden bekeken of overheden, en mogelijk ook andere bij de vergunningverlening betrokken instanties, voor wederrechtelijke vergunningverlening aansprakelijk kunnen worden gesteld en zo ja, op welke wijze deze aansprakelijkheid op grond van de bestaande milieustrafbepalingen dogmatisch kan worden gekwalificeerd.

Dit hoofdstuk is als volgt opgebouwd. Allereerst komt de vraag aan bod of de strafrechter bevoegd is vergunningen op hun wet- en rechtmatigheid te toetsen. Het belang van deze vraag ligt voor de hand. De mogelijk strafuitsluitende werking van onrechtmatige vergunningen krijgt een bijzondere crimineel-politieke dimensie indien de strafrechter de bevoegdheid mist om vergunningen op wet- en rechtmatigheid te controleren en hij deze niet onverbindend kan verklaren. Is strafrechtelijke toetsing uitgesloten dan betekent dit immers dat de strafbaarheid van de milieuverstorende gedraging zou kunnen worden opgeheven door een onrechtmatige vergunning $(\S 2)$. Vervolgens wordt besproken aan welke normen de strafrechter de rechtmatigheid van de betwiste vergunning kan toetsen om tot een onrechtmatigheidsoordeel te komen. Daarbij is van belang in welke mate de strafrechter de belangenafweging en beslissingsruimte (freies Ermessen) van het bestuur in zijn oordeel kan betrekken. Ook is van belang de vraag of iedere bestuursrechtelijke onrechtmatigheid automatisch tot het oordeel moet leiden dat het tenlastegelegde feit in strafrechtelijke zin als wederrechtelijk moet worden aangemerkt. Dienen bijvoorbeeld louter formele gebreken aan de vergunning reeds te leiden tot het oordeel dat de gedraging strafrechtelijk gezien wederrechtelijk is? Deze vraag is van groot belang indien men voorstander is van een meer Verwaltungsrechtsakzessorische benadering van het milieustrafrecht. Een onderzoek naar de inhoud van de wederrechtelijkheid van de vergunningverlening is daarom noodzakelijk, zowel voor de strafbaarheid van de vergunninghouder als voor die van de vergunningverlener. Immers, bij beide staat de vergunningverlening vanwege zijn strafuitsluitende werking centraal. Voor de vergunninghouder betekent dit dat moet worden beantwoord welke invloed een onrechtmatige vergunning heeft voor de

1193. Zie hierover hoofdstuk IV. 
kwalificatie en strafbaarheid van zijn verweten gedragingen. Voor de vergunningverlener betekent dit dat moet worden beantwoord onder welke omstandigheden het in strijd met wet en/of recht afgeven van een vergunning strafrechtelijk wederrechtelijk is. Men kan zich immers voorstellen dat niet iedere afgifte van een onrechtmatige vergunning strafrechtelijk relevant is. Indien de onrechtmatigheid van de vergunning bijvoorbeeld slechts betrekking heeft op een inbreuk op een formeel voorschrift, dat geen rechtstreeks verband houdt met de bescherming van de ecologische rechtsgoederen, is er iets voor te zeggen deze bestuursrechtelijke onrechtmatigheid niet aan te merken als een strafrechtelijk relevante onrechtmatigheid (§3). Dit brengt ons uiteindelijk tot de vraag in welke gevallen de voor de vergunningverlening verantwoordelijke overheden en ambtenaren strafrechtelijk aansprakelijk zijn indien een onzorgvuldige vergunningverlening mede ten grondslag ligt aan de milieuverstoring. De afgifte van wederrechtelijke vergunningen is immers als zodanig niet strafbaar gesteld. Daarbij wordt hoofdzakelijk stil gestaan bij de kwestie of de bestaande materiële milieustrafbepalingen ook op de wederrechtelijke vergunningverlening toepasselijk zijn. Van belang is dan vooral of de voor de vergunningverlening verantwoordelijke overheden en functionarissen als deelnemers aan een milieudelict kunnen worden beschouwd ( $(4)$. Dit hoofdstuk wordt afgesloten met enkele samenvattende en rechtsvergelijkende conclusies $(\S 5)$.

\section{§ 2. De toetsingsbevoegdheid van de strafrechter}

\section{A. NEDERLAND \\ 1. Inleiding}

Bij strafrechtelijke toetsing van vergunningen, die volgens de regels van het milieurecht niet hadden mogen worden verleend, kunnen twee gevallen van elkaar worden onderscheiden. ${ }^{1194}$ Allereerst is de situatie denkbaar waarin de vergunninghouder zich op deze onrechtmatige vergunning wenst te beroepen, indien hem wordt verweten dat hij zonder vergunning heeft gehandeld. Vanuit het standpunt van het OM beschikt de verdachte niet over een rechtmatige vergunning en handelt hij derhalve zonder vergunning. ${ }^{195}$ Het is alleen zuiver formeel gezien dat hij niet het verbod om een bepaalde activiteit zonder vergunning te verrichten overtreedt. ${ }^{1196}$ Daarnaast kan het voorkomen dat een vergunninghouder wordt vervolgd voor de overtreding van een vergunningsvoorschrift dat in strijd met het recht in de vergunning is opgenomen. Kan de strafrechter dit voorschrift onverbindend verklaren of is hij daaraan gebonden? In het ene geval bestaat de strafbaarheid dus in de afwezigheid van een bevrijdende beschikking; in het andere geval in de schending van een belastende beschikking. ${ }^{1197}$ Of de strafrechter vergunningen mag toetsen is principieel een

1194. Vgl. Hendriks, L.E.M. en Wöretshofer, J., o.c., 1995, 66-67.

1195. Zie hierover Faure, M.G., 'De gevolgen van de administratieve afhankelijkheid van het milieustrafrecht: een inventarisatie van knelpunten', in Faure, M.G., Oudijk, J.H.C. en Schaffmeister, D. (red), o.c., 1991, 100-102.

1196. Hendriks, L.E.M. en Wöretshofer, o.c., 1995, 66.

1197. $\mathrm{Er}$ is iets voor te zeggen om terminologisch afstand te nemen van het klassieke onderscheid tussen begunstigende of bevrijdende beschikkingen enerzijds en belastende beschikkingen 
staatsrechtelijke kwestie. Het gaat fundamenteel om de vraag of de rechterlijke macht een oordeel mag vellen over rechtshandelingen van het bestuur. Teneinde deze vraag te beantwoorden zal eerst kort de toetsingsbevoegdheid van de strafrechter worden uiteengezet ervan uitgaande dat er geen administratieve rechtsgang openstaat (2). Daarna wordt bekeken in hoeverre het bestaan van een administratieve rechtsgang een invloed op deze toetsingsbevoegdheid kan uitoefenen. Daarbij wordt een onderscheid gemaakt in de situatie waarin de openstaande administratieve rechtsgang door de justitiabele onbenut is gelaten en de beschikking formele rechtskracht geniet, en de situatie waarin door de administratieve rechter een oordeel over de beschikking is uitgesproken (3 en 4).

\section{De toetsingsbevoegdheid van de strafrechter: doel en beginselen}

In de literatuur heerst eensgezindheid over de vraag of de strafrechter bestuurshandelingen mag toetsen. Dit doet zich hoofdzakelijk voor bij de zogenaamde exceptie van onwettigheid (of onverbindendheid). ${ }^{1198}$ Het is niet onbelangrijk dat de strafrechter eerder bestuurlijke rechtshandelingen kon toetsen dan de burgerlijke rechter. ${ }^{1199}$ Reeds in 1879 werd in het Meerenberg-arrest de vraag of de strafrechter bestuurshandelingen kon toetsen in positieve zin beantwoord. ${ }^{1200}$ In deze zaak werd door de Haarlemse rechtbank het bestuur van de krankzinnigen-inrichting Meerenberg ontslagen van rechtsvervolging omdat het door het bestuur overtreden $\mathrm{KB}$ geen grondslag had in de wet en dus onverbindend moest worden verklaard. De Hoge Raad bevestigde deze uitspraak. Op het einde van de vorige eeuw kwam de problematiek opnieuw naar voren in een aantal arresten waarin gemeentelijke verordeningen werden getoetst aan artikel $7 \mathrm{Gw}$ (de vrijheid van drukpers). Ook daar gold als principe dat de strafrechter overheidshandelingen mag toetsen. ${ }^{1201}$ En in 1912 oordeelde de strafkamer van de Hoge Raad over de rechtmatigheid van een verordening over de winkelsluiting van Amsterdam. ${ }^{1202}$ Uit latere jurisprudentie blijkt dat de strafrechter niet alleen bij verordeningen maar ook bij vergunningen (dus individuele

anderzijds. Bij een milieuvergunning kan immers beter worden gesproken van een beschikking die gedeeltelijk bevrijdend - want een zekere mate van verontreiniging is toegestaan en gedeeltelijk belastend werkt - want de verontreiniging is slechts toegelaten binnen de gestelde voorwaarden. Zie Hendriks, L.E.M. en Wöretshofer, J., o.c., 71. en Van Wijk, H.D. en Konijnebelt, W., o.c., 1994, 225 e.v. Om redenen van duidelijkheid houden we ons echter aan de bekende en algemeen aanvaarde termino-logie.

1198. Zie Faure, M.G., 'De gevolgen van de 'administratieve afhankelijkheid in het milieustrafrecht: een inventarisatie van enkele knelpunten', in Faure, M.G., Oudijk, J.H.C. en Schaffmeister, D. (red.), o.c., 1991, 96; Koopmans, I.M., o.c., 1996, 115. Daarnaast doet het toetsingsvraagstuk zich ook voor bij de interpretatie van administratieve voorschriften. De strafrechter zal indien nodig deze voor-schriften zelf uitleggen. De Hoge Raad daarentegen gaat niet over tot het uitleggen van beschikkingen zoals vergunningsvoorschriften, omdat dit een oordeel van feitelijke aard is. Hij toetst alleen of de feitenrechter geen onberijpelijke interpretatie aan het voorschrift heeft gegeven. Zie HR 27 juni 1995, MenR 1996, nr. 6, met noot Hendriks, L.E.M. Zie hierover tevens Faure, M. en Visser, M, o.c., 1999, 85-86.

1199. Zie over de toetsing door de civiele rechter hoofdstuk IV.

1200. HR 13 januari 1879 , W. 4330.

1201. Zie o.m. HR 7 november 1892, W. 6259. Daarin werd een in een APV opgenomen ventverbod onverbindend verklaard. Zie tevens Koopmans, I.M, o.c., 120.

1202. HR 25 maart 1912, W. 9322. 
beschikkingen) dient te onderzoeken of deze zodanige gebreken vertonen dat zij als onverbindend moeten worden beschouwd. Zo besloot de Hoge Raad in verband met de rechtmatigheid van een jachtvergunning

'dat geen enkele wetsbepaling den rechter verbiedt te onderzoeken, of de Minister bij het verleenen van een dergelijke vergunning is gebleven binnen de grenzen, voor het verleenen van een zodanige vergunning door de wet gesteld. ${ }^{1203}$

In een arrest betreffende een loterijvergunning oordeelde de Hoge Raad dat het

'tot de taak des rechters behoort besluiten van gemeentelijke organen daaronder begrepen die van B. en W. - onverbindend te verklaren op grond van hem gebleken strijdigheid met de wet. ${ }^{1204}$

In latere rechtspraak wordt een zelfde lijn gevolgd. Zo werd in het Camping Domburgarrest geoordeeld dat het Hof zonder miskenning van enige rechtsregel tot het oordeel mag komen dat een kampeerexploitatievergunning met de Verordening op de kampeerplaatsen en op de kampeermiddelen van de gemeente Domburg in strijd is. ${ }^{1205}$ Een ander voorbeeld betreft het vliegveld Beek-arrest. In deze zaak werd verdachte, directeur van NV luchthaven Zuid-Limburg, vervolgd voor het in strijd met een anti-lawaaibeschikking toestemming geven aan een Boeing 707 om 's nachts met een lading eendagskuikens op te stijgen. Verdachte beriep zich echter op de door de havenmeester verleende ontheffing. De rechtbank oordeelde (in hoger beroep) dat deze ontheffing niet rechtsgeldig was gegeven aangezien zij naar aanleiding van een valselijk aangevoerde omstandigheid, namelijk dat de aanlevering van de kuikens vertraagd was, werd verleend. De Hoge Raad hield de uitspraak van de rechtbank in stand met als overweging:

'6.2. De Rb heeft echter kennelijk geoordeeld (...) en ook kunnen oordelen dat de door Wildering verleende ontheffing niet als rechtsgeldig kon worden aangemerkt, aangezien zij op een valse grondslag berustte. ${ }^{1206}$

Bovendien merkt de Hoge Raad op dat zelfs indien de aangevoerde reden voor ontheffing niet valselijk zou zijn geweest dit nog geen uitzondering toelaat op de anti-lawaaibeschikking die de voorwaarden aanduidt op basis waarvan eventueel ontheffingen van het nachtelijk vliegverbod kunnen worden verleend.

Het is helemaal niet vreemd dat het eerste belangrijke arrest aangaande de strafrechtelijke toetsing van bestuurshandelingen ruim 25 jaar eerder tot stand is kunnen komen dan het

1203. HR 31 oktober 1938, $N J 1939,139$, met noot Pompe.

1204. HR 10 mei 1955, NJ 1956, 21; $A B$ 1955, 485, met noot Troostwijk, M. Zie tevens HR 14 december 1954, $A B$ 1955, 212, met noot Troostwijk, M.; HR 20 december 1955, NJ 1956, 209.

1205. HR 13 november 1984, $N J 1985,294$.

1206. HR 10 februari 1987, $N J 1987,662$, met noot 't Hart, A.C. 
civielrechtelijke arrest Guldenmond-Noordwijkerhout waarin, na een absoluut dieptepunt op het vlak van rechtsbescherming van de burger, toetsing door de civiele rechter werd aanvaard. ${ }^{1207}$ Dit laat zich grotendeels verklaren door het feit dat achter de civielrechtelijke en strafrechtelijke toetsingsbevoegdheden andere ratio's schuil gaan. Het toetsingsrecht van de burgerlijke rechter moet worden geplaatst tegen de achtergrond van een streven naar meer rechtsbescherming van de burger tegen onrechtmatig overheidsoptreden. Doordat begin deze eeuw administratieve rechtsbescherming nauwelijks iets voorstelde en het publiekrechtelijk optreden aan de kritische blik van een onafhankelijke rechter was onttrokken, kon in de praktijk aan deze ongunstige situatie slechts een einde worden gemaakt door aan de burgerlijke rechter de bevoegdheid toe te kennen ook publiekrechtelijke handelingen te toetsen.

Voor het toetsingsrecht van de strafrechter geldt daarentegen zowel een andere ontstaansgeschiedenis als een andere grondslag. De strafrechtelijke grondslag voor het beoordelen van de wettigheid en/of rechtmatigheid van beschikkingen ligt niet in het verlenen van een (aanvullende) rechtsbescherming tegen een overheid die gebrekkige beschikkingen uitvaardigt. $\mathrm{Zij}$ is primair bedoeld voor de correcte strafrechtelijke handhaving van de rechtsorde. ${ }^{1208}$ Natuurlijk moet worden toegegeven dat telkenmale de strafrechter de rechtmatigheid van beschikkingen moet toetsen niet alleen de rechtshandhaving maar ook de rechtsbescherming van de burger op het spel staat: integere strafrechtelijke rechtshandhaving vooronderstelt steeds degelijke rechtsbescherming. Maar de rechtsbescherming, die wordt gegarandeerd in het strafproces, is hier een andere dan de bescherming die wordt gewaarborgd tijdens de civielrechtelijke of administratiefrechtelijke procedures. Bij deze laatste procedures gaat het rechtstreeks om de bescherming van de subjectieve rechten van de burger tegen het onrechtmatig handelen van het bestuur. De burger is eisende partij en de schending van een subjectief recht vormt voorwerp van het geschil. De rechtsbescherming in het strafproces betreft daarentegen niet de relatie burgerbestuur maar de verhouding verdachte-OM. Wanneer de strafrechter de rechtmatigheid van bestuurlijke beschikkingen moet beoordelen gaat het dus niet primair om de bescherming van de burger die door de admini-stratie in zijn rechten is aangetast. Het gaat dan voornamelijk om de garantie dat de basis waarop de burger zou kunnen worden veroordeeld inderdaad rechtsgeldig is ${ }^{1209}$ Vanuit die optiek is toetsing van beschikkingen door de strafrechter noodzakelijk omdat zowel vanuit handhavings- als vanuit rechtsbeschermingsperspectief het inopportuun zou zijn wanneer een burger zou kunnen worden veroordeeld voor de overtreding van onrechtmatige beschikkingen. ${ }^{1210}$ Enerzijds is het strafrecht niet bedoeld om onrecht maar om recht te handhaven. Anderzijds moet het strafprocesrecht een zodanige rechtsbescherming kunnen garanderen dat een verdachte niet voor overtreding van onrechtmatige voorschriften kan worden veroordeeld. De rechtsbescherming van het strafproces is in die zin steeds een bescherming tegen de vervolgende

1207. Vgl. Stroink, F., o.c., 1994, 159.

1208. Cluysenaer, J.H.K., 'De toetsing van administratieve beschikkingen door de strafrechter', NJB, 1970, 1000-1007.

1209. Koopmans, I.M., o.c., 1996, 129-130.

1210. Faure, M. en Visser, M., o.c., 1999, 96. 
overheid en niet zozeer een bescherming tegen het bestuur dat de onrechtmatige beschikking heeft uitgevaardigd. De toetsingsbevoegdheid van de strafrechter kan daarom in tegenstelling tot die van de burgerlijke rechter - niet uitsluitend worden gezien als een streven om de administratie ter bescherming van de burger onder controle te brengen van de onafhankelijke rechter. Primair heeft de strafrechtelijke toetsing tot doel een integere strafrechtelijke handhaving van de rechtsorde.

Dat de toetsingsgrondslag van de strafrechter ligt in de eigen aard van de strafrechtelijke procedure en rechtshandhaving is eigenlijk ook met zoveel woorden wettelijk tot uitdrukking gebracht. De strafrechter moet ambtshalve, conform het processuele beslissingsmodel van de artikelen 348-350 Sv, de vervolgbaarheid en de strafbaarheid van feiten die hem door het OM worden voorgebracht onderzoeken. ${ }^{1211}$ Deze taak is hem exclusief door de Grondwet (art. 113 lid 1) en de Wet RO (het inmiddels vervallen art. 2 en wat de verdeling van de competentie betreft: de artikelen $44,56,68$ en 95) toebedeeld. Uit deze regeling kan men afleiden dat de strafrechter niet alleen bevoegd is om te toetsen maar dat hij zelfs verplicht is de rechtsgeldigheid van bestuurlijke rechtshandelingen te beoordelen omdat hij anders niet kan vaststellen of het feit strafbaar is. ${ }^{1212}$ In die zin is geen sprake van een parallel tussen de toetsing door de burgerlijke rechter en de toetsing door de strafrechter. ${ }^{1213}$

Samengevat kan worden besloten dat in beginsel de strafrechter de rechtmatigheid van beschikkingen dient te toetsen. Daaruit kan worden afgeleid dat voor de strafrechtelijke aansprakelijkheid van zowel de vergunninghouder als de vergunningverlener geen principieel beletsel bestaat een vergunning op zijn wet- en/of rechtmatigheid te toetsen. Het is in zekere zin zelfs de plicht van de strafrechter deze kwestie te onderzoeken daar de rechtmatigheid van de vergunning(verlening) een onoverkomelijk onderdeel uitmaakt van de hoofdvraag of de verdachte al dan niet een strafbaar feit heeft gepleegd. De (on)rechtmatigheid van de vergunning leidt immers tot een positief of negatief antwoord op de strafbaarheidsvraag.

\section{De invloed van de formele rechtskracht op de strafrechtelijke toetsing}

Het in de vorige paragraaf benadrukte onderscheid tussen civielrechtelijke en strafrechtelijke toetsingsbevoegdheid is niet alleen van belang voor het verschil in oorsprong en karakter van de rechterlijke competentie. Het staat ook toe meer zicht te krijgen op de invloed van administratieve rechtsgangen op de mogelijkheid beschikkingen strafrechtelijk te toetsen.

De bestuursprocesrechtelijke rechtsbescherming met betrekking tot beschikkingen (en dus ook vergunningen) is vrij nauwkeurig en uitvoerig geregeld. De vraag rijst of de toetsings-

1211. Zie hierover Koopmans, F.A.J., Het beslissingsmodel van 348/350, Groningen, WoltersNoordhof, 1991.

1212. Zie o.a. Enschedé, Ch.J., Rūter, C.F. en Stolwijk, S.A.M, Beginselen van strafrecht, Deventer, $1990,39$.

1213. Cluysenaer, J.L.H., l.c., 1970, 1003. 
bevoegdheid van de strafrechter zich nog wel uitstrekt tot beschikkingen waartegen een administratieve rechtsgang openstaat, maar die niet is benut. ${ }^{1214}$ Deze vraag heeft in het milieustrafrecht voornamelijk een praktisch belang in het geval een vergunninghouder wordt vervolgd voor overtreding van vergunningsvoorschriften waarvan hij de rechtmatigheid betwist alsook in gevallen waar het OM een handelen zonder (rechtmatige) vergunning tenlastelegt. Maar ook voor een mogelijke strafrechtelijke aansprakelijkheid van de vergunningverlener is dit natuurlijk een belangrijke kwestie, daar de aansprakelijkheid van de vergunningverlener, bijvoorbeeld als medepleger of als medeplichtige, veelal afhankelijk is van de strafbaarheid van het grondfeit, de verboden milieuverstoring, dat door de vergunninghouder is gepleegd.

Om deze vraag te beantwoorden is het interessant eerst te bekijken in welke mate het niet benutten van de administratieve rechtsgang de civielrechterlijke toetsing beïnvloedt. Vaak wordt immers in (bestuursrechtelijke) literatuur voor de beperking van de strafrechtelijke toetsing een aantal argumenten gehaald uit de civielrechtelijke situatie. ${ }^{1215}$ Het is maar de vraag of de beperkingen op de toetsing in civilibus meteen ook hoeven te gelden voor de toetsing in criminalibus.

\section{a. De civiele rechter en formele rechtskracht}

In het geval dat een openstaande bestuursrechtelijke procesgang niet is benut, dient de civiele rechter zich te confirmeren aan de wettigheid en rechtmatigheid van de inhoud en de wijze van de totstandkoming van de beschikking. Dit beginsel van de formele rechtskracht is het meest uitgesproken geformuleerd in het Heesch-Van de Akker-arrest. ${ }^{1216}$ In deze inmiddels klassiek geworden uitspraak stelt de Hoge Raad:

\subsection{2. (...) Voorop moet worden gesteld dat wanneer tegen een} beschikking een met voldoende waarborgen omklede administratiefrechtelijke rechtsgang heeft opengestaan (zoals die ingevolge de Wet Arob), de burgerlijke rechter, zo deze beroepsgang niet is gebruikt, in geval de geldigheid van de beschikking in het voor hem gevoerde geding in geschil is, ervan dient uit te gaan dat die beschikking zowel wat haar wijze van tot stand komen als wat haar inhoud betreft in overeenstem-

1214. Zie over formele rechtskracht (in het strafrecht) de studie van Van der Linden, E.C.H.J., Formele en materiële rechtskracht. De kleren van de Keizer, Den Haag, Sdu, 1998, 97-108.

1215. Zie o.a. Van Wijk H.D. en Konijnenbelt, W., o.c., 1999, 612; Stroink, F.A.M., o.c., 166 e.v. en Stroink, F.A.M, Rechterlijke organisatie en rechtspraak in beweging, Zwolle, W.E.J. Tjeenk Willink, 1993, 161. e.v.

1216. HR 16 mei 1986, NJ 1986, 723, met noot Scheltema; AB Klassiek, Zwolle, 1991, 157, met noot ten Berge; $A A$ 1986, 642, met noot Hennekens. Reeds eerder sprak de Hoge Raad zich uit over de formele rechtskracht, zij het minder expliciet. Zo onder meer in het Semper Crescendo-arrest (HR 19 november 1976, NJ 1979, 216, met noot Scheltema) waar werd geoordeeld dat wanneer van een bijzondere beroepsgang geen gebruik is gemaakt in de procedure voor de gewone rechter er van moet worden uitgegaan dat het bestuursbesluit rechtmatig is. Zie tevens HR 4 februari 1983 (Hei-en Boeicopse parkeerplaats), $N J$ 1985, 21, met noot Scheltema en HR 22 november 1985 (Super Doc), $N J$ 1986, 722, met noot Scheltema. 
Wederrechtelijke vergunningverlening

ming is met de desbetreffende wettelijke voorschriften en algemene rechtsbeginselen.'

In de civielrechtelijke procedure dient de beschikking dus te worden beschouwd als zowel formeel als materieel rechtmatig. Ook in latere jurisprudentie wordt in dezelfde zin geoordeeld. ${ }^{1217} \mathrm{Zo}$ onder meer in het Aharchi-Bedrijfsvereniging-arrest waar formele rechtskracht wordt omschreven als:

'het beginsel dat moet worden uitgegaan van de geldigheid van een besluit van een bestuursorgaan indien daartegen een met voldoende waarborgen omklede rechtsgang heeft opengestaan en deze rechtsgang hetzij niet is gebruikt, hetzij niet tot vernietiging van het besluit heeft geleid..$^{1218}$

Er is dus ook sprake van formele rechtskracht wanneer een openstaande bestuursprocesrechtelijke rechtsgang is gevolgd maar deze niet de vernietiging van de beschikking als uitkomst had. De Hoge Raad geeft aan de formele rechtskracht een nog engere betekenis met de overweging dat dit beginsel ook dient te gelden:

'indien dit de burgerlijke rechter ertoe zou nopen aan zijn uitspraak de rechtsgeldigheid ten grondslag te leggen van een beschikking waarvan als vaststaand mag worden aangenomen dat zij, àls daartegen tijdig administratiefrechtelijk beroep zou zijn ingesteld, zou zijn vernietigd. ${ }^{1219}$

De hoofdregel van formele rechtskracht steunt hoofdzakelijk op een viertal overwegingen. In de eerste plaats is de rechtszekerheid er niet mee gediend dat er langdurige twijfel blijft bestaan omtrent de rechtmatigheid van de beschikking. Het systeem van de administratieve rechtsgang en de daaraan gekoppelde strikte beroepstermijnen bestaan juist mede om onzekerheid zoveel en zo snel mogelijk uit te schakelen. Indien een administratiefrechtelijk systeem openstaat moet het dus ook door de belanghebbende worden benut. Daaruit vloeit een tweede argument voort, namelijk dat vermeden moet worden dat de burger voor zijn rechtsbescherming zou gaan 'forum shoppen'. Dat risico zou bestaan indien na (on)opzettelijk verzuim van de termijnen de burger alsnog de burgerlijke rechter gaat adiëren. ${ }^{1220}$ Een derde overweging heeft te maken met de zogeheten specialiteitsgedachte: vragen die bij uitstek bestuursrechtelijk van aard zijn dienen bij voorkeur door de administratieve rechter te worden beantwoord. ${ }^{1221}$ In de vierde plaats is er het argument van de eenheid van rechtsorde. De eenheid van rechtsorde wordt allerminst gediend met de mogelijkheid dat twee verschillende rechters tot onderscheiden oordelen komen over de

1217. Zie voor een overzicht van deze rechtspraak Mok ,M.R. en Tjittes, R.P.J.L., 'Formele rechtskracht en overheidsaansprakelijkheid', RMThemis, 1995, 384.

1218. HR 2 juni 1995, RvdW 1995, 123c.

1219. HR 16 mei 1986, $N J 1986,527$.

1220. Van Wijk, H.D. en Konijnenbelt, W., o.c., 1999, 608.

1221. HR 26 februari 1988 (HOT Air-Staat), NJ 1989, 528, met noot Scheltema (r.o. 3.3.). Zie tevens Mok, M.R. en Tjittes, R.P.J.L., l.c., 1995, 385. 
(on)rechtmatigheid van een beschikking. ${ }^{1222}$ Deze sterk met elkaar verweven uitgangspunten van het leerstuk van de formele rechtskracht verwijzen duidelijk naar de specifieke grondslag van de toestingscompetentie van de burgerlijke rechter: het bieden van aanvullende rechtsbescherming. Zij kunnen dan ook enkel worden begrepen vanuit de gedachte een zo'n efficiënt mogelijke rechtsmachtverdeling te construeren om aldus het stelsel van rechtsbescherming zo consistent mogelijk te maken.

Hoe strak het beginsel ook moge zijn geformuleerd, het is niet dermate absoluut dat op de hoofdregel geen uitzonderingen zijn toegelaten. Deze uitzonderingsmogelijkheid kwam voor het eerst aan bod in het reeds genoemde Heesch-Van de Akker-arrest:

'De daaraan (de formele rechtskracht, DR) verbonden bezwaren kunnen evenwel door bijkomende omstandigheden zo klemmend worden dat op dat beginsel een uitzondering moet worden aanvaard. Of voor zulk een uitzondering plaats is, hangt bijgevolg af van de bijzonderheden van het gegeven geval. ${ }^{1223}$

In latere rechtspraak werd de mogelijkheid van klemmende bezwaren en uitzonderingen nader uitgediept en verfijnd. Voorbeeld van een mogelijke uitzondering is onder meer de omstandigheid dat de burger niet wist of kon weten dat er een administratiefrechtelijke procesgang openstond. Dan kan hem ook niet worden verweten deze procedure te hebben verzuimd. ${ }^{1224}$ Ook de situatie waarin het bestuur niet betwist dat de beschikking onrechtmatig is, rechtvaardigt een afwijking van de hoofdregel. ${ }^{1225}$ Belangrijk afwegingscriterium is veelal de vaststelling dat het onrecht dat aan de burger door de (gevolgen van) formele rechtskracht zou worden aangedaan onevenredig groot is in verhouding tot de belangen die worden gediend met het vasthouden aan de hoofdregel van de formele rechtskracht. ${ }^{1226}$ In die situaties dat de individuele rechtvaardigheid en rechtsbescherming zwaarder doorwegen dan meer algemene belangen van rechtszekerheid en rechtsmachtverdeling dient voorrang te worden verleend aan het individuele belang. ${ }^{1227}$

1222. De Hoge Raad verwijst daar zelf naar in de zin dat 'vooropgestelde regel mede ertoe strekt te voorkomen dat de burgerlijke rechter inzake vragen waarover ook de administratieve rechter tot oordelen is geroepen, tot een ander oordeel komt dan deze.' HR 16 mei 1986, $N J$ 1986, 723 (r.o. 3.3.2. laatste alinea).

1223. HR 16 mei 1986, $N J 1986,723$.

1224. HR 11 november 1988 (Ekro-Staat), NJ 1990, 563; HR 16 oktober 1992, NJ 1993, 638.

1225. Om op deze uitzondering beroep te kunnen doen is het volgens de Hoge Raad 'voldoende dat de burger zich op het standpunt stelt dat van onrechtmatigheid sprake is en hij uit de verklaringen en gedragingen van het overheidslichaam begrijpt en in de gegeven omstandigheden redelijkerwijs mag begrijpen dat het overheidslichaam die onrechtmatigheid erkent, zodat op dit punt geen geschil bestaat, dat voor de beslissing door een administratieve rechter in aanmerking komt.' HR 18 juni 1993, NJ 1993, 642, met noot Scheltema (r.o. 3.2.). Zie ook HR 6 juni 1995, NJ 1995, 696 , met noot Scheltema.

1226. Zie o.m. de conclusie van A-G Koopmans voor het Lanser-Haarlemmermeer-arrest, HR 13 november 1992, $N J 1993,639$, met noot Scheltema.

1227. Mok, M.R. en Tjittes, R.P.J.L., L.c., 1995, 386-387. 


\section{b. De strafrechter en formele rechtskracht}

Geldt de leer van de formele rechtskracht van beschikkingen bij verzuim een bestuursprocesrechtelijke rechtsgang te gebruiken nu ook in een strafrechtelijke procedure? Opnieuw moet het belang van deze vraag worden onderstreept zowel vanuit het oogpunt van de strafrechtelijke aansprakelijkheid van de vergunningplichtige als vanuit het perspectief van de strafrechtelijke aansprakelijkheid van de vergunningverlener. Immers, indien formele rechtskracht onverkort ook in het strafrecht gelding heeft, is het mogelijk dat beide, de een als dader en de ander als deelnemer, straffeloos blijven louter en alleen omdat de vergunningverlener een onrechtmatige vergunning heeft verleend en daartegen geen administratieve rechtsgang is benut.

In tegenstelling tot de civielrechtelijke jurisprudentie is deze vraag niet eenduidig te beantwoorden. Duidelijk is wel dat in de situatie waarin alleen administratief beroep openstaat, het nalaten van dergelijke beroepsmogelijkheid de toetsingsbevoegdheid onaangetast laat. ${ }^{1228}$ Maar zoals is opgemerkt, staat met het bestuursprocesrecht van de Awb tegen beschikkingen vrijwel steeds een beroep bij de bestuursrechter open. We dienen ons dus vooral te concentreren op het niet benutte beroep op de administratieve rechter.

In ieder geval behoudt het $\mathrm{OM}$, als vervolgingsmonopolist en dominus litis van het strafproces, het recht om tot vervolging over te gaan en dit ongeacht het verzuim van de justitiabele de administratiefrechtelijke procesgang te hebben benut. Er is geen formele rechtskracht voor het $\mathrm{OM}$. In tegenstelling tot de civielrechtelijke procedure leidt de vordering van het $\mathrm{OM}$ bij het openstaan van een bestuursprocesrechtelijke rechtsgang (die met voldoende rechtwaarborgen is omkleed) dan ook niet tot niet-ontvankelijkheid. Dit is logisch. Het OM is geen belanghebbende partij in de zin van de Awb en heeft a priori dus niet de mogelijkheid de rechtmatigheid van de vergunning anders dan via het strafrecht, meer bepaald via het bestuursrecht, aan te vechten. ${ }^{1229} \mathrm{De}$ strafvordering van het $\mathrm{OM}$ heeft, anders dan de civielrechtelijke vordering van de burger, geen betrekking op de eis van rechtsbescherming tegen het bestuur. Bovendien zou een andere opvatting ertoe leiden dat de vervolging afhankelijk wordt gemaakt van de (moedwillige) nalatigheid van de verdachte beroep in te stellen bij de administratieve rechter. Ook zou het OM worden herleid tot een appendix van de bestuurlijke overheid. ${ }^{1230}$ De formele rechtskrachtproblematiek heeft in het strafproces dus uitsluitend betekenis bij de toetsing door de strafrechter.

1228. HR 20 december 1955, $N J$ 1956, 209; HR 11 februari 1986, $N J$ 1986, 673; anders Rb Dordrecht 28 januari 1966, $N J 1968,156$ waar de toetsing van een belastende vergunningsvoorwaarde aan de Hinderwet werd afgewezen omdat 'de Hinderwet voor de totstandkoming van een beschikking als de onderhavige een zodanig met waarborgen omklede rechtsgang biedt, waarbij de mogelijkheid van beroep op de Kroon is ingesteld, dat moet worden aangenomen, dat naar de bedoeling van de Wetgever en de Kroon met uitsluiting van de rechterlijke macht het oordeel over de rechtmatigheid van een dergelijke beschikking en van de eventueel daaraan verbonden voorwaarden is overgelaten.' Zie tevens Koopmans, I.M., o.c., 126-127.

1229. Zie over het begrip belanghebbende Stroink, F.A.M., o.c., 1996, 124-126.

1230. Buruma, Y. en Daalder, E.J., 'Formele rechtskracht in het strafrecht', RMThemis, 1994, 323. 
In een aantal arresten van de jaren zestig blijkt de Hoge Raad de voorkeur te hebben gegeven aan de regel dat ook de strafrechter gebonden is aan de rechtskracht van beschikkingen indien een administratieve rechtsgang heeft opengestaan. Het betrof telkens belastende beschikkingen. Dit is, zoals later zal blijken, niet zonder belang. Zo kwam de Hoge Raad in een arrest van 23 november 1965 tot het oordeel:

'dat de rechtbank het verweer dat die vergunning was verleend onder een voorwaarde die nietig was, voor het overige terzijde kan stellen, aangezien voorwaarden, in strijd met art. 18, eerste lid, Keurenwet aan een vergunning verbonden, niet van rechtswege nietig zijn, doch overeenkomstig het bepaalde in het tweede lid van evengenoemd artikel kunnen worden vernietigd overeenkomstig de regels omtrent de vernietiging van besluiten van de besturen van waterschappen (...), zodat de $\mathrm{Rb}$ voor wat dit punt betreft kan volstaan met te overwegen, dat voor de rekwirant een aan redelijke eisen voldoende administratieve rechtsgang openstond. ${ }^{1231}$

In de jaren tachtig lijkt de Hoge Raad van dit standpunt af te wijken. Reeds werd vastgesteld dat zowel in het Camping Domburg-arrest als in het Vliegveld Beek-arrest de Hoge Raad geen beletsel ziet in het kunnen toetsen van vergunningen aan achterliggende regelingen. Wel moet worden toegegeven dat met betrekking tot de specifieke formele rechtskrachtproblematiek uit deze arresten moeilijk algemene conclusies kunnen worden getrokken. Zie ik het goed, dan werd in beide arresten immers geen verweer in die zin gevoerd. De Hoge Raad kon zich dientengevolge enkel uitspreken over de meer algemene vraag of de strafrechter beschikkingen mag toetsen. Dit houdt verband met het feit dat in beide zaken de onrechtmatigheid van de vergunningen door het $\mathrm{OM}$ en niet (als verweer) door de verdachte werd aangevoerd ${ }^{1232}$ : Het betrof dan ook, in tegenstelling tot de jaren zestig jurisprudentie, steeds een toetsing van bevrijdende beschikkingen. Betekent dit nu dat bij toetsing van bevrijdende beschikkingen, waarvan de onrechtmatigheid door het $\mathrm{OM}$ wordt aangevoerd, het bestaan van een administratieve rechtsgang blijkbaar niet belet dat de strafrechter de beschikking op zijn rechtmatigheid kan toetsen? Er zijn verschillende argumenten die deze conclusie kunnen rechtvaardigen.

Als het OM besluit iemand te vervolgen voor het handelen zonder een (rechtmatige) vergunning, dan kan hij de aanwezigheid van een strafbaar feit op geen andere manier naar voren brengen dan door voor de strafrechter de onrechtmatigheid van de beschikking aan te voeren. Immers, alleen formeel beschikt de verdachte over een vergunning, materieel handelt hij onrechtmatig. Het OM moet de onrechtmatigheid van de vergunning in het strafproces aan de orde stellen wil hij de tenlastegelegde gedraging - het handelen zonder vergunning - bewijzen. Hij kan niet eerst de onrechtmatigheid van de beschikking in de administratieve rechtsgang aanvechten, daar deze voor hem niet openstaat. De strafrechter

1231. HR 23 november 1965, NJ 1966, 331; Zie tevens HR 2 maart 1965, NJ 1965, 273 en HR 28 november $1967, N J 1968,143$.

1232. Het verweer van de verdachte in beide zaken concentreerde zich grotendeels op de verwijtbaarheid. 
kan zich derhalve moeilijk van toetsing onthouden. De formele rechtskracht geldt niet voor het $\mathrm{OM}$.

Ondersteuning voor deze redenering is trouwens voor een deel in de civielrechtelijke jurisprudentie en literatuur terug te vinden. Zoals gezien, worden door de burgerlijke rechter uitzonderingen op de formele rechtkracht aanvaard in die gevallen waar van een burger niet kan worden gevergd dat hij de administratiefrechtelijke procedure volgde, omdat hij niet wist dat hij dit kon ${ }^{1233}$. Hieruit kan worden afgeleid dat er geen beletsel bestaat om de formele rechtskracht opzij te zetten wanneer een (derde) belanghebbende een administratiefrechtelijke beroepsmogelijkheid zou ontberen. ${ }^{1234}$ Zelfs Van Angeren, een groot voorstander van een strakke toepassing van de formele rechtskracht, meent dat de mogelijkheid van uitzonderingen op formele rechtskracht niet alleen van belang is voor de belanghebbende die zelf heeft nagelaten de administratiefrechtelijke procedure te gebruiken,
'maar ook voor een derde belanghebbende, die in zo'n geval, zoals gezegd te maken krijgt met een beschikking waarvan de rechtskracht in beginsel voor de gewone rechter vaststaat. Het ontbreken van een rechtsgang voor de derde belanghebbende kan, onder omstandigheden, tot onaanvaardbare situaties leiden. Inbreuk op de hoofdregel moet dan gemaakt kunnen worden.' 1235

Analoog aan de civielrechtelijke situatie is het niet meer dan begrijpelijk en wenselijk dat een inbreuk op de formele rechtskracht bij de strafrechtelijke rechtmatigheidstoets van bevrijdende beschikkingen in de rede ligt, nu voor het $\mathrm{OM}$, die de onrechtmatigheid aanvoert, de administratieve rechtsgang ontbreekt.

De vraag rijst of een toetsing door de strafrechter van bevrijdende beschikkingen niet ten nadele van de verdachte kan werken. Is het voor de verdachte niet beter dat de strafrechter gewoonweg gebonden is aan de formele rechtskracht ongeacht door wie de onrechtmatigheid van de beschikking wordt aangevoerd en los van het onderscheid tussen belastende en bevrijdende beschikkingen? Ongetwijfeld zou dit de strafprocessuele positie van de verdachte versterken, maar dan wel volledig ten koste van de rechtshandhaving. Het $\mathrm{OM}$ zou dan telkens wanneer hij handelen zonder bevrijdende vergunning tenlastelegt te horen krijgen dat het feit niet kan worden bewezen verklaard of dat de verdachte moet worden ontslagen van alle rechtsvervolging, louter en alleen omdat door het verstrijken van de administratieve beroepstermijn de vergunning als rechtsgeldig moet worden beschouwd. Dat zou te ver gaan. Er zijn andere meer strafrechtelijk verantwoorde wegen, waarbij op flexibele wijze rekening kan worden gehouden met de bijzonderheden van het individuele

1233. Zie HR 11 november 1990, $N J 1990,563$; HR 16 mei 1986, $N J 1986,723$, met noot Scheltema.

1234. Duk, W. en Nicolal, P., 'Nulliteiten in het bestuursrecht', RMThemis, 1991, 12 en 15-16.

1235. Van Angeren, J.A.M., 'De aanvullende functie van de gewone rechtspraak ten opzichte van andere rechtsgangen', RMThemis, 1991, 6. Zie tevens zijn recente studie: Van Angeren, J.A.M., De gewone rechter en de bestuursrechtspraak, Zwolle, W.E.J. Tjeenk Willink, 1998, 61-62. 
geval, om te garanderen dat een verdachte niet onnodig door een strafsanctie wordt benadeeld. Daarvoor heeft men in het strafrecht het leerstuk van de formele rechtskracht niet nodig en daarvoor is de formele rechtskracht, gelet op zijn civielrechtelijke ontstaansgeschiedenis, ook niet bedoeld. Als de verdachte terecht heeft kunnen uitgaan van de rechtmatigheid van een vergunning, dan dient dit door de strafrechter te worden opgevangen bij de beantwoording van de schuldvraag. Het gaat er dan niet meer om of het gepleegde feit strafbaar is - daarvan is in beginsel sprake vanaf het moment dat de vergunning onrechtmatig is - maar of desondanks de vergunninghouder toch niet-strafbaar heeft gehandeld. Indien de verdachte terecht heeft gedwaald over de rechtmatigheid van de vergunning en zich kan beroepen op het feit dat hem geen schuldverwijt kan worden gemaakt, dient hij strafrechtelijk vrijuit te gaan. Zo wordt niet alleen vermeden dat vergunninghouders die een gerechtvaardigd vertrouwen hebben op de rechtsgeldigheid van de vergunning ten onrechte met straf worden bezwaard. Ook wordt voorkomen dat vergunninghouders die wel zelf schuld hebben aan de onwettigheid van de vergunning (bvb. door misleiding, bedrog of zelfs omkoping), ${ }^{1236}$ of tegen beter weten in toch van een onrechtmatige vergunning gebruik maken, simpelweg straffeloos blijven omdat een administratieve rechtsgang niet is gevolgd. Zulks is blijkbaar ook de opvatting van de rechtspraak. Illustratief is het eerder aangehaalde camping Domburg-arrest. Als uitgangspunt neemt de Hoge Raad dat het Hof zonder miskenning van enige rechtsregel de nietigheid van de bevrijdende beschikking kon vaststellen. Maar daar wordt meteen aan toegevoegd:

'De houder van een vergunning mag in het algemeen erop vertrouwen dat deze vergunning overeenkomstig de wettelijke voorschriften is verstrekt en dat hij gerechtigd is van deze vergunning gebruik te maken, ook wanneer later zou blijken dat zij in strijd is met een wettelijk voorschrift en derhalve ten onrechte is gegeven. Zulks leidt echter uitzondering in een geval als het onderhavige, waarin uit hetgeen door het Hof is overwogen is af te leiden dat de verlening van de vergunning een ook voor de verdachte zo onmiskenbare wetsschending opleverde dat hij had moeten begrijpen dat $\mathrm{B}$ en $\mathrm{W}$ hem deze niet hadden mogen verlenen. ${ }^{1237}$

Maar hoe zit het nu met de formele rechtskracht van belastende beschikkingen? Het gaat dan om gevallen waarin de verdachte het overtreden van een vergunningsvoorschrift wordt tenlastegelegd en deze zich beroept op de onrechtmatigheid van het vergunningsvoorschrift. Het verschil met toetsing van bevrijdende vergunningen is dat nu niet het $\mathrm{OM}$ maar de verdachte de onrechtmatigheid bij de strafrechter opwerpt. De rechtbank Utrecht lijkt met een uitspraak inzake het Utrechtse tippelverbod toetsing van belastende beschikkingen te aanvaarden. ${ }^{1238}$ De rechtbank bepaalde dat aan een beschikking van een

1236. Zie tevens het Vliegveld Beek-arrest waar de vergunning door misleiding was verkregen: HR 10 februari 1987, $N J 1987,662$. Zie ook de volgende paragraaf waar de toetsingsbevoegdheid van de Duitse strafrechter wordt besproken.

1237. HR 13 november 1984, NJ 1985, 294; zie ook HR 14 december 1954, NJ 1955, 119.

1238. Rb Utrecht, 4 september 1984, $A B$ 1985, 39. 
hoofdcommissaris van politie op grond van een APV Utrecht geen rechtskracht kon worden toegekend, nu die beschikking in strijd was met artikel 2 lid 3 van het vierde protocol van het EVRM en artikel 12 lid 3 van het IVBPR. Het vonnis werd door de Hoge Raad in stand gehouden. ${ }^{1239}$ Toch kunnen hieruit geen vaststaande conclusies worden getrokken. In het vonnis, noch in het Hoge Raad arrest kwam de vraag of tegen de beschikking van de hoofdcommissaris een administratiefrechtelijke rechtsgang heeft opengestaan aan de orde.

In het bekende Mobil Oil-arrest neemt de Hoge Raad een meer uitgesproken standpunt in. ${ }^{1240}$ In deze zaak beroept verdachte zich op de innerlijke tegenstrijdigheid en daardoor op de onverbindendheid van twee vergunningsvoorschriften. Het Hof oordeelde dat voor betwisting van de belastende vergunningsvoorschriften een andere rechtsgang openstaat en voorts dat bij strijdigheid van beide voorschriften het zwaarste voorschrift moet worden nageleefd. De Hoge Raad hield deze uitspraak in stand met als kernoverweging:

's Hofs verwerping van het gevoerde verweer moet aldus worden begrepen dat het Hof heeft vooropgesteld dat in beginsel van de rechtmatigheid van de vergunning dient te worden uitgegaan, nu deze kennelijk niet is bestreden in de daartoe openstaande rechtsgang (...) Dit oordeel geeft geen blijk van een onjuiste rechtsopvatting. ${ }^{.241}$

De strafkamer van de Hoge Raad heeft met deze uitspraak onmiskenbaar de leer van de formele rechtskracht aanvaard. In geval van strijdigheid van een (belastend) vergunningsvoorschrift met het recht moet de burger in eerste instantie de administratieve rechter adiëren. Laat hij dit na, dan kan hij niet alsnog deze strijdigheid bij de strafrechter opwerpen.

De vraag rijst of de strafrechter ook uitzonderingen op de formele rechtskracht mag aanvaarden. Het Mobil Oil-arrest beantwoordt deze vraag positief. Doordat slechts 'in beginsel' moet worden uitgegaan van de rechtmatigheid van een beschikking laat de Hoge Raad ruimte open voor uitzonderingen. Zo zou de rechter (belastende) beschikkingen kunnen blijven toetsen waarvan de inhoud in strijd is met een of meer grondrechten. ${ }^{1242}$ In een Lex Mulder-zaak ging de strafkamer van de Hoge Raad meer expliciet op uitzonderingsmogelijkheden in. Aan betrokkene werd een Mulder-boete opgelegd wegens het in strijd met een parkeerverbod parkeren op een invalide-parkeerplaats. Toen de beschikking, houdende de oplegging van de administratieve boete, onherroepelijk was geworden en niet werd betaald, werd een dwangbevel uitgevaardigd. Tegen de tenuitvoerlegging van het dwangbevel werd door de betrokkene bij de Kantonrechter verzet gedaan. Het verzet richtte zich in eerste instantie niet tegen het dwangbevel maar tegen de geldigheid van de oorspronkelijke boetebeschikking daar volgens betrokkene de politie hem had toegezegd 
dat de boete zou worden ingetrokken. De Kantonrechter heeft vervolgens het verzet ongegrond verklaard daar de toezegging van de politie door betrokkene niet voldoende aannemelijk was gemaakt. In cassatie oordeelt de Hoge Raad dat ingevolge artikel 26, derde lid WAHV het verzet tegen de tenuitvoerlegging van een dwangbevel niet gericht kan zijn tegen de beschikking waarbij een administratieve boete is opgelegd:

'Aan die bepaling ligt het beginsel ten grondslag dat tegen de oplegging
van de administratieve sanctie een met waarborgen omklede rechtsgang
heeft opengestaan en dat, ingeval deze rechtsgang niet is gebruikt, de
rechter die in de verzetprocedure heeft te oordelen over de gegrondheid
van de tenuitvoerlegging van een dwangbevel, ervan kan, en moet,
uitgaan dat de inleidende beschikking zowel wat haar wijze van tot stand
komen als wat haar inhoud betreft in overeenstemming is met de
desbetreffende wettelijke voorschriften en algemene rechtsvoor-
schriften.'1243

De formulering van de leer van de formele rechtskracht is opvallend gelijkluidend met de overwegingen in het civielrechtelijke Heesch/Van de Akker-arrest. Ook aan de mogelijkheid van uitzonderingen op de formele rechtskracht geeft de strafkamer op dezelfde wijze vorm:

'De aan dit beginsel verbonden bezwaren kunnen evenwel door bijkomende omstandigheden zo klemmend worden dat hierop, gezien de bijzonderheden van het geval, een uitzondering moet worden aanvaard (vgl. HR 16 mei 1986, $N J$ 1986, 723). Van zodanige uitzondering kan met name sprake zijn wanneer een betrokkene uit verklaringen en gedragingen van de overheid in redelijkheid heeft mogen afleiden dat de bij de inleidende beschikking opgelegde sanctie niet zou worden geëffectueerd. ${ }^{1244}$

De uitzondering betrof met andere woorden een situatie waar eigenlijk het bestuur zelf erkent dat het besluit (i.c. de boetebeschikking) onjuist was. Tegen deze achtergrond acht de Hoge Raad de beslissing van de Kantonrechter niet voldoende gemotiveerd en werd de zaak teruggewezen.

Bij de toetsing van belastende beschikkingen (vergunningsvoorschriften) geldt blijkbaar als regel dat de strafrechter in beginsel gebonden is an de (fictieve) rechtmatigheid van de bestuurlijke beschikking. ${ }^{1245}$ Daarvoor zouden dan dezelfde argumenten gelden als in civielrechtelijke zaken. Nochtans kan de geldingskracht van een aantal argumenten vanuit

1245. Faure, M. en Visser, M., o.c., 1999, 91-95. 
strafrechtelijk oogpunt worden gerelativeerd ${ }^{1246} \mathrm{Zo}$ gaat het argument van het vermijden van forum shoppen niet op. Een risico van forumkeuze bestaat slechts indien de burger inderdaad de keuze zou hebben tussen twee rechters (fora) om de onrechtmatigheid van de beschikking aan te vechten. De strafrechter kan echter moeilijk worden beschouwd als één van de fora waaruit de burger zou kunnen kiezen. In de strafprocedure is het immers nog steeds het $\mathrm{OM}$ en niet de burger die de strafrechter adieert. De gevolgde strafprocedure is niet het gevolg van een keuze van de burger en reeds daarom niet te vergelijken met een civielrechtelijke procedure waarvoor de burger, na het verstrijken van de administratieve beroepstermijn, inderdaad zou kunnen opteren moest er geen formele rechtskracht bestaan. In een strafproces wordt de onrechtmatigheid van de beschikking door de verdachte opgeworpen, niet om de bestuursrechtelijke rechtsgang te ontwijken, maar om zich te verweren tegen de tenlastelegging van het OM. Het aanvoeren van de onrechtmatigheid in een strafproces door de verdachte speelt zich af in een totaal verschillende procesconstellatie met andere partijen en andere belangen. Het gaat inhoudelijk niet meer om de bescherming van een 'gewoon burger' tegen de overheid die de beschikking heeft uitgevaardigd. Het draait fundamenteel om de garantie voor een afdoende rechtsbescherming van een 'verdachte burger' tegen de vervolgende overheid. Vanuit de strafprocessuele rechtsbeschermingsidee dient de rechter dan ook zelfstandig op het verweer te kunnen antwoorden en maakt hij het zichzelf al te makkelijk door de verdachte het niet gebruiken van een administratieve rechtsgang te verwijten. In een dergelijke opvatting wordt uiteindelijk de strafprocesrechtelijke rechtsbescherming afhankelijk gemaakt van de nalatigheid van de verdachte en dat op een moment dat deze helemaal nog niet in een strafproces betrokken is. Tevens wordt de rechtsbescherming van het strafproces uitgehold door een aan dat strafproces voorafbestaande bestuursprocesrechtelijke rechtsbescherming. Dat lijkt mij een ongelukkige situatie. De ratio van de formele rechtskracht in civielrechtelijke zaken is dat een onrechtmatige daadsactie geen laatste rechtsmiddel mag zijn voor degene die zijn bestuursrechtelijke beurt heeft voorbij laten gaan. ${ }^{1247}$ Die ratio is in strafzaken in veel mindere mate aanwezig. Het verweer van de verdachte is geen laatste rechtsmiddel tegen de vergunningverlenende instantie maar vaak juist een eerste rechtsmiddel tegen de vervolgende instantie. Er kunnen trouwens gevallen aanwezig zijn waarin het begrijpelijk is dat de verdachte bewust het administratief beroep niet heeft benut, bijvoorbeeld omdat de voorschriften hem niet als dusdanig gebrekkig leken dat beroep noodzakelijk was. ${ }^{1248}$

Natuurlijk moet worden toegegeven dat de oplossing van de Hoge Raad tot meer rechtseenheid en rechtszekerheid leidt. De prijs die daarvoor moet worden betaald, vooral in termen van individuele rechtvaardigheid, lijkt me echter te hoog. De consequentie is immers dat verdachten kunnen worden veroordeeld voor het overtreden van voorschriften die strijdig zijn met de wet of rechtsbeginselen. Dit lijkt in strijd met de fundamentele beginselen van het strafrecht. Ook ontstaat zo een dubbele standaard voor verdachten. In dit verband merkt Koopmans op:

1246. Koopmans, I.M., o.c., 1996, 128-129; Faure, M. en Visser, M., o.c., 1999, 96; Cluysenaer, J.H.L., l.c., 1970, 1006.

1247. Buruma, Y. en Daalder, E.J., l.c., 1994, 320.

1248. Duk, W. en Nicolaï, P., l.c., 1991, 11. 
'een wegens overtreding van een commuun delict vervolgde verdachte, zou tijdens het strafproces in dat geval beschikken over meer verweersmogelijkheden dan een verdachte die wordt vervolgd wegens overtreding van een administratief delict. ${ }^{1249}$

Het lijkt daarom wenselijk dat op zijn minst uitzonderingen op de formele rechtskracht mogelijk blijven in die situaties waar de individuele rechtsbescherming zwaarder doorweegt dan de meer algemene belangen van rechtszekerheid en rechtsmachtverdeling.

Tegen de achtergrond van de toetsing van bevrijdende beschikkingen leidt het standpunt van de Hoge Raad nog tot een andere dichotomie. De strafrechter dient zich nu van toetsing te onthouden indien de verdachte (voor wie een administratieve rechtsgang openstaat) op de onrechtmatigheid beroep doet, maar gaat (blijkbaar) wel tot toetsing over indien het OM (voor wie geen beroep op de administratieve rechter openstaat) de onrechtmatigheid aanvoert. Hierdoor mag dan wel tot op zekere hoogte de eenheid tussen strafrecht en bestuursrecht zijn gediend, maar de rechtseenheid, -zekerheid èn -gelijkheid binnen het strafproces als zodanig is zoek. Daarom meen ik met Cluysenaer:

'de rechter heeft de strafbaarheid van het feit ambtshalve te onderzoeken, ongeacht of op de niet-strafbaarheid door één van de partijen een beroep is gedaan en zeker ongeacht de omstandigheid of op de niet-strafbaarheid een beroep is gedaan door verdachte of door het OM..$^{1250}$

Het belang van rechtseenheid tussen bestuursrecht en strafrecht moet trouwens niet te zeer worden overschat. Dat werd nog maar eens bevestigd in twee arresten waarin het weliswaar niet ging om de onverbindendverklaring van vergunningsvoorschriften, maar om de uitleg van deze voorschriften. In beide arresten oordeelt de Hoge Raad dat de uitleg van vergunningsvoorschriften van feitelijke aard is. De Hoge Raad ziet geen problemen in de omstandigheid dat de strafrechter autonoom tot een andere feitelijke uitleg komt dan de administratieve rechter. ${ }^{1251}$ Het belang van de strafrechtshandhaving in het concrete geval bleek zwaarder door te wegen dan het belang van rechtseenheid.

Samengevat: uit de jurisprudentie inzake formele rechtskracht in het milieustrafrecht kan worden afgeleid dat moet worden gedifferentieerd tussen bevrijdende beschikkingen en belastende beschikkingen (vergunningsvoorschriften). Bij toetsing van bevrijdende vergunningen lijkt de formele rechtskracht niet te spelen. Dit zou kunnen worden verklaard doordat de onrechtmatigheid van de vergunning door het $\mathrm{OM}$ en niet door de verdachte

1249. Koopmans, I.M, o.c., 1996, 129.

1250. Cluysenaer, J.L.H., l.c., 1970, 1003. Zie in dezelfde zin Van Der Burg, F.H., 'Formele rechtskracht, vertrouwensbeginselen en derde-beroep', in Een stellig annotator, Zwolle, W.E.J. Tjeenk Willink, 1982, 9.

1251. HR 23 mei 1995, MenR 1996, nr. 5, met noot Hendriks en HR 27 juni 1995, MenR 1996, nr.6, met noot Hendriks. 
wordt opgeworpen. Bij belastende beschikkingen heeft de formele rechtskracht voor de strafrechter wel geldingskracht. Dit is vanuit een bepaalde visie op de eenheid van rechtsorde begrijpelijk omdat voor de betwisting van de rechtmatigheid van vergunningsvoorschriften voor de burger een afzonderlijke administratieve rechtsgang openstaat of heeft opengestaan. Vanuit strafprocessueel rechtsbeschermingsperspectief, maar ook vanuit het oogpunt van doelmatige rechtshandhaving, is dit geen ideale oplossing.

\section{De invloed van de administratiefrechtelijke uitspraak op de toetsing}

a. De uitspraak van de administratieve rechter en de civiele rechter

Over de wijze waarop de civiele rechter omgaat met een uitspraak van de administratieve rechter kunnen we kort zijn. In het geval dat de civiele rechter geconfronteerd wordt met een beschikking die door een administratieve rechter is vernietigd, is deze uitspraak voor hem bindend. In het arrest St. Oedenrode-Driessen oordeelde de Hoge Raad:

'dat het oordeel over de vraag of de beschikkingen in strijd met het recht als nader bepaald in art. 8 lid 1 Wet Arob - zijn genomen, bij de Afd. rechtspraak berust zodat het Hof van de uitspraken van de Afd. had uit te gaan. $^{1252}$

In het Van Gog-Nederweert-arrest werd dit uitgangspunt nog eens duidelijk beklemtoond ${ }^{1253}$ :

'Indien een overheidslichaam een onrechtmatige daad pleegt door een beschikking te nemen en te handhaven die naderhand door de rechter wordt vernietigd wegens strijd met de wet of op enige andere in art. 8 lid 1 Wet Arob vermelde grond - dan wel een overeenkomstige grond vermeld in enig andere administratieve wet -, is daarmede de schuld van het overheidslichaam in beginsel gegeven. ${ }^{.1254}$

Het oordeel van de administratieve rechter is bindend, ook al zou in een procedure voor de burgerlijke rechter anders zijn geoordeeld. ${ }^{1255}$ De rechtspraak erkent dus een overeenkomst tussen bestuursrechtelijke en civielrechtelijke onrechtmatigheid. Natuurlijk zal voor een daadwerkelijke toewijzing van de onrechtmatige daad-vordering aan de andere voorwaarden van art. 6:162 BW moeten zijn voldaan.

1252. HR 24 februari $1984, N J 1984,669$.

1253. Zie voor een overzicht van vroegere jurisprudentie Mok, M.R. en Tjittes, R.P.J.L., l.c., 1995, 389.

1254. HR 31 mei 1991, NJ 1993, 112, met noot Brunner. Zie tevens HR 8 maart 1991, NJ 1991, 379, met noot Brunner; HR 1 juli 1993, $N J$ 1995, 150, met noot Brunner en HR 2 juni 1995, RvdW $1995,123 \mathrm{c}$.

1255. Hennekens, H.Ph.J.A.M., 'De Hoge Raad en de formele rechtskracht', de Gemeenstem, 1993, 149. 
Aan deze zogenaamde oneigenlijke formele rechtskracht liggen mutatis mutandis dezelfde overwegingen ten grondslag als bij de eigenlijke formele rechtskracht. Daarnaast is tevens van belang dat moet worden vermeden dat partijen opnieuw moeten strijden over een punt waaromtrent reeds is beslist in een met voldoende rechtswaarborgen omklede rechtsgang. ${ }^{1256}$

Maar ook hier zijn uitzonderingen mogelijk. In het zonet genoemde arrest oordeelde de Hoge Raad:

'Niet uitgesloten is dat bijzondere omstandigheden in verband met de aard van het oordeel tot een andere beslissing omtrent deze bindende kracht nopen. ${ }^{.1257}$

Als mogelijke uitzondering kan worden gedacht aan de situatie waarin de burger zelf tot de schade heeft bijgedragen door bijvoorbeeld het geven van onjuiste informatie aan de overheid. Ook is een uitzondering denkbaar wanneer hij op grond van een beschikking handelt, wetende dat deze onrechtmatig is. ${ }^{1258}$

\section{b. De uitspraak van de administratieve rechter en de strafrechter}

Indien de administratieve rechter een uitspraak heeft gedaan, is de strafrechter dan net als zijn civielrechtelijke collega door deze uitspraak gebonden? De jurisprudentie lijkt als uitgangspunt te nemen dat de toetsingsbevoegdheid niet meer bestaat na een uitspraak over de rechtmatigheid van een beschikking door de administratieve rechter. Zo wordt vermeden dat verschillende rechters tot verschillende uitspraken zouden komen, wat vanuit het idee van rechtseenheid en rechtszekerheid niet wenselijk wordt geacht. ${ }^{1259}$ Dit standpunt is begrijpelijk. In tegenstelling tot de situatie waarin de rechtskracht louter het gevolg is van het verlopen van de beroepstermijn hebben we hier te maken met een daadwerkelijke beoordeling van een beschikking door een onafhankelijke administratieve rechter in een met alle waarborgen omklede rechtsgang. De formele rechtskracht is dan het resultaat van de daadwerkelijke contentieuze procedure. Er is een expliciete rechtmatigheidstoets uitgevoerd door een onafhankelijke rechter die toch geacht wordt daarvoor de best geplaatste te zijn. Het lijkt daarom wenselijk dat de strafrechter deze uitspraak niet zomaar naast zich neer kan leggen.

Nochtans menen enkele auteurs dat de toetsingsbevoegdheid moet kunnen blijven bestaan, ongeacht de uitspraak van de administratieve rechter. ${ }^{1260}$ Cluysenaer gaat hierin zeer

1256. Van Wijk, H.D. en Konijnenbelt, W., o.c., 1999, 606.

1257. HR 31 mei 1991, $N J 1993,112$.

1258. Mok, M.R. en Tjittes, R.P.J.L., l.c., 1995, 392.

1259. Zie de conclusie van A-G Meyers voor HR 11 februari 1986, NJ 1987, 673.

1260. Cluysenaer, J.L.H., l.c., 1970, 1004; Enigszins gematigd aansluitend bij Cluysenaer: Duk, W. en Nicolail, P., L.c., 1991, 9-10. 
ver. ${ }^{1261}$ Wel bepleit hij voor de praktijk van de toetsing een zeker realisme en terughoudendheid. De strafrechter moet zo veel mogelijk de beslissing van de administratieve rechter in zijn oordeel betrekken; de toetsing zal steeds beperkt moeten blijven. ${ }^{1262}$ Minder extreem is de opvatting van Duk en Nicolaï. Als principe dient te gelden dat de strafrechter zich dient te conformeren aan het oordeel van zijn bevoegde collega. Maar tegelijk moet er ruimte zijn voor (zij het wel zeer buitengewone) uitzonderingen. De uitzonderingen die door de auteurs worden geviseerd zijn vooral die gevallen waar de administratieve rechter de beschikking intact laat en hij geen vernietiging heeft uitgesproken. Er ligt dan wel een beslissing van een administratieve rechter maar de iure is de rechtskracht niet het gevolg van de rechterlijke uitspraak maar vloeit deze (nog steeds) rechtstreeks uit de beschikking voort. Het betreft dan nog steeds de eigenlijke formele rechtskracht. Het kan dan voorkomen dat in de strafrechtelijke procedure argumenten voor nietigheid opkomen die voor de administratieve rechter geen aandacht hebben gekregen. Indien de strafrechter meent dat er alsnog reden is voor nietigheid, dan moet hij kunnen afwijken van het rechtsgeldigheidsoordeel van de administratieve rechter: 'in geen geval mag iemand worden veroordeeld voor overtreding van een nietig voorschrift. ${ }^{1263}$ Ook in situaties waarin duidelijk sprake is van een mal-jugé moet de strafrechter zelfstandig kunnen toetsen. De stellingname van Duk en Nicolaï lijkt mij gegrond omdat, zonder dat afstand wordt genomen van het principe dat de strafrechter in beginsel is gebonden aan het oordeel van zijn bestuursrechtelijke collega, toch ruimte voor uitzonderingen blijft bestaan.

\section{Samenvatting}

De vraag of de Nederlandse strafrechter beschikkingen aan wet en recht mag toetsen is niet eenvoudig te beantwoorden. Op grond van de rechtspraak kan worden geconcludeerd dat belastende beschikkingen (vergunningsvoorschriften) door de strafrechter in beginsel niet worden getoetst en dat derhalve de formele rechtskracht geldt. Of dit ook zo is wanneer hem gevraagd wordt een oordeel te vellen over de rechtmatigheid van bevrijdende beschikkingen (vergunningen) is niet helemaal duidelijk. Het lijkt erop dat wanneer het OM zich bij de strafvervolging beroept op de onrechtmatigheid van een bevrijdende vergunning, de strafrechter deze beschikking kan toetsen, zodat de strafbaarheid van het feit kan worden vastgesteld. De formele rechtskracht lijkt dan niet te spelen. Dit zou kunnen worden verklaard door het simpele gegeven dat bij toetsing van bevrijdende beschikkingen niet de burger om een rechterlijke toetsing vraagt, maar het OM die moeilijk formele rechtskracht kan worden tegengeworpen. $\mathrm{Bij}$ belastende beschikkingen (vergunningsvoorschriften) daarentegen beroept niet het $\mathrm{OM}$ maar de burger zich op de onrechtmatigheid. De strafrechter verwerpt dit verweer met het argument dat de justitiabele de administratieve rechtsgang had kunnen benutten om de voorschriften aan te vechten.

1261. Hij nuanceert zijn extreem uitgangspunt echter in de zin dat hij de strafrechter in beginsel wel gebonden acht indien de administratieve rechter zelf een verleende vergunning intrekt of alsnog een gevraagde vergunning verleent. Dan hebben we niet met een declaratoire maar met een constitutieve beslissing te maken. Aan een constitutief vonnis van een rechter is een andere rechter in principe wel gebonden. Cluysenaer, J.L.H., l.c., 1970, 1004, voetnoot 5.

1262. Idem, 1005.

1263. Duk, W. en Nicolar, P., l.c., 1991, 9. 
Of de strafrechter gebonden is aan uitspraken van zijn administratiefrechtelijke collega is makkelijker te beantwoorden. Eens de administratieve rechter zich over de rechtmatigheid van een beschikking heeft uitgesproken is de strafrechter gebonden aan dit oordeel. Dit is begrijpelijk omdat een onafhankelijke rechter zich immers over de beschikking heeft kunnen buigen. De strafrechter is dan niet gebonden aan een beslissing van het bestuur, maar aan een uitspraak van een rechter. Enkel in bepaalde gevallen zou nog een afzonderlijke toetsing door de strafrechter te rechtvaardigen zijn.

Op de beperkte toetsingsmogelijkheden van de strafrechter kan de nodige kritiek worden geleverd. In de eerste plaats wordt via de formele rechtskracht de strafrechter volledig afhankelijk gemaakt van zuiver bestuursprocesrechtelijke doelstellingen. Dit betekent in de praktijk dat een burger kan worden veroordeeld voor de overtreding van onrechtmatige voorschriften. Dat dit nadeel op het niveau van strafoplegging kan worden opgevangen doet hier niet aan af. Indien niet alleen bij belastende beschikkingen, maar ook bij bevrijdende beschikkingen de formele rechtskracht zou gelden, dan zou dit zelfs betekenen dat onrechtmatige vergunningen een strafuitsluitende werking zouden krijgen. Maar zoals gezegd, het lijkt erop dat naar Nederlands recht bij bevrijdende beschikkingen de formele rechtskracht geen nefaste rol speelt. De formele rechtskracht werkt dus alleen ten nadele van de burger, en niet ten nadele van het $\mathrm{OM}$, hetgeen trouwens een merkwaardige situatie is. Door de formele rechtskracht wordt de burger een essentieel verweer, de exceptie van onwettigheid, ontnomen. Strafrechtsdogmatisch betekent dit dat het oordeel van de strafbaarheid van de gedraging vrijwel uitsluitend bestuursprocesrechtelijk wordt ingevuld: het feit is strafbaar doordat de administratieve rechtsgang niet is benut. Bovendien blijkt een belangrijk argument voor formele rechtskracht in het strafrecht te zijn dat ook de civiele rechter gebonden is aan beschikkingen waarvan de beroepstermijn is verstreken. Deze redenering gaat echter alleen op indien de ratio's voor het bestaan van formele rechtskracht in civilibus in dezelfde mate ook aanwezig zouden zijn in criminalibus. Dat is niet het geval. De belangrijkste ratio van formele rechtskracht in het civiele recht is een behoorlijke verdeling van de rechtsbescherming van de burger tegen de overheid. Er moet, begrijpelijkerwijs, worden vermeden dat de burger van rechter naar rechter 'shopt'. Van dergelijk risico is in het strafrecht geen sprake, daar de taak van de strafrechter een andere is dan die van de civiele of administratieve rechter.

\section{B. DUITSLAND}

\section{Inleiding}

Ook de Duitse milieustrafbepalingen $\S \S 324$ e.v. StGB worden gekenmerkt door een administratieve afhankelijkheid. Net als in Nederland wordt de strafrechtelijke norm nader ingevuld door de milieuinstanties. Deze administratieve afhankelijkheid doet zich hoofdzakelijk op tweeërlei wijze voor.

Bij de gemene milieudelicten van $\S \S 324$ en 326 StGB vindt de administratieve invulling plaats op het niveau van de wederrechtelijkheid (Rechtswidrigkeitsebene). Zo is volgens $\S$ 
324 StGB slechts diegene strafbaar die het water 'unbefugt' verontreinigt of anderszins de eigenschappen van het water nadelig verandert. ${ }^{1264}$ Het begrip 'unbefugt' verwijst naar de wederrechtelijkheid van de waterverontreiniging. Derhalve wordt zuiver water als ecologisch rechtsgoed op rechtstreekse wijze beschermd. Dit betekent dat iedere gedraging, die een nadelige verandering van de eigenschappen van het water tot gevolg heeft, ${ }^{1265}$ reeds de delictsomschrijving vervult, maar tegelijk slechts strafbaar is wanneer deze 'unbefugt' plaatsvindt, bijvoorbeeld wegens het ontbreken van een vergunning. Eenzelfde redenering geldt met betrekking tot de 'Umweltgefährende Abfallbeseitigung' van § $326 \mathrm{StGB}$. Strafbaar is het 'unbefugt' behandelen, verwerken, opslaan of op een andere manier omgaan met afval, waardoor gevaar kan ontstaan voor de gezondheid van mens of dier, of waardoor water, lucht of bodem wordt verontreinigd. ${ }^{1266}$ Wanneer derhalve een rechtsgeldige vergunning voorligt, is de afvalverwerking niet wederrechtelijk. Met andere woorden, bij de gemene milieudelicten krijgen vergunningen het karakter van rechtvaardigingsgronden.

Bij de kwaliteitsmilieudelicten van $\S \S 325,327,328$ en 329 StGB ligt de situatie anders want daar vindt de koppeling met het bestuursrecht plaats op het niveau van de delictsomschrijving (Tatbestandsebene). Zo is luchtverontreiniging slechts strafbaar wanneer er sprake is van een 'Verletzung verwaltungsrechtlicher Pflichten' ( $325 \mathrm{StGB}$ ) en is de exploitatie van bepaalde inrichtingen of de omgang met kernbrandsstoffen slechts strafbaar voor zover dit plaatsvindt 'ohne die erforderliche Genehmigung' ( $\S 327$ en 328 StGB). Deze zinsneden maken deel uit van de delictsomschrijving. Dit betekent dat wanneer er geen sprake is van een inbreuk op bestuursrechtelijke plichten of een handelen zonder vergunning de delictsomschrijving niet is vervuld en er derhalve geen strafbaar feit voorligt. Met andere woorden, bij de kwaliteitsmilieudelicten hebben vergunningen een kwalificatie- of bestanddeeluitsluitende werking. ${ }^{1267}$

Bemerk dat zowel bij de gemene als bij de kwaliteitsmilieudelicten de verantwoordelijkheid van de vergunningverlenende instanties niet kan worden onderschat. Het zijn zij die door de nadere invulling van de strafrechtelijke normen de voorwaarden voor de strafbaarheid bepalen. Wanneer nu door een foutieve vergunningverlening milieuoverheden bijdragen tot milieuverontreiniging, rijst de vraag in welke mate (1) de vergunninghouders zich nog op dergelijke onrechtmatige vergunningen kunnen beroepen en (2) of niet slechts de vergunninghouder maar ook de vergunningverlener daarvoor strafrechtelijk ter verantwoording kan worden geroepen. ${ }^{1268}$ Voor het beantwoorden van beide vragen is

1264. Zie hierover o.m. Koopmans, I.M., o.c., 1996, 89-91.

1265. § 324 StGB is geformuleerd als een door het gevolg gekwalificeerd delict. Voor de voltooiing van het delict is vereist dat er sprake is van verontreiniging in de zin van een nadelige verandering van de natuurlijke eigenschappen van het water. De rechtspraak heeft $\S 324 \mathrm{StGB}$ echter als een abstract gevaarzettingsdelict benaderd. Toereikend voor de vervulling van het bestanddeel 'nadelige eigenschapsverandering' is dat de fysische, chemische of biologische status-quo van een opper-vlaktewater door de handeling is veranderd, waardoor op één of andere wijze materieel nadeel kan ontstaan, ofwel deze verandering abstract gevaarzettend is.

1266. Zie hierover o.m. Koopmans, I.M., o.c., 1996, 93-94.

1267. Zie hierover o.m. Koopmans, I.M., o.c., 1996, 91-93 en 94-98.

1268. Rogall, K., o.c., 1991, 169-199. 
natuurlijk ook naar Duits recht de mate van strafrechtelijke toetsingsbevoegdheid cruciaal. Is toetsing uitgesloten dan vloeit daaruit voort dat de voor vergunninghouder en -verlener vereiste strafbaarheid van het feit zou kunnen worden opgeheven door een door deze laatste zelf verleende onrechtmatige vergunning. Hiermee zou dan niet alleen de strafrechtelijke aansprakelijkheid van de vergunninghouder maar tevens die van de vergunningverlenende instantie bij voorbaat zijn uitgesloten. ${ }^{1269} \mathrm{Bij}$ de bespreking van de toetsingsbevoegdheid van de Nederlandse strafrechter werd reeds vastgesteld dat dit gevaar reëel aanwezig is wanneer onrechtmatige vergunningen in staat zijn strafuitsluitend te werken. Dat bestuursrechtelijk rechtmatige vergunningen de strafbaarheid van de verontreiniging uitsluiten is vanzelfsprekend en derhalve niet problematisch. Cruciaal is veeleer de vraag of ook onrechtmatige, bijvoorbeeld in strijd met hogere regelgeving afgegeven vergunningen, door de strafrechter moeten worden gerespecteerd. Is dit het geval dan heeft de gebondenheid van de strafrechter aan onrechtmatige vergunningen een straffeloosheid van zowel vergunning-houder als vergunningverlener tot gevolg. Ook hier geldt als uitgangspunt: hoe geringer de reikwijdte van de strafrechtelijke toetsingsbevoegdheid, des te moeilijker het wordt om de veroorzakers van de milieuverstoring strafrechtelijk aansprakelijk te stellen.

Deze paragraaf is als volgt opgebouwd. Allereerst wordt stil gestaan bij de principiële uitgangspunten van strafrechtelijke toetsing in het Duitse recht (2). Vervolgens worden enkele door de heersende leer aanvaarde uitzonderingen op deze uitgangspunten nader bekeken (3). Bemerk dat het vraagstuk van strafrechtelijke toetsing naar Duits recht zeer omstreden is en daarom niet is uitgekristalliseerd. Met name binnen het kader van het milieustrafrechtelijke Amtsträgerstrafbarkeit-debat, wordt de vraag of de strafrechter vergunningen mag toetsen ernstig bediscussieerd. Volledigheidshalve moet derhalve ook aandacht worden besteed aan de toenemende kritiek van de Mindermeinung op de argumenten van de heersende leer voor een strafrechtelijk toetsingsverbod (4). Ter wille van de duidelijkheid besluit ik met een samenvatting (5).

\section{Een principieel toetsingsverbod: strafrechtelijke rechtmatigheid is bestuurs- rechtelijke rechtsgeldigheid}

Om maar onmiddellijk met de deur in huis te vallen: het Duitse recht aanvaardt slechts een zeer beperkte toetsingsbevoegdheid van de strafrechter. De meerderheid in de literatuur neemt als uitgangspunt dat de strafrechter niet slechts gebonden is aan rechtmatige beschikkingen, maar dat hij ook onrechtmatige beschikkingen moet respecteren zolang deze rechtsgeldig zijn. ${ }^{1270}$ Van belang is dus te weten wanneer een beschikking rechtsgeldig

1269. Rogall, K., o.c., 1991, 159 en 164-166.

1270. Bloy, R., 'Die Straftaten gegen die Umwelt im System des Rechtsgüterschutzes', ZStW, 1988, 485; Breuer, R., 'Empfehlen sich Änderungen des strafrechtlichen Umweltschutzes insbesondere in Verbindung mit dem Verwaltungsrecht?', NJW, 1988, 2072 en 2080; Schönke A., Schröder, H. en Cramer, P. o.c., $\S \S 324$, Nr. 16a; Dahs, H. en Pape, A., 'Die behördliche Duldung als Rechtferti-gungsgrund im Gewässerstrafrecht ( $\S 324$ StGB), NStZ, 1988, 393; Dolde, K.-P., 'Zur Verwaltungs-akzessorietăt von $\S 327$ StGB, NJW, 1988, 2329; Franzheim, H., 'Die Bewăltigung der Verwaltungsaksezzorietăt in der Praxis, $J R, 1988,321$; Geisler, C., 'Strafbarkeit von Amtsträgern im Umweltrecht', NJW, 1982, 11; Horn, E., l.c., 1981, 3; Immel, B., Strafrechtliche 
(rechtswirksam) is. Een administratieve beschikking (Verwaltungsakt), dus ook een vergunning, is volgens $\S 43 \mathrm{Abs} .1$ Verwaltungsverfassungsgesetz (VwVfG) rechtsgeldig vanaf haar verstrekking en/of bekendmaking aan de betrokkene(n). ${ }^{1271}$ Van belang is dat de mogelijke onrechtmatigheid van de beschikking geen afbreuk doet aan de rechtsgeldigheid ervan. Deze automatische rechtsgeldigheid vloeit voort uit $\S 43 \mathrm{Abs} .2 \mathrm{VwVfG}$ :
'Ein Verwaltungsakt bleibt wirksam, solange und soweit er nicht zurück- genommen, widerrufen, anderweitig aufgehoben oder durch Zeitablauf oder auf andere Weise erledigt ist.'

Ook onrechtmatige beschikkingen zijn dus rechtsgeldig zolang zij niet zijn ingetrokken of krachtens de andere in $\S 43 \mathrm{Abs} .2 \mathrm{VwVfG}$ genoemde gronden zijn komen te vervallen. ${ }^{1272}$

De enige wettelijke uitzondering op de automatische rechtsgeldigheid van beschikkingen is neergelegd in $\S 43 \mathrm{Abs} .3 \mathrm{VwVfG}$ waarin wordt bepaald dat 'ein nichtiger Verwaltungsakt unwirksam ist'. Volgens $\S 44 \mathrm{Abs} .1 \mathrm{VwVfG}$ is een beschikking nietig
'soweit er an einem besonders schwerwiegenden Fehler leidet und dies bei verständiger Würdigung aller in Betracht kommende Umstände offen- kundig ist'.

Een beschikking is dus nietig wanneer aan twee voorwaarden is voldaan. Allereerst moet er sprake zijn van een bijzonder zwaarwegend gebrek. Als bijzonder zwaarwegende gebreken in de zin van $\S 44 \mathrm{Abs} .1 \mathrm{VwVfG}$ komen in aanmerking fouten die
'in einem so bedeutenden Widerspruch zur geltenden Rechtsordnug stehen, daß es unerträglich wäre, wenn der Verwaltungsakt die mit ihm bezweckten Rechtswirkungen hätte. ${ }^{1273}$

Verantwortlichkeit von Amtsträgern im Umweltstrafrecht, Frankfurt a. M., 1987, 130 e.v.; Lenckner, Th., 'Behördliche Genehmigungen und der Gedanke des Rechtsmisbrauchs im Strafrecht', in Strafrecht, Unternehmensrecht, Anwaltsrecht, Festschrift für G. Pfeiffer, Köln, 1988, 30; Linnendrink, D., Der Wegfall der strafrechtlichen Verantwortlichkeit des Garanten, Aachen, 1995, 243-244; Odersky, W., 'Zur strafrechtlichen Verantwortlichkeit für Gewässerverunreinigungen', in Festschrift für H. Tröndle zum 70. Geburtstag 1989, Berlin, 1989, 292; Papier, H.J., Umweltschutz durch Strafrecht?, Göttingen, 1987, 7; Rengier, R., 'Die offentlichrechtliche Genehmigung im Strafrecht, ZStW, 1989, 886; Rogall, K., o.c., 1991, 176186; Rudolphi, H.-J., 'Probleme der strafrechtlichen Verantwortlichkeit von Amtsträgern für Gewässerverunreinigungen', in Festschrift für H. Dünnebier zum 75. Geburts-tag 1982, Berlin, 1982, 562; Zeitler, S., Die strafrechtliche Haftung für Verwaltungsentscheidungen nach dem neuen Umweltstrafrecht, Dargestellt an dem $\S 324$ StGB, Tübingen, 1982, 70 en 112.

1271. Erichsen, H.-U., Allgemeines Verwaltungsrecht, Berlin, 1995, 270-271.

1272. Erichsen, H.-U., o.c., 1995, 271; Scheele, R., Zur Bindung des Strafrichters an fehlerhafte behördliche Genehmigungen im Umweltstrafrecht, Berlin, 1993, 35.

1273. Rogall, K., o.c., 1991, 164. 
Daarnaast is de Offenkundigkeit een vereiste voor de nietigheid. Er moet sprake zijn van een duidelijk herkenbare of aperte schending. Dit betekent in de praktijk dat het aan de beschikking klevende gebrek

'für einen unvoreingenommenen, mit den in Betracht kommenden Umständen vertrauten und verständigen Beobachter ohne weiteres ersichtlich sein und sich geradezu aufdrängen mü̈ ${ }^{1}{ }^{1274}$

Maatstaf is dus de beoordeling van de doorsnee burger. In § 44 Abs. 2 VwVfG wordt dan een aantal nietigheidsgronden opgesomd. Nietig zijn in het bijzonder beschikkingen die door onbevoegde instanties of in strijd met de goede zeden zijn afgegeven. Nu nietige beschikkingen niet rechtsgeldig zijn, is de strafrechter daaraan niet gebonden. Maar daarbij mag niet worden vergeten dat gelet op de strenge nietigheidsvoorwaarden de nietigheid van een beschikking slechts in zeldzame gevallen kan worden vastgesteld.

Wel bestaat de mogelijkheid dat een beschikking wegens gebreken ingetrokken wordt ( $\$ 43$ Abs. 2 VwVfG). De geadresseerde kan de beschikking binnen de daarvoor geldende termijn krachtens $\S 42$ VwGO (Anfechtungsklage) en/of $\S 68$ VwGO (Widerspruche) aanvechten. Beide procedures hebben schorsende werking. Ook het bestuursorgaan kan een onrechtmatige vergunning intrekken. Deze mogelijkheid blijft zelfs bestaan nadat de termijnen zijn verstreken en de beschikking eigenlijk onherroepelijk is geworden. Maar zolang deze niet is ingetrokken blijft de strafrechter aan de beschikking gebonden. Dit betekent dat ook beschikkingen waartegen een rechtsmiddel kan worden ingesteld door de strafrechter niet mogen worden getoetst. Dit is uitsluitend aan de administratieve rechter voorbehouden. ${ }^{1275}$

Deze strikte gebondenheid van de strafrechter aan de rechtsgeldigheid van de beschikking geldt in principe zowel voor belastende als bevrijdende beschikkingen. ${ }^{1276}$ De toetsingsbevoegdheid van de strafrechter is dus nog beperkter dan in Nederland. We hebben immers gezien dat naar Nederlands recht de strafrechter bevrijdende beschikkingen lijkt te kunnen toetsen. Ook belastende beschikkingen kunnen door de Nederlandse strafrechter worden beoordeeld zolang deze geen formele rechtskracht genieten. In Duitsland is daarentegen de formele rechtskracht (formelle Bestandskraft) van ondergeschikt belang. ${ }^{1277}$ De gebondenheid van de strafrechter vloeit immers rechtstreeks voort uit de rechtsgeldigheid van de

1274. Rogall, K., o.c., 1991, 165.

1275. Koopmans, I.M., o.c., 1996, 177.

1276. Schmitz, R., Verwaltungshandeln und Strafrecht. Zur Verwaltungsakzessorietät des Umweltstrafrechts, Heidelberg, C.F. Müller Juristischer Verlag, 1992, 14-15 en 19-20.

1277. Zie tevens Roozendaal, B.J.P.G., 'Een andere kijk op formele rechtskracht', in Cleiren, C.P.M., Foqué, R.M.E.G., Gribnau, J.L.M., Van Male, R.M. en Mevis, P.A.M. (red.), Voor risico van de overheid?, Amhem, Gouda Quint, 1996, 125: 'Aan deze "formelle Bestandskraft" wordt geen grote betekenis toegekend, gezien het feit dat zelfs een handboek over het bestuursprocesrecht hier in het geheel aan voorbij gaat.' 
beschikking en is niet, zoals in Nederland, afhankelijk van het al dan niet openstaan van een behoorlijke administratieve rechtsgang voor de belanghebbende ${ }^{.1278}$

$\mathrm{Nu}$ slechts nietige beschikkingen door de strafrechter mogen worden getoetst, heeft dit tot gevolg dat onrechtmatige vergunningen die niet nietig zijn in het milieustrafrecht een bestanddeeluitsluitende of rechtvaardigende werking blijven behouden. In de sfeer van waterverontreiniging betekent dit bijvoorbeeld dat een lozingsvergunning, die helemaal niet mocht worden verleend omdat deze een emissie toelaat die volgens de 'allgemeine Regeln der Technik' vermijdbaar is ( $\$ 7$ a 1 WHG), toch als een strafrechtelijke rechtvaardigingsgrond moet worden aangemerkt. Ook een vergunning waarvan de voorwaarden zodanig soepel zijn dat hieruit 'eine Gefährdung der öffentlichen Wasserversorgung' te verwachten is ( $\S 6$ WGH), werkt strafuitsluitend. ${ }^{1279}$

De belangrijkste ratio van deze strikte gebondenheid van de strafrechter aan bestuurlijke beschikkingen is de eenheid van rechtsorde. Volgens de heersende leer en rechtspraak betekent de eenheid van rechtsorde dat de onrechtmatigheid van een bepaalde gedraging voor de gehele rechtsorde eenzelfde inhoud moet hebben. Dit zogeheten 'einheitliche Rechtswidrigkeitsbegriff' impliceert dat een gedraging die onrechtmatig is in één van de rechtsgebieden meteen ook onrechtmatig is voor de ganse rechtsorde. ${ }^{1280}$

'Die Rechtsordnung als einheitliche Sollensordnung könne nicht in einem Teilbereich ein bestimmtes Verhalten erlauben, in einem anderen aber Verbieten..$^{1281}$

Zoals gezien, beroept de Nederlandse wetgever zich ook op eenheid van rechtsorde teneinde aan het begrip wederrechtelijkheid van de artikelen 173a en 173b Sr een vergunningafhankelijke inhoud te geven, zodat wederrechtelijkheid niet inhoudt in strijd met het objectieve recht', maar in strijd met een vergunningsvoorschrift. Ook de Duitse rechtspraak verwijst uitdrukkelijk naar de eenheid van rechtsorde als leidend beginsel. Illustratief is een uitspraak van het OLG Köln. In deze zaak werd de directeur van een rederij vrijgesproken van de hem tenlastegelegde waterverontreiniging ( $\$ 324$ StGB) omdat de vervuiling - het lozen van keuken- en toiletafvalwater - op grond van het scheepvaartrechtelijk gewoonterecht zou zijn toegestaan. Centraal stond de algemene vraag in welke mate de strafrechter ter beoordeling van de onrechtmatigheid (Unbefugtheit) van de verontreiniging afhankelijk is van noties uit andere rechtsgebieden, in casu het scheepvaartrecht. Het OLG neemt het

1278. Zie hierover ook Faure, M. en Oudijk, J.C., 'Die strafgerichtliche Öberprüfung von Verwaltungsakten im Umweltrecht', $J Z, 1994,86-91$; Faure, M., 'De gevolgen van de "administratieve afhankelijkheid" van het milieustrafrecht: een inventarisatie van knelpunten', in Faure, M., Oudijk, J.C. en Schaffmeister, D. (red.), o.c., 1991, 91-150.

1279. Rademacher, M., Die Strafbarkeit wegen Verunreinigung eines Gewässers ( $\$ 324$ StGB) unter besondere Berücksichtigung der behördlichen Genehmigung als Rechtfertigungsgrund, Frankfurt a. M., 1989, 22.

1280. Jescheck, H.-H. en Weigend, Th, o.c., 1996, 327.

1281. Scheele, R., o.c., 1993, 44. 
reeds 'einheitlicher Rechtswidrigkeitsbegriff' als uitgangspunt, hetgeen betekent dat wat toegestaan is in het ene rechtsgebied niet kan verboden zijn in een ander rechtsgebied:

'Grundsätzlich ist die Frage der Rechtswidrigkeit einheitlich für die gesamte Rechtsordnung zu beantworten; wenn ein bestimmtes Verhalten aufgrund zivilrechtliche oder öffentlich-rechtlicher Vorschriften erlaubt ist, kann der Rechtswidrigkeit auch unter strafrechtlichen Gesichtspunkten entfallen. Demgemäß handelt auch i.S. d. § 324 StGB derjenige nicht unbefugt, dem nach zivil- oder verwaltungsrechtlichen Bestimmungen das Tun gestattet ist. Das Schiffahrtsrecht kann daher für die Beurteilung des Begriffs "unbefugt" nicht außer Betracht bleiben (...) Dem für den Rhein geltenden Schiffahrtsrecht kann also nicht das Verbot entnommen werden, Küchen- oder Toilettenabwasser in das Gewässer einzuleiten.' ${ }^{1282}$ (cursief, DR)

In gelijke zin oordeelde het OLG Celle. Het begrip wederrechtelijkheid is niet verschillend per rechtsgebied maar verwijst naar de

'Widerspruch zur rechtsordnung im ganzen (...), so daß sie auch nur einheitlich für die gesamte Rechtsordnung gelten kann. ${ }^{1283}$

Dat de eenheid van rechtsorde ook tot gevolg heeft dat de strafrechter gebonden is aan onrechtmatige vergunningen zolang ze rechtsgeldig zijn, werd bevestigd in een principiële uitspraak van het OLG Frankfurt. Het interessante aan deze zaak is dat zowel de vergunninghouder - meer bepaald via $\S 14$ StGB de directeur van de vergunningplichtige onderneming ${ }^{1284}$ - als de vergunningverlenende ambtenaar werden vervolgd.

Allereerst brengt het OLG in herinnering dat gelet op de administratieve afhankelijkheid in beginsel uitsluitend formeel rechtsgeldige vergunningen waterverontreiniging kunnen toestaan.

'Somit ist nicht gerechtfertigt, wer Abwasser ohne Erlaubnis in ein Gewässer einleitet oder wer die erteilte Erlaubnis überschreitet, d.h. die in der Erlaubnis fetsgesetzten absoluten Höchstwerte, mit denen ihr Gegenstand und damit zugleich ihre rechtfertigende Wirkung begrenzt werden, nicht einhält (...) Dem entspricht der Standpunkt, daß die bloße Erlaubnisfähigkeit nicht rechtfertigend wirkt, vielmehr der formale Gestattungsakt erforderlich ist'. ${ }^{1285}$

1283. OLG Celle 4 juni 1986, ZfW 1987, 128.

1284. Zie over het toepassingsgebied en de voorwaarden van $\S 14$ StGB hoofdstuk III.

1285. OLG Frankfurt, 22 mei 1987, JR 1988, 169-170. 
Het OLG laat vervolgens geen twijfel bestaan over de kwestie dat de strafrechter ook gebonden is aan onrechtmatige vergunningen:

'Insoweit entspricht es auch ganz h. M., daß es bei der behördlichen Gestattung alleine auf die Verwaltungsrechtliche (formelle) Wirksamheit ankommt; eine zu Unrecht ausgesprochene oder fehlerhaft gewordene Gestattung macht das Verhalten bis zur Rücknahme oder zum Widerruf grundsätzlich rechtmäßig. ${ }^{1286}$

De strafrechter moet dus onrechtmatige vergunningen respecteren zolang deze niet zijn ingetrokken hetgeen impliceert dat de vergunninghouder in dergelijk geval niet zonder rechtsgeldige vergunning handelt en dus geen strafbaar feit pleegt. In casu werkt de beperkte toetsingsbevoegdheid echter in het nadeel van de verdachte want hem werd niet lozen zonder rechtsgeldige vergunning maar overschrijding van de in de vergunning neergelegde voorwaarden (Höchstwerte) tenlastegelegd. Het feit dat deze voorwaarden onrechtmatig (te soepel) zijn vastgesteld, tast geenszins de wederrechtelijkheid van het handelen van de vergunninghouder aan, want de strafrechter is gebonden aan de rechtsgeldigheid en niet aan de rechtmatigheid van de vergunning(svoorwaarden): ook de overtreding van onrechtmatige maar rechtsgeldige voorwaarden is strafbaar. Om risico van straf te ontwijken had de vergunninghouder deze voorwaarden via de administratieve rechtsgang moeten aanvechten, wat hij natuurlijk niet had gedaan omdat deze voorwaarden in zijn voordeel waren. In de woorden van het OLG: de strikte gebondenheid van de strafrechter dient ook

'für die von der Verwaltungsbehörde festgesetzten Höchstwerten zu gelten, zumal es dem Normadressaten freisteht, im Wege der Verwaltungsklage gegen zu Unrecht festgesetzte Höchstwerte vorzugehen. ${ }^{1287}$

\section{Uitzonderingen op het principiële toetsingsverbod}

Op het door de heersende leer verdedigde Verwaltungsaktsakzessorische uitgangspunt, dat strafrechtelijke toetsing van vergunningen verbiedt, wordt evenwel een aantal belangrijke nuanceringen of beperkingen aanvaard. Men kan zelfs de vraag stellen of intussen de uitzonderingen niet zo talrijk zijn geworden, dat zij van de regel (een strafrechtelijk toetsingsverbod) zelf een uitzondering hebben gemaakt, hetgeen voor de Mindermeinung een belangrijk argument oplevert om de bestaansreden van de regel zelf in twijfel te trekken.

a. Met terugwerkende kracht ingetrokken beschikkingen

Een eerste belangrijke nuancering verwijst naar de situatie waarin onrechtmatige beschikkingen door het bestuursorgaan met terugwerkende kracht worden ingetrokken. 
Reeds is vastgesteld dat voor het strafrecht van belang is of een beschikking rechtsgeldig is, waarbij de rechtmatigheid van die beschikking voor de rechtsgeldigheid en dus ook voor de gebondenheid van de strafrechter van geen belang is. Volgens $\S 48 \mathrm{Abs}$. $1 \mathrm{VwVfG}$ kan een bestuursorgaan een rechtsgeldige vergunning wegens het onrechtmatige karakter ervan met terugwerkende kracht intrekken zodat er bestuursrechtelijk gezien nooit een vergunning verleend is geworden. Is de strafrechter nu gebonden aan de oorspronkelijke vergunning, die beoordeeld op het tijdstip van de overtreding rechtsgeldig was, of moet hij veeleer de intrekking ex tunc - immers ook een beschikking - respecteren zodat hij ervan moet uitgaan dat nooit een rechtsgeldige vergunning is afgegeven, hetgeen betekent dat de adressaat een strafbaar feit heeft gepleegd door te handelen zonder vergunning. Indien de strafrechter in een dergelijke situatie nu zou gebonden zijn aan de bestuursrechtelijke regels zou dit als consequentie hebben dat de eerdere uit de rechtsgeldigheid voortvloeiende strafrechtelijke rechtvaardiging door de intrekking ex tunc zou komen te vervallen. De overtreding moet dan alsnog als een strafbaar feit worden aangemerkt. Dit acht de heersende leer onaanvaardbaar aangezien het legaliteitsbeginsel ertoe verplicht de strafbaarheid van het feit uitsluitend te beoordelen op het tijdstip van de overtreding. ${ }^{1288}$ Dit betekent dat bevrijdende vergunningen die met terugwerkende kracht worden ingetrokken hun rechtvaardigende werking blijven behouden. ${ }^{1289}$ De strafrechter volgt dus op dit punt niet de bestuursrechtelijke logica: 'die herrschende Auffassung ignoriert also die verwaltungsrechtliche verbindliche Rücknahme. Sie gibt spezifisch strafrechtlichen Überlegungen den Vorrang vor dem Gedanken der Einheit der Rechtsordnung'. ${ }^{1290} \mathrm{Nu}$ rijst bij belastende beschikkingen een bijkomend probleem, want hoe moet de strafrechter omgaan met de overtreding van een rechtsgeldige belastende vergunning(svoorwaarde) die door het bestuur wegens onrechtmatigheid met terugwerkende kracht wordt ingetrokken? Ook dan geldt in beginsel dat voor de beoordeling van de strafbaarheid de situatie op het tijdstip van de overtreding beslissend is, hetgeen impliceert dat de belastende beschikking rechtsgeldig was en dus had moeten worden nageleefd. Het uitgangspunt is immers dat ook de overtreding van onrechtmatige belastende beschikkingen strafbaar is. Maar is dit nog wel te verdedigen wanneer het bestuursorgaan zelf de beschikking intrekt? Op dit punt is zelfs de heersende leer zeer verdeeld. Sommige auteurs menen dat aangezien op het tijdstip van de overtreding de beschikking rechtsgeldig was en de strafrechter gebonden is aan de rechtsgeldigheid, de intrekking van de beschikking geen gevolgen kan hebben voor de strafbaarheid van de overtreding. Dit vloeit nu eenmaal voort uit de principiële gebondenheid van de strafrechter aan rechtsgeldige vergunningsvoorschriften. ${ }^{1291}$ Andere schrijvers menen daarentegen dat het niet de taak van de strafrechter kan zijn om onrechtmatige belastende beschikkingen, die door het bestuur zijn ingetrokken, te handhaven. Dit zou tot onrechtvaardige en absurde situaties aanleiding geven. De gebondenheid van de strafrechter aan administratieve beschikkingen en de daaraan ten grondslag liggende eenheid van rechtsorde dwingen de strafrechter juist de intrekking ex tunc te respecteren. Dit betekent dat in voorkomend geval

1288. Rademacher, M., o.c., 1989, 24.

1289. Horn, E., l.c., 1981, 3; Zeitler, S., o.c., 1982, 117.

1290. Hübenett, C., o.c., 1986, 24.

1291. Dreher, E. en Tröndle, H., o.c., 1993, § 325, Nr. 3a; Laufhütte, H. en Möhrenschlager, M., 'Umweltstrafrecht in neuer Gestalt', ZStW, 1980, 921; Rudolphi, H.-J., l.c., 1984, 253. 
de intrekking van een belastende vergunning moet worden gezien als een objectieve strafopheffingsgrond. ${ }^{1292}$

\section{b. Door rechtsmisbruik aangetaste vergunningen}

De tweede en meest belangrijke beperking op het principiële toetsingsverbod moet worden gezocht in het leerstuk van rechtsmisbruik. De strafrechter is niet gebonden aan vergunningen die door rechtsmisbruik zijn angetast. ${ }^{1293}$ Van belang is dus te weten wat moet worden verstaan onder rechtsmisbruik. Ook hier is de heersende leer sterk verdeeld. In de eerste plaats is er sprake van rechtsmisbruik wanneer de vergunning door misleiding, bedreiging of omkoping werd verkregen en de vergunning derhalve niet verleend had mogen worden. Dergelijke vergunningen moeten door de strafrechter niet worden gerespecteerd. Dit is opmerkelijk aangezien ook door misleiding, bedreiging of omkoping verkregen vergunningen rechtsgeldig zijn zolang deze niet op grond van $\S 48 \mathrm{Abs}$. 1, Abs 2 VwVfG met terugwerkende kracht zijn ingetrokken. ${ }^{1294}$ Bepaalde schrijvers eisen dan ook consequent dat de door rechtsmisbruik verleende vergunning eerst moet zijn ingetrokken alvorens de strafrechter daarmee rekening mag houden. ${ }^{1295}$ Pas dan is de rechtsgeldigheid opgeheven. $\mathrm{Nu}$ deze auteurs geen uitzonderingen op het toetsingsverbod toelaten en de strafrechter dus ook gebonden achten aan door rechtsmisbruik aangetaste beschikkingen zolang deze niet zijn ingetrokken, verdedigen zij niet een beschikkingsafhankelijkheid (Verwaltungsaktsakzessorietät) maar een bestuursprocesrechtelijke afhankelijkheid (Verwaltungsverfahrensakzessorietät) van het strafrecht. ${ }^{1296}$ Doorslaggevend blijft immers de intrekking door het bestuursorgaan.

In feite is er bij de vaststelling van rechtsmisbruik sprake van een nietigheidstoetsing door de strafrechter en dit onafhankelijk van het bestuursrecht. De eenheid van rechtsorde wordt dan op basis van autonome strafrechtelijke noties doorbroken. Het wordt immers als fundamenteel strijdig met de functies van het strafrecht beschouwd wanneer een verdachte zich zou kunnen beroepen op een bevrijdende vergunning die door middel van misleiding, bedreiging of omkoping is verleend.

Sommige auteurs breiden het rechtsmisbruik ook tot andere situaties uit. Zo zou het beginsel kunnen worden gebruikt indien de betrokkene zich beroept op een 'klaarblijkelijke verouderde en achterhaalde' vergunning. ${ }^{1297}$ Ook collusie tussen vergunningaanvrager en de vergunningverlener zou onder rechtsmisbruik vallen. ${ }^{1298}$ Een enkele auteur meent dat er ook sprake is van rechtsmisbruik wanneer de vergunninghouder op de hoogte is van de

1292. Schönke, A., Schröder, H. en Cramer, P., o.c., §§ 324, Nr. 21.

1293. Schőnke, A. , Schröder, H. en Lenckner, Th., o.c., 1991, Vorbem. $\S \S 324$ ff., Nr. 17; Horn, E., l.c., 1981, 3; Rudolphi, H.-J., l.c., 1984, 194; Dolling, D., l.c. 1985, 469; Winkelbauer, W., o.c., 1986, 68 e.v.; Hübenett, C., o.c., 1986, 118 e.v.

1294. Weber, U., o.c., 37; Rogall, K., o.c., 1991, 180.

1295. Vgl.Lanckner, K., o.c, 1995 , § 324, Rn. 10.

1296. Aldus Scheel, R., o.c., 1993, 38.

1297. Horn, E., l.c., 1983, 366; Zie voor verdere verwijzingen Rogall, K., o.c., 1991, 186.

1298. Dölling, D., L.c.,1985, 469; Bloy, R., l.c., 1988, 504. 
onrechtmatigheid van zijn vergunning. ${ }^{1299}$ Deze uitbreidingen van het rechtsmisbruikbeginsel zijn zeer discutabel. Zo kan worden opgemerkt dat bijvoorbeeld de kennis bij de adressaat van de onrechtmatigheid van een beschikking volgens $\S 48$ III 2 jo III 3 VwVfG niet de rechtsgeldigheid van de beschikking aantast; deze wetenschap ontneemt de vergunninghouder enkel zijn recht op schadevergoeding wanneer het bestuur besluit deze beschikking in te trekken. ${ }^{1300}$

Het moge duidelijk zijn dat er geen eenduidigheid bestaat over de invulling van rechtsmisbruik:
'Ansonsten beschränkt man sich auf eine mehr, meist weniger umfang- reiche Kasuistik, ohne durchgängige Kriterien dafür zu benennen, wann die Inanspruch-nahme rechtswidriger Gestattungen rechtsmißbräuchlich sein soll., ${ }^{1301}$

Bij dit alles mag trouwens niet uit het $00 \mathrm{~g}$ worden verloren dat het onderscheid tussen bestanddeeluitsluitende en rechtvaardigende vergunningen, dus ook het onderscheid tussen de kwaliteitsmilieudelicten en de gemene milieudelicten, van cruciaal belang is. Het rechtsmisbruikbeginsel kan immers alleen van toepassing zijn bij rechtvaardigende vergunningen. Indien de afwezigheid van de vergunning een bestanddeel is van de delictsomschrijving, dus bestanddeeluitsluitend werkt, kan volgens de heersende leer vanuit het oogpunt van het legaliteitsbeginsel geen rekening worden gehouden met rechtsmisbruik. ${ }^{1302}$ De strafrechter blijft dan gebonden aan door rechtsmisbruik verkregen vergunningen die bestanddeeluitsluitend werken, dus zelfs wanneer de vergunning het resultaat zou zijn van omkoping.

\section{c. Strafrechtelijke toetsing en $\S 330 \mathrm{~d}$ Nr. 5 StGB}

De Duitse wetgever is op het vlak van de gevolgen van het rechtsmisbruik in het milieustrafrecht enigszins tegemoetgekomen. Op 1 november 1994 is het Einund-dreißigste Strafrechtsänderungsgesetz - Zweites Gesetz zur Bekämpfung der Umweltkriminalität in werking getreden. Hiermee is een aantal wijzigingen aangebracht in het bestaande Duitse milieustrafrecht. ${ }^{1303}$ Eén van de belangrijke veranderingen regelt de kwestie in welke mate de strafrechter nog gebonden is aan door rechtsmisbruik aangetaste vergunningen. $\S 330 \mathrm{~d}$ Nr. 5 bepaalt thans dat

1299. Sack, H.-J.,Umweltschutz - Strafrecht, Berlin, 1986, Nr. 62a; en in beperkte zin Winkelbauer, W., o.c., 1986, 70 e.v.

1300. Dolde, K.-P., 'Zur Verwaltungsrechtsakezessorietăt von § 327 StGB', NJW, 1988, 2334.

1301. Rademacher, M., o.c., 1989, 27.

1302. Lenckner, Th., l.c., 1988, 32 e.v. Volgens Rengier verzet het legaliteitsbeginsel zich zelfs tegen toepassing van het rechtsmisbruikbeginsel bij rechtvaardigende vergunningen. Zie Rengier, R., l.c., 1989,888 e.v.

1303. Zie o.m. Breuer, R., 'Verwaltungsrechtlicher und strafrechtlicher Umweltschutz - Vom Ersten zum Zweiten Umweltkriminalitătsgesetz', JZ, 1994, 1077 e.v.; Möhrenschlager, M., 'Revision des Umweltstrafrechts - Das Zweite Gesetz zur Bekämpfung der Umweltkriminalităt -' , NStZ, 1994, 513-519 en 566-569; Schmidt, A., 'Das neue Umweltstrafrecht', NJW, 1994, 2514-2519. 
'ein Handeln ohne Genehmigung, Planfeststellung oder sonstige Zulassung ist auch ein Handeln auf Grund einer Drohung, Bestechung oder Kollusion erwirkten oder durch unrichtige oder unvollständige Angaben erschlichen Genehmigung, Planfeststellung oder sonstigen Zulassung.'

Hiermee is vastgelegd dat de adressaat handelt zonder vergunning of andere bestuurlijke Zulassung - dus tevens een Erlaubnis of een Bewilligung - wanneer deze beschikkingen door bedreiging, omkoping en collusie zijn tot stand gekomen of op grond van onjuiste of onvolledige opgaven arglistig zijn verworven. In deze gevallen kan de adressaat zich niet beroepen op een vergunning en pleegt hij dus een strafbaar feit. Wel mag niet worden vergeten dat bestuursrechtelijk gezien dergelijke vergunningen rechts-geldig blijven zolang zij niet zijn ingetrokken. ${ }^{1304} \S 330 \mathrm{~d} \mathrm{Nr}$. 5 bepaalt alleen dat via bepaalde ondeugdelijke middelen verkregen vergunningen strafrechtelijk niet langer enige geldingskracht hebben. Met deze wijziging heeft de wetgever de gebondenheid van de strafrechter aan bepaalde onrechtmatige vergunningen in belangrijke mate doorbroken. Er kan worden gesproken van een doorbreking van de eenheid van rechtsorde en de Verwaltungsaktsakzessorietät. ${ }^{1305}$ Belangrijk is vooral dat deze bepaling niet alleen geldt voor vergunningen die als rechtvaardigingsgrond in aanmerking komen ( $\S 324$ en $326 \mathrm{StGB}$ ), maar ook geldt voor vergunningen die, deel uitmakend van de delictsomschrijving, bestanddeeluitsluitend werken (bijvoorbeeld $\S 327 \mathrm{StGB}$ ). Hiermee is tevens tegemoetgekomen aan de tot dan toe beperkte toepassing van het rechtsmisbruikbeginsel op rechtvaardigende vergunningen. De strafrechter is dus niet langer gebonden aan bestanddeeluitsluitende vergunningen die op de in $\S 330 \mathrm{~d} \mathrm{Nr}$. 5 bepaalde wijze zijn verkregen. Wel vallen belastende beschikkingen niet onder het toepassingsgebied van deze nieuwe regeling.

'Entscheidend ist also, wie schon die exemplarisch genannten Begriffe der "Genehmigung" und der "Planfeststellung" zeigen, das Vorliegen eines Verwaltungsaktes mit gestattender Wirkung. (...) Dagegen liegt keine "sonstige Zulassung" vor, wenn der Täter mit unlautern Mitteln erwirkt, $\mathrm{da} B$ belastende Regelungen, z.B. nachträgliche Auflagen, wenige streng als bei rechtmäßiger Entscheidung der Behörde ausfallen.' ${ }^{1306}$

Dit impliceert dat tot op heden een overtreding van onrechtmatige belastende èn bestanddeeluitsluitende vergunningen nog steeds strafbaar is.

\section{d. Strafrechtelijke toetsing bij lichamelijk letsel}

Een laatste uitzondering op het toetsingsverbod wordt aanvaard wanneer de door een rechtsgeldige vergunning gedekte milieuverontreiniging dodelijk letsel of zware mishan-

1304. Paetzold, H., 'Die Neuregelung rechtsmißbrauchlich erlangter Genehmigungen durch $\S 330 \mathrm{~d} N \mathrm{~N}$. 5 StGB', NStZ, 1996, 171.

1305. Breuer, R., l.c., 1994, 1090.

1306. Paetzold, H., I.c., 1996, 171. 
deling tot gevolg heeft. Een verontreiniging met dusdanige voor de mens ernstige gevolgen is strafrechtelijk wederrechtelijk ook al is er een rechtsgeldige vergunning voorhanden. ${ }^{1307}$ De achterliggende idee is dat de milieuinstantie nooit een vergunning kan geven voor het veroorzaken van zwaar lichamelijk letsel of de dood: een 'licence to pollute' is nog geen 'licence to kill'. Ten aanzien van één milieustrafbepaling in het Strafgezetzbuch, namelijk § 330 a (schwere Gefährdung durch Freisetzen von Giften), wordt dan ook aanvaard dat een vergunning geen strafuitsluitende werking kan hebben. In dit geval blijft bestraffing mogelijk, zelfs indien voor het handelen een rechtsgeldige vergunning is verleend. De draagwijdte van deze bepaling is met het Strafrechtsänderungsgesetz van 1994 trouwens danig uitgebreid. Vóór 1994 had deze bepaling weinig waarde omdat deze alleen van toepassing was indien de giftige stoffen opzettelijk werden verspreid en dit de dood of zwaar lichamelijk letsel tot gevolg had. Nu is $\S 330 \mathrm{a}$ StGB in dubbele zin gewijzigd. Enerzijds hoeft de verspreiding van giftige stoffen niet langer een zwaar lichamelijk letsel of de dood tot gevolg te hebben: zware gezondheidschade of het gevaar van gezondheidsschade bij een groot aantal mensen volstaat reeds. Daarnaast is ook de poging tot en het culpoos verspreiden van giftige stoffen reeds strafbaar. ${ }^{1308}$ Dit betekent dat iedere verspreiding van giftige stoffen die beantwoordt aan de delictsomschrijving van $\S 330 \mathrm{a}$ $\mathrm{StGB}$ in beginsel strafbaar is en niet kan worden gedekt door een rechtsgeldige vergunning.

Enkele auteurs aanvaarden dat ook eenvoudig lichamelijke letsel of zelfs bepaalde zaakbeschadigingen niet door een vergunning kunnen worden gedekt zodat ook dan de strafrechter niet aan een rechtsgeldige vergunning gebonden is. Andere schrijvers menen daarentegen dat in bepaalde gevallen vergunningen wel lichamelijk letsel kunnen rechtvaardigen wanneer bij de vergunningverlening dit risico uitdrukkelijk door de milieuinstantie is meegewogen. ${ }^{1309}$ Ook hier ontbreekt elke eenduidigheid over de vraag wanneer nu precies de vergunning zijn strafuitsluitende werking verliest bij lichamelijk letsel. Volgens sommigen is daarvan reeds sprake wanneer het gevaar bestaat dat lichamelijk letsel wordt veroorzaakt. ${ }^{1310}$ Anderen menen dat er daadwerkelijk letsel moet zijn berokkend. ${ }^{1311}$ Ook over de rechtsgrond van deze beperking is geen echte duidelijkheid. Deels wordt de strafuitsluitende werking van de vergunning ontkend op grond van rechtsmisbruik, ${ }^{1312}$ deels ziet men het veroorzaken van lichamelijk letsel als een zelfstandige grond voor het wegvallen van de strafuitsluitende werking van de vergunning.

1307. Laufhutte, H. en Möhrenschlager, M., L.c., 1980, 920; Dreher, E. en Tröndle, H., o.c., 1993, $\S$ 324, Nr. 7; Dölling, D., l.c., 1985, 469; Schall, H., l.c., 1993, 1267; Bloy, R., l.c., 1988, 501; Heine, G. en Meinberg, V., o.c., 1988, D 51.

1308. Otto, H., 'Das neue Umweltstrafrecht', Jura, 1995, 137.

1309. Horn, E., l.c., 1981, 3.

1310. Laufhütte, H. en Möhrenschlager, M., L.c., 1980, 912 e.v.

1311. Tiedemann, K.,Die Neuordmung des Strafrechts, Berlin, De Gruyter, 1980, 27.

1312. Idem. 


\section{Argumenten voor en tegen een strafrechtelijk toetsingsverbod}

\section{a. Algemeen}

In het voorgaande is duidelijk geworden dat de heersende leer zich op een aantal argumenten beroept ter rechtvaardiging van het strafrechtelijke toetsingsverbod. Dit verbod is het gevolg van de enge Verwaltungsaktsakkzessorische koppeling van de materiële wederrechtelijkheid aan de formele rechtsgeldigheid van de Verwaltungsakt. Deze argumenten staan intussen meer en meer ter discussie. Zonder al te veel stil te staan bij de finesses van deze discussie is het wenselijk daar enigszins dieper op in te gaan. Niet mag worden vergeten dat we via het toetsingsvraagstuk terecht komen bij een probleem, dat de kwestie van strafrechtelijke overheidsaansprakelijkheid overstijgt. Namelijk, de vraag wie in het milieustrafrecht de grenzen van de strafrechtelijke aansprakelijkheid bepaalt en of de strafrechter nog wel autonoom genoeg is om daar enige invloed op uit te oefenen. Deze vraag heeft niet slechts een praktisch belang - denk bijvoorbeeld aan de problematiek van formele rechtskracht - maar grijpt naar het hart van het milieustrafrecht, zoals dat in de meeste Europese landen is geconcipieerd, namelijk de administratieve afhankelijkheid. In de milieustrafrechtelijke literatuur - alsook in deze studie - wordt de administratieve afhankelijkheid, in de zin van een beschikkingsafhankelijkheid, om verschillende rechtstheoretische en praktische redenen gehekeld en wordt gepleit voor een meer van het bestuur onafhankelijk machtskritisch milieustrafrecht, waar de administratieve afhankelijkheid moet worden gezien als een Verwaltungsrechtsakzessorietät. Een dergelijk meer machtskritisch milieustrafrecht is cruciaal voor een verantwoorde en uitgebalanceerde strafrechtelijke verantwoordelijkheid van overheden. Echter, een dergelijke paradigmawissel binnen het milieustrafrecht vooronderstelt dat de strafrechter tegenover het bestuur een zodanige onafhankelijke positie kan innemen dat hij in staat moet zijn om de beslissingen van het bestuur aan het objectieve (milieu)recht te toetsen. Anders heeft een meer Verwaltungsrechtsakzessorisch milieustrafrecht weinig zin. Dit betekent dan ook dat een pleidooi voor een meer Verwaltungsrechtsakzessorisch milieustrafrecht alleen kans van slagen heeft, indien duidelijk wordt gemaakt dat de ratio's van de beperkingen op de strafrechtelijke toetsing van beschikkingen niet altijd overtuigen. $\mathrm{Nu}$ in de Duitse literatuur, juist vanwege het principiële strafrechtelijke toetsingsverbod, meer uitvoerig dan in Nederland op de ratio's van het toetsingsverbod wordt ingegaan, kunnen uit deze meningenstrijd ook voor het Nederlandse milieustrafrecht waardevolle lessen worden getrokken.

Achtereenvolgens worden in deze paragraaf de volgende argumenten voor een beperkte strafrechtelijke toetsingsbevoegdheid in het licht van de Mindermeinung geëvalueerd: de staatsautoriteit (b), de eenheid van rechtsorde (c), het vertrouwensbeginsel (d), de rechtszekerheid (e), de goede werking van het bestuur (f), de machtenscheiding ( $\mathrm{g}$ ) en het legaliteitsbeginsel (h). 


\section{b. De staatsautoriteit}

Een eerste belangrijke ratio van de gebondenheid van de strafrechter aan rechtsgeldige maar niettemin onrechtmatige beschikkingen is - volgens de Duitse heersende leer - terug te voeren tot het bijzondere karakter van administratieve beschikkingen:

\section{'Der Verwaltungsakt ist - unbeschadet seiner OrdnungsmäBigkeit oder}

Fehlerhaftigkeit - in jedem Fall eine Bekundung der Staatsautorität und hat als solche Anspruch auf Beachtung. ${ }^{1313}$

De vraag rijst of de loutere 'Staatsautorität' een afdoende rechtvaardiging kan bieden voor de gebondenheid van de strafrechter aan onrechtmatige beschikkingen. In een democratische rechtsstaat waar de macht van het bestuur gebonden is aan wet en recht kan het overheidsgezag als dusdanig niet alleen de rechtsgeldigheid van onrechtmatige beschikkingen verklaren:

Diese grundsätzliche Verbindlichkeit auch des rechtswidrigen Verwaltungsaktes kann nicht metaphysisch erklärt werden mit der "überwiegende Autorität" des Staates: die Norm hat doch gewiß keine geringere Autorität als der Verwaltungsakt. ${ }^{1314}$

Er moet dus fundamenteel naar andere verklaringen worden gezocht en deze moeten vervolgens afzonderlijk en tezamen op hun overtuigingskracht worden beoordeeld. Cruciaal is dan vooral de vraag in welke mate de eenheid van rechtsorde en daarmee samenhangende beginselen, zoals het vertrouwensbeginsel, ertoe dwingen de strafrechter te verbieden beschikkingen te toetsen.

\section{c. Eenheid van rechtsorde}

Eenheid van rechtsorde zou betekenen dat de onrechtmatigheid van een bepaalde gedraging voor de gehele rechtsorde eenzelfde inhoud moet hebben. Dit zogeheten 'einheitliche Rechtswidrigkeitsbegriff' impliceert dat een gedraging die onrechtmatig is in éen van de rechtsgebieden (civiel recht, strafrecht en bestuursrecht) meteen ook onrechtmatig is voor de ganse rechtsorde. ${ }^{1315}$ 'Die Rechtsordnung als einheitliche Sollensordnung könne nicht in einem Teilbereich ein bestimmtes Verhalten erlauben, in einem anderen aber Verbieten. ${ }^{1316}$

1313. Forsthoff, E., Lehrbuch des Verwaltungsrechts, München, 1979, 224.

1314. Vogel, K., 'Die Lehre vom Verwaltungsakt nach Erlaß der Verwaltungsverfahrengesetze', BayVBl, 1977, 617. Tevens aangehaald in Rademacher, M., o.c., 1989, 64.

1315. Jescheck, H.-H. en Weigend, Th., o.c., 1996, 327: 'Die Rechtsordnung kennt nur einen einheitlichen Begriff der Rechtswidrigkeit. Verschieden sind in den einzelnen Rechtsgebieten allein die Rechts-folgen der rechtswidrigen Handlung.'; Schönke, A., Schröder, H. en Lenckner, Th., o.c., 1991, Vorbem $\S \S 32$ ff., Nr. 8. Zie tevens BGH, 13 maart 1975, aangehaald in Hübennet, C., o.c., 1986, 9.

1316. Scheele, R., o.c., 1993, 44. 
$\mathrm{Nu}$ in het Duitse bestuursrecht ook een onrechtmatige beschikking vanaf haar bekendmaking rechtsgeldig is, dat wil zeggen voor de betrokkene(n) bepaalde rechten en plichten creëert, en deze rechtsgeldigheid blijft bestaan zolang de eerdere beschikking niet door een latere beschikking is ingetrokken, moet ook de strafrechter deze rechtsgeldigheid respecteren. Volgens dit beginsel is het ontoelaatbaar dat de strafrechter de rechtmatigheid van een beschikking beoordeelt omdat dit aanleiding zou geven tot ongewenste tegenspraken tussen wat bestuursrechtelijk en wat strafrechtelijk geoorloofd is. Om dit te vermijden moet de strafrechter iedere administratieve beschikking respecteren zolang deze niet is ingetrokken of niet nietig is. Volgens Rudolphi verbiedt de eenheid van rechtsorde de strafrechter

'die rechtliche Wirksamheit der erteilten Erlaubnis für das Strafrecht zu leugnen. Es würde einen unauflöslichen Wertungswiderspruch bedeuten, wenn ein Verhalten, das nach dem Verwaltungsrecht wirksam erlaubt worden ist, von dem Strafrecht als verboten oder sogar als strafbar erachtet werden würde. ${ }^{1317}$

De heersende literatuur concludeert dan ook dat aangezien rechtsgeldige beschikkingen nu eenmaal voor eenieder principieel bindend zijn, dit ook zo moet zijn voor het openbaar ministerie en de strafrechter. Het strafrecht mag niet in het bestuursrecht 'wildern'. ${ }^{1318}$

Ook in Nederland wordt de formele rechtskracht van beschikkingen veelal gerechtvaardigd met de eenheid van rechtsorde. Er wordt betoogd dat de rechtseenheid allerminst wordt gediend met de mogelijkheid dat twee rechters tot onderscheiden oordelen komen over de (on)rechtmatigheid van een beschikking. Volgens de Hoge Raad strekt de formele rechtskracht ertoe 'te voorkomen dat de burgerlijke rechter inzake de vragen waarover ook de administratieve rechter tot oordelen is geroepen, tot een ander oordeel komt dan deze." ${ }^{1319} \mathrm{Nu}$ ook de strafrechter zich gebonden acht aan de formele rechtskracht van (belastende) beschikkingen, geldt waarschijnlijk eenzelfde argumentatie: de eenheid van rechtsorde zou doorbroken worden indien hij zich over de rechtmatigheid van beschikkingen zou uitspreken. Reeds is besproken dat dit argument wellicht voor de civiele rechter opgaat, maar daarom nog niet automatisch voor de strafrechter: zij hebben een verschillende taak. Bovendien is met een strafrechtelijke gebondenheid aan de formele rechtskracht van beschikkingen, net als met een gebondenheid aan de Wirksamheit van een Verwaltungsakt, niet beoogd dat de rechter (terecht) het oordeel van zijn administratiefrechtelijke collega respecteert, maar dat hij gebonden is aan het bestuurlijk oordeel, ook al is dat oordeel in strijd met wet of recht.

Een dergelijke visie op de eenheid van rechtsorde wordt door de Duitse Mindermeinung om verschillende redenen bekritiseerd. 
Verwijst eenheid van rechtsorde naar een materiële rechtmatigheid of slechts naar een formele rechtmatigheid?

Allereerst moet worden beklemtoond dat de eenheid van rechtsorde al vlug een containerbegrip blijkt te zijn. Het postulaat van de eenheid van rechtsorde wordt veelvuldig gebruikt als een 'handliche Allzweckwaffe in juristischer Begründungsnot'. ${ }^{1320}$ Het is een typische konijn-in-de-hoed-term. Men stopt er stiekem die voorwaarden in, die men er later ineens uithaalt om het eigen gelijk te demonstreren.

De Duitse rechtsleer omschrijft eenheid van rechtsorde als 'eine allgemeingültige Grenze zwischen Rechtswidrigkeit und Rechtmäßigkeit'.1321 Dit betekent dat aan de onderscheiden rechtsgebieden slechts één eenduidig rechtmatigheidsbegrip ten grondslag ligt. Het idee van de eenheid van rechtsorde eist dan dat onrechtmatigheid moet worden begrepen als 'strijdigheid met het objectieve recht', hetgeen betekent dat een gedraging die in het ene rechtsgebied rechtmatig is niet tegelijk onrechtmatig kan zijn in een ander rechtsgebied. Daaruit volgt dat een rechtvaardigingsgrond afkomstig uit het ene rechtsgebied ook een rechtvaardigingsgrond oplevert in een ander rechtsgebied. Vanuit het perspectief van dit 'einheitlicher Rechtswidrigkeitsbegriff' ligt in het functionele rechtsgebied van het milieurecht dus aan het privaatrecht, het bestuursrecht en het strafrecht eenzelfde onrechtmatigheidsnotie ten grondslag. $\mathrm{Er}$ is dan sprake van een inbreuk op de eenheid van rechtsorde telkens wanneer een bepaalde gedraging in het ene rechtsgebied rechtmatig is terwijl die in het andere rechtsgebied als onrechtmatig wordt bestempeld.

'Der Staat würde entgegen seiner Funktion, Ordnung zu schaffen, mit zweierlei Zungen sprechen, wenn strafrechtlich verboten wäre, was verwaltungsrechtlich erlaubt ist. ${ }^{1322}$

Eenzelfde uitgangspunt wordt in Nederland verdedigd. Zo wordt tijdens de parlementaire voorbereiding van de artikelen 173a en 173b Sr benadrukt dat onder het delictsbestanddeel 'wederrechtelijkheid' dient te worden verstaan 'in strijd met een vergunning':

'In de voorgestelde bepalingen wordt beoogd hiermee het volgende aan te geven. Verschillende bijzondere milieuwetten kennen het vereiste van een vergunning voor het verrichten van daarbij omschreven handelingen die verband houden met het milieu. Handelt iemand in overeenstemming met zo een vergunning, dan is dit niet wederrechtelijk. Ook al zou hij voor het overige voldoen aan alle bestanddelen van de voorgestelde bepaling, dan nog is zijn handelingen niet strafbaar. Niet alle bestanddelen van het strafbaar feit zijn aanwezig en in geval van vervolging zou een vrijspraak

1320. Günther, H.-L., o.c., 89.

1321. Jescheck, H.-H. en Weigend, Th., o.c., 1996, 233; Schmitz, R., o.c., 1992, 31 e.v.

1322. Scheele, R., o.c., 55. 
moeten volgen. Het is dus niet nodig dat hij zich op een strafuitsluitingsgrond beroept..$^{1323}$

Dit betekent dat de naleving van de voorwaarde van een vergunning rechtvaardigend werkt. Dit wordt met een beroep op de eenheid van rechtsorde beargumenteerd:

'Handelt iemand in overeenstemming met een dergelijke vergunning, dan is dit niet wederrechtelijk.'

(...)

'Het is billijk dat degene die handelt in overeenstemming met de voorschriften die de milieu-autoriteiten in zijn concrete geval hebben gegeven, zich niet daarnaast zorgen hoeven te maken dat hij mogelijk in aanraking zal komen met de strafrechter. De overheid tone tegenover de burger één gelaat. Het kan niet zo zijn dat wat de milieuautoriteiten toestaan langs strafrechtelijk weg wordt verboden ${ }^{1324}$

Uit dit blinde vertrouwen op de milieu-instanties blijkt opnieuw dat de Nederlandse wetgever een absolute administratieve afhankelijkheid (een vergunningafhankelijkheid) voorstaat, zelfs bij de commune milieustrafbepalingen. De consequentie van deze visie is dat degene die overeenkomstig de aan hem verleende vergunning en de daarin beschreven voorwaarden stoffen in het milieu brengt, in beginsel niet strafbaar is.

De Duitse heersende leer en rechtspraak leiden uit de eenheid van rechtsorde af dat ook in het strafrecht de rechtsgeldigheid van beschikkingen moet worden gerespecteerd. De rechtsgeldigheid is immers bedoeld om de burger ervoor te behoeden dat het bestuur zonder voorafgaande intrekkingsprocedure de door dit bestuur toegestane gedraging door bestuurlijk ingrijpen (bestuursdwang) zou kunnen verhinderen. Dit zou neerkomen op willekeur. Nu de rechtsgeldigheid is bedoeld om bestuurlijk ingrijpen tegen te gaan zolang de beschikking niet is ingetrokken, is het maar logisch dat deze rechtsgeldigheid ook enig strafrechtelijk ingrijpen belet. Strafrechtelijk ingrijpen is dan, net als bestuurlijk ingrijpen, uitsluitend toegestaan nadat de beschikking is ingetrokken.

Wanneer eenheid van rechtsorde zo wordt ingevuld -als een afhankelijkheid van bestuurlijke beschikkingen-, kan terecht de vraag worden gesteld of hierdoor niet veeleer de eenheid van rechtsorde wordt geschonden door juist de materiële strafrechtelijke rechtmatigheid met formele bestuursrechtelijke begrippen als rechtsgeldigheid of formele rechtskracht gelijk te schakelen. Een dergelijke interpretatie van eenheid van rechtsorde ontkent immers dat het bestuursrecht zelf ook het begrip materiële rechtmatigheid kent. Uit het oog wordt verloren dat noch de bestuursrechtelijke rechtsgeldigheid, noch de formele rechtskracht een onrechtmatige beschikking rechtmatig maakt. Rechtsgeldigheid en rechtmatig- 
heid zijn ook in het bestuursrecht begrippen die elkaar niet dekken. ${ }^{1325}$ De vraag rijst dan waarom dat in het strafrecht wel zou moeten. Dit betekent dat aan het gebod dat een gedraging strafrechtelijk niet verboden kan zijn als deze bestuursrechtelijk is geoorloofd pas recht wordt gedaan wanneer daadwerkelijk kan worden bekeken of de gedraging bestuursrechtelijk is toegestaan. Een blindelings aanvaarden van een beschikking is daarmee fundamenteel in strijd. Het is juist door de strafrechter te binden aan onrechtmatige beschikkingen dat dit gebod wordt geschonden aangezien dit betekent dat een gedraging tegelijk materieel strafrechtelijk geoorloofd en materieel milieurechtelijk verboden is, dat wil zeggen bestuurlijke maatregelen (intrekking en bestuursdwang) kan uitlokken maar geen strafsanctie. De strafsanctie zou immers in die optiek pas mogelijk worden nà de intrekking van de beschikking - wat door enkele Duitse auteurs dan ook wordt bepleit - hetgeen echter evident in strijd is met het legaliteitsbeginsel dat ertoe dwingt de strafbaarheid te beoordelen op het tijdstip van de overtreding.

Kortom, de koppeling van de materiële strafrechtelijke rechtmatigheid aan formele rechtsgeldigheid is niet zozeer een gevolg van de eenheid van rechtsorde maar is daarmee veeleer in strijd. Niet valt in te zien waarom de strafrechtelijke materiële rechtmatigheid met de bestuursrechtelijke formele rechtsgeldigheid zou moeten worden gelijkgeschakeld indien evenmin de bestuursrechtelijke materiële rechtmatigheid van een beschikking samenvalt met de formele rechtsgeldigheid ervan. De eenheid van rechtsorde per se is niet in staat op die vraag een duidelijk antwoord op te geven. Dat de koppeling van de strafrechtelijke materiële rechtmatigheid, met formele rechtsgeldigheid moeilijk is te rijmen met de eenheid van rechtsorde, wordt in de praktijk ook duidelijk aan de hand van de talrijke uitzonderingen die op dit uitgangspunt worden aanvaard. Deze uitzonderingen wijzen op de onhoudbaarheid van deze strikt verwaltungsaktsakzessorische visie. Zo kan opnieuw worden verwezen naar de omstandigheid dat de strafrechter niet gebonden is aan de intrekking ex tunc omdat het legaliteitsbeginsel dat verbiedt. Ook het beroep op het rechtsmisbruikbeginsel - nu zelfs gedeeltelijk in het Strafgesetzbuch opgenomen (§ 330d Nr. 5 StGB) - is een uitzondering die apert in strijd is met het uitgangspunt dat de strafrechter aan beschikkingen is gebonden zolang ze niet nietig zijn of zijn ingetrokken. Tegen de achtergrond van deze talrijke uitzonderingen is het niet onzinnig de regel van een principieel toetsingsverbod in twijfel te stellen. ${ }^{1326}$

\section{De mythe van een eenduidig wederrechtelijkheidsbegrip}

Afgezien van de vaststelling dat een einheitlich Rechtswidrigkeitsbegriff er niet toe verplicht de strafrechtelijke rechtmatigheid te laten afhangen van de bestuursrechtelijke rechtsgeldigheid of, zoals in Nederland, van de formele rechtskracht van de beschikking, rijst de meer fundamentele vraag of deze visie op de eenheid van rechtsorde als zodanig nog wel vol te houden is. Volgens sommigen moet eenheid van rechtsorde niet zozeer worden opgevat als de markering van een 'generelle Grenze von Recht und Unrecht', maar

1325. Zie hierover o.m. Van der Linden, E.C.H.J., Formele en materiële rechtskracht. De kleren van de Keizer, Den Haag, Sdu Uitgevers, 1998.

1326. Rogall, K., o.c., 1991, 175-192; Schmitz, R., o.c., 1992, 45-49. 
als een 'Gebot der Widerspruchfreiheit': een beginsel dat tot doel heeft tegenspraken tussen rechtsgebieden te vermijden, niet omdat die er vanuit een eenduidig wederrechtelijkheidsbegrip niet zouden (mogen) bestaan, maar omdat tegenspraken andere beginselen onnodig zouden verstoren, zoals de rechtsgelijkheid, de rechtszekerheid en het vertrouwensbeginsel. ${ }^{1327}$ Met andere woorden, eenheid van rechtsorde is niet zozeer een Zijn maar een Behoren. Eenheid van rechtsorde moet niet ontologisch worden opgevat, maar axiologisch. Dit wil zeggen dat het beginsel vooral instrumenteel of functioneel van aard is in de zin dat het in functie staat van andere beginselen, maar als zodanig zelf geen echte autonome functie heeft. Dat zou het alleen hebben indien er daadwerkelijk zoiets zou bestaan als een universele (on)rechtmatigheid eigen aan de rechtsorde als geheel. Dat is volgens een sterke minderheid in de Duitse rechtsleer niet het geval:

'Das Rechtswidrig-keitsurteil sei auf die jeweilige Teilrechtsordnung bezogen und könne nicht auf die Gesamtrechtsordnung erstreckt werden. ${ }^{1328}$

Deze meer moderne uitleg van het postulaat komt niet alleen vanuit strafrechtelijke hoek, ${ }^{1329}$ maar wordt ook door enkele privatisten ${ }^{1330}$ en bestuursjuristen ${ }^{1331}$ vurig verdedigd. De idee is dat ieder rechtsgebied zijn eigen ratio's, functies en rechtsgevolgen heeft, hetgeen betekent dat ook het rechtmatigheidsbegrip niet absoluut is maar relatief, dat wil zeggen afhankelijk van rechtsgebiedtypische ratio's:

'der Begriff der Rechtswidrigkeit sei ein funktionsbestimmter Begriff der einzelne Rechtsgebiete. Das Rechtswidrigkeitsurteil entfalte demnach zwingend nur Wirkung innerhalb der Teilrechtsordnung, in der das Urteil gefällt wurde. ${ }^{1332}$

Of zoals Kirchof het treffend formuleert: het postulaat van de eenheid van rechtsorde

1327. In die zin Günther, H.-L., o.c., 1983, 7 en 247-248.; Stratenwerth, G., Strafrecht, Allgemeiner Teil I, Berlin, 1981, Nr. 186; Seebode, M., 'Polizeiliche Notwehr und Einheit der Rechtsordnung, in Kohlmann, G. (Hrsg.), Festschrift für Ulrich Klug, Band II, Köln, 1983, 371; Hübenett, C., o.c., 1986, 82; Rademacher, M., o.c., 1989, 52; Schmitz, R., o.c., 1992, 35 e.v.; Brauer, J., Die strafrechtliche Behandlung genehmigungsfähigen, aber nicht genehmigten Verhaltens, Berlin, $1988,118$.

1328. Scheele, R., o.c., 1993, 59. Zie ook de daarin vermelde literatuur.

1329. Reeds begin deze eeuw werd door enkele penalisten een rechtsgebiedtypisch rechtmatigheidsbegrip verdedigd. Zie o.m. Von thering, R., Der Zweck im Recht, Band 1, 1904, 382 e.v.; Von Liszt, F., Lehrbuch des Deutschen strafrechts, 1903, 181; Dahlem, F., Das Verhältnis des Zivilrechts zum Strafrecht mit besonderer Berücksichtigung der Disharmonien, Heidelberg, 1919, 26.

1330. Larenz, K., Methodenlehre der Rechtswissenschaft, Berlin, 1991, 463 e.v.; Deutsch, E., Haftungsrecht, Band I, Köln, 1976, 95 en 207 e.v.

1331. Kirchhof, P., Unterschiedliche Rechtswidrigkeiten in einer einheitlichen Rechtsordnung, Heidelberg, 1978, 10 en 31; Böckenforde, E.-W., 'Der verdrăngte Ausnahmezustand. Zum Handeln der Staatsgewalt in außergewöhnlichen Lagen', NJW, 1978, 1881. Zie tevens de verwijzingen bij Scheele, R., o.c., 1993, 59.

1332. Scheele, R., o.c., 1993, 59. 
'will nämlich nicht eine differenzierte und einzelfallgerechte Rechtsordnung vergröbern und vereinfachen'. ${ }^{1333}$

Het postulaat heeft eerder tot doel 'im Einzelfall Recht mit Blick auf die Gesamtrechtsordnung zu finden'. ${ }^{1334}$ Dat een dergelijke visie op eenheid van rechtsorde door de rechtspraktijk wordt bevestigd, kan bijvoorbeeld worden geillustreerd aan de hand van de problematiek van het wapengebruik door de politie in noodweersituaties. Het wapengebruik blijkt in het politierecht aan strengere eisen te zijn onderworpen dan in het strafrecht. Dit betekent dat een succesvol beroep op de rechtvaardigingsgrond neergelegd in $\S$ 32 StGB (Notwehr) onverlet laat dat het wapengebruik in noodweersituaties toch 'polizeirechtswidrig' blijft. De strafrechtelijke rechtvaardigingsgrond heeft derhalve geen automatische werking in het politierecht. Met andere woorden, het strafrecht heeft een ander, want enger wederrechtelijkheidsbegrip dan het politierecht, hetgeen betekent dat in voorkomend geval een politieagent niet wegens doodslag ( $§ 212 \mathrm{StGB}$ ) strafbaar is maar wel tuchtrechtelijk voor het feit kan worden bestraft. ${ }^{1335}$ Vanuit de klassieke visie op eenheid van rechtsorde is dergelijke tegenspraak onverklaarbaar en onaanvaardbaar. ${ }^{1336}$

Een dergelijke rechtsgebiedtypische opvatting van eenheid van rechtsorde heeft onvermijdelijk gevolgen voor de geldingskracht van buitenstrafrechtelijke rechtvaardigingsgronden in het milieustrafrecht. Daar waar in de eenduidige zienswijze een rechtvaardigingsgrond afkomstig van het ene rechtsgebied normaliter ook geldingskracht heeft in een ander rechtsgebied, verdedigt de rechtsgebiedtypische visie een ander standpunt, dat veel meer strookt met de praktijk en het rechtsgevoel. Allereerst eist ook een rechtsgebiedtypische benadering van wederrechtelijkheid dat een gedraging die rechtmatig is in het privaatrecht en bestuursrecht ook rechtmatig is in het strafrecht. Dit vloeit echter niet voort uit de eenheid van het onrechtmatigheidsbegrip maar veeleer uit het bestaan van een hiërarchie binnen de verschillende onrechtmatigheden. Daarmee hangt samen dat het strafrecht als ultimum ratio per definitie het strengste onrechtmatigheidsbegrip zou moeten hebben, hetgeen impliceert dat het strafrecht onmogelijk kan verbieden wat in de andere rechtsgebieden is toegestaan. Voor het milieurecht betekent dit dat een gedraging onmogelijk milieurechtelijk geoorloofd kan zijn en tegelijk strafrechtelijk verboden. Niet zozeer omdat aan beide rechtsgebieden eenzelfde wederrechtelijkheidsbegrip ten grondslag zou liggen maar omdat, simpel gezegd, een 'harder' rechtsgebied logischerwijs niet kan verbieden wat een 'zachter' rechtsgebied reeds heeft toegestaan. Omgekeerd geldt deze redenering vanzelfsprekend niet; een gedraging die strafrechtelijk wederrechtelijk is impliceert niet $a$

1333. Kirchhof, P., 'Polizeiliche Eingriffsbefugnisse und private Nothilfe', NJW, 1978, 972.

1334. Idem.

1335. Schmidhăuser, E., 'Notwehr und Nothilfe des Polizeibeambten aus strafrechtlicher Sicht', in Merten, D. (Hrsg.), Aktuelle Probleme des Polizeirechts, Berlin, 1977, 91 e.v.; Kirchhof, P., I.c., $1978,969$.

1336. Aldus o.m. Schönke, A., Schröder, H. en Lenckner, Th., o.c., 1991, § 32, Nr. 42b, die een dergelijke splitsing in wederrechtelijkheden strijdig acht met de eenheid van rechtsorde. Volgens Lenckner sluit een strafrechtelijke rechtvaardigingsgrond een tuchtrechtelijk ingrijpen daarom uit. 
priori een onrechtmatigheid in de andere rechtsgebieden. ${ }^{1337}$ Dat moet binnen die rechtsgebieden afzonderlijk worden bekeken. Op die manier zijn ook ongeoorloofde tegenspraken tussen de rechtsgebieden uitgesloten, echter zonder beroep te doen op een eenduidig onrechtmatigheidsbegrip. De aanvaarding van een rechtsgebiedtypische en derhalve hiërarchische onrechtmatigheid heeft dan wel het opmerkelijke gevolg dat een bestuursrechtelijk ${ }^{1338}$ onrechtmatige gedraging niet meteen gelijk strafrechtelijk wederrechtelijk hoeft te zijn, nu het strafrecht ten opzichte van het bestuursrecht strengere eisen zou moeten stellen aan het begrip wederrechtelijkheid. Of dergelijke gedraging ook nog strafrechtelijk wederrechtelijk is wordt weliswaar reeds door het bestuursrecht geïndiceerd, bijvoorbeeld door de afwezigheid van een rechtmatige vergunning, maar hangt uiteindelijk af van strafrechtstypische beoordelingsmaatstaven, die dan samenhangen met de vraag of het door het strafrecht beschermde rechtsgoed door de bestuursrechtelijke onrechtmatigheid is geschonden. We zullen later zien dat vooral dit laatste gevolg van een meerduidige visie op de eenheid van rechtsorde vruchtbare mogelijkheden biedt voor een ruimere strafrechtelijke toetsingsbevoegdheid alsook voor een meer Verwaltungsrechtsakzessorische invulling van het milieustrafrecht.

Duidelijk is in ieder geval dat ook de eenheid van rechtsorde opgevat als verwijzend naar een rechtsgebiedtypisch onrechtmatigheidsbegrip evenmin de koppeling van strafrechtelijke rechtmatigheid aan de rechtsgeldigheid of de formele rechtskracht van beschikkingen kan verklaren. Integendeel, het ligt dan veeleer voor de hand in dergelijke visie uit te gaan van afzonderlijke onrechtmatigheden die niet identiek zijn, hoewel ze hiërarchisch met elkaar in een zodanig verband staan dat ongeoorloofde tegenspraken tussen de rechtsgebieden zijn uitgesloten. In ieder geval is in een meerduidige benadering van eenheid van rechtsorde geen plaats voor een automatische strafrechtelijke gebondenheid aan de enkele rechtsgeldigheid van beschikkingen.

Samengevat kan worden gesteld dat noch de ene, noch de andere opvatting van eenheid van rechtsorde een afdoende verklaring levert voor een beperkte strafrechtelijke toetsingsbevoegdheid. Die verklaring moet veeleer worden gezocht in andere beginselen die als het ware schuil gaan achter de eenheid van rechtsorde. ${ }^{1339}$ Het gaat om de reeds aangeduide beginselen van rechtszekerheid, vertrouwen en de machtenscheiding. Deze beginselen houden rechtstreeks verband met de bestaansreden van het begrip rechtsgeldigheid in het

1337. Dit zou wel zo moeten zijn bij een eenduidig onrechtmatigheidsbegrip.

1338. Of een tuchtrechtelijke onrechtmatigheid. Zie de problematiek van onrechtmatig vuurwapengebruik in het politierecht.

1339. Met andere woorden, de eenheid van rechtsorde volstaat niet als verklaring omdat dit beginsel nog niet uitlegt waarom er moet worden uitgegaan van een eenheid van rechtsorde (hoe ook opgevat). Het is dus cruciaal te weten waarom er geen tegenspraken tussen rechtsgebieden mogen bestaan. Het antwoord op deze vraag moet worden gezocht in andere beginselen en belangen zoals rechtszekerheid, machtenscheiding en dergelijke meer. Door de discussie bijna dwangmatig te beperken tot de 'mythe' van de eenheid van rechtsorde kan uit het oog worden verloren dat de discussie veelal over andere principes en belangen gaat waarvan het nog maar de vraag is of deze steeds wel moeten gelden. Het postulaat van de eenheid van rechtsorde kan in die zin versluierend of verhullend werken. Het is nodig deze sluier te doorprikken teneinde de daarachter liggende belangen expliciet zichtbaar te maken. 
Duitse bestuursrecht en het leerstuk van de formele rechtskracht in het Nederlandse bestuursrecht. Zij kunnen worden gezien als 'Wirksamheitsvoraussetzungen', beginselen die het primaat van de rechtsgeldigheid van een beschikking vooronderstellen en rechtvaardigen. ${ }^{1340}$ Meer in concreto moet nu worden bekeken of de functies en de ratio's van de 'rechtsgeldigheid' in het bestuursrecht enige doorslaggevende betekenis hebben in het strafrecht. Enkel indien dit het geval is, lijkt het wenselijk niet alleen in het bestuursrecht maar ook in het strafrecht het primaat van de 'Wirksamheit' te aanvaarden. ${ }^{1341}$ Wordt echter gaandeweg duidelijk dat de bestaansredenen van de rechtsgeldigheid typisch zijn voor het bestuursrecht en in het strafrecht ofwel niet opgaan ofwel door strafrechtstypische instrumenten kunnen worden ondervangen, lijk het al veel minder aangewezen de strafrechter te binden aan de rechtsgeldigheid van beschikkingen.

\section{d. Het vertrouwensbeginsel}

Een belangrijk argument voor een gebondenheid van de strafrechter aan beschikkingen is het rechtsstatelijk gefundeerde vertrouwensbeginsel (Vertrauensgrundsatz). ${ }^{1342}$ Dat beginsel heeft tot gevolg dat de strafrechter zich van rechtmatigheidstoetsing moet onthouden. Het vertrouwensbeginsel krijgt in dit verband een tweevoudige betekenis die samenhangt met het onderscheid tussen bevrijdende en belastende beschikkingen. Allereerst brengt het vertrouwensbeginsel in de verhouding tussen burgers met zich mee dat onrechtmatige beschikkingen voor eenieder bindend zijn. Dit aspect van het vetrouwensbeginsel is vooral van belang bij belastende beschikkingen. De Duitse literatuur verwijst o.m. naar het verkeersrecht waar de overtredingen van onrechtmatige administratieve rechtshandelingen, zoals het verkeerd plaatsen van verkeerstekens, toch sancties kunnen uitlokken. Verkeerstekens vervullen immers ordeningsfuncties zonder dat daarbij van belang is of deze rechtmatig zijn of niet. ${ }^{1343}$ Moest de handhaving van het verkeersrecht afhangen van de rechtmatigheid van de verkeerstekens dan zou dit tot een onaanvaardbare chaos leiden en de door het verkeersrecht nagestreefde ordening en veiligheid van de burgers op het spel zetten. Volgens de heersende leer geldt dit uitgangspunt tevens voor belastende beschikkingen in het milieurecht:

'Die mit dem Verwaltungsakt bezweckte Ordnung der (Rechts-) Verhältnisse läßt sich im Falle mehrerer konträr Betroffener nur gewährleisten, wenn der Verwaltungsakt unbeschadet seiner Rechtswidrigkeit bis zu seiner förmlichen Aufhebung wirksam ist. ${ }^{1344}$

Dit betekent dat ook de overtreding van onrechtmatige belastende vergunningsvoorwaarden strafbaar is. Daarnaast brengt het vertrouwensbeginsel in de verhouding overheidburger volgens het Duitse strafrecht met zich mee dat ook onrechtmatige bevrijdende

1340. Rademacher, M., o.c., 1989, 62.

1341. Zie hierover Schmitz, R., o.c., 1992, 34-45 en 58-60.

1342. Schmitz, R., o.c., 1992, 41-42.

1343. Koopmans, I.M., o.c., 1996, 179.

1344. Rademacher, M., o.c., 1989, 67. 
beschikkingen voor de strafrechter bindend zijn. ${ }^{1345}$ Dit is, zoals gezien, anders in het Nederlandse strafrecht. Het vertrouwensbeginsel verlangt dat het bestuur moet beantwoorden aan de verwachtingen, het vertrouwen van de burgers en dit vertrouwen van de burger is niet afhankelijk van de feitelijke rechtmatigheid van de beschikking: rechtmatigheid van de beschikking is in de verhouding overheid-burger het uitgangspunt, niet de mogelijke onrechtmatigheid. Dit uitgangspunt impliceert dat tevens onrechtmatige bevrijdende beschikkingen rechtsgeldig zijn en schept in die zin voor de begunstigde, die normaliter op de rechtmatigheid van de beschikking mag vertrouwen, de vereiste zekerheid omtrent zijn rechtspositie zonder dat dit van de daadwerkelijke rechtmatigheid moet afhangen. ${ }^{1346}$ Wanneer nu de strafrechter niet langer gebonden zou zijn aan iedere rechtsgeldige beschikking, zou dit onvermijdelijk een verstoring van het vertrouwensbeginsel tot gevolg hebben. ${ }^{1347}$ Zie ik het goed, dan schendt de Nederlandse strafrechter volgens de Duitse heersende leer het vertrouwensbeginsel daar deze immers bevrijdende beschikkingen aan wet en recht toetst.

Het vertrouwensbeginsel verlangt dus dat bestuursorganen het bij de burgers gewekte vetrouwen niet mogen beschamen: 'Der Bürger darf darauf vertrauen, daß bestehende Verhältnisse von der Verwaltung nicht überraschend und willkürlich geändert werden. ${ }^{1348}$ De vraag rijst nu of dit beginsel inderdaad wordt aangetast indien de strafrechter een (bevrijdende of belastende) beschikking aan wet en recht zou mogen toetsen of beschikt het strafrecht over een eigen instrumentarium om toch recht te doen aan het vertrouwen van de burger.

Verschillende Duitse schrijvers menen dat het vertrouwensbeginsel er zich niet tegen verzet dat de strafrechter de onrechtmatigheid vaststelt van een beschikking. ${ }^{1349}$ Allereerst is het vertrouwensbeginsel ook in het bestuursrecht relatief, hetgeen betekent dat steeds aan bepaalde voorwaarden moet zijn voldaan wil de burger zich hierop kunnen beroepen. Meer bepaald is in het bestuursrecht het vertrouwen van de burger slechts beschermenswaardig indien de burger daadwerkelijk en terecht ervan kon uitgaan dat zijn handelen door een rechtmatige beschikking werd toegestaan. Daarvan is echter geen sprake meer wanneer de adressaat de onrechtmatigheid van de rechtsgeldige beschikking kent. Het bestuursrecht maakt in een dergelijk geval de terugname van de beschikking mogelijk. In $\S \S 48$ en 49 VwVfG zijn de voorwaarden neergelegd volgens dewelke het bestuursorgaan een beschikking kan intrekken. Allereerst kan het bestuursorgaan iedere onrechtmatige beschikking intrekken ook in de situatie dat de burger er terecht vanuit kon gaan dat deze rechtmatig was. Het aldus door het bestuur geschonden vertrouwen creëert dan wel een recht op schadevergoeding ( $\S 48$ Abs. 1 , Abs. $3 \mathrm{VwVfG}$ ). ${ }^{1350}$ De intrekking vindt echter plaats zonder schadevergoeding wanneer dit vertrouwen niet langer beschermenswaardig is. Dat is volgens $\S 48 \mathrm{Abs} .2 \mathrm{VwVfG}$ steeds het geval wanneer

1345. Schmitz, R., o.c., 1992, 44-45.

1346. Bull, H.P., Allgemeines Verwaltungsrecht, Heidelberg, 1986, 218 e.v.

1347. Rademacher, M., o.c., $1989,67$.

1348. Schmitz, R., o.c., 1992, 42.

1349. Zie voor een overzicht Rademacher, M., o.c., 1989, 79.

1350. Rademacher, M., o.c., 1989, 79. 
'der Inhaber hinsichtlich der Rechtswidrigkeit grob fahrlässig oder sogar vorsätzlich war, wenn er die Genehmigung aufgrund von Täuschung, Drohung oder Bestechung, oder aufgrund unrichtiger oder unvollständiger Angaben erlangt hat.'

Het vertrouwensbeginsel geldt dus niet langer wanneer de adressaat op de hoogte is van de onrechtmatigheid van de beschikking, hetgeen een intrekking zonder schadevergoeding mogelijk maakt. Eigenlijk gaat $\S 48$ Abs. 2 VwVfG zelfs verder. De adressaat kan immers evenmin een beroep doen op het vertrou-wensbeginsel wanneer de onrechtmatigheid het gevolg is van onjuiste of onvolledige opgave van gegevens. Deze grond staat los van het al dan niet (horen te) kennen van de onrechtmatigheid van de beschikking. Het is best denkbaar dat de adressaat onvolledige gegevens verleent zonder dat dit meteen betekent dat hij op de hoogte is van de daaruit voortvloeiende onrechtmatigheid van de beschikking. ${ }^{1351}$

$\mathrm{Nu}$ de precieze draagwijdte van het vertrouwensbeginsel in het (Duitse) bestuursrecht duidelijk is, moet worden vastgesteld of het vertrouwensbeginsel door strafrechtelijke toetsing wordt geschonden. Dit kan het best worden verduidelijkt aan de hand van een voorbeeld. Stel dat A beschikt over een lozingsvergunning. Deze vergunning is echter onrechtmatig omdat het bestuur in zijn belangenafweging geen rekening heeft gehouden met een bepaalde in het afvalwater aanwezige gifstof. Dit heeft tot gevolg dat de vergunning onrechtmatig is, maar niet nietig. Stel nu dat de adressaat niet verantwoordelijk is voor deze onrechtmatigheid - hij heeft geen onjuiste of onvolledige informatie verleenden evenmin daarvan op de hoogte is. In een dergelijk geval mag de adressaat bestuursrechtelijk gezien vertrouwen op de beschikking; hij kan zich voor het bestuur beroepen op een beschermenswaardig vertrouwen, hetgeen betekent dat enkel tegen een schadevergoeding de vergunning zal mogen worden ingetrokken. Wat heeft dit voor gevolg indien de adressaat voor de strafrechter verantwoording moet afleggen? Volgens de heersende leer dient de strafrechter zich te onthouden van elke toetsing, moet hij de rechtsgeldigheid van de beschikking respecteren, omdat anders het vertrouwen van de adressaat zou zijn geschonden en deze aldus het risico loopt een strafrechtelijke sanctie te krijgen opgelegd. Maar is dit risico wel zo reëel? De strafrechtelijke toetsing laat het vertrouwensbeginsel onaangetast, want de adressaat zal zich kunnen beroepen op onoverkomelijke dwaling. De strafbaarheid van de adressaat is hiermee uitgesloten. Strafrechtelijk wordt het vertrouwensbeginsel dus ondervangen via de beoordeling van de schuldvraag. Het is interessant vast te stellen dat bij toetsing van bevrijdende beschikkingen dit nu net de Nederlandse benadering is. De schuldvraag is zelfs het ideale moment waarop het vertrouwen(sbeginsel) volledig tot zijn recht kan komen omdat dit rechtstreeks samenhangt met de mate van verwijtbaarheid van de overtreder en los staat van de objectieve (on)rechtmatigheid van het gepleegde feit. ${ }^{1352}$ Stel nu dat de adressaat (mede)verantwoordelijk is voor de onrechtmatigheid of deze in ieder geval kent of gelet op zijn functie behoorde te kennen. Ook dan ontstaan er geen onoverkomelijke problemen of tegenspraken tussen bestuursrecht en strafrecht. Bestuursrechtelijk gezien kan de adressaat zich niet langer

1352. Hübenett, C., o.c., 1986, 88; Horn, E., L.c., 1981, 2. 
beroepen op het vertrouwensbeginsel, wat intrekking zonder schadevergoeding mogelijk maakt. Strafrechtelijk gezien kan de verdachte zich niet langer beroepen op dwaling wat een strafsanctie mogelijk maakt. Het strafrecht is zelfs milder dan het bestuursrecht. Volgens $\S 48 \mathrm{VwVfG}$ is er geen beschermenswaardig vertrouwen meer vanaf het moment dat er onjuiste of onvolledige informatie is gegeven en dit ongeacht de kennis in hoofde van de betrokkene van de onrechtmatigheid van de beschikking. In een dergelijk geval waar de onrechtmatigheid inderdaad het gevolg is van onjuiste informatie maar de adressaat niet de onrechtmatigheid kende of hoorde te kennen aanvaardt het strafrecht nog wel dwaling. Dit vloeit voort uit de omstandigheid dat de strafrechter het vertrouwen in de eerste plaats vanuit de positie van de dader beoordeelt, en niet uitsluitend op basis van objectieve data, zoals de onvolledigheid van gegevens. ${ }^{1353}$

Kortom, het vertrouwensbeginsel is inderdaad een belangrijke ratio van de beperking op strafrechtelijke toetsing. De centrale betekenis die in het bestuursrecht aan de rechtsgeldigheid of aan de formele rechtskracht wordt toegekend is begrijpelijk aangezien dit voor het bestuur de enige mogelijkheid is om het vertrouwensbeginsel te waarborgen. In het bestuursrecht bestaan immers maar twee beoordelingsniveaus: rechtsgeldigheid/nietigheid en rechtmatigheid/onrechtmatigheid. Het bestuursrecht is niet bekend met voor het strafrecht essentiële begrippen als schuld (verwijtbaarheid), hetgeen een koppeling van het vertrouwensbeginsel met de rechtsgeldigheid van een beschikking noodzakelijk maakt. Het strafrecht daarentegen is onbekend met het begrip rechtsgeldigheid. De voor het strafrecht meest logische manier om deze bestuursrechtelijke notie dogmatisch te vertalen is dan op het niveau van de schuldvraag. ${ }^{1354}$ Het primaat van de rechtsgeldigheid in het bestuursrecht dwingt de strafrechter niet deze rechtsgeldigheid blindelings te aanvaarden. De strafrechter kan na vaststelling van de onrechtmatigheid naar behoren rekening houden met het vertrouwensbeginsel door bij de beoordeling van de schuldvraag te onderzoeken of in hoofde van de adressaat sprake is van dwaling. Is deze dwaling niet aanwezig dan is het consequent dat de overtreder een straf riskeert.

\section{e. De rechtszekerheid voor de burger}

De strafrechtelijke toetsing zou ook de rechtszekerheid op het spel zetten. De rechtszekerheid is er immers niet mee gediend dat er twijfel bestaat omtrent de rechtmatigheid van een beschikking. Het primaat van de rechtsgeldigheid in het strafrecht garandeert deze rechtszekerheid door te beletten dat verschillende rechters tot onderscheiden oordelen zouden komen over de (on)rechtmatigheid van de beschikking. De burger mag niet het slachtoffer worden van verschillende juridische maatstaven waarmee zijn gedrag wordt beoordeeld. ${ }^{1355}$

Het belangrijkste aspect van rechtszekerheid betreft de rechtszekerheid voor de burger. Deze zou worden aangetast wanneer strafrechters inhoudelijk zouden mogen toetsen. Zo zou volgens Cramer het risico ontstaan dat strafrechters verschillend zouden oordelen over

1355. Schönke, A., Schröder, H. en Cramer, P., o.c., 1991, §§ 324, Nr. 16 b. 
de rechtmatigheid van beschikkingen. ${ }^{1356}$ Het is echter niet ongewoon dat verschillende rechters een voor hen liggende rechtsvraag verschillend benaderen. 'Diese Art der "Rechtsunsicherheit" kann daher kein Argument für die Ansicht der hM sein. ${ }^{1357}$ Bovendien ligt het gevaar van rechtsonzekerheid niet zozeer in de toetsingsbevoegdheid maar in de toetsingsinhoud, meer bepaald de invulling van de strafrechtelijke wederrechtelijkheid. De onzekerheid zal toenemen in de mate dat de strafrechter onafhankelijker staat van het bestuursrecht. Zolang echter de strafrechter het bestuursrecht als toetsingsinstrument hanteert is de vrees voor rechtsonzekerheid ongegrond.

Bovendien is het rechtszekerheidsbeginsel, zoals ieder beginsel, niet absoluut. Het wordt meer bepaald door het beginsel van materiële rechtvaardigheid (materiellen Gerechtigkeit) en het gelijkheidsbeginsel begrensd. Dit betekent dat in een concreet geval telkens moet worden onderzocht of mogelijke tegenspraken tussen bijvoorbeeld bestuursrecht en strafrecht tegen de achtergrond van de materiële rechtvaardigheid of andere beginselen niet gerechtvaardigd zijn. ${ }^{1358}$ Rechtszekerheid heeft immers niet alleen te maken met kennis, toegankelijkheid en consistentie van het recht. Dit betreft slechts de formele kant van rechtszekerheid. Formele rechtszekerheid als zodanig hoeft nog niet automatisch tot rechtvaardige resultaten te leiden. Rechtszekerheid heeft daarom in de eerste plaats te maken met het maatschappelijk verkeer en met wat daarin redelijkerwijs van anderen mag worden verwacht. ${ }^{1359}$ De Duitse heersende leer erkent trouwens zelf het relatieve karakter van de rechtszekerheid wanneer zij de strafrechter niet gebonden acht aan de intrekking ex tunc van beschikkingen omdat dit strijdig wordt bevonden met de materiële rechtvaardigheid en het legaliteitsbeginsel. ${ }^{1360}$

\section{f. De Funktionsfähigkeit van het bestuur}

Naast de rechtszekerheid wordt ook de zogenaamde 'Funktionsfähigkeit' van het bestuur als argument tegen strafrechtelijke toetsing ingeroepen. De goede werking van het bestuur zou zwaar verstoord worden indien lange tijd onduidelijkheid zou blijven bestaan over de rechtmatigheid van door het bestuur gestelde administratieve rechtshandelingen. De Funktionsfähigkeit bestaat hierin dat het bestuur de mogelijkheid moet hebben om tot op het moment van de opheffing van de rechtsgeldigheid administratieve rechtshandelingen te verrichten zonder dat de verbindendheid daarvan telkens zou moeten afhangen van de rechtmatigheid.

'Es würde zum Niedergang der Staatstätigkeit führen, wenn der Bürger jede ihm gegenüber ergangene Regelung, die er für fehlerhaft hält, als unbeachtlich ansehen könnte. Die alleinige Verfügung der Behörde über

1356. Idem.

1357. Schmitz, R., o.c., 41 .

1358. Scheele, R., o.c., 62.

1359. Witteveen, W., o.c., 1996, 58.

1360. Zie hierover Rademacher, M., o.c., 1989, 24 e.v. 
die Wirksamheit des Akts sichert also die Funktionsfähigkeit der Verwaltung. ${ }^{1361}$

Tast een strafrechtelijke toetsing de Funktionsfähigkeit van het bestuur aan? De Funktionsfähigkeit heeft bestuursrechtelijk immers vooral een praktisch belang. Het heeft tot doel een efficiënt en effectief bestuur mogelijk te maken. Dit wordt allerminst door een strafrechtelijke toetsing verstoord nu de strafrechter niet de rechtsgeldigheid (of wat Nederland betreft: de formele rechtskracht) kan opheffen, maar alleen de onrechtmatigheid kan vaststellen, en dan nog voor zover deze strafrechtelijk relevant is. Anders gesteld, de strafrechtelijke toetsing tast de rechtsgeldigheid van een beschikking niet aan en daarmee dus ook niet de Funktionsfähigkeit. Als de Funktionsfähigkeit al strafrechtelijk van enig belang is dan is dat in de eerste plaats bij belastende beschikkingen aangezien het bestuur de plicht heeft belastende voorschriften te handhaven. Maar zelfs dan kan de Funktionsfähigkeit niet verklaren waarom het strafrecht verplicht zou zijn bijvoorbeeld 'onrechtmatige' belastende beschikkingen te moeten handhaven.

Is de Funktionsfähigkeit een belangrijke bestaansreden voor de rechtsgeldigheid in het bestuursrecht, dan geldt dat al veel minder in het strafrecht. Bovendien rijst de vraag of een instrumenteel effectieve maar ook rechtvaardige strafrechtelijke handhaving minstens niet even belangrijk is dan de doelmatigheid van het bestuur. Waarom zou bestuurlijke doelmatigheid moeten prevaleren boven strafrechtelijke doelmatigheid vooral wanneer dit dan ook nog ten koste gaat van de rechtsbeschermende garanties die het strafrecht traditioneel biedt?

\section{g. Machtenscheiding}

Een klassiek argument voor een strikte gebondenheid van de strafrechter aan de rechtsgeldigheid van de beschikking is natuurlijk de machtenscheiding. Het is ongeoorloofd dat de strafrechter een oordeel velt over het bestuurlijk handelen des temeer nu alleen de administratieve rechter de rechtmatigheid van bestuurlijke handelingen mag beoordelen. De uitsluiting van strafrechtelijke beoordeling wordt beargumenteerd door de machtenscheiding te beschouwen als een strikte scheiding tussen zowel organen als functies, in die zin dat de 'Gewaltenteilung' neergelegd in Art. 20 Abs. 2 GG impliceert dat alle organen slechts één functie hebben, en zich niet mogen bemoeien met de wijze waarop de andere organen hun functie uitoefenen.

'Wenn die Verwaltung im Rahmen des Verwaltungsverfahrens die Vereinbarkeit der beantragten Nutzung von Umweltgütern beurteilt (...) so macht die Verwaltung von der ihr zugewiesenen Bewertungskompetenz Gebrauch, deren Kontrolle allein den Verwaltungsgerichten obliegt könnte. Dementsprechend könnte aus dem verfassungsrechtlichen Gewaltenteilungsgrundsatz zwingend die Bindung der ordentlichen Gerichte an Verwaltungsakte folgen. ${ }^{1362}$ 
Dit lijkt inderdaad een belangrijk argument. Toch wordt dit argument in Duitsland door verschillende schrijvers genuanceerd. Met evenveel verve kan worden verdedigd dat de principiële gebondenheid van de strafrechter aan de Verwaltungsakt, zolang deze niet door het bestuur wordt ingetrokken, strijdig is met de scheiding der machten, doordat de rechter afhankelijk wordt gemaakt van de executieve. ${ }^{1363}$ Dit is ook de Belgische visie op de machtenscheiding, waaruit zelfs een toetsingsplicht voor de strafrechter wordt afgeleid. In de volgende paragraaf wordt hier dieper op ingegaan.

Volgens sommigen is deze strikte binding zelfs in strijd met het rechtspraakmonopolie dat in Art. 92 GG is neergelegd. Daarnaast is er ook sprake van de schending van de rechterlijke onafhankelijkheid (Art. $97 \mathrm{GG}$ ). ${ }^{1364}$ Een enkele schrijver meent zelfs dat de beperkte toetsingsbevoegdheid strijdig is met de grondwettelijke waarborg van effectieve rechtsbescherming (Art. 19 Abs. 4 GG). ${ }^{1365}$

Dat de strafrechter het oordeel van de administratieve rechter moet respecteren staat buiten twijfel. Dit vloeit voort uit de 'Gleichwertigkeit der Gerichtszweige'. ${ }^{1366}$ Maar betekent dit meteen dat hij ook de beslissing van het bestuursorgaan zonder meer moet eerbiedigen? Daartegen kan immers worden ingebracht dat 'die Behörde nicht über und nicht gleichgeordnet neben, sondern unter dem Gesetz steht'. ${ }^{1367}$ Daarenboven zijn er situaties denkbaar dat het helemaal niet tot een rechtmatigheidstoets door de administratieve rechter komt. In Nederland is dit natuurlijk het geval indien de beschikking formele rechtskracht heeft. Voor Duitsland is nog van belang dat de Anfechtungsklage volgens $\S 42 \mathrm{Abs} 2 \mathrm{VwGO}$ alleen mogelijk is wanneer 'der Kläger geltend macht, durch den Verwaltungsakt (...) in seinen Rechten verletzt zu sein'. Dit betekent dat bij onrechtmatige bevrijdende vergunningen de adressaat geen Anfechtungsklage kan of zal instellen aangezien de onrechtmatigheid hem niet in zijn rechten aantast. Anderzijds zullen derden vaak geen Anfechtungsklage kunnen instellen omdat de onrechtmatigheid van de vergunning niet voortspruit uit de schending van normen die tot doel hebben derden te beschermen (Drittschutzwirkung). Vereist is immers steeds dat de klager moet zijn getroffen in een individueel belang: 'Die vom Kläger geltend gemachte Rechtswidrigkeit des Verwaltungsaktes muß gerade auf dem Versto $\beta$ gegen eine Vorschrift beruhen, deren Schutzrichtung seine Individualbelange einschließt. ${ }^{1368}$ Normen, die uitsluitend het algemeen belang dienen volstaan veelal niet voor een ontvankelijke klacht. Zo verwijzen bijvoorbeeld de voorwaarden tot vergunningverlening neergelegd in $\S \S 6$ en 7 a WHG naar het algemeen belang en kan een overtreding door het bestuur van deze normen niet worden gezien als een grond voor een individuele klacht. ${ }^{1369}$ Dit betekent dat in dergelijke gevallen nauwelijks controle door een admini-

1363. Rademacher, M., o.c., 1989, 84; Schall, H., L.c., 1990, 1263 en 1267.

1364. Haaf, E., Die Fernwirkung gerichtlicher und behördlicher Entscheidungen, Paderborn, 1984; Schall, H., I.c., 1990, 1268.

1365. Haaf, E., o.c., 1989, 257 e.v.

1366. Rademacher, M., o.c., 1989, 83.

1367. Mezger, E., Lehrbuch des Strafrechts, München, 1949, 226.

1368. Rademacher, M., o.c., 1989, 84.

1369. Hübenett, C., o.c., 1986, 93. 
stratieve rechter open staat. Een strikte binding van de strafrechter aan het bestuur wordt tegen deze achtergrond onaanvaardbaar. ${ }^{1370}$

\section{h. Het legaliteitsbeginsel}

Een laatste argument tegen een ruim toetsingsrecht van de strafrechter wordt in de Duitse literatuur gevonden in het legaliteitsbeginsel, neergelegd in Art. 103 II Grundgesetz (GG). Het legaliteitsbeginsel verzet zich met name tegen de strafrechtelijke toetsing van onrechtmatige vergunningen die bestanddeeluitsluitend werken. Dit argument is dus van belang bij de kwaliteitsmilieudelicten. $\mathrm{Bij}$ deze delicten vindt de administratieve afhankelijkheid of bestuursrechtelijke koppeling plaats op het niveau van de delictsomschrijving (Tatbestandsebene). De in deze delicten omschreven leefmilieuschadelijke gedragingen bijvoorbeeld de exploitatie van een inrichting ( $\$ 325$ StGB) - zijn slechts strafbaar wanneer zij geschieden 'ohne die erforderliche Genehmigung'. Deze zinsnede is in tegenstelling tot het begrip 'unbefugt' ( $\$ \S 324$ en 326 StGB) een bestanddeel van de delictsomschrijving. Het legaliteitsbeginsel verzet zich tegen een voor de verdachte nadelige interpretatie van delictsbestanddelen. ${ }^{1371}$ Van een schending van Art. 103 II 2 GG is derhalve reeds sprake wanneer onder 'erforderliche Genehmigung' uitsluitend een rechtmatige vergunning zou mogen worden verstaan. ${ }^{1372}$ Immers, de afwezigheid van de vereiste vergunning is bestanddeel, niet de afwezigheid van de rechtmatige vergunning. ${ }^{1373}$ Dit betekent dat zelfs in die gevallen waarin de door $\S \S 325,327,328,329$ StGB beschermde rechtsgoederen daadwerkelijk worden bedreigd of gekrenkt de verontreinigende gedraging niet de delictsomschrijving vervult wanneer de adressaat beschikt over een onrechtmatige vergunning, want ook een onrechtmatige vergunning is een 'erforderliche Genehmigung'. In die zin is het onverbindend verklaren door de Nederlandse strafrechter van bevrijdende (onrechtmatige) vergunningen dus in strijd met het legaliteitsbeginsel, zoals dit door de Duitse rechtsleer en rechtspraak wordt uitgelegd.

De Duitse zienswijze kan wellicht vanuit het perspectief van de bescherming van het leefmilieu als fundamenteel onrechtvaardig worden ervaren maar zoals Horn treffend in herinnering brengt:

1370. Rademacher, M., o.c., 1989, 84 .

1371. Zo ook het Bundesverfassungsgericht. Zie o.m. BVerfG, 6 mei 1987, StV 1987, 432: 'Prinzipiell muß der Normadressat mithin anhand der gesetzlichen Regelung voraussehen können, ob ein Verhalten strafbar isr; in Grenzfallen geht er dann, für ihn erkennbar, das Risiko einer Bestrafung ein. Beides ist nur möglich, wenn in erster Linie der für den Adressaten verstehbare Wortlaut des gesetzlichen Straftatbestandes maßgebend ist. Fürt erst eine über den erkennbaren Wortsinn der Vorschrift hinausgehende Interpretation zu dem Ergebnis der Strafbarkeit eines Verhaltens, so kann diese nicht zu Lasten des Bürgers gehen.'

1372. Lenckner, Th., l.c., 1988, 32; Weber, U., o.c., 1988, 38.

1373. Scheele, R., o.c., 1993, 104: 'Daher ist der Bestimmtheitsgrundsatz des Art. 103 Abs. 2 GG verletzt, wenn man das Merkmal der "Erforderlichkeit" in "Rechtswidrigkeit" uminterpretiert und damit bereits bei Vorliegen einer rechtswidrigen Genehmigung Kriminalstrafe ausspricht.' 
'das Strafgesetzbuch ist nun einmal die Magna Charta des Verbrechers, nicht des Opfers. Der Strafrichter ist an das Gesetz gebunden, auch wenn es ihm nicht paßt. ${ }^{1374}$

Dit zogenaamde voordeel voor de verdachte moet tegelijk wel worden genuanceerd. De vraag rijst immers in welke mate het strafrecht nog een Magna Charta van de verdachte kan worden genoemd wanneer de onrechtmatige bestanddeeluitsluitende vergunning belastend is voor de geadresseerde. Ook dan geldt immers het principe dat de strafrechter Art. 103 II GG moet respecteren, hetgeen impliceert dat een overtreding van een onrechtmatige belastende vergunningsvoorschrift, die deel uitmaakt van de delictsom-schrijving, strafbaar is.

\section{Samenvatting}

Naar Duits recht is de strafrechtelijke toetsingsbevoegdheid uiterst beperkt. Volgens de heersende rechtspraak en rechtsleer is de strafrechter principieel gebonden aan rechtsgeldige beschikkingen ook al zijn deze onrechtmatig. Alleen nietige beschikkingen zijn voor de strafrechter onverbindend. De strafrechtelijke toetsing wordt dus gekenmerkt door een beschikkingsafhankelijkheid of Verwaltungsaktsakzessorietät.

Het doorslaggevende karakter van de rechtsgeldigheid in het milieustrafrecht wordt primair gebaseerd op de eenheid van rechtsorde. Een strafrechtelijke beoordeling van vergunningen zou tot ongeoorloofde tegenspraken tussen bestuursrecht en strafrecht leiden. Of de strafrechter gebonden is aan onrechtmatige vergunningen hangt tevens af van de structuur van de delictsomschrijving. Is de strafbaarstelling beperkt tot het verontreinigen 'zonder of in strijd met de vergunning' - met andere woorden, is er sprake van een kwaliteitsdelict dan verzet het legaliteitsbeginsel (Art. 103 II GG) zich in beginsel tegen elke vorm van strafrechtelijke toetsing aangezien dit in strijd zou zijn met de wet.

De beperkte strafrechtelijke toetsingsbevoegdheid heeft allerlei nadelige consequenties. Zo gaat de adressaat die beschikt over een onrechtmatige maar rechtsgeldige vergunning toch vrijuit wanneer hem een handelen zonder vergunning wordt tenlastegelegd. Dit frustreert de strafrechtelijke handhaving van de milieuvoorschriften. Anderzijds is de overtreding van onrechtmatige maar rechtsgeldige vergunningsvoorwaarden wel strafbaar. Hiermee wordt het strafrecht niet alleen ingezet voor de handhaving van onrechtmatige normen maar wordt ook de rechtsbescherming op onaanvaardbare wijze uitgehold.

Het valt licht te begrijpen dat op de beschikkingsafhankelijkheid van de strafrechter veel kritiek is gekomen. Het bleek dan interessant om in dat verband recente kritische geluiden uit de Duitse literatuur weer te geven en in dat licht enkele ratio's van een strafrechtelijk toetsingsverbod te bespreken. De hoofdkritiek van de Mindermeinnung op deze ratio's berust op de redenering dat de gebondenheid van de rechter aan rechtsgeldige, maar niettemin onrechtmatige beschikkingen enkel te rechtvaardigen is wanneer de bestaansredenen

1374. Horn, E., 'Bindung des Strafrechts an Entscheidungen der Atombehörde?', NJW, 1988, 2337. 
van het primaat van de 'Wirksamheit' in het bestuursrecht ook een even overtuigende geldingskracht hebben in het strafrecht. Dit bleek niet steeds het geval te zijn. Allereerst voldoet de eenheid van rechtsorde - hoe ook opgevat - niet als verklaring voor een strafrechtelijke toetsingsverbod. Daarnaast is het nog maar de vraag of de rechtszekerheid wel zo onnodig wordt aangetast door een strafrechtelijke toetsing. Het vertrouwensbeginsel - de voornaamste ratio van het primaat van de 'Wirksamheit' in het Duitse milieustrafrecht - kan naar behoren bij de beantwoording van de schuldvraag strafrechtelijk worden opgevangen. Tenslotte is de machtenscheiding - en tot die conclusie zijn we al eerder gekomen - een argument dat zowel ten voordele als ten nadele van een strafrechtelijke toetsing kan worden gehanteerd.

Om de nadelen van het strafrechtelijke toetsingsverbod en de groeiende kritiek daarop enigszins op te vangen, aanvaardt de heersende rechtsleer en rechtspraak enkele uitzonderingen op het beperkte toetsingsrecht. Zo is de strafrechter niet gebonden aan vergunningen die door rechtsmisbruik zijn aangetast. Het is echter interessant om vast te stellen dat zelfs de heersende rechtsleer en rechtspraak niet duidelijk omgaat met het leerstuk van rechtsmisbruik, en in die zin de mogelijkheid om te toetsen ernstig wordt bemoeilijkt. Vanwege deze onduidelijkheid heeft in 1994 de Duitse wetgever ingegrepen door in $\S 330 \mathrm{~d}$ Nr. 5 StGB te bepalen dat de strafrechter niet langer gebonden is aan door collusie, omkoping, misleiding, dreiging en via onjuiste of onvolledige opgaven tot stand gekomen bevrijdende vergunningen. Het voordeel van deze bepaling is dat deze ook toepasselijk is op bestanddeeluitsluitende vergunningen. Het obstakel van het legaliteitsbeginsel is in die zin grotendeels weggenomen. Is een rechtvaardigende of bestanddeeluitsluitende vergunning door rechtsmisbruik, zoals in de wet omschreven, tot stand gekomen dan kan de adressaat zich hierop niet beroepen en wordt het alsnog mogelijk de vergunninghouder (en, zoals we later zullen zien, mogelijk ook de vergunningverlener) te vervolgen.

De kritiek van de Duitse Mindermeinung kan wellicht ook een nuttig aanknopingspunt bieden voor de in Nederland gevoerde discussie naar de plaats van formele rechtskracht in het strafrecht. We hebben immers gezien dat de formele rechtskracht van beschikkingen ook in het strafrecht geldt, hoewel dit meestal ten nadele van de burger werkt en niet ten nadele van het OM. Als argumenten voor formele rechtskracht wordt veelal verwezen naar de in de vorige paragraaf besproken beginselen, zoals eenheid van rechtsorde en het vertrouwensbeginsel, naast argumenten als het tegengaan van 'forum shoppen'. We kunnen stellen dat de meeste argumenten voor formele rechtskracht in het strafrecht niet of veel minder gelding hebben dan in het bestuursrecht of het civiele recht, zodat in beginsel zich niets tegen een strafrechtelijke toetsing van vergunningen hoeft te verzetten. Dat een strafrechtelijke toetsing inderdaad niet per se onmogelijk of sterk beperkt hoeft te zijn, kan mooi worden geillustreerd aan de hand van het Belgische recht. 


\section{BELGIË \\ 1. Inleiding}

Ook het Belgische milieustrafrecht wordt gekenmerkt door een administratieve afhankelijkheid. Bij de concretisering van milieunormen in de vorm van vergunningen spelen milieuoverheden een belangrijke rol. Net als in Nederland en Duitsland rijst daarmee de vraag in welke mate de strafrechter vergunningen mag toetsen.

Deze cruciale vraag krijgt in de Belgische situatie een bijzondere dimensie omdat, in tegenstelling tot het Nederlandse en Duitse recht, in België de rechterlijke toetsingsbevoegdheid van administratieve rechtshandelingen uitdrukkelijk in de Grondwet is neergelegd. Krachtens artikel 159 van de Belgische Grondwet (BGW) - oud artikel 107 - passen de hoven en de rechtbanken de algemene, provinciale en plaatselijke besluiten en verordeningen alleen toe in zover zij met de wetten overeenstemmen. ${ }^{1375}$

In hoofdstuk $\mathrm{V}$ werd reeds uitvoerig aandacht besteed aan de toetsingsbevoegdheid van de Belgische strafrechter in het licht van de meer abstracte vraagstelling of de machtenscheiding een valabel argument vormt tegen strafrechtelijke controle op overheidshandelen. Duidelijk is geworden dat dit niet het geval hoeft te zijn. Zelfs artikel 159 BGW kan alleen worden begrepen als een reactie van de Belgische Grondwetgever tegen de absolute visie van de Franse revolutionairen op de machtenscheiding. In deze paragraaf komt deze theoretische kwestie niet meer aan bod. Nu wordt onderzocht in welke mate deze grondwettelijke rechterlijke toetsingsbevoegdheid een invloed heeft op de mogelijkheid vergunningen die in strijd met wet en/of recht zijn verleend te toetsen, en welke consequenties dit heeft voor de aansprakelijkheid van de vergunninghouder.

Eerst wordt gekeken naar de precieze omvang van de strafrechtelijke toetsingsbevoegdheid (2). Daarna wordt besproken in hoeverre het bestaan van een administratieve rechtsgang de strafrechtelijke controle van een vergunning(svoorschrift) verhindert. We hebben reeds gezien dat in Nederland de strafrechtelijke toetsingsbevoegdheid in bepaalde gevallen wordt uitgesloten indien de termijn voor het stellen van een administratiefrechtelijke procedure is verstreken en de vergunning daardoor 'formele rechtskracht' heeft verkregen. Nu moet worden bekeken in welke mate dit probleem ook in België speelt. Daarbij wordt opnieuw het onderscheid gemaakt tussen de situatie waarin de openstaande administratieve rechtsgang niet is benut (3) en de situatie waar de administratieve rechter zich heeft uitgesproken (4). Ook wordt onderzocht in hoeverre de Belgische strafrechter hangende de administratieve rechtsgang de vervolging dient te schorsen (5). Meteen kan worden opgemerkt dat eigenlijk slechts de laatste vraag in de Belgische rechtspraak en rechtsleer wordt geproblematiseerd.

1375. Artikel 107 (oud) BGW is bij de laatste Grondwetsherziening in 1994 vernummerd tot artikel 159 BGW. 


\section{Het karakter van de strafrechtelijke toetsingsbevoegdheid}

\section{a. Artikel $159 \mathrm{BGW}$ is van openbare orde en dwingend}

Oorspronkelijk werd de rechterlijke toetsing via toepassing van artikel 159 BGW beperkt geïnterpreteerd in de zin dat in dit artikel slechts een exceptie van onwettigheid zou besloten liggen, hetgeen inhoudt dat een administratieve beslissing niet rechtstreeks, maar slechts bij wijze van verweer voor de gewone rechter zou kunnen worden aangevochten. Deze enge opvatting vindt geen steun in het recht. ${ }^{1376}$ Zowel rechtstheoretisch als rechtshistorisch zijn geen dragende argumenten te vinden om de rechterlijke controle te beperken tot een incidenteel verweermiddel. Heden ten dage is dan ook de communis opinio dat artikel 159 BGW zich niet tegen een rechtstreekse aanvechting van bestuurlijke beslissingen verzet. Integendeel, deze ruime opvatting is volledig in overeenstemming met de bewoordingen van het grondwetsartikel zelf. Met andere woorden, artikel $159 \mathrm{BGW}$ is van openbare orde en heeft een imperatieve en algemene draagwijdte. ${ }^{1377}$ Het is niet alleen een mogelijkheid maar de plicht van de rechter om administratieve rechtshandelingen op hun rechtmatigheid te toetsen. ${ }^{1378}$ Slechts een klein aantal uitspraken, die van de negentiende eeuw dateren, verkondigde een andere opvatting. ${ }^{1379}$ In geval van strijdigheid met de wet

1376. Reeds Bourquin komt begin deze eeuw - toen de restrictieve benadering de heersende leer was tot de conclusie dat 'rien, (...) ni dans le texte de l'article 107, ni dans son origine historique, ni dans le commentaire que les travaux préparatoires nous en donnent, ne lui assigne nécessairement une portée limitative.' Bourquin, M., La protection des droits individuels contre les abus de pouvoir de l'autorité administrative en Belgique, Brussel, 1912, 58.

1377. Cass. 3 maart 1972, RW, 1971-72, 1638, Conclusie Procureur-Generaal Ganshof van der Meersch.

1378. Zie reeds een uitspraak van Cass., 15 juni 1885, Pas., I, 183: ' (...), la question de savoir si les règlements communaux dont l'exécution était poursuivie étaient conformes à la loi, si elle n'était soulevée par les parties, s'imposait d'office, (...)'. Zie tevens principieel Cass., 10 maart 1955, RW, 1955-1956, 529; Cass., 21 november 1963, Pas., 1964, I, 309. De ambtshalve opwerping van schending van artikel 159 BGW vond trouwens in strafzaken veel eerder plaats dan in civiele zaken. Dit is te verklaren door de afwezigheid van de verplichte wettelijk motivering van de voorziening in cassatie in strafzaken. In civiele zaken daarentegen moet het verzoekschrift tot cassatie op straffe van nietigheid de wettelijke bepalingen vermelden, waarvan de schending wordt aangevoerd. Gebeurt dit niet, dan verklaart het Hof van Cassatie het middel niet ontvankelijk en, kan het Hof, in tegenstelling tot in strafzaken, nooit ambtshalve een middel, zelfs al is het van openbare orde, opwerpen.

1379. De grondslag van deze rechtspraak werd gevestigd door het bekende arrest-Cramer van het Hof van Beroep van Brussel van 26 april 1834. Dit arrest werd gewezen op conclusie van Fernelmont die een aanhanger was van Henrion de Pansey. Deze laaste verdedigde vurig een beperkte opvatting van de rechterlijke controletaak. Tot aan het Flandria-arrest van 1920, waar het Hof van Cassatie het fundamentele verschil beklemtoont tussen de Franse en de Belgische benadering van de machtenscheiding, heeft deze enge visie van Henrion de Pansey een vernietigende invloed gehad op de Belgische rechtspraak. Daarnaast kan in herinnering worden gebracht dat het arrest-Cramer werd gewezen door het Hof van Beroep van Brussel. Uit onderzoek blijkt dat artikel 159 BGW niet alleen een reactie was op het Franse en Nederlandse systeem maar tevens op de rechtspraak van het Brusselse Hooggerechtshof dat zich in sterke mate beriep op de Franse visie betreffende de machtenscheiding om de rechterlijke wettigheidscontrole af te wijzen. Zie Alen, A., l.c., 1983-1984, 1733. 
moet de rechter dus ambtshalve de toepassing van de administratieve rechtshandeling weigeren ook als geen der partijen terzake iets opwerpt.

Het dwingende karakter van artikel 159 BGW wordt bevestigd in een aantal milieustrafzaken. Illustratief is een vonnis van de correctionele rechtbank van Gent. De beklaagde werd een inbreuk op de gemeentelijke bouwverordening van de Stad Gent tenlastegelegd. De beklaagde zou geen gevolg hebben gegeven aan de aanmaning van de burgemeester om binnen de gestelde termijn aanpassings-en verfraaiingswerken uit te voeren. Interessant is dat het openbaar ministerie hier zelf vrijspraak vorderde omdat de geschonden gemeentelijke verordening onwettig zou zijn wegens strijdigheid met de Nieuwe Gemeentewet. In casu was immers door het college van burgemeester en schepenen nagelaten voorafgaand advies te vragen aan de gemeentelijke Commissie van advies. Hoewel het $\mathrm{OM}$ hier de onwettigheid van de verordening opwerpt bij wijze van exceptie benadrukt de correctionele rechtbank van Gent voor alle duidelijkheid de imperatieve draagwijdte van artikel 159 BGW:

'Krachtens (...) het Gerechtelijk Wetboek hebben de rechterlijke beslissingen geen algemene en als regel geldende draagwijdte. Elke rechter heeft dan ook de controletaak die de grondwetgever hem heeft opgedragen t.a.v. de wettigheid van de bestuurshandelingen. Artikel 159 van de gecoördineerde Grondwet bepaalt immers dat de hoven en rechtbanken, de algemene, provinciale en plaatselijke besluiten en verordeningen alleen toepassen in zoverre zij met de wetten overeenstemmen. Ook de strafrechter is gehouden de wettigheid te toetsen. Zelfs ambtshalve, en dus niet enkel wanneer hij geconfronteerd wordt met een exceptie van illegaliteit die, zoals in casu, door het openbaar ministerie wordt opgeworpen (...) Het besluit van het college van burgemeester en schepenen kan derhalve op grond van artikel 159 van de gecoördineerde Grondwet niet worden toegepast. De beklaagde dient dan ook ontslagen te worden van rechtsvervolging. ${ }^{1380}$

\section{b. Artikel $159 \mathrm{BWG}$ betreft ook toetsing van vergunningen}

Hoewel de tekst slechts spreekt van 'besluiten en verordeningen' zijn rechtspraak en rechtsleer het erover eens dat artikel 159 BGW tevens dient te worden toegepast op nietreglementaire administratieve rechtshandelingen, zoals individuele beschikkingen. Dit betekent dat vergunningen onder deze grondwettelijke controle vallen. In die zin is artikel 159 BGW dus van primordiaal belang bij de strafrechtelijke beoordeling van de draagwijdte van milieuvergunningen. Zo oordeelde het Hof van Beroep te Gent:

(...) art. 159 van de Grondwet (verplicht) het Hof (...) de algemene, provinciale en plaatselijke besluiten en verordeningen alleen toe te passen

1380. Corr. Gent, 19 september 1995, TMR 1996, 283. Zie tevens Corr. Gent, 4 juni 1992, TMR 1993, 50; Corr. Gent, 13 september 1993, TMR 1994, 124. 
in zoverre zij met de wetten overeenstemmen; deze bepaling maakt geen onderscheid tussen de handelingen die zij beoogt; zij is toepasselijk op de zelfs niet-reglementaire beslissingen van het bestuur en op de administratieve handelingen, ook al zijn zij van individuele aard. Op grond van deze wettelijke bepaling heeft het Hof, zoals de beklaagde stelt, de macht en de plicht na te gaan of de besluiten, reglementen of verordeningen waarvan de toepassing in geding is, met de wetten overeenstemmen. ${ }^{1381}$

De 'verplichte' strafrechterlijke legaliteitscontrole heeft verstrekkende gevolgen. Zo zal een vergunninghouder die wegens overtreding van een onwettige vergunningsvoorwaarde strafrechtelijk wordt vervolgd, door de strafrechter moeten worden vrijgesproken zelfs indien deze zelf de onwettigheid van de vergunning niet aanvoert. Omgekeerd zal een in strijd met hogere regelgeving verleende bevrijdende vergunning niet langer een strafuitsluitende werking toekomen zodat een veroordeling kan volgen voor het handelen zonder vergunning. Meteen kan dus worden vastgesteld dat de toetsingsbevoegdheid van de Belgische rechter in sterke mate verschilt van de toetsingsbevoegdheden van zijn Nederlandse en Duitse collega's.

\section{c. Onderscheid met het annulatieberoep bij de Raad van State}

Het is van belang de draagwijdte van de rechterlijke controle verankerd in artikel 159 BGW te onderscheiden van het annulatieberoep bij de Raad van State.

Allereerst betreft het annulatieberoep een objectief beroep hetgeen betekent dat de Raad van State de bestreden bestuurshandeling vernietigt en de geschonden wettigheid herstelt maar geen uitspraak doet over een subjectief recht. Daarentegen berust het op artikel 159 BGW gegronde beroep op onwettigheid voor de civiele rechter ook op een schending van een rechtsregel maar slechts in zover deze schending tegelijk een inbreuk inhoudt van een subjectief recht. En wordt voor de strafrechter beroep gedaan op de onwettigheid van een administratieve rechtshandeling dan betreft het ook hier een beroep op een inbreuk van een rechtsregel maar slechts binnen het kader van de beoordeling van de kwalificatie- of wederrechtelijkheidsvraag. Kortom, bij het annulatieberoep gaat het om 'een proces van de bestuurshandeling en dit proces reikt verder dan de persoon van de verzoeker of van hem op wie de bestreden maatregel rechtstreeks toepasselijk is'. ${ }^{1382}$

Daaruit volgt een tweede punt van onderscheid: de uitspraak van de Raad van State waarbij een administratieve rechtshandeling wordt vernietigd heeft retroactieve werking en geldt erga omnes, terwijl de uitspraak van de gewone rechter ten opzichte van die beslissing slechts geldt inter partes. ${ }^{1383}$ Met andere woorden, de uitspraak waarin de rechter een besluit voor onwettig houdt laat dit besluit bestaan, zodat deze nog door een andere (of

1383. Vande Lanotte, J., Inleiding tot het publiek recht. Deel 2. Overzicht van het publiek recht, Brugge, die Keure, 1994, 447. 
zelfs dezelfde) rechter in een andere zaak kan worden toegepast. Betreft het onverbindend verklaarde besluit echter een individuele beschikking, zoals een vergunning, dan zal deze in de praktijk geen uitwerking meer kunnen hebben en elke betekenis verliezen, hoewel de beschikking formeel onaangetast blijft. ${ }^{1384}$

Een laatste belangrijk verschil met de administratieve procedure voor de Raad van State is dat de exceptie van onwettigheid op grond van artikel 159 BGW zonder beperking van termijn kan worden ingeroepen, terwijl het annulatieberoep voor de Raad van State binnen 60 dagen moet worden ingesteld. Het hoeft nauwelijks betoog dat dit de bruikbaarheid van artikel $159 \mathrm{BGW}$ sterk vergemakkelijkt.

Moet nog worden opgemerkt dat de onwettigheid van administratiefrechtelijke beslissingen op grond van artikel 159 BGW ook bij wijze van exceptie voor de Raad van State en alle andere administratieve rechtscolleges kan worden opgeworpen. De werking van artikel 159 BGW is dus niet beperkt tot de gewone rechter. Er is wel tegenspraak tussen de visie van de gewone hoven en rechtbanken en de visie van de Raad van State met betrekking tot de reikwijdte van artikel 159 BGW. Volgens de Raad van State kan artikel 159 BGW enkel toegepast worden op reglementaire handelingen en dus niet op individuele beslissingen hetgeen betekent dat volgens de Raad van State individuele beslissingen die niet binnen een termijn van 60 dagen zijn aangevochten definitief rechtsgeldig zijn. ${ }^{1.85}$ Hun wettigheid kan niet meer worden aangevochten voor de Raad van State, ook niet via de exceptie van onwettigheid. De gewone hoven en rechtbanken volgen deze opvatting niet. Artikel 159 BGW kan steeds voor hen worden ingeroepen. ${ }^{1386}$

\section{De invloed van de niet-gevolgde administratieve rechtsgang}

Ook in België beschikt de burger over verschillende mogelijkheden om de onrechtmatigheid van een administratiefrechtelijke rechtshandeling aan te vechten. De meest verregaande mogelijkheid van aanvechting van bestuurlijke beslissingen is ongetwijfeld het annulatieberoep bij de Raad van State. Wat zijn nu de gevolgen voor het strafproces als de burger deze administratieve rechtsgang niet heeft gevolgd of de beroepstermijn is verstreken? Is de strafrechter dan gebonden aan de rechtsgeldigheid van de bestreden bestuurlijke rechtshandeling? Het betreft hier de vraag naar de verhouding tussen de strafrechtelijke procedure en de niet-gevolgde administratiefrechtelijke procedure. Deze vraag is naar Belgisch recht eenvoudig te beantwoorden. Naar Belgisch recht heeft het niet volgen van een administratieve rechtsgang geen invloed op de mogelijkheid van de burger om de rechtmatigheid van een bestuurlijke beslissing voor de gewone rechter aan te vechten. Strafrechtelijk gezien betekent dit dat zowel de verdachte als het OM de onrechtmatigheid van een bepaalde administratieve rechtshandeling voor het eerst aan de

1384. Ryckborst, D., 'Legaliteitscontrole en marginale toetsing bij vergunningen', TMR, 1993, 52.

1385. R.v.St., Molle, Nr. 7.343, 27 oktober 1959; Terasse, nr. 26.724, 25 juni 1986, gepubliceerd in Dujardin, J. en Vande Lanotte, J., Inleiding tot het publiek recht. Deel I. Basisbegrippen, Brugge, die Keure, 1994, 94-96.

1386. Cass., 24 november 1988, $R W$ 1988-1989, 1306. 
strafrechter kunnen voorleggen. Het is zelfs de plicht van de strafrechter om ambtshalve een controle op bestuurlijke beslissingen uit te oefenen ook als de partijen terzake niets opwerpen. Illustratief is een uitspraak van het Hof van Beroep te Gent waar de wettigheid van een lozingsvergunning ter discussie stond. Het Hof oordeelt:

De beklaagde houdt voor dat de lozingsvergunning onwettig zou zijn, welnu de omstandigheid dat terzake geen administratief beroep werd ingesteld neemt niet weg dat op basis van het huidige art. 159 G.W. deze rechtsmacht toch de plicht heeft om de interne en externe wettigheid ervan te toetsen wat terzake positief mag worden beantwoord. ${ }^{1387}$

Kortom, de omstandigheid dat geen administratieve rechtsgang is benut of dat de beroepstermijn van deze rechtsgang is verstreken, doet aan de grondwettelijke plicht tot toetsing geen afbreuk. Dit betekent dat in het geval een openstaande bestuursrechtelijke procesgang niet is gevolgd, de strafrechter zicht niet dient te confirmeren aan de inhoud en de wijze van totstandkoming van de bestuurlijke beslissing. Het feit dat tegen de voor de strafrechter betwiste beslissing een annulatieberoep voor de Raad van State openstond heeft geenszins tot gevolg dat de strafrechter gebonden is aan de administratieve rechtshandeling.

Wel moet volledigheidshalve worden opgemerkt dat de situatie enigszins anders is wanneer voor de Raad van State de exceptie van onwettigheid wordt ingeroepen. Zoals geschetst, moet het annulatieberoep voor de Raad van State op straffe van niet-ontvankelijkheid binnen de wettelijke termijn van 60 dagen na bekendmaking of betekening van de bestreden beslissing ingesteld worden. De onwettigheid van een administratieve rechtshandeling kan na het verstrijken van de termijn niet meer vernietigd worden door de Raad van State. De administratieve rechtshandeling is dan definitief geworden. Wel kunnen de partijen zolang het gaat om verordeningsbepalingen aan de Raad van State vragen dat hij met toepassing van artikel $159 \mathrm{BGW}$ weigert ze toe te passen. ${ }^{1388}$ Deze mogelijkheid om na beroepstermijn voor de Raad van State op grond van artikel 159 BGW toch nog de onwettigheid van een administratieve rechtshandeling bij wijze van exceptie aan te voeren, bestaat echter niet voor individuele administratieve rechtshandelingen, zoals vergunningen. De rechtstoestand die ten opzichte van bepaalde subjectieve rechten bij een zelfs onwettige beschikking is vastgesteld, is dan definitief en althans voor de Raad van State niet meer vatbaar voor betwisting. ${ }^{1389}$ In die zin kan worden betoogd dat in dergelijk geval de Raad van State anders dan de gewone rechter wel gebonden is aan de formele rechtskracht van beschikkingen. De Raad van State heeft dus een andere opvatting over de draagwijdte van artikel 159 BGW dan de gewone hoven en rechtbanken. Deze laatsten zijn immers niet gebonden aan de formele rechtskracht van beschikkingen. De gewone rechter kan steeds, ook na het verstrijken van de administratieve beroepstermijn, de bestreden bestuurlijke beschikking toetsen. Dit laat zich verklaren doordat naar Belgisch recht de grondwettelijke gewoonrechtelijke toetsingsbevoegdheid van openbare orde is, dus ambtshalve moet 
worden toegepast en niet kan worden beperkt door de termijnen die gelden in de administratiefrechtelijke rechtsgang. ${ }^{1390}$ Een gebondenheid van de gewone (straf)rechter aan een bestuurlijke beslissing waarvan de rechtsgeldigheid eigenlijk alleen het gevolg is van het verstrijken van een administratiefrechtelijke beroepstermijn zou de controleplicht van de gewone rechter op bestuurshandelingen opzij zetten en daarmee de door de Belgische grondwetgever verdedigde visie op de machtenscheiding ontoelaatbaar uithollen. Anders gezegd, een gebondenheid van de gewone rechter aan de formele rechtskracht van bestuur-lijke beschikkingen, zoals die in Nederland bestaat, zou naar Belgisch recht een inbreuk betekenen op de machtenscheiding en de daarmee samenhangende grondwettelijk erkende rechterlijke controletaak. Daarnaast mag tevens niet worden vergeten dat het beroep op artikel $159 \mathrm{BGW}$ voor de gewone hoven en rechtbanken qua voorwerp van geschil verschilt van het beroep op artikel 159 BGW voor de Raad van State. Bij de gewone hoven en rechtbanken gebeurt de toetsing immers steeds ofwel binnen het civielrechtelijke kader van de schendig van een subjectief recht ofwel binnen het strafrechtelijke kader van de beantwoording van de kwalificatie- of wederrechtelijkheidsvraag. De exceptie van onwettigheid ingeroepen voor de Raad van State blijft daarentegen steeds een vorm van objectief beroep.

\section{De invloed van een administratiefrechtelijke uitspraak}

De strafrechter mag dan naar Belgisch recht niet gebonden zijn aan een bestuurlijke beslissing maar geldt dit ook ten aanzien van een uitspraak van een administratieve rechter? Is de strafrechter gebonden aan een administratiefrechtelijke uitspraak, met name aan de uitspraak van de Raad van State, of kan hij deze naast zich neer leggen?

Als principe geldt dat de op artikel $159 \mathrm{BGW}$ gegronde exceptie niet voor de rechter tegen beslissingen van de administratieve rechtscolleges zelf kan worden ingeroepen. Gewone rechters kunnen niet de beslissing van hun administratiefrechtelijke collega's op grond van artikel 159 BGW buiten toepassing verklaren. Zij zijn gebonden aan de administratiefrechtelijke uitspraak. Met andere woorden, in de situatie waarin de Raad van State een bepaalde beschikking voor wettig houdt, kan de strafrechter niet alsnog deze beschikking buiten toepassing verklaren. ${ }^{1391}$ Mocht de burger over dat rechtsmiddel beschikken en onverminderd beroep blijven doen op artikel 159 BGW dan zou het beginsel van de administratieve rechtspraak genegeerd worden terwijl het bestaan daarvan uitdrukkelijk in de Grondwet is neergelegd (artikel 145 BGW). Wel moet deze principiële gebondenheid van de gewone hoven en rechtbanken aan het oordeel van de administratieve rechtscolleges op één punt worden genuanceerd. Het Hof van Cassatie heeft immers uitgemaakt dat de gewone rechter uitsluitend gebonden is door de beslissingen van de administratieve rechtscolleges voor zover die rechtscolleges wettelijk bevoegd waren en zij geen uitspraak 
hebben gedaan over geschillen die tot de uitsluitende bevoegdheid van de gewone rechter behoren. ${ }^{1392}$

Dat de gewone rechter en dus ook strafrechter gebonden is aan het oordeel van de Raad van State lijkt begrijpelijk. De best geplaatste om over de rechtmatigheid van een beschikking te oordelen, lijkt inderdaad de administratieve rechter te zijn. Bovendien zijn de wettelijke voorwaarden waaronder de Raad van State vernietigingsarresten velt en het door de wet gegeven recht van onderzoek ten aanzien van de betwiste administratieve rechtshandelingen zodanig dat zij het hem mogelijk maken met betere kennis van zaken dan de gewone rechter zijn controletaak op de administratieve overheid uit te oefenen. ${ }^{1393}$ Een gebondenheid van de strafrechter aan de administratieve rechter past ook - in tegenstelling tot de gebondenheid van de strafrechter aan het bestuur - in het systeem van de eenheid van rechtsorde omdat de gewone rechter zich schikt aan het oordeel van de administratieve rechter. ${ }^{1394}$ Anders zou de gewone rechter een beschikking buiten toepassing kunnen verklaren wegens onrechtmatigheid terwijl de Raad van State zojuist heeft beslist dat de beschikking rechtsgeldig is. Dit zou impliceren dat de gewone rechter een soort superrechter wordt die niet alleen de werking van het bestuur controleert maar ook nog de oordeelsvorming van zijn administratiefrechtelijke collega heroverweegt. Dat kan onmogelijk de bedoeling zijn.

Nog een woord over de consequenties voor de vergunninghouder. Indien sprake is van een vernietiging (ex tunc) van een bevrijdende beschikking wordt het uitgangspunt gehanteerd dat wie op regelmatige wijze een vergunning heeft gekregen erop mag vertrouwen dat hij rechtmatig handelt wanneer hij daarvan gebruik heeft gemaakt. Dit vloeit voort uit het vertrouwensbeginsel. ${ }^{1395}$ De verdachte mag van de vernietiging niet het slachtoffer worden en kan zich dus beroepen op een schuldverweer. In de Belgische jurisprudentie inzake de 'onoverkomelijk rechtsdwaling' is regelmatig beslist dat de justitiabele in beginsel erop moet kunnen vertrouwen dat hij, indien hij de vergunningsvoorschriften naleeft, niet nadien strafrechtelijk gesanctioneerd kan worden. Dit impliceert dat ook het naleven van een onwettige en nadien vernietigde vergunning in beginsel een onoverkomelijk rechtsdwaling kan opleveren. Dit beginsel kent begrijpelijkerwijs uitzondering wanneer de betrokkene kennis had of diende te hebben van de onrechtmatigheid van de vergunning. ${ }^{1396}$

\section{De schorsing van de strafvervolging hangende de administratieve rechtsgang}

Het laatste, maar wellicht het lastigste probleem is de vraag of de strafrechter hangende de administratiefrechtelijke rechtsgang de strafzaak dient te schorsen zolang er nog niet door

1392. Zie o.m. Cass., 12 maart 1942, R.J.D.A. 1946, 24-27, met noot De Visscher; Cass., 13 oktober 1969, Arr. Cass. 1970, 156-160. Mast, A. en Dujardin, J., o.c., 1993, 637.

1393. Mast, A. en Dujardin, J., o.c., 1993, 635.

1394. Faure, M.G., 'De gevolgen van de "administratieve afhankelijkheid" van het milieustrafrecht: een inventarisatie van knelpunten', in Faure, M.G., Oudijk, J.C. en Schaffmeister, D. (red.), o.c., 1991, 122-123.

1395. Zie Faure, M. en Visser, M., o.c., 1999, 97.

1396. Faure, M., l.c., 1991-92, 937-950. 
de administratieve rechter is beslist. Dit is allesbehalve een louter theoretisch probleem. Het is best denkbaar dat de beklaagde (of derden) een administratief beroep instelt - indien de termijn van 60 dagen nog niet is verstreken - nadat een strafvervolging werd aangevat. Dit probleem is uiterst precair door de retroactieve werking van de vernietigingsarresten van de Raad van State. Daaruit volgt dat indien de strafrechter het administratiefrechtelijk oordeel niet afwacht zulks tot tegenstrijdige uitspraken zou kunnen leiden.

Er zijn voldoende argumenten om schorsende werking toe te kennen aan de administratiefrechtelijke procedure omdat het resultaat van dergelijke procedure - dat wil zeggen, een uitspraak door een administratieve rechter - bindend is voor de strafrechter. ${ }^{1397}$ Veronderstel dat de verdachte een overtreding van een vergunningsvoorwaarde wordt tenlastegelegd en hij als verweer anvoert dat deze voorwaarde in strijd met de wet is opgelegd. Indien de strafrechter de vervolging niet zou schorsen kan het risico ontstaan dat hij tot het oordeel komt dat de door de verdachte bestreden vergunningsvoorwaarde wettig is en de verdachte veroordelen. Indien nu later deze vergunningsvoorwaarde door de Raad van State toch zou worden vernietigd, zou dit als nadelige consequentie hebben dat er een strafrechtelijke veroordeling heeft plaatsgevonden naar aanleiding van een overtreding van een voorwaarde die retroactief wordt vernietigd. Veronderstel nu dat de uitspraak van de Raad van State zou vallen vóór de uitspraak door de strafrechter dan zou de strafrechter begrijpelijkerwijs wel gebonden zijn aan het oordeel van de Raad van State. Me dunkt dat dergelijke inconsistenties, in de eerste plaats vanuit het perspectief van een integere rechtsbescherming, zoveel mogelijk moeten worden vermeden. Het lijkt dus geboden dat de bestuursrechtelijke procedure voor het strafproces een schorsende werking toekomt.

Een belangrijk praktisch nadeel van de schorsing van de strafvervolging is evenwel dat de strafprocedure nodeloos kan worden vertraagd. Het is zelfs denkbaar dat de schorsing uitsluitend als vertragingsmanoeuvre wordt ingeroepen. Daarmee rijst de vraag of aan de schorsing van een strafvervolging ook de consequentie kan worden verbonden dat de verjaring van de strafvordering wordt geschorst gedurende de periode dat de administratieve rechtsgang nog niet is beëindigd. Dat zou immers het belangrijkste nadeel van een schorsing van de strafvervolging - de verjaringsproblematiek - uit de wereld helpen.

De rechtspraak is ten aanzien van deze vraag van de schorsing verdeeld. ${ }^{1398} \mathrm{Zo}$ is het vaste rechtspraak van het Hof van Beroep te Gent dat er geen reden is om de procedure te schorsen totdat de Raad van State uitspraak zal hebben gedaan. Illustratief is een arrest van 2 februari 1995 waarin uitvoerig wordt ingegaan op de vraag hoe de strafrechtelijke procedure zich dient te verhouden tot het hangende administratieve beroep. De verdachte werd in casu vervolgd voor het uitbaten van een varkensbedrijf zonder de daarvoor vereiste vergunning. Deze werd hem immers op basis van de toen geldende wetgeving door de Bestendige Deputatie van de Provincieraad van West-Vlaanderen geweigerd. De bevoegde Gemeenschapsminister wees vervolgens het beroep van de beklaagde tegen deze beslissing

1397. Faure, M.G., 'De gevolgen van de "administratieve afhankelijkheid" van het milieustrafrecht', in Faure, M.G., Oudijk, J.C. en Schaffmeister, D., o.c., 1991, 124.

1398. Zie hierover Faure, M., 'Strafuitsluitingsgronden in het milieustrafrecht', TMR, 1998, 192-193. 
af. Tegen deze laatste afwijzing werd door de beklaagde annulatieberoep bij de Raad van State ingesteld. Over dit beroep tegen de weigeringsbeslissing van de minister was tijdens de strafprocedure nog niet door de Raad van State beslist zodat de beklaagde verzoekt om de schorsing van de strafvervolging. De schorsing wordt door de strafrechter uitdrukkelijk verworpen:

\begin{abstract}
'Vooreerst is de bewijslevering van het tenlastgelegde feit niet rechtstreeks afhankelijk van de beslissing van de Raad van State (...) Het is immers zo dat zelfs zo zijn beroep zou worden ingewilligd de beklaagde nog niet automatisch over een vergunning beschikt, gelet op het niet bestaan van een aan de bestreden beslissing, voorafgaande toekenning van een exploitatievergunning: het blijft derhalve zo dat hij de hinderlijke inrichting heeft uitgebaat op een ogenblik dat hij niet werkelijk over een voorafgaande schriftelijke vergunning beschikte; de wetgever heeft precies dit laatste willen beteugelen in de wetsbepaling vermeld in de tenlastlegging. De vaststelling dat in geval van inwilliging van het beroep bij de Raad van State opnieuw zal dienen te worden beslist over de oorspronkelijke aanvraag en deze beslissing, weze zij gunstig voor de beklaagde (...) retroactief in de plaats zal treden van de oorspronkelijke beslissing doet hieraan geen afbreuk. Verder is het zo dat art. 159 van de Grondwet (oud art. 107) het Hof zelf verplicht de algemene, provinciale en plaatselijke besluiten en verordeningen alleen toe te passen in zoverre zij met de wetten overeenstemmen. (...) Op grond van deze wettelijke bepaling heeft het Hof, zoals de beklaagde stelt, de macht en de plicht na te gaan of de besluiten, reglementen of verordeningen waarvan de toepassing in het geding is, met de wetten overeenstemmen. ${ }^{1399}$
\end{abstract}

Gelet op de feitelijke toedracht van deze zaak kan weinig worden ingebracht tegen de door het Hof gebruikte redenering. Het is inderdaad zo dat een voor de beklaagde gunstig oordeel van de Raad van State, namelijk een vernietiging van de weigeringsbeslissing van de minister, onverlet laat dat hij indertijd niet beschikte over een exploitatievergunning. Toch past bij deze uitspraak een kanttekening. Allereerst kan, hoewel het standpunt van Hof formeel juist is, worden betoogd dat door de vernietiging door de Raad van State de administratie retroactief toch nog een exploitatievergunning zou kunnen toekennen zodat de mogelijkheid bestaat dat de beklaagde helemaal niet onrechtmatig handelde. De vraag rijst dan of deze mogelijkheid niet voldoende reden is om te schorsen totdat de bevoegde instantie opnieuw heeft beslist over de oorspronkelijke aanvraag. Natuurlijk zijn daarmee niet alle problemen opgelost. Stel dat de betrokkene alsnog een vergunning krijgt en de strafrechter de debatten heropent na kennisneming van deze administratieve beslissing, betekent dit dan dat de strafrechter $a$ priori gebonden is aan deze vergunning? Vanzelfsprekend niet. Hij zal deze vergunning ambtshalve toetsen en mogelijkerwijs buiten toepassing verklaren wanneer deze in strijd met de wet is verleend geworden. Hiermee 
wordt een ander nadeel duidelijk, namelijk dat een dergelijke schorsing wel zeer lang duurt omdat moet worden gewacht op een (nieuwe) beslissing van het bestuur. Het gaat dan al lang niet meer om een schorsing in afwachting van een oordeel van een administratieve rechter, maar om een schorsing in afwachting van een beslissing van het bestuur. De vraag is of dit voor het strafproces wel zo wenselijk is.

Daarnaast zijn ook nog allerlei situaties denkbaar waar de redenering van het Hof van Beroep te Gent niet langer opgaat en het veel logischer en rechtvaardiger lijkt de strafvervolging te schorsen. Veronderstel dat de eigenaar van het varkensbedrijf wel beschikt over een vergunning maar dat één van de voorwaarden, bijvoorbeeld het maximum aantal toegestane varkens, volgens hem in strijd met het redelijkheidsbeginsel is opgelegd. Stel nu dat hangende het annulatieberoep tegen de belastende vergunningsvoowaarde tegen de betrokkene een strafvervolging wordt ingesteld wegens overschrijding van de voorwaarde. Het is dan niet denkbeeldig dat de strafrechter tot het oordeel komt dat de voorwaarde wettig is en de verdachte terzake veroordeelt. Als nu later blijkt dat de Raad van State de voorwaarde toch vernietigt ontstaat de merkwaardige situatie dat een veroordeling op grond van een overtreding van een onrechtmatig voorschrift heeft plaatsgevonden. Om dergelijke tegenstrijdigheden te voorkomen lijkt het dus zeer wenselijk dat de strafrechter overgaat tot schorsing van de strafvervolging. Kortom, het hangt duidelijk van de feiten af of de strafrechter moet overgaan tot schorsen. Me dunkt dat in ieder geval in situaties waar de verdachte een beroep heeft ingesteld tegen een belastende vergunningsvoorwaarde de strafrechter moet schorsen.

Anders dan het Gentse Hof lijkt het Hof van Beroep te Antwerpen schorsing van de strafvervolging wel toe te laten. Het Hof van Beroep te Antwerpen heeft in enkele (ongepubliceerde) arresten de schorsing der vervolging uitgesproken teneinde de uitspraak op administratiefrechtelijk vlak af te wachten. Zo werden in een arrest van 15 januari 1992 de debatten heropend teneinde kennis te nemen van de eindbeslissingen in verband met twee voor de Raad van State hangende procedures; de zaak werd op onbepaalde datum uitgesteld en de verjaring van de strafvordering werd opgeschorst tot op de datum van voormelde eindbeslissingen. ${ }^{1400}$ Illustratief is een arrest van het Hof van Beroep te Antwerpen van 10 januari 1995. In deze zaak werd de beklaagde de exploitatie zonder vergunning van een veebedrijf voor melkvee tenlastegelegd. Deze vergunning werd door de bevoegde instantie geweigerd en tegen deze weigering werd annulatieberoep ingesteld. Het Hof besluit terzake tot schorsing van de strafvordering met de volgende uitvoerige overweging:

'Overwegende dat het Hof (...) vaststelt dat het mogelijk is dat de administratieve overheid ook retroactief beslist dat de vergunningen worden verleend of dat in deze aangelegenheden geen vergunning vereist was en dat beklaagden administratief rechtmatig handelden;

1400. Antwerpen, 7e kamer, 15 januari 1992 inzake OM, Cuppens, Jacobs e.a. t. Steensels, ongepubliceerd. Inmiddels is in deze zaak een eindarrest tussengekomen: Antwerpen, $7 \mathrm{e}$ kamer, 19 april 1995, zelfde partijen, ongepubliceerd. 
Overwegende dat ook (...) blijkt dat in casu de bewijslevering van de ten laste gelegde feiten rechtstreeks afhangt van de aangewezen te treffen beslissingen dat de al dan niet geldigheid van de administratieve weigeringen onontbeerlijk zijn voor de beoordeling van de grond van de zaak; dat het Hof over deze prejudiciële vragen zelf geen oordeel kan vellen; dat de afwezigheid van de betrokken beslissingen de wettelijke beletselen uitmaken waardoor de berechting van de zaak wordt verhinderd;

Overwegende dat een eventueel verschil in de administratieve en strafrechtelijke beslissing een inbreuk zou uitmaken op het beginsel van de eenheid van rechtsorde: dat het immers feitelijk niet kan zijn dat de administratieve overheid bevoegd voor het vergunningenbeleid zou toestaan wat door de strafrechter wordt verboden;

Overwegende dat overigens de strafrechter niet bevoegd is dergelijke toelating te verstrekken of te weigeren en ofwel vrijspreekt ofwel vaststelt dat het bedrijf werd geëxploiteerd en de gebouwen werden opgericht zonder vergunning. ${ }^{.1401}$

De uitspraak van het Hof van Beroep te Antwerpen is om verschillende redenen interessant. Allereerst wordt ter rechtvaardiging van de schorsing beroep gedaan op het beginsel van de eenheid van rechtsorde. Dit lijkt zeer verdedigbaar omdat toch moeilijk kan worden volgehouden dat enerzijds de strafrechter een reeds uitgesproken oordeel van zijn administratieve collega moet respecteren, maar dat hij anderzijds niet de vervolging zou mogen schorsen teneinde dit rechterlijke oordeel af te wachten. Dat is onlogisch en leidt tot onaanvaardbare tegenstrijdigheden.

Van belang is ook dat het praktische bezwaar als zou de schorsing automatisch het risico van verjaring met zich meebrengen, wordt verworpen op grond van de redenering dat de schorsing van de strafvordering moet worden beschouwd als een wettelijk beletsel voor de berechting van de strafzaak en dus kan worden gezien als een wettelijke grond tot schorsing van de verjaring. Dat lijkt me een aanvaardbare redenering. Het is vaste rechtspraak dat de verjaring wordt geschorst telkens er een beletsel is dat de uitoefening van de strafvervolging in de weg staat. Dit is een toepassing van het adagium contra non valentam non curit praescriptio. ${ }^{1402}$ De wet geeft geen limitatieve en systematische opsomming van de gevallen waarin de verjaring van de strafvordering wordt geschorst. Bovendien zijn vele gevallen van schorsing door de rechtspraak ontwikkeld. Eén van de voornaamste gevallen van schorsing van de verjaring is neergelegd in artikel 24 Voorafgaande Titel van Strafvordering; wanneer, bij een prejudicieel geschil, de zaak naar een ander rechtscollege wordt verwezen, is de verjaring van de strafvordering geschorst totdat dit rechtscollege uitspraak heeft gedaan. Daaronder kunnen tevens worden begrepen prejudiciële geschillen die niet door de strafrechter zelf maar door één van de partijen bij een andere instantie worden aanhangig gemaakt. De wet laat ruimte genoeg om een schorsing van de strafver-

1402. Van den Wijngaert, C., Strafrecht en strafprocesrecht in hoofdlijnen, Antwerpen, Maklu, 1991, 542. 
volging met het oog op een uitspraak van de administratieve rechter aangaande een voor de vaststelling van de strafbaarheid essentiële vraag te zien als een wettelijke grond tot schorsing van de verjaring.

Desondanks lijkt het Hof van Cassatie geen voorstander te zijn van de schorsing van de strafvordering. In een arrest van 4 oktober 1994 heeft het Hof van Cassatie beslist dat de omstandigheid dat bij de Raad van State een beroep tot nietigverklaring van de weigering tot het verlenen van een regularisatievergunning aanhangig is, geen wettelijk beletsel vormt voor het instellen of het uitoefenen van de strafvordering. Derhalve schorst een dergelijk beroep bij de Raad van State volgens het Hof van Cassatie de verjaring van de strafvordering niet. ${ }^{1403} \mathrm{Bij}$ een schorsing kunnen er zich dus eventueel problemen voordoen, hoewel dat niet steeds zo moet zijn, daar vele milieudelicten voortdurende of voortgezette delicten zijn. Overigens moet wel worden benadrukt dat het Hof van Cassatie slechts heeft gesteld dat een beroep bij de Raad van State geen wettelijk beletsel vormt voor de uitoefening van de strafvordering. Met andere woorden, er is dan geen grond voor schorsing van de verjaring van de strafvordering. Daaruit volgt dat de strafrechter weliswaar de strafvervolging niet moet schorsen, maar dit nog steeds mag als de concrete omstandigheden dit nodig maken. ${ }^{1404}$

\section{Samenvatting}

Naar Belgisch recht is de strafrechtelijke toetsingsbevoegdheid zeer ruim. Artikel 159 BGW verplicht de gewone rechter de reglementaire en niet-reglementaire administratieve rechtshandelingen buiten toepassing te verklaren wanneer zij niet met wet of recht overeenstemmen. Artikel 159 BGW moet worden begrepen als een herstel door de Belgische grondwetgever van een evenwichtige visie op de machtenscheiding waarbij aan de onafhankelijke strafrechter de taak is opgedragen te waarborgen dat het bestuur zich houdt aan de wet. Het grondwetsartikel heeft een imperatieve draagwijdte, hetgeen onder meer betekent dat de rechter steeds kan toetsen ook al werpen de partijen terzake niets op en is de administratieve rechtsgang ongebruikt gebleven. De Belgische strafrechter is niet gebonden, zoals in Nederland, aan de formele rechtskracht of, zoals in Duitsland, aan de 'Wirksamheit' van beschikkingen en dit ongeacht of ze belastend of bevrijdend zijn. De enige beperking op de strafrechtelijke controle is gelegen in een gebondenheid van de strafrechter aan de uitspraken van de administratieve rechter. Zou de strafrechter het administratiefrechtelijke oordeel opzij kunnen zetten, dan zou dit leiden tot ondermijning van de administratiefrechtelijke rechtspraak. Daaruit vloeit tevens de noodzaak aan de administratieve procedure een voor de verjaring van de strafvordering schorsende werking toe te kennen, hoewel geen regel daartoe verplicht en tot op heden het Hof van Cassatie een dergelijk schorsing niet geoorloofd acht. 


\section{RECHTSVERGELUKENDE CONCLUSIES}

Omdat de macht om de inhoud van de materiële milieunormen te bepalen in het huidige milieustrafrecht primair bij de administratieve overheden ligt, wordt de omvang van de strafrechtelijke aansprakelijkheid voor milieuverstoring voornamelijk door hen bepaald. Via de vergunningverlening bepaalt de overheid welke milieuverstoring strafbaar is en welke niet. Deze belangrijke bevoegdheid is natuurlijk niet onbeperkt. Het bestuur dient zich bij vergunningverlening te houden aan de materiële milieuwetten, het door de milieuwetgever vastgestelde doel van de wet en de betreffende bepaling, de in het milieuwet opgenomen voorschriften en voorwaarden die het bestuur bij zijn belangenafweging moet betrekken, en natuurlijk ook nog de algemene beginselen van behoorlijk bestuur. ${ }^{1405}$

De vraag rijst wat de strafrechtelijke gevolgen zijn indien een vergunning (belastend of bevrijdend) in strijd met wet of recht wordt verleend. Cruciaal is dan of de strafrechter aan dergelijke beschikkingen gebonden is. Moet hij blind varen op de onrechtmatige beschikking of is hij bevoegd deze te toetsen. Wanneer we deze vraag rechtsvergelijkend bekijken stellen we een aantal belangrijke verschillen vast, die een bijzonder licht werpen op dit toetsingsvraagstuk.

Zo blijkt in Duitsland de strafrechtelijke toetsing van vergunningen de meeste problemen op te leveren. De strafrechtelijke toetsingsbevoegdheid is in beginsel uiterst beperkt. De strafrechter is principieel gebonden aan rechtsgeldige beschikkingen ook al zijn ze onrechtmatig. De strafrechtelijke toetsing wordt gekenmerkt door een sterke beschikkingsafhankelijkheid of Verwaltungsaktsakzessorietät. Dit heeft als consequentie dat de justitiabele die beschikt over een onrechtmatige maar rechtsgeldige vergunning toch vrijuit gaat wanneer hem een handelen zonder vergunning wordt tenlastegelegd. Sinds 1994 wordt evenwel in bepaalde gevallen van rechtsmisbruik volgens $\S 330$ StGB aan rechtsgeldige vergunningen een strafuitsluitende werking ontzegd.

In Nederland lijkt het beeld wat genuanceerder. De strafrechter is gebonden aan de formele rechtskracht van beschikkingen, maar het is de vraag of dit geldt voor alle beschikkingen. De formele rechtskracht lijkt in het milieustrafrecht alleen bij belastende beschikkingen een beslissende rol te spelen. Dit betekent dat de beperkte toetsingsbevoegdheid geen belemmering hoeft te zijn voor de strafrechtelijke handhaving van het milieurecht omdat het $\mathrm{OM}$ blijkbaar probleemloos zich op de onrechtmatigheid van bevrijdende beschikkingen kan beroepen en dergelijke vergunningen derhalve geen strafuitsluitende werking hebben. Langs de andere kant is wel duidelijk geworden dat de beperking van de strafrechtelijke toetsingsbevoegdheid soms ten nadele werkt van de verdachte, daar hij zich niet voor het eerst bij de strafrechter op de onrechtmatigheid van een door hem overtreden voorschrift kan beroepen. Ten overstaan van de burger geldt de formele rechtskracht. 
Het Belgische recht lijkt met de strafrechtelijke toetsing het verst te gaan. De strafrechter heeft immers ambtshalve de plicht om elke administratieve rechtshandeling die hij toepast te toetsen op zijn wettigheid en rechtmatigheid. Deze ruime toetsingsplicht heeft tot gevolg dat zowel het OM als de burger zich steeds op de onrechtmatigheid van beschikkingen kunnen beroepen.

Zetten we de drie onderzochte landen even op een rij dan zien we dat in Duitsland de strafrechter (behoudens wettelijke uitzonderingen) vrijwel geen toetsingsbevoegdheid heeft, dat de Nederlandse strafrechter in beginsel mag toetsen, maar gebonden is aan de formele rechtskracht van (belastende) beschikkingen en dat, tenslotte, de Belgische strafrechter een zeer ruime toetsingsplicht heeft.

\section{§3. De inhoud van de milieustrafrechtelijke wederrechtelijkheid}

\section{A. INLEIDING}

Nu duidelijk is geworden dat er voor de strafrechtelijke toetsing van overheidshandelen in het algemeen en van beschikkingen in het bijzonder geen principiële bezwaren hoeven te zijn, kan nader worden bekeken wanneer het overheidshandelen, met name de vergunningverlening, daadwerkelijk onrechtmatig is. Immers, de strafrechter kan hierover slechts een inhoudelijk oordeel vellen indien hij bevoegd is te toetsen. Anders gezegd, eens wordt aanvaard dat de strafrechter kan toetsen, moet hij een onrechtmatigheidsoordeel uitspreken. Dat roept een aantal wezenlijke vragen op. ${ }^{1406}$

Allereerst rijst de vraag aan welke normen de strafrechter de rechtmatigheid van de betwiste vergunning(svoorschriften) kan toetsen om tot een onrechtmatigheidsoordeel te kunnen komen. Daarbij is ook van belang in welke mate de rechter de belangenafweging en beslissingsruimte van het bestuur in zijn oordeel kan betrekken. Deze vraag zal hoofdzakelijk aan de hand van het Nederlandse en Belgische recht worden beantwoord (B).

Vervolgens rijst de vraag of iedere bestuursrechtelijke onrechtmatigheid ook strafrechtelijk relevant hoeft te zijn. Dit vraagt om enige toelichting. Zolang men uitgaat van een strafrechtelijk toetsingsverbod of een strikte binding van de strafrechter aan de rechtsgeldigheid (Duitsland) of formele rechtskracht (Nederland) van bestuurlijke beschikkingen is de vraag of de tenlastegelegde gedraging strafbaar is vrij makkelijk te beantwoorden: immers, het bestuur heeft deze vraag via de vergunning(svoorschriften) ex ante al beantwoord. Voor de strafrechter betekent dit dat de verboden gedraging, zoals een lozing, als een strafbaar feit moet worden gekwalificeerd indien de verdachte niet beschikt over een vergunning of in strijd handelt met een vergunningsvoorschrift. Eens men aanvaardt dat de strafrechter niet gebonden hoeft te zijn aan de in beginsel strafuitsluitende vergunningen, moet hij toetsen en rijst automatisch de vraag of ieder gebrek aan een

1406. Vragen die natuurlijk bij een strafrechtelijk toetsingsverbod niet beantwoord hoeven te worden, daar ze niet kunnen worden gesteld: de strafrechter is dan immers a priori gebonden aan de vergunningen en door het bestuur daarin neergelegde voorschriften. 
vergunning(svoorschrift) dient te leiden tot het oordeel dat de tenlastegelegde gedraging ook strafbaar is. Dienen bijvoorbeeld louter formele gebreken aan de vergunning reeds te leiden tot het oordeel dat de gedraging niet langer is gedekt door een rechtmatige vergunning? Deze vraag is niet te ontwijken indien men voorstander is van een meer Verwaltungsrechtsakzessorische benadering van het milieustrafrecht. De kwestie of iedere bestuursrechtelijke onrechtmatigheid ook strafrechtelijk relevant is, wordt in deze paragraaf voornamelijk vanuit het Duitse strafrecht onderzocht, omdat daar de discussie rond Verwaltungsaktsakkzessorietät versus Verwaltungsrechtsakzessorietät in het milieustrafrecht zeer centraal staat (C).

Een onderzoek naar de inhoud van de wederrechtelijkheid van de vergunningverlening is van belang zowel voor de strafbaarheid van de vergunninghouder/vergunningplichtige als voor de strafbaarheid van de vergunningverlener. Immers, bij beiden staat de vergunningverlening vanwege zijn strafuitsluitende werking centraal. Voor de vergunninghouder betekent dit dat moet worden beantwoord welke invloed een onrechtmatige vergunning heeft voor de strafbaarheid van de hem verweten gedragingen. Voor de vergunningverlener betekent dit dat moet worden beantwoord onder welke omstandigheden het in strijd met wet en/of recht afgeven van een vergunning ook strafrechtelijke wederrechtelijkheid impliceert.

Moet nog worden benadrukt dat in Nederland met Pikmeer II de inhoud van de wederrechtelijkheid ook voor overheden een nieuwe dimensie heeft gekregen. Zoals is besproken, heeft de Hoge Raad in Pikmeer II geoordeeld:

'indien tegen een openbaar lichaam dan wel tegen de opdrachtgevers of leidinggevers een vervolging wordt ingesteld, kan de rechter met hantering van het stelsel van rechtvaardigingsgronden beslissen dat de verweten en ter behartiging van een specifieke bestuurstaak verrichte gedraging, hoewel strijdig met wettelijke voorschriften, in de omstandigheden van het geval gerechtvaardigd is en daarom tot straffeloosheid moet leiden. ${ }^{1407}$

Hieruit kan worden afgeleid dat ook al overtreedt de overheid de milieurechtelijke voorschriften er plaats is voor rechtvaardigingsgronden, dus ook wanneer de overheid handelt zonder vergunning of in strijd met vergunningsvoorschriften. Kortom, na Pikmeer II ontkomt de strafrechter niet aan een oordeel over de rechtmatigheid van overheidsgedragingen en derhalve ook niet aan een oordeel over de toepasselijke (vergunnings)voorschriften. Zo rijst de vraag of overheden, die zich voor de strafrechter beroepen op de onrechtmatigheid van het door hen overtreden voorschrift, ook de formele rechtskracht zullen krijgen tegengeworpen of dat de strafrechter inhoudelijk moet bekijken of ondanks de overtreding van het voorschrift nog plaats is voor een rechtvaardigingsgrond. Bovenstaande overweging van de Hoge Raad lijkt toetsing niet onmogelijk te maken, want hoe zou anders in zo'n geval kunnen worden bekeken of inderdaad een rechtvaardigingsgrond

1407. HR 6 januari 1998, $N J 1998,367$ (r.o. 5.8) met noot 't Hart, A.C. 
voorligt? Uit het voorgaande is duidelijk geworden dat ik geen groot voorstander ben van de formele rechtskracht van (belastende) beschikkingen, zodat in mijn visie de strafrechter niet aan een toetsing ontkomt of nu particulieren of overheden terecht staan.

Daarnaast, indien een overheid het handelen zonder vergunning wordt tenlastegelegd omdat deze beschikking onrechtmatig is, rijst de vraag of de strafrechter deze vergunning kan toetsen. Deze casuspositie is interessant, want indien de strafrechter dergelijke beschikkingen niet zou mogen toetsen, dan kan hij ook niet tot het oordeel komen dat een strafbaar feit voorligt en kunnen onrechtmatige vergunningen alsnog het overheidsoptreden van de werking van het strafrecht uitsluiten. Maar zoals is vastgesteld, lijkt de Nederlandse strafrechter niet gebonden aan onrechtmatige bevrijdende beschikkingen.

\section{B. AAN WELKE RECHTSNORMEN KAN DE VERGUNNING(SVOORWAARDE) WORDEN GETOETST?}

\section{De inhoud van de strafrechtelijke toetsing in Nederland}

\section{a. Wettelijke toetsingsgronden}

Een eerste criterium waaraan vergunningen en de daarin opgenomen voorwaarden kunnen worden getoetst, is de wet (in materiële of formele zin). ${ }^{1408}$ In de reeds vernoemde rechtspraak betrof het trouwens meestal een onverbindendverklaring van een vergunning wegens strijdigheid met de wet. Zo werd in het camping Domburg-arrest de nietigheid van de kampeervergunning vastgesteld wegens strijdigheid met de Verordening op de kampeerplaatsen en op de kampeermiddelen van de gemeente Domburg. ${ }^{1409}$

De wettelijke toetsingsgronden kunnen zowel betrekking hebben op de bevoegdheid om beschikkingen uit te vaardigen alsook verwijzen naar de inhoud en de wijze van totstandkoming van de beschikking. ${ }^{1410}$ Doorgaans zal steeds van geval tot geval moeten worden bepaald wat de relevante wettelijke voorschriften zijn waaraan dient te worden getoetst. Dit kan in de praktijk een complexe affaire worden. Indien bijvoorbeeld de rechtmatigheid van een Wm-vergunning ter discussie staat, spreekt het voor zich dat de dubiueze vergunning allereerst aan de Wet milieubeheer kan worden getoetst. De Wm geeft echter zelf een aantal toetsingsgronden die niet in Wm zelf zijn terug te vinden. Dit betekent onder meer dat niet alleen rechtstreeks aan de Wm moeten worden getoetst, maar tevens aan relevante amvb's en provinciale verordeningen. Uit artikel 8.10. lid $2 \mathrm{Wm}$ blijkt immers dat een vergunning niet mag worden verleend wanneer dat niet in overeenstemming zou zijn met hetgeen overeenkomstig artikel $8.8 \mathrm{lid} 3 \mathrm{Wm}$ in acht moet worden genomen. Het gaat

1408. Faure, M.G., 'De gevolgen van de "administratieve afhankelijkheid" van het milieustrafrecht: een inventarisatie van knelpunten', in Faure, M.G., Oudijk, J.C. en Schaffmeister, D. (red.), o.c., $1991,106$.

1409. HR 13 november 1984, NJ 1985, 294; In HR 14 december 1954 , NJ 1955, 119 werd een dansvergunning nietig geoordeeld verklaard aangezien de burgermeester de vergunning strijdig met artikel 56 lid 2 van de Drankwet had verleend.

1410. Van Wijk, H.D. en Konijnenbelt, W., o.c., 1999, 321. 
daarbij onder meer om instructie-amvb's (artikel $8.45 \mathrm{Wm}$ ) en de in provinciale milieuverordeningen opgenomen instructieregels (artikel $8.46 \mathrm{Wm}$ ). Daarin zijn specifieke grenswaarden neergelegd waarmee de Wm-vergunning in strijd kan zijn. Daarnaast kunnen in het kader van de Wm-vergunning ook andere milieuwetten toetsingsgronden aanleveren. Artikel 8.10 lid 2 juncto artikel $8.9 \mathrm{Wm}$ eist dat de vergunning niet mag worden verleend in strijd met de in artikel 13.1.lid $2 \mathrm{Wm}$ genoemde wetten. ${ }^{1411}$ Ten slotte moet wat wettelijke toetsingsgronden betreft ook steeds worden gekeken naar een mogelijke strijdigheid met de Algemene wet bestuursrecht (artikel $8.6 \mathrm{Wm}$ ). Dan zal de toetsing vooral betrekking hebben op de wijze van totstandkoming van de vergunning.

\section{b. Grondwettelijke, internationale en Europeesrechtelijke bepalingen}

Een tweede belangrijke groep van toetsingscriteria betreffen bepalingen van hoger recht, dat wil zeggen internationale verdragen als het EVRM en het BUPO-verdrag, communautair recht en de Grondwet. ${ }^{1412}$ Beschikkingen kunnen zonder problemen aan de Grondwet worden getoetst. Het in artikel $120 \mathrm{Gw}$ verankerde toetsingsverbod betreft alleen een toetsing van een formele wet aan de Grondwet. Van groot belang zijn uiteraard de grondrechtenverdragen. Zo werd in de uitspraak van de Utrechtse Rechtbank een tippelverbod onverbindend verklaard wegens strijdigheid met artikel 2 lid 3 van het vierde protocol van het EVRM en artikel 12 lid 3 van het IVBPR. ${ }^{1413}$ De Hoge Raad hield deze uitspraak in stand. ${ }^{1414}$

Ook het Europees Gemeenschapsrecht speelt in deze een rol van betekenis. Via artikel 94 Gw kan Nederlandse regelgeving, dus ook vergunningen, op grond van het communautair recht onverbindend worden verklaard. Aan een belangrijk deel van het Europese recht komt bovendien rechtstreekse werking toe met als gevolg dat iedere burger zich bij de nationale rechter kan beroepen op het EG-recht om van een strafzaak af te komen. ${ }^{1415}$ Op verordeningen kan in principe steeds beroep worden gedaan: zij bezitten in de regel directe of rechtstreekse werking. Burgers kunnen tevens beroep doen op bepalingen uit richtlijnen mits deze rechtstreekse werking hebben. Volgens vaste rechtspraak van het Hof van Justitie is daarvan sprake wanneer de bepaling inhoudelijk onvoorwaardelijk en voldoende nauwkeurig is bepaald en niet afhankelijk is van een discretionaire uitvoeringsmaatregel. ${ }^{1416}$ Een

1411. De bedoelde wetten zijn de Mijnwet 1903, de Destructiewet, de Kernenergiewet. de Wet geluidshinder. de Grondwaterwet, de Wet inzake luchtverontreiniging, de Wet verontreiniging oppervlaktewateren, de Wet verontreiniging zeewater, de Wet milieugevaarlijke stoffen en de Wet bodembescherming.

1412. Van Wijk, H.D. en Konijnenbelt, W., o.c., 1999, 322.

1413. Rb Utrecht 4 september $1984, A B 1985,39$.

1414. HR 11 juni $1985, N J 1986,41$, met noot 't Hart.

1415. Sevenster, H.G., 'Milieustrafrecht in EEG-verband. "Het Europa van de milieucrimineel"', in Faure, M.G., Oudijk, J.C. en Schaffmeister, D. (red.), o.c, 1991, 421.

1416. HvJEG zaak 28/67 (Molkerei Zentrale), Jur. 1968, 204; HvJEG zaak 8/81 (Becker), Jur. 1982, 53; HvJEG zaak 71/85 (Nederland/FNV), Jur. 1986, 3855; HvJEG zaak C-76/91 (Caves Neto), Jur 1993, I-117; HvJEG zaak C-128/92 (Banks), Jur. 1994, I-1209. Zie tevens Barents, R. en Brinkhorst, L.J., Grondlijnen van Europees recht, Alphen aan den Rijn, 1996, 56-62; Craig, P. en de Búrca, G., EC Law. Text, Cases \& Materials, Oxford, 1995, 165-184. 
bekend voorbeeld waar een verdachte zich met succes kon beroepen op het Europees Gemeenschapsrecht is de zaak Gourmetterie van der Burg. ${ }^{1417}$ Volgens artikel 7 van de Nederlandse Vogelwet was het de verdachte verboden Schotse sneeuwhoenders in te voeren en/of te bezitten. Hij voerde als verweer dat dit verbod, nu hij de vogels in het Verenigd Koninkrijk had gekocht alwaar de dieren niet worden beschermd, in strijd was met de regels van het vrij verkeer van goederen (oud artikel 30 en 36 EEG-Verdrag) en de Vogelrichtlijn (79/409), die Schotse sneeuwhoenders niet als een bedreigde diersoort beschouwd. ${ }^{1418}$ Het Hof van Justitie oordeelde dat de Nederlandse wetgeving op dit punt inderdaad ten onrechte strenger was dan de Richtlijn. ${ }^{1419}$

Voor de strafbaarheid van overheden is natuurlijk van belang dat het OM ook een schending van communautair recht, waaronder overtreding van Verordeningen en Richtlijnen, kan ten laste leggen voor zover deze in Nederlandse strafnormen zijn vertaald. Men zou zelfs kunnen verdedigen dat, nu op alle overheidsinstanties een verplichting tot uitvoering van EG-recht rust, het OM in voorkomend geval - natuurlijk steeds in overeenstemming met zijn bevoegdheden - verplicht is beroep te doen op de schending van het Gemeenschapsrecht. ${ }^{1420}$

\section{c. De algemene beginselen van behoorlijk bestuur}

De tot hiertoe besproken toetsingsgronden hebben alle betrekking op geschreven recht. Een derde groep van toetsingscriteria betreft deels ongeschreven recht: de algemene beginselen van behoorlijk bestuur (a.b.b.b.'s). ${ }^{1421}$ Traditioneel wordt een onderscheid gemaakt tussen materiële en formele beginselen. De eerste groep betreft de eigenlijke inhoud van de beschikking. Tot deze categorie kunnen worden gerekend het zorgvuldigheidsbeginsel, het rechtszekerheids- en vertrouwensbeginsel, het verbod van détournement de pouvoir en het gelijkheids- en evenredigheidsbeginsel. De tweede groep heeft betrekking op de wijze van besluitvorming. Het gaat dan vooral om het beginsel van zorgvuldige voorbereiding, het Fair Play-beginsel, het verbod van détournement de procédure, het motiverings- en rechtszekerheidsbeginsel. $\mathrm{Nu}$ a.b.b.b.'s bij uitstek rechtsnormen inhouden voor het bestuurlijk handelen is het zeer verdedigbaar dat ook de strafrechter aan deze beginselen

1417. HvJEG, zaak c-169/89 (Gourmetterie van der Burg), Jur. 1990, 2143.

1418. Zie Jans, J.H., Europees Milieurecht in Nederland, Groningen, 1994, 213.

1419. HvJEG zaak C-169/89 (Gourmetterie van der Burg), Jur. 1990, 2143: 'Article 36 of the Treaty, read in conjuction with Council Directive 79/409 of 2 April 1979 on the conservation of wild birds, must be interpreted as meaning that a prohibition on importation and marketing cannot be justified in respect of a species of bird which does not occur in the territory of the legislating Member State but is found in another Member State where it may lawfully be hunted under the terms of that directive and under the legislation of that other State, and which is neither migratory nor endangered within the meaning of the directive.' Zie voor een kritische bespreking van dit arrest Krämer, L., European Environmental Law. Casebook, London, 1993, 149-159.

1420. Koopmans, I.M., o.c., 1996, 162; Sevenster, H.G., o.c., 1991, 423.

1421. Een deel van de a.b.b.b.'s zijn in hoofdstuk 3 van de Awb in geschreven recht omgezet. Dit verandert echter niets in de bevoegdheid van de rechter het overheidshandelen aan de a.b.b.b's te toetsen. 
moet kunnen toetsen ${ }^{1422}$ Hoewel, bij mijn weten, tot op heden een strafrechter geen beschikkingen onverbindend heeft verklaard wegens inbreuk op algemene beginselen, is denkbaar dat met name a.b.b.b.'s die betrekking hebben op de inhoud van een vergunning bij de toetsing een belangrijke rol kunnen spelen. ${ }^{1423}$

Bij toetsing aan a.b.b.b.'s gaat het nog meer dan bij de andere toetsingscriteria om rechtmatigheidstoetsing. Meteen moet in herinnering worden gebracht dat het hierbij nog steeds gaat om een toetsing aan achterliggende (deels ongeschreven) regels. Een toetsing van de opportuniteit van de bestuurshandeling is uitsluitend mogelijk in geval van administratief bezwaar (en beroep) bij het (hoger) bestuursorgaan. Problematisch is wel dat niet steeds een duidelijk onderscheid kan worden gemaakt tussen een loutere rechtmatigheidstoetsing en een opportuniteitstoetsing. ${ }^{1424}$ De vraag rijst dan aan welke beginselen zo al zou kunnen worden getoetst. Sommige auteurs gaan ervan uit dat de strafrechter wel kan toetsen aan het verbod van willekeur en van détournement de pouvoir, maar niet aan andere a.b.b.b's. Zo zouden in het geval van toetsing aan het zorgvuldigheidsbeginsel rechtmatigheids- en opportuniteitscontrole in elkaar vloeien. ${ }^{1425}$ Een reden voor deze beperking ligt waarschijnlijk in het feit dat lange tijd de civiele rechter, voor zover het bestuur beleidsvrijheid heeft, ook enkel kon toetsen aan het verbod van willekeur en het verbod van détournement de pouvoir. ${ }^{1426}$ Deze regel vloeide voort uit de Landsmeerarresten van $1963 .^{1427}$ Aan andere beginselen kon de civiele rechter slechts indirect toetsen in het kader van de willekeurtoetsing. ${ }^{1428}$ Inmiddels is sinds het IKON-arrest de Landsmeerdoctrine uitdrukkelijk verlaten. ${ }^{1429}$ Het betrof hier een schending van het gelijkheidsbeginsel. De Hoge Raad overwoog:

'Een overheidslichaam behoort bij het uitoefenen van zijn bevoegdheden uit een erfpachtverhouding de algemene beginselen van behoorlijk bestuur - en derhalve ook het gelijkheidsbeginsel als een van de beginselen in acht te nemen (...) dat het gelijkheidsbeginsel hier slechts aan de orde zou kunnen komen in het kader van de toepassing van een aan de overheid meer ruimte latende redelijkheidsmaatstaf en daarom hier een

1422. Koopmans, I.M., o.c., 1996, 140.

1423. Faure, M. en Visser, M., o.c., 1999, 87 en 112; Koopmans, I.M., o.c., 1996, 140.

1424. Faure, M.G., 'De gevolgen van de "administratieve afhankelijkheid" van het milieustrafrecht: een inventarisatie van knelpunten', in Faure, M.G., Oudijk, J.C. en Schaffmeister, D. (red.), o.c., $1991,108$.

1425. Van der Burg, F.H., Cartigny, G.J.M. en Overkleeft-Verburg, G., Rechtsbescherming tegen de overheid, Nijmegen, 1985, 177-178.

1426. Van Wijk, H.D. en Konijnenbelt, W., o.c., 1999, 625.

1427. HR 4 januari $1963, N J 1964,202-204$.

1428. Van Wijk, H.D. en Konijnenbelt, W., o.c., 1994, 625.

1429. Reeds cerder werd teruggekomen op de Landsmeerdoctrine in een kort gedingzaak inzake Haagse tolkentarieven: het optreden van de gemeente Den Haag werd onrechtmatig gevonden, niet via de weg van willekeur, maar rechtstreeks wegens schending van het zorgvuldigheidbeginsel. HR 27 juni 1986, $N J 1987,726$, met noot Scheltema. 
zwakkere werking dan in het bestuursrecht zou hebben, gaat uit van een onjuiste rechtsopvatting. ${ }^{1430}$

$\mathrm{Nu}$ de burgerlijke rechter aan alle a.b.b.b.'s mag toetsen zie ik niet in waarom de strafrechter dat niet zou mogen. Bij toetsing aan a.b.b.b.'s rijst wel het probleem van de omvang van de toetsing. Vergunningen zijn vrijwel steeds het resultaat van een bestuurlijke belangenafweging, welke in de praktijk neerkomt op een afweging tussen bescherming van het leefmilieu en de waarde van industriële of sociaal-economische belangen. Bestuurlijke belangenafweging vormt op zijn beurt een concretisering van een belangenafweging op het niveau van de wetgever. Vaak zijn in de onderscheiden milieuwetten criteria ter invulling van de belangenafweging vaag of zelfs afwezig. Nu is het denkbaar dat sommige gebreken van een vergunning zijn te herleiden tot een verkeerde belangenafweging. De vraag rijst dan in welke mate de strafrechter de belangenafweging of de beslissingsruimte (freies Ermessen) van het bestuur in zijn oordeel mag betrekken. Het gevaar bestaat immers dat de strafrechter in de opportuniteit van de beschikking treedt en aldus op de stoel van het bestuur plaats neemt. Daar ook op legislatief niveau veelal een belangenafweging heeft plaatsgevonden bestaat niet alleen het risico dat de strafrechter de doelmatigheid van de beschikking toetst, maar dat hij tevens in conflict treedt met de intenties en de keuzes van de wetgever. Dit lijkt op gespannen voet te staan met het beginsel van de scheiding der machten vooral daar waar de overheid bij de vergunningverlening beschikt over een behoorlijke mate van beoordelingsvrijheid. ${ }^{1431}$

Het risico van opportuniteitscontrole hoeft niet meteen tot de conclusie te leiden dat de strafrechter aperte schendingen van a.b.b.b.'s niet mag vaststellen. Dat is een ongenuanceerde stelling. Wat in de praktijk moet worden vermeden is dat de strafrechter de grenzen van zijn toetsingsbevoegdheid overschrijdt. Er moet op de rechterlijke beoordeling wel een rem worden gezet. Dat geldt voor iedere rechterlijke beoordeling en heeft als dusdanig weinig te maken met de rol van de strafrechter in dit verband. Dit betekent dat de strafrechter slechts 'marginaal' zal mogen toetsen. Dat heeft tot gevolg dat de strafrechter telkens moet nagaan of de beschikking is verleend in het licht van het doel van die verlening en of de vergunningverlener daarbij zodanig is te werk gegaan dat hij gelet op de te hanteren voorwaarden en normen in redelijkheid tot de verlening heeft kunnen overgaan. Indien blijkt dat de belangenafweging kennelijk onredelijk is, dan kan de rechter tot het oordeel komen dat de vergunning(svoorwaarde) onverbindend is. Dit betekent niet dat hij zijn belangenafweging in de plaats stelt van die van het bestuur. Hij kan slechts tot dat oordeel komen indien hij meent dat het bestuur in redelijkheid niet tot de gegeven beschikking heeft kunnen komen. Het is trouwens belangrijk erop te wijzen dat ook de

1430. HR 27 maart 1987, NJ 727, met noot Scheltema.

1431. Koopmans, I.M., o.c., 1996, 139-141; Faure, M.G., 'De gevolgen van de "administratieve afhankelijkheid" van het milieustrafrecht: een inventarisatie van knelpunten', in Faure, M.G., Oudijk, J.C. en Schaffmeister, D. (red.), o.c., 1991, 109-110. Beide auteurs bespreken deze problematiek hoofdzakelijk in het kader van de strafuitsluitingsgrond noodtoestand. Het gaat dan om de vraag in hoeverre de strafrechter na vaststelling van de rechtmatigheid van een vergunning de belangenafweging van het bestuur kan negeren door zelf in het kader van de noodtoestand, waarop de vergunninghouder zich beroept, tot een andere belangenafweging te komen. 
burgerlijke rechter kan controleren of het bestuurlijk handelen binnen de marges van de beslissingsruimte is gebleven. ${ }^{1432}$

\section{d. Milieubeleidsregels en richtlijnen}

In zijn algemeenheid kan nog worden opgemerkt dat de beslissingsruimte van het bestuur nooit een volkomen vrije bevoegdheid veronderstelt. De vrijheid van het bestuur wordt niet in een normatief vacuüm uitgeoefend. De aan het bestuur gegeven bevoegdheden zijn bedoeld om bepaalde aan hen opgedragen taken en belangen te behartigen. 'Freies Ermessen' is steeds ook 'pflichtgemässes Ermessen'. Of zoals van der Hoeven het uitdrukt: 'de vrijheid van de burger is, althans in onze samenleving, in belangrijke mate een "vrijheid van": de vrijheid van het bestuur is altijd een "vrijheid tot"'. ${ }^{1433}$

Bestuursorganen krijgen geen bevoegdheden om daarmee persoonlijke desiderata of die van bepaalde belangengroepen te dienen. Dat betekent dat de administratie enkel op basis van weloverwogen en kenbare criteria van zijn discretionaire bevoegdheden gebruik mag maken. Willekeur is rechtsstatelijk onverantwoord. ${ }^{1434} \mathrm{Om}$ willekeur te vermijden wordt beleid gemaakt: algemene regels die moeten worden gerespecteerd bij de invulling van de bestuurlijke beslissingsruimte. Een beleidsregel kan dan ook worden omschreven als

'een besluit, niet inhoudende een algemeen verbindend voorschrift, dat een algemene regel geeft omtrent de afweging van belangen, de vaststelling van de feiten of de uitleg van wettelijke voorschriften bij het gebruik van een bevoegdheid van een bestuursorgaan. ${ }^{1435}$

In het milieurecht spelen beleidsregels een belangrijke rol. Zij normeren rechtstreeks de bestuurlijke bevoegdheden. Zo bieden de Nederlandse Emissie Richtlijnen (NER) normen voor vergunningverlenende instanties met betrekking tot proces-emissies naar de lucht. Een andere voorbeeld is de ecologierichtlijn (Richtlijn Ammoniak en Veehouderij 1991) waarin milieukwaliteitseisen staan opgesomd waarmee vergunningen in strijd kunnen zijn. Dergelijke richtlijnen zijn vooral van belang zolang andere 'wettelijke' instrumenten zoals amvb's geen equivalente normering bieden. ${ }^{1436}$ Beleidsregels en richtlijnen kunnen eigen-

1432. Van Wijk, H.D. en Konijnenbelt, W., o.c., 1999, 620-623. Daarnaast is het toch niet zonder betekenis dat de strafrechter al enigszins vertrouwd is met marginale toetsing in het kader van het toetsen van het optreden van politie en $\mathrm{OM}$ aan de ongeschreven beginselen van een goede procesorde. Zie HR 12 december 1978 (Braak bij binnentreden), NJ 1979, 142 HR 22 december 1981 (Niet-ontvankelijkheid openbaar ministerie), $N J$ 1982, 233. Beide arresten vormen een erkenning van de marginale toetsingsbevoegdheid van de strafrechter. Zie tevens Cleiren, C.P.M., Beginselen van een goede procesorde, Arnhem, Gouda Quint, 1989.

1433. Van der Hoeven, J., 'De grenzen van de rechterlijke functie in de administratieve rechtspraak', RMThemis, 1974, 671 .

1434. Van Wijk, H.D. en Konijnenbelt, W., o.c., 1999, 270.

1435. Zie Tonnaer, F.P.C.L., Handboek van het Nederlands milieurecht, Utrecht, 1994, 545. De definitie is zo ruim dat ook richtlijnen hieronder vallen.

1436. Zo is ter vervanging van de ecologierichtlijn op 16 augustus 1994 op basis van de Interimwet ammoniak en veehouderij (Stb. 1994, 634) de Uitvoeringsregeling ammoniak en veehouderij 
lijk worden gezien als pseudowetgeving waar, behoudens afwijkingsbevoegdheid, het bestuur zich in beginsel aan moet houden. Vergunningen zijn in die zin bij uitstek milieubeleidsinstrumenten. Wanneer deze 'instrumenten' tegen het beleid ingaan of daarvan zonder duidelijke motivering afwijken, is het wenselijk dat de rechter het bestuurlijk handelen ook aan de relevante beleidsregels kan toetsen. We kunnen dan eigenlijk spreken van een vierde groep van toetsingscriteria. Vooral wanneer beleidsregels naar hun inhoud kunnen worden opgevat als 'recht' in de zin van artikel 99 RO moet de rechter dit beleid in zijn oordeel kunnen betrekken. In dit verband kan worden gewezen op een Hoge Raadarrest van 28 maart 1990. Daarin stond de vraag centraal of de leidraad administratieve boeten 1984 als recht kon worden beschouwd. De Hoge Raad overwoog:

'Een en ander geeft grond om (...) onder 'recht' in meergemelde zin mede te begrijpen door een bestuursorgaan binnen zijn bestuursbevoegdheid vastgestelde en behoorlijk bekend gemaakte regels omtrent de uitoefening van zijn beleid, die weliswaar niet kunnen gelden als algemeen verbindende voorschriften omdat zij niet krachtens enige wetgevende bevoegdheid zijn gegeven, maar die het bestuursorgaan wel op grond van enig algemeen beginsel van behoorlijk bestuur binden, en die zich naar inhoud en strekking ertoe lenen jegens de bij de desbetreffende regeling betrokkenen als rechtsregels te worden toegepast..$^{1437}$

Kortom, wanneer beleidsregels voor het bestuur (zelf)bindend zijn, dan moet de strafrechter in voorkomend geval aan deze regels kunnen toetsen.

Samengevat kan worden geconcludeerd dat de strafrechter vergunningen en vergunningsvoorwaarden kan toetsen aan vier categorieën van toetsingcriteria:

- de wettelijke toetsingscriteria zoals die in de milieuwetgeving, bijvoorbeeld in de Wm, amvb's en verordeningen, maar ook in de Awb zijn neergelegd.

- de toetsingscriteria van hoger recht, zoals de Grondwet, internationale verdragen en communautair recht;

- de algemene beginselen van behoorlijk bestuur die verwijzen naar het karakter van de vergunning als bestuursrechtelijke rechtshandeling;

- de (milieu)beleidsregels en richtlijnen als buitenwettelijke criteria.

vastgesteld. De Interimwet en de Uitvoeringsregeling geven toetsingscriteria voor het verlenen van Wm-vergunningen met het oog op enerzijds het laten voortbestaan van veehouderijen en anderzijds het terugdringen van ammoniakemissie. Zie Tonnaer, F.P.C.L., o.c., 1994, 1300.

1437. HR 28 maart 1990, NJ 1991, 118, met noot Scheltema. 


\section{De inhoud van de strafrechtelijke toetsing in België}

\section{a. Interne en externe wettigheid}

Wat de inhoud van de toetsingsbevoegdheid betreft, wordt naar Belgisch recht aanvaard dat dit niet alleen een controle is van de externe of formele wettigheid, maar ook van de interne wettigheid, vergelijkbaar met de controle door de Raad van State en andere administratiefrechtelijke rechtscolleges. ${ }^{1438} \mathrm{De}$ administratieve rechtshandeling wordt dus in de eerste plaats aan de wet getoetst. Het begrip 'wet' wordt net als in Nederland in zijn algemene materiële betekenis gebruikt. Eveneens wordt aanvaard dat het verdragsrecht en in het bijzonder de communautaire verdragen en het EVRM toetsingsgronden opleveren. ${ }^{1439} \mathrm{De}$ interne wettigheidscontrole impliceert dat de strafrechter evenals de administratieve rechter een beschikking onverbindend kan verklaren wegens détournement de pouvoir of strijdigheid met algemene beginselen van behoorlijk bestuur. ${ }^{1440}$ Ook op dit punt is er dus weinig verschil met Nederland.

Vragen die in het kader van de externe wettigheidscontrole aan bod komen zijn: was het bestuur bevoegd om in kwestie een rechtshandeling te stellen? Zijn alle procedurele vormvereisten naar behoren nagekomen? De externe controle is dus vrij onproblematisch en een negatief antwoord op deze vragen leidt meteen tot de conclusie dat het genomen besluit in strijd is met de wet. ${ }^{1441}$

Moeilijker is het onderzoek door de rechter naar de interne wettigheid. Dan betreft het immers de vraag of de betwiste bestuurlijke handeling naar inhoud in overeenstemming is met de wet en hogere regelgeving. ${ }^{1442}$ De rechter moet daarbij rekening houden met het doel en de betekenis van de rechtsregel aan dewelke wordt getoetst hetgeen betekent dat moet worden bekeken wat de werkelijke drijfveren waren van het bestuur om de beslissing te nemen. ${ }^{1443}$ Handelt de overheid in strijd met de ratio van de wet en gebruikt zij haar bevoegdheid voor andere doeleinden dan het nastreven van het algemeen belang, zoals dat in de rechtsregel naar voren komt, dan maakt deze zich schuldig aan détournement de pouvoir. Daarvan kan ook sprake zijn in die situaties waar de bestuurlijke beslissing een externe toets doorstaat en er dus geen sprake is van een wetsovertreding of een schending van formele vereisten. Het spreekt voor zich dat de grens tussen het onderzoek naar de interne wettigheid en vooral de controle op machtsafwending enerzijds en een onderzoek naar de opportuniteit van de bestuurlijke handeling anderzijds vrij vaag kan zijn. De

1438. Ryckbost, D., l.c., 1993, 54.

1439. Mast, A. en Dujardin, J., o.c., 1993, 703; Alen, A., 'De raadsels van artikel 107 van de Belgische Grondwet', $R W, 1984,1734$.

1440. Ryckbost, D., l.c., 1993, 54.

1441. Idem.

1442. Faure, M.G., 'De gevolgen van de "administratieve afhankelijkheid" van het milieustrafrecht: een inventarisatie van knelpunten', in Faure, M.G., Oudijk, J.C. en Schaffmeister, D. (red.), o.c., $1991,112$.

1443. Ryckbost, D., l.c., 1993, 54. 
rechterlijke controle mag in geen enkel geval afglijden tot een opportuniteitscontrole. ${ }^{1444}$ Dat zou immers een ontoelaatbare uitbreiding van de rechterlijke macht tot gevolg hebben met als gevaarlijke consequentie een totale verlamming van het bestuurlijk apparaat. Kort gezegd, de rechterlijke toetsing van artikel 159 BGW laat nimmer toe dat de rechter op de stoel van het bestuur gaat zitten. De rechter dient dus met de grootste voorzichtigheid te werk te gaan.

Een interessant voorbeeld van hoe de strafrechter met de discretionaire bevoegdheid van het bestuur in milieustrafzaken omgaat, biedt een vonnis van de correctionele rechtbank te Gent van 1991. In deze zaak werd een aantal bedrijfsvoerders van een wolspinnerij vervolgd voor het overtreden van in een lozingsvergunning neergeschreven voorwaarden. De beklaagden betwisten, wegens de schending van het redelijkheidsbeginsel, de wettigheid van de vergunning voor het lozen van ongezuiverd afvalwater omdat deze strengere normen oplegde dan de aanvankelijke vergunning, zonder in een wettelijke overgangsperiode en subsidieregeling te voorzien. De beklaagden vragen de strafrechter de interne wettigheid van de nieuwe lozingsvergunning te toetsen aan het redelijkheidsbeginsel. Na eerst te hebben vastgesteld dat noch de overgangsregeling, noch de subsidieregeling van toepassing waren, verricht de strafrechter vervolgens een toetsing naar de kennelijke onredelijkheid van de strengere lozingsvoorwaarden:

'Inzoverre de wetgever aan de administratieve overheid een discretionaire macht heeft toegewezen gebeurt het onderzoek naar de redelijkheidsgrens van de principiële beoordelingsvrijheid van deze overheid bij wijze van marginale toetsing. Hierbij is het de rechter alleen toegelaten op te treden wanneer over de klaarblijkelijke onjuistheid van het overheidsoptreden geen twijfel bestaat. Gezocht moet worden naar de gedachtegang die kon leiden tot de betwiste beslissing..$^{1445}$

De strafrechter gaat vervolgens over tot het onderzoek van de feitelijke beweegredenen van de overheid tot het verlenen van de vergunning en komt tot de slotsom dat

'de gedachtegang van de administratieve overheid bij het bepalen van deze algemene normen (...) niet kennelijk onredelijk (was) ${ }^{1.446}$

Evenmin konden de lozingsvoorwaarden als exorbitant worden bestempeld. De lozingsvergunning kon dus een toetsing weerstaan en leidde derhalve tot een strafrechtelijke veroordeling.

1444. Delva, J., 'Het rechtstreeks bestrijden van overheidsdaden voor de burgerlijke rechtscolleges', $T P R, 1967,453$.

1445. Corr. Gent, 5 december 1991, TMR 1992, 102.

1446. Idem. 


\section{b. Toetsing van de beleidsvrijheid aan redelijkheid en behoorlijkheid}

Het feit dat de beleidsvrijheid de rechterlijke toetsing beperkt, betekent niet dat de rechter de uitoefening van deze beleidsvrijheid niet zou mogen controleren; hij mag toetsen zolang hij maar niet in de plaats treedt van het bestuur. In situaties waarin de overheid gebruik maakt van een discretionaire bevoegdheid onderzoekt de rechter de rechtshandeling op haar redelijkheid en behoorlijkheid. De overheid moet voldoende zorgvuldigheid aan de dag leggen bij de voorbereiding, het nemen en de uitvoering van haar beslissingen en in geen geval het rechtmatige vertrouwen van de burger beschamen. De bestuurlijke handelingen die zijn gesteld binnen het kader van een discretionaire bevoegdheid mogen niet arbitrair zijn. De rechterlijke controle is juist gecreëerd om machtswillekeur te vermijden. ${ }^{1447}$ In concreto zal marginaal moeten worden getoetst in hoeverre de beslissing in met een algemeen gedeelde rechtsovertuiging overeenstemmende redelijkheid en billijkheid is genomen. ${ }^{1448}$

Zo oordeelde het Hof van Beroep te Gent in een strafzaak waar de beklaagde de onwettigheid van de geschonden lozingsvoorwaarden wegens schending van de motiveringsplicht aanvoerde als volgt:

'Het behoort dus niet aan het Hof om de opportuniteit van de opgelegde voorwaarden in casu te beoordelen. Het Hof heeft wel een marginaal toetsingsrecht waarbij "het onredelijk of onbillijk gedrag van het betrokken orgaan door de rechter gesanctioneerd wordt wanneer de onredelijkheid of onbillijkheid zo evident is dat het oordeel van de rechter met een algemeen gedeelde rechtsovertuiging overeenstemt (...) De marginale toetsing is dus een vorm van beperkte rechterlijke toetsing, welke de rechter slechts toelaat op te treden, wanneer over de onjuistheid van het overheidsoptreden geen twijfel bestaat" (...) Nu de lozingsvergunning (...) motiveert waarom een bepaalde bovengrens niet mag overschreden worden (...), kan er over de juistheid van het overheidsoptreden geen twijfel bestaan, zodat de lozingsvergunning als wettelijk voorkomt en derhalve het niet naleven ervan door het Hof dient gesanctioneerd te worden $^{1449}$

De toetsing van de beleidsvrijheid aan de voorwaarden van redelijkheid en billijkheid is zowel extern als intern van aard. ${ }^{1450}$ De externe behoorlijkheidscontrole betreft een toetsing van de bestuurshandeling aan de wijze waarop bepaalde belangen worden beschermd. Het is een toetsing van de gevolgde procedure. Van belang zijn in dit verband de algemene beginselen van behoorlijk bestuur, zoals het vertrouwensbeginsel, gelijkheidsbeginsel, hoorplicht, onpartijdigheid, het rechtszekerheidsbeginsel of, zoals in bovenstaand arrest, de 
motiveringsplicht. De interne behoorlijkheidstoets van een bestuurshandeling betreft de vraag of deze inhoudelijk wel aanvaardbaar is gelet op de erdoor gediende of geschade belangen. Het gaat dan om een onderzoek naar de aanvaardbaarheid van het door de overheid gevoerde beleid en de daarmee samenhangende vraag of de aan de overheid toevertrouwde belangen wel zorgvuldig genoeg worden gewaardeerd. ${ }^{1451}$ De rechter kan slechts marginaal deze zorgvuldigheidscontrole uitvoeren en desgevallend besluiten tot de vaststelling van willekeur in hoofde van de overheid. Het spreekt voor zich dat de rechter de belangenafweging niet mag overdoen. In een uitspraak van de correctionele rechtbank van Antwerpen werd duidelijk dit principe beklemtoond. In casu hadden beklaagden een perceel met chalet gekocht zonder dat voor dit bouwwerk ooit een bouwvergunning was afgegeven. De beklaagden waren duidelijk op de hoogte van het feit dat zij een illegale constructie hadden gekocht. Niettemin verzuimden zij aan het bestaan van de wederrechtelijk uitgevoerde werken een einde te maken. Aan de beklaagden werd vervolgens door de gemeente Antwerpen een herstelvordering opgelegd, hetgeen betekende dat zij de chalet moesten slopen. In de tegen hen gevoerde strafzaak werd de wettigheid van de herstelvordering betwist omdat deze in strijd zou zijn met het gelijkheidsbeginsel. Er werd als verweer aangevoerd dat in vergelijkbare situaties een herstelvordering veel soepeler is opgesteld en veelal wordt geopteerd voor aanpassing van het bouwwerk in plaats van sloping. De rechtbank herhaalt eerst de algemene beginselen van rechterlijke toetsing:

'Het behoort tot de bevoegdheid van de rechterlijke macht de vordering van de gemachtigde ambtenaar op haar externe en interne wettigheid te toetsen en te onderzoeken of ze strookt met de wet dan wel op machtsoverschrijding of machtsafwending berust, terwijl het niet aan de rechter staat de opportuniteit van die vorderingen te beoordelen; Naar de concrete invulling van deze "legaliteits" - controle dient bij de uitoefening van deze controle de Rechter ook - in gevallen waar de overheid gebruik maakte van haar beleidsvrijheid - de overheidshandelingen te onderzoeken op hun redelijkheid en behoorlijkheid, zonder hierbij in de plaats te treden van dit bestuur: Deze marginale toetsing zal zowel slaan op de externe als interne behoorlijkheid van de overheidsdaad. ${ }^{1452}$

Vervolgens toetst de rechtbank in concreto de wettigheid en de behoorlijkheid van de vordering en oordeelt dat

'minstens (dient) vastgesteld dat voor het gemaakte onderscheid naar wijze van herstelvordering (aanpassingswerken versus sloping) in dezelfde situatie (...) geen objectieve rechtvaardiging bestaat; minstens is de motivering van de herstelvordering gebrekkig (...) Inzake dient dan ook vastgesteld dat de hier genomen herstelvordering willekeurig is en

1451. Idem.

1452. Corr. Antwerpen, 15 mei 1996, Nr. 2398 (OM t. Kampers en Halans), ongepubliceerd. 
aldus strijdig met de algemene beginselen van behoorlijk bestuur; Aldus

(...) verklaart de rechtbank deze herstelvordering niet toepasselijk. ${ }^{1453}$

Wat de toetsingsinhoud betreft kan worden gesteld dat in België niet alleen een controle aan de externe wettigheid, maar ook aan de interne wettigheid wordt aanvaard. Ook wordt het gebruik van de discretionaire bevoegdheid marginaal aan de beginselen van behoorlijk bestuur getoetst.

\section{Samenvatting}

In een administratief afhankelijk milieustrafrecht ligt de macht om de inhoud van materiële normen te bepalen in de eerste plaats bij het bestuur. Deze macht is natuurlijk niet onbeperkt. Het bestuur is gebonden aan wet en recht. Op het vlak van strafrechtelijke toetsing betekent dit dat de strafrechter in voorkomend geval aan een aantal normen de voor hem liggende bestuurshandeling, waaronder vergunning(svoorschriften) kan toetsen. Zowel in Nederland als in België kan de strafrechter in de eerste plaats toetsen aan de verschillende milieuwetten en de daarin opgenomen voorwaarden die het bestuur moet betrekken bij het vaststellen van de materiële normen. Daarnaast zijn er grondwettelijke, internationale en Europeesrechtelijke toetsingsgronden. Ook de a.b.b.b.'s kunnen als toetsingsgronden een rol van betekenis spelen. Wel moet worden benadrukt dat, vermits het dan steeds dient te gaan om een rechtmatigheidstoets van vrij overheidshandelen, de strafrechter zich dient te onthouden van een opportuniteitstoetsing. Tot slot kunnen milieubeleidsregels en richtlijnen in aanmerking komen als strafrechtelijke toetsingsgronden.

\section{DE INHOUD VAN DE MILIEUSTRAFRECHTELIJKE WEDERRECHTELIJKHEID}

\section{Van Verwaltungsaktsakzessorietät naar Verwaltungsrechtsakzessorietät}

Thans moet worden bekeken onder welke voorwaarden een vergunningverlening niet langer strafuitsluitend kan werken, of, vanuit het perspectief van de vergunningverlener, wanneer een onrechtmatige vergunningverlening strafrechtelijk gezien wederrechtelijk is. Vooral in het Duitse milieustrafrecht is veel andacht besteed aan deze vragen. Dit is begrijpelijk daar vanwege de strikte Verwaltungsaktsakzessorietät de Duitse strafrechter het meest is beperkt in zijn toetsingsbevoegdheid. Vanwege dit nadeel heeft de literatuur zich, meer dan in Nederland of België, gebogen over de vraag of er geen bruikbare alternatieven zijn voor deze Verwaltungsaktsakzessorietät. Bemerk dat deze kwestie in Duitsland voornamelijk van belang is voor de gemene milieudelicten, die rechtstreeks het leefmilieu beschermen en waar de vergunning geen delictsbestanddeel, maar een rechtvaardigingsgrond uitmaakt. Vergunningen die bestanddeel zijn van de delictsomschrijving, zoals bij de kwaliteitsmilieudelicten, kunnen immers noch volgens de heersende leer, noch volgens de Mindermeinung worden getoetst, omdat het legaliteitsbeginsel zich hier tegen zou verzetten. Dit lijkt anders te zijn in Nederland waar de strafrechter blijkbaar wel bevrijdende vergunningen, die bestanddeel uitmaken van de delictsomschrijving en waarvan de 
onrechtmatigheid door het $\mathrm{OM}$ wordt opgeworpen, kan toetsen op wet- en rechtmatigheid. Daaruit volgt dat de nu volgende opmerkingen over de strafuitsluitende werking van de vergunning, voor Nederland ook interessant zijn bij die milieudelicten waar de vergunning kwalificatieuitsluitend werkt.

Enkele Duitse schrijvers bepleiten dat de strafrechtelijke rechtmatigheid van (potentieel) milieuverstorende gedragingen niet alleen van de bestuursrechtelijke rechtsgeldigheid van beschikkingen dient af te hangen, maar van de materiële rechtmatigheid van deze beschikkingen. Rengier spreekt hier van een 'Durchgriff auf das materielle Recht'. ${ }^{1454}$ De achterliggende idee is dat ook het bestuur aan wet en recht gebonden is en het onverzoenbaar is met de functies en beginselen van het strafrecht wanneer beschikkingen die evident in strijd zijn met wet of recht een strafbaar gestelde gedraging zouden kunnen rechtvaardigen of dat omgekeerd een overtreding van een onrechtmatig administratief voorschrift een strafbaar feit zou opleveren. Deze opvatting bepleit dus een Verwaltungsrechtsakzessorische visie op het milieustrafrecht en op de toetsingsbevoegdheid van de strafrechter in het bijzonder. Er kan opnieuw worden verwezen naar het reeds besproken beginsel van de eenheid van rechtsorde. Het doel van de eenheid van rechtsorde dient te zijn om op het niveau van de materiële rechtmatigheid tegenstellingen tussen het bestuursrecht en het strafrecht te voorkomen. Dus kan in beginsel geen bestraffing plaatsvinden indien de handeling ook milieurechtelijk niet verboden is. Het is dan logisch de mogelijkheid om strafrechtelijk in te grijpen af te laten hangen van de milieurechtelijke onrechtmatigheid die het bestuursrechtelijk ingrijpen mogelijk maakt. Praktisch gezien betekent dit dat bestuursrechtelijk onrechtmatige beschikkingen geen strafrechtelijke rechtvaardigingsgrond kunnen inhouden. Dit laat vanzelfsprekend onverlet dat de adressaat die te goeder trouw op de rechtmatigheid van de beschikking mocht vertrouwen niet strafbaar is als hij beroep kan doen op onoverkomelijke rechtsdwaling. Nemen we een Verwaltungsrechtsakzessorische koppeling van de strafrechtelijke onrechtmatigheid aan de bestuursrechtelijke onrechtmatigheid als uitgangspunt, dan zijn verschillende alternatieven mogelijk al naargelang men de aandacht richt op de formele of materiële milieurechtelijke regels.

\section{Eerste alternatief: koppeling aan de materiële rechtmatigheid of ook aan de formele rechtmatigheid?}

Eens men aanvaardt dat voor de beoordeling van de wederrechtelijkheid van een milieuverstorende gedraging de vergunning en de daarin opgenomen voorschriften niet blindelings moeten worden aanvaard, rijst de vraag of iedere bestuursrechtelijk onrechtmatige vergunning tot gevolg heeft dat de vergunning niet langer als een strafrechtelijke rechtvaardigingsgrond kan worden beschouwd. Met andere woorden, leidt ieder gebrek aan de vergunning tot het verlies van de strafuitsluitende werking van de vergunning, of moet het gebrek substantieel zijn? De meningen zijn hierover in de Duitse literatuur verdeeld. Volgens Mezger ${ }^{1455}$ en Goldmann ${ }^{1456}$ kan een vergunning slechts 
rechtvaardigend werken en is de strafrechter dus slechts aan de vergunning gebonden indien zowel aan de materiële als aan de formele bestuursrechtelijke voorschriften is voldaan. De adressaat handelt dus zonder rechtmatige vergunning en pleegt in die zin een strafbaar feit telkens wanneer zijn vergunning door een materieel of formeel gebrek is aangetast.

Andere schrijvers gaan niet zo ver en beschouwen uitsluitend de materiële rechtmatigheid van beschikkingen als strafrechtelijk relevant. ${ }^{1457}$ Volgens hen dwingen formele onrechtmatigheden niet tot de conclusie dat een vergunning niet langer strafrechtelijk rechtvaardigend kan werken. Als belangrijkste argument voor de enkele koppeling van het strafrecht aan het materiële bestuursrecht wordt de rechtsgoedbeschermende functie van het strafrecht aangehaald. Daaruit kan worden afgeleid dat de rechtvaardigende werking van de vergunning primair afhangt van de vraag of er materieelrechtelijke milieunormen zijn geschonden. Uitsluitend deze normen verwijzen immers rechtstreeks naar de ecologische rechtsgoederen. Wanneer de onrechtmatigheid van een vergunning alleen bestaat in een schending door het bestuur van een formeel administratief voorschrift leidt dit niet tot de vaststelling dat het gepleegde feit strafrechtelijk wederrechtelijk is aangezien dergelijke schendingen niet de ecologische rechtsgoederen aantasten. Doorslaggevend is dus de materiële onrechtmatigheid van de vergunning en niet ook nog de formele onrechtmatigheid. Formele gebreken hebben strafrechtelijk geen belang nu deze voortvloeien uit de schending van normen die niet de ecologische rechtsgoederen maar de administratiefrechtelijke plichten tot bescherming hebben. Het strafrecht kan niet alleen maar de functie hebben louter 'Verwaltungsungehorsam' te beschermen. ${ }^{1458}$ Illustratief is het 'Anhörungsrecht'(neergelegd in $\S 66 \mathrm{Abs} .1 \mathrm{VwVfG}$ ). Deze bepaling is een belangrijk formeel voorschrift waarvan de schending leidt tot onrechtmatigheid van de vergunning. Deze formele onrechtmatigheid hoeft echter geen strafrechtelijke wederrechtelijkheid tot gevolg te hebben nu § 66 Abs. 1 VwVfG niet het belang van het leefmilieu dient, maar het belang van de betrokkenen, in het bijzonder de vergunningaanvrager:

Der Verstoß gegen Anhörungsrechte macht die Genehmigung zwar rechtswidrig, jedoch könnte dieser Fehler aus strafrechtlicher Sicht zu vernachlässigen sein, weil insoweit das geschützte Rechtsgut nicht tangiert ist.' ${ }^{1459}$

Deze visie impliceert dat vergunningen steeds rechtvaardigend werken wanneer zij 'die jeweiligen Umweltrechtsgüter so schützen, wie es das entsprechende Umweltverwaltungsgesetz will. ${ }^{1460}$ In de praktijk betekent dit dat minstens in die gevallen waarin het bestuursrecht ondanks de aanwezigheid en het volgen van een rechtsgeldige vergunning

1456. Goldmann, H.-G., Die behördliche Genehmigung als Rechtfertigungsgrund, Freiburg, 1967, 153. 1457. Zie Lagodny, K., L.c.,1989, 936.

1458. Hübenett, C., o.c., 1986, 86: 'Es ist (...) nicht Aufgabe des $\$ 324$ StGB, eine ordnungsgemäße Verwaltung sicherzustellen. Er soll vielmehr die Reinhaltung der Gewässer gewährleisten.'

1459. Schmitz, K., o.c., 1992, 51.

1460. Kühl, K., l.c., 1990, 853. 
een ingrijpen mogelijk maakt (intrekking, bestuursdwang...) ook strafbaarheid mogelijk is. De reden is dat in die situaties het bestuursrecht ook geen rechtvaardigende werking aan de vergunning toekent. ${ }^{1461}$

\section{Tweede alternatief: koppeling aan zowel materiële als formele voorschriften die het leefmilieu beschermen}

Sommige schrijvers nemen een tussenpositie in en menen dat in bepaalde gevallen niet alleen materiële gebreken maar ook bepaalde formele onrechtmatigheden een aantasting van ecologische rechtsgoederen tot gevolg kunnen hebben, hetgeen betekent dat vergunningen niet alleen materieel rechtmatig maar tot op zekere hoogte tevens formeel rechtmatig moeten zijn om in het strafrecht rechtvaardigend te kunnen werken. De achterliggende idee is dat het bestuur de plicht heeft bij de vergunningverlening alle met elkaar strijdige belangen behoorlijk af te wegen en dit met het oog op de bescherming van het leefmilieu. Formele voorschriften zien er op toe dat deze belangenafweging op de juiste wijze plaatsvindt. Overtreedt het bestuur deze formele normen, dan is daarmee dus ook onrechtstreeks het leefmilieu geschonden en kan onmogelijk de vergunning nog worden aangemerkt als een strafrechtelijke rechtvaardigingsgrond. Duidelijke voorbeelden van formele voorschriften waarvan de schending wel degelijk het leefmilieu kan aantasten zijn bevoegdheidsregels. Wordt een vergunning door een niet-bevoegd orgaan gegeven dan kan moeilijk worden ontkend dat het leefmilieu daarvan geen schade zou ondervinden. Bovendien leidt een onbevoegd verleende vergunning reeds tot nietigheid van de beschikking zodat ook volgens de heersende leer de strafrechter niet gebonden is aan een dergelijke beschikking. Een ander 'Rechtsgutbezogen' formeel voorschrift is de zogeheten Untersuchungsgrundsatz ( $\S 24 \mathrm{VwVfG}$ ). Wanneer deze onderzoeksplicht wordt geschonden is het best denkbaar dat hiermee tevens het leefmilieu is geschaad. In de visie van de heersende leer laat de schending van § $24 \mathrm{VwVfG}$ de rechtmatigheid van de verontreinigende handeling onaangetast. In de opvatting dat uitsluitend materiële gebreken de vergunningverlening wederrechtelijk maken, blijft de verontreinigende handeling eveneens niet-strafbaar. Echter, in de visie dat strafrechtelijk rechtmatig slechts die handeling kan zijn die ook bestuursrechtelijk materieel én formeel rechtmatig is, kan de strafrechter dergelijk gebrekkige vergunning naast zich neer leggen en derhalve tot de vaststelling komen dat het feit wederrechtelijk is, want gepleegd zonder rechtmatige vergunning. Van het uitgangspunt dat formele onrechtmatigheden de wederrechtelijkheid niet kunnen opheffen, kan dan enkel worden afgeweken indien blijkt dat het geschonden formele voorschrift niet mede de bescherming van het leefmilieu dient. ${ }^{1462}$

Zowel de opvatting waarin uitsluitend de schending van materiële normen als de zienswijze waarin ook de overtreding van bepaalde aan het leefmilieu gerelateerde formele normen een wederrechtelijk, dus strafbaar feit kunnen opleveren, worden gekenmerkt door een

1461. Heine, G., 'Verwaltungsakzessorietăt des Umweltstrafrechts. Rechtsvergleichende Funktionsanalysen - unbestimmte Rechtsbegriffe, Reichweite von Genehmigungen', NJW, 1990, 24252434.

1462. Schmitz, R., o.c., 1992, 51. 
meerduidig onrechtmatigheidsbegrip. Aan beide alternatieve opvattingen over strafrechtelijke toetsing ligt een moderne benadering van de eenheid van rechtsorde ten grondslag. Als uitgangspunt geldt dat een bestuursrechtelijk rechtmatige handeling niet tegelijk strafrechtelijk wederrechtelijk kan zijn, maar omgekeerd hoeft niet iedere onrechtmatigheid te worden vertaald in een strafbaar feit. Dat hangt af van het karakter van de onrechtmatigheid die aan de vergunning kleeft. Dit geeft weliswaar aanleiding tot tegenspraken tussen bestuursrecht en strafrecht, maar enkel in de zin dat een bepaalde gedraging best bestuursrechtelijk onrechtmatig kan zijn zonder dat deze ook meteen strafrechtelijk wederrechtelijk hoeft te zijn. Dergelijke tegenspraak wordt niet als ongeoorloofd beschouwd daar binnen deze Verwaltungsrechtsakzessorische benadering het strafrecht als ultimum remedium een strenger rechtmatigheidsbegrip hanteert.

Voor alle duidelijkheid moet worden beklemtoond dat deze alternatieve visies aangaande toetsing en de inhoud van de milieustrafrechtelijke wederrechtelijkheid naar Duits recht één probleem niet kunnen oplossen. De bepleite mogelijkheid om de strafrechter vergunningen op hun materiële en/of formele rechtmatigheid te laten toetsen teneinde de strafbaarheid van vergunninghouder en/of vergunningverlener niet zozeer af te laten hangen van de rechtsgeldigheid als wel van de rechtmatigheid van de vergunning, is enkel mogelijk bij rechtvaardigende vergunningen. Met andere woorden, een meer ruime toetsingsbevoegdheid en zelfstandige invulling van de wederrechtelijkheid is naar Duits recht slechts mogelijk bij de gemene milieudelicten. Vergunningen die daarentegen als bestanddeel deel uitmaken van de delictsomschrijving kunnen door de Duitse strafrechter immers niet worden getoetst. Dit zou een schending van het legaliteitsbeginsel betekenen. Art. 103 II GG heeft tot gevolg dat de strafrechter gebonden blijft aan de rechtsgeldigheid van bestanddeeluitsluitende vergunningen ook al zijn ze materieel en/of formeel onrechtmatig verleend. De enige toegelaten uitzonderingen zijn door de wetgever in $\S 330 \mathrm{~d} \mathrm{Nr}$. $5 \mathrm{StGB}$ limitatief opgesomd. Bestanddeeluitsluitende vergunningen die op de daarin omschreven wijze tot stand zijn gekomen hebben geen rechtsgeldigheid meer in het strafrecht. Er mag echter niet uit het oog worden verloren dat deze bepaling enkel geldt voor bevrijdende vergunningen. Dus zelfs in de visie waarbij de toetsingsbevoegdheid Verwaltungsrechtsakzessorisch zou moeten worden ingevuld, blijft de overtreding van onrechtmatige belastende vergunningsvoorwaarden, die deel uitmaken van de delictsomschrijving strafbaar. Zoals gezien, is dat, vanwege de formele rechtskracht, ook in Nederland het geval.

\section{Derde alternatief: een autonoom strafrechtelijk wederrechtelijkheidsbegrip}

Enkele schrijvers bepleiten op radicale wijze het los laten van de administratieve afhankelijkheid in het milieustrafrecht en pleiten in die zin dus ook voor een volledig autonome strafrechtelijk toetsing van vergunningen. ${ }^{1463}$ Deze visie staat lijnrecht tegenover de Verwaltungsaktsakzessorische visie, maar gaat ook verder dan de Verwaltungsrechtsakzessorische benadering aangezien ook de koppeling met het bestuursrechtelijke (materiële) rechtmatigheidsbegrip wordt verlaten. De belangrijkste voorstander van een autonome toetsing is Schünemann. Hij ontkent - in navolging van een belangrijk deel van

1463. Schünemann, B., l.c., 1986, 239 en in meer genuanceerde zin Hübenett, C., o.c., 137. 
de literatuur - het primaat van de rechtsgeldigheid (Wirksamheit) van beschikkingen in het strafrecht. Dat de rechtsgeldigheid een centraal gegeven uitmaakt in het bestuursrecht is begrijpelijk daar dit onlosmakelijk samenhangt met beginselen zoals rechtszekerheid en het vertrouwensbeginsel, die in het bestuursrecht nu eenmaal uitsluitend via de rechtsfiguur van rechtsgeldigheid kunnen worden gewaarborgd. In het strafrecht gaat het echter om totaal andere zaken:

'Denn wie das Institut der Rücknahme eines fehlerhaften Verwaltungsaktes ex tunc gemäß $\S 48 \mathrm{VwVfG}$ zeigt, geht es bei den Vorschriften des Verwaltungsrechts nicht - wie im Strafrecht - um die Formulierung von Verhaltensnormen, sondern um vereinfachende Gesamtregelungen von Vertrauenstatbestanden, Entschädigungsfragen und prozessualen Rechtslagen. ${ }^{1464}$

Tegen deze achtergrond is de gebondenheid van de strafrechter aan de rechtsgeldigheid van beschikkingen inderdaad moeilijk te verdedigen. Schünemann verwijt de heersende leer ook op de beperkte toetsingsmogelijkheden van de strafrechter uitzonderingen toe te laten via 'zweifelhafter Konstruktionen' als het leerstuk van rechtsmisbruik. Derhalve kan volgens hem aan de strafrechtelijke toetsingsbevoegdheid en aan de inhoud van de toetsing maar op één manier voldoende recht worden gedaan: iedere vorm van administratieve afhankelijkheid, dus ook een koppeling aan het materiële milieurecht, moet worden afgewezen en worden beschouwd als strijdig met de autonomie van het strafrecht:

'es muß vielmehr anhand genuin strafrecht-licher Kriterien entscheiden werden, ob und in welchem Umfang bei der Rechtswidrigkeit an die Grundsätze des Verwaltungsrechts zur Wirksamheit fehlerhafter Verwaltungsakte anzuknüpfen ist, und zwar sowohl für die Strafbarkeit des Gewässerbenutzers als auch für diejenige des Amtsträgers. ${ }^{1465}$

Met andere woorden, de strafrechter moet autonoom de strafbaarheid (wederrechtelijkheid) van de vergunningverlening kunnen beoordelen. Dit betekent volgens hem niet dat de strafrechter bij de toetsing van de vergunning de beoordelingsvrijheid waarover de overheid beschikt volledig naast zich neer mag leggen. De strafrechter moet deze vrijheid respecteren, maar hij voegt daar orakelend aan toe:

'doch bleibt der Grad der Berücksichtigung dann immer eine Frage autonomer strafrechtsdogmatischer Entscheidung, die von den maßgeblichen strafrechtlichen Wertungen gesteuert wird. ${ }^{1466}$

Het nadeel van Schünemann's opvatting is dat niet duidelijk is wat zou moeten worden verstaan onder 'genuin strafrechtlicher Kriterien' of 'autonomer strafrechtsdogmatischer 
Entscheidung'. In de praktijk lijkt trouwens ook in zijn visie een koppeling met het bestuursrecht noodzakelijk te zijn. ${ }^{1467}$ Zo merkt hij op dat de strafrechter niet gebonden is aan vergunningen wanneer zij zijn aangetast door gebreken die vergelijkbaar zijn met de in $\S 44 \mathrm{VwVfG}$ aangeduide nietigheidsgronden. Dit is een duidelijke bestuurs(proces)rechtelijke invulling van de strafrechtelijke toetsingsbevoegdheid die ook door de heersende leer wordt aanvaardt. Ook volgens de heersende leer is de strafrechter niet gebonden aan nietige vergunningen. Schünemann aanvaardt daarnaast ook strafrechtelijke onrechtmatigheden die onder 'der Nichtigkeitsschwelle des $\S 44 \mathrm{VwVfG}$ liegen'. ${ }^{1468}$ Maar ook dan verwijst hij opnieuw naar het bestuursrecht, want hij acht de strafrechter niet gebonden aan vergunningen die 'gemäß $\S 48 \mathrm{VwVfG}$ die Rücknahme ex tunc ermöglichen', bijvoorbeeld vergunningen die via omkoping zijn verleend geworden ${ }^{1469}$ Het theoretische voordeel van zijn 'autonome' opvatting is wellicht dat geen beroep moet worden gedaan op het leerstuk van rechtsmisbruik om toetsing mogelijk te maken. Het is in die zin strafrechtsdogmatisch zuiverder om bij onrechtmatigheden vanaf het begin het zuiver bestuursrechtelijke begrip van rechtsgeldigheid los te laten en

'in strafrechtlicher Hinsicht von einer originär unbefugten Gewässerverunreinigung auszugehen, so daß die rechtsfolgen die gleichen sind wie bei der nichtigen Genehmigung. ${ }^{1470}$

Daar is inderdaad iets voor te zeggen, maar niet valt in te zien waarom daarvoor een autonoom strafrechtelijk wederrechtelijkheidsbegrip nodig zou zijn: met een koppeling aan het materiële bestuursrecht kan immers eenzelfde resultaat worden bereikt.

\section{CONCLUSIES}

In deze paragraaf worden twee vragen behandeld die rechtstreeks samenhangen met de mate van toetsingsbevoegdheid waarover de strafrechter beschikt. Allereerst is er de vraag aan welke normen de strafrechter vergunningen kan toetsen: dit is de vraag naar de eigenlijke toetsingsinhoud. Er werd vastgesteld dat tussen de onderzochte landen waar strafrechtelijke toetsing mogelijk is, namelijk Nederland en België, geen aanmerkelijke verschillen bestaan. In beide landen kan de strafrechter vergunningen toetsen op wet- en rechtmatigheid, hetgeen betekent dat zowel kan worden getoetst aan geschreven rechtsregels, waaronder toetsing aan formele wetten, de Grondwet en internationale en Europeesrechtelijke bepalingen, alsook aan ongeschreven rechtsregels, waaronder de algemene beginselen van behoorlijk bestuur. Het voornaamste verschil tussen Nederland en België ligt dus niet zozeer op het vlak van de toetsingsinhoud als wel op het vlak van de toetsingsbevoegdheid zelf. België kent een in de Grondwet verankerde toetsingsplicht voor de strafrechter. In Nederland beschikt de strafrechter over een meer beperkte toetsingsbe-

1467. Zie voor een gegronde kritiek op Schünemann's opvatting: Scheele, R., o.c., 1986, 41-49.

1468. Schünemann, B., l.c., 1986, 240.

1469. Idem.

1470. Idem. 
voegdheid daar hij in bepaalde gevallen, namelijk bij belastende beschikkingen, gebonden is aan de formele rechtskracht.

De tweede vraag, die in deze paragraaf centraal staat, is wanneer een toetsing door de strafrechter van de vergunning op wet- en rechtmatigheid leidt tot het oordeel dat de tenlastegelegde gedraging als strafrechtelijk wederrechtelijk moet worden aangemerkt. Simpeler gezegd, wanneer handelt de vergunninghouder strafrechtelijk gezien zonder vergunning of in strijd met de vergunningsvoorschriften? Of in termen van een mogelijke strafbaarheid van de vergunningverlener: wanneer kan een onzorgvuldige vergunningverlening worden aangemerkt als strafrechtelijk wederrechtelijk? Deze kwestie wordt vooral in de Duitse literatuur besproken. Dit laat zich hoofdzakelijk verklaren doordat in Duitsland, anders dan in Nederland of in België, de strafrechter nauwelijks bevoegd is vergunningen te toetsen op wet- en rechtmatigheid: de Duitse strafrechter is, behoudens wettelijke uitzonderingen, gebonden aan de Wirksamheit of de rechtsgeldigheid van de vergunning, hetgeen betekent dat ook onrechtmatige vergunningen strafuitsluitend kunnen zijn, ook wanneer het $\mathrm{OM}$ het handelen zonder (rechtmatige) vergunning tenlastelegt. Vanwege de talrijke theoretische en praktische nadelen van de gebondenheid van de strafrechter aan de bestuursrechtelijke rechtsgeldigheid van vergunningen, pleit een belangrijk deel van de literatuur daarom voor een doorbreking van de Verwaltungsaktsakzessorietät van het milieustrafrecht en geeft deze een aantal voorstellen die aan de inhoud van de strafrechtelijke toetsing en derhalve ook aan de inhoud van de wederrechtelijkheid van milieuverstoring een meer Verwaltungsrechtsakzessorische invulling kunnen geven.

Nadere beschouwing van een en ander brengt ons tot de conclusie dat ter beoordeling van de wederrechtelijkheid van in het milieurecht strafbaar gestelde gedragingen grosso modo drie alternatieven mogelijk zijn:

1. De strafbaar gestelde gedraging is wederrechtelijk indien zonder vergunning of in strijd met vergunningsvoorschriften is gehandeld. Voor de vaststelling van de wederrechtelijkheid is de onrechtmatigheid van de vergunning of het voorschrift van geen belang. Het betreft hier een strikte beschikkingsafhankelijke benadering, die typisch is voor het Duitse milieustrafrecht. De inhoud van de wederrechtelijkheid van de verboden gedraging is Verwaltungsaktsakzessorisch ingevuld. In iets mindere mate wordt ook de toetsingsbevoegdheid van de Nederlandse strafrechter ingeperkt door een Verwaltungsaktsakzessorietät, daar de strafrechter bij belastende beschikkingen gebonden is aan de formele rechtskracht. Het is echter beter hier te spreken van een Verwaltungsverfahrensakzessorische of een bestuursprocesrechtelijke inperking van de strafrechtelijke toetsing, daar de toetsingsbevoegdheid afhankelijk is van het al dan niet onbenut laten van een met voldoende waarborgen omklede administratieve rechtsgang en niet, zoals in Duitsland, van de rechtsgeldigheid van de vergunning op zichzelf. Daarnaast kan worden herhaald dat een dergelijke beschikkingsafhankelijke invulling van de wederrechtelijkheid in Nederland ook nog een mogelijk nadelige rol speelt bij de concrete gevaarzettingsdelicten van 173a en 173b Sr. Zoals reeds is besproken, wordt het wederrechtelijkheidsconcept van deze delicten niet in de ruime 
Verwaltungsrechtsakzessorische zin opgevat van 'strijdig met het objectieve (milieu)recht', maar in de meer beperkte Verwaltungsaktsakzessorische zin van in strijd met de vergunningsvoorwaarden. Het gevolg van een dergelijke bestuursafhankelijke interpretatie is dat in Nederland emissies waarvan concreet gevaar voor de gezondheid of zelfs levensgevaar te duchten is, niet strafbaar zijn ingevolge artikel 173 a en $173 \mathrm{~b}$ zolang zij vergunningconform plaatsvonden. ${ }^{1471}$

2. De strafbaar gestelde gedraging is wederrechtelijk indien in strijd met het objectieve milieurecht is gehandeld. Voor de vaststelling van de wederrechtelijkheid van de tenlastegelegde gedraging wordt niet slechts gekeken naar de bestuursrechtelijke rechtsgeldigheid of, zoals in Nederland (naar de formele rechtskracht van) de vergunning, maar is tevens van belang of de vergunning en de vergunningsvoorschriften zelf in overeenstemming zijn met het milieurecht. In tegenstelling tot de Verwaltungsaktsakzessorische benadering vaart de strafrechter niet langer blind op de vergunning wanneer hij de strafbaarheid van de gedraging moet vaststellen. Onrechtmatige vergunningen kunnen in deze benadering niet strafuitsluitend werken. Evenmin zou iemand veroordeeld mogen worden voor het overtreden van onrechtmatige voorschriften. Dit is een relatief administratiefrechtelijk afhankelijke benadering van het milieustrafrecht, waarbij de milieubestuursrechtelijke regels de inhoud van de wederrechtelijkheid bepalen. De inhoud van de wederrechtelijkheid van de verboden gedraging is dus Verwaltungsrechtsakzessorisch ingevuld. De Nederlandse strafrechter lijkt deze benadering te volgen bij de toetsing van bevrijdende vergunningen. We hebben immers gezien, dat wanneer het $\mathrm{OM}$ een handelen zonder vergunning tenlastelegt omdat de vergunningplichtige niet beschikt over een rechtmatige vergunning, de strafrechter zich niet gebonden acht aan de formele rechtskracht van de vergunning: de strafrechter toetst in een dergelijke geval de vergunning op wet- en rechtmatigheid en doorbreekt in die zin de Verwaltungs(verfahrens)akzessorietät. Dit in tegenstelling tot Duitsland waar de gebondenheid van de strafrechter aan de rechtsgeldigheid van vergunningen, behoudens de wettelijke uitzonderingen, zowel geldt voor bevrijdende vergunningen als voor belastende vergunningen. Nederland lijkt dus een opmerkelijke positie in te nemen als het gaat om de concrete uitwerking van de strafrechtelijke toetsingsbevoegdheid. Immers, bij belastende beschikkingen acht de strafrechter zich wel gebonden aan de formele rechtskracht. Indien de verdachte een overtreding van belastende vergunningsvoorschriften wordt tenlastegelegd en hij de rechtmatigheid van deze voorschriften voor de strafrechter aanvecht, dan wordt hem de formele rechtskracht van de vergunning tegengeworpen. Dit is enigszins vreemd, want een

1471. Het wederrechtelijkheidsconcept in deze artikelen is dus paradoxaal te noemen. Enerzijds breidt het de strafbaarheid uit door elke schending van formele regelgeving als wederrechtelijk te bestempelen, maar anderzijds limiteert het de strafbaarheid op onwenselijke wijze door bij elke vergunningconforme emissie de wederrechtelijkheid uit te sluiten. Wel moet worden benadrukt dat door de hierboven besproken toetsingsbevoegdheid van de Nederlandse strafrechter toch nog enige correctie op deze beschikkingsafhankelijke invulling van de wederrechtelijkheid mogelijk is, wat o.m. betekent dat wanneer een verdachte zich op een bevrijdende (maar mogelijk onrechtmatige) vergunning beroept om te beargumenteren dat hij niet wederrechtelijk heeft gehandeld, de rechter toch de mogelijkheid heeft de vergunning te toetsen. Zie hierover hoofdstuk VI en Faure, M. en Visser, M., o.c., 1999, 237-239; Waling, C., o.c., 1990, 56-57 
zuiver Verwaltungsrechtsakzessorische invulling van de strafrechtelijke toetsing zou niet alleen moeten impliceren dat onrechtmatige vergunningen niet strafuitsluitend kunnen werken, maar ook dat niemand kan worden veroordeeld voor de overtreding van onrechtmatige voorschriften. Anders gezegd, een strafrechtelijke toetsing van beschikkingen op wet- en rechtmatigheid zou niet alleen in het voordeel van het OM moeten werken, maar ook in het voordeel van de burger, die zich op de onrechtmatigheid van tot hem gerichte voorschriften beroept.

Uit het voorgaande blijkt tevens dat een Verwaltungsrechtsakzessorische benadering van toetsing, wat de vaststelling van de strafrechtelijke wederrechtelijkheid betreft, nader kan worden gedifferentieerd in:

a. een koppeling van de strafrechtelijke wederrechtelijkheid aan zowel de materiële als de formele regels van het milieubestuursrecht. Niet alleen materiële gebreken, maar ook zuiver formele gebreken van de vergunning leiden tot de vaststelling dat de verboden gedraging strafrechtelijk gezien wederrechtelijk is. De verboden gedraging is wederrechtelijk indien is gehandeld zonder een materieel én formeel rechtmatige vergunning;

b. een koppeling van de strafrechtelijke wederrechtelijkheid aan uitsluitend de materiële regels van het milieubestuursrecht. Zuiver formele gebreken, zoals bijvoorbeeld het nalaten van een onderzoeksplicht, zouden dan de vergunning in strafrechtelijke zin niet onrechtmatig maken. Anders gezegd, een formeel onrechtmatige vergunning behoudt zijn strafuitsluitende werking. De verboden gedraging is slechts wederrechtelijk indien is gehandeld zonder een materieel rechtmatige vergunning.

c. een koppeling van de strafrechtelijke wederrechtelijkheid aan zowel de materiële als de formele regels van het milieubestuursrecht voor zover de formele regels gericht zijn op de bescherming van het leefmilieu. Formele gebreken van de vergunning leiden dan slechts tot strafrechtelijke wederrechtelijkheid indien deze gebreken voortvloeien uit de overtreding van formele regels die tevens het leefmilieu beschermen. Laat bijvoorbeeld het bestuur de voor de bescherming van het leefmilieu voorgeschreven onderzoeksplicht na, dan is de vergunning niet alleen bestuursrechtelijk maar ook strafrechtelijk onrechtmatig zodat deze niet langer een strafuitsluitende werking heeft.

3. De strafbaar gestelde gedraging is autonoom wederrechtelijk. De strafrechter moet volkomen zelfstandig beoordelen of de gedraging in strijd is met het recht. Dit is een volledig zelfstandige strafrechtelijke benadering van het milieustrafrecht waarbij de band tussen strafrecht en het milieubestuursrecht volledig is losgelaten. 
Zetten we de drie alternatieve visies over de inhoud van de strafrechtelijke wederrechtelijkheid even op een rij dan kan allereerst worden opgemerkt dat een autonome strafrechtelijke toetsing weinig navolging verdient. Op het eerste gezicht lijkt een autonome strafrechtelijke toetsing aan de hand van een zelfstandig wederrechtelijkheidsbegrip inderdaad zeer aantrekkelijk:

'Die Strafjustiz könnte in jedem Fall von verwaltungsrechtlichen Dogmen unbelastet ihr eigenes Urteil über die Beachtlichkeit solcher Verwaltungsakte fällen. ${ }^{1472}$

Anderzijds kan niet worden ontkend dat deze visie zeer

'ergebnisorientiert und auf die Etablierung einer zweiten, strafrechtlichen Bewertungskompetenz gerich-tet ist.' ${ }^{1473}$

Er kleven evenwel veel nadelen aan een autonome toetsing. Allereerst rijst de vraag of een autonome toetsing, volledig losgekoppeld van het milieubestuursrecht, nog wel te verzoenen is met het beginsel van de eenheid van rechtsorde. Welke opvatting men ook over de eenheid van rechtsorde aanhangt, het beginsel is in ieder geval bedoeld om op het niveau van de rechtmatigheid tegenspraken tussen rechtsgebieden te vermijden. Zoals besproken, is een strafrechtelijke toetsingsbevoegdheid die gekoppeld is aan de bestuursrechtelijke rechtmatigheid in plaats van aan de rechtsgeldigheid (zoals in Duitsland) of aan de formele rechtskracht (zoals in Nederland) het meest geschikt om het beginsel van de eenheid van rechtsorde te waarborgen. Een autonome toetsing daarentegen is duidelijk in strijd met de eenheid van rechtsorde, tenzij via een achterdeur toch weer inspiratie wordt gezocht in het milieubestuursrecht - wat Schünemann bijvoorbeeld doet - maar dan kan nog moeilijk worden gesproken van een volledig autonome toetsing. Daarnaast leidt een zelfstandig milieustrafrechtelijk wederrechtelijkheidsbegrip tot rechtsonzekerheid. Bij een volledig zelfstandige toetsing ontstaat het risico dat verschillende strafrechters over eenzelfde gedraging een onderscheiden rechtmatigheidsoordeel gaan vellen. Dit risico is veel minder aanwezig indien een koppeling met het objectieve milieurecht blijft bestaan. Bovendien, en dit is wellicht het belangrijkste bezwaar, is een autonome toetsing strijdig met de bedoelingen van de milieuwetgever, die er duidelijk voor heeft gekozen milieuverontreiniging principieel middels een of andere vorm van administratieve afhankelijkheid strafbaar te stellen. Een autonome toetsing past daarom enkel in een systeem waar de ecologische rechtsgoederen ook autonoom zijn strafbaar gesteld. In een stelsel waar trouwens om gegronde redenen - ecologische rechtsgoederen worden beschermd via administratief afhankelijke strafbaarstellingen moet de strafrechter het bestuursrecht eerbiedigen en niet eigen strafrechtelijke noties in de plaats stellen. Een autonome toetsing zou het doel van effectieve en rechtvaardige strafrechtelijke handhaving voorbij schieten daar zowel de instrumentele functies als de rechtsbeschermende garanties van het strafrecht op de helling worden gezet. Instrumenteel gezien zal dergelijke toetsing tot schadelijke 
neveneffecten aanleiding geven daar dit indruist tegen de door de wetgever voorgestane administratieve afhankelijkheid waarbij de nadruk ligt op bestuurlijke toetsing ex ante en niet op strafrechtelijke toetsing ex post. Dit kan de verhouding tussen het bestuursrechtelijke en het strafrechtelijke apparaat danig bezwaren en een effectieve bescherming van het leefmilieu niet ten goede komen. Langs de andere kant is vanuit het perspectief van de rechtsbescherming het gevaar niet denkbeeldig dat belangrijke garanties, zoals rechtszekerheid en gelijkheid, worden uitgehold.

Laat een autome visie op de toetsingsbevoegdheid en op milieustrafrechtelijke wederrechtelijkheid te veel de band met het milieurecht los, dan zien we dat aan de andere kant een te strikte gebondenheid van de strafrechter aan de beslissingen van de bestuurlijke overheid tot vrijwel onoverkomelijke problemen leidt. Het Duitse milieustrafrecht illustreert dit zeer goed. Het is dan ook begrijpelijk dat juist in Duitsland veel kritiek is gekomen tegen een al te strikte beschikkingsafhankelijkheid van het milieustrafrecht. Een belangrijk deel van de Duitse literatuur bepleit dan ook een gulden middenweg, die zowel de nadelen van een volledig autonome milieustrafrechtelijke wederrechtelijkheid als de nadelen van een absolute administratieve afhankelijkheid kan opvangen, terwijl de voordelen van een relatieve administratieve afhankelijkheid behouden blijven. Men dient zich te realiseren dat zelfs in de ruimste visie op de toetsingsbevoegdheid, zoals die bijvoorbeeld in het Belgische recht aanwezig is, de taak van de strafrechter bij het vaststellen van de grenzen van de strafrechtelijke aansprakelijkheid steeds beperkt is. Uit de milieudelictsomschrijving, ook bij de meer Verwaltungsrechtsakzessorische strafbaarstellingen, zoals concrete gevaarzettingsdelicten, vloeit immers voort dat de omvang van de toegelaten milieuverstoring primair door het bestuur wordt bepaald. Uitgangspunt blijft dat de mate waarin schade aan het leefmilieu kan worden toegebracht in eerste instantie door het bestuur, via algemene regels en beschikkingen, zoals vergunningen, wordt bepaald. Het bestuur beschikt immers over de relevante informatie en is ook beter geschikt om de belangenafweging te maken op basis waarvan wordt bepaald welke milieuverstoring is toegelaten. Dit is ook een taak die blijkens de onderlinge bevoegdheidsverdeling, die ons milieurecht kenmerkt, behoort te worden vervuld door het bestuur. Dat is niet de taak van de strafrechter. Maar dit hoeft nog niet te betekenen dat de strafrechter geen eigen rol kan vervullen en volledig afhankelijk dient te worden gemaakt van de bestuurlijke beslissingen. De cruciale vraag is daarom of de toetsing en derhalve ook de strafrechtelijke controle op de toegelaten omvang van de milieuverstoring uitsluitend afhankelijk dient te zijn van deze bestuurlijke beslissingen, ook wanneer deze onrechtmatig zijn, of dat deze veeleer moeten gericht zijn op de behartiging en de handhaving van het objectieve milieurecht waaraan niet alleen de burger maar ook het bestuur zich dient te houden. Me dunkt dat zowel voor de bescherming van het leefmilieu, als voor de rechtsbescherming van de burger, alsook voor een verantwoorde strafrechtelijke controle op het bestuurlijk handelen de Verwaltungsrechtsakzessorische benadering de voorkeur verdient. Toetsing biedt de strafrechter weliswaar mogelijkheden om de door het bestuur toegelaten milieuverstoring te controleren, maar de facto wordt slechts gecontroleerd of niet alleen de burger maar ook de bestuurlijke overheid zelf bij het verlenen van een vergunning en het vastleggen van de 
voorwaarden de regels van het milieurecht eerbiedigt en binnen de haar toegekende bevoegdheden is gebleven. ${ }^{1474}$

Kortom, wil men de machtskritische functie van het strafrecht alsook de positie van de strafrechter in het milieurecht versterken zonder volledig afbreuk te doen aan het noodzakelijk accessoire karakter van het milieustrafrecht, dan verdient een Verwaltungsrechtsakzessorietät duidelijk de voorkeur boven de twee uitersten van enerzijds Verwaltungsakzessorietät en anderzijds een totale autonomie van het strafrecht. In concreto betekent dit dat het milieustrafrecht niet slechts overheidsondersteunend of bestuursafhankelijk dient te zijn, maar dat de administratieve afhankelijkheid dient te worden begrepen als een gebondenheid van zowel burger, bestuur als strafrechter aan de normen van het milieubestuursrecht. Het zijn de in het milieurecht neergelegde regels, waaraan niet alleen de burger, maar ook het bestuur is onderworpen, die dienen te bepalen welke milieuverstorende gedragingen als een strafbaar feit moeten worden beschouwd.

Nu in grote lijnen duidelijk is geworden op welke wijze met de strafrechtelijke toetsing van vergunningen en met de milieustrafrechtelijke wederrechtelijkheid kan worden omgegaan, moet nader worden bekeken wat hiervan de gevolgen zijn voor een mogelijke strafrechtelijke aansprakelijkheid van de vergunningverlenende instanties.

\section{§4. De strafrechtelijke aansprakelijkheid voor wederrechtelijke vergunningverlening}

\section{A. INLEIDING}

Zoals op verschillende plaatsen in deze studie wordt aangegeven is een, vanuit rechtspolitiek oogpunt, belangrijke vraag of overheden ook strafrechtelijk aansprakelijk kunnen worden gesteld indien zij via een onzorgvuldige vergunningverlening bijdragen tot een of andere vorm van milieuverstoring. We hebben reeds vastgesteld dat zo'n aansprakelijkheid slechts mogelijk is indien aan een aantal voorwaarden is voldaan. Zetten we deze voorwaarden voor alle duidelijkheid nog even op een rij.

Zo moet natuurlijk in de eerste plaats strafvervolging van de vergunningverlenende overheid mogelijk zijn. Zowel Nederland als België sluiten die mogelijkheid uit. De Belgische wetgever heeft immers in het nieuwe artikel $5 \mathrm{BSw}$ overheden volledig buiten de werking van het strafrecht geplaatst. De Nederlandse rechtspraak heeft sinds Pikmeer II weliswaar op het vlak van de strafvervolging van openbare lichamen een belangrijke opening gecreëerd, maar tot op heden blijft een immuniteit voor wederrechtelijke vergunningverlening bestaan daar dit moet worden gezien als een exclusieve bestuurstaak die rechtens alleen door bestuursfunctionarissen kan worden uitgevoerd. Een onderzoek naar de strafrechtelijke aansprakelijkheid van overheden voor wederrechtelijke vergunningverlening is derhalve voor beide landen voornamelijk een theoretische exercitie. Niettemin 
blijft de vraag naar een strafrechtelijke aansprakelijkheid voor wederrechtelijke vergunningverlening ook voor deze landen van belang omdat de immuniteit van overheden immers in beginsel niet uitsluit dat ambtenaren op grond van eigen daderschap aansprakelijk kunnen worden gesteld. In België blijft het zelfs nog steeds mogelijk individuele functionarissen strafrechtelijk aansprakelijk te stellen voor delicten begaan door de overheid waartoe zij behoren. Daarnaast is het denkbaar dat externe instanties, zoals ingenieursbureaus, strafrechtelijk worden vervolgd indien zij via een verkeerd advies bijdragen tot de totstandkoming van de onrechtmatige vergunning en aldus meewerken aan de milieuverstoring.

Van de onderzochte landen verdient Duitsland wederom de meeste aandacht. Want hoewel Duitsland niet de strafbaarheid van de (publiekrechtelijke) rechtspersoon kent, wordt immers wel aangenomen dat de ambtenaren die tot de vergunningverlenende overheid behoren onder de werking van het milieustrafrecht vallen en dientengevolge ook kunnen worden vervolgd voor het verlenen van onrechtmatige vergunningen. Dit betekent evenwel niet dat een 'Amtsträgerstrafbarkeit in den Fällen der Erteilung fehlerhafter Verwaltungsakte' geheel zonder problemen is. Er moet immers ook nog aan andere voorwaarden zijn voldaan.

Een tweede belangrijke voorwaarde voor een strafrechtelijke aansprakelijkheid voor wederrechtelijke vergunningverlening is de bevoegdheid van de strafrechter om de vergunning op wet- en rechtmatigheid te toetsen. We hebben gezien dat op dit punt tussen Nederland, België en Duitsland grote verschillen optreden. Het spreekt voor zich dat deze verschillen niet slechts consequenties hebben voor de strafbaarheid van de vergunninghouder maar ook voor de strafbaarheid van vergunningverlener, indien men zou overwegen om (ook) tegen deze laatste een strafvervolging in te stellen. De aansprakelijkheid van de vergunningverlener zal immers doorgaans op grond van een deelnemingsvorm moeten worden gekwalificeerd, hetgeen veronderstelt dat in hoofde van eigenlijke pleger een bewezen en strafbaar grondfeit voorligt. Men kan stellen, dat hoe geringer de strafrechtelijke toetsingsbevoegdheid des te kleiner de kans is om de vergunningverlener strafrechtelijk aansprakelijk te stellen. In het ergste geval betekent dit dat zowel vergunninghouder als vergunningverlener straffeloos blijven. Bij delicten waar de vergunning bestanddeel is, zal immers het grondfeit niet kunnen worden bewezen verklaard - want er ligt immers formeel een vergunning voor - bij delicten waar de vergunning een rechtvaardigingsgrond uitmaakt zal het grondfeit door de vergunning niet-wederrechtelijk zijn.

Is strafrechtelijke toetsing mogelijk, dan dient vervolgens te worden bekeken of iedere onrechtmatige vergunningverlening ook moet worden gezien als een wederrechtelijke vergunningverlening. Dit betreft de vraag naar de inhoud van de milieustrafrechtelijke wederrechtelijkheid van het (grond)feit. In voorgaande paragraaf is reeds bepleit dat een onrechtmatige vergunningverlening slechts tot een strafbaar grondfeit aanleiding zou moeten geven indien de onrechtmatigheid van de vergunning het gevolg is van een schending van de materiële milieurechtsregels en/of formele voorschriften die gericht zijn op de bescherming van de ecologische rechtsgoederen. Wel dient de beoordelings- en beleidsvrijheid van de functionaris strafrechtelijk te worden gerespecteerd. Dit betekent dat 
een vergunningverlening slechts als wederrechtelijk moet worden aangemerkt indien deze apert in strijd is met de ecologische rechtsgoedbeschermende milieuregels of wanneer de functionaris zijn beslissingsruimte heeft overschreden. Bij de bespreking van de Duitse rechtspraak zullen dienaangaande verschillende voorbeelden worden gegeven.

Een laatste, maar zeker niet het minste probleem is of de materiële milieustrafbepalingen ook op de wederrechtelijke vergunningverlening toepasselijk zijn. Dit lijkt primair afhankelijk van de delictsomschrijving. Indien bijvoorbeeld alleen het handelen zonder vergunning is strafbaar gesteld, richt de strafbaarstelling zich expliciet tegen de vergunninghouder en niet tegen de vergunningverlener, en zal, indien men bijvoorbeeld meent dat de overheid wederrechtelijk een vergunning heeft verleend, slechts via een deelnemingsconstructie de vergunningverlener bestraft kunnen worden, gewoon omdat de delictsomschrijving zich tot een handelen zonder vergunning beperkt. Talrijke materiële milieustrafbepalingen zijn immers geen gemene delicten maar kwaliteitsdelicten. ${ }^{1475}$ Met andere woorden, vanwege de (absolute) administratieve afhankelijkheid missen vergunningverlenende overheden doorgaans de vereiste kwaliteit om als pleger van een milieudelict in aanmerking te komen. Een mogelijke strafbaarheid van de vergunningverlener kan bij milieudelicten daarom enkel via de deelnemingsfiguren tot stand worden gebracht. Voor deelneming is immers niet vereist dat de deelnemer dezelfde hoedanigheid bezit als de pleger van het grondfeit. Dit betekent natuurlijk wel dat het foutieve overheidshandelen strafrechtsdogmatisch moet voldoen aan de klassieke voorwaarden voor deelneming. Zo zal, vanwege de accessoriteit van de deelneming, in hoofde van de dader sprake moeten zijn van een bewezen en strafbaar gronddelict. De vergunningverlener kan immers niet deelnemen aan een niet-strafbaar gronddelict. Opnieuw komt dan de toetsingsproblematiek om de hoek kijken, want de strafbaarheid van het gronddelict - bijvoorbeeld het lozen zonder (rechtmatige) vergunning hangt af van de vraag of de strafrechter onrechtmatige vergunningen mag toetsen. Het moge intussen duidelijk zijn hoezeer een milieustrafrechtelijke aansprakelijkheid van zowel de vergunninghouder als van de vergunningverlener op voorhand al kan worden beperkt door zowel de administratieve afhankelijkheid van de milieudelictsomschrijvingen alsook door beperkingen op de strafrechtelijke toetsing.

Deze paragraaf is als volgt opgebouwd. Eerst wordt bekeken op welke wijze in het Duitse milieustrafrecht wederrechtelijke vergunningverlening kan worden aangepakt (B). Daarna komen Nederland en België aan bod. (C en D). Ik eindig met enkele rechtsvergelijkende conclusies en de beantwoording van de vraag of een zelfstandige strafbaarstelling van wederrechtelijke vergunningverlening noodzakelijk is (E).

\section{B. DUTSLAND}

\section{Inleiding}

Nu omvang en inhoud van de toetsingsbevoegdheid van de Duitse strafrechter zijn vastgesteld, kan worden onderzocht wat hiervan de strafrechtelijke gevolgen zijn voor de ambte- 
naar, die zich schuldig maakt aan wederrechtelijke vergunningverlening. In dat verband mogen de verschillen tussen Nederland en Duitsland op het vlak van de daderschaps- en deelnemingsregeling niet over het hoofd worden gezien. Daarom moet met de volgende opmerkingen rekening worden houden.

In Nederland worden doen plegen, medeplegen, uitlokken van en medeplichtigheid aan een delict gezien als deelnemingsvormen, die de strafrechtelijke aansprakelijkheid van het (onmiddellijke) daderschap uitbreiden tot bepaalde andere gedragingen die aan de totstandkoming van het gepleegde delict bijdragen. ${ }^{1476}$ De eerste drie deelnemingsvormen zijn wat hun strafwaardigheid betreft door de Nederlandse wetgever aan het daderschap gelijkgesteld. Dit blijkt uit de tekst van artikel 47 lid $1 \mathrm{Sr}$ : de daar genoemde deelnemers worden 'als daders' gestraft. Bemerk dat daarmee niet is bedoeld dat men deze deelnemers slechts gestraft wenste te zien alsof zij daders waren. ${ }^{1477}$ De wetgever heeft wel degelijk bedoeld een opsomming te geven van de ware daders. Artikel 47 hanteert dus een juridischtechnisch daderschapsbegrip, dat ruimer is dan wat men onder het spraakgebruik onder daderschap verstaat. Daartegenover staat de medeplichtige, die op grond van artikel $48 \mathrm{Sr}$ alleen strafbaar is als het om een misdrijf gaat, zij het krachtens artikel $49 \mathrm{Sr}$ minder dan de dader.

Het Duitse strafwetboek onderscheidt drie vormen van daderschap: unmittelbare Alleintäterschaft (§ $25 \mathrm{I}, 1 \mathrm{StGB})$, mittelbare Täterschaft (§ $25 \mathrm{I}, 2 \mathrm{StGB})$ en Mittäterschaft ( $\$ 25$ II StGB) ${ }^{1478}$ Alleintäterschaft is naar Nederlands recht vergelijkbaar met het echte (onmiddellijke) daderschap, terwijl mittelbare Täterschaft en Mittäterschaft min of meer overeenkomen met de Nederlandse deelnemingsvormen doen plegen en medeplegen. Het Duitse strafrecht kent daarnaast twee vormen van deelneming (Teilnahme) namelijk Anstiftung (uitlokking: § $26 \mathrm{StGB}$ ) en Beihilfe (medeplichtigheid: § $27 \mathrm{StGB}$ ). Het is dus van belang voor ogen te houden, dat het daderschapskarakter van doen plegen en medeplegen in Duitsland veel sterker naar voren komt, daar deze niet als deelnemingsvormen worden aangemerkt. ${ }^{1479}$ Dit verschil heeft vanzelfsprekend ook voor de dogmatische kwalificatie van de strafrechtelijke aansprakelijkheid van de vergunningverlener belangrijke gevolgen. Zo is Mittäterschaft aan een kwaliteitsdelict uitgesloten, wanneer de Mittäter de vereiste daderschapskwaliteit mist. In Nederland daarentegen kan iemand best medepleger zijn van een kwaliteitsdelict ook al mist hij de vereiste hoedanigheid. Deelnemers behoeven immers niet de hoedanigheid van de dader te hebben. ${ }^{1480}$ Hetzelfde verschil treedt op tussen mittel-bare Täterschaft en doen plegen. Iemand die de daderschapshoedanigheid mist kan geen mittelbare Täter zijn van een kwaliteitsdelict, terwijl naar Nederlands recht iemand zonder de vereiste daderschapskwaliteit best doen pleger kan zijn van het gronddelict.

1476. De Jong, D.H., 'Vormen van strafbare deelneming', in Van der Neut, J.L. (red.), Daderschap en deelneming, Arnhem, Gouda Quint, 1993, 76.

1477. Kelk, C., Studieboek materieel strafrecht, Arnhem, Gouda Quint, 1998, 328.

1478. Jescheck, H.-H. en Weigend, Th., o.c., 1996, 641-661.

1479. Idem, 683-697.

1480. Van Bemmelen, J.M. en Van Veen, Th.W., Ons Strafrecht 1. Het materiële strafrecht. Algemeen deel, Amhem, Gouda Quint, 1995, 192. 
Een ander opmerkelijk verschil is dat men naar Duits recht geen culpose delicten kan medeplegen of doen plegen. Evenmin kan men aan culpose delicten deelnemen. Zij die op enigerlei wijze betrokken zijn bij het begaan van culpose delicten worden als Täter aangemerkt, en dienen derhalve ook de daderschapskwaliteit te hebben. ${ }^{1481}$ Het Nederlandse strafrecht aanvaardt daarentegen wel deelneming aan een culpoos delict. Vanwege deze verschillen zal in het hiernavolgende, wanneer over de Duitse daderschaps- en deelnemingsregeling wordt gesproken, de Duitse terminologie zo strikt mogelijk worden gehandhaafd.

Deze paragraaf is als volgt opgebouwd. Eerst volgt een bespreking van de Amtsträgerstrafbarkeit volgens de heersende leer, die, zoals gezien, een strikte Vewaltungsaktsakzessorische visie op het milieustrafrecht voorstaat (2). Daarna volgen enkele illustraties uit de rechtspraak (3). Vervolgens wordt besproken wanneer volgens een Verwaltungsrechtsakzessorische visie op het milieustrafrecht ambtenaren voor wederrechtelijke vergunningverlening strafbaar zijn (4). Inmiddels heeft het Bundesgerichtshof zich ook over de Amtsträgerstrafbarkeit voor wederrechtelijke vergunningverlening uitgesproken. Interessant is vooral dat in deze uitspraak expliciet wordt ingegaan op de voorwaarden van Mittäterschaft en mittelbare Täterschaft waaraan het foutieve optreden van de vergunningverlener moet voldoen. Gelet op het belang van deze hoogstrechterlijke beslissing wordt deze afzonderlijk besproken (5). Ik eindig met een samenvatting van de Duitse situatie (6).

\section{Amtsträgerstrafbarkeit volgens de heersende leer}

Om inzicht te krijgen in de Amtsträgerstrafbarkeit voor wederrechtelijke vergunningverlening wordt door de heersende leer traditioneel een onderscheid gemaakt tussen de verlening van nietige vergunningen, de verlening van rechtsgeldige maar niettemin onrechtmatige vergunningen en tenslotte de verlening van door rechtsmisbruik tot stand gekomen vergunningen. Dit onderscheid is naar Duits recht fundamenteel voor de draagwijdte van de strafrechtelijke toetsing en is derhalve ook bepalend voor de milieustrafrechtelijke aansprakelijkheid van de vergunningverlener. Daarnaast moet ook telkens rekening worden gehouden met het onderscheid tussen de gemene en de kwaliteitsmilieudelicten daar de delictsomschrijving bepalend is voor de vraag of de ambtenaar niet slehts als Teilnehmer, maar mogelijk ook als mittelbare Täter of Mittäter kan worden vervolgd.

\section{a. Verlening van nietige vergunningen}

Is de verleende vergunning door zulke gebreken aangetast dat deze volgens $\S 44 \mathrm{VwVfG}$ nietig is, dan heeft dit tot gevolg dat de vergunning volgens $\S 43 \mathrm{Abs}$. $3 \mathrm{VwVfG}$ niet langer rechtsgeldig is. Nu volgens de heersende leer de Duitse strafrechter niet gebonden is aan nietige vergunningen kan hij zonder problemen het tenlastegelegde milieudelict als wederrechtelijk kwalificeren. De vergunninghouder pleegt in voorkomend geval een strafbaar feit daar hij niet langer beschikt over een rechtsgeldige vergunning. Dit heeft voor de straf-

1481. Jescheck, H.-H en Weigend, Th., o.c., 1996, 654-655. 
rechtelijke aansprakelijkheid van de ambtenaar, die de nietige vergunning heeft verleend, enkele belangrijke consequenties.

In de situatie waarin door de vergunninghouder een gemeen milieudelict is overtreden bijvoorbeeld § $324 \mathrm{StGB}$ - kan de ambtenaar voor het verlenen van een nietige vergunning niet alleen worden vervolgd op grond van Teilnahme aan het grondfeit, bijvoorbeeld als medeplichtige, maar ook op basis van de delictsvormen Mittäterschaft en mittelbare Täterschaft. Immers, gemene milieudelictsomschrijvingen richten zich niet uitsluitend tot vergunninghouders of vergunningplichtigen, maar tot eenieder, zodat ook vergunningverlenende ambtenaren mogelijk als medepleger of doen pleger van het delict kunnen worden aangemerkt. ${ }^{1482}$ Natuurlijk moet de vergunningverlening voldoen aan de voorwaarden van deze delictsvormen. Deze voorwaarden zullen hierna, bij de bespreking van de uitspraak van het Bundesgerichtshof, uitgebreid aan bod komen. Nu volstaat het te bekijken hoe de aard van het milieudelict en de beperkingen op de strafrechtelijke toetsingsbevoegdheid de dogmatische kwalificatie van de wederrechtelijke vergunningverlening kunnen beönvloeden.

Is een kwaliteitsmilieudelict overtreden dan zijn de dogmatische mogelijkheden meer beperkt. Bij een kwaliteitsdelict kan de ambtenaar uitsluitend Teilnahme worden tenlastegelegd, naar Duits recht dus uitlokking of medeplichtigheid. Voor Teilnahme is niet vereist dat de deelnemer beschikt over de hoedanigheid van de pleger van het grondfeit. Mittäterschaft en Mittelbare Täterschaft zijn daarentegen uitgesloten. De ambtenaar mist de daderschapskwaliteit. ${ }^{1483}$ Daar met de nietigheid van de vergunning tevens de wederrechtelijkheid van het grondfeit vaststaat, is het strafrechtsdogmatisch mogelijk om de ambtenaar voor het gepleegde feit als Teilnehmer mede te vervolgen. De wederrechtelijkheid van het grondfeit vloeit immers automatisch voort uit de nietigheid van de vergunning. Natuurlijk dient ook aan de andere voorwaarden van Teilnahme te zijn voldaan. Er is niet alleen een strafbaar grondfeit vereist. De ambtenaar moet daarnaast zowel opzet hebben gehad op het deelnemen, als ook op de totstandkoming van het delict. Daarnaast dient het gronddelict zelf ook opzettelijk te zijn begaan. Deelneming aan culpose (milieu)delicten is naar Duits recht uitgesloten. ${ }^{1484}$

\section{b. Verlening van onrechtmatige (rechtsgeldige) vergunningen}

Problematisch zijn vooral die gevallen waarin weliswaar een onrechtmatige maar niettemin rechtsgeldige vergunning is verleend. De Duitse strafrechter is immers in beginsel gebonden aan dergelijke vergunningen. ${ }^{1485}$ De vergunninghouder pleegt geen strafbaar feit zolang deze beschikt over een formeel rechtsgeldige vergunning. ${ }^{1486}$ Onrechtmatige vergunningen hebben in beginsel een strafuitsluitende werking. Dan bestaat de kans dat een onrecht-

1482. Rogall, K., o.c., 1991, 172-173.

1483. Schönke, A. en Schröder, H., o.c., 1991, nr. vor $\S \S 25 \mathrm{ff}$.

1484. Jescheck, H.-H. en Weigend, Th., o.c., 1996, 656.

1485. Schmitz, R., o.c., 1992, 25-45; Rogall, K., o.c., 1991, 176-186.

1486. Rogall, K., o.c., 1191, 191. 
matige, maar niet nietige vergunning voor de vergunninghouder strafuitsluitend werkt en dat juist vanwege deze strafuitsluitende werking evenmin de vergunningverlener, bij gebrek aan een strafbaar grondfeit, kan worden vervolgd. ${ }^{1487} \mathrm{Er}$ moet evenwel opnieuw rekening worden gehouden met het verschil tussen gemene en kwaliteitsdelicten

In het geval een kwaliteitsdelict is overtreden heeft dit tot gevolg, dat niet alleen de vergunninghouder maar ook de vergunningverlener vrijuit gaat aangezien er geen sprake is van een strafbaar grondfeit. ${ }^{1488}$ Zonder een strafbaar grondfeit kan de vergunningverlener niet als Teilnehmer worden aangemerkt. Evenmin kan de vergunningverlener als mittelbare Täter of als Mittäter worden aangemerkt, daar de norm zich uitsluitend richt tot de vergunninghouder ${ }^{1489}$ Omdat vanwege de Verwaltungsaktsakzessorietät van het milieustrafrecht de meeste milieudelicten moeten worden beschouwd als kwaliteitsdelicten, betekent dit dat een wederrechtelijke vergunningverlening zowel in hoofde van de vergunninghouder als in hoofde van de vergunningverlener in een groot aantal gevallen van milieuverstoring geen strafrechtelijke reactie kan uitlokken.

Bij gemene milieudelicten is de situatie iets ingewikkelder. Daar waar men overweegt de ambtenaar te vervolgen als Mittäter of als Teilnehmer geldt dezelfde conclusie als bij Teilnahme aan een kwalititeitsdelict: aangezien onrechtmatige vergunningen strafuitsluitend werken, ontbreekt het aan een strafbaar grondfeit zodat zowel Teilnahme als Mittäterschaft in hoofde van de ambtenaar bij voorbaat zijn uitgesloten. Men kan immers niet een nietstrafbaar gronddelict medeplegen of daaraan deelnemen ${ }^{1490}$ Bemerk dat deze straffeloosheid niet het gevolg is van de strafrechtsdogmatische eisen waaraan de Teilnahme of het Mittäterschaft van de ambtenaar moeten voldoen, maar dat dit uitsluitend het gevolg is van de gebondenheid van de Duitse strafrechter aan de rechtsgeldigheid in plaats van aan de rechtmatigheid van de vergunning.

Overweegt men daarentegen om de ambtenaar als mittelbare Täter te vervolgen dan hoeft volgens de heersende leer het ontbreken van een strafbaar grondfeit geen beletsel te zijn voor diens aansprakelijkheid. Bij een inbreuk op een gemeen milieudelict is de ambtenaar zelf normadressaat en kan de onrechtmatige vergunningverlening worden beschouwd als een zelfstandige schending van de $\S \S 324$ en $326 \mathrm{StGB}$. In een dergelijke situatie staat de vergunningverlenende ambtenaar als mittelbare Täter terecht en dwingt het rechtmatig handelen van de vergunninghouder - omdat deze beschikt over een rechtsgeldige vergunning - niet tot de vaststelling dat ook het handelen van de ambtenaar rechtmatig is. De heersende leer aanvaardt dus dat, bijvoorbeeld bij een lozing zonder rechtmatige vergunning, in hoofde van de vergunninghouder, de eigenlijke pleger, geen sprake is van een strafbaar feit, maar mogelijk wel in hoofde van de ambtenaar: ${ }^{1491}$

1487. Rogall, K., o.c., 1991, 192-193.

1488. Weber, U., o.c., 1988, 35.

1489. Geisler, C., 'Strafbarkeit von Amtstrâgern im Umweltrecht', $N J W, 12$; Winkelbauer, l.c. 1986, 150; Weber, U., o.c., 1988, 35.

1490. Weber, U., o.c., 1988, 35.

1491. Schünemann, B., 'Die Strafbarkeit von Amtsträgern im Gewåsserstrafrecht', Wistra, 1986, 239; Horn, l.c., 1981, 3; Rogall, K., o.c., 1991. 


\begin{abstract}
'Die Rechtswidrigkeit tatbestandmäßigen Verhaltens ist für jeden Beteiligten getrennt zu untersuchen. Das bedeutet: Das tatbestandmäßige Amtsträgerverhalten kann als rechtswidrig zu beurteilen sein, wenn es sich als begünstigendes Verwaltungshandelen auf ein rechtmäßiges Bürgerverhalten bezieht. Es wäre falsch anzunehmen, wo immer der Bürger rechtmäßig handelt, könne für den Amtsträger nicht anderes gelten. ${ }^{1492}$
\end{abstract}

Vanuit zuiver strafrechtsdogmatisch perspectief is hiertegen weinig in te brengen. Langs de andere kant is het opmerkelijk dat eenzelfde milieuovertreding voor de vergunninghouder rechtmatig en voor de vergunningverlener wederrechtelijk kan zijn. Vanuit het door de heersende leer zo sterk beklemtoonde eenduidige wederrechtelijkheidsbegrip is dit enigszins vreemd. Hoe het door de heersende leer verdedigde uitgangspunt dat tegenspraken tussen bestuursrecht en strafrecht moeten worden vermeden, kan worden verzoend met de stellingname dat binnen het strafrecht éénzelfde gedraging, namelijk de vergunningverlening, voor de vergunninghouder strafuitsluitend en voor de vergunningverlener wederrechtelijk kan zijn, is niet geheel duidelijk. Deze paradox heeft trouwens een interessante consequentie. De cruciale vraag die de doctrine, door beroep te doen op de eenheid van rechtsorde, steeds heeft willen vermijden, namelijk in welke mate de strafrechter de vergunningverlening mag toetsen, komt nu expliciet naar voren. Bij de vervolging van de milieu-ambtenaar als mittelbare Täter moet de strafrechter immers expliciet stilstaan bij de vraag of er sprake is van 'rechtswidrigen Amtsträgerhandelns'. ${ }^{1493}$ Hij moet onderzoeken of de onrechtmatige vergunningverlening al dan niet in termen van $\$ \S 324$ en 326 StGB een 'unbefugte' verontreiniging uitmaakt. Daar waar in hoofde van de vergunninghouder relatief eenvoudig, want formeel kan worden vastgesteld of deze wederrechtelijk heeft gehandeld, aangezien dit louter en alleen afhangt van het voorhanden zijn van een rechtsgeldige vergunning, moet de wederrechtelijkheid van het ambtelijk handelen nu aan de hand van een materiële toetsing aan het administratief recht worden vastgesteld. ${ }^{1494}$ Opmerkelijk is wel dat volgens de heersende leer de machtenscheiding zich niet verzet tegen een dergelijke toetsing, terwijl de machtenscheiding wel wordt aangegrepen als argument tegen toetsing wanneer de vergunninghouder terecht staat. Wel is iedereen het erover eens dat de strafrechter de beoordelingsvrijheid waarover de betrokken ambtenaar beschikt moet respecteren. ${ }^{1495} \mathrm{Er}$ kan daarom alleen van een wederrechtelijke en dus strafbare vergunningverlening sprake zijn indien de ambtenaar de wettelijke beoordelingsvrijheid niet of strijdig met het recht heeft uitgeoefend. Het spreekt voor zich dat de strafrechter bij deze toetsing geen doelmatigheidsoverwegingen mag laten meespelen. Opportuniteitscontrole zou een te grote inbreuk op het freies Ermessen van het bestuur betekenen:

1492. Frank, R., Strafrechtliche Relevanz rechtswidrigen begünstigenden Verwaltungshandelns erläutert am Beispiel der Gewässerverunreinigung ( 324 StGB), Berlin, 1985, 45. Rudolphi, H.J., l.c., 1982, 570.

1493. Winkelbauer, W., L.c., 1986, 152.

1494. Idem.

1495. Müller, W., l.c., 1990, 372. 
'Soweit der Behörde ein Handlungs- oder Unterlassungsermessen eingeräumt wird, darf der Staatsanwalt oder Strafrichter eigene Zweckmäßigkeitserwägungen nicht an die der Behörde setzen; ein sich im Bereich zulässiger Ermessenensausübnung bewegendes Verhalten darf also nicht AnlaB für ein strafrechtliches Einschreiten sein. ${ }^{1496}$

Uit het voorgaande blijkt dat de mogelijkheid om ambtenaren voor onrechtmatige vergunningverlening strafrechtelijk aansprakelijk te stellen gering is, want in beginsel zeer beperkt door de beperkte toetsingsbevoegdheid van de Duitse strafrechter. Teilnahme aan en Mittäterschaft van een milieudelict zijn bij voorbaat al uitgesloten, gelet op het ontbreken van een strafbaar grondfeit. Mittelbare Täterschaft is daarentegen enkel mogelijk wanneer door de uitvoerder of de onmiddellijke dader (de vergunninghouder) een gemeen milieudelict ( $\S \S 324$ en $326 \mathrm{StGB}$ ) is overtreden. Er mag evenwel niet worden vergeten dat de nadelen van de strikte gebondenheid van de strafrechter aan onrechtmatige vergunningen en de daaruit voortvloeiende beperkingen op het vlak van de strafrechtelijke aansprakelijkheid van de vergunningverlener, grotendeels worden gecompenseerd via het leerstuk van rechtsmisbruik. ${ }^{1497}$

\section{c. Verlening van door rechtsmisbruik aangetaste vergunningen}

Reeds werd vastgesteld dat de literatuur op de gebondenheid van de strafrechter aan onrechtmatige vergunningen belangrijke uitzonderingen toelaat via het leerstuk van rechtsmisbruik. Is er sprake van rechtsmisbruik dan kan de strafrechter de vergunning naast zich neer leggen. Is een vergunning door rechtsmisbruik aangetast dan pleegt de vergunninghouder in beginsel een strafbaar feit aangezien hij strafrechtelijk gezien niet langer beschikt over de vereiste vergunning. ${ }^{1498}$ Wat zijn hiervan de gevolgen voor de strafrechtelijke aansprakelijkheid van de vergunningverlener?

In de eerste plaats moet worden verwezen naar $\S 330 \mathrm{~d} \mathrm{Nr}$. 5 StGB. Vergunningen die op de in deze bepaling omschreven wijze zijn tot stand gekomen, verliezen in het strafrecht hun rechtsgeldigheid. Dit geldt zowel voor rechtvaardigende als bestanddeeluitsluitende vergunningen, dus zowel bij gemene als kwaliteitsdelicten, hetgeen betekent dat in voorkomend geval steeds sprake is van een strafbaar grondfeit wat de vervolging van de ambtenaar als Teilnehmer en bij gemene milieudelicten ook als Mittäter mogelijk maakt. Tegelijk moet deze opening die door $\S 330 \mathrm{~d} \mathrm{Nr}$. $5 \mathrm{StGB}$ wordt gecreëerd niet worden overschat. Immers, vereist is steeds dat de vergunning door bedreiging, omkoping, collusie of door onvolledige en onjuiste opgaven is tot stand gebracht. In dit rijtje is voor de strafrechtelijke aansprakelijkheid van de ambtenaar vooral omkoping en collusie relevant. In situaties waarin een vergunning onrechtmatig is verleend omdat de milieu-ambtenaar is bedreigd of misleid, is geen crimineel-politieke noodzaak aanwezig ook de ambtenaar strafrechtelijk te vervolgen. Bovendien kan de bedreigde ambtenaar zich beroepen op 
noodtoestand ( $\$ 35 \mathrm{StGB})$. Bij misleiding zal hij zich veelal kunnen beroepen op dwaling. In ieder geval is zowel bij bedreiging als bij misleiding in hoofde van de ambtenaar het voor de deelneming vereiste opzet niet aanwezig. Hetzelfde geldt voor onrechtmatige vergunningen die door onjuiste of onvolledige informatie zijn tot stand gekomen. Ook dan zal de ambtenaar zich kunnen beroepen op dwaling. Hoogstens zou hem kunnen worden verweten dat hij zich niet voldoende heeft ingespannen om de betrouwbaarheid van de aan hem verleende gegevens na te gaan. Deze nalatigheid kan echter moeilijk worden vertaald in de voor de deelneming noodzakelijke opzet. In die zin heeft $\S 330 \mathrm{~d}$ Nr. 5 StGB voor de strafrechtelijke aansprakelijkheid van de ambtenaar voornamelijk betekenis in de gevallen van omkoping en collusie. Dit is begrijpelijk aangezien deze bepaling door de Duitse wetgever is bedoeld om de vervolging van vergunninghouders te vergemakkelijken en niet zozeer om de strafbaarheid van vergunningverlenende ambtenaren uit te breiden.

Bij de bespreking van door rechtsmisbruik aangetaste vergunningen werd ook vastgesteld dat vergunningen nimmer dodelijk letsel of zwaar lichamelijk letsel kunnen rechtvaardigen. ${ }^{1499}$ Ten aanzien van de strafbepaling $\S 330 \mathrm{a}$ StGB (schwere Gefährdung durch Freisetzen von Giften) wordt dan ook aangenomen dat een vergunning geen strafuitsluitende werking kan hebben. In deze bepaling is strafbaar gesteld de verspreiding van giftige stoffen die zware gezondheidsschade of het gevaar van gezondheidsschade bij een groot aantal mensen tot gevolg heeft. Deze handeling is strafbaar, ook al is er een rechtsgeldige vergunning. Dit betekent dat wanneer aan de vergunninghouder overtreding van $\S 330 \mathrm{a}$ StGB wordt tenlastegelegd het mogelijk is de ambtenaar als Teilnehmer of als Mittäter te vervolgen. Daarnaast kan de ambtenaar mogelijk ook als mittelbare Täter voor overtreding van $\S 330 \mathrm{a}$ StGB worden vervolgd nu deze bepaling niet uitsluitend tot vergunningadressaten is gericht. Wel zal telkens moeten worden aangetoond dat de foutieve vergunningverlening causaal was voor de gezondheidschade.

Uit het voorgaande blijkt dat in ieder geval zowel bij door rechtsmisbruik tot stand gekomen vergunningen, in het bijzonder wanneer sprake is van omkoping en collusie, als bij de (voor de mens) meest bedreigende vormen van milieuverstoring een vervolging van zowel vergunninghouder als vergunningverlener dogmatisch mogelijk wordt en deze niet reeds bij voorbaat wordt belet door 'de macht' van de onrechtmatige vergunning.

Samengevat kan worden vastgesteld dat in de visie van de heersende leer de strafrechtelijke aansprakelijkheid van milieu-ambtenaren voor de verlening van nietige vergunningen dogmatisch vrij eenvoudig kan worden onderbouwd. In beginsel is bij nietige vergunningverlening een Amtsträgerstrafbarkeit mogelijk, zij het dat deze bij de kwaliteitsdelicten enkel op grond van deelneming kan worden geformuleerd. Is de vergunning onrechtmatig verleend maar niettemin rechtsgeldig dan kan de ambtenaar uitsluitend via mittelbare Täterschaft worden vervolgd. Dit is echter enkel mogelijk bij de gemene milieudelicten ( $\S \S$ 324 en $326 \mathrm{StGB}$ ). De strafrechter moet dan het ambtelijk handelen aan het bestuursrecht toetsen en is daarbij gebonden aan de beoordelingsvrijheid van de ambtenaar. Bij door rechtsmisbruik tot stand gekomen vergunningen is een strafrechtelijke aansprakelijkheid

1499. Laufhütte, H. en Mörenschlager, M., l.c., 1980, 920; Heine, G. en Meinberg, V., o.c., 1988, 51. 
van de ambtenaar dan weer iets makkelijker, namelijk wanneer sprake is van omkoping en collusie ( $\S 330 \mathrm{~d}$ Nr. 5 StGB). Daarnaast kunnen ambtenaren als Teilnehmer, Mittäter of mittelbare Täter worden vervolgd voor het verlenen van vergunningen, die conform § 330a StGB een gevaar voor de menselijke gezondheid opleveren.

\section{Enkele illustraties uit de rechtspraak}

De rechtspraak erkent in beginsel geen ruime toetsingsbevoegdheid van de strafrechter. De strafrechter is gebonden aan rechtsgeldige beschikkingen zelfs indien deze onrechtmatig zijn. De strafrechtelijke toetsing wordt dus principieel Verwaltungsaktsakzessorisch ingevuld. ${ }^{1500}$ Dit bemoeilijkt de mogelijkheid om ambtenaren strafrechtelijk aansprakelijk te stellen voor wederrechtelijke vergunningverlening.

Een belangrijke uitspraak in dat verband is de beslissing van OLG Frankfurt. Het interessante aan deze zaak is dat zowel de vergunninghouder - meer bepaald via $\S 14 \mathrm{StGB}$ de directeur van de vergunningplichtige onderneming ${ }^{1501}$ - als de vergunningverlenende ambtenaar werden vervolgd. De eerste werd vervolgd en veroordeeld voor het in strijd met de vergunningsvoorwaarden lozen van afvalwater, de laatste werd vervolgd voor Strafvereitelung ( $\$ 258 \mathrm{StGB})$ maar werd daarvan vrijgesproken omdat niet aan de voorwaarden van Strafvereitelung was voldaan. Hoewel de ambtenaar in casu dus niet voor de overtreding van $\S 324$ StGB terecht stond, is deze uitspraak niettemin van groot belang omdat het OLG in dit 'Revision-Urteil' expliciet ingaat op enkele belangrijke vragen betreffende de strafrechtelijke toetsingsbevoegdheid en de daaruit voortvloeiende gevolgen voor de Amtsträgerstrafbarkeit.

\section{a. Principieel toetsingsverbod}

Allereerst brengt het OLG in herinnering dat gelet op de Verwaltungsaktsakzessorietät in beginsel uitsluitend formeel rechtsgeldige vergunningen waterverontreiniging kunnen toestaan.

\footnotetext{
'Somit ist nicht gerechtfertigt, wer Abwasser ohne Erlaubnis in ein Gewässer einleitet oder wer die erteilte Erlaubnis überschreitet, d.h. die in der Erlaubnis fetsgesetzten absoluten Höchstwerte, mit denen ihr Gegenstand und damit zugleich ihre rechtfertigende Wirkung begrenzt werden, nicht einhält (...) Dem entspricht der Standpunkt, daß die bloße Erlaubnisfähigkeit nicht rechtfertigend wirkt, vielmehr der formale Gestattungsakt erforderlich ist'. ${ }^{1502}$
}

1500. Keller, R., Zur strafrechtlichen Verantwortlichkeit des Amtsträgers für fehlerhafte Genehmigungen im Umweltrecht', in Festschrift K. Rebmann zum 65. Geburtstag, München, $1989,246$.

1501. Zie over het toepassingsgebied en de voorwaarden van § 14 StGB hoofdstuk III.

1502. OLG Frankfurt, 22 mei 1987, JR 1988, 169-170. 
Het OLG laat geen twijfel bestaan over de kwestie dat de strafrechter ook gebonden is aan onrechtmatige vergunningen:

\begin{abstract}
'Insoweit entspricht es auch ganz h. M., daß es bei der behördlichen Gesttatung alleine auf die Verwaltungsrechtliche (formelle) Wirksamheit ankommt; eine zu Unrecht ausgesprochene oder fehlerhaft gewordene Gestattung macht das Verhalten bis zur Rücknahme oder zum Widerruf grundsätzlich rechtmäßig.' ${ }^{1503}$
\end{abstract}

De strafrechter moet dus onrechtmatige vergunningen respecteren zolang deze niet zijn ingetrokken, hetgeen impliceert dat de vergunninghouder in dergelijk geval niet zonder rechtsgeldige vergunning handelt en dus geen strafbaar feit pleegt. In casu werkt de beperkte toetsingsbevoegdheid in het nadeel van de vergunninghouder, want hem werd niet lozen zonder rechtsgeldige vergunning maar overschrijding van de in de vergunning neergelegde voorwaarden (Höchstwerte) tenlastegelegd. Het feit dat deze voorwaarden onrechtmatig (te soepel) zijn vastgesteld, tast geenszins de wederrechtelijkheid van het handelen van de vergunninghouder aan, want de strafrechter is gebonden aan de rechtsgeldigheid en niet aan de rechtmatigheid van de vergunning(svoorwaarden): ook de overtreding van onrechtmatige maar rechtsgeldige voorwaarden is strafbaar. Om risico van straf te ontwijken had de vergunninghouder deze voorwaarden via de administratieve rechtsgang moeten aanvechten. In de woorden van het OLG, de strikte gebondenheid van de strafrechter dient ook

'für die von der Verwaltungsbehörde festgesetzten Höchstwerten zu gelten, zumal es dem Normadressaten freisteht, im Wege der Verwaltungsklage gegen zu Unrecht festgesetzte Höchstwerte vorzugehen. ${ }^{1504}$

\title{
b. Gevolgen voor de Amtsträgerstrafbarkeit bij gemene milieudelicten
}

Het OLG Frankfurt onderzoekt vervolgens wat de gevolgen zijn van de beperkte toetsingsmogelijkheden van de strafrechter voor de strafrechtelijke aansprakelijkheid van de ambtenaar met name in de situatie waarin een vergunninghouder zelf 'befugt' handelt omdat deze beschikt over een rechtsgeldige zij het onrechtmatige vergunning. Kan de vergunningverlener, juist in het geval waarin de vergunninghouder vrijuit gaat, toch nog aansprakelijk worden gesteld?

In de meeste gevallen geldt als regel dat wanneer in hoofde van de vergunninghouder geen wederrechtelijk grondfeit voorligt ook de vergunningverlener vrijuit moet gaan. Dit vloeit voort uit de omstandigheid dat in de praktijk de vergunningverlener meestal als Teilnehmer of als Mittäter zal worden vervolgd en daarvoor is nu eenmaal een strafbaar grondfeit vereist. Maar zoals reeds werd vastgesteld, gaat deze regel niet op wanneer men overweegt 
de vergunningverlener als mittelbare Täter te vervolgen. Het OLG formuleert de criminele betrokkenheid van de vergunningverlener als mittelbare Täter als volgt:

'Liegt in dem dargestellten Sinne unbefugtes Handeln des Amtsträgers vor, so ist er als mittelbarer Täter der Gewässerverunreinigung anzusehen, die er durch ein rechtmäßig handelndes Werkzeug herbeiführt. ${ }^{1505}$

Voor mittelbare Täterschaft is evenwel vereist dat de uitvoerder of onmiddellijke dader (de vergunninghouder) straffeloos moet zijn. ${ }^{1506}$ Die straffeloosheid kan verschillende oorzaken hebben. De uitvoerder kan handelen zonder opzet of beroep doen op een strafuitsluitingsgrond. De straffeloosheid van de onmiddellijke dader vormt in casu geen probleem nu een rechtsgeldige vergunning in principe rechtvaardigend werkt en de vergunninghouder in die zin formeel rechtmatig en derhalve straffeloos handelt. Meer zelfs, de straffeloosheid van de uitvoerder is een noodzakelijke voorwaarde voor de strafbaarheid van de mittelbare Täter. Dat de vergunninghouder, als unmittelbare Täter, rechtmatig heeft gehandeld en dus vrijuit gaat, speelt voor de vaststelling van de wederrechtelijkheid van de vergunningverlening in hoofde van de ambtenaar als mittelbare Täter geen rol. Moet dus worden onderzocht in hoeverre de strafrechter in staat is om het optreden van de ambtenaar te toetsen. Met andere woorden, wanneer is de vergunningverlening 'unbefugt' in de zin van $\S$ $324 \mathrm{StGB}$ ? Het OLG neemt terzake een helder standpunt in:

'Tatsächliche Anknüpfungspunkte einer strafrechtlichen Verantwortlichkeit des Angeklakten B. (de verdachte ambtenaar, DR) im Blick auf § 324 StGB können der Erlaß einer materiell fehlerhaften, etwa die Mindestanforderungen nach $\S 7 \mathrm{a}$ WHG nicht beachtenden Erlaubnis (...) sein. Soweit als Tathandlung die fehlerhafte Erteilung der wasserrechtlichen Erlaubnis in Betracht kommt, ist zunächst zu prüfen, ob diese Handlungsweise für den Erfolg "Gewässerverunreinigung" ursachlich geworden ist. Anhand des materiellen Verwaltungsrechts - insbesondere des $\S 7 \mathrm{a}$ WHG - ist sodann zu entschieden, ob die erteilte Erlaubnis rechtmäßig war oder nicht. Hiernach richtet sich, ob der Amtsträger befugt i.S. von $\S 324$ StGB gehandelt hat. Ist der Amtsträger danach innerhalb eines ihm vom Wasserhaushaltsrecht eingeräumten Ermessensoder Beurteilungsspielraumes geblieben, hat er verwaltungsrechtlich und demnach auch strafrechtlich nicht rechtswidrig gehandelt. Bei der Überprüfung dieser Frage darf der Strafrechter jedoch seine eigenen Zweckmäßigkeitserwägungen nicht an die Stelle des Amtsträgers setzen. (Cursief, DR) $)^{1507}$

Het uitgangspunt is duidelijk. De vergunningverlening moet worden getoetst aan het bestuursrecht, meer bepaald het materiële milieurecht (in casu het Wasserhaushaltsrecht). 
Daarbij moet de strafrechter de bestaande beoordelingsvrijheid van de ambtenaar respecteren en mag hij zijn oordeel niet in de plaats van het bestuur stellen. Is de ambtenaar binnen de beoordelingsruimte gebleven, dan valt hem strafrechtelijk niets te verwijten. Met andere woorden, de wettelijk toegestane beoordelingsruimte is voor de ambtenaar een strafrechtelijke rechtvaardigingsgrond en maakt de door de vergunningverlening veroorzaakte verontreiniging 'befugt'. Het spreekt voor zich dat de strafrechter niet de doelmatigheid van de vergunning mag toetsen. Maar een rechtmatigheidstoetsing van de beoordelingsruimte sluit het OLG geenszins uit:

Die darin zum Ausdruck kommende Verwaltungsakzessorietät des
Umweltstrafrechts verbietet es dem Strafrechter jedoch nicht, das Verwal-
tungsermessen auf Fehler zu überprüfen. Der Strafrichter wird dadurch,
daß der Gesetzgeber eine Strafrechtsnorm geschaffen hat, die ihre
rechtfertigende Elemente aus einem anderen Rechtsgebiet ableitet, zum
gesetzlichen Richter für die Feststellung der materiellen Rechtswidrigkeit
von Verwaltungsakten. Soweit sich daher mögliche Rechtfertigungs-
gründe aus dem Verwaltungsrecht ergeben, ist der Strafrichter gehalten,
auch insoweit eine umfassende Prüfung vorzunehmen. Bei der Bestim-
mung der Reichweite des Rechtfertigingsgrundes ist die wasserhaushalts-
rechtliche Pflichtenstellung des Amtsträgers zu berücksichtigen, da die
Regeln des Wasserhaushaltsrechts nicht vom strafrecht her aufgerollt
werden dürfen. Denn es würde einen unauflösbaren Wertungswider-
spruch bedeuten, wenn ein Verhalten, das verwaltungsrechtlich zulässig
ist, vom Strafrichter als verboten erachtet wird. (Cursief, DR) ${ }^{1508}$

De strafrechter moet de beoordelingsvrijheid niet blindelings aanvaarden; hij beschikt over de mogelijkheid het freies Ermessen te toetsen. Dit vloeit volgens het OLG rechstreeks voort uit de strafbaarstelling van $\S 324$ StGB ${ }^{1509}$ Of de vergunningverlening 'unbefugt' is in de zin van $\S 324 \mathrm{StGB}$ moet in concreto worden beoordeeld aan de hand van het geldende bestuursrecht. Het OLG doet daarbij beroep op de eenheid van rechtsorde hetgeen in dit verband betekent dat de strafrechter weliswaar niet autonoom maar wel aan het materiële bestuursrecht mag toetsen. Het is aardig om te zien hoe in eenzelfde uitspraak een dubbel(zinnig) beroep wordt gedaan op de eenheid van rechtsorde: enerzijds wordt, als het gaat om de beoordeling van het handelen van de vergunninghouder als unmittelbare Täter, de eenheid van rechtsorde ingeroepen om een strikte gebondenheid van de strafrechter aan de formele rechtsgeldigheid van vergunningen te rechtvaardigen; anderzijds wordt, als het gaat om de beoordeling van de vergunningverlening in hoofde van de ambtenaar als mittelbare Täter, op de eenheid van rechtsorde beroep gedaan om een veel ruimere strafrechtelijke toetsing aan het bestuursrecht mogelijk te maken.

Waterrechtelijk gezien beschikken milieuambtenaren over een ruim 'Bewirtschaftungsermessen' ( $\S$ 1a Abs. 1 WHG). De strafrechter is hieraan gebonden: wat binnen deze

1509. Mutatis mutandis gelden deze overwegingen van het OLG Frankfurt dus ook voor $\S 326$ StGB. 
beoordelingsruimte blijft is waterrechtelijk gezien rechtmatig en kan niet tegelijk strafrechtelijk wederrechtelijk zijn. Daaruit volgt omgekeerd dat de vergunningverlening wederrechtelijk is telkens wanneer de ambtenaar de beoordelingsruimte overschrijdt:

'Daraus folgt jedoch nicht, daß behördliches Handeln nur dann unbefugt wird, wenn es die Form objektiver Willkür erreicht hat. Entscheidend ist vielmehr, ob die erteilte Erlaubnis noch im Rahmen des vom Wasserhaushaltsrecht eingeräumten Ermessens- oder Beurteilungsspielraums liegt. (Cursief, DR) $)^{1510}$

Het OLG voegt hieraan nog toe dat indien de ambtenaar zich zou hebben vergist omtrent de precieze omvang van de beoordelingsvrijheid, hij zich zou kunnen beroepen op rechtsdwaling (§ $17 \mathrm{StGB})$ :

'Sollte der Amsträger insoweit die Grenzen seines Verwaltungsermessens verkannt haben, sich somit subjektiv pflichtgemäß verhalten haben, ist an einen Verbotsirrtum gemäß § $17 \mathrm{StGB}$ zu denken.' ${ }^{1511}$

Aangezien de strafrechter kan toetsen aan het materiële bestuursrecht, betekent dit wel dat formele onrechtmatigheden geen wederrechtelijke vergunningverlening opleveren.

'Form-, Zuständigkeits- oder Begrundungsfehler vermögen allerdings eine strafrechtliche Verantwortlichkeit des Amtsträgers nach § 324 StGB nicht zu begründen. ${ }^{1512}$

Uit deze uitspraak komen met betrekking tot de Amtsträgerstrafbarkeit voor overtreding van gemene milieudelicten vier belangrijke vuistregels duidelijk naar voren: ${ }^{1513}$

1. De strafrechter is voor de beoordeling van de milieuverstorende gedraging van de vergunninghouder gebonden aan onrechtmatige vergunningen zolang ze rechtsgeldig zijn;

2. Een strafrechtelijke aansprakelijkheid van de vergunningverlener via Teilnahme of Mittäterschaft is dan uitgesloten wegens het ontbreken van een wederrechtelijk hoofdfeit;

3. De ambtenaar kan derhalve uitsluitend mittelbare Täterschaft worden tenlastegelegd; 


\section{De ambtenaar heeft als mittelbare Täter een strafbaar feit gepleegd} wanneer de vergunning opzettelijk in strijd met het materiële bestuursrecht is verleend.

Bemerk evenwel dat sinds 1994, met de invoering van $\S 330$ d Nr. 5 StGB, de mogelijkheid om de vergunningverlener op grond van Teilnahme en Mittäterschaft te vervolgen is uitgebreid, daar in de door de wetgever opgesomde gevallen van rechtsmisbruik, met name bij omkoping en collusie, niet langer sprake is van een strafuitsluitende vergunning. Dit betekent dat in een dergelijk geval steeds een wederrechtelijk hoofdfeit voorligt wat vervolging van de vergunningverlener als Teilnehmer of als Mittäter mogelijk maakt.

\section{c. Gevolgen voor de Amtsträgerstrafbarkeit bij kwaliteitsmilieudelicten}

Dat vooral bij kwaliteitsmilieudelicten de beperkte strafrechtelijke toetsingsbevoegdheid tot onbevredigende resulaten leidt, wordt zeer duidelijk in het omstreden 'ALKEM-Urteil' van het LG Hanau. De onderneming ALKEM GmbH exploiteerde reeds sinds 1964 een kernbrandstoffenfabriek. $\mathrm{Zij}$ had daarvoor een op grond van het Atomgezets verleende exploitatievergunning en dit voor een termijn van 10 jaar. Na het verstrijken van deze termijn (1975) werd door ALKEM bij de bevoegde vergunningverlenende instantie, het Hessische ministerie voor economie en techniek, een nieuwe vergunning aangevraagd. De vergunningsprocedure nam in totaal ruim 10 jaar in beslag zodat pas in oktober 1987 een eerste 'Teilerrichtigungsgenehmigung' werd verleend. In de tussentijd bracht de onderneming wel een aantal belangrijke veranderingen aan in de kerntechnische inrichting zonder dat daarvoor de noodzakelijke procedure was gevolgd en de vereiste vergunning was verleend. Het ministerie was van dit alles op de hoogte maar liet de bedrijfsveranderingen uitdrukkelijk toe, echter niet middels de daarvoor noodzakelijke vergunning maar op grond van vooruitakkoorden, zogeheten 'Vorabzustimmungen'. Het openbaar ministerie besluit zowel de bedrijfsvoerders van ALKEM als de verantwoordelijke ambtenaren van het bewuste ministerie te vervolgen voor het 'ohne die erforderliche Genehmigung' aanbrengen van wezenlijke veranderingen in de kerntechnische inrichting (schending van $\S$ 327 Abs. 1 StGB). De Vorabzustimmungen hebben immers geen bestanddeeluitsluitende werking, nu zij geen erforderliche Genehmigungen in de zin van $\S 327 \mathrm{StGB}$ zijn. Evenmin hebben zij een rechtvaardigende werking, daar ze door 'kollusiven Zusammenwirkens' waren tot standgekomen. De betrokken ambtenaren wordt deelneming, meer bepaald Beihilfe (medeplichtigheid) aan het gepleegde feit tenlastegelegd aangezien $\S 327 \mathrm{StGB}$ als kwaliteitsdelict de ambtenaren van Mittäterschaft uitsluit.

Alvorens tot een oordeel te komen over de tenlastegelegde medeplichtigheid van de ambtenaren, moet het LG Hanau kort gezegd drie belangrijke voorvragen beantwoorden: (1) kunnen de Vorabzustimmungen worden beschouwd als erforderliche Genehmigungen in de zin van § $327 \mathrm{StGB}$; (2) indien niet, kunnen zij dan als rechtvaardigingsgronden worden beschouwd en zo alsnog de strafbaarheid van het gepleegde feit uitsluiten en (3) is ter beoordeling van deze rechtvaardigende werking de strafrechter gebonden aan de formele rechtsgeldigheid of aan de materiële rechtmatigheid van deze beschikkingen? 
Wat de eerste vraag betreft is het LG zeer duidelijk. Vorabzustimmungen zijn weliswaar administratieve beschikkingen maar zijn niet aan te merken als de door $\S 327 \mathrm{StGB}$ vereiste vergunningen:

\begin{abstract}
'Die sog. Vorabzustimmungen sind nämlich nicht die erforderliche Genehmigung i.S. des $\S 327$ StGB (...) Hierunter sind nicht jegliche Gestattungsakt zu verstehen, sondern nur solche, die zumindest dem Typ nach eine Genehmigung i. S. des $\S 7$ AtG darstellen (...) Für die 6 angeklagten Änderungen im Betrieb der Alkem GmbH waren Genehmigungen nach § 7 I AtG erfoderlich (...) § 7 AtG ist die einzige Vorschrift im AtG, die die Gestattung wesentlicher Änderungen regelt und diese ohne Einschränkung dem förmlichen Genehmigungserfordenis unterwirft. 1514
\end{abstract}

De conclusie is dan ook dat de veranderingen in de kerntechnische inrichting de delictsomschrijving van $\S 327$ StGB vervullen: de vooruitakkoorden hebben derhalve geen bestanddeeluitsluitende werking.

Veel belangrijker is dan de vraag of de bedrijfsveranderingen toch geen strafbaar grondfeit opleveren omdat ze alsnog door de Vorabzustimmungen zijn toegestaan. Het feit dat deze vooruitakkoorden niet bestanddeeluitsluitend zijn, wil immers nog niet zeggen dat zij niet alsnog als rechtvaardigingsgrond kunnen worden aangemerkt. Het belangwekkende van deze affaire is natuurlijk dat de Vorabzustimmungen als zodanig onrechtmatig waren:

\begin{abstract}
'Die Vorabzustimmungsbescheide sind (...) rechtswidrig. Für den Erlaß von Vorabzustimmungen fehlt es an einer Rechtsgrundlage im Atomgesetz. Sie bedürfen einer solchen gesetzlichen Grundlage jedoch, soweit sie wesentliche Änderungen gegenstatten, weil sie nicht nur begünstigenden Charakter haben, sondern auch belastenden, soweit sie geeignet sind, die Gefahren für Leben und Gesundheit der im Umfeld der Anlage wohnenden und arbeitenden Bevölkerung zu erhöhen. ${ }^{1515}$
\end{abstract}

Rest dus de vraag of de strafrechter ondanks de onrechtmatigheid van de vooruitakkoorden deze toch moet respecteren en derhalve moet aanmerken als rechtvaardigingsgronden omdat hij gebonden is aan de rechtsgeldigheid van deze beschikkingen en niet aan de rechtmatigheid ervan. Het LG volgt in deze kwestie de heersende leer en concludeert dan ook dat zelfs deze onrechtmatige Vorabzustimmungen in beginsel een rechtvaardigingsgrond opleveren zolang zij niet nietig zijn. De consequentie van deze gebondenheid van de strafrechter aan de vooruitakkoorden ligt voor de hand: medeplichtigheid is in hoofde van de verdachte ambtenaren in beginsel uitgesloten daar er geen strafbaar grondfeit voorligt. Interessant is echter dat het LG op deze principiële gebondenheid een aantal belangrijke 
uitzonderingen toelaat door beroep te doen op het (toen nog niet in $\S 330 \mathrm{~d} \mathrm{Nr}$. $5 \mathrm{StGB}$ neergeschreven) leerstuk van rechtsmisbruik:

'Das Handeln der Geschäftsführer der Alkem GmbH war durch die Vorabzustimmung des Hessischen Ministers für Wirtschaft und Technik jedenfalls gerechtfertigt (...) Auch rechtswidrige Verwaltungsakte stellen Rechtfertigungsgründe dar, wenn sie nicht nichtig sind, es sei denn, daß sie aufgrund der Kenntnis der Adressaten von der Rechtswidrigkeit keinen Vertrauenstatbestand schaffen (...) Wirksame und zur Rechtfertigung eines Verhaltens geeignete Verwaltungsakte sind in ihrer Rechtfertigungswirkung zurückgedrängt, wenn der Empfänger der behördliche Gestattung deren Rechtswidrigkeit bei Vornahme seiner Handlungen kannte. ${ }^{1516}$

De strafrechter is volgens het LG dus niet alleen niet gebonden aan nietige beschikkingen, maar kan tevens, op grond van rechtsmisbruik, beschikkingen waarvan de adressaat weet dat ze onrechtmatig zijn naast zich neer leggen. De beperkingen op de gebondenheid van de strafrechter die het LG in casu toelaat gaan in die zin zelfs verder dan algemeen door de literatuur wordt aanvaard. ${ }^{1517}$ Uiteindelijk mag dit alles niet baten, want het LG spreekt alle verdachten vrij wegens gebrek aan bewijs:

'Die rechtswidrigen Verwaltungsakte stellen geeignete Rechtfertigungsgründe für das Handeln der Geschäftsführer der Alkem GmbH dar, da sie nicht nichtig sind. Die Vorabzustimmungensbescheide wären nichtig, weil sittenwidrig i.S. von $\S 44 \mathrm{II}$ Nr. 6 Hess. VwVfG, wenn die angeklagten Beambten sie in Kenntnis ihrer Rechtswidrigkeit sowie des Gebots der Öffentlichkeitsbeteiligung erlassen hätten. Derartiges hat die Kammer aber nicht feststellen können (...) Die damit trotz ihrer Rechtswidrigkeit nach außen wirksamen Vorabzustimmungen sind auch nicht im Einzelfall in ihrer rechtfertigenden Wirkung zurückgedrängt. Dies wäre zwar möglich, wenn die ehemaligen Mitangeklagten S und W die Rechtswidrigkeit der Verwaltungsakte gekannt hätten. Derartiges hat die Kammer aber nicht feststellen können. ${ }^{1518}$

Kortom, de bedrijfsvoerders worden vrijgesproken aangezien hen geen strafbaar feit kan worden verweten; zij kunnen zich beroepen op de onrechtmatige maar niettemin rechtsgeldige Vorabzustimmungen. De ambtenaren worden vrijgesproken nu bij gebrek aan

1516. Idem.

1517. Het LG gaat trouwens ook verder dan het in 1994 ingevoerde $\S 330 \mathrm{~d} \mathrm{Nr}$. 5 StGB: volgens deze bepaling volstaat het louter op de hoogte zijn van de onrechtmatigheid van de vergunning niet 1518. Idem. om de vergunning iedere strafrechtelijke rechtsgeldigheid te ontzeggen. 
een strafbaar grondfeit zij niet als Teilnehmer strafrechtelijk aansprakelijk kunnen worden gesteld. $^{1519}$

Het pijnlijke van deze uitspraak ligt vooral in de omstandigheid dat de ambtenaren door (althans door het LG aangenomen) onwetendheid omtrent de onrechtmatigheid van de vooruitakkoorden niet alleen voor de vrijspraak van de bedrijfsvoerders maar ook voor hun eigen vrijspraak hebben gezorgd. Het valt dan ook licht te begrijpen dat op deze uitspraak veel kritiek is gekomen, temeer nu het hier gaat om een voor mens en leefmilieu uiterst gevaarlijke inrichting. Een belangrijk punt van kritiek is dat moeilijk kan worden begrepen dat de bedrijfsvoerders en de ambtenaren niet op de hoogte zouden zijn geweest van de onrechtmatigheid van de vooruitakkoorden. Vooral de vrijspraak van de ambtenaren is in die zin onbegrijpelijk. Van hen mag toch wel worden verwacht dat ze het Atomgesetz kennen en juist toepassen. ${ }^{1520}$

Uit deze uitspraak kunnen met betrekking tot de Amtsträgerstrafbarkeit voor schending van kwaliteitsmilieudelicten de volgende drie vuistregels worden afgeleid:

1. de vergunningverlener kan, omdat hij de daderschapskwaliteit mist, uitsluitend op grond van Teilnahme worden vervolgd, hetgeen betekent dat een strafbaar grondfeit is vereist;

2. het grondfeit is niet wederrechtelijk zolang de vergunning waarover de adressaat beschikt rechtsgeldig is;

3. uitzonderingen op deze gebondenheid van de strafrechter, en dus ook op de straffeloosheid van vergunninghouder en vergunningverlener zijn mogelijk bij rechtsmisbruik.

Bemerk dat ook hier opnieuw rekening moet worden gehouden met de in $\S 330 \mathrm{~d} N r .5$ StGB neergelegde vormen van rechtsmisbruik die de strafuitsluitende werking van vergunningen opheffen. In de praktijk is het rechtsmisbruik in de vorm van omkoping en collusie relevant omdat slechts dan ook sprake is van een strafwaardige criminele betrokkenheid van de ambtenaar bij het milieudelict. De andere gevallen van rechtsmisbruik, zoals misleiding, bedreiging of kennis in hoofde van de adressaat van de onrechtmatigheid van de vergunning, indiceren enkel een mogelijke strafrechtelijke aansprakelijkheid van de vergunninghouder.

1519. Keller, R., l.c., 1989, 253.

1520. Horn, E., l.c, 1988, 2336: 'Der Strafrechter wundert sich aber, daß den hochqualifizierten, ausschließlich mit Verwaltungsrechtsfragen dieser Art befaßten Beambten des Genehmigungsministeriums "nicht nachgewiesen werden (konnte), daß sie die Notwendigkeit einer Öffentlichkeitsbedingung erkannten.' Wellicht zou ook met de huidige $\S 330 \mathrm{~d}$ Nr. 5 StGB het tot een vrijspraak zijn gekomen. De vrijspraak is immers eerder het gevolg van feitelijke overwegingen (gebrek aan bewijs) en niet van rechtsoverwegingen. 
Samengevat kan worden vastgesteld dat de rechtspraak treffend de gevolgen illustreert van de strikte koppeling van de materiële strafbaarheid aan de formele rechtsgeldigheid van administratieve beschikkingen. Zelfs de door de rechtspraak en thans via $\S 330 \mathrm{~d} \mathrm{Nr}$. 5 StGB door de wetgever aanvaarde uitzonderingen op deze gebondenheid van de strafrechter zijn niet steeds in staat de nadelen van deze beperkte toetsingsbevoegdheid op te heffen en leiden eerder tot ingewikkelde dogmatische constructies dan tot voor de praktijk vruchtbare oplossingen. Een belangrijk deel van de literatuur heeft dan ook ongezouten kritiek op de heersende leer en tracht tot alternatieve oplossingen te komen die zowel theoretisch als praktisch aanvaardbaar zijn.

\section{De Amtsträgerstrafbarkeit volgens de Verwaltungsrechtsakzessorische visie}

Zoals besproken, wordt in Duitsland door enkele schrijvers een Verwaltungsrechtsakzessorische visie op strafrechtelijke toetsing gezien als een bruikbaar en verdedigbaar alternatief voor de nadelen die kleven aan het strafrechtelijke toetsingsverbod. ${ }^{1521}$ Een belangrijk voordeel van deze benadering is dat de vergunninghouder zich niet langer kan verschuilen achter onrechtmatige vergunningen. Daarnaast dient volgens deze visie geen beroep te worden gedaan op rechtsmisbruik om de principiële gebondenheid van de strafrechter aan onrechtmatige vergunningen te doorbreken. Nu kan nader worden bekeken wat hiervan de gevolgen zijn voor de Amtsträgerstrafbarkeit.

\section{a. Verlening van nietige vergunningen}

Net als bij de heersende leer kan de strafrechtelijke wederrechtelijkheid van de vergunningverlening eenvoudig worden vastgesteld indien er sprake is van nietige vergunningen. Is een vergunning aangetast door gebreken die volgens $\S 44$ VWVfG nietigheid opleveren, dan is daarmee ook meteen de wederrechtelijkheid van het delict gegeven.

$\mathrm{Al}$ naargelang een gemeen of kwaliteitsmilieudelict is overtreden kan dit de vervolging van de betrokken ambtenaar als mittelbare Täter, Mittäter of Teilnehmer mogelijk maken. Wel moet worden opgemerkt dat in tegenstelling tot de heersende leer niet alle bestuursrechtelijke nietigheden dwingen tot de conclusie dat de vergunningverlening ook strafrechtelijk gezien wederrechtelijk is. In deze alternatieve opvatting moet immers nog worden onderzocht wat de oorzaak is van de nietigheid. ${ }^{1522}$ Dit kan het best aan de hand van een voorbeeld worden verduidelijkt. Stel dat $\mathrm{A}$ heeft gehandeld zonder rechtsgeldige vergunning omdat deze is verleend door een niet-bevoegde instantie B. Volgens de heersende leer is de vergunning nietig en hebben daarom zowel A als B een strafbaar feit gepleegd. De vergunningverlener maakt zich schuldig aan een strafbaar feit aangezien de strafrechtelijke wederrechtelijkheid eenvoudigweg voortvloeit uit het ontbreken van rechtsgeldigheid. De Verwaltungsaktsakzessorische visie op strafrechtelijke toetsing impliceert een binding aan de rechtsgeldigheid, hetgeen betekent dat wanneer de vergun-

1521. Zie voor een heldere bespreking van deze Mindermeinung Schmitz, R., o.c., 1992, 45-58.

1522. Schmitz, R., o.c., 1991, 49-56. 
ning nietig is meteen ook de strafrechtelijke wederrechtelijkheid vaststaat. ${ }^{1523}$ Daarentegen hangt in een Verwaltungsrechtsakzessorische visie op toetsing de strafrechtelijke wederrechtelijkheid in de eerste plaats af van de vraag door welke onrechtmatigheid de nietigheid van de vergunning werd veroorzaakt. Is de nietigheid het gevolg van een louter formeel gebrek, zoals in het voorbeeld, dan hoeft dit nog niet te betekenen dat het grondfeit ook strafbaar is. Dit zal - althans volgens sommige schrijvers ${ }^{1524}$ - alleen zo zijn als het geschonden formele voorschrift ook de bescherming van het ecologische rechtsgoed dient. $\mathrm{Nu}$ dienen de bevoegdheidsregels onmiskenbaar ook de bescherming het leefmilieu en vanuit dat perspectief is de vergunningverlening niet alleen nietig maar meteen ook strafrechtelijk wederrechtelijk. Het is echter van belang te onderstrepen dat deze wederrechtelijkheid niet het automatische gevolg is van de (formele) nietigheid, maar van een daadwerkelijke toetsing door de strafrechter aan het bestuursrecht. Dit vloeit voort uit de reeds eerder aangehaalde moderne opvatting van eenheid van rechtsorde. Daarin staat een meerduidig en hiërarchisch gestructureerd wederrechtelijkheidsbegrip centraal. ${ }^{1525}$ Dit betekent enerzijds dat wat bestuursrechtelijk rechtmatig is niet strafrechtelijk onrechtmatig kan zijn - in die zin wordt aan de eenheid van rechtsorde recht gedaan - maar anderzijds hoeft niet iedere bestuursrechtelijke onrechtmatigheid een strafrechtelijke onrechtmatigheid te impliceren, wat wel het geval is indien wordt uitgegaan van een eenduidig onrechtmatigheidsbegrip. In een meerduidige kijk op de eenheid van rechtsorde daarentegen wordt door de bestuursrechtelijke onrechtmatigheid, die al dan niet een nietigheid kan opleveren, de strafrechtelijke wederrechtelijkheid alleen maar geïndiceerd. Of het feit daadwerkelijk strafrechtelijk gezien wederrechtelijk is en in die zin strafwaardig, moet worden bekeken aan de hand van de vraag of de geschonden norm meer doet dan louter administratieve plichten beschermen. Er is dan vanzelfsprekend wel het risico van tegenspraken tussen bestuursrecht en strafrecht, want wat bestuursrechtelijk onrechtmatig is kan best tegelijk strafrechtelijk rechtmatig zijn, maar deze tegenspraak geldt slechts in één richting en is geoorloofd gelet op enerzijds het ultimum ratio-karakter van het strafrecht en anderzijds de rechtsgoedbeschermende functie van het strafrecht. ${ }^{1526}$

Wel mag niet worden vergeten dat deze benadering volgens de literatuur alleen opgaat bij de gemene delicten omdat daar inderdaad het ecologische rechtsgoed als zodanig strafrechtelijk wordt beschermd. Bij de kwaliteitsdelicten loopt een rechtsgutbezogentoetsing mank aangezien bij deze delicten door de wetgever veeleer de schending van administratieve plichten is strafbaar gesteld en niet de aantasting van het ecologische

1523. Met andere woorden, aangezien volgens de heersende rechtspraak en rechtsleer de strafrechter blind vaart op de rechtsgeldigheid van vergunningen, neemt hij even blindelings de nietigheid van de vergunning voor strafrechtelijk relevant aan. Dit zal uitsluitend in de situatie waarin bij gemene delicten de ambtenaar als middelijke dader wordt vervolgd anders zijn. Daar heeft de rechtspraak immers aangenomen dat uitsluitend materiële onrechtmatigheden de strafbaarheid van de ambtenaar kunnen constitueren, hetgeen betekent dat in ons voorbeeld de vergunningverlener geen strafbaar feit heeft gepleegd. (Zie OLG Frankfurt, 22 mei 1987, JR 1988, 169170).

1524. Zie o.m. R. Schmitz, o.c., 1992, 51 en de daar aangehaalde literatuur.

1525. Rogall, K., o.c., 1991, 186-191; Schmitz, R., o.c., 1991, 49-56.

1526. Schmitz, R., o.c., 1991, 52-53. 
rechtsgoed als dusdanig. ${ }^{1527}$ Ook moet worden opgemerkt dat de meeste formele voorschriften waarvan de schending een nietigheid oplevert, ook tegelijk de ecologische rechtsgoederen beschermen. In die zin maakt het verschil in uitgangspunt tussen heersende leer en Mindermeinung bij nietige vergunningen voor de praktijk weinig uit. Vanuit het perspectief van een dogmatisch aanvaardbare onderbouwing en rechtvaardiging van de strafrechtelijke aansprakelijkheid van zowel vergunninghouder als vergunningverlener daarentegen is er echter veel voor te zeggen de aansprakelijkheid van beiden daadwerkelijk te laten afhangen van een zelfstandige toetsing aan die materiële èn formele normen die gericht zijn op de bescherming van het leefmilieu. Het voordeel blijft immers dat de nadelen van twee uitersten worden vermeden. Enerzijds vervalt men niet in het uiterste van de heersende leer waarbij iedere nietigheid het gepleegde feit meteen ook wederrechtelijk en dus strafbaar maakt. In die zin is er strafprocesrechtelijk gezien mogelijk ook meer ruimte voor debat over de strafwaardigheid van de verboden gedraging en komt het contradictoire karakter van het strafproces meer tot zijn recht. Anderzijds vermijdt men de extreme opvatting van een autonome strafrechtelijke controle waarbij iedere band met het objectieve milieurecht wordt losgelaten en waarbij helemaal niet duidelijk is aan welke normen moet worden getoetst.

\section{b. Verlening van onrechtmatige (maar rechtsgeldige) vergunningen}

Wat ons vooral interesseert zijn die gevallen waarin onrechtmatige, maar niettemin rechtsgeldige vergunningen zijn verleend. In tegenstelling tot de heersende leer is een Verwaltungsrechtsakzessorische visie op toetsing wel in staat de wederrechtelijkheid van een dergelijke vergunningverlening vast te stellen. Volgens deze visie hoort de strafrechter immers niet principieel gebonden te zijn aan de rechtsgeldigheid van onrechtmatige vergunningen. ${ }^{1528}$ Door de strafrechter het recht te geven ook rechtsgeldige vergunningen te toetsen aan het materiële én formele milieubestuursrecht, is het mogelijk op flexibele wijze in ieder concreet geval te bekijken of de vergunninghouder en mogelijk ook de vergunningverlener zich schuldig hebben gemaakt aan een strafbaar feit. Bovendien is het niet nodig dat de strafrechter een beroep moet doen op constructies zoals rechtsmisbruik om de nadelen van de gebondenheid aan de rechtsgeldigheid van vergunningen op te heffen.

In de casuspositie waarin een kwaliteitsmilieudelict is overtreden impliceert de rechtsgeldigheid van de vergunning niet meteen dat de vergunninghouder en daarmee ook de vergunningverlener vrijuit gaat. Dit is wel zo volgens de heersende leer tenzij er sprake is van (bepaalde vormen van) rechtsmisbruik. ${ }^{1529}$ Is een vergunning in strijd met wet of recht verleend dan is volgens een Verwaltungsrechtsakzessorische visie op toetsing in beginsel ook het gepleegde grondfeit wederrechtelijk. ${ }^{1530}$ En eens er een wederrechtelijk grondfeit voorligt, bestaat de mogelijkheid de ambtenaar als Teilnehmer te vervolgen.

1527. Vgl. Faure, M. en Visser, M., o.c., 1999, 65-75.

1528. Schmitz, R., o.c., 1992, 45-48.

1529. Rogall, K., o.c., 1991, 192-195.

1530. Schmitz, R., o.c., 1992, 45-56; Rogall, K., o.c., 1991, 186-188. 
In het geval waarin een gemeen milieudelict is overtreden, is het niet alleen mogelijk de ambtenaar als mittelbare Täter te vervolgen. Een Verwaltungsrechtsakzessorische visie op toetsing opent ook de mogelijkheid om de vergunningverlener als Mittäter of als Teilnehmer te vervolgen. Volgens de heersende leer is dat alleen mogelijk bij rechtsmisbruik. ${ }^{1531}$ In alle andere gevallen van wederrechtelijke vergunningverlening blijft het grondfeit niet-strafbaar zodat de vergunninghouder straffeloos blijft en de vergunningverlenende ambtenaar slechts kan worden aansprakelijk gesteld indien hij als mittelbare Täter bij het delict betrokken is. We hebben gezien dat wederrechtelijke vergunningverlening, gekwalificeerd als mittelbare Täterschaft, evenwel een tegenspraak binnen het strafrecht tot gevolg heeft: de vergunninghouder handelt in een dergelijk geval rechtmatig, want hij beschikt over een rechtsgeldige vergunning, terwijl de ambtenaar als mittelbare Täter een strafbaar feit pleegt omdat hij een onrechtmatige vergunning heeft verleend. Een dergelijke tegenspraak is bij de Verwaltungsrechtsakzessorische visie op toetsing afwezig daar aan de strafrechtelijke aansprakelijkheid van zowel de vergunninghouder als de vergunningverlener eenzelfde milieustrafrechtelijke toetsing en wederrechtelijkheidsnotie ten grondslag liggen. Daartegen zou kunnen worden ingebracht dat de mogelijke strafbaarheid van de vergunninghouder te veel wordt uitgebreid. Immers, de zuivere rechtsgeldigheid van de vergunning rechtvaardigt volgens de Verwaltungsrechtsakzessorsische visie niet langer automatisch de milieuverstorende gedraging. Het gevaar dat aldus de vergunninghouder aan een ongeoorloofd risico van strafoplegging zou worden blootgesteld is echter beperkt daar hij zijn gerechtvaardigd vertrouwen in de rechtmatigheid van de vergunning als strafuitsluitingsgrond kan aanvoeren door beroep te doen op dwaling. Is dat gerechtvaardigd vertrouwen niet aanwezig, bijvoorbeeld wanneer hij kennis heeft van de onrechtmatigheid van de vergunning, dan is er ook geen reden waarom de vergunninghouder zich op deze vergunning zou mogen beroepen.

Bemerk dat ook volgens de Mindermeinung de beoordelingsvrijheid van de ambtenaar moet worden geëerbiedigd en dat derhalve de strafrechter niet de doelmatigheid van de vergunningverlening mag beoordelen. ${ }^{1532}$ Het voornaamste verschil tussen de (heersende) Verwaltungsaktsakzessorische leer en de Verwaltungsrechtsakzessorische leer ligt hierin dat deze laatste visie meer (kritische) ruimte laat voor een strafrechtelijke aansprakelijkheid van zowel vergunninghouder als vergunningverlener doordat de strafrechter niet gebonden is aan onrechtmatige vergunningen, die tot de milieuverstoring hebben bijgedragen. ${ }^{1533}$

Uit het voorgaande blijkt dat een Verwaltungsrechtsakzessorsiche visie op strafrechtelijke toetsing zowel theoretisch als praktisch gezien de mogelijkheid om ambtenaren voor onrechtmatige vergunningverlening strafrechtelijk aan te pakken duidelijk vergemakkelijkt. Zowel bij een overtreding van gemene als kwaliteitsmilieudelicten is het in beginsel steeds mogelijk de vergunningverlener strafrechtelijk ter verantwoording te roepen voor zijn bijdrage aan het gepleegde feit. Anders gezegd, wederrechtelijke vergunningverlening kan

1533. Rogall, K., o.c., 1991, 192 e.v. 
steeds aan een strafrechtelijke controle worden onderworpen, zowel bij een vervolging van de vergunninghouder als wanneer men overweegt ook de vergunningverlener te vervolgen. Het gevaar van een oeverloze aansprakelijkheid is grotendeels denkbeeldig. Enerzijds heeft de koppeling van de strafrechtelijke toetsing aan leefmilieubeschermende normen voor de aansprakelijkheid niet alleen een legitimerende maar tevens ook een limiterende werking. Louter formele onrechtmatigheden impliceren, anders dan door de heersende leer wordt verdedigd, nog geen strafbaar (grond)feit. Daarnaast wordt het vertrouwen van de burger op voldoende en gepaste wijze opgevangen bij de beoordeling van de schuldvraag. Wat de mogelijke strafbaarheid van de vergunningverlener betreft mag ook niet worden vergeten dat deze niet wordt losgekoppeld van de milieubestuursrechtelijke logica en noties hetgeen impliceert dat de beoordelingsruimte waarover hij beschikt wordt gerespecteerd. Daarnaast dient zijn criminele betrokkenheid aan de milieuverstorende gedraging van de vergunninghouder nog steeds te voldoen aan de dogmatische voorwaarden van Täterschaft en Teilnahme. Met andere woorden, de wederrechtelijke vergunningverlening moet een zodanige zijn dat de ambtenaar, hetzij als dader, hetzij als deelnemer kan worden aangemerkt. Over deze kwestie heeft het Bundesgerichtshof zich uitgesproken.

\section{Amtsträgerstrafbarkeit volgens het Bundesgerichtshof}

a. Strafrechtelijke aansprakelijkheid voor (advies tot) verlening van een illegale afvalvergunning

In 1993 heeft het Bundesgerichtshof (BGH) zich over de Amtsträger-strafbarkeit voor wederrechtelijke vergunningverlening uitgesproken. Wat waren de feiten?

Een onderneming baatte reeds sinds de jaren 60 een eigen stortplaats uit voor (voornamelijk) bedrijfsafval. Daar deze stortplaats dringend moest worden hersteld en het bedrijf deze inrichting ook voor andere doeleinden wou gebruiken, vroeg de onderneming in 1985 aan het daarvoor volgens het Hessische Abfallgesetz bevoegde Regierungspräsidium om een vergunning tot verplaatsing van het afval naar een huisafvalstortplaats in een naburige gemeente. Na overleg stemde de gemeente daarmee in, onder de uitdrukkelijke voorwaarde dat het bedrijfsafval conform het Abfallgesetz met huishoudelijk afval kon worden gelijkgesteld. De vergunning werd comform de procedure door de Regierungspräsident verleend op basis van een positief advies dat was opgesteld door een externe deskundige, die in dienst was van het Präsidium. In maart 1987 was het overgrote deel van het bedrijfsafval naar de gemeentelijke stortplaats overgebracht. Later bleek dat meer dan 112.000 kubieke meter afval met zware metalen was verontreinigd. Het bedrijfsafval had dus nooit op de gemeentelijke stortplaats mogen worden gestort. De vergunning was duidelijk in strijd met het Hessische Abfallgesetz verleend geworden. De functionaris wiens advies was gevolgd bij het verlenen van de vergunning werd vervolgd en uiteindelijk door het LG Darmstadt veroordeeld tot 11 maanden gevangenisstraf voor overtreding van $\S$ $326 \mathrm{StGB}$. In deze zaak gaat het dus strikt genomen niet om een strafrechtelijke aansprakelijkheid van een vergunningverlenende ambtenaar, maar om de aansprakelijkheid van een externe functionaris die vanwege zijn technische expertise en adviserende functie een beslissende rol heeft in de totstandkoming van de vergunning. Niettemin is deze 
uitspraak ook voor de strafrechtelijke aansprakelijkheid van de vergunningverlener van groot belang, daar het BHG rechtsregels formuleert die in beginsel op alle voor de wederrechtelijke vergunningverlening verantwoordelijke personen van toepassing zijn.

Het BGH houdt de veroordeling in stand en spreekt zich eerst in algemene zin uit over de betrokkenheid van de functionaris bij het illegale afvalstort:

'Daß der Sondermüll auf die Hausmülldeponie in D. verbracht wurde, beruhte entscheidend auf der Stellungnahme des Angeklagten (...)Hätte er als zuständiger Dezernent (...) darin das Vorhaben der Firma H. nicht der Sache nach für durchführbar erklärt, hätte der Regierungspräsident es nicht genehmigt, und die Umlagerung nach D. wäre unterblieben ${ }^{\prime 1534}$

Vervolgens volgt een beschouwing over de vraag of de juridische positie van de functionaris binnen de overheidsinstantie (het Regierungspräsidium) van enig belang is voor zijn mogelijke strafbaarheid. Hij voert immers als verweer dat hij formeel niet als vergunningverlener kan worden aangemerkt en dat hij bovendien niet als ambtenaar in dienst was van het Regierungspräsidium. Het BGH oordeelt:

'Der Umstand, daß der Angeklagte (...) nicht als Bediensteter des Regierungspräsidiums gehandelt hat, ist rechtlich ohne Bedeutung. Der Angeklagte hatte zur Entscheidung des Regierungspräsidenten in gleicher Weise zu beizutragen wie wenn er in dessen Behörde tätig gewesen wäre (...) für die strafrechtliche Beurteilung entscheidend ist der tatsächliche Einfluß, den der Angeklagte auf den Geschehensablauf hatte. Nach den Feststellungen des LG folgte der Regierungspräsident seinen Vorschlägen ohne weitere Prüfung, und dies war ihm bekannt. ${ }^{.1535}$

Hier zien we een interessante gelijkenis met de Nederlandse strafrechtsfiguur van het feitelijk leidinggeven. Zoals gezien is voor het feitelijk leidinggeven niet van belang welke officiële positie de functionaris binnen de organisatie inneemt, maar is determinant in welke mate hij feitelijke zeggenschap had over de (totstandkoming van de) verboden gedraging. ${ }^{1536}$ Het $\mathrm{BGH}$ volgt hier ook een realistische benadering.

Het BHG beantwoordt vervolgens de vraag of de verboden gedraging onder de delictsomschrijving van de milieustrafbepaling valt:

'Nach den Feststellungen ist durch die von der Firma H. vorgenommene Umlagerung von Abfall der Kategorie II von einer Sonderabfalldeponie auf eine Hausmülldeponie der in $\S 326$ Abs. $1 \mathrm{Nr}, 3 \mathrm{StGB}$ vorausgesetzte tatbestandliche Erfolg eingetreten. Der umgelagerte Abfall war nach Art, 
Beschaffenheit un Menge geeignet, nachhaltig Gewässer, Luft oder Boden $\mathrm{zu}$ verunreinigen. Für Materialien von einer Umwelt-Gefährlichkeit jenseits der Kategorie I war die Hausmülldeponie in D. nicht zugelassen. $\mathrm{Ob}$ durch die Umlagerung eine konkrete Gefahr für die Umwelt eintrat, ist unerheblich. § 326 Abs. 1 StGB ist ein abstraktes Gefährdungsdelikt in dem Sinne, daß schon die generelle Eignung, eines der drei genannten Schutzgüter oder Menschen zu gefährden, ausreicht (...) Für dieses tatsbestandlichen Erfolg ist der Angeklagte als Täter verantwortlich. Eine Straftat nach $\S 326$ StGB Abs. 1 StGB kann von jedermann begangen werden, also auch von einem Amtsträger. Für die strafrechtliche Beurteilung seines Verhaltens gelten die allgemeinen Grundsätze. Eine eigenhändige Vornahme der umweltgefährdenden Abfallbeseitigung verlangt der Tatbestand des $\S 326$ Abs. 1 StGB nicht. Hier haftet der Angeklagte als Mittäter oder aber als mittelbarer Täter.' ${ }^{1537}$

$\S 326 \mathrm{StGB}$ is een gemeen delict dat door eenieder kan worden gepleegd, dus ook door de verdachte functionaris. Dit betekent dat de bijdrage van de functionaris aan het milieudelict mogelijk op grond van Mittäterschaft of mittellbare Täterschaft kan worden onderbouwd. Alvorens tot een oordeel te komen of de functionaris in casu als Mittäter of als mittelbare Täter moet worden beschouwd, voert het BGH eerst enkele beschouwingen over de voorwaarden van beide vormen van daderschap. Bemerk dat deze overwegingen in algemene bewoordingen zijn geformuleerd en dus moeten worden aangemerkt als rechtsregels die in beginsel op alle bij de vergunningverlening betrokken ambtenaren van toepassing zijn.

\section{b. Strafrechtelijke aansprakelijkheid op grond van Mittäterschaft}

Het BGH onderzoekt eerst onder welke voorwaarden het handelen van de functionaris kan worden aangemerkt als Mittäterschaft. Volgens § 25 II StGB is sprake van Mittäterschaft wanneer 'mehrere die Straftat gemeinschaftlich begehen.' Dit betekent dat de functionaris in zodanige mate en intensitiviteit bij het milieudelict betrokken moet zijn geweest, dat kan worden gezegd dat hij heeft medegepleegd. In de eerste plaats is natuurlijk pas van Mittäterschaft sprake indien zowel de eigenlijke pleger als de medepleger strafrechtelijk aansprakelijk kunnen worden gesteld voor hun handelen, zij het dat zij beiden niet alle delictsbestanddelen moeten hebben vervuld. Mittäterschaft is immers niet gecreëerd met het oog op personen die alle delictsbestanddelen vervullen. ${ }^{1538}$ Voor Mittäterschaft volstaat dat zij gezamenlijk de complete delictsomschrijving realiseren.

Een eerste voorwaarde voor Mittäterschaft is de aanwezigheid van een of andere vorm van 'gemeinsame Tatentschluss' gericht op het verwezenlijken van de delictsomschrijving. ${ }^{1539}$ Volgens het BGH is hieraan voldaan indien 'zumindest stillschweigendes Einverständnis' 
bestaat tussen de functionaris en het bedrijf aangaande de verboden gedraging, i.c. de illegale overheveling van het bedrijfsafval naar de gemeentelijke stortplaats. Er moet, met andere woorden, sprake zijn van collusie tussen de leidinggevenden van het bedrijf en de functionaris. Daarvan is volgens het BGH sprake wanneer

\section{'[...] die Verantwortlichen der Firma $H$. wußten ebenso wie der Angeklagte von Anfang an, daß das Vorhaben, aus dem verdichteten Material der Sonderabfalldeponie K. Abfälle der Kategorie II hinreichend sicher auszusondern und nur solchen der Kategorie I auf die Hausmüll- deponie D. zu verbringen, nicht durchfürbar war. Dies hat das LG zugunsten des Angeklagten unterstellt. Dann bestand hierüber zumindest stillschweigendes Einverständnis zwischen dem Angeklagten und der Firma H., so daß Mittäterschaft vorliegt.'}

Een tweede voorwaarde voor Mittäterschaft is een 'gemeinschaftliche Tatausführung' waarop de 'gemeinsame Tatentschluss' moet zijn gericht. ${ }^{1540}$ Met andere woorden, aan Mittäterschaft is pas voldaan indien de opzet van de medeplegers gericht is geweest op het gezamenlijk verwezenlijken van het strafbaar feit. Het is evenwel niet noodzakelijk dat van iedere medepleger afzonderlijk moet worden bewezen dat zijn opzet op alle bestanddelen van het delict is gericht. Het is immers eigen aan Mittäterschaft dat er een zekere rolverdeling kan zijn. Aan de vaststelling van Mittäterschaft

'steht nicht entgegen, daß der Angeklagten an der eigentlichen Tathandlung nach § 326 Abs.1 StGB nicht beteiligt war. Mittäterschaft kann auch durch die Beteiligung an Vorbereitungshandlungen begründet werden.'

De bijdrage van de Mittäter moet wel van dien aard zijn dat deze van Beihilfe (medeplichtigheid) kan worden onderscheiden. Dit impliceert dat de gedraging van de functionaris een zodanige is dat deze mede oorzakelijk is voor het gepleegde feit. Indien zonder zijn bijdrage de eigenlijke gedraging toch zou zijn gebeurd, kan slechts medeplichtigheid voorliggen. In het Duitse strafrecht moet daarom de bijdrage van de functionaris als Mittäter onder een of andere vorm van Tatherrschaft, dominus causae, kunnen worden geplaatst, hetgeen betekent dat hij een zodanige causale invloed op het delictuele gebeuren moet hebben dat kan worden gezegd dat hij mede de afloop van het delict beheerst:

'Voraussetzung dafür ist nur, daß der Betreffende auf der Grundlage gemeinsamen Wollens einen die Tatbestandsverwirklichung fördern Beitrag leistet, welcher sich nach seiner Willensrichtung nicht als bloße Förderung fremden Tuns, sondern als Teil der Tätigkeit aller darstelt, und der dementsprechend die Handlungen der anderen als Ergänzung seines eigenen Tatanteils erscheinen läßt. Wesentliche Anhaltspunkten können sein der Grad des eigenen Interesses am Erfolg, der Umfang der Tatbeteiligung, die Tatherrschaft oder die Wille zur Tatherrschaft, so daß 
Durchführung und Ausgang der Tat maßgeblich vom Willen des Betreffenden abhängen. Vorliegend war der Beitrag des Angklagten von entscheidender Bedeutung, weil es ohne seine befürwortende Stellungnahme nicht zur Zustimmung des Regierungspräsidenten, die allein der Firma $\mathrm{H}$. die unmittelbare Tatausführung ermöglichte, gekommen wäre. Der Angeklagte hatte auch ein eigenes Interesse am Erfolg; er war bestrebt, seinem Ruf als effizienter "Abfallmanager", den er bei Industrieund Behördenvertretern geno $B$, und der bereits viele drängende Abfallprobleme praktikabel und "unbürokratisch" schnell zu lösen verstanden hatte, "koste es was es wolle", gerecht zu werden. ${ }^{1541}$

De voor het 'medeplegen' vereiste Tatherrschaft vloeit dus rechtstreeks voort uit de beslissende rol van de functionaris met betrekking tot de totstandkoming van de vergunning en dus ook de verwezenlijking van het delict; zijn advies was immers doorslaggevend voor het bevoegde gezag om tot vergunningverlening over te gaan. Interessant is ook de opmerking van het BGH dat de functionaris zelf een persoonlijk belang had bij de verlening van de vergunning, en dit ten koste van het milieubelang. Zijn reputatie binnen de bedrijfswereld als 'efficiënte' afvalmanager stond immers op het spel indien hij er niet in zou zijn geslaagd een snelle oplossing te zoeken voor het afvalprobleem. In deze zaak zien we een duidelijke illustratie van wat door de rechtseconomie 'capturing' wordt genoemd. 'Capturing' houdt kort gezegd in dat het bedrijsleven zal trachten gebruik te maken van zijn informatievoordeel om de administratieve overheid die haar zou moeten controleren 'in te kapselen' waardoor zij de facto zelf de voorwaarden van deze controle bepalen. De 'capture'-theorie legt de nadruk op het risico van een collusierelatie tussen controleurs en gecontroleerden en makt deel uit van de meer algemene 'public-choice'-benadering die milieuregulering ziet als het resultaat van vraag en aanbod op een politieke markt bestaande uit nutsmaximaliserende politici en winst zoekende belangengroepen. ${ }^{1542}$

Zoals reeds is besproken, kan slechts sprake zijn van Mittäterschaft indien het grondfeit strafbaar is. Van doorslaggevend belang is natuurlijk de mogelijk strafuitsluitende werking van de onrechtmatige vergunning, die door het Regierungspräsidium is verleend. Indien de onrechtmatige vergunning niet door de strafrechter kan worden opzijgezet, ontbreekt het immers aan een strafbaar grondfeit en is een strafrechtelijke aansprakelijkheid van de medepleger bij voorbaat reeds uitgesloten. Het BGH oordeelt, in de lijn van de heersende leer, dat wanneer sprake is van rechtmisbruik, zoals in een geval van collusie, de strafrechter niet aan de onrechtmatige vergunning is gebonden en het grondfeit derhalve als wederrechtelijk moet worden aangemerkt:

'Der Tatbeitrag des Angeklagten im Vorfield der behördlichen Zustimmung war rechtswidrig; darüber hinaus wäre das Zusammenwirken des Angeklagten mit der Firma H. als gemeinschaftlicher Rechtsbruch zu beurteilen (Kollusion). Bei Kollusion zwischen dem

1542. Zie hierover o.m. Faure, M. en Van den Bergh, R., o.c., 148. 
Adressaten der Genehmigung und der Verwaltung ist aber die Ausnutzung der formell wirksamen begünstigenden Verwaltungsakts wenn man nicht schon, allerdings abweichend von der verwaltungsrechtlichen Praxis, nichtigheit annimmt, jedenfalls ein Rechtsmißbrauch und kann deshalb aus strafrechtlicher Sicht nicht als Rechtfertigungsgrund anerkant werden.'

\section{c. Strafrechtelijke aansprakelijkheid op grond van mittelbare Täterschaft}

Volgens $\S 25$ I StGB is Mittelbare Täter 'wer die Straftat durch einen anderen begeht'. Van mittelbare Täterschaft is sprake indien iemand opzettelijk teweegbrengt dat een ander, namelijk de uitvoerder of onmiddellijke dader, een strafbaar feit begaat, terwijl die ander voor zijn gedraging niet strafrechtelijk aansprakelijk kan worden gesteld.

'Mittelbarer Täter ist, wer den Straftatbestand in der Weise verwirklicht, daß er sich zur Ausführung der tatbestandmäßigen Handlung eines anderen als 'Werkzeug' bedient. ${ }^{, 1543}$

De onmiddellijke dader is als het ware een werktuig of instrument door middel waarvan de middellijke dader het delict begaat. Met andere woorden, aan deze daderschapsvorm is pas voldaan indien de uitvoerder straffeloos is. Is door de strafbaarheid van de uitvoerder mittelbare Täterschaft uitgesloten dan komt mogelijk de deelnemingsfiguur Anstiftung (uitlokking) in aanmerking.

De straffeloosheid van de uitvoerder kan verschillende oorzaken hebben. $\mathrm{Zo}$ is de uitvoerder straffeloos indien hij handelt zonder opzet (vorsatzloses handelndes Werkzeug), niet toerekeningsvatbaar is (schuldunfähiges Werkzeug), in dwaling is gebracht (das Werkzeug handelt in einem unvermeitbaren Verbotsirtum), zich bevindt in een overmachtssituatie (unfrei handelnden Werkzeugs) of nog wanneer hij zich op een rechtvaardigingsgrond kan beroepen (rechtmäßig handelndes Werkzeug). ${ }^{1544}$ Voor het (Duitse) milieustrafrecht zijn vooral die gevallen interessant waar de vergunninghouder als onmiddellijke dader straffeloos blijft omdat hij zich kan beroepen op een onrechtmatige, maar niettemin rechtsgeldige vergunning. We hebben immers gezien, dat in gevallen waar geen sprake is van rechtsmisbruik of lichamelijk letsel, de Duitse strafrechter gebonden blijft aan de vergunning ook wanneer deze onrechtmatig is. Een dergelijke vergunning behoudt zijn strafuitsluitende werking. Dit betekent dat niet alleen de vergunninghouder strafrechtelijk vrijuit gaat, maar dat bovendien, wegens het ontbreken van een strafbaar grondfeit, de vergunningverlener noch via Teilname, noch via Mittäterschaft voor de onzorgvuldige vergunningverlening strafrechtelijk aansprakelijk kan worden gesteld. In zo'n geval kan de bijdrage van de vergunningverlener, of zoals in casu van de deskundige functionaris, aan het (gemene) milieudelict uitsluitend via de figuur van mittelbare Täterschaft worden gekwalificeerd. In de woorden van het BGH: 
'Die andere Sachverhalts-Variante ist die, daß die Verantwortlichen der Firma H. die Umlagerung des Abfalls von der Deponie K. auf die Hausmülldeponie D. in gutem Glauben an die Rechtmäßigkeit des Genehmigungsbescheides des Regierungspräsidenten vornahmen. Dann fehlt es, was die Firma H. als unmittelbar Ausführende angeht, entweder schon an einer tatsbestandmäßigen Handlung, oder sie handelte bei Anwendung der Grundsätze über die Verwaltungsakzessorietät, wie sie überwiegend vertreden werden "befugt", mithin nach herrschender Meinung objektiv gerechtfertigt, oder sie befand sich zumindest in einem Verbotsirrtum, wenn nicht in einem Vorsatz ausschließenden Irrtum über das Vorliegen eines Erlaubnistatbestandes. In diesem Falle ist der Angeklagte mittelbarer Täter. Der Senat folgt insoweit dem Ansatz der herrschenden Meinung, die bei Erteilung einer zwar materiell fehlerhaften, aber verwaltungsrechtlich gültigen Genehmigung den unmittelbar Ausführenden allerdings überwiegend unter der hier offengelassenen Prämisse, er handle rechtmäßig - als Werkzeug des genehmigenden Amtsträgers ansieht, weil der Amtsträger durch die Genehmigung unter vorsätzlicher Mißachtung des materiellen Umweltrechts die entscheidende "Rechtsschranke" für die Herbeiführung des tatbestansmäßigen Erfolgs öffne.'

Met deze laatste overweging van het BGH raken we een belangrijk twistpunt in de Duitse rechtsleer. De vraag rijst immers of het wederrechtelijk verlenen van een vergunning dogmatisch gezien wel kan worden geplaatst onder de voor de mittelbare Täterschaft vereiste Tatherrschaft. Om van mittelbare Täterschaft te kunnen spreken is immers vereist dat de middelijke dader dominus causae is van het strafbaar feit en wel op een zodanige wijze dat kan worden gezegd dat vooral hij, en niet zozeer de onmiddellijke dader, de uitvoering en afloop van het delict beheerst:

'Die Täterschaft des mittelbaren Täters beruht regelmäßig auf seiner Tatherrschaft. Diese wiederrum ist in seiner Herrschaft über das Werkzeug begründet. Der mittelbare Täter spielt gegenuber dem Tatmittler eine derart überlegene Rolle, daß er mit dem Tatmittler auch das Tatgeschehen beherrscht. ${ }^{1545}$

De Tatherrschaft van de middellijke dader over het werktuig, de onmiddellijke dader, veronderstelt traditioneel een sterke mate van willoosheid in hoofde van deze laatste:

'Kennzeichned (...) ist die 'überlegene' Stellung des mittelbaren Täters und die 'unterlegene' Stellung des Tatmittlers. ${ }^{1546}$ 
Het overwicht van de middellijke dader op de eigenlijke pleger bestaat erin dat hij zelf en niet de uitvoerder het feitelijk gebeuren beheerst en stuurt. Dit heeft tot gevolg dat de Hintermann voor de gedraging van de pleger strafrechtelijk aansprakelijk is. In beginsel is dus geen sprake meer van middellijk daderschap indien de eigenlijke pleger zelf volledig verantwoordelijk heeft gehandeld. Uitgangspunt is dat deze dan zelf Handlungsherrschaft heeft en dienovereenkomstig als onmiddellijke dader aansprakelijk kan worden gesteld. ${ }^{1547}$ Het blijft natuurlijk wel mogelijk dat de andere pleger als mededader of als deelnemer (uitlokker of medeplichtige) strafbaar is. Een aantal auteurs merkt dan ook op dat wederrechtelijke vergunningverlening nimmer kan worden aangemerkt als een vorm van mittelbare Täterschaft, daar diegene die voor de onzorgvuldige vergunningverlening verantwoordelijk is, geen Herrschaft heeft over de feitelijke milieuverstorende gedragingen van de vergunninghouder:

'Eine tatsächliche steuerung des Bürgerhandelns werde nicht bewirkt, da dem Bürger unbenommen sei, von der Genehmigung Gebrauch zu machen oder die umweltschädigende Handlung zu unterlassen; Der Amtsträger könnte weder die Handlungen des Bürgers auf ganz spezielle Rechtsgutverletzung lenken, noch habe er durch sie eine Befehlsgewalt, welche die Handlung in Gang setzen könnte. Die Genehmigung sei (...) keine notwendige Voraussetzung für das Handeln; lediglich deren Rechtfertigung hänge von der Existenz der Genehmigung ab. Tatherr der behördlich genehmigten Umweltbeeinträchtigung sei daher typischerweise nicht der Amtsträger, sondern der Bürger als private Initiator und Akteur. Ziel des Amtsträgers sei nur die Zulassung der Benutzung und nicht die Verunreinigung. ${ }^{1548}$

Wat de vergunningverlener door de verlening van een onrechtmatige vergunning bewerkstelligt, is dat de (voorgenomen) milieuverstorende gedraging van de vergunninghouder wordt toegestaan, niet dat hij daardoor feitelijk de uitvoering van het milieuverstorende feit beheerst. Van een dergelijke feitelijke, haast fysieke vorm van Tatherrschaft is in hoofde van de vergunningverlener geen sprake, daar mogelijk ook zonder de verlening van de onrechtmatige vergunning, het milieudelict zou zijn gepleegd. ${ }^{1549}$ Deze beperkte opvatting van Tatherrschaft wordt echter door de heersende leer niet aanvaard omdat men ten onrechte uitgaat van een 'rechtsuntreuen' burger, die, of deze nu beschikt over een rechtmatige vergunning of niet, toch steeds een strafbare milieuverstorende gedraging zou hebben begaan. Met andere woorden, indien hij wel over een rechtmatige vergunning zou hebben beschikt, zou hij deze toch hebben overtreden. Dat is natuurlijk een foutief uitgangspunt. De 'macht' van de vergunningverlener om te bepalen wat een strafbare graad van milieuverstoring is en wat niet, wordt zo volledig over het hoofd 
gezien. De heersende leer neemt dus wel mittelbare Täterschaft in hoofde van de vergunningverlenende ambtenaar aan. ${ }^{1550} \mathrm{Zo} \mathrm{meent} \mathrm{Horn:}$

'mit ihrer Genehmigung gibt die Behörde dem (z.B. zur tatbestandmäBigen Wasserverunreinigung entschlossenen) Bürger das Gewässer ("Tatobjekt) "frei"; sie gibt ihm - wie man sagt - "grünes Licht"'. ${ }^{155.1}$

Hij illustreert dit daderschap aan de hand van een analogie. Wanneer een slagboomwachter voortijdig de slagboom opent zodat een autobestuurder op een aankomende trein inrijdt en dit de dood van de medebestuurder tot gevolg heeft, dan is de slagboomwachter niet slechts deelnemer aan het ongeluk maar is hij ook middelijke dader. De slagboomwachter is 'Herr dieser Tat' en aldus strafbaar wegens doodslag. Mutatis mutandis geldt eenzelfde redenering voor de vergunningverlenende ambtenaar die de juridische slagboom van de vergunningverlening op onrechtmatige wijze opent. Horn stelt:

'Genehmigungsbehörden haben mit ihren Gestaltungs- und Zwangrechten eine so erhebliche (auch faktische) Macht, daß sie jedenfals auch (also neben dem dann unmittelbar handelnden Bürger ("als Vordermann") seinerseits vorsätzlich, fahrlässig, "befugt" oder rechtswidrig, schuldhaft oder im unvermeidbaren Verbotsirrtum verhält. ${ }^{1552}$

Deze sterk tot de verbeelding sprekende voorstelling van de ambtenaar als juridische slagboomwachter is vervolgens door verscheidene auteurs verfijnd geworden teneinde het mittelbare Täterschaft van de ambtenaar te onderbouwen. Zo leidt Hüwels het middellijke daderschap af van de zogenaamde institutionele competentie van de ambtenaar voor de bescherming van het leefmilieu. Daar de ambtenaar bevoegd is het leefmilieu te behartigen, is hij te beschouwen als dader wanneer door het verkeerde gebruik van zijn bevoegdheid het rechtsgoed dat aan hem werd toevertrouwd (het milieu) meer wordt gekrenkt dan milieurechtelijk is toegestaan. De Tatherrschaft en de daaruit resulterende aansprakelijkheid is dan niet zozeer gebaseerd op een 'vorrangige Zuständigkeit des mittelbaren Täters kraft seiner überlegenen Entscheidungskraft', maar op een 'institutionele Zuständigkeit' over het beschermde rechtsgoed. ${ }^{1553}$

Het BGH gaat expliciet op de netelige kwestie van Tatherrschaft in en bevestigt de heersende leer:

'Die Gegenansicht meint, es fehle an der erfordlichen Tatherrschaft des Amtsträgers, weil es allein von den Empfänger der Genehmigung abhän-

1550. OLG Frankfurt, NJW 1987, 2757; Meinberg, V., l.c., 1986, 2227.; Winkelbauer, W., l.c., 1986, 150; Keller, R., 'Anmerkung zu OLG Frankfurt 22.5.1987', JR, 1988, 172; Zeitler, S., o.c., 100 e.v.

1551. Horn, E., l.c., 1981, 4.

1552. Idem, 4.

1553. Hüwels, o.c., 1986, 56. 


\begin{abstract}
ge, ob er von diese auch wirklich Gebrauch mache. Dieser Einwand greift hier jedoch nicht durch [...] Bei wertender Beurteilung ist aber kein überzeugender Grund dafür ersichtlich, es einem Amtsträger, mit dessen Genehmigung die Durchführung eines Umweltverstoßes steht und fällt, nicht als Täterschaft zuzurechnen, wenn er vorsätzlich unter Versto $B$ gegen das Umweltrecht die Tatbestandsverwirklichung durch einen gutgläubigen Unternehmer "freigibt". Denn dadurch stellt sich aus der Sicht des Amtsträgers und auch objektiv der in Gang gesetzte Umweltversto $B$ als "sein Werk" dar; er ist zwar nicht unbedingt die treibende Kraft, aber infolge seines tatsächlichen und rechtlichen Überblicks über das Geschehen dessen Zentralsgestalt. Normativ bestätigt wird diese Sicht durch die Erwägung, daß der Amtsträger, der eine mit dem materiellen Recht nicht zu vereinbarende Genehmigung erteilt hat, im Rahmen des rechtlich Möglichen zu deren Beseitigung verpflichtet ist, sobald er die Rechswidrigkeit erkennt; bleibt er untätig, kann er sich ebenfalls als Täter, wenn auch durch Unterlassen, strafbar machen.'
\end{abstract}

Het oordeel van het BGH is duidelijk: wederrechtelijke vergunningverlening kan wel degelijk als een vorm van mittelbare Täterschaft worden aangemerkt, daar de vergunningverlener weliswaar geen feitelijke maar wel een functionele Tatherrschaft heeft over de verboden gedraging. Het zijn immers de vergunning en de daarin voorgeschreven emissievoorwaarden die bepalen of de door de vergunninghouder verrichte gedragingen een strafbaar feit uitmaken. Het is de verguningverlener die 'groen licht' geeft voor de milieuverstoring en in die zin is hij ook dominus causae van het gepleegde milieudelict. ${ }^{1554}$ Het BGH beklemtoont evenwel dat het moet gaan om een opzettelijk verlenen van een vergunning in strijd met het materiële milieurecht. Louter formele gebreken maken de vergunningverlening strafrechtelijk gezien nog niet wederrechtelijk.

Op grond van de door het LG vastgestelde feiten komt het BGH uiteindelijk tot de conclusie dat in casu de functionaris als mittelbare Täter moet worden aangemerkt:

'Hiernach ist mittelbare Täterschaft des Amtsträgers jedenfalls anzunehmen, wenn sein Tatbeitrag im Rahmen des Gesamtgeschehens so gewichtig ist, daß es - bei isolierter Betrachtung - täterschaftlichen Rang hat. Diese Voraussetszung liegt vor. Die Deponie K. mußte schnell geräumt werden, weil die Abdichtung defekt war und Schadstoffe das Grundwasser verunreinigten. Der Regierungspräsident hatte der Firma $\mathrm{H}$. deshalb schon Ende 1982 die Sanierung der Deponie aufgegeben. Nachdem merhere Sanierungskonzepte verworfen worden waren, standen andere Lösungen als die Umlagerung nicht mehr zur Debatte. Andererseits benötigte die Firma das Gelände in K. dringend als Klärschlammdeponie. Wegen der gegebenen Sachzwänge war allen Beteiligten klar,

1554. Horn, E., l.c., 1981, 4; Rogall, K., o.c., 1991, 194. 
daß die Umlagerung nach der Genehmigung alsbald in Angriff genommen werden mußte und nur von der Stellungnahme des Angeklagten abhing. Unter diesen Umständen lag es faktisch allein in seiner Hand zu bestimmen, ob und in welchem Ausmaß eine umweltgefährdende Abfallbeseitigung vorgenommen werden konnte und vorgenommen werden würde. Darüber hinaus wäre der Angeklagte nach der Erteilung der Genehmigung verpflichtet gewesen, auf ihre Rücknahme hinzuwirken; dies ergibt sich aus seinem vorangegangenen rechtswidrigen Tun. Der Angeklagte war hiernach mittelbarer Täter.'

\section{Samenvatting}

Cruciaal onderdeel van de Amtsträgerstrafbarkeit is de toetsing van de vergunningverlening. Om te weten of een ambtenaar door het verlenen van een vergunning op wederrechtelijke wijze een milieudelict heeft begaan of daartoe heeft bijgedragen moet de Duitse strafrechter eerst de mogelijkheid hebben de vergunning aan wet en recht te toetsen. Dit zal meestal gebeuren bij de beoordeling van de strafbaarheid van het grondfeit, tenzij de vergunningverlener op grond van mittelbare Täterschaft van een gemeen milieudelict wordt vervolgd. Dan aanvaardt de heersende leer immers een directe toetsing van de vergunningverlening bij de beoordeling van de vraag of de functionaris als doen pleger door de afgifte van een onrechtmatige vergunning zich schuldig heeft gemaakt aan het wederrechtelijk (unbefugt) verontreinigen van oppervlaktewater (§ $324 \mathrm{StGB}$ ) of het wederrechtelijk (unbefugt) omgaan met afval ( $\$ 326 \mathrm{StGB}$ ).

Wordt de ambtenaar overtreding van een gemeen milieudelict tenlastegelegd, zoals $\S 324$ $\mathrm{StGB}$, dan is het in beginsel mogelijk de wederrechtelijke vergunningverlening te kwalificeren als mittelbare Täterschaft, Mittäterschaft of Teilnahme. Daarbij mag niet uit het oog worden verloren dat wanneer de ambtenaar als mittelbare Täter wordt vervolgd een strafrechtelijke toetsing van de vergunningverlening aan het materiële bestuursrecht wordt aanvaard. De beoordelings- en beleidsvrijheid van de functionaris wordt evenwel gerespecteerd. Is hij binnen de grenzen van zijn beslissingsruimte gebleven, dan ligt een rechtvaardigingsgrond voor. Belangrijk zijn ook de delictsvormen Mittäterschaft en Teilnahme. Voor beide delictsvormen is echter een wederrechtelijk hoofdfeit vereist, hetgeen impliceert dat een veroordeling van vergunninghouder en vergunningverlener enkel in de rede ligt wanneer de strafrechter niet langer gebonden is aan de onrechtmatige vergunning. Dit is het geval wanneer de vergunning door rechtsmisbruik (collusie en omkoping) is tot stand gekomen of wanneer de milieuverstorende gedraging heeft geleid tot lichamelijk of dodelijk letsel.

Wordt de ambtenaar overtreding van een kwaliteitsmilieudelict verweten, zoals $\S 327$ $\mathrm{StGB}$, dan kan uitsluitend Teilnahme worden tenlastegelegd. Ook dan is vervolging van de ambtenaar enkel mogelijk wanneer het grondfeit niet langer door een rechtsgeldige vergunning is gedekt of wanneer sprake is van rechtsmisbruik of een lichamelijk letsel veroorzakende milieuverstoring. 
Wat de toepasselijkheid van de Duiste daderschaps- en deelnemingsregeling op wederrechtelijke vergunningverlening betreft, kan nog worden opgemerkt, dat de Duitse wetgever tot op zekere hoogte de aansprakelijkheidslacunes heeft opgelost door in $\S 330 \mathrm{~d} \mathrm{Nr} 5 \mathrm{StGB}$ uitdrukkelijk te bepalen dat vergunningen, die door rechtsmisbruik zijn verkregen, door de strafrechter kunnen worden opzijgezet. Hierdoor zijn de gevallen waar de vergunninghouder zich op een onrechtmatige vergunning kan beroepen verkleind en de gevallen waar de vergunningverlener als Teilnehmer of Mittäter kan worden vervolgd vergroot.

Uit het voorgaande blijkt duidelijk dat vooral de beperkingen op de strafrechtelijke toetsingsbevoegdheid - gemotiveerd door een beroep op een eenheid van rechtsorde- een strafrechtelijke aansprakelijkheid van vergunninghouder en -verlener kan bemoeilijken. Het valt dan ook licht te begrijpen dat op deze stand van zaken veel kritiek is gekomen. Het is daarom interessant om de recente tendens aangaande deze problematiek in de Duitse literatuur weer te geven. Enkele schrijvers hebben het voorstel gedaan om de impasse te doorbreken door de strafrechter niet zozeer afhankelijk te maken van de beschikking (Verwaltungsakt) als wel van het bestuursrecht (Verwaltungsrecht). Deze Mindermeinung stelt dat het doel van de eenheid van rechtsorde is om tegenstellingen tussen het strafrecht en het bestuursrecht op het niveau van de rechtmatigheid te voorkomen. Daaruit volgt dat in beginsel geen bestraffing kan platsvinden wanneer de vergunning bestuursrechtelijk rechtmatig is. Is de vergunning echter onrechtmatig dan is het vanuit de eenheid van rechtsorde maar logisch dat daarmee ook in het strafrecht rekening wordt gehouden hetgeen betekent dat de strafrechter de vergunning aan het bestuursrecht moet kunnen toetsen. Het gaat hier dus om een Verwaltungsrechtsakzessorische benadering van de strafrechtelijke toetsingsbevoegdheid. Daarbij is van essentieel belang dat de strafrechter enkel de rechtmatigheid toetst en dat dit niet gebeurt aan de hand van autonome strafrechtelijke criteria maar op grond van de bestuursrechtelijke regelgeving. Een autonome strafrechtelijke toetsing verdient geen navolging in een administratief afhankelijk systeem waar de schending van de ecologische rechtsgoederen niet volledig autonoom is strafbaar gesteld: een zekere koppeling van de strafrechtelijk toetsing aan het bestuursrecht blijft zowel vanuit een instrumenteel als rechtsbeschermingsperspectief noodzakelijk. De Verwaltungsrechtsakzessorische visie vergemakkelijkt de mogelijkheid om zowel de vergunninghouder als de vergunningverlener strafrechtelijk aansprakelijk te stellen voor de door hen veroorzaakte milieuverontreiniging zonder dat dit meteen het risico van een grenzenloze aansprakelijkheid met zich meebrengt. Bovendien wordt de strafrechtelijke wederrechtelijkheid strenger ingevuld dan de bestuursrechtelijke onrechtmatigheid. Slechts voor zover de bestuursrechtelijke onrechtmatigheid is terug te voeren tot materiële gebreken (of formele gebreken) die rechtstreeks een gevaar betekenen voor het leefmilieu lijkt een strafrechtelijk ingrijpen geboden. Hiermee is de strafrechtelijke aansprakelijkheid van zowel de vergunninghouder als die van de vergunningverlener niet alleen gelegitimeerd maar ook tegelijk ook gelimiteerd door de regels van het milieurecht waaraan zowel burger als bestuur onderworpen zijn Bovendien onderstreept dit ook het contradictoire en daarmee machtskritische karakter van het strafproces. Niet langer staat het blindelings aanvaarden van bestuurlijke beschikkingen maar de normconformiteit van zowel de gedragingen van de burger als die van de overheid in het strafproces centraal. 


\section{NEDERLAND \\ 1. Inleiding}

Hoewel de in het Pikmeer II-arrest geformuleerde rechtsregel lijkt uit te sluiten dat overheden en leidinggevende ambtenaren kunnen worden vervolgd voor het wederrechtelijk verlenen van een vergunning - het gaat dan immers om een exclusieve bestuurstaak $^{1555}$ - is het niettemin aardig om te bekijken hoe een strafrechtelijke aansprakelijkheid voor wederrechtelijke vergunningverlening eruit zou kunnen zien, eens ook deze restimmuniteit zou worden doorbroken. Daarnaast mag men niet vergeten dat een strafrechtelijke aansprakelijkheid niet alleen van belang is voor de vergunningverlenende autoriteiten, die zelf hebben bijgedragen tot de ontoelaatbare graad van milieuverstoring. Men kan bijvoorbeeld denken aan externe deskundigen of instanties die aan het bevoegde gezag advies geven, op basis waarvan een onrechtmatige vergunning wordt verleend, en zo mede verantwoordelijk zijn voor de milieuverstoring. Ook is het denkbaar dat een individuele ambtenaar, die weliswaar behoort tot de bevoegde vergunningverlenende overheid, in strijd met het recht en het door de overheid gevoerde beleid, op eigen houtje een onrechtmatige vergunning afgeeft.

Twee vragen staan in deze paragraaf centraal. Allereerst wordt aandacht besteed aan de vraag in hoeverre de formele rechtskracht van een vergunning en het oordeel van de administratieve rechter over de rechtmatigheid van een vergunning een strafrechtelijke aansprakelijkheid voor wederrechtelijke vergunningverlening kan beïnvloeden. Het gaat dan opnieuw om de vraag in welke mate de Nederlandse strafrechter vergunningen aan wet en recht kan toetsen, maar dan in het licht van de strafbaarheid van de bij de onrechtmatige vergunningverlening betrokken overheden. We hebben reeds bij de bespreking van de Duitse situatie gezien dat beperkingen op de strafrechtelijke toetsing niet alleen de strafrechtelijke aansprakelijkheid van de eigenlijke pleger van het milieudelict kunnen bemoeilijken, maar dat deze tevens de aansprakelijkheid van de vergunningverlener als deelnemer aan het milieudelict kunnen uitsluiten. De vraag rijst of dergelijke problemen zich ook in het Nederlandse milieustrafrecht voordoen ( 2 en 3). Vervolgens wordt bekeken hoe de bijdrage van de voor de vergunningverlening verantwoordelijke overheden aan de milieuverstoring dogmatisch zou kunnen worden gekwalificeerd (4).

\section{De invloed van de formele rechtskracht}

Een mogelijke strafbaarheid van de vergunningverlener zal doorgaans enkel via de deelnemingsfiguren tot stand kunnen worden gebracht. De milieustrafbepalingen stellen immers doorgaans het verrichten van milieuverstorende gedragingen zonder of in strijd met een vergunning strafbaar, niet het verlenen van een onrechtmatige vergunning. Een milieustrafrechtelijke aansprakelijkheid van de vergunningverlener op grond van daderschap, dat wil zeggen als onmiddellijke pleger van een milieudelict, is moeilijk denkbaar omdat de meeste bestaande milieustrafbepalingen zich niet richten tot vergunningver- 
lenende overheden. Daarnaast lijkt mij trouwens dogmatisch gezien een aansprakelijkheid op grond van deelneming ook de meest realistische manier om de vergunningverlener voor zijn bijdrage aan de milieuverstoring strafrechtelijk aan te pakken: de feitelijke veroorzaker van de milieuverstoring, de eigenlijke pleger van het milieudelict blijft immers steeds de vergunninghouder.

Dit betekent natuurlijk wel dat het foutieve overheidshandelen moet voldoen aan de klassieke voorwaarden voor deelneming. Zo zal, vanwege de accessoriteit van de deelneming, in hoofde van de dader sprake moeten zijn van een bewezen en strafbaar gronddelict. Opnieuw komt dan de toetsingsproblematiek om de hoek kijken, want het bewijs (bij bestandeeluitsluitende vergunningen) of de strafbaarheid (bij rechtvaardigende vergunningen) van het gronddelict - bijvoorbeeld het lozen zonder (rechtmatige) vergunning hangt af van de vraag of de strafrechter onrechtmatige vergunningen mag toetsen. Is toetsing niet mogelijk dan lijkt een strafvervolging van de vergunningverlener op grond van een deelnemingsfiguur uitgesloten wegens het ontbreken van een door de vergunninghouder gepleegd grondfeit.

Allereerst behoeft aandacht de casuspositie waar de vergunningverlenende overheid of functionaris wordt vervolgd voor deelneming aan een milieudelict, terwijl de openstaande administratieve beroepsgang tegen de litigieuze vergunning niet (tot op het einde) is benut. De vergunning heeft dan formele rechtskracht ${ }^{1556}$ Kan de strafrechter alsnog de vergunning aan wet en recht toetsen of is hij daarentegen gebonden aan de uit de formele rechtskracht voortvloeiende onaantastbaarheid van de beschikking?

Bemerk dat wanneer de vergunningverlenende overheid of ambtenaar deelneming aan een milieudelict wordt ten laste gelegd, bijvoorbeeld medeplegen of medeplichtigheid, het toetsingsvoorwerp steeds een bevrijdende vergunning zal zijn. De meest voor de hand liggende casus is die van een cumulatieve vervolging van vergunninghouder en vergunningverlener, waar enerzijds aan de vergunninghouder wordt tenlastegelegd dat hij zonder een (rechtmatige) vergunning heeft gehandeld, en anderzijds an de verantwoordelijke overheid of ambtenaar deelneming aan dit handelen wordt tenlastegelegd omdat deze de vergunning wederrechtelijk heeft verleend en aldus heeft bijgedragen tot de ontoelaatbare graad van milieuverstoring. Een andere, wellicht meer zeldzame situatie is die waar het $\mathrm{OM}$ er voor kiest uitsluitend de vergunningverlener te vervolgen. Het kan zijn dat er op zich geen voldoende gronden aanwezig zijn om de vergunninghouder te vervolgen - bijvoorbeeld omdat deze zich met succes zou kunnen beroepen op een schulduitsluitingsgrond - maar dat desondanks wel voldoende redenen overblijven om de vergunnigverlener te vervolgen. Ook is het denkbaar dat naar aanleiding van een strafzaak tegen de vergunninghouder blijkt dat een groot aandeel in de milieuverstoring (tevens) ligt bij de vergunningverlenende instanties of bij externe deskundigen. Het OM kan dan alsnog beslissen om over te gaan tot een vervolging van de bij de onrechtmatige vergunningverlening betrokken instanties en personen als deelnemers

1556. Zie hierover Faure, M. en Visser, M., o.c., 1999, 91-95; Koopmans, L.M., o.c., 1996, 126-132 en paragraaf 2 van dit hoofdstuk. 
an het milieudelict. Het is immers niet noodzakelijk de dader te vervolgen om tot een ansprakelijkheid van de deelnemer te komen. ${ }^{1557}$ Zowel in het geval waar de vergunninghouder tezamen met de vergunningverlener wordt vervolgd, de een als pleger en de ander als deelnemer, als in het geval waarin uitsluitend de vergunningverlener wordt vervolgd zal de strafrechter moeten overgaan tot een toetsing van een onrechtmatige bevrijdende vergunning. Het strafbare grondfeit is immers een handelen zonder een bevrijdende vergunning waaraan de vergunningverlener heeft deelgenomen.

Aan de hand van de in paragraaf 2 bestudeerde rechtspraak kon worden vastgesteld dat de strafrechter bevrijdende vergunningen aan wet en recht kan toetsen. ${ }^{1558}$ De strafrechter lijkt dan niet gebonden aan de formele rechtskracht van de vergunning. Dit brengt ons tot de volgende belangrijke conclusie: als strafrechtelijke toetsing reeds mogelijk is bij de enkele vervolging van de vergunninghouder, valt niet in te zien waarom toetsing zou zijn uitgesloten wanneer daarnaast ook de vergunningverlener als deelnemer wordt vervolgd. Het toetsingsvoorwerp, de litigieuze vergunning, blijft immers hetzelfde. Als argument voor toetsing kan bovendien worden herhaald dat het OM hier de partij is die de onrechtmatigheid aanvoert - hij legt immers een handelen zonder vergunning ten laste - en voor deze staat geen administratieve beroepsgang open: het $\mathrm{OM}$ is verplicht via de tenlastelegging op de onrechtmatigheid beroep te doen. Meer fundamenteel kan worden opgemerkt dat het strafproces in het teken staat van de strafrechtelijke rechtshandhaving en rechtsbescherming en in dit opzicht niet concurreert met de bestuursprocesrechtelijke weg zodat de voornaamste ratio's van de formele rechtskracht mijns inziens geen geldingskracht hebben in een strafproces. ${ }^{1559}$

Het is natuurlijk wel mogelijk dat in voorkomend geval de vergunninghouder geen schuldverwijt treft omdat hij zich keurig aan de vergunning heeft gehouden en een gerechtvaardigd vertrouwen kon hebben in de rechtmatigheid van de vergunning ${ }^{1560}$ Dit subjectief vertrouwen laat echter onverlet dat de vergunning onrechtmatig kan zijn en als dusdanig door de strafrechter kan worden onverbindend verklaard zodat een strafbaar grondfeit voorligt, hetgeen betekent dat een strafrechtelijke veroordeling van de vergunningverlener op grond van deelneming mogelijk blijft, ook in die gevallen waar de vergunninghouder zich kan beroepen op een schulduitsluitingsgrond. Afzonderlijk dient natuurlijk wel te worden bekeken of de bijdrage van de voor de vergunningverlening verantwoordelijke overheid aan het grondfeit een zodanige is dat kan worden gesproken van een of andere vorm van deelneming. Op het vlak van de vaststelling van de onrechtmatigheid van de vergunning zie ik in ieder geval geen onoverkomelijke problemen. Dit is reeds een groot verschil met het Duitse recht waar de strafrechter alleen in gevallen van rechtsmisbruik of in situaties waar de milieuverstoring lichamelijk letsel tot gevolg heeft niet gebonden is aan onrechtmatige vergunningen. De Nederlandse straf-

1557. Van Veen, Th.W. en Wedzinga, W., 'Medeplegen', in Van der Neut (red.), o.c., 1993, 92.

1558. HR 14 december 1954, NJ 1955, 119; HR 10 mei, $N J$ 1956, 21; HR 13 november 1984, $N J 1985$, 294; HR 10 februari 1987, $N J 1987,662$.

1559. Faure, M. en Visser, M., o.c., 1999, 96.

1560. Koopmans, L.M., o.c., 1996, 136-137. 
rechter zal anders dan zijn Duitse collega de onrechtmatigheid van de vergunning(verlening) kunnen vaststellen, hetgeen meteen ook de weg opent voor een strafrechtelijke aansprakelijkheid van de vergunningverlener als deelnemer.

\section{De invloed van de administratiefrechtelijke toetsing}

Hoe zit het met de situatie waarin een administratieve rechter zich reeds over de rechtmatigheid van de vergunning(verlening) heeft uitgesproken? Dit vraagstuk kan in relatie tot de strafrechtelijke aansprakelijkheid voor wederechtelijke vergunningverlening hoofdzakelijk op drieërlei wijze aan bod komen. Allereerst is het mogelijk dat de betwiste vergunning door de administratieve rechter is vernietigd. In dat geval is vervolging van de vergunningverlener mogelijk daar reeds door de administratieve rechter is vastgesteld dat de vergunning niet deugt. Bemerk wel dat een strafvervolging mijns inziens slechts wenselijk is indien blijkt dat de vergunning in strijd met de materiële of formele leefmilieubeschermende normen is verleend. Louter formele gebreken rechtvaardigen mijns inziens niet een strafvervolging van de vergunningverlener. Een tweede casuspositie betreft die waarin de beschikking door de administratieve rechter wordt in stand gehouden. In dergelijk geval lijkt mij een vervolging uitgesloten nu over de rechtmatigheid van de vergunningverlening positief is geoordeeld.

Ook van belang is de situatie waar administratief beroep wordt ingesteld nadat een strafvervolging tegen de vergunningverlener werd aangevat en de administratieve rechter over de vergunning uitspraak doet terwijl de strafrechter zich nog over het feit moet uitspreken. Er zijn dan twee mogelijkheden. Ofwel wordt de vergunning in stand gehouden - de vergunning blijft dan rechtsgeldig -, ofwel wordt deze door de administratieve rechter vernietigd. In het eerste geval lijkt het me een juist uitgangspunt dat de strafrechter zich conformeert aan het oordeel van de administratieve rechter. Voor zowel de vergunninghouder als de vergunningverlener volgt dan vrijspraak of OVAR al naar gelang de vorm van de tenlastelegging. Het is niet wenselijk dat de strafrechter zomaar het oordeel van de administratieve rechter kan doorkruisen. Toch kan het voorkomen dat tijdens de strafprocedure nieuwe informatie over de wijze van totstandkoming van de vergunning aan het licht komt die, moest die informatie aan bod zijn gekomen tijdens de administratieve procedure, de nietigheid van de vergunning tot gevolg zou hebben gehad. In een dergelijke situatie dient nog wel ruimte te zijn voor een aparte toetsing door de strafrechter. In dat verband kan ook worden verwezen naar de mogelijkheid van uitzonderingen op de oneigenlijke formele rechtskracht in het civiele recht. Hoewel tot op heden een concrete uitzondering op de oneigenlijke formele rechtskracht nog niet is aangenomen wordt in de literatuur wel een aantal hypothetische voorbeelden gegeven. Zo wordt gedacht aan de situatie waarin de burger zelf tot de schade heeft bijgedragen ${ }^{1561}$ of het geval waarin de burger op grond van een beschikking handelde, wetende dat deze onrechtmatig was. Wanneer nu tijdens een strafprocedure zou blijken dat bijvoorbeeld sprake was van misleiding van de kant van de burger of onoirbare afspraken tussen ambtenaar en vergunning-

1561. Zie annotatie van Brunner bij HR 31 mei 1991 (Van Gog-Nederweert), NJ 1993, 112 en Mok, M.R. en Tjittes, R.P.J.L., L.c., 329. 
houder (collusie), lijkt mij voldoende reden aanwezig om de strafrechter toe te laten alsnog het oordeel van de administratieve rechter te doorbreken. Wel moet worden toegegeven dat dit slechts bij hoge uitzondering zal voorkomen.

Het geval waarin de vergunning, hangende de strafprocedure, wordt vernietigd, is op het eerste gezicht iets ingewikkelder. Dan rijst de vraag of de strafrechter nu moet uitgaan van de oorspronkelijke fictieve rechtmatigheid van de beschikking die bestond op het moment van de vergunningverlening (de eigenlijke formele rechtskracht) of daarentegen moet uitgaan van de door de rechter vastgestelde onrechtmatigheid. Het probleem bestaat hierin dat door het bestuursrecht een juridische fictie in werking treedt, aangezien de desbetreffende vergunning geacht wordt nooit te hebben bestaan. De vergunning is ex tunc nietig: er is nooit een rechtmatige vergunning geweest. Me dunkt dat de strafrechter ook hier in beginsel geen zelfstandige toetsingsbevoegdheid behoudt. ${ }^{1562}$ Gelet op het feit dat een onafhankelijke administratieve rechter heeft vastgesteld dat de vergunning onrechtmatig is en deswege heeft vernietigd, lijkt het me wenselijk dat de strafrechter aan dat oordeel gebonden is. Natuurlijk is hiermee nog niet de strafbaarheid van vergunninghouder als dader en mogelijk ook die van de vergunningverlenende instantie als deelnemer gegeven. In ieder geval dient als beginsel te gelden dat wat door de administratieve rechter als onrechtmatig wordt beschouwd in de regel niet opnieuw voor de strafrechter rechtmatig kan worden. Dit kan in geval van een vernietiging van een bevrijdende vergunning nadelig werken voor de vergunninghouder. Deze heeft door de vernietiging van de vergunning juridisch gezien steeds gehandeld zonder vergunning en daarmee in beginsel een strafbaar feit gepleegd. Dit nadeel moet echter niet te veel worden overschat. Voor een oplossing van dit probleem kan worden verwezen naar de reeds besproken heersende jurisprudentie. Daaruit blijkt dat de vergunningplichtige die een vergunning krijgt erop mag vertrouwen dat deze rechtmatig is en dus zonder problemen gebruikt mag worden. Dit geldt ook

\footnotetext{
'wanneer later zou blijken dat zij in strijd met een wettelijk voorschrift en derhalve onterecht is gegeven ${ }^{1563}$
}

Enkel wanneer blijkt dat de vergunninghouder zelf wist of diende te weten dat de vergunning onrechtmatig is, riskeert hij een veroordeling.

\section{De dogmatische kwalificatie van de wederrechtelijke vergunningverlening}

a. De toepasselijkheid van de deelnemingsvormen op de (kwaliteits)milieudelicten

Aan de hand van het Duitse recht is vastgesteld dat de aard van het milieudelict de mogelijkheden om wederrechtelijke vergunningverlening milieustrafrechtelijk aan te pakken danig kan beperken. $Z_{0}$ is duidelijk geworden dat een strafrechtelijke aansprakelijkheid op grond van mittelbare Täterschaft (doen plegen) en Mittäterschaft (medeplegen) 
enkel mogelijk is bij de gemene milieudelicten ( $\$ 324$ en $\S 326 \mathrm{StGB}$ ). Gaat het om een kwaliteitsmilieudelict, zoals het zonder vergunning exploiteren van een inrichting ( $\$ 327$ StGB), dan kan de vergunningverlener slechts op grond van Anstiftung (uitlokking) of Beihilfe (medeplichtigheid) aansprakelijk worden gesteld, en dan natuurlijk alleen wanneer de onrechtmatige vergunning voor de pleger geen strafuitsluitende werking heeft.

Het is duidelijk dat ook naar Nederlands recht de vergunningverlener moeilijk pleger (in de zin van onmiddellijke dader) kan zijn van een milieudelict. De meeste milieudelicten zijn immers abstracte gevaarzettingsdelicten, die doorgaans als kwaliteitsdelicten moeten worden beschouwd. De bestanddelen van deze delicten worden immers door een absolute administratieve afhankelijkheid gekenmerkt. Dit type van milieudelicten stelt gedragingen strafbaar voor zover zij in strijd met of zonder een vergunning plaatsvinden. De strafbepaling richt zich dan doorgaans niet tot 'eenieder', maar tot de persoon die voor de vergunning in aanmerking komt. Daarnaast zijn talrijke abstracte gevaarzettingsdelicten ook nog kwaliteitsdelicten, omdat zij vaak zijn gekoppeld aan een of andere (vergunningplichtige) beroepsactiviteit of bedrijfswerkzaamheid. Zo verbiedt artikel 8.1 Wet Milieubeheer het zonder daartoe verleende vergunning oprichten, veranderen of in werking hebben van een inrichting. Ook de minder administratief afhankelijke strafbaarstellingen, zoals de concrete gevaarzettingsdelicten en de zorgplichtbepalingen, die zich veeleer tot een ieder richten, zijn milieudelicten waarbij men zich moeilijk de vergunningverlener als pleger kan voorstellen. Nemen we de artikelen 173a en 173b Sr als voorbeeld, dan is dader 'hij die opzettelijk en wederrechtelijk een stof op of in de bodem, in de lucht of in het oppervlaktewater brengt'. Bovendien worden ook deze commune milieustrafbepalingen gekenmerkt door een administratieve afhankelijkheid. Zoals besproken, dient het bestanddeel 'wederrechtelijk' bestuursafhankelijk te worden uitgelegd, in de zin van 'zonder of in strijd met een vergunning. ${ }^{1564}$ Het spreekt voor zich dat de vergunningverlener moeilijk als eigenlijke pleger van deze commune milieudelicten kan worden aangemerkt: dat is immers steeds de vergunninghouder. Kortom, een milieustrafrechtelijke aansprakelijkheid voor wederrechtelijke vergunningverlening is alleen mogelijk op grond van een deelnemingsfiguur.

Volledigheidshalve moet worden opgemerkt dat niet steeds even duidelijk is of een milieudelict als een kwalititeitsdelict moet worden aangemerkt. Het lijkt logisch te veronderstellen dat telkens wanneer de wetgever een handelen in strijd met of zonder vergunning heeft strafbaar gesteld, meteen ook sprake is van een kwaliteitsdelict. Helaas is de problematiek minder eenvoudig. Om te kunnen bepalen of een milieudelict een kwaliteitsdelict is, dient te worden beantwoord wat bestanddeel is van de delictsomschrijving. Of een milieustrafbepaling een kwaliteitsdelict uitmaakt is derhalve afhankelijk van de strafrechtelijke betekenis van de zinsneden 'zonder vergunning' of 'in strijd met de vergunningsvoorschriften': zijn deze termen bestanddeel van de delictsomschrijving en is de vergunning dus bestanddeeluitsluitend of vormt de vergunning een rechtvaardigingsgrond? Volgens de heersende leer moet niet de redactionele opzet, maar de wil van de wetgever als 
uitgangspunt worden genomen. ${ }^{1565}$ Deze vraag zal dus telkens per artikel interpretatiegewijs moeten worden beantwoord. Doorgaans biedt de redactionele opzet trouwens wel voldoende duidelijkheid. ${ }^{1566}$ Staat de restrictie in hetzelfde zinsverband, dan dient deze te worden opgevat als een bestanddeel van de delictsomschrijving. Dit is ook zo wanneer in het zinsverband wordt verwezen naar andere bestuursrechtelijke regelingen die zo voor het verboden gedrag uitzonderingen openlaten. Indien daarentegen de uitzondering op de strafbaarheid los staat van het zinsverband van de delictsomschrijving gaat het om een rechtvaardigingsgrond. Wetstechnisch betreft het vooral formuleringen in de zin van 'het verbod in lid 1 geldt niet, indien...' en dan volgt de uitzondering die aldus een rechtvaardigend karakter krijgt. Uit de rechtspraak van de Hoge Raad komt echter naar voren dat de redactionele opzet niet steeds even beslissend is om te bepalen tot wie de norm zich richt. De bedoeling van de wetgever is van doorslaggevend belang. De Hoge Raad heeft dan ook geoordeeld dat ook hij die geen vergunninghouder is of geen bedrijfsmatige activiteit verricht, pleger kan zijn van artikel 1 Wvo. ${ }^{1567}$ De Hoge Raad heeft steeds de mogelijkheid opengehouden dat vergunningafhankelijke strafbepalingen ook door een ander dan de vergunningplichtige kunnen worden gepleegd. ${ }^{1568}$

Nu ook in Nederland de grootste categorie van milieudelicten kwaliteitsdelicten zijn, rijst de vraag in welke mate dit de toepasselijkheid van de deelnemingsvormen op de milieustrafbepalingen beïnvloedt. Van belang is vooral de vraag of de vergunningverlener kwaliteitsmilieudelicten kan medeplegen of doen plegen, of is daarentegen, zoals in Duitsland, slechts vervolging op grond van medeplichtigheid of uitlokking mogelijk? De deelnemingsbepalingen zorgen er immers voor dat niet alleen het volledig aan een delictsomschrijving in al haar bestanddelen beantwoordde gedrag strafbaar is (het plegen), maar ook andere gedragingen die aan de totstandkoming van het delict hebben bijgedragen, namelijk indien deze gedragingen zijn aan te merken als doen plegen, medeplegen, uitlokken van of medeplichtigheid aan dit delict. Wanneer nu bijvoorbeeld aan een onderneming een onrechtmatige vergunning is afgegeven en deze zich derhalve schuldig maakt aan het zonder vergunning brengen van schadelijke stoffen in oppervlaktewateren (artikel 1, eerste lid Wet Verontreiniging Oppervlaktewateren juncto artikel la sub 1 WED), is het best verdedigbaar dat de vergunningverlener hiervoor mede strafrechtelijk aansprakelijk wordt gesteld. Indien de vergunningverlener zijn verantwoordelijkheid naar behoren had vervuld en een rechtmatige vergunning had verleend, was er immers geen strafbare graad van waterverontreiniging opgetreden. De vergunningverlener is nu eenmaal mede verantwoordelijk voor de ontoelaatbare milieuverstoring. Niet mag worden vergeten dat door de administratieve afhankelijkheid de verantwoordelijkheid om te bepalen welke graad van milieuverstoring geoorloofd is en welke niet primair ligt bij de vergunningverlenende instanties.

1565. Zie hierover o.m. Buiting, Th.J.B., Strafrecht en milieu, Amhem, Gouda Quint, 1993, 45; Faure, M. en Visser, M., o.c., 1999, 157-160.

1566. Faure, M. en Visser, M., o.c., 1999, 158.

1567. HR 20 mei 1986, NJ 1987, 990.

1568. HR 29 juni 1936, $N J 1937,9$ en HR 15 juni 1976, $N J 1976,565$. 
$\mathrm{Nu}$ de vergunningverlener geen pleger kan zijn van een kwaliteitsmilieudelict, moet worden bekeken of deze wel medepleger of doen pleger kan zijn. Het lijkt immers logisch dat men geen delicten kan medeplegen of doen plegen indien men deze zélf niet kan plegen. Dat is de Duitse benadering. Naar Duits recht zou bij een overtreding van artikel 1, eerste lid Wet Verontreiniging Oppervlaktewater, of enig ander kwaliteitsdelict, een aansprakelijkheid van de vergunningverlener slechts via medeplichtigheid of uitlokking (Teilnahme) kunnen worden gekwalificeerd. Medeplegen of doen plegen is naar Duits recht uitgesloten, doodeenvoudig omdat men geen medepleger of doen pleger kan zijn van een kwaliteits-delict: doen plegen en medeplegen zijn immers vormen van Täterschaft, dus dient de doen pleger en medepleger ook te beantwoorden aan de vereiste daderschapskwaliteit, zoals het zijn van vergunninghouder of het in werking hebben van een inrichting.

Een mogelijk argument dat men ook in Nederland geen kwalititeitsdelicten zou kunnen doen plegen of medeplegen is dat (naast de pleger) alle deelnemers van artikel $47 \mathrm{Sr}$ - dat zijn dus de medepleger, de doen pleger en de uitlokker - 'daders' worden genoemd. Daarmee is niet bedoeld: alsof zij daders zijn, maar is bedoeld een opsomming te geven van de ware 'daders'. ${ }^{1569}$ Daartegenover staat de medeplichtige, die op grond van artikel 48 alleen strafbaar is als het om een misdrijf gaat, zij het krachtens artikel $49 \mathrm{Sr}$ minder dan de 'daders'. In die zin is er wetstechnisch inderdaad iets voor te zeggen om, net als in Duitsland, doen plegen en medeplegen uit te sluiten indien men niet de vereiste kwaliteit bezit. Welnu, de Hoge Raad oordeelde anders. In respectievelijk het Reispas-arrest ${ }^{1570}$ en het Magazijnbediende-arrest ${ }^{1571}$ heeft de Hoge Raad geoordeeld dat een persoon best doen pleger en medepleger kan zijn van een kwaliteitsdelict. ${ }^{1572}$ Een belangrijk argument daarvoor vond de Hoge Raad in artikel $50 \mathrm{Sr}$, op grond waarvan 'persoonlijke omstandigheden die de strafbaarheid uitsluiten, verhogen of verminderen uitsluitend werken ten aanzien van die dader of medeplichtige wien zij persoonlijk betreffen.' De Hoge Raad leidde hieruit a-contrario af, dat nu artikel $50 \mathrm{Sr}$ niet spreekt over strafbepalende omstandigheden, dus de bestanddelen van het strafbaar feit, deze derhalve onpersoonlijk werken. Dit impliceert dat persoonlijke delictsbestanddelen tussen pleger en deelnemer kunnen worden uitgewisseld, voor zover het natuurlijk objectieve bestanddelen (zoals daderschapshoedanigheden) en geen subjectieve bestanddelen (zoals opzet en schuld) betreffen. Subjectieve bestanddelen zijn immers persoonlijk van aard. ${ }^{1573} \mathrm{Naar}$ Nederlands recht kan men dus een kwaliteitsmilieudelict medeplegen of doen plegen, ook al is men geen normadressaat en heeft men niet de vereiste daderschapshoedanigheid. ${ }^{1574}$ Voldoende voor strafrechtelijke aansprakelijkheid is dat deze kwaliteit door de pleger is vervuld en dat de medepleger of doen pleger daarvan op de hoogte is. ${ }^{1575}$ Hierdoor wordt het in beginsel

1569. Kelk, C., o.c., 1998, 328.

1570. HR 21 april 1913, NJ 1913, 961.

1571. HR 21 juni 1926, $N J 1926,995$.

1572. Zie hierover o.m. Remmelink, J., o.c., 1995, 429-430 en 438-439.

1573. Kelk, C., o.c., 1998, 332.

1574. Zie hierover Remmelink, J., o.c., 1995, 428-429 en 438; Van Bemmelen, J.M. en Van Veen, Th.W., Ons Strafrecht 1. Het materiële strafrecht. Algemeen deel, Arnhem, Gouda Quint, 1998, 192.

1575. De Jong, D.H., 'Vormen van strafbare deelneming', in Van der Neut (red.), o.c., 1993, 85. 
mogelijk om niet alleen bij de gemene milieudelicten, zoals de artikelen 173a en 173b Sr, maar om ook bij de kwaliteitsmilieudelicten de vergunningverlener op grond van medeplegen of doen plegen strafrechtelijk te vervolgen, terwijl naar Duits recht slechts medeplichtigheid of uitlokking mogelijk is.

Daarnaast dient men ook een ander verschil voor ogen te houden, namelijk dat men in Duitsland niet kan deelnemen aan culpose delicten. ${ }^{1576}$ Indien de eigenlijke pleger van de milieuverstoring zich dus heeft schuldig gemaakt aan een culpoos milieudelict, is een vervolging van de vergunningverlener op grond van medeplichtigheid of uitlokking uitgesloten. Dit heeft opnieuw nadelige consequenties voor een mogelijke aansprakelijkheid van de vergunningverlener. Dit is niet zo in Nederland: men kan best culpose delicten doen plegen of medeplegen, evenals men een culpoos delict kan uitlokken of daaraan medeplichtig kan zijn. ${ }^{1577}$

Hoewel het volgens de regels van de Nederlandse dogmatiek theoretisch mogelijk lijkt om een functionaris, die een wederrechtelijke vergunning heeft verleend, als medepleger of doen pleger van een kwaliteitsdelict te vervolgen, past hier toch een belangrijke relativerende opmerking. Een vervolging van de vergunningverlener als deelnemer aan een kwaliteitsdelict - en dan in het bijzonder aan een abstract gevaarzettingsdelict - lijkt mij in de praktijk niet echt denkbaar, noch wenselijk. Op verschillende momenten in deze studie is vastgesteld dat de abstracte gevaarzettingsdelicten niet rechtstreeks milieuverstoring strafbaar stellen, maar het handelen zonder of in strijd met een vergunning. Deze bestuursaccessoire delicten zijn door de bijzondere milieuwetgever in de eerste plaats bedoeld om inbreuken op administratieve beschikkingen, die ten hoogste indirect het leefmilieu beschermen, strafbaar te stellen. ${ }^{1578}$ Daarom richten zij zich ook uitsluitend tot de vergunningadressaten en niet tot eenieder. Strafrechtsdogmatisch vertaalt dit zich onder meer in de omstandigheid dat het hebben van een rechtmatige vergunning en het handelen conform de vergunningsvoorwaarden doorgaans bestanddeeluitsluitend werkt. Het enkele feit dat zuiver dogmatisch gezien deelneming aan deze delicten niet a priori lijkt uitgesloten, verandert niets aan de bedoelingen van de wetgever om slechts de overtreding op administratieve voorschriften strafbaar te stellen. Door de bijzondere milieuwetgever zijn de verantwoordelijkheden voor de bescherming van de ecologische rechtsgoederen zodanig verdeeld dat de milieuoverheden de graad van toelaatbare milieuverstoring bepalen en dat slechts diegene strafbaar is die verder gaat dan door die overheden is toegestaan. Dat is het kenmerkende van een absoluut administratief afhankelijk milieustrafrecht ${ }^{1579}$ De strafbaarstelling is dan ook niet gericht op een rechtstreekse bescherming van ecologische rechtsgoederen en dus ook niet op het via een wederrechtelijke vergunningverlening bijdragen tot een aantasting van het leefmilieu. ${ }^{1580}$ Het is duidelijk dat voor dergelijke delicten niet van belang is of het leefmilieu (ernstig) is verstoord; er is zelfs geen concrete

1576. Jescheck, H.-H. en Weigend, Th., o.c., 1996, 655.

1577. Remmelink, J., o.c., 432 en 440.

1578. Zie hierover Faure, M. en Visser, M., o.c., 1999, 113. Zie tevens hoofdstuk II.

1579. Koopmans, L.M., o.c., 1996, 17-20.

1580. Faure, M. en Visser, M. o.c., 1999, 65-74. 
gevaarzetting vereist. Daaruit volgt dat een strafrechtelijke aansprakelijkheid van de vergunningverlenende instanties en functionarissen op grond van deelneming aan abstracte gevaarzettingsdelicten moeilijk denkbaar is, doodeenvoudig omdat deze delicten daarvoor niet zijn bedoeld, zich niet ook tot de vergunningverlenende autoriteiten richten, en omdat zij evenmin concreet gevaar voor of schending van het leefmilieu rechtstreeks strafbaar stellen. Slechts wanneer de wederrechtelijke vergunning bijdraagt tot een concrete gevaarzetting of krenking lijkt mij een vervolging van de vergunningverlener wenselijk; daarin ligt immers de voornaamste ratio van de strafwaardigheid van de wederrechtelijke vergunningverlening. Die strafwaardigheid komt niet of nauwelijks tot uitdrukking indien men aan de vergunningverlener deelneming aan een abstract gevaarzettingsdelict zou tenlasteleggen. Wat men dan eigenlijk strafrechtelijk afkeurt is uitsluitend het verlenen van een onrechtmatige vergunning en niet dat deze heeft bijgedragen tot een ontoelaatbare graad van milieuverstoring.

Daar het slechts gepast lijkt de milieuambtenaar als deelnemer aan een milieudelict te vervolgen wanneer het foutieve overheidshandelen inderdaad bijdraagt tot een concrete gevaarzetting van het leefmilieu of een daadwerkelijke krenking van het ecologische rechtsgoed, lijkt het daarom aangewezen om de deelnemingsconstructies dan ook slechts toe te passen op milieustrafbepalingen die gericht zijn op een meer rechtstreekse bescherming van het leefmilieu. In termen van mogelijke modellen van strafbaarstelling moet men dan denken aan gemene concrete gevaarzettingsdelicten of strafbepalingen die ernstige milieuverstoring strafbaar stellen. Het probleem is evenwel dat tot op heden de Nederlandse concrete gevaarzettingsdelicten van de artikelen 173a en 173b Sr niet werken, al was het maar omdat het bestanddeel wederrechtelijk, zoals besproken, absoluut administratief afhankelijk worden ingevuld: wederrechtelijk moet volgens de MvT worden gelezen als 'zonder of in strijd met de vergunning'. ${ }^{1581}$ Dit betekent dan ook dat een mogelijke vervolging van de vergunningverlener op grond van deelneming aan 173a en $173 \mathrm{~b} \mathrm{Sr}$, net zoals bij de abstracte gevaarzettingsdelicten, een gewrongen constructie blijft. Bovendien ligt het tekort van deze strafbepalingen ook hierin dat zij eigenlijk niet rechtstreeks de milieuverstoring strafbaar stellen, maar het gevaar voor de openbare gezondheid. ${ }^{1582}$

Kortom, ik kan me nauwelijks voorstellen dat het ooit tot een vervolging zal komen van een ambtenaar op grond van deelneming aan een milieudelict, hoewel daarvoor dogmatisch geen beletsel lijkt te zijn. Hoe men het ook draait of keert: het is een vreemde constructie wanneer men nota bene de vergunningverlener vervolgt voor deelneming aan bijvoorbeeld het lozen van afvalwater zonder vergunning. Binnen de huidige structuur van het milieustrafrecht waar een absolute administratieve afhankelijkheid heersend is, past derhalve nauwelijks een strafrechtelijke aansprakelijkheid van de vergunningverlenende overheden of functionarissen, ook al bestaat dogmatisch daartoe wellicht de mogelijkheid. Dat probleem zou echter eenvoudig kunnen worden opgelost indien de wetgever werk zou 
maken van de herijking van het milieustrafrecht. De voorstellen die dienaangaande door o.m. Faure en Visser zijn gedaan, vormen daartoe een vruchtbare inspiratiebron. ${ }^{1583}$

Uit het voorgaande blijkt dat een milieustrafrechtelijke aansprakelijkheid voor wederrechtelijke vergunningverlening uitsluitend mogelijk is op grond van een deelnemingsfiguur. Nogmaals, wederrechtelijk vergunningverlening is als dusdanig niet strafbaar gesteld en kan evenmin onder een bestaande milieustrafbepaling als een vorm van plegen worden gekwalificeerd. Maar anders dan in Duitsland beperkt dit niet bij voorbaat de mogelijkheden voor een strafrechtelijke aansprakelijkheid voor wederrechtelijke vergunningverlening, daar de Nederlandse deelnemingsregeling ruimer is geformuleerd. Net zoals bij de toetsingsproblematiek zien we hier een opmerkelijk en belangrijk verschil tussen de beide landen. Zowel in Duitsland als in Nederland kan de vergunningverlener weliswaar niet als onmiddellijke pleger (unmittelbare Alleintäter) van een milieudelict worden vervolgd, maar anders dan in Duitsland lijkt het in Nederland dogmatisch gezien eenvoudiger om op grond van een deelnemingsfiguur wederrechtelijke vergunningverlening strafrechtelijk aan te pakken. Natuurlijk moet de wederrechtelijke vergunningverlening een zodanige bijdrage aan het milieudelict constitueren dat deze als een deelnemingshandeling kan worden aangemerkt. Laten we daarom nagaan onder welke voorwaarden de vergunningverlener, indien deze vervolgbaar zou zijn, strafrechtelijk aansprakelijk kan worden gesteld op grond van de bestaande deelnemingsvormen. Vlug zal blijken dat we in dat verband inspiratie kunnen putten uit de hierboven besproken Duitse rechtspraak.

\section{b. Strafbare vergunningverlening op grond van medeplegen en medeplichtigheid}

Wanneer kan wederrechtelijke vergunningverlening worden aangemerkt als medeplegen van een milieudelict? Artikel 47 lid 1 sub 1 Sr geeft geen definitie van medeplegen. De MvT spreekt van 'opzettelijk tot het plegen van een strafbaar feit medewerken'. ${ }^{1584}$ Volgens rechtspraak en doctrine is voor medeplegen vereist: een bewuste samenwerking gericht op een gezamenlijke uitvoering van de strafbare gedraging. ${ }^{1585}$ Ontbreekt de bewuste samenwerking, dan is er geen medeplegen. Mogelijk is dan nog wel sprake van een andere deelnemingsvorm, zoals doen plegen of medeplichtigheid. In beginsel veronderstelt bewuste samenwerking een gezamenlijk gemaakte afspraak, maar noodzakelijk is dit niet. Aan het vereiste van bewuste samenwerking kan reeds zijn voldaan indien er tussen de pleger en de medepleger sprake is van een wederzijdse begrip, een 'stillschweigendes Einverständnis', een 'understanding' gericht op het gezamenlijk nastreven van hetzelfde doel. ${ }^{1586}$ In milieustrafrechtelijk opzicht kan dan worden gedacht aan een collusierelatie tussen vergunningaanvrager en vergunningverlener. 
Medeplegen is natuurlijk meer dan een gezamenlijke intentie tot het begaan van een strafbaar feit. Er moet ook aan de tweede voorwaarde zijn voldaan: de gezamenlijke uitvoering. Het vereiste van gezamenlijke uitvoering betekent in het algemeen dat door de pleger en medepleger samen uitvoeringshandelingen moeten zijn verricht, delictsbestanddelen moeten zijn gerealiseerd, zij het dat niet alle bestanddelen door alle medeplegers moeten worden vervuld. ${ }^{1587}$ Bemerk evenwel dat een mogelijk 'tekort' aan de objectieve component van het medeplegen, op het vlak van de gezamenlijke uitvoering, kan worden opgevangen door de subjectieve component van het medeplegen, de bewuste samenwerking. De twee voorwaarden van medeplegen dienen dus te worden beschouwd als communicerende vaten: hoe nauwer de bewuste samenwerking is geweest, des te minder relevant is het wie van de medeplegers de uitvoeringshandeling heeft verricht en wie niet. $^{1588}$

De vraag rijst in welke mate het wederrechtelijk verlenen van een vergunning kan worden beschouwd als een voor het medeplegen vereiste uitvoeringshandeling van een milieudelict. De in de milieustrafbepaling omschreven gedragingen zijn immers doorgaans gedragingen die feitelijk niet als zodanig door de vergunningverlener (mede) kunnen worden uitgevoerd. Het is de houder van de onrechtmatige vergunning, die de milieuverstorende handelingen (zonder rechtmatige vergunning) verricht, niet de vergunningverlener. Indien men zich medeplegen alleen maar traditioneel voorstelt als een gezamenlijke operatie van de plegers op de plaats van het delict, dan is medeplegen van een milieudelict door het verlenen van een onrechtmatige vergunning natuurlijk moeilijk denkbaar. De vergunningverlening gaat immers vooraf aan het eigenlijke begaan van het delict. Het ligt dan wellicht meer voor de hand de wederrechtelijke vergunningverlening te zien als een vorm van voorafgaande medeplichtigheid. Maar een dergelijke fysiek getinte en zuiver objectieve benadering van gezamenlijke uitvoering is niet langer beslissend om van medeplegen te kunnen spreken. ${ }^{1589}$ Het medeplegen kan ook functioneler worden opgevat. Zo wordt bijvoorbeeld algemeen aanvaard dat in bepaalde gevallen niet de fysieke aanwezigheid van alle medeplegers bij de uitvoering van het delict is vereist. ${ }^{1590}$ Van belang is dan veeleer de rol die de medeplegers tegenover elkaar hebben ingenomen bij de uitvoering van het delict. In die zin is er wel degelijk plaats om de afgifte van een wederrechtelijke vergunning (of wanneer een externe deskundige wordt vervolgd, het geven van een onzorgvuldig advies) aan te merken als zijnde een onderdeel van de gezamenlijke uitvoering van de strafbare gedraging. Indien de vergunning rechtmatig zou zijn geweest, zou er immers geen strafbaar feit zijn gepleegd. De rol van de vergunningverlener ten aanzien van het door de vergunninghouder uitgevoerde feit is doorslaggevend. Het is immers de vergunningverlener, die, op grond van de gezamenlijke afspraak of de wederzijdse overeenstemming, soepelere voorwaarden heeft bepaald voor de milieuverstoring dan milieurechtelijk is toegestaan. Het voorschrijven van dergelijke met het milieurecht strijdige voorwaarden maakt duidelijk onderdeel uit van de gezamenlijke 
uitvoering. In dat verband kan ook worden herinnerd aan de hierboven besproken uitspraak van het BGH: Mittäterschaft in hoofde van een externe deskundige kan worden aangenomen wanneer zijn advies tot vergunningverlening een voor de verwezenlijking van het delict noodzakelijke voorbereidingshandeling constitueert. Aan de vaststelling van Mittäterschaft

'steht nicht entgegen, daß der Angeklagten an der eigentlichen Tathandlung nach $\S 326$ Abs.1 StGB nicht beteiligt war. Mittäterschaft kann auch durch die Beteiligung an Vorbereitungshandlungen begründet werden. $^{.1591}$

Van belang is ook dat voor medeplegen van een overtreding niet moet worden bewezen dat het opzet van de medepleger was gericht op de uitvoeringshandeling. Het bewijs van een bewuste samenwerking volstaat:

\begin{abstract}
Teneinde tot een bewezenverklaring te kunnen komen van het medeplegen van ene overtreding dient, voor zover voor de beoordeling van het middel van belang, uit de gebezigde bewijsmiddelen slechts te kunnen worden afgeleid dat sprake was van bewuste samenwerking tussen de verdachte en zijn mededader(s). Anders dan in het middel wordt betoogd, is niet vereist dat uit de gebezigde bewijsmiddelen blijkt dat het opzet van de verdachte was gericht op de bewezenverklaarde gedraging. Indien het opzet van de verdachte daarop was gericht, zou er immers sprake zijn van een misdrijf ${ }^{1592}$
\end{abstract}

Als de wederrechtelijke vergunningverlening niet als een vorm van medeplegen kan worden gekwalificeerd - bijvoorbeeld wegens het ontbreken van een bewuste samenwerking - dient te worden bekeken of wellicht medeplichtigheid voorligt. In de praktijk zal trouwens naast medeplegen (subsidiair) veelal ook medeplichtigheid worden tenlastegelegd. De wet onderscheidt in artikel $48 \mathrm{Sr}$ twee typen medeplichtigen: enerzijds zij die opzettelijk behulpzaam zijn bij het plegen van het misdrijf (gelijktijdige medeplichtigheid) en anderzijds zij die opzettelijk gelegenheid, middelen of inlichtingen verschaffen tot het plegen van het misdrijf (voorafgaande medeplichtigheid). ${ }^{1593}$ Het verschil tussen beide vormen van medeplichtigheid is dat de eerste niet en de laatste wel aan limitatief opgesomde wettelijke middelen is gebonden. Voorts is voor medeplichtigheid, net zoals bij medeplegen, dubbel opzet vereist: opzet op het misdrijf en opzet op het bevorderen van het misdrijf. ${ }^{1594}$ Passen we deze klassieke medeplichtigheidsvoorwaarden toe op de wederrechtelijke vergunningverlening, dan lijkt het mij best mogelijk dat deze zowel onder een gelijktijdige als een voorafgaande medeplichtigheid kan worden gekwalificeerd. Voorafgaande medeplichtigheid ligt het meest voor de hand daar de vergunningverlening nu 
eenmaal voorafgaat aan het gepleegde grondfeit. Het opzettelijk verlenen van een onrechtmatige vergunning kan dan worden beschouwd als het verschaffen van gelegenheid of mogelijk zelfs als middel tot het plegen van het milieudelict. In bepaalde gevallen kan de betrokken overheid of functionaris ook gelijktijdige medeplichtigheid worden verweten omdat de hulpverlening bij het delict kan bestaan in passiviteit. Hiervan lijkt mij bijvoorbeeld sprake indien de vergunningverlenende instantie de onrechtmatig verleende vergunning niet intrekt terwijl deze daartoe wel een rechtsplicht heeft. ${ }^{1595}$ Zolang de wederrechtelijke vergunning niet wordt ingetrokken (of gewijzigd) werkt de overheid immers mee aan het instandhouden van een ontoelaatbare graad van milieuverstoring.

Nu artikel $49 \mathrm{Sr}$ voorschrijft, dat het maximum der hoofdstraffen op het misdrijf gesteld bij medeplichtigheid met een derde wordt verminderd én omdat medeplichtigheid aan een overtreding nooit strafbaar is, rijst de vraag naar een afbakening tussen medeplegen en medeplichtigheid. Of de vergunningverlening valt onder medeplegen of medeplichtigheid zal natuurlijk van de omstandigheden van het geval afhangen. Richtinggevend voor de afbakening tussen beide deelnemingsvormen lijken mij, zowel de aard van de opzet als de aard van de vergunningverlening ${ }^{1596}$ Aan de subjectieve kant moet allereerst worden beoordeeld of sprake is van bewuste samenwerking. Is er geen bewuste samenwerking, dan is medeplegen uitgesloten. Daarbij is van belang of de vergunningverlener het feit zelf mede wilde begaan en daar dus ook een persoonlijk belang bij had en niet de pleger alleen maar wilde helpen. ${ }^{1597}$ In het laatste geval ligt uitsluitend medeplichtigheid voor. Aan de objectieve kant lijkt mij voor medeplegen doorslaggevend of de vergunningverlening gelet op de feitelijke vaststellingen mede oorzakelijk en niet slechts bevorderend was voor het gepleegde feit.

\section{c. Strafbare vergunningverlening op grond van doen plegen en uitlokking}

Naar Duits recht is een strafvervolging van de vergunningverlener op grond van doen plegen (mittelbare Täterschaft) vooral van belang in situaties waar de onmiddellijke pleger wegens de strafuitsluitende werking van de onrechtmatige vergunning straffeloos blijft. Vervolging op grond van medeplegen, medeplichtigheid of uitlokking is dan immers uitgesloten. Voorwaarde is evenwel dat de pleger een doleus gemeen milieudelict moet hebben begaan. Het toepassingsgebied van het Nederlandse doen plegen is daarentegen ruimer: de vergunningverlener kan zich ook schuldig maken aan het doen plegen van een kwaliteitsdelict. In het zogenaamde Reispas-arrest is immers uitgemaakt dat bij de doen pleger de vereiste kwaliteit mag ontbreken, mits de onmiddellijke dader deze dan heeft en de doen pleger hiervan op de hoogte is. ${ }^{1598}$ Daarnaast is het ook mogelijk culpose milieudelicten te doen plegen. Wat zijn nu de voorwaarden om wederrechtelijke vergunningverlening als een vorm van doen plegen van een milieudelict te kwalificeren? Met

1595. Rogall, K., o.c., 1991, 201 e.v.

1596. Kelk, C., o.c., 1998, 352-353.; Remmelink, J., o.c., 1995, 452.

1597. Remmelink, J., o.c., 1995, 450.

1598. HR 21 april 1913, $N J 1913,961$. 
andere woorden, wanneer kan de vergunningverlener worden beschouwd als middelijke dader van een milieudelict?

Uit de jurisprudentie komt naar voren dat sprake is van doen plegen als iemand opzettelijk teweegbrengt dat een ander (de uitvoerder of onmiddellijke dader) een strafbaar feit begaat, terwijl die ander voor zijn handelen strafrechtelijk niet aansprakelijk kan worden gesteld. Oorspronkelijk huldigde men de opvatting dat de straffeloosheid van de uitvoerder het gevolg moest zijn van onwetendheid, het ontbreken van opzet of schuld, dan wel dat de uitvoerder in dwaling verkeerde of ontoerekenbaar was. In de woorden van de MvT:

\begin{abstract}
'Dader is evenzeer hij die het feit pleegt, niet persoonlijk maar door tussenkomst van een ander, als werktuig in zijn hand, wanneer die ander wegens de onwetendheid waarin hij verkeert, de dwaling waarin hij is gebracht of het geweld waarvoor hij zwicht, handelt zonder opzet, schuld of toerekenbaarheid. ${ }^{1599}$
\end{abstract}

De strafwetgever stelde dus de werktuigpositie van de uitvoerder en de daaruit voortvloeiende straffeloosheid centraal: de onmiddellijke dader moest dus als een willoos werktuig door de middellijke dader worden gebruikt. Daarin lag zijn straffeloosheid. De reikwijdte van het doen plegen is door de rechtspraak echter al spoedig uitgebreid tot andere situaties van straffeloosheid van de uitvoerder. Zo oordeelde de Hoge Raad in het zogenaamde Terp-arrest dat een veroordeling op grond van doen plegen ook mogelijk is als de straffeloosheid van de uitvoerder is gebaseerd op het niet hebben van een in de delictsomschrijving als bestanddeel vermelde kwaliteit. ${ }^{1600}$ De deelnemingsvorm doen plegen is hierdoor van gedaante veranderd. Remmelink omschrijft doen plegen dan ook als
'het opzettelijk bewerkstelligen door A van het uitvoeren van een strafbaar feit door B, waarvoor B zelf om een of andere reden niet kan worden gestraft. Het wezen van het doen plegen - het "ondergeschikte", het "instrumentale" - is niet meer doorslaggevend. ${ }^{1601}$

De straffeloosheid van de uitvoerder mag evenwel niet het gevolg zijn van de nietstrafbaarheid van het grondfeit, daar de straffeloosheid zich dan ook uitstrekt tot de deelnemer aan het grondfeit: men kan nu eenmaal niet deelnemen aan een niet-strafbaar grondfeit. Dit is anders in het Duitse strafrecht. Omdat mittelbare Täterschaft geen deelnemingsvorm is, kan deze daderschapsfiguur ook worden gebruikt in gevallen waar de onmiddellijke dader zich kan beroepen op een rechtvaardigingsgrond, zoals een vergunning. Nu zou de enkele omstandigheid dat doen plegen in het Nederlandse strafrecht een deelnemingsvorm is een strafvervolging van de vergunningverlener kunnen bemoeilijken indien de strafrechter gebonden zou zijn aan onrechtmatige vergunningen. De uitvoerder van het milieudelict, de vergunninghouder, zou dan immers de vergunning als rechtvaar- 
digingsgrond kunnen aanvoeren, hetgeen zou betekenen dat een niet-strafbaar grondfeit voorligt en derhalve deelneming is uitgesloten. Maar, zoals gezien, is de Nederlandse strafrechter niet gebonden aan een onrechtmatige vergunning, kan hij deze naast zich neerleggen, en kan hij dus tot het oordeel komen dat, wegens het ontbreken van een rechtmatige vergunning, een strafbaar grondfeit voorligt. Dit betekent dan ook dat een strafrechtelijke aansprakelijkheid van de vergunningverlener op grond van doen plegen mogelijk blijft.

Natuurlijk moet aan de voorwaarde van straffeloosheid van de uitvoerder zijn voldaan. In milieustrafrechtelijk opzicht moet dan worden gedacht aan die gevallen waar de vergunninghouder zich met succes kan beroepen op rechtsdwaling. De onmiddellijke dader moet volkomen ter goeder trouw zijn. Het moet dus om iemand gaan die dacht te handelen conform een rechtmatige vergunning, terwijl de strafrechter op grond van een rechtmatigheidstoets tot het oordeel komt dat de vergunning waarop de betrokkene zich beroept onverbindend is. De vergunning waarop de pleger van het grondfeit zich beroept zal dan voor onverbindend worden gehouden zodat het tenlastegelegde emiteren zonder vergunning bewezen kan worden verklaard. Als algemene regel kan worden aangenomen dat indien een vergunning wordt afgegeven door een bevoegde overheid en de justitiabele geen reden dient te hebben om aan de rechtmatigheid van deze vergunning te twijfelen, hij erop dient te kunnen vertrouwen dat hij, indien hij de voorwaarden van deze vergunning naleeft, niet nadien strafrechtelijk zal worden vervolgd. ${ }^{1602}$ De Hoge Raad formuleert dit als volgt:

'De houder van een vergunning mag in het algemeen er op vertrouwen dat deze vergunning overeenkomstig de wettelijke voorschriften is verstrekt en dat hij gerechtigd is van deze vergunning gebruik te maken, ook wanneer later zal blijken dat zij in strijd met een wettelijk voorschrift en derhalve onterecht is afgegeven. ${ }^{1603}$

De onrechtmatige vergunning leidt natuurlijk alleen tot strafuitsluitende dwaling indien de betrokkene geen kennis had of diende te hebben van de onrechtmatigheid van de afgegeven vergunning.

Moeilijker is wellicht de voorwaarde dat de vergunningverlener als doen pleger het delict via de uitvoerder moet bewerkstelligen. Dit impliceert dat de vergunningverlener Tatherr moet zijn. In navolging van enkele Duitse auteurs zou kunnen worden verdedigd dat de vergunningverlener geen causale invloed heeft op het delict, dat hij geen feitelijke Herrschaft heeft over de milieuverstorende gedragingen van de vergunninghouder en dus geen doen pleger kan zijn. ${ }^{1604}$ Het enige dat de vergunningverlener bewerkstelligt, is de milieuverstorende gedraging toelaten: hij beheerst echter niet feitelijk de uitvoering van het delict. Dit probleem van Tatherrschaft kan vrij eenvoudig als volgt worden opgelost. Of de vergunningverlener Tatherr is van het gepleegde feit hangt voornamelijk af van de wijze waarop men kijkt naar de relatie tussen doen pleger en uitvoerder, en dan in het bijzonder 
van de mate waarin men de ondergeschikte werktuigpositie van de uitvoerder nog van belang acht voor een aansprakelijkheid van de doen pleger. Immers, hoe zelfstandiger de positie van de onmiddellijke dader, des te minder kan deze als een instrument in handen van de doen pleger worden beschouwd. Maar nu doen plegen door de rechtspraak wezenlijk van karakter is veranderd, in de zin dat de uitvoerder niet langer een mamus ministra hoeft te zijn, kan aan het vereiste van Tatherrschaft best een andere invulling worden gegeven. De vergunningverlener heeft weliswaar geen feitelijke maar daarentegen wel een functionele Tatherrschaft over de verboden gedraging. Het zijn immers de vergunning en de daarin voorgeschreven emissievoorwaarden die bepalen of de door de vergunninghouder verrichte gedragingen een strafbaar feit uitmaken. Het is de vergunningverlener die 'groen licht' geeft voor de ontoelaatbare graad van milieuverstoring en in die zin is hij ook dominus causae van het gepleegde milieudelict. ${ }^{1605}$ Op grond van de Duitse rechtspraak is duidelijk geworden dat het doen plegen van de vergunningverlener dogmatisch best kan worden onderbouwd.

Mede omdat doen plegen ook denkbaar is in gevallen waar de onmiddellijke dader niet ondergeschikt is aan de middellijke dader, rijst de vraag naar een afbakening met uitlokking. Zowel doen plegen als uitlokken impliceren immers dat iemand een ander beweegt tot het uitvoeren van het gronddelict. ${ }^{1606}$ Wanneer kan nu een wederrechtelijke vergunningverlening als een vorm van uitlokking worden aangemerkt? En waarvan onderscheidt uitlokking zich nog van doen plegen? Een wezenlijk verschil tussen beide deelnemingsvormen is natuurlijk de straffeloosheid van de uitvoerder, de eigenlijke pleger van het milieudelict.

Volgens artikel 47 lid 1 sub $2 \mathrm{Sr}$ moet er in de eerste plaats opzet zijn om een ander te bewegen tot de verboden gedraging, terwijl dit bewegen moet geschieden met behulp van een of meer bepaalde, in de wet opgesomde uitlokkingsmiddelen, te weten: giften, beloften, misbruik van gezag, geweld, bedreiging of misleiding, of het verschaffen van gelegenheid, middelen of inlichtingen. Daarnaast moet bij de uitgelokte het wilsbesluit om de verboden gedraging te verrichten door de uitlokker zijn gewekt en de uitgelokte moet het door de uitlokker bedoelde feit plegen. ${ }^{1607}$

Passen we deze klassieke uitlokkingsvoorwaarden toe op wederrechtelijke vergunningverlening, dan is het best denkbaar dat de vergunningverlener (voorwaardelijk) opzet heeft om de vergunningplichtige tot grotere emissies te bewegen dan wettelijk is toegestaan. Er kan bijvoorbeeld worden gedacht aan een situatie waar de overheid er zelf alle belang bij heeft dat een onderneming onder soepelere voorwaarden mag lozen dan wettelijk is toegestaan. Ook is het mogelijk om de vergunningverlening onder één van de uitlokkingsmiddelen te plaatsen. Zo verschaft de onrechtmatige vergunning aan de vergunningplichtige de gelegenheid tot het plegen van het delict. Een onrechtmatige, maar door de bevoegde instantie als rechtmatig voorgestelde vergunning kan mogelijk ook als een vorm 
van misleiding worden gezien, zij het dat dan veeleer sprake zal zijn van doen plegen, mits bij de vergunninghouder rechtsdwaling voorligt. ${ }^{1608}$ De lastigste voorwaarde lijkt mij dat het wilsbesluit om de verboden gedraging - bijvoorbeeld het lozen van afvalwater - te volbrengen door de vergunningverlener bij de ander moet zijn gewekt. ${ }^{1609}$ Met andere woorden, het initiatief en de oorzaak tot het begaan van de milieudelict moeten in hoofdzaak aanwezig zijn bij de vergunningverlener en niet bij de eigenlijke pleger. Deze laatste moet door de overheid of functionaris zijn bewogen tot het plegen van het milieudelict. Dat veronderstelt dat vóór de vergunningverlening de vergunningplichtige er nog niet toe bewogen was het feit te begaan, maar dat lijkt mij nauwelijks bewijsbaar. Wat moet worden bewezen is niet slechts dat de vergunningverlener opzettelijk in strijd met het milieurecht een vergunning voor een verboden activiteit afgeeft - dat hoeft op zich nog geen onoverkomelijke problemen te geven -, maar vooral dat daardoor het 'omslagpunt' bij de vergunninghouder ontstaat om in strijd met het milieurecht gedragingen te verrichten. Er zou kunnen worden betoogd dat dit bewijs geleverd is wanneer wordt aangetoond dat de vergunninghouder op de hoogte is van de onrechtmatigheid. Maar dat lijkt mij een verkeerde redenering: uit de kennisname van de onrechtmatigheid vloeit nog geen 'bewogen zijn' tot het veroorzaken of in stand houden van milieuverstorende gedragingen voort. Wel kan mogelijk worden verdedigd dat het bewijs van de wending richting strafbaar gedrag niet problematisch is, omdat de justitiabele voor zijn verboden activiteit een vergunning heeft aangevraagd, hetgeen betekent dat hij vóór de afgifte van de onrechtmatige vergunning tenzij sprake is van collusie - niet zinnens was een strafbaar feit te begaan. Via de vergunningaanvraag wil hij juist vermijden dat zijn milieuverstorende activiteiten strafbaar zijn. Blijft de vergunninghouder na de afgifte van de vergunning, ondanks het feit dat hij op de hoogte is van de onrechtmatigheid van de vergunning, zijn milieuverstorende gedragingen voortzetten dan kan worden gesteld, dat hij door de onrechtmatige vergunning is bewogen tot het plegen van het strafbaar feit. Was hij daarvoor al zinnens zich niet aan de milieurechtelijke voorschriften te houden, dan had hij immers geen vergunning aangevraagd. Al bij al lijkt het me toch moeilijk om via de klassieke uitlokkingsfiguur te komen tot een strafrechtelijke aansprakelijkheid van de vergunningverlener. Dat sluit natuurlijk niet uit dat de vergunningverlener uit anderen hoofde strafbaar is, bijvoorbeeld als medepleger of als medeplichtige.

\section{BELGIË}

\section{Inleiding}

Het uitgangspunt is dat bestuursfunctionarissen voor de delicten die zij in de uitoefening van hun functie plegen strafrechtelijk aansprakelijk zijn, vervolgd en bestraft kunnen worden, tenzij de wet in een bijzondere immuniteit voorziet. Dat blijkt ook uit de in hoofdstuk III bestudeerde rechtspraak. De in artikel 5, lid 4 BSw neergeschreven uitsluiting van overheden van de werking van het strafrecht verandert aan dit beginsel niets. In dat verband is ook opgemerkt dat dit een rechtsongelijkheid veroorzaakt tussen de 
bestuursfunctionarissen en de overheden waartoe zij behoren. Het lijkt immers logisch dat wanneer de overheid niet-strafrechtelijk verantwoordelijk is, ook de bestuursfunctionaris van vervolging zou moeten worden uitgesloten, in ieder geval voor feiten die in overheidsverband en in functie zijn gepleegd.

Deze eerste vaststelling is reeds van groot belang. Het betekent immers dat indien rechtstreekse milieuverstoring door een overheid wordt veroorzaakt er geen reden is om het milieustrafrecht niet op de betreffende functionaris toe te passen, ook al is dat in een aantal gevallen niet alleen inefficiënt, maar ook onrechtvaardig. Net zoals vroeger bij een privaatrechtelijke rechtspersoon zal nog steeds moeten worden nagegaan aan welke functionaris het door de overheid gepleegde strafbare feit kan worden toegerekend.

De vraag die nu rijst, is of overheidsfunctionarissen ook strafrechtelijk aansprakelijk zijn indien door een wederrechtelijke vergunningverlening milieuverstoring tot stand komt of in stand wordt gehouden ${ }^{1610}$ Terloops zij opgemerkt dat het probleem van de wederrechtelijke vergunningverlening ook even aan bod kwam tijdens de parlementaire bespreking van een wetsvoorstel van Daras en Cuyvers. ${ }^{1611}$ Dit voorstel bevatte een groot aantal vernieuwingen voor het milieustrafrecht. Interessant is dat men voorstelde een artikel 259bis BSw in te voeren dat ambtenaren strafbaar stelt voor milieudelicten die door hun onzorgvuldigheid of laksheid bij vergunningverlening of toezicht zijn tot stand gekomen of bevorderd. Het voorgestelde artikel 259-bis stelt iedere gezagsdrager die niet is opgetreden tegen een milieudelict, hoewel hij over de middelen beschikt om aan dat delict een einde te maken, strafbaar met een geldboete, die nog wordt verhoogd indien de schuldige minister of staatssecretaris was. Dit wetsvoorstel is echter nimmer aangenomen, hetgeen illustreert dat de idee van de 'Amtsträgerstrafbarkeit' nog op weerstand stuit. ${ }^{1612}$

Ook naar Belgisch recht moeten thans twee vragen worden beantwoord. Allereerst dient vanuit het oogpunt van de strafbaarheid van de vergunningverlener te worden bekeken in hoeverre de strafrechter tot de vaststelling kan komen dat de bewuste vergunning wederrechtelijk is verleend. Omdat deze aansprakelijkheid doorgaans via een deelnemingsfiguur zal worden geconstrueerd, dient deze toetsing voornamelijk te gebeuren aan de hand van de vraag of het grondfeit strafbaar is (2). Vervolgens dient te worden onderzocht in welke mate de Belgische deelnemingsregeling toepasselijk is op wederrechtelijke vergunningverlening, mede gelet op de soorten milieudelicten die het Belgische milieustrafrecht kent (3).

1610. De strafrechtelijke aansprakelijkheid is natuurlijk ook nog van belang voor die gevallen waar andere instanties dan de in artikel 5, lid 4 BSw genoemde overheden (mede)verantwoordelijk zijn voor de afgifte van een onzorgvuldige vergunning.

1611. Parl.St., Kamer, 1990-1991, 1728/1.

1612. Zie hierover Faure, M., o.c., 1992, 124. 


\section{De strafrechtelijke toetsing van de vergunningverlening}

De Belgische strafrechtelijke toetsing van vergunningen wordt gekenmerkt door een relatieve administratieve afhankelijkheid en niet door een absolute administratieve afhankelijkheid. ${ }^{1613}$ In Duitse termen: de strafrechtelijke toetsing is in België Verwaltungsrechtsakzessorisch en niet Verwaltungsaktsakzessorisch. Daaruit volgt dat de Belgische strafrechter niet gebonden is aan de rechtsgeldigheid van vergunningen, maar deze zelf op wet- en rechtmatigheid mag controleren. Op inhoudelijk vlak strekt de toetsing zich niet alleen uit tot een toetsing aan de formele wet, maar ook tot een toetsing aan verdragen en aan de zogenaamde algemene beginselen van behoorlijk bestuur.

Veronderstel dat het $\mathrm{OM}$ iemand vervolgt wegens handelen zonder vergunning terwijl de beklaagde beweert wel over een vergunning te beschikken. Veronderstel vervolgens dat de beklaagde opmerkt wel over een rechtsgeldige vergunning te beschikken terwijl het $\mathrm{OM}$ opmerkt dat met deze zogenaamde bevrijdende vergunning geen rekening mag worden gehouden, bijvoorbeeld omdat het $\mathrm{OM}$ aanvoert dat deze vergunning op onrechtmatige wijze werd verleend of omdat deze in strijd is met hogere normen. Onmiddellijk blijkt dat de Belgische strafrechter teneinde de strafbaarheid in de concrete zaak te kunnen beoordelen, verplicht zal zijn zich uit te spreken over de rechtmatigheid van de vergunning. ${ }^{1614}$ Anders dan in Nederland bestaat in Belgiě een zelfde toetsingsplicht wanneer belastende vergunningsvoorwaarden ter discussie staan. Wordt bijvoorbeeld een ondernemer tenlastegelegd dat hij heeft gehandeld in strijd met een vergunningsvoorwaarde, terwijl hij beweert dat deze vergunningsvoorwaarde onwettig is, dan kan de strafrechter de voorwaarde onverbindend verklaren ook al heeft de verdachte nagelaten daartegen annulatieberoep in te stellen. Het Belgische strafrecht kent geen formele rechtskracht van beschikkingen zodat ook na het verstrijken van de administratieve beroepstermijn door de strafrechter niet alleen kan maar zelfs moet worden getoetst. Deze ruime strafrechtelijke toetsingsbevoegdheid betekent in de praktijk dat de strafrechter alleen gebonden is aan het oordeel van de administratieve rechter. Het is dus van belang dat de mogelijkheid tot rechtmatigheidscontrole niet door de niet-gevolgde administratieve rechtsgang wordt aangetast. Ook wanneer de administratieve beroepstermijn is verstreken en voor de Raad van State de litigieuze vergunning definitief rechtsgeldig is en administratiefrechtelijk niet meer kan worden betwist, kan alsnog tegen de vergunninghouder en/of de vergunningverlener een strafprocedure worden opgestart en kan nog steeds de vergunning worden getoetst.

Het spreekt voor zich dat een dergelijke ruime toetsingsbevoegdheid tevens de mogelijkheid om functionarissen voor wederrechtelijke vergunningverlening strafrechtelijk aansprakelijk te stellen aanzienlijk verruimt. Het gaat dan natuurlijk om die situaties waar iemand meent te handelen conform een rechtmatige vergunning, terwijl de strafrechter achteraf op grond van een rechtmatigheidscontrole tot het oordeel komt dat de vergunning waarop de betrokkene zich beroept onverbindend is. Indien in zo'n geval ook de vergunningverlener strafrechtelijk wordt vervolgd als deelnemer aan het milieudelict, rijzen 
er naar Belgisch recht op het vlak van de toetsing geen onoverkomelijke problemen. De strafrechter kan de vergunningverlening toetsen, het grondfeit strafbaar verklaren en vervolgens onderzoeken in welke mate de vergunningverlener zich schuldig heeft gemaakt aan strafbare deelneming.

Duidelijk is tevens de situatie waarin vooraf aan de strafvervolging reeds een uitspraak van de administratieve rechter over de litigieuze vergunning voorligt. Allereerst is het mogelijk dat het (veelal door derden ingestelde) annulatieberoep resulteert in een vernietiging van de vergunning door de Raad van State. Door de administratieve rechter is dan reeds beslist dat de bestreden vergunning niet deugt. Na dergelijk negatief administratiefrechtelijk oordeel is het best denkbaar dat het OM tot vervolging van de functionaris wenst over te gaan. In de praktijk zal de keuze tot al dan niet vervolgen vanzelfsprekend afhangen van de aard van de vernietigingsgrond en de ernst van de onrechtmatigheid. Als principe geldt in ieder geval dat de strafrechter zich moet confirmeren aan het oordeel van zijn administratieve collega, hetgeen betekent dat in het kader van het strafproces de vergunningverlening voor wederrechtelijk moet worden gehouden.

Een andere casuspositie betreft die waarin de vergunning door de Raad van State wordt in stand gehouden. De bestreden vergunning is dan definitief rechtmatig. In dergelijk geval lijkt een vervolging al bij voorbaat uitgesloten nu over de rechtmatigheid van de vergunningverlening erga omnes in positieve zin is geoordeeld.

Het is (theoretisch) denkbaar dat een administratief annulatieberoep wordt ingesteld indien de termijn van 60 dagen nog niet is verstreken - nadat een strafvervolging tegen de vergunningplichtige en/of de ambtenaar werd aangevat. Zoals reeds betoogd, is het aanbevelenswaardig de strafvordering te schorsen in afwachting van de administratiefrechtelijke uitspraak. Indien de strafrechter niet zou schorsen ontstaat immers het risico dat hij de vergunning voor onwettig houdt en een veroordeling uitspreekt. Indien nu later de vergunning door de Raad van State toch in stand wordt gehouden, zou dit als nadelige consequentie hebben dat iemand voor een rechtmatig handelen wordt veroordeeld. Voor de functionaris zou dit betekenen dat hij uiteindelijk is veroordeeld voor het verlenen van een rechtmatige vergunning. Dat kan onmogelijk de bedoeling zijn. Om dergelijke tegenstrijdigheden te voorkomen, dient de strafrechter dan ook tot schorsing over te gaan. ${ }^{1615}$

Wordt na de administratiefrechtelijke uitspraak de strafprocedure voortgezet, dan rijst wel de vraag in welke mate de strafrechter rekening moet houden met deze uitspraak. Er zijn dan opnieuw twee mogelijkheden. Ofwel wordt de vergunning, hangende de strafprocedure, retroactief vernietigd hetgeen strafrechtelijk voor gevolg heeft dat een veroordeling van de vergunninghouder en/of de vergunningverlener mogelijk wordt. Nu een onafhankelijke administratieve rechter heeft vastgesteld dat de vergunning in strijd met het recht is afgegeven en dienovereenkomstig heeft vernietigd, is het begrijpelijk dat de strafrechter gebonden is aan deze uitspraak.

1615. Zie hierover Faure, M. en Visser, M., o.c., 1999, 100-105. 
Zoals reeds verschillende keren is opgemerkt, impliceert de loutere onrechtmatigheid van de vergunning nog geen automatische strafbaarheid van de vergunningverlener. Mede op grond van de Duitse rechtspraak is geconcludeerd dat eerst moet worden bekeken of de vergunning op een zodanige wijze onrechtmatig is, dat een inbreuk is gepleegd op de materiële en formele milieurechtelijke regels, die gericht zijn op de bescherming van de ecologische rechtsgoederen. ${ }^{1616}$ In dat verband kan de vergunningverlener steeds ook beroep doen op het feit dat hij binnen zijn beleids- en beoordelingsvrijheid is gebleven. Vervolgens dient dan ook in zijn hoofde de schuldvraag te worden bekeken, hetgeen conform de deelnemingsvereisten op zijn minst voorwaardelijk opzet moet zijn.

Wordt de vergunning, hangende het strafproces, door de Raad van State in stand gehouden, dan geldt in beginsel een gebondenheid van de strafrechter aan de administratiefrechtelijke uitspraak hetgeen resulteert in een vrijspraak of OVAR van zowel de vergunningplichtige als de vergunningverlener. Het wordt moeilijker wanneer tijdens de strafprocedure nieuwe informatie over de wijze van totstandkoming van de vergunning aan het licht komt, die, wanneer die informatie bekend zou zijn geweest tijdens de administratieve procedure, de vernietiging van de vergunning tot gevolg zou hebben gehad. In een dergelijke, weliswaar uiterst zeldzame situatie dient nog wel ruimte te zijn voor een aparte toetsing door de strafrechter. Het bezwaar dat de strafrechter dan het oorspronkelijke oordeel van de administratieve rechter opzij zet, gaat niet helemaal op omdat de strafrechter immers niet zozeer de administratiefrechtelijke uitspraak opnieuw beoordeelt - wat een kwalijke zaak zou zijn - maar juist oordeelt over een vraag die nooit aan de administratieve rechter is voorgelegd.

Wat de strafrechtelijke controle van de vergunningverlening betreft, zien we dus een opmerkelijk verschil met het Duitse strafrecht. Daar waar het Duitse strafrecht in beginsel de vergunning niet aan wet en recht kan toetsen, tenzij in gevallen van rechtsmisbruik, is het de Belgische strafrechter steeds toegestaan de vergunningverlening aan een strafrechtelijke controle te onderwerpen. Daanuit volgt dat de mogelijkheid om niet slechts de vergunninghouder, maar om ook de vergunningverlener strafrechtelijk aansprakelijk te stellen niet onnodig wordt bemoeilijkt door een gebondenheid van de strafrechter aan de rechtsgeldigheid van de vergunning.

\section{De dogmatische kwalificatie van de wederrechtelijke vergunningverlening}

\section{a. Inleiding}

Daar ook in het Belgische milieustrafrecht de afgifte van een wederrechtelijke vergunning als dusdanig niet is strafbaar gesteld, zal de vergunningverlener doorgaans slechts strafrechtelijk aansprakelijk zijn indien het foutieve overheidsoptreden kan worden gekwalificeerd als een vorm van deelneming aan een milieudelict. Het is daarom niet overbodig eerst de voornaamste Belgische deelnemingsvormen even op een rij te zetten. 
Deelneming wordt in het algemeen geregeld in hoofdstuk VII (artikelen 66-69) van Boek I van het strafwetboek. De wetgever maakt een onderscheid tussen twee categorieën van deelneming: 'daders' (auteurs), ook wel 'mededaders' genoemd, en 'medeplichtigen (complices). Dit onderscheid is van belang omdat de laatsten minder zwaar worden gestraft dan de eersten. Volgens artikel $69 \mathrm{BSw}$ wordt medeplichtigheid aan een misdaad gestraft met een straf die, overeenkomstig artikel 80 en 81 BSw, onmiddellijk lager is dan die waarmee zij als daders van die misdaad zouden worden gestraft, dat wil zeggen de straf die in de volgorde der straffen die door voormelde artikelen wordt bepaald, onmiddellijk volgt op deze die op de misdaad zelf staat. Medeplichtigen aan een wanbedrijf worden gestraft met een straf die niet hoger mag zijn dan twee derden van de straf die op hen zou worden toegepast indien zij (mede)daders zouden zijn. ${ }^{1617}$

Artikel $66 \mathrm{BSw}$ bepaalt dat als daders van een misdaad of een wanbedrijf worden gestraft: zij die een misdaad of het wanbedrijf hebben uitgevoerd of aan de uitvoering rechtstreeks hebben meegewerkt (artikel 66, lid 2 BSw); zij die door enige daad tot de uitvoering een zodanige hulp hebben verleend dat de misdaad of het wanbedrijf zonder hun bijstand niet had kunnen worden gepleegd (artikel 66, lid 3 BSw); zij die door giften, beloften, bedreigingen, misbruik van gezag of macht, misdadige kuiperijen of arglistigheden, de misdaad of het wanbedrijf rechtstreeks hebben uitgelokt (artikel 66, lid 4 BSw), en tenslotte zij die hetzij door woorden in openbare bijeenkomsten of plaatsen gesproken, hetzij door enig geschrift, drukwerk, prent of zinnebeeld, aangeplakt, rondgedeeld of verkocht, te koop geboden of openlijk tentoongesteld, het plegen van het feit rechtstreeks hebben uitgelokt (artikel 66, lid $5 \mathrm{BSw}$ ). Er worden in artikel $66 \mathrm{BSw}$ dus vijf soorten daders genoemd: de rechtstreekse of onmiddellijke dader, de rechtstreekse medewerker of mededader, de noodzakelijke medehelper, de zedelijke dader door individuele uitlokking en de zedelijke dader door openbare of collectieve uitlokking. ${ }^{1618}$

Artikel 67 BSw bepaalt dat als medeplichtigen aan een misdaad of een wanbedrijf worden gestraft zij die onderrichtingen hebben gegeven om de misdaad of het wanbedrijf te plegen (artikel 67, lid 2 BSw); zij die wapens, werktuigen of enig ander middel hebben die tot de misdaad of het wanbedrijf hebben gediend, wetende dat ze daartoe zouden dienen (artikel 67 , lid $3 \mathrm{BSw}$ ) en tenslotte zij die buiten het geval van artikel 66, lid 3, met hun weten de dader of mededader hebben geholpen of bijgestaan in daden die de misdaad of het wanbedrijf hebben voorbereid, vergemakkelijkt of voltooid (artikel 67, lid 4 BSw). Er worden in artikel $67 \mathrm{BSw}$ dus drie soorten medeplichtigen genoemd: de morele medeplichtige, de materiële medeplichtige en de nuttige medehelper ${ }^{1619}$

Voor de strafbaarheid van de deelneming is vanzelfsprekend niet vereist dat de deelnemingshandeling alle bestanddelen van het delict in zich draagt. Deelneming is immers niet gecreëerd met het oog op personen die alle delictsbestanddelen vervullen. Die personen zijn reeds rechstreekse daders. Voor deelneming volstaat dat rechtstreekse dader 
en deelnemer gezamenlijk de complete delictsomschrijving realiseren. Voor alle deelnemingsvormen geldt natuurlijk wel dat een strafbaar grondfeit moet voorliggen. ${ }^{1620}$ Voor de strafrechtelijke aansprakelijkheid van de vergunningverlener zou deze klassieke deelnemingsvoorwaarde nadelig werken indien de strafrechter de strafuitsluitende werking van onrechtmatige vergunningen zou moeten respecteren. Maar zoals is besproken, is de Belgische strafrechter niet gebonden aan onrechtmatige vergunningen, kan hij deze onverbindend verklaren en ligt derhalve in voorkomend geval een strafbaar grondfeit voor.

Voorts is voor alle deelnemingsvormen opzet vereist. Het opzet is immers de gemeenschappelijke band die deelnemers aan een delict tot een actiegemeenschap maakt en toelaat ze voor het ene delict strafbaar te stellen. ${ }^{1621}$ Daaruit volgt dat de deelnemer niet alleen opzet op de deelnemingshandeling moet hebben, maar ook opzet op het delict waaraan hij deelneemt, zij het niet op alle delictsbestanddelen. ${ }^{1622}$ Deelneming vereist in beginsel opzet in de zin van 'wetens en willens verlenen van medewerking tot het bereiken van een gemeenschappelijk strafbaar doel'. ${ }^{1623}$ Dit betekent dan ook dat de deelnemer weet of dient te weten dat door zijn optreden het plegen van het hoofddelict werd bevorderd of ondersteund. $^{1624}$

Uit genoemde artikelen blijkt dat strafbare deelneming is beperkt tot misdaden en wanbedrijven, dat wil zeggen die strafbare feiten die met een criminele straf of een correctionele straf worden bedreigd. ${ }^{1625}$ Deelneming aan overtredingen is dus in beginsel uitgesloten, behoudens enkele afwijkingen in de bijzondere strafwetten. ${ }^{1626}$ Daarnaast is het van belang dat door het Belgische strafrecht deelneming aan onopzettellijke (culpose) delicten wordt uitgesloten ${ }^{1627}$ Deze belangrijke beperkingen op de toepasselijkheid van de deelnemingsvormen worden evenwel door de rechtspraak 'gerepareerd' in die zin dat de in artikel 66, lid 2 en lid 3 BSw genoemde deelnemingsfiguren met rechtstreeks daderschap worden gelijkgesteld. Het Hof van Cassatie ziet de deelnemingsvormen rechtstreekse medewerking (medeplegen) en noodzakelijke medehulp als uitvoeringsmodaliteiten van

1620. Idem, 315.

1621. Idem, 334 .

1622. Zie i.v.m. valsheid in geschriften: Cass, 1 februari 1984, Pas., 1984, I, 617; i.v.m. bankbreuk: Cass., 5 december 1984, Arr. Cass., 1984-1985, 477.

1623. Dupont, L. en Verstraeten, R., o.c., 1190, 334; Henneau, Ch. en Verhaegen, J., o.c., 238-241; Van den Wijngaert, C., o. c., 334-335.

1624. Faure, M, o.c., 1992, 104.

1625. Voor alle duidelijkheid: de Belgische strafwetgever heeft de delicten ingedeeld in misdaden, wanbedrijven en overtredingen. Deze dreledige indeling is gebaseerd op de zwaarte van de wettelijk omschreven straf. Artikel 1 BSw bepaalt: 'Het misdrijf, naar de wetten strafbaar met een criminele straf, is een misdaad. Het misdrijf, naar de wetten strafbaar met een correctionele straf, is een wanbedrijf. Het misdrijf, naar de wetten strafbaar met een politiestraf, is een overtreding.' Om de toepasselijke straf te bepalen en om van daaruit de aard van het delict vast te stellen, dient te worden verwezen naar Hoofdstuk II van Boek I van het Strafwetboek (artikelen 7-43), waarin de verschillende soorten straffen opgesomd worden, en waarin hun aard en duur nader zijn omschreven. Zie hierover Dupont, L. en Verstraeten, R., o.c., 167-168 en 315-316.

1626. Idem, 315.

1627. Cass., 16 oktober 1972, Arr. Cass. 1973, 165; Cass., 15 oktober 1986, Arr. Cass., 1986-1987, 200. 
rechtstreeks daderschap. ${ }^{1628}$ Daaruit volgt dat de beperkingen die voor uitlokking en medeplichtigheid gelden niet van toepassing zijn op de in artikel 66, lid 2 en lid 3 BSw genoemde vormen van daderschap. De woorden dader en mededaders zijn dus onderling verwisselbaar en dragen een identieke betekenis. ${ }^{1629}$ Een beroep op de regels van strafbare deelneming is eigenlijk overbodig wanneer de betrokkenen persoonlijk hebben meegewerkt of noodzakelijke hulp hebben verleend aan de uitvoering van het delict. ${ }^{1630}$

\section{b. De toepasselijkheid van de deelnemingsregeling op (kwaliteits)milieudelicten}

Om te bepalen of wederrechtelijke vergunningverlening op grond van de deelnemingsregeling strafbaar kan zijn, dient te worden bekeken of die deelnemingsregeling wel op de bestaande milieustrafbepalingen toepasselijk is.

Het is bekend dat het milieustrafrecht in België hoofdzakelijk bestaat uit strafbepalingen die als aanhangsel bij enkele wetten van doorgaans administratief karakter zijn toegevoegd. Dit bestuursaccessoir karakter van het milieustrafrecht blijkt niet alleen in de oude federale Belgische milieuwetgeving, zoals de oude oppervlaktewaterenwet van 26 maart 1971, maar ook in de geregionaliseerde decreten, zoals het Vlaamse afvalstoffendecreet van 2 juli 1981 en het milieuvergunningsdecreet van 28 juni $1985 .{ }^{1631} \mathrm{Nu}$ het Belgische milieustrafrecht bij uitstek een bijzonder strafrecht is moet voor de toepasselijkheid van de deelnemingsregeling in de eerste plaats worden gewezen op artikel $100 \mathrm{BSw}$. Dit artikel bepaalt dat bij gebreke van andersluidende bepalingen in bijzondere wetten en verordeningen, de bepalingen van Boek I ook worden toegepast op de delicten die bij wetten en verordeningen strafbaar zijn gesteld, met uitzondering evenwel van hoofdstuk VII (betreft de strafbare deelnemingsbepalingen; de artikelen 66-69 BSw) en van artikel 85 BSw (betreft de toepassing van verzachtende omstandigheden bij wanbedrijven). Dit betekent dat indien de bijzondere wetgever ook de bepalingen inzake deelneming op inbreuken uit de bijzondere wetgeving toepasselijk wil maken, dit uitdrukkelijk moet worden vermeld in de bijzondere wet. Bij ontstentenis van een dergelijke andersluidende bepaling zouden mededaders en medeplichtigen aan een milieudelict niet strafrechtelijk aansprakelijk zijn. In de praktijk rijzen hier echter geen problemen daar de meeste milieuwetten en -decreten via een geijkte formule uitdrukkelijk zowel hoofdstuk VII van Boek I als artikel 85 BSw van toepassing verklaren. De in artikel $100 \mathrm{BSw}$ neergeschreven regel, die in beginsel strafbare deelneming in het bijzonder strafrecht uitsluit, is daardoor in de praktijk een uitzondering. Bovendien moet worden opgemerkt dat niettegenstaande de principiële uitsluiting van de strafbare deelneming, volgens heersende rechtspraak de gemeenrechtelijke beginselen ver-

1628. Cass., 15 oktober 1985, $R W, 1987-1988,21$ met noot De Swaef, M. 'Over daders en mededaders'.

1629. Vanhoudt, C.J. en Calewaert, W., Belgisch strafrecht, 1976, I, 15.; zie hierover ook meer kritisch D'Haenens, J., 'Strafbare deelneming', A.P.R., 1959, nrs. 110-111.

1630. Dupont, L. en Vestraeten, R., o.c., 1990, 323.

1631. Zie hierover Faure, M. en Visser, M., o.c., 1999, 60-61. 
vat in de artikelen 66 , lid 2 en lid 3 BSw toch van toepassing zijn op de bijzondere delicten. ${ }^{1632}$

Wat de toepassing van de strafbare deelneming op milieudelicten betreft, rijst mogelijk wel een ander probleem. Het is kenmerkend voor het Belgische milieustrafrecht, dat in de milieudelictsomschrijving meestal geen subjectief (moreel) bestanddeel is gepreciseerd. De meeste milieudelicten kennen geen bijzondere schuldvorm (opzet of onachtzaamheid). Dit betekent evenwel niet dat deze delicten geen subjectief (moreel) element vereisen. De theorie van de materiële inbreuken ${ }^{1633}$ volgens dewelke bepaalde strafbare gedragingen (overtredingen en contraventionele wanbedrijven) geen moreel element vereisen, moet ook in het milieustrafrecht worden verworpen. ${ }^{1634}$ Ook het Hof van Cassatie heeft de leer van de materiële inbreuken afgewezen. ${ }^{1635} \mathrm{Om}$ te weten welke schuldvorm bij gebrek aan een subjectief bestanddeel is vereist, dienen de algemene beginselen van het strafrecht te worden toegepast. Volgens de klassieke leer moet worden aangenomen dat algemeen opzet is vereist voor wanbedrijven omschreven in de bijzondere strafwetten die uitsluitend of hoofdzakelijk strafbepalingen bevatten, tenzij de strafbepaling in kwestie onachtzaamheid (culpa) als schuldvorm voorschrijft. ${ }^{1636}$ Onachtzaamheid is dan vereist voor wanbedrijven omschreven in de bijzondere strafwetten waarin strafbepalingen slechts als annexbepalingen voorkomen, tenzij de strafbepaling in kwestie opzet voorschrijft. $\mathrm{Nu}$ in de meeste bijzondere milieuwetten en -decreten strafbepalingen slechts een bescheiden plaats innemen, volstaat voor milieudelicten onachtzaamheid als schuldelement. ${ }^{1637} \mathrm{Nu}$ deelneming aan culpose delicten wordt uitgesloten, zou daaruit kunnen volgen dat deelneming aan een milieudelict slechts mogelijk zou zijn indien de bijzondere wetgever opzet als delictsbestanddeel voorschrijft, hetgeen zeer zeldzaam is. Echter, ook hier moet worden aangenomen dat de in artikel 66, lid 2 en lid 3 BSw uitgedrukte gemeenrechtelijke beginselen toepasselijk zijn op alle bijzondere (milieu)delicten. Een beroep op de deelnemingsregeling - met als nadeel de daaruit voortvloeiende beperkingen - is in die zin vaak overbodig.

Net zoals in Nederland zijn de meest voorkomende milieudelicten abstracte gevaarzettingsdelicten, die een handelen zonder of niet conform een vergunning strafbaar stellen. De meeste milieudelicten zijn daarmee ook kwaliteitsdelicten. Rest dus de vraag of deelneming aan kwaliteitsdelicten wel mogelijk is. Een typisch voorbeeld van een Belgisch abstract

1632. Zie o.m. Cass., 16 november 1959, Pas. 1960, 1, 323, Arr. Cass., 1960, 231; Cass. 13 maart 1961, Pas., 1961, I, 761; Cass., 1 april 1963, I, 835. Zie ook Faure, M., o.c., 1992, 81.

1633. Deze theorie is vooral door R. Legros uitgewerkt in zijn in 1952 gepubliceerde proefschrift $L$ ' élément moral dans les infractions en nadien in Legros, R., 'Voorontwerp van Strafwetboek', Brussel, Belgisch Staatsblad, 1985. Op deze leer is veel kritiek gekomen. Zie hierover Dupont, L. en Verstraeten, R., o.c., 264-266.

1634. Faure, M., o.c., 1992, 21-23; Gorlé, F., 'Nogmaals over het morele bestanddeel van het misdrijf, $R W, 1980-1981,92$.

1635. Cass., 12 mei 1987, Arr. Cass., 1986-1987, 1104; RW, 1987-1988, 538; Cass., 10 oktober 1989, Arr. Cass., 1989-1990; Cass., 13 december 1994, RW, 1995-1996, 533 met noot Spriet, B.

1636. Dupont, L. en Verstraeten, R., o.c., 263.

1637. Faure, M., o.c., 1990, 41 . 
gevaarzettingsdelict is het reeds aangehaalde artikel 39 van het Vlaamse Milieuvergunningsdecreet van 28 juni 1985: strafbaar is

'1. hij die zonder vergunning een vergunningplichtige inrichting exploiteert of verandert;

2.hij die de bepalingen van dit decreet en zijn uitvoeringsbesluiten of de vergunningsvoorwaarden niet naleeft;

3. hij die het bij of krachtens dit decreet geregeld toezicht op de inrichtingen verhindert;

4. hij die geen gevolg geeft aan de opgelegde dwangmaatregelen.'

Krachtens de aanhef van deze bepaling 'wordt gestraft met een gevangenisstraf van acht dagen tot één jaar en met een geldboete van BEF 100,- tot BEF 100.000,- of met één van die straffen alleen.' waarna de zojuist gegeven opsomming volgt. ${ }^{1638} \mathrm{Kan}$ de vergunningverlener aan dit delict deelnemen, in het bijzonder aan het zonder vergunning exploiteren van een vergunningplichtige inrichting? Artikel 39, lid 1 richt zich immers uitsluitend tot de vergunningplichtige exploitant; de vergunningverlenende functionaris mist duidelijk de vereiste daderschapskwaliteit. Van belang is dan vooral de vraag of de ambtenaar niet slechts medeplichtige kan zijn, maar ook mededader: moet de mededader immers ook niet de hoedanigheid van de rechtstreekse dader hebben? Welnu, voor delicten waar de hoedanigheid van de dader - zoals het zijn van exploitant of vergunninghouder - bepalend is voor de kwalificatie van het delict wordt aangenomen dat deze omstandigheid objectief van aard is. ${ }^{1639}$ Daaruit volgt dat de deelnemer niet de vereiste daderschapskwaliteit dient te hebben. Bovendien kan men mededader zijn van een delict dat men zelf helemaal niet kan plegen. Het volstaat dat de rechtstreekse dader het gronddelict heeft gepleegd en dat de mededader hieraan bewust heeft meegewerkt in een van de in artikel 66 lid 2 en lid $3 \mathrm{BSw}$ bepaalde vormen. ${ }^{1640} \mathrm{Het}$ is helemaal niet nodig dat deze (een van) de delictsbestanddelen vervult. Zoals gezien, is dit anders in het Duitse (milieu)strafrecht waar bijvoorbeeld mededaderschap van een kwaliteitsdelict wordt uitgesloten. In Nederland is daarentegen medeplegen van een kwaliteitsdelict wel weer mogelijk.

Hoewel het volgens de regels van de Belgische dogmatiek theoretisch mogelijk is om een functionaris, die een wederrechtelijke vergunning heeft verleend, als mededader van en niet slechts als medeplichtige aan een kwaliteitsdelict te vervolgen en te bestraffen, past hier toch een belangrijke relativerende opmerking. Reeds bij de bespreking van de Nederlandse deelnemingsregeling is geconcludeerd dat een vervolging van de vergunningverlener als deelnemer an een kwaliteitsdelict - en dan in het bijzonder aan een abstract gevaarzettingsdelict - niet echt opportuun is. Er is vastgesteld dat dergelijke milieudelicten niet rechtstreeks milieuverstoring strafbaar stellen, maar het handelen zonder of in strijd met een vergunning. $\mathrm{Zij}$ zijn door de bijzondere milieuwetgever in de eerste plaats bedoeld om inbreuken op administratieve beschikkingen, die ten hoogste indirect het leefmilieu 
beschermen, strafbaar te stellen. ${ }^{1641}$ Daarom richten zij zich ook uitsluitend tot de vergunningadressaten en niet tot eenieder. Het enkele feit dat dogmatisch deelneming aan deze delicten niet is uitgesloten, verandert niets aan de bedoelingen van de wetgever om slechts de overtreding op administratieve voorschriften strafbaar te stellen en daarbij de verantwoordelijkheden aangaande de bescherming van het leefmilieu zodanig te verdelen dat de milieuoverheden de graad van toelaatbare milieuverstoring bepalen en dat slechts diegene strafbaar is die verder gaat dan door die overheden is toegestaan. De strafbaarstelling is doorgaans dan ook niet gericht op een rechtstreekse bescherming van ecologische rechtsgoederen. Het is duidelijk dat voor dergelijke delicten niet van belang is of het leefmilieu is verstoord en evenmin is een concrete gevaarzetting vereist. Daar het slechts gepast lijkt de milieuambtenaar als deelnemer aan een milieudelict te vervolgen wanneer het foutieve overheidshandelen inderdaad bijdraagt tot een concrete gevaarzetting van het leefmilieu of een daadwerkelijke krenking van het ecologische rechtsgoed, lijkt het me daarom aangewezen om de deelnemingsconstructies dan ook slechts toe te passen op milieustrafbepalingen die gericht zijn op een meer rechtstreekse bescherming van het leefmilieu. In termen van mogelijke modellen van strafbaarstelling moet men dan bijvoorbeeld denken aan gemene concrete gevaarzettingsdelicten. Het probleem is evenwel dat tot op heden het Belgische milieustrafrecht nauwelijks concrete gevaarzettingsdelicten kent. ${ }^{1642} \mathrm{Ik}$ kan me daarom moeilijk een vervolging van een ambtenaar op grond van deelneming aan een abstract gevaarzettingsdelict voorstellen, hoewel daarvoor dogmatisch geen beletsel lijkt te zijn. Het blijft immers een vreemde constructie wanneer men de vergunningverlener vervolgt voor deelneming aan bijvoorbeeld het zonder vergunning lozen van schadelijke stoffen. Binnen de huidige structuur van het milieustrafrecht waar een absolute administratieve afhankelijkheid heersend is, past derhalve nauwelijks een strafrechtelijke aansprakelijkheid van de vergunningverlenende overheden of functionarissen, ook al bestaat dogmatisch daartoe wellicht de mogelijkheid.

Wat de mogelijke strafbaarheid van de vergunningverlener op grond van de bestaande milieustrafbepalingen aangaat, moet trouwens ook worden gewezen op een andere eigenaardigheid, die typisch een gevolg is van een ondoordachte milieustrafwetgeving. Daar talrijke strafbepalingen vaak niet meer zijn dan het strafbaar stellen van 'het overtreden van de bepalingen van de wet, het decreet of de uitvoeringsbesluiten' betekent dit dat zodra op een of andere wijze door de overheid een bepaling niet is nageleefd, deze in beginsel de delictsomschrijving vervult en dus een strafbaar feit begaat. $Z_{0}$ is volgens het hierboven genoemde artikel 39, lid 2 van het Vlaamse milieuvergunningsdecreet eenieder strafbaar 'die de bepalingen van dit decreet en zijn uitvoeringsbesluiten (...) niet naleeft.' Hoewel dit artikel naar alle waarschijnlijkheid slechts is bedoeld gericht te zijn tot de burger, is de delictsomschrijving zo ruim dat ook de overheid daaronder valt. Vooral in de uitvoeringsbesluiten, in het bijzonder dan het besluit van 1 juni 1995 houdende algemene en sectorale bepalingen inzake milieuhygiëne, beter bekend als het VLAREM-II besluit, zijn talrijke milieukwaliteitsnormen, sectorale milieuvoorwaarden voor ingedeelde inrichtingen evenals algemene milieuvoorwaarden voor ingedeelde en niet-ingedeelde inrichtingen voorge- 
schreven. Dit VLAREM-II besluit komt tegemoet aan de wens om de voorwaarden waaraan de vergunninghouders dienen te voldoen niet slechts van de administratieve willekeur van de vergunningverlenende overheid te laten afhangen. Wanneer nu de vergunningverlenende overheid zich bij de vergunningverlening niet houdt aan deze normen, pleegt deze conform artikel 39, lid 2 van het Decreet een strafbaar feit. Het merkwaardige is dan dat een beroep op de strafbare deelnemingsregeling niet meer nodig is, want de betrokken overheid of functionaris is rechtstreekse dader. Interessant is ook dat de delictsomschrijving geen subjectief bestanddeel voorschrijft, zodat het culpoos overtreden van de bepalingen uit het decreet of uitvoeringsbesluiten voor een veroordeling reeds volstaat.

Er zijn trouwens ook nog andere voorbeelden te vinden van milieustrafbepalingen die zich rechtstreeks tot (vergunningverlenende) overheden richten. Illustratief is de zorgplichtbepaling die in artikel 14 van het Vlaamse Decreet betreffende het natuurbehoud en het natuurlijk milieu ${ }^{1643}$ van 21 oktober 1997 is opgenomen. Deze bepaling luidt:

'Ieder die handelingen verricht of hiertoe opdracht verleent, en die weet of redelijkerwijs kan vermoeden dat de natuurelementen in de onmiddellijke omgeving daardoor worden vernietigd of ernstig geschaad, is verplicht om alle maatregelen te nemen die redelijkerwijze van hem kunnen worden gevergd om de vernietiging of de schade te voorkomen, te beperken of te herstellen.'

De niet-naleving van deze wel zeer ruim omschreven bepaling is strafbaar gesteld in artikel $58 \S 1$ van het Decreet natuurbehoud met een gevangenisstraf van acht dagen tot drie jaren en/of een geldboete van $26 \mathrm{BEF}$ ( x $200=5.200 \mathrm{BEF}$ ) tot $1.000 .000 \mathrm{BEF}($ x $200=$ $200.000 .000 \mathrm{BEF})$. Volgens de commentatoren richt deze zorgplichtbepaling zich zowel tot burger als tot de overheid. ${ }^{1644}$ Terloops zij herhaald dat ik geen groot voorstander ben van het strafbaar stellen van dergelijke vage bepalingen.

c. Strafbare vergunningverlening op grond van mededaderschap en medeplichtigheid

Hoewel naar huidig recht een strafrechtelijke aansprakelijkheid van de vergunningverlenende functionaris wegens deelneming aan een milieudelict niet meteen voor de hand ligt, omdat de meeste milieustrafbepalingen abstracte gevaarzettingsdelicten zijn, is het toch aardig te bekijken hoe een dergelijke aansprakelijkheid dogmatisch kan worden gekwalificeerd. Het is immers best denkbaar dat in de toekomst de wetgever besluit om milieuverstoring wel rechtstreeks strafbaar te stellen. Er zijn in die richting al verschillende

1643. $B S, 10$ januari 1998.

1644. Van Hoorick, G., De Roo, K. en Rutten, J., 'Het decreet betreffende het natuurbehoud en het natuurlijk milieu', TMR, 1998, 2-19; Zie hierover ook Faure, M. en Visser, M., o.c., 1999, 330. 
voorstellen gedaan. ${ }^{1645}$ Dan lijkt mij een strafrechtelijke aansprakelijkheid van de vergunningverlener wel meer in de rede te liggen, indien hij door zijn foutief optreden heeft meegewerkt aan de milieuverstorende gedraging.

De meest toepasselijke vormen van mededaderschap zijn die van rechtstreekse medewerking (artikel 66, lid 2 BSw) en die van noodzakelijke medehulp (artikel 66, lid 3 BSw). Rechtstreekse medewerking en noodzakelijke medehulp lijken sterk op de Nederlandse deelnemingsvorm medeplegen en het Duitse Mittäterschaft. Men kan deze deelnemingsvormen min of meer zien als uitvoeringsmodaliteiten van medeplegen.

Rechtstreekse medewerkers zijn deelnemers die het delict materieel mede hebben uitgevoerd, zonder dat hun handelen op zichzelf beschouwd valt onder de delictsomschrijving. ${ }^{1646}$ Aan de subjectieve kant van het mededaderschap is een zekere mate van wilsovereenstemming, gericht op het gezamenlijk verwezenlijken van het strafbare feit, vereist. Het is evenwel niet nodig dat daartoe overleg is gepleegd. Een stilzwijgende overeenstemming volstaat. ${ }^{1647}$ In gevallen van collusie is bewuste medewerking dus de ideale deelnemingsfiguur. Aan de objectieve kant moet de mededader natuurlijk het milieudelict mee hebben uitgevoerd. Dat maakt immers de kern van de medewerking uit. Kan de wederrechtelijke vergunningverlening nu worden aangemerkt als een rechtstreekse medewerking aan het milieudelict? De in een milieustrafbepaling omschreven gedragingen zijn immers doorgaans gedragingen die feitelijk niet als zodanig door de vergunningverlener (mede) kunnen worden uitgevoerd. Het is de vergunninghouder, die de milieuverstorende handelingen (zonder rechtmatige vergunning) verricht, niet de vergunningverlener. Indien men zich rechtstreekse medewerking voorstelt als een gezamenlijk handelen van de daders op de plaats van het delict, dan is rechtstreekse medewerking aan een milieudelict door het verlenen van een onrechtmatige vergunning natuurlijk moeilijk

1645. Zie bijvoorbeeld het Voorontwerp Decreet Milieubeleid in het Vlaamse Gewest, voorbereid door de Interuniversitaire Commissie voor Herziening van het Milieurecht. Artikel 7.3.4. kent een strafbepaling, die als volgt luidt: 'Hij die rechtstreeks of onrechtstreeks stoffen, microorganismen, geluid en andere trillingen of stralingen in of op water, bodem, atmosfeer inbrengt of verspreidt, en weet of dient te weten dat dit concreet gevaar oplevert voor de menselijke gezondheid wordt gestraft met een gevangenisstraf van één maand tot vijf jaar en met een geldboete van 100 frank tot 10 miljoen frank of met één van deze straffen alleen.' Zie artikel 7.3.4. Interuniverstaire Commissie voor herziening van het Milieurecht, Voorontwerp Decreet Milieubeleid, Brugge, Die Keure, 1995, 82. Deze strafbepaling stelt ernstige milieuverstoring rechtstreeks strafbaar. Indien nu een ambtenaar door het verlenen van een onrechtmatige vergunning bijdraagt tot de milieuverstoring, is het beter denkbaar deze daarvoor te vervolgen en te bestraffen dan wanneer hem slechts deelneming aan een abstract gevaarzettingsdelict kan worden tenlastegelegd. De Vlaamse Regering heeft op 23 juli 1998 een voorontwerp van handhavingsdecreet goedgekeurd. In die goedgekeurde versie is artikel 7.3.4. overgenomen in een artikel 5.1.5., maar wel met de beperking dat de gevaarzettende emissie slechts tot strafbaarheid leidt wanneer deze plaatsvindt 'in strijd met wettelijke voorschriften, hetzij in strijd met een verleende vergunning.' Hierdoor is deze strafbepaling administratief afhankelijk gemakt en heeft deze dus niet veel meerwaarde in vergelijking met de huidige milieustrafbepalingen. Zie hierover Faure, M. en Visser, M., o.c., 1999, 285.

1646. Dupont, L. en Verstraeten, R., o.c., 1990, 324.

1647. Idem, 335. 
denkbaar. De vergunningverlening gaat immers vooraf aan het eigenlijke begaan van het delict. Naar Belgisch recht ligt het dan wellicht meer voor de hand de wederrechtelijke vergunningverlening te zien als een vorm van noodzakelijke medehulp, de mededaderschapsvorm van artikel 66 , lid 3 BSw, of als een vorm van medeplichtigheid (nuttige medehulp, artikel 67, lid 4 BSw). Geven we aan de rechtstreekse medewerking echter een meer functionele inhoud dan kan de afgifte van een wederrechtelijke vergunning (of wanneer een externe deskundige wordt vervolgd, het geven van een onzorgvuldig advies) worden aangemerkt als zijnde een vorm van rechtstreekse medewerking aan de strafbare gedraging. Het is immers de vergunningverlener die soepelere voorwaarden heeft bepaald voor de milieuverstoring dan milieurechtelijk is toegestaan. Het voorschrijven van dergelijke met het milieurecht strijdige voorwaarden is dan duidelijk een rechtstreekse medewerking aan het milieudelict. Indien de wederrechtelijke vergunningverlening niet als een vorm van rechtstreekse medewerking kan worden uitgelegd, dan lijkt mij mededaderschap nog steeds mogelijk op grond van noodzakelijke medehulp. Wat dan in concreto moet worden beoordeeld is of de vergunningverlening noodzakelijk was voor het plegen van het strafbaar feit. ${ }^{1648}$ Opnieuw kan hier inspiratie worden geput uit de Duitse dogmatiek: de noodzakelijkheid van de medehulp kan worden afgeleid uit de functionele Tatherrschaft die de vergunningverlener over de milieuverstorende gedraging heeft.

In die gevallen waar vervolging op grond van rechtstreekse medewerking of noodzakelijke medehulp niet voor de hand ligt, kan mogelijk beroep worden gedaan op de deelnemingsvorm medeplichtigheid, zij het dat dit wel een lagere straf tot gevolg heeft. De toepasselijke vorm van medeplichtigheid lijkt mij dan vooral die van artikel 67 , lid 4 BSw, de nuttige medehulp of bijstand. De wederrechtelijke vergunningverlening kan immers in relatie tot de milieuverstorende gedraging worden aangemerkt als een bevorderende voorbereidingshandeling. Wel is de toepasselijkheid van deze deelnemingsvorm beperkt tot doleuse milieudelicten, daar medeplichtigheid aan een culpoos delict niet mogelijk is. Wat de medeplichtigheid betreft is het nog interessant op te merken dat hieraan minder strenge voorwaarden zijn verbonden dan in Nederland, nu artikel 67, lid 4 BSw geen medeplichtigheidsmiddelen opsomt. Er is slechts vereist dat er handelingen zijn verricht die het delict hebben voorbereid, vergemakkelijkt of voltooid. ${ }^{1649}$

Kortom, de Belgische deelnemingsregeling laat mijns inziens voldoende mogelijkheden open voor een mogelijke strafvervolging van de vergunningverlener. Natuurlijk zou kunnen worden opgemerkt dat een aansprakelijkheid op grond van de deelnemingsregeling omslachtig is en bovendien aan een aantal zware eisen is onderworpen, zoals de aanwezigheid van opzet bij de vergunningverlener. Dit brengt ons dan ook tot de vraag of het wellicht niet beter zou zijn om wederrechtelijke vergunningverlening als dusdanig strafbaar te stellen.

1648. Is de medehulp slechts nuttig en niet noodzakelijk dan ligt nuttige medehulp voor (artikel 67 , lid 4 BSw); Dupont, L. en Verstraeten, R., o.c., 1990, 324.

1649. Idem, 331. 


\section{E. NAAR EEN STRAFBAARSTELLING VAN WEDERRECHTELIJKE VERGUNNINGVERLENING?}

Uit het voorgaande blijkt dat er vanuit strafrechtsdogmatisch perspectief een belangrijk argument voor de strafrechtelijke aansprakelijkheid voor wederrechtelijke vergunningverlening is, namelijk de administratieve afhankelijkheid van het milieustrafrecht. Doordat in de bestudeerde rechtsstelsels de milieuverstoorder zelf meestal alleen strafbaar is indien een welbepaald administratiefrechtelijk voorschrift is geschonden, hebben de milieuoverheden een belangrijke bevoegdheid om te beslissen wat de strafbare graad van milieuverstoring is. Indien nu op onrechtmatige wijze een vergunning wordt verleend en de milieuverstoring als dusdanig niet rechtstreeks strafbaar is gesteld zou de vergunninghouder zelf mogelijk aan bestraffing ontsnappen. Dit betekent dat de aansprakelijkheid van de vergunningverlener een correctief zou kunnen zijn dat er toe dient de vergunningverlenende instanties extra prikkels te geven bij de vergunningverlening. De vraag is echter of dit op zichzelf een voldoende reden is om wederrechtelijke vergunningverlening zelfstandig strafbaar te stellen. Ik meen van niet en wel om de volgende redenen.

In de eerste plaats moet worden opgemerkt dat het probleem van wederrechtelijke vergunningverlening eigenlijk alleen maar speelt wanneer men aanneemt dat de vergunning een absoluut strafuitsluitende werking heeft voor de milieuverstorende gedraging. Rechtsvergelijkend is vastgesteld dat dit alleen in de Duitse Bondsrepubliek het geval is. Zowel de Nederlandse als de Belgische strafrechter is het toegestaan onrechtmatige vergunningen te toetsen en onverbindend te verklaren, zodat de onrechtmatigheid van de vergunning niet een strafrechtelijke aansprakelijkheid van de rechtstreekse milieuverstoorder verhindert. In het Duitse (milieu)strafrecht daarentegen is het de strafrechter in beginsel niet toegestaan om onrechtmatige vergunningen te toetsen en onverbindend te verklaren, hetgeen het risico verhoogt dat zowel de vergunninghouder, die zich op de onrechtmatige vergunning kan beroepen, als de vergunningverlener straffeloos blijven. Het is dan ook begrijpelijk dat een aantal Duitse auteurs voorstander is van een zelfstandige strafbaarstelling van wederrechtelijke vergunningverlening. ${ }^{1650}$ Niettemin lijkt mij dit een verkeerd uitgangspunt. Indien het milieustrafrecht lacunes kent met betrekking tot de strafrechtelijke aansprakelijkheid van de rechtstreekse milieuverstoorders, dan lijkt het me niet de juiste weg om dergelijke problemen op te lossen door een strafbaarstelling van de vergunningverlener. Wat dan nodig is, is veeleer een herziening van het uitgangspunt dat een vergunning steeds in alle gevallen strafuitsluitend zou moeten werken. De meeste Duitse schrijvers hebben dan ook in die richting oplossingen gesuggereerd. Zo bepleit een aantal schrijvers de doorbreking van het principiële toetsingsverbod van de strafrechter. Het is dan interessant vast te stellen dat in 1994 de Duitse wetgever aan deze wens enigszins is tegemoetgekomen door in $\S 330 \mathrm{~d} \mathrm{Nr} .5$ StGB neer te schrijven dat de strafrechter niet langer gebonden is aan door rechtsmisbruik verkregen vergunningen. Daarmee is een belangrijk argument voor een strafbaarstelling van wederrechtelijke vergunningverlening weggevallen. 
In de tweede plaats lijkt mij een afzonderlijke strafbaarstelling niet echt noodzakelijk omdat met behulp van de deelnemingsregeling reeds tot op zekere hoogte een strafrechtelijke aansprakelijkheid voor wederrechtelijke vergunningverlening kan worden gekwalificeerd. Hoewel naar Duits recht de toepasselijkheid van de deelneming ernstig wordt beperkt door zowel de beperkingen op strafrechtelijke controle van vergunningen als door de omstandigheid dat men geen kwaliteitsmilieudelicten kan medeplegen of doen plegen, zijn deze obstakels in veel mindere mate in het Nederlandse en Belgische strafrecht aanwezig. Ik ben dan ook veel meer voorstander van het toepassen van de deelnemingsfiguren dan voor een uitbreiding van de strafrechtelijke aansprakelijkheid van overheden en hun functionarissen door een strafbaarstelling van de wederrechtelijke vergunningverlening als dusdanig. Een dergelijke strafbaarstelling lijkt mij te verregaand om de eenvoudige reden dat dit uiteindelijk betekent dat men dan de onrechtmatige uitvoering van een publiekrechtelijke rechtshandeling op zichzelf rechtstreeks strafbaar stelt. Mijns inziens is een strafrechtelijke aansprakelijkheid echter alleen gepast en noodzakelijk indien de vergunningverlening een bestanddeel uitmaakt van een strafbaar feit, met andere woorden, indien de wederrechtelijke vergunningverlening een door een ander gepleegd milieudelict heeft bevorderd of heeft ondersteund. Daartoe zijn de deelnemingsbepalingen het meest geschikt.

Daartegen zou kunnen worden opgemerkt dat strafbare deelneming in hoofde van de vergunningverlener niet voor de hand ligt, gelet op het feit dat de meeste milieudelicten op grond waarvan tegen de rechtstreekse milieuverstoorders vervolging wordt ingesteld abstracte gevaarzettingsdelicten zijn. Een strafvervolging van de vergunningverlener - er natuurlijk van uitgaande dat deze vervolgbaar zou zijn - op basis van deelneming aan een abstract gevaarzettingsdelict is niet alleen moeilijk voor te stellen, maar is ook niet effectief, daar deze delicten niet rechtstreeks het leefmilieu beschermen. Dat probleem is echter geen argument voor een zelfstandige strafbaarstelling van wederrechtelijke vergunningverlening, maar vormt slechts een (extra) arrgument om in het Nederlandse (en zeker ook het Belgische) milieustrafrecht strafbepalingen in te voeren die op meer rechtstreekse wijze ecologische rechtsgoederen beschermen. De Nederlandse wetgever zou daarom werk moeten maken van een herziening van de commune milieustrafbepalingen (artikelen 173a en 173b Sr). Het wezenlijke probleem ligt dus op een ander vlak, namelijk dat gelet op de huidige milieustrafbepalingen, die meestal door een absolute administratieve afhankelijkheid worden gekenmerkt, eigenlijk geen ruimte is voor een strafrechtelijke aansprakelijkheid voor wederrechtelijke vergunningverlening.1651 Eens men echter zou besluiten, om naar Duits voorbeeld, milieustrafbepalingen in te voeren, die zich in beginsel tot eenieder richten (dus ook tot de milieuoverheden) en die ook meer dan nu het geval is de rechtstreekse bescherming van het leefmilieu centraal stellen, openen zich ook meteen meer mogelijkheden deze milieustrafbepalingen op de vergunningverlenende overheden toe te passen.

In de derde plaats lijkt een zelfstandige strafbaarstelling van vergunningverlening onwenselijk omdat dit een te sterke benadrukking van de strafrechtelijke aansprakelijkheid van functionarissen tot gevolg heeft, waardoor het risico bestaat dat deze laatsten hun activiteit

1651. Tot deze conclusie waren we reeds in het meer rechtstheoretische hoofdstuk II gekomen. 
uitsluitend zullen toespitsen op het vermijden van de eigen aansprakelijkheid, in plaats van zich in te zetten voor de uitoefening van hun bestuurstaak. ${ }^{1652}$ In dat verband mag niet worden vergeten dat men bij de vervolging van milieudelicten juist aangewezen is op een goede samenwerking tussen het $\mathrm{OM}$ en de milieuoverheden. Deze verhouding zou sterk in gevaar komen indien de functionarissen bij deze samenwerking voortdurend onder druk staan van een bedreiging van strafsancties. ${ }^{1653}$ Dit betekent hoegenaamd niet dat een wederrechtelijke vergunningverlening nimmer tot een strafrechtelijke reactie zou moeten leiden. Deze mogelijkheid moet blijven bestaan, maar alleen in de ernstige gevallen, namelijk wanneer sprake is van collusie of corruptie (in dat laatste geval zijn natuurlijk reeds de omkopingsbepalingen toepasselijk) en wanneer de vergunning opzettelijk in strijd met wet en recht is verleend en tot een ernstige graad van milieuverstoring heeft bijgedragen. Voor die gevallen volstaat het beroep te doen op de deelnemingsbepalingen en is een zelfstandige strafbaarstelling niet noodzakelijk. Een zelfstandige strafbaarstelling zou averechtse effecten kunnen hebben.

Tegen het toepassen van de deelnemingsregeling zou tenslotte nog kunnen worden opgemerkt, dat hiermee een strafrechtelijke aansprakelijkheid voor wederrechtelijke vergunningverlening tot een klein aantal gevallen is beperkt. Zo zal het steeds moeten gaan om een (voorwaardelijk) opzettelijke afgifte van een wederrechtelijke vergunning en zal doorgaan het opzet gericht moeten zijn op de verwezenlijking van het strafbaar feit. Mijns inziens vormen deze beperkingen van de deelnemingsregeling nu juist wenselijke begrenzingen van de strafrechtelijke aansprakelijkheid voor het foutieve overheidsoptreden. Het lijkt me bijvoorbeeld niet gepast om ook op culpose wederrechtelijke vergunningverlening strafrechtelijk te reageren. Het mag zeker niet de bedoeling zijn om een heksenjacht op functionarissen te openen op grond van een zeer ruime strafbaarstelling. Evenmin heeft het zin om de vergunningverlener strafrechtelijk aansprakelijk te stellen omdat deze een andere (naar achteraf bleek verkeerde) interpretatie van de vergunningsvoorwaarden had. ${ }^{1654}$ Dat zou de afgifte van onrechtmatige vergunningen te zeer criminaliseren. Men mag daarenboven niet vergeten dat er ook nog voldoende andere en betere, vooral bestuursrechtelijke instrumenten zijn om tegen onrechtmatige vergunningen te reageren. Pas indien deze in hun werking niet het beoogde effect hebben en wanneer daarnaast sprake is van een bevordering door de overheid van ontoelaatbare milieuverstorende activiteiten, is er nog ruimte voor een strafrechtelijke reactie.

\section{$\S 5$. Conclusies}

Een vanuit rechtspolitiek oogpunt interessante vraag is of een strafrechtelijke aansprakelijkheid van overheden en hun functionarissen voor wederrechtelijke vergunningverlening mogelijk zou zijn, eens men in Nederland ertoe zou overgaan de restimmuniteit voor exclusieve bestuurstaken op te heffen. De administratieve afhankelijkheid van het milieustrafrecht levert immers een belangrijk argument voor een strafrechtelijke aansprake- 
lijkheid van overheden (maar ook van andere instanties, zoals onderzoeksbureaus) indien zij door een onzorgvuldige vergunningverlening bijdragen tot een ontoelaatbare graad van milieuverstoring. Dit probleem speelt vooral wanneer een onrechtmatige vergunning een strafuitsluitende werking heeft. Daarom is er voor gekozen in dit hoofdstuk voornamelijk aandacht te besteden aan enkele meer algemene vraagstukken, die rechtstreeks verband houden met 'de macht' van de vergunning in het milieustrafrecht. De positie van de vergunning in het milieustrafrecht bepaalt immers grotendeels het antwoord op de vraag naar een strafrechtelijke aansprakelijkheid voor wederrechtelijke vergunningverlening. Drie hoofdvragen staan in dit hoofdstuk op rechtsvergelijkende wijze centraal.

Allereerst is onderzocht wat de strafrechtelijke gevolgen zijn voor de strafrechter en de vergunninghouder indien een vergunning in strijd met wet of recht wordt verleend. Cruciaal is dan of de strafrechter aan dergelijke beschikkingen is gebonden. Moet hij blind varen op de onrechtmatige beschikking of is hij bevoegd deze te toetsen? Wanneer we deze vraag rechtsvergelijkend beantwoorden, stellen we een aantal belangrijke verschillen vast. Zo blijkt in Duitsland de strafrechtelijke toetsing van vergunningen de meeste problemen op te leveren. De strafrechtelijke toetsingsbevoegdheid is in beginsel zeer beperkt. De strafrechter is principieel gebonden aan rechtsgeldige beschikkingen ook al zijn ze onrechtmatig. De strafrechtelijke toetsing wordt gekenmerkt door een sterke beschikkingsafhankelijkheid of Verwaltungsaktsakzessorietät. Dit heeft als consequentie dat de justitiabele die beschikt over een onrechtmatige maar rechtsgeldige vergunning toch vrijuit gaat wanneer hem een handelen zonder vergunning wordt tenlastegelegd. Sinds 1994 wordt evenwel in bepaalde gevallen van rechtsmisbruik volgens $\S 330 \mathrm{~d} \mathrm{Nr} .5 \mathrm{StGB}$ aan rechtsgeldige vergunningen een strafuitsluitende werking ontzegd.

In Nederland is de situatie niet helemaal duidelijk. De strafrechter is gebonden aan de formele rechtskracht van beschikkingen, maar het is de vraag of dit geldt voor alle beschikkingen. De formele rechtskracht lijkt in het milieustrafrecht alleen bij belastende beschikkingen een beslissende rol te spelen, wanneer de justitiabele als verweer aanvoert dat de vergunningsvoorwaarden die hij heeft geschonden onrechtmatig zijn. Legt het OM een handelen zonder (rechtmatige) vergunning ten laste dan lijkt echter niets zich te verzetten tegen een strafrechtelijke toetsing Dit betekent dat de beperkte toetsingsbevoegdheid geen belemmering hoeft te zijn voor de strafrechtelijke handhaving van het milieurecht omdat het OM blijkbaar probleemloos de onrechtmatigheid van bevrijdende vergunningen kan inroepen. De strafrechter kan in zo'n geval toetsen, hetgeen betekent dat onrechtmatige bevrijdende vergunningen geen automatische strafuitsluitende werking hebben. Anderzijds is wel duidelijk geworden dat de beperking van de strafrechtelijke toetsingsbevoegdheid nadelig is voor de rechtspositie van de verdachte, daar hij zich niet voor het eerst bij de strafrechter op de onrechtmatigheid van een door hem overtreden voorschrift kan beroepen. De strafrechter acht zich dan gebonden aan de formele rechtskracht. Er is bepleit dat voor een dergelijke gebondenheid geen afdoende redenen aanwezig zijn en dat de rechtspraak dienaangaande moet worden bijgesteld. De strafrechter zou steeds de bevoegdheid moeten hebben om vergunningen aan wet en recht te toetsen. Er zou op dat punt geen verschil mogen bestaan tussen bevrijdende vergunningen en belastende vergunningsvoorschriften. Indien deze onrechtmatig zijn, zou de strafrechter 
deze onverbindend moeten kunnen verklaren. Dat blijkt ook het Belgische systeem te zijn. Het Belgische recht lijkt met de strafrechtelijke toetsing immers het verst te gaan. De Belgische strafrechter heeft ambtshalve de plicht om elke administratieve rechtshandeling die hij toepast te toetsen op zijn wettigheid en rechtmatigheid. Deze ruime toetsingsplicht heeft tot gevolg dat zowel het $\mathrm{OM}$ als de burger steeds de onrechtmatigheid van beschikkingen kunnen aanvoeren. Het wezenlijke probleem in het Belgische milieustrafrecht inzake strafrechtelijke toetsing is veeleer de kwestie of de strafrechter tot schorsing van de strafvordering dient over te gaan, indien tijdens de strafprocedure een administratieve rechtsgang hangende is. Om tegenspraken tussen de rechterlijke uitspraken te vermijden is gepleit voor een dergelijke schorsing, maar tot op heden schrijft de heersende rechtspraak dit niet voor.

Een volgende vraag had meer betrekking op de inhoud van de strafrechtelijke toetsing en daarmee verband houdend de inhoud van de milieustrafrechtelijke wederrechtelijkheid. Uitgangspunt moet blijven dat de mate waarin schade aan het leefmilieu kan worden toegebracht in eerste instantie door het bestuur, via algemene regels en beschikkingen, zoals vergunningen, wordt bepaald. Het bestuur beschikt immers over de relevante informatie en is ook beter geschikt om de belangenafweging te maken op basis waarvan wordt bepaald welke milieuverstoring is toegelaten. Dit is ook een taak die blijkens de onderlinge bevoegdheidsverdeling, die ons milieurecht kenmerkt, behoort te worden vervuld door het bestuur. Dat is niet de taak van de strafrechter. Maar dit hoeft nog niet te betekenen dat de strafrechter geen eigen rol kan vervullen en volledig afhankelijk dient te worden gemaakt van de bestuurlijke beslissingen. De cruciale vraag is daarom of de toetsing en derhalve ook de strafrechtelijke controle op de toegelaten omvang van de milieuverstoring uitsluitend afhankelijk dient te zijn van deze bestuurlijke beslissingen, ook wanneer deze onrechtmatig zijn, of dat deze veeleer moeten gericht zijn op de behartiging en de handhaving van het objectieve milieurecht waaraan niet alleen de burger maar ook het bestuur zich dient te houden. Me dunkt dat zowel voor de bescherming van het leefmilieu, als voor de rechtsbescherming van de burger, alsook voor een verantwoorde strafrechtelijke controle op het bestuurlijk handelen het de voorkeur verdient dat vergunningen slechts strafuitsluitend kunnen werken indien zij zijn verleend geworden conform de materiële en formele regels van het milieurecht voor zover deze laatsten van belang zijn voor de bescherming van het leefmilieu. Toetsing biedt de strafrechter mogelijkheden om de door het bestuur toegelaten milieuverstoring te controleren, maar de facto moet slechts worden gecontroleerd of niet alleen de burger maar ook de bestuurlijke overheid zelf bij het verlenen van een vergunning en het vastleggen van de voorwaarden de regels van het milieurecht eerbiedigt en binnen de haar toegekende bevoegdheden is gebleven. Voor een mogelijke strafrechtelijke aansprakelijkheid van de vergunningverlener betekent dit dat in zijn hoofde slechts sprake is van wederrechtelijke vergunningverlening indien de vergun-ning is afgegeven in strijd met de materiële milieurechtsregels en de formele rechtsregels die gericht zijn op de bescherming van het leefmilieu. Daaruit volgt ook dat indien de vergunningverlener binnen zijn beslissingsruimte (beoordelings- en beleidsvrijheid) is gebleven de vergunning niet onrechtmatig is verleend. 
Ervan uitgaande dat vergunningverlenende overheden vervolgbaar zouden moeten zijn is tenslotte bekeken op welke wijze een strafrechtelijke aansprakelijkheid voor wederrechtelijke vergunningverlening de lege lata op grond van de bestaande milieustrafbepalingen zou kunnen worden gekwalificeerd. Er is vastgesteld dat er op dat vlak tussen de bestudeerde landen grote verschillen bestaan. Zo is in de Duitse Bondsrepubliek een strafrechtelijke aansprakelijkheid van vergunningverlenende ambtenaren (de rechtspersoon is immers niet strafbaar gesteld) in beginsel slechts mogelijk indien de vergunning geen strafuitsluitende werking heeft. Daar is evenwel één uitzondering op: indien straffeloosheid van de vergunninghouder voorligt, omdat deze zich kan beroepen op een onrechtmatige vergunning, is vervolging en bestraffing van de vergunningverlener dogmatisch mogelijk op grond van mittelbare Täterschaft (doen plegen). Het moet dan wel gaan om een gemeen milieudelict, zoals het 'unbefugt' verontreinigen van het oppervlaktewater ( $324 \mathrm{StGB}$ ). De aard van het milieudelict vormt daarom, naast de beperkingen op de strafrechtelijke toetsingsbevoegdheid, de voornaamste hinderpaal om tot een strafrechtelijke aansprakelijkheid van de vergunningverlener te komen. Naar Duits recht kan de vergunningverlener immers niet aansprakelijk zijn voor het doen plegen of medeplegen van een kwaliteitsmilieudelict. Dit is anders in Nederland en België. Strafrechtsdogmatisch gezien zijn er geen onoverkomelijke bezwaren om de deelnemingsregeling op milieudelicten toe te passen en om via die weg tot een strafrechtelijke aansprakelijkheid van de vergunningverlener te komen. Wel is benadrukt dat een strafrechtelijke aansprakelijkheid voor wederrechtelijke vergunningverlening op grond van deelneming moeilijk denkbaar is zolang er geen bruikbare milieustrafrechtelijke alternatieven zijn voor de abstracte gevaarzettingsdelicten. In die zin levert het onderzoek naar een strafrechtelijke aansprakelijkheid voor wederrechtelijke vergunningverlening een extra argument op voor een herijking van het Nederlandse en Belgische milieustrafrecht. 



\section{Eindconclusies en aanbevelingen}

\section{§1. Inleiding}

In voorliggend hoofdstuk worden rond de belangrijkste thema's, die in dit boek worden behandeld, eindconclusies geformuleerd alsook enkele aanbevelingen ter verbetering van de vastgestelde knelpunten. Hoewel reeds in de voorgaande hoofdstukken al enkele belangrijke aanbevelingen zijn gedaan, is het wenselijk deze afzonderlijk op een meer geïntegreerde en systematische wijze bondig samen te vatten.

\section{§ 2. Primaat van rechtsstatelijk realisme: overheden zijn onderworpen aan de regels van het strafrecht}

In dit boek wordt gepoogd twee vragen te beantwoorden. In de eerste plaats de vraag in welke gevallen overheden naar huidig recht voor milieuverstoring strafrechtelijk aansprakelijk zijn. In de tweede plaats de vraag of een strafrechtelijke aansprakelijkheid van overheden alsnog mogelijk moet zijn wanneer deze in bepaalde gevallen wordt uitgesloten. $\mathrm{Er}$ is vastgesteld dat de strafrechtelijke positie van overheden een netelige kwestie is, die talrijke vragen doet rijzen. In de eerste plaats rijzen er vragen die betrekking hebben op de plaats en functie van ons milieustrafrecht in onze moderne samenleving, maar daarnaast ook belangrijke rechtstheoretische vragen, die, het milieustrafrecht overstijgend, de kern van de rechtsstaat raken: de eis dat de overheid gebonden is aan wet en recht lijkt immers in het strafrecht niet altijd op te gaan. We hebben gezien dat een strafrechtelijke controle op overheidshandelen allerminst vanzelfsprekend is. Aan de hand van een rechtsvergelijkende analyse is onder meer duidelijk geworden dat zowel in Frankrijk als in Nederland de staat volledig buiten de werking van het strafrecht wordt geplaatst en dat lagere overheden een immuniteit genieten wanneer zij zogenaamd als 'overheid' optreden. Naar Belgisch recht zijn (alle) overheden niet strafrechtelijk verantwoordelijk, ook wanneer zij strafbare feiten begaan binnen het kader van gedragingen die ook door particulieren kunnen worden verricht.

De vraag rijst dan of er inderdaad overtuigende redenen zijn om overheden van de werking van het strafrecht uit te sluiten. Ik meen van niet. Uitgangspunt dient te zijn dat in beginsel ieder overheidshandelen aan de regels van het strafrecht is onderworpen en derhalve 
voorwerp moet kunnen zijn van strafrechtelijke controle indien dit handelen een strafbaar feit constitueert. De voornaamste argumenten contra de strafrechtelijke vervolging en aansprakelijkheid van overheden, namelijk de machtenscheiding en de democratische controle, overtuigen niet. Afgezien van het feit dat de meeste argumenten ook zouden kunnen worden gebruikt bij strafbare feiten gepleegd bij niet-typische overheidstaken, is duidelijk geworden dat zij niet voldoende in staat zijn een uitsluiting van overheden van de werking van het strafrecht te rechtvaardigen. Een belangrijke rode draad in de meeste argumenten is dat het primaat moet liggen bij niet-strafrechtelijke controlemechanismen, zoals bestuurlijk toezicht of politieke controle. Maar daarbij wordt veelal doelmatigheidscontrole met rechtmatigheidscontrole verward en wordt de zelfstandige waarde en functie van strafrechtelijke controle ontkend. Daarnaast kan de machtenscheiding veeleer als een argument voor dan als een argument tegen strafrechtelijke controle worden uitgelegd. Ook kan worden opgemerkt dat de bij overheden aanwezige beslissingsruimte (beoordelings- en beleidsvrijheid) geen beletsel vormt voor civielrechtelijke of bestuursrechtelijke controle. Niet valt in te zien waarom deze beslissingsruimte dan wel een strafrechtelijke controle zou beletten. Het nut van een strafrechtelijke controle wordt trouwens in de praktijk bevestigd door de vaststelling dat in een aantal gevallen een bestuurlijke of politieke controle niet werkt. Met name in situaties waar de ecologische rechtsgoederen rechtstreeks worden geschonden of de gezondheid en veiligheid van de mens worden bedreigd, is een strafrechtelijke reactie op zijn plaats en kan een bestuurlijke of politieke reactie moeilijk worden aangemerkt als een volwaardig alternatief voor een strafvervolging.

Meer fundamenteel kan worden geconcludeerd dat de visie dat overheden boven de strafwet dienen te staan, getuigt van een eenzijdige benadering van het strafrecht, dat slechts waarde of nut zou hebben als instrument in handen van de overheid voor de regulering en de controle van het gedrag van burgers. Dit instrumentalistische uitgangspunt lijkt zowel rechtsstatelijk als vanuit de na te streven bescherming van het leefmilieu niet langer verantwoord. Vooral in de ongeclausuleerde strafrechtelijke immuniteit van de staat kunnen we een etatistische visie op staatssoevereiniteit ontwaren, die achterhaald is en die grotendeels teruggrijpt op een opvatting over recht als niet meer dan een samenstel van bevelsconstructies. Door de staatsimmuniteit wint de overheid echter niet aan gezag, maar wordt juist het gerechtvaardigde vertrouwen van burgers in de overheid danig ondermijnt.

Kortom, het principe dient te zijn dat overheidshandelen niet a priori aan het oordeel van de strafrechter moet worden onttrokken. Vanuit dit rechtsstatelijke en machtskritische uitgangspunt kan wezenlijke kritiek worden geuit op een strafrechtelijke immuniteit van overheden en verdient het aanbeveling dat zowel de in het Pikmeer II-arrest als de in het Volkel-arrest neergelegde rechtsregels in de richting van een principiële vervolgbaarheid van overheden worden herzien. Vertrouwen in democratische en bestuurlijke controle is goed, maar een vertrouwen in rechtsstatelijk realisme is beter. 


\section{§3. De strafrechtelijke positie van openbare lichamen: afscheid van de partiële immuniteit}

In Nederland is sinds Pikmeer II een belangrijke opening gecreëerd in de strafvervolging van lagere overheden. De strafrechtelijke immuniteit is in ieder geval wat openbare lichamen betreft, beperkt tot strafbare feiten die zijn gepleegd bij de uitvoering van een specifieke wettelijke bestuurstaak die uitsluitend door bestuursfunctionarissen kan worden verricht. Met dit arrest heeft de Hoge Raad tevens uitdrukkelijk afstand genomen van het oorspronkelijke standpunt dat politieke en bestuursrechtelijke controlemechanismen een strafrechtelijke aansprakelijkheid in de weg zouden staan. Niettegenstaande dat het aantal gevallen waarbij overheden een strafrechtelijke immuniteit genieten nu in de praktijk sterk is beperkt, is dit geen zuivere oplossing van de problematiek.

In de eerste plaats is kritiek mogelijk op (de aanscherping van) het taakcriterium. De vraag wanneer taken uitsluitend door overheden kunnen worden verricht is niet steeds eenduidig te beantwoorden. Bovendien ontwijkt het taakcriterium een meer fundamentele en materiële oplossing. Een belangrijk bezwaar tegen de immuniteitscriteria (openbaar lichaam en overheidstaak), die reeds golden vóór Pikmeer II, was steeds dat deze uitsluitend een formeel karakter hadden. De Hoge Raad wilde, in navolging van de MvT op artikel $51 \mathrm{Sr}$, een duidelijk onderscheid maken tussen handelen van de overheid 'als zodanig' en handelen van de overheid 'op gelijke voet met een particulier'. De zoektocht naar het verschil tussen acta iure imperii en acta iure gestionis, die op het vlak van de civielrechtelijke aansprakelijkheid al lang werd opgegeven, kreeg zo een centrale betekenis in de afbakening van de strafvervolging van overheden. De achterliggende idee was dat met deze formele criteria iedere materiële en inhoudelijke toetsing van het overheidshandelen kon worden vermeden door de zaak te doen stranden bij de ontvankelijkheidsvraag. Uitgangspunt was immers dat de controle op bestuurstaken moest plaatsvinden via het bestuurlijk toezicht en niet (ook) via de strafrechtelijke handhaving. Nu de Hoge Raad van dit standpunt terecht afstand heeft genomen, rijst de vraag wat de meerwaarde is van zowel het openbaar lichaam- als het aangescherpte taakcriterium. De argumenten die de Hoge Raad aanhaalt om tot een bijstelling te komen van zijn eerdere jurisprudentie rechtvaardigen evenzeer vervolgbaarheid van overheden voor handelingen die alleen door hun functionarissen kunnen worden verricht.

Meer algemeen kan worden opgemerkt dat met het huidige tweesporen-systeem - vervolgingsuitsluitingsgronden naast rechtvaardigingsgronden - de oorspronkelijke ratio van strafrechtelijke onvervolgbaarheid van overheden op de helling is komen te staan. De vóór Pikmeer II bestaande immuniteiten werden hoofdzakelijk gemotiveerd door de veronderstelling dat strafbare feiten eigenlijk reeds op voorhand zijn gerechtvaardigd wanneer ze zijn gepleegd in het kader van een wettelijke overheidstaak. Het is echter duidelijk dat noch het algemeen belang, noch de kwalificatie overheidstaak als zodanig het plegen van strafbare feiten kunnen rechtvaardigen en strafrechtelijke controle overbodig maken. Sinds Pikmeer II kan de vraag of een strafbaar feit, gepleegd in het kader van een niet-exclusieve overheidstaak, in concreto gerechtvaardigd is door de strafrechter worden getoetst. Deze materiële beoordeling van de strafrechtelijke rechtmatigheid van overheidsgedragingen 
gebeurt strafprocessueel aan de hand van de rechtvaardigingsgronden. Het is dan vreemd dat een strafrechtelijke controle uitgesloten blijft wanneer het gaat om exclusieve overheidstaken, dat wil zeggen, taken die alleen door bestuursfunctionarissen kunnen worden uitgevoerd. Blijkbaar gaat de Hoge Raad er nog steeds van uit dat bij dit soort overheidstaken de rechtvaardiging tot het plegen van strafbare feiten wel reeds op voorhand bestaat en zij dus daarom niet strafrechtelijk mogen worden gecontroleerd. Niettemin kan moeilijk worden volgehouden dat het in strijd met wet en recht verrichten van strikte overheidstaken, zoals bijvoorbeeld het verlenen van illegale vergunningen, reeds op voorhand gerechtvaardigd zou zijn omdat het om een exclusieve overheidstaak gaat en dus om die reden iedere strafrechtelijke controle zou zijn uitgesloten.

Een eerste mogelijke aanbeveling aan de rechter is daarom dat aan de huidige immuniteitscriteria een nadere motivering wordt gegeven. Deze behoeven op zijn minst een nadere verklaring, te meer nu men zich nauwelijks van de indruk kan ontdoen dat de ommegang van de Hoge Raad hoofdzakelijk lijkt te zijn ingegeven door pragmatisme en maatschappelijke verontwaardiging.

Deelt men echter de in deze studie verdedigde stelling dat er geen overtuigende argumenten voor immuniteit zijn, noch duidelijke criteria om aan te geven wanneer overheden van strafvervolging moeten worden uitgesloten, dan verdient het aanbeveling dat definitief afstand wordt genomen van de thans bestaande vervolgingsuitsluitingsgrond. De vraag rijst dan wel of hiervoor wetgevend ingrijpen noodzakelijk is. Ik meen van niet. De huidige redactie van artikel $51 \mathrm{Sr}$ laat in beginsel vervolging van overheden als publiekrechtelijke rechtspersonen toe. Zoals gezien, is de strafrechtelijke immuniteit van overheden een produkt van de Hoge Raad en is in de rechtspraak al lang afstand genomen van de zogenaamde 'bedoeling van de wetgever' ten tijde van de invoering van artikel $51 \mathrm{Sr}$. Reeds met Pikmeer II is de Hoge Raad voor een belangrijk deel omgegaan. Het verdient derhalve aanbeveling dat de Hoge Raad de ingeslagen weg voortzet en kiest voor het meest zuivere en rechtsstatelijk verantwoorde uitgangspunt, namelijk dat openbare lichamen in beginsel steeds aan strafrechtelijke controle onderworpen zijn.

\section{§4. De strafrechtelijke positie van de staat: doorbreking van de absolute immuniteit en de civielrechtelijke rechtspersoonlijkheid}

Kan reeds om gegronde redenen de partiële immuniteit van openbare lichamen worden bekritiseerd, helemaal problematisch is de strafrechtelijke positie van de staat. Ten gevolge van het Volkel-arrest geniet de staat tot op heden nog steeds een ongeclausuleerde immuniteit. Er zijn echter geen doorslaggevende argumenten om de staat strafrechtelijk anders te behandelen dan openbare lichamen. Er kan worden geconcludeerd dat de verschillende argumenten tegen een aansprakelijkheid van de staat één ding gemeen hebben: namelijk het gegeven dat de staat als een ondeelbaar geheel wordt waargenomen. Deze eenzijdige voorstelling van de staat als een monolitisch blok strookt niet met het recht, noch met de maatschappelijke realiteit. Immers, met eenzelfde argumentatie dient dan ook te worden uitgesloten dat de staat zichzelf civielrechtelijk aansprakelijk stelt, of aan zichzelf belastingen betaalt. 
De immuniteit van de staat komt trouwens door de Hoge Raad zelf enigszins op de helling te staan. Hoewel de Hoge Raad zich in het Tweede Pikmeer-arrest niet uitspreekt over de vervolgbaarheid van de staat, wordt wel uitdrukkelijk vooropgesteld dat politieke en bestuurlijke controle zich niet tegen een strafrechtelijke controle van overheidshandelen verzetten. Nu in het Volkel-arrest de immuniteit van de staat voor een belangrijk deel wordt gemotiveerd met de onverzoenbaarheid van de strafrechtelijke aansprakelijkheid met parlementaire controle en ministeriële verantwoordelijkheid, verdient het aanbeveling dat de Hoge Raad ook hier 'omgaat' en de staat vervolgbaar acht. In ieder geval behoeft de bijzondere positie van de staat nadere motivering.

De problematiek van de vervolgbaarheid van de staat, kan echter ook op een andere, wellicht zelfs meer realistische manier worden opgelost. De 'ondeelbaarheid' van de staat en de daarmee samenhangende argumenten tegen vervolging van de staat, speelt in het strafrecht voornamelijk omdat de strafrechtelijke ansprakelijkheid via artikel $51 \mathrm{Sr}$ is gekoppeld aan een civielrechtelijk gekleurd rechtspersoonlijkheidsbegrip. Het is de rechtspersoon 'de staat' die moet worden vervolgd indien binnen haar organisatie door een publiekrechtelijke entiteit, die geen rechtspersoonlijkheid bezit, een strafbaar feit wordt begaan. Dat dit leidt tot ongerijmdheden is geillustreerd aan de hand van de zbo's. Hebben zbo's een eigen rechtspersoonlijkheid, dan zijn deze altijd vervolgbaar, zelfs wanneer het gaat om strikte overheidstaken. Kennen zbo's om wat voor reden ook geen rechtspersoonlijkheid dan genieten zij ten alle tijde de immuniteit van de staat waartoe zij automatisch behoren. Er kan dan ook worden verdedigd dat voor een strafrechtelijke aanpak en controle van publiekrechtelijke organisaties, die tot 'de staat' behoren, strafrechtelijk realisme moet primeren. Dit betekent dat men de strafrechtelijke blik niet langer op de rechtspersoonlijkheid van de staat dient te richten, maar op de publiekrechtelijke organisaties, die als zelfstandige strafrechtelijke rechtssubjecten moeten worden beschouwd. Dit niet zozeer omdat het absoluut onmogelijk zou (moeten) zijn om de staat als dusdanig te vervolgen of te bestraffen, maar omdat zo recht wordt gedaan aan de maatschappelijke realiteit alsook aan de legitieme doelstellingen die het strafrecht bij de aanpak van overheidscriminaliteit moet kunnen vervullen. Meteen vallen zo ook alle argumenten weg die voor de staatsimmuniteit worden aangevoerd. Het gaat immers niet meer om de staat, maar om de publiekrechtelijke organisaties die daar deel van uitmaken. Het vraagstuk van strafrechtelijke controle van strafbare feiten die binnen 'de staat' worden gepleegd, wordt zo tot zijn werkelijke proporties teruggebracht.

Het verdient dan wel aanbeveling artikel $51 \mathrm{Sr}$ aan te passen in die zin dat ook publiekrechtelijke organisaties die behoren tot de staat, maar geen eigen civielrechtelijke rechtspersoonlijkheid genieten gelijk worden gesteld met het begrip 'rechtspersoon' in de zin van artikel $51 \mathrm{Sr}$. Dergelijke legislatieve wijziging betekent evenwel niet dat een vervolging van de rechtspersoon 'de staat' bij voorbaat ondenkbaar zou zijn. Wel moet een strafvervolging van de staat een uitzondering blijven, mede gelet op de problemen die kunnen rijzen bij het bewijs van het daderschap van de staat. Zo lijkt een vervolging van de staat als dusdanig slechts aangewezen wanneer uit het strafrechtelijk onderzoek blijkt dat er ook op departementeel niveau sprake is van laakbaar gedrag dat als strafwaardig kan 
worden aangemerkt, bijvoorbeeld wanneer de verantwoordelijke topambtenaren, staatssecretaris of minister op de hoogte waren van de strafbare feiten maar daartegen geen maatregelen namen hoewel zij daartoe gehouden waren. In een dergelijk geval is het wellicht opportuun de staat zelf aan te spreken al dan niet tezamen met de verantwoordelijke topfunctionaris. In andere gevallen waar de verantwoordelijkheid van het gepleegde delict vooral doorweegt bij de 'lagere' publiekrechtelijke sub-organisatie waarbinnen het feit is gepleegd (zoals in de Volkel-casus) en niet (ook) bij de departementele top, ligt meer een vervolging van deze sub-organisatie zelf in de rede.

\section{§5. De opportuniteit van de strafvervolging van overheden}

De principiële toepassing van het strafrecht op overheden impliceert niet dat in alle gevallen waar mogelijk strafbaar overheidsoptreden in het geding is, een strafrechtelijke reactie moet volgen. Het argument dat de prioriteit bij de politieke of bestuursrechtelijke controle zou moeten liggen, kan weliswaar geen immuniteit rechtvaardigen maar wel dat niet onbehoedzaam met strafvervolging moet worden omgegaan.

De kwestie wanneer wel en wanneer niet een strafrechtelijke reactie gepast is, moet daarom eerst bij de opportuniteit van de vervolging worden beoordeeld. Het is toe te juichen dat de Hoge Raad dit ook met zoveel woorden in het Pikmeer II-arrest heeft voorgeschreven. In die zin verdient het aanbeveling dat het $\mathrm{OM}$ niet lichtvaardig tot vervolging overgaat. Een ondoordacht gebruik van het strafrecht zou bestuurlijke apathie tot gevolg kunnen hebben. Ook wat wetsovertredende overheden betreft, dient het strafrecht bij voorkeur ultimum remedium te blijven en slechts te worden toegepast wanneer andere verantwoordingsfora niet werken of hebben gefaald. Het is dan ook een goede zaak dat door het OM zelf, onder meer in de door de Procureurs-Generaal opgestelde vervolgingsrichtlijnen, is gekozen voor een genuanceerde, realistische en uitgebalanceerde toepassing van het opportuniteitsbeginsel. Het is aan het OM om terzake in goed maar kritisch overleg met de andere handhavingspartners een consistent en verantwoord vervolgingsbeleid te voeren. Zo dient in het vervolgingsbeleid centraal uitgangspunt te zijn dat niet tot vervolging wordt overgegaan indien de verboden overheidsgedraging voorwerp uitmaakt van een interne democratische controle, bestuurlijk toezicht of een procedure voor de bestuursrechter. Al naargelang de uitkomst van deze buitenstrafrechtelijke procedures kan desgevallend tot een transactie, sepot of vervolging worden overgegaan. Vervolging ligt in de rede indien blijkt dat nietstrafrechtelijke alternatieven niet hebben geleid tot normconform gedrag van de betrokken overheid of wanneer een behoorlijk herstel van de verboden situatie uitblijft. Hiervan kan ook sprake zijn indien de democratische organen de verboden overheidsgedraging toch goedkeuren. Een positief politiek oordeel kan als zodanig niet automatisch de strafbaarheid van het gepleegde delict wegnemen of een vervolging bij voorbaat uitsluiten.

Andere factoren die een rol zouden moeten spelen in de beslissing om al dan niet strafrechtelijk te vervolgen, zijn de aard en ernst van het gepleegde feit (gaat het om een misdrijf of een overtreding), de door het delict veroorzaakte schade of gevaarzetting, recidive, de houding van de overheid ten aanzien van de wetsovertreding, of door de 
overheid in kwestie reeds de nodige maatregelen zijn genomen om de schade te herstellen alsook het feit of er regelingen zijn getroffen ter voorkoming van herhaling.

Wat de strafvervolging van overheden betreft past ook nog een enkele opmerking over de aanwijzingsbevoegdheid van de Minister van Justitie. Juist in deze ook (partij)politiek gevoelige materie is een uiterst kritische distantie tussen OM en Minister geen overdreven luxe. In dossiers waarin het overheidshandelen strafrechtelijk ter discussie staat, is de rechtsgemeenschap enkel gediend met een $\mathrm{OM}$ dat voldoende machtskritische onafhankelijkheid bezit om overheden die de regels overtreden te kunnen vervolgen. Het verdient daarom aanbeveling dat de Minister van Justitie zijn aanwijzingsbevoegdheid niet mag gebruiken in zaken waar strafbaar overheidsoptreden in het geding is. In die zin kan worden gedacht aan een wetswijziging van artikel 127 RO waarin wordt neergelegd dat de aanwijzingsbevoegdheid niet kan worden gebruikt wanneer overheden, in het bijzonder de staat, verdacht worden van een strafbaar feit. Maar zelfs zonder een wetswijziging zou op basis van een invoering van een nieuwe regel van staatsrechtelijke gewoonterecht kunnen worden bepaald dat in strafzaken tegen overheden artikel $127 \mathrm{RO}$ niet mag worden gebruikt.

Hiermee samenhangend rijst de vraag of voor de strafvervolging van de staat, in de veronderstelling dat de Hoge Raad ook op dit punt 'omgaat', in navolging van de vervolging van departementshoofden voor ambtsmisdrijven en de Wet ministeriële verantwoordelijkheid, een specifieke procedure noodzakelijk is. Dit lijkt voor de meeste niet politiek-gevoelige gevallen een te zware procedure. In situaties zoals de bodemverontreiniging op de Vliegbasis Volkel is het onzinnig dat alleen zou kunnen worden vervolgd indien de Kroon of de Tweede Kamer de P-G bij de Hoge Raad daartoe een bevel geeft en dat de bestraffing alleen door de Hoge Raad kan worden uitgesproken. Het moet mogelijk zijn dat in dergelijke casusposities een OvJ de strafvervolging instelt. In mijn voorstel zou trouwens in zo'n geval de vliegbasis zelf worden vervolgd en niet de staat, zodat de vraag naar een aparte procedure hier niet rijst. Uitsluitend wanneer ministers of staatssecretarissen zelf betrokken zijn bij het gepleegde delict, lijkt het aangewezen dat de vervolging niet door een OvJ wordt ingesteld, maar door een hogere autoriteit binnen het OM, zoals de P-G bij de Hoge Raad. Deze beschikt traditioneel ook over een grotere onafhankelijkheid ten aanzien van de Minister van Justitie.

\section{§ 6. Geen vervolgingsuitsluitingsgronden maar rechtvaardigingsgronden als oplossing}

Het moge inmiddels duidelijk zijn dat gelet op de kritiek op de strafrechtelijke immuniteit(scriteria) er geen afdoende redenen zijn om vast te houden aan de onvervolgbaarheid van overheden. Er kan daarom beter volledig en niet slechts ten dele worden gekozen voor een materiële benadering van de problematiek. Indien de opportuniteitsvraag positief wordt beantwoord en tegen de verdachte overheid (de staat of een lagere overheid) een strafvervolging wordt ingesteld, dient door de strafrechter op het niveau van de wederrechtelijkheid te worden bekeken of de overheidsgedraging een strafrechtelijke reactie rechtvaardigt. Dat is vanuit strafrechtelijk oogpunt ook de meest aangewezen weg. 
Aan de door overheden gepleegde strafbare feiten ligt vaak een belangenconflict ten grondslag. De vraag is steeds of de gemaakte belangenafweging rechtmatig is. Om te kunnen beoordelen of het gepleegde feit moet worden aangemerkt als een strafbaar en dus wederrechtelijk feit is het noodzakelijk dat de strafrechter de bestuurlijke belangenafweging aan het recht toetst. Natuurlijk zal dergelijke toetsing beperkt zijn wanneer in hoofde van het bestuur sprake is van een beoordelings- of beleidsvrijheid. Maar de strafrechter kan dan evenals de administratieve en burgerlijke rechter het overheidshandelen op zijn rechtmatigheid toetsen. Immers, ook de uitoefening van de beleidsvrijheid moet zodanig zijn dat deze in overeenstemming is met de wet en geen strafbaar feit oplevert. In de praktijk betekent dit dat de overheid in kwestie beroep zal kunnen doen op de rechtvaardigingsgrond 'wettelijk voorschrift' (art. $42 \mathrm{Sr}$ ) en de rechtvaardigingsgrond 'overmacht in de zin van noodtoestand' (art. $40 \mathrm{Sr}$ ). Wat noodtoestand betreft moet dan wel duidelijk sprake zijn van een hoger rechtsbelang dan het rechtsbelang dat door het strafbaar feit is geschonden. Dat zal niet vaak het geval zijn. Eigen financiële-economische belangen van overheden mogen in ieder geval geen prioritaire rol spelen. Er mag immers niet worden vergeten dat het belangenconflict tussen milieubescherming en sociaal-econmische belangen in eerste instantie reeds door de wetgever en in tweede instantie door de vergunningverlenende instanties is beslecht. Dat betekent onder meer dat noodtoestand ook in hoofde van overheden alleen mag worden aangenomen indien de naleving van de (milieu)wetgeving in een concreet geval tot exceptionele niet door de wetgever voorziene consequenties zou leiden.

\section{§ 7. Het daderschap van overheden en het feitelijk leidinggeven}

In dit boek is ook aandacht besteed aan de wijze waarop het daderschap in hoofde van overheden dient te worden vastgesteld. Er kan worden geconcludeerd dat het niet mogelijk, noch wenselijk is één algemeen geldend daderschapscriterium uit te denken op basis waarvan overheden (of andere rechtspersonen) voor milieuverstoring strafrechtelijk aansprakelijk kunnen worden gesteld. Tevens is vastgesteld dat in de rechtspraak over het leerstuk van het daderschap nog steeds veel onduidelijkheid bestaat en dat vooral op het vlak van bewijs een niet denkbeeldig risico bestaat dat al te vlug aan de vaststelling van de verwijtbaarheid (schuld) in hoofde van de organisatie wordt voorbijgegaan.

Aanbeveling aan de rechter is derhalve bij de formulering van het rechtspersoonlijke daderschap meer rekening te houden met zowel de instrumentele als de rechtsbeschermende dimensie van het schuldbeginsel in het strafrecht. In de praktijk betekent dit dat expliciet van geval per geval moet worden gekeken naar de aard van de organisatie (gaat het om een kleine, transparante gemeente of om een complexere organisatie) en het type milieudelict dat in een concreet geval wordt tenlastegelegd. Wat zeker moet worden vermeden, is een objectieve aansprakelijkheid of een aansprakelijkheid waarvan de toerekeningscriteria te zeer worden genormativeerd. Het gevaar is steeds aanwezig dat de strafrechter naar een sociaal wenselijke uitkomst toe redeneert waardoor niet alleen onrecht wordt gedaan aan de klassieke rechtswaarborgen, maar het strafrecht ook zijn sturende werking dreigt te verliezen. Deze aanbeveling is natuurlijk niet slechts van belang voor de strafrechtelijke aansprakelijkheid van overheden, maar ook voor de strafbaarheid van privaatrechtelijke rechtspersonen en natuurlijke personen. Wat moet worden vermeden is 
dat via de 'omweg' van de strafrechtelijke aansprakelijkheid van de rechtspersoon de klassieke strafrechtelijke leerstukken en waarborgen ook in hoofde van natuurlijke personen op den duur worden uitgehold.

Een andere aanbeveling aan rechtspraak en rechtsleer is dat de organisatorische of corporatieve 'schuld' op strafrechtsdogmatisch vlak, meer dan thans het geval is als een zelfstandige en volwaardige vorm van schuld wordt erkend en onderzocht. De strafbaarheid van de rechtspersoon wordt soms nog te veel benaderd als een vraagstuk van menselijke verantwoordelijkheid of als een afgeleide van individuele verwijtbare gedragingen. Gaat het om complexe organisaties en in tijd gespreide risicovolle activiteiten dan kan het daderschap van de rechtspersoon dogmatisch worden gelegitimeerd en gefundeerd op de feitelijke bedrijfsvoeringsschuld, de 'Lebensführungsschuld' van de organisatie. Deze schuld moet op basis van concrete bewijsmiddelen worden vastgesteld en niet slechts normatief worden bepaald.

Een andere aanbeveling aan de rechter is om meer duidelijkheid te scheppen in de kwestie wanneer een overheidsfunctionaris (ambtenaar of arbeidscontractant) als feitelijk leidinggever van een door de overheid gepleegd delict kan worden beschouwd. De uitspraken van de feitenrechters in het Pikmeer-dossier illustreren dat hierover nog te veel onzekerheid bestaat. Een belangrijk probleem dat hiermee samenhangt is hoe zo zuiver mogelijk kan worden onderscheiden tussen enerzijds een strafrechtelijke aansprakelijkheid van een overheidsfunctionaris voor eigen daderschap en een aansprakelijkheid van een functionaris voor feitelijk leidinggeven. Een eerste indicatie voor eigen daderschap kan zijn of de verantwoordelijkheid voor het gepleegde delict het zwaarste doorweegt bij de organisatie als geheel of bij de individuele functionaris. Dit betekent dat uit het enkele feit dat een functionaris op eigen initiatief heeft gehandeld niet meteen kan worden geconcludeerd dat slechts sprake is van eigen daderschap en dat de overheid daarom automatisch kan worden geacht geen strafbaar feit te hebben begaan. Het is immers best mogelijk dat de functionaris het delict op eigen houtje heeft gepleegd mede omdat binnen de bestaande bedrijfscultuur dergelijke feiten stilzwijgend werden goedgekeurd of omdat dit ten goede komt aan de organisatie. Met andere woorden, het is best mogelijk dat, om in Duitse termen te spreken, de Tatherrschaft eerder bij de organisatie dan bij het individu ligt, ook al heeft het er alle schijn van dat deze laatste eigenhandig heeft gehandeld. Er dient dus tijdens het strafrechtelijke onderzoek indringend te worden gekeken naar alle organisatorische factoren die mogelijk aan de door de functionaris verrichte verboden gedragingen hebben meegewerkt of deze hebben vergemakkelijkt. Wat moet worden vermeden is dat individuele functionarissen als zondebok worden opgeofferd voor strafbare gedragingen die bij nader inzien ook of zelfs eerder aan de overheid als dusdanig kunnen worden verweten. Langs de andere kant moet worden vermeden dat de individuele functionaris tracht zich te verschuilen achter de organisatie en zo zijn eigen verantwoordelijkheid probeert te ontwijken. Voortdurend moet voor ogen worden gehouden dat bij overheidscriminaliteit zowel de overheidsorganisatie zelf, de daarin werkzame verantwoordelijke bewindslieden als de feitelijke uitvoerders handelen binnen hun eigen verantwoordelijkheidsfeer. Daarbij is het van belang te beseffen dat de in de overheidsorganisatie werkende individuen veelal overgaan tot criminele feiten juist omdat binnen de organisatieopzet en -structuur, of de feitelijke 
besluitvorming alle daarvoor noodzakelijke criminogene voorwaarden aanwezig zijn. Het al te vlug aannemen van eigen daderschap van een functionaris kan ertoe leiden dat men het falen van de overheidsorganisatie te vlug uit het oog verliest. Mede daarom lijkt mij een belangrijke tweede indicatie ter bepaling van het eigen daderschap wie uiteindelijk baat heeft gehad of zou hebben gehad bij het gepleegde feit. Dat hoeft niet noodzakelijk geldelijk gewin te zijn. Het kan ook gaan om een verbetering van de machtspositie van of binnen de organisatie. Heeft de functionaris zijn macht en de organisatie gebruikt met het oog op eigen voordeel of het voordeel van derden, dan ligt eerder eigen daderschap in de rede, dan wanneer het delict is gepleegd uitsluitend ten voordele van de overheid. In dat geval kan natuurlijk nog wel sprake zijn van feitelijk leidinggeven.

In algemene zin moet steeds voor ogen worden gehouden dat het er, ook bij milieudelicten, niet alleen maar om gaat om 'daders' te vinden waaraan de milieuverstorende gedraging kan worden toegerekend, maar dat de centrale vraag moet blijven een gedragsbeïnvloeding te weeg te brengen die de naleving van de milieuvoorschriften ten goede komt. Indien men uit het oog verliest dat de strafrechtelijke aansprakelijkheid zo veel mogelijk dient aan te sluiten op een verwijtbaar handelen, dus schuld, zal een strafrechtelijke reactie niet de normbevestigende en vergeldende werking hebben die wordt beoogd. Daar is uiteindelijk ook het leefmilieu niet mee gediend. De op zichzelf legitieme strijd tegen milieuverstoring kan daarom nimmer een vervuiling van het strafrecht rechtvaardigen. Het gaat daarom niet slechts om de bescherming van het leefmilieu, maar ook om de bescherming van de 'natuur' van het strafrecht.

\section{§ 8. Strafrechtelijke vraagstukken bij wederrechtelijke vergunningverlening}

Vergunningverlening kan worden aangemerkt als een strikte bestuurstaak, die uitsluitend door bestuursfunctionarissen kan worden uitgevoerd. Dit betekent dat naar huidig recht overheden en hun ambtenaren in beginsel niet strafrechtelijk kunnen worden vervolgd voor een wederrechtelijke vergunningverlening. Uitzondering hierop is wanneer de wederrechtelijke vergunningverlening ook als een ambtsdelict kan worden aangemerkt, maar dan gaat het veelal om situaties waar niet zozeer de vergunningverlenende overheid zelf in het geding is, maar een individuele functionaris die zijn bevoegdheid misbruikt.

Vanuit milieustrafrechtelijk perspectief zijn echter vooral die gevallen van belang waarin de milieuoverheid als dusdanig in strijd met wet en recht vergunningen afgeeft en zo indirect bijdraagt tot milieuverstorende gedragingen. Zoals reeds is opgemerkt, dienen alle overheidsgedragingen in beginsel onder de werking van de strafwet te vallen. Een allereerste aanbeveling bestaat er dan ook in dat vergunning-verlening, net als alle andere zuivere bestuurshandelingen, niet van strafrechtelijke controle wordt uitgesloten.

In de veronderstelling dat vergunningverlenende overheden kunnen worden vervolgd, rijst de vraag of deze naar huidig recht zouden kunnen worden aansprakelijk gesteld. Of is er daarentegen nood aan een afzonderlijk strafbaarstelling van wederrechtelijke vergunningverlening, zoals door enkele Duitse auteurs wordt bepleit. Er moet inderdaad een aantal 
juridische obstakels worden overwonnen teneinde een vergunningverlenende overheid als pleger van een milieudelict aan te kunnen merken.

Een eerste belangrijk obstakel is dat talrijke milieunormen zich niet tot vergunningverleners richten, maar uitsluitend tot vergunninghouders en vergunningplichtigen, zodat de vergunningverlenende instanties de vereiste daderschapskwaliteit missen. De vergunningverlener kan dan slechts worden vervolgd als deelnemer aan het door de vergunninghouder gepleegde delict. Strafrechtsdogmatisch is het in beginsel mogelijk de vergunningverlener als medepleger, doen pleger of als medeplichtige te vervolgen. Daarnaast is natuurlijk van belang dat de strafrechter bevoegd moet zijn om de vergunningverlening aan wet en recht te toetsen. Indien de strafrechter gebonden is aan vergunningen, ook al zijn deze evident materieel onrechtmatig, dan is een strafrechtelijke aansprakelijkheid van zowel vergunninghouder als vergunningverlener immers uitgesloten.

Deze mogelijke hinderpalen rechtvaardigen echter nog geen wetgevend ingrijpen in de zin dat een seperate strafbaarstelling voor wederrechtelijke vergunningverlening zou moeten worden gecreëerd. Allereerst blijkt het met de toetsingsbevoegdheid van de Nederlandse strafrechter nogal mee te vallen, in die zin dat de formele rechtskracht niet van toepassing lijkt te zijn wanneer het $\mathrm{OM}$ de onrechtmatigheid van de vergunning, waarop de justitiabele zich beroept, aanvoert. De formele rechtskracht lijkt hoofdzakelijk te zijn ingegeven door de bekommernis dat de burger zich niet voor het eerst voor de strafrechter op de onrechtmatigheid van de vergunning kan beroepen. Hoewel het aanbeveling verdient dat volledig afstand wordt genomen van de formele rechtskracht in het strafrecht, bestaat de lege lata dus wel reeds de mogelijkheid voor de Nederlandse strafrechter om de rechtmatigheid van de vergunningverlening te beoordelen wanneer deze door het OM wordt aangevochten. Dit is een groot verschil met bijvoorbeeld Duitsland waar de strafrechtelijke toetsing van vergunningen de meeste problemen oplevert en vergunninghouders, die een milieudelict begaan, zich ook achter onrechtmatige vergunningen kunnen verschuilen. Het is vooral door deze beperkte toetsingsbevoegdheid van de Duitse strafrechter dat wederrechtelijke vergunningverlening in het Duitse milieustrafrecht zoveel problemen oplevert. Het is ook mede daarom dat in de literatuur zo sterk wordt gepleit voor een 'Amsträgerstrafbarkeit für fehlerhafte Genehmigung', omdat door de strafuitsluitende werking van onrechtmatige vergunningen de eigenlijke daders vrijuit kunnen gaan. In Nederland zijn deze nadelen veel minder aanwezig daar vergunninghouders nauwelijks beroep kunnen doen op onrechtmatige vergunningen. In die zin lijkt dan ook geen aanwijsbare reden aanwezig om in het Nederlandse strafrecht over te gaan tot een separate strafbaarstelling van wederrechtelijke vergunningverlening. Bovendien dient de milieustrafrechtelijke aandacht zich primair te richten op de verantwoordelijkheid van de vergunningplichtige en pas in tweede instantie op die van de vergunningverlener.

De crux van het probleem bij vrijwel alle strafrechtelijke vraagstukken die rijzen in verband met wederrechtelijke vergunningverlening dient te worden geplaatst bij de administratieve afhankelijkheid, meer bepaald de vergunningafhankelijkheid in het milieustrafrecht. Het is belangrijk voor ogen te houden dat een strafrechtelijke aansprakelijkheid voor wederrechtelijke vergunningverlening voornamelijk wordt verdedigd als tegengewicht voor de 
vergunningafhankelijke structuur van de strafbaarstellingen, die zeer nauw met de schending van administratieve plichten zijn verbonden. Met name uit de beschrijving van het Duitse milieustrafrecht is duidelijk geworden hoe een Verwaltungsaktsakzessorische onderbouwing van het milieustrafrecht een strafrechtelijke aansprakelijkheid van vergunninghouder en vergunningverlener kan bemoeilijken. Mijns inziens kunnen daarom de belangrijkste problemen die met de wederrechtelijke vergunningverlening samenhangen, inclusief de mogelijke strafbaarheid van de vergunningverlener, grotendeels worden opgelost door de strafbaarstellingen in het milieustrafrecht aan te passen in de richting van een meer administratiefrechtelijke of milieubeheersrechtelijke afhankelijkheid waarbij de macht van de vergunning wordt ingeperkt. Dit betekent onder meer dat de discretionaire beoordelingsbevoegdheid van ambtenaren bij de vergunningverlening steeds zo goed mogelijk moet kunnen worden begrensd door in algemene normen nader te bepalen waaraan de vergunning dient te voldoen. Daardoor zou het risico van te soepele vergunningen al grotendeels worden weggenomen en beschikt de strafrechter dan ook steeds over duidelijkere materiële normen waaraan hij een mogelijk onrechtmatige vergunning kan toetsen. Daarnaast zijn de normadressaten van een meer administratiefrechtelijk afhankelijk milieustrafrecht niet alleen de vergunninghouders, maar in beginsel een ieder, dus ook de vergunningverlenende (en controlerende) overheden. Eigenlijk beantwoorden de artikelen 173a en 173b Sr reeds aan een dergelijke meer administratiefrechtelijke strafbaarstelling en zouden deze artikelen dus in beginsel ook van toepassing kunnen zijn op wederrechtelijke vergunningverlening. Maar zoals gezien, kleven aan deze strafbepalingen talrijke nadelen, waaronder het feit dat het bestanddeel wederrechtelijk niet autonoom of zelfs niet objectief milieurechtelijk, maar vergunningafhankelijk moet worden opgevat. Een belangrijke aanbeveling is dan ook dat eindelijk werk wordt gemaakt van een herijking van deze strafbepaling.

Zoals reeds verschillende keren in deze studie is opgemerkt, wordt in de recente milieustrafrechtelijke literatuur in toenemende mate gepleit voor een meer Verwaltungsrechtsakzessorische wijze van strafbaarstellen in het milieustrafrecht, die meer recht doet aan zowel de bescherming van de ecologische rechtsgoederen als aan de rechtsstatelijke waarborgen. Dergelijke voorgestelde hervormingen van het milieustrafrecht nemen de belangrijkste pijnpunten van de administratieve afhankelijkheid en derhalve ook de nadelen van wederrechtelijke vergunningverlening weg.

Moet nog worden opgemerkt, dat, hoewel in beginsel een strafrechtelijke aansprakelijkheid van wederrechtelijke vergunningverlening niet bij voorbaat moet worden uitgesloten, het aanbeveling verdient slechts tot strafvervolging over te gaan wanneer de vergunningverlener milieunormen schendt die rechtstreeks betrekking hebben op de bescherming van ecologische rechtsgoederen en bovendien deze vergunningverlening duidelijk in verband staat met de opgetreden milieuverstoring. Met andere woorden, de vergunningverlening dient een noodzakelijk onderdeel te zijn van het gepleegde milieudelict Niet iedere onzorgvuldige vergunningverlening is strafrechtelijk relevant. Slechts wanneer de onrechtmatigheid mede verantwoordelijk is voor een concrete gevaarzetting of een schending van een ecologisch rechtsgoed of de menselijke gezondheid schaadt of in gevaar brengt, lijkt een strafvervolging opportuun. 


\section{§9. Slotopmerking}

Ik kom tot een afronding. In deze studie staat de vraag centraal of overheden strafrechtelijk aansprakelijk moeten kunnen worden gesteld voor milieuverstoring. Aan de hand van een kritische evaluatie van zowel het Nederlandse, Belgische, Duitse (en deels ook het Franse) recht werd geconcludeerd dat er geen afdoende redenen aanwezig zijn om overheden boven de strafwet te plaatsen. In principe dienen alle overheden onder de werking van het strafrecht te vallen en moet elke overheidsgedraging strafrechtelijk kunnen worden gecontroleerd wanneer deze een strafbaar feit oplevert. Dit draagt bij tot een meer consequente, effectieve, rechtvaardige en ook een meer machtskritische strafrechtelijke handhaving van het milieurecht. Het strafrecht zal ook naar overheden een repressieve en preventieve werking kunnen hebben. Bovendien kunnen een goed doordachte vervolging en bestraffing van overheden de democratische controle ondersteunen en geeft het een belangrijk signaal aan burgers en politiek verantwoordelijken. De enkele vervolging zal door middel van een openbaar en sereen uitgevoerd strafproces tevens kunnen zorgen voor de nodige duidelijkheid met betrekking tot de vaak complexe achtergronden van het gepleegde feit. Het openbaar ministerie heeft door de (dreiging met) vervolging de mogelijkheid in te spelen op de zuiverende en 'doofpot-vermijdende' werking die een strafproces kan hebben. Natuurlijk moet een strafrechtelijke controle op overheidsoptreden eerder uitzondering dan regel blijven en dient, waar mogelijk en wenselijk, het primaat te liggen bij de politieke en bestuurlijke controle. Maar waar deze faalt of niet volstaat, daarbij mede rekening houdend met de ernst van de overtreding, moet steeds plaats zijn voor het strafrecht. Uitgangspunt is in ieder geval dat elke overheid, die van haar burgers onder dreiging van een straf respect voor het recht eist, rechtsstatelijk slechts geloofwaardig is indien ook zij, bij overtreding van de wet, strafrechtelijk ter verantwoording kan worden geroepen. 



\section{Samenvatting}

Dit boek is een verslag van een rechtsvergelijkend onderzoek naar de strafrechtelijke aansprakelijkheid van overheden voor milieuverstoring. Het onderzoek heeft betrekking op de vraag in welke gevallen overheden strafrechtelijk aansprakelijk kunnen worden gesteld, en of een strafrechtelijke aansprakelijkheid mogelijk moet zijn wanneer deze in bepaalde gevallen wordt uitgesloten. Concrete aanleiding voor het onderzoek is de jurisprudentie van de Hoge Raad over de strafvervolging van overheden. Volgens de Hoge Raad geniet de Staat der Nederlanden een absolute strafrechtelijke immuniteit (Volkel-arrest 1994), en genieten openbare lichamen een strafrechtelijke immuniteit wanneer het gepleegde feit is begaan bij de uitvoering van een exclusieve bestuurstaak (Pikmeer II-arrest 1998). Op basis van de bevindingen uit dit onderzoek wordt de vraag beantwoord of de strafrechtelijke immuniteit voor overheden moet blijven bestaan. Ook worden aanbevelingen geformuleerd die kunnen bijdragen aan een oplossing van deze problematiek

In hoofdstuk I wordt het onderwerp van het onderzoek nader toegelicht en wordt een plan van aanpak gepresenteerd. Hoewel een strafrechtelijke aansprakelijkheid van overheden niet slechts betekenis heeft voor milieudelicten, blijkt deze probleemstelling juist voor het milieustrafrecht van groot belang. Twee situaties dienen daarbij van elkaar te worden onderscheiden. De eerste is die waarin het milieudelict zelf rechtstreeks door een overheid wordt begaan, zoals het uitbaten van een illegale stortplaats van een gemeente. Belangrijk is echter ook de situatie waarin een overheid op onrechtstreekse wijze, door onzorgvuldige vergunningverlening of gebrekkige controle, bijdraagt tot milieuverstoring. Beide situaties komen in dit boek aan bod. Juist in een rechtsgebied als het milieurecht, waar overheden zelf via de verantwoordelijke bewindslieden vorm en inhoud geven aan regelgeving enerzijds en de handhaving ervan anderzijds, is de vraag gerechtvaardigd of deze overheden strafrechtelijk ter verantwoording kunnen worden geroepen wanneer zij zelf de milieuwetgeving overtreden.

In hoofdstuk II wordt een schets gegeven van het rechtskarakter van het milieustrafrecht, en wordt beschreven hoe dit zijn schaduw vooruitwerpt op de vervolgbaarheid en de strafbaarheid van overheden. Het milieustrafrecht blijkt voor een belangrijk deel instrumentalistisch en overheidsondersteunend te zijn georiënteerd. Dit houdt verband met de wijze waarop het milieustrafrecht in onze risicomaatschappij is geconcipieerd. Het milieustrafrecht is 
gekenmerkt door een administratieve afhankelijkheid, meer in het bijzonder door een vergunningafhankelijkheid. De voorwaarden van strafbaarheid worden in belangrijke mate door milieuoverheden vastgelegd door het vaststellen van emissienormen in vergunningen en ontheffingen. $\mathrm{Zij}$ zijn eveneens verantwoordelijk voor het toezicht op de naleving van de milieuregelgeving. De meeste milieustrafbaarstellingen richten zich daarom hoofdzakelijk tot burgers en niet ook tot de overheden, die in de eerste plaats als de bewakers van het leefmilieu worden beschouwd en niet als mogelijke verstoorders van het leefmilieu. Hierdoor is er weinig ruimte voor een milieustrafrechtelijke aansprakelijkheid van overheden, vooral wanneer zij als 'overheden' optreden en bijvoorbeeld via onzorgvuldige vergunningverlening of handhaving bijdragen aan een ontoelaatbare vorm van milieuverstoring. Er is dan ook gepleit voor een machtskritische herijking van de fundamenten van het milieustrafrecht. Dit betekent onder meer dat de bestaande milieustrafbaarstellingen minder bestuursafhankelijk moeten worden geformuleerd, waardoor de nadelen van een absolute administratieve afhankelijkheid kunnen worden opgevangen, en in beginsel niet alleen vergunningplichtige particulieren, maar ook de voor het leefmilieu verantwoordelijke overheden onder de werking van het milieustrafrecht vallen.

In hoofdstuk III wordt vanuit de rechtsvergelijking bekeken op welke wijze overheden strafrechtelijk aansprakelijk kunnen worden gesteld. Eerst wordt de Nederlandse jurisprudentiële ontwikkeling tot aan Pikmeer II besproken waarna vervolgens een inventarisatie wordt gegeven van de belangrijkste knelpunten in de andere bestudeerde landen. Frankrijk en Nederland hebben gekozen voor een drievoudige oplossing. In de eerste plaats geldt voor de staat een absolute immuniteit. In de tweede plaats is er voor de lagere overheden een immuniteit die slechts bestaat wanneer de overheid in kwestie een delict pleegt bij de uitoefening van een exclusieve overheidstaak. Daarvan is sprake indien het gaat om gedragingen die uitsluitend door bestuursfunctionarissen kunnen worden verricht (Nederland) of gedragingen die niet aan private (rechts)personen kunnen worden gedelegeerd (Frankrijk). Andere publiekrechtelijke rechtspersonen blijven strafrechtelijk aansprakelijk. Een verschil is evenwel dat naar Frans recht in tegenstelling tot in Nederland niet de vervolgbaarheid van bepaalde overheden wordt uitgesloten, maar de strafrechtelijke verantwoordelijkheid. Een ander verschil is dat Frankrijk heeft geopteerd voor een expliciete wettelijke regeling, terwijl in Nederlandse recht werd gekozen voor een buitenwettelijke jurisprudentiële oplossing. Ook in België zijn overheden niet strafrechtelijk verantwoordelijk voor de door hen gepleegde delicten. Het nieuwe artikel 5 van het Belgische strafwetboek sluit zowel de centrale overheid als de decentrale overheden uit van de in 1999 ingevoerde strafrechtelijke aansprakelijkheid van rechtspersonen. In tegenstelling tot het Franse en het Nederlandse recht wordt niet gedifferentieerd tussen decentrale overheden en de staat, noch in soorten overheidsgedragingen. Er is geen onderscheid gemaakt in de hoedanigheid waarin de overheid optreedt, hetgeen een discriminatie doet ontstaan met particuliere bedrijven. Voor de strafrechtspraktijk betekent dit dat in het geval van een door een overheid gepleegd milieudelict, moet worden gezocht naar een natuurlijke persoon binnen de overheidsorganisatie waaraan het delict kan worden toegerekend. Aan de hand van een analyse van de Belgische rechtspraak werd vastgesteld dat zo'n individualistische benadering zeer ingewikkeld is, en in de meeste gevallen geen recht doet aan de organisatorische of corporatieve verwijtbaarheid die vaak aan het delict ten grondslag ligt. Ook uit een analyse van 
de Duitse rechtspraak blijkt dat een louter individualistische aanpak niet volstaat. In Duitsland wordt getracht de afwezigheid van de strafrechtelijke aansprakelijkheid van de (publiekrechtelijke) rechtspersoon te compenseren door een stelselmatige uitbreiding van de individuele 'Amtsträgerstrafbarkeit'. Er wordt voornamelijk gebruik gemaakt van zorgplichten waarvan de rechtsbeschermende draagkracht kan worden betwijfeld. Zowel uit de Duitse als de Belgische aanpak blijkt duidelijk wat de moeilijkheden zijn die rijzen bij afwezigheid van een strafbaarstelling van overheden. Er moet dan noodgedwongen worden gezocht naar verantwoordelijke natuurlijke personen binnen de overheidsorganisatie hetgeen zowel inefficiënt is als vanuit de optiek van de rechtsbescherming van de individuele verdachten onrechtvaardig.

In hoofdstuk IV worden de in de Nederlandse jurisprudentie ontwikkelde criteria voor immuniteit van decentrale overheden besproken: het openbaar lichaam - of subjectcriterium en het exclusieve bestuurstaakcriterium. Het subjectcriterium is vrij arbitrair, onduidelijk, en grotendeels achterhaald. Ervan uitgaande dat het subjectcriterium zijn verklaring vindt in het verband tussen de organisatorische inrichting van een openbaar lichaam en het bestaan van publiekrechtelijke controle- en verantwoordingsmechanismen binnen dat lichaam moet worden geconcludeerd dat de bestaansreden van het subjectcriterium duidelijk op de helling is komen te staan nu in Pikmeer II is bepaald dat het stelsel van politieke verantwoordelijkheid en dat van bestuurlijk toezicht niet in strijd zijn met de strafrechtelijke vervolgbaarheid. Het subjectcriterium lijkt te zijn ingegeven door een louter willekeurige differentiatie in typen publiekrechtelijke rechtspersonen en biedt geen deugdelijke basis voor de begrenzing van de strafrechtelijke immuniteit. Daarnaast is vastgesteld dat het (aangescherpte) taakcriterium niet voldoende in staat is de immuniteit van overheden te rechtvaardigen. Allereerst is onduidelijk wanneer in concreto sprake is van een exclusieve bestuurstaak. Zowel op theoretisch als op praktisch vlak kan een principiële differentiatie tussen overheid als zodanig en overheid als particulier worden in vraag gesteld. Bovendien blijkt mede uit een vergelijking met het civiele recht dat de erkenning van beslissingsruimte in hoofde van de overheid rechterlijke controle niet in de weg hoeft te staan. Nu enerzijds de Hoge Raad heeft bepaald dat politieke en bestuurlijke controle strafvervolging niet hoeven uit te sluiten, en anderzijds de administratieve en civiele rechter beleidsvrij overheidshandelen kunnen toetsen, blijft onbeantwoord wat de meerwaarde is van het taakcriterium. Er is daarom geen afdoende reden om vast te houden aan de immuniteit van openbare lichamen. Er kan beter worden gekozen voor een materiële benadering van de problematiek via het stelsel van rechtvaardigingsgronden, ook wanneer het feit is gepleegd bij de uitvoering van een exclusieve bestuurstaak.

In hoofdstuk $\mathrm{V}$ wordt aandacht besteed aan enkele argumenten voor en tegen een strafrechtelijke aansprakelijkheid van overheden. De voornaamste argumenten tegen een strafrechtelijke aansprakelijkheid zijn de machtenscheiding, de doorkruising van politieke en bestuurlijke controle en het vertrouwensverlies. Deze argumenten zijn niet in die mate overtuigend dat ze een uitsluiting van overheden van de werking van het strafrecht kunnen rechtvaardigen. Een belangrijke rode draad in veel van de argumenten is dat het primaat moet liggen bij niet-strafrechtelijke controlemechanismen, zoals bestuurlijk toezicht of politieke controle. De bij overheden aanwezige beslissingsruimte hoeft evenwel geen belet- 
sel te zijn voor strafrechterlijke controle. Ook wanneer overheden over beoordelings- en beleidsvrijheid beschikken, moet de strafrechter het overheidshandelen bij de beoordeling van de strafbaarheid van het feit op een vergelijkbare wijze als de bestuursrechter aan het recht kunnen toetsen. De mogelijke beperkingen van democratische en bestuursrechtelijke controle kunnen vanwege het karakter van deze instrumenten niet in die zin worden opgelost dat zij strafrechtelijke controle volledig overbodig maken. Het primaat van alternatieve controlemechanismen kan wel rechtvaardigen dat niet onbehoedzaam met strafvervolging moet worden omgegaan. Dit moet bij de opportuniteit van de vervolging worden beoordeeld. Het vestzak-broekzak argument en het bezwaar dat de staat zichzelf vervolgt, zijn de belangrijkste argumenten voor immuniteit van de staat. Deze argumenten hebben één basisfilosofie gemeen: de staat wordt als een bijna mythisch ondeelbaar geheel waargenomen. In zijn algemeenheid strookt een monolitische voorstelling van de staat, als rechtvaardiging voor staatsimmuniteit, niet met het recht, noch met de maatschappelijke realiteit. Immers, met een zelfde argumentatie dient dan ook te worden uitgesloten dat de staat zichzelf civielrechtelijk aansprakelijk stelt, of aan zichzelf belastingen betaalt. De 'ondeelbaarheid' van de staat speelt in het strafrecht voornamelijk parten omdat de strafrechtelijke aansprakelijkheid van overheden via artikel $51 \mathrm{Sr}$ is gekoppeld aan een civielrechtelijk gekleurd rechtspersoonlijkheidsbegrip. Het is de rechtspersoon 'de staat' die moet worden vervolgd indien binnen haar organisatie door een andere 'entiteit', die geen rechtspersoonlijkheid bezit, een strafbaar feit wordt begaan. Er kan dan ook worden betoogd dat voor een strafrechtelijke aanpak en controle van publiekrechtelijke organisaties, die tot 'de staat' behoren, rechtsstatelijke realisme moet primeren. Dit betekent dat men de strafrechtelijke blik niet langer op de rechtspersoonlijkheid van de staat dient te richten, maar op de publiekrechtelijke organisaties, die als zelfstandige strafrechtelijke rechtssubjecten moeten worden beschouwd, omdat zo veel meer recht wordt gedaan aan de maatschappelijke realiteit alsook aan de legitieme doelstellingen die het strafrecht bij de aanpak van overheidscriminaliteit moet kunnen vervullen. De strafrechtelijke controle op centraal overheidshandelen wordt zo tot zijn werkelijke proporties teruggebracht.

In hoofdstuk VI staat het daderschap van overheden voor milieuverstoring centraal. Aan de orde komen verschillende daderschapscriteria, die per type milieudelict in het licht van het schuldbeginsel worden geëvalueerd. Het blijkt vanuit strafrechtelijk handhavingsperspectief niet mogelijk noch wenselijk één algemeen geldend daderschapscriterium uit te denken op basis waarvan een overheid (of een andere rechtspersoon) voor milieuverstoring strafrechtelijk aansprakelijk kan worden gesteld. Wil men het corporatieve daderschap werkelijk ernstig nemen dan moet rekening worden gehouden met zowel de instrumentele als met de rechtsbeschermende dimensie van het strafrecht. In de praktijk betekent dit dat men dan geval per geval moet kijken naar de aard van de organisatie en het type milieudelict dat in een concrete casus wordt tenlastegelegd. Een objectieve aansprakelijkheid moet worden vermeden. Daarbij is het van belang dat bewijsrechtelijk rekening wordt gehouden met de eigen verantwoordelijkheidssfeer van de rechtspersoon als onderscheiden van die van de daarin werkzame natuurlijke personen. De corporatieve 'schuld' moet uit de concrete bewijsmiddelen blijken, wil men niet afglijden naar een risico-aansprakelijkheid. Gaat het om complexe organisaties en in tijd gespreide risicovolle activiteiten dan kan het daderschap van de rechtspersoon worden gefundeerd op de feitelijke bedrijfsvoerings- 
schuld, de 'Lebensführungsschuld' van de organisatie, mits deze maar uit concrete feitelijke elementen blijkt.

In hoofdstuk VII wordt op rechtsvergelijkende wijze aandacht besteed aan 'de macht' van de vergunning in het milieustrafrecht. De administratieve afhankelijkheid van het milieustrafrecht levert een belangrijk argument voor een strafrechtelijke aansprakelijkheid van overheden indien zij door een onzorgvuldige vergunningverlening bijdragen tot een ontoelaatbare graad van milieuverstoring. Dit probleem speelt vooral wanneer een onrechtmatige vergunning een strafuitsluitende werking heeft. Daarom is eerst onderzocht wat de strafrechtelijke gevolgen zijn voor de strafrechter en de vergunninghouder indien een vergunning in strijd met wet of recht wordt verleend. Zo blijkt in Duitsland de strafrechtelijke toetsing zeer beperkt te zijn door een sterke Verwaltungsaktsakzessorietät. Dit heeft als consequentie dat de justitiabele die beschikt over een onrechtmatige maar rechtsgeldige vergunning in een aantal gevallen toch vrijuit gaat wanneer hem een handelen zonder (rechtmatige) vergunning wordt tenlastegelegd. In Nederland is de strafrechter gebonden aan de formele rechtskracht van beschikkingen, maar dit lijkt alleen bij belastende beschikkingen een beslissende rol te spelen, namelijk wanneer de justitiabele als verweer aanvoert dat de vergunningsvoorwaarden die hij heeft geschonden onrechtmatig zijn. Legt het OM een handelen zonder (rechtmatige) bevrijdende vergunning ten laste dan lijkt niets zich te verzetten tegen een strafrechtelijke toetsing Dit betekent dat de beperkte toetsingsbevoegdheid in Nederland geen belemmering hoeft te zijn voor de strafrechtelijke handhaving van het milieurecht omdat het $\mathrm{OM}$ de onrechtmatigheid van bevrijdende vergunningen kan aanvoeren. De strafrechter kan in zo'n geval toetsen, hetgeen betekent dat onrechtmatige bevrijdende vergunningen geen automatische strafuitsluitende werking hebben. Anderzijds is wel duidelijk geworden dat de beperking van de strafrechtelijke toetsingsbevoegdheid nadelig is voor de rechtspositie van de verdachte, daar hij zich niet voor het eerst bij de strafrechter op de onrechtmatigheid van een door hem overtreden voorschrift kan beroepen. De strafrechter acht zich dan gebonden aan de formele rechtskracht. $\mathrm{Er}$ is daarom bepleit dat de strafrechter steeds de bevoegdheid zou moeten hebben om vergunningen aan wet en recht te toetsen. Het Belgische recht lijkt met de strafrechtelijke toetsing het verst te gaan. De Belgische strafrechter heeft ambtshalve de grondwettelijke plicht om elke administratieve rechtshandeling die hij toepast te toetsen. Deze ruime toetsingsplicht heeft tot gevolg dat zowel het $\mathrm{OM}$ als de verdachte steeds de onrechtmatigheid van beschikkingen kunnen aanvoeren.

In dit hoofdstuk komt ook aan de orde of er nood is aan een afzonderlijke strafbaarstelling van wederrechtelijke vergunningverlening. Wederrechtelijke vergunningverlening is immers niet als zodanig strafbaar gesteld, en talrijke milieunormen richten zich uitsluitend tot vergunninghouders en vergunningplichtigen, zodat de vergunningverlenende instanties de vereiste daderschapskwaliteit missen. De vergunningverlener kan dan slechts worden vervolgd als deelnemer aan het door de vergunninghouder gepleegde delict. Strafrechtsdogmatisch lijken er geen onoverkomelijke bezwaren om de deelnemingsregeling op milieudelicten toe te passen en om via die weg tot een strafrechtelijke aansprakelijkheid van de vergunningverlener te komen. Wel is benadrukt dat een strafrechtelijke aansprakelijkheid op grond van deelneming moeilijk denkbaar is zolang er geen bruikbare milieu- 
strafrechtelijke alternatieven zijn voor de abstracte gevaarzettingsdelicten, die hoofdzakelijk het overtreden van administratieve plichten strafbaar stellen en niet rechtstreeks het leefmilieu beschermen. In die zin levert het onderzoek naar een strafrechtelijke aansprakelijkheid voor wederrechtelijke vergunningverlening een extra argument op voor een herijking van het huidige milieustrafrecht. Daarnaast is van belang dat de strafrechter bevoegd moet zijn om de vergunningverlening aan wet en recht te toetsen. Indien de strafrechter gebonden is aan vergunningen, ook al zijn deze evident materieel onrechtmatig, dan is een strafrechtelijke aansprakelijkheid van zowel vergunninghouder als vergunningverlener immers uitgesloten. Deze mogelijke hinderpalen rechtvaardigen echter geen wetgevend ingrijpen in die zin dat een seperate strafbaarstelling voor wederrechtelijke vergunningverlening zou moeten worden gecreëerd. Allereerst blijkt het met de toetsingsbevoegdheid van de Nederlandse strafrechter nogal mee te vallen, in die zin dat de formele rechtskracht niet van toepassing lijkt te zijn wanneer het OM de onrechtmatigheid van de vergunning, waarop de justitiabele zich beroept, aanvoert. Dit is een groot verschil met Duitsland waar de strafrechtelijke toetsing van vergunningen de meeste problemen oplevert en vergunninghouders, die een milieudelict begaan, zich ook achter onrechtmatige vergunningen kunnen verschuilen. Het is vooral door deze beperkte toetsingsbevoegdheid van de Duitse strafrechter dat in het Duitse milieustrafrecht wordt gepleit voor een 'Amsträgerstrafbarkeit für fehlerhafte Genehmigung', omdat door de strafuitsluitende werking van onrechtmatige vergunningen de eigenlijke daders vrijuit kunnen gaan. In Nederland zijn deze nadelen veel minder aanwezig daar vergunninghouders nauwelijks beroep kunnen doen op onrechtmatige vergunningen. In die zin lijkt dan ook geen aanwijsbare reden aanwezig om in het Nederlandse strafrecht over te gaan tot een separate strafbaarstelling van wederrechtelijke vergunningverlening. Bovendien dient de milieustrafrechtelijke aandacht zich primair te richten op de verantwoordelijkheid van de vergunningplichtige en pas in tweede instantie op die van de vergunningverlener.

In hoofdstuk VIII worden eindconclusies geformuleerd alsook enkele aanbevelingen ter verbetering van de vastgestelde knelpunten. De voornaamste conclusie is dat het uitgangspunt dat overheden (in bepaalde gevallen) boven de strafwet dienen te staan, getuigt van een eenzijdige benadering van het strafrecht, dat slechts waarde zou hebben als instrument in handen van de overheid voor de regulering en de controle van het gedrag van burgers. Dit uitgangspunt is zowel vanuit rechtsstatelijk perspectief als vanuit de na te streven bescherming van het leefmilieu niet langer verantwoord. Daar er geen overtuigende argumenten zijn voor een strafrechtelijke immuniteit voor overheden, en het niet mogelijk is duidelijke criteria aan te geven op grond waarvan overheden van strafvervolging moeten worden uitgesloten, verdient het aanbeveling dat definitief afstand wordt genomen van de thans bestaande immuniteiten. Er kan beter volledig worden gekozen voor een materiële benadering van de problematiek. Dit betekent dat wanneer de opportuniteitsvraag positief wordt beantwoord en tegen de verdachte overheid een strafvervolging wordt ingesteld, door de strafrechter op het niveau van de wederrechtelijkheid moet worden bekeken of het gepleegde feit een strafrechtelijke reactie rechtvaardigt. Een andere aanbeveling is dat artikel $51 \mathrm{Sr}$ wordt aangepast in die zin dat ook publiekrechtelijke organisaties die behoren tot de staat, maar zelf geen rechtspersoonlijkheid hebben, gelijk worden gesteld met het begrip 'rechtspersoon' in de zin van artikel $51 \mathrm{Sr}$. Wat het vraagstuk van wederrechtelijke 
vergunningverlening betreft, kunnen de meeste problemen, zoals beperkingen op het vlak van strafrechtelijke toetsing, worden verklaard door de sterke administratieve afhankelijkheid van het milieustrafrecht. Een mogelijke strafrechtelijke aansprakelijkheid voor wederrechtelijke vergunningverlening wordt daarom vaak verdedigd als een correctief op deze administratieve afhankelijkheid. Het verdient evenwel geen aanbeveling om die reden een seperate starfbaarstelling voor wederrechtelijke vergunningverlening in te voeren. Het lijkt verstandiger de nadelen van de administratieve afhankelijkheid op te vangen via een herijking van het milieustrafrecht door het (her)formuleren van minder bestuursafhankelijke strafbaarstellingen, die op meer rechtstreekse wijze het leefmilieu beschermen. 



\section{Summary}

This book deals with a comparitive research on the criminal liability of public entities for environmental pollution. The research deals with the question whether public entities can be prosecuted for environmental crimes, and whether existing immunities from prosecution should be abandoned. The main reason for this research is the recent jurisprudence of the Dutch Supreme Court. According to the Supreme Court the State has an absolute immunity from prosecution (Volkel-decission 1994). Other entities under public law, public authorities like municipalities, have an immunity from prosecution when the criminal offence is commited within the framework of an exclusive administrative task (PikmeerIIdecission 1998). The same rule applies to the directing civil servants. On the basis of the outcome of this research recommendations are given that can contribute to a solution of this problem of immunity of public authorities.

In Chapter $I$ the subject of the research is explained. This chapter includes also a description of the comparitive methodology. Although the criminal liability of public entities is not only a problem in environmental criminal law, it is a topic that plays an important role in this particular field. The criminal liability of public authorities in the sphere of environmental pollution has many faces. First, there is the most common situation where public authorities commit in a direct way environmental criminal offences; a situation which is quite similar to the environmental pollution caused by private entities (enterprises). The sole difference is the public law nature of the offender. Second, there is the situation where public authorities are in a more indirect way responsible for environmental pollution, e.g. by granting unlawful licenses. In our welfare-state and risksociety administrative agencies play a crucial role in environmental law because they can determine the legally permitted amount of pollution by setting emission standards through the use of licences. The way in which these agencies perform their administrative duties has therefore a strong impact on the quality of the environment. Hence the question arises whether these administrative agencies can be held criminally liable in cases of unlawful granting of licences or when they are responsible for a deficient exercise of their surveillance duties, thus failing to intervene in cases of environmental pollution. Therefore this book is not only focused on the criminal liability of public entities in cases where they have directly caused environmental pollution, it deals also with the question whether criminal liability is possible when they grant unlawful licences. 
Chapter II gives a description of the main legal characteristics of current environmental criminal law. The purpose of this chapter is to show how these characteristics may create theoretical and practical impediments for the prosecution and criminal liability of public entities. Environmental criminal law has a strong instrumentalistic orientation, i.e. that most of the criminal provisions are set up as an instrument or a 'tool box' for guaranteeing administrative authority. In other words, current environmental criminal law offers not a direct protection of the environment, but is based upon a command and control basis. Environmental criminal law is characterized by an administrative dependency, a dependency upon individual decisions of administrative agencies (Verwaltungsaktsakzessorietät): the conditions of criminal liablity are laid down by administrative agencies in licences. Most of the environmental offences follow the model of abstract endangerment and are thus focussed on the environmental risk-behaviour of private enterprises and not as much on the failing risk-management of the administrative agencies. This has for a consequence that there is not much room for a criminal liability of these public entities, especially when these entities contribute to environmental pollution in the furtherance of their administrative tasks, e.g. when granting unlawful licences. Therefore this chapter is also focused on the need for a reform of environmental criminal law. The legislator must provide a more adequate protection of environmental values by means of creating less administrative dependend criminal provisions. Such a reform should also include the review of the environmental provisions in the Penal Code (articles 173a en 173b) in a sense that these provisions can be more easily applied not only on private entities, but also on the licensors.

Chapter III deals with the question under what conditions public entities can be held criminally liable for environmental pollution. This chapter uses a comparitive approach, because most of the dilemmas have been discussed in the legal doctrine of other western countries, especially in Germany and Belgium. After commenting the recent developments in Dutch jurisprudence I describe the different problems in the other legal systems. The result of this comparitive research can be summed up as follows. From a substantive-law point of view the Netherlands and France have more or less chosen for a similar threefold solution. First, both countries have excluded the State from any criminal liability: the State has an absolute immunity from prosecution. Second, decentralised public authorities, like municipalities, only have an immunity from prosecution when they have commited a crime within the framework of an exclusive administrative task (Netherlands), or when that task can not be delegated to private persons or enterpises (France). Third, other public entities, like state-universities, remain criminal liable. However, an important difference between these two legal systems is that France has chosen in 1994 for an explicit statutory provision that has introduced these immunities in the French Penal Code (article 121-1), while the Dutch solution is the result of a difficult and complex jurisprudence. The Belgian system is quite unique, because it has chosen for a radical, but undesirable approach. The new article 5 of the Belgian Penal Code, introducing in 1999 the criminal liability of legal persons, excludes all public authorities from criminal liability, without making any distinction between the State and decentralised public authorities, and without differentiating between different (private or public) kinds of governmental wrongdoing. This creates a discrimination between public and private entities. It has for a consequence that the Belgian 
prosecution remains focused on the liability of individuals within public authorities, also when the latter are in fact collectively responsible for the environmental pollution. An analysis of Belgian jurisprudence clearly shows that such an individualistic approach is complicated, unrealistic and insufficient, because in most cases of environmental crimes the responsibility is a corporate or collective one, and can therefore not be efficiently limited to the criminal liability of one or more individuals within the organisation of the public entity. The German jurisprudence offers the same conclusion. Theoretically the German legal system provides in the possibility of imposing fines on public entitities through the use of the Ordnungswidrigkeitengesetz, which is a kind of administrative criminal law, but in practice the prosecution remains mainly focused on the criminal liability of individual civil servants, the so-called Amtsträgerstrafbarkeit. It is striking that the criminal liability of civil servants is for a very large part based upon a violation of rather vague duty of care norms. This is being criticised in the German doctrine, because such a criminal liability is not effective due to the collective responsibility of the public entity involved, and also because such a large individualisation of collective 'guilt' can be questioned from the perspective of the rule of law. Such individualism can lead to prosecuting larger numbers of lower personnel. This is an enforcement strategy which is inegalitarian in tendency.

Chapter $I V$ deals with the two criteria for immunity that are developed in Dutch jurisprudence: the public body or subjectcriterion and the exclusive administrative taskcriterion. Similar criteria can be found in the French system (article 121-1 Penal Code). These criteria are the backbone of the immunity, because public entities (other than the State) are only excluded from criminal prosecution when these criteria can be invoked by the public entity. A public entity must be a public body in the sense of article 7 of the Dutch Constitution and the criminal offence must be commited within the framework of an exclusive administrative task, i.e. a task that according to the Supreme Court can only be executed by civil servants. I conclude that the subjectcriterion is quite arbitrary and unclear. It seems that the subjectcriterion is merely motivated by the presence of democratic controle within the organisation of the public bodies that are mentioned in article 7 of the Constitution. But since the Supreme Court has decided in Pikmeer II that political responsibility and democratic control do not exclude criminal liability, this criterion needs more clarification: the question remains unanswered why only democratically organised public bodies can have an immunity from prosecution, especially when this democratic control in itself does not hinder the already existing criminal liability of individual civil servants operating within these bodies. The subjectcriterion does not give a reasonable basis for the immunity and offers only an arbitrary distinction between different kinds of public entities. The second criterion prescribing that immunity is only possible when the criminal offence is commited within the framework of an exclusive administrative task gives rise to many problems. First, one may conclude that making a clearcut distinction between exclusive administrative (or governmental) tasks and other (administrative) tasks is very difficult. It can also be questioned whether such a distinction works in practice. When we compare this rule with the current system of civil liability of public bodies it is interesting to see that there are no objections against civil judicial control of exclusive administrative tasks. It is unclear why a comparable judicial control should remain 
impossible for the criminal judge. Therefore the conclusion is that exclusive administrative tasks should no longer be exempt of criminal judicial control.

Chapter $V$ deals with some arguments for and against the immunity of public entities. The most important arguments for immunity are the seperation of powers (trias politica), the primacy of democratic or political and administrative control, and the loss of confidence in public authorities when the latter are procecuted. An important ratio of these arguments seems to be that it should remain impossible for the criminal judge to control the discretionary power of public authorities: criminal liability thwarts democratic and administrative control. Furthermore it is argued that these instruments are already a good alternative for criminal prosecution and make a criminal liability superfluous. These arguments are however not very convincing. First, the primacy of democratic control is as much valid in cases where public entities do not have an immunity, e.g. when they commit criminal offences within the framework of an ordinary (not exclusive) governmental task. Second, the sole fact that public bodies have a discretionary power is in itself not an impediment for judicial control by a criminal judge, because other judges can already exercise this control. The criminal judge must therefore have the same competence as the civil or administrative judge in matters of unlawful conduct of public authorities. Second, democratic and administrative control are no alternative effective instruments for criminal liability, especially when serious criminal offences are committed. Applying the democratic or administrative instruments in cases of serious criminal offences as an alternative for prosecution could lead to an undesirable change of the political or administrative nature of these instruments. Of course, the primacy of democratic control can justify and explain that the instrument of criminal lialbility should be used diligently by the Public Prosecution. Society is not served with a which hunt against public authorities and civil servants.

The arguments against the criminal liability of the State are dealt with seperatly in this chapter. The two main arguments for State-immunity are: (1) a criminal liability is impossible because it means that the State has to prosecute itself; (2) a criminal liability is not efficient because in the end the State pays to itself the judicially imposed fine. Both arguments are however not convincing, because the mistake is being made of viewing the State as an indivisible super-entity. Such a view is not realistic. In other fields of law (civil and administrative law) it is accepted that the State 'sanctions' itself. Again the question arises why this should be different in criminal law. What really happens when a fine is judicially impose on the State is that one government departement, with its own seperate budget, pays for the fine to another government department. If the accounts of government are to reflect the true costs and benefits of running each department then the recording of a judicially imposed fine as an item in the outgo of one department and the income of another department is an entirely proper procedure. The fine paid by one department (e.g. Defense) to another (Justice) can have an deterrent effect. The so-called indivisibility of the State is rather fictious, and is mainly the result of the fact that the criminal liability of public entities is linked in article 51 of the Dutch Penal Code with the concept of civil legal personality. It is the State which has legal personality, and not the public entities operating within the State. It seems therefore more reasonable to focus the criminal liability on the public entity or organisation which has de facto violated the law, in stead of prosecuting the State. This 
is a more realistic approach. The advantage of such a system would also be that the arguments for State-immunity are no longer valid, because the prosecution is no longer concentrated on the State itself, but on the real offenders, the public entities that operate within the State.

Chapter $И I$ deals with the question how the perpetration of public entities can be succesfully established in substantive criminal law, once they can be prosecuted for an environmental offence. In order to answer this question this chapter gives a critical overview of the different perpetration (or offender) criteria that are being developed in jurisprudence and legal doctrine. The purpose of such an overview is to evaluate the perpetration (and the criminal liability) of public entities from the perspective of the principle of guilt. I conclude that it is not possible to define one all encompassing criterion for the corporate perpetratorship of public (or private) entities. If one wants to make corporate perpetration effective, one must take into account the different organisational setups and specific characteristics of public entities. I also advocate that different perpetration criteria should be used for the different environmental crimes (e.g. by taking into account the distinction between offences and misdemeanours). There exists a certain danger that public entities risk criminal liability for everything that goes wrong within their organisation: a risk-liability must therefore be avoided by demanding a more differentiated use of more explicit perpetration-criteria.

Chapter VII compares the "power" of licenses in the various national criminal laws governing the environment. The administrative dependency of environmental criminal law provides a major argument for making public authorities criminally liable if through their negligent granting of licenses they contribute to an intolerable degree of environmental pollution. The problem occurs in particular where the unlawful granting of licenses has an exculpatory effect, or when these licences are being invoked by the licensee as justification grounds. For this reason, this chapter first examines the consequences for the criminal judge and the licensee under the criminal law if a license is granted in contravention of written or unwritten law. In Germany, for instance, testing to the criminal law (judicial review of the licence) proves to be very limited as a result of a strong "Verwaltungsaktsakzessorietät". Consequently, the justiciable (the licencee) possessing an unlawfully granted, but valid, license will be acquitted in a number of cases, if charged with trading without a (lawful) license. In the Netherlands, the criminal judge must respect the formal legal power of individual administrative decisions, but this only seems to play a decisive role in administrative decisions that are obligatory in nature, namely where the justiciable argues in his defence that the license conditions which he allegedly violated are unlawful. If the Public Prosecutor charges the defendant with trading without a lawful extinctive license, nothing seems to prevent judicial review by the criminal judge. This entails that, in the Netherlands, limited testing power (judicial review) does not necessarily constitute an impediment to the criminal enforcement of environmental law: the Public Prosecutor can assert the unlawfulness of extinctive licenses. In such cases, the criminal judge has the power to test the decision, which means that unlawful extinctive licenses do not automatically exculpate a person. On the other hand, it has become clear that the formal legal power of licences may be detrimental to the defendant's legal position, because he 
cannot invoke the unlawful nature of the condition breached by him before the criminal court. In such instances, criminal judges have no choice but to respect its formal legal power. It was therefore advocated that criminal judges be empowered to test all licenses to written and unwritten law. Belgian law seems to provide for the most far-reaching judicial review or testing to the criminal law. The Belgian criminal judge has an ex officio constitutional duty to test each administrative action (article 159 Belgian Constitution). As a result of this broad testing duty, both the Public Prosecutor and the citizen may in all instances allege the unlawfulness of the administrative decision.

This Chapter also examines the need for separate criminal provisions governing the unlawful granting of licenses. After all, unlawfully granting licenses does not constitute a criminal offence in itself and numerous environmental norms are exclusively addressed at licensees and those subject to licensing, so that licensing authorities lack the required perpetrator quality. The licensor can only be prosecuted as an accomplice in the offence committed by the licensee. Dogmatically, there seem to be no overwhelming objections against applying the rules of criminal participation to environmental offences, which would render the licensor criminally liable. It must be stressed, however, that criminal liability on the grounds of complicity can hardy be accomplished where there are no alternatives to the abstract offences endangering life or property, in as much as they mainly make breaching administrative duties a criminal offence and do not protect the environment directly. In this respect, the study into criminal liability for the unlawful granting of licenses produces an additional argument for a review of existing environmental criminal law. In addition to this, it is important to remember that criminal judges must have the power to test the granting of licenses to written and unwritten law. If criminal judges are held to respect (the formal legal power of) licenses, in spite of their clearly being unlawful substantively, both the licensee and the licensor cannot be held criminally liable. However, these possible impediments do not justify legislative intervention in the sense that a separate offence ought to be created for the unlawful granting of licenses. First and foremost, the testing powers (or judicial review) of Dutch criminal judges are not limited to the extent that the license invoked by the justiciable does not possess formal legal power, if the Public Prosecutor alleges the unlawfulness of the license. The Netherlands varies greatly in this respect with Germany, where criminal testing of licenses is most problematic and where licensees committing an environmental crime are also able to hide behind unlawfully granted licenses. It is this limited testing power of the German criminal judge in particular, which has brought forward arguments for an "Amsträgerstrafbarkeit für fehlerhafte Genehmigung" in environmental criminal law, because as a result of the exculpatory effect of unlawfully granted licenses the real perpetrators are able to escape liability. In the Netherlands, these drawbacks are not so prominent, because licensees have very few possibilities of invoking the unlawfulness of a license.

In chapter VIII the most problematic issues are summarized and recommendations are given. The most important conclusion is that the absolute immunity of the State and the partial immunity of public bodies, in other words, the principle that public authorities should (in some cases) be excluded a priori from criminal liability, represents a one sided view of the purpose of criminal law; a view that criminal law is (only) an instrument, a 'tool 
box' in the hands of the government for policing society and the regulation of citizens and private entities. Such a view is no longer justified: not only from the perspective of the rule of law, but also from the perspective of the protection of the environment. It is unrealistic to expect from citizens and enterprises that they act in accordance with environmental regulations, while the public 'regulators' themselves can not be prosecuted, especially when they are failing in their environmental law duties. The arguments for immunity are often one sided and not convincing. Another conclusion is that the immunity criteria for public bodies that are developed by the Supreme Court are theoretically not well founded, not working in practice and rather arbitrary. As a whole there is no longer any ratio for the existing immunities. I therefore recommend that all public bodies (including the State) should in principle be considered as prosecutable. Exceptions to this rule must not be solved on the level of prosecutability, but on the substantive level of justification grounds. Another recommendation concerns the criminal liability of public entities that belong to the State. I recommend a review of article 51 Penal Code in order to make prosecution of these public entities possible: this means that public entities that lack legal personality and therefore fall automatically under the legal personality (and also under the absolute immunity) of the State, have to be considered in criminal law as legal persons in the meaning of article 51 Penal Code. In other words, the legal person concept of article $51 \mathrm{Sr}$ has to be enlarged in such a way that it also includes public entities that lack legal personality. Other recommendations deal with the problem of criminal liability of public bodies for granting unlawful licences. I recommend that the problems that may arise when administrative agencies grant unlawful licences - for example questions with regard to the judicial review of these licences, and whether unlawful licences can still be invoked as justification grounds- have to be solved by a substantive reform of current environmental criminal law, and not by using criminal law for the punishment of licencors. There is no need for a seperate criminal provision that punishes the unlawful granting of permits, once the legislator creates a less administrative dependend environmental criminal law, because than the rules of criminal participation to environmental offences can be more easily applied. In the legal doctrine the absolute administrative dependency (Verwaltungsaktsakzessorietät) is often used as an argument for criminal liability of administrative agencies who fail to fullfill their environmental tasks, but a more reasonable solution of the disadvantages of an absolute administrative dependency can be found in a reform of this administrative dependency, rather than introducing a seperate criminal liability for the unlawful granting of licences. The prime focus of environmental criminal law should remain on those who pollute the evironment, the licencees, and not on the public authorities, the licensors. 



\section{Literatuur}

Achterhuis, H., Het rijk van de schaarste, Baarn, Ambo, 1988.

Achterhuis, H., Natuur tussen mythe en techniek, Baarn, Ambo, 1995.

Ackermans-Wijn, J.F.C., Contracten met de overheid, Deventer, Kluwer, 1989.

Addink, G.H., Afvalstoffen, Zwolle, W.E.J. Tjeenk Willink, 1996; MenR, 1993/12, Themanummer afvalstoffen.

Albrecht, P.A., 'Das Strafrecht auf dem Weg vom liberalen Rechtsstaat zum sozialen Interventionsstaat', KritV, 1988, 182-209.

Albrecht, P.A., 'Erosionen des rechtsstaatlichen Strafrechts', KritV, 1993, 163-182.

Alen, A., Rechter en bestuur in het Belgische publiekrecht. De grondslagen van de wettigheidskontrole, Antwerpen, Kluwer, 1984.

Alen, A., 'De raadsels van artikel 107 van de Belgische Grondwet', $R W, 1984$.

Alwart, H., 'Strafrechtliche Haftung des Unternehmens - vom Unternehmenstäter zum Täterunternehmen', ZStW, 1993, 757-770.

Androulakis, N., Rechtsproblematische Studien über die unechten Unterlassungsdelikte, München, 1962.

Arendt, H., On Revolution, New York, 1973.

Arnhold, D., 'Strafbarer Ungehorsam gegen rechtswidrige Verwaltungsakte', JZ, 1977, 789-790.

Arzt, G., 'Zur Garantenstellung beim unechten Unterlassungsdelikt', JA, 1980, 553-561 en 647-654. 
Baert, K., 'De rechter en de overheid', $T B P, 1981,35-48$.

Barents, R. en Brinkhorst, L.J., Grondlijnen van Europees recht, Alphen aan den Rijn, 1996.

Barrata, A., 'Jenseits der Strafe -Rechtsgüterschutz in der Risikogesellschaft', in Festschrift Kaufmann, 1993, 393-416.

Beck, U. (u.a), Politik in der Risikogesellschaft, Frankfurt am Main, Suhrkamp Verlag, 1991.

Belaid, S., Essai sur le pouvoir créateur et normatif du juge, Parijs, 1974.

Bernard, P., 'De la responsabilité des fonctionnaires publics', Rev. crit. législ. jur., 1876, 528-537.

Bloy, R., 'Die Straftaten gegen die Umwelt im System des Rechtsguterschutzes', ZStW, 1988, 485-507.

Böckenförde, E.-W., 'Der verdrängte Ausnahmezustand. Zum Handeln der Staatsgewalt in außergewöhnlichen Lagen', NJW, 1978, 1875-1881.

Boersema, D.A.A., 'Strafbare overheid: een contradictio in terminis?', in Elzinga, D.J. e.a. (red.), Strafbaarheid van overheden, Zwolle, W.E.J. Tjeenk Willink, Publikaties van de staatsrechtkring, 1998, 21-36.

Borgers, M.J., Koopmans, I.M. en Kristen, F.G.H. (red.), Verwijtbare uitholling van schuld?, Nijmegen, Ars Aequi Cahiers, 1998.

Boujong, K. en Cramer, P., Karlsruher Kommentar zum Gesetz über Ordnungswidrigkeiten, München, C.H. Beck'sche Verlags-Buchhandlung, 1989.

Bouloc, B., 'Le domaine de la responsabilité pénale des personnes morales', Rev. Soc., 1993, 291-297.

Bourquin, M., La protection des droits individuels contre les abus de pouvoir de l'autorité administrative en Belgique, Brussel, 1912.

Bovens, M.A.P., Verantwoordelijkheid en organisatie: beschouwingen over aansprakelijkheid, institutioneel burgerschap en ambtelijke ongehoorzaamheid, Zwolle, W.E.J. Tjeenk Willink, 1990.

Bovens, M.A.P., 'Ambtelijke verantwoordelijkheid', in De Jong, P. (red.), Verantwoordelijkheid en verantwoording in het openbaar bestuur, 's Gravenhage, 1995, 133-144. 
Boxum, J.L., 'Zelfstandige bestuursorganen en de greep van ministers op de bestuurlijke organisatie', in Engels, J.W.M., Lambers, C., Niemeijer, E., Scheltema, E., Schuiling, K.F., Vis, B.C. en Vuçsán, R.L. (red.), De rechtsstaat herdacht, Zwolle, W.E.J. Tjeenk Willink, 1989, 257 e.v.

Boxum, J.L., 'Ministeriële verantwoordelijkheid en zelfstandige bestuursorganen', in Elzinga, D.J. (red.), De ministeriële verantwoordelijkheid in Nederland, Zwolle, W.E.J. Tjeenk Willink, 1994, 257-278.

Brants, Chr., 'Slavenburg: een geslaagde transactie?', $R \& K, 1987,7$ e.v.

Brants, Chr., 'Slavenburg en de grenzen van het strafrecht', $R \& K, 1988,26$.

Brants, C.H. en De Lange, R., Strafvervolging van overheden, Arnhem, Gouda Quint, 1996.

Brants, Chr., The King can do no wrong. Daderschap, feitelijk leidinggeven en de staat',1996, 509-532.

Brants, C.H., 'The king can do no wrong: naschrift', $D D, 1996,655-659$.

Brants, C.H., 'Strafvervolging van de overheid: het Pikmeer II-arrest, Militair rechtelijk tijdschrift, 1998a, 309-319.

Brants, C.H., 'Wordt vervolgd... Het Pikmeer II-arrest (HR 6 januari 1998)', DD, 1998, 318-343.

Brauer, J., Die strafrechtliche Behandlung genehmigungsfähigen, aber nicht genehmigten Verhaltens, Berlin, 1988.

Breuer,R., 'Empfehlen sich Änderungen des strafrechtlichen Umweltschutzes insbesondere in Verbindung mit dem Verwaltungsrecht?', $N J W, 1988,2072-2084$.

Breuer, R.,'Verwaltungsrechtlicher und strafrechtlicher Umweltschutz - Vom Ersten zum Zweiten Umwelt-kriminalitätsgesetz', JZ, 1994, 1077-1091.

Brijs, S., 'Nieuwe wetgeving: de absolute uitvoeringsimmuniteit van de overheid doorbroken', $R W$, 1994-95, 625-633.

Bruns, H.J., Die Befreiung des Strafrechts vom zivilistischen Denken, Berlin, 1938.

Buiting, Th.J.B., Strafrecht en milieu, Arnhem, Gouda Quint, 1993.

Buiting, Th.J.B. en Huygen, A.E.H., "Milieustrafrecht: een ondoordachte chaos", in Van Buuren, P.J.J., Betlem, G. en IJstra, T. (red.), Milieurecht in stelling, Utrechtse opstellen over actuele thema's in het milieurecht, Zwolle, W.E.J. Tjeenk Willink, 1990, 72-95. 
Bull, H.P., Allgemeines Verwaltungsrecht, Heidelberg, 1986.

Burkens, M.C. Beginselen van de democratische rechtsstaat, Zwolle, W.E.J. Tjeenk Willink, 1990.

Bloembergen, A.R., 'Overheidsprivaatrecht: schets van een algemeen deel', WPNRspecial, 1992, 950 e.v.

Buruma, Y., 'Het schuldig subject', in Borgers, M.J., Koopmans, I.M. en Kristen, F.G.H. (red.), Verwijtbare uitholling van schuld?, Ars Aequi Cahiers, Nijmegen, 1998.

Buruma, Y., 'Veranderingen in het ondernemingsstrafrecht', in Van Kraaij, M. en Van Veen, A., Strafrecht en onderneming, Ars Aequi, 1-5.

Buruma, Y. en Daalder, E.J., 'Formele rechtskracht in het strafrecht', RMThemis, 1994, 320-335.

Cambier, C., Principes du contentieux administratif, I, Brussel, 1961.

Claeys-Bouuaert, $\mathrm{Ph}$., 'Algemene beginselen van het recht - Vijftien jaar rechtspraak van het Hof van Cassatie', $R W, 1986-87,913-934$ en 977-998.

Cleiren, C.P.M., Beginselen van een goede procesorde, Arnhem, Gouda Quint, 1989.

Cleiren, C.P.M. en Nijboer, J.F. (red.), Strafrecht, Tekst en Commentaar, Deventer, Kluwer, 1997.

Cluysenaer, J.L.H., 'De toetsing van administratieve beschikkingen door de strafrechter', NJB, 1970, 1000-1007.

Coeuret, A., 'La nouvelle donne en matière de responsabilité', Droit social, 1994, 627637.

Colaes, J., 'De strafrechtelijke aansprakelijkheid van mandatarissen van rechtspersonen', in Dekeersmaeker, J. en Van Steenberge, J. (red.), Sociaal strafrecht, Antwerpen, Kluwer, 1984, 149-182.

Coleman, J.S., The Assymetric Society, New York, Syracuse University Press, 1982.

College van Procureurs-Generaal, Aanwijzing voor de opsporing en vervolging van overheden, Staatscourant, 1998, nr. 82.

Commissie bestuursrechtelijke en privaatrechtelijke handhaving, Handhaven op niveau, Deventer, W.E.J. Tjeenk Willink, 1998. 
Commissie Toetsing van Wetgevingsprojecten, Advies van de Commissie voor de Toetsing van Wetgevings-projecten inzake zorgplichtbepalingen, CTW 90/6, 20 augustus 1990.

Constant, J., 'La protection pénale de l'environnement en droit belge', in Rapports Belges aux Xe Congrès International de Droit Comparé, Brussel, Bruylant, 1978, 565602.

Corstens, G.J.M., Het Nederlandse strafprocesrecht, Arnhem, Gouda Quint, 1999.

Cotta, S., 'Montesquieu, la séparation des pouvoirs et la Constitution fédérale des EtatsUnis', Rev. hist. pol. const., 1951, 225-257.

Craig, P. en De Búrca, G., EC Law. Text, Cases \& Materials, Oxford, 1995.

Dahlem, F., Das Verhältnis des Zivilrechts zum Strafrecht mit besonderer Berücksichtigung der Disharmonien, Heidelberg, 1919.

Dahs, H., 'Zur strafrechtlichen Haftung des Gewässersschutzbeauftragten nach $\S 324$ StGB', NStZ, 1986, 97-103.

Dahs, H. en Pape, A., 'Die behördliche Duldung als Rechtfertigungsgrund im Gewässerstrafrecht (§ $324 \mathrm{StGB})$, NStZ, 1988, 393 e.v.

De Doelder, H. en 't Hart, A.C., 'De meerwaarde van het OM', Trema, 1990, 250-252.

De Doelder, H., 'Van Paasbrief tot herfstweer. Over de begroting van Justitie', 1993, $D D, 911-921$.

De Doelder, H. en Rogier, L.J.J. (red.), Opstellen over bestuursstrafrecht, Arnhem, Gouda Quint, 1994.

De Doelder, H., 'Criminal Liability of Corporations - Netherlands', in De Doelder H. en Tiedemann, K. (red.), Criminal Liability of Corporations, The Hague-London-Boston, Kluwer Law International, 1996, 291-300.

De Haan, P, Drupsteen, Th.G. en Fernhout, R., Bestuursrecht in de sociale rechtsstaat. Deel 1. Ontwikkeling, Organisatie, Instrumentarium, Deventer, Kluwer, 1996.

De Hullu, J. en De Roos, Th.A., 'De strafrechtelijke positie van publiekrechtelijke rechtspersonen, Advocaten-blad, 1994, nr. 17, 766-768.

De Hullu, J., 'Een bijzondere strafrechtelijke positie voor de verdachte overheid?', in Elzinga, D.J. en De Jong, H.M. (red.), Strafbaarheid van overheden, Deventer, W.E.J. Tjeenk Willink, Publikaties van de Staatsrechtkring deel 15, 1998, 47-65. 
De Jong, D.H., De macht van de tenlastelegging in het strafproces, Arnhem, Gouda Quint, 1981.

De Jong, D.H., 'Vormen van strafbare deelneming', in Van der Deut, J.L. (red.), Daderschap en deelneming, Arnhem, Gouda Quint, 1993.

De Jong, D.H., 'Het strafrechtelijke schuldbegrip: ontwikkeling of ontbinding', $D D, 1999$, 1-6.

Deketelaere, K., 'De voorstellen van de interuniversitaire commissie tot herziening van het milieurecht in het Vlaamse Gewest inzake de aansprakelijkheid voor milieuschade', in Deketelaere, M., Deltour, B., Gille, B. en Deketelaere, K. (red.), Recente ontwikkelingen inzake de aansprakelijkheid voor milieuschade, Brugge, Die Keure, $1993,55-98$.

Deketelaere, K. (red.), Milieurechtstandpunten, nr.10. Milieurecht in België. Status Questionis anno 1997, Brugge, Die Keure, 1997.

Delatte, P., 'La question de la responsabilité pénale des personnes morales en droit belge', $R D P, 1980,191-223$.

De Lange, A., 'De dictatuur van de magistratuur', NJB, 1995, 441-447.

De Lange, A., 'Herijking van het milieustrafrecht', in Aalders, M.V.C. en Van Grieken, D. (red.), Bestuursrechte-lijke en strafrechtelijke handhaving van het milieurecht, 1996, 7183.

De Lange, R., 'Openbare lichamen, rechtspersonen en bestuursorganen: kortsluiting in het publiekrecht?', in Vucán, R.L. (red.), De Awb-mens: boeman of underdog? Opstellen aangeboden aan Leo Damen, Nijmegen, Ars Aequi, 1996.

Delmas-Marty, M., Le flou du droit. Du code pénal aux droits de l'homme, Paris, Presses Universitaires de France, 1986.

Delva, J., 'Het rechtstreeks bestrijden van overheidsdaden voor de burgerlijke rechtscolleges', TPR, 1967, 453 e.v.

Demeersseman, H.A., De autonomie van het materiële strafrecht, Arnhem, Gouda Quint, 1985.

De Nauw, A., Les métamorphoses administratives du droit pénal de l'entreprise, Gent, Mys \& Breesch, 1994.

De Nauw, A. en Deruyck, F., 'De strafrechtelijke verantwoordelijkheid van rechtspersonen', $R W, 2000,897-914$. 
De Roos, Th., 'De strafzaak tegen UNISER - een case study', in Van de Bunt, H.G., De Jonge, G. e.a. (red.), De macht van het O.M., Nijmegen, Ars Aequi Libri, 1983, 261- 277.

De Roos, Th.A., Strafbaarstelling van economische delicten; een crimineel-politieke studie, Arnhem, Gouda Quint, 1987.

De Roos, Th.A., 'Recht, orde en het nut van het algemeen', $R \& R, 1997,28-33$.

De Roos, Th.A., 'Het Pikmeerarrest en zijn gevolgen', AAe, 1997, 226-233.

De Roos, Th,A., 'Geen strafrechtelijke aansprakelijkheid voor de Staat? Minister Korthals als Oblomow, AAe, 2000, 92-96.

Deruyck, F., 'Over de problematiek van de rechtspersoon (en ermee gelijkgestelde groeperingen) in het strafrecht naar Belgisch en Duits recht: de administratieve weg?', $R W, 1990-91,1251-1267$.

Deruyck, F., 'Societas delinquere potest... en wat dan nog? Over het ontbreken van strafrechtelijke verantwoordelijkheid van rechtspersonen naar Belgisch recht', Panopticon, 1991, 249-259.

Deruyck, F., De rechtspersoon in het strafrecht, Gent, Mys \& Breesch, 1996.

Deruyck, F., 'Naar een strafrechtelijke aansprakelijkheid van de rechtspersoon in België?', in Faure, M. en Schwarz, K. (red.), De strafrechtelijke en civielrechtelijke aansprakelijkheid van de rechtspersoon en zijn bestuurders, Antwerpen, Intersentia, $1998,33-48$.

Deruyck, F., 'De strafrechtelijke verantwoordelijkheid voor door publiekrechtelijke rechtspersonen gepleegde misdrijven' in Milieuaansprakelijkheid van gemeenten, Antwerpen, Kluwer, 1998, 121-135.

Desportes, F. en Le Gunehec, F., 'Présentation des dispositions du nouveau Code pénal', Sem. Jur., 1992, I, 411-436.

Desportes, F., 'Le nouveau régime de la responsabilité pénale des personnes morales', Sem. Jur., 1993, 71-85.

De Swaef, M., 'Over de strafrechtelijke verantwoordelijkheid van rechtspersonen' (noot onder Antwerpen, 22 september 1984), $R W, 1985-86,1851-1852$.

Deutsch, E., Haftungsrecht, I, Köln, 1976.

De Vries, C.W., 'Het arrest van den Hoogen Raad van 31 december 1915, W.v.h.R. no. 9974, aangaande de bevoegdheid van de rechterlijk macht krachtens art. 2 der Wet op de Rechterlijke Organisatie', RMThemis, 1917, 337 -352. 
De Vries-Leemans, J.H.J., 'Enkele aspecten van daderschap', in 't Hart, A.C. (red.), Strafrecht in balans. Opstellen over strafrecht aangeboden aan A.C. Geurts, Arnhem, Gouda Quint, 1983, 315-331.

D'Haenens, J., 'Sanctions pénales et personnes morales', R.D.P., 1975-1976, 731-759.

D’Haenens, J., 'Strafbare deelneming', A.P.R., 1959.

Dolde, K.-P., 'Zur Verwaltungsakzessotietät von § 327 StGB', NJW, 1988, 2329-2325.

Dolling, D., 'Umweltstraftat und Verwaltungsrecht', JZ, 1985, 461-469.

Dolling, D., 'Empfehlen sich Änderungen des Umweltstrafrechts?', ZRP, 1988, 334-339.

Doorenbos, D.R., 'Schuldkwadratuur. Iets over de betekenis van art. 2, eerste lid WED', $D D, 1990,810-819$.

Doorenbos, D.R., Financieel strafrecht. Een studie inzake strafrechtelijk gesanctioneerde voorschriften uit de bank- en effectenwetgeving, Deventer, Kluwer, 1992.

Drion, J., Administratie contra de rechter tot de intrekking van het conflictenbesluit, 's Gravenhage, 1950.

Duk, W. en Nicolaï, P., 'Nulliteiten in het bestuursrecht', RMThemis, 1991, 3-31.

Dupont, L. en Verstraeten, R., Handboek Belgisch strafrecht, Leuven, Acco, 1990.

Ebert, U., Strafrecht. Allgemeiner Teil, Heidelberg, C.F. Müller Juristischer Verlag, 1994.

Elzinga, D.J., 'Heethoofdige reacties op het Pikmeerarrest', BB, 1997, 39 e.v.

Engisch, K., Die Einheit der Rechtsordnung, Heidelberg, 1935.

Enschedé, Ch. J., Rüter, C.F. en Stolwijk, S.A.M, Beginselen van strafrecht, Deventer, 1990.

Erichsen, H.-U., Allgemeines Verwaltungsrecht, Berlin, 1995.

Etzioni, A., A Sociological Reader on Complex Organizations, New York/Holt/Rinehart and Winston, 1969.

Evernden, E., The Social Creation of Nature, Baltimore and London, The John Hopkins University Press, 1992.

Ewald, F., L'Etat Providence, Paris, Grasset, 1986. 
Faure, M., Financiële problemen als rechtvaardigingsgrond voor milieuverontreiniging?', $R W, 1988-89,286-297$.

Faure, M., Preadvies milieustrafrecht, Antwerpen, Maklu, 1990.

Faure, M., 'De onoverkomelijke rechtsdwaling in milieustrafzaken', $R W, 1991-92,937$ 950.

Faure, M.G., 'De gevolgen van de administratieve afhankelijkheid van het milieustrafrecht: een inventarisatie van knelpunten', in Faure, M.G., Oudijk, J.H.C. en Schaffmeister, D. (red.), Zorgen van heden. Opstellen over het milieustrafrecht in theorie en praktijk, Arnhem, Gouda Quint, 1991, 91-150.

Faure, M., De strafrechtelijke toerekening van milieudelicten, Antwerpen, Maklu, 1992.

Faure, M., Oudijk, J.C. en Koopmans, I.M., 'Strafrechtelijke aansprakelijkheid van ambtenaren in het milieurecht - een rechtseconomische analyse', TMR, 1993, 12-23.

Faure, M., De handhaving van het bodemsaneringsdecreet via toezicht, dwangmaatregelen en strafsancties', in Deketelaere, K. (red.), Milieurechtstandpunten, $n r$.7. Het decreet betreffende de bodemsanering, Brugge, die Keure, 1995, 215-254.

Faure, M en Visser, M., 'How to punish Environmental Pollution? Some Reflexions on various Models of Crimi-nalisation of Environmental Harm', European Journal of Crime, Criminal Law and Criminal Justice, 1995, 316-368.

Faure, M. en Roef, D., 'Naar een wettelijke formulering van de strafrechtelijke aansprakelijkheid van de rechts-persoon', $R W, 1995,417-432$.

Faure, M., 'Het Nederlandse milieustrafrecht: dringend aan herziening toe!', RMThemis, 1997, 3-12.

Faure, M. en Visser, M., 'Het tekort van het Nederlandse milieustrafrecht', in Van Kraaij en Van Veen, A. (red.), Onderneming en strafrecht, Nijmegen, Ars Aequi Libri, 1997, 123-144.

Faure, M., 'Strafuitsluitingsgronden in het milieustrafrecht', TMR, 1998, 192-193.

Faure, M. en De Roos, Th.A., De berekening van het wederrechtelijk verkregen voordeel uit milieudelicten, Den Haag, Sdu, 1998.

Faure, M. en Visser, M., De strafrechtelijke bescherming van het leefmilieu in België, Duitsland en Nederland. Modellen van strafbaarstelling en hun bewijsrechtelijke implicaties, Antwerpen-Groningen, Intersentia, 1999. 
Ficq, C.R.L.R.M., 'De officier van jusititie, magistraat (of bestuursambtenaar?)', Trema, 1991, 158-166.

Fisse, B., 'Controlling Governmental Crime: issues of individual and collective liability', in Gabrosky, P. (ed.), Government Illegality, Canberra, 1986.

Fokkens, J.W., 'De rechtspersoon als dader', DD, 1980, 339-404.

Foqué, R. en 't Hart, A.C., Instrumentaliteit en Rechtsbescherming, Arnhem, Gouda Quint, 1990.

Foqué, R.M.G.E., De Ruimte van het Recht, Arnhem, Gouda Quint, 1992.

Foqué, R.M.G.E., 'Legitimiteit van het strafrechtssysteem', in De Doelder, H., Foqué, R.M.G.E en Gerding, R.A.F. (red.), Taak en functioneren van het $O M$, Arnhem, Gouda Quint, 1994, 11-26.

Forsthoff, E., Lehrbuch des Verwaltungsrechts, München, 1979.

François, L., 'Remarques sur quelques questions de droit pénal social, particulièrement sur l'imputabilité', RDP, 1968-69, 489-518.

Frank, R., Strafrechtliche Relevanz rechtwidrigen begünstigenden Verwaltungshandelns erläutert am Beispiel der Gewässerverunreinigung (§ 324 StGB), Berlin, 1985.

Fransen, A.M., 'Crimineel overheidsgedrag in de doofpot. Een ongeschreven titel van het Wetboek van Straf'-recht, NJB, 1997, 10-15.

Franzheim, H., 'Die Bewaltigung der Verwaltungsrechtsakzessorietät in der Praxis', JR, 1988, 319-322.

French, P.A., Collective and corporate responsibility, New York, 1984.

Geeroms, S., 'La responsabilité pénale de la personne morale: une étude comparative', R.I.D.C., 1996, 545-566.

Geisler, C., 'Strafbarkeit von Amtsträgern im Umweltrecht', NJW, 1982, 11-15.

Godechot, J., Les institutions de la France sous la Révolution et l'Empire, Paris, 1968.

Göhler, E., Ordnungswidrigkeitengesetz, München, C.H. Beck'sche VerlagsBuchhandlung, 1995.

Goldmann, H.-G., Die behördliche Genehmigung als Rechtfertigungsgrund, Freiburg, 1967. 
Goldschmidt, J., Das Verwaltungsstrafrecht. Eine Untersuchung der Grenzgebiete zwischen Strafrecht und Verwaltungsstrafrecht auf rechtsgeschichtlicher und rechtsvergleichender Grundlage, Berlin, 1902.

Gollier, M. en Lagasse, M., 'La responsabilité pénale des personnes morales: une extension due filet pénal modalisée', J.T., 1999, 653-660.

Goorden, C.P.J., Rechtsbevoegdheid in het bestuursrecht; Een rechtsvergelijkende studie naar het bevoegdhedenvraagstuk in het bestuursrecht, Zwolle, W.E.J. Tjeenk Willink, 1990.

Groenhuijsen, M.S., 'Schuld en boete. Een beschouwing over strafrechtelijke verantwoordelijkheid', in Bovens, M.A.P. e.a. (red.), Verantwoordelijkheid: Retoriek en Realiteit, Zwolle, W.E.J. Tjeenk Willink, 1989, 45-46.

Groß, U. en Pfohl, M., 'Zur Strafbarkeit von Bürgermeister im Bereich kommunaler Abwasserreinigungsanlagen - Zugleich Anmerkung zu OLG Saarbrücken, NStZ, 1991, 119-122.

Guirimand, D., 'La responsabilité pénale des personnes morales. La mise en oeuvre du nouveau dispositif', Droit Social, 1994, 647-653.

Gunsteren, H.R., 'Zbo's en het vraagstuk van politieke en bestuurlijke verantwoordelijkheid', in WRR, Studiemiddag zelfstandige bestuursorganen, 12 november 1985, serie voorstudies en achtergronden V54, 's Gravenhage, 1986.

Günther, H.L., Strafrechtswidrigkeit und Unrechtsausschluß, Köln, 1983.

Günther, K., 'Von der Rechts- zur Pflichtverletzung. Ein "Paradigmawechsel" im Strafrecht?' in Vom unmöglichen Zustand des Strafrechts, Frankfurt, 1995, 445-459.

Gutwirth, S., Waarheidsaanspraken in recht en wetenschap, Antwerpen-Apeldoorn, Maklu, 1993.

Guthrie, K., The Pythagorean Sourcebook and Library, Michigan, Phanes Press, 1987.

Haaf, E., Die Fernwirkung gerichtlicher und behördlicher Entscheidungen, Paderborn, 1984.

Hajer, M. en Schwarz, M., 'Countouren van de risicomaatschappij', in Beck, U., De wereld als risicomaatschappij, Amsterdam, De Balie, 1997.

Hallwaß, C., 'Rechtmäßigkeit behördlich geduldeter Umweltbeeintrachtungen?', $N u R$, 1987, 296-301.

Hallwaß, C., Die behördliche Duldung als Unrechtsauschließungsgrund im Umweltstrafrecht, Kiel, 1987. 
Hange, S., 'Verantwortlichkeit für Kanalisationsanschluß eines Schwimmbades', NJW, $1989,115-122$.

Hartmann, A.R. en Van Russen Groen, P.M., 'Van strafrecht naar bestuursstrafrecht: de derde criminaliseringsgolf?', in De Doelder, H. en Rogier, L.J.J. (red.), Opstellen over bestuursstrafrecht, Arnhem, Gouda Quint, 1994, 61-78.

Hassemer, W., 'Kennzeichnen und Krisen des modernen Strafrechts', ZRP, 1992, 378383.

Heine, G., 'Umweltstrafrecht in der Bundesrepublik Deutschland: Entwicklung und gegenwartiger Stand, Grundprobleme und Alternativen', in Eser, A. en Kaiser, G., Drittes deutsch-sowjetisches Kolloquium über Straf-recht und Kriminologie, BadenBaden, NOMOS, 1985, 67-129.

Heine, G., en Meinberg, V., 'Empfehlen sich Änderungen im strafrechtlichen Umweltschutz, insbesondere in Verbindung mit dem Verwaltungsrecht?', Gutachten für den 57. Deutschen Juristentag, Munchen, Beck, 1988.

Heine, G., 'Ökologie und Recht. Zur historischen Entwickelung normativen Umweltschutzes', GA, 1989, 116-131.

Heine, G., 'Zur Rolle des strafrechtlichen Umweltschutzes', ZStW, 1989, 722-755.

Heine, G en Meinberg, V., 'Das Umweltstrafrecht - Grundlagen und Perspektiven einer erneuten Reform', GA, 1990, 1-33.

Heine, G., 'Verwaltungsakzessorietät des Umweltstrafrechts. Rechtsvergleichende Funktionsanalysen - unbestimmte Rechtsbegriffe, Reichweite von Genehmigungen', NJW, $1990,2425-2434$.

Heine, G., 'Verwaltungsakzessorietät des Umweltstrafrechts. Rechtsvergleichende Funktionsanalysen - unbestimmte Rechtsbegriffe - Reichweite von Genehmigungen' in Schulz, L., Ökologie und Recht, Köln, 1991, 55-80.

Heine, G., 'Die Verwaltungsakzessorietät im deutschen Umweltstrafrecht unter Berücksichtigung des österreichischen Rechts', OJZ, 1991, 370-377.

Heine, G., 'Umweltstrafrecht im Rechtsstaat', ZfU, 1995, 63-71.

Heine, G., 'Beweislastumkehr im Strafverfahren?', JZ, 1995, 651-657.

Heine, G., 'Von individueller zu kollektiver Verantwortlichkeit. Einige Grundfragen der aktuellen Kriminalpolitik', in Arnold, J., Burkhardt, B., Gropp, W. en Koch, H.G., Grenzüberschreitungen, Freiburg, 1996, 51-76. 
Heine, G., Die strafrechtliche Verantwortlichkeit von Unternehmen. Von individuellen Fehlverhalten zu kollektiven Fehlentwickelungen, inbesondere bei Grorisiken, BadenBaden, Nomos Verlagsgesellschaft, 1996.

Hendriks, L.E.M., Techniek en normstelling in het milieustrafrecht. Een rechtsvergelijkende studie naar de strafrechtelijke handhaving van emissievoorschriften, Zwolle, W.E.J. Tjeenk Willink, 1994.

Hendriks, L.E.M., 'De Hoge Raad en artikel 14 Wbb', MenR, 1994, 139-144.

Hendriks, L.E.M. en Wöretshofer, J., Milieustrafrecht, Zwolle, W.E.J. Tjeenk Willink, 1995.

Hendriks, L.E.M. en De Lange, A., 'Strafvervolging van overheden na het Tweede Pikmeer-arrest', MenR, 1998, 41-47.

Hennekens, H., 'Gebruik van privaatrechtelijke bevoegdheden dat publiekrechtelijke regeling doorkruist', in AB Klassiek, Zwolle, 1991, 212-224.

Hennekens, H.Ph.J.A.M., 'De Hoge Raad en de formele rechtskracht', de Gemeentestem, $1993,149-155$.

Hennekens, H.Ph.J.A.M., Van Geest, H.J.A.M. en Fernhout, R., Decentralisatie, Nijmegen, Ars Aequi, 1995.

Herrmann, J., 'Die Rolle des Strafrechts beim Umweltschutz in der Bundesrepublik Deutschland', ZStW, 1979, 280-292.

Herzog, F., 'Über die Grenzen der Wirksamheit des Strafrechts', KritV, 1993, 247-254.

Hilgendorf, E., 'Gibt es ein "Strafrecht der Risikogesellschaft?"', NStZ, 1993, 10-16.

Hofstee, E.J., 'Straf naar de mate van schuld?', in Enschedé, Ch.J. e.a. (red.), Naar eer en geweten, Arnhem, 1987, 195-214.

Hogg, P.W., Liability of the Crown, Sydney, 1971.

Hoitink, J.E., Hille, M.G.F en Janssen, A.F.J.M., 'Handhaving van de bouwvergunningvereiste. Een onderzoek naar het contra legem verlenen van bouwvergunningen', in Commissie bestuursrechtelijke en privaatrechtelijke handhaving, Handhaven op niveau, Zwolle, W.E.J. Tjeenk Willink, 1998, 353-378.

Horn, E.,'Strafbares Fehlverhalten von Genehmigungs- und Aufsichtsbehörden', NJW, 1981, 1-11.

Horn, E., 'Bindung des Strafrechts an Entscheidungen von die Atombehörde?', NJW, 1988, 2335-2338. 
Hoyer, A.,'Gewässerverunreinigung durch Bürgermeister', NStZ, 1992, 387-388.

Hübenett, C., Rechtswidrige behördliche Genehmigung als Rechtferdigungsgrund - ein gelöstes strafrechtliches Problem? Dargestellt an $\S 324$ StGB (Gewässerverunreinigung), Bonn, 1986.

Immel, B., Strafrechtliche Verantwortlichkeit von Amtsträgern im Umweltstrafrecht, Frankfurt a. M., 1987.

Immel, B., 'Die Notwendigkeit eines Sondertatbestandes im Umweltstrafrecht Umweltreue', ZRP, 1989, 105-110.

Interuniversitaire Commissie tot Herziening van het Milieurecht, Voorontwerp Decreet Milieubeleid, Brugge, Die Keure, 1995, 799-805.

Jescheck, H.-H., 'Zur Frage der Strafbarkeit von Personenverbänden', DÖV, 1953, 539544.

Jung, H., 'Garantenstellung des Bürgermeisters für Abwasserbeseitigung', JuS, 1993, 336-347.

Jurgens, G.T.J.M., Bestuurlijk gedogen. Aanvaardbaarheid en gevolgen van bestuurlijk gedogen in het milieu-recht en het ruimtelijk recht, Zwolle, W.E.J. Tjeenk Willink, 1996.

Kaufmann, A., Die Dogmatik der Unterlassungsdelikte, Göttingen, 1959.

Keijzer, N., 'Enkele opmerkingen over de praesumptio innocentiae in strafzaken', in Enschedé, Ch.J. e.a. (red.), Naar eer en geweten, Arnhem, Gouda Quint, 1987.

Kelk, C., De menselijke verantwoordelijkheid in het strafrecht, Arnhem, Gouda Quint, 1994.

Kelk, C., Studieboek materieel strafrecht, Amhem, Gouda Quint, 1998.

Keller, R., 'Zur strafrechtlichen Verantwortlichkeit des Amtsträgers für fehlerhafte Genehmigungen im Umweltrecht', in Festschrift K. Rebmann zum 65. Geburtstag, München, 1989, 2241-257.

Kessler, M., 'Het daderschap van de rechtspersoon. Een pleidooi voor afschaffing van het aanvaardingscriterium', $D D, 1997,228-235$.

Kessler, M., 'Afwezigheid van alle schuld in de economische rechtspraak', in Borgers, M.J., Koopmans, I.M. en Kristen, F.G.H. (red.), Verwijtbare uitholling van schuld?, Nijmegen, Ars Aequi Cahiersi, 1998, 75-86. 
Kirchhof, P., Unterschiedliche Rechtswidrigkeiten in einer einheitlichen Rechtsordnung, Heidelberg, 1978.

Kirchhof, P., 'Polizeiliche Eingriffsbefugnisse und private Nothilfe', NJW, 1978, 965-972.

Kist, F.C., 'Dient het Wetboek van Strafrecht bepalingen te bevatten betreffende het daderschap en de strafrechtelijke aansprakelijkheid van andere dan natuurlijke personen?', Preadvies, Handelingen NJV, Zwolle, W.E.J. Tjeenk Willink, 1966, deel I, $1-71$.

Kleerekoper, S., De fictie van het algemeen belang, Deventer, Kluwer, 1964.

Kleiman, W.M en Van den Berg, E.A.I.M., Overtredende overheden. Vervolgingsbeleid inzake milieudelicten, Den Haag, Ministerie van Justitie, WODC, nummer 35, 1995.

Kleinknecht, T. en Meyer-Gossner, L., Strafprozeßordnung, München, Beck'sche Verlags-Buchhandlung, 1993.

Knigge, G., 'Het subsociale en de structuur van het strafbare feit', in Naar eer en geweten. Liber Amicorum Remmelink, J., Arnhem, Gouda Quint, 1987, 285-292.

Knigge, G., 'Doen en laten; enkele opmerkingen over daderschap', $D D, 1992,147$ e.v.

Knigge, G., 'Dat deed mijn handje. Enige opmerkingen over het daderschap van de rechtspersoon', in Van Kraaij, M. en Van Veen, A. (red.), Onderneming en strafrecht, Nijmegen, Ars Aequi Libri, 1997, 18 e.v.

Knopp, L., 'Zur Strafbarkeit von Amtsträgern in Umweltverwaltungsbehörden unter besonderer Berücksich-tigung der BGH-Rechtsprechung', DÖV, 1994, 676-684.

Kobussen, M., 'Een privaatrechtelijke legaliteitseis?', NTB, 1989, 97-109.

Kobussen, M., De vrijheid van de overheid. Een vergelijking van de privaatrechtelijke en bestuursrechtelijke beoordelingskaders om te komen tot een beantwoording van de vraag of, en in hoeverre het privaatrecht voor de overheid remplaçant kan zijn voor het bestuursrecht, Zwolle, W.E.J. Tjeenk Willink, 1991.

Koopmans, F.A.J., Het beslissingsmodel van 348/350, Groningen, Wolters-Noordhof, 1991.

Koopmans, I.M., De strafbaarstelling van milieuverontreiniging, Arnhem, Gouda Quint, 1996.

Koopmans, I.M., 'Zeven jaar milieustrafrecht in Nederland: een evaluatie', $D D, 1996,350$ 363. 
Korthals Altes, F., 'De verhouding tussen minister van Justitie en het openbaar ministerie', Trema, 1988, 372-376.

Kortmann, C.A.J.M., Constitutioneel recht, Deventer, 1994.

Krabbe, H.G.M., De ontvankelijkheid van het OM en de beginselen van een goede procesorde', in Knigge, G. (red.), o.c., 67.

Krämer, L., European Environmental Law. Casebook, London, 1993.

Krauß, D., 'Strafgesetzgebung im Rechtsstaat', KritV, 1993, 183-197.

Kristen, F.G.H., Borgers, M.J. en Koopmans, I.M., 'Schuld in het strafrecht', in Borgers, M.J., Koopmans, I.M. en Kristen, F.G.H. (red.), Verwijtbare uitholling van schuld?, Nijmegen, Ars Aequi Cahiers, 1998, 15-23.

Lackner, K. en Kühl, K., Strafgesetzbuch mit Erläuterungen, München, Beck'sche Verlags-Buchhandlung, 1995.

Laferrière, A., Traité de la jurisdiction administrative, 1896, I.

Lammers, C.J., Organiseren van bovenaf en van onderop. Een beknopte inleiding in de organisatiesociologie, Utrecht, 1993.

Larenz, K., Methodenlehre der Rechtswissenschaft, Berlin, 1991.

Laufhütte, H. en Möhrenschlager, M., 'Umweltstrafrecht in neuer Gestalt', ZStW, 1980, 912-972.

Legros, R., 'A propos du projet de loi sur les amendes administratives', JTT, 1971, 97 100.

Legros, R., 'Voorontwerp van Strafwetboek', Brussel, Belgisch Staatsblad, 1985.

Lehner,F., 'Aufbruch statt Abbruch? Staatsaufgaben und Staatstätigkeit in den modernen Industriegesellschaften', KritV, 1988, 251-265.

Lenckner, Th., 'Behördliche Genehmigungen und der Gedanke des Rechtsmisbrauchs im Strafrecht', in Strafrecht, Unternehmensrecht, Anwaltsrecht, Festschrift für G. Pfeiffer, Köln, 1988.

Linnendrink, D., Der Wegfall der strafrechtlichen Verantwortlichkeit des Garanten, Aachen, 1995.

Loth, M.A., Handeling en aansprakelijkheid in het recht, Amhem, Gouda Quint, 1988. 
Lubberdink, H.G., De betekenis van de ministeriële verantwoordelijkheid voor het openbaar bestuur, Deventer, Kluwer, 1982.

Marxen, K., Die strafrechtliche Organ- und Vertreterhaftung - eine Waffe im Kampf gegen die Wirtschaftskriminalität?', JZ, 1988, 285-291.

Mast, A. en Dujardin, J., Overzicht van het Belgisch administratief recht, Antwerpen, Kluwer, 1993.

Meijers, E.M.,'De onrechtmatige overheidsdaad', deel II, WPNR, 1925, 241-244.

Mezger, E., Lehrbuch des Strafrechts, München, 1949.

Michalke, R., 'Die Strafbarkeit von Amtsträgern wegen Gewässerverunreinigung ( $\$ 324$ StGB) und umweltge-fährdender Abfallbeseitigung ( $\S 326 \mathrm{StGB})$ in neuem Licht', $N J W$, 1994, 1693-1698.

Mok, M.R. en Tjittes, R.P.J.L., 'Formele rechtskracht en overheidsaansprakelijkheid', RMThemis, 1995, 383-404.

Möhrenschlager, M., 'Revision des Umweltstrafrechts - Das Zweite Gesetz zur Bekämpfung der Umweltkrimina-lität', NStZ, 1994, 513-519 en 566-569.

Mouloungui, C. 'La nature de la responsabilité pénale des personnes morales en France', $R D P, 1995,143-161$.

Mulder, A., 'De gemeenten en de verbodsbepaling van art. 17 Wederopbouwwet', De Nederlandse gemeente, 1963, 517-521.

Mulder, A., Schets van het economisch strafrecht, Zwolle, W.E.J. Tjeenk Willink, 1983.

Mulder, A., 'Feitelijke leidinggeven aan de verboden gedraging, indien het strafbaar feit door een rechtspersoon is begaan', Maandblad voor Onderneminsgrecht en rechtspersonen, 1988, 213-219.

Mulder A. en Doorenbos, D.R, Schets van het economisch strafrecht, Zwolle, W.E.J. Tjeenk Willink, 1995.

Müller, E., Die Stellung der juristischen Person im Ordnungswidrigkeitenrecht, Köln, 1985.

Müller, W., 'Zur Haftung der Amtsträger und politischen Mandatsträger im Umweltstrafrecht', UPR, 1990, 367-373.

Müller-Tuckfeld, J.C., 'Traktat für die Abschaffung des Umweltstrafrechts', in Vom Unmöglichen Zustand des Strafrechts, Frankfurt, 1995, 461-481. 
Munneke, H.F., Ten Berge, J.B.J.M., Stroink, F.A.M., Haighton, P. en Den Hoed, P., Organen en rechtspersonen rondom de centrale overheid, WRR-serie Voorstudies en Achtergronden van de WRR, V35, 's Graven-hage, 1983.

Naucke, W., 'Schwerpunktverlagerungen im Strafrecht', KritV, 1993, 135-162.

Naucke, W., 'Die Aushöhling der strafrechtlichen Gesetzlichkeit durch den relativistischen, politisch aufgeladen strafrechtlichen Positivismus', in Vom unmöglichen Zustand des Strafrechts, 1995, 483-498.

Nestler,C., 'Die strafrechtliche Verantwortlichkeit eines Bürgermeisters für Gewässerverunreinigungen der Bürger', GA, 1994, 514-530.

Nicolaï, P., Olivier, B.K., Damen. L.J.A. en Troostwijk, H. (red.), Bestuursrecht, Amsterdam, 1992.

Nieboer, W., Schets materieel strafrecht, Arnhem, Gouda Quint, 1990.

Nijboer, H., 'Milieuzorg en strafwet: opmerkingen over de strafbaarstelling van verontreiniging van lucht, bodem en water in het licht van de systematiek van de strafrechtelijke codificaties', in Faure, M.G., Oudijk, J.H.C. en Schaffmeister, D. (red), Zorgen van heden. Opstellen over milieustrafrecht in theorie en praktijk, Amhem, Gouda Quint, 1991, 49-90.

Nijboer, H. en De Koning, A.-M, De vervolging en berechting van overheden. Een bekonopte analyse van de "Pikmeer"-rechtspraak', NJB, 1988, 732-737.

Nijboer, H. en De Koning, A.-M., 'Strafrechtelijke verantwoordelijkheid van de Nederlandse Staat', NJB, 1997, 680-682.

Nijboer, J.F., 'Schuldbegrip en schuldbeginsel als oriëntatiepunten in het strafrecht', Recht en Kritiek, 1989, 365-381.

Odersky, W., 'Zur strafrechtlichen Verantwortlichkeit für Gewässerverunreinigungen', in Festschrift für H. Tröndle zum 70. Geburtstag 1989, Berlin, 1989, 291-304.

Ostendorf, H., 'Die strafrechtliche Rechtmäßigkeit rechtswidrigen hoheitlichen Handelns', JZ, 1981, 165-175.

Otto, H. en Brammsen, J., 'Die Grundlagen der strafrechtlichen Haftung des Garanten wegen Unterlassens', Jura, 1985, 530-542 en 592-602.

Otto, H., 'Das neue Umweltstrafrecht', Jura, 1995, 134-144.

Paetzold, H., 'Die Neuregelung rechtsmißbrauchlich erlangter Genehmigungen durch § 330d Nr. 5 StGB', NStZ, 1996, 170-173. 
Papier, H.J., Umweltschutz durch Strafrecht?, Göttingen, 1987.

Peters, A.A.G., Opzet en schuld in het strafrecht, Arnhem, Gouda Quint,1966.

Peters, A.A.G., 'Het rechtskarakter van het strafrecht', in Peters, A.A.G., Recht als kritische discussie, Arnhem, Gouda Quint, 1991, 15-34.

Peters, J.A.F., Publiekrechtelijke rechtspersonen, Deventer, W.E.J., Tjeenk Willink, 1997.

Peters, J.A.F., 'Zbo's, verzelfstandiging en privatisering', NTB, 1997, 139-146.

Peters, J.A.F., 'Wordt vervolgd? Over de criteria gebruikt bij het beleid inzake vervolging van overheden', $N T B, 1997 \mathrm{~b}, 379-389$.

Peters, J.A.F., 'Wordt vervolgd: aantekeningen bij het Pikmeer II-arrest, NTB, 1998, 3135.

Pfohl, M., 'Strafbarkeit von Amtsträgern wegen Duldung unzureichender Abwasserreinigungsanlagen', $N J W, 1994,418-420$.

Picard, E., 'La responsabilité pénale des personnes morales de droit public: fondements et champ d'application', Rev. Soc., 1993, 261-287.

Pietzcker, J., 'Mitverantwortung des Staates, Verantwortung des Bürgers', JZ, 1985, 209-216.

Piret, J.M., 'Filosofische beschouwingen bij de grondslagen van het milieurecht', in Gutwirth, S. en Van Maanen, G. (red.), De natuur van het milieurecht. Verkenningen naar de grondslagen van het milieurecht, Ars Aequi Libri, Nijmegen, 1995.

Pompe, W., Handboek van het Nederlandse strafrecht, Zwolle, W.E.J. Tjeenk Willink, 1959.

Posner, R., Economic Analysis of Law, Boston, Little, Brown and company, 1986.

Rademacher, M., Die Strafbarkeit wegen Verunreinigung eines Gewässers (§ 324 StGB) unter besondere Berücksichtigung der behördlichen Genehmigung als Rechtfertigungsgrund, Frankfurt a. M., 1989.

Raes, K., 'Een samenleving van onverantwoordelijken. Grenzen aan deresesponsabilisering', in WODC, Schuld, Justitiële Verkenningen, nr.5, 1999.

Remmelink, J., 'De officier van justitie, magistraat of bestuursambtenaar?', Trema, 1991, 167-179. 
Remmelink, J., Mr. D. Hazewinkel-Suringa's Inleiding tot de studie van het Nederlandse strafrecht, Arnhem, Gouda Quint, 1995.

Rengier, R., Die öffentlich-rechtliche Genehmigung im Strafrecht, ZStW, 1989, 874-907.

Rogall, K., Die Strafbarkeit von Amtsträgern im Umweltbereich, Berlin, 1991.

Ryckborst, D., 'Legaliteitscontrole en marginale toetsing bij vergunningen', TMR, 1993, 45-52.

Ryckborst, D., 'Bijsturing van het Decreet betreffende de Bodemsanering', TMR, 1998, 334-352.

Roef, D., 'Kan de Staat in zijn eigen staart bijten?', DD, 1995, 332-348.

Roef, D., 'Zoektocht naar een meer-zinnige betekenis van het strafrecht voor het leefmilieu', in Gutwirth, S. en Van Maanen, G. (red.), De natuur van het milieurecht. Verkenningen naar de grondslagen van het milieurecht, Nijmegen, Ars Aequi Libri, 1995, 160-190.

Roef, D., 'Strafrecht versus leefmilieu: van geschiktheid naar ondergeschiktheid', TMR, $1995,466-476$.

Roef, D., 'M. Serres. Het contract met de natuur', in Gutwirth, S. en Van Maanen, G. (red.), De natuur van het milieurecht. Verkenningen naar de grondslagen van het milieurecht, Nijmegen, Ars Aequi Libri, 1995, 557-563.

Roef, D., 'De strafbaarheid van overheden en leidinggevende ambtenaren; enkele beschouwingen naar aanleiding van het Pikmeer-arrest', JB, 1996, 1110-1118.

Roef, D., 'Voordeelsontneming via het Ordnungswidrigkeitenrecht', in Faure, M. en De Roos, Th., De berekening van het wederrechtelijk verkregen voordeel uit milieudelicten, Den Haag, Sdu, 1998, 139-159.

Roef, D. en de Roos, Th., 'De strafrechtelijke aansprakelijkheid van de rechtspersoon en zijn bestuurders: rechtstheoretische beschouwingen bij enkele praktische knelpunten', in Faure, M en Schwarz, K. (red.), De strafrechtelijke en civielrechtelijke aansprakelijkheid van de rechtspersoon en zijn bestuurders, Antwerpen, Intersentia, 1998, 49-122.

Roef, D., 'De strafrechtelijke aansprakelijkheid van de rechtspersoon in het milieustrafrecht', in Belgische vereniging van bedrijfsjuristen, vereniging van praktijkjuristen in sociaal recht en vereniging voor arbeidsrecht, Vennootschappen weldra strafbaar. Wat is de weerslag op het bestaan van de ondernemingen?, Brussel, Bruylant, 1999, 65-174.

Röling, B.V.A., 'De strafbaarheid van de rechtspersoon', TvS, 1957, 1-30. 
Röling, B.V.A., 'De strafbaarheid van de rechtspersoon', $D D, 1980,1-9$.

Roozendaal, B.J.P.G., 'Een andere kijk op formele rechtskracht', in Cleiren, C.P.M., Foqué, R.M.E.G., Gribnau, J.L.M., Van Male, R.M. en Mevis, P.A.M. (red.), Voor risico van de overheid?, Arnhem, Gouda Quint, 1996.

Roquet, F., 'Sanctions pénales et personnes morales', RDP, 1975-76, 689-706.

Rösenkötter, G., Das recht der Ordnungswidrigkeiten, München, C.H. Beck'sche Verlags-Buchhandlung, 1988.

Roxin, C., Strafrecht Allgemeiner Teil. Grundlagen der Aufbau der Verbrechenslehre, München, C.H. Beck'sche Verlags-Buchhandlung, 1994.

Rozemond, K., 'Preadvies Pleidooi voor een kritisch instrumentalisme', $R \& R, 1996$, 169-191.

Rozemond, K., Strafvorderlijke Rechtsvinding, Deventer, Gouda Quint, 1998.

Rudolphi, H.-J., 'Probleme der strafrechtlichen Verantwortlichkeit von Amtsträgern für Gewässerverunreini-gungen', in Festschrift für H. Dünnebier zum 75. Geburtstag 1982, Berlin, 1982, 562.

Rudolphi, H.J., 'Primat des Strafrechts im Umweltschutz?', NStZ, 1984, 193-199 en 248254.

Rudolphi, H.J., Horn, ,E. en Samson, E., Strafgesetzbuch. Systematischer Kommentar, Berlin, 1989.

Sack, H.-J.,Umweltschutz - Strafrecht, Berlin, 1986.

Schaffmeister, D., 'De strafrechtelijke bescherming van ecologische rechtsgoederen', in Faure, M., Oudijk, J.C. en Schaffmeister, D. (red), Zorgen van heden. Opstellen over milieustrafrecht in theorie en praktijk, Arnhem, Gouda Quint, 1991, 187-192.

Schalken, T.M., 'Het taboe van art. 5 RO', Trema, 1991, 179 e.v.

Schall, H., 'Zur Strafbarkeit von Amtsträgern in Umweltverwaltungsbehörden - BGHSt $38,325 ', J u S, 1993,719-724$.

Scheele, R., Zur Bindung des Strafrichters an fehlerhafte behördliche Genehmigungen im Umweltstrafrecht, Berlin, 1993.

Scheltema, F.G., 'Het grensterrein van publiek en privaatrecht', RMThemis, 1927, 233265 . 
Scheltema, M. en Lubberdink, H.G., Ministeriële verantwoordelijkheid en parlementaire controle, in Parlemen-taire controle en democratie in de verzorgingsstaat, staatsrechtcongres, Utrecht, 1980, 8-11.

Schlössels, R.J.N., Het specialiteitsbeginsel. Over de structuur van bestuursbevoegdheden, wetmatigheid van bestuur en beleidsvrijheid, Den Haag, Sdu, 1998.

Schmidhäuser, E., 'Notwehr und Nothilfe des Polizeibeambten aus strafrechtlicher Sicht', in Merten, D. (Hrsg.), Aktuelle Probleme des Polizeirechts, Berlin, 1977.

Schmidt, A., 'Das neue Umweltstrafrecht', NJW, 1994, 2514-2519.

Scholl, F., Strafrechtliche Verantwortlichkeit von Gemeinde-, Kreisräten und Mitgliedern der Zweckverbandssammlungen im Umweltrecht -\$§ 324, 326 Abs. 1, 327 Abs. 2 Nr. 3 StGB , Schorndorf, 1996.

Scholten, P., Handleiding tot de beoefening van het Nederlands burgerlijk recht, algemeen deel, Zwolle, W.E.J. Tjeenk Willink, 1974.

Schonfeld, K.M., Montesquieu en 'La bouche de la loi', Leiden, 1979.

Schönke, A., Schröder, H. en Lenckner, Th., Strafgesetzbuch, München, C.H. Beck'sche Verlags-Buchhandlung, 1991.

Schönke, A. , Schröder, H. en Stree, W., Strafrecht, München, Beck'sche VerlagsBuchhandlung, 1991.

Schreuder, C.A., Publiekrechtelijke taken, private rechtspersonen, Deventer, Kluwer, 1994.

Schrott, H.J., 'Der Regelungsgehalt des 2. Gesetzes zur Bekämpfung der Wirtschaftskriminalität im Bereich des Ordnungswidrigkeitenrechts', Wistra, 1986, 212234.

Schünemann, B., Unternehmenskriminalität und Strafrecht, Köln, Carl Heymanns Verlag, 1979.

Schünemann, B., 'Die Bedeutung der "Besonderen persönlichen Merkmale" für die strafrechtliche Teilnehmer- und Vertreterhaftung', Jura, 1980, 545-568.

Schünemann, B., 'Die Strafbarkeit von Amtsträgern im Gewässerstrafrecht', Wistra, 1986, 235-246.

Schuyt, C.J.M., 'Sturing in het recht', in Bovens, M.A.P. (red.), Het schip van staat. Beschouwingen over recht, staat en sturing, Zwolle, W.E.J. Tjeenk Willink, 1985, 113124. 
Screvens, S., 'Les sanctions applicables aux personnes morales dans les Etats des Communautés européennes', $R D P, 1980,163-190$.

Seebode, M., 'Polizeiliche Notwehr und Einheit der Rechtsordnung, in Kohlmann, G., (Hrsg.) Festschrift für Ulrich Klug, Band II, Köln, 1983.

Seelmann, K., 'Risikostrafrecht', KritV, 1992, 452-471.

Sevenster, H.G., 'Milieustrafrecht in EEG-verband. "Het Europa van de milieucrimineel"', in Faure, M.G., Oudijk, J.C. en Schaffmeister, D. (red.), Zorgen van heden. Opstellen over milieustrafrecht in theorie en praktijk, Arnhem, Gouda Quint, 1991.

Sheldrake, R., De wedergeboorte van de natuur, Utrecht, Kosmos, 1995.

Simon, H., Publiekrecht of Privaatrecht? Een geschiktheidsonderzoek aan de hand van het nutsmaximalisatie-beginsel toegespitst op het gebruik van het privaatrecht door het bestuur, Zwolle, W.E.J. Tjeenk Willink, 1993.

Spier, J., Overeenkomsten met de overheid, Deventer, 1981.

Steindorf, K., Strafgesetzbuch. Leipziger Kommentar, Berlin, 1988.

Stevenson en Byerly, The many faces of Science. An introduction to Scientists, Values and Society, Oxford, Westview Press, 1995.

Stone, C.D., 'The Place of Enterprise Liability in the Control of Corporate Conduct', Yale Law Journal, 1980, 1-77.

Stratenwerth, G., Strafrecht, Allgemeiner Teil I, Berlin, 1981.

Stratenwerth, G., Das Strafrecht in der Krise der Industriegesellschaft, Basel, 1993.

Strijards, G.A.M., Aansprakelijkheidsgronden, Zwolle, W.E.J. Tjeenk Willink, 1988.

Strijards, G.A.M., Hoofdstukken van materieel strafrecht, Utrecht, Lemma, 1992.

Stroink, F.A.M., Het leerstuk der deconcentratie, 's Gravenhage, 1978.

Stroink, F.A.M, Rechterlijke organisatie en rechtspraak in beweging, Zwolle, W.E.J. Tjeenk Willink, 1993.

Stroink, F.A.M. en Steenbeek, J.C., Inleiding in het staats- en bestuursrecht, Alphen aan den Rijn, Samson, 1993.

Stroink, F.A.M., Algemeen bestuursrecht. Een inleiding, Zwolle, W.E.J. Tjeenk Willink, 1996. 
Struiksma, J., 'De bouwvergunning', in Michiels, F.C.M.A. en Van der Schans, E., Bestuursrechtelijk bouwrecht, Den Haag, 1996, B-28.

Sutherland, E.H., White Collar Crime, the uncut Version, New Haven, Yale University Press, 1983.

Tak, A.Q.C., Overheidsbestuur en privaatrecht, Alphen aan den Rijn, Samson Uitgeverij, 1978.

Tak, A.Q.C., 'Drie magische lijnen', Ars Aequi, 1987, 22-35.

Tak, A.Q.C en Bakker, R.E., 'De centrale rol van het willekeurverbod bij de toetsing van overheidshandelen', in Heringa, A.W. en Verheij, N., Publiekrechtelijke bewegingen, Deventer, Kluwer, 1990.

Tak, A.Q.C., 'Overheid en Burgerlijk Wetboek', Recht en Kritiek, 1993, 174-185.

Tak, A.Q.C., De overheid in het burgerlijk recht, 's Gravenhage, VUGA, 1997.

Teunissen, J.M.F.H. en Tak, A.Q.C., 'Recht ist was der Umwelt nützt? Over zorgplichtbepalingen, civiele acties en tweewegenleer. Een overdenking n.a.v. de opneming van een zorgplichtbepaling in de Wet milieubeheer', $N J B, 1994,605-616$.

Teunissen, J.M.H.F., Het burgerlijk kleed van de staat. Beschouwingen over de tweewegenleer, Zwolle, W.E.J. Tjeenk Willink, 1996.

't Hart, A.C., en De Vries-Leemans, M.J.H.J., 'Enige opmerkingen betreffende het feitelijke leidinggeven', in Balkema, J.P. (red.), Gedenkboek honderd jaar Wetboek van Strafrecht, Arnhem, Gouda Quint, 1986, 289-301.

't Hart, A.C., Recht als schild van Perseus, Arnhem, Gouda Quint, 1991.

't Hart, A.C., Openbaar Ministerie en rechtshandhaving, Arnhem, Gouda Quint, 1994.

't Hart, A.C., Mensenwerk? Over rechtsbegrip en mensbeeld in het strafrecht van de rechtsstaat, Mededelingen van de Afdeling Letterkunde van de KNAW, deel $58 \mathrm{nr}$. e, Amsterdam/New York/Oxford/Tokyo, 1995.

't Hart, A.C., De Meerwaarde van het Strafrecht, Den Haag, Sdu, 1997.

Tiedemann, K., Die Neuordnung des Umweltstrafrechts. Gutachtliche Stellungnahme zu dem Entwurf eines 16. Strafrechtsänderungsgesetzes (Gesetz zur Bekämpfung der Umweltkriminalität), Berlin, Walter de Gruyter, 1980.

Tonnaer, F.P.C.L., Handboek van het Nederlands milieurecht, Utrecht, Lemma, 1994. 
Torringa, R.A., Strafbaarheid van rechtspersonen, Arnhem, Gouda Quint, 1984.

Torringa, R.A., De rechtspersoon als dader; strafbaar leidinggeven aan rechtspersonen, Arnhem, Gouda Quint, 1988.

Traest, Ph., Het bewijs in strafzaken, Gent, Mys en Breesch, 1992.

Traest, Ph., 'De wet van 4 mei 1999 tot invoering van de strafrechtelijke verantwoordelijkheid van rechtsper-sonen', TRV, 1999, 451-489.

Van Angeren, J.A.M., 'De aanvullende functie van de gewone rechtspraak ten opzichte van andere rechtsgangen', RMThemis, 1991, 6-15.

Van Angeren, J.A.M., De gewone rechter en de bestuursrechtspraak, Zwolle, W.E.J. Tjeenk Willink, 1998.

Van Bavel, H., 'De wet van 4 mei 1999 tot invoering van de strafrechtelijke verantwoordelijkheid van rechtsper-sonen', AJT, 1999-00, 209-226.

Van Bemmelen, J.M. en Van Veen, Th.W., Ons strafrecht I. Het materiële strafrecht, Algemeen deel, bewerkt door De Jong, D.H. en Knigge, G., Arnhem, Gouda Quint, 1995 .

Van de Heuvel, G.A.A.J., Onderhandelen of Straffen. Over organisatie-criminaliteit en overheidscontrole, Arnhem, Gouda Quint, 1993.

Vande Lanotte, J., Inleiding tot het publiek recht. Deel I. Basisbegrippen, Brugge, die Keure, 1994.

Vande Lanotte, J.,Inleiding tot het publiek recht. Deel 2. Overzicht van het publiek recht, Brugge, die Keure, 1994.

Van den Berg, E.A.I.M. en Eshuis, R.J.J., Grote strafrechtelijke milieuonderzoeken, WODC, Arnhem, Gouda Quint, 1996.

Van den Wijngaert, C., Strafrecht en strafprocesrecht in hoofdlijnen, Antwerpen, Maklu, 1999.

Van der Burg, F.H., 'Formele rechtskracht, vertrouwensbeginselen en derde-beroep', in Een stellig annotator, Zwolle, W.E.J. Tjeenk Willink, 1982, 1-21.

Van der Burg, F.H., Cartigny, G.J.M. en Overkleeft-Verburg, G., Rechtsbescherming tegen de overheid, Nijmegen, 1985.

Van der Hoeven, J., 'De magische lijn. Verkenningen op de grens van publiek- en privaatrecht', in Honderd jaar rechtsleven, Zwolle, W.E.J. Tjeenk Willink, 1970, 201219. 
Van der Hoeven, J., 'De grenzen van de rechterlijke functie in de administratieve rechtspraak', RMThemis, 1974, 658-679.

Van der Hoeven, J., De drie dimensies van het bestuursrecht; Ontstaan en vorming van het Nederlandse algemene bestuursrecht, VAR-reeks 100, Alphen aan den Rijn, Samson/H.D. Tjeenk-Willink, 1989.

Van der Jagt, J.A.E., Decentraal bestuur vervolgbaar?, Deventer, Gouda Quint, 2000.

Van der Meulen, B.M.J., 'Handhaving', in Van der Linden, E.C.H.J. en Tak, A.Q.C. (red.), Eenzijdig en weder-kerig?, Deventer, Kluwer, 1995.

Van Duyne, P.C., 'Schuldig zijn of schuldig verklaard worden. De "goede voerman" in schuld- en rechtvaar-digingsgronden', $R \& K, 1991,435-445$.

Van Elst, R., Strafbare rechtspersonen en hun leidinggevers, Nijmegen, Ars Aequi Cahiers Strafrecht, deel 8, 1997.

Van Garsse, S., De strafrechtelijke verantwoordelijkheid van publiekrechtelijke rechtspersonen', C.D.P.K., 2000, 347-359.

Van Gestel, R.A.J., 'Milieuzorg op maat', in Bedrijfsinterne milieuzorg en vergunningverlening. 'Is het gras groener bij de buren?', Zwolle, W.E.J. Tjeenk Willink, 1998, 26-68.

Van Hoorick, G., De Roo, K. en Rutten, J., 'Het decreet betreffende het naturbehoud en het natuurlijk milieu', TMR, 1998, 2-19.

Van Hukkelhoven, M.M.G., 'De zelfstandigheid van de Arbeidsvoorzieningsorganisatie', Bestuurskunde, 1994, 13-20.

Van Kuijck, Y. en De Lange, A., 'Strafvervolging van overheden', Opportuun, 1997, 12 13.

Van Maanen, G.E., De wonderbaarlijke geschiedenis van de onrechtmatige overheidsdaad in de $19 e$ en $20 e$ eeuw, Ars Aequi Cahiers Rechtsvergelijking en rechtsgeschiedenis, deel 5, Nijmegen, Ars Aequi Libri, 1996.

Van Maanen, G.E. en de Lange, R., Onrechtmatige overheidsdaad, Kluwer, W.E.J. Tjeenk Willink, 2000.

Van Maarseveen, H.Th.J.F., 'Een opmerking over de onrechtmatige overheidsdaad', NJB, 1954, 914-920.

Van Nus, J.G.J., Overheidstoezicht op afstand. Verzelfstandiging van toezichthoudende taken naar zelfstandige bestuursorganen verkend, Antwerpen-Apeldoorn, Maklu, 1995. 
Van Oordt, W.C., Overheidsaansprakelijkheid in België en Nederland. Een rechtsvergelijkende studie, Arnhem, G.W. van der Wiel \& Co, 1963.

Van Praag, L., Op de grenzen van publiek en privaat recht, 's-Gravenhage, 1930.

Van Steenbergen, B., 'De toekomst vanuit het onderbouwperspectief (2): de postverspillingsmaatschappij', in Van Hoof, J. en Van Ruysseveldt, J. (red.), Sociologie en de moderne samenleving, Amsterdam, Boom, 1996, 484-494.

Van Strien, A.L.J., 'De strafrechter en de bestuurlijke mantel der liefde, Over de vervolgbaarheid van publiekrechtelijke rechtspersonen', $D D, 1987,584-600$.

Van Strien, A.L.J., 'Het daderschap van de rechtspersoon voor milieudelicten', in Faure, M.G., Oudijk, J.C., Schaffmeister, D. (red.), Zorgen van heden. Opstellen over milieustrafrecht in theorie en praktijk, Arnhem, Gouda Quint, 1991, 257-301.

Van Strien, A.L.J., De rechtspersoon in het strafproces. Een onderzoek naar de procesrechtelijke aspecten van de strafbaarheid van de rechtspersoon, Den Haag, Sdu, 1996.

Van Strien, A.L.J, 'Het (bewijs van het) daderschap van de rechtspersoon naar Australisch en naar Nederlands recht', in Faure, M. en Schwarz, K. (red.), De strafrechtelijke en civielrechtelijke aansprakelijkheid van de rechtspersoon en zijn bestuurders, Antwerpen, Intersentia, 1998, 137-138.

Van Swaaningen, R., 'Justitie als verzekeringsmaatschappij. Actuarial justice in Nederland', in De Risico-maatschappij, Justitiële Verkenningen, WODC, Arnhem, Gouda Quint, 1996.

Van Tuijn, J., 'Shell mag van provincie eigen milieuvergunning schrijven', Ingenieurskrant, 3 juni 1993, 3 .

Van Veen, Th.W., 'De strafrechtelijke aansprakelijkheid van de overheid', RMThemis, 2000, 163-167.

Van Vugt, G.W.M. en Boet, J.F., Zuiver handelen in een vuile context. Over (grensoverschrijdende) afval-stromen, milieucriminaliteit en integer handelen in het openbaar bestuur, Arnhem, Gouda Quint, 1994.

Van Wijk, H.D. en Konijnenbelt, W., Hoofdstukken van Bestuursrecht, Den Haag, Elseviers Bedrijfsinformatie, 1999.

Van Zeben, C.J. e.a. (red.), Parlementaire geschiedenis van het nieuwe Burgerlijk Wetboek. Boek 2. Rechtspersonen, Deventer/Antwerpen. 
Vegting, M.G., Het Algemeen Nederlands Administratiefrecht, deel II, Alphen aan den Rijn, 1957.

Vellinga-Schootstra, F., Vellinga, W.H. en Van Strien, A.L.J., 'Het daderschap van de rechtspersoon', in Van der Neut, J.L. (red.), Daderschap en deelneming, Arnhem, Gouda Quint, 1993.

Verstraeten, R., Handboek strafvordering, Antwerpen, Maklu, 1999.

Vervloet, J.R., 'Strafrechtelijke aspecten van het sociaal strafrecht', in Liber Amicorum F. Dumon, Antwerpen, Kluwer, 1983, 537-557.

Viering, M.L.W.M. en Widdershoven, R.J.G.M., 'De strafrechtelijke positie van de overheid na Pikmeer II', in Elzinga, D.J. en De Jong, H.M. (red.), Strafbaarheid van overheden, Deventer, W.E.J. Tjeenk Willink, Publikaties van de staatsrechtkring deel $15,1998,67-85$.

Visser, M., 'Strafrechtelijke zorgplichtbepalingen over de grens? De strafrechtelijke afdwingbaarheid van milieuzorgplichtbepalingen in België en Nederland', in Faure, M. en Deketelaere, K. (red.), Ius Commune en milieurecht. Actualia in het milieurecht in België en Nederland, Antwerpen-Groningen, Intersentia, 1997, 203-236.

Visser, M., 'Uitholling van het schuldbeginsel', in Borgers, M.J., Koopmans, I.M. en Kristen, F.G.H. (red.), Verwijtbare uitholling van schuld?, Nijmegen, Ars Aequi Cahiers, 1998.

Waeterinckx, P., 'De cumulatie van de strafrechtelijke verantwoordelijkheid van de rechtspersoon met die van de natuurlijke persoon. Art. 5, tweede lid Sw., een staaltje van onbehoorlijke regelgeving,' $R W, 1217-1229$.

Waling, C., Het materiële milieustrafrecht, Arnhem, Gouda Quint, 1990.

Weber, U., Strafrechtliche Verantwortlichkeit von Bürgermeistern und leitenden Verwaltungsbeambten im Umweltrecht, Stuttgart, 1988.

Wemes, L.T., 'Commune delicten betreffende de milieuvervuiling in de sleutel van de schuld', in Faure, M., Oudijk, J.C. en Schaffmeister, D. (red.), Zorgen van heden. Opstellen over milieustrafrecht in theorie en praktijk, Arnhem, Gouda Quint, 1991.

Wilber, K., Up from Eden, Boston, Shamballa, 1986.

Wimmer, K., 'Strafbarkeit des Handelns aufgrund einer erschlichenen behördlichen Genehmigung', $J Z, 1993,67-73$.

Winkelbauer, W., 'Die strafrechtliche Verantwortung von Amtsträgern im Umweltstrafrecht', NStZ, 1986, 149-153. 
Witteveen, W.J., Evenwicht der machten, Zwolle, W.E.J. Tjeenk Willink, 1991.

Witteveen, W.J., De geordende wereld van het recht. Een inleiding, Amsterdam, University Press, 1996.

Witteveen, W.J., 'Staatssoevereiniteit: machtswoord en toverspreuk', in Elzinga, D.J. e.a. (red.), Strafbaarheid van overheden, Zwolle, W.E.J. Tjeenk Willink, Publikaties van de staatstrechtkring 1998.

Woensel, A.M., In de daderstand verheven, Arnhem, Gouda Quint, 1993.

Wortel, J., De onderneming in het strafrecht, Lelystad, Vermande, 1987.

Wortel, J., 'Verdachte overheden', $N J B, 1988,1515-1519$.

Zeitler, S., Die strafrechtliche Haftung für Verwaltungsentscheidungen nach dem neuen Umweltstrafrecht. Dargestellt an dem § 324 StGB, Tübingen, 1982. 



\section{Jurisprudentieregister}

\section{Europees Hof voor de Rechten van de Mens}

EHRM 7 oktober 1988, $N J$ 1991, 351 (Salabiaku)

EHRM 25 september 1992, $N J$ 1995, 593 (Pham Hoang)

\section{Nederland}

HR 22 mei en 26 juni 1863, W. 2499 (Zuidplaspolder)

HR 13 januari 1879, W. 4330 (Meerenberg)

HR 7 november 1892, W. 6259

HR 29 mei 1896, W. 6817 (Vrouwe Elske)

HR 21 april 1898, W. 7116 (Rhedense Koe)

HR 19 december 1910, W. 7146

HR 25 maart 1912, W. 9322

HR 21 april 1913, $N J 1913,961$

HR 1 november $1915, N J 1915,1212-1213$

HR 31 december 1915, $N J$ 1916, 407 (Guldemond/Noordwijkerhout)

HR 14 februari 1916, $N J$ 1916, 618 (Water en Melk)

HR 31 januari 1919, $N J$ 1919, 161 (Lindenbaum/Cohen)

HR 21 juni 1926, $N J$ 1926, 995

HR 30 januari, $N J 1928$, p. $215-218$, met noot vD.

HR 29 juni 1928, $N J$ 1928, 684 (Strooppot)

HR 5 mei 1933, $N J$ 1933, 875 met noot Meijers (Meerboei)

HR 29 juni 1936, $N J 1936,9$

HR 31 oktober 1938, $N J$ 1939, 193 met noot W.P.

HR 29 maart 1940, $N J$ 1940, 1128 (Heldenkermis)

HR 14 oktober 1940, NJ 1940, 165, met noot W.P.

HR 5 november 1946, $N J 1947$, 132, met noot W.P.

HR 27 januari 1948, $N J$ 1948, 197 met nootW.P. (Vroom \& Dreesman) HR 14 januari 1949, $N J$ 1949, 557 (Zandvoortse Woonruimtevordering) HR 25 februari 1949, $N J$ 1949, 558 (Doetinchemse Woonruimtevordering) HR 27 februari 1951, $N J$ 1951, 474 met noot Roling (ATO) HR 18 maart 1952, $N J$ 1952, 314 (Kleurloos opzet) 
HR 23 februari 1954, NJ 1954, 378, met noot B.V.A. Roling (IJzerdraad)

HR 14 december 1954, NJ 1955, 119

HR 10 mei 1955, NJ 1956, 21 ; $A B$ 1955, 485 met noot Troostwijk (Loterijvergunning)

HR 20 december 1955, NJ 1956, 209

HR 4 januari 1963, $N J$ 1964, 202-204 (Landsmeer)

HR 2 maart 1965, NJ 1965, 273

HR 23 november 1965, $N J$ 1966, 331

HR 28 november 1967, $N J 1968,143$

HR 15 juni 1976, $N J 1976,565$

HR 19 november 1976, NJ 1979, 216 met noot Scheltema (Semper Crescendo)

HR 24 mei 1977, NJ 1978, 330 (Nicotinezuur)

HR 12 december 1978, $N J$ 1979, 142 (Braak bij binnentreden)

HR 6 april 1979, NJ 1980, 34 (Kleuterschool Babbel)

HR 16 juni 1981, $N J$ 1981, 568 (Papa Blanca)

HR 1 juli 1981, $N J$ 1982, 80, met noot ThWvV (Kabeljauw)

HR 27 oktober 1981, NJ 1982, 474, met noot GEM (Tilburgse verkeersdrempels)

HR 22 december 1981, NJ 1982, 233 (Niet-ontvankelijkheid openbaar ministerie)

HR 2 maart 1982, $N J$ 1982, 446 met noot 'tH (Witte Grammofoonplaten)

HR 4 februari 1983, NJ 1985, 21 met noot Scheltema (Hei- en Boeicopse parkeerplaats)

HR 12 april 1983, NJ 1983, 602

HR 24 februari 1984, NJ 1984, 669 (St. Oedenrode-Driesen)

HR 13 november 1984, NJ 1985, 294 (Camping Domburg)

HR 11 juni 1985, $N J 1986$ met noot'tH (Utrechtse tippelverbod)

HR 19 november 1985, $N J 1986,125$, met noot 'tH (Slavenburg I)

HR 22 november 1985, NJ 1986, 722, met noot Scheltema (Super Doc)

HR 11 februari 1986, $N J 1986,673$

HR 16 mei 1986, NJ 1986, 723 met noot Scheltema (Heesch-Van de Akker)

HR 20 mei 1986, NJ 1987, 990

HR 27 juni 1986, NJ 1987, 726, met noot Scheltema (Haagse tolkentarieven)

HR 16 december 1986, NJ 1987, 321, met noot 'tH (Slavenburg II)

HR 10 februari 1987, $N J$ 1987, 662, met noot 'tH (Vliegveld Beek)

HR 27 maart 1987, NJ 1987, 727 (Ikon/Amstedam)

HR 23 juni 1987, $N J$ 1988, 44

HR 14 september 1987, NJ 1988, 45 met noot 'tH (Rijtijden)

HR 10 november 1987, $N J$ 1988, 303, met noot ThWvV (Rijksuniversiteit Groningen)

HR 26 februari 1988, $N J$ 1989, 528, met noot Scheltema (Hot Air-Staat)

HR 11 november 1988, $N J 1990,563$ (Ekro-Staat)

HR 6 december 1988, MenR 1989, 38

HR 26 januari 1990, NJ 1991, 393 met noot Scheltema.

HR 23 oktober 1990, NJ 1991, 496, met noot Sch, Gst 6923, 6, met noot HH, MenR, 1991, 54, met noot Tideman, $A B$ 1991, 413, met noot FHvdB (Voorburgse

reigersnesten)

HR 11 november 1990, NJ 1990, 563

HR 8 maart 1991, NJ 1991, 379, met noot Brunner

HR 13 mei 1991, NJ 1993, 112, met noot Brunner (Van Gog-Nederweert)

HR 19 maart 1991, $N J$ 1992, 122, met noot C. (Omgevallen hijskraan)

HR 19 november 1991, $N J$ 1991, 250 met noot 'tH 
HR 14 januari 1992, $N J$ 1992, 413, met noot 'tH (Discriminerende Disco)

HR 8 juni 1992, $N J$ 1993, 12 (Visafslag Urk)

HR 9 juni 1992, $N J$ 1992, 794, MenR, 1993, met noot P.J.P. Tak en W. J. Kooy

(Streekgewest Oostelijk Zuid-Limburg)

HR 23 februari 1993, $N J$ 1993, met noot 'tH (Furazolidon)

HR 1 juni 1993, $N J$ 1994, 53, met noot 'tH. (Klaver Fashion)

HR 18 juni 1993, $N J$ 1993, 642, met noot Scheltema

HR 1 juli 1993, $N J 1995$, 150, met noot Brunner

HR 11 januari 1994, MenR 1994, 85 met noot Hendriks (Mobil Oil)

HR 25 januari 1994, NJ 1994, 598, met noot C., MenR, 1994, 104, met noot De Lange, AA 1995, 1, 50-56, met noot J de Hullu, MRT, 1995, 6, 210-219, met noot Th.J.B.

Buiting (Vliegbasis Volkel)

HR 15 november 1994, MenR 1995, 10K

HR 6 januari 1995, $N J$ 1995, 696, met noot Scheltema

HR 23 mei 1995, MenR 1996, 5, met noot Hendriks

HR 2 juni 1995, $R v d W 1995,123$ c (Aharchi-Bedrijfsvereniging)

HR 2 juni 1995, RvdW 1995, 123c

HR 6 juni 1995, $N J$ 1995, 696, met noot Scheltema

HR 27 juni 1995, MenR 1996, 6, met noot Hendriks

HR 20 februari 1996, MenR 1997, 62

HR 23 april 1996, $N J$ 1996, 512, AB 1996, 456, MenR 1996, 113, TMA 1997, 1, met noot A.M Fransen (Waterschap West-Friesland)

HR 23 april 1996, NJB 1996, afl. 24, nr. 61, Gst 7040, 4, met noot HH, TMA, 1997, 1, met noot A.M. Fransen (Provincie Noord-Holland)

HR 6 januari 1998, $N J$ 1998, 367, met noot JdH, $A B$ 1998, 45, met noot ThGD, Gst 7073, 3, met noot HH, MenR, 1998, 19, Mileurechtspraak, 1998, 4, met noot H.J.E.

Hambruekers, $J B, 1998,4, A A 1998$, 4, met noot I.C. van der Vlies, $N J B$, 1998, afl. 25, 274 (Pikmeer II)

HR 30 juni 1998, $N J 1998,819$, Gst 7090, 3, met noot HH (Gouden Bodem)

HR 2 februari 1999, NJ 1999, 554

Hof Amsterdam 31 januari 1996, MenR 1996, 38k

Hof Arnhem 30 november 1982, NJ 1983, 222

Hof Arnhem 22 mei 1989, MenR 1989, 81, met noot G.H. Addink en P.J.P. Tak

(Gemeente Druten)

Hof Arnhem 19 december 1997, AB 1998, 46, MenR 1998, 50, met noot Hendriks

(Gemeente Nijmegen)

Hof Leeuwarden 6 juni 1995, MenR 1996, 4 (Gemeente Sneek)

Hof Leeuwarden 12 november 1996, MenR 1997, 1, met noot De Lange (Pikmeer I)

Hof Leeuwarden 4 november 1997, MenR 1998, 18, met noot De Lange (Gouden

Bodem)

Hof 's-Gravenhage 17 april 1996, $N J$ 1996, 574 (TCR)

Rb Amsterdam 18 december 1990, MenR 1992, 14

Rb Amsterdam, 26 april 1991, MenR 1991, 121,1

$\mathrm{Rb}$ Amsterdam 5 januari 1993, TMA 1993, 77- 83, met noot Faure (Cindu)

Rb Breda 15 febrauri 1982, $N J$ 1983, 6 (UNISER) 
Rb Breda 5 juli 1989, MenR 1990, 37 met noot Tideman

Rb Den Bosch 2 januari 1990, MenR 1990, 66.

$\mathrm{Rb}$ Leeuwarden 23 december 1987, Tijdschrift voor Gezondheidsrecht 1988, 175 met noot Roscam Abbing

$\mathrm{Rb}$ Maastricht 5 december 1990, MenR 1991, 55, met noot Tideman (Streekgewest

Oostelijk Zuid-Limburg)

Rb Rotterdam 4 december 1992, MenR 1993, 38 (Kerstboomverbranding)

Rb Rotterdam 6 mei 1993, MenR 1994, 49

Rb Rotterdam 13 oktober 1995, MenR 1996, 24 met noot De Lange (TCR)

$\mathrm{Rb}$ 's-Gravenhage 15 december 1995, MenR 1996, 22K (Reigers in 't park 't Loo)

Rb Utrecht 4 september 1984, $A B$ 1985, 39

\section{België}

Cass. 15 juni 1885, Pas., 1885, I, 183

Cass. 13 februari 1905, Pas., 1905, I, 127

Cass. 30 maart 1911, Pas., 1911, I, 193

Cass. 19 juni 1933, Pas., 1933, I, 270

Cass. 26 februari 1934, Pas., 1934, I, 180

Cass. 12 maart 1942, R.J.D.A., 1946, 24

Cass. 8 april 1946, A.C., 1946, 137

Cass. 16 december 1948, J.T., 1949, 150

Cass. 10 maart 1955, $R W, 1955-56,529$

Cass. 16 november 1959, Pas., 1960, I, 323

Cass. 13 maart 1961, Pas., 1961, I, 761

Cass. 17 september 1962, Pas., 1963, I, 61

Cass. 1 april 1963, Pas., 1963, I, 835

Cass. 21 november 1963, Pas., 1964, I, 309

Cass. 13 oktober 1969, Arr. Cass., 1970, 156

Cass. 3 maart 1972, $R W, 1971-72,1638$

Cass. 19 september 1972, A.C., 1973, 69

Cass. 15 oktober 1972, Arr. Cass., 1973, 165

Cass. 1 oktober 1973, A.C., 1974, 105

Cass. 7 oktober 1974, A.C., 1975, 169

Cass. 15 april 1975, A.C., 1975, 890

Cass. 12 december 1978, A.C., 1978-79, 423

Cass. 10 april 1979, A.C., 1978-79, 953

Cass. 12 juni 1979, A.C., 1978-79, 1216

Cass. 1 februari 1984, Pas., 1984, I, 617

Cass. 5 december 1984, Arr. Cass., 1984-85, 477

Cass. 15 oktober 1985, $R W, 1987-88,21$ met noot De Swaef

Cass. 15 oktober 1986, Arr. Cass., 1986-87, 200

Cass. 12 mei 1987, Arr. Cass., 1986-87, 1104

Cass. 24 november 1988, $R W, 1988-89,1306$

Cass. 31 januari 1989, Arr.Cass., 1988-89, 648

Cass. 25 april 1989, A.C., 1988-89, 990

Cass. 10 oktober 1989, T.B.H., 1990, 393 
Cass. 4 oktober 1994, $R W, 1997-98,675$

Hof Antwerpen 24 april 1982, TMR, 1992, 18, met noot Deruyck Hof Antwerpen 22 november 1984, $R W, 1985-86,1850$, met noot De Swaef Hof Antwerpen 10 april 1990 inzake OM t. BRC (ongepubliceerd)

Hof Antwerpen 1 juni 1990 inzake OM t. De Schepper; Christiaensern, Beeckman, VECOM en ETERNIT (ongepubliceerd)

Hof Antwerpen 10 januari 1995, TMR, 1996, 89

Hof Antwerpen, 19 april 1995 inzake OM, Cuppens, Jacobs e.a. t. Steensels (ongepubliceerd)

Hof Bergen, 26 november 1996, Aménagement-Environnement, 1997, 143

Hof Brussel 24 april 1984, $R W, 1985-86,882$, met noot De Swaef

Hof Gent 27 juni 1985, $R W, 1986-87,1691$, met noot Vandeplas

Hof Gent 2 april 1992, TMR, 1992, 99

Hof Gent 16 december 1994, TMR, 1996, 191

Hof Gent 2 februari 1995, TMR, 1996, 91

Hof Gent 3 mei 1996, TMR, 1996, 55

Hof Gent 25 oktober 1996, TMR, 1998, 23

Corr. Brugge, 2 januari 1983 inzake OM t. Alleene e.a. (ongepubliceerd)

Corr. Antwerpen, 17 juni 1991 inzake OM t. Herreman e.a. (ongepubliceerd)

Corr. Gent 5 december 1991, TMR, 1992, 102

Corr. Gent 4 juni 1992, TMR, 1993, 50

Corr. Gent 13 september 1993, TMR, 1994, 124

Corr. Gent 19 september 1995, TMR, 1996, 283

Corr. Antwerpen 15 mei 1996, inzake OM t. Kampers en Halans (ongepubliceerd)

\section{Duitsland}

BverfG 6 mei 1987, St $V, 1987,432$

BGH 6 juni 1990, NStZ, 1990, 588

BGH 19 augustus 1992, BGHST (38) 1992, 325 ; NJW, 1992, 3247

BGH 3 november 1993, JZ, 1994, 634

OLG Koln 26 november 1985, St $V$, 1986, 537-538

OLG Celle 4 juni 1986, ZfW, 1987, 128

OLG Frankfurt 22 mei 1987, NStZ, 1987, 509

OLG Koln 17 mei 1988, NJW, 1988, 2119

OLG Stuttgart 2 december 1988, NStZ, 1989, 123

OLG Dusseldorf 7 maart 1989, MDR, 1989, 932

OLG Saarbrucken 27 juni 1991, NJW, 1991, 3045

AG Cochem 5 juli 1985, NStZ, 1985, 506

AG Wertheim 4 november 1987 (ongepubliceerd)

LG Munchen 19 juni 1985, NUR, 1986, 260

LG Koblenz 22 december 1986, NStZ, 281 
Jurisprudentieregister

LG Hanau, 12 november 1987, NStZ, 1988, 180

LG Paderdorn 9 oktober 1991 (ongepubliceerd) 


\section{Curriculum Vitae}

David Roef werd geboren op 10 oktober 1970 te Lier (België). In 1989 deed hij eindexamen klassieke talen aan het Atheneum te Lier. Van 1989 tot 1993 studeerde hij Belgisch recht met als specialisatie (rechtsvergelijkend) Strafrecht aan de Vrije Universiteit Brussel. Hij studeerde daar met grote onderscheiding af. In september 1993 ging hij als assistent in opleiding werken bij het Maastrichts Europees Instituut voor Transnationaal Rechtswetenschappelijk Onderzoek van de Universiteit Maastricht. Sinds 1995 maakt hij deel uit van de (met ingang van mei 1998 erkende) onderzoeksschool lus Commune. Sinds november 1996 is hij werkzaam als Universitair Docent straf(proces)recht bij de capaciteitsgroep Strafrecht \& Criminologie aan de Universiteit Maastricht. Binnen het onderwijs verzorgt hij de keuzeblokken Materieel strafrecht en criminele politiek en Strafrecht en onderneming. 
Een boekenreeks waarin de gemeenschappelijke grondslagen in de rechitsstelsels van de landen binnen de Europese gemeenschap centraal staan. De lus Commune Europaeum Reeks bevat zowel horizontaal rechtsvergelijkende studies als onderzoeken naar de doorwerking van verdragsteksten in nationale stelsels. Alle klassieke domeinen van het recht worden bestreken. De boeken worden utgegeven in verscheidene Europese talen en staan ander auspicièn van METRO, het rechtswetenschappelijk onderzoeksinstituut van de Universifeit Maastricht.

Dit boek is een verstag van een rechtsvergelijkend onderzoek naar de strafrechtelijke aansprakelijkheid van overheden voor milieuverstoring. $\mathrm{De}$ concrete aanleiding voor deze studie is de jurisprudentie van de Hoge Paad. Volgens deze jurisprudentie genieten overheden in bepaalde gevallen een strafrechtelijke immuniteit. Zo heeft de Hoge Raad geoordeeld dat de Staat der Nederlanden voor zijn handelingen niet strafrechtelijk verantwoordelijk is en daarom niet kan worden vervolgd (Volkel). Daarnaast zijn ook decentrale overheden en hun leidinggevende functionarissen van de werking van het strafrecht uitgesloten, zij het onder de voorwaarde dat het gepleegde delict moet zijn begaan bij de behartiging van een exclusieve wettelijke bestuurstaak (Pikmeer II). Hoewel de strafbearheid van overheden niet slechts betekenis heeft voor milieudelicten, is deze problematiek voor het milieustrafrecht van groot belang Juist in het milieurecht, waar overheden zelf vorm en inhoud geven aan regelgeving enerzijds en handhaving anderzijds, is de vraag gerechtvaardigd of deze overheden strairechtelijk ter verantwoording kunnen worden geroepen wanneer zij zelf de milieuregelgeving met de voeten treden. 